\title{
2018 Seismology of the Americas Meeting
}

\author{
Latin American and Caribbean Seismological Commission \\ Seismological Society of America \\ 14-17 May 2018 \\ Miami, Florida
}

\section{SEISMOLOGY OF THE AMERICAS}

A joint international conference of the Seismological Society of America (SSA) and the Latin American and Caribbean Seismological Commission (LACSC) will be held in Miami, Florida on 14-17 May 2018. The conference is the first joint meeting of SSA and LACSC, one of four Regional Commissions of the International Association of Seismology and Physics of the Earth's Interior (IASPEI).

\section{PROGRAM COMMITTEE}

This year's Technical Program Committee consists of Co-Chairs Carol S. Prentice (United States Geological Survey) and Elizabeth A. Vanacore (University of Puerto Rico at Mayagüez); Sergio Barrientos (University of Chile); Christa G. von Hillebrandt-Andrade (National Oceanic and Atmospheric Administration); Xyoli Pérez-Campos (National Autonomous University of Mexico); Mario Ruiz (Instituto Geofisico Escuela Politecnica Nacional, Ecuador).

\section{Meeting Contacts}

Technical Program Co-Chairs

Carol Prentice and Elizabeth Vanacore

program@seismology2018.org

Abstract Submissions

Rikki Anderson

510.525.5474

abstracts@seismology2018.org

Registration

Sydni Schieber

510.525.5474

registration@seismology2018.org

\section{Exhibits}

Sydni Schieber

510.525 .5474

exhibits@seismology2018.org

Media Registration and Press Releases

Becky Ham

602.300.9600

press@seismology2018.org

\section{TECHNICAL PROGRAM}

The SSA Technical Program comprises three days of oral and poster presentations. The session descriptions, detailed program schedule, and all abstracts appear in the following pages.

\section{LECTURES}

\section{President's Address}

Andrew Michael will present the President's Address at the SSA Annual Luncheon on Tuesday 15 May 2018.

\section{William B. Joyner Memorial Lecture: Ellen M. Rathje \\ Wednesday 16 May, 5:30-6:30 PM \\ University of Texas at Austin Professor Ellen M. Rathje has been selected as the 2018 recipient of the William B. Joyner Lecture Award. Rathje is the Warren S. Bellows Centennial Professor in the Department of Civil, Architectural, and Environmental Engineering and also a Senior Research Scientist at the Bureau of Economic Geology at the University of Texas at Austin.}

\section{Seismic Landslide Assessments: Bridging the Gap between Engineers and Earth Scientists}

Ellen M. Rathje, Ph.D., P.E., F.ASCE, University of Texas

Earthquake-induced landslides represent a significant seismic hazard, as evidenced by recent earthquakes in Kaikoura, New Zealand and Gorkha, Nepal, and proper planning/mitigation requires accurate evaluation of the potential for seismic landslides. Engineers often tackle this problem through a detailed evaluation of individual slopes and more recently have introduced performance-based engineering (PBE) concepts into the analysis. Recognizing the compounding effects of multiple landslides across an area, earth scientists often evaluate seismic landslides at a regional scale. This approach sacrifices details, but provides a broader assessment of the impacts of earthquake induced landslides. This presentation will describe the integration of performance-based engineering concepts into regional-scale seismic landslide assessments. The basic PBE framework for seismic landslides will be introduced along with the modifications required to apply it at a regional scale. The application of the approach for a seismic landslide hazard map will be presented. The use of seismic landslide inventories to validate regional landslide assessments will be discussed, along with advancements in developing seismic landslide inventories using remote sensing techniques. Finally, research 
needs required to further advance regional seismic landslide assessments will be presented.

\section{LIGHTNING TALKS}

The Lightning Talks comprise an hour of 10 five-minute talks. The talks start at 6:00 PM on Tuesday 15 May.

\section{Earthquake-Induced Gravity Changes Heralding the Arrival of the Direct Seismic Waves}

Martin Vallée (vallee@ipgp.fr)

After an earthquake, the earliest deformation signals are not expected to be carried by the fastest $(\mathrm{P})$ elastic waves but by the speed-of-light changes of the gravitational field. The observations of these weak signals, and their full understanding, would provide a new data type with a strong potential for a rapid estimate of the earthquake magnitude. We show here that gravity perturbations are particularly well observed with broadband seismometers at distances between 1,000 and 2,000 kilometers from the source of the 2011, moment magnitude 9.1, Tohoku earthquake. We can accurately model them by a new formalism, taking into account both the gravity changes and the gravity-induced motion. These prompt elasto-gravity signals open the window for minute time-scale magnitude determination for great earthquakes, in particular in places where good-quality broadband seismometers are installed in front of the megathrust area, at distances ranging from a few hundreds to a few thousands of kilometers. In North America, the seismic monitoring of both the Cascadia and Alaska subduction zones would benefit from the early detection of such gravity changes.

\section{Volcanic Thunder from Explosive Eruptions at Bogoslof Volcano, Alaska}

Matthew Haney (mhaney@usgs.gov)

I've submitted an abstract for a normal oral presentation on infrasound observations of volcanic thunder from the recent eruption of Bogoslof Volcano in Alaska. These are the first documented observations of volcanic thunder, which is thunder due to lightning occurring in a volcanic ash plume. Detection of volcanic lightning on global lightning location networks is a new technique used for real time alerts of eruptive activity at volcanoes. It's especially useful for volcanoes in remote regions and contains information on the dynamics of volcanic plumes. The ability to observe volcanic thunder offers a new window into the physical process of volcanic lightning generation.

\section{Similar Seismicity at Turrialba and Poas, Costa Rica: What Can It Tell Us?}

Rebecca Salvage (beckysalvage@gmail.com)

Seismicity in volcanic settings is thought to be related to a number of physical processes at depth, including the migration of magmatic fluids and fracturing of the conduit itself. In addition to this, seismicity can also be generated by surface processes such as pyroclastic flows and rockfall events.
The extreme variety of seismic signals generated in volcanic settings is a reflection of the number of different processes and the great structural heterogeneities found in this context. I will present an introduction to seismicity in volcanic settings from an observatory perspective, including: the types of seismicity observed; the ways in which we characterise seismic events; how seismicity can help us distinguish different ongoing processes at depth; and forecasting volcanic eruptions using seismicity. I will focus upon seismicity at active volcanoes in Costa Rica (Turrialba, Poas, Rincon de la Vieja, Irazu and Arenal), and how it is at the forefront of monitoring and determining changes in volcanic activity, in particular in real time and during crisis events.

\section{Heliotrope: A DIY Free Flying Infrasound Sensor Network}

Daniel C. Bowman (dbowma@sandia.gov)

The focus of this talk: the world's first free flying infrasound network in the stratosphere, with sensors built from open source Arduino hardware and the balloons constructed from materials purchased at the local hardware store.

\section{Geodesy and Seismogeodesy for Hazards in the Americas}

Linda Rowan and Beth Bartel (rowan@unavco.org)

Significant portions of the west coasts of the Americas are bordered by major subduction zones that can produce large earthquakes, volcanic unrest and devastating tsunamis. The Caribbean is the focus of complex plate tectonics and complex weather patterns, and this complexity can lead to significant natural hazards affecting people, places and property. UNAVCO, with support from NSF and in partnership with many governments and institutions in the Americas, operates and maintains a Network of the Americas (NOTA) - a geodetic, seismogeodetic and meteorologic network spanning North, Central and South America plus the Caribbean. Research has shown that NOTA can help with severe weather forecasts, hurricane tracking, earthquake early warning, tsunami early warning and monitoring volcanic unrest or landslides. Here we will discuss efforts to integrate geodetic and seismogeodetic observations into hazard preparedness, warning and response. There is a critical need to apply the infrastructure, data and research to the appropriate and authoritative systems for forecasts, warning and response for damaging hazards in different countries and through international collaborations.

\section{Drilling Through the Seismogenic Zone of Large Megathrust Earthquakes: An On-Land Opportunity in Osa Peninsula, Costa Rica}

Marino Protti (marino.protti.quesada@una.cr)

A great opportunity exists in Osa Peninsula, Costa Rica, to drill and instrument a locked segment of the Middle America Subduction Zone, where the plate interface beneath the peninsula is only 4 to $8 \mathrm{~km}$ deep. 
The Canadian Cordillera Array: Towards a Multi-Disciplinary Geoscience Program for Canada

Tim Parker (timbobparker@gmail.com)

The Canadian Cordillera Array (CCArray) is an initiative to install a Cordilleran-scale open-data network with the goal of holistically examining the Earth system from the core to the magnetosphere. Building on the scientific momentum of previous Earth systems research and data acquisition initiatives in North America (e.g. Lithoprobe (1984 to 2004) and EarthScope (2004 to 2018 or later)), the vision for CCArray is to install a network of multidisciplinary telemetered observatories. The core CCArray network is envisaged to include broadband seismometers (including ocean bottom seismometers in the Beaufort Sea and offshore British Columbia) and Global Navigation Satellite System (GNSS) receivers. Additional instrumentation and measurements at selected locations could include meteorological and atmospheric gas sensors, borehole temperature and moisture sensors, riometers and magnetometers, relative and absolute gravity measurements. Education-outreach-communication programs will be integral to CCArray. While some instruments may only be in place for up to three years, some techniques, such as GNSS monitoring of crustal motions, require longer operational times. The intention is to continue operation of some stations to densify long-term monitoring across Canada. CCArray represents the initial component of an envisaged future pan-Canadian Earth observation network called Earth-system Observing Network-Réseau d'Observation du Système TerrestrE (EON-ROSE).

\section{Updates on the Finite-Fault Rupture Detector Algorithm (Finder v.2)}

Deborah E.Smith (desmith144@gmail.com)

The Finite-Fault Rupture Detector (FinDer) algorithm determines a real-time line-source model that is best suited to explain current spatial ground-motion patterns observed at any given time in a dense seismic network.

\section{Performance of the Seismic Early Warning System during the Mexico September Earthquakes \\ Gerardo Suarez (gersua@yahoo.com)}

The Mexican seismic early warning system was the first to begin issuing open and public warnings. In September, Mexico suffered two large magnitude earthquakes that are relatively unusual from a tectonic point of view. The warning time available in Mexico for these two events was very different. The 8 September M8.2 event offered almost two minutes of warning to Mexico City. In contrast, strong motion shaking of the destructive 19 September event (M7.1) arrived almost simultaneously to the emission of the alert. These two sharply contrasting events offer a useful lesson to future efforts to install seismic early warning systems. I believe that future seismic early warning systems should learn from this experience. The lessons are both technical, in terms the algorithms used and the station spacing and the resulting time that is necessary to issue an early warning. Secondly, the experience of these two large earthquakes underscores the need to accompany the technical developments with social and governmental programs and plans to make use of the seismic early warnings.

\section{Small Town Geoscientist, Scientific Outreach for Better Communities in Colombia}

Albert Aguilar (alaguilars@unal.edu.co)

What do the Armero, Chinchiná and Florencia tragedies have in common? We had the geological knowledge to prevent most of the losses. The Armenia 1999, Páez 1994 and Popayán 1983 earthquakes although small in magnitude (6.1 Mw, 6.8 Mw and 5.5 Mw respectively) are the greatest and most destructive in the recent history of Colombia producing thousands of casualties. The Geological Society of Colombia together with other student and professional associations are carrying out a project to put an earth scientist in every town in Colombia so as to help advance risk mitigation not only associated to earthquakes but also to landslides, flooding and climate change in order to prevent those catastrophes from happening again. We show the major scientific and political challenges of providing communities the geological, geophysical and seismological knowledge in a country where science seems to be considered secondary by the government.

\section{EVENTS}

\section{Opening Ceremony and Welcome Reception}

Monday 14 May, 5:00-7:30 PM

\section{SSA Annual Luncheon and Awards Ceremony}

Tuesday 15 May, Noon-2:00 PM

\section{Public Policy Luncheon}

Wednesday 16 May, Noon-2:00 PM

Speaker: Alejandro De La Campa, Caribbean Area Division Director-FEMA Region II

\section{LACSC-SSA Reception}

Wednesday 16 May, 6:30-8:00 PM

\section{Women in Seismology Reception}

Wednesday 16 May, 8:00-9:30 PM

\section{LACSC-SSA Thursday Evening Celebration Cruise}

Thursday 17 May, 5:30 PM

\section{Special Interest Group: Articulating the Mission of State and Regional Earthquake Centers}

Tuesday 15 May, 6:00 PM

We invite participation in this brief meeting from anyone interested in the capabilities and future directions of state and regional earthquake facilities. The meeting will build on the ideas and content of the technical session Regional Seismic Network Approaches and Stakeholder Collaborations. By identifying common themes across organizations, our goal is 
to help articulate the importance and common needs of these facilities. The exact outcomes will be determined by the attendees, but potential directions include summary publications, organized advocacy and frameworks for closer collaboration. While the emphasis of this meeting is on U.S. organizations, we welcome the experience and input of international colleagues.

We encourage you to join us and lend your voice. Light refreshments will be served.

Conveners: Michael West, Kristine Pankow, Margaret Hellweg, Aaron Velasco

\section{WORKSHOPS}

\section{Getting Published-Writing Papers, Working with Editors, Responding to Reviews}

Monday 14 May, Noon-4 PM

Learn what makes an excellent peer-reviewed paper and how to handle constructive-and not so constructive-reviews from those who know-editors at Science, SRL and BSSA. This free SSA workshop is geared toward students and early-career seismologists but is open to all Annual Meeting attendees.

The workshop will include plenty of time to ask any and all questions, including specific questions about manuscripts under development. Lunch will be provided.

The workshop is free to attendees, but RSVP is required.

The instructors are Roland Bürgmann of University of California, Berkeley, BSSA associate editor emeritus; John Ebel of Boston College, founding editor-in-chief of $S R L$; and Brent Grocholski of Science and editor of all seismology papers for the journal.

\section{Probabilistic Seismic Hazards Assessment: Subduction Zone Sources and Borders}

Monday 14 May, 1-4 PM

This year's Probabilistic Seismic Hazard Assessment Workshop will explore both technical and political issues. The workshop will start with an examination of how to define and parameterize subduction zone sources, including the new Slab2 model of global subduction zones. Next, we will explore issues that arise when attempting to standardize seismic hazard assessments across national boundaries.

The instructors will include Gavin Hayes and Hugo Yepes. Gavin Hayes works at the U.S. Geological Survey in Golden, Colorado, is the lead author of the Slab2 model and is a 2012 recipient of the Presidential Early Career Award for Scientists and Engineers. Hugo Yepes, director of the Instituto Geofísico at the National Polytechnic School in Quito, Ecuador, is responsible for the seismic hazard assessment in Ecuador and received SSA's Frank Press Award for Public Service in 2010.
Social Media: Not Just Kid Stuff!

Monday 14 May, 7:30-9:00 PM

Join us for a hands-on seminar that will give you an opportunity to practice with several popular social media platforms. Everyone is welcome, regardless of career status: whether you are new to social media or familiar with platforms but interested to learn more about how they can be useful in your professional lives. Social media veterans Susan Hough, Emily Wolin and Julian Lozos will lead a 90-minute workshop that will allow you to use the Annual Meeting as a productive practice ground for engaging effectively on Twitter, Facebook, Instagram or the tool of your choosing. Hands-on work and one-to-one training will help you develop your skills.

\section{ShakeMap Post-Meeting Workshop}

Friday 18 May, 8:30 AM-5:00 PM

The U. S. Geological Survey will host a workshop on ShakeMap on Friday 18 May 2018 following the meeting. The workshop is aimed at ShakeMap operators, researchers and core users and will focus on the science and software underpinning ShakeMap Version 4, a major re-engineering of the entire ShakeMap system. Time will be set aside for discussion, feedback, strategizing and operations questions. Workshop attendees are also encouraged to share their ShakeMap-related examples, research, operations and needs during the SSA meeting at a related Special Session: ShakeMap-Related Research, Development, Operations and Applications.

There will be an optional social hour and no-host dinner Friday evening. The workshop is free to attendees, but RSVP is required as space is limited.

The instructors are Eric Thompson, David Wald and Bruce Worden of the U. S. Geological Survey.

\section{Aftershock Forecasting Post-Meeting Workshop}

Friday 18 May, 8:30 AM-12:30 PM

Software for making both spatial and temporal forecasts during aftershock sequences will be released by the U.S. Geological Survey during this workshop. The session will cover the statistics of aftershock behavior used in making these forecasts, the applications of aftershock forecasts in past earthquakes, and will include time to install, test and learn how to run this software. For that purpose, participants are encouraged to bring a laptop with Java 8 (JRE) installed. This project was partially funded by a grant from the U.S. Office of Foreign Disaster Assistance and is aimed at providing countries who have not developed their own methods with the means of making their own forecasts.

The workshop is free to attendees, but RSVP is required as space is limited. Due to the goals of this project, priority will be given to attendees from the LACSC countries.

The instructors are Nicholas van der Elst, Jeanne Hardebeck, Sara K. McBride, Andrew Michael and Morgan Page of the U. S. Geological Survey. 


\section{PRELIMINARY SCHEDULE}

Events will be held at the Hyatt Regency-Miami in Miami, Florida. This schedule is subject to change.

\section{Monday 14 May}

- Board of Directors Meeting (7:30 AM-3:30 PM)

- Workshop: Getting Published (Noon-4:00 PM)

- Workshop: Probabilistic Seismic Hazards Assessment: Subduction Zone Sources and Borders (1:00-4:00 PM)

- Registration (3:00-7:30 PM)

- Opening Ceremony and Welcome Reception (5:00-7:30 PM)

- Workshop: Social Media: Not Just Kid Stuff! (7:30-9:00 PM)

\section{Tuesday 15 May}

- Technical Sessions (8:30 AM-5:30 PM)

- Annual SSA Award Ceremony and Business Meeting Luncheon (Noon-2:00 PM)

- Pint and Poster (5:30-6:00 PM)

- Lightning Talks (6:00-7:00 PM)

- Special Interest Group (6:00 PM start)

- Early Career and Student Reception (7:00-9:00 PM)

\section{Wednesday 16 May}

- Mentoring Breakfast (7:00-8:15 AM)

- Technical Sessions (8:30 AM-5:30 PM)

- Public Policy Luncheon (Noon-2:00 PM)

- Pint and Poster (3:30-4:15 PM)

- Joyner Lecture (5:30-6:30 PM)

- LACSC/SSA Reception (6:30-8:00 PM)

- LACSC Public General Assembly (8:00-9:00 PM)

- Women in Seismology Reception (8:00-9:30 PM)

\section{Thursday 17 May}

- Technical Sessions (8:30 A M-5:00 PM)

- Luncheon (Noon-1:15 PM)

- Pint and Poster (2:45-3:45 PM)

- Cruise (5:30 PM)

\section{Friday 18 May}

- Workshop: Aftershock Forecasting (8:30 A M-12:30 PM)

- Workshop: ShakeMap (8:30 A M-5:00 PM) 


\section{Overview of Technical Program}

\section{ORAL SESSIONS}

\section{Tuesday 15 May}

\begin{tabular}{|c|c|c|c|c|}
\hline Time & Brickell & Flagler & Hibiscus A & Hibiscus B \\
\hline $\begin{array}{r}8: 30- \\
9: 45 \mathrm{AM}\end{array}$ & \multirow{2}{*}{$\begin{array}{l}\text { Numerical Modeling } \\
\text { of Earthquake Ground } \\
\text { Motion, Rupture } \\
\text { Dynamics and Seismic } \\
\text { Wave Propagation }\end{array}$} & \multirow[t]{2}{*}{$\begin{array}{l}\text { Interaction Between } \\
\text { Observations and Models } \\
\text { in Seismo-Volcanic Studies }\end{array}$} & \multirow[t]{2}{*}{$\begin{array}{l}\text { Tsunami Modeling and } \\
\text { Hazard Assessment }\end{array}$} & \multirow[t]{2}{*}{$\begin{array}{l}\text { Essentials of Seismic Risk } \\
\text { Estimates }\end{array}$} \\
\hline $\begin{array}{r}10: 45- \\
\text { Noon }\end{array}$ & & & & \\
\hline $2: 15-3: 30$ & \multirow[t]{2}{*}{$\begin{array}{l}\text { Fault to Seismic Hazard } \\
\text { Assessment (Fault } 2 \text { SHA) } \\
\text { in Latin (Central and } \\
\text { South) America }\end{array}$} & \multirow{2}{*}{$\begin{array}{l}\text { Advances in the } \\
\text { Theory, Modeling, } \\
\text { and Observation of } \\
\text { Anelastic Seismic Wave } \\
\text { Propagation-Recent } \\
\text { Anelastic Models of the } \\
\text { Earth }\end{array}$} & $\begin{array}{l}\text { Urban Liquefaction } \\
\text { and Lateral Spread } \\
\text { Investigations and } \\
\text { Mapping }\end{array}$ & \multirow[t]{2}{*}{$\begin{array}{l}\text { Environmental Seismology: } \\
\text { Glaciers, Rivers, Landslides } \\
\text { and Beyond }\end{array}$} \\
\hline $4: 15-5: 30$ & & & $\begin{array}{l}\text { Ground Motion and } \\
\text { Earthquake Engineering }\end{array}$ & \\
\hline $5: 30-6: 00$ & \multicolumn{4}{|c|}{ Pint and Poster, Riverfront South } \\
\hline $6: 00-7: 00$ & \multicolumn{4}{|c|}{$\begin{array}{c}\text { Lightning Talks, Riverfront North } \\
\text { also Special Interest Group: Articulating the Mission of State and Regional Earthquake Centers, Tuttle }\end{array}$} \\
\hline $7: 00-9: 00$ & \multicolumn{4}{|c|}{ Early Career and Student Reception, Upper and Lower Promenade } \\
\hline
\end{tabular}

\section{Wednesday 16 May}

\begin{tabular}{|c|c|c|c|c|}
\hline Time & Brickell & Flagler & Hibiscus A & Hibiscus B \\
\hline $\begin{array}{r}8: 30- \\
9: 45 \mathrm{AM}\end{array}$ & \multirow{2}{*}{$\begin{array}{l}\text { Exploring Rupture } \\
\text { Dynamics and Seismic } \\
\text { Wave Propagation along } \\
\text { Complex Fault Systems }\end{array}$} & $\begin{array}{l}\text { Structure and Dynamics of } \\
\text { Earth's Mantle }\end{array}$ & \multirow{2}{*}{$\begin{array}{l}\text { U.S. National Seismic } \\
\text { Hazard Model Updates: } \\
\text { 2018, } 2020 \text { and Beyond }\end{array}$} & \\
\hline $\begin{array}{r}10: 45- \\
\text { Noon }\end{array}$ & & $\begin{array}{l}\text { Development and } \\
\text { Validation of Statistical } \\
\text { Models of Small-Scale } \\
\text { Heterogeneities } \\
\end{array}$ & & $\begin{array}{l}\text { Ocean Bottom } \\
\text { Seismology-Hurdles, } \\
\text { Strategies and Outcomes }\end{array}$ \\
\hline $2: 15-3: 30$ & $\begin{array}{l}\text { Observations and the } \\
\text { Physics Behind Complex } \\
\text { Earthquakes }\end{array}$ & $\begin{array}{l}\text { Observed Characteristics } \\
\text { of Induced Seismicity: } \\
\text { From Laboratory to Field } \\
\text { Scale }\end{array}$ & $\begin{array}{l}\text { Testing PSHA Input Data, } \\
\text { Source Models and Hazard } \\
\text { Estimates }\end{array}$ & $\begin{array}{l}\text { Microzonation Studies- } \\
\text { Site Effects }\end{array}$ \\
\hline $3: 30-4: 15$ & \multicolumn{4}{|c|}{ Pint and Poster, Riverfront South } \\
\hline $4: 15-5: 30$ & $\begin{array}{l}\text { New Frontiers in Seismic } \\
\text { and Acoustic Data Analysis }\end{array}$ & $\begin{array}{l}\text { Observed Characteristics } \\
\text { of Induced Seismicity: } \\
\text { From Laboratory to Field } \\
\text { Scale } \\
\text { (continued Thursday) }\end{array}$ & $\begin{array}{l}\text { Seismic Structure of } \\
\text { Convergent Plate Margins }\end{array}$ & $\begin{array}{l}\text { Microzonation Studies- } \\
\text { Site Effects }\end{array}$ \\
\hline $5: 30-6: 30$ & \multicolumn{4}{|c|}{ Joyner Lecture, Riverfront North } \\
\hline $6: 30-8: 00$ & \multicolumn{4}{|c|}{ LACSC/SSA Reception, Upper \& Lower Promenade } \\
\hline $8: 00-9: 00$ & \multicolumn{4}{|c|}{ LACSC Public General Assembly, Brickell } \\
\hline $8: 00-9: 30$ & \multicolumn{4}{|c|}{ Women in Seismology Reception, Japengo } \\
\hline
\end{tabular}




\begin{tabular}{|c|c|c|c|c|}
\hline Time & Jasmine & Monroe & Orchid $A B$ & Tuttle \\
\hline $\begin{array}{r}8: 30- \\
9: 45 \mathrm{AM}\end{array}$ & \multirow[t]{4}{*}{$\begin{array}{l}\text { Regional Seismic } \\
\text { Network Approaches } \\
\text { and Stakeholder } \\
\text { Collaborations }\end{array}$} & \multirow[t]{2}{*}{$\begin{array}{l}\text { Advances in Seismic } \\
\text { Site Response Studies } \\
\text { Given Limitations in } \\
\text { Understanding of Site } \\
\text { Conditions }\end{array}$} & $\begin{array}{l}\text { Onshore Quaternary and } \\
\text { Contemporary Tectonics: } \\
\text { Implications for Seismic } \\
\text { Hazards }\end{array}$ & \multirow[t]{2}{*}{$\begin{array}{l}\text { 3D/4D Seismic Imaging } \\
\text { and Their Interpretation } \\
\text { for Seismic Hazard } \\
\text { Assessment }\end{array}$} \\
\hline $\begin{array}{r}10: 45- \\
\text { Noon }\end{array}$ & & & $\begin{array}{l}\text { The Next Big Earthquake: } \\
\text { The Usual and the Unusual } \\
\text { Suspects }\end{array}$ & \\
\hline $2: 15-3: 30$ & & \multirow[t]{2}{*}{$\begin{array}{l}\text { Advances in Explosion } \\
\text { Seismo-Acoustic Research }\end{array}$} & $\begin{array}{l}\text { Science Gateways and } \\
\text { Computational Tools for } \\
\text { Improving Earthquake } \\
\text { Research } \\
\end{array}$ & \multirow[t]{2}{*}{$\begin{array}{l}\text { Megathrust Earthquakes } \\
\text { Recurrence, Rupture } \\
\text { Modes and Tsunamis } \\
\text { (continued Wednesday) }\end{array}$} \\
\hline $4: 15-5: 30$ & & & & \\
\hline $5: 30-6: 00$ & \multicolumn{4}{|c|}{ Pint and Poster, Riverfront South } \\
\hline $6: 00-7: 00$ & \multicolumn{4}{|c|}{$\begin{array}{c}\text { Lightning Talks, Riverfront North } \\
\text { also Special Interest Group: Articulating the Mission of State and Regional Earthquake Centers, Tuttle }\end{array}$} \\
\hline $7: 00-9: 00$ & \multicolumn{4}{|c|}{ Early Career and Student Reception, Upper and Lower Promenade } \\
\hline
\end{tabular}

\begin{tabular}{|c|c|c|c|c|}
\hline Time & Jasmine & Monroe & Orchid $A B$ & Tuttle \\
\hline $\begin{array}{r}8: 30- \\
9: 45 \mathrm{AM} \\
10: 45- \\
\text { Noon }\end{array}$ & $\begin{array}{l}\text { Early Warning for } \\
\text { Large Earthquakes and } \\
\text { Tsunamis: Challenges, } \\
\text { Case Studies and } \\
\text { Innovations }\end{array}$ & $\begin{array}{l}\text { Recent Advances in Dense } \\
\text { Array Seismology }\end{array}$ & Seismic Event Screening & $\begin{array}{l}\text { (Continued from Tuesday) } \\
\text { Megathrust Earthquakes: } \\
\text { Recurrence, Rupture } \\
\text { Modes and Tsunamis }\end{array}$ \\
\hline $2: 15-3: 30$ & $\begin{array}{l}\text { Real-Time GNSS Network } \\
\text { Operations and Advances } \\
\text { towards Early Warning } \\
\text { Systems }\end{array}$ & $\begin{array}{l}\text { Advances on the } \\
\text { Parameterization of } \\
\text { Seismic Attenuation: } \\
\text { Current Challenges and } \\
\text { Opportunities }\end{array}$ & $\begin{array}{l}\text { Present-Day Plate } \\
\text { Boundary Deformation } \\
\text { and Seismic Hazard in the } \\
\text { Caribbean }\end{array}$ & $\begin{array}{l}\text { The Future of Telemetered } \\
\text { Seismic Arrays-Where the } \\
\text { Operation of the Network } \\
\text { Ends and the Science } \\
\text { Begins }\end{array}$ \\
\hline $3: 30-4: 15$ & \multicolumn{4}{|c|}{ Pint and Poster, Riverfront South } \\
\hline $4: 15-5: 30$ & $\begin{array}{l}\text { Real-Time GNSS Network } \\
\text { Operations and Advances } \\
\text { towards Early Warning } \\
\text { Systems }\end{array}$ & $\begin{array}{l}\text { Advances on the } \\
\text { Parameterization of } \\
\text { Seismic Attenuation: } \\
\text { Current Challenges and } \\
\text { Opportunities }\end{array}$ & \begin{tabular}{|l} 
Seismic Hazards and \\
Historic Earthquakes \\
in Puerto Rico and the \\
Northern Caribbean \\
Region \\
\end{tabular} & $\begin{array}{l}\text { The Future of Telemetered } \\
\text { Seismic Arrays-Where the } \\
\text { Operation of the Network } \\
\text { Ends and the Science } \\
\text { Begins }\end{array}$ \\
\hline $5: 30-6: 30$ & \multicolumn{4}{|c|}{ Joyner Lecture, Riverfront North } \\
\hline $6: 30-8: 00$ & \multicolumn{4}{|c|}{ LACSC/SSA Reception, Upper \& Lower Promenade } \\
\hline $8: 00-9: 00$ & \multicolumn{4}{|c|}{ LACSC Public General Assembly, Brickell } \\
\hline $8: 00-9: 30$ & \multicolumn{4}{|c|}{ Women in Seismology Reception, Japengo } \\
\hline
\end{tabular}




\section{Thursday 17 May}

\begin{tabular}{|c|c|c|c|c|}
\hline Time & Brickell & Flagler & Hibiscus A & Hibiscus B \\
\hline $\begin{array}{r}8: 30- \\
9: 45 \mathrm{AM}\end{array}$ & $\begin{array}{l}\text { Tsunami Outreach, } \\
\text { Education and Warning } \\
\text { Dissemination: Cross- } \\
\text { disciplinary Opportunities } \\
\text { for Increasing Tsunami } \\
\text { Resiliency } \\
\end{array}$ & \multirow[t]{2}{*}{$\begin{array}{l}\text { (Continued from } \\
\text { Wednesday) Observed } \\
\text { Characteristics of } \\
\text { Induced Seismicity: From } \\
\text { Laboratory to Field Scale }\end{array}$} & $\begin{array}{l}\text { USGS Seismic Hazard } \\
\text { User-Needs }\end{array}$ & $\begin{array}{l}\text { Increasing Testability- } \\
\text { Expanding Possibilities } \\
\text { and Future Developments } \\
\text { of the Collaboratory for } \\
\text { the Study of Earthquake } \\
\text { Predictability }\end{array}$ \\
\hline $\begin{array}{r}10: 45- \\
\text { Noon }\end{array}$ & \multirow[t]{2}{*}{$\begin{array}{l}\text { The Recent Earthquakes } \\
\text { that Shocked Mexico in } \\
\text { September } 2017\end{array}$} & & \multirow[t]{2}{*}{$\begin{array}{l}\text { Applications of Machine } \\
\text { Learning and Data Science } \\
\text { in Seismology }\end{array}$} & \multirow[t]{2}{*}{$\begin{array}{l}\text { Uncertainty in Ground } \\
\text { Motion Estimation: } \\
\text { Seismological and } \\
\text { Engineering Perspectives }\end{array}$} \\
\hline $1: 30-2: 45$ & & $\begin{array}{l}\text { Seismic Studies of Earth's } \\
\text { Crust and Lithosphere }\end{array}$ & & \\
\hline $2: 45-3: 45$ & \multicolumn{4}{|c|}{ Pint and Poster, Riverfront South } \\
\hline $3: 45-5: 00$ & $\begin{array}{l}\text { The 8th September } \\
\text { Mw8.2 Tehuantepec } \\
\text { and 19th September } \\
\text { Mw7.1 Puebla-Morelos, } \\
\text { Mexico Earthquakes: } \\
\text { Reconnaissance Findings } \\
\text { and Impact on Urban Areas } \\
\text { in South-central Mexico }\end{array}$ & $\begin{array}{l}\text { ShakeMap-Related } \\
\text { Research, Development, } \\
\text { Operations and } \\
\text { Applications }\end{array}$ & $\begin{array}{l}\text { Forecasting Aftershock } \\
\text { Sequences in the Real } \\
\text { World }\end{array}$ & \\
\hline $5: 30$ & \multicolumn{4}{|c|}{ Cruise, Upper Promenade } \\
\hline
\end{tabular}

\section{POSTER SESSIONS}

\section{Tuesday 15 May}

- 3D/4D Seismic Imaging and Their Interpretation for Seismic Hazard Assessment

- Advances in Explosion Seismo-Acoustic Research

- Advances in Seismic Site Response Studies Given Limitations in Understanding of Site Conditions

- Ground Motion and Earthquake Engineering

- Environmental Seismology: Glaciers, Rivers, Landslides and Beyond

- Fault to Seismic Hazard Assessment (Fault2SHA) in Latin (Central and South) America

- Interaction Between Observations and Models in SeismoVolcanic Studies

- Numerical Modeling of Earthquake Ground Motion, Rupture Dynamics and Seismic Wave Propagation

- Onshore Quaternary and Contemporary Tectonics: Implications for Seismic Hazards

- The Next Big Earthquake: The Usual and the Unusual Suspects

- Regional Seismic Network Approaches and Stakeholder Collaborations

- Science Gateways and Computational Tools for Improving Earthquake Research

- Tsunami Modeling and Hazard Assessment

\section{Wednesday 16 May}

- Advances on the Parameterization of Seismic Attenuation: Current Challenges and Opportunities

- Development and Validation of Statistical Models of Small-Scale Heterogeneities

- Early Warning for Large Earthquakes and Tsunamis: Challenges, Case Studies and Innovations

- Exploring Rupture Dynamics and Seismic Wave Propagation along Complex Fault Systems

- The Future of Telemetered Seismic Arrays - Where the Operation of the Network Ends and the Science Begins

- Megathrust Earthquakes: Recurrence, Rupture Modes and Tsunamis

- Microzonation Studies - Site Effects

- New Frontiers in Seismic and Acoustic Data Analysis

- Observations and the Physics Behind Complex Earthquakes

- Ocean Bottom Seismology - Hurdles, Strategies and Outcomes

- Real-Time GNSS Network Operations and Advances towards Early Warning Systems

- Recent Advances in Dense Array Seismology

- Seismic Event Screening

- Present-Day Plate Boundary Deformation and Seismic Hazard in the Caribbean 


\begin{tabular}{|c|c|c|c|c|}
\hline Time & Jasmine & Monroe & Orchid $A B$ & Tuttle \\
\hline $\begin{array}{r}8: 30- \\
9: 45 \mathrm{AM}\end{array}$ & \multirow[t]{3}{*}{$\begin{array}{l}\text { Earthquake Source } \\
\text { Parameters: Theory, } \\
\text { Observations and } \\
\text { Interpretations }\end{array}$} & $\begin{array}{l}\text { Retrieval of Fine Scale } \\
\text { Information Using Seismic } \\
\text { Noise }\end{array}$ & & $\begin{array}{l}\text { Structure and } \\
\text { Geodynamics of } \\
\text { the Caribbean Plate } \\
\text { Boundaries }\end{array}$ \\
\hline $\begin{array}{r}10: 45- \\
\text { Noon }\end{array}$ & & $\begin{array}{l}\text { Emergency Management, } \\
\text { Resilience and } \\
\text { Preparedness }\end{array}$ & & \multirow[t]{2}{*}{$\begin{array}{l}\text { Plate Boundary } \\
\text { Segmentation and } \\
\text { Coupled-to-Creeping Plate } \\
\text { and Block Boundary Faults }\end{array}$} \\
\hline $1: 30-2: 45$ & & $\begin{array}{l}\text { Adaptation of New } \\
\text { Technologies and Methods } \\
\text { to Drive New Discoveries } \\
\text { in Seismology and Geodesy }\end{array}$ & & \\
\hline $2: 45-3: 45$ & \multicolumn{4}{|c|}{ Pint and Poster, Riverfront South } \\
\hline $3: 45-5: 00$ & $\begin{array}{l}\text { Earthquake Source } \\
\text { Parameters: Theory, } \\
\text { Observations and } \\
\text { Interpretations }\end{array}$ & $\begin{array}{l}\text { Challenges and Chances } \\
\text { for the Widespread } \\
\text { Implementation of } \\
\text { Earthquake Early Warning } \\
(\text { EEW) }\end{array}$ & & $\begin{array}{l}\text { Plate Boundary } \\
\text { Segmentation and } \\
\text { Coupled-to-Creeping Plate } \\
\text { and Block Boundary Faults }\end{array}$ \\
\hline $5: 30$ & \multicolumn{4}{|c|}{ Cruise, Upper Promenade } \\
\hline
\end{tabular}

- Seismic Hazards and Historic Earthquakes in Puerto Rico and the Northern Caribbean Region

- Seismic Structure of Convergent Plate Margins

- Structure and Dynamics of Earth's Mantle

- Testing PSHA Input Data, Source Models and Hazard Estimates

- U.S. National Seismic Hazard Model Updates: 2018, 2020 and Beyond

\section{Thursday 17 May}

- The 8th September Mw8.2 Tehuantepec and 19th September Mw7.1 Puebla-Morelos, Mexico Earthquakes: Reconnaissance Findings and Impact on Urban Areas in South-central Mexico

- Adaptation of New Technologies and Methods to Drive New Discoveries in Seismology and Geodesy

- Applications of Machine Learning and Data Science in Seismology

- Challenges and Chances for the Widespread Implementation of Earthquake Early Warning (EEW)
- Earthquake Source Parameters: Theory, Observations and Interpretations

- Emergency Management, Resilience and Preparedness

- Forecasting Aftershock Sequences in the Real World

- Increasing Testability-Expanding Possibilities and Future Developments of the Collaboratory for the Study of Earthquake Predictability

- Observed Characteristics of Induced Seismicity: From Laboratory to Field Scale

- Plate Boundary Segmentation and Coupled-to-Creeping Plate and Block Boundary Faults

- Retrieval of Fine Scale Information Using Seismic Noise

- Seismic Studies of Earth's Crust and Lithosphere

- ShakeMap-Related Research, Development, Operations and Applications

- Structure and Geodynamics of the Caribbean Plate Boundaries

- Uncertainty in Ground Motion Estimation: Seismological and Engineering Perspectives 



\section{Technical Sessions}

\section{D/4D Seismic Imaging and Their Interpretation for Seismic Hazard Assessment}

Thanks to the recent development of imaging and monitoring techniques, we can obtain much higher spatial resolution of subsurface structures and/or time-lapse changes of them. In previous years, imaging and monitoring techniques have developed rapidly due to the advent of high-density networks, new modeling techniques and unprecedented computation capacities. In addition to using them for interpreting subsurface geology and mechanics, such 3D/4D structural information is useful for modeling and interpreting high-frequency seismic waves or understanding the dynamic behaviors of structures, both of which are important for seismic hazard assessment.

In this session, we would like to cover both theoretical and methodological aspects as well as novel approaches for solving common practical problems for $3 \mathrm{D} / 4 \mathrm{D}$ imaging and monitoring. We welcome contributions for the interpretation of obtained structural information for seismic hazard assessment such as ground motion prediction, more accurate estimation of earthquake magnitude and moment tensor and understanding the near-surface nonlinear effects. We further encourage abstracts focusing on multiscale imaging applications which involve novel processing such as higher-order correlations, double beamforming, multi-dimensional deconvolution, nonlinear optimization techniques, machine learning and large-scale data analysis or very dense receiver array analysis. Presentations related to amplitude extraction, attenuation, higher-mode Rayleigh/Love waves, body waves or usage of multi-component signals are also encouraged.

Session Chairs: Marco Pilz (pilz@gfz-potsdam.de), Nori Nakata (nnakata@ou.edu).

\section{The 8th September Mw8.2 Tehuantepec and 19th September Mw7.1 Puebla-Morelos, Mexico Earthquakes: Reconnaissance Findings and Impact on Urban Areas in South-Central Mexico}

On September 8th, 2017 a Mw8.2 intermediate-depth, normal-faulting earthquake struck southeastern Mexico. The earthquake, with an epicentral location near the coast of Chiapas, is the largest recorded event in Mexico's recent history. The Tehuantepec event resulted in many casualties and collapses, as well as landslides and damage to the infrastructure in several cities and towns in the states of Oaxaca and Chiapas. Soon after, on September 19th, 2017, a Mw7.1 intraslab, normal faulting earthquake occurred in central Mexico. The earthquake, approximately $120 \mathrm{~km}$ from Mexico City, caused the collapse of more than 40 buildings and affected infrastructure operation not only in the capital of Mexico, but in several urban areas near the epicentral region. The official death toll for both events is 471 people.
This session covers many engineering aspects of both events. Topics include, but are not limited to, strong ground motion observations and networks, macroseismic intensities, broadband ground motion simulations, site effects in the Mexico City Basin and other urban areas, soil-structure and site-city interactions, building codes and their implications in similar seismic prone regions together with hazard and risk management issues.

Session Chairs: Emel Seyhan (emel.seyhan@rms.com), Jorge Aguirre (joagg@pumas.iingen.unam.mx), Leonardo Ramírez-Guzmán (Lramirezg@iingen.unam.mx).

\section{Adaptation of New Technologies and Methods to Drive New Discoveries in Seismology and Geodesy}

In recent years, advancements in seismology and geodesy have been made possible by innovative adaptation of new methods and technology from other fields. Improved earthquake detection and ground motion characterization have been achieved by using consumer MEMS accelerometers, consumer GPS chips, wireless nodal systems and other new sensor technology that enable dense sensor networks. Deep learning, fingerprinting and linkage methods originally developed for Internet search engines and image recognition can substantially improve our ability to detect and categorize seismic events, including earthquakes and low frequency earthquakes. In this session, we encourage submissions on any approach that expands the horizons of seismology and geodesy beyond traditional instruments and methods.

Session Chairs: Sarah E. Minson (sminson@usgs.gov), Elizabeth S.Cochran (ecochran@usgs.gov).

\section{Advances in Seismic Site Response Studies Given Limitations in Understanding of Site Conditions}

Site response in seismic hazard assessment studies is significantly affected by the accuracy and resolution of the near-surface material properties. Within the limitations of the understanding of site conditions, our session brings together a wide variety of topics on the advances and limitations of current methodologies for site response analysis of earthquake-induced ground motions. Our purpose is to promote discussion that bridges the gap between the empirical and simulation-based methods in estimating seismic site response. We encourage presentations on state-of-the-knowledge and -art site response analyses; the role of ergodic and non-ergodic site response studies in reducing epistemic uncertainty; the effect of variability of shear-wave velocity $\left(V_{S}\right)$ profiles, as a result of non-uniqueness (inversion) or lateral variations in $V_{S}$ ( $2 \mathrm{D}$ effects), on site response; the correlation of the site-specific high-frequency spectral decay of Fourier amplitude spectra $\left(\varkappa_{0}\right)$ to the timeaveraged $V_{S}$ of the upper $30 \mathrm{~m}$ from the surface $\left(V_{S 30}\right)$ and 
other proxies; the performance of $\varkappa_{0}$ for shallow and deep sedimentary basins; performance, estimation and correlations of basin-depth proxies with other parameters; regionalization of crustal velocity $Q$ models; limitations of full-waveform inversion studies; and the effectiveness of derivation of site effects in the response spectra and Fourier domain. We cap the presentations with an open discussion with all speakers regarding the overall state of knowledge about the role of site conditions in advanced site response studies. We also welcome presentations on topics related to seismic site characterization, advances in invasive/non-invasive measurement techniques, microzonation studies and particularly developments in site characterization or ground motion studies in Latin America.

Session Chairs: Emel Seyhan (emel.seyhan@rms.com), Sean K.Ahdi (Sahdi@ucla.edu), Eric M. Thompson (emthompson@usgs.gov), Alan Yong (yong@usgs.gov).

\section{Advances in Explosion Seismo-Acoustic Research}

Seismo-acoustic approaches serve as primary tools in monitoring explosions around the world. Improvements in these fields have led to new analytical techniques including correlation methods, advanced array analysis, multimodal surface wave methods and quantitative uncertainty estimates for source and propagation models and derived parameters. We invite contributions highlighting research to improve detection, location and interpretation of explosion sources, as well as associated uncertainties.

Session Chairs: Charlotte Rowe (char@lanl.gov), Catherine Snelson-Gerlicher (snelsonc@lanl.gov), Sean Ford (ford17@llnl.gov), Christopher Young (cjyoung@sandia.gov), Junghyun Park (junghyunp@mail.smu.edu).

\section{Advances in the Theory, Modeling and Observation of Anelastic Seismic Wave Propagation-Recent Anelastic Models of the Earth}

Recent advances in the theory, modeling and observation of anelastic seismic waves reveal new insights regarding methodologies to infer the anelastic structure of the Earth. For example, recent developments in general ray theory for anelastic media reveal ray paths and corresponding characteristics of travel time and attenuation curves, which are not predicted by elasticity theory or one-dimensional anelastic waves, yet have important implications for some forward modeling and inverse problems. Recent developments in elastic single- and multicomponent full waveform inversion and monitoring of exploration seismic data indicate that proper parameterization and incorporation of $\mathrm{P}$ - and $\mathrm{S}$-wave quality factors is a critical need. This session invites papers on the latest advances in anelastic wave-propagation theory, processing/inversion methods for anelastic media, and anelastic (Q) models of the Earth, as inferred from exploration geophysics data, crustal reflectionrefraction data, teleseismic data, surface-wave, ocean-acoustic, and normal-mode data. With many travel-time and amplitude anomalies yet to be explained, this session plans to be an exciting forum to review and explore implications of the latest advances in the theory and modeling of anelasticity towards explanation of some of these anomalies.

Session Chairs: Roger D. Borcherdt (borcherdt@usgs.gov), Kristopher A. Innanen (kinnanen@ucalgary.ca).

\section{Advances on the Parameterization of Seismic Attenuation: Current Challenges and Opportunities}

The characterization of attenuation at various scales (e.g., regional or local attenuation) constitutes a critical aspect in the prediction of ground motions, site response analyses and the assessment of seismic hazards. However, isolating the effects of different attenuation mechanisms requires not only a fundamental understanding of the wave propagation phenomenon, but also a proper statistical treatment of the uncertainties associated with data collected in the field, the laboratory and through analysis of background noise and ground motion records. Hence, efforts toward defining parametric descriptors of seismic attenuation are inevitably associated with challenges in collecting reliable experimental data and the proper interpretation of their corresponding range of applicability.

There is a critical need for further research on current seismic attenuation parameters to improve methodologies that measure energy dissipation in earth materials and to better understand how to capture different attenuation mechanisms at different scales. In this session, we welcome studies focused on investigating the parameterization of seismic attenuation, the limitations of the existing methodologies to capture it, the associated uncertainties and the corresponding implications on ground motion modeling, site-specific seismic hazard analysis and site response analysis. Challenges and opportunities encountered in these processes are also welcome, whether they relate to limitations of a methodology to measure a specific parameter in the field, or the introduction of new analytical methods to better decouple the effects of different attenuation mechanisms in ground motions (e.g., separating inelastic attenuation from scattering effects).

Session Chairs: Ashly Cabas (amcabasm@ncsu.edu), Stefano Parolai (sparolai@inogs.it), Celine Gélis (celine. gelis@irsn.fr), Albert Kottke (albert.kottke@gmail.com).

\section{Applications of Machine Learning and Data Science in Seismology}

The increase in computational capability in the past decade has made it possible to introduce and apply novel machine learning/data science algorithms and tools to the field of seismology, with the hope of extracting useful information from large and complex seismic data sets. Recent attempts in the seismology applications have shown encouraging results in, for example, seismic signal detection and classification, seismic data interpolation, earthquake parameter estimation, seismic noise analysis and reduction, subsurface structure imaging and complex signals/models visualization. More advanced techniques and 
algorithms are emerging with new possibilities, for instance: deep learning based on learning data representations has the potential to extract superior results from large-scale datasets. The application of these new techniques can help improve our understanding of Earth structure and seismic sources from a brand new perspective. This session invites all abstracts relevant to applications and developments of machine learning and data science in seismology.

Session Chairs: Qingkai Kong (kongqk@berkeley.edu), Chengping Chai (cchai1@utk.edu), Zefeng Li (zefengli@ gps.caltech.edu), Min Chen (chenmi22@msu.edu), Rongrong Wang (wangron6@msu.edu).

\section{Challenges and Chances for the Widespread Implementation of Earthquake Early Warning (EEW)}

The recent strong earthquakes in Southern Mexico with magnitudes of 8.0 and 7.3 have demonstrated the usefulness of Earthquake Early Warning (EEW) to a massive audience in Latin America and the world. In the social media people showed their surprise about the existence and functionality of the Mexican EEW system and discussed whether such a system could be established in their country. We invite contributions about the possible application of EEW in Latin America and other less developed regions taking into account the specifics of the prevailing building types (e.g. adobe) and construction practices. We invite contributions proposing how EEW can be implemented in less developed nations and whether EEW could be a relatively cheap and fast way for poor countries with high seismic risk to give some protection to their populations against the massive loss of life in great earthquakes and how it can be combined, in the long term, with measures to improve the building stock. We particularly solicit studies dealing with how EEW can be effectively established and operated, including: densification of seismic networks with new low-cost EEW-compatible seismic equipment; the development of new efficient EEW methods that are robust in the face of challenging seismicity and network operation; transfer of EEW methods into operational software compatible with general seismic monitoring; the establishment of new automatic seismic processing centers in many countries; and studies dealing with technical and social aspects for delivering alerts to the general population.

Session Chairs: Wilfried Strauch (wilfried.strauch@yahoo. com), Victor A. Huerfano (victor.huerfano@gmail.com).

\section{Development and Validation of Statistical Models of Small-Scale Heterogeneities}

Realistic small-scale variation of the media (velocity and/or density) and surface topography is important for modeling phases and coda amplitudes of broadband waves from regional seismic (earthquakes or explosions) sources. While the precise strength, locations, sizes and shapes of the heterogeneities are often unknown, statistical characterization of the heterogene- ity can be used to simulate the ground motion variability due to seismic scattering processes. A wide variety of parameterizations, however, are available to characterize the statistical models (e.g., shape of the heterogeneity power spectrum and its depth dependence, as well as crack shapes, concentrations and orientations). Different parameterizations can produce similar seismograms that match aspects of observed ground motion, so association of observations with specific scattering mechanisms that can narrow the model space is critical to confident transport of prediction capability to new source-receiver paths.

We welcome submissions focused on constraining values of and reducing the number of free parameters of statistical models of media heterogeneity, on observations of seismic scattering processes and on methods and results for modeling the scattered wave fields.

Session Chairs: G. Eli Baker (glenn.baker.3@us.af.mil), Kim B. Olsen (kbolsen@mail.sdsu.edu), Yang Shen (y.shen@ icloud.com), Vernon Cormier (vernon.cormier@uconn.edu), W. Scott Phillips (wsp@lanl.gov).

\section{Early Warning for Large Earthquakes and Tsunamis: Challenges, Case Studies and Innovations}

Earthquake early warning (EEW) algorithms attempt to characterize earthquake ruptures and ground motion in real time and provide advance notifications before the arrival of damaging seismic waves and subsequent hazards (e.g., tsunamis). EEW approaches and their products have evolved over the past decade with recent advances in instrumentation, rapid source characterization, real-time ground motion prediction and communication technologies. Today's early warning systems can go much beyond this basic function, providing estimates of shaking intensity and potential damage for implementation of post-event emergency action plans. However, many challenges still exist in for creating effective EEW systems. For instance, while medium-sized earthquakes are sufficiently well described with very simple point source models, characterizing large ruptures is complex. Recent experiences with EEW systems that were in operation during large earthquakes (e.g. the Mw7.0 2016 Kumamoto, Japan and Mw7.1 2017 Morelos-Puebla, Mexico earthquakes), as well as offline studies, are starting to shape our expectations of the performance we can realistically expect from EEW systems.

In this session, we invite scientists, engineers, practitioners and policy makers to present work related to EEW applications and case studies. Some topics might include:

- innovative event recognition, source characterization and false alert avoidance algorithms;

- characterization of uncertainties stemming from EEW algorithms and ground motion prediction in real-time;

- comparison of point-source and finite-fault approaches;

- performance assessment for long-duration and complex ruptures;

- integration of real-time GPS data in EEW systems;

- real-time ground motion and damage prediction; 
- exploration of local and global tsunami early warning;

- EEW case studies, testing and performance evaluation of existing systems; and

- discussion of implications for earthquake hazard, risk and response models with respect to the science community as well as private and government entities.

Session Chairs: Christine J. Ruhl (cruhl@berkeley.edu), Emrah Yenier (emrahyenier@nanometrics.ca), Men-Andrin Meier (mmeier@caltech.edu), Neil Spriggs (neilspriggs@nanometrics.ca), Diego Melgar (dmelgarm@uoregon.edu), Marlon D. Ramos (ramosmd@umich.edu), David Easton (davideaston@ nanometrics.ca),

\section{Earthquake Source Parameters: Theory, Observations and Interpretations}

Understanding origin and spatio-temporal evolution of seismicity needs a careful quantitative analysis of earthquake source parameters for large sets of earthquakes in studied seismic sequences. Determining focal mechanisms, seismic moment tensors, static stress drop, apparent stress and other earthquake source parameters provides an insight into tectonic stress and crustal strength in the area under study, material properties and prevailing fracturing mode (shear/tensile) in the focal zone and allows the investigation of earthquake source processes in greater details. In addition, studying relations between static and dynamic source parameters and earthquake size is essential to understand the self-similarity of rupture process and scaling laws and to improve our knowledge on ground motion prediction equations.

This session focuses on methodological as well as observational aspects of earthquake source parameters of natural or induced earthquakes in broad range of magnitudes from large to small earthquakes, including acoustic emissions in laboratory experiments. Presentations of new approaches to focal mechanisms determination, seismic moment tensors and other source parameters as well as case studies related to analysis of earthquake source parameters are welcome. We also invite contributions related to scaling of static and dynamic source parameters and to self-similarity of earthquakes.

Session Chairs: Vaclav Vavrycuk (vv@ig.cas.cz), Grzegorz Kwiatek (kwiatek@gfz-potsdam.de),DouglasDreger (dreger@ seismo.berkeley.edu).

\section{Emergency Management, Resilience and Preparedness}

Emergency and disaster management and preparedness approaches involve the mitigation, preparation, response and recovery and aim to reduce vulnerability to hazards and to cope with disasters from both natural events and human-induced events. The planning phase involves a coordinated, co-operative process of preparing to match anticipated urgent needs with all available resources. All the phases require research, evaluation, testing/validation, implementation and updating; the final product will be a living emergency plan that should be periodically reviewed and adapted to changing circumstances and real-life situations. In this session, we call for participants to focus on emergency planning, management, continuity of operations, technology, social processing and guidance. In a real world that is subject to accelerating physical, social and economic change, the challenge of managing emergencies well depends on effective planning and foresight and the ability to connect disparate elements of the emergency response into coherent strategies.

Session Chairs: Victor A. Huerfano (victor@prsnmail. uprm.edu), Christa G. von Hillebrandt-Andrade (christa. vonh@noaa.gov), Elizabeth A.Vanacore (elizabeth.vanacore@ upr.edu), Ronald Jackson (ronald.jackson@cdema.org).

\section{Environmental Seismology: Glaciers, Rivers, Landslides and Beyond}

Environmental seismology is the study of seismic signals generated at and near the surface created by environmental forces in the atmosphere, hydrosphere or solid Earth. Contributions to this session are welcome on a wide variety of topics including (but not limited to) the seismic signals associated with landslides, rock falls, debris flows, lahars, snow avalanches, cliff or pinnacle resonance, bedload transport, fluid flow in open and confined channels, open water waves, tides, glacial stick-slip, iceberg calving, crevassing, extreme wind and weather and wind turbines or other anthropogenic sources. Contributions that seek to conduct monitoring, create physical or statistical models of source processes or systems, detect events, characterize a wave propagation environment, or interact with other branches of the Earth or social sciences are additionally encouraged.

Session Chairs: Bradley P. Lipovsky (brad_lipovsky@fas. harvard.edu), Kate Allstadt (kallstadt@usgs.gov), Rick Aster (rick.aster@colostate.edu).

\section{Essentials of Seismic Risk Estimates}

Estimating the seismic risk for a region is important for officials as well as for individuals for deciding what mitigating action, if any, is to be taken. The risk can be expressed in units of number of strongly affected people, fatalities, injured or monetary losses. This session will focus on methods of estimating risk and the data sets necessary to calculate it are essential elements that need to be discussed. The underlying question of seismic hazard must be understood for the region in general, although this session does not focus on it. The seismic risk problems in the regions of Central and South America are of special interest. Estimates of the differences in the seismic risk for the affluent and the poorer sections of society are invited. Methods for structural measures to reduce seismic risk have been developed, but new ideas, especially those applicable to Latin America, are welcome. Quantitative means to educate decision-makers and the public are also of interest. 
Session Chairs: Max Wyss (max@maxwyss.ch), Sergio Barrientos (sbarrien@dgf.uchile.cl), Ramón Zúñiga (ramon@ geociencias.unam.mx).

\section{Exploring Rupture Dynamics and Seismic Wave Propagation along Complex Fault Systems}

Investigations related to how complexities in fault parameters could potentially impact the behavior of earthquake rupture and affect seismic hazard are areas of active and challenging research. This session will highlight recent advances in rupture dynamics on complex fault systems. We are open to a wide range of studies related to numerical, experimental and observational fault rupture dynamic studies with heterogeneities such as fault geometry, fault roughness, frictional parameters, creeping mechanisms, stress asperities, off-fault material properties, bi-material interfaces and wedge structures along subduction zones. We also encourage contributions on research that explores links between earthquake source physics, tsunami generation/propagation and ground motion variability.

Session Chairs: Roby Douilly (roby.douilly@ucr.edu), Kenny Ryan (kryan@usgs.gov), David D. Oglesby (david. oglesby@ucr.edu), Ruth Harris (harris@usgs.gov), Eric Geist (egeist@usgs.gov).

\section{Fault to Seismic Hazard Assessment (Fault2SHA) in Latin (Central and South) America}

In seismic hazard analysis, increasing importance is given to geodynamic and tectonic data for modeling seismic sources by actual faults. Fast deforming regions like California, New Zealand, Japan and Turkey that have led the development of this practice since the 90 s, are now facing new lessons, whilst slowly deforming areas (i.e., Europe) are learning how to deal with their datasets. Latin America is a broad region of interest for earth scientists as it is characterized by both intense seismic activity along the subduction zones and distributed continental faulting. Assessment and mitigation of seismic hazards from the growing set of active faults identified and mapped in Latin America poses unique challenges due to the high variability of data types and qualities.

This session aims to present new data sets and the latest integration of fault sources in SHA models. We invite contributions related to the description of earthquake sources, from the field to the modeling, as well as discussions about whether and how uncertainties in field data are transposed into the source models. In particular, we solicit studies that provide discussions about the comparison and analysis of fault parameters and fault models in South and Central America. We also solicit contributions on how 3D, geometrically complex fault segments are identified and defined, their impact on probabilistic seismic hazard results and studies that incorporate geodetical and geophysical observations. The session aims at linking the "New" and "Old" Worlds, i.e., the Americas and Europe, by strengthening common rules and procedures inside the international community that works on these subjects.
Session Chairs: Laurence Audin (laurence.audin@ird.fr), Felipe Aron (faron@ing.puc.cl), Marianne Saillard (saillard@ geoazur.unice.fr), Laura Peruzza (lperuzza@inogs.it), Franck Audemard (faudemard@funvisis.gob.ve), Oona Scotti (oona. scotti@irsn.fr),

\section{Forecasting Aftershock Sequences in the Real World}

In the last few years, increasingly sophisticated earthquake forecast models have been applied in many regions around the globe in response to ongoing earthquake activity. Traditionally, aftershock models have been used to forecast short time-windows of days or weeks and this type of aftershock forecasting has remained the most common application. However, as demonstrated in recent New Zealand sequences (e.g., Canterbury in 2010-2011 and Kaikoura in 2016), when end-users become more familiar with forecast modelling, their need for other means of understanding the forecasting, such as through longer time frames, increases. Further, there is evidence that a variety of decisions were made by emergency managers, building engineers and key decision-makers based on these forecasts that had previously not been anticipated by the scientific community. Other complexities included forecasts and predictions made publicly by alternate theorists.

Experience from New Zealand has highlighted some of the limitations in our current understanding and modeling approaches, such as: 1) understanding the forecast skill of aftershock models as they extend to longer time-periods; 2) forecast models that provide useful information for medium-term time-frames; 3) spatial distribution of earthquake sequences; 4) forecasts of ground motion and losses; and 5) communication methods and tools that allow for successful uptake of relevant information during heightened earthquake response times. In this session, we welcome presentations that cover these or any other operational earthquake forecast model development and communication topics.

Session Chairs: Matthew C. Gerstenberger (m.gerstenberger@gns.cri.nz), Sara K. Mcbride (skmcbride@ usgs.gov), Nick Horpsool (n.horspool@gns.cri.nz), David A. Rhoades (d.rhoades@gns.cri.nz).

\section{The Future of Telemetered Seismic Arrays- Where the Operation of the Network Ends and the Science Begins}

Seismic science generally starts with a quality waveform archive and a rich catalog of well located events with accurate magnitudes. This session will explore new and innovative ways of field operations and discuss input on more efficient approaches to delivering this scientific starting point. This could include cloud and network services, engineering services, improved instrumentation, co-located complimentary instruments and less expensive installations. An integrative approach to station building and management using many geophysical observations should become standard in most supported telemetered 
networks. Arrays of seismometer and geophysical instruments that address more use cases for less investment are the key going forward. We invite abstracts on a wide range of topics that affect the creation, management and type of geophysical stations built: early earthquake warning, public hazard reporting, environmental monitoring, science observatories, cost, performance, data use case, data latency, noise characteristics, regional concerns and the cost of data per gigabyte.

Session Chairs: Tim Parker (timbobparker@gmail.com), Dario Baturan (dariobaturan@nanometrics.ca), David Eaton (eatond@ucalgary.ca).

\section{Ground Motion and Earthquake Engineering}

Modeling of ground motion and analysis of the response of structures to earthquakes are key to increasing earthquake resiliency in communities. This session solicits presentations on advances in ground motion modeling, case studies of regional ground motions, and especially the response of man-made structures to earthquakes.

Session Chairs: Sinan Akkar (sinan.akkar@boun.edu.tr), Thomas Herring (tah@mit.edu).

\section{Increasing Testability-Expanding Possibilities and Future Developments of the Collaboratory for the Study of Earthquake Predictability}

The Collaboratory for the Study of Earthquake Predictability (CSEP) has expanded over the years to many different testing areas hosted at multiple testing centers. Hundreds of earthquake forecast models have been submitted to CSEP and are being tested. New testing metrics were developed and implemented and a lot of progress was made to establish CSEP as an institution that cannot be ignored when issuing earthquake forecasts. Its rigor and independence became the standard in evaluating earthquake forecasts and in reporting on the results.

Although the tests CSEP has conducted have been successful and well-received, they have also shown the limitations of the CSEP approach. What is a sufficient testing period for models? Are time-invarying models really describing the longterm seismic activity? Are long-term models testable at all? Do short-term models provide significant information for the forecasting problem or do they only model aftershock sequences? What other signals should be included in forecasting models to improve them? Do improvements in forecasting models translate into improvements of hazard models? How can the tests be improved? Many aspects of seismic hazard or earthquake forecasting remain inherently untestable if only the model forecasts are tested and not the model ingredients. We propose to create new areas of activity for CSEP, namely targeted experiments that cannot be conducted with the current CSEP software system.

We solicit contributions addressing forecasting models, forecast testing problems, new ideas for CSEP experiments, possibilities of further CSEP developments, ways of expanding
CSEP into the hazard and risk domain and more general views on the forecasting problem.

Session Chairs: Andrew J. Michael (michael@usgs.gov), Danijel Schorlemmer (ds@gfz-potsdam.de), Maximilian J. Werner (max.werner@bristol.ac.uk), Warner Marzocchi (warner.marzocchi@ingv.it).

\section{Interaction Between Observations and Models in Seismo-Volcanic Studies}

Seismo-volcanic studies demand a deep understanding of volcanic systems. Such a study requires one to determine the internal structure of volcanic edifices to illuminate the configuration of the plumbing-feeding system, the nature and role of the fluids that fill internal cracks and cavities of complex geometries, the properties of seismic waves that cross the volcanic edifice, the role of tectonic stresses and faults and many other intriguing aspects of these complex systems. Numerous seismic instruments have been deployed on active volcanoes in recent decades either in a permanent role for volcano surveillance or for temporary campaigns. We extend this invitation to discuss recent contributions in the fields of modelling, based on a foundation of observations of volcanic activity ranging from simple seismic networks to high resolution multi-parametric approaches. We expect to have an exciting interactive session between seismologists and the personnel of volcanic observatories from Latin America, USA and elsewhere.

Session Chairs: Mario C. Ruiz (mruiz@igepn.edu.ec), Mauricio Mora (mmorarsn@gmail.com).

\section{Megathrust Earthquakes: Recurrence, Rupture Modes and Tsunamis}

This session will address megathrust faulting at subduction zones. Topics include: 1) patterns of earthquake recurrence; 2 ) differences among fault ruptures that overlap; 3 ) interseismic, coseismic and postseismic deformation; 4) splay faults as clues to megathrust rupture mechanics and tsunami hazards; and 5) subduction zones, as in the Caribbean, where the very occurrence of great tsunamigenic earthquakes has yet to be demonstrated.

Session Chairs: Peter Molnar (molnar@colorado.edu), Peter Haeussler (pheuslr@usgs.gov), Brian F. Atwater (atwater@usgs.gov).

\section{Microzonation Studies-Site Effects}

As the world population increasingly moves to big metropolitan urban areas, the risk associated with earthquakes increases in these areas. This is particularly evident in developing countries. Local soil conditions are a first order parameter that controls seismic response and therefore building damage due to earthquake shaking. Careful planning of urban development with respect to soil conditions must be exercised to prevent loss of structures and fatalities. Due to restricted space and city regulations, microzonation studies have gained popularity over 
traditional geophysical methods over the past decades as rapid, cost-effective and environmentally friendly.

Damage that occurred in Mexico City due to the September 19, 2017 Puebla-Morelos earthquake, compared to damage from September 19, 1985 Michoacán earthquake, demonstrates the importance of understanding soil response and interaction with buildings for different source characteristics and soil conditions. Other recent earthquakes, such as the 2016 Pedernales earthquake in Ecuador, the 2010 Maule earthquake in Chile, and the 2010 earthquake in Haiti demonstrate the importance of site effects for damage distribution. Knowledge gained from these earthquakes can help mitigate damage from future earthquakes.

This special session is about case studies of seismic microzonation around the World, what we have learned about seismic response in urban areas, and how we can help planners to develop earthquake resilient cities.

Session Chairs: Ilias Papadopoulos (ilias@uwiseismic. com), Michael Schmitz (schmitzschutt@gmail.com).

\section{New Frontiers in Seismic and Acoustic Data Analysis}

Advances in computing power, novel sensing systems and analytical techniques have revealed valuable new perspectives on seismic and acoustic wave fields. For example, computationally intensive methods like the Empirical Wavelet Transform can give much sharper time/frequency representations than Fourier-based methods. Large $\mathrm{N}$ seismic arrays, free-flying infrasound stations and distributed fiber optic sensor cables acquire nontraditional data sets that then require new signal detection, association and location methods. This session will focus on innovative ways of presenting and analyzing seismic data, with an emphasis on new developments. We invite contributors who have developed or are exploring new techniques and/or who wish to offer relevant evaluations of widely used methodologies.

Session Chairs: Daniel C. Bowman (dbowma@sandia.gov), Sarah A. Albert (salber@sandia.gov), Matthew M. Haney (mhaney@usgs.gov).

\section{The Next Big Earthquake: The Usual and the Unusual Suspects}

Recent large and great earthquakes have altered the terrain, economies and lives of people in Haiti, Chile, New Zealand, Nepal and Japan. The potential for future damaging earthquakes in these and other populated regions near tectonically active plate boundaries are well known and pose increasingly significant risk to societies there. But what observational evidence do we have to understand where the next big earthquake will be? This session seeks paleoseismic and historical earthquake studies that examine large and great earthquakes around the world that pose such hazards. Analyses that include the number of people impacted, past and future effects on urban infrastructures or cultural systems and the size or level of ground deformation are of particular interest. Additionally, field investigation and analysis of recent surface-rupturing earthquakes and studies that examine the variability of past ruptures in size and time with a special emphasis on how such paleoseismic data can be used for seismic risk mitigation are welcome. Submissions from studies in Central and Latin America are particularly encouraged, as are studies of global fault networks.

Session Chairs: Sinan O. Akciz (sakciz@fullerton.edu), KateScharer (kscharer@usgs.gov).

\section{Numerical Modeling of Earthquake Ground Motion, Rupture Dynamics and Seismic Wave Propagation}

Continuous development of numerical modeling methods in seismology is driven by emerging requirements in observational seismology, advances in the mathematical sciences, evolution of computer architectures and programming models, adaptation of methods originating in other scientific fields, as well as by practical applications including site-specific seismic hazard assessment.

This session is a forum for presenting advances in numerical methodology, whether the principal context is observational, mathematical/numerical, computational or applicationbased.

We invite contributions focused on development, verification and validation of numerical-modeling methods and methodologically important applications especially to earthquake ground motion, seismic noise and rupture dynamics, including applications from the field of induced seismicity with particular focus on multi-physics aspects, for example, combining fluid migration and stress transfer in porous media with rupture dynamics and wave propagation in poro-elastic media and integration of dynamic event modeling with simulation of the full seismic cycle. We encourage contributions on the analysis of methods, fast algorithms, high-performance implementations, large-scale simulations, non-linear behavior, multi-scale problems and confrontation of methods with data.

Session Chairs: Peter Moczo (moczo@fmph.uniba.sk), Steve M. Day (sday@mail.sdsu.edu), Jozef Kristek (kristek@ fmph.uniba.sk).

\section{Observations and the Physics Behind Complex Earthquakes}

New observations of large earthquakes are challenging the simple model of a smoothly expanding rupture on a planar fault. Some recent events have involved multiple faults (e.g., 2012 M 8.6 Sumatra, 2016 M 7.8 Kaikoura, New Zealand), re-rupturing of a single fault patch (e.g., 2015 M 7.5 Hindu Kush), dynamic triggering of later sub-events (e.g., 1997 M 7.1 Harnai, Pakistan) and the interaction between intraplate and interplate faults (e.g., 2009 M 8.1 Samoa-Tonga, 2016 M 7.9 Papua New Guinea). Are these earthquakes outliers? Or does our increased ability to resolve a detailed picture capture a new norm? How can we define a new common behavior? What are 
the physical mechanisms that control the signatures of complex earthquakes? We welcome contributions on geodetic, seismic and field observations of complex earthquakes, new source inversion/imaging techniques, as well as physical analysis and simulation of complex earthquakes.

Session Chairs: Zhongwen Zhan (zwzhan@gps.caltech. edu), Gavin Hayes (ghayes@usgs.gov), Marine Denolle (mdenolle@fas.harvard.edu).

\section{Observed Characteristics of Induced Seismicity: From Laboratory to Field Scale}

A wide variety of methods have been employed to examine the physical mechanisms and site-specific conditions that control anthropogenically induced seismicity. Laboratory experiments and mesoscale experiments of fluid injection into active faults investigate the role of fluids and friction on fault stability and the contribution of aseismic slip to the nucleation process. Seismic array installations including large- $\mathrm{N}$ array deployments characterize the seismic wave-field, microseismicity and fault structure. Advanced earthquake detection and location techniques are being used to identify complex spatial and temporal migration patterns and statistical methods are used to differentiate between tectonic and induced events. Deployment of pressure monitoring networks explore the migration of fluids in the subsurface and illuminate how earthquakes modify the poroelastic environment. Geomechanical reservoir simulations relate fluid injection volumes/rates to subsurface fluid-pressure changes and numerical methods couple reservoir models to earthquake simulators to understand how induced seismicity sequences evolve due to changes in injection operations. These methods reveal that the character and evolution of induced seismicity are more complex than previously thought. We solicit contributions from laboratory/field experiments and observational, geomechanical and numerical modeling studies that explore the wide variety of characteristics, as well as the physical conditions and mechanisms, that control behavior of induced seismic sequences. In addition, we encourage contributions that discuss datasets and techniques needed to further understand and mitigate the risk associated with fluid injection.

Session Chairs: Kayla A. Kroll (kroll5@llnl.gov), Elizabeth S. Cochran (ecochran@usgs.gov), Brett Carpenter (brett.carpenter@ou.edu).

\section{Ocean Bottom Seismology—Hurdles, Strategies and Outcomes}

The field of Ocean Bottom Seismology has been rapidly expanding, with many types of deployments for a wide variety of targets. Ocean floor sensors have been used for structural and geodynamic studies, enhanced seismic monitoring and improved source location. Different marine environments and tectonic settings require innovative solutions to deployment logistics, sensor emplacement and data recovery. Following the extraction of data, special problems relating to a sometimes very noisy environment pose new challenges to maximize data utility. We welcome contributions addressing all aspects of active and passive ocean-bottom seismology, technical innovations, data analysis and the scientific results obtained from OBS or amphibious projects.

Session Chairs: Charlotte A. Rowe (char@lanl.gov), Francisco J. Núñez-Cornú (pacornu77@gmail.com), Susan L. Bilek (sbilek@nmt.edu).

\section{Onshore Quaternary and Contemporary Tectonics: Implications for Seismic Hazards}

We solicit abstracts that focus on work related to earthquake history of onshore faults, regional or site-specific tectonic deformation (e.g., changes in marine terrace elevations or in stream gradients), current crustal stress orientations and/or seismicity, that contribute to the understanding of the hazards posed by onshore faults in the Caribbean region. Papers could also include the use of the information available about the activity of onshore faults in the assessment of seismic hazards for structures of various types or information from offshore studies that implicate onshore faults.

Session Chairs: Lucille Piety (lpiety@usbr.gov), Joanna Redwine (jredwine@usbr.gov).

\section{Plate Boundary Segmentation and Coupled-to- Creeping Plate and Block Boundary Faults}

This session aims to begin characterizing the range of fault behaviors on plate and block-boundary faults in the Caribbean and Latin American regions. Presentation of case studies that use seismological, geodetic, geological, geomorphic and other approaches to study individual locked, creeping and intermediate faults and segments are invited. We also seek out the presentation of work that uses both empirical evidence and modeling to understand the physical causes for these differing fault behaviors. A major goal of the session is to begin understanding how and why individual plate and block boundaries are segmented and how locked and creeping segments link in space and time.

Session Chairs: John C. Weber (weberj@gvsu.edu), Omar J. Perez (ojperez@usb.ve).

\section{Present-Day Plate Boundary Deformation and Seismic Hazard in the Caribbean}

Seismic hazard is an integral part of the Caribbean. Earthquakes can be particularly devastating to countries of the region that have seen a significant rise in population density- often with a concentration in coastal areas and substandard building practices. A number of research and observation programs are however underway with the goal of better understanding seismic hazard and the physical processes that control the occurrence of earthquakes in the Caribbean, with the potential to inform decisions and contribute to capacity building. This session aims at bringing together geoscientists with an interest 
in seismic hazard characterization and active plate-boundary deformation in the Caribbean through seismology, paleoseismology, geodesy, tectonics, geodynamics or any other relevant discipline.

Session Chairs: Eric Calais (eric.calais@ens.fr), Steeve Symithe (symithesteevej@gmail.com), O’Leary Gonzalez Matos (oleary@cenais.cu), Valérie Clouard (clouard@ipgp.fr).

\section{Real-Time GNSS Network Operations and Advances towards Early Warning Systems}

A fundamental aspect of Real-Time GNSS operations is the capability to obtain physical charactersitics of the rupture process after the onset of an earthquake. Of particular interest is the ability to use rupture parameters to assess the effects of strong ground motions and a potentially ensuing tsunami. This session seeks contributions of the latest approaches in using RealTime GNSS data to be applied in source inversion algorithms and to produce seismic parameters in seconds to minutes after the occurrence of an earthquake. Contributions describing how such results are applied for shaking and tsunami intensity forecasts (i.e. for early warning systems) are highly welcome and desirable. The use of casters or other protocols to collect and distribute the data, the computer infrastructure required to manage data operations, correction schemes employed for precise point positioning, data manipulation, visualization of data and other steps carried out in the estimation of source parameters are likely contributions expected for this session. We also welcome contributions that discuss operational issues such as: what is required in the field to ensure highly reliable data flow, what can be done to maintain low-latency, high-rate data steams without overburdening communications, how can redundancy be built into data paths and how to leverage existing infrastructure in seismic networks to enable GNSS data flow and vice versa?

Session Chairs: Alberto M. Lopez (alberto.lopez3@upr. edu), Kathleen M. Hodgkinson (hodgkinson@unavco.org), Diego Melgar (dmelgarm@uoregon.edu), Sebastian Riquelme (sebastian@dgf.uchile.cl), David Mencin (dmencin@unavco. org), Victor A. Huerfano (victor@prsnmail.uprm.edu),

\section{Recent Advances in Dense Array Seismology}

The availability of dense seismic arrays is desired to record well-sampled and unaliased wavefields. The recording of full wavefields combined with advanced data analysis techniques has the potential to image the subsurface and to study source characteristics with unprecedented resolution. The recent availability of low-cost and easy-to-deploy seismic sensors and emerging technologies such as Distributed Acoustic Sensors (DAS) have made it possible to deploy large and dense arrays in a reasonable time frame. Data acquired by such dense systems promote the development of many new data analysis methods that study seismic signals in a more comprehensive fashion. This session aims to compile innovative efforts that engage in recent advances in dense array seismology. We invite contribu- tions from all research focus areas that are broadly related to dense arrays. Example topics include, but are not limited to, instrument development, field experiment with Large- $\mathrm{N}$ or DAS array, high-resolution imaging of subsurface structure, full wavefield reconstruction, environmental seismology and seismic source characterization.

Session Chairs: Ting Chen (tchen@lanl.gov), Fan-Chi Lin (fanchi.lin@utah.edu), Norimitsu Nakata (nnakata@ou.edu), Catherine Snelson (snelsonc@lanl.gov).

\section{The Recent Earthquakes that Shocked Mexico in September 2017}

Last September, Mexico experienced two large earthquakes that seriously affected the south and central parts of the country. Both earthquakes were intraslab normal-faulting ruptures within the oceanic Cocos plate. The first one $(\mathrm{Mw}=8.1)$ occurred on September 8 in the Tehuantepec Gulf, collapsing thousands of small to medium size buildings in several provinces around the epicentral area. Numerous aftershock sequences (or triggered seismicity) followed the main earthquake increasing the damage to the Tehuantepec Isthmus. The second event $(\mathrm{Mw}=7.1)$ occurred eleven days later, on September 19, south of the border between the Morelos and Puebla States and close to important cities such as Cuernavaca and Mexico City ( 100 $\mathrm{km}$ to the north of the epicenter), where hundreds of buildings collapsed or were seriously damaged. In total, the authorities estimate that about 400 people died nationwide as a consequence of both events. This session welcomes papers addressing various seismological aspects of both earthquakes, such as source modelling, aftershock sequences, ground motion and tsunami modeling, strong motions, triggered seismicity and tectonic implications among others.

Session Chairs: Arturo Iglesias (arturo@geofisica.unam. mx), Vala Hjörleifsdóttir (vala@geofisica.unam.mx), Víctor M. Cruz-Atienza (cruz@geofisica.unam.mx), Roberto OrtegaRuiz (ortegarobe@gmail.com).

\section{Regional Seismic Network Approaches and Stakeholder Collaborations}

Seismic monitoring is a collaborative effort typically carried out by a broad array of state, university and federal partners. This distributed approach provides standardized earthquake analysis while adapting to the needs of specific regions and stakeholders. Many seismic networks in the U.S. coordinate through the Advanced National Seismic System. There are numerous organizations, both long-established and new, that operate independently. This is the case for most national networks within the Americas and other regions of the world. This session highlights the unique observations, opportunities and adaptations of so-called regional seismic networks. The purpose of the session is to foster collaboration and showcase specific regional success stories.

We welcome a wide range of contributions spanning science, operations and/or stakeholder engagement and particu- 
larly encourage submissions based on lesser-known organizations. Examples include but are in no way limited to: response to major earthquakes, unique tectonic considerations, nonearthquake sources, industry applications, forensic seismology, detection and processing workflows, facilities monitoring, custom products and services and support for local stakeholders. The only prerequisites are (i) real-time data and (ii) adaptation to a regional need or phenomenon. If your hometown network does something you are proud of, this session is the place to show it off.

Session Chairs: Michael West (mewest@alaska.edu), Sergio Barrientos (sbarrien@dgf.uchile.cl), Paul Bodin (bodin@uw.edu), Victor A. Huerfano (victor@prsnmail.uprm. edu), Xyoli Peréz-Campos (xyolipc@gmail.com), Alexandros Savvaidis (alexandros.savvaidis@beg.utexas.edu),

\section{Retrieval of Fine Scale Information Using Seismic Noise}

The use of ambient noise and other passive sources, coupled with the advent of large- $\mathrm{N}$ deployments, has been applied to an exponentially increasing number experiments in the last decade. Parallel advances in numerical methods and a deeper understanding of the physics and statistics of these passive wavefields has led to a number of highly inventive methodological advances affecting both the spatial and temporal resolution of recovered structures. Namely, ambient noise body wave tomography, passive temporal monitoring of dynamically varying structure through $\mathrm{dt} / \mathrm{t}$ measurements or other approaches, full waveform modeling of the ambient field and improved statistical models for diffusely scattered coda, have made substantial impacts in the way researchers now approach classically intractable problems. In this session, we seek to display such advances in the use of passive sources, either through seismic interferometry or other novel approaches, that result in the retrieval of fine scale information in new settings or the improvement of algorithms allowing for retrieval of more accurate physical parameters from previously tested datasets and media. Submissions are encouraged for research tackling current difficulties in resolution and physical parameter retrieval, as well as computational limitations and solutions to such problems.

Session Chairs: Julien Chaput (jchaput82@gmail.com), Thomas Lecocq (thomas.lecocq@oma.be).

\section{Science Gateways and Computational Tools for Improving Earthquake Research}

Science gateways allow research communities to access shared data, software, computing services, instruments, educational materials and other resources. Advances in earthquake science are becoming increasingly tied to the ability to fuse and model multiple data types, requiring advances in computational infrastructure. Earthquake scientists must rely on computational laboratories to integrate disparate data sets and perform simulation experiments, particularly because earthquake pro- cesses span multiple spatial and temporal scales, ranging from microscopic, millisecond source physics to long-term, global tectonic scales. This session focuses on advances in computational infrastructure and data synthesis for enhancing earthquake science, including software, supercomputing, simulation models, sensor technology, heterogeneous data sets, cloud computing, management of huge data volumes and development of community standards.

Session Chairs: Andrea Donnellan (andrea.donnellan@ jpl.nasa.gov), Lisa Grant Ludwig (lgrant@uci.edu).

\section{Seismic Event Screening}

One of the products from global seismic monitoring provisional to entry-into-force of the Comprehensive Nuclear-Test-Ban Treaty (CTBT) is a Standard Event Bulletin (SEB). The SEB contains event characterization parameters that can be used to screen-out seismic sources that are almost certainly not nuclear test explosions. During the two decades since the CTBT was opened for signature, research has resulted in a wide range of new source characterization methods. Based partly on results from this research, many seismic sources currently included in the SEB could be confidently identified as naturally occurring earthquakes. The new developments include, but are not limited to, comparison with empirical templates based on well calibrated past events, more precise depth constraint through simultaneous location of multiple events, ratios of spectral amplitudes of local and regional phases, ratios of different magnitudes computed from local, regional and teleseismic data, determination of moment tensor solutions from regional and teleseismic data and joint use of seismic and infrasonic data. This session comprises contributions related to evaluating which methods have advanced sufficiently to be ready for operational use in CTBT monitoring and what further research would be required to implement other methods in operations.

Session Chairs: Raymond Willemann (raymond.willemann@us.af.mil),David Bowers (bowers@blacknest.gov.uk).

\section{Seismic Hazards and Historic Earthquakes in Puerto Rico and the Northern Caribbean Region}

The USGS seismic hazard assessment for Puerto Rico and the U.S. Virgin Islands was last updated in 2003. For this session, we solicit papers that discuss new developments in probabilistic seismic hazard analysis in PRVI and the broader Caribbean region, as well as studies of historical earthquakes that inform the modern hazard models. We invite researchers to present new results that are critical to seismic hazard modeling and evaluation, including ongoing efforts by GEM and the USGS. Seismic hazard evaluation requires: 1) high-quality earthquake catalogs; 2) fault slip rates; 3) earthquake recurrence models; 4) region-specific ground motion models; and 5) local site amplification models. We encourage presentations on novel and creative concepts that will contribute to advancing seismic hazard models in the region. 
Session Chairs: Roland LaForge (laforgegeoconsulting@ gmail.com), Dan McNamara (mcnamara@usgs.gov), Charles Mueller (cmueller@usgs.gov).

\section{Seismic Structure of Convergent Plate Margins}

Convergence between tectonic plates is accomodated in multiple ways, including subduction, large-scale transform motion and continent-continent collision. This convergence is manifested through the creation of volcanic arcs, orogenic plateau formation and high seismicity rates. As a result, lithosphericscale reworking of the converging plates is common in these systems.

The tectonics of convergent plate margins have been well studied. However, how convergence is manifested in the seismic structure of these regions is still debated due to the complexity of the regions and differences in datasets and methodology. This session aims to shed light on how the processes that accompany convergence are expressed in the lithospheric structure of the crust and upper mantle of these margins, in the context of the increased availability and coverage of seismic data and recent advances in seismic tomography and imaging techniques. Examples of convergent plate boundary systems include but are not limited to: the Mediterranean, Alpine-Himalayan, American Cordillera, Caribbean and western Pacific systems.

Session Chairs: Min Chen (chenmi22@msu.edu), Jonathan R.Delph (jrdelph@rice.edu).

\section{Seismic Studies of Earth's Crust and Lithosphere}

Seismicity, seismic catalogs, and structure of Earth's crust and lithosphere are key components to understanding regional seismic risk and tectonics. The session includes studies of seismicity and imaging of Earth's crust and lithosphere as well as advances in seismic catalogs recording local seismicity.

Session Chair: Elizabeth A. Vanacore (elizabeth.vanacore@upr.edu).

\section{ShakeMap-Related Research, Development, Operations and Applications}

ShakeMap Version 4 represents a major re-engineering of the entire ShakeMap software package, including the way groundmotion parameters are interpolated, both geospatially and as a function of frequency. The new multivariate-normal interpolation strategy naturally accommodates uncertain intensity as well as ground-motion parameters, along with the correlations between the different parameters. While this new software and capabilities add important new functionality, they require (among other gaps) additional R\&D on ground motion and intensity models, duration/intensity models, model selection and spatial cross correlations. Thus, this session explores current research in the modeling and validation of ground motion and intensity relations as well as new or emerging efforts to improve ground motion prediction, site amplification and geospatial analyses (along with uncertainties) pertinent to
ShakeMap. Presentations on new ShakeMap products, formats and web-rendering are also encouraged.

A ShakeMap Workshop will be held on the Friday (May 18th) following the SSA meeting at the meeting venue. Workshop attendees are particularly encouraged to share their ShakeMap-related examples, research, operations and needs. We also encourage presentations on more general research, operations, or applications related to ShakeMap. Such applications include, but are not limited to: earthquake scenarios, risk assessment, loss estimation, earthquake response tools and engineering and other analyses that utilize ShakeMap ground motion estimates and associated uncertainty information.

Session Chairs: David J. Wald (wald@usgs.gov), Eric M. Thompson (emthompson@usgs.gov), Charles B. Worden (cbworden@usgs.gov).

\section{Structure and Dynamics of Earth's Mantle}

Understanding the structure and dynamics of Earth's mantle provides key insights into the fate of subducted slabs, the evolution of Earth, the dynamic forces that help drive large scale surface tectonics and core-mantle interactions amongst other topics of interest. Recent advancements in global seismic station coverage as well as advances in computational techniques have led to a current renaissance in studies of Earth's interior. For example, recent P-coda scattering studies and waveform tomography have provided new insight into the distribution of mantle heterogeneity and axisymmetric $2.5 \mathrm{D}$ theoretical waveform modeling has provided insight into the influence of topography on waveforms on major boundaries including the transition zone and core-mantle boundary. This broad session invites submissions from observational or theoretical studies in seismology, geophysics and geodynamics exploring Earth's mantle.

Session Chairs: Elizabeth A. Vanacore (elizabeth.vanacore@upr.edu), Fenglin Niu (niu@rice.edu).

\section{Structure and Geodynamics of the Caribbean Plate Boundaries}

The Caribbean plate (CAR) is unusual for a number of reasons. The region's history includes numerous destructive large magnitude earthquakes and tsunamis. An intermediate sized plate $(3.3 \times 106 \mathrm{~km} 2), \mathrm{CAR}$ is surrounded on its north, east and south by the much larger American plates, but since much of CAR is a large igneous province (LIP), its buoyancy makes it difficult to subduct. As a consequence, it is girdled by inward directed subduction zones; the Antilles on the east, the Puerto Rico Trench in the northeast and the Central American Trench on the west. Further, the large El Pilar-San Sebastian strike-slip system along northeastern South America (SA) connects the southern Antilles trench to the Southern Caribbean Deformed Belt and a poorly defined subduction zone in northwestern $\mathrm{SA}$, at which CAR subducts beneath northern Colombia and western Venezuela. The flat CAR subduction has created the Merida Andes, Perija and Santa Marta uplifts. Since the SA 
plate is subducting beneath CAR at the southern Antilles subduction zone and CAR is subducting southeastward beneath western $S A$, the two plates are subducting beneath one another. The number and volume of plates descending beneath CAR as imaged in different tomography studies (e.g., Bezada et al, JGR, 2010 and Van Benthem et al, JGR, 2013) create interesting space problems in the upper mantle beneath CAR and its neighbors, influencing upper mantle flow.

In north and northwestern CAR a complex series of strike slip and oblique slip faults extend from Puerto Rico across and around Hispaniola to join with the strike slip faults of the Cayman trough. These include what may be incipient northward subduction of CAR along the Muertos trough south of Hispaniola and Puerto Rico.

The plate boundaries around Panama are complicated and include what appears to be incipient CAR subduction just east of the Panama arc and the northeastern boundary of the recently identified Coiba and Malpelo plates (Zhang et al., GRL, 2017), bounded by the Panama arc, Cocos, Nazca and SA.

This diversity of tectonic boundaries provides an unusually rich source for seismicity and tsunamigenic earthquakes. Regional seismicity and GPS velocities suggest that a number of small tectonic blocks, moving quasi-independently and deforming internally, are caught in the boundary zones between CAR and the surrounding plates.

We invite contributions on any aspect of seismic structure, plate structure, deformation, seismicity and geodynamics in and around the Caribbean.

Session Chairs: Alan Levander (alan@rice.edu), Fenglin Niu (niu@rice.edu).

\section{Testing PSHA Input Data, Source Models and Hazard Estimates}

Many open, transparent probabilistic seismic hazard assessment (PSHA) models have become available, each involving many types of input data and assumptions. To inspire confidence, their input data, source models (i.e., earthquake forecasts) and hazard estimates require rigorous testing and validation.

UCERF3, the most advanced and comprehensive earthquake forecast ever, serves as an important example of a PSHA source model. It uses earthquake history, geologic fault data, geodetic and geologic strain rates and many assumptions. It is used in the US National Seismic Hazard Maps and the Uniform Building Code. With 1440 logic tree branches in just the time-independent models, it calculates off-fault epicenter rate density and rates of about 250,000 fault rupture scenarios, offering targets to evaluate the internal consistency and influence of model parameters and data values.

We welcome contributions to testing PSHA input data, including earthquake history, paleo-seismic event rates, geological and geodetic fault slip rates; strategies for integrating those data into source models; ground motion prediction equations; and resulting hazard estimates.
Session Chairs: David D. Jackson (djackson@g.ucla.edu), Yufang Rong (yufang.rong@fmglobal.com), Harold Magistrale (harold.magistrale@fmglobal.com), Jeremy Zechar (jeremy. zechar@axiscapital.com).

\section{Tsunami Outreach, Education and Warning Dissemination: Cross-disciplinary Opportunities for Increasing Tsunami Resiliency}

Tsunami-vulnerable areas continue to grow as coastal development expands and more people reside in tsunami-at-risk areas. However, as time passes from the last major ocean-wide tsunami in 2011, the urgency for and attention on tsunami risk reduction has taken a back seat to more recent events such as hurricanes, wildland fires and earthquakes. This session provides a broad forum for tsunami outreach, education and warning studies and related mitigation efforts. We particularly invite contributions from researchers working across disciplines, including multi hazard frameworks, that involve solutions to evacuation and warning issues and have addressed how other more recent events such as hurricanes can be used to promote tsunami resilience and risk reduction.

Session Chairs: Lori Dengler (lori.dengler@humboldt. edu), Christa G. von Hillebrandt-Andrade (christa.vonh@ noaa.gov), Rick I. Wilson (rick.wilson@conservation.ca.gov).

\section{Tsunami Modeling and Hazard Assessment}

Many recent advances have been made in the fields of tsunami modeling and hazard assessment. For example, the U.S. National Tsunami Hazard Mitigation Program has sponsored benchmarking workshops on the numerical modeling of tsunami propagation and inundation, tsunami currents and tsunamigenic landslides. In addition, the study of tsunami hazard has evolved to include loss estimates and mitigation measures, and tsunami hazard analysis is scheduled to become part of the building codes in several states in the next few years. There has been an increase of capabilities for tsunami risk reduction for the Pacific, Caribbean and adjacent regions. We also seek contributions on how to address, in a consistent fashion, seismic source definition for seismic and tsunami hazard assessments. This session will provide a forum for all aspects of tsunami modeling and hazard assessment and also for studies of tsunamis with a non-megathrust source.

Session Chairs: Stephanie L. Ross (sross@usgs.gov), Silvia Chacón (silviachaconb@gmail.com), Juan J. Horillo (horrill@@ tamug.edu), Alberto Lopez (alberto.lopez3@upr.edu), Hong Kie Thio (hong.kie.thio@aecom.com).

\section{Uncertainty in Ground Motion Estimation; Seismological and Engineering Perspectives}

Quantifying, understanding sources of, and reducing uncertainty in, methods of ground motion estimation are critical for improving seismic hazard assessment, as well as for working towards an understanding of the underlying seismological 
processes behind ground motion. Large uncertainty has often plagued estimates of physical parameters; it is important to reduce this uncertainty to discern the underlying seismological trends. Collaboration between the engineering and seismological communities is mutually beneficial. This session aims to bring together these communities to increase communication of new developments in targeting and understanding sources of uncertainty or variability in ground motion estimation, as well as working towards quantifying and reducing uncertainty for appications of seismic hazard assessment.

We welcome studies focused on understanding the foundations of variability in the seismological processes or parameters affecting ground motion estimation (earthquake source parameters, source characterization, etc.), on improving crustal models and techniques for ground motion simulations, on methods of quantifying uncertainty in seismological processes, as well as on strategies for reducing aleatory uncertainty as represented in ground motion prediction equations and probabillistic seismic hazard analysis.

Session Chairs: Valerie J. Sahakian (vsahakian@usgs. gov), Annemarie S. Baltay (abaltay@usgs.gov), Kathryn E. Wooddell (wooddell@seismo.berkeley.edu).

\section{Urban Liquefaction and Lateral Spread Investigations and Mapping}

Liquefaction and lateral spreading are major coseismic geohazards that have an especially large impact on lifelines, in particular when they occur in urban areas. A number of recent events (e.g. Christchurch, New Zealand and the recent 2017 Mexico City event) demonstrate that further geological and geotechnical investigations and models are required to better understand where liquefaction and lateral spreading will take place in order to avoid or design to mitigate these coseismic hazards. This session focuses on urban liquefaction and lateral spread investigations and mapping efforts to better understand occurrence and recurrence of this strong-ground motion derived geohazard. The field of liquefaction hazard mapping has advanced substantially since initial projects in the $1980 \mathrm{~s}$ through 1990s established the practice. This session is focused on reviewing advances brought about by documentation of effects from earthquakes over the past few decades and ongoing advances and application of new technologies and analytical understanding.

Specific topics of interest include integration of remote sensing exploration (lidar, satellite observations, etc) of recent liquefaction and lateral spreading, in addition to geological (trenching), geotechnical (CPT and drilling) and geophysical (e.g. shear wave, seismic reflection or refraction mapping, resistivity or radar) investigations to advance the predictive capabilities of hazard mapping. Also of interest are comparative studies between predictive hazard maps and actual occurrence of damaging liquefaction to assess the effectiveness of current mapping techniques.

Session Chairs: Gregory P. De Pascale (snowyknight@ gmail.com), Jeffrey Bachhuber (jxbs@pge.com).

\section{USGS Seismic Hazard User-Needs}

The US Geological Survey (USGS) National Seismic Hazard Modeling Project (NSHMP) invites our user community to present how they use the National Seismic Hazard Models and resulting products, such as hazard curves, ground motion maps, deaggregations, web services, computer codes, catalogs and source parameter data. Considering future updates in 2020 and beyond, and possibly including one-year forecasts for induced seismicity, the NSHMP would like to know more about how the user community uses its products and thereby how the models might need to be improved. In addition to changes to current products, we would also like to know what additional products would be helpful. Although the structural engineering community is the primary user of the National Seismic Hazard Models, many members of the SSA community consider the models and their components, in a broad array of research and industry applications, such as liquefaction and landslide stability studies and insurance risk assessments.

Session Chairs: Susan M. Hoover (shoover@usgs.gov), Nico Luco (nluco@usgs.gov), Peter M. Powers (pmpowers@ usgs.gov), Sanaz Rezaeian (srezaeian@usgs.gov).

\section{U.S. National Seismic Hazard Model Updates: 2018, 2020 and Beyond}

The US Geological Survey (USGS) National Seismic Hazard Models (NSHMs) are a bridge for translating "best-available" earthquake science into public policy. Historically, the NSHM for the conterminous U.S. has been updated every six years. The 2018 update will be a four-year update. Compared to the six-year cycle, the 2018 update will have fewer changes, thereby distributing sensitivity testing that becomes difficult when numerous changes are considered at once. This session focuses on the 2018, 2020 and future updates to the conterminous U.S. model. The deadline for any suggested modifications or additions to be considered to the 2018 model has passed; during this session we will summarize the scientific improvements in the 2018 model and discuss the outcome of the USGS 2018 NSHM update workshop (March 2018) in California. Looking forward, the deadline for published research to be included into the 2020 model is quickly approaching (June 2018). For this session, we invite contributions in all topics and areas that will influence future hazard models, for example: NGA-East, NGA-Subduction, physics-based ground motion models (3D simulations) and source models (UCERF4), source model implementations, directivity methods, fault characterizations, scaling equations, site amplifications and catalogs, among others.

Session Chairs: Allison M. Shumway (ashumway@ usgs.gov), Susan M. Hoover (shoover@usgs.gov), Morgan P. Moschietti (mmoschetti@usgs.gov), Mark D. Petersen (mpetersen@usgs.gov), Peter M. Powers (pmpowers@usgs. gov). 


\section{Program for 2018 SSA Annual Meeting}

Presenting author is indicated in bold.

\section{Tuesday 15 May-Oral Sessions}

\begin{tabular}{|c|c|c|c|c|}
\hline Time & Brickell & Flagler & Hibiscus A & Hibiscus B \\
\hline & $\begin{array}{l}\text { Numerical Modeling } \\
\text { of Earthquake Ground } \\
\text { Motion, Rupture Dynamics } \\
\text { and Seismic Wave } \\
\text { Propagation } \\
\text { Session Chairs: Peter Moczo, } \\
\text { Steve M. Day, and Jozef } \\
\text { Kristek (see page } 804 \text { ) }\end{array}$ & $\begin{array}{l}\text { Interaction Between } \\
\text { Observations and Models } \\
\text { in Seismo-Volcanic Studies } \\
\text { Session Chairs: Mario C. } \\
\text { Ruiz and Mauricio Mora (see } \\
\text { page 798) }\end{array}$ & $\begin{array}{l}\text { Tsunami Modeling and } \\
\text { Hazard Assessment } \\
\text { Session Chairs: Stephanie } \\
\text { L. Ross, Silvia Chacón, Juan } \\
\text { J. Horillo, Alberto Lopez, } \\
\text { and Hong Kie Thio (see page } \\
\text { 813) }\end{array}$ & $\begin{array}{l}\text { Essentials of Seismic Risk } \\
\text { Estimates } \\
\text { Session Chairs: Max Wyss, } \\
\text { Sergio Barrientos, and } \\
\text { Ramón Zúñiga (see page } \\
\text { 793) }\end{array}$ \\
\hline $8: 30 \mathrm{AM}$ & $\begin{array}{l}\text { A Computational Model of } \\
\text { the Seismic Response in the } \\
\text { Valley of Mexico after the } \\
\text { Damaging M 7.1 Earthquake } \\
\text { of September 19, 2017. Cruz- } \\
\text { Atienza, V. M., Villafuerte, } \\
\text { C. D., Tago, J., Chaljub, E., } \\
\text { Sanabria-Gomez, J. D. }\end{array}$ & $\begin{array}{l}\text { INVITED: Interpreting } \\
\text { Seismic Signals and Processes } \\
\text { at Active Volcanic Systems. } \\
\text { McNutt, S. R. }\end{array}$ & $\begin{array}{l}\text { INviTED: Benchmarking } \\
\text { Multilayer-Hysea Model } \\
\text { for Landslide Generated } \\
\text { Tsunamis. Macías, J., } \\
\text { Escalante, C., Castro, M. J. }\end{array}$ & $\begin{array}{l}\text { Attribute Index and } \\
\text { Classification Method of } \\
\text { Earthquake Damage Photos } \\
\text { for Seismic Risk. Lu, M. }\end{array}$ \\
\hline $8: 45 \mathrm{AM}$ & $\begin{array}{l}\text { A Unified Discrete } \\
\text { Representation of the Elastic, } \\
\text { Viscoelastic, and Poroelastic } \\
\text { Interface and Strong Material } \\
\text { Heterogeneity in the Finite- } \\
\text { Difference Modeling of } \\
\text { Seismic Wave Propagation. } \\
\text { Moczo, P., Gregor, D., } \\
\text { Kristek, J. } \\
\end{array}$ & $\begin{array}{l}\text { Monitoring Nyiragongo's } \\
\text { Lava Lake Activity (D.R. } \\
\text { Congo) Using Seismic, } \\
\text { Infrasound and SAR } \\
\text { Measurements. Barrière, } \\
\text { J., D’Oreye, N., Oth, A., } \\
\text { Geirsson, H., Mashagiro, } \\
\text { N., Johnson, J. B., Smets, B., } \\
\text { Kervyn, F. } \\
\end{array}$ & $\begin{array}{l}\text { INVITED: The Probabilistic } \\
\text { Tsunami Hazard Assessment } \\
\text { Map for the Neam Region: } \\
\text { Results of the Tsumaps- } \\
\text { Neam Project. Basili, R. }\end{array}$ & $\begin{array}{l}\text { Defense Nuclear Facilities } \\
\text { Safety Board Natural } \\
\text { Phenomena Hazard } \\
\text { Database. Li, Y. L., } \\
\text { Schleicher, L. S. }\end{array}$ \\
\hline $9: 00 \mathrm{AM}$ & $\begin{array}{l}\text { Numerical Simulation of M9 } \\
\text { Megathrust Earthquakes } \\
\text { in the Cascadia Subduction } \\
\text { Zone. Roten, D., Olsen, K. } \\
\text { B., Takedatsu, R. }\end{array}$ & $\begin{array}{l}\text { INVITED: Seismo-Acoustic } \\
\text { Wavefield of Strombolian } \\
\text { Explosions at Yasur Volcano, } \\
\text { Vanuatu, Using a Broadband } \\
\text { Seismo-Acoustic Network. } \\
\text { Matoza, R. S., Chouet, B., } \\
\text { Dawson, P., Jolly, A., Fee, D., } \\
\text { et al. } \\
\end{array}$ & $\begin{array}{l}\text { Testing Empirical } \\
\text { Inundation in the Definition } \\
\text { of Inundation Zones for } \\
\text { Tsunami Early Warning. } \\
\text { Tonini, R., Lorito, S., Di } \\
\text { Manna, P., Selva, J., Volpe, } \\
\text { M., et al. }\end{array}$ & $\begin{array}{l}\text { Exploring the Uncertainty } \\
\text { of Earthquake Catastrophe } \\
\text { Models Through a Risk } \\
\text { Assessment Study in } \\
\text { Central America Using } \\
\text { Openquake and a Vendor } \\
\text { Cat Model. Mouyiannou, } \\
\text { A., Kalakonas, P. } \\
\end{array}$ \\
\hline $9: 15 \mathrm{AM}$ & $\begin{array}{l}\text { STUDENT: Can Triggered } \\
\text { and Induced Earthquakes be } \\
\text { Supershear Rupture Events? } \\
\text { A Numerical Investigation. } \\
\text { Jin, L., Zoback, M. D. }\end{array}$ & $\begin{array}{l}\text { INVITED: Very Long Period } \\
\text { and Short Period Eruption } \\
\text { Seismograms and Progressive } \\
\text { Conduit Changes at Erebus } \\
\text { Volcano, Antarctica. Aster, } \\
\text { R. C., Knox, H. A., Chaput, } \\
\text { J. A., Kyle, P. R. }\end{array}$ & $\begin{array}{l}\text { A Probabilistic Tsunami } \\
\text { Hazard Model for New } \\
\text { Zealand. Ali, S. T., } \\
\text { Barberopoulou, A., Yang., } \\
\text { W., Shen-Tu, B., Mahdyiar, } \\
\text { M., Klein, E. C. }\end{array}$ & $\begin{array}{l}\text { STUDENT: Probabilistic } \\
\text { Seismic Hazard Analysis } \\
\text { in Mexico City Using } \\
\text { Synthetic Seismograms and } \\
\text { Three-Dimensional Models. } \\
\text { Martínez, B., Ramírez- } \\
\text { Guzmán, L., Leonardo- } \\
\text { Suárez, M. }\end{array}$ \\
\hline
\end{tabular}




\begin{tabular}{|c|c|c|c|c|}
\hline Time & Jasmine & Monroe & Orchid AB & Tuttle \\
\hline & $\begin{array}{l}\text { Regional Seismic } \\
\text { Network Approaches and } \\
\text { Stakeholder Collaborations } \\
\text { Session Chairs: Michael } \\
\text { West, Sergio Barrientos, Paul } \\
\text { Bodin, Victor A. Huerfano, } \\
\text { Xyoli Pérez-Campos, and } \\
\text { Alexandros Savvaidis (see } \\
\text { page } 807 \text { ) }\end{array}$ & $\begin{array}{l}\text { Advances in Seismic } \\
\text { Site Response Studies } \\
\text { Given Limitations in } \\
\text { Understanding of Site } \\
\text { Conditions } \\
\text { Session Chairs: Emel Seyhan, } \\
\text { Sean K. Ahdi, Eric M. } \\
\text { Thompson, and Alan Yong } \\
\text { (see page 786) }\end{array}$ & $\begin{array}{l}\text { Onshore Quaternary and } \\
\text { Contemporary Tectonics: } \\
\text { Implications for Seismic } \\
\text { Hazards } \\
\text { Session Chairs: Lucille Piety } \\
\text { and Joanna Redwine (see } \\
\text { page } 806 \text { ) }\end{array}$ & $\begin{array}{l}\text { 3D/4D Seismic Imaging } \\
\text { and Their Interpretation } \\
\text { for Seismic Hazard } \\
\text { Assessment } \\
\text { Session Chairs: Marco Pilz } \\
\text { and Nori Nakata (see page } \\
\text { 783) }\end{array}$ \\
\hline $8: 30 \mathrm{AM}$ & $\begin{array}{l}\text { Low-Cost Seismic Data } \\
\text { Acquisition Module Based } \\
\text { on Open-Source Hardware } \\
\text { and Software Tools. } \\
\text { Ramdeane, A., McGillivary, } \\
\text { K., Lynch, L. L. }\end{array}$ & $\begin{array}{l}\text { Can the Earthquake Site } \\
\text { Response Be Predicted by the } \\
\text { Ambient Noise Amplitude? } \\
\text { Insight from Two Case } \\
\text { Studies. Perron, V., Gélis, } \\
\text { C., Froment, B., Hollender, } \\
\text { F., Bard, P. Y., et al. }\end{array}$ & $\begin{array}{l}\text { INVITED: Quaternary Faults } \\
\text { in the Vicinity of Puerto Rico } \\
\text { and the Virgin Islands and } \\
\text { Their Seismic Hazard. ten } \\
\text { Brink, U. S., Chaytor, J. D. }\end{array}$ & $\begin{array}{l}\text { STUDENT: Comparison } \\
\text { between Frequency and Time } \\
\text { Domain Cross-Correlation } \\
\text { of Seismic Noise Data in } \\
\text { South Korea. Del Valle- } \\
\text { Rosales, M., Chávez-García, } \\
\text { F. J., Kang, T. S. }\end{array}$ \\
\hline $8: 45 \mathrm{AM}$ & $\begin{array}{l}\text { Near Real-Time Network- } \\
\text { Wide Station State of Health } \\
\text { and Waveform Quality } \\
\text { Monitoring. Hutko, A. R., } \\
\text { Hartog, J. R., Marczewski, } \\
\text { K., Connolly, J., Reusch, M., } \\
\text { Bodin, P. }\end{array}$ & $\begin{array}{l}\text { Application of Near-Source } \\
\text { Factors to Deterministic } \\
\text { Response Spectra. Hudson, } \\
\text { K. H., Hudson, M. B. }\end{array}$ & $\begin{array}{l}\text { Guaicaramo Fault } \\
\text { System, Boyaca, Casanare, } \\
\text { Cundinamarca and Meta } \\
\text { Departments, Colombia: } \\
\text { A Review. Chicangana, } \\
\text { G., Bocanegra, A., Vargas } \\
\text { Jimenez, C. A., Kammer, A., } \\
\text { Arboleda, L. }\end{array}$ & $\begin{array}{l}\text { Enhancement of Body } \\
\text { Wave Signals in the Coda of } \\
\text { Seismic Noise Interferometry } \\
\text { through Random Fluctuation } \\
\text { Suppression. Liu, X., Beroza, } \\
\text { G. C. }\end{array}$ \\
\hline $9: 00 \mathrm{AM}$ & $\begin{array}{l}\text { Local and Regional } \\
\text { Earthquake Solutions from } \\
\text { Joining Raspberry Shake and } \\
\text { International Seismological } \\
\text { Stations. Blanco Chia, J. F., } \\
\text { Christensen, B. }\end{array}$ & $\begin{array}{l}\text { The Characteristics of } x 0 \text { in } \\
\text { Longmenshan Region and } \\
\text { Its Application in Estimation } \\
\text { of Source, Path, and Site } \\
\text { Parameters. Fu, L., Li, X. J., } \\
\text { Chen, S. }\end{array}$ & $\begin{array}{l}\text { Marine Terraces and } \\
\text { Quaternary Tectonic Uplift } \\
\text { in Puerto Rico. Prentice, C. } \\
\text { S., Muhs, D. R., Simmons, K. } \\
\text { R., Schumann, R., Joyce, J. }\end{array}$ & $\begin{array}{l}\text { Single-Station Imaging of a } \\
\text { Low-Velocity Layer Using } \\
\text { Reflected Waves from the } \\
2014 \text { Earthquake Swarm } \\
\text { at Long Valley Caldera, } \\
\text { California. Nakata, N., } \\
\text { Shelly, D. R. }\end{array}$ \\
\hline $9: 15 \mathrm{AM}$ & $\begin{array}{l}\text { Virtual Seismic Networks } \\
\text { - Case Studies in Europe } \\
\text { and the Arabian Peninsula. } \\
\text { Franke, } \mathbf{M} \text {. }\end{array}$ & $\begin{array}{l}\text { Accounting for Vs } \\
\text { Uncertainty in Seismic Site } \\
\text { Response Analyses Using the } \\
\text { Experimental Site Signature: } \\
\text { A Case Study of the Garner } \\
\text { Valley Downhole Array. Cox, } \\
\text { B. R., Teague, D. P., Rathje, } \\
\text { E. M. }\end{array}$ & $\begin{array}{l}\text { Holocene Surface Rupture } \\
\text { on the Salinas Fault and the } \\
\text { Southeast Great Southern } \\
\text { Puerto Rico Fault Zone } \\
\text { and Implication for Seismic } \\
\text { Hazard Assessments. Piety, } \\
\text { L. A., Redwine, J. R., } \\
\text { Prentice, C. S., Derouin, S. } \\
\text { A., Kelson, et al. } \\
\end{array}$ & $\begin{array}{l}\text { Seismic Imaging of the } \\
\text { West Napa Fault in Napa, } \\
\text { California. Goldman, M. } \\
\text { R., Catchings, R. D., Chan, } \\
\text { J. H., Sickler, R. R., Nevitt, J., } \\
\text { Criley, C. J. }\end{array}$ \\
\hline
\end{tabular}




\begin{tabular}{|c|c|c|c|c|}
\hline Time & Brickell & Flagler & Hibiscus $A$ & Hibiscus B \\
\hline \multirow[b]{2}{*}{$9: 30 \mathrm{AM}$} & $\begin{array}{l}\text { Numerical Modeling } \\
\text { of Earthquake Ground } \\
\text { Motion, Rupture... }\end{array}$ & $\begin{array}{l}\text { Interaction Between } \\
\text { Observations and Models } \\
\text { in Seismo-Volcanic Studies }\end{array}$ & $\begin{array}{l}\text { Tsunami Modeling and } \\
\text { Hazard Assessment }\end{array}$ & $\begin{array}{l}\text { Essentials of Seismic Risk } \\
\text { Estimates }\end{array}$ \\
\hline & $\begin{array}{l}\text { Developments in Propagation } \\
\text { of Seismic Waves with the } \\
\text { Generalized Finite Difference } \\
\text { Method: Application at } \\
\text { Interfaces. Ureña, M., Salete, } \\
\text { E., Benito, J. J., Ureña, F., } \\
\text { Gavete, L. }\end{array}$ & $\begin{array}{l}\text { Monitoring Recent Unrest } \\
\text { of Sierra Negra Volcano, } \\
\text { Galápagos Islands. Ruiz, M. } \\
\text { C., Amelung, F., Mothes, P. } \\
\text { A., Pacheco, D. A., Palacios, } \\
\text { P. B., et al. }\end{array}$ & $\begin{array}{l}\text { Simulation of PDC } 2017 \\
\text { Asteroid Ocean Impact, } \\
\text { Tsunami Generation, and } \\
\text { Consequences on Japan's } \\
\text { Coastlines. Ezzedine, S., } \\
\text { Dearborn, D., Miller, P., } \\
\text { Oman, L., Koshimura, S. }\end{array}$ & $\begin{array}{l}\text { Seismic Risk Assessment } \\
\text { in Areas with Low- } \\
\text { Quality Data: The Case } \\
\text { of the Jama-Pedernales } 7.8 \\
\text { Mw Earthquake and the } \\
\text { Detailed Study of Portoviejo } \\
\text { (Ecuador) - Part 1: Data } \\
\text { Processing. Marrero, J. M., } \\
\text { Yepes, H. A., Palacios, P. B., } \\
\text { Ramón, P. }\end{array}$ \\
\hline $\begin{array}{r}9: 45- \\
10: 45 \mathrm{AM}\end{array}$ & \multicolumn{4}{|c|}{ Posters and Break } \\
\hline & $\begin{array}{l}\text { Numerical Modeling } \\
\text { of Earthquake Ground } \\
\text { Motion, Rupture Dynamics } \\
\text { and Seismic Wave (contin- } \\
\text { ued) }\end{array}$ & $\begin{array}{l}\text { Interaction Between } \\
\text { Observations and Models } \\
\text { in Seismo-Volcanic Studies } \\
\text { (continued) }\end{array}$ & $\begin{array}{l}\text { Tsunami Modeling and } \\
\text { Hazard Assessment (con- } \\
\text { tinued) }\end{array}$ & $\begin{array}{l}\text { Essentials of Seismic Risk } \\
\text { Estimates (continued) }\end{array}$ \\
\hline $10: 45 \mathrm{AM}$ & $\begin{array}{l}\text { Influence of Normal Pressure } \\
\text { on the Stick-Slip Behavior } \\
\text { of Sheared Granular Fault } \\
\text { Gouge Using the Combined } \\
\text { Finite-Discrete Element } \\
\text { Method. Gao, K., Rougier, } \\
\text { E., Euser, B. J., Guyer, R. A., } \\
\text { Johnson, P. A., et al. }\end{array}$ & $\begin{array}{l}\text { Automatic Detection and } \\
\text { Location of Seismo-Volcanic } \\
\text { Signals Based on the Seismic } \\
\text { Network Covariance Matrix: } \\
\text { Examples from Tenerife } \\
\text { (Canary Islands) and the } \\
\text { Klyuchevskoy Volcanic } \\
\text { Group (Kamchatka). } \\
\text { Soubestre, J., Barrancos, J., } \\
\text { D'Auria, L., Padilla, G. D., } \\
\text { Shapiro, N. M., et al. } \\
\end{array}$ & $\begin{array}{l}\text { INviTED: Field Survey of } \\
\text { the } 1946 \text { Tsunami in the } \\
\text { Dominican Republic Based } \\
\text { on Eyewitness Interviews. } \\
\text { Fritz, H. M., Rivera, W. E., } \\
\text { Salado, J., Martinez, C. }\end{array}$ & $\begin{array}{l}\text { Seismic Risk Assessment } \\
\text { in Areas with Low- } \\
\text { Quality Data: The Case } \\
\text { of Jama-Pedernales } 7.8 \\
\text { Mw Earthquake and the } \\
\text { Detailed Study of Portoviejo } \\
\text { (Ecuador) -Part 2: Risk } \\
\text { Quantification. Yepes, H. } \\
\text { A., Marrero, J. M., Palacios, } \\
\text { P. B., Ramón, P. }\end{array}$ \\
\hline $11: 00 \mathrm{AM}$ & $\begin{array}{l}\text { EDGE: Towards Extreme- } \\
\text { Scale Nonlinear Earthquake } \\
\text { Simulations. Breuer, A., } \\
\text { Heinecke, A., Cui, Y. }\end{array}$ & $\begin{array}{l}\text { STUDENT: Seismicity of the } \\
\text { Lazufre Volcanic System, } \\
\text { Northern Chile/Argentina. } \\
\text { McFarlin, H. L., McNutt, } \\
\text { S. R., Braunmiller, J., } \\
\text { Thompson, G. }\end{array}$ & $\begin{array}{l}\text { Tsunami Mitigation } \\
\text { Mapping Effort in the Gulf } \\
\text { of Mexico. Juan Horrillo, J. }\end{array}$ & $\begin{array}{l}\text { Seismic Risk Assessment } \\
\text { for British Columbia, } \\
\text { Canada, through the Use of } \\
\text { Global Earthquake Model's } \\
\text { OpenQuake. Bird, A. L., } \\
\text { Journeay, J. M., Hastings, N., } \\
\text { Cassidy, J. F. }\end{array}$ \\
\hline $11: 15 \mathrm{AM}$ & $\begin{array}{l}\text { Modeling of Seismic } \\
\text { Liquefaction Effects on } \\
\text { Structure in the City } \\
\text { of Medellin, Colombia. } \\
\text { Montoya-Noguera, S., } \\
\text { Lopez-Caballero, F. }\end{array}$ & $\begin{array}{l}\text { Similar Seismicity at } \\
\text { Turrialba and Poas, Costa } \\
\text { Rica: What Can It Tell Us? } \\
\text { Salvage, R. O., Pacheco- } \\
\text { Alvarado, J. F., Brenes-Marin, } \\
\text { J. }\end{array}$ & $\begin{array}{l}\text { Long-Lived Tsunami Edge } \\
\text { Waves during the } 2017 \\
\text { M8.2 Tehuantepec, Mexico, } \\
\text { Earthquake and Their } \\
\text { Implications for Hazards. } \\
\text { Melgar, D., Ruiz-Angulo, } \\
\text { A., Ramirez-Herrera, M. T., } \\
\text { Corona Morales, N., Zavala- } \\
\text { Hidalgo, J. }\end{array}$ & $\begin{array}{l}\text { STUDENT: The Gutenberg- } \\
\text { Richter Law and } \\
\text { Completeness of the RSN } \\
\text { Earthquake Catalog, Costa } \\
\text { Rica. Arroyo Solórzano, M., } \\
\text { Linkimer, L. }\end{array}$ \\
\hline
\end{tabular}




\begin{tabular}{|c|c|c|c|c|}
\hline Time & Jasmine & Monroe & Orchid AB & Tuttle \\
\hline & $\begin{array}{l}\text { Regional Seismic } \\
\text { Network Approaches and } \\
\text { Stakeholder Collaborations }\end{array}$ & $\begin{array}{l}\text { Advances in Seismic Site } \\
\text { Response Studies Given } \\
\text { Limitations... }\end{array}$ & $\begin{array}{l}\text { Onshore Quaternary and } \\
\text { Contemporary Tectonics... }\end{array}$ & $\begin{array}{l}\text { 3D/4D Seismic Imaging } \\
\text { and Their Interpretation } \\
\text { for Seismic Hazard... }\end{array}$ \\
\hline $9: 30 \mathrm{AM}$ & $\begin{array}{l}\text { Geophysical Networks in } \\
\text { Peru: A National Effort } \\
\text { for Earthquake Disaster } \\
\text { Management. Norabuena, } \\
\text { E. O., Oliva, J. C., Salazar, } \\
\text { J. E. }\end{array}$ & $\begin{array}{l}\text { STUDENT: Development of } \\
\text { a United States Community } \\
\text { Shear Wave Velocity Profile } \\
\text { Database. Ahdi, S. K., } \\
\text { Stewart, J. P., Kwak, D. Y., } \\
\text { Yong, A., Sadiq, S., et al. }\end{array}$ & $\begin{array}{l}\text { Active Plate Tectonics and } \\
\text { Main Fault Systems in } \\
\text { Colombia: An Updated } \\
\text { Model for 3D Fault } \\
\text { Geometries and Magnitudes. } \\
\text { Tobón López, A. M., } \\
\text { Herrera García, D. C., } \\
\text { Yamin, L. E., Tary, J. B. }\end{array}$ & $\begin{array}{l}\text { Tomographic Imaging of the } \\
\text { Central California Crust } \\
\text { with Multiple Methods. } \\
\text { Thurber, C. H., Nayak, A., } \\
\text { Fang, H., Zeng, X., Zhang, } \\
\text { H. }\end{array}$ \\
\hline $\begin{array}{r}9: 45- \\
10: 45 \mathrm{AM}\end{array}$ & \multicolumn{4}{|c|}{ Posters and Break } \\
\hline & $\begin{array}{l}\text { Regional Seismic } \\
\text { Network Approaches and } \\
\text { Stakeholder Collaborations } \\
\text { (continued) }\end{array}$ & $\begin{array}{l}\text { Advances in Seismic } \\
\text { Site Response Studies } \\
\text { Given Limitations in } \\
\text { Understanding of Site } \\
\text { Conditions (continued) }\end{array}$ & $\begin{array}{l}\text { The Next Big Earthquake: } \\
\text { The Usual and the Unusual } \\
\text { Suspects } \\
\text { Session Chairs: Sinan O. } \\
\text { Akciz and Kate Scharer (see } \\
\text { page } 802 \text { ) }\end{array}$ & $\begin{array}{l}\text { 3D/4D Seismic Imaging } \\
\text { and Their Interpretation } \\
\text { for Seismic Hazard } \\
\text { Assessment (continued) }\end{array}$ \\
\hline $10: 45 \mathrm{AM}$ & $\begin{array}{l}\text { The Brazilian Seismographic } \\
\text { Network: Present Status and } \\
\text { Society Related Applications. } \\
\text { Collaço, B. B., Bianchi, M., } \\
\text { Assumpção, M. A., Calhau, J. } \\
\text { C., Barbosa, J. R., et al. }\end{array}$ & $\begin{array}{l}\text { Which Site Proxy Should } \\
\text { We Use in Ground-Motion } \\
\text { Models? Sandikkaya, M. A. }\end{array}$ & $\begin{array}{l}\text { INVITED: Paleo } \\
\text { Earthquakes, Historical- } \\
\text { Prehistorical Warnings, } \\
\text { Surface Ruptures, and } \\
\text { Unsuspected Active Faults } \\
\text { in Peru and Ecuador. Audin, } \\
\text { L., Benavente Escobar, C. } \\
\text { L., Alvarado, A., Zerathe, S., } \\
\text { Hall, S. R., et al. }\end{array}$ & $\begin{array}{l}\text { STUDENT: Crustal Structure } \\
\text { beneath Seismic Stations } \\
\text { Located in Paraná and } \\
\text { Chaco-Paraná Basins } \\
\text { from Joint Inversion of } \\
\text { Surface Wave Dispersion } \\
\text { and Receiver Functions. } \\
\text { Christiansen, L. A., Rosa, } \\
\text { M. L. }\end{array}$ \\
\hline 11:00 AM & $\begin{array}{l}\text { The National Seismological } \\
\text { Network of Costa Rica } \\
\text { (Rsn): An Overview and } \\
\text { Recent Developments. } \\
\text { Linkimer, L., Arroyo, I. } \\
\text { G., Alvarado, G. E., Arroyo- } \\
\text { Solórzano, M., Bakkar, H. }\end{array}$ & $\begin{array}{l}\text { STUDENT: Integration of } \\
\text { Site Effects Into PSHA: A } \\
\text { Comparison between Two } \\
\text { Fully Probabilistic Methods } \\
\text { for the Euroseistest Case. } \\
\text { Aristizábal, C., Bard, P. Y., } \\
\text { Beauval, C., Gómez, J. C. }\end{array}$ & $\begin{array}{l}\text { Hazards from the Sea: } \\
\text { Rupture Scenarios for the } \\
\text { San Diego Trough and } \\
\text { San Pedro Basin Fault } \\
\text { Systems, Offshore Southern } \\
\text { California. Bormann, J. } \\
\text { M., Ruhl, C. J., Kent, G. M., } \\
\text { Driscoll, N. W. }\end{array}$ & $\begin{array}{l}\text { STUDENT: Does the } \\
\text { Integration of Two Different } \\
\text { Datasets Affect Tomographic } \\
\text { Images and Earthquake } \\
\text { Location? The Case Study } \\
\text { of the High Agri Valley } \\
\text { (Southern Italy). Serlenga, } \\
\text { V., Stabile, T. A. }\end{array}$ \\
\hline $11: 15 \mathrm{AM}$ & $\begin{array}{l}\text { The Chilean Seismic } \\
\text { Network: Recent Advances. } \\
\text { Barrientos, S. E. }\end{array}$ & $\begin{array}{l}\text { Application of Non-Ergodic } \\
\text { Site Response for a Unique } \\
\text { Facility in Los Angeles, } \\
\text { California. Teague, D. P., } \\
\text { Heidarzadeh, B., Wurman, } \\
\text { G., Espinosa, P. J., Stewart, } \\
\text { J. P. }\end{array}$ & $\begin{array}{l}\text { Lidar Reveals New } \\
\text { Geomorphic Evidence of } \\
\text { Shaking and Slip on the } \\
\text { Reelfoot Fault in the New } \\
\text { Madrid Seismic Zone, } \\
\text { Western Tennessee, USA. } \\
\text { Delano, J. E., Gold, R. D., } \\
\text { Briggs, R. W., DuRoss, C. B., } \\
\text { Jibson, R. W. }\end{array}$ & $\begin{array}{l}\text { Geometry of the Los Angeles } \\
\text { Basin Using Full H/V } \\
\text { Spectral Ratio Inversion. } \\
\text { Spica, Z., Perton, M., } \\
\text { Beroza, G. C. }\end{array}$ \\
\hline
\end{tabular}




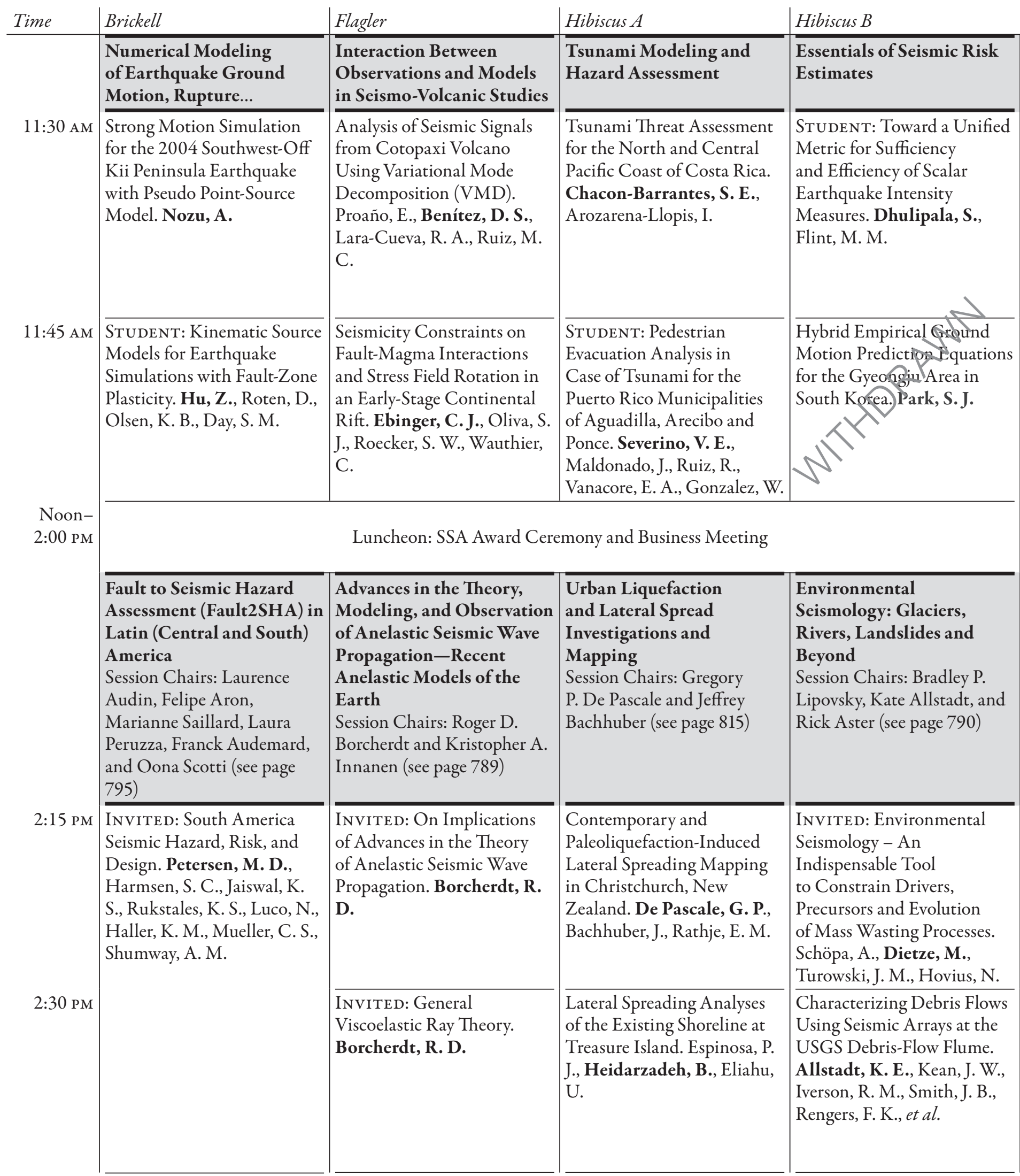


Time

Regional Seismic

Network Approaches and Stakeholder Collaborations

11:30 AM Assessment of the Impact of Hurricanes Irma and Maria on the Monitoring Capability of the Pacific Tsunami Warning Center for the Caribbean Region.

Sardiña, V. H. R., Walsh, D., Koyanagi, K., Becker, N. C., Weinstein, S. A., et al.

11:45 AM

Invited: Puerto Rico

Seismic Network Operations, Damages, and Recovery from a Natech Disaster. Vanacore, E. A., Baez-Sánchez, G., Lugo, J., Lopez, A. M., Huerfano, V. A.

Jasmine

Monroe

Advances in Seismic Site

Response Studies Given

Limitations...

STUDENT: Sensitivity of

Nonlinear Site Amplification

Factors to the Models Used

to Simulate and Constrain

Rare Events. Shi, J., Asimaki,

D.

Non-Linear and Plastic Soil

Response in the Greater

Tokyo Area during the 2011

Tohoku-Oki Earthquake.

Viens, L., Denolle, M. A.,

Hirata, N., Nakagawa, S.

Luncheon: SSA Award Ceremony and Business Meeting

2:00 PM

Regional Seismic Network Approaches and Stakeholder Collaborations (continued)

:15 PM

Improved Regional Seismic

Monitoring at the USGS

National Earthquake

Information Center. Earle,

P. S., Yeck, W. L., Hayes, G.

P., Guy, M. R., Patton, J. M.,

Ambruz, N. B., Arnold, M.

A., Benz, H. M.

2:30 PM

Keeping Up Appearances

in the Pacific Northwest

Seismic Network (PNSN).

Bodin, P., Biundo, M.,

Connolly, J., Creager, K. C.,

Crowell, B. W., et al.
Advances in Explosion Seismo-Acoustic Research

Session Chairs: Charlotte

Rowe, Catherine Snelson-

Gerlicher, Sean Ford,

Christopher Young, and

Junghyun Park (see page

784)

INVITED: Modeling of Rg

Wave Sources for SPE and

DAG Series. Larmat, C.

S., Delorey, A. A., Lei, Z.,

Rougier, E., Bradley, C. R.

Estimating Seismic Source

Time Functions in Stochastic

Earth Models. Poppeliers,

C., Preston, L., Eliassi, M.
The Next Big Earthquake:

The Usual and the Unusual Suspects

Paleoseismic Investigation

of Sackung Features Extends

the Late Quaternary

Earthquake Record along the

Reelfoot Fault, New Madrid

Seismic Zone, U.S.A. Gold,

R. D., DuRoss, C. B., Jibson,

R. W., Briggs, R. W., Delano, J. E., et al.

A 2000 Year Lacustrine

Paleoseismic Record on

the Peninsular Segment of

the Northern San Andreas

Fault at Lake Merced, San

Francisco. Goldfinger, C.,

Hausmann, R. B., Black, B.,

Beeson, J., Reidy, L.
Orchid AB
Science Gateways and

Computational Tools for

Improving Earthquake

Research

Session Chairs: Andrea

Donnellan and Lisa Grant

Ludwig (see page 812)

INVITED: Science Gateways for Enhancing Earthquake Science. Pierce, M. E., Wang, J.

INVITED: SCEC Tool

for Distribution and

Integration of Simulated

Ground Motions within the

NEHRI-CI Portal. Goulet,

C. A., Mazzoni, S., Silva, F.,

Maechling, P. J., Rathje, E.

M., et al.
Tuttle

3D/4D Seismic Imaging and Their Interpretation for Seismic Hazard...

STUdent: Seismic

Tomography of the Nepal

Himalayas and Geodynamic

Implications for the 2015

Nepal Earthquake. Raoof, J.,

Mukhopadhyay, $S$.

STUDENT: Temporal

Changes of Seismic Velocities

in the San Jacinto Fault Zone

Associated with the 2016

Borrego Springs Earthquake.

Qiu, H., Hillers, G., Ben-

Zion, Y.
Megathrust Earthquakes: Recurrence, Rupture Modes and Tsunamis Session Chairs: Peter Molnar, Peter Haeussler, and Brian F. Atwater (see page 800)

Reconciling Short- and Long-Term Observations of Megathrust Earthquake Cycles at Subduction Zones. Govers, R., Herman, M., Broerse, T., Furlong, K.

INVITED: Subduction Zone Geometry and Its Influence on the Locations of Megathrust Earthquakes. Hayes, G. P., Moore, G., Plescia, $\mathrm{S}$. 


\begin{tabular}{|c|c|c|c|c|}
\hline Time & Brickell & Flagler & Hibiscus $A$ & Hibiscus B \\
\hline \multirow[b]{2}{*}{$2: 45 \mathrm{PM}$} & $\begin{array}{l}\text { Fault to Seismic Hazard } \\
\text { Assessment (Fault2SHA) in } \\
\text { Latin... }\end{array}$ & $\begin{array}{l}\text { Advances in the Theory, } \\
\text { Modeling, and Observation } \\
\text { of Anelastic... }\end{array}$ & $\begin{array}{l}\text { Urban Liquefaction } \\
\text { and Lateral Spread } \\
\text { Investigations... }\end{array}$ & $\begin{array}{l}\text { Environmental } \\
\text { Seismology: Glaciers, } \\
\text { Rivers, Landslides... }\end{array}$ \\
\hline & $\begin{array}{l}\text { INVITED: Seismotectonics } \\
\text { of North Faults of Algeciras } \\
\text { Fault System, Colombia, } \\
\text { from an Analysis of the } \\
\text { Earthquakes That Occurred } \\
\text { during the Period 2016-2017. } \\
\text { Chicangana, G., Bocanegra, } \\
\text { A., Kammer, A., Vargas } \\
\text { Jimenez, C. A., Salcedo, E., } \\
\text { Gomez-Capera, A. A. }\end{array}$ & $\begin{array}{l}\text { INVITED: Estimating Q and } \\
\text { Scattering Using Waveform } \\
\text { Inversion and Imaging. } \\
\text { Kamei, R., Nakata, N. }\end{array}$ & $\begin{array}{l}\text { Urban Liquefaction Mapping } \\
\text { for Water System Seismic } \\
\text { Reliability, Portland, Oregon. } \\
\text { Hitchcock, C., Hoeft, J., } \\
\text { Greenfield, M., McCormick, } \\
\text { E., Brossy, C., Bachhuber, J., } \\
\text { Nisar, A. }\end{array}$ & $\begin{array}{l}20 \text { Years of Landslide } \\
\text { Activity in Alaska from } \\
\text { Automated Machine- } \\
\text { Learning Based Seismic } \\
\text { Detection. Hibert, C., } \\
\text { Michéa, D., Malet, J. P., } \\
\text { Provost, F., Geertsema, M. }\end{array}$ \\
\hline 3:00 PM & $\begin{array}{l}\text { Geological Data as an } \\
\text { Input for Seismic Hazard } \\
\text { Assessment Including Fault } \\
\text { Sources; Example in Central } \\
\text { Ecuador. Baize, S., Audin, } \\
\text { L., Alvarado, A., Beauval, C., } \\
\text { Champenois, J., et al. }\end{array}$ & $\begin{array}{l}\text { INVITED: STUDENT: } \\
\text { Accounting for Attenuation } \\
\text { Physics Uncertainty in FWI. } \\
\text { Keating, S. D., Inannen, K. } \\
\text { A. }\end{array}$ & $\begin{array}{l}\text { Seismic and Liquefaction } \\
\text { Hazard Maps for Lake } \\
\text { County, Northwestern } \\
\text { Tennessee. Cramer, C. H., } \\
\text { Van Arsdale, R. B., Arellano, } \\
\text { D., Pezeshk, S., Horton, S. } \\
\text { P., et al. }\end{array}$ & $\begin{array}{l}\text { INviTED: Repeating } \\
\text { Quakes Detected at } \\
\text { Moosfluh Rockslide (Valais, } \\
\text { Switzerland). Helmstetter, } \\
\text { A., Larose, E., Baillet, L., } \\
\text { Mayoraz, R. }\end{array}$ \\
\hline $3: 15 \mathrm{PM}$ & $\begin{array}{l}\text { A Long-Term Slip Model } \\
\text { for the San Ramón Fault, } \\
\text { Santiago de Chile, from } \\
\text { Tectonically Reconcilable } \\
\text { Boundary Conditions. } \\
\text { Aron, F., Pérez-Estay, N., } \\
\text { Cembrano, J., Yáñez, G. }\end{array}$ & $\begin{array}{l}\text { INVITED: Subsurface } \\
\text { Parameters Estimation } \\
\text { by Taking into Account } \\
\text { Attenuation and Anisotropy. } \\
\text { Moradi, S. A., Innanen, K. } \\
\text { A. }\end{array}$ & $\begin{array}{l}\text { NGL: An Open Source } \\
\text { Global Database for Next- } \\
\text { Generation of Liquefaction } \\
\text { Assessment. Zimmaro, P., } \\
\text { Kwak, D. Y., Brandenberg, S. } \\
\text { J., Stewart, J. P. }\end{array}$ & $\begin{array}{l}\text { Using Freeze Events to } \\
\text { Characterize Two Types } \\
\text { of Lake-Generated Seismic } \\
\text { Signals. Anthony, R. E., } \\
\text { Ringler, A. T., Wilson, D. C., } \\
\text { Aster, R. C. }\end{array}$ \\
\hline $\begin{array}{c}3: 30- \\
4: 15 \mathrm{PM}\end{array}$ & \multicolumn{4}{|c|}{ Posters and Break } \\
\hline \multirow[b]{2}{*}{$4: 15 \mathrm{PM}$} & $\begin{array}{l}\text { Fault to Seismic Hazard } \\
\text { Assessment (Fault2SHA) in } \\
\text { Latin (Central and South) } \\
\text { America (continued) }\end{array}$ & $\begin{array}{l}\text { Advances in the Theory, } \\
\text { Modeling, and Observation } \\
\text { of Anelastic Seismic Wave } \\
\text { Propagation-Recent } \\
\text { Anelastic Models of the } \\
\text { Earth (continued) }\end{array}$ & $\begin{array}{l}\text { Ground Motion and } \\
\text { Earthquake Engineering } \\
\text { Session Chairs: Sinan Akkar } \\
\text { and Thomas Herring(see } \\
\text { page } 797)\end{array}$ & $\begin{array}{l}\text { Environmental } \\
\text { Seismology: Glaciers, } \\
\text { Rivers, Landslides and } \\
\text { Beyond (continued) }\end{array}$ \\
\hline & $\begin{array}{l}\text { Uncertainties in Probabilistic } \\
\text { Seismic Hazard Analysis: A } \\
\text { Case Study from Northern } \\
\text { Chile. Li, F., Hull, A. G., } \\
\text { Martinez, M. E., Rossiter, } \\
\text { M., Lowry, D. }\end{array}$ & $\begin{array}{l}\text { INVITED: Recent } \\
\text { Development of Seismic } \\
\text { Attenuation Modeling and } \\
\text { Imaging in Exploration } \\
\text { Seismology. Zhu, T. }\end{array}$ & $\begin{array}{l}\text { Ground Motion Recordings } \\
\text { from the } 8 \text { August } 2017 \mathrm{Ms} \\
\text { 7.0 Jiuzhaigou Earthquake. } \\
\text { Tao, D. W., Wang, Z., Ma, } \\
\text { Q., Yang, C., Li, S. Y. }\end{array}$ & $\begin{array}{l}\text { INVITED: STUDENT: } \\
\text { Spectral Monitoring of } \\
\text { Rock Arches. Geimer, P. R., } \\
\text { Moore, J. R. }\end{array}$ \\
\hline
\end{tabular}




\begin{tabular}{|c|c|c|c|c|}
\hline Time & Jasmine & Monroe & Orchid $A B$ & Tuttle \\
\hline & $\begin{array}{l}\text { Regional Seismic } \\
\text { Network Approaches and } \\
\text { Stakeholder Collaborations }\end{array}$ & $\begin{array}{l}\text { Advances in Explosion } \\
\text { Seismo-Acoustic Research }\end{array}$ & $\begin{array}{l}\text { Science Gateways and } \\
\text { Computational Tools for } \\
\text { Improving... }\end{array}$ & $\begin{array}{l}\text { Megathrust Earthquakes: } \\
\text { Recurrence, Rupture } \\
\text { Modes and Tsunamis }\end{array}$ \\
\hline $2: 45 \mathrm{PM}$ & $\begin{array}{l}\text { Seismic Monitoring of the } \\
\text { Trans-Alaska Pipeline. } \\
\text { Gardine, M. D., Ruppert, N. } \\
\text { A., West, M. E. }\end{array}$ & $\begin{array}{l}\text { Comparison between } \\
\text { Seismological Characteristics } \\
\text { of Underground Nuclear } \\
\text { Explosions and Subsequent } \\
\text { Cavity Collapses at North } \\
\text { Korea Test Site. Zhao, L. } \\
\text { F., Xie, X. B., Wang, W. M., } \\
\text { Zhao, X., Yao, Z. X. }\end{array}$ & $\begin{array}{l}\text { INVITED: Exploring the } \\
\text { Potential for Hosting a } \\
\text { Geoscience Data Center in } \\
\text { the Cloud. Trabant, C., } \\
\text { Ahern, T., Watson, I., Stults, } \\
\text { M., Weekly, R. T. }\end{array}$ & $\begin{array}{l}\text { INVITED: Missing Great } \\
\text { Earthquakes. Hough, S. E. }\end{array}$ \\
\hline 3:00 PM & $\begin{array}{l}\text { The University of Utah } \\
\text { Seismograph Stations: } \\
\text { Mission and Operations. } \\
\text { Pankow, K. L., Koper, K. } \\
\text { D., Burlacu, R., Pechmann, J. } \\
\text { C., Blycker, W. L., et al. }\end{array}$ & $\begin{array}{l}\text { Shear Motion Generation in } \\
\text { Dry Alluvium Geology: Pre- } \\
\text { Shot Stochastic Simulations } \\
\text { of the Source Physics } \\
\text { Experiments. Ezzedine, S., } \\
\text { Vorobiev, O., Townsend, M., } \\
\text { Antoun, T., Walter, W. R., } \\
\text { Bonner, J. }\end{array}$ & $\begin{array}{l}\text { Displaying Multiple Data } \\
\text { Types in the Geogateway } \\
\text { Public Mapping System } \\
\text { Inclucing a System for Rapid } \\
\text { Surface Fracture Detection in } \\
\text { Raw and Unwrapped Radar } \\
\text { Interferograms. Parker, J. } \\
\text { W., Donnellan, A., Pierce, M. } \\
\text { E., Wang, J. }\end{array}$ & $\begin{array}{l}\text { INVITED: 3-D Simulations } \\
\text { of Megathrust Earthquakes } \\
\text { in Cascadia - Implications } \\
\text { for Strong Ground Motions, } \\
\text { Basin Amplification, and } \\
\text { Coseismic Deformation. } \\
\text { Wirth, E. A., Frankel, A. } \\
\text { D., Marafi, N., Vidale, J. E., } \\
\text { Stephenson, W. J. }\end{array}$ \\
\hline $3: 15 \mathrm{PM}$ & $\begin{array}{l}\text { Collaborative Real-Time } \\
\text { Risk Reduction through } \\
\text { Early Warning and } \\
\text { Earthquake Monitoring with } \\
\text { Stakeholders in Southern } \\
\text { California. Hauksson, E., } \\
\text { Andrews, J., Bhadha, R., Yu, } \\
\text { E., Ross, Z. E., et al. }\end{array}$ & $\begin{array}{l}\text { Near-Field Modeling of the } \\
\text { Source Physics Experiments } \\
\text { (SPE) Phase I. Vorobiev, O. }\end{array}$ & $\begin{array}{l}\text { Developing Software to } \\
\text { Evaluate the Liquefaction } \\
\text { Potential by Using 2D } \\
\text { Numerical Modeling: } \\
\text { Applications. Duque, E. P., } \\
\text { Cruz, D. R., Collahuazo, A. } \\
\text { A., Serrano, R. G., Rojas, H. } \\
\text { V., Briceño, T. C. }\end{array}$ & $\begin{array}{l}\text { Understanding Estimates } \\
\text { of the Location, Size, and } \\
\text { Frequency of Cascadia's } \\
\text { Megathrust Earthquakes. } \\
\text { Gomberg, J., The Cascadia } \\
\text { Recurrence Project Team }\end{array}$ \\
\hline
\end{tabular}

$3: 30-$

$4: 15 \mathrm{PM}$

:15 PM

\section{Regional Seismic}

Network Approaches and Stakeholder Collaborations (continued)

Keeping Tabs on Oklahoma Seismicity: The Oklahoma Geological Survey Regional Network. Walter, J. I., Chang, J. C.
Posters and Break
Advances in Explosion

Seismo-Acoustic Research (continued)

INVITED: Upper

Stratosphere Wind

Variations and Their Effect on Regional Infrasound

Propagation. Lees, J. M., Bowman, D. C.
Megathrust Earthquakes: Recurrence, Rupture Modes and Tsunamis (continued)

STUdent: Newly Detected, Small Earthquakes to Delineate Fault Heterogeneities in the Cascadia Seismogenic Zone. Morton, E. A., Bilek, S. L., Rowe, C. A. 


\begin{tabular}{|c|c|c|c|c|}
\hline Time & Brickell & Flagler & Hibiscus $A$ & Hibiscus $B$ \\
\hline \multirow[b]{2}{*}{$4: 30 \mathrm{PM}$} & $\begin{array}{l}\text { Fault to Seismic Hazard } \\
\text { Assessment (Fault2SHA) in } \\
\text { Latin... }\end{array}$ & $\begin{array}{l}\text { Advances in the Theory, } \\
\text { Modeling, and Observation } \\
\text { of Anelastic... }\end{array}$ & $\begin{array}{l}\text { Ground Motion and } \\
\text { Earthquake Engineering }\end{array}$ & $\begin{array}{l}\text { Environmental } \\
\text { Seismology: Glaciers, } \\
\text { Rivers, Landslides... } \\
\end{array}$ \\
\hline & $\begin{array}{l}\text { Ground Motion Estimation } \\
\text { of Recently Identified } \\
\text { Crustal Faults in Central } \\
\text { Chile. Crempien, J. G. F., } \\
\text { Aron, F., Santibáñez, I., } \\
\text { Seguel, M. }\end{array}$ & $\begin{array}{l}\text { Physical Models of Rock } \\
\text { Anelasticity. Morozov, I. B. }\end{array}$ & $\begin{array}{l}\text { GPS Measurements of } \\
\text { Large Oscillations of a Tall } \\
\text { Building due to a Magnitude } \\
\text { 7.3 Earthquake. Herring, } \\
\text { T., Gu, C., Toköz, M. N., } \\
\text { Büyüköztürk, O., Parol, } \\
\text { J., Al-Enezi, A., Al-Jeri, F., } \\
\text { Al-Qazweeni, J., Kamal, H. }\end{array}$ & $\begin{array}{l}\text { STUDENT: Tracking } \\
\text { Groundwater Levels Using } \\
\text { the Ambient Seismic Field. } \\
\text { Clements, T. H., Denolle, } \\
\text { M. A. }\end{array}$ \\
\hline 4:45 PM & $\begin{array}{l}\text { Seismic Evidence for } \\
\text { Complex Faulting through } \\
\text { the Gulf of Guayaquil. } \\
\text { Régnier, M., Ponce, G., } \\
\text { Alvarado, A., Saillard, M., } \\
\text { Audin, L., et al. }\end{array}$ & $\begin{array}{l}\text { STUDENT: Exploring the } \\
\text { Extent of Wave Propagative } \\
\text { Effects on Teleseismic } \\
\text { Attenuation Measurements } \\
\text { within the Sierra Nevada. } \\
\text { Bernardino, M. V., Jones, } \\
\text { C. H. }\end{array}$ & $\begin{array}{l}\text { What Does a 1000-s or More } \\
\text { Tall Building Response } \\
\text { Record Mean? Celebi, M. K. }\end{array}$ & $\begin{array}{l}\text { STUDENT: Tracking } \\
\text { Tropical Cyclones } \\
\text { with Backprojection. } \\
\text { Lamontagne, A. M., } \\
\text { Tanimoto, T., Anderson, A. }\end{array}$ \\
\hline 5:00 PM & $\begin{array}{l}\text { STUDENT: Spatiotemporal } \\
\text { Seismic Hazard and Risk } \\
\text { Assessments for Large } \\
\text { Aftershocks Triggered by } \\
\text { Mega-Thrust Subduction } \\
\text { Earthquakes in Japan. } \\
\text { Zhang, L., Werner, M. J., } \\
\text { Goda, K. } \\
\end{array}$ & $\begin{array}{l}\text { Finite-Frequency } \\
\text { Tomography of 3-D } \\
\text { Attenuation Using Rayleigh } \\
\text { Waves Recorded by OBS } \\
\text { Array. Ruan, Y., Forsyth, D. } \\
\text { W., Bell, S. W. }\end{array}$ & $\begin{array}{l}\text { STUDENT: Nonlinear } \\
\text { Seismic Soil-Structure } \\
\text { Interaction Analysis of } \\
\text { Long-Span Railway Bridge } \\
\text { Subjected to Different } \\
\text { Earthquake Ground } \\
\text { Motions. Faizan, A. A., } \\
\text { Kirtel, O. } \\
\end{array}$ & $\begin{array}{l}\text { Near-Surface Elastic Changes } \\
\text { in the Ross Ice Shelf Arising } \\
\text { from Transient Storm and } \\
\text { Melt Forcing Observed with } \\
\text { High-Frequency Ambient } \\
\text { Seismic Noise. Chaput, J. A., } \\
\text { Aster, R. C., Baker, M. G., } \\
\text { Gerstoft, P., et al. }\end{array}$ \\
\hline 5:15 PM & $\begin{array}{l}\text { Ground Motion in Kuwait } \\
\text { from Regional and Local } \\
\text { Earthquakes: Potential } \\
\text { Effects on Tall Buildings. } \\
\text { Gu, C., Prieto, G. A., } \\
\text { Al-Enezi, A., Al-Jeri, F., } \\
\text { Al-Qazweeni, J., et al. } \\
\end{array}$ & $\begin{array}{l}\text { Anisotropic Attenuation } \\
\text { in Rocks: Theory and Lab } \\
\text { Measurements. Vavrycuk, } \\
\text { V., Svitek, T., Lokajicek, T., } \\
\text { Petruzalek, M., Kern, H. }\end{array}$ & $\begin{array}{l}\text { A Study to Define the Long- } \\
\text { Period Corner Periods for } \\
\text { Code-Based Displacement } \\
\text { Spectrum. Akkar, S., Kale, } \\
\text { O. }\end{array}$ & $\begin{array}{l}\text { Active-Source Investigations } \\
\text { of Lemon Creek Glacier, } \\
\text { Alaska, Using Nodal } \\
\text { Seismometers and a Betsy } \\
\text { Seismic Gun Source. Veitch, } \\
\text { S. A., Karplus, M., Kaip, G., } \\
\text { Graves, E., Schalk, J., et al. }\end{array}$ \\
\hline $\begin{array}{r}5: 30- \\
6: 00 \mathrm{PM}\end{array}$ & \multicolumn{4}{|c|}{ Pint and Poster } \\
\hline $\begin{array}{r}6: 00- \\
7: 00 \mathrm{PM}\end{array}$ & \multicolumn{4}{|c|}{ Lightning Talks } \\
\hline $\begin{array}{r}6: 00- \\
7: 00 \mathrm{PM}\end{array}$ & \multicolumn{4}{|c|}{ Special Interest Group } \\
\hline $\begin{array}{r}7: 00- \\
9: 00 \mathrm{PM}\end{array}$ & \multicolumn{4}{|c|}{ Early Career and Student Reception } \\
\hline
\end{tabular}

\section{Poster Sessions}

3D/4D Seismic Imaging and Their Interpretation for Seismic Hazard Assessment (see page 816)

1. Student: Seismic Structure of the Río De La Plata Craton from Surface Wave Tomography. Balestrini, F. I., Rosa, M. L.
2. Student: Crustal Structure in the Pantanal and Chaco Basin from Receiver Function. Rivadeneyra-Vera, J. C., Bianchi, M.

3. Joint Inversion of Rayleigh Waves Dispersion Curves and Ps-Receiver Functions in Libya for Crustal Thickness and 1D Shear Wave Velocity Model. Sosa, U. A., Agail, A., Velasco, A. A., Zamora, A.

4. Student: Crustal Structure of the Amazonian Craton and Adjacent Provinces in Brazil. Albuquerque, D. F., 


\begin{tabular}{|c|c|c|c|c|}
\hline Time & Jasmine & Monroe & Orchid $A B$ & Tuttle \\
\hline & $\begin{array}{l}\text { Regional Seismic } \\
\text { Network Approaches and } \\
\text { Stakeholder Collaborations }\end{array}$ & $\begin{array}{l}\text { Advances in Explosion } \\
\text { Seismo-Acoustic Research }\end{array}$ & & $\begin{array}{l}\text { Megathrust Earthquakes: } \\
\text { Recurrence, Rupture } \\
\text { Modes and Tsunamis }\end{array}$ \\
\hline \multirow[t]{2}{*}{ 4:30 PM } & $\begin{array}{l}\text { Meeting Alaska's Earthquake } \\
\text { Needs in 2018. West, M. E., } \\
\text { Ruppert, N. A., Gardine, M. } \\
\text { D., Suleimani, E., Dickson, I., } \\
\text { Buurman, H., Gardine, L. }\end{array}$ & $\begin{array}{l}\text { Assessment of Infrasound } \\
\text { Signals Recorded on } \\
\text { Single Seismometers and } \\
\text { Infrasound Arrays in the } \\
\text { Western United States Using } \\
\text { Ground Truth Sources. Park, } \\
\text { J., Hayward, C., Stump, B. } \\
\text { W. }\end{array}$ & & $\begin{array}{l}\text { INVITED: Microfossil } \\
\text { Measures of Subsidence } \\
\text { During Past Plate-Boundary } \\
\text { Earthquakes: Their Accuracy } \\
\text { Revealed by a Sudden Tidal- } \\
\text { Flooding Experiment in } \\
\text { Cascadia. Dura, T., Horton, } \\
\text { B. P., Milker, Y., Wang, K., } \\
\text { Bridgeland, W. T., et al. }\end{array}$ \\
\hline & $\begin{array}{l}\text { The Lamont-Doherty } \\
\text { Cooperative Seismographic } \\
\text { Network (LCSN) Service to } \\
\text { Education and Community. } \\
\text { Kim, W. Y., Gold, M., } \\
\text { Ramsay, J. }\end{array}$ & $\begin{array}{l}\text { Estimating Scaled Depth of } \\
\text { Burial from Acoustic Period. } \\
\text { Bowman, D. C. }\end{array}$ & & $\begin{array}{l}\text { Evidence for Segmented } \\
\text { Ruptures in Cascadia, an } \\
\text { Analysis of Alternatives. } \\
\text { Goldfinger, C., Black, B., } \\
\text { Enkin, R., Hamilton, T., } \\
\text { Hausmann, R. B., et al. }\end{array}$ \\
\hline 5:00 PM & $\begin{array}{l}\text { One Year of Texas } \\
\text { Seismological Network } \\
\text { Seismic Data. Savvaidis, A., } \\
\text { Huang, D., Young, B. E. }\end{array}$ & $\begin{array}{l}\text { Seismo-Acoustic Analysis of } \\
\text { Chemical Explosions at the } \\
\text { Nevada National Security } \\
\text { Site. Pasyanos, M. E., Kim, } \\
\text { K. }\end{array}$ & & \multirow[t]{2}{*}{$\begin{array}{l}\text { INVITED: A 6,600-Year } \\
\text { Historic and Stratigraphic } \\
\text { Record of } 9 \text { Giant } \\
\text { Megathrust Earthquakes } \\
\text { and the Seismic Cycle at the } \\
\text { Copper River Delta, Alaska. } \\
\text { Plafker, G., Haeussler, P. J., } \\
\text { Witter, R. C., Sherrod, B. }\end{array}$} \\
\hline 5:15 PM & $\begin{array}{l}\text { The Berkeley Digital Seismic } \\
\text { Network. Hellweg, M., } \\
\text { Allen, R. M., Taira, T., } \\
\text { Henson, I., Uhrhammer, R. } \\
\text { A., Zuzlewski, S. }\end{array}$ & $\begin{array}{l}\text { Interactive Block } \\
\text { Thresholding for Seismic } \\
\text { Signal Processing. Langston, } \\
\text { C. A., Mousavi, S. M. }\end{array}$ & & \\
\hline $\begin{array}{r}5: 30- \\
6: 00 \mathrm{PM}\end{array}$ & \multicolumn{4}{|c|}{ Pint and Poster } \\
\hline $\begin{array}{r}6: 00- \\
7: 00 \mathrm{PM}\end{array}$ & \multicolumn{4}{|c|}{ Lightning Talks } \\
\hline $\begin{array}{r}6: 00- \\
7: 00 \mathrm{PM}\end{array}$ & \multicolumn{4}{|c|}{ Special Interest Group } \\
\hline $\begin{array}{r}7: 00- \\
9: 00 \mathrm{PM}\end{array}$ & \multicolumn{4}{|c|}{ Early Career and Student Reception } \\
\hline
\end{tabular}

França, G. S., Moreira, L. P., Assumpção, M., Bianchi, M., Barros, L. V., Quispe, C. C., Oliveira, M. E.

5. Seismic Structures beneath the Oklahoma Region and the Eastern Tennessee Seismic Zone. Chai, C., Maceira, M., Delorey, A. A., Johnson, P. A., Ammon, C. J., Herrmann, R. B.

6. Student: Seismic Anisotropy and Mantle Dynamics beneath the Arabian Plate. Qaysi, S. I., Liu, K., Gao, S.
7. Student: Rayleigh Wave Group-Velocity across the Southern United States from Ambient Noise Tomography. Barman, D., Pulliam, J., Quiros, D. A.

8. Student: Crustal Structure Across the Appalachian Basin Using Joint Inversion of P-Wave Receiver Functions and Surface Wave Dispersion. Homman, K. A., Nyblade, A. A. 
9. Student: Development of a 3D Seismic Velocity Model of the Bengal Basin and Adjacent Regions. Huda, M. M., Taborda, R.

Advances in Explosion Seismo-Acoustic Research (see page 818 )

10. Local Monitoring of Underground Mining Explosions at Redmond, Utah. Downey, N. J., Albert, S. A., Arrowsmith, S. J.

11. Seismic and Infrasound Analysis of Rocket Launches and Explosions at Kennedy Space Center. Thompson, G., McNutt, S. R., Braunmiller, J., Brown, R. G., Farrell, A. K., Mehta, C. A., Steffan, C. K.

12. An Alternative Detection Model for Waveform Correlation. Ganter, T., Sundermier, A., Ballard, S.

13. Regional 3-D Geophysical Characterization of the Nevada National Security Site. Preston, L., Poppeliers, C., Schodt, D.

14. Application and Validation of a Relative Relocation Technique for Explosion Monitoring. Begnaud, M. L., Anderson, D. N., Blom, P. S., Euler, G. G., Phillips, W. S., Rowe, C. A., Pabian, F.

15. Student: Low Yield Seismic Source Analysis Using Local and Regional Observations. Kintner, J. A., Ammon, C. J., Homman, K. A., Nyblade, A. A.

16. Underground Explosions in Anisotropic Media: Coupling of Near- and Far-Field Motions and Implications for SPE. Hirakawa, E. T., Ezzedine, S.

17. Finite-Difference Algorithm for 3D Orthorhombic Elastic Wave Propagation. Jensen, R. P., Preston, L.

18. Analysis of 3-Component Rotational and Translational Ground Motions from SPE Chemical Explosions, Historical Nuclear Explosions and Earthquakes. Ichinose, G. A., Mellors, R. J., Ford, S. R., Abbott, R. E.

Advances in Seismic Site Response Studies Given Limitations in Understanding of Site Conditions (see page 820)

19. Student: Evaluating Inversion Techniques for Soft Sites in Windsor, Ontario, Canada. Sharma, H. S., Molnar, S., Darko, A. B.

20. Student: Understanding the Variations in Shear Wave Splitting Measurements Using Empirical and Simulated Seismic Waveforms. Graham, K. M., Savage, M. K., Arnold, R., Zal, H. J.

21. Lateral Variations in Vs30 at Six Sites Near Napa, California. Catchings, R. D., Goldman, M. R., Chan, J. H.

22. STUdent: Insights into the Influence of Local Site Amplification on Magnitude Determination: Key Observations and Modeling Using the Stochastic Method. Holt, J., Edwards, B.

23. Student: Basin Effects in Kathmandu Valley, Nepal, during Strong Ground Motion of 2015 Gorkha
Earthquake Using Kinematic Source Model. Ayoubi, P., Asimaki, D.

24. Student: Adjustments of the Amplification Factors for Site Response in Israel Based on Average Shear Wave Velocity and Peak Frequency. Baram, A., Kamai, R., Yagoda-Biran, G.

25. Student: Bedrock Site Conditions and Kappa in Charlevoix, Quebec. Palmer, S. M., Atkinson, G. M.

26. A Bayesian Application of SPAC to Resolve Vs30 Using Nodal Seismic Instruments. Zhang, H., Pankow, K. L.

27. Student: Application of Active- and Passive-Seismic Array Techniques at Hard Rock Sites in Eastern Canada. Ladak, S., Molnar, S., Atkinson, G. M., Palmer, S.

28. Improving the Potential of the $\mathrm{H} / \mathrm{v}$ Spectral Ratio Technique by Using the Coda of Seismic Noise Autocorrelations. Tchawe Nziaha, F., Froment, B., Campillo, $\mathrm{M}$.

29. Comparison of S-Wave HVSR from Earthquake Recordings and 1-D Site Response Modeling. Carpenter, N. S., Wang, Z., Woolery, E. W.

30. Student: Investigating Basin Amplification Factors for Shaking in the Reno, Nevada, Region for Local and Regional Events. Dunn, M., Louie, J., Smith, K. D., Dickenson, $S$.

31. Numerical Simulation of Microtremor Array Measurements at 2D and 3D Structures Using 3D Finite-Difference Method. Hayashi, K. H., Suzuki, H. S., Ryu, E. R., Tahara, M. T.

32. Comparison of Vs30 Determined from Rayleigh Waves and Love Waves at Six Strong Ground Motion Sites in Napa, California. Chan, J. H.

Ground Motion and Earthquake Engineering (see page 823)

33. Assessment of Code-Based Vertical Spectrum Functional Forms. Kale, O., Akkar, S.

Environmental Seismology: Glaciers, Rivers, Landslides and Beyond (see page 823)

34. Seismic Signatures of Changing Water Resources. Syracuse, E. M., Delorey, A. A., Muir, J.

35. Wave-Driven Ice Shelf Rift Propagation. Lipovsky, B. P.

36. Neotectonics. Gomes, A. A., Assumpção, M.

37. Student: Landslide Micro-Seismicity: Description and Classification of Seismic Sources. Provost, F., Malet, J. P., Hibert, C., Helmstetter, A., Amitrano, D.

38. Repeating Quakes Triggered by Snow-Falls at Gugla Rock-Glacier: Transition between Stable Slip and StickSlip? Helmstetter, A., Lipovsky, B. P., Larose, E., Baillet, L., Mayoraz, R.

39. Seismic Observations Following the July 2017 Pasco County, West Florida, Sinkhole Collapse. Braunmiller, J., Thompson, G., McNutt, S. R., Dorn, K. M., Graybeal, D., Farrell, A. K., Collins, L. D., Doering, T., Eilers, 
D., Gonzales, J., Kiflu, H. G., Kruse, S., Landry, S., Robinson, T., Speed, G., McKenzie, R.

40. Seismic Monitoring of the Rattlesnake Ridge Rockslide, Union Gap, Washington. Moore, J. R., Geimer, P. R. Burjánek, J., Gibbons, D. A., Malone, S. D.

41. The Exotic Seismic Events Catalog (ESEC) Data Product. Bahavar, M., Van Fossen, M., Allstadt, K. E., Malone, S. D., Trabant, C.

Fault to Seismic Hazard Assessment (Fault2SHA) in Latin (Central and South) America (see page 825)

42. Estimation of Seismic Source Recurrence Parameters without Knowledge of Time-Varying Level of Completeness. Kijko, A., Smit, A.

43. Student: Structural Architecture of the Western Transverse Ranges and Potential for Large Earthquakes - Trishear Forward Models. Levy, Y., Rockwell, T. K., Shaw, J. H., Plesch, A., Driscoll, N. W., Perea, H.

44. Temporal Patterns of Earthquakes: Devil's Staircases and the Possible Causes. Liu, M., Chen, Y., Luo, G.

45. From the Seismic Cycle to Long-Term Deformation: Linking Seismic Coupling and Quaternary Coastal Geomorphology along the Andean Megathrust. Saillard, M., Audin, L., Rousset, B., Avouac, J. P., Chlieh, M., Hall, S. R., Husson, L., Farber, D. L.

46. Student: Investigation of $\mathrm{H} / \mathrm{V}$ Spectral Ratio (HVSR), Spectral Decay Parameter ( $\kappa)$, and StrongMotion Duration Based on a Ground-Motion Database of Chilean Subduction-Zone Earthquakes. Yang, S., Mavroeidis, G. P., Sonnemann, T., Halldorsson, B., Hrafnkelsson, B., de la Llera, J. C., Aguirre, P., Poulos, A.

47. FAULT2SHA Working Group: Linking Faults to Seismic Hazard Assessment. Scotti, O., Peruzza, L.

48. Exposure of Chilean Tailings to Earthquake Hazards from Potentially Seismogenic Crustal Faults. Edwards, S., Aron, F., Cembrano, J., Crempien, J. G. F., Gardner, J., Nazar, R., Ovalle, C., Santibáñez, I.

49. Sensitivity of Seismic Hazard Assessments to Earthquake Catalogue Quality. Onur, T., Gok, R., Godoladze, T.

50. Seismic Hazard Assessment of the Kashmir Basin, Northwestern Himalaya: A Probabilistic Approach. Sana, $\mathbf{H}$.

51. Probabilistic Seismic Hazard Assessment for Large Dam Area, Georgia (Sakartvelo) Case. Tsereteli, N. S., Varazanashvili, O., Arabidze, V., Gogoladze, Z.

52. A New Seismic Hazard Model for Mainland China. Rong, Y., Xu, X., Magistrale, H., Cheng, J., Chen, G., Shen, Z.

53. Historical Records of Seismic Activities in Coxim, Pantanal Wetlands. Silva, L. J., Assumpção, M., Facincani, E. M., Pereira, W. P., Dourado, G. F.
Interaction Between Observations and Models in

Seismo-Volcanic Studies (see page 827)

54. Student: Earthquake Stress Changes before, during, and after the 2015 Eruption at Axial Seamount. Moyer, P. A., Boettcher, M. S., Bohnenstiehl, D. R.

55. Student: Earthquake Detection and High-Resolution Body-Wave Tomography at Okmok Volcano, Alaska. Hart, L. A., Bennington, N. L., Lanza, F., Roecker, S. W., Haney, M. M., Key, K. W.

56. Unrest at Masaya and Momotombo Volcano, Nicaragua, Investigated with a Temporary Seismic Network. Obermann, A., Molinari, I., Grigoli, F., Strauch, W., Wiemer, S.

57. Coda Wave Interferometry, Cross-Terms Analysis of EGF at Popocatepetl Volcano, Mexico. Cardenas-Soto, M., Reyes-Pimentel, T. A.

58. The Volcano-Tectonic Seismicity of Teide Volcano (Tenerife). Padilla, G. D., Barrancos, J., Burns, F., Cabrera Peréz, I., D’Auria, L., García-Hernández, R., Morales, C., Przeor, M., Soubestre, J., Peréz, N.

59. Upper Crustal Structure of the Ceboruco Volcano (Mexico) Revealed by Ambient Seismic Noise Tomography. De Plaen, R. S. M., Leon, E., NúñezCornú, F. J., Núñez Escribano, D., Sandoval, J. M.

60. Student: Ambient Noise Tomography of Okmok Volcano, Alaska. Miller, D. J., Bennington, N. L., Haney, M. M., Key, K. W.

61. Student: Analysis of Reflected Body Wave Phases at the Altiplano-Puna Magma Body near Uturuncu Volcano, Bolivia. Farrell, A. K., McNutt, S. R., Thompson, G.

62. Seismic and Acoustic Monitoring at Volcán De Colima, Mexico. Arámbula, R.

63. Student: Toward an Automatic Recognition System Based on Machine Learning Techniques at Cotopaxi Volcano. Bautista, M. A., Lara-Cueva, R. A., Larco, J. C., Benítez, D. S., Ruiz, M. C.

64. Student: Evolution of Harmonic Tremor Coda Associated to Lp Events Recorded Previous to the January 4th, 2010, Eruption and 2016 Eruptive Cycle at Turrialba Volcano (Costa Rica). van der Laat, L., Mora, M., Pachecho Alvarado, S. F., Cornejo, G.

65. Student: Spectral Analysis for Characterizing Microseisms Produced in the Cotopaxi Volcano. Aguinaga, D. S., Lara-Cueva, R. A., Ruiz, M. C., Benítez, D.S.

66. Identifying Changes in Magmatic Activity at Veniaminof Volcano, Alaska, over Multiple Eruptive Cycles via Ambient Noise Interferometry. Bennington, N. L., Haney, M. M.

67. Western Eger Rift in Central Europe: Active Magmatic Emplacement from Combined Seismological and Isotope Study. Hrubcova, P., Geissler, W. H., Braeuer, K., Vavrycuk, V., Kaempf, H.

68. Earthquake-Volcano Conversations at Volcán Guagua Pichincha, Ecuador. Hernandez, S., Ruiz, M. C. 
69. Microseismicity Studies in Chacana Megacaldera. Córdova, A. E., Ruiz, M. C., Segovia, M. R.

70. Student: Analysis of the Seismicity in the Los Humeros Mexican Geothermal Field within the Framework of the Consortium Gemex. Oregel, L., Figueroa-Soto, A., Calo, M., Jousset, P., Márquez-Ramírez, V. H.

71. Student: Clarifying the Velocity Structure of the Yellowstone Volcanic System. Cronin, R. A., Bennington, N. L., Farrell, J.

72. STudent: Hidden Markov Models (HMM) Applied to Primary Processing of the Seismicity Activity of Nevado Del Huila Volcano, Colombia. Trujillo-Castrillón, N., Valdés-González, C. M.

73. Student: Spatio-Temporal Distribution of VolcanicTectonic Swarms in the Northern Interandean Valley, Ecuador. García, A. P., Hernandez, S., Ruiz, A. G., Plain, M. J., Cordova, A. E., Ruiz, M. C.

74. What Caused the Local Stress Perturbation in Long Valley, California? Lin, G., Christian, F., Amelung, F.

75. Student: Using SAR Data to Monitor the Dynamics of Ecuadorian Volcanoes. Mirzaee, S., Amelung, F., Ruiz, M. C., Mothes, P. A.

76. Active Source Seismic Imaging of the Magmatic Plumbing System beneath Mount St. Helens. Levander, A. R., Kiser, E. D., Schmandt, B., Hansen, S. M., Creager, K. C.

Numerical Modeling of Earthquake Ground Motion, Rupture Dynamics and Seismic Wave Propagation (see page 832)

77. Jizhaigou Ms 7.0 Earthquake High-Frequency Ground Motion Simulation and Zhangzha Town Intensity Estimation. Chen, $\mathbf{X}$.

78. Deterministic Waveform Modeling to Aid Gmpe Development in Areas of Induced Seismicity, the Importance of Kinematic Finite Faults. Zurek, B. D., Burnett, W. B., deMartin, B.

79. Applications of the Generalized Finite Differences Method in Viscoelastic Media. Salete, E., Ureña, M., Benito, J. J., Ureña, F., Gavete, L.

80. Student: Comparison of Observed and Synthetic Dynamic Ground Strains and Rotations in the NearFault Region of the 2004 Parkfield Earthquake. Cao, Y., Mavroeidis, G. P., Ashoory, M.

81. The SCEC Broadband Platform: Open-Source Software for Strong Ground Motion Simulation and Validation. Silva, F., Maechling, P. J., Goulet, C. A., Vidale, J. E.

82. Student: Differentiating the P and SV Contribution to the Vertical Ground Motions, Using 3D WavePropagation Simulations. Frid, M., Kamai, R.

83. Simulation of Strong Ground Motion for Northeastern Region of India Using Empirical Green's Function Method. Sharma, B., Miyake, H., Yokoi, T., Hayashida, T., Mishra, O. P.
84. Near-Fault Broadband Ground Motion Simulations of the 2016 Meinong, Taiwan, Earthquake. Diao, H., Miyake, H., Koketsu, K.

85. Student: A New Ground-Motion Model for Iran. Farajpour, Z., Pezeshk, S., Zare, M., Zafarani, H.

86. Student: Numerical Simulations of Stress Variations with Depth near the Brittle-Ductile Transition of a Strike-Slip Fault. Abolfathian, N., Johnson, C. W., BenZion, Y.

87. Studying the Shear Resistance Response to Rapid Normal-Stress Variations near the Free Surface on Experimental Thrust Faults. Tal, Y., Lapusta, N., Rubino, V., Rosakis, A.

88. Student: The Effect of Small-Scale Random Heterogeneities in Local Surface Sedimentary Structures on Spatial Variability of Earthquake Ground Motion. Stripajova, S., Kristek, J., Moczo, P., Bard, P. Y., Hollender, F.

89. The 2017 Kos-Bodrum Earthquake. Cakti, E., Sesetyan, K., Alcik, H., Hancilar, U.

90. Salvus: A High-Performance Software Suite for FullWaveform Modelling and Inversion. Afanasiev, M., Boehm, C., van Driel, M., Krischer, L., Fichtner, A.

Onshore Quaternary and Contemporary Tectonics:

Implications for Seismic Hazards (see page 835)

91. Geophysical Imaging of a Near-Surface Fault System at Billecocha High Plateau, Ecuador. Pacheco, D. A., Saqui, D. C., Alvarado, A., Barros, J. G., Espín, P. A., Santo, N. J., Viracucha, C. R.

92. Student: Earthquake-Induced Landslides Estimates Based on Ground Motion Parameter Maps for Central Mexico. Valencia, D. I., Ramírez-Guzmán, L.

93. Student: Sequence Stratigraphy of Upper Paleogene to Neogene Carbonates Exposed from Guánica Bay to Guayanilla, Southern Puerto Rico. Flores, V. E., Santos, $\mathrm{H}$.

The Next Big Earthquake: The Usual and the Unusual

Suspects (see page 832)

94. Repeated Earthquake Uplift at Icy Point, Glacier Bay National Park, Alaska: Strain Partitioning at a Restraining Bend in the Fairweather Fault? Witter, R. C., Kelsey, H. M., Bender, A. M., Scharer, K. M., Lease, R. O.

95. Preliminary Paleoseismology of the Buffalo Bowl Trench Site on the Teton Fault. DuRoss, C. B., Gold, R. D., Briggs, R. W., Delano, J. E., Ostenaa, D. A., Zellman, M. S., Scharer, K. M., McPhillips, D., Cholewinski, N., Hetzel, R., Hampel, A., Wittke, S.

96. What Is the Source Fault of the 1562 Earthquake in the Dominican Republic? Scharer, K. M., Prentice, C. S., DeLong, S. B., Gold, R. D., Peña, L.

97. A Paleoseismic Investigation of the Northern Teton Fault at the Steamboat Mountain Trench Site, Grand Teton 
National Park, Wyoming. Zellman, M. S., DuRoss, C. B., Thackray, G. D., Briggs, R. W., Cholewinski, N., Reyes, T., Patton, N., Mahan, S. A.

Regional Seismic Network Approaches and Stakeholder Collaborations(see page 837 )

98. Improvements to CISN Ground-Motion Packet Association Scheme. Hagos, L., Haddadi, H., Baltay, A. S., Hellweg, M., Stephens, C.

99. Student: Ana-Net Seismic Network: Eskisehir and Bursa, Turkey. Mutlu, S. M., Tün, M. T., Pekkan, E. P., Güney, Y. G.

100. Student: The Jalisco Seismic Accelerometric Telemetric Network (RESAJ). Sandoval, J. M., Núñez Cornú, F. J., Alarcon, E., Suarez-Plascencia, C., Núñez Escribano, D., Trejo-Gomez, E., Gomez, A.

101. Student: Seismometer Orientation of the Broadband Network of the Mexican Servicio Sismológico Nacional. Pérez-Velázquez, M. A., Pérez-Campos, X., Estrada, J. A., Cruz, J. L., Hurtado, A., Navarro Estrada, F., Mendoza Carvajal, A. J.

102. Student: Noise and Detection Levels of the Seismic Network of the Mexican Servicio Sismológico Nacional. Montoya Quintanar, E., Pérez-Campos, X., Cardenas Monroy, C., Espíndola, V. H., Pérez, J., Estrada, J. A., Bello, D. I., Cárdenas, A., Contreras Ruiz Esparza, M. G., Cruz, J. L., González Ávila, D., González-López, A., Hurtado, A., Mendoza Carvajal, A. J., Navarro Estrada, F., Rodríguez Rasilla, I., Tan, Y., Vela Rosas, M. A., Maldonado, R.

103. Student: Seismicity in Pennsylvania and the Pennsylvania State Seismic Network. Homman, K. A., Nyblade, A. A.

104. xQuake: Re-Imagining Regional Network Operations. Johnson, C. E.

105. Development of the Red Sísmica Canaria (C7). Barrancos, J., Padilla, G. D., D’Auria, L., GarcíaHernández, R., Cabrera Peréz, I., Soubestre, J., Hernández, P. A., Melian, G., Padrón, E., Peréz, N.

106. Preserving Seismic Data at the University of Utah Seismograph Stations. Rusho, J. A., Burlacu, R., Blycker, W. L., Drobeck, D. L., Hatch, C. S., Pankow, K. L., Koper, K. D.

107. The Northern California Seismic System: History, Operations, and Upgrades to Seismic Monitoring for Earthquake Early Warning. Terra, F., Hellweg, M., Croker, D., Gee, L.

108. Monitoring and Early Warning Center for Earthquakes and Tsunamis at INETER, Nicaragua - 2018. Tenorio, V., Strauch, W., Talavera, E., Arguello-Miranda, G. S., Ramirez, J., Sanchez, J., Herrera, M., Acosta, A., Morales, A., Flores, P., Guzman, C., Garcia, F., Namendi, D., Guzman, J. C.
109. Station and Telemetry Impact Metrics for Earthquake Early Warning Seismic Network Performance Evaluation. Biasi, G. P., Alvarez, M. G.

110. Reclamation Dam Safety Office - Strong Motion Monitoring Program. Meremonte, M., Besana-Ostman, G., Schwarzer, J., Snover, D., Maybin, N., Nakamura, S.

Science Gateways and Computational Tools for Improving Earthquake Research (see page 840)

111. Sensor Suite: The Albuquerque Seismological Laboratory Instrumentation Testing Suite. Holland, A. A., Kearns, A., Ringler, A. T., Holland, J., Storm, T., Wilson, D. C.

112. Design and Status of a Next Generation Miniseed Format. Clinton, J. F., Trabant, C., Krischer, L., FDSN WGII, A.

113. Using GeoGateway to Reveal Fracture-Advancing Step Tectonics following the $2010 \mathrm{Mw} 7.2$ El Mayor-Cucapah Earthquake. Donnellan, A., Parker, J. W., Heflin, M., Lyzenga, G. A., Grant Ludwig, L., Rundle, J. B., Wang, J., Pierce, M. E.

114. MSNoise-Not Only dv/v! (and ObsPy). Lecocq, T., Mordret, A., Krischer, L.

115. Parsing and Transforming Textual Seismic Data Using Parser Generators. MacCarthy, J. K.

Tsunami Modeling and Hazard Assessment (see page 954)

116. Student: Run-up Estimation Using Non-Uniform Stochastic Sources: The South American Subduction Zone. Medina, M., Riquelme, S., Fuentes, M. A., Hayes, G. P., Moore, G.

117. Modeling the Tsunami Potential along the Pacific Coast of Central America. Chacon-Barrantes, S. E., ZamoraSauma, N., Mendoza-Garcia, D. P.

118. A Working Group on Tsunami Source Synthesis for Hazards Mitigation in the United States. Ross, S. L., Eble, M. C., Nicolsky, D. J., Wilson, R. I., Ryan, K. J.

119. Operational Significance of the Quality of the Earthquake Source Parameters Listed in the Pacific Tsunami Warning Center's Observatory Messages versus the Tsunami Bulletins That Followed. Sardiña, V. H. R., Weinstein, S. A.

120. Student: Speeding Up and Boosting Tsunami Warning Alerts in Chile. Fuentes, M. A., Riquelme, S., Arriola, S.

121. Student: Modeling Tsunami Inundation Effects from a Hypothetical Submarine Landslide from the Arecibo Amphitheater on the Coastal San Juan Metropolitan Area. Feliciano-Centeno, L. M., López-Venegas, A.

122. Invited: Honduras Tsunami Evacuation Maps, Plans, Procedures (Tempp). Torres Bernhard, L. E., Escobar, J. J., Cardona, A. J. 
Wednesday 16 May-Oral Sessions

\begin{tabular}{|c|c|c|c|}
\hline Time & Brickell & Flagler & Hibiscus A \\
\hline & $\begin{array}{l}\text { Exploring Rupture } \\
\text { Dynamics and Seismic } \\
\text { Wave Propagation along } \\
\text { Complex Fault Systems } \\
\text { Session Chairs: Roby } \\
\text { Douilly, Kenny Ryan, David } \\
\text { D. Oglesby, Ruth Harris, and } \\
\text { Eric Geist (see page } 848 \text { ) }\end{array}$ & $\begin{array}{l}\text { Structure and Dynamics of } \\
\text { Earth's Mantle } \\
\text { Session Chairs: Elizabeth A. } \\
\text { Vanacore and Fenglin Niu } \\
\text { (see page } 872 \text { ) }\end{array}$ & $\begin{array}{l}\text { U.S. National Seismic } \\
\text { Hazard Model Updates: } \\
\text { 2018, } 2020 \text { and Beyond } \\
\text { Session Chairs: Allison M. } \\
\text { Shumway, Susan M. Hoover, } \\
\text { Morgan P. Moschietti, Mark } \\
\text { D. Petersen, and Peter M. } \\
\text { Powers (see page } 875 \text { ) }\end{array}$ \\
\hline $8: 30 \mathrm{AM}$ & $\begin{array}{l}\text { STUDENT: Fully Physics- } \\
\text { Based PSHA: Coupling } \\
\text { RSQSim with Deterministic } \\
\text { Ground Motion Simulations. } \\
\text { Milner, K. R., Shaw, B. E., } \\
\text { Jordan, T. H., Callaghan, S. }\end{array}$ & $\begin{array}{l}\text { INVITED: Lithospheric } \\
\text { Structure and Dynamics of } \\
\text { the Upper Mantle beneath } \\
\text { East Asia. Chen, M., Niu, F., } \\
\text { Liu, Q., Tromp, J. }\end{array}$ & $\begin{array}{l}2018 \text { U.S. National Seismic } \\
\text { Hazard Models. Petersen, } \\
\text { M. D., Shumway, A. M., } \\
\text { Mueller, C. S., Powers, P. M., } \\
\text { Moschetti, M. P., et al. }\end{array}$ \\
\hline $8: 45 \mathrm{AM}$ & $\begin{array}{l}\text { Dynamic Models of } \\
\text { Earthquake Rupture along } \\
\text { Branch Faults of the Eastern } \\
\text { San Gorgonio Pass Region in } \\
\text { California Using Complex } \\
\text { Fault Structure. Douilly, R., } \\
\text { Oglesby, D. D., Cooke, M. L., } \\
\text { Beyer, J. L. }\end{array}$ & $\begin{array}{l}\text { STUDENT: Detailed } \\
\text { Structure of the Upper- } \\
\text { Mantle Discontinuities } \\
\text { Using a Novel Approach and } \\
\text { High-Frequency Triplication } \\
\text { Data. Park, S., Ishii, M. }\end{array}$ & $\begin{array}{l}\text { Multi-Period and Multi-Vs30 } \\
\text { Design Ground Motions. } \\
\text { Rezaeian, S., Kircher, C. A., } \\
\text { Shumway, A. M., Powers, P. } \\
\text { M. }\end{array}$ \\
\hline $9: 00 \mathrm{AM}$ & $\begin{array}{l}\text { Effect of the Gaochuan Right } \\
\text { Bend on Fault Spontaneous } \\
\text { Rupture Propagation in the } \\
2008 \text { Wenchuan Earthquake: } \\
\text { Interpretation of Seismic } \\
\text { Hazard in the Beichuan } \\
\text { Area. Zhu, S., Yuan, J. } \\
\end{array}$ & $\begin{array}{l}\text { Upper Mantle Transition } \\
\text { Zone Thickness Variation } \\
\text { under the Parnaíba Basin of } \\
\text { Northeast Brazil. Julià, J., } \\
\text { Coelho, D. L. O., White, N. } \\
\text { J., Rodríguez-Tribaldos, V. }\end{array}$ & $\begin{array}{l}\text { INVITED: NGA-Subduction } \\
\text { Research Program. } \\
\text { Bozorgnia, Y., Kishida, T., } \\
\text { Abrahamson, N. A., Ahdi, S. } \\
\text { K., Ancheta, T., et al. }\end{array}$ \\
\hline $9: 15 \mathrm{AM}$ & $\begin{array}{l}\text { The Effect of Along-Strike } \\
\text { Variation in Dip on Rupture } \\
\text { Propagation on Strike-Slip } \\
\text { Faults. Lozos, J. C. }\end{array}$ & $\begin{array}{l}\text { STUDENT: Shear Wave } \\
\text { Anisotropy, Mantle Flow, } \\
\text { and Its Relationship to a } \\
\text { Possible Slab Tear in the } \\
\text { South Cocos Plate, Mexico. } \\
\text { Vazquez Aragon, L. A., } \\
\text { Valenzuela, R. W., Pérez- } \\
\text { Campos, X., Clayton, R. W. }\end{array}$ & $\begin{array}{l}\text { INVITED: Cybershake } \\
\text { Models of Seismic Hazards } \\
\text { in Southern and Central } \\
\text { California. Jordan, T. H., } \\
\text { Callaghan, S., Graves, R. W., } \\
\text { Wang, F., Milner, K. R., et al. }\end{array}$ \\
\hline
\end{tabular}




\begin{tabular}{|c|c|c|c|c|}
\hline Time & Jasmine & Monroe & Orchid AB & Tuttle \\
\hline & $\begin{array}{l}\text { Early Warning for } \\
\text { Large Earthquakes and } \\
\text { Tsunamis: Challenges, } \\
\text { Case Studies and } \\
\text { Innovations } \\
\text { Session Chairs: Christine J. } \\
\text { Ruhl, Emrah Yenier, Men- } \\
\text { Andrin Meier, Neil Spriggs, } \\
\text { Diego Melgar, Marlon D. } \\
\text { Ramos, and David Easton } \\
\text { (see page 846) }\end{array}$ & $\begin{array}{l}\text { Recent Advances in Dense } \\
\text { Array Seismology } \\
\text { Session Chairs: Ting Chen, } \\
\text { Fan-Chi Lin, Norimitsu } \\
\text { Nakata, and Catherine } \\
\text { Snelson (see page 592) }\end{array}$ & $\begin{array}{l}\text { Seismic Event Screening } \\
\text { Session Chairs: Raymond } \\
\text { Willemann and David } \\
\text { Bowers (see page } 868 \text { ) }\end{array}$ & $\begin{array}{l}\text { Megathrust Earthquakes: } \\
\text { Recurrence, Rupture } \\
\text { Modes and Tsunamis } \\
\text { Session Chairs: Peter Molnar, } \\
\text { Peter Haeussler, and Brian F. } \\
\text { Atwater (see page } 800 \text { ) }\end{array}$ \\
\hline $8: 30 \mathrm{AM}$ & $\begin{array}{l}\text { Earthquake Early Warning: } \\
\text { The Road to Implementation. } \\
\text { Nishenko, S., Molnar, G., } \\
\text { De Guzman, R., Anderson, } \\
\text { B. }\end{array}$ & $\begin{array}{l}\text { Using the Large-n Array to } \\
\text { Constrain Shallow Velocity } \\
\text { Structure in Oklahoma. } \\
\text { Herrmann, R. B. }\end{array}$ & $\begin{array}{l}\text { An Improved Semi- } \\
\text { Automatic Shallow } \\
\text { Event Depth Estimation } \\
\text { Algorithm, Based on } \\
\text { Cepstral Analysis. Kemerait, } \\
\text { R., Tibuleac, I. M., } \\
\text { Capuano, M. A., Pascual, J. } \\
\text { A., Thursby, M. }\end{array}$ & $\begin{array}{l}\text { INviTED: What Does the } \\
\text { Present State of Locking } \\
\text { along the Aleutian } \\
\text { Megathrust Tell Us about } \\
\text { Earthquake and Tsunami } \\
\text { Hazard? Witter, R. C., } \\
\text { Engelhart, S. E., Briggs, R. } \\
\text { W., Koehler, R. D., Nelson, } \\
\text { A. R., et al. } \\
\end{array}$ \\
\hline $8: 45 \mathrm{AM}$ & $\begin{array}{l}\text { Quantitative Ground- } \\
\text { Motion Evaluation of } \\
\text { ShakeAlert Earthquake } \\
\text { Early Warning Performance. } \\
\text { Aagaard, B. T., Minson, S. } \\
\text { E., Baltay, A. S., Cochran, E. } \\
\text { S., Hanks, T. C. }\end{array}$ & $\begin{array}{l}\text { INVITED: Earthquake } \\
\text { Relocation above the Socorro } \\
\text { Magma Body, Central New } \\
\text { Mexico, Using an } 800+ \\
\text { Seismic Station Array. Bilek, } \\
\text { S. L., Schmidt, J., Vieceli, } \\
\text { R. E. }\end{array}$ & $\begin{array}{l}\text { Mapping Spectral Ratios } \\
\text { to Discriminate between } \\
\text { Shallow Low-Magnitude } \\
\text { Earthquakes and Blasts. } \\
\text { Kolaj, M. }\end{array}$ & $\begin{array}{l}\text { INVITED: The Northern } \\
\text { Caribbean Megathrust. ten } \\
\text { Brink, U. }\end{array}$ \\
\hline 9:00 AM & $\begin{array}{l}\text { A Pseudo Real Time } \\
\text { Assessment of Earthquake } \\
\text { Early Warning Algorithms. } \\
\text { Yenier, E., Spriggs, N. }\end{array}$ & $\begin{array}{l}\text { Joint Body-Wave and Surface- } \\
\text { Wave Tomography over a } \\
\text { Partially Collapsed Nuclear } \\
\text { Test, Nevada National } \\
\text { Security Site. Abbott, R. } \\
\text { E., Preston, L., Onyango, E., } \\
\text { Worthington, L. L. } \\
\end{array}$ & & $\begin{array}{l}\text { The CASEIS Project: Toward } \\
\text { a Better Understanding } \\
\text { of the Seismic Cycle and } \\
\text { Paleoseismology of the Lesser } \\
\text { Antilles Megathrust. Feuillet, } \\
\text { N., Ratzov, G., Seibert, C., } \\
\text { Morena, P. F., Bieber, A., et al.. }\end{array}$ \\
\hline $9: 15 \mathrm{AM}$ & $\begin{array}{l}\text { Earthquake Early Warning } \\
\text { Using Late-Onset P-Waves } \\
\text { from Growing Ruptures. } \\
\text { Kodera, Y. }\end{array}$ & $\begin{array}{l}\text { STUDENT: Characteristics } \\
\text { of Airplanes and Helicopters } \\
\text { Recorded by a Dense Seismic } \\
\text { Array near Anza, California. } \\
\text { Meng, H., Ben-Zion, Y. }\end{array}$ & $\begin{array}{l}\text { Investigating the Limits of } \\
\text { Correlation Detectors as } \\
\text { Discriminants. Yeck, W. } \\
\text { L., Benz, H. M., Earle, P. S., } \\
\text { Harris, D. B. }\end{array}$ & $\begin{array}{l}\text { INVITED: Megathrusts and } \\
\text { Tsunamis in the Caribbean. } \\
\text { von Hillebrandt-Andrade, } \\
\text { C. G. }\end{array}$ \\
\hline
\end{tabular}




\begin{tabular}{|c|c|c|c|c|}
\hline Time & Brickell & Flagler & Hibiscus $A$ & Hibiscus $B$ \\
\hline & $\begin{array}{l}\text { Exploring Rupture } \\
\text { Dynamics and Seismic } \\
\text { Wave Propagation ... }\end{array}$ & $\begin{array}{l}\text { Structure and Dynamics of } \\
\text { Earth's Mantle }\end{array}$ & $\begin{array}{l}\text { U.S. National Seismic } \\
\text { Hazard Model Updates: } \\
\text { 2018, } 2020 \text { and Beyond }\end{array}$ & \\
\hline $9: 30 \mathrm{AM}$ & $\begin{array}{l}\text { Earthquake Rupture } \\
\text { Propagation and } \\
\text { Termination in Fault Zones } \\
\text { with Along-Strike Variation } \\
\text { of Damage. Huang, Y. H., } \\
\text { Lozos, J. C. }\end{array}$ & $\begin{array}{l}\text { INVITED: The 3-D Reference } \\
\text { Earth Model: Status and } \\
\text { Preliminary Results. Lekic, } \\
\text { V., Moulik, P., Romanowicz, } \\
\text { B. }\end{array}$ & $\begin{array}{l}\text { Incorporating Long-Period } \\
\text { (T>1 S) 3D Simulations into } \\
\text { the U.S. National Seismic } \\
\text { Hazard Model. Moschetti, } \\
\text { M. P., Thompson, E. M., } \\
\text { Shumway, A. M., Boyd, O. S., } \\
\text { Petersen, M. D., et al. }\end{array}$ & \\
\hline $\begin{array}{r}9: 45- \\
10: 45 \mathrm{AM}\end{array}$ & & Posters & id Break & \\
\hline
\end{tabular}

\begin{tabular}{|c|c|c|c|c|}
\hline & $\begin{array}{l}\text { Exploring Rupture } \\
\text { Dynamics and Seismic } \\
\text { Wave Propagation along } \\
\text { Complex Fault Systems } \\
\text { (continued) }\end{array}$ & $\begin{array}{l}\text { Development and } \\
\text { Validation of Statistical } \\
\text { Models of Small-Scale } \\
\text { Heterogeneities } \\
\text { Session Chairs: G. Eli Baker, } \\
\text { Kim B. Olsen, Yang Shen, } \\
\text { Vernon Cormier, and W. } \\
\text { Scott Phillips (see page } 845 \text { ) } \\
\end{array}$ & $\begin{array}{l}\text { U.S. National Seismic } \\
\text { Hazard Model Updates: } \\
\text { 2018, 2020 and Beyond } \\
\text { (continued) }\end{array}$ & $\begin{array}{l}\text { Ocean Bottom } \\
\text { Seismology-Hurdles, } \\
\text { Strategies and Outcomes } \\
\text { Session Chairs: Charlotte } \\
\text { A. Rowe, Francisco J. } \\
\text { Núñez-Cornú, and Susan L. } \\
\text { Bilek(see page } 862 \text { ) }\end{array}$ \\
\hline $10: 45 \mathrm{AM}$ & $\begin{array}{l}\text { The Effects of Roughness } \\
\text { and Off-Fault Plasticity on } \\
\text { the Rupture Process during } \\
\text { Multiple Slip Events. Tal, Y., } \\
\text { Lapusta, N. }\end{array}$ & $\begin{array}{l}\text { INVITED: Source Spectra } \\
\text { for Explosion Monitoring. } \\
\text { Phillips, W. S., Yoo, S. H., } \\
\text { Olsen, K. B. }\end{array}$ & $\begin{array}{l}\text { INviTED: Fault Scaling } \\
\text { Relationships Depend on } \\
\text { the Average Fault Slip Rate. } \\
\text { Anderson, J. G., Biasi, G. P., } \\
\text { Wesnousky, S. G. }\end{array}$ & $\begin{array}{l}\text { InviTED: Mermaid, } \\
\text { Mug-Obs, Manta-Obs, } \\
\text { Hydr-Obs; New Versatile } \\
\text { Multidisciplinary } \\
\text { Instruments for Monitoring } \\
\text { Seismology in Deep Ocean. } \\
\text { Hello, Y. M., Nolet, G., } \\
\text { Yegikyan, M., Royer, J. Y., } \\
\text { Charvis, P. }\end{array}$ \\
\hline 11:00 AM & $\begin{array}{l}\text { InviTED: Dynamic Rupture } \\
\text { Simulations at the Scale of } \\
\text { Megathrust Fault Systems. } \\
\text { Gabriel, A. A., Ulrich, T., } \\
\text { Madden, E. H., Wollherr, S., } \\
\text { Duru, K. C. }\end{array}$ & $\begin{array}{l}\text { INVITED: Modeling of High- } \\
\text { Frequency Seismic Wave } \\
\text { Scattering and Propagation } \\
\text { Using Radiative Transfer } \\
\text { Theory. Zeng, Y. }\end{array}$ & $\begin{array}{l}\text { INVITED: Recent Findings } \\
\text { and Recommendations } \\
\text { for an Updated Hazard } \\
\text { Characterization of the } \\
\text { Eglington Fault in Las Vegas } \\
\text { Valley, Nevada. Dee, S. M., } \\
\text { dePolo, C. M., Gold, R. D., } \\
\text { Briggs, R. W. } \\
\end{array}$ & $\begin{array}{l}\text { INviteD: Smart Cables- } \\
\text { Sensing the Oceanographic } \\
\text { and Geophysical Pulse of the } \\
\text { Planet. Howe, B. M. }\end{array}$ \\
\hline $11: 15 \mathrm{AM}$ & $\begin{array}{l}\text { Three-Dimensional Rupture } \\
\text { Dynamics of Tsunamigenic } \\
\text { Earthquakes Incorporating } \\
\text { Inelastic Wedge Failure. Ma, } \\
\text { S., Nie, S. }\end{array}$ & $\begin{array}{l}\text { INVITED: Imaging the } \\
\text { Heterogeneous Earth } \\
\text { with Radiative Transfer. } \\
\text { Margerin, L., Calvet, M. }\end{array}$ & $\begin{array}{l}\text { Rethinking the Seismic } \\
\text { Hazard Characterization } \\
\text { of the Cheraw Fault, } \\
\text { Southeastern Colorado. } \\
\text { Zellman, M. S., Ostenaa, } \\
\text { D. A. }\end{array}$ & $\begin{array}{l}\text { INVITED: The Necessity } \\
\text { for Long-Term OBS } \\
\text { Deployments in } \\
\text { Understanding Mid-Ocean } \\
\text { Ridge Processes. Tolstoy, M., } \\
\text { Tan, Y. J., Waldhauser, F., } \\
\text { Wilcock, W. S. D. }\end{array}$ \\
\hline
\end{tabular}




\begin{tabular}{|c|c|c|c|c|}
\hline Time & Jasmine & Monroe & Orchid $A B$ & Tuttle \\
\hline & $\begin{array}{l}\text { Early Warning for } \\
\text { Large Earthquakes and } \\
\text { Tsunamis... }\end{array}$ & $\begin{array}{l}\text { Recent Advances in Dense } \\
\text { Array Seismology }\end{array}$ & Seismic Event Screening & $\begin{array}{l}\text { Megathrust Earthquakes: } \\
\text { Recurrence, Rupture } \\
\text { Modes and Tsunamis }\end{array}$ \\
\hline $9: 30 \mathrm{AM}$ & $\begin{array}{l}\text { Real-Time Correction of } \\
\text { Frequency-Dependent Site } \\
\text { Amplification Factors in } \\
\text { Time Domain: Introduction } \\
\text { of Phase Delay for Real-Time } \\
\text { Prediction of Duration of } \\
\text { Ground Motion. Hoshiba, } \\
\text { M. }\end{array}$ & $\begin{array}{l}\text { InviTED: Dense Array } \\
\text { Observations of Induced } \\
\text { Seismicity: The LArge-n } \\
\text { Seismic Survey in Oklahoma } \\
\text { (LASSO) Experiment. } \\
\text { Dougherty, S. L., Cochran, } \\
\text { E. S., Harrington, R. M., } \\
\text { Ross, Z. E. }\end{array}$ & $\begin{array}{l}\text { Applications of Body-Wave } \\
\text { Methods of Distinguishing } \\
\text { Between Explosions, Cavity } \\
\text { Collapses and Earthquakes } \\
\text { to the Recent DPRK Events } \\
\text { With Insights From the } \\
\text { Nevada Source Physics } \\
\text { Experiments. Walter, W. R., } \\
\text { Dodge, D. A., Ichinose, G. A., } \\
\text { Myers, S. C., Ford, S. R., et al. }\end{array}$ & $\begin{array}{l}\text { Drilling Through the } \\
\text { Seismogenic Zone of Large } \\
\text { Megathrust Earthquakes: } \\
\text { An On-Land Opportunity in } \\
\text { Osa Peninsula, Costa Rica. } \\
\text { Protti, J. M., Wiersberg, T., } \\
\text { Noren, A., Schwartz, S. Y., } \\
\text { Bangs, N., et al. }\end{array}$ \\
\hline
\end{tabular}

$9: 45-$

$10: 45 \mathrm{AM}$

10:45 AM

11:00 AM

Performance of Seismic and Geodetic Earthquake Early Warnings for a Suite of Large Earthquakes Worldwide: Rapid Forecasts of Ground Motion. Ruhl, C. J., Melgar, D., Chung, A. I., Grapenthin, R., Allen, R. M.

11:15 AM

Reliability of the W-Phase Inversion for Earthquakes with $\mathrm{MW}>6.0$ to Be Used by the Central American Tsunami Advisory Center (CATAC). Arguello-

Miranda, G. J., Tanioka, Y., Strauch, W.
Posters and Break

\begin{tabular}{|c|c|c|}
\hline $\begin{array}{l}\text { Recent Advances in Dense } \\
\text { Array Seismology } \\
\text { (continued) }\end{array}$ & $\begin{array}{l}\text { Seismic Event Screening } \\
\text { (continued) }\end{array}$ & $\begin{array}{l}\text { Megathrust Earthquakes: } \\
\text { Recurrence, Rupture } \\
\text { Modes and Tsunamis (con- } \\
\text { tinued) }\end{array}$ \\
\hline $\begin{array}{l}\text { INVITED: Large-N } \\
\text { Gradiometry with Nodal } \\
\text { Instrument Arrays. } \\
\text { Langston, C. A. }\end{array}$ & $\begin{array}{l}\text { Discrimination of the DPRK } \\
\text { Announced Underground } \\
\text { Explosions and Their } \\
\text { Aftershocks Using the Pg/ } \\
\text { lg Spectral Amplitude Ratio. } \\
\text { Kitov, I., Le Bras, R. J., } \\
\text { Rozhkov, M., Sanina, I. }\end{array}$ & $\begin{array}{l}\text { INviteD: How Large Can } \\
\text { Megathrust Earthquakes } \\
\text { Be in the Central American } \\
\text { Subduction Zone? Suarez, } \\
\text { G. }\end{array}$ \\
\hline $\begin{array}{l}\text { Distributed Acoustic Sensing } \\
\text { of the Seismic Wavefield at } \\
\text { SAFOD. Ellsworth, W. L., } \\
\text { Yuan, S., Karrenbach, M., } \\
\text { Zumberge, M. A. }\end{array}$ & $\begin{array}{l}\text { Uncertainty Estimation } \\
\text { of Moment Tensor Source } \\
\text { Types. Tape, C., Alvizuri, C. } \\
\text { R., Tape, W. }\end{array}$ & $\begin{array}{l}\text { INVITED: Interseismic } \\
\text { Coupling and Quaternary } \\
\text { Coastal Tectonics along the } \\
\text { Andean Megathrust. Audin, } \\
\text { L., Saillard, M., Benavente, } \\
\text { C., Alvarado, A. }\end{array}$ \\
\hline $\begin{array}{l}\text { STUDENT: Towards } \\
\text { Noise Tomography and } \\
\text { Passive Monitoring Using } \\
\text { Distributed Acoustic } \\
\text { Sensing. Paitz, P., Fichtner, } \\
\text { A. }\end{array}$ & $\begin{array}{l}\text { Identification of Small } \\
\text { Seismic Events around North } \\
\text { Korean Nuclear Test Site } \\
\text { following the } 3 \text { September } \\
2017 \text { Underground Nuclear } \\
\text { Test. Kim, W. Y., Richards, } \\
\text { P. G. }\end{array}$ & $\begin{array}{l}\text { INviTED: Large } \\
\text { Earthquakes in Central } \\
\text { Chile as Evidenced by } \\
\text { Coastal Elevation Changes. } \\
\text { Barrientos, S. E., del } \\
\text { Campo, F. }\end{array}$ \\
\hline
\end{tabular}




\begin{tabular}{|c|c|c|c|c|}
\hline Time & Brickell & Flagler & Hibiscus $A$ & Hibiscus $B$ \\
\hline \multirow[b]{2}{*}{$11: 30 \mathrm{AM}$} & $\begin{array}{l}\text { Exploring Rupture } \\
\text { Dynamics and Seismic } \\
\text { Wave Propagation... }\end{array}$ & $\begin{array}{l}\text { Development and } \\
\text { Validation of Statistical } \\
\text { Models... }\end{array}$ & $\begin{array}{l}\text { U.S. National Seismic } \\
\text { Hazard Model Updates: } \\
\text { 2018, } 2020 \text { and Beyond }\end{array}$ & $\begin{array}{l}\text { Ocean Bottom } \\
\text { Seismology-Hurdles, } \\
\text { Strategies and Outcomes }\end{array}$ \\
\hline & $\begin{array}{l}\text { Reawakening of the Wharton } \\
\text { Basin (Indian Ocean) } \\
\text { Led to Unusual Ocean } \\
\text { Plate Earthquakes during } \\
\text { 2004-2016. Rajendran, } \\
\text { K., Parameswaran, R. M., } \\
\text { Rajendran, C. P. }\end{array}$ & $\begin{array}{l}\text { INVITED: Trade-Offs in } \\
\text { Parameters Describing } \\
\text { Earth's Heterogeneity } \\
\text { Spectrum and Intrinsic } \\
\text { Attenuation. Cormier, V. F., } \\
\text { Sanborn, C. J. }\end{array}$ & $\begin{array}{l}\text { The Western Limit of Major } \\
\text { Extension Associated with } \\
\text { the Iapetan Rifted Margin } \\
\text { in the Southern and Central } \\
\text { Appalachians: Implications } \\
\text { for the National Seismic } \\
\text { Hazard Maps. Powell, C. A., } \\
\text { Thomas, W. A., Hatcher Jr., } \\
\text { R. D. }\end{array}$ & $\begin{array}{l}\text { INviteD: The Caribe } \\
\text { Norte Project: Studying the } \\
\text { Southern Hispaniola Island } \\
\text { Seismic Structure Using } \\
\text { OBS. Núñez Escribano, D., } \\
\text { Cordoba, D. }\end{array}$ \\
\hline \multirow[t]{3}{*}{$11: 45 \mathrm{AM}$} & $\begin{array}{l}\text { The Fault Geometry Explains } \\
\text { the Rupture Complexity } \\
\text { of the } 2012 \text { Mw } 8.6 \\
\text { Indian Ocean Earthquake. } \\
\text { Parameswaran, R. M., } \\
\text { Rajendran, K., Somala, S. } \\
\text { N., Rajendran, C. P. }\end{array}$ & $\begin{array}{l}\text { INVITED: Developing } \\
\text { Integrated Deterministic and } \\
\text { Stochastic Earth Models. } \\
\text { Bao, X., Wei, X. Z., Shen, Y. }\end{array}$ & $\begin{array}{l}\text { Impact of Improved Gulf } \\
\text { Coast Seismic Attenuation } \\
\text { Boundary and Stress } \\
\text { Parameter Estimates on Our } \\
\text { Understanding of Seismic } \\
\text { Hazard in the Southeastern } \\
\text { United States. Cramer, C. } \\
\text { H. }\end{array}$ & $\begin{array}{l}\text { STUDENT: Seismicity in the } \\
\text { Northern Hikurangi Margin, } \\
\text { New Zealand, and Spatial } \\
\text { and Temporal Relationship } \\
\text { with the October } 2014 \text { Slow } \\
\text { Slip Event. Yarce, J., Sheehan, } \\
\text { A. F., Nakai, J. S., Schwartz, } \\
\text { S. Y., Mochizuki, K. }\end{array}$ \\
\hline & \multicolumn{4}{|c|}{ Public Policy Luncheon } \\
\hline & $\begin{array}{l}\text { Observations and the } \\
\text { Physics Behind Complex } \\
\text { Earthquakes } \\
\text { Session Chairs: Zhongwen } \\
\text { Zhan, Gavin Hayes, and } \\
\text { Marine Denolle (see page } \\
858 \text { ) }\end{array}$ & $\begin{array}{l}\text { Observed Characteristics } \\
\text { of Induced Seismicity: } \\
\text { From Laboratory to Field } \\
\text { Scale (Parts } 1 \text { and 2) } \\
\text { Session Chairs: Kayla A. } \\
\text { Kroll, Elizabeth S. Cochran, } \\
\text { and Brett Carpenter(see page } \\
\text { 859) }\end{array}$ & $\begin{array}{l}\text { Testing PSHA Input Data, } \\
\text { Source Models and Hazard } \\
\text { Estimates } \\
\text { Session Chairs: David D. } \\
\text { Jackson, Yufang Rong, } \\
\text { Harold Magistrale, and } \\
\text { Jeremy Zechar (see page } \\
874 \text { ) }\end{array}$ & $\begin{array}{l}\text { Microzonation Studies- } \\
\text { Site Effects } \\
\text { Session Chairs: Ilias } \\
\text { Papadopoulos and Michael } \\
\text { Schmitz (see page } 855 \text { ) }\end{array}$ \\
\hline $2: 15 \mathrm{PM}$ & $\begin{array}{l}\text { Considering Green's } \\
\text { Functions in Back-Projection. } \\
\text { Wang, D. }\end{array}$ & $\begin{array}{l}\text { Reservoir Induced Seismicity } \\
\text { in Brazil: Characteristics and } \\
\text { New Cases. Barros, L. V., } \\
\text { Assumpção, M., Ribotta, L., } \\
\text { Carvalho, J. M., Drumond, } \\
\text { B., Albuquerque, D. F. }\end{array}$ & $\begin{array}{l}\text { INVITED: } 2018 \text { One-Year } \\
\text { Forecast for Induced and } \\
\text { Natural Earthquakes in the } \\
\text { Central and Eastern United } \\
\text { States. Petersen, M. D., } \\
\text { Mueller, C. S., Moschetti, M. } \\
\text { P., Hoover, S. M., Rukstales, } \\
\text { K. S., et al. } \\
\end{array}$ & $\begin{array}{l}\text { INviTED: Shear-Wave } \\
\text { Velocity Model of the } \\
\text { Santiago de Chile Basin as a } \\
\text { Basis for the Identification } \\
\text { of Stratigraphic and } \\
\text { Topographic Site Effects. } \\
\text { Pilz, M. }\end{array}$ \\
\hline $2: 30 \mathrm{PM}$ & $\begin{array}{l}\text { INVITED: Search for } \\
\text { Generic Rupture Properties } \\
\text { Hidden by Earthquakes } \\
\text { Diversity : Insights from the } \\
\text { SCARDEC Source Time } \\
\text { Functions Catalog. Vallée, } \\
\text { M., Renou, J., Chounet, A. }\end{array}$ & $\begin{array}{l}\text { Criteria Used to Characterize } \\
\text { and Classify Discrete } \\
\text { Clusters of Earthquakes from } \\
\text { 2012-2016 in North-Central } \\
\text { Arkansas as Natural or } \\
\text { Induced. Ausbrooks, S. M., } \\
\text { Horton, S. P. }\end{array}$ & $\begin{array}{l}\text { Verification of the } \\
\text { Probabilistic Seismic } \\
\text { Hazard Maps for Japan by } \\
\text { Comparing with Actually } \\
\text { Observed Seismic Intensities. } \\
\text { Koketsu, K., Kondo, T. }\end{array}$ & $\begin{array}{l}\text { Mapping of Vs30 and } \\
\text { Seismic Microzones in } \\
\text { Quito, Ecuador. Leon, A. L., } \\
\text { Schmitz, M., Yepes, H. A., } \\
\text { Ordoñez, J., Hernández, J. J., } \\
\text { Alvarado, A., García, K. }\end{array}$ \\
\hline
\end{tabular}




\begin{tabular}{|c|c|c|c|c|}
\hline Time & Jasmine & Monroe & Orchid $A B$ & Tuttle \\
\hline & $\begin{array}{l}\text { Early Warning for } \\
\text { Large Earthquakes and } \\
\text { Tsunamis... }\end{array}$ & $\begin{array}{l}\text { Recent Advances in Dense } \\
\text { Array Seismology }\end{array}$ & Seismic Event Screening & $\begin{array}{l}\text { Megathrust Earthquakes: } \\
\text { Recurrence, Rupture } \\
\text { Modes and Tsunamis }\end{array}$ \\
\hline $11: 30 \mathrm{AM}$ & $\begin{array}{l}\text { Local Tsunami Warnings } \\
\text { Using GNSS and Seismic } \\
\text { Data. Hirshorn, B. F. }\end{array}$ & $\begin{array}{l}\text { INVITED: A Large-Aperture } \\
\text { Distributed Acoustic } \\
\text { Sensing Array in Goldstone, } \\
\text { California. Zhan, Z., } \\
\text { Lindsey, N. J., Idini, B., Ajo- } \\
\text { Franklin, J. B., Williams, E. }\end{array}$ & $\begin{array}{l}\text { Combined Seismic/Geodetic } \\
\text { Source-Type Inversion of the } \\
\text { September 03, 2017, DPRK } \\
\text { Nuclear Test. Dreger, D. } \\
\text { S., Rodgers, A., Ichinose, G. } \\
\text { A., Chiang, A., Ford, S. R., } \\
\text { Wang, T. }\end{array}$ & $\begin{array}{l}\text { Seismic Gaps and Asperities } \\
\text { Along the South American } \\
\text { Subduction Zone: An } \\
\text { Update. Nishenko, S., Lay, } \\
\text { T. }\end{array}$ \\
\hline $11: 45 \mathrm{AM}$ & $\begin{array}{l}\text { Tsunami Data Assimilation } \\
\text { for Rapid Forecast: } \\
\text { Application to Cascadia and } \\
\text { New Zealand. Sheehan, A. } \\
\text { F., Gusman, A. R., Satake, } \\
\text { K., Maeda, T. }\end{array}$ & $\begin{array}{l}\text { STUDENT: Earthquake } \\
\text { Characterization with a } \\
\text { Dark Fiber DAS Array in } \\
\text { Sacramento, California. } \\
\text { Lindsey, N. J., Dou, S., } \\
\text { Rademacher, H., Tracy, C., } \\
\text { Monga, I., Ajo-Franklin, J. } \\
\text { B., Robertson, M. }\end{array}$ & $\begin{array}{l}\text { Deconvolution of the Source } \\
\text { Spectra for the North Korean } \\
\text { Underground Nuclear Tests. } \\
\text { Stroujkova, A. }\end{array}$ & $\begin{array}{l}\text { Case of an Orphan Tsunami } \\
\text { on the Konkan Coast, } \\
\text { Western India: A Distant } \\
\text { Megathrust or a Near- } \\
\text { Field Source? Rajendran, } \\
\text { C. P., Heidarzadeh, M., } \\
\text { Karthikeyan, A., Rajendran, } \\
\text { K., Sanwal, J., et al. }\end{array}$ \\
\hline
\end{tabular}

Noon-

Data Network Operations for ShakeAlert. Aranha, M.

\section{Public Policy Luncheon}

Advances on the Parameterization of Seismic Attenuation: Current Challenges and Opportunities Session Chairs: Ashly Cabas, Stefano Parolai, Celine Gélis, and Albert Kottke (see page 843)

\section{Attenuation Differences} between the Canadian Shield and Appalachian Orogeny in Eastern Canada. Bent, A. L. Perry, H. K. C.

\section{On Strong Positive}

Frequency Dependencies of Seismic Quality Factors. Morozov, I. B., Jhajhria, A., Deng, W.
Present-Day Plate Boundary Deformation and Seismic Hazard in the Caribbean Session Chairs: Eric Calais, Steeve Symithe, O'Leary Gonzalez Matos, and Valérie Clouard(see page 863)

Is the Ancient Nortecubana Fold-and-Thrust Fault System Reactivated in Extension Today? Briggs, R. W., Gold, R. D.

\section{Rayleigh Wave Group-}

Velocity across the

Dominican Republic and Puerto Rico from Ambient Noise Tomography. Quiros, D. A., Pulliam, J., Barman, D., Polanco Rivera, E., Huerfano, V. A.
The Future of Telemetered Seismic Arrays-Where the Operation of the Network Ends and the Science

Begins

Session Chairs: Tim Parker, Dario Baturan, and David Eaton (see page 850 )

InVited: Plate Boundary

Observatory GNSS

Operations in Alaska:

Challenges and Performance.

Austin, K. E., Boyce, E.,

Feaux, K. F., Hodgkinson, K. M., Mattioli, G. S., et al.

INVITED: Evolution of the Alaska Volcano Observatory (Avo) Seismic Network.

Paskievitch, J. F., Read, C. W., Ketner, D. M., Kaufman, A. M. 


\begin{tabular}{|c|c|c|c|c|}
\hline Time & Brickell & Flagler & Hibiscus $A$ & Hibiscus $B$ \\
\hline & $\begin{array}{l}\text { Observations and the } \\
\text { Physics Behind Complex } \\
\text { Earthquakes }\end{array}$ & $\begin{array}{l}\text { Observed Characteristics } \\
\text { of Induced Seismicity... } \\
\text { (Parts } 1 \text { and } 2 \text { ) }\end{array}$ & $\begin{array}{l}\text { Testing PSHA Input Data, } \\
\text { Source Models and Hazard } \\
\text { Estimates }\end{array}$ & $\begin{array}{l}\text { Microzonation Studies- } \\
\text { Site Effects }\end{array}$ \\
\hline $2: 45 \mathrm{PM}$ & $\begin{array}{l}\text { Toward a Temporal } \\
\text { Evolution of the Earthquake } \\
\text { Energy Budget: Body-Wave } \\
\text { Radiated Energy Rate. } \\
\text { Denolle, M. A. }\end{array}$ & $\begin{array}{l}\text { Induced Seismicity in the } \\
\text { High Agri Valley (Southern } \\
\text { Italy): First Observations } \\
\text { from the INSIEME Seismic } \\
\text { Network. Stabile, T. A., } \\
\text { Satriano, C., Romanelli, M., } \\
\text { Gueguen, E., Serlenga, V., et } \\
\text { al. }\end{array}$ & $\begin{array}{l}\text { Testing Fault-Based Rupture } \\
\text { Models. Jackson, D. D. }\end{array}$ & $\begin{array}{l}\text { Recent Seismic } \\
\text { Microzonation Study for the } \\
\text { Aburra Valley, Colombia. } \\
\text { Yamin, L. E., Rincón, R., } \\
\text { Prada, E., Herrera, D. C., } \\
\text { Daza, J. M., Garcia, A. P. }\end{array}$ \\
\hline 3:00 PM & $\begin{array}{l}\text { INVITED: Earthquake } \\
\text { Complexity Due to } \\
\text { Interaction of Fault } \\
\text { Geometry, Constitutive } \\
\text { Properties, Prior Slip, } \\
\text { Fluid Effects, and Inelastic } \\
\text { Processes. Lapusta, N. }\end{array}$ & $\begin{array}{l}\text { INVITED: How Widespread } \\
\text { Is Human-Induced } \\
\text { Seismicity in the USA and } \\
\text { Canada? Van der Baan, M., } \\
\text { Calixto, F. J. }\end{array}$ & $\begin{array}{l}\text { INVITED: Simulation-Based } \\
\text { Evaluation for Probabilistic } \\
\text { Seismic Hazard Models-A } \\
\text { Case Study for Japan. Mak, } \\
\text { S., Hirata, N., Nagao, H., } \\
\text { Cotton, F., Schorlemmer, D. }\end{array}$ & $\begin{array}{l}\text { Hvsr Site Characterization } \\
\text { of Texnet Seismic Stations in } \\
\text { West Texas. Young, B. E., } \\
\text { Savvaidis, A., Rathje, E. M. }\end{array}$ \\
\hline $3: 15 \mathrm{PM}$ & $\begin{array}{l}\text { Complexity of } \\
\text { Spatiotemporal } \\
\text { Microfracturing Processes } \\
\text { and Stress Field Evolution } \\
\text { before and after Fault Slip: } \\
\text { Laboratory Perspective. } \\
\text { Kwiatek, G., Goebel, T. } \\
\text { H. W., Orlecka-Sikora, B., } \\
\text { Martínez-Garzón, P., et al. }\end{array}$ & $\begin{array}{l}\text { STUDENT: The Binary } \\
\text { Forecast Approach to } \\
\text { Induced Seismicity. Kahue, } \\
\text { R., Shcherbakov, R. }\end{array}$ & $\begin{array}{l}\text { Development of New } \\
\text { Australian Magnitude } \\
\text { Conversion Equations and } \\
\text { Its Effects on Seismic Hazard } \\
\text { Analyses. Ghasemi, H., } \\
\text { Allen, T. }\end{array}$ & $\begin{array}{l}\text { The Trinidad and Tobago } \\
\text { Microzonation Project: } \\
\text { Understanding and } \\
\text { Quantifying Earthquake } \\
\text { Hazard. Papadopoulos, I., } \\
\text { Reddock, K. H., Manzano, } \\
\text { J., George, C., Jackson, V. B., } \\
\text { et al. }\end{array}$ \\
\hline $\begin{array}{r}3: 30- \\
4: 15 \mathrm{PM}\end{array}$ & \multicolumn{4}{|c|}{ Pint and Poster } \\
\hline & $\begin{array}{l}\text { New Frontiers in Seismic } \\
\text { and Acoustic Data Analysis } \\
\text { Session Chairs: Daniel C. } \\
\text { Bowman, Sarah A. Albert, } \\
\text { and Matthew M. Haney (see } \\
\text { page } 857 \text { ) }\end{array}$ & $\begin{array}{l}\text { Observed Characteristics } \\
\text { of Induced Seismicity: } \\
\text { From Laboratory to Field } \\
\text { Scale (continued) }\end{array}$ & $\begin{array}{l}\text { Seismic Structure of } \\
\text { Convergent Plate Margins } \\
\text { Session Chairs: Min Chen } \\
\text { and Jonathan R. Delph (see } \\
\text { page } 871 \text { ) }\end{array}$ & $\begin{array}{l}\text { Microzonation Studies- } \\
\text { Site Effects (continued) }\end{array}$ \\
\hline 4:15 PM & $\begin{array}{l}\text { The Signature of Wind } \\
\text { Turbines in Seismic } \\
\text { Background Noise. Marcillo, } \\
\text { O. E., Carmichael, J. }\end{array}$ & $\begin{array}{l}\text { STUDENT: Variations in } \\
\text { Source Properties with } \\
\text { Evolving Deep Injection at } \\
\text { Ngatamariki Geothermal } \\
\text { Field, New Zealand. Hopp, } \\
\text { C., Savage, M. K., Sewell, S., } \\
\text { Mroczek, S., Townend, J. }\end{array}$ & $\begin{array}{l}\text { INVITED: Contributions of } \\
\text { Modern Seismic Imaging to } \\
\text { Understanding the Andean } \\
\text { Convergent Margin. Beck, S. } \\
\text { L., Portner, D. E., Bishop, B. } \\
\text { T., Koch, C. D., Rodriguez, } \\
\text { E. E., et al. }\end{array}$ & $\begin{array}{l}\text { Seismic Microzoning Study } \\
\text { in Portoviejo, Ecuador. } \\
\text { Schmitz, M., Yepes, H. A., } \\
\text { Hernández, J. J., Koch, R., } \\
\text { Palacios, P. B., et al. }\end{array}$ \\
\hline
\end{tabular}


Time

2:45 PM

3:00 PM

$3: 30-$

$4: 15$ PM

4:15 PM
Jasmine

Real-Time GNSS Network Operations and Advances towards Early Warning...

InviteD: West Coast RealTime GPS in Support of Earthquake Early Warning. Melbourne, $T$.

INVITED: Large

Earthquake and Tsunami Characterization in Chile Using High Rate GPS and Strong Motion Data. Riquelme, S.

INVITED: Enhancing

Tsunami Early Warning across the Americas through the Network of the Americas (NOTA) GNSS-Met Infrastructure. Feaux, K. F., Hodgkinson, K. M., Mattioli, G. S., Mencin, D.
Monroe

Advances on the Parameterization of Seismic Attenuation...

Imaging Seismic Attenuation at the Brady Geothermal Field Using Interferometry. Matzel, E., Morency, C., Feigl, K., Thurber, C. H.

A Fortuitous Experiment on the Effect of Station Installation Parameters on Measures of Apparent Attenuation. Bezada, M. J., Byrnes, J., Eilon, Z.

Selection and Weighing of Ground Motion Models for Subduction Source Zones in Chile. Martinez, M. E., Li, F., Hull, A. G.
Orchid $A B$

Present-Day Plate

Boundary Deformation and Seismic Hazard...

STUdENT: Seismic

Anisotropy of the Crust and

Upper Mantle across the

Caribbean-North American

Plate Boundary from Shear-

Wave Splitting on Haiti.

Possee, D. J., Keir, D.,

Rychert, C. A., Harmon, N., Eakin, C., et al.

The Unusual January 2014

Northern Cuba Earthquake

Sequence - A (Small)

Shake-Up for Southern

Florida. Braunmiller, J.,

Thompson, G., McNutt, S. R.

Seismic Hazard Analysis

in Jamaica Incorporating

Quaternary Faults. Wong, I.

G., Thomas, P. A., Koehler,

R. D., Lewandowski, N. S.
Tuttle

The Future of Telemetered Seismic Arrays-Where the Operation ...

Towards Generating

Research Grade Seismic

Catalogs in Near Real-Time.

Reynen, A., Yenier, E.,

Baturan, D.

INVITED: Enhancing

Explosive Volcanic

Eruption Detection and

Characterization Using

Integrated Seismo-Acoustic

Networks. Matoza, R. S.

INVITED: Transportable

Array Alaska-Power and

Telemetry System Design and

Performance. Bloomquist,

D. K., Busby, R. W., Enders,

M. L., Miner, J. E., Bierma,

R. M., Theis, J. M.

\section{Pint and Poster}

Real-Time GNSS Network Operations and Advances towards Early Warning Systems (continued)

INVITED: Development and Testing of a Real-Time Geodetic Component for ShakeAlert. Murray, J. R., Crowell, B. W., Grapenthin, R., Hodgkinson, K. M., Langbein, J., et al.

Advances on the
Parameterization of
Seismic Attenuation:
Current Challenges and
Opportunities (continued)

INVITED: Parameterizations, Uncertainties, and Spatial Scales of Seismic Attenuation. Morozov, I. B.
Seismic Hazards and Historic Earthquakes in Puerto Rico and the Northern Caribbean Region Session Chairs: Roland LaForge, Dan McNamara, and Charles Mueller (see page 870)

INVITED: Comparison of Two Probabilistic Seismic Hazard Models for Puerto Rico and the U.S. Virgin Islands. Mueller, C. S., LaForge, R. C.
The Future of Telemetered Seismic Arrays-Where the Operation of the Network Ends and the Science Begins (continued)

INVITED: The Southern California Seismic Network, a Telemetered Array for Seismology and Earthquake Early Warning. Stubailo, I., Alvarez, M. G., Biasi, G. P., Thomas, V. I., Hauksson, E., et al. 


\begin{tabular}{|c|c|c|c|c|}
\hline Time & Brickell & Flagler & Hibiscus $A$ & Hibiscus B \\
\hline & $\begin{array}{l}\text { New Frontiers in Seismic } \\
\text { and Acoustic Data Analysis }\end{array}$ & $\begin{array}{l}\text { Observed Characteristics } \\
\text { of Induced Seismicity: } \\
\text { From Laboratory... } \\
\end{array}$ & $\begin{array}{l}\text { Seismic Structure of } \\
\text { Convergent Plate Margins }\end{array}$ & $\begin{array}{l}\text { Microzonation Studies- } \\
\text { Site Effects }\end{array}$ \\
\hline 4:30 PM & $\begin{array}{l}\text { Tracking Scattered Signals } \\
\text { in the Acoustic Coda Using } \\
\text { Independent Component } \\
\text { Analysis in a Topographically } \\
\text { Complex Setting. Albert, S. } \\
\text { A., Bowman, D. C. }\end{array}$ & $\begin{array}{l}\text { Using Fluid-Induced } \\
\text { Microseismicity for Reservoir } \\
\text { Characterization at Decatur. } \\
\text { Goertz-Allmann, B. P., } \\
\text { Kuehn, D., Langet, N., } \\
\text { Jordan, M., Bauer, R., Oye, } \\
\text { V., Greenberg, S. }\end{array}$ & $\begin{array}{l}\text { Evidence for Slab } \\
\text { Permeability-Controlled } \\
\text { Tremor along the Cascadia } \\
\text { Margin. Delph, J. R., } \\
\text { Levander, A. R., Niu, F. }\end{array}$ & $\begin{array}{l}\text { STUDENT: Geotechnical } \\
\text { Microzonation of Portoviejo } \\
\text { City: Index Properties of Soils } \\
\text { and Correlations between } \\
\text { Shear Wave Velocity (Vs) } \\
\text { and Standard Penetration } \\
\text { Test (SPT-N). Alvarado, K., } \\
\text { Cárdenas, D. R., Realpe, G. } \\
\text { R., Muñoz, A. J., Yepes, H. A. }\end{array}$ \\
\hline 4:45 PM & $\begin{array}{l}\text { Distinct Crater and Conduit } \\
\text { Infrasound Reveal an Open } \\
\text { Vent Volcano Running Out } \\
\text { of Gas. Lyons, J. J., Fee, D., } \\
\text { Haney, M. M., Diefenbach, } \\
\text { A., Carn, S. }\end{array}$ & $\begin{array}{l}\text { Assessing the Connectivity } \\
\text { of a Hydraulic Fractured } \\
\text { Network Using 3D } \\
\text { Topological Approaches. } \\
\text { Viegas, G., Bosman, K., } \\
\text { Urbancic, T. }\end{array}$ & $\begin{array}{l}\text { STUDENT: High Resolution } \\
\text { Imaging of the Plate } \\
\text { Interface in Central Alaskan } \\
\text { Subduction Zone Using } \\
\text { Autocorrelation with Local } \\
\text { Earthquakes. Kim, D., } \\
\text { Keranen, K. M., Abers, G. A., } \\
\text { Brown, L. D. }\end{array}$ & $\begin{array}{l}\text { Measuring Shear Wave } \\
\text { Velocity with Permanently } \\
\text { Deployed Cross-Hole Arrays. } \\
\text { Steidl, J. H., Hegarty, P. }\end{array}$ \\
\hline 5:00 PM & $\begin{array}{l}\text { INVITED: STUDENT: } \\
\text { Remote Explosive } \\
\text { Volcanic Eruption } \\
\text { Detection, Location, and } \\
\text { Characterization Using the } \\
\text { Earthscope Transportable } \\
\text { Array in Alaska. Sanderson, } \\
\text { R. W., Matoza, R. S., Fee, D., } \\
\text { Haney, M. M., Lyons, J. J. }\end{array}$ & $\begin{array}{l}\text { INVITED: Seismicity Induced } \\
\text { by Hydraulic Fracturing } \\
\text { in Ohio. Brudzinski, } \\
\text { M. R., Friberg, P. A., } \\
\text { Kozłowska, M., Skoumal, } \\
\text { R. J., Langenkamp, T. R., } \\
\text { Loughner, E. A., Currie, B. } \\
\text { S., Fasola, S. L. }\end{array}$ & $\begin{array}{l}\text { STUDENT: Minimum } \\
\text { 1D Velocity Model For } \\
\text { The Central Ecuadorian } \\
\text { Subduction Zone Inferred } \\
\text { From The Aftershock } \\
\text { Sequence Of The } 2016 \mathrm{Mw} \\
\text { 7.8 Pedernales Earthquake. } \\
\text { León-Ríos, S., Rietbrock, } \\
\text { A., Edwards, B., Holt, J., } \\
\text { Agurto-Detzel, H., et al. }\end{array}$ & $\begin{array}{l}\text { Seismic Microzonation } \\
\text { and Amplification Factor } \\
\text { Determination in the North- } \\
\text { Northeast Area of Managua } \\
\text { City, Nicaragua. Castrillo, } \\
\text { E. N., Eto, K., Yokoi, T., } \\
\text { Hayashida, T. }\end{array}$ \\
\hline 5:15 PM & $\begin{array}{l}\text { Volcanic Thunder from } \\
\text { Explosive Eruptions at } \\
\text { Bogoslof Volcano, Alaska. } \\
\text { Haney, M. M., Van Eaton, } \\
\text { A. R., Lyons, J. J., Kramer, R. } \\
\text { L., Fee, D., Iezzi, A. M. }\end{array}$ & $\begin{array}{l}\text { STUDENT: On the } \\
\text { Variability of the Seismic } \\
\text { Response during Multiple } \\
\text { Decameter-Scale Hydraulic } \\
\text { Stimulations. Villiger, L. G., } \\
\text { Selvadurai, P. A., Gischig, V. } \\
\text { S., Doetsch, J., Krietsch, H., } \\
\text { et al. }\end{array}$ & $\begin{array}{l}\text { INVITED: The Two } \\
\text { Subduction Zones of the } \\
\text { Caribbean-South American } \\
\text { Plate Boundary. Levander, } \\
\text { A. R., Cornthwaite, J. P., } \\
\text { Bezada, M. J., Niu, F., Miao, } \\
\text { W. }\end{array}$ & $\begin{array}{l}\text { STUDENT: Seismic } \\
\text { Amplifications in the Valley } \\
\text { of Mexico Using Spectral } \\
\text { Ratios of Teleseismic } \\
\text { Surface Waves Recorded } \\
\text { with Broadband Stations. } \\
\text { Martinez-Mendoza, G., } \\
\text { Valdés-González, C. M. } \\
\end{array}$ \\
\hline $\begin{array}{r}5: 30- \\
6: 30 \mathrm{PM}\end{array}$ & \multicolumn{4}{|c|}{ Joyner Lecture } \\
\hline $\begin{array}{r}6: 30- \\
8: 00 \mathrm{PM}\end{array}$ & \multicolumn{4}{|c|}{ LACSC/SSA Reception } \\
\hline $\begin{array}{r}8: 00- \\
9: 00 \mathrm{PM}\end{array}$ & \multicolumn{4}{|c|}{ LACSC Public General Assembly } \\
\hline $\begin{array}{r}8: 00- \\
9: 30 \mathrm{PM}\end{array}$ & \multicolumn{4}{|c|}{ Women in Seismology Reception } \\
\hline
\end{tabular}




\begin{tabular}{|c|c|c|c|c|}
\hline Time & Jasmine & Monroe & Orchid $A B$ & Tuttle \\
\hline & $\begin{array}{l}\text { Real-Time GNSS Network } \\
\text { Operations and Advances } \\
\text { towards Early Warning... }\end{array}$ & $\begin{array}{l}\text { Advances on the } \\
\text { Parameterization of } \\
\text { Seismic Attenuation... }\end{array}$ & $\begin{array}{l}\text { Seismic Hazards and } \\
\text { Historic Earthquakes in } \\
\text { Puerto Rico... } \\
\end{array}$ & $\begin{array}{l}\text { The Future of Telemetered } \\
\text { Seismic Arrays-Where the } \\
\text { Operation... }\end{array}$ \\
\hline $4: 30 \mathrm{PM}$ & $\begin{array}{l}\text { Plate Boundary Observatory } \\
\text { GNSS Real Time Field } \\
\text { Operations. Walls, C. P., } \\
\text { Mann, D., Hodgkinson, K. } \\
\text { M., Austin, K. E., Dittman, } \\
\text { S. T., Feaux, K. F., Mattioli, } \\
\text { G. S. }\end{array}$ & $\begin{array}{l}\text { INVITED: The Contribution } \\
\text { of Scattering to Near-Surface } \\
\text { Attenuation. Pilz, M. }\end{array}$ & $\begin{array}{l}\text { Assessing Earthquake } \\
\text { Hazard in the Caribbean and } \\
\text { Central America within the } \\
\text { CCARA Project. Garcia, } \\
\text { J. A., Pagani, M., Gee, } \\
\text { R., Poggi, V., Styron, R., } \\
\text { Johnson, K. }\end{array}$ & $\begin{array}{l}\text { Earthscope Transportable } \\
\text { Array in Alaska: Overview } \\
\text { and Future Plans. Busby, } \\
\text { R. W., Woodward, R. L., } \\
\text { Aderhold, K., Enders, M. L. }\end{array}$ \\
\hline $4: 45 \mathrm{PM}$ & $\begin{array}{l}\text { COCONet Mirror Data } \\
\text { Center at INETER, } \\
\text { Nicaragua, and Early } \\
\text { Warning in Central America. } \\
\text { Ramirez, A., Strauch, W. }\end{array}$ & $\begin{array}{l}\text { Effective Amplitude } \\
\text { Spectrum (EAS) as a } \\
\text { Metric for Ground Motion } \\
\text { Modeling Using Fourier } \\
\text { Amplitudes. Goulet, C. A., } \\
\text { Kottke, A., Boore, D. M., } \\
\text { Bozorgnia, Y., Hollenback, } \\
\text { J., et al. }\end{array}$ & $\begin{array}{l}\text { Assessment of Ground } \\
\text { Motion Prediction Equations } \\
\text { and Site Corrections for } \\
\text { Use in Haiti. Bent, A. L., } \\
\text { Cassidy, J. F. }\end{array}$ & $\begin{array}{l}\text { INVITED: High Latitude } \\
\text { Telemetry: Trades between } \\
\text { Sample Rate, Power and } \\
\text { Latency. Carpenter, P., } \\
\text { Nikolaus, K., Beaudoin, B. } \\
\text { C. }\end{array}$ \\
\hline $5: 00 \mathrm{PM}$ & $\begin{array}{l}\text { Red Geodésica del Noroeste } \\
\text { de México (REGNOM) in } \\
\text { Northern Baja California. } \\
\text { Gonzalez-Ortega, J. A., } \\
\text { Ramon Morales, E., Vidal- } \\
\text { Villegas, J. A., Valdez, A., } \\
\text { Arregui Ojeda, S. }\end{array}$ & $\begin{array}{l}\text { INVITED: Robustness of } \\
\kappa 0 \text { Measurement: Insight } \\
\text { from a Site-Specific Study } \\
\text { in the Low-to-Moderate } \\
\text { Seismicity Context of } \\
\text { Southeastern France. Perron, } \\
\text { V., Hollender, F., Bard, P. Y., } \\
\text { Gélis, C., Guyonnet-Benaize, } \\
\text { C., Ktenidou, O. J. }\end{array}$ & $\begin{array}{l}\text { INviTED: Seismic Hazard } \\
\text { Model for the Caribbean } \\
\text { Region. Torpey, M., } \\
\text { Shen-Tu, B., Shabestari, K., } \\
\text { Ali, S. T., Mahdyiar, M., Li, } \\
\text { S., Vlachos, C., Kianirad, E., } \\
\text { Zhu, J., Yin, Y. }\end{array}$ & $\begin{array}{l}\text { Long-Period Signals During } \\
\text { Large Earthquakes on } \\
\text { Alaska Transportable Array. } \\
\text { Aderhold, K., Busby, R. W., } \\
\text { Frassetto, A. }\end{array}$ \\
\hline 5:15 PM & $\begin{array}{l}\text { STUDENT: Toward a } \\
\text { Geodetic Near-Real Time } \\
\text { System for Tectonic and } \\
\text { Crustal Deformation Studies } \\
\text { in Colombia and Venezuela } \\
\text { South America. Mora-Paez, } \\
\text { H., Audemard, F., Mencin, } \\
\text { D., Cardona-Piedrahíta, L. A. }\end{array}$ & $\begin{array}{l}\text { INVITED: Kappa Effects on } \\
\text { Hard-Rock Ground Motions: } \\
\text { An On-Going Research. } \\
\text { Abrahamson, N. A., Silva, W. } \\
\text { J., Darragh, R. B., Ktenidou, } \\
\text { O. J., Yong, A., Bozorgnia, } \\
\text { Y. }\end{array}$ & $\begin{array}{l}\text { INVITED: Address-Level } \\
\text { Effects of the } 1918 \text { Puerto } \\
\text { Rico Earthquake. LaForge, } \\
\text { R. C., McCann, W. R. }\end{array}$ & $\begin{array}{l}\text { The Canadian Cordillera } \\
\text { Array: Towards a Multi- } \\
\text { Disciplinary Geoscience } \\
\text { Program for Canada. Bent, } \\
\text { A. L., Boggs, K., Eaton, } \\
\text { D., James, T. S., Audet, P., } \\
\text { Sideris, M., Ulmi, M., Fayek, } \\
\text { M., Aster, R., Schutt, D. }\end{array}$ \\
\hline $\begin{array}{r}5: 30- \\
6: 30 \mathrm{PM}\end{array}$ & \multicolumn{4}{|c|}{ Joyner Lecture } \\
\hline $\begin{array}{r}6: 30- \\
8: 00 \mathrm{PM}\end{array}$ & \multicolumn{4}{|c|}{ LACSC/SSA Reception } \\
\hline $\begin{array}{r}8: 00- \\
9: 00 \mathrm{PM}\end{array}$ & \multicolumn{4}{|c|}{ LACSC Public General Assembly } \\
\hline $\begin{array}{r}8: 00- \\
9: 30 \mathrm{PM}\end{array}$ & \multicolumn{4}{|c|}{ Women in Seismology Reception } \\
\hline
\end{tabular}




\section{Poster Sessions}

Advances on the Parameterization of Seismic Attenuation: Current Challenges and Opportunities (see page 877 )

1. An Attenuation Study in the South Region of the Gulf of California, Mexico. Castro, R. R., Singh, S. K., Joshi, A., Singh, $S$.

2. Student: Crustal Lg-Wave Attenuation in Northwest China and Its Surrounding Areas. Zhao, L. F., Xie, X. B., Yao, Z.X.

3. Student: Investigation of the Dependence of Kappa Values on the Onset of Soil Nonlinearity. Ji, C., Cabas, A. C.

4. Sensitivity Kernels for the Separation of Attenuation Processes: Scattering, Absorption, and Scattering Anisotropy. Margerin, L., Calvet, $M$.

5. Preliminary Investigations of the Kappa Parameter: From Exploration of Its Physical Interpretation to Application in a Host-to-Target Study. Gélis, C., Bonilla, L. F., Calvet, M., Gatti, F., Lopez-Caballero, F., Margerin, L., Provost, L., Bertrand, E., Colvez, M., Courboulex, F., Froment, B., Guéguen, P. Langlaude, P., Mayor, S., Monfret, T., Tchawe Nziaha, F., Touhami, S.

6. Student: A New Model for Vertical-to-Horizontal Response Spectral Ratios for Central and Eastern North America. Pezeshk, S., Farhadi, A. F., Haji-Soltani, A.

7. Student: Separation of Intrinsic and Scattering Attenuation in the NMSZ of the Central United States. Nazemi, N., Pezeshk, S., Sedaghati, F.

8. Student: Comprehensive Study of Attenuation Properties of the New Madrid Seismic Zone in the Central United States. Nazemi, N., Pezeshk, S., Sedaghati, F.

9. K0: Origin and Usability. Parolai, $\mathbf{S}$.

10. Lg Attenuation in Oklahoma and Its Surrounding Regions. Al Noman, M. N., Langston, C. A., Cramer, C. $\mathbf{H}$.

11. Student: Spatial Variation of Crustal Attenuation Properties in Western Tibet. Biswas, R., Singh, C.

Development and Validation of Statistical Models of Small-Scale Heterogeneities (see page 879)

12. Student: Seismic Scattering from Topography and Small-Scale Crustal Heterogeneity: Application to the 2009 North Korean Nuclear Test. Yeh, T., Olsen, K. B.

13. Student: Is It Possible to Use Teleseismic Scattered Waves to Determine the Receiver-Side Stochastic Velocity Model? Wei, X. Z., Shen, Y., Bao, X., Chen, L., Jiang, M.

14. Modeling of Coda Wave Attenuation by Local Heterogeneity Scattering. Larmat, C. S., MacCarthy, J. K., Phillips, W. S.
15. Examination of the Reference-Phase Concept in Seismology in the Presence of Small-Scale Heterogeneities. Zheng, Y.

Early Warning for Large Earthquakes and Tsunamis: Challenges, Case Studies and Innovations (see page 880)

16. Smart Seismic Hardware: New Strategies for Networking and Mitigation of False Alerts. Allardice, S. A., Hill, P.

17. Determining Magnitudes of Large Earthquakes in Japan Using Seismic Stations in China. Wang, D.

18. Reducing the False Alert Problem in Earthquake Early Warning: ElarmS Version 3.0. Chung, A. I., Henson, I., Hellweg, M., Allen, R. M.

19. Updates on the Finite-Fault Rupture Detector Algorithm (Finder v.2). Böse, M., Smith, D. E., Massin, F., Andrews, J., Felizardo, C., Carrasco, S., Clinton, J. F.

20. First Experience with Seiscomp3 Based Tsunami Software for the Central American Tsunami Advisory Center (CATAC) at INETER, Nicaragua. Strauch, W., Weber, B., Moeller, M., Blanco, F., Ramirez, J., Talavera, E., Tenorio, V., Arguello-Miranda, G. J.

21. Progress of the Japanese-Nicaraguan Project for the Establishment of the Central American Tsunami Advisory Center (CATAC). Furukawa, N., Kumagai, Y., Strauch, W., Talavera, E., Tenorio, V., Ramirez, J., Arguello-Miranda, G. J., Cabrera, A., Herrera, M., Acosta, N., Morales, A.

22. SCSN Data Quality Control and Station Health Assessment Tools. Stubailo, I., Alvarez, M. G., Bhadha, R., Bruton, C., Hauksson, E., Watkins, M., Thomas, V. I.

Exploring Rupture Dynamics and Seismic Wave Propagation along Complex Fault Systems (see page 882)

23. Student: Deterministic Seismic Hazard Analyses of Victoria, British Columbia, Canada: Considering an Active Leech River Fault. Kukovica, J. J., Molnar, S., Ghofrani, H.

24. 3d Dynamic Rupture Simulations along Dipping Faults, with a Focus on the Salt Lake City Segment of the Wasatch Fault, Utah. Withers, K. W., Moschetti, M. P., Duru, K. C.

25. Weakening of Fault Planes by Flash Melting Implies Near-Fault Anelastic Failure. Sleep, N. H.

26. Ground Motion Simulation and Topography Amplification Effect on an ms6.6 Minxian Earthquake. Fu, C. H.

27. Student: Constraints on Spatial Distribution of Earthquakes within a 2-D Damaged Fault Zone in Seismic Cycles. Thakur, P., Huang, Y. H.

28. Three-Dimensional Simulation Methodology of Seismic Wave Propagation and Its Application in Wudu Basin, China. Li, X. J., Zhang, X. L., Zhou, Z. H., Peng, X. B. 
The Future of Telemetered Seismic Arrays-Where the Operation of the Network Ends and the Science Begins (see page 883 )

29. Station, Data, and Instrument Analysis of the Cascades Volcano Observatory's Seismic Network Using Xmax and Other Tools. Darold, A. P., Holland, A. A.

30. Student: Optimization of the Coefficients of a Filter Function That Maximizes the Performance of a Real Time Microseismics Detector. Rodriguez, M. J., LaraCueva, R. A., Larco, J. C., Ruiz, M. C., Benítez, D. S.

31. The Broadband Seismic Network Kivusnet in the Virunga Volcanic Province (Democratic Republic of the Congo): Seismicity Catalogues and Fundamental Seismological Models after More Than 2 Years of Continuous Operation. Oth, A., Barrière, J., D'Oreye, N., Mavonga, G., Kervyn, F.

32. Invited: Prototype Testing of the Trillium 360 Version 2 Seismometer with Improved Noise Performance. Bainbridge, G., Upadhyaya, S., Townsend, B., Moores, A., Parker, T.

33. InviteD: Keeping USArray Stations in Alaska: Which Ones, How Many, and Where? Buurman, H., West, M. E., Alaska Earthquake Center Staff.

Megathrust Earthquakes: Recurrence, Rupture Modes and Tsunamis (see page 884 )

34. Gempa Nusantara: A New Digital Database of Felt Intensity for Historical Earthquakes in the Indonesian Archipelago. Martin, S. S., Locati, M., Sieh, K. E.

35. Cascadia Onshore-Offshore Site Response, Submarine Sediment Mobilization, and Earthquake Recurrence. Gomberg, J. S.

36. Tree-Ring Dating of the Penultimate Great Alaska Earthquake to the Winter of 1029-1030 Ce. Haeussler, P. J., Barclay, D. J.

37. Student: Earthquake Recurrence of the Northern Lesser Antilles Arc: Paleoseismologic Approach. Morena, P. F., Cattaneo, A., Ratzov, G., Feuillet, N., Beck, C., Goldfinger, C., Patton, J. R., Moreno, E., Seibert, C., Klingelhoefer, F.

38. Student: Modeling "The Big One": Insights from 2-D Dynamic Rupture Simulations. Ramos, M. D., Huang, Y. H.

39. 20th-Century Strain Accumulation on the Lesser Antilles Megathrust Based on Coral Microatolls. Philibosian, B., Feuillet, N., Jacques, E., Mériaux, A. S., Guihou, A., Anglade, A.

40. Student: Postseismic Deformation: The Esmeraldas, Ecuador, Seismic Sequence following the 2016 Pedernales Megathrust Earthquake. Hoskins, M. C., Meltzer, A., Soto-Cordero, L., Stachnik, J. C., Sirait, A. M. M., Beck, S. L., Lynner, C., Ruiz, M. C., Alvarado, A., Hernandez, S., Charvis, P., Font, Y., Nocquet, J. M., Régnier, M., Argurto-Detzel, H., León-Ríos, S., Rietbrock, A., Rolandone, F.
41. Student: The Mw 7.82016 Pedernales, Ecuador Earthquake Aftershock Sequence: a Detailed SpatioTemporal Analysis of the Rupture Processes, Stress Patterns and Slip Behavior. Soto-Cordero, L., Meltzer, A., Stachnik, J. C., Agurto-Detzel, H., Alvarado, A., Beck, S. L., Benz, H. M., Bergman, E., Charvis, P., Font, Y., Hayes, G. P., Hernandez, S., Hoskins, M. C., Lynner, C., Nealy, J., Régnier, M., Rietbrock, A., Yeck, W. L., Ruiz, M. C., León-Ríos, $S$.

42. Student: Characterizing the Temporal and Spatial Distribution of Earthquake Swarms in the Puerto Rico-Virgin Island Block. Hernandez Ramirez, F. J., Lopez, A. M., Vanacore, E. A.

Microzonation Studies-Site Effects (see page 886)

43. Standardized Seismic Microzoning to Estimate Probabilistic Seismic Hazard in Conurbated Areas of Veracruz State, Mexico. Torres Morales, G. F., Leonardo Suárez, M., Dávalos Sotelo, R., Mora González, I., Castillo Aguilar, $S$.

44. Integrated Geophysical Study of the Kingston Metropolitan Area Using Ambient Noise. Papadopoulos, I., Higgins, M., Smith, D.

45. Student: On the Impacts of Disregarding the Correct Soil Type and/or Correct Structural Period of Assets on the Portfolio Risk Assessment. Sedaghati, F., Daneshvaran, $S$.

46. H/V Spectral Ratio Analysis for Site Characterization Beneath LPA (La Plata) Station, Buenos Aires, Argentina. Rosa, M. L.

47. Preliminary Soil Characterization of the Most Affected Coastal Villages after the 16 April $2016 \mathrm{Mw}$ 7.8 Pedernales Earthquake, Ecuador. Barros, J. G., Laurendeau, A., Pacheco, D. A., Alvarado, A., Aguilar, J.

48. The Preliminary Study of Seismic Microsonation and Seismic Hazard Assessment for Urban Areas of Gori (Georgia). Gogoladze, Z., Moscatelli, M., Tsereteli, N. S, Albarello, D., Giallini, S.

49. Student: Typology of Horizontal-to-Vertical Ambient Noise Measurements in the Quito Basin, Ecuador. Reyes, M. F., Laurendeau, A., Alvarado, A., Bonilla, L. F., Barros, J. G., Guéguen, P., Mercerat, D., Pacheco, D. A., Schmitz, M., Courboulex, F.

50. Site Effects Characterization at Portoviejo City (Ecuador) by Normalizing Seismic Noise Spectra Using Aftershocks. Palacios, P. B., Yepes, H. A., Marrero, J. M., Ramón, P.

New Frontiers in Seismic and Acoustic Data Analysis (see page 888 )

51. Moment Tensor Inversion in an Optimized, ThreeDimensional Seismic Earth's Model. Guillot, L. F., Burgos, G., Landes, M., Trilla, A., Shapiro, N. M.

52. Seismo-Acoustic Signatures of Industrial Facilities. Marcillo, O. E., Maceira, M., Gammans, C. 
53. Student: Stochastic Summation of Smaller Earthquakes to Simulate Synthetic Strong Ground Motions: Extension to Double Corner Frequency Source Models. Sedaghati, F., Pezeshk, S., Tavakoli, B.

54. Crowd Sourcing Data Collection to Enhance the Understanding of Ground Truth Events. Hertzog, J. T., Antolik, M., Marin, N., Brogan, R., Nava, S.

55. Detecting Real Earthquakes Using Imaginary Templates: Matched-Filter Detection without A-Priori Information. Chamberlain, C. J., Townend, J., Baratin, L. M.

56. Prediction and Separation of Surface Waves into Fundamental Mode and Overtones Based on the Nonlinear Dispersion Measurement. Hu, H., Zheng, Y.

57. Student: Teleseismic P-Wave Coda Auto-Correlations versus P-Wave Receiver Functions : A Case Study from the Mackenzie Mountains, Yukon, Canada, and Utility for Icecap and Ice Shelf Stations. Baker, M. G., Aster, R. C., Schutt, D., Chaput, J. A., Witt, D.

58. Student: Multi-Scale Study of Ground Motion Coherence in Piñon Flats and the San Jacinto Fault Zone. Qin, L., Ben-Zion, Y., Vernon, F. L.

59. Development of UNAM Institute of Engineering Multipurpose Seismic Data Logger. Torres, M., Santiago, L., Ayala-Hernández, M., Ramirez, L., CastroParra, G., Velasco-Miranda, J. M., Aguilar-Calderón, L. A., Almora, D., Molina Avila, I., Mora-Contreras, A., Vázquez-Larquet, $\mathrm{R}$.

Observations and the Physics Behind Complex

Earthquakes (see page 890 )

60. Student: Exploring the Relation between Backprojection Images and Earthquake Source Processes. Yin, J., Denolle, M. A.

61. Student: Subevent Characterization of the 2016 M7.8 Kaikoura Earthquake. Jia, Z., Zhan, Z.

62. Conditional Probabilities of Multi-Fault Ruptures and Earthquake Sequences in California from the PhysicsBased Rupture Simulator RSQSim. Gilchrist, J. J., Jordan, T. H., Milner, K. R.

63. Data-Driven Estimation of Earthquake Rupture Dimensions from Early Aftershock Distributions. Meier, M. A., Ampuero, J. P., van der Elst, N. J., Hauksson, E., Ross, Z. E.

64. High-Precision Relocation of the Aftershock Sequence of the November 14, 2016, Mw 7.8 Kaikoura Earthquake, New Zealand. Lanza, F., Chamberlain, C. J., Jacobs, K., Warren-Smith, E. J., Thurber, C. H., Savage, M. K., Townend, J., Kortink, M., Godfrey, H. J.

65. Student: Diverse Volumetric Faulting Patterns in the San Jacinto Fault Zone. Cheng, Y., Ross, Z. E., BenZion, Y.

66. Student: How Much Can We Resolve Acceleration and Deceleration of Earthquake Rupture Evolution? Okuwaki, R., Yagi, Y.
67. Fault Slip Associated with the M 5.3 September 2, 2017, Sulphur Peak, Idaho, Earthquake and Aftershock Sequence. Pollitz, F. F., Wicks, C. W., Yeck, W. L., Evans, J.

68. Student: Complex Seismic Sources for LP Events in Volcanic Environments: Model and Radiation Patterns. Contreras Arratia, R. A., Neuberg, J. W.

Ocean Bottom Seismology-Hurdles, Strategies and Outcomes (see page 892)

69. Study of the May 2016 Seismic Swarm at Rivera Plate Using OBS and Onland Stations. Núñez-Cornú, F. J., Córdoba Barba, D., Dañobeitia, J. J., Bandy, W., Mortera-Gutierrez, C., Núñez Escribano, D., Alarcon, E., Sandoval, J. M.

70. Güralp Systems: Illuminating the Oceans with an Ocean Bottom Family for All Requirements. Allardice, S. A., Mangano, G.

71. Increased Global Seismic Sampling via Proposed Transoceanic SMART Cable Sensors - Comparing Ray Coverage through the SALSA3D Global Model. Rowe, C. A., Begnaud, M. L., Syracuse, E. M., Howe, B. M.

72. Improved Focal Mechanisms and Spatial Stress Patterns Pertaining to Shallow Slow Slip in the Northern Hikurangi, New Zealand. Warren-Smith, E. J., Chon, E. R., Fry, B., Sheehan, A. F., Wallace, L. M., Mochizuki, K., Schwartz, S. Y.

73. Insights from Operations of the U.S. Ocean Bottom Seismograph Instrument Pool. Woodward, R. L., Aderhold, K.

74. Student: Temporal Variations in Seismic Anisotropy during the 2014 Gisborne SSE, New Zealand. Zal, H. J., Jacobs, K., Savage, M. K., Mroczek, S., Graham, K. M., Yarce, J., Todd, E., Shaddox, H., Nakai, J. S., Iwasaki, Y., Sheehan, A. F., Mochizuki, K.

75. Ocean Bottom Seismometer Data Quality Using MUSTANG. Aderhold, K., Woodward, R. L., Sharer, G., Keyson, L.

Real-Time GNSS Network Operations and Advances towards Early Warning Systems (see page 893)

76. Meeting the Requirements of Early Warning Systems in Real-Time GNSS Operations. Hodgkinson, K. M., Mencin, D., Sievers, C., Fox, O., Mattioli, G. S.

77. Real Time GNSS Network in Northern Ecuador. Jarrin Tamayo, P., Mothes, P. A., Nocquet, J. M., Alvarado, A., Rolandone, F., Ruiz, M. C.

78. COCONet Mirror Data Center at INETER, Nicaragua, and Early Warning in Central America. Ramirez, A., Strauch, W.

79. Student: GPS2EW: A Python Class That Can Be Used to Transmit GNSS Data to an Earthworm System. Hernandez Ramirez, F. J., Lopez, A. M., Vanacore, E. A., Huerfano, V. A. 
80. The GNSS Component of the Puerto Rico Seismic Network. Lopez, A. M., Huerfano, V. A., Vanacore, E. A.

81. GNSS Network of the Mexican National Seismological Service. Mendoza Carvajal, A. J., Estrada, J. A., Pérez, J., Navarro Estrada, F., Cruz, J. L., Hurtado, A., Rodríguez Rasilla, I., Tan, Y., Pérez-Campos, X., Cabral-Cano, E., Salazar Tlaczani, L., Hurtado, H. M.

Recent Advances in Dense Array Seismology (see page

895)

82. Student: Shallow Rigidity Structure From LowFrequency Wind-Induced Ground Motions Using Co-Located Pressure and Seismic Sensors. Wang, J., Tanimoto, $\mathrm{T}$.

83. Student: Anatomy of Old Faithful from Subsurface Seismic Imaging of Yellowstone National Park, Upper Geyser Basin. Wu, S. M., Lin, F. C., Farrell, J. M., Ward, K. M., Karplus, M., Smith, R. B.

84. Advanced Structural Health Monitoring System for US Department of Veterans Affairs Hospital Buildings. Kalkan, E., Fletcher, J., Friberg, P. A., Baker, L. M., Archilla, J.

85. Zland 3C 5Hz Node Test Results. Sweet, J. R., Anderson, K. R.

86. Student: Using Cross-Correlation Methods to Characterize Earthquakes Associated with the Socorro Magma Body. Vieceli, R. E., Bilek, S. L., Worthington, L. L., Schmandt, B., Aster, R. C., Dodge, D. A., Pyle, M. L., Walter, W. R.

87. Student: Local-Similarity Based Seismic Event Detection and Location in the Western Alps with a Dense Linear Array. Zhai, Q., Peng, Z., Li, Z., Zhao, L.

88. Student: High-Resolution Reflection Imaging of Fractures Using Cross-Dipole Shear Source in a Wellbore. Li, D., Tian, X., Hu, H., Tang, X., Zheng, Y.

89. Student: Utilization of Dense Surface Seismic Array for Detection of Low Magnitude Intermediate Depth Earthquakes from Bucaramanga Nest. Alalli, A. A., Beroza, G. C.

90. Seismic Tomography at Brady Geothermal Field, Nevada, With Dense Nodal and Fiber-Optic Seismic Arrays. Nayak, A., Thurber, C. H., Parker, L., Li, P., Fratta, D., Zeng, X., Ak, E., Feigl, K., Lord, N., PoroTomo Team, .

91. Large-N Seismic Deployment at the Source Physics Experiment (SPE) Phase II Site. Chen, T., Snelson, C.

92. Seismic Reflection Imaging With Earthquake Sources and Dense Arrays: Beyond Structural Imaging From P-Wave Reflections. Quiros, D. A., Pulliam, J.

93. Shallow Sedimentary Structure of the Tangshan Earthquake Region Unveiled by Dense Seismic Array and Microtremor Survey. Bao, F., Li, Z. W.

\section{Seismic Event Screening (see page 897)}

94. Student: Further Development and Testing of ML-MC as a Depth Discriminant at Local Distances. Scales, M. M., Voyles, J. R., Hale, J. M., Koper, K. D., Burlacu, R., Pechmann, J. C.

95. Discrimination of Anthropogenic Events and Tectonic Earthquakes in Utah Using a Quadratic Discriminant Function Approach with Local-Distance Amplitude Ratios. Tibi, R., Koper, K. D., Pankow, K. L., Young, C.

Present-Day Plate Boundary Deformation and Seismic Hazard in the Caribbean (see page 898 )

96. Moment Tensor Solutions along the Northern Caribbean Plate Boundary in Western Hispaniola (Haiti). Corbeau, J., Clouard, V., Gonzalez, O. L., Rolandone, F., Leroy, S., Mercier de Lépinay, B.

97. Student: The Role ofLong-Term Tectonic Deformation on the Distribution of Present-Day Seismic Activity in the Caribbean and Central America. Schobelock, J. J., Stamps, D. S., Pagani, M., Garcia, J. A., Styron, R.

Seismic Hazards and Historic Earthquakes in Puerto Rico and the Northern Caribbean Region (see page 898)

98. Student: Hazard Implications from High-Precision Earthquake Relocations in the Dominican Republic. Martinez, C. M., Mejia, H. P., Pulliam, J., Polanco, E., Martinez, F., Leonel C, J. M., Huerfano, V. A.

99. Probabilistic Seismic Hazard Modeling for Puerto Rico and the U.S. Virgin Islands. McNamara, D. E., Mueller, C. S., Petersen, M. D., Powers, P. M., Shumway, A. M., Hoover, S. M.

Seismic Structure of Convergent Plate Margins (see page 899)

100. Margin-Wide Continental Crust Anisotropy in the Mexican Subduction Zone. Huesca-Perez, E., Valenzuela, R. W., Ortega, R., Husker, A. L., Gutierrez, E., CabralCano, E.

101. Student: Seismic Structure of the Austral Basin, Patagonia, Using Surface Wave Phase Velocity. Duca, L., Rosa, M. L., Flores, G.

102. Student: Lg Q Model for Western Tibet. Jaiswal, N., Singh, C.

103. Student: Characteristics of the Double Benioff Zones in the Hikurangi Subduction Zone, New Zealand, Based on Nested Regional-Global Seismic Tomography and Waveform Cross-Correlation Relocation. Aziz Zanjani, F., Lin, G., Thurber, C. H.

104. Student: Frequency-Dependent Crustal Attenuation from Lg-Waves in Alaska. Jambo, E.

105. The Seismic Strong Motion Array Project (SSMAP) and September 5, 2012, Mw=7.6 Nicoya, Costa Rica, 
Earthquake Investigation during 2006-2016. Simila, G. W., Mohammadebrahim, E., Quintero, R.

106. Student: Interdisciplinary Seismotectonic Analysis in the Broken Foreland of the NW Argentine Andes. Zeckra, M., Arnous, A., Aranda Viana, G., Criado Sutti, E. J. M., Krüger, F., Strecker, M. R., Hongn, F.

\section{Structure and Dynamics of Earth's Mantle (see page}

900)

107. Student: Upper-Mantle Seismic Anisotropy beneath the Amazonian Craton and Central Brazil from Analysis of Shear-Wave Splitting. Villanova, L., Condori, C., Gonzaga, M., França, G. S.

108. Structural Complexity and Anisotropy of the Crust and Upper Mantle along the St. Lawrence Corridor, Eastern Canada. Bent, A. L., Kao, H., Darbyshire, F. A.

109. Multi-Scale Mantle Structure underneath North America from a New Tomographic Model of Seismic Shear Velocity. Porritt, R. W., Becker, T. W., Auer, L., Boschi, L.

110. Student: Sks Seismic Anisotropy Observations in MidPlate South America: Investigating Mantle Flow and Effects of Cratonic Keels. de Melo, B. C., Assumpção, M.

111. Spiral 1.0: Global Tomography Model of Travel Times and Surface Waves with Transversely Isotropic Crust and Mantle. Simmons, N. A., Myers, S. C.

112. Influence of Postcritical Reflection and Refraction on SmKS. Wang, L., Niu, F.

Testing PSHA Input Data, Source Models and Hazard

Estimates (see page 901)

113. Overview and Testing Validation of NSHM for Japan with Earthquake Records. Morikawa, N., Hao, K. X. S., Fujiwara, H.

114. Finite Fault Distance Distribution in Probabilistic Seismic Hazard and the Relationship between Extended Source Distances. Ortega, R., Gutierrez, E., Carciumaru, D., Huesca-Perez, E.

115. Student: Assessing the Applicability of GroundMotion Models for Induced Seismicity Application in Central and Eastern North America. Farhadi, A. F., Pezeshk, S.
116. Study on the Uniform Earthquake Catalogue and Seismicity of Himalaya Areas. Xu, G., Wang, S.

117. Student: Selection of Ground Motion Models for Probabilistic Seismic Hazard Analysis in Iran. Farajpour, Z., Kowsari, M., Pezeshk, S., Halldorsson, B.

118. One-Year Hazard Models, Their Performance and Uncertainties. Mousavi, S. M., Beroza, G. C.

U.S. National Seismic Hazard Model Updates: 2018, 2020 and Beyond (see page 903)

119. Sensitivity of Performance-Based Design to Ground Motion Characteristics. Safak, E., Cakti, E.

120. Implementation of Western U.S. Sedimentary Basin Effects into the 2018 Update of the USGS National Seismic Hazard Model. Shumway, A. M., Petersen, M. D., Boyd, O. S., Thompson, E. M., Frankel, A. D., Moschetti, M. P., Luco, N., Rezaeian, S., Powers, P. M.

121. 2018 Update to the Earthquake Catalog Applied in the National Seismic Hazard Model. Hoover, S. M., Mueller, C. S., Moschetti, M. P., Petersen, M. D.

122. Implementation of NGA-East Ground Motion Models into the 2018 Update of the USGS National Seismic Hazard Model. Shumway, A. M., Petersen, M. D., McNamara, D. E., Rezaeian, S., Powers, P. M.

123. Basin Amplification Factors for Cascadia Estimated from the 2011 Tohoku, Japan, Earthquake. Skarlatoudis, A., Somerville, P., Hosseini, M.

124. A Hybrid Empirical Ground Motion Model for the Island of Hawaii. Haji-Soltani, A., Pezeshk, S.

125. Hybrid Empirical Ground-Motion Prediction Equations for the Gulf Coast Region. Pezeshk, S., Zandieh, A., Haji-Soltani, A.

126. The 2018 Working Group on Nevada Seismic Hazards: Future Directions for Improvement of the National Seismic Hazards Map in Nevada. Koehler, R. D., Anderson, J. G.

127. New Paleoseismic Data from the Frenchman Mountain Fault, Las Vegas, Nevada. Dee, S. M., dePolo, C. M., Taylor, W. J., Mahan, S. A.

128. A Preliminary Model to Evaluate Long-Term Earthquake Risk Associated With National Bridge Inventory Infrastructure. Jaiswal, K. S., Luco, N., Lin, K., Rozelle, J. 
Thursday 17 May-Oral Sessions

\begin{tabular}{|c|c|c|c|c|}
\hline Time & Brickell & Flagler & Hibiscus A & Hibiscus B \\
\hline & $\begin{array}{l}\text { Tsunami Outreach, } \\
\text { Education and Warning } \\
\text { Dissemination: Cross- } \\
\text { Disciplinary Opportunities } \\
\text { for Increasing Tsunami } \\
\text { Resiliency } \\
\text { Session Chairs: Lori Dengler, } \\
\text { Christa G. von Hillebrandt- } \\
\text { Andrade, and Rick I. Wilson } \\
\text { (see page 931) }\end{array}$ & $\begin{array}{l}\text { Observed Characteristics } \\
\text { of Induced Seismicity: } \\
\text { From Laboratory to Field } \\
\text { Scale (Parts } 3 \text { and 4) } \\
\text { Session Chairs: Kayla A. } \\
\text { Kroll, Elizabeth S. Cochran, } \\
\text { and Brett Carpenter (see page } \\
\text { 918) }\end{array}$ & $\begin{array}{l}\text { USGS Seismic Hazard } \\
\text { User-Needs } \\
\text { Session Chairs: Susan M. } \\
\text { Hoover, Nico Luco, Peter M. } \\
\text { Powers, and Sanaz Rezaeian } \\
\text { (see page 934) }\end{array}$ & $\begin{array}{l}\text { Increasing Testability- } \\
\text { Expanding Possibilities and } \\
\text { Future Developments of the } \\
\text { Collaboratory for the Study } \\
\text { of Earthquake Predictability } \\
\text { Sesson Chairs: Andrew } \\
\text { Michael, Danijel } \\
\text { Schorlemmer, Maximilian } \\
\text { Werner, and Warner(see page } \\
917) \\
\end{array}$ \\
\hline $8: 30 \mathrm{AM}$ & $\begin{array}{l}\text { InviTED: The Tsunami } \\
\text { during the September 8, } \\
\text { 2017, Tehuantepec, Mexico } \\
\text { Earthquake-Physical } \\
\text { Observations and Warning } \\
\text { Response. Ramirez-Herrera, } \\
\text { M. T., Corona Morales, N., } \\
\text { Ruiz-Angulo, A., Melgar, D., } \\
\text { Zavala-Hidalgo, J. }\end{array}$ & $\begin{array}{l}\text { Earthquakes and Human } \\
\text { Activities to Induce Them } \\
\text { in Oklahoma. Walter, J. I., } \\
\text { Chang, J. C., Murray, K. E., } \\
\text { Boak, J. }\end{array}$ & $\begin{array}{l}\text { Feedback from the } 2015 \\
\text { ATC/USGS Seismic Hazard } \\
\text { User-Needs Workshop. } \\
\text { Olsen, A. H., Luco, N., } \\
\text { Powers, P. M. }\end{array}$ & $\begin{array}{l}\text { The Collaboratory for } \\
\text { the Study of Earthquake } \\
\text { Predictability: Achievements } \\
\text { and Priorities. Jackson, } \\
\text { D. D., Werner, M. J., } \\
\text { Schorlemmer, D. }\end{array}$ \\
\hline $8: 45 \mathrm{AM}$ & $\begin{array}{l}\text { INVITED: Tsunami } \\
\text { Public Awareness and } \\
\text { Education Strategy for the } \\
\text { Caribbean and Adjacent } \\
\text { Regions - Principles and } \\
\text { Implementation. Brome, A., } \\
\text { Aliaga, B. }\end{array}$ & $\begin{array}{l}\text { How Faults Wake Up: } \\
\text { The Guthrie-Langston, } \\
\text { Oklahoma, Earthquakes. } \\
\text { Schoenball, M., Walsh, } \\
\text { F. R., Weingarten, M., } \\
\text { Ellsworth, W. L. }\end{array}$ & $\begin{array}{l}\text { Overview of the USGS } \\
\text { Unified Hazard Tool. } \\
\text { Powers, P. M. }\end{array}$ & $\begin{array}{l}\text { STUDENT: Simulations of } \\
\text { Data Based Scenarios to } \\
\text { Investigate the Significance } \\
\text { of Data Quality in Seismicity } \\
\text { Studies. Adamaki, A. K. }\end{array}$ \\
\hline 9:00 AM & $\begin{array}{l}\text { Lessons for Tsunami and } \\
\text { Earthquake Resilience } \\
\text { from Hurricanes Irma and } \\
\text { Maria in the Northeastern } \\
\text { Caribbean. von Hillebrandt- } \\
\text { Andrade, C. G., Vanacore, } \\
\text { E. A., Baez-Sánchez, G. }\end{array}$ & $\begin{array}{l}\text { More Stress Drop Estimates } \\
\text { for Injection-Induced } \\
\text { Earthquakes in Oklahoma } \\
\text { and Southern Kansas. Wong, } \\
\text { I. G., Darragh, R. B., Silva, } \\
\text { W. J., Kishida, T. }\end{array}$ & $\begin{array}{l}\text { Project '17: Improving } \\
\text { Earthquake Ground Motion } \\
\text { Maps for Building Codes. } \\
\text { Luco, N., Rezaeian, S., } \\
\text { Stewart, J. P., Hamburger, R. } \\
\text { O., Crouse, C. B., Furr, J. C., } \\
\text { Kircher, C. A. }\end{array}$ & $\begin{array}{l}\text { Testing Planned USGS } \\
\text { Aftershock Forecasts } \\
\text { Requires Simulation- } \\
\text { based Tests, Which } \\
\text { Demonstrate Limitations } \\
\text { of the Reasenberg and Jones } \\
\text { Method. Michael, A. J. }\end{array}$ \\
\hline $9: 15 \mathrm{AM}$ & $\begin{array}{l}\text { Tsunami Response Lessons } \\
\text { Learned in Puerto Rico } \\
\text { from the January 10, 2018, } \\
\text { 7.6 Mw Honduras Event. } \\
\text { Baez-Sánchez, G., Colon, } \\
\text { B., Martinez, J. F., Mendez- } \\
\text { Yulfo, R., Vanacore, E. A., } \\
\text { Huerfano, V. A. } \\
\end{array}$ & $\begin{array}{l}\text { STUDENT: Determining } \\
\text { Periodicity in Non- } \\
\text { Homogeneous Catalogs } \\
\text { Using a Modified Schuster } \\
\text { Test with Application } \\
\text { to Induced Seismicity in } \\
\text { Oklahoma. Pearson, K. M., } \\
\text { Thomas, A. M., Lekic, V. } \\
\end{array}$ & $\begin{array}{l}\text { An Overview of the Use of } \\
\text { NSHMP Products in the } \\
\text { Insurance Industry. Shome, } \\
\text { N., Nyst, M. }\end{array}$ & $\begin{array}{l}\text { Turing-Style Tests for } \\
\text { Synthetic Earthquake } \\
\text { Catalogs. Page, M. T., van } \\
\text { der Elst, N. J. }\end{array}$ \\
\hline $9: 30 \mathrm{AM}$ & $\begin{array}{l}\text { A Century Later: An } \\
\text { Historical Novel of the } 1918 \\
\text { Puerto Rico Earthquake and } \\
\text { Tsunami. von Hillebrandt- } \\
\text { Andrade, C. G., Bayrón } \\
\text { Toro, F. }\end{array}$ & $\begin{array}{l}\text { STUDENT: Physics-Based } \\
\text { Induced Earthquake } \\
\text { Forecasting: Case Studies } \\
\text { from Texas and Oklahoma. } \\
\text { Zhai, G., Shirzaei, M. }\end{array}$ & Discussion & $\begin{array}{l}\text { Regional Evolution of Coda } \\
\text { Waves' Attenuation in the } \\
\text { NW South America. Vargas } \\
\text { Jimenez, C. A., Ochoa, L. } \\
\text { H. }\end{array}$ \\
\hline $\begin{array}{r}9: 45- \\
10: 45 \mathrm{AM}\end{array}$ & \multicolumn{4}{|c|}{ Posters and Break } \\
\hline
\end{tabular}


Jasmine

Theory, Observations and

Interpretations

Session Chairs: Vaclav Vavrycuk, Grzegorz Kwiatek, and Douglas Dreger (see page 911)

8:30 AM

eomechanical Insights from

Numerical Modeling of Intact Rock

Failure: Event Characteristics and Stress

Drops. Van der Baan, M., Chorney, D.

8:45 AM

STUdent: A Unified Theory for

Faulting Style, Tectonic Regime, and Earthquake-Size Distribution.

Petruccelli, A., Schorlemmer, D.,

Tormann, T., Rinaldi, A. P., Wiemer, S., Gasperini, P., Vannucci, G.

9:00 AM

Utilizing Stochastic Methods to

Characterize Deformation Associated with Hydraulic Fracture Stimulations. Viegas, G., Urbancic, T.

9:15 AM

Stress Drop and Scaling of Earthquakes at the Geysers Geothermal Field, California. Dreger, D. S., Boyd, O. S., Taira, T., Gritto, R.

9:30 AM

Validation of a 3-Stage Source Scaling for Crustal Earthquakes. Miyake, H., Irikura, K., Miyakoshi, K., Kamae, K.
Monroe

Retrieval of Fine Scale Information

Using Seismic Noise

Session Chairs: Julien Chaput and

Thomas Lecocq (see page 923)

Applications of Blind Signal Separation to Ambient Seismic Field Cross-

Correlation. Liu, X., Beroza, G. C.,

Nakata, N.

Towards Structural Imaging Using

Scattering Artifacts Detected

in Ambient Field Correlations.

Retailleau, L., Beroza, G. C.

STUDENT: Global-Scale Full Waveform

Ambient Noise Inversion. Sager, K.,

Ermert, L., Boehm, C., Krischer, L.,

Afanasiev, M., Fichtner, A.

Imaging Medium Changes at Depth

Using 3-D Probabilistic Body- and

Surface-Wave Sensitivity Kernels.

Obermann, A., Planès, T.

STUDENT: On the Nature of

Higher-Order Ambient Seismic Field

Correlations. Sheng, Y., Nakata, N.,

Beroza, G. C.
Tuttle

Structure and Geodynamics of the Caribbean Plate Boundaries

Session Chairs: Alan Levander and Fenglin Niu (see page 927)

Invited: Mantle Structure of the Caribbean and Its Geodynamic Consequences. Govers, R., Broerse, T., van Benthem, S., Spakman, W., Wortel, R.

INVITED: Seismic Imaging of the Lesser Antilles Subduction Zone with the VOILA Project. Rychert, C. A., Harmon, N., Chichester, B., Collier, J., Henstock, T., Hicks, S., Kruger, F., Rietbrock, A.

InviTED: Mutual Subduction: A Review of Observations from the Southern Caribbean Margin and Some Outstanding Questions. Bezada, M. J., Cornthwaite, J. P., Niu, F., Levander, A. R.

InviteD: What Can Earthquakes Tell Us of Plate Interactions in Northern South America? Prieto, G. A., Dionicio, V., Monsalve, G.

Inferences of Slab Tears throughout the Caribbean from Integrated Seismic Methods. Miller, M. S., Harris, C. W., Porritt, R. W., Hodges, M.
9:45-

10:45 AM
Posters and Break 


\begin{tabular}{|c|c|c|c|c|}
\hline Time & Brickell & Flagler & Hibiscus A & Hibiscus B \\
\hline & $\begin{array}{l}\text { The Recent Earthquakes } \\
\text { that Shocked Mexico in } \\
\text { September } 2017 \\
\text { Session Chairs: Arturo } \\
\text { Iglesias, Vala Hjörleifsdóttir, } \\
\text { Víctor M. Cruz-Atienza, and } \\
\text { Roberto Ortega-Ruiz (see } \\
\text { page 928) }\end{array}$ & $\begin{array}{l}\text { Observed Characteristics } \\
\text { of Induced Seismicity: } \\
\text { From Laboratory to Field } \\
\text { Scale (continued) }\end{array}$ & $\begin{array}{l}\text { Applications of Machine } \\
\text { Learning and Data Science } \\
\text { in Seismology } \\
\text { Session Chairs: Qingkai } \\
\text { Kong, Chengping Chai, } \\
\text { Zefeng Li, Min Chen, and } \\
\text { Rongrong Wang (see page } \\
\text { 907) }\end{array}$ & $\begin{array}{l}\text { Uncertainty in Ground } \\
\text { Motion Estimation; } \\
\text { Seismological and } \\
\text { Engineering Perspectives } \\
\text { Session Chairs: Valerie J. } \\
\text { Sahakian, Annemarie S. } \\
\text { Baltay, and Kathryn E. } \\
\text { Wooddell (see page 932) } \\
\end{array}$ \\
\hline $10: 45 \mathrm{AM}$ & $\begin{array}{l}\text { The September 19th, 2017, } \\
\text { (M7.1), Intermediate-Depth } \\
\text { Mexican Earthquake: An } \\
\text { Energetically Inefficient } \\
\text { Deadly Shock. Mirwald, } \\
\text { A., Cruz-Atienza, V. M., } \\
\text { Iglesias, A., Diaz-Mojica, J., } \\
\text { Hjörleifsdóttir, V., et al. }\end{array}$ & $\begin{array}{l}\text { STUDENT: Quasi-Static Fault } \\
\text { Dislocation Driven by Fluid } \\
\text { Diffusion and Poroelastic } \\
\text { Stressing as a Possible Source } \\
\text { Model of Slow Slip Events: A } \\
\text { Numerical Investigation. Jin, } \\
\text { L., Zoback, M. D. }\end{array}$ & $\begin{array}{l}\text { Training a Deep Neural } \\
\text { Network to Generate Full } \\
\text { Seismograms. Krischer, L., } \\
\text { Fichtner, A. }\end{array}$ & $\begin{array}{l}\text { Analysis of the Effect of } \\
\text { Near Surface Slips on } \\
\text { Strong Ground Motion: An } \\
\text { Example of the Main Shock } \\
\text { of the } 2016 \text { Kumamoto } \\
\text { Earthquakes. Nagasaka, Y., } \\
\text { Nozu, A. }\end{array}$ \\
\hline $11: 00 \mathrm{AM}$ & $\begin{array}{l}\text { Intraslab Earthquake } \\
\text { Faulting in Subduction } \\
\text { Zones: The Role of Seafloor } \\
\text { Fabric During the M 7.1 } \\
\text { and M 8.2 September } \\
\text { 2017 Mexico Earthquakes. } \\
\text { Melgar, D., Ruiz-Angulo, A., } \\
\text { Pérez-Campos, X., Garcia, E. } \\
\text { S., Manea, M., et al. }\end{array}$ & $\begin{array}{l}\text { Active Pressure Management } \\
\text { as a Tool to Reduce Induced } \\
\text { Seismicity. Kroll, K. A., } \\
\text { White, J. A., Richards- } \\
\text { Dinger, K. B. }\end{array}$ & $\begin{array}{l}\text { INVITED: Deep Learning } \\
\text { Aftershock Location } \\
\text { Patterns. DeVries, P., Viegas, } \\
\text { F., Wattenberg, M., Meade, } \\
\text { B. }\end{array}$ & $\begin{array}{l}\text { The Case for Mean Rupture } \\
\text { Distance in Ground Motion } \\
\text { Estimation. Thompson, E. } \\
\text { M., Baltay, A. S. }\end{array}$ \\
\hline $11: 15 \mathrm{AM}$ & $\begin{array}{l}\text { A Study of Excitation and } \\
\text { Ground Motion Relations } \\
\text { in Central Mexico Based } \\
\text { on the Earthquakes of } \\
\text { September 2017. Ortega, R., } \\
\text { Carciumaru, D., Quintanar, } \\
\text { L. }\end{array}$ & $\begin{array}{l}\text { STUDENT: Monte Carlo } \\
\text { Simulations for Analysis and } \\
\text { Prediction of Non-Stationary } \\
\text { Magnitude-Frequency } \\
\text { Distributions in Probabilistic } \\
\text { Seismic Hazard Analysis. } \\
\text { Reyes Canales, M., Van der } \\
\text { Baan, M. }\end{array}$ & $\begin{array}{l}\text { INVITED: STUDENT: High } \\
\text { Resolution Travel Time } \\
\text { Tomography with Local } \\
\text { Sparsity Regularization and } \\
\text { Dictionary Learning, with } \\
\text { Application to Ambient } \\
\text { Noise Tomography on } \\
\text { a Dense Seismic Array. } \\
\text { Bianco, M. J., Gerstoft, P., } \\
\text { Olsen, K. B., Lin, F. C. }\end{array}$ & $\begin{array}{l}\text { INVITED: Reducing } \\
\text { Uncertainties of Ground } \\
\text { Motion Estimations-The } \\
\text { Effect of Rupture Directivity. } \\
\text { Kurzon, I. }\end{array}$ \\
\hline $11: 30 \mathrm{AM}$ & $\begin{array}{l}\text { Earthquake Triggering } \\
\text { and Stress Changes in the } \\
\text { September } 2017 \text { Mexican } \\
\text { Earthquake Sequence. } \\
\text { Fielding, E. J., Gombert, B., } \\
\text { Duputel, Z., Huang, M. H., } \\
\text { Liang, C., et al. }\end{array}$ & $\begin{array}{l}\text { INVITED: Improving } \\
\text { Earthquake Rate Models for } \\
\text { One-Year Hazard Forecasts } \\
\text { in Southern Kansas. Llenos, } \\
\text { A. L., Michael, A. J., } \\
\text { Norbeck, J. H., Rubinstein, } \\
\text { J. L. }\end{array}$ & $\begin{array}{l}\text { STUDENT: Rapid } \\
\text { Earthquake-Induced Damage } \\
\text { Detection Using Satellite } \\
\text { Imagery and Machine } \\
\text { Learning Algorithms for the } \\
\text { September 19, 2017, M7.1 } \\
\text { Central Mexico Earthquake. } \\
\text { Rashidian, V., Koch, M., } \\
\text { Baise, L. G. } \\
\end{array}$ & $\begin{array}{l}\text { Moving Toward Region- } \\
\text { Specific Ground-Motion: } \\
\text { Reducing Uncertainty } \\
\text { in Gmpes with Physical } \\
\text { Representations of Path } \\
\text { Effects. Sahakian, V. J., } \\
\text { Baltay, A. S., Hanks, T. C., } \\
\text { Buehler, J. S., Vernon, F. L., } \\
\text { Kilb, D. } \\
\end{array}$ \\
\hline $11: 45 \mathrm{AM}$ & $\begin{array}{l}\text { The September } 2017 \\
\text { Earthquakes in Mexico from } \\
\text { Social Media. Vela Rosas, } \\
\text { M. A., Pérez-Campos, X., } \\
\text { Pérez, J., Cardenas Monroy, } \\
\text { C., Espíndola, V. H., et al. }\end{array}$ & $\begin{array}{l}\text { What Is the Maximum Spatial } \\
\text { Reach of Fluid-Injection } \\
\text { Operations? Examining } \\
\text { Seismicity Decay and Poro- } \\
\text { Elastic Effects around } \\
\text { Injection Wells. Goebel, T. } \\
\text { H. W., Brodsky, E. E. }\end{array}$ & $\begin{array}{l}\text { WaveNet-An Open } \\
\text { Geoscience Database } \\
\text { Initiative for Automatic } \\
\text { Event Picking and Beyond. } \\
\text { Tu, N., Wang, R. }\end{array}$ & $\begin{array}{l}\text { Probabilistic Seismic Hazard } \\
\text { Analysis Using Non-Ergodic } \\
\text { Ground-Motion Prediction } \\
\text { Equations. Abrahamson, N. } \\
\text { A., Kuehn, N. M., Walling, } \\
\text { M., Landwehr, N. }\end{array}$ \\
\hline $\begin{array}{c}\text { Noon- } \\
1: 15 \mathrm{PM}\end{array}$ & \multicolumn{4}{|c|}{ Luncheon } \\
\hline
\end{tabular}


$T_{i m e}$

10:45 AM

Characteristics of Recent Aftershock

Sequences of Moderate Earthquakes in Japan. Mori, J. J.
11:00 AM

11:15 AM

STUDENT: Complex Source Spectra in Small Earthquakes Caused by Multiple Asperities. Wang, Y., Day, S. M.

STUDENT: Three-Dimensional Directivity Analysis for Resolving Source Parameters and Rupture Complexities. Park, S., Ishii, M.
11:45 AM Student: The Virginia City, Nevada, Earthquake Sequence: Exploring Complexities in Source Properties of Small Events $(\mathrm{M} \sim 3)$ and Fault Geometry. Hatch, R. L., Ruhl, C. J., Abercrombie, R. E., Smith, K. D.
Monroe

Emergency Management, Resilience and Preparedness

Session Chairs: Victor A. Huerfano, Christa G. von Hillebrandt-Andrade, Elizabeth A. Vanacore, and Ronald Jackson (see page 915)

2018 Honduras Earthquake and

Tsunamis: Notification and Response Process. von Hillebrandt-Andrade, $C$. G., Brome, A., Aliaga, B.

The Effects of Natural Disasters on the Demand for Education and Outreach in Puerto Rico: Why Now? Gomez, G., Vanacore, E. A.

Developing Local-Context Messages for Protective Actions during Earthquakes in Anse-a-Veau, Haiti. Mentor William, G., Rodgers, J. E., Devilme, G., Ortiz Millan, M.

Previsioni Operative Del Terremoto, Sōsa-Jō No Jishin Yochi, and Operational Earthquake Forecasts: Exploring How Operational Earthquake Forecasts Are Communicated in Italy, Japan, New Zealand, and the United States.

McBride, S. K., Wein, A. M., Marzocchi, W., Kamaya, N., et al. INVITED: No Blank Slates: SocioTechnical Systems Theory as a Guiding Principle for Disaster Response and Recovery. Perez-Lugo, M., Ortiz Garcia, C., Lopez, I.
Tuttle

Plate Boundary Segmentation and Coupled-to-Creeping Plate and Block Boundary Faults Session Chairs: John C. Weber and Omar J. Perez (see page 920)

A Geologic Recipe for Transient Slip within the Seismegenic Zone: Insight from the Guerrerol Seismic Gap, Mexico. Husker, A. L., Ferrari, L., Arango-GAdran, C., Corbo-Camargo, F., Arzate-Flores, J. A.

STUdENT: Along Strike Locking Characteristics of the Plate Boundary

Zone of the Southeastern Caribbean

Basin. Higgins, M., LaFemina, P., Weber, J. C., Geirsson, H.

INVITED: STUDENT: Episodic Forearc Sliver Creep during Relocking of the Nicoya, Costa Rica, Megathrust: An Unexpected Observation. Hobbs, T. E., Newman, A. V., Protti, J. M.

Invited: Factors Controlling Plate Boundary Segmentation in the Gulf of California. Persaud, P., Stock, J. M.

Fault Creep and Strain Partitioning in Trinidad and Tobago: Geodetic Measurements, Models, and Origin of Creep. Weber, J. C., Geirsson, H., La Femina, P., Robertson, R., Latchman, J. L., Churches, C., Shaw, K., Higgins, M., Miller, K. 


\begin{tabular}{|c|c|c|c|c|}
\hline Time & Brickell & Flagler & Hibiscus A & Hibiscus B \\
\hline & $\begin{array}{l}\text { The Recent Earthquakes } \\
\text { that Shocked Mexico in } \\
\text { September } 2017 \text { (continued) }\end{array}$ & $\begin{array}{l}\text { Seismic Studies of Earth's } \\
\text { Crust and Lithosphere } \\
\text { Session Chair: Elizabeth A. } \\
\text { Vanacore (see page 924) }\end{array}$ & $\begin{array}{l}\text { Applications of Machine } \\
\text { Learning and Data Science } \\
\text { in Seismology (continued) }\end{array}$ & $\begin{array}{l}\text { Uncertainty in Ground } \\
\text { Motion Estimation; } \\
\text { Seismological and } \\
\text { Engineering Perspectives } \\
\text { (continued) }\end{array}$ \\
\hline $1: 30 \mathrm{PM}$ & $\begin{array}{l}\text { The } 8 \text { September } 2017 \\
\text { Earthquake: An Example } \\
\text { of Large Scale Lithospheric } \\
\text { Faulting in the Subducted } \\
\text { Cocos Plate. Suarez, } \\
\text { G., Santoyo, M. A., } \\
\text { Hjörleifsdóttir, V., Iglesias, } \\
\text { A., Villafuerte, C., et al. }\end{array}$ & $\begin{array}{l}\text { STUDENT: New Constraints } \\
\text { on Seismic Anisotropy } \\
\text { beneath the Eastern Ghats } \\
\text { Mobile Belt and Adjacent } \\
\text { Archean Cratons Contact } \\
\text { Boundary. Jana, N., Singh, } \\
\text { A., Tiwari, A. K., Singh, C. }\end{array}$ & $\begin{array}{l}\text { STUDENT: PhaseNet: A } \\
\text { Deep-Neural-Network-Based } \\
\text { Seismic Arrival Time Picking } \\
\text { Method. Zhu, W., Beroza, } \\
\text { G. C. }\end{array}$ & $\begin{array}{l}\text { INVITED: STUDENT: } \\
\text { Near-Surface P- and } \\
\text { S-Wave Speeds Estimated } \\
\text { Based upon Body-Wave } \\
\text { Polarization. Park, S., Ishii, } \\
\text { M. }\end{array}$ \\
\hline $1: 45 \mathrm{PM}$ & $\begin{array}{l}\text { The 2017/09/08 Mw } 8.2 \\
\text { Tehuantepec, Mexico, } \\
\text { Earthquake: A Large but } \\
\text { Compact Dip-Slip Faulting } \\
\text { Event Severing the Slab. } \\
\text { Hjörleifsdóttir, V., Iglesias, } \\
\text { A., Suarez, G., Santoyo, M. } \\
\text { A., Villafuerte, C. D., et al. }\end{array}$ & $\begin{array}{l}\text { STUDENT: Remote Dynamic } \\
\text { Triggering in Southeast } \\
\text { Africa. Neves, M., Peng, Z., } \\
\text { Custódio, S. }\end{array}$ & $\begin{array}{l}\text { INVITED: Machine Learning } \\
\text { Applied to Probing Fault } \\
\text { Physics. Johnson, P. A., } \\
\text { Hulbert, C. L., Rouet- } \\
\text { LeDuc, B. P. G., Marone, C. } \\
\text { J., Trugman, D. T., et al. }\end{array}$ & $\begin{array}{l}\text { The Influence of Site } \\
\text { Response on Corner } \\
\text { Frequency Obtained Using } \\
\text { Spectral Ratio and Direct } \\
\text { Spectral Fitting Methods. } \\
\text { Boyd, O. S. }\end{array}$ \\
\hline 2:00 PM & $\begin{array}{l}\text { STUDENT: Numerical } \\
\text { Simulations of Tsunami } \\
\text { Scenarios for the Southern } \\
\text { Coast of Mexico. Salazar- } \\
\text { Monroy, E. F., Cruz- } \\
\text { Jímenez, H., Silva-Casarin, } \\
\text { R., Ramírez-Guzmán, L. }\end{array}$ & $\begin{array}{l}\text { From Individual Station } \\
\text { Magnitudes to Event } \\
\text { Average: What Does Average } \\
\text { Mean and Does It Matter? } \\
\text { Bent, A. L. }\end{array}$ & $\begin{array}{l}\text { InVITED: STUdEnT: Deep } \\
\text { Convolutional Neural } \\
\text { Networks for Phase Picking } \\
\text { in Oklahoma Based on } \\
\text { Transfer Learning. Zhu, L., } \\
\text { Li, C., Peng, Z., Meng, X., } \\
\text { McClellan, J. H. }\end{array}$ & $\begin{array}{l}\text { Evaluating and Improving } \\
\text { Ground Motion Predictions } \\
\text { for Scenario Earthquakes in } \\
\text { the San Francisco East Bay } \\
\text { by Integrating Earthquake } \\
\text { Ground-Motion Simulations } \\
\text { and Noise-Derived Empirical } \\
\text { Green's Functions. Taira, T., } \\
\text { Rodgers, A. }\end{array}$ \\
\hline 2:15 PM & $\begin{array}{l}\text { Intraslab Morelos-Puebla, } \\
\text { Mexico, Earthquake of 19 } \\
\text { September } 2017 \text { (Mw7.1): } \\
\text { Ground Motion and Damage } \\
\text { Pattern in Mexico City. } \\
\text { Singh, S. K., Reinoso, E., } \\
\text { Arroyo, D., Ordaz, M., Cruz- } \\
\text { Atienza, V. M., et al. }\end{array}$ & $\begin{array}{l}\text { STUDENT: Lithospheric } \\
\text { Structure of the Pantanal } \\
\text { Basin from the Analysis of } \\
\text { Fundamental and Higher } \\
\text { Modes Surface Waves. } \\
\text { D’Onofrio, A. F., Flores, G., } \\
\text { Rosa, M. L. }\end{array}$ & $\begin{array}{l}\text { STUDENT: A Convolutional } \\
\text { Neural Network for } \\
\text { Intermediate-Depth } \\
\text { Earthquake Detection and } \\
\text { Magnitude Estimation. } \\
\text { Florez, M. A., Prieto, G. A. }\end{array}$ & $\begin{array}{l}\text { Variability in Ground } \\
\text { Motions Due to the Presence } \\
\text { of the Built Environment. } \\
\text { Taborda, R., Isbiliroglu, Y. }\end{array}$ \\
\hline 2:30 PM & $\begin{array}{l}\text { Analysis of the } 19 \\
\text { September } 2017(\mathrm{Mw}=7.1) \\
\text { Mexico Earthquake and } \\
\text { Its Aftershock Sequence. } \\
\text { Iglesias, A., Méndez, M., } \\
\text { Hjörleifsdóttir, V., Franco, S. } \\
\text { I., Singh, S. K., et al. }\end{array}$ & $\begin{array}{l}\text { Evidence of a Low Frequency } \\
\text { Wave-Packet within Records } \\
\text { of the } 2016 \text { Central Italy } \\
\text { Seismic Sequence. Famiani, } \\
\text { D., Cultrera, G., Mercuri, A., } \\
\text { Michele, M., Vassallo, M. }\end{array}$ & $\begin{array}{l}\text { Operational Experience with } \\
\text { Next-Generation Automatic } \\
\text { Association Software NET- } \\
\text { VISA. Le Bras, R. J., Arora, } \\
\text { N., Kushida, N., Mialle, P., } \\
\text { Tomuta, E. }\end{array}$ & $\begin{array}{l}\text { STUDENT: Implementing } \\
\text { Inter-Period Correlations } \\
\text { into the SDSD Broadband } \\
\text { Ground Motion Method. } \\
\text { Wang, N., Takedatsu, R., } \\
\text { Olsen, K. B., Day, S. M. }\end{array}$ \\
\hline $\begin{array}{r}2: 45- \\
3: 45 \mathrm{PM}\end{array}$ & \multicolumn{4}{|c|}{ Pint and Poster } \\
\hline
\end{tabular}


Jasmine

Earthquake Source Parameters: Theory, Observations and Interpretations (continued)

1:30 PM

INVITED: The Eigenvalue Lune as a Window on Moment Tensors. Tape, C., Tape, W.

$1: 45 \mathrm{PM}$ STUdent: Seismic Source Parameters Inversion for Earthquakes in Bardarbunga Volcano for the Current Seismicity and the 2014-2015 Caldera Collapse Related Events. Cardozo, F. R., Hjörleifsdóttir, V., Jónsdóttir, K., Geirsson, $\mathrm{H}$.

STUDENT: Inversion for Focal Mechanisms Using Waveform Envelopes and Inaccurate Velocity Models. Carvalho, J. M., Barros, L. V., Zahradnik, J.

2:15 PM

Directly Estimating Earthquake Rupture Area Using Second Moments to Reduce the Uncertainty in Stress Drop. McGuire, J., Kaneko, Y., Fan, W.

Odd Moment Tensor. Aldridge, D. F., Haney, M. M., Leaney, W. S., Chapman, C. H.
Monroe

Adaptation of New Technologies and Methods to Drive New Discoveries in Seismology and Geodesy Session Chairs: Sarah E. Minson and Elizabeth S. Cochran (see page 906)

INVITED: STUDENT: A FAST

Data-Mining Approach for Similar Earthquake Detection. Yoon, C. E., Beroza, G. C., Bergen, K. J., Rong, K., Elezabi, H., Bailis, P., Levis, P.

INVITED: Generalized Seismic Phase Detection with Deep Learning. Ross, Z. E., Meier, M. A., Hauksson, E.

Multiscale Analysis of the Global Seismicity. D’Auria, L., Barrancos, J., García-Hernández, R., Padilla, G. D.

Earthquake-Induced Gravity Changes as Precursors of the Direct Seismic Waves. Vallée, M., Ampuero, J. P., Juhel, K., Bernard, P., Montagner, J. P., Barsuglia, M.

How Well Can We Resolve Surface Deformation Using Lidar, UAVSAR and Optical Imagery? DeLong, S. B., Donnellan, A., Pickering, A. J., Scott, C. P., Parker, J. W.
Tuttle

Plate Boundary Segmentation and

Coupled-to-Creeping Plate and Block Boundary Faults (continued)

Invited: How Are Fault Zone Architecture and Mode of Slip Affected by Normal Stress and Alternating Cycles of Gouge Production and Attenuation? Fletcher, J. M., Teran, O. J., Rockwell, T. K., Oskin, M. E.

INVITED: Geodetic Characterization of Kinematic Segmentation Along the Presqu'ile Du Sud / Enriquillo Fault System in Southern Haiti. Symithe, $\mathbf{S}$. J., Calais, E.

STUdent: The Kinematics of the Southwestern Caribbean from Geodetic GPS Data Modeling. Ruiz, A. G., La Femina, P., Camacho, E. I., Espinoza, O., Mora, $\mathrm{H}$.

Interaction between Seismicity and Slow Deformation Signals in the Eastern Sea of Marmara Region, Turkey. Martínez-Garzón, P., Kwiatek, G., Mencin, D., Bohnhoff, M., Johnson, W., Dresen, G., Nurlu, M.

Long-Term OBS Observations in the Sea of Marmara, Northwest Turkey. Pinar, A., Coşkun, Z., Kalafat, D., Yamamoto, Y., Takahashi, N., Çıtak, S., Polat, R., Turhan, F., Kaneda, Y., Ozener, $\mathrm{H}$. 


\begin{tabular}{|c|c|c|c|c|}
\hline Time & Brickell & Flagler & Hibiscus $A$ & Hibiscus B \\
\hline & $\begin{array}{l}\text { The 8th September Mw } \\
\text { 8.2 Tehuantepec and 19th } \\
\text { September Mw7.1 Puebla- } \\
\text { Morelos, Mexico Earthquakes: } \\
\text { Reconnaissance Findings and } \\
\text { Impact on Urban Areas in } \\
\text { South-Central Mexico } \\
\text { Session Chairs: Emel Seyhan, } \\
\text { Jorge Aguirre, and Leonardo } \\
\text { Ramírez-Guzmán (see page } \\
\text { 905) }\end{array}$ & $\begin{array}{l}\text { ShakeMap-Related } \\
\text { Research, Development, } \\
\text { Operations and } \\
\text { Applications } \\
\text { Session Chairs: David J. } \\
\text { Wald, Eric M. Thompson, } \\
\text { and Charles B. Worden (see } \\
\text { page 925) }\end{array}$ & $\begin{array}{l}\text { Forecasting Aftershock } \\
\text { Sequences in the Real } \\
\text { World } \\
\text { Session Chairs: Matthew } \\
\text { C. Gerstenberger, Sara K. } \\
\text { Mcbride, Nick Horpsool, and } \\
\text { David A. Rhoades (see page } \\
\text { 916) }\end{array}$ & \\
\hline $3: 45 \mathrm{PM}$ & $\begin{array}{l}\text { The M8.2 and M7.1 September } \\
\text { Seismic Events in Mexico: A } \\
\text { Perspective from the Strong } \\
\text { Motion Recording Center at } \\
\text { UNAM. Perez-Yañez, C., } \\
\text { Ramírez-Guzmán, L., Macias, } \\
\text { M. A., Ruiz, A. L., Delgado, } \\
\text { R., et al. }\end{array}$ & $\begin{array}{l}\text { Integrated Research, } \\
\text { Development, and Operations } \\
\text { of USGS Real-Time } \\
\text { Earthquake Shaking and } \\
\text { Impact Information Systems. } \\
\text { Wald, D. J., Allstadt, K. E., } \\
\text { Hayes, G. P., Hearne, M., } \\
\text { Jaiswal, K. S., et al. }\end{array}$ & $\begin{array}{l}\text { Non-Parametric Aftershock } \\
\text { Forecasts Based on Similar } \\
\text { Sequences in the Past. van } \\
\text { der Elst, N. J., Page, M. T. }\end{array}$ & \\
\hline 4:00 PM & $\begin{array}{l}\text { Analysis of the Ground } \\
\text { Motions of the September 7th } \\
\text { and 19th } 2017 \text { Tehuantepec } \\
\text { and Puebla-Morelos } \\
\text { Earthquakes. Sahakian, V. J., } \\
\text { Melgar, D., Ramírez-Guzmán, } \\
\text { L., Quintanar, L., et al. }\end{array}$ & $\begin{array}{l}\text { ShakeMap Ground-Motion } \\
\text { Interpolation Using the } \\
\text { Multivariate Normal } \\
\text { Distribution. Worden, C. B., } \\
\text { Thompson, E. M., Wald, D. J. }\end{array}$ & $\begin{array}{l}\text { Evolution of Aftershock } \\
\text { Sequences Based on the } \\
\text { Geometry of Successive Focal } \\
\text { Mechanisms. Townend, J. }\end{array}$ & \\
\hline $4: 15 \mathrm{PM}$ & $\begin{array}{l}\text { Spectral Ratios of Mexico } \\
\text { City Motions during the } \\
19 \text { September } 2017 \text { Mw7.1 } \\
\text { Puebla Earthquake Confirm } \\
\text { Frequencies in the Zoning } \\
\text { Maps. Celebi, M. K., } \\
\text { Sahakian, V. J., Melgar, D., } \\
\text { Quintanar, L., et al. }\end{array}$ & $\begin{array}{l}\text { INVITED: Introducing } \\
\text { a European Integrated } \\
\text { Shakemap System. Cauzzi, } \\
\text { C., Clinton, J. F., Faenza, L., } \\
\text { Heimers, S., Koymans, M., } \\
\text { et al. }\end{array}$ & $\begin{array}{l}\text { Earthquake Statistics in the } \\
\text { Eastern Tennessee and New } \\
\text { Madrid Seismic Zones Are } \\
\text { Inconsistent with Ongoing } \\
\text { Aftershock Sequences. } \\
\text { Levandowski, W., Powell, } \\
\text { C. A. }\end{array}$ & \\
\hline $4: 30 \mathrm{PM}$ & $\begin{array}{l}\text { STUDENT: 3-D Velocity } \\
\text { Structure of the Mexico City } \\
\text { Basin and Ground Motion } \\
\text { Simulation of the } 7.119 \\
\text { September } 2017 \text { Earthquake. } \\
\text { Rabade, S., Baena-Rivera, } \\
\text { M., Contreras, M., Ramírez- } \\
\text { Guzmán, L., et al. }\end{array}$ & $\begin{array}{l}\text { INVITED: Shake-Map Movie } \\
\text { by Using Data Assimilation } \\
\text { and Correction of Site } \\
\text { Amplification in Time } \\
\text { Domain. Hoshiba, M. }\end{array}$ & $\begin{array}{l}\text { Examples of Various } \\
\text { Operational Earthquake } \\
\text { Forecasting Products Using } \\
\text { the HayWired Planning } \\
\text { Scenario, including One Very } \\
\text { Quick (and Not-So-Dirty) } \\
\text { Hazard-Map Option. Field, } \\
\text { E. H., Milner, K. R. }\end{array}$ & \\
\hline $4: 45 \mathrm{PM}$ & $\begin{array}{l}\text { Uncertainty and Analysis of } \\
\text { Soil Fundamental Periods } \\
\text { Changes in the Valley of } \\
\text { Mexico. Baena-Rivera, M., } \\
\text { Rabade, S., Contreras, M., } \\
\text { Ramírez-Guzmán, L., Aguirre- } \\
\text { Gonzalez, J., et al. }\end{array}$ & $\begin{array}{l}\text { InviTED: Real-Time } \\
\text { Earthquake Impact Mapping } \\
\text { in Indonesia: The Case of the } \\
2016 \text { Aceh Earthquake (M } \\
\text { 6.5). Pramono, S., Murjaya, } \\
\text { J., Permana, D., Rudyanto, } \\
\text { A., Sakti, A., et al. }\end{array}$ & $\begin{array}{l}\text { Expanding the US } \\
\text { Geological Survey's Efforts } \\
\text { to Effectively Communicate } \\
\text { Operational Earthquake } \\
\text { Forecasts. McBride, S. K., } \\
\text { Hardebeck, J. L., Wein, A. } \\
\text { M., Michael, A. J., et al. }\end{array}$ & \\
\hline $5: 30 \mathrm{PM}$ & \multicolumn{4}{|c|}{ Cruise } \\
\hline
\end{tabular}




\section{Time} the 1925 Santa Barbara, California, Earthquake. Hough, S. E., Martin, S. S.

4:00 PM Rupture Lengths of Intraplate Earthquakes in Brazil Determined by Relative Location of Aftershocks: Evidence for Depth Dependence of Stress Drops. Assumpção, M., Ciardelli, C.

4:15 PM Earthquake Stress Drops Determined from Arias Intensity. Baltay, A. S., Hanks, T. C.

4:30 PM

Systematic Observations of the SlipPulse Properties of Large Earthquakes. Melgar, D., Hayes, G. P.
4:45 PM

Student: Variability in Seismic Source Spectra and Stress Drop from Repeating Earthquake Sequences along the Nicoya Peninsula Megathrust. Chaves, E. J., Schwartz, S. Y., Abercrombie, R. E.
Monroe

Challenges and Chances for the Widespread Implementation of Earthquake Early Warning (EEW) Session Chairs: Wilfried Strauch and Victor A. Huerfano (see page 909)

INVITED: Toward Earthquake Early Warning in Central America. Strauch, W., Clinton, J. F., Massin, F., Ramirez, $\mathrm{J}$.

The Potential Utility of an Earthquake Early Warning System in Eastern Canada. Crane, S. J., Perry, H. K. C., McCormack, D.

STUDENT: Earthquake Early Warning Feasibility Study for the New Madrid Seismic Zone. Ogweno, L. P., Withers, M. M., Cramer, C. H.

STUdent: MyShake - Building an Earthquake Early Warning System Using Smartphones. Kong, Q., Inbal, A., Allen, R. M.

An Analysis of Real-Time GNSS Solutions from the M8.2 September 2017 Tehuantepec Earthquake and M7.9 January 2018 Kodiak Earthquake and Implications for Earthquake and Tsunami Early Warning Systems. Mencin, D., Hodgkinson, K. M., Mattioli, G. S., Sievers, C.
Tuttle

Plate Boundary Segmentation and Coupled-to-Creeping Plate and Block Boundary Faults (continued)

Modern Kinematics of the Cordillera Blanca Fault, Northern-Central Peru, from GPS Geodesy. Norabuena, E. O., Weber, J. C., De la Cruz, Y., Salazar, J. E.

Seismo-Geodetic Monitoring of the Marmara Seismic Gap. Ozener, H., Bulut, F., Dogru, A.

Spatial Complementarity of Tectonic Earthquake Swarms on a Transform Plate Boundary in North Iceland. Passarelli, L., Rivalta, E., Jonsson, S., Hensch, M., Metzger, S., Jakobsdottir, S., Maccaferri, F., Corbi, F., Dahm, T.

Long-Term and Short-Term Slow Slip Events at the Southcentral Alaska Subduction Zone. Fu, Y., McGuire, J., Freymueller, J. T.

On the Interaction of the North Andes Plate With the Caribbean and South American Plates in Northwestern South America From Gps Geodesy and Seismic Data. Perez, Omar J., Uzcategui, R., Mora-Paez, H., Wesnousky, S. G., Szeliga, W. 


\section{Poster Sessions}

Adaptation of New Technologies and Methods to Drive New Discoveries in Seismology and Geodesy (see page 935)

1. Development of Integrated Accelerographs Using Mems Technology with Efficient Real-Time Data Transmission and Deployment of a Collaborative Seismic Network. Martín Agúndez, E., Martín García, E., Bravo Monge, J. B.

2. Determination of the B-Value through a Novel Multiscale Spatio-Temporal Approach. García-Hernández, R., D’Auria, L, Barrancos, J., Padilla, G. D.

3. Student: Optimization of Data Functionals for Full-3D Tomography by Seismogram Decomposition and Resynthesis. Juarez, A., Jordan, T. H.

4. Vision and Numerical Simulation-Based Ground Deformation Testing Method. Chen, S., Zhao, S. C., Fu, L., Li, X. J.

5. Exploring Subtle Temporal Changes in Earthquake Catalogs to Guide Identification of Dynamically Triggered Events. Kilb, D., Pankow, K. L.

6. Fiber Optic Gyroscope Road-Map for Highest Rotational Ground Motion Sensitivity on the Field. Guattari, F., de Toldi, E., Bigueur, A., Bernauer, F., Wassermann, J., Gebauer, A., Schreiber, K. U.

7. RTX Correction Accuracy and Real-Time Data Processing of the New Integrated SeismoGeodetic System with Real-Time Acceleration and Displacement Measurements for Earthquake Characterization Based on High-Rate Seismic and GPS Data. Zimakov, L., Raczka, J., Barrientos, S. E.

8. Next Generation Autonomous Broadband Node. Parker, T., Pigeon, S., Pelyk, N.

9. Student: Spatial Improvement in the Location of Mid-Alaska Faults Using the Condensation Method. Azizzadeh-Roodpish, S., Cramer, C. H.

Applications of Machine Learning and Data Science in Seismology (see page 937)

10. The Decadal Periodicity of Large Mexican Earthquakes (Magnitude $\geq 7$ ). Velasco Hererra, V. M. N.

11. Student: Detection of Seismic Signals under Low Snr Condition Using an Artificial Neural Network: Toward the Development of a Dense Low-Cost Citizen Seismic Network in Japan. Takahashi, K., Uematsu, H. U., Zhe, S. Z., Micheletto, R. M., Kim, A.

12. Student: Earthquake Catalog Reconstruction from Analog Seismograms: Application to the Rangely Experiment Microfilms. Wang, K., Ellsworth, W. L., Beroza, G. C., Rubinstein, J. L.

13. Time-Domain Receiver Function Deconvolution Using Genetic Algorithm. Moreira, L. P.
14. A Non-Linear Filter to Enhance Microearthquake Detection. Salehiozoumchelouei, R., Rajaeitabrizi, Y., D’Auria, L., Sánchez de la Rosa, J. L.

15. Making Realistic Synthetic Seismic Waveforms with Generative Adversarial Networks. Li, Z., Hauksson, E., Meier, M. A., Zhan, Z.

16. Waveform Classification Using Statistical Learning Algorithms to Characterize Data Features from a Dense Deployment of Geophones atop an Active Fault Zone. Johnson, C. W., Vernon, F. L., Ben-Zion, Y.

17. Student: Machine Learning Aspects in the Smartphone Seismic Network. Kong, Q., Inbal, A., Allen, R. M.

18. DeepDetect: An Application of Deep Densely Connected Convolutional Neural Network to Earthquake Detection. Wu, Y., Zhou, Z., Chen, T., Lin, Y.

19. Detection of Background Seismic Waves Anomalies with a Hierarchical Temporal Memory (HTH) Cortical Algorithm. Takahashi, K., Micheletto, R. M.

20. Student: A Deep Learning Approach for Enhanced Classification of Global Seismic Waveforms. Smith, K. E., Smith, A. O., Peter, A. M.

21. Student: MLP Networks to Associate Arrival Times in Noisy and Dense Earthquake Sequences. McBrearty, I. W., Delorey, A. A., Johnson, P. A.

Challenges and Chances for the Widespread

Implementation of Earthquake Early Warning (EEW)

(see page 939)

22. Rapid Estimation of Instrumental Intensity Using Shakemap in South Korea. Han, S., Jo, E., Hwang, E. H., Yun, H. J.

23. Machine Learning Magnitude Estimate in Earthquake Early Warning Systems. Li, Z., Hauksson, E., Heaton, T. H.

24. Building Eew in Nicaragua: Performance and Perspectives. Massin, F., Strauch, W., Clinton, J. F., Boese, M., Ramirez, J.

25. Student: Determination of Earthquake Early Warning Parameters for the New Madrid Seismic Zone. Ogweno, L. P., Withers, M. M., Cramer, C. H.

Earthquake Source Parameters: Theory, Observations and Interpretations (see page 940)

26. Student: Towards Quasi-Automated Estimates of Directivity and Related Source Properties of Small to Moderate Southern California Earthquakes with Second Seismic Moments Using Weighted Stacked EGFs. Meng, H., Ben-Zion, Y., McGuire, J.

27. Student: Comparison of Brune-Type Stress Drops Obtained from the Improved Coda-Q Method and Spectra Decomposition Method. Wang, W., Shearer, P. S. 
28. The mblg 3.9 September 13, 2017, Earthquake on the Virginia-West Virginia Border: A Significant Shock in the Giles County Seismic Zone. DePaolis, J. M., Chapman, M. C.

29. The 1 May 2017 British Columbia Earthquake Doublet and Implications for Complexity near the Southern End of the Denali Fault System. He, X., Ni, S. D., Zhang, P., Freymueller, J. T., Wang, K.

30. Deviatoric Moment Tensor Solutions for Small Intraplate Earthquakes in Northeast Brazil from P, SV, and SH Spectral Amplitudes. Ferreira, P. A. R., Julià, J., da Silva, S. L. E. F.

31. Seismic Activity Migration in a Strike-Slip Fault of Porto Dos Gaúchos Seismic Zone (Pgsz)-Amazon Craton Brazil. Barros, L. V., Assumpção, M., Quintero, R., Carvalho, J. M., Bowen, B. D.

32. Constraints on the Source Mechanism of the Damaging Seismic Event of August 21, 2017, on Ischia Island (Southern Italy). Braun, T., Famiani, D., Cesca, S.

33. The 2017 Earthquake Sequence near Sulphur Peak, Idaho. Koper, K. D., Pechmann, J. C., Hale, J. M., Burlacu, R., Pankow, K. L., Yeck, W. L., Benz, H. M., Herrmann, R. B., Trugman, D. T., Shearer, P. M.

34. Student: New Relocated Seismicity Using an Improved Crustal Structure Model in the Eastern Sierras Pampeanas $\left(29^{\circ} \mathrm{s}-32^{\circ} \mathrm{s}\right)$, Andean Retroarc of Argentina. Venerdini, A. L., Alvarado, P., Ammirati, J. B., Araujo, M., Gilbert, H., Linkimer, L., Beck, S. L., Anderson, M.

35. Seismic Swarm Activity in a Non-Volcanic Area-UmmLujj, Western Saudi Arabia. Youssof, M., Mai, P. M., Hosny, A., Parisi, L., Zahran, H., Sami, M.

36. Focal Mechanism of the $5.1 \mathrm{Mw} 2014$ Aldjal Ia thquake, Bolivia: Probing the Tra rsitior Betwotn Extensional Stresses of the Cehtral A tiplaho and Compressional Stressos of th Sub-Andes. Fernandez, A. M., Assurnptad, M, Ciardelli, C., Nieto, M

37. Student: Non-Linear Inversion of the Earthquake Source Spectrum Using a Seismic Cluster Method. Rivera, E., Leyton, F., Ruiz, S., Prieto, G. A.

38. Student: Stress Drop Investigation of M>4 Induced Earthquakes in Western Canada Using Empirical Green's Function Method. Holmgren, J. M., Atkinson, G. M.

39. Student: Study of the Earthquake of October 06, 2011. in Jujuy and Its Distribution of Aftershock. Lopez, L., Sánchez, G., Araujo, M.

40. The 2016 Capellades Earthquake and Its Seismic Sequence: Expression of Strike-Slip Faulting in the Volcanic Arc of Costa Rica. Linkimer, L., Arroyo, I. G., Soto, G. J., Porras, J., Araya, M. C., Mora, M. M., Taylor, M.

41. Small Effective Stress Drop of Hydraulic Induced Seismicity and Aseismic Deformation. Fischer, T. J., Hainzl, $S$.

42. Student: Understanding the Source Fault of the 5 April 2017 Earthquake Sequence near Mashhad, Iran,
Using Regional Moment Tensor Analysis. Graybeal, D. B., Braunmiller, J.

43. Temporal Stress Drop Variation of Microearthquakes Potentially Induced by Highly Pressurized Fluid Observed in the 2009 Hakone Volcano, Japan. Kim, A., Yukutake, Y., Fujioka, M.

44. Intraplate Stress Field in South America Derived from Earthquake Focal Mechanisms. Dias, F. L., Assumpção, M.

45. Student: Determination of Focal Mechanisms and Depths of Small Magnitude Local and Regional Earthquakes Recorded by a Sparse Seismic Network. Dahal, N. R., Ebel, J. E.

46. Student: Co-Seismic Slip Distribution Inversion Applied to the Mutata Earthquake, Colombia. Naranjo, D. F., Tary, J. B.

47. Student: Inversion of S-Coda and P-Coda for the Prospection of Mud Diapirs in the Sinú Belt, Colombia. Suarez Carvajal, C. F., Vargas Jimenez, C. A.

48. Earthquake Source Mechanisms and Their Characteristics in the Dominican Republic. Leonel C., J. M., Polanco, E., Mejia, H. P., Pulliam, J., Huerfano, V. A., Martinez, $F$.

49. A Unified Earthquake Catalog in the Caucasus. Gok, R., Godoladze, T., Onur, T., Yetirmishli, T.

50. Relocation of the Aftershock Sequence of the 1982 Miramichi, New Brunswick, Canada, Mb 5.7 Earthquake. Ma, S. M., Motazedian, D. M.

51. Student: Source Parameter Variability of IntermediateDepth Earthquakes in Japan Estimated from Empirical Green's Functions. Chu, S. A., Beroza, G. C., Ellsworth, W. L.

52. Student: Earthquake Source Parameters for Chilean Events for Use in the NGA-Subduction Project. Contreras, V., Stewart, J. P., Darragh, R. B., Kishida, T., Youngs, R.

53. Stress Processes and Their Relation to the Tectonic Environment. Zuniga, F. R., Rodriguez-Perez, Q., Marquez-Ramirez, V. H.

54. Student: Spectral Analysis of Earthquakes with Hypocenter in Basin of Mexico. Ramírez, J. E., Bello, D. I.

55. Estimating Source Time Functions Using Empirical Green's Function Methods in the Presence of Noise. Gallegos, A. C., Xie, J.

The 8th September Mw8.2 Tehuantepec and 19th September Mw7.1 Puebla-Morelos, Mexico Earthquakes: Reconnaissance Findings and Impact on Urban Areas in South-Central Mexico (see page 946)

56. Initial Aftershock Locations of the September 2017 Tehuantepec, Mexico, $(\mathrm{m}=8.2)$ Earthquake from a Temporary Seismic Network. Velasco, A. A., Karplus, M., Ornelas, O., Gonzalez-Huizar, H., Husker, A. L., Pérez-Campos, X., Ayala, $S$. 
57. Macroseismic Intensities from the Puebla-Morelos Earthquake of 19 September 2017 (Mw 7.1). MontalvoArrieta, J. C., Pérez-Campos, X., Ramírez-Guzmán, L., Sosa-Ramirez, R. L.

58. Student: Remotely-Triggered Slip in Mexico City Induced by the September 2017 Mw7.1 Puebla Earthquake. Solano-Rojas, D., Havazli, E., CabralCano, E., Wdowisnki, S.

59. Student: Analysis of the Alpha Combination Rules in the Seismic Response of Typical Buildings in Mexico City. Sánchez, J., Ramírez-Guzmán, L.

60. Student: Spatial Distribution of Site Response and Building Damage in Mexico City Resulting from the September 19, 2017, M7.1 Central Mexico Earthquake. Pontrelli, M. A., Baise, L. G.

Emergency Management, Resilience and Preparedness (see page 947)

61. Annualized Earthquake Loss Estimations for Istanbul. Hancilar, U., Sesetyan, K., Cakti, E.

62. The Diploma in Seismology for High-School Teachers. Bello, D. I., Pérez-Campos, X., Dominguez, J., Cruz, J. L., Navarro, F., Mendoza, A. J., Pérez-Santana, J. A., Campos, Y.

63. Implementation of the Tsunami Ready Pilot Project in Grenada. Hincapié-Cárdenas, C., von HillebrandtAndrade, C. G., Rodríguez, C.

64. Toward a Reliable Tsunami Early Warning System in Puerto Rico. Huerfano, V. A., Baez-Sánchez, G.

Forecasting Aftershock Sequences in the Real World (see page 948)

65. Using Aftershock Forecast Modeling to Refine the Location and Magnitude of the 1936 Milton-Freewater Earthquake near the Oregon-Washington Border, U.S.A. Brocher, T. M., Sherrod, B.

66. Real-Time Completeness of the USGS ComCat Earthquake Catalog and Implications for Operational Aftershock Forecasting. Hardebeck, J. L., Llenos, A. L., Michael, A. J., Page, M. T., van der Elst, N. J.

Increasing Testability-Expanding Possibilities and Future Developments of the Collaboratory for the Study of Earthquake Predictability (see page 948)

67. Status of the Collaboratory for the Study of Earthquake Predictability (CSEP) and Prospects for Future Infrastructure Development. Savran, W. H., Werner, M. J., Silva, F., Yu, J., Maechling, P. J., Vidale, J. E., Jordan, T. H.
Observed Characteristics of Induced Seismicity: From

Laboratory to Field Scale (see page 948)

68. Development of a Matched Filter Catalog in Southern Kansas. Cochran, E. S., Ross, Z. E., Harrington, R. M., Dougherty, S. L., Rubinstein, J. L.

69. Reconciliation of Fault Maps and Induced Seismicity in Oklahoma Through Aeromagnetic Imaging of the Crystalline Basement. Shah, A. K., Crain, K., Schultz, W. H., Williams, R. A.

70. Influence of Crustal Structure on High-Frequency $(\mathrm{F}>1 \mathrm{~Hz})$ Ground Motions from Induced Earthquakes in Oklahoma. Moschetti, M. P., Herrmann, R. B., Ramírez-Guzmán, L., Frankel, A. D.

71. A Rare Case of Seasonal Induced Seismicity in Southeast Brazil. Convers, J. A., Assumpção, M., Barbosa, J. R.

72. Re-Analyses of Seismic Data from Temporary and Permanent Networks as a Tool for Monitoring Induced Seismicity: A Case Study from the Cavone Oilfield (Central-Northern Italy). Anselmi, M., Iovine, S., De Gori, P., Buttinelli, M., Chiarabba, C., Battaglia, M.

73. Interferometric Time-Lapse Velocity Analysis: Application to a Salt-Water Disposal Well in British Columbia, Canada. Vaezi, Y., Van der Baan, M.

74. Student: Hypocentral Focal Depth Determination Based on Pn and Pg Relative Location Method: A Case Study of the 2016 Mw5.1 Fairview Sequence, Oklahoma. Wang, X. T., Li, Z. W., Ni, S. D.

75. Comparative Study of Earthquake Clustering in Relation to Hydraulic Activities at Geothermal Fields in California. Martínez-Garzón, P., Zaliapin, I., BenZion, Y., Kwiatek, G., Bohnhoff, M.

76. InviteD: Identifying the Trigger of the Irving-Dallas, North Texas, Earthquake Sequence. DeShon, H. R., Quinones, L., Ogwari, P., Jeong, S., Brudzinski, M. R., Magnani, M. B.

77. Discerning and Characterizing Induced Seismicity in Texas Using Regional Multistation Template Matching. Brudzinski, M. R., Skoumal, R. J., DeShon, H. R., Smith, S., Currie, B. S., Smart, K. J., Morris, A. P.

78. A Notable Earthquake Swarm in Alabama: Natural or Anthropogenic? Chen, J., Wolf, L.

Plate Boundary Segmentation and Coupled-toCreeping Plate and Block Boundary Faults (see page 951)

79. Student: The Case of Western Corinth Gulf (Greece): A Detachment Zone or Seismic - Aseismic Transition? Mesimeri, M., Karakostas, V.

80. Student: Systematic Detections of Microearthquakes and Repeators in Parkfield Long before and after the 2004 M6 Earthquake. Neves, M., Peng, Z., Meng, X., Daniels, C., Lin, G.

81. Student: A High-Precision Continuous Catalogue of Low-Magnitude Earthquakes in the Central Southern 
Alps, New Zealand. Michailos, K., Chamberlain, C. J., Smith, E. G. C., Savage, M. K., Townend, J.

82. Student: Mejillones Peninsula in Northern Chile Controlled by Hydrated Interface and Subducted Oceanic Plate. Pasten-Araya, F., Salazar, P., Ruiz, S., Rivera, E., Potin, B., Cruz, E., Jaldín, D., Villarroel, J., Torres, E., Echeverría, J., Bloch, W., Bloch,

83. Constraints from 3D Earthquake Location for Aftershocks of the Mw=7.8 2016 Pedernales Earthquake (Ecuador Subduction Zone). Font, Y., Agurto-Detzel, H., Alvarado, A., Régnier, M., Rolandone, F., Charvis, P., Mothes, P. A., Nocquet, J. M., Jarrin Tamayo, P., Ambrois, D., Maron, C., Cheze, J., Ruiz, M. C., Singaucho, J. C., De Barros, L., Ramos, C., Rietbrock, A., Deschamps, A., Courboulex, F., Ponce, G., Beck, S. L., Meltzer, A.

84. Estimating the Locations of Past and Future Large Earthquake Ruptures Using Recent M4 and Greater Events. Ebel, J. E.

85. Student: Ground Motion to Intensity Conversion Equations (GMICEs) for Chilean Megathrust Earthquakes. Cilia, M. G., Baker, L. M.

86. Student: Spatiotemporal Evolution of Source Properties in the Colombia Seismic Sequence. Aguilar, A. L., Prieto, G. A.

87. Student: Collecting New High-Resolution Seismic Data across the Hayward Fault Zone. Quesenberry, C. E.

88. Structural Setting along the Western North Anatolian Fault and Its Influence on the 2014 North Aegean Earthquake (M 6.9). Bulut, F., Ozener, H., Dogru, A., Aktug, B., Yaltırak, C.

Retrieval of Fine Scale Information Using Seismic Noise (see page 953)

89. Improving the Cross-Correlation of Ambient Noise Using Discrete Wavelets. Cabrera Peréz, I., D’Auria, L., Soubestre, J., Barrancos, J., Padilla, G. D.

90. Crustal Radial Anisotropy Model along the PolenetAnet Transect. Mordret, A., Xu, Z., Mikesell, T. D.

91. Preliminary Results of the LARGE-MEM Project. Lecocq, $\mathrm{T}$.

Seismic Studies of Earth's Crust and Lithosphere (see page 954)

92. Seismicity in the Taquari Megafan: Pantanal Basin in Mato Grosso do Sul, Brazil. Facincani, E. M., Assumpção, M., Silva, T. G., Silva, L. J., Dias, F. L., Pereira, W. P., Dourado, G. F.

93. The Importance of Additional Travel Times from Temporary Deployments for the Bulletin of the ISC. Korger, E. I. M., Brown, L., Lieser, K., Harris, J., Eve, J., Storchak, D. A.
ShakeMap-Related Research, Development, Operations and Applications (see page 954)

94. Measurement and Modeling of Ground Motions in Myanmar for Seismic Hazard Assessment. Wolin, E., Htwe, Y. M. M., Kyaw, T. L., Tun, P. P., Htwe, S. H., Wai, K. M. L., Hough, S. E.

95. Near-Real-Time Ground Failure Estimates: A New USGS Real-Time Earthquake Product. Allstadt, K. E., Thompson, E. M., Hearne, M., Wald, D. J., Nowicki Jessee, M. A., Biegel, K. M., Hamburger, M. W.

96. Tectonic Classification of Earthquakes for Gmpe Selection. Thompson, E. M., Hearne, M., Worden, C. B., Hayes, G. P., Wald, D. J.

97. Shakemap Based on Instrumental and Macroseismic Data in France: Feedback on Modified v3.5 and Expectation on V4. Schlupp, A., Grunberg, M.

98. ShakeMaps for Nicaragua and Central America Based on Seiscomp3 at INETER. Cauzzi, C., Clinton, J. F., Massin, F., Strauch, W., Ramirez, J.

99. Estimating Fatalities Associated with Seismically Induced Landslides. Nowicki Jessee, M. A., Hamburger, M. W., Allstadt, K. E., Thompson, E. M., Wald, D. J., Ferrara, M. R., McLean, A., FitzGerald, C.

100. The 1918 Puerto Rico Earthquake as a Test Case of ShakeMap 4.0 Multi-GMPE Capabilities. Marano, K. D., Wald, D. J., Hearne, M., Thompson, E. M., Worden, C. B.

101. Intensity Prediction Equations for Costa Rica. Porras, J., Linkimer, L.

Structure and Geodynamics of the Caribbean Plate Boundaries (see page 956)

102. 2-D Modeling of the Crustal Structure of Merida Andes, Venezuela, from Wide-Angle Seismic and Gravity Studies. Yegres, L. A., Schmitz, M., Sanchez, J. R., Ávila, J. M., Rondon, F. J.

103. Student: Analysis of Travel Time Curves for Puerto Rico Seismic Network Stations. Ventura, W. A., Vanacore, E. A.

104. Student: Lithospheric Structure beneath Northwestern Venezuela from Deep Seismic Profiling. Mazuera, F., Schmitz, M., Escalona, A., Levander, A. R., Zelt, C.

105. Student: Crustal Structure in the Dominican Republic from Receiver Function Analysis. Kumar, S., Ntuli, G., Agrawal, M., Pulliam, J., Polanco Rivera, E., Huerfano, V.A.

106. Student: Lithospheric Structure and Tectonic Implications of the Dominican Republic from Local and Teleseismic Tomography. Mejia, H. P., Pulliam, J., Huerfano, V. A., Polanco Rivera, E.

107. Shear Wave Velocity Structure of the Lithosphere beneath the Eastern Caribbean Revealed by Ambient Noise Tomography. Arnaiz-Rodríguez, M. S., Niu, F., Schmitz, M., Levander, A. R. 
108. The Seismicity of the Isthmus of Panama: Recent Findings. Camacho, E. I., Tapia, A. A.

Uncertainty in Ground Motion Estimation;

Seismological and Engineering Perspectives (see page

958)

109. Further Validation of a Dynamic Earthquake Model to Produce Realistic Near-Field Ground Motion. Ma, S.

110. Student: An Empirical Model for Fourier Amplitude Spectra Using the NGA-West2 Database. Bayless, J. R., Abrahamson, N. A.
111. Bayesian Uncertainty Quantification and Sensitivity Analysis of PSHA Results. Kuehn, N. M., Abrahamson, N. A., Molkenthin, C.

112. Student: Investigating Ground Motion Variability from Shaking Simulations with Complex Earthquake Sources. Sivasubramonian, J., Mai, P. M.

113. Investigation of the Regional Effects on Ground Motion Predictive Models for Western Turkey: Preliminary Results. Tanircan, G., Yenier, E., Akkar, S., Pinar, A., Kale, O.

114. Student: Assessment of Strong Ground Motion Variability in Japan. Nampally, S., Mai, P. M. 


\section{SSA 2018 \\ Abstracts of the Annual Meeting}

Late changes at www.seismosoc.org/meetings/2018/abstracts/.

\section{D/4D Seismic Imaging and Their Interpretation for Seismic Hazard Assessment \\ Oral Session - Tuesday 15 May · 8:30 A · Tuttle \\ Session Chairs: Marco Pilz and Nori Nakata}

Comparison between Frequency and Time Domain Cross-Correlation of Seismic Noise Data in South Korea

DEL VALLE-ROSALES, M., Instituto de Geofísica, Distrito Federal, Mexico, mdelvaller@iingen.unam.mx; CHÁVEZ-GARCÍA, F. J., Instituto de Ingeniería Universidad Nacional Autónoma de México, Mexico City, México, paco@ pumas.iingen.unam.mx; KANG, T. S., Korea Institute of Geoscience and Mineral Resources, Daejeon, South Korea, tskang@kigam.re.kr

Seismic noise records are commonly used to investigate the subsoil structure. In recent years, seismic noise cross-correlation techniques have been successfully used at global, continental, and regional scales. In this study, we analyze 12 month of continuous seismic noise ( 8760 hours) recorded by the permanent accelerograph network of the South Korean Republic to explore the advantages and disadvantages of frequency-domain cross-correlation (the SPAC method) and time-domain cross-correlation (seismic interferometry) to estimate subsoil structure. The network consists of 23 autonomous stations, which allows for 253 station pairs. We analyze exclusively the vertical component to investigate dispersion of Rayleigh waves. To work in the frequency domain, we first prepare the data by applying a time-frequency normalization. We compute average crosscorrelation using time windows between 1800 and $14400 \mathrm{~s}$. The result is analyzed with the SPAC method to estimate phase velocity dispersion curves. In the time domain, we compute cross-correlation for all station pairs using same time windows as the used in frequency. We explored the use of the non linear stacking of cross correlation, rather than linear one, weighting each cross correlation with a function of phase coherence in order to improve our Green's functions estimations and thus the group velocity dispersion curve. We invert the dispersion curves from both methods and compare the resulting models. For future work, given the large number of stations, we use all the information of ray paths to estimate the regional structure by a seismic tomography.

Enhancement of Body Wave Signals in the Coda of Seismic Noise Interferometry through Random Fluctuation Suppression

LIU,X., Stanford University, California, USA, liuxin@stanford.edu; BEROZA, G. C., Stanford University, California, USA, beroza@stanford.edu

The seismic interferometry function based on a finite amount of data contains predictable random errors in the direct surface wave and coda (e.g. Liu \& Beroza 2018). These random fluctuations in the coda can hide the true signals, whether they are scattered surface wave or body wave phases. We present an optimization algorithm that squeezes the random fluctuations in the coda of noise crosscorrelation by combining measured statistics of the noise cross-correlations (Liu et al., 2016). We perform synthetic tests that embed wavelet signals in the coda of simulated noise cross-correlations that contain only random fluctuations and no scattered waves. Our results show that we can recover the wavelet signals if the signal amplitude is comparable to the standard deviation of the random fluctuation in the coda. We apply this optimization algorithm to continuous waveform data recorded on broadband stations in southern California as part of the linear LASSIE array that stretched across the Los Angeles Basin. We compare our results with the 1D seismic response of the AK135 Earth model, and find phases that correspond I arrival time to the body wave phases P410P and PcP. Spurious arrivals due to non-diffuse noise sources can be separated based on multiple-component cross-correlations (Liu et al. 2018). This method only requires one pair of stations and increases the applicability of seismic interferometry to imaging the deep interior of the earth.
Single-Station Imaging of a Low-Velocity Layer Using Reflected Waves from the 2014 Earthquake Swarm at Long Valley Caldera, California

NAKATA, N., University of Oklahoma, Oklahoma, USA, nnakata@ou.edu; SHELLY, D. R., US Geological Survey, California, USA, dshelly@usgs.gov

The waveforms generated by the 2014 Long Valley Caldera earthquake swarm recorded at station MLH show clear reflected waves that are often stronger than direct $\mathrm{P}$ and $\mathrm{S}$ waves. The reflected waves first propagate downward from the source locations and then reflect back to the ground surface. With waveform analyses, we discover that these waves are reflected at the top of a low velocity body, which may be residual magma from the $\sim 767 \mathrm{ka}$ caldera-forming eruption. The polarity of the reflection compared to direct $P$ and $S$ waves suggests that the reflection is SP waves ( $\mathrm{S}$ from hypocenters to reflector and then convert to $P$ waves). Because the wavefields are coherent among different earthquakes and hold high signal-to-noise ratios, we apply them to a wavefield migration method for imaging reflectors. For the migration, we use earthquake locations estimated from a previous study. The depth of the imaged magmatic-system roof is around $8.2 \mathrm{~km}$ below the surface. Even though we use only one station and waveforms from one earthquake swarm, the dense cluster of accurately located earthquakes provides a high-resolution image of the roof.

\section{Seismic Imaging of the West Napa Fault in Napa, California}

GOLDMAN, M. R., US Geological Survey, California, USA, goldman@usgs. gov; CATCHINGS, R. D., US Geological Survey, California, USA, catching@ usgs.gov; CHAN, J. H., US Geological Survey, California, USA, jchan@usgs. gov; SICKLER, R. R., US Geological Survey, California, USA, sickler@usgs. gov; NEVITT, J., US Geological Survey, California, USA, jnevitt@usgs.gov; CRILEY, C. J., US Geological Survey, California, USA, criley@usgs.gov

In October 2016, we acquired high-resolution P-and S-wave seismic data along a 120-m-long, SW-NE-trending profile in Napa, California. Our seismic survey was designed to image a strand of the West Napa Fault Zone (WNFZ), which ruptured during the 24 August $2014 \mathrm{Mw}$ 6.0 South Napa Earthquake. We separately acquired $\mathrm{P}$ - and $\mathrm{S}$-wave data at every station using multiple hammer hits, which were edited and stacked into individual shot gathers in the lab. Each shot was co-located with and recorded by $118 \mathrm{P}$-wave $(40-\mathrm{Hz})$ geophones, spaced at $1 \mathrm{~m}$, and by $118 \mathrm{~S}$-wave $(4.5-\mathrm{Hz})$ geophones, spaced at $1 \mathrm{~m}$. We developed both $\mathrm{P}$ - and S-wave tomographic velocity models, as well as Poisson's ratio and a Vp/ $\mathrm{Vs}$ ratio models. We observed a well-defined zone of elevated $\mathrm{Vp} / \mathrm{Vs}$ ratios below about $10 \mathrm{~m}$ depth, centered beneath the observed surface rupture. P-wave reflection images show that the fault forms a flower-structure in the upper few tens of meters. This method has been shown to delineate fault structures even in areas of rough terrain.

Tomographic Imaging of the Central California Crust with Multiple Methods THURBER, C. H., University of Wisconsin-Madison, Wisconsin, USA, cthurber@wisc.edu; NAYAK, A., University of Wisconsin-Madison, Wisconsin, USA, avinash07guddu@gmail.com; FANG, H., University of Science and Technology of China, Anhui, China, fanghj@mail.ustc.edu.cn; ZENG, X., Chinese Academy of Sciences, Hubei, China, zengxf@whigg.ac.cn; ZHANG, H., University of Science and Technology of China, Anhui, China, zhang11@ ustc.edu.cn

Following the discovery of the Shoreline Fault along the coast of central California by Hardebeck (2010) and the occurrence of the tsunami disaster at the Fukushima nuclear power plant in 2011, there has been increased attention on the potential seismic hazards of the central California region in relation to the Diablo Canyon nuclear power plant. The Pacific Gas \& Electric Company has supported related research both offshore and onshore, and the Southern California Earthquake Center (SCEC) has established a Central California Seismic Project (CCSP) to develop a Community Velocity Model (CVM) and Community Fault Model for the region and use them for strong motion simulations and hazard estimation. The existing SCEC Central California CVM was developed from a USGS velocity model, velocity measurements from wells and seismic surveys, and refinement using waveform tomography. We are working to further refine the Central California CVM by (1) incorporating surface-wave dispersion data from an expanded set of stations and extended to shorter periods ( 3 to 4 seconds) and (2) incorporating body-wave arrival-time data from earthquakes and P-wave travel times from explosions. The current SCEC Central California CVM will 
be used as the starting model for new surface-wave inversions, new body-wave inversions, and ultimately joint body wave-surface wave inversions. Inversions using the new data will result in a finer resolution CVM for central California. Research supported by SCEC Award \#17188 and USGS Award G16AP00111.

Crustal Structure beneath Seismic Stations Located in Paraná and ChacoParaná Basins from Joint Inversion of Surface Wave Dispersion and Receiver Functions

CHRISTIANSEN, L. A., Departamento de Sismología, Facultad de Ciencias Astronómicas y Geofísicas, Universidad Nacional de La Plata, Buenos Aires, Argentina, seismoml@gmail.com; ROSA, M. L., Departamento de Sismología, Facultad de Ciencias Astronómicas y Geofísicas, Universidad Nacional de La Plata, Buenos Aires, Argentina,mlrosa@fcaglp.unlp.edu.ar

The seismic structure of the crust and uppermost mantle under the central and eastern region of South America is being a matter of study in recent years due to the installation of new temporary and permanent seismological stations. In this study the $S$-wave velocity structure beneath seismic stations located in Paraná and Chaco-Paraná Basins is modeled by jointly inverting receiver functions and surface wave dispersion velocities. Receiver functions have been computed from teleseismic recordings of earthquakes at epicentral distances in the range from $30^{\circ}$ to $90^{\circ}$ and surface wave group velocity dispersion have been taken from earlier surface wave tomographic studies in South America. Our models show a good correspondence with previous geological and seismological studies. The results obtained in this work help constrain the regional tectonics of the area and will also be used to better define the seismic characteristics of the basins.

Does the Integration of Two Different Datasets Affect Tomographic Images and Earthquake Location? The Case Study of the High Agri Valley (Southern Italy)

SERLENGA, V., National Research Council of Italy, Potenza, Italy, vincenzo. serlenga@imaa.cnr.it; STABILE, T. A., National Research Council of Italy, Potenza, Italy, tony.stabile@imaa.cnr.it

Local earthquake tomography is a useful tool for both imaging the subsurface elastic properties of an area and for locating earthquakes. The accuracy of the velocity model and source location depends on the resolution provided by the ray coverage, which, in turn, depends on the source-station configuration and on the number of travel time data. On these grounds, we investigate how the integration of two datasets recorded by different seismic networks may affect the final resolution of the tomographic images and earthquake location in the High Agri Valley (southern Italy). In addition to the natural seismicity of the study area, there were documented a) fluid-induced microseismic swarms due to the injection through a single well of the wastewater produced from the exploitation of the Val d'Agri oil field, and b) continued reservoir induced seismicity associated with the artificial Pertusillo Lake. The first dataset consists of natural and induced seismicity collected by the trigger-mode monitoring network of the oil Company in the period between 2002/01 and 2012/12. The high-quality selection criteria we adopted, provided a dataset consisting of 984 earthquakes with 7,277 P-and $5,567 \mathrm{~S}$-phases. The second dataset is the integration in the first one of the seismic data collected by the 2005-2006 INGV dense temporary network, and made available by Improta et al. (2017). The number of earthquakes increased up to 1580 , with 27,344 available P- and S-phases. In both cases the travel-time data were inverted through Simulps-14 code. Here we show the comparison of results obtained from the two datasets, both showing a low Vp anomaly close to the injection well. The next purposes of our study is to further integrate these datasets with data collected by the experimental dense temporary network installed in the area in the framework of the research project INSIEME (INduced Seismicity in Italy: Estimation, Monitoring, and sEismic risk mitigation).

Geometry of the Los Angeles Basin Using Full H/V Spectral Ratio Inversion SPICA, Z., Stanford University, California, USA, zspica@stanford.edu; PERTON, M., Universidad Nacional Autónoma de México, Mexico, mathieu. perton@gmail.com; BEROZA, G.C., Stanford University, California, USA, beroza@stanford.edu

The H/V spectral ratio (HVSR) of the auto-correlated signal at a seismic station is proportional to the ratio of the imaginary parts of the Green's functions. Following this approach, observations of $\mathrm{H} / \mathrm{V}$ can be compared to their theoretical counterpart for a locally layered elastic media in order to constrain the velocity structure. We use the broadband stations of the "Los Angeles Syncline Seismic Interferometry Experiment" (LASSIE) to perform a combined inversion of multiple HVSR measurements along 2D lines of sensors. The presence of low frequency peaks in the observed HVSR and their modelling allow us to be sensitive to the deep structure of the basin and then identify its geometry.
Seismic Tomography of the Nepal Himalayas and Geodynamic Implications for the $\mathbf{2 0 1 5}$ Nepal Earthquake

RAOOF, J., Indian Institute Technology Roorkee, India, Uttarakhand, India, rjavediitroorkee@gmail.com; MUKHOPADHYAY, S., Indian Institute of Technology Roorkee, Uttarakhand, India, rjavediitroorkee@gmail.com

3-D Seismic tomography using local and regional earthquake data reveals variations of crustal thickness beneath the Nepal Himalayas. A low-velocity anomaly in upper part of the model down to depths of $\sim 40$ to $80 \mathrm{~km}$ represents crust. Lower limit of this anomaly represents Moho depth variations. Thick transitional zone may represent underthrusting of one continental block underneath another one, which leads in doubling of Moho depth. The obtained variations of crustal thickness match fairly well with free-air gravity anomalies: thinner crust patterns correspond to lower gravity values and vice versa. We propose that elevated magnetic values can be associated with more rigid segments of the incoming Indian crust which cause more compression in the thrust zone and lead to stronger crustal thickening. Several episodes of collisions and rotation of the Indian plate after collision may also lead to variation in crustal thickness along the tectonic trend of the Himalayas. We have also corroborated estimated seismic velocity structure and crustal thickness with the recent Nepal earthquakes (magnitude 27) occurred on April 25, 2015 and May 12, 2015 in the eastern Nepal. These earthquakes occurred at places where Main Central Thrust shows a very sharp bend and where faults/lineaments cut across the tectonic trend of the Himalayas. It is observed that first earthquake of magnitude $\geq 7$ initiated in a zone where crustal thickness is relatively lower and rupture propagated eastward towards a region where both crustal thickness and S-wave velocity is higher, i.e. towards a more rigid part of the crust. This may have led to stress loading in the rigid part that subsequently led to occurrence of second magnitude $\geq 7$ earthquake in that area within a month. The velocity and crustal thickness maps estimated in this study nicely explains why two earthquakes of magnitude $\geq 7$ occurred within a short span of time within such close distance range.

Temporal Changes of Seismic Velocities in the San Jacinto Fault Zone Associated with the $\mathbf{2 0 1 6}$ Borrego Springs Earthquake

QIU, H., University of Southern California, California, USA, hongruiq@usc. edu; HILLERS, G., University of Helsinki, Finland, gregor.hillers@helsinki.fi; BEN-ZION, Y., University of Southern California, California, USA, benzion@ usc.edu

We study temporal changes of seismic velocities associated with the June 2016 Mw 5.2 Borrego Springs earthquake that occurred at $12 \mathrm{~km}$ depth in the San Jacinto fault zone. This is done with 9 component Green's function estimates from daily cross correlation functions of ambient noise between stations of two spatially dense linear arrays. The two arrays cross the fault surface trace and are located at Dry Wash (DW) and Jackass Flat (JF) about $2 \mathrm{~km}$ northwest and southeast of the epicenter, respectively. The DW and JF arrays have 9 and 12 stations, respectively, with instrument spacing $25-100 \mathrm{~m}$. We first rotate the cross correlations into a system of fault perpendicular, along strike, and vertical directions. For each component, a reference waveform is obtained from stacking correlations from one year before the earthquake. We estimate relative velocity change (dv/v) from arrival time changes in the daily correlation coda waveforms compared to the reference stack. The obtained dv/v time series exhibit variations associated with seasonal velocity changes, linear trends, and the Borrego Springs event. The earthquake signal is characterized by an abrupt velocity drop at the time of the event that is followed by a gradual recovery. This behavior is consistently observed for different components in various frequency bands at both arrays obtained with a time- and frequency-domain analysis methods. After removal of the seasonal and linear components, the velocity drop observed with the vertical-vertical correlation data is around $\sim 5 \%, 0.2 \%$, and $0.1 \%$ at DW array, and $\sim 0.6 \%, 0.2 \%$, and $0.2 \%$ at JF array, for $0.1-0.5 \mathrm{~Hz}, 0.5-2 \mathrm{~Hz}$, and $0.8-4 \mathrm{~Hz}$, respectively. The larger changes for lower frequencies imply variations not limited to the very shallow material. The larger changes at the DW array may be associated with directivity of the Borrego Springs earthquake.

Advances in Explosion Seismo-Acoustic Research Oral Session - Tuesday 15 May · 2:15 PM • Monroe Session Chairs: Charlotte Rowe, Catherine Snelson-Gerlicher, Sean Ford, Christopher Young, and Junghyun Park

Modeling of Rg Wave Sources for SPE and DAG Series

LARMAT, C.S., Los Alamos National Laboratory, New Mexico, USA, carene@ lanl.gov; DELOREY, A. A., Los Alamos National Laboratory, New Mexico, USA, andrew.delorey@lanl.gov; LEI, Z., Los Alamos National Laboratory, New 
Mexico, USA, zlei@lanl.gov; ROUGIER, E., Los Alamos National Laboratory, New Mexico, USA, erougier@lanl.gov; BRADLEY, C. R., Los Alamos National Laboratory, New Mexico, USA, cbradley@lanl.gov

This paper presents numerical modeling efforts to improve knowledge of the processes that affect seismic wave generation and propagation from underground explosions, with a focus on $\mathrm{Rg}$ waves. Validation datasets are provided by the Source Physics Experiment (SPE) which is a series of chemical explosions at the Nevada National Security Site with yields from $100 \mathrm{~kg}$ to $5000 \mathrm{~kg}$. The first series of explosions in a granite emplacement has just been completed. A second series of explosions in dry alluvium geology (DAG) is planned for 2018. We use numerical modeling based on the linking of hydrodynamic simulation codes (such as ABAQUS or HOSS) with a 3D full waveform propagation code (SPECFEM3D). The linking interface is a series of grid points of the SPECFEM3D mesh situated at the edge of the hydrodynamic code domain. Velocity histories are recorded at these grid points and passed from the hydrodynamic code to the waveform propagation code. The hydrodynamic codes model the region near the source via equations of state for the explosive and the surrounding material which is subjected to fragmentation, shock waves and high-strain deformation. In this paper, we will investigate how the linked numerical codes perform in terms of predicting the amplitude of the Rg waves. We compare hard-rock modeling to the SPE series. We have previously shown that the damage processes happening in the vicinity of the explosions create secondary seismic sources. These sources interfere with the recovery of the original explosion moment and reduces the apparent seismic moment at the origin of $\mathrm{Rg}$ waves up to $20 \%$. Rg waves are also sensitive to the velocity models which are initially built from the $3 \mathrm{D}$ geologic information of the area and subsequently adjusted to fit the data. We compare the modeling of the explosion in the sediment to data recorded during the 1965 Merlin test.

\section{Estimating Seismic Source Time Functions in Stochastic Earth Models}

POPPELIERS, C., Sandia National Laboratories, New Mexico, USA, cpoppel@ sandia.gov; PRESTON, L., Sandia National Laboratories, New Mexico, USA, Ipresto@sandia.gov; ELIASSI, M., Sandia National Laboratories, New Mexico, USA,meliass@sandia.gov

This work describes three current research efforts in estimating the mechanisms of explosive seismic sources using simulations and actual field data. In all of the work here, we use linear inverse methods to invert the seismic data for an equivalent linear source type. However, in the case that seismic energy is created by an explosion, the deformation in the region of the source is highly non-linear. For the first part of this presentation, we explore the effects of non-linear source mechanisms in our linear-equivalent inverse methods. The second part of this presentation explores the effects of unmapped geologic heterogeneity on our inversions. Specifically, we create realistic geologic models but include high wavenumber stochastic heterogeneities that tomography cannot typically resolve. Using synthetic data, we explore the effects of stochastic heterogeneity on our ability to estimate seismic source time functions (STFs) using linearized inverse methods. Finally, we present preliminary results of a controlled field experiment. In this experiment, we collected seismic data from a dense seismic network that we deployed to record a series of well-perforation shots at a geothermal injection well adjacent to Blue Mountain, NV, USA. We show the data and preliminary results of our linear-equivalent STF inversions as well as the effects of near-source nonlinearities and stochastic Earth models on inversion certainty. Sandia National Laboratories is a multimission laboratory managed and operated by National Technology and Engineering Solutions of Sandia LLC, a wholly owned subsidiary of Honeywell International Inc. for the U.S. Deparment of Energy's National Nuclear Security Administration under contract DE-NA0003525.

\section{Comparison between Seismological Characteristics of Underground Nuclear} Explosions and Subsequent Cavity Collapses at North Korea Test Site ZHAO, L. F., Institute of Geology and Geophysics, CAS, China, zhaolf@mail. iggcas.ac.cn; XIE, X. B., Institute of Geophysics and Planetary Physics, UC Santa Cruz, California, USA, xxie@ucsc.edu; WANG, W. M., Key Laboratory of Continental Collision and Plateau Uplift, Institute of Tibetan Plateau Research, Chinese Academy of Sciences, Beijing, China, wangwm @itpcas.ac.cn; ZHAO, X., Institute of Geology and Geophysics, CAS, Beijing, China, zhaox@mail. iggcas.ac.cn; YAO, Z. X., Institute of Geology and Geophysics, CAS, Beijing, China,yaozx@mail.iggcas.ac.cn

Since 2006, North Korea conducted 6 underground nuclear explosions at its test site near the China-North Korea border. Due to its large magnitude of $\mathrm{mb}(\mathrm{Lg})=5.56$, the explosion detonated on 3, September 2017 caused subsequent cavity collapses, i.e., the 3 September 2017 event $[\mathrm{mb}(\mathrm{Lg})=3.95] 8$ minutes after the test, the 23 September and 12 October 2017 events $[\mathrm{mb}(\mathrm{Lg})=3.3$ and 2.9] a few weeks later. These collapses had been suspected to be nuclear tests. Both explosions and their aftershocks generated abundant broad band digital seismograms within regional distances. Seismograms were collected to investigate event attributes, including the discrimination, yield estimation, and relocations of epicenters. The spectral ratios $\mathrm{Pg} / \mathrm{Lg}, \mathrm{Pn} / \mathrm{Lg}$, and $\mathrm{Pn} / \mathrm{Sn}$ were calculated for all 6 explosions, 3 aftershocks caused by cavity collapses, 4 nearby nature earthquakes, and a mining earthquake. These sources show apparently different features in their spectral ratios. Taking the logarithmic spectral ratio $\log (\mathrm{Pg} / \mathrm{Lg})$ as an example, for explosions their values raise quickly from -0.8 to 0.25 between 0.5 and $4.0 \mathrm{~Hz}$, and keep above 0.25 at frequencies higher than that. In contrast, the $\log (\mathrm{Pg} / \mathrm{Lg})$ values for earthquakes raise slowly from -0.8 to near 0 between 0.5 and $6.0 \mathrm{~Hz}$ and keep below 0 above $6.0 \mathrm{~Hz}$. As a comparison, the $\log (\mathrm{Pg} / \mathrm{Lg})$ values for cavity collapses raise quickly at low frequencies, similar to those fromexplosions, but start to decrease at approximately $4-5 \mathrm{~Hz}$. At high frequencies, their $\log (\mathrm{Pg} / \mathrm{Lg})$ values are low, even below earthquake populations. The spectral ratio from mining earthquake is similar to that from the cavity collapse. The results demonstrated that the network averaged $\mathrm{P} / \mathrm{S}$ type ratios can unambiguously separate explosions, cavity collapses, and natural earthquakes. This research was supported by the National Natural Science Foundation of China (grants 41674060, 41630210 and 41374065).

Shear Motion Generation in Dry Alluvium Geology: Pre-Shot Stochastic Simulations of the Source Physics Experiments

EZZEDINE, S., Lawrence Livermore National Laboratory, California, USA, ezzedine1@Ilnl.gov; VOROBIEV, O., Lawrence Livermore National Laboratory, California, USA, vorobiev1@llnl.gov; TOWNSEND, M., MSTS, Nevada, USA, townsemj@nv.doe.gov; ANTOUN, T., Lawrence Livermore National Laboratory, California, USA, antoun1@llnl.gov; WALTER, W. R., Lawrence Livermore National Laboratory, California, USA, walter5@llnl.gov; BONNER, J., MSTS, California, USA, bonnerjl@nv.doe.gov

The Source Physics Experiments (SPE) are ongoing efforts to improve explosion monitoring by conducting a series of controlled chemical explosions at the Nevada National Security Site and validate physics-based simulations of explosion phenomena. SPE Phase I was conducted injointed granite, however, SPE Phase II will be conducted in Dry Alluvium Geology, DAG, which is characterized byheterogeneous alluvial deposits. This work describes a methodology used for large scale modeling of wave propagation from chemical underground explosions to understand the genesis of shear motions. Shear motion enables discriminating between explosions and earthquakes. To build a reliable model we integrated the geological, geomechanical, and geophysical characterizations of the site. Simulating the behavior of alluvial deposits under explosive loading requires non-linear constitutive models. Thus, the rock behavior is described using an isotropic elastic-viscoplastic model, coupled with a rate-dependent damage mode, and a Mie-Grüneisen EOS, coupled with a porous compaction-dilation model. The constitutive model is implemented in GEODYN, a 3D Eulerian code. The model was further upscaled and calibrated to reproduce the well-known Perret and Bass correlations. The final constitutive model is then used for a parametric study of the effect of the key characteristics of alluvium on the magnitude of shear motion generation using GEODYN-L, 3D Lagrangian code. The series of planned four underground chemical explosions are simulated under conditions of uncertainty; the spatial distribution of the geophysical properties is generated stochastically conditional to observed data. Simulations of the shear motion generation is achieved, explained, compared to SPE Phase I and legacy nuclear shots. Surface displacement and velocities are predicted and used for acoustic predictions. This work performed under the auspices of the U.S. DOD by LLLNL under Contract DE-AC52-07NA27344.

\section{Near-Field Modeling of the Source Physics Experiments (SPE) Phase I}

VOROBIEV, O., Lawrence Livermore National Laboratory, California, USA, vorobiev1@llnl.gov

Phase I of the Source Physics Experiment was conducted at Nevada NNSS site in granite. The goal of this experiment was to study the ground motion generated by underground chemical explosion sources. Of particular interest is the understanding of mechanisms of shear wave generation observed during underground explosions, which may look like natural seismicity in the far field. To understand observed ground motion, we have conducted numerical modeling of the SPE. This talk reviews the main results discovered during the last 5 years of the modeling efforts. It was found that the rock mass mechanical response is not isotropic due to the presence of joints. Transverse ground motion is generated due to mechanical anisotropy which can be characterized if joint orientation is known. Azimuthal variations of both magnitude of this shear motion and its polarity seem to correlate with the joint set orientations. Numerical modeling of the wave propagation through such medium is computationally expensive if these joints are represented explicitly, because of the joint spacing is typically 
two orders of magnitude smaller than the wave length. We have undertaken such modeling only in the near-field region. Since exact orientation of every joint in the rock mass never can be found, we have used stochastic approaches to build various equally probably realizations of joint distributions for our modeling efforts. With this approach we were able to predict the extend of the tangential motion observed in the near field during the experiment. This work performed under the auspices of the U.S. Department of Energy by Lawrence Livermore National Laboratory under Contract DE-AC52-07NA27344.

\section{Upper Stratosphere Wind Variations and Their Effect on Regional Infrasound Propagation}

LEES, I. M., University of North Carolina, North Carolina, USA, jonthan. lees@unc.edu; BOWMAN, D. C., Sandia National Laboratories, New Mexico, USA, dbowma@sandia.gov

Infrasound is a valuable technique for monitoring phenomena such as surface explosions and volcanic eruptions from hundreds of kilometers away. However, uncertainties in the wind and temperature structure of the upper stratosphere $(35-45 \mathrm{~km})$ result in predicted wave propagation patterns that often deviate from reality. We discuss two infrasound measurement campaigns that used chemical explosions as sources; ground and balloon-borne infrasound microphones captured the resulting signals. The motion of the balloon platforms provides an in situ measure of wind perturbations in the lower/middle stratosphere that we extrapolate to the upper stratosphere in order to improve predicted arrival times and waveform amplitudes. Balloon-derived wind vectors are shown to differ dramatically from operational models such as the Global Forecast System and ECMWF. Since the models predict shadow zones where known observations occur, inverse modeling of the atmosphere is desired to correct model inadequacies. Since acoustic rays turn between $35-45 \mathrm{~km}$ elevation, balloon wind measurements form a critical constraint on acoustic propagation models.

Assessment of Infrasound Signals Recorded on Single Seismometers and Infrasound Arrays in the Western United States Using Ground Truth Sources

PARK, J., Southern Methodist University, Texas, USA, junghyunp@smu.edu; HAYWARD, C., Southern Methodist University, Texas, USA, hayward@smu. edu; STUMP, B. W., Southern Methodist University, Texas, USA, bstump@smu. edu

Ground truth sources in Utah during 2003-2013 are used to assess the contribution of temporal atmospheric conditions to infrasound detection and the predictive capabilities of atmospheric models. Ground truth sources consist of 28 , long-duration static rocket motor burn tests and 28 , impulsive rocket body demolitions. Automated infrasound detections from a hybrid of regional seismometers and infrasound arrays use a combination of STA/LTA ratios and spectral analyses. These detections are grouped into station triads using a Delaunay triangulation network, and then associated to estimate phase velocity and azimuth to filter signals associated with a particular source location. The resulting range and azimuth distribution from sources to detecting stations varies seasonally and is consistent with predictions based on seasonal atmospheric models. Impulsive signals from rocket body detonations are observed at greater distances $(\geq 700 \mathrm{~km})$ than the extended duration signals generated by the rocket burn test (up to 600 $\mathrm{km})$. Ray tracing results using ground-to-space (G2S) atmospheric specifications are compared to these observations and illustrate the degree to which the time variations in characteristics of the observations can be predicted over a multiple year time period.

\section{Estimating Scaled Depth of Burial from Acoustic Period}

BOWMAN, D. C., Sandia National Laboratories, New Mexico, USA, dbowma@ sandia.gov

Buried explosions can produce an acoustic wave detectable at ranges of tens to hundreds of kilometers. Since they are a record of forces imposed across the solid Earth/atmosphere boundary, these waves may contain information about the explosive source. Indeed, analysis of infrasound data acquired during the Source Physics Experiment (SPE) Phase 1 series in granite suggests a simple relationship between scaled depth of burial (SDOB) and signal period. While these chemical explosions were large (100s to 1000 s of $\mathrm{kg}$ TNT equivalent), analogous relationships may exist for much smaller blasts $(0.3-1 \mathrm{~kg})$ at similar scaled depths of burial. Here, the SDOB/period relationship for the SPE Phase I explosions is compared to that of sub-kilogram scale blasts conducted during an experimental volcanology initiative. Implications for the upcoming SPE Phase II series in alluvium as well as the remote monitoring of other buried volcanic and humancaused blasts are discussed.
Seismo-Acoustic Analysis of Chemical Explosions at the Nevada National Security Site

PASYANOS, M. E., Lawrence Livermore National Laboratory, California, USA, pasyanos1@llnl.gov; KIM, K., Lawrence Livermore National Laboratory, California, USA, kim84@llnl.gov

Over the past several years, two sets of chemical explosions have been conducted at the Nevada National Security Site (NNSS). Phase I of the Source Physics Experiment (SPE) conducted 6 chemical explosions in granite ranging from $\sim 0.1-5$ tons yield and 30-90 m depth. More recently, the Forensics Surface Events (FSE) conducted 4 near-surface chemical explosions ranging from $0.01-1$ tons yield and at a height of $0-2 \mathrm{~m}$. For both sets of events, we estimated the explosive yield and depth-of-burial from the seismic signal by fitting the local and regional waveform envelopes over a wide frequency band (Pasyanos et al., 2012). This method works well for the deeply-buried SPE explosions. When looking at the near-surface explosions from the FSE, however, the seismic signal can be alternatively explained by a smaller fully-coupled explosion at depth or by an increasingly larger yield approaching and above the free surface. This non-uniqueness due to the energy partitioning between seismic and acoustic energy at the free surface was incorporated into the waveform envelope method and applied to near-surface explosions in New Mexico and Syria (Pasyanos and Ford, 2015). This tradeoff between yield and depth/height can be broken by including complementary analysis of the acoustic signal using the acoustic waveform inversion method (Kim and Rodgers, 2016). The acoustic signal also has a strong tradeoff between a smaller yield event at or above the free surface or a larger yield event underground. However, since this tradeoff is opposite of that from the seismic signal, the two can be combined through the use of a likelihood function to more reliably estimate the source parameters from the FSE explosions, and estimate their associated uncertainties.

\section{Interactive Block Thresholding for Seismic Signal Processing}

LANGSTON, C.A., The University of Memphis, Tennessee, USA, clangstn@ memphis.edu; MOUSAVI, S. M., Stanford University, California, USA, smousavi05@gmail.com

A software tool has been developed to utilize time-frequency representations (TFR) of time domain signals based on the continuous wavelet transform (CWT) where the seismogram is converted into a $2 \mathrm{D}$ map of wavelet scale (analogous to Fourier period) as a function of time. The 2D map is an intuitive description of the signal since major signal arrivals in the CWT can often be seen correlating with inferred signals in the seismogram and separated from bands of noise. The tool allows the choice of simple block thresholding schemes analogous to bandpass filtering to remove obvious noise bands. The remainder can further be analyzed by interactively choosing irregular blocks that represent different parts of the signal for removal or for separate analysis. Inverse transforming the processed CWT yields signals with substantial Signal-to-Noise (SNR) improvement. The tool is used to process explosion data recorded by the IRIS Community Wavefields experiment in early July 2016. Four explosions $(909 \mathrm{~kg}, 455 \mathrm{~kg}, 2$ at $228 \mathrm{~kg}$ ) at 3 different shot points (ranges of $\sim 16 \mathrm{~km}, 35 \mathrm{~km}$, and $65 \mathrm{~km}$ ) from the experiment were detonated by the Air Force Research Laboratory to examine local wave propagation and signal characteristics. Interactive block thresholding incorporating the Morlet wavelet significantly improves the SNR for $909 \mathrm{~kg}$ and $455 \mathrm{~kg}$ shots. Three dominant wavetrains are evident in the data including the low scale (high frequency) $\mathrm{P}$ wave and 2 dispersed higher and fundamental mode surface wave trains. Each wave train can be extracted from the CWT map separately for further modeling, such as for group and phase velocity dispersion. The smaller shots are usually lost in the 'noise' that sometimes include swarms of local induced earthquakes, easily seen in the CWT map. Preprocessing the data to improve the SNR also improves array beamforming at high frequency for dense arrays constructed from subsets of nodal stations of the IRIS experiment.

\section{Advances in Seismic Site Response Studies Given Limitations in Understanding of Site Conditions} Oral Session - Tuesday 15 May · 8:30 AM • Monroe Session Chairs: Emel Seyhan, Sean K. Ahdi, Eric M. Thompson, and Alan Yong.

Can the Earthquake Site Response Be Predicted by the Ambient Noise Amplitude? Insight from Two Case Studies

PERRON, V., Swiss Seismological Service, Swiss Federal Institute of Technology of Zurich, Switzerland, vincent.perron.mail@gmail.com; GÉLIS, C., IRSN, Fontenay-aux-Roses, France, celine.gelis@irsn.fr; FROMENT, B., IRSN, 
Fontenay-aux-Roses, France, berenice.froment@irsn.fr; HOLLENDER, F., CEA/DEN, Saint-Paul-lez-Durance, France, France, fabrice.hollender@cea.fr; BARD, P. Y., University of Grenoble Alpes, ISTerre/CNRS/IRD/IFSTTAR, Grenoble, France, pierre-yves.bard@univ-grenoble-alpes.fr; CULTRERA, G., INGV, Roma, Italia, giovanna.cultrera@ingv.it; CUSHING, E. M., IRSN, PRPDGE/SCAN/BERSSIN, Fontenay-aux-Roses, France, edward.cushing@irsn.fr

While earthquake-based approaches such as the standard spectral ratio (SSR) require good quality records of numerous earthquakes, the use of ambient noise appears as a suitable possible solution for easy and rapid site effect assessments. Two main approaches are tested here: the horizontal-to-vertical spectral ratio (HVSR) and the noise-based standard spectral ratio (SSRn). The HVSR use the relative amplitude of the horizontal and vertical components of the ambient noise. Differently, the SSRn perform the ratio between seismic noise recorded simultaneously at a site and a rock reference station, similarly to theearthquakebased SSR. While the HVSR is currently used in hundreds of site-specific studies, the SSRn approach has been gradually abandoned since the 1990s. In this study, we compare the results obtain from these two approaches with those of the earthquake-based SSR. This is done for two sedimentary basins, in Provence (Southeastern France) and in Argostoli (Western Greece), where both earthquakes and seismic noise were recorded. In agreement with the literature, the HVSR does not provide more than the fundamental resonance frequency of the site (f0). The SSRn leads to an overestimation of the amplification factors for frequencies higher than the minimal fo of the basin (fomin). This discrepancy between SSRn and SSR is discussed and appears to be mainly dependent on the local geological configuration. We thus introduce the hybrid standard spectral ratio approach (SSRh) that aims to improve the SSRn by adding an intermediate station inside the basin for which the SSR is known, this station being used in turn as a local reference inside the basin for the SSRn computation. The SSRh provides site transfer functions very similar to the SSR ones in a broad frequency range. Based on that, we consider that the SSRn (or SSRh) should receive a renewed attention for the estimation of the spatial variability of the site response inside sedimentary basins.

\section{Application of Near-Source Factors to Deterministic Response Spectra}

HUDSON, K. H., Amec Foster Wheeler, California, USA, kenneth.s.hudson@ gmail.com; HUDSON, M. B., Amec Foster Wheeler, California, USA, marty. hudson@amecfw.com

Response spectra for use in design of new buildings are presented in ASCE 7-16. The ASCE 7-16 design response spectra are to be based on both a probabilistic evaluation and a deterministic evaluation. For the evaluating design deterministic maximum component (RotD100) spectra, National Earthquake Hazards Reduction Program (NEHRP) factors as recommended in ASCE 7-16 are to be applied to the RotD50 spectra; these factors are based on RotD100/RotD50 ratios obtained using the 2008 Next Generation Attenuation (NGA-West1) database. Additional studies based on the NGA-West2 database have resulted in several directivity models to account for directionality effects, namely ShahiBaker (2013), Bayless-Somerville (2013), Spudich-Chiou (2013), and Watson Lamprey (2013). In recent practice in Los Angeles for evaluating directionality effects, a factor computed as the average of the Shahi-Baker and BaylessSomerville factors has been applied to both the probabilistic and deterministic response spectra. This paper investigates the use of the directionality factors, in particular considering application of various rupture scenarios for the deterministic response spectra computed using the Bayless-Somerville method. An event on the Anacapa-Dume/Santa Monica combined fault was used to compute the deterministic response spectrum for an example site in the Century City District in Los Angeles, California. The resulting response spectra are compared to evaluate which rupture scenario should be applied for application to the deterministic response spectrum.

The Characteristics of $x_{0}$ in Longmenshan Region and Its Application in Estimation of Source, Path, and Site parameters

FU, L., Institute of Geophysics, CEA, Beijing, China, fuleichina@yeah.net; LI, X. J., Institute of Geophysics, CEA, Beijing, China, beerli@vip.sina.com; CHEN, S., Institute of Geophysics, CEA, Beijing, China, chensuchina@126.com

In this study, data recorded from 2009 to 2015 by 104 strong motion stations and 36 seismic stations are used to study the characteristics of $\kappa_{0}$ in Longmenshan region. The average $x_{0}$ of Songpan-Garze Orogen (SGO) and Western Sichuan Basin (WSB) is $0.0227 \pm 0.0065 \mathrm{~s}$ and $0.0423 \pm 0.0107 \mathrm{~s}$, respectively. The difference may be mainly attributed to the variation of near-surface geology. Both for SGO and WSB, $\kappa_{0}$ increases as VS30 increases, which is discrepancy with the assumption that higher VS30 may inferred lower $\kappa_{0}$. Fortunately, a correlation of $\kappa_{0} 0$ and topographic elevation $(h)$ is observed. To further verify the correla- tion, $\kappa_{0}$ obtained from the 36 seismic stations, which located on hard rock site condition, are used. We obtained $\ln \left(\kappa_{0}\right)=(-0.466 \pm 0.509)+(-0.426 \pm 0.074)$ $\ln (\mathrm{h})$, correlation coefficient is $49 \%$. The correlation coefficient of $x_{0}$-h correlation is higher than $30 \%$, which is, as concluded by Ktenidou et al. (2014), a good correlation coefficient that most $\kappa_{0}$-VS30 correlation could reach. Moreover, the phenomenon that distance-dependent component of $k(\mathrm{~m})$ increasing with $\mathrm{h}$ is also observed. Combining site amplification factor calculated by $1 / 4$ wavelength method and site-specific $\kappa_{0}$, empirical reference site conditions are constructed. GIT was applied to estimate stress drop $(\Delta \sigma)$, quality factor $(\mathrm{Q})$ and local site response. It is observed that $\Delta \sigma$ tend to increases with time until a large-magnitude earthquake occurred. For SGO and WSB, we obained Q(f) $=264 \mathrm{f} 0.75$ and $Q(f)=223 f$ 1.01, respectively. The obtained site responses are compared with those from HVSR and classical GIT. Comparison between GIT and HVSR shows that the shapes and predominant frequencies are similar and the amplification of GIT is higher at frequencies above the predominant frequency. Site responses estimated from both GIT methods are coinciding. This result demonstrated that the empirical reference site condition is reasonable and could be used when a real rock site is hard to find.

\section{Accounting for Vs Uncertainty in Seismic Site Response Analyses Using the Experimental Site Signature: A Case Study of the Garner Valley Downhole Array}

COX,B.R., The University of Texas, Texas, USA, brcox@utexas.edu; TEAGUE, D. P., ENGEO, Inc., California, USA, dteague@engeo.com; RATHJE, E. M., The University of Texas, Texas, USA, e.rathje@utexas.edu

This presentation compares measured and predicted seismic site response at the Garner Valley Downhole Array (GVDA) using a wide range of shear wave velocity (Vs) profiles developed from both borehole methods and inversion of surface wave data. Only low amplitude ground motions, resulting in approximately linear-viscoelastic site response between the downhole accelerometer and the surface accelerometers, were considered in this study. Thus, uncertainties associated with the small-strain Vs profiles used for site response predictions play a considerable role in attempting to match the recorded site response and its associated variability. Prior to our study, two borehole Vs profiles extending into rock were available for the site. However, their predicted/theoretical transfer functions (TTFs) were quite different and in poor agreement with the measured/empirical transfer functions (ETFs). These differences provided motivation to collect and interpret an extensive set of active-source and passive-wavefield surface wave measurements in an attempt to develop deep Vs profiles for the site that might be used to more accurately match the measured site response and its associated variability. Suites of non-unique Vs profiles developed from inversion of the surface wave data, and in conjunction with experimental horizontal-to-vertical spectral noise ratios (HVSR), visually exhibited considerable differences. However, their predicted TTFs matched the measured ETFs very well. Accordingly, we propose that surface wave dispersion and HVSR noise data represent an experimental "site signature" that can be used as a quantitative means of assessing whether candidate Vs profiles are appropriate for use in site response analyses.

\section{Development of a United States Community Shear Wave Velocity Profile Database}

AHDI, S. K. UC Los Angeles, California, USA, sahdi@g.ucla.edu; STEWART, J. P., UC Los Angeles, California, USA, jstewart@seas.ucla.edu; KWAK, D. Y., RMS, Inc., California, USA, dongyoup.kwak@rms.com; YONG, A., US Geological Survey, California, USA, yong@usgs.gov; SADIQ, S., Hanyang U., South Korea, shamshersadi@ hanyang.ac.kr; ILHAN, O., UIUC, Illinois, USA, oilhan2@illinois.edu; PARK, D., Hanyang U., South Korea, dpark@hanyang. ac.kr; HASHASH, Y. M. A., UIUC, Illinois, USA, hashash@illinois.edu; BOZORGNIA, Y., UC Los Angeles, California, USA, yousef.bozorgnia@ucla. edu

We describe a multi-institution effort to develop an open-access shear-wave velocity (VS) profile database (PDB), which will include a public repository for VS profile data and associated metadata in the United States. VS profiles are an essential resource for ground motion modeling and other applications. The minimum requirements for a site to be included in the database are in situ geophysical VS measurements and location metadata. Other information is included as available, including geotechnical logs, penetration resistance, laboratory test data, ground water elevation, and P-wave velocity profiles. Various secondary site information such as surficial geology and topographic slope will be included from available geospatial data. The data collection stage of the project is largely complete, with over 4500 VS profiles in our possession. A prototype data model and database schema have been developed, and ongoing work includes digitization of data and its unification across various disparate formats. The database will be presented as an online map-based interface with downloadable VS profile and metadata 
information. This abstract serves as a progress report to the engineering seismology community, as we continue to seek engagement and support, and continue to seek out new potential data sources. Funding for this project was provided by the USGS Earthquake Hazards Program under contract number G17AP00018.

\section{Which Site Proxy Should We Use in Ground-Motion Models? \\ SANDIKKAYA, M. A., Hacettepe University, Ankara, Turkey,} abdullahsandikkaya@hacettepe.edu.tr

The database is compiled from KIKNet Archieve of Japan (kyoshin.bosai.go.jp) with following criteria: shallow crustal events between 2000-2016, recorded within $300 \mathrm{~km}$ and $\mathrm{Mw}$ range is $3.5-7$. Time-based average of shear wave velocity profiles up to different depths $10 \mathrm{~m}$ (VS10), 20m (VS20), 30m (VS30) and $50 \mathrm{~m}$ (VS50) are computed. Only stations with $200<\mathrm{VS} 30<1500 \mathrm{~m} / \mathrm{s}$ are used. These proxies are used as site parameters in surface ground-motion models (SGMMs). Then site variabilities of the SGMMs are compared. VS50 model has the highest variability at short periods, for other models comparable results are obtained. For longer periods, considering deeper depths leads to lower site variability. Borehole models (BGMM, uses borehole velocity) and surface-to-borehole ratio models (SBRM, uses impedance ratio)are also developed. Applying the BGMM and SBRM, estimated surface motions are obtained. The difference between observed and estimated motions are less than 3\%. So SBRM can be used as a site amplification indicator. The modified impedance ratios $(\alpha \mathrm{m})$ are computed as replacing the top layers with the reference site condition. That is if $20 \mathrm{~m}$ depth is considered, the top layers up to $20 \mathrm{~m}$ are replaced with $760 \mathrm{~m} / \mathrm{s}$. The BGMM and SBRM (with $\alpha \mathrm{m})$ are used to compute the reference surface motion. Then the site amplification (observed motion/reference motion) are computed. The differences between site amplificationare compared. The minimum misfit is obtained by VS50 modelat longer periods. At short periods the misfits are similar. The results reveal that as deeper depths are considered more reliable site amplification estimates are obtained. Although VS30 proxy is debatable in some aspects, taking shallower depths misses some information about site amplification especially at longer periodsandcounter to Japanese stations, deeper Vs profiles are not well-documented in other regions as well as its usage over 40 years are the main reasons to choose it is a site proxy in GMMs.

\section{Integration of Site Effects Into PSHA: A Comparison between Two Fully} Probabilistic Methods for the Euroseistest Case

ARISTIZÁBAL, C., ISTerre, Grenoble, France, claudia.aristizabal@univgrenoble-alpes.fr; BARD, P. Y., ISTerre, Grenoble, France, pierre-yves.bard@ univ-grenoble-alpes.fr; BEAUVAL, C., ISTerre, Grenoble, France, celine. beauval@univ-grenoble-alpes.fr; GÓMEZ, J. C., IUSS-Istituto Universitario diStudiSuperiori di Pavia, Lombardía, Italy, jcgomezz1910@gmail.com

The integration of site effects into Probabilistic Seismic Hazard Assessment (PSHA) is a constant subject of discussion within the seismic hazard community due to its high impact on hazard estimates. To include this effect in PSHA, different approaches have been proposed by different authors. The aim of this research is to compare the hazard curves (HC) obtained for a soft, nonlinear site with two different fully probabilistic site specific seismic hazard methods: 1) The Analitical Approximation of the Full Convolution Method (AM) (Bazzurro and Cornell 2004a, b) and 2) what we call the Full Probabilistic Stochastic Method (SM) The AM computes the site-specific $\mathrm{HC}$ by convolving the site-specific bedrock HC, $\operatorname{Sar}(\mathrm{f})$, with a simplified representation of the probability distribution of the amplification function, $A F(f)$ at the considered site. While the SM is nothing else that the HC built from stochastic time histories on soil corresponding to a representative, long enough catalogue of seismic events. This comparison is performed for the example case of the Euroseistest site near Thessaloniki (Greece). For this purpose, we generate sythetic hazard-consistent earthquake catalogue, apply host-to-target corrections and calculate synthetic time histories. We propagate the rock stochastic time histories, from depth to surface using two different 1D site response analysis, a linear equivalent and nonlinear codes, to evaluate the code-to-code variability. Lastly, we compute the site-specific HC with both approaches. The results found with both methods are in relatively satisfactory agreement whatever the site response code along all the studied periods. Finally, we encourage the use of stochastic simulations to integrate site effects into PSHA, since it allows to better investigate the variability of the site response better linked to more physical models, something that currently is not possible with real data due to its scarcity (specially at high acceleration levels).

\section{Application of Non-Ergodic Site Response for a Unique Facility in Los Angeles, California}

TEAGUE, D. P., ENGEO Incorporated, California, USA, dteague@engeo.com; HEIDARZADEH, B., ENGEO Incorporated, California, USA, bheidarzadeh@ engeo.com; WURMAN, G., ENGEO Incorporated, California, USA, gwurman@engeo.com; ESPINOSA, P. J., ENGEO Incorporated, California, USA, pespinosa@engeo.com; STEWART, J. P., UC Los Angeles, California, USA,jstewart@seas.ucla.edu

The state of practice for seismic hazard analysis (SHA) uses semi-empirical ground motion models (GMMs) with average source, path, and site effects derived from global catalogs (ergodic models). Ergodic models require application of relatively high aleatory variability, which increases hazard at long return periods. We report the results of SHA performed for the Lucas Museum of Narrative Art (LMNA) in Los Angeles, using both ergodic and non-ergodic site response models. The non-ergodic procedure follows that described in Stewart et al. (2017). The LMNA building is designed with an effective isolated period of $\sim 4 \mathrm{sec}$. The base isolation system decreases the participation of higher modes of vibration, so the primary focus of the SHA was on 5\%-damped pseudo-spectral accelerations at the fundamental period of the base-isolated building for a return period of 2500 years. We computed hazard curves for a reference site condition and convolved them with a site-specific mean amplification function, along with its associated uncertainty, in order to obtain hazard curves at the ground surface. The mean amplification function was developed using both local ground motion observations and ground response analyses. OpenSHA was used to develop the hazard curves at the reference site condition at periods of $0.01-10 \mathrm{sec}$ using four NGA-West2 GMMs. An important parameter in the development of the hazard curves at the reference site condition is the within-event variability of the input ground motions at the reference site condition prior to modification for nonlinear effects. This term was derived from a single-station model (GeoPentech, 2015), so a lower total standard deviation was used in the reference site hazard calculation due to the removal of site-to-site variability. Though the mean site response was similar to ergodic models at $4 \mathrm{sec}$ when basin depth is considered, non-ergodic mean hazard results were lower at the 2500-year hazard level, averting a redesign of the structure.

\section{Sensitivity of Nonlinear Site Amplification Factors to the Models Used to Simulate and Constrain Rare Events}

SHI, I., Caltech, California, USA, jian.shi@caltech.edu; ASIMAKI, D., Caltech, California, USA, domniki@caltech.edu

As part of the 2014 United States National Seismic Hazard Maps (NSHM) revision, the national seismic hazard model incorporated a number of recently developed Ground Motion Prediction Equations (GMPEs) such as NGA-West2. GMPEs frequently employ numerical simulations to complement the recorded motions in the poorly sampled, high ground motion intensity range, in order to constrain their nonlinear site amplification factors. Currently, site amplification factors in NGA_west 2 have been constrained using the equivalent linear method, which may significantly affect ground motion predictions of rare events at soil sites, particularly in the high frequency range $(\geq 1 \mathrm{~Hz})$ that is of central importance in earthquake engineering designs. In this study, we use a newly developed nonlinear method to generate simulated ground motions, and then compute site amplification factors with them. We compare the new site amplification factors with those in NGA-West2, and identify scenarios where the new factors differ from the old ones. Additionally, we use our computed site amplification factors to identify general trends with soil and ground motion parameters, and test how the site response method selection affects the parameterization of nonlinear site amplification factors. Our result indicates the extent to which nonlinear site amplification factors in NSHM need to be revisited and potentially revised to improve high-frequency seismic hazard predictions for larger events on soil sites.

\section{Non-Linear and Plastic Soil Response in the Greater Tokyo Area during the 2011 Tohoku-Oki Earthquake}

VIENS, L., Harvard University, Massachusetts, USA, loicviens@fas.harvard. edu; DENOLLE, M. A., Harvard University, Massachusetts, USA, mdenolle@ fas.harvard.edu; HIRATA, N., ERI, The University of Tokyo, Japan, hirata@ eri.u-tokyo.ac.jp; NAKAGAWA, S., ERI, The University of Tokyo, Japan, nakagawa@eri.u-tokyo.ac.jp

Strong ground motion from earthquakes can induce dynamic strains large enough for the shallow subsurface to respond non-linearly and cause permanent velocity changes. We investigate the behavior of the near-surface in the greater Tokyo area during the $2011 \mathrm{Mw} 9.0$ Tohoku-Oki earthquake sequence using continuous records from 234 seismometers of the Metropolitan Seismic Observation network (MeSO-net). This network, which was deployed in shallow 20-m depth boreholes, recorded large strong ground motions during the main event. For each MeSO-net station, we compute the near-surface response using the single-station cross-correlation technique between vertical and horizontal components, every 6 hours for 2.5 months around the main event. Comparing each near-surface response against a pre-event reference, we find shallow $(\sim 100 \mathrm{~m})$ seismic velocity 
drops up to $10 \%$ during the mainshock. The amplitude of the coseismic velocity drop increases with increasing ground shaking and decreasing VS30, which is the $\mathrm{S}$-wave velocity in the upper $30-\mathrm{m}$ of the ground. Furthermore, the waveforms experience a loss of coherence that recovers exponentially over a time. While most of the velocity changes recover within a few days, we also find permanent changes at stations that experienced liquefaction and the strongest ground motions. The ambient seismic field captures the coseismic velocity changes in the shallow structure and the following healing process, and can be used to detect permanent damage.

\section{Advances in the Theory, Modeling, and Observation of Anelastic Seismic Wave Propagation-Recent Anelastic Models of the Earth \\ Oral Session · Tuesday 15 May · 2:15 PM · Flagler \\ Session Chairs: Roger D. Borcherdt and Kristopher A. \\ Innanen}

\section{On Implications of Advances in the Theory of Anelastic Seismic Wave Propagation}

BORCHERDT, R. D., US Geological Survey, California, USA, rdborcherdt@ gmail.com

Recent advances in the theory and modeling of anelastic seismic waves reveal new insights regarding characteristics of seismic waves in the Earth that are not apparent from elastic models. Examples of insights, as implied by general viscoelastic solutions for $\mathrm{P}$ and $\mathrm{S}$ body waves, reflection-refraction coefficients, Rayleigh- and Love-Type surface waves, head waves, and general ray theory, are: Anelastic $P$ and $S$ body waves are predominantly inhomogeneous with physical characteristics such as phase and energy speeds, particle motions, and fractional energy loss (reciprocal quality factor) dependent on the wave's inhomogeneity, which varies with angle of incidence and contrasts in intrinsic material characteristics at each boundary, Two types of anelastic inhomogeneous $S$ waves exist (SI and SII), each with distinct particle motions, energy wave velocities, and reciprocal quality factors, Anelastic reflection-refraction coefficients at boundaries with contrasts in intrinisic absorption indicate energy may be refracted away from the boundary for all angles of incidence, giving rise to anelastic ray paths not anticipated from elastic models, that are in agreement with ray paths confirmed by laboratory and surface seismic measurements, Measurable differences in distances, travel times, and amplitude attenuation that exist due to contrasts in anelastic intrinsic material absorption encountered by seismic rays traversing the crust and mantle. These and additional insights revealed by advances in the theory of anelastic seismic wave propagation will be discussed. Further quantification of their implications as they manifest themselves in measured distances, travel time, and amplitude attenuation is an important ongoing step in refining anelastic models for near-surface exploration and for the whole Earth.

\section{General Viscoelastic Ray Theory}

BORCHERDT, R. D., US Geological Survey, California, USA, rdborcherdt@ gmail.com

General ray theory recently developed for $\mathrm{P}$ and $\mathrm{S}$ body waves in layered viscoelastic media provides new insights for the travel-time and amplitude-attenuation characteristics of seismic waves in an anelastic Earth. Solutions of the forward ray tracing problems for horizontal and spherical media account for changes in velocity and attenuation of general $\mathrm{P}$ and $\mathrm{S}$ waves, which are due to changes in wave inhomogeneity induced by contrasts in intrinsic anelastic material parameters encountered by anelastic rays. These changes, which may manifest themselves as measurable variations in travel-time and amplitude-attenuation as observed at the surface, are not predicted by elastic models. In addition, viscoelastic solutions for general head waves provide a plane-wave explanation for seismic head-wave arrivals, in that the refracted anelastic solution may carry significant components of energy parallel and away from the boundary and result in ray paths reflected from deeper boundaries that are not predicted by elastic models. Solutions of inverse problems to infer the intrinsic material absorption and wave speed of anelastic Earth materials are developed to account for changes in measured travel-time and amplitude-attenuation curves due to changes in inhomogeneity of the waves along an anelastic ray path. Generalizations of the Herglotz-Wiechert integral solution from elastic to viscoelastic media are developed as an essential step in the solution of the inverse problem for anelastic horizontal and spherical media with gradients in intrinsic material absorption. These insights will be discussed in the context of the mathematical framework for general viscoelastic ray theory.
Estimating $\mathbf{0}$ and Scattering Using Waveform Inversion and Imaging KAMEI, R., University of Western Australia, University of Oklahoma, Australia, rie.kamei.r@gmail.com; NAKATA, N., University of Oklahoma, Oklahoma, USA,nnakata@ou.edu

Estimating an accurate fine-scale Q distribution of the Earth is essential for a wide-range of applications in both earthquake and exploration seismology. Waveform-based methods such as waveform inversion are expected to generate a wavelength-scale $\mathrm{Q}$ model, as have done for velocity models. However, $\mathrm{Q}$ inversion has been significantly more challenging than velocity inversion. Effects of $Q$ most strongly appear in seismic records as frequency-dependent amplitude loss. Thus, $\mathrm{Q}$ inversion relies on waveform amplitudes that also depend on velocities. Indeed, most of amplitude variations can be explained by velocity heterogeneities, and $\mathrm{Q}$ inversion is commonly performed after velocity inversion to mitigate the problem. Still extracting $\mathrm{Q}$ from residual information tends to be unstable, since remaining velocity errors may not be negligible, and since frequency-dependent amplitude loss is not fully incorporated in waveform inversion methods. Here we consider a simple case where diffracted waves from sub-wavelength scattering objects interfere with transmitted waves. The frequency-dependent phenomena due to the two mechanisms (scattering and Q) complicate interpretation of seismic amplitudes. Scatterers may be difficult to characterize fully by waveform inversion because of their small size. We examine the problem in field data, and conduct analytical and numerical investigation. We aim to develop stable Q-estimation methods by combining waveform-based imaging and inversion methods. Reverse-time migration methods are used to locate and characterize the small scattering objects. Waveform-based inversion methods are then used to eliminate the interference and estimate $\mathrm{Q}$ models.

\section{Accounting for Attenuation Physics Uncertainty in FWI}

KEATING, S. D., University of Calgary, AB, Canada, scott.keating@ucalgary. ca; INANNEN, K. A., University of Calgary, AB, Canada, k.innanen@ucalgary. ca

Attenuation and dispersion have a significant impact in full waveform inversion and are essential to achieving greater resolution and fidelity in the inversion. These properties are often modeled in full waveform inversion using empirical nearly constant Q models. Significantly, these models do not hold universally, especially when large ranges of frequencies are considered. In this numerical study, we demonstrate that discrepancies between the attenuation physics in the subsurface and those used in the inversion can have severely negative impacts on the results of the inversion. This problem can be alleviated by adopting an updating strategy in the inversion in which relatively small bands of frequencies are considered at each iteration, allowing for empirical attenuation models to be applied in full waveform inversion with greater confidence.

\section{Subsurface Parameters Estimation by Taking into Account Attenuation and Anisotropy \\ MORADI, S. A., University of Calgary, AB, Canada, moradis@ucalgary.ca;} INNANEN, K. A., University of Calgary, AB, Canada, k.innanen@ucalgary.ca

The method of volume scattering is utilized to develop the framework for sensitivity analysis of Full Waveform Inversion (FWI) in a media with both attenuation and anisotropy. Specifically, Born scattering is used to extract the sensitivity kernels so called scattering potentials and Amplitude Variation with Offset/ Azimuth $(\mathrm{AVO} / \mathrm{Az})$. Scattering potentials or radiation patterns versus phase and azimuth angles are utilized to choose the right model parameterizations for FWI. A successful FWI procedure depends on the model parameterization, for example, a specific model parametrization might lead to artifacts in density model however these artifacts vanish by choosing a different model of parametrization. The sensitivity of subsurface imaging to the model parametrization is the tool to determine the suitable initial model for the earth which can be performed in the framework of scattering theory. Based on the volume scattering framework that we developed for the anisotropic-attenuative media, we would find the optimum model parametrization for FWI in presence of both anisotropy and attenuation. This is the key step to estimate the real model of the earth to enhance the resolution of the subsurface image.

Recent Development of Seismic Attenuation Modeling and Imaging in Exploration Seismology

ZHU, T., Penn State, Pennsylvania, USA, tyzhu@psu.edu

Seismic approaches based on the phase/traveltimes are widely and successfully used to image the subsurface geological structure. On the other hand, the amplitude of seismic waveform that is hoping for providing more physicalinformation about geology has not been explored in a consistent way. There exists a gap 
between current seismic capability and the full physics of seismic waveform. For example, asEarth media always attenuate seismic waves during propagation seismic data includes attenuation effects that contributes seismic amplitude seriously. To fill the gap, we have to deal with seismic attenuation (intrinsic and scattering) physically and practically in next-generation seismic techniques. In this talk, I will review recent progress on the development of theory of viscoacoustic and viscoelastic wave equations to model wave attenuation in the Earth. The theory is based on the frequency-independent $\mathrm{Q}$ model, but it can be generalized to frequency-dependent $Q$. Then I'll show how this wave equation facilitates the compensation of attenuation effects in seismic imaging in the context of time-reversal seismic imaging, reverse-time migration (RTM), and full waveform inversion using synthetic data and field data. Finally, I will discuss the prospective research in seismic attenuation modeling, imaging, and full waveform inversion.

\section{Physical Models of Rock Anelasticity}

MOROZOV, I. B., University of Saskatchewan, igor.morozov@usask.ca

Physically meaningful characterization of seismic-wave attenuation is critical in theoretical and observational seismology. However, currently, descriptions of "attenuation" are somewhat mystified by reliance on empirical concepts, such as time-delayed strain-stress responses and frequency-dependent material properties. Attenuation is often treated as abstract "mechanical energy dissipation" measured by the quality factor $(\mathrm{Q})$ of the medium. Nevertheless, in physics, no such medium properties exist, and energy dissipation rate represents only one aspect of the process of deformation. For example, compare the four commonly used attenuation measures: the geotechnical damping ratio $(\mathrm{x})$, spectral decay parameter $(\mathrm{k})$ in site characterization studies, and $1 / \mathrm{Q}$ and $\mathrm{t}^{*}$ in seismology. Of these measures, only $\mathrm{x}$ is a true medium property, which is the viscosity of the near-surface mechanical resonator. By contrast, quantities $\mathrm{k}, 1 / \mathrm{Q}$ and $\mathrm{t}^{*}$ are parameters of certain types of transfer functions, such as spectral or stress/strain ratios or logarithmic decrements of amplitudes measured in certain experiments. This means that these properties are apparent, and they may (and typically do) depend on boundary conditions, measurement procedures and assumptions. Hypothesizing that such properties (for example, the P- and S-wave, Young's-modulus, surfacewave, or free-oscillation Qs) are mutually related as predicted by the viscoelastic model is generally incorrect. To overcome these problems, the "attenuation" phenomenon should be approached ab initio, by starting from material properties, differential equations of wave mechanics and the appropriate boundary and initial conditions. Such physical approaches are well known in poro- and thermoelasticity and hydro-mechanics, but they are still poorly utilized in seismology. Several examples of anelastic (but non-Q) forward and inverse physical models of laboratory and field experiments are used to illustrate the above statements.

\section{Exploring the Extent of Wave Propagative Effects on Teleseismic Attenuation} Measurements within the Sierra Nevada

BERNARDINO, M. V., University of Colorado Boulder, Colorado, USA, melissa.bernardino@colorado.edu; JONES, C. H., University of Colorado Boulder, Colorado, USA, cjones@colorado.edu

Previous attempts at imaging the upper mantle intrinsic attenuation structure beneath the southern Sierra Nevada have strongly indicated that propagative effects on $\mathrm{t}^{*}$ measurements predominate over anelastic ones. Teleseismic shear wave $t^{*}$ measurements from a handful of events at stations proximal to the Isabella anomaly, a high velocity upper mantle feature, exhibit higher $t^{*}$ values (and therefore higher attenuation) than stations to the east residing in the Basin and Range province, where slower velocities and higher temperature are observed. These results suggest that multipathing and/or defocusing effects on shear-wave amplitudes occur for rays that travel through the high velocity material precluding any straightforward attempts at constraining anelastic attenuation. We explore the spatial extent and azimuthal dependence of multipathing/defocusing effects on $t^{*}$ measurements within the Sierra Nevada using teleseismic $S$ - and SKS- phases recorded by the Sierra Nevada Earthscope Project (SNEP) and the Sierran Paradox Experiment (SPE) seismic networks. However, we also investigate the directional dependence of shear wave amplitude spectra by first accounting for seismic anisotropy in our measurements. Waveforms are first rotated into the Sierran SKSFast, $\mathrm{N} 75^{\circ} \mathrm{E}$, and SKSSlow, $\mathrm{N} 15^{\circ} \mathrm{W}$, direction. Following the method of Stachnik et al., (2004), shear-wave spectra for each event are jointly inverted for a single seismic moment, M0k, and corner frequency, fck, and separate $t^{*}$ for each ray path. Defocusing and anelastic effects on $t^{*}$ measurements are modeled using E3D, an elastic finite-difference wave propagation code that can incorporate attenuation. Defocusing effects are modeled using simple high-velocity geometries including a spherical "drip" and a tabular, east-plunging structure.
Finite-Frequency Tomography of 3-D Attenuation Using Rayleigh Waves Recorded by OBS Array

RUAN, Y., Nanjing University, Jiangsu, China, youyir@nju.edu.cn; FORSYTH, D. W., Brown Univesity, Rhode Island, USA, donald_forsyth @ brown.edu; BELL, S. W., University of Rhode Island, Rhode Island, USA, swbell11@gmail.com

The distinct sensitivities of seismic velocity and attenuation (1/Q) to water content, melt, and major element composition yield important constraints on midocean ridge processes and the associated mantle flow pattern, melt distribution, and the interaction of spreading centers with hotspots. Beneath the Juan de Fuca ridge, both body-wave and surface-wave studies observed strong attenuation and slow velocity anomalies. However, it is still under debate which mechanism is favored: Either the direct effects of in situ melt extending to depths of $150 \mathrm{~km}$ or more, or the pre-melting effects of a hydrous mantle upwelling with about $200 \mathrm{ppm}$ of water in which melting commences at about $100 \mathrm{~km}$. Neither the depth-integrated S-wave attenuation nor the averaged 1-D shear attenuation for surface waves can provide further constraints; to resolve the debate a 3-D attenuation structure is required. Surface-wave tomography of 3-D attenuation structure is known as a challenging task due to difficulties in separating elastic focusing effects on seismic amplitudes from intrinsic attenuation and the relatively small effects of attenuation on amplitude over short distances. Taking this into account, we introduced the finite-frequency kernels for attenuation and imaged 3D shear attenuation and velocity structures in the vicinity of the Juan de Fuca plate. Owing to the extensive arrays of ocean bottom seismometers (OBS) with high quality, long deployment periods, and novel noise removal techniques, we obtained 3-D attenuation and shear velocity model with the best resolution to date of any spreading center based on fundamental-mode Rayleigh waves. With 3-D models of shear attenuation and shear velocity, we evaluate the two competing paradigms and shall present a summary of the inversion results and favored interpretation.

\section{Anisotropic Attenuation in Rocks: Theory and Lab Measurements}

VAVRYCUK, $\mathrm{V}$., Institute of Geophysics, The Czech Academy of Sciences, Czech Republic, vv@ig.cas.cz; SVITEK, T., Institute of Geology, The Czech Academy of Sciences, Czech Republic, svitek@gli.cas.cz; LOKAJICEK, T., Institute of Geology, The Czech Academy of Sciences, Czech Republic, lokajicek@ gli.cas.cz; PETRUZALEK, M., Institute of Geology, The Czech Academy of Sciences, Czech Republic, petruzalek@gli.cas.cz; KERN, H., Institut für Geowissenschaften, Universität Kiel, Germany, kern@min.uni-kiel.de

Anisotropic attenuation affects seismic observations and complicates their interpretations. Its accurate determination is, however, difficult and needs extensive measurements of wawefields in many directions. We developed and numerically tested an iterative inversion scheme for determining the parameters of anisotropic attenuation. We present a lab facility that allows for measuring anisotropic attenuation using the P-wave ultrasonic sounding of spherical samples in 132 directions distributed regularly over the sphere. The applicability of the proposed inversion method and the performance of the experimental setup are exemplified by determining triclinic anisotropic attenuation of the serpentinite rock from Val Malenco, Northern Italy. Measurements were done at room temperature and hydrostatic pressures up to $400 \mathrm{MPa}$ in a pressure vessel with oil as a pressure medium. Three significant directions of the foliated sample were selected to study changes of the directional dependence (anisotropy) of velocity, amplitude and Q-factor with increasing pressure. Remarkable differences are observed in the changes of velocity and attenuation anisotropy as pressure is increased. While the velocity anisotropy is quite stable through all pressure levels, the attenuation anisotropy and the $\mathrm{Q}$-factor vary significantly in magnitude and orientation. The variations are probably caused by closing of microcracks due to acting hydrostatic pressure, so the contact conditions between individual minerals consolidate and the transmitting energy is less attenuating.

\section{Environmental Seismology: Glaciers, Rivers, Landslides and Beyond}

Oral Session · Tuesday 15 May · 2:15 PM · Hibiscus B

Session Chairs: Bradley P. Lipovsky, Kate Allstadt, and Rick

Aster

Environmental Seismology - An Indispensable Tool to Constrain Drivers, Precursors and Evolution of Mass Wasting Processes

SCHÖPA, A., GFZ Potsdam, Germany, schoepa@gfz-potsdam.de; DIETZE, M., GFZ Potsdam, Germany, mdietze@gfz-potsdam.de; TUROWSKI, J. 
M., GFZ Potsdam, Germany, turowski@gfz-potsdam.de; HOVIUS, N., GFZ Potsdam, Germany, hovius@gfz-potsdam.de

Mass wasting processes such as rock falls, debris flows and land slides are often the initial elements of sediment cascades that shape the Earth's surface, from high mountain peaks to the ocean basins, and they are driven by intrinsic and extrinsic mechanisms. While these drivers can usually be measured straightforwardly by classic approaches, the actual mass wasting processes are difficult to constrain, because they show infrequent and rapid occurrence in locations that are hard to predict, span several orders of magnitude in size, and typically involve a series of successive and combined processes. Environmental seismology, the study of the seismic signals emitted by Earth surface processes, provides a valuable alternative to this shortcoming. It allows insights to the evolution of mass wasting processes, assigning precise timing and location information (including tracking of moving sources), estimating the mobilised volumes, and monitoring precursor signals of large mass wasting processes. This contribution explores the validity and limitations of seismic methods to detect and locate small mass wasting processes, shows how retrospective analysis reveals the relative contribution of different process drivers, and how prospective analysis helps identifying early warning and rapid response opportunities. These themes are based on case studies from natural laboratory settings, explored by the GFZ Geomorphology Section: the Askja caldera flank collapse on Iceland, the rock fall prone Lauterbrunnen Valley and debris flow dominated Illgraben in Switzerland, and a chalk cliff coast on the island of Rügen in Germany.

\section{Characterizing Debris Flows Using Seismic Arrays at the USGS Debris-Flow} Flume

ALLSTADT, K. E., US Geological Survey, Colorado, USA, kallstadt@usgs. gov; KEAN, J. W., US Geological Survey, Colorado, USA, jwkean@usgs.gov; IVERSON, R. M., US Geological Survey, Washington, USA, riverson@usgs. gov; SMITH, J. B., US Geological Survey, Colorado, USA, jbsmith@usgs.gov; RENGERS, F. K., US Geological Survey, Colorado, USA, frengers@usgs.gov; OBRYK, M., US Geological Survey, Washington, USA, mobryk@usgs.gov; LOGAN, M., US Geological Survey, Washington, USA, mlogan@usgs.gov; GEORGE, D. M., US Geological Survey, Washington, USA, dgeorge@usgs.gov

Seismic recordings of debris flows contain information about conditions within and at the base of flows. These characteristics are difficult or impossible to measure directly. In order to use seismic techniques to make quantitative measurements, it is critical that we understand how the radiated seismic energy relates to debris flow dynamics. This is best accomplished in a controlled, experimental setting. One of the few facilities in the world that allows such investigations at large scales is the USGS debris-flow flume in Oregon. The flume is a $95-\mathrm{m}$-long channel sloping at 31 degrees in which man-made debris flows can be created and observed. In 2016 and 2017, we installed over 120 seismometers within 50 $\mathrm{m}$ of the flume. We installed the instruments in linear arrays $(2-3 \mathrm{~m}$ spacing) and nested circular arrays (apertures ranging from 2-30 m). We recorded twelve debris-flow experiments in which the debris composition, volume, and initiation mechanism were systematically varied in order to isolate the effect of each variable. Accompanying our seismic recordings were direct measurements of basal stresses, pore-water pressures, and flow heights, as well as imagery acquired with stereo-video cameras, and a high-sample-rate lidar profiler. We also directly measured site and path effects using a force hammer to generate empirical Green's functions representing the impulse response between points along the flume and each seismic station. Using these data, we test which debris-flow parameters (e.g., velocity, basal stresses) can be retrieved from seismic recordings under what conditions. We show that it is possible to track debris flows using seismic arrays, but techniques that rely on the location of the loudest source may, at times, track secondary surges rather than the flow front. Advancements in our understanding of debris flow seismicity can be used not only to study debris flow dynamics, but also to improve existing debris flow detection and tracking methodologies.

\section{Years of Landslide Activity in Alaska from Automated Machine-Learning Based Seismic Detection}

HIBERT, C., EOST_CNRS / University of Strasbourg, Bas-Rhin, France, hibert@unistra.fr; MICHÉA, D., ICube-CNRS / University of Strasbourg, France, d.michea@unistra.fr; MALET, J. P., EOST_CNRS / University of Strasbourg, France, jeanphilippe.malet@unistra.fr; PROVOST, F., EOST, University of Strasbourg, France, f.provost@unistra.fr; GEERTSEMA, M., Ministry of Forests, Lands and Natural Resource Operations, University of Victoria, Prince George, marten.geertsema@gov.bc.ca

Detection of landslide occurrences and measurement of their dynamics properties during run-out is a high research priority but a logistical and technical challenge. Seismology has started to help in several important ways. Taking advantage of the densification of networks of broadband seismic stations, recent advances now permit the seismic detection and location of landslides in near-real-time. This seismic detection could potentially greatly increase the spatio-temporal resolution at which we study landslides triggering, which is critical to better understand the influence of external forcings such as rainfalls and earthquakes. However, detecting automatically seismic signals generated by landslides still represents a challenge, especially for events with small mass. The low signal-tonoise ratio classically observed for landslide-generated seismic signals and the difficulty to discriminate these signals from those generated by regional earthquakes or anthropogenic and natural noises are some of the obstacles that have to be circumvented. We present a new method for automatically constructing instrumental landslide catalogues from continuous seismic data. We developed a robust and versatile solution, which can be implemented in any context where a seismic detection of landslides or other mass movements is relevant. The method is based on a spectral detection of the seismic signals and the identification of the sources with a Random Forest machine learning algorithm. We present here the results of the application of this processing chain for 20 years of continuous seismic records by the Alaskan permanent seismic networks. The instrumental catalogues produced allow us to investigate the impact of seasonality and high magnitude earthquakes on the landslide activity in this region.

\section{Repeating Quakes Detected at Moosfluh Rockslide (Valais, Switzerland)} HELMSTETTER, A., University Grenoble Alpes, France, agnes.helmstetter@ univ-grenoble-alpes.fr; LAROSE, E., University Grenobole Alpes, France, eric. larose@univ-grenoble-alpes.fr; BAILLET, L., University Grenoble Alpes, France, laurent.baillet@univ-grenoble-alpes.fr; MAYORAZ, R., Service Géologique Canton du Valais, Switzerland, raphael.mayoraz@admin.vs.ch

Repeating earthquakes are associated with the repeated failure of an asperity surrounded by aseismic slip. These events are interesting because they may provide a way to estimate aseismic slip, and because they offer a repetitive source to track temporal changes in the medium. Similar events have also been observed at the base of glaciers, ice streams and landslides. Repeating landquakes have been observed a few minutes to a few days preceding landslide failure (Yamada et al., 2016; Poli, 2017). Here we describe repeating events that have been detected on Moosfluh rockslide (Valais, Switzerland). This rockslide has a volume of about 100 millions $\mathrm{m} 3$, and has likely been reactivated by the retreat of Aletsch glacier at the base of the rockslide. Two seismometers were installed on October 3rd 2016 at the top of the active zone, when the rockslide was moving at about $1 \mathrm{~m} /$ day. Since this date, the movement has been slowing down, showing only much weaker transient accelerations. This suggests that repeating landquakes are not always precursors of failure, but may also occur as long as a landslide is moving. Thousands of repeating events, classified in 189 clusters, have been detected by template matching filter. Clusters are active for a few days up to several months. Some clusters display very regular amplitudes and recurrence times, while others are more random. While the total rate of activity is correlated with landslide movement, individual sequences have very different behaviors, with no clear correlation with either landslide movement or meteorological data. This suggests that temporal fluctuations of amplitude and recurrence rate are due to a local effect, possibly the evolution of the interface roughness or of the stress on the asperity induced by landslide movement. Seismic waveforms also slowly evolve with time, due to changes in the seismic wave velocity and/or due to the displacement of the source relative to the seismometer.

\section{Using Freeze Events to Characterize Two Types of Lake-Generated Seismic Signals}

ANTHONY, R. E., US Geological Survey-Albuquerque Seismological Laboratory, New Mexico, USA, reanthony@usgs.gov; RINGLER, A. T., US Geological Survey-Albuquerque Seismological Laboratory, New Mexico, USA, aringler@usgs.gov; WILSON, D. C., US Geological Survey-Albuquerque Seismological Laboratory, New Mexico, USA, dwilson@usgs.gov; ASTER, R. C., Colorado State University, Colorado, USA, rick.aster@colostate.edu

During the winter of 2014, a weak polar vortex brought record cold temperatures to the Midwestern United States, and the Great Lakes reached the highest extent of ice coverage (92.5\%) since 1979. This event shut down the generation of seismic signals caused by wind-driven wave action within the lakes (termed "lake microseisms"), giving an unprecedented opportunity to isolate and characterize these novel signals through comparison with non-frozen time periods. Using seismic records at 72 broadband stations, we observe Great Lake microseism signals at distances $\geq 300 \mathrm{~km}$ from the lakes. In contrast to conventional oceanic microseisms, there is no clear relationship between the frequency content of the seismic signals (observed from $\sim 0.5$ to $5 \mathrm{~s}$ period) and the dominant swell period. Additionally, we observe transiently excited, short-period $(<0.5 \mathrm{~s}$ period $)$ increases in seismic power on stations located in close proximity $(<\sim 1 \mathrm{~km})$ to the 
shorelines of both the Great Lakes and Great Bear Lake (Northwest Territories, Canada) that is distinct from the lake microseism signal. Using observations from the Great Lakes, we found that these signals scale with local wind-speed, reach maximum amplitude when the wind is blowing towards the shoreline, and disappear when the lakes freeze over. We suggest that this short-period energy is locally generated and may arise through energy transfer associated with breaking waves. Thus, these signals may provide utility in further understanding and quantitatively characterizing erosional processes that arise from wave-shoreline interactions.

\section{Spectral Monitoring of Rock Arches}

GEIMER, P. R., University of Utah, Utah, USA, paul.geimer@utah.edu; MOORE, J. R., University of Utah, Utah, USA, jeff.moore@utah.edu

The delicate geometry of natural rock arches creates a unique spectral signature that enables non-invasive monitoring for structural damage. We identify and characterize resonant frequencies of arches by calibrating measured spectral attributes from sparse broadband arrays with $3 \mathrm{D}$ numerical modal analysis. The resulting model allows us to visualize mode shapes and infer bulk material properties. We interpret recoverable variations in resonant frequencies as changes in these material properties due to daily and seasonal environmental factors. Predictive modeling, based on a year of continuous seismic monitoring at one study site, shows that the largest deviations in resonant frequencies appear to be driven primarily by thermal expansion and the formation of pore ice, causing stress-stiffening cycles in the arch. While no permanent change or damage was measured at the study site, we propose that stress changes caused by these processes are important drivers of fatigue and subcritical crack growth, ultimately contributing to the collapse of natural arches.

\section{Tracking Groundwater Levels Using the Ambient Seismic Field}

CLEMENTS, T. H., Harvard University, Massachusetts, USA, thclements@g. harvard.edu; DENOLLE, M. A., Harvard University, Massachusetts, USA, mdenolle@fas.harvard.edu

Aquifers are vital groundwater reservoirs for domestic, agricultural, and industrial activities worldwide. Tracking their state with high temporal and spatial resolution is critical for water resource management, yet rarely achieved from a single data set. Here, we show that groundwater level varitions can be mapped at basinscale using perturbations in seismic velocity, $\mathrm{dv} / \mathrm{v}$. We recover daily changes in $\mathrm{dv} / \mathrm{v}$ in the San Gabriel Valley, California, from cross-correlation of the ambient seismic field for the years 2000-2017. dv/v recovers the multi-year depletions and rapid recharge that mark the drought-wet cycles in southern California. dv/v correlates spatially with vertical surface displacements and deformation measured from local GPS stations. These results suggest that velocity change measurements have the potential to improve established monitoring efforts of aquifers.

\section{Tracking Tropical Cyclones with Backprojection}

LAMONTAGNE, A. M., UC Santa Barbara, California, USA, annievalovcin@ umail.ucsb.edu; TANIMOTO, T., UC Santa Barbara, California, USA, toshiro@geol.ucsb.edu; ANDERSON, A., UC Santa Barbara, California, USA, aka@umail.ucsb.edu

Tropical cyclones (hurricanes and typhoons) are mostly atmospheric phenomena but they also generate significant ground motions in the solid earth when they become strong. Previous studies have shown it is possible to track and monitor hurricanes that pass through dense seismic networks on land (Tanimoto and Valovcin, 2015). This limits the amount of hurricanes available to study, and so the next step is to study them while they are still out over the ocean. In this study we looked at Atlantic hurricanes from 2011 to 2016. We perform a backprojection of $0.2 \mathrm{~Hz}$ P waves recorded at a network of Southern California stations for the durations of the hurricanes. For many of the hurricanes in this time span, the peak amplitudes of the $0.2 \mathrm{~Hz}$ waves occur near the reported locations of the storms and track them through time, although the peak is off-set from the center of the hurricane. The off-set is likely a result of wave interaction between ocean waves and waves excited by the hurricane winds. It appears that the strength of the hurricane also contributes to whether or not a peak is observed. For many of the storms there is only a clear associated peak when the storm (and wind speeds) were stronger. We do not tend to observe a peak for less intense cyclones that do not reach hurricane strength winds.
Near-Surface Elastic Changes in the Ross Ice Shelf Arising from Transient Storm and Melt Forcing Observed with High-Frequency Ambient Seismic Noise

CHAPUT, J. A., Colorado State University, Colorado, USA, jchaput82@ gmail.com; ASTER, R. C., Colorado State University, Colorado, USA, rick. aster@colostate.edu; BAKER, M. G., Colorado State University, Colorado, USA, michael.g.baker@colostate.edu; GERSTOFT, P., Scripps Institute of Oceanography, California, USA, pgerstoft@ucsd.edu; NYBLADE, A. A., Penn State, Pennsylvania, USA, aan2@psu.edu; STEPHEN, R., Woods Hole Institute of Oceanography, Massachusetts, USA, rstephen@whoi.edu; WIENS, D., Washington University, Missouri, USA, doug@wustl.edu

Ice shelf collapse can herald subsequent grounded ice instability. However, robust understanding of external mechanisms capable of triggering rapid changes remains elusive. Improved understanding therefore requires improved remote and in-situ measurements of ice shelf properties and the environmental processes that can affect them. Using nearly three years of continuous data from a recently deployed 34-station broadband seismic array on the Ross Ice Shelf, we analyze persistent temporally varying, anisotropic near-surface resonant wave modes at frequencies above $\sim 1 \mathrm{~Hz}$ that are highly sensitive to small changes in elastic shelf properties to depths of several $\mathrm{m}$. These modes exhibit both progressive (on the scale of months) and rapid (on the scale of hours) amplitude and frequency changes. The largest and most rapid excursions are associated with local storms and with a large regional ice shelf melt event in January 2016, but changes are apparent throughout the records, which we attribute related to abrupt and progressive structural evolution of the firn layer. These modal variations can be forward modeled and inverted for structural changes using synthetic spectra calculated via numerical wave propagation, and thus present an opportunity for 4-D structural monitoring of local shallow glacial elasticity and structure using continuous high-frequency seismic recordings.

Active-Source Investigations of Lemon Creek Glacier, Alaska, Using Nodal Seismometers and a Betsy Seismic Gun Source

VEITCH, S. A., University of Texas at El Paso, Texas, USA, saveitch@utep.edu; KARPLUS, M., University of Texas at El Paso, Texas, USA, mkarplus@utep. edu; KAIP, G., University of Texas at El Paso, Texas, USA, gkaip@utep.edu; GRAVES, E., University of Texas at El Paso, Texas, USA, egraves@miners.utep. edu; SCHALK, J., University of Texas at El Paso, Texas, USA, joachim.schalk@ gmail.com; AMUNDSON, J., University of Alaska-Southeast, Alaska, USA, jmamundson@alaska.edu; BARTHOLOMAUS, T., University of Idaho, Idaho, USA, tbartholomaus@uidaho.edu; LABEDZ, C., Caltech, California, USA, clabedz@caltech.edu; TSAI, V., Caltech, California, USA, tsai@caltech.edu

The use of seismology as a means to study glacier dynamics has rapidly expanded in recent years as we seek to better understand the present and future behaviour of glaciers in a rapidly changing climate. While smaller in mass than their Antarctic or Greenlandic cousins, sub-arctic mountain glaciers may be particularly vulnerable to rapid changes in climate, making them a worthy target of study. During June 2017, we acquired a 1-km-long seismic reflection and refraction survey on Lemon Creek Glacier, a 5.7-km-long subarctic mountain glacier in the Juneau Icefield of Southeast Alaska. We used 51 5-Hz Z-Land Fairfield nodal seismometers recording at $1000 \mathrm{~Hz}$ and a Betsy Seismic Gun source with 400-grain, 8 -gauge blanks. Fairfield nodal seismometers are small, highly-portable sensors that may rapidly be deployed in dense networks in challenging environments. The seismic survey was located in the upper portion of the glacier within the accumulation zone, oriented parallel to the flow direction, and approximately followed the glacier's center line. In this survey, the receivers were initially spaced at $20-\mathrm{m}$, and shots were fired between them at 20-m spacing. We fired multiple shots near the ends of the line to allow stacking to enhance the signal. After we recorded the initial active-source survey, we re-deployed the nodes in a regional array across the upper part of the glacier at $~ 350$-m spacing. In mid-July, we fired additional shots adjacent to $\sim 25$ of those nodes to provide further constraints on ice thickness. We apply seismic reflection and refraction methods that have been applied successfully in high-arctic environments to image the interior and subglacial properties of Lemon Creek Glacier. In this abstract, we present our findings from the active-source deployment described here. Future work may include data from an additional, contemporaneous nodal deployment which includes the nearerterminus region of the glacier, nearby broadband stations, and a coincident GPS deployment. Our work serves to elucidate the firn and ice structure, the rheology of the glacier, as well as the basal properties of the glacier. 
Essentials of Seismic Risk Estimates

Oral Session • Tuesday 15 May • 8:30 AM • Hibiscus B

Session Chairs: Max Wyss, Sergio Barrientos, and Ramón Zúñiga

\section{Attribute Index and Classification Method of Earthquake Damage Photos for} Seismic Risk

LU, M., Institute of Crustal Dynamics, China Earthquake Administration, Beijing, China, luming6@yeah.net

In order to deal more effectively with the future earthquake risk, two important issues need to be solved: 1 . How can the government and the public imagine the disaster scenario caused by the earthquake risk in these areas? 2. Can officials and the general public systematically see the damage caused by historical earthquakes in the area or other areas, and they understand the characteristics and distribution of earthquakes? Both of these issues are related to earthquake damage photos and survey data. In order to improve the utilization of survey data, this paper proposes a method to classify and attribute the seismic damage photos based on the need of future seismic hazard assessment. 1. The Mark of the seismic intensity or ground motion parameters in pictures. Also includes the name and number of the earthquake damage pictures, shooting location. According to the contents of the earthquake damage pictures, the following two categories can be used for the division and annotation. 2. The surface features, include faults, landslides, dammed lakes, sand liquefaction etc. 3. Engineering structure categories: building structure, water conservancy, electricity, petrochemicals, transportation, infrastructure and other important projects. Based on the above, seismic damage images are more refined attribute classification, 4 . The details of the damage attribute, according to the different characteristics of the image object were marked. According to the above method, this paper presents some examples of earthquake damage photographs that have been classified and defined by attributes, and will try hard to set up an earthquake disaster database in the future. The authors suggest that international organizations should establish a global database of earthquakes and respond more appropriately to future earthquake risks.

\section{Defense Nuclear Facilities Safety Board Natural Phenomena Hazard} Database

LI, Y.L., Defense Nuclear Facilities Safety Board, Maryland, USA, yongl@dnfsb. gov; SCHLEICHER, L. S., Defense Nuclear Facilities Safety Board, District of Columbia, USA, lisas@dnfsb.gov

Department of Energy (DOE) Order 420.1c requires that all DOE nuclear facility sites periodically review their Natural Phenomena Hazard (NPH), including earthquake, wind, flood and volcanic hazards, just list a few. Any significant changes to data, model and methodology related to a site NPH could lead to a site hazard reassessment and then potential design changes. The periodic review and possible following reassessment relies significantly on understanding site-specific $\mathrm{NPH}$ information and its changes. Therefore, establishing a NPH database and updating it continuously will ensure the availability of up-to-date NPH information for each nuclear facility site. Defense Nuclear Facilities Safety Board (DNFSB) provides independent analysis, advice, and recommendations to DOE on adequate protection of public health and safety at defense nuclear facilities. Establishing a NPH database will enhance the Board's safety oversight of DOE nuclear facilities. Because NPH data are geospatial data, NPH database will be built upon a Geographic Information System (GIS) platform. Specifically, the GIS NPH database will allow the staff member understanding the hazard in an integrated manner. The database will also reduce future data requests to various DOE sites and their contractors and will ensue knowledge transfer among the Board staff members and also to prioritize site reviews based on estimated hazard change. In sum, the GIS NPH database will enable the staff member's oversight of DOE's NPH periodic review more proactive, informative and effective. The database can also be an effective tool for assisting the staff's review of emergency preparation and hazard mitigation when NPH events or human related events occur.

Exploring the Uncertainty of Earthquake Catastrophe Models Through a Risk Assessment Study in Central America Using Openquake and a Vendor Cat Model

MOUYIANNOU, A., Aspen Insurance Group, Switzerland, amaryllis. mouyiannou@aspen-re.com; KALAKONAS, P., UME Graduate School, Italy, p.kalaonas@meees.org

Central America has been the focus of many recent seismic risk studies, carried out for both public and private purposes. Public risk assessments are usually carried out for risk mitigation purposes so that the public are informed of the risk, building codes can be improved and emergency plans can be made. Private risk assessments carried out by the (re)insurance industry look at only a subset of buildings (the insured or insurable mix) in order to derive adequate pricing for insurance contracts. Even if the end use is different, the two assessments share many similarities. For example, the seismic hazard component can be identical for the two assessments. In this study, we carried out a seismic risk assessment for Central America, focussing on Guatemala, using the publically available OpenQuake model (Global Earthquake Model) and a privately-licenced vendor catastrophe model. Our objectives were twofold; first, to gain a good understanding of the similarities and the differences between the two models, and second, to quantify the uncertainty of intermediate model components and their contribution to the overall risk estimation. The uncertainty in the risk calculation can indubitably affect the quality and the value of the risk assessment. A model with open architecture, such as OpenQuake, allows the investigation of primary and secondary uncertainty. Our approach to quantify the uncertainties within OpenQuake is also presented. The outcome of this study has shown that the most significant impact of uncertainty, both epistemic and aleatory, comes from the hazard component. Therefore, this presentation also aims to initiate a dialogue with the seismological community about the main contributors of hazard uncertainty in risk assessment. The contributors include, but are not limited to: 1 . Seismic catalogue-seismic zonation 2. Selection of GMPEs 3. Soil model

Probabilistic Seismic Hazard Analysis in Mexico City Using Synthetic Seismograms and Three-Dimensional Models

MARTÍNEZ, B., Instituto de Ingeniería, Universidad Nacional Autónoma de México, Mexico City, Mexico, bmartinezt@iingen.unam.mx; RAMÍREZGUZMÁN, L., Instituto de Ingeniería, Universidad Nacional Autónoma de México, Distrito Federal, Mexico, Lramirezg@iingen.unam.mx; LEONARDOSUÁREZ, M., Instituto de Ingeniería, Universidad Nacional Autónoma de México, Mexico City, Mexico, mleonardos@iingen.unam.mx

We present a comparison of Probabilistic Seismic Hazard Analyses computed at reference sites in Mexico City using Ground Motion Prediction Equations (GMPE) and synthetic seismograms. The computation of the latter is achieved by using a hybrid approach employing the Strain Green's Tensor (SGT) formalism (e.g., Lee et al., 2011) with a realistic 3D model of Central Mexico (Juarez-Zuñiga, 2016) and Empirical Green's functions. The assessment considers the seismotectonic regionalization of Mexico and seismicity parameters determined by Zuñiga (2017). Our estimates, constrained to response spectral accelerations for periods $\mathrm{T}=0.5,1,1.5,2,3$ and $5 \mathrm{~s}$, reveal substantial differences between GMPE and synthetically based values. Additionally, we discuss the implications of our results regarding the design spectra in Mexico's capital. This project was funded by the Secretaria de Ciencia, Tecnología e Innovación (SECITI) of Mexico City. Project SECITI/073/2016.

Seismic Risk Assessment in Areas with Low Quality Data: The Case of the Jama-Pedernales 7.8 Mw Earthquake and the Detailed Study of Portoviejo (Ecuador)—Part 1: Data Processing

MARRERO, J. M., Instituto Geofisico Escuela Politecnica Nacional, Pichincha, Ecuador, jmarrero@igepn.edu.ec; YEPES, H. A., Instituto Geofisico Escuela Politecnica Nacional, Pichincha, Ecuador, hyepes@igepn.edu.ec; PALACIOS, P. B., Instituto Geofisico Escuela Politecnica Nacional, Pichincha, Ecuador, ppalacios@igepn.edu.ec; RAMÓN, P., Instituto Geofisico Escuela Politecnica Nacional, Pichincha, Ecuador, pramon@igepn.edu.ec

Currently, even in socioeconomically deprived areas, useful data for earthquake risk assessment is present. The problem in fact is that those data need extensive preprocessing before being used for risk analyses. Although this situation preclude their use for quick response in emergency situations, detailed studies can be conducted with ample time allowed. An important issue in making these data useful is the support and participation of all institutions managing relevant data, because their improvement depends on our capacity to combine and interrelate a variety of data sources. Here imagination and data processing capacities are important skills. After the April 16th 2016 earthquake, a detailed study was carried out at Portoviejo (Ecuador). Among others, one of the aims of this study was to understand the earthquake impact in Portoviejo's buildings inventory. This work is focused in the methodologies developed to prepare the data for risk analysis. Such methodologies, in addition to ad-hoc corrections, includes algorithms to a) correct the geographical coordinates related to the damage assessment, b) get the exposure and reposition costs for economic losses, c) characterize the buildings (their plan shape and regularity, level of isolation from other buildings, orientation). The procedures were applied mostly in the urban area, where roughly 80000 structures are present, being conducted at the individual level, namely building by building and it took one and a half year. Data processing applications were developed in ANSI C code language, combined with scripts in Python 
and $\mathrm{R}$, which allows to recalculate the results very efficiently. The software also compute basic statistics, calculations used to describe the before-the-earthquake city and to correlate the damage with different cadastral, morphometric and onsite variables. This study also highlights the damage assessment and form damage scenario calculations.

Seismic Risk Assessment in Areas with Low-Quality Data: The Case of JamaPedernales 7.8 Mw Earthquake and the Detailed Study of Portoviejo (Ecuador) - Part 2: Risk Quantification

YEPES, H. A., Instituto Geofisico Escuela Politecnica Nacional, Ecuador, hyepes@igepn.edu.ec; MARRERO, I. M., Instituto Geofisico Escuela Politecnica Nacional, Pichincha, Ecuador, jmarrero@igepn.edu.ec; PALACIOS, P. B., Instituto Geofisico Escuela Politecnica Nacional, Pichincha, Ecuador, ppalacios@igepn.edu.ec; RAMÓN, P., Instituto Geofisico Escuela Politecnica Nacional, Pichincha, Ecuador, pramon@igepn.edu.ec

In order to obtain sound risk assessments, it is important to quantify, among others, building characteristics and socioeconomic and environmental, attributes of the potential impacted area. Risk assessment studies conducted at detailed scale (individual dwellings) are not common because of difficulties in getting the appropriate data both, at the intensity of shaking and at the vulnerability levels. Here we present the main results of the risk study carried out in Portoviejo after the 7.8 Mw Jama-Pedernales earthquake. Damage is concentrated in tall buildings (about $31.7 \%$ for 4 or more story buildings versus $8.4 \%$ for $1-2$ story), mostly located downtown Portoviejo, although soil properties there are not different from others around the city. The damage ratio persists in new buildings (built after 2001), even for those built under the first national Construction Building Code that includes locally calculated seismic zonation (2001). Damage to official buildings was also high (hospitals, schools, police departments, local and national government). Old buildings were heavily damaged too, so there are no evidences of vulnerability reduction in recent years. Most of fatalities, 133 in Portoviejo, were caused by tall buildings collapses, but it could have been worse if the earthquake would have occurred during business ours. Economic losses assessment considered the exposure (based on the cadastral value of the buildings) and the replacement cost. Such losses were estimated in 450-700 million US\$. The first ever empirical fragility and vulnerability curves in Ecuador were also calculated after assigning to buildings a typology based on cadastral, morphometric and site information. Portoviejo is a standard city in the Ecuadorian context, so our results could be extrapolated to others in the country for the same type of earthquakes. In Portoviejo the paradigm that directly correlates social vulnerability with high earthquake risk has been challenged so new approaches must be considered.

Seismic Risk Assessment for British Columbia, Canada, through the Use of Global Earthquake Model's OpenQuake

BIRD, A. L., Natural Resources Canada, Sidney, BC, Canada, alison.bird@ canada.ca; JOURNEAY, J. M., Natural Resources Canada, Ottowa, ON, Canada, murray.journeay@canada.ca; HASTINGS, N., Natural Resources Canada, Ottowa, ON, Canada, nicky.hastings@canada.ca; CASSIDY, J. F., Natural Resources Canada, Ottowa, ON, Canada, john.cassidy@canada.ca

Natural Resources Canada (NRCan) has employed Global Earthquake Model's (GEM) OpenQuake engine to undertake a national-scale earthquake risk assessment, beginning with a provincially-focussed evaluation of British Columbia $(\mathrm{BC})$, the most seismically hazardous region of the country. The assessment includes an implementation of the probabilistic seismic hazard model derived for the National Building Code of Canada (2015), and the development of deterministic seismic hazard models to represent a range of potentially damaging earthquake scenarios that could impact populated areas along BC's coastline and in some interior regions. In order to obtain impact models, anticipated ground motions were combined with vulnerability data (including site conditions, buildings and infrastructure, and population). The probabilistic risk results will be presented along with a selection of deterministic scenarios, including a megathrust earthquake of M 9.0 along the Cascadia Subduction Zone, an M 7.1 crustal earthquake adjacent to the City of Victoria's waterfront, an $\mathrm{M} \sim 7.0$ within a gap along the Queen Charlotte Fault off Haida Gwaii, and a deep M 6.9 beneath the Strait of Georgia just west of the City of Vancouver. Such comprehensive assessments are invaluable for effective emergency planning, risk mitigation measures and disaster management. The results will therefore be made available via a publicly accessible web portal. Future modelling is slated to incorporate evaluations of secondary hazards such as tsunami and liquefaction, will include additional natural hazards (e.g. landslides, volcanic activity, flooding) and will be expanded to cover the remainder of Canada. This work will support Canada's efforts toward meeting the recommendations within the Sendai Framework for Disaster Risk Reduction (United Nations Office for Disaster Risk Reduction).
The Gutenberg-Richter Law and Completeness of the RSN Earthquake Catalog, Costa Rica

ARROYO SOLÓRZANO, M., Universidad de Costa Rica, Alajuela, Costa Rica, marros01210@gmail.com; LINKIMER, L., Universidad de Costa Rica, San José, Costa Rica, linkimerl@gmail.com

Costa Rica is characterized by a high seismicity due to its location in a subduction zone and near to the triple point of the plates Coco, Caribbean and Nazca. This study evaluates the stability of the mean rate earthquake occurrence and the spatial and temporal distribution of seismicity in Costa Rica, in order to calculate the completeness magnitude for the RSN seismic catalog and the Gutenberg-Richter relationship for 1975-2017. Results show that the completeness magnitude for the catalog is 5.0, but it could be as low as $3.0 \mathrm{Mw}$ for certain periods of time. The preliminary "b" value and maximum likelihood magnitude obtained for this catalog are 0.96 , and 7.8 , respectively. The geographic distribution of seismicity highlights the main active tectonic structures. In particular, clusters of seismicity revels highly deformed crustal areas, which are located along the inland projected path of seamount chains and the Panama Fracture Zone. These clusters do not correlate exactly with the largest energy released zones. These results are vital for understanding the tectonic setting of the region and the correct assessment of the seismic hazard and risk mitigation.

\section{Toward a Unified Metric for Sufficiency and Efficiency of Scalar Earthquake Intensity Measures}

DHULIPALA, S., Virginia Tech, Virginia, USA, lakshd5@vt.edu; FLINT, M. M., Virginia Tech, Virginia, USA, mflint@vt.edu

Earthquake Intensity Measures (IM) are commonly employed in seismic risk assessment to link seismological parameters $(M, R, \varepsilon)$ with Engineering Demand Parameters (EDP). Consequently, the selection of appropriate IMs consistent with the structural type and location has become increasingly important using criteria such asefficiency (standard deviation in EDP given an IM) andsufficiency (conditional independence of EDP from seismological parameters given an IM). As sufficiency of IMs has been only assessed qualitatively using p-values-which provide no information beyond pass/fail-we first describe a recently proposed quantitative method to gauge sufficiency using a Total Information Gain (TIG) metric. We apply the TIG to a four-story steel moment frame building for a large number of combinations of IMs, EDPs, and record-sets to realize that the choice of ground motion set can play a huge role in determining an IM's sufficiency. Next, we investigate the relation between the efficiency and sufficiency metrics and find that these quantities are Bi-variate Normal distributed with a weak correlation. We further utilize this finding to derive a unified metric for sufficiency and efficiency of an IM using a Mahalanobis transformation and a Euclidean norm.

\section{Hybrid Empirical Ground Motion Prediction Equations for the Gyeongju Area in South Korea}

PARK, S. J., Korea Institute of Nuclear Safety, Republic of Korea, sjpa ' @ @ins. re.kr

The Gyeongju area is in and around area of the Gyeongju city loc ted the southeastern part of the Korean Peninsula. The Gyeongju area has heen one or the most interesting regions in the Korean Peninsula among eismo ogisu nd engineers due to its relatively higher seismicity. Seismological an e thquake engineering studies on the Gyeongju area, however, have beo. limiteu due to deficiency of data. In this study, ground motion prediction qu tions (GMPEs) are developed for the Gyeongju area using the hy $1 \mathrm{~d}$ mpiri al method (HEM)suggested by Campbell (2003). Western Unitec State (WUS, is selected asa host region and five NGA-West2 GMPEs are used empirical GMPEs of the host region. GMPEs derived in this study ar for m nnt des from 5.0 to 7.5 and rupture distances from 10 to $500 \mathrm{~km}$. Mu fian GMi Es are provided with aleatory standard deviations. Predictive value by theriy d GMPEs were compared with ground motions from the available ea hqu. 1 . records for moment magnitudes 5.0 and 5.5. The comparison st ws good greement, which implies that the GMPEs can be applied to not nly the Gyeongju area but also the southern part of the Korean Peninsula. The not ble adva tages of the GMPEs developed in this study are as follows: All p vious s. dies for GMPEs in South Korea used the same stochastic method. Be aus this study uses a distinct HEM, it supplements the limitations of the that tic mod, such as lack of near-source ground motion characteristics. S te-sped fic input parameters for the Gyeongju area are used in the simulations. The ground motions predicted by the developed GMPEs are compared with tho. from available observed data to check their applicability. Aleatory standard deviations are provided so that they can be directly used in PSHA. 
Fault to Seismic Hazard Assessment (Fault2SHA) in Latin (Central and South) America

Oral Session - Tuesday 15 May · 2:15 PM • Brickell

Session Chairs: Laurence Audin, Felipe Aron, Marianne

Saillard, Laura Peruzza, Franck Audemard, and Oona Scotti

\section{South America Seismic Hazard, Risk, and Design}

PETERSEN, M. D., US Geological Survey, Colorado, USA, mpetersen@usgs. gov; HARMSEN, S. C., US Geological Survey, Colorado, USA, harmsen@usgs. gov; JAISWAL, K. S., US Geological Survey, Colorado, USA, kjaiswal@usgs. gov; RUKSTALES, K. S., US Geological Survey, Colorado, USA, rukstales@ usgs.gov; LUCO, N., US Geological Survey, Colorado, USA, nluco@usgs.gov; HALLER, K. M., US Geological Survey, Colorado, USA, haller@usgs.gov; MUELLER, C. S., US Geological Survey, Colorado, USA, cmueller@usgs.gov; SHUMWAY, A. M., US Geological Survey, Colorado, USA, ashumway@usgs. gov

South America is one of the most earthquake prone regions of the world. During the past century, earthquakes have caused billions of dollars of damage and tens of thousands of casualties across the northern and western part of the South American continent. The seismic activity in this continent is characterized by the South American Subduction Zone and other complex fault interactions. Future losses can be mitigated through making informed decisions about where future earthquakes may occur, how often they might occur, and how strong the ground will shake. The USGS collaborated with scientists from South America to develop such seismic hazard information that are applied in building codes, insurance models, and public policy. We apply standardized methodologies and tools for hazard and risk assessments, to reduce border discrepancies, and to identify areas of high hazard and risk for different countries. We rely on five important datasets and methodologies: (1) an updated earthquake catalog, (2) models of well-mapped faults, (3) latest seismic ground motion models, (4) USGS PAGER vulnerability models, and (5) methodologies applied in U.S. building codes. The new results indicate that over 160 million people (or about a third of the total population in South America) live in areas with significantly elevated seismic hazard, primarily within the northern and western portions of the continent where earthquakes associated with subduction and crustal faulting are most common. Countries such as Venezuela, Colombia, Ecuador, and Peru face high hazard and the risk; Chile also faces high hazard, but the vulnerability of the built stock is much lower compared with the northern countries. These new models can be used for analyzing building design standards and improving risk assessments which can save lives and dollars by providing information on where and how to strengthen buildings in vulnerable areas.

Seismotectonics of North Faults of Algeciras Fault System, Colombia, from an Analysis of the Earthquakes That Occurred during the Period 2016-2017

CHICANGANA, G., Universidad Santo Tomas, Villavicencio, Colombia, germanchicangana@usantotomas.edu.co; BOCANEGRA, A., Universidad Santo Tomas, Villavicencio, Colombia, alfonsinabocanegra@usantotomas. edu.co; KAMMER, A., Universidad Nacional de Colombia, Bogotá, Colombia, akammer@unal.edu.co; VARGAS JIMENEZ, C. A., Universidad Nacional de Colombia, Bogota, Distrito Capital, Colombia, cavargasj@unal. edu.co; SALCEDO, E., Universidad del Valle, Valle del Cauca, Colombia, esalcedohurtado@yahoo.com; GOMEZ-CAPERA, A. A., Istituto Nazionale di Geofísica e Vulcanologia, Milano, Italy, antonio.gomez@ingv.it

The Algeciras Fault System (AFS) is part of the Eastern Frontal Fault System. With the help of the historical seismic intensity evaluation and instrumental historical seismicity record (1967 earthquake mainly) have been assigned the $1785,1827,1917$ and, 1967 historical earthquakes. These earthquakes were felt in Bogota and several Colombian cities located towards the center and southwest of the country. The Guayuriba Fault is reverse with $142,3 \mathrm{~km}$ of cumulative length is part of the AFS and corresponds to the northern fault of the fault system. Towards the west of the región where the Guayuriba Fault crosses, there are two semi-parallel reverse faults which are Altamira, and Nazareth toward the watershed of the cordillera. In this región ocurred recently the earthquakes $\mathrm{M}=5.4$ and $M=5.0$ of october $30,2016, M=4.7$ of december 16,2016 , and $M=5.7$ of february 6,2017 , which were located near to watershed of the cordillera near to town of Colombia, in the Huila department. Also occur the earthquake $\mathrm{M}=5.1$ of june 2, 2017 whose epicenter was located toward north of the Macarena Range near to Mesetas town in the Meta department. The hypocentres of earthquakes were located by the National Seismological Network of Colombia (RSNC). The location of the epicenters of earthquakes near to town of Colombia in Huila department were verified here with field work, which are coincident with the location of the hypocenters given by RSNC makes estimate that the asperities are related with the interception in deep between Altamira and Nazareth faults with Guayuriba Fault together with the Ambica Fault that is antithetic fault to the AFS strike. In conclusion here estimated that the main seismicity source is the Guayuriba Fault and the second seismicity source in this región are Altamira, Ambica and Nazareth faults for the earthquakes that occurred near to Colombia town, and the Guayuriba Fault for the the earthquake that occurred near to Mesetas town.

Geological Data as an Input for Seismic Hazard Assessment Including Fault Sources; Example in Central Ecuador

BAIZE, S., Institut de Radioprotection et de Surete Nucleaire, Hauts-deSeine, France, stephane.baize@irsn.fr; AUDIN, L., Institut pour la Recherche et le Developpement-ISTERRE, Isere, France, laurence.audin@ird.fr; ALVARADO, A., Instituto Geofisico-Escuela Politecnica Nacional, Ecuador, aalvarado@igepn.edu.ec; BEAUVAL, C., Institut pour le Recherche et le Developpement-ISTERRE, Isere, France, celine.beauval@univ-grenoblealpes.fr; CHAMPENOIS, J., Institut de Radioprotection et Surete Nucleaire/ CEA, Hauts-de-Seine, France, champenoisjohann @ gmail.com; CHARTIER, T., Ecole Normale Superieure, Paris, France, thomas.chartier@ens.fr; JOMARD, H., Institut de Radioprotection et de Surete Nucleaire, Hauts de Seine, France, herve.jomard@irsn.fr; MARINIERE, J., Institut pour le Recherche et le Developpement-ISTERRE, Isere, France, judith.mariniere@univ-grenoblealpes.fr; NOCQUET, J. M., Institut pour le Recherche et le DeveloppementGEOAZUR, Alpes Maritimes, France, nocquet@geoazur.unice.fr; SCOTTI, O., Institut de Radioprotection et de Surete Nucleaire, Hauts-de-Seine, France, oona.scotti@irsn.fr; YEPES, H. A., Instituto Geofisico-Escuela Politecnica Nacional, Ecuador, hyepes@igepn.edu.ec

Central Ecuador includes a series of crustal active faults, including the PunaPallatanga strike-slip fault zone (PPFZ) crossing obliquely the entire Andes Range. Those faults caused large historical and crustal earthquakes (M 7+). We mapped active fault sections based on morphotectonic and geological evidences of offset landforms or deposits. Slip rates, that could be estimated for several sections, range between $\sim 1$ and $7 \mathrm{~mm} / \mathrm{a}$. The identified fault sections could rupture separately during M6.0 to M7 earthquakes. However, we argue that multiplesection earthquake ruptures should be invoked to generate the large magnitude events documented in the historical and paleoseismic catalogues. Based on empirical relationships, we claim that those multiple segment ruptures could not have been impeded by geometrical discontinuities, for instance because rupture could jump over those narrow jogs. We conclude that multiple fault earthquake ruptures could even reach magnitudes up to 7.8. Using the SHERIFS code (Chartier et al., 2017), we determine the rate of earthquakes that PPFZ could generate according to our geological dataset. This method allows to relax the fault segmentation and calculate the rate of multiple fault section ruptures, following two constraints: 1) the Magnitude Frequency Distribution (MFD) of earthquakes in the fault system follows an imposed Gutenberg-Richter shape; 2) the earthquake rates on each fault section is determined by its specific slip rate and by the possible multiple section rupture scenarios defined as input. We explore several hypotheses of the set of possible multi section ruptures in a logic tree. For Central Ecuador, our model results obtained with geologically-based slip rates are consistent with the seismic catalogue. Results from the same model but with geodetical slip rates (Beauval et al., 2017) provide higher earthquake rates.

\section{A Long-Term Slip Model for the San Ramón Fault, Santiago de Chile, from Tectonically Reconcilable Boundary Conditions}

ARON, F., Pontificia Universidad Católica de Chile/Chilean Ministry of Foreign Affairs/Research Center for Integrated Disaster Risk Management, Santiago, Chile, faron@ing.puc.cl; PÉREZ-ESTAY, N., Pontificia Universidad Católica de Chile, Santiago, Macul, Región Metropolitana, Chile, nnperez@ uc.cl; CEMBRANO, J., Pontificia Universidad Católica de Chile/Research Center for Integrated Disaster Risk Management, Santiago, Chile, jcembrano@ ing.puc.cl; YÁNEZ, G., Pontificia Universidad Católica de Chile/Research Center for Integrated Disaster Risk Management, Santiago, Chile, gyanez@ing. puc.cl

We constructed a 3D boundary elements model simulating subduction of the Nazca plate underneath South America, from $29^{\circ}$ to $38^{\circ} \mathrm{S}$, to compute long-term surface deformation and slip rates on crustal faults imbedded in the upper-plate wedge of the Andean orogen. We tested our model on the San Ramón Fault (SRF), a major E-dipping, thrust structure limiting the western front of the Main Cordillera with surface expression along the entire, $40 \mathrm{~km}$ long, extension of the Santiago de Chile basin. Long-lived thrusting has produced more than $2 \mathrm{~km}$ of differential uplift of the mountains. Given its proximity to the country's largest city, this potentially seismogenic fault-dormant during historic times- has 
drawn increasing public attention. The simulation reproduces plate convergence and mechanic decoupling of the lithospheric plates across the subduction seismic cycle using mixed boundary conditions. Relative plate motion is achieved prescribing uniform, far-field horizontal displacement over the depth extension of the lithospheric plates. Long-term deformation is carried out in two steps. First, the modeled surfaces are allowed to slip freely emulating continuous slip on the subduction megathrust; subsequently, zero displacement is prescribed on the locking zone of the megathrustwhile keeping the rest of the surfaces traction free, mimicking interseismic conditions. Long-term slip rate fields obtained for the SRF range between 0.1 and $1 \%$ the plate convergence rate, with maximum values near the surface. Interestingly, at an estimated $76-77 \mathrm{~mm} / \mathrm{yr}$ relative plate motion velocity, those rates agree well with what has been reported on studies at one paleoseismic trench site across the fault. These results might contribute to determining possible seismic scenarios for Santiago but perhaps more importantly, our approach could be use in estimations of long-term slip rates and surface deformation due to other crustal structures with unknown displacement history.

\section{Uncertainties in Probabilistic Seismic Hazard Analysis: A Case Study from Northern Chile}

LI, F., Golder Associates, Washington, USA, feli@golder.com; HULL, A. G., Golder Associates, Oregon, USA, ahull@golder.com; MARTINEZ, M. E., Golder Associates, Chile, mmartinez@golder.com; ROSSITER, M., Golder Associates, Washington, USA, mrossiter@golder.com; LOWRY, D., Golder Associates, Colorado, USA, dlowry@golder.com

We report the results of a probabilistic seismic hazard analysis for Iquique, northern Chile located near the Nazca-South America plate boundary subduction zone. We constructed aseismic source model to characterize the geometry and earthquake activity at the plateinterface $(0$ to $40 \mathrm{~km}$ depth $)$ and for the deep subduction zone intraslab sources ( 40 to $\geq 150 \mathrm{~km}$ depth). Because of the high uncertainties associated withintraslab earthquake locations, the intraslab source has two equally weighted models - a 3D surface model and a progressively deeper stepped area source model. The source zone model also includes potential earthquakes generated by crustal faultsand shallow crustal area sources to account for background earthquakes and unmapped faults. Ground motion prediction equations (GMPE) were selected and weighted using the method proposed by Scherbaum et al. (2009) and the Chile strong motion database developed by Bastías and Montalva (2016). The final GMM applied both global and local GMPEs selected and weighted based on their goodness-of-fit to the Chile strong motion dataset. Epistemic uncertainties in the seismic sourceand ground motion models were incorporatedusing a logic tree approach. Tornado plots indicate that the estimated seismic hazard at Iquique at short structural periods is most sensitive to the GMPE selection and recurrence parameters for theintraslab sources, followed by sensitivity to the alternative intraslab source models. The estimated seismic hazard at 1-second structural period is most sensitive to the selection and weighting of the subduction GMPE for both the interface and intraslab subduction sources. The 95th fractile PGA, 0.2- and 1.0-second spectral accelerations for the 475-year return period are about 1.3, 1.4 and 1.5 times of the mean spectral accelerations, respectively. Local fault sources(e.g., Atacama fault)make little contribution to the 475 -year return period hazard, probably because of their low average slip rates of $\leq 0.5 \mathrm{~mm} / \mathrm{yr}$.

\section{Ground Motion Estimation of Recently Identified Crustal Faults in Central Chile}

CREMPIEN, J. G. F., Pontificia Universidad Católica de Chile-Research Center for Integrated Disaster Risk Management, Chile, Región Metropolitana, Chile, jocrempien@ing.puc.cl; ARON, F., Pontificia Universidad Católica de Chile-Chilean Ministry of Foreign Affairs-Research Center for Integrated Disaster Risk Management, Chile, Región Metropolitana, Chile, faron@ing. puc.cl; SANTIBÁÑEZ, I., Pontificia Universidad Católica de Chile-Research Center for Integrated Disaster Risk Management, Chile, Región Metropolitana, Chile, ivsantibanez@uc.cl; SEGUEL, M., Pontificia Universidad Católica de Chile, Región Metropolitana, Chile, miseguel@uc.cl

Lately, there have been newly identified, potentially seismogenic crustal faults (PSCFs) in Chile, many of them are now published by the South America Risk Assessment Project of the Global Earthquake Model. These faults pose a great risk to the community and infrastructure; therefore, it is necessary to estimate ground motion that can be produced by these seismic sources. Unfortunately, there are very few recorded ground motion data from these active faults, not sufficient to build ground motion prediction equations - a necessary element to estimate earthquake hazard. Because of the lack of recorded data, it has become necessary to estimate ground motion with physics-based models. With recorded ground motion, we have estimated path and site attenuation parameters, namely kappa, for different sites in Central Chile. Preliminary results show that the regional value of kappa is approximately $40 \mathrm{~ms}$. The PSCFs database contain variable information depending on the different sources used to compile the fault datum. Nevertheless, if absent, the necessary parameters to simulate seismic scenarios such as the dimension, sense of slip and dip angle and direction can be extracted from the fault traces themselves and inferred from the seismotectonic setting of each individual fault. We used the 2010 Leonard scaling relationships to determine a magnitude based on the length of each active fault. For each fault, we computed several kinematic earthquake rupture scenarios, and propagated seismic waves using Green's functions with the UCSB method (Crempien and Archuleta, 2015). The Green's functions incorporate the attenuation measured previously and are calculated up to $25 \mathrm{~Hz}$. For all earthquake scenarios, we estimate peak ground acceleration intensities of over $1 \mathrm{~g}$ within $10 \mathrm{~km}$ of the closest distance to the fault. These preliminary results show that these active crustal faults need to be studied in depth in order to better characterize the earthquake hazard in Central Chile.

\section{Seismic Evidence for Complex Faulting through the Gulf of Guayaquil}

RÉGNIER, M., Université Côte d'Azur, IRD, CNRS, Observatoire de la Côte d'Azur, Géoazur, France, regnier@geoazur.unice.fr; PONCE, G., Instituto Geofísico, Escuela Politécnica Nacional, Quito, Ecuador, gponce@igepn. edu.ec; ALVARADO, A., Instituto Geofísico, Escuela Politécnica Nacional, Quito, Ecuador, aalvarado@igepn.edu.ec; SAILLARD, M., Université Côte d'Azur, IRD, CNRS, Observatoire de la Côte d'Azur, Géoazur, France, saillard@geoazur.unice.fr; AUDIN, L., IRD, CNRS, Université GrenobleAlpes, ISTerre, France, audin@ird.fr; VACA, S., Instituto Geofísico, Escuela Politécnica Nacional, Quito, Ecuador, svaca@igepn.edu.ec; NOCQUET, J. M., Université Côte d'Azur, IRD, CNRS, Observatoire de la Côte d'Azur, Géoazur, France, nocquet@geoazur.unice.fr; JARRIN TAMAYO, P., Instituto Geofísico, Escuela Politécnica Nacional, Quito, Ecuador, pjarrin @igepn.edu.ec; FONT, Y., Université Côte d'Azur, IRD, CNRS, Observatoire de la Côte d'Azur, Géoazur, France,font@geoazur.unice.fr

Along the Ecuadorian margin, the North Andean Sliver is moving in the northeastward direction due to the oblique subduction of the Nazca plate. The opening of the gulf of Guayaquil is a consequence of this motion. Two principal models compete to explain the opening. One proposes an opening achieved essentially with strike slip motion along a single major fault through the gulf, the other with a combination of strike slip and normal faulting on both sides of the gulf. The consequences in term of seismic hazard are very different. A single strike slip fault model could imply a long fault segment capable of generating large magnitude events. In contrast, a multi segments composite fault system will give conditions for producing small to medium size earthquakes. The southern Ecuador subduction zone is characterized by the absence of large historical earthquake. Data from the historical and instrumental seismicity for magnitude above 4 show the fore arc has a high level of seismic activity within and around the gulf that connects to the crustal seismic activity of the volcanic arc. In contrast, the fore arc elsewhere shows very little or no seismic activity between the interplate zone and the volcanic arc. Regional and global CMTS data show mostly diffuse strike slip mechanisms that do not line up on a single fault system. We present new earthquake data from the recently upgraded national seismic network of Ecuador. They provide the first image of SW-NE trending crustal faults stretching in the central part of the gulf and running eastward between Puna island and the southern coast of the gulf. It appears to be a complex multi segments fault system. The observed seismic alignments do not cross the Puna island as it was postulated in previous regional tectonic studies. Others seismic clusters are observed parallel to the northern coast of the gulf, indicating active structures eventually accommodating the North South opening of the gulf through normal faulting.

\section{Spatiotemporal Seismic Hazard and Risk Assessments for Large Aftershocks Triggered by Mega-Thrust Subduction Earthquakes in Japan}

ZHANG, L., University of Bristol, United Kingdom, lz0560@bristol.ac.uk; WERNER, M. J., University of Bristol, United Kingdom, max.werner@bristol. ac.uk; GODA, K., University of Bristol, United Kingdom, katsu.goda@bristol. ac.uk

Large historical mega-thrust subduction earthquakes, such as the 2004 AcehAndaman, 2010 Maule, and 2011 Tohoku earthquakes, have triggered numerous aftershocks in subduction plate interfaces and continental crusts. The crustal seismicity occurs much closer to the population and buildings than the subduction earthquake which is likely to occur with a larger magnitude and at a greater distance. Therefore, the crustal earthquake can have a greater potential impact on seismic damage and loss than the subduction earthquake. Generally, times between major events may be too short to inspect and repair damaged buildings; in such situations, damage accumulation of buildings can be major issues. A new method for assessing spatiotemporal seismic hazard and risk due to a mega-thrust 
subduction earthquake that triggers both subduction and crustal aftershocks is developed. The Epidemic Type Aftershock Sequences (ETAS) model is used to generate synthetic earthquake catalogs and capture spatiotemporal earthquake clustering. The conventional isotropic ETAS simulation is extended to account for spatial anisotropic distribution of aftershocks by applying the scaling law of the rupture model, and implementing a $2 \mathrm{D}$ uniform distribution and a power law decay inside and outside of the rupture area, respectively. Moreover, to evaluate seismic hazard and risk, the ETAS model is convolved with ground motion prediction equations (GMPEs) and seismic fragility curves. A case study is set up for the $2011 \mathrm{Mw} 9$ Tohoku event in Japan. By incorporating more realistic spatial anisotropy of aftershocks, we quantify how the spatiotemporal seismic hazard rate is changed by the triggered crustal and subduction aftershocks in comparison with long-term time-independent hazard rate. Furthermore, we propose to evaluate the impact of increased crustal and subduction aftershocks to seismic hazard and risk assessments for making various risk management decisions more effectively in the post-mainshock period.

Ground Motion in Kuwait from Regional and Local Earthquakes: Potential Effects on Tall Buildings

GU,C., Massachusetts Institute of Technology, Massachusetts, USA, guchch@ mit.edu; PRIETO, G. A., Universidad Nacional de Colombia, Bogota, Colombia, gaprietogo@unal.edu.co; AL-ENEZI, A., Kuwait Institute for Scientific Research, Kuwait, aenezi@kisr.edu.kw; AL-JERI, F., Kuwait Institute for Scientific Research, Kuwait, fjerri@kisr.edu.kw; AL-QAZWEENI, J., Kuwait Institute for Scientific Research, Kuwait, jqazweni@kisr.edu.kw; KAMAL, H., Kuwait Institute for Scientific Research, Kuwait, hsnkml@gmail. com; KULELI, S., Massachusetts Institute of Technology, Massachusetts, USA, kuleli@quake.mit.edu; MORDRET, A., Massachusetts Institute of Technology, Massachusetts, USA, mordret@mit.edu; BÜYÜKÖZTÜRK, O., Massachusetts Institute of Technology, Massachusetts, USA, obuyuk@mit.edu; TOKSÖZ, M. N., Massachusetts Institute of Technology, Massachusetts, USA, toksoz@mit. edu

In recent years, many countries, including Kuwait and other Gulf states, have been constructing many tall buildings. These tall buildings are especially sensitive to ground shaking due to long period seismic surface waves. Although Kuwait is relatively aseismic, it has been affected by large $(\mathrm{Mw} \geq 6)$ regional earthquakes in the Zagros Fold-Thrust Belt (ZFTB). Accurate ground motion prediction for large earthquakes is important to assess the seismic hazard to tall buildings. In this study, we first analyze the observed ground motions in Kuwait due to the 08/18/2014 Mw 6.2 earthquake, $360 \mathrm{~km}$ NNE of Kuwait City, and due to the 11/12/2017 Mw 7.3 earthquake, $642 \mathrm{~km} \mathrm{NNE}$ of Kuwait City. The peak spectral displacement periods of the ground motion from the 08/18/2014 Mw 6.2 earthquake matched well with the ambient vibration spectra of the tallest building - the Al-Hamra Tower. We calculate the ground motion from potential regional and local earthquakes using the discrete-wavenumber method. After validating the method and velocity model of our ground motion calculations using the 2014 and 2017 earthquakes, we predicted ground motions due to a regional $\mathrm{Mw}=7$ earthquake, and two local $\mathrm{Mw}=4.1$ and $\mathrm{Mw}=4.5$ earthquakes. Our study shows that the main seismic hazard to tall buildings in Kuwait comes from the regional tectonic earthquakes. However, local earthquakes have the potential to generate high peak ground accelerations $(\geq 0.1 \mathrm{~g})$ close to their hypocenters and damage structures not designed to sustain such accelerations.

\section{Ground Motion and Earthquake Engineering}

Oral Session · Tuesday 15 May · 4:15 AM · Hibiscus A

Session Chairs: Sinan Akkar and Thomas Herring

\section{Ground Motion Recordings from the 8 August 2017 Ms 7.0 Jiuzhaigou Earthquake}

$\underline{\mathrm{TAO}}, \mathrm{D}$. W., Institute of Engineering Mechanics, China Earthquake Administration, Kentucky, USA, dongwang.tao@uky.edu; WANG, Z., Kentucky Geological Survey, University of Kentucky, Kentucky, USA, zhenming. wang@uky.edu; MA, Q., Institute of Engineering Mechanics, China Earthquake Administration, Heilongjiang, China, maqiang@iem.ac.cn; YANG, C., Institute of Engineering Mechanics, China Earthquake Administration, Heilongjiang, China, bjsmoc@qq.com; LI, S. Y., Institute of Engineering Mechanics, China Earthquake Administration, Heilongjiang, China, lishanyou@vip.126.com

On August 8 2017, an Ms 7.0 earthquake struck the Jiuzhaigou County, Sichuan Province, China. 67 stations of China Strong Motion Network Center (CSMNC) were triggered and recorded ground motions from the event. There were eight stations with epicentral distance less than $100 \mathrm{~km}$ of the earthquake.
Two temporary stations were installed near station Jiuzhai Zhangzha (JZZ) after the main event. 18 aftershocks with magnitude between 1.2 and 3.9 were recorded from August 19 to August 23, 2017. The largest PGA, greater than 1.0g, was recorded at station JZZ. However, this large ground motion recording is under investigation for possible instrumental or other contaminations. The horizontal peak ground accelerations (PGA) and peak ground velocities (PGV) were obtained and compared to ground motion prediction equation (GMPE) used in the 5 th generation of seismic ground motion parameters zonation map of China. The comparisons show that PGAs and PGVs at all stations, except station JZZ are below the GMPE. The $S$-wave horizontal to vertical spectral ratios (HVSR) were calculated for the main event and aftershocks at station JZZ and the two temporary stations. The results show that the HVSRs at the three sites are quite similar. The HVSRs at station JZZ also show nonlinear site response: the peak frequency shifting from $\sim 10 \mathrm{~Hz}$ to $\sim 2 \mathrm{~Hz}$ with amplitude decreasing. Stochastic finite fault source model with dynamic corner frequency was used to simulate ground motions at the eight stations for the main event. The simulated ground motions were compared to the recordings at the eight stations.

\section{GPS Measurements of Large 0scillations of a Tall Building due to a Magnitude 7.3 Earthquake}

HERRING, T., Massachusetts Institute of Technology, Massachusetts, USA, tah@mit.edu; GU, C., Massachusetts Institute of Technology, Massachusetts, USA, guchch@mit.edu; TOKSÖZ, M. N., Massachusetts Institute of Technology, Massachusetts, USA, toksoz@mit.edu; BÜYÜKÖZTÜRK, O., Massachusetts Institute of Technology, Kuwait, obuyuk@mit.edu; PAROL, J., Kuwait Institute for Scientific Research, Kuwait, hsnkml@gmail.com; AL-ENEZI, A., Kuwait Institute for Scientific Research, Kuwait, aenezi@kisr. edu.kw; AL-JERI, F., Kuwait Institute for Scientific Research, Kuwait, fjerri@ kisr.edu.kw; AL-QAZWEENI, J., Kuwait Institute for Scientific Research, Kuwait, jqazweni@kisr.edu.kw; KAMAL, H., Kuwait Institute for Scientific Research, Kuwait, hsnkml@gmail.com

Tall buildings, increasing in number throughout the world, including the Middle East, are greatly affected by long trains of seismic waves from regional earthquakes. Seismic motions, measurable with accurate GPS, are greatly amplified with the increasing height of buildings. Here we show the first successful GPS measurements of the motions of the $414 \mathrm{~m}$ tall, Al-Hamra Tower in Kuwait, due to the 11/12/2017 magnitude 7.3 earthquake, $642 \mathrm{~km}$ north of Kuwait City on the Iran-Iraq border. The GPS direct measurements of the movements near the top of this building show oscillations of the building, lasting more than ten minutes, with maximum peak-to-peak displacements of $30 \mathrm{~cm}$. The period of the oscillations corresponds to the fundamental mode of the building, and the scalloping nature of the oscillations is produced by the interference of two lowest modes with 7.1 and 5.7 second periods. The large oscillations, occurring in two broad pulses-one and three minutes-after the initial shaking, correlate with GPS and seismic measured ground displacements in the resonance band of the building. GPS measurements show that there was no permanent deformation despite the large swaying of the building. The response of other tall buildings to seismic wave trains can be determined from the seismic power in the resonance band of these buildings and these methods can be applied widely around the world. Measurements of this type with low-cost GPS receivers will soon be possible.

\section{What Does a 1000-s or More Tall Building Response Record Mean?} CELEBI, M. K., Retired, California, USA, celebi@usgs.gov

The new generation of recorderscapture longer responses from ground or structural arrays. Within the last decade, many records released by various data centers exhibit longer and longer durations of shaking - allowingstudies of longer earthquake shaking responses of buildings and/or other structures. In this paper, I examine the causes and implications of longer shaking of the structures using recent examples. Two particular issues constitute the scope of this paper. First, longer shaking duration in structures usually means slower dissipation of shaking energy. Critical damping values recently determined from response records of tall ( $\geq 10$ stories) buildings, in particular, are found to be around $2.5 \%$, much lower than the value of $5 \%$ widely assumed and utilized during the design and analysis processes. Thus, when the measured critical damping percentage is in the vicinity of or less than $2.5 \%$ or less [which is the latest recommendation of Los Angeles Tall Buildings Design Council [LATBDC, 2015] as well as Tall Building Initiative $[\mathrm{TBI}]$ of Pacific Earthquake Engineering Research Center [PEER , 2017], the 5\% damped design response spectrum for design and analysis analyses/design becomes a liberal criteria, with wide implications for existing as well as new and future designs. For example, what needs to be done to a tall building designed with a criterion of $5 \%$ critical damping percentage but exhibits $2.5 \%$ damping after building construction is finished and is in service? Retrofit 
possibilities exist but are costly. Second, many of the long records from tall buildings exhibit a beating effect, caused by combination of low critical damping percentages and closely coupled translational and torsional frequencies [Borosheck and Mahin, 1991; Çelebi and others, 2014]. A beating effect yields prolonged responses and discomfort to occupants as well as adding to low-cycle fatigue. Two examples (one from US andone from Japan) demonstrate both the first and second issues.

Nonlinear Seismic Soil-Structure Interaction Analysis of Long-Span Railway Bridge Subjected to Different Earthquake Ground Motions

FAIZAN, A. A., Department of Civil Engineering, Sakarya University, Sakarya, Turkey, ab.ahad_faizan@yahoo.com; KIRTEL, O., Department of Civil Engineering, Sakarya University, Sakarya, Turkey, okirtel@sakarya.edu.tr

In this paper, the dynamic behavior of an existing long-span railway bridge in Afyon-Turkey, subjected to different earthquake ground motion is investigated. In this study a full two-dimensional finite element model of the railway bridge system was established, in which the soil-structure interactions were considered. Time domain dynamic analyses of the bridge-soil models and also a 2D version of PLAXIS, a specially developed finite element software for solving geotechnical problems, have been performed. Considering the soil property of railway bridge site, analysis was performed for one type of soil, which is specified as soft. Manjil (Iran, 1990), Kobe (Japan, 1995) and Kocaeli (Turkey, 1999) earthquakes are defined as input motions. According to the result of the dynamic analysis, the relative displacements in both directions ( $\mathrm{x}$ and $\mathrm{y}$ ) for the top point of bridge (Point A), base point of bridge (Point $\mathrm{B}$ ) and soil levels (Point $\mathrm{C}$, without bridge structure) were obtained and showed as graphic form. The displacement values are different for each kind of earthquake ground motions, hence it means that the bridge structure and soil have different responses to each kind of earthquake ground motions. Keywords: Railway Bridge, Seismic Behaviour, Soil-Structure Interaction, Finite Element Method (FEM), Soft Soil, Displacement, Plaxis 2D.

\section{A Study to Define the Long-Period Corner Periods for Code-Based Displacement Spectrum}

AKKAR, S., Bogazici University Kandilli Observatory and Earthquake Research Institute, Istanbul, Turkey, sinan.akkar@boun.edu.tr; KALE, O., TED University Department of Civil Engineering, Ankara, Turkey, ozkan.kale@tedu. edu.tr

Proper definitions of elastic horizontal pseudo-acceleration (PSa) and displacement $(\mathrm{Sd})$ spectra for a wide spectral period range have become more and more important because the implementation of displacement-based design is now wellestablished among the earthquake engineering community. The reliability and consistency between PSa and Sd is also important for probability-based seismic damage assessment (PBSDA) because some of the PBSDA approaches assess the structural behavior by making use of spectrum-compatible accelerograms for a period range much shorter and longer than the fundamental periods of the buildings. To this end, the definition of long-period corner period (referred to as TL or TD) that delineates the commencement of maximum spectral displacement plateau deserves a careful consideration. Currently, Eurocode 8 fixes this period at $\mathrm{TD}=2 \mathrm{~s}$ and $\mathrm{TD}=1.2 \mathrm{~s}$ for Type 1 (high-seismicity) and Type 2 (low-seismicity) spectra, respectively. The Italian earthquake code uses a TD expression that is a function of return-period and peak ground acceleration. The ASCE 7-10 guidelines describethe long-period corner-period from the modal magnitudes determined from the disaggregation of 2475-year national probabilistic seismic hazard results at $\mathrm{T}=2.0 \mathrm{~s}$. TheTL values in the US seismic codes are significantly longer than their counterparts in Europe. In this paper, we followed the US approach to estimate the modal magnitudes at 72-year, 475 -year and 2475 -year return periods by using the revised probabilistic seismic hazard maps of Turkey. We also developed an expression to relate the modal magnitude and TL. We used this information to map TL at different return periods throughout the mainland Turkey. We compared our results with those provided in the aforementioneddesign codes. The comparisons indicate that TD values of the European codes are smaller than those computed in this study. On the other hand, the TL values of the US codes are longer than our estimations.

\section{Interaction Between Observations and Models in Seismo- Volcanic Studies}

Oral Session · Tuesday 15 May · 8:30 AM · Flagler

Session Chairs: Mario C. Ruiz and Mauricio Mora

\section{Interpreting Seismic Signals and Processes at Active Volcanic Systems}

MCNUTT, S. R., University of South Florida, Florida, USA, smcnutt@usf.edu

Volcanoes are the sources for a variety of seismic signals, representing different physical processes. A common sequence of events prior to eruptions, the generic volcanic earthquake swarm model (GVESM), provides a unifying framework. First to appear are deep long-period (DLP) events, which may represent fluid injection at depth. From background, high-frequency (HF) events (aka VT events) increase in rate and occur in swarms. The likely HF source is shear failure on pre-existing faults. Increasing pressure manifests as a decrease in the b-value, suggesting changing crustal conditions. Shoaling of HF earthquakes has been observed, but is not common. Instead, the appearance of hybrid and lowfrequency (LF) events often indicates that magma has reached shallow depths. These events likely represent fluid involvement, either a fracture adjacent to a fluid cavity (hybrids) or vibration of the cavity itself (LF events). They are common at depths of $\geq 3 \mathrm{~km}$, and swarms of such events have high b-values, suggesting high thermal gradients, high pore pressure, or highly fractured material. Shallow verylong period (VLP) events have been modeled as pulses of fluid flow in both dikes and sills. Volcanic tremor also generally occurs at shallow depths, and has similar frequencies to LF events, suggesting a common source. Weak tremor is characteristic of hydrothermal activity, whereas stronger tremor suggests magmatic involvement. The reduced displacement of tremor is proportional to the VEI during eruptions. In some cases, deep HF events occur after eruptions, suggesting that stresses have been modified in the country rock near the magma chamber. The different events comprising the GVESM imply that different processes are occurring, and the processes combined with different depths suggest that the underlying cause of the GVESM is magma ascent. Thus rates and locations of the different types of events may be used to infer the subsurface conditions along the magma pathway.

\section{Monitoring Nyiragongo's Lava Lake Activity (D.R. Congo) Using Seismic, Infrasound and SAR Measurements}

BARRIÈRE, J., European Center for Geodynamics and Seismology, Luxembourg, julien.barriere@ecgs.lu; D’OREYE, N., National Museum of Natural History, Luxembourg, ndo@ecgs.lu; OTH, A., European Center for Geodynamics and Seismology, Luxembourg, adrien.oth@ecgs.lu; GEIRSSON, H., University of Iceland, Iceland, hgeirs@ hi.is; MASHAGIRO, N., Goma Volcano Observatory, Democratic Republic of the Congo, nichemashagiro@gmail.com; JOHNSON, J. B., Boise State University, Idaho, USA, jeffreybjohnson@boisestate.edu; SMETS, B., Royal Museum for Central Africa, Belgium, benoit.smets@ africamuseum.be; KERVYN, F., Royal Museum for Central Africa, Belgium, francois.kervyn.de.meerendre@africamuseum.be

Nyiragongo volcano, in North Kivu (D.R. Congo) is among the most active volcanoes in Africa and on Earth, with the presence of a persistent lava lake from at least 1928 to 1977 and since 2002. After its drainage during the last eruption in 2002, the crater filled up on $\sim 400 \mathrm{~m}$ thickness until 2008 and resumed rising in 2016. The persistent lava lake at Nyiragongo gives a unique opportunity to studythe dynamics of the upper magmatic system of the volcano over long time scales. Its monitoring also offers a chance to detect pressure change in the magmatic activity. A continuous background, shallow tremor source has been identified since the deployment of a local seismic network (October 2015) and has been related to short-term cyclic meter-scale variations attributed to gas-piston activity. Since late 2016, the increased number of highly similar, discrete long-period events accompanies several decameter-scale level rises or falls, which convey major pressure changes in the upper magmatic system. The source region of this cluster at shallow depth is confirmed by the observation of associated infrasound transients. Additionally, high-resolution satellite SAR images allow to infer the lava lake level fluctuations by measuring the length of the SAR shadow casted by the edge of the bottom of crater on the lava lake surface. Up to 70 estimations of the lava lake level are obtained with this technique between August 2016 and November 2017. These isolated measurements allow to constrain continuous colocated infrasound and seismic observations at the closest station $(\sim 6 \mathrm{~km}$ to the crater). We show here that slight changes in the spectral properties of the seismoacoustic signals are related to successive drop and increase of the lava lake level, thus highlighting the potential to monitor continuously Nyiragongo's lava lake activity at several kilometers away to the crater using a single station with infrasound and seismic records. 
Seismo-Acoustic Wavefield of Strombolian Explosions at Yasur Volcano, Vanuatu, Using a Broadband Seismo-Acoustic Network

MATOZA, R. S., UC Santa Barbara, California, USA, matoza@geol.ucsb. edu; CHOUET, B., Arzier-Le Muids, Switzerland, chomolangma@aol.com; DAWSON, P., US Geological Survey, California, USA, dawson@usgs.gov; JOLLY, A., GNS Science, New Zealand, a.jolly@gns.cri.nz; FEE, D., University of Alaska, Fairbanks, Alaska, USA, dfee1@alaska.edu; IEZZI, A. M., University of Alaska, Fairbanks, Alaska, USA, amiezzi@alaska.edu; JOHNSON, R., GNS Science, New Zealand, r.johnson@gns.cri.nz; KILGOUR, G., GNS Science, New Zealand, g.kilgour@gns.cri.nz; CHRISTENSON, B., GNS Science, New Zealand, b.christenson@gns.cri.nz; GARAEBITI, E., Vanuatu Meteorology and Geohazards Department, Vanuatu, gesline@vanuatu.gov.vu; KENNEDY, B., University of Canterbury, New Zealand, ben.kennedy@canterbury. ac.nz; FITZGERALD, R., University of Canterbury, New Zealand, rebecca. fitzgerald@pg.canterbury.ac.nz; KEY, N., University of Canterbury, New Zealand, nicholas.key@canterbury.ac.nz

Seismo-acoustic wavefields at volcanoes contain rich information on shallow magma transport and subaerial eruption processes and inform our understanding of how volcanoes work. We conducted a collaborative multiparametric field experiment at the active Yasur volcano, Tanna Island, Vanuatu from 26 July to 2 August 2016. Our observations include data from a temporary network of 11 broadband seismometers, 6 single infrasonic microphones, 7 small-aperture 3 -element infrasound arrays, 2 infrasound sensor packages on tethered balloons (aerostats), an FTIR, a FLIR, 2 scanning Flyspecs, and various visual imaging data; scoria and ash samples were collected for petrological analyses. This unprecedented dataset should provide a unique window into processes operating in the shallow magma plumbing system and their relation to subaerial eruption dynamics. Network-coincident STA/LTA automatic triggering indicates that the 6-day dataset contains over 8,400 infrasound explosions and over 10,400 seismic events. The infrasonic signatures of Yasur's Strombolian explosions consist of short-duration explosion waveforms with non-linear characteristics. The seismic signals are numerous repetitive long-period (LP) seismic events underlain by verylong-period (VLP) signals with periods of $\sim 10 \mathrm{~s}$. In addition to these dominant signal types, we also record a near-continuous broadband $(\sim 0.1-20 \mathrm{~Hz})$ infrasonic tremor associated with the vigorous degassing activity. We observe strong variability in the synchronization of seismic and acoustic sources. Explosion events, clearly delineated by infrasonic waveforms, are underlain by seismic VLPs. However, strong seismic VLPs also occur with only a weak infrasonic expression. Our analyses include full seismic waveform inversion for a point-source momenttensor and single force vector representation of the VLP source.

Very Long Period and Short Period Eruption Seismograms and Progressive Conduit Changes at Erebus Volcano, Antarctica

ASTER, R.C., Colorado State University, Colorado, USA, rick.aster@ colostate. edu; KNOX, H. A., Sandia National Laboratories, New Mexico, USA, haknox@ sandia.gov; CHAPUT, J. A., Colorado State University, Colorado, USA, julien. chaput@colostate.edu; KYLE, P. R., New Mexico Institute of Mining and Technology, New Mexico, USA, philip.kyle@nmt.edu

We analyze near-repeating broadband seismograms from nearly 3,000 eruptions (2003-2011) from the Erebus volcano lava lake to investigate temporal changes in the shallow eruptive dynamics of an open conduit volcano. Cross-correlation analysis reveals progressive variable time lags between correlation-aligned short period (SP) and very long period (VLP) seismogram components ranging over approximately $+-1 \mathrm{~s}$, and evolving over weeks to months. Lava lake eruptions both excite an SP explosion seismic signal and gravitationally unload the conduit. After a delay of several $s$ this unloading excites a post-eruptive, minutes-long VLP seismic signal that persist for several minutes until the lava lake is refilled. VLP_SP lag variations are consistent across multiple seismic stations, and are independent of eruption size, spectral characteristics, eruption frequency, and lava lake morphology changes. Lag changes are interpreted in terms of variable communication time between eruptions and the subsequent elastic and gravitational response of a tomographically imaged near-summit magma storage and VLP source region several hundred $\mathrm{m}$ below the lava lake. Tomographic and VLP moment tensor studies, combined with modeling, suggest that the elastodynamic communication time between the distinct SP and VLP source regions is mediated by conduit-guided Stoneley waves within the uppermost magma-filled conduit system that are sensitive to small shallow conduit geometry changes. Conduit geometry changes may be driven by internal or external processes, including conduit wall melting and refreezing, repeated eruptive slug erosion, and deformation from Inner Crater inflation or collapse.
Monitoring Recent Unrest of Sierra Negra Volcano, Galápagos Islands RUIZ, M. C., Escuela Politecnica Nacional, Instituto Geofisico, Ecuador, mruiz@igepn.edu.ec; AMELUNG, F., University of Miami, RSMAS, Florida, USA, famelung@rsmas.miami.edu; MOTHES, P. A., Escuela Politecnica Nacional, Instituto Geofisico, Ecuador, pmothes@igepn.edu.ec; PACHECO, D. A., Escuela Politecnica Nacional, Instituto Geofisico, Ecuador, dpacheco@igepn. edu.ec; PALACIOS, P. B., Escuela Politecnica Nacional, Instituto Geofisico, Ecuador, ppalacios@igepn.edu.ec; RAMÓN, P., Escuela Politecnica Nacional, Instituto Geofisico, Ecuador, pramon@igepn.edu.ec; HERNANDEZ, S., Escuela Politecnica Nacional, Instituto Geofisico, Ecuador, shernandez@igepn. edu.ec; VIRACUCHA, G., Escuela Politecnica Nacional, Instituto Geofisico, Ecuador, gviracucha@igepn.edu.ec; AGUAIZA, S., Escuela Politecnica Nacional, Instituto Geofisico, Ecuador, saguaiza@igepn.edu.ec; LEES, J. M., University of North Carolina at Chapel Hill, North Carolina, USA, jonathan. lees@unc.edu

Sierra Negra volcano is located at the southern portion of Isabela island and exhibits a large caldera $(7 \mathrm{x} 9 \mathrm{~km})$. Since 1948 , the average eruptive interval time is 11.4 yrs. Using a permanent BB network operated by the Instituto Geofisico, a steady increase in the number and size of earthquakes was detected beginning in Jun 2017. The number of detected events increased from about a dozen local events per day in Jun to a maximum of 107 on 02 Jan, 2018. Since Oct 2017, six events with magnitudes $\geq 3.5$ have been detected, with the largest (MLv 4.3) occurring in Jan 2018. This event's spectrum was characteristic of an LP, even at the closest station just a few $\mathrm{km}$ from the epicenter. While most large events have a LP appearance, the majority of smaller events have wide spectra indicative of VTs. Locations have shallow foci presumably above either a horizontal magmatic reservoir or sill. Deformation gleaned from InSAR shows $98 \mathrm{~cm}$ of caldera floor uplift detected since early 2017 and $18 \mathrm{~cm}$ of uplift in January, 2018. The caldera floor has inflated more than $5 \mathrm{~m}$ since the deflationary episode following the 2005 eruption. Combining historical activity with recent seismic and geodetic records, we speculate that a new Sierra Negra eruption will likely occur in the near future.

Automatic Detection and Location of Seismo-Volcanic Signals Based on the
Seismic Network Covariance Matrix: Examples from Tenerife (Canary Islands) and the Klyuchevskoy Volcanic Group (Kamchatka)

SOUBESTRE, J., Instituto Volcanológico de Canarias, S/C de Tenerife, Spain, jsoubestre@iter.es; BARRANCOS, J., Instituto Volcanológico de Canarias, S/C de Tenerife, Spain, jbarrancos@iter.es; D’AURIA, L., Instituto Volcanológico de Canarias, S/C de Tenerife, Spain, Idauria@iter.es; PADILLA, G. D., Instituto Volcanológico de Canarias, S/C de Tenerife, Spain, german@iter.es; SHAPIRO, N. M., Institut de Physique du Globe de Paris, France, nshapiro@ipgp.fr; SEYDOUX, L., Université Grenoble Alpes, ISTerre, France, leonard.seydoux@ univ-grenoble-alpes.fr; PERÉZ, N., Instituto Volcanológico de Canarias, S/C de Tenerife,Spain,nperez@iter.es

We developed a network-based method for detecting and locating seismo-volcanic signals such as volcano-tectonic earthquakes, long-period events, and volcanic tremors. The method is based on the analysis of eigenvalues and eigenvectors of the seismic network covariance matrix, the equivalent in the frequency domain of the cross-correlation matrix. First, the width of the network covariance matrix eigenvalues distribution is used to detect different types of seismo-volcanic events. Then, the first eigenvector of the covariance matrix corresponding to each event is extracted. Our main hypothesis is that, by representing the principal component of the recorded wavefield, this first eigenvector characterizes the dominant event filtering the information related to the noise. Sources of the different events are finally located using the cross-correlation moveout information of the corresponding first eigenvector. The method is applied to two data sets to automatically detect and locate volcano-tectonic earthquakes, long-period events and volcanic tremors. We analyze seismic data continuously recorded by the Red Sísmica Canaria, a permanent monitoring network composed of 15 broadband stations operated by the Instituto Volcanológico de Canarias (INVOLCAN) on the island of Tenerife (Canary Islands). Results are also obtained from four and a half years of continuous data recorded by 19 permanent seismic stations operated by the Kamchatka Branch of the Geophysical Survey (KBGS) in the vicinity of the Klyuchevskoy volcanic group in Kamchatka (Russia). The developed method does not require a priori knowledge, is fully automatic, and the database of network-based events fingerprints can be continuously enriched with newly available data.

Seismicity of the Lazufre Volcanic System, Northern Chile/Argentina MCFARLIN, H. L., University of South Florida, Florida, USA, hlmcfarlin@ mail.usf.edu; MCNUTT, S. R., University of South Florida, Florida, USA, smcnutt@usf.edu; BRAUNMILLER, J., University of South Florida, Florida, 
USA, jbraunmiller@usf.edu; THOMPSON, G., University of South Florida, Florida, USA, thompsong@mail.usf.edu

Cordon del Azufre and Lastarria are two volcanoes on the border of Chile and Argentina that have been shown to have an unusual deformation signature. The main center of deformation is between the two volcanoes, with the top of the modelled deformation source at a depth of $7-15 \mathrm{~km}$. A smaller deformation signal is near the summit of Lastarria, with a deformation source at $\sim 1 \mathrm{~km}$ below the surface. The most recent eruptions at these volcanoes occurred $\sim 150 \mathrm{ka}$ at Lastarria, and $\sim 0.3 \mathrm{Ma}$ at Cordon del Azufre. Current geologic activity, which is not centered on just the volcanoes, but also in between the two, consists of fumarolic activity, seismic activity, and degassing with a possible change in gas composition between 2009 and 2012 that may be indicative of a change from a hydrothermal to a magmatic nature. The PLUTONS Project deployed 8 seismic stations around the Lazufre complex from November 2011 to March 2013. Preliminary results from analyzing the seismic activity show an average of 1 autodetected event per day within a $20 \mathrm{~km}$ radius of Lazufre with the majority of depths less than $10 \mathrm{~km}$ below sea level. The average magnitude is $\mathrm{ML} 1$, and does not exceed $\mathrm{ML}=2.8$. The b-value for these events is $\sim 1.03 \pm 0.08$ (a typical tectonic value), with a magnitude of completeness threshold $\mathrm{Mc}=0.3$. The peak event rate is 17 events per day in the beginning of May 2012. These results suggest moderately high volcanic and/or hydrothermal activity at the Lazufre Volcanic complex, with most events occurring beneath the summit of Lastarria.

\section{Similar Seismicity at Turrialba and Poas, Costa Rica: What Can It Tell Us?}

SALVAGE, R. O., Observatorio Vulcanológico y Sismológico de Costa Rica, Heredia, Costa Rica, beckysalvage@gmail.com; PACHECO-ALVARADO, J. F., Observatorio Vulcanológico y Sismológico de Costa Rica, Heredia, Costa Rica, javier.pacheco.alvarado@una.cr; BRENES-MARIN, J., Observatorio Vulcanológico y Sismológico de Costa Rica, Heredia, Costa Rica, jorge.brenes. marin@una.cr

Repeating seismic events (which have a similar frequency content and waveform shape) have been identified at a number of active volcanoes around the world, including: Redoubt, Alaska; Mt. St. Helens, Washington; Tungurahua, Ecuador; and Soufriere Hills, Montserrat; and appear to be particularly persistent during episodes of volcanic activity. In Costa Rica, we have identified similar seismicity at two active volcanoes: Turrialba and Poas, which appears to be focused beneath the active craters of these volcanoes and related to the movement of magmatic fluid at depth. We present a detailed overview of repeating seismicity at these volcanoes from July 2016 to present. We present a number of very interesting families of repeating seismicity at Turrialba, including: the dominant family which has been persistently active, and contains over 3000 events from January-December 2017; and a period of high frequency drumbeat seismicity in January 2017. The drumbeat signal lasted less than 3 hours in duration and contained hundreds of events. Approximately 8 hours later, a small eruption with an ash plume of less than $200 \mathrm{~m}$ above the crater occurred. We speculate that these signals are related to magmatic movement at depth towards the surface; a precursory signal to this eruption. At Poas, we investigate the emergence of a number of families related to the reactivation of large phreatic-magmatic eruptions in April 2017. In particular, we note that at least one family of similar seismicity appears to accelerate prior to the most energetic eruption on 22 April 2017 at 22:10 (local time). Additionally, 6 families appear to abruptly cease in July 2017 within 2 hours of one another, potentially related to two $\geq$ ML 3.2 regional earthquakes located approximately $3 \mathrm{~km}$ beneath the volcanic complex during this two hour period. It is possible that the regional earthquakes have inhibited the volcanic processes which were responsible for generating the families of seismicity.

\section{Analysis of Seismic Signals from Cotopaxi Volcano Using Variational Mode Decomposition (VMD)}

PROANNO, E., Universidad San Francisco de Quito, Pichincha, Ecuador, estebanandresproano@gmail.com; BENÍTEZ, D. S., Universidad San Francisco de Quito, Pichincha, Ecuador, dbenitez@usfq.edu.ec; LARA-CUEVA, R. A., Universidad de las Fuerzas Armadas ESPE, Pichincha, Ecuador, ralara@ espe.edu.ec; RUIZ, M. C., Instituto Geofisico, Escuela Politécnica Nacional, Pichincha, Ecuador, mruiz@igepn.edu.ec

In volcanology analyzing seismic signals is an essential part for determining the condition of volcanoes. Many research papers have reported the analysis of seismograms signals using (Fast Fourier Transform) FFT techniques, which have their own drawback with non- stationary signals. Therefore, there is a need for developing new methodologies to infer information from seismic signal of non-stationary nature. In this paper a novel algorithm called Variational Mode Decomposition (VMD) is used for the analysis of seismic signals obtained from the Cotopaxi Volcano in Ecuador. VMD obtains concurrently the principal modes of a signal. A mode is a band-limited signal around a center frequency and is obtained by a process called alternative direction method of multipliers (ADMM) which is a series of optimizations in the Fourier domain. The main advantage of the VMD over previous studied methods is its robustness to noise and the reduction of the number of features necessary to distinguish amongst the signals. Preliminary analysis shows that seismic events such as volcano-tectonic (VT) earthquakes and long-period (LP) events can be identified after applying the VMD to the seismic signal due to the fact that its 4 main modes are much different amongst the different types of signals. Further observations show that the same process for obtaining the modes of the signal can also be applied to detect the presence of events using a fixed-size window.

\section{Seismicity Constraints on Fault-Magma Interactions and Stress Field Rotation in an Early-Stage Continental Rift}

EBINGER, C. I., Tulane University, Louisiana, USA, cebinger@tulane. edu; OLIVA, S. J., Tulane University, Louisiana, USA, soliva@tulane.edu; ROECKER, S. W., RPI, New York, USA, roecks@rpi.edu; WAUTHIER, C., Penn State, Pennsylvania, USA, cuw25@psu.edu

Although magmatism may occur during the earliest stages of continental rifting, its role in strain accommodation remains weakly constrained by largely $2 \mathrm{D}$ studies. We analyze seismicity data from a 13 -month, 39-station broadband seismic array to determine the role of magma intrusion on state-of-stress and strain localization, and their along-strike variations. Precise earthquake locations using cluster analyses and a new 3D velocity model reveal lower crustal earthquakes beneath the central basins and along projections of steep border faults that degas $\mathrm{CO} 2$. Seismicity forms several disks interpreted as sills at $6-10 \mathrm{~km}$ below a monogenetic cone field. The sills overlie a lower crustal magma chamber that may feed eruptions at Oldoinyo Lengai volcano. After determining a new ML scaling relation, we determine a b-value of $0.87 \pm 0.03$. Focal mechanisms for 65 earthquakes, and 13 from a catalogue prior to our array reveal an along-axis stress rotation of $\sim 60 \mathrm{o}$ in the magmatically active zone. New and prior mechanisms show predominantly normal slip along steep nodal planes, with extension directions $\mathrm{N} 90^{\circ} \mathrm{E}$ north and south of an active volcanic chain consistent with geodetic data, and $\sim \mathrm{N} 150^{\circ} \mathrm{E}$ in the volcanic chain. The stress rotation facilitates strain transfer from border fault systems, the locus of early stage deformation, to the zone of magma intrusion in the central rift. Our seismic, structural, and geochemistry results indicate that frequent lower crustal earthquakes are promoted by elevated pore pressures from volatile degassing along border faults, and hydraulic fracture around the margins of magma bodies. The new results enable re-interpretation of a faulting and dike intrusion episode sequence between Gelai and Oldoinyo Lengai volcanoes, and that may have triggered the 2007 eruption of Lengai volcano, with re-analyses of models of InSAR data.

\section{Megathrust Earthquakes: Recurrence, Rupture Modes and Tsunamis (Parts 1 and 2)}

Oral Session - Tuesday 15 May · 2:15 PM · Tuttle

Session Chairs: Peter Molnar, Peter Haeussler, and Brian F.

Atwater

\section{Reconciling Short- and Long-Term Observations of Megathrust Earthquake Cycles at Subduction Zones}

GOVERS, R., Utrecht University, Netherlands, r.govers@uu.nl; HERMAN, M., Utrecht University, Netherlands, m.w.herman@uu.nl; BROERSE, T., Utrecht University, Netherlands, d.b.t.broerse@uu.nl; FURLONG, K., Penn State, Pennsylvania, USA, kpf1@psu.edu

Regional models of the earthquake cycle have become increasingly sophisticated tools to understand the seismological and geodetic observations. They capture critical physical processes like (partial) locking of the plate interface, the detailed co-seismic slip, poro-elastic and mantle relaxation and afterslip. Emerging from both the observations and the models is that similar physical processes are active at different margins, and that part of the observed complexity is controlled by them being in different stages of the earthquake cycle. We use geodynamic models to isolate the geodetic signature of these physical processes over many megathrust earthquake cycles. Co-seismic and subsequent slip on the subduction interface are dynamically (and consistently) driven. We find that the mega-thrust earthquakes induce significant tensile stresses in the overriding plate near the down-dip end of the co-seismic fault. Subsequent afterslip reduces these tensile stresses. The results suggest that aftershocks down-dip of the main event correlate with relatively rapid post-seismic slip in the weeks to months after the earthquake. Permanent deformation of the overriding plate accumulates slowly inboard of the 
locked plate contact in response to long-term compression. Formal inversion of the synthetic geodetic velocities reproduces the imposed $100 \%$ locking of the seismogenic fault only during the interseismic stage. We review pre-, co- and postseismic GNSS observations and conclude that our models capture the kinematics of megathrust earthquake cycles that are shared by many margins, including that in Chile, in Alaska-Aleutians, Sumatra-Andaman, and in the Japan Trench margin. Most of the observed variability in surface velocities between the individual margins appears to be controlled by their different stages in the earthquake cycle.

\section{Subduction Zone Geometry and Its Influence on the Locations of Megathrust Earthquakes}

HAYES, G. P., US Geological Survey, Colorado, USA, ghayes@usgs.gov; MOORE, G., University of Washington, Washington, USA, ginevra@uw.edu; PLESCIA, S., University of Colorado Boulder, Colorado, USA, steven.plescia@ colorado.edu

In early 2018, the US Geological Survey will release Slab2, an updated database of 3D subduction zone geometry models that covers themajority of global slabs. Informed by a large dataset built from a variety of geophysical sources (e.g., regional and teleseismic earthquake hypocenters, moment tensors, active-source seismic surveys, tomography models, receiver functions, bathymetry, trench ages, and sediment thickness information), Slab2 offers a more complete (more slab models), more stable (more data sets), and reproducible (codes will be distributed) collection of geometry models than its predecessor, Slab1.0. In addition to providing a fascinating look at the fate of slabs, and the similarities and differences between global subduction zones, Slab2 gives us the ability to study how megathrust geometry influences where megathrust earthquakes occur. Coupled with our recently published database of finite fault models for globally distributed M7.5+ earthquakes since 1990, we use Slab2 to infer characteristics of earthquake rupture. For example, we can address questions that are fairly prevalent in seismological literature. Do large ruptures preferentially occur where subduction zones are flat? Can 'flatness' be mapped toquantify earthquake potential? Do the ends of ruptures correlate with changes in slab geometry, and/or bathymetric features entering the subduction zone? Do subduction zone geometry changes spatially correlate with areas of low slip in rupture models? Is there a correlation between seismogenic zone dip, and/or seismogenic zone width, and earthquake size? Addressing these issues are fundamental to the understanding of earthquake rupture dynamics and subduction zone seismogenesis, and yet many are poorly understood or are still debated in the scientific literature. We speak to these questions and similar issues in this presentation, and show how these models can be used to improve our understanding of earthquake hazards in subduction zones.

\section{Missing Great Earthquakes \\ HOUGH, S. E., US Geological Survey, California, USA, hough@usgs.gov}

The occurrence of nine earthquakes with Mw greater than 8.5 between $2004-$ 2012 raised interest in the long-term global rate of great earthquakes. Studies exploring the significance of apparent clustering (e.g., Michael, 2011) focused on analysis of earthquakes since 1900. Prior to this time the catalog is less complete and magnitude estimates are more uncertain. Yet substantial information is available for earthquakes prior to 1900 . Reviewing the catalog of historical earthquakes back to 1700 , including numbers of events and moment release rates, I suggest that approximately half of all $\mathrm{Mw} \geq 8.5$ earthquakes are likely missing or underestimated in the 19th century. The 8 February 1843 Lesser Antilles earthquake is an example of a known historical earthquake that could have been significantly larger than initially estimated. I reconsider the felt effects of this earthquake, including a first thorough assessment of felt reports from the United States. One recent study estimated a preferred magnitude of 8.5 based on near-field macroseismic effects (Feuillet et al., 2011), but the generally accepted value has been 7.5-8. A consideration of the regional and far-field macroseismic effects reveals a felt distribution comparable to those of recent great $(\mathrm{Mw} \geq 9.0)$ earthquakes. A modest tsunami is described by two witnesses; two other accounts describe uplift of a stone wharf in Antigua, and along the northern coast of Guadaloupe. For the 1843 earthquake, the far-field intensity distribution provides a stronger constraint on magnitude. The observations support the inference of a high $(\mathrm{Mw} \geq 8.5)$ magnitude, and significant moment release towards or possibly around the northern corner of the Lesser Antilles Arc. The results suggest that incorporation of best-available catalogs of historical earthquakes will likely lead to a significant underestimation of seismic hazard and/or the maximum possible magnitude in many regions, including parts of the Caribbean.

3-D Simulations of Megathrust Earthquakes in Cascadia - Implications for Strong Ground Motions, Basin Amplification, and Coseismic Deformation WIRTH, E. A., US Geological Survey, Washington, USA, emoriarty@usgs. gov; FRANKEL, A. D., US Geological Survey, Washington, USA, afrankel@ usgs.gov; MARAFI, N., University of Washington, Washington, USA, marafi@ uw.edu; VIDALE, J. E., University of Southern California, California, USA, jvidale@usc.edu; STEPHENSON, W. J., US Geological Survey, Colorado, USA,wstephens@usgs.gov

The Cascadia subduction zone has a history of large megathrust earthquakes up to magnitude 9. The last Cascadia megathrust earthquake occurred in 1700, and thus, there are no seismic recordings of ground shaking. We combine 3-D finite difference simulations with high-frequency stochastic synthetics using a matched filter at $1 \mathrm{~Hz}$, to produce broadband $(0-10 \mathrm{~Hz})$ synthetic seismograms for 50 magnitude 9 earthquakes on the Cascadia megathrust. Slip on the fault consists of multiple high-stress-drop subevents with short rise times on the deeper portions of the megathrust, superimposed on a background slip distribution with longer rise times. We find $\mathrm{a} \geq 10 \mathrm{x}$ variation in the intensity of ground shaking (i.e., 1-10 s spectral accelerations), depending upon several key parameters: the hypocenter location (due to rupture directivity), the location of strong-motiongenerating subevents, and the down-dip rupture extent. Spectral accelerations are amplified by a factor of $\sim 2-5 \mathrm{x}$ for sites within the Seattle and Tacoma sedimentary basins, and we observe a coupling between rupture directivity and the strength of basin amplification. Comparison of our M9 earthquake simulations to geologic evidence for coseismic coastal subsidence suggests (1) a down-dip rupture extent that closely corresponds to the geodetically inferred $1 \mathrm{~cm} / \mathrm{yr}$ locking contour and (2) possible locations for strong-motion-generating subevents during the 1700 Cascadia earthquake based on along-strike variability in the estimates of coseismic offset. This work demonstrates the wide range of possible ground motions from an M9 Cascadia earthquake and underlines the need to further constrain key rupture parameters using geologic and geophysical observations.

\section{Understanding Estimates of the Location, Size, and Frequency of Cascadia's Megathrust Earthquakes}

GOMBERG, L., US Geological Survey, Washington, USA, gomberg@usgs.gov; the Cascadia Recurrence Project Team, US Geological Survey, Washington, USA,gomberg@usgs.gov

Interpretations of differing types of data, analyses, and modeling yield different rates of recurrence for Cascadia's great (M8-9) megathrust earthquakes. Learning the source of these differences will improve seismic hazard assessments and forecasts. Understanding these differences will require asking fundamental questions about cycles of earthquake strain accumulation and release on various temporal and spatial scales, how earthquake ruptures nucleate and evolve, and how seismic energy is radiated. To address these questions the Cascadia Recurrence Project Team is undertaking an effort to produce a detailed and holistic knowledge of the history of Cascadia's past megathrust events. We are focusing on improving our understanding Cascadia earthquake history and processes by integrating the results of studies of earthquake-triggered 1) ground failures (particularly landslides), 2) coastal land-level changes, 3) tsunami inundation and deposition, and 4) offshore slope failures and turbidites. Other contextual studies examine 5) structural controls on rupture segmentation, 6) rupture modeling, 7) seismic ground motion simulation and onshore and offshore site response, 8) modes of plate-boundary locking and slip, and 9) interactions among upper- and lower-plate faults.

\section{Newly Detected, Small Earthquakes to Delineate Fault Heterogeneities in the} Cascadia Seismogenic Zone

MORTON, E. A., New Mexico Institute of Mining \& Technology, New Mexico, USA, emily.morton87@gmail.com; BILEK, S. L., New Mexico Institute of Mining \& Technology, New Mexico, USA, susan.bilek@nmt.edu; ROWE, C. A., Los Alamos National Laboratory, New Mexico, USA, char@lanl.gov

Great earthquakes, including the M9 event of January, 1700, have repeatedly occurred within the Cascadia Subduction Zone (CSZ) as inferred from paleoseismic studies and tsunami models. To better assess exposure to the next great earthquake here for at-risk populations, there is great interest in estimating downdip rupture extent and the distribution of high moment release on the megathrust. Small magnitude interplate earthquakes $(<\mathrm{M} 4)$ can be used to define seismic patches and variable frictional conditions on the fault. The 2011-2015 Cascadia Initiative (CI) amphibious seismic array augments land seismometers with $\geq 60$ ocean-bottom seismometers (OBS) positioned over the presumed seismogenic zone. We search the CI dataset for small, previously undetected interplate earthquakes to identify seismic patches and fault zone heterogeneities. We apply subspace detection, using as templates the waveforms from small events occurring at the plate interface, selected from existing earthquake catalogs. We extract the template waveforms on the CI OBS and nearby land seismometers for scanning. Our previous work targeted two clusters off the coast of Oregon which spanned all 4 years of the deployment; both of these occur on the downdip edge of mod- 
eled high slip patches for the 1700 event, and one also locates at the southern tip of a suggested asperity. Here we expand earlier results to include detection and location throughout the margin during the first 2 years of CI deployment. Preliminary results show that the most productive clusters $(\geq 200$ detections during year 1) occur on the coast of northern Oregon and along the coast of the Olympic peninsula, Washington. The templates used for scanning in these clusters are from earthquakes located in the vicinity of the 1700 event; the first source area is downdip of an inferred asperity and a modeled high moment patch, and the second is within an inferred asperity and at the edge of modeled patch of $\geq 10 \mathrm{~m}$ slip associated with this event.

\section{Microfossil Measures of Subsidence During Past Plate-Boundary Earthquakes: Their Accuracy Revealed by a Sudden Tidal-Flooding Experiment in Cascadia}

DURA, T., Humboldt State University, California, USA, cd130@humboldt. edu; HORTON, B. P., Earth Observatory of Singapore and Asian School of the Environment, Nanyang Technological University, Singapore, bphorton@ ntu.edu.sg; MILKER, Y., University of Leipzig, Germany, yvonne.milker@unihamburg.de; WANG, K., Geological Survey of Canada, kelin.wang@canada. ca; BRIDGELAND, W. T., Oregon Coast National Wildlife Refuge Complex, Oregon, USA, bill_bridgeland@fws.gov; BROPHY, L., Institute for Applied Ecology, Oregon, USA, brophyonline@gmail.com; EWALD, M., Institute for Applied Ecology, Oregon, USA, mewald@geomaticsresearch.com; KHAN, N.S., Earth Observatory of Singapore and Asian School of the Environment, Nanyang Technological University, Singapore, nicoleskhan@gmail.com; ENGELHART, S. E., University of Rhode Island, Rhode Island, USA, engelhart@uri.edu; NELSON, A. R., US Geological Survey, Geologic Hazards Science Center, Colorado, USA, anelson@usgs.gov; WITTER, R. C., US Geological Survey, Alaska Science Center, Alaska, USA, rwitter@usgs.gov

Comparison of pre- and post-earthquake microfossil assemblages in intertidal sediment is the most widely applicable and accurate means to measure coseismic subsidence at coastal sites from past plate-boundary earthquakes at subduction zones. Quantitative methods typically state only the analytical uncertainty associated with predicted subsidence. However, uncertainty on subsidence estimates may not be well constrained because the response times of fossil taxa to coseismic relative sea-level (RSL) rise are unknown. We explored the response of diatoms and foraminifera to a sudden increase in tidal inundation following dike removal during restoration of a former salt marsh in southern Oregon. Tidal flooding following dike removal caused an increase in inundation equivalent to a RSL rise of $\sim 1 \mathrm{~m}$, as might occur by coseismic subsidence during Mw 8.1-8.8 earthquakes on this section of the Cascadia subduction zone. Less than two weeks after dike removal, diatoms colonized low marsh and tidal flats, showing that they can record seismically-induced subsidence soon after earthquakes. In contrast, it took at least 10 months for notable numbers of low-marsh foraminifera to colonize the restored marsh. A comparison of diatom and foraminifera-based transfer functions-which use the empirical relationship between modern microfossil assemblages and elevation within the tidal frame to convert fossil assemblages into quantitative estimates of past RSL_reflects the delayed foraminifera response. This suggests that postseismic uplift or subsidence may cause foraminiferal-based transfer functions to underestimate or overestimate, respectively, coseismic subsidence if sedimentation rates post-earthquake exceed $1-2 \mathrm{~cm} / \mathrm{yr}$ given a typical fossil core/outcrop sampling resolution of $1 \mathrm{~cm}$. Our results suggest that different response times of diatoms and foraminifera may provide useful information on post-seismic vertical deformation in the months following past megathrust earthquakes.

\section{Evidence for Segmented Ruptures in Cascadia, an Analysis of Alternatives}

GOLDFINGER, C., Oregon State University, Oregon, USA, gold@oce.orst. edu; BLACK, B., Oregon State University, Oregon, USA, bran.black3125@ gmail.com; ENKIN, R., Geological Survey of Canada, randy.enkin@canada. ca; HAMILTON, T., Camosun College, tark_hamilton@yahoo.com; HAUSMANN, R. B., Oregon State University, Oregon, USA, hausmanr@ oregonstate.edu; GALER, S., Oregon State University, Oregon, USA, steve. galer82@gmail.com; ROMSOS, C., Oregon State University, Oregon, USA, cromsos@ceoas.oregonstate.edu

Evidence of segmented ruptures along the Cascadia margin comes in the form of correlated turbidites offshore, lacustrine turbidites, and coastal paleoseismic records. Alternatives to segmentation of earthquake frequency have been suggested based on slope stability, sediment supply, and variation in local ground motions. Steeper slopes in S. Cascadia have been suggested as a mechanism to increase turbidite frequency on the southern margin. However, upper canyon slopes are steeper in Washington canyons $\left(15-24^{\circ}\right)$, and cores at the base of the steep reaches contain the same lower frequency records found on low gradient reaches $\left(.5-2^{\circ}\right)$, even those with locally expanded sedimentary sections. Sediment supply could also pertain, given the high sediment load delivered by the Eel River in southern Cascadia. However, core records show that the well-documented high-frequency turbidite record from the Eel system is largely contained between the Mendocino Ridge and the Trinidad Canyon plunge pool and fan. This leaves the turbidite frequency largely unchanged between the Rogue and Trinidad systems, with a slight southward increase. Grain size and proxies show a southward coarsening source, but no evidence of systematic southward increase in bed thickness, with some beds actually thinning southward. Sediment supply and stronger shaking in $S$. Cascadia are thus not likely causes of higher event counts. Vancouver Island records also show no increase in event frequency despite the higher Q (low attenuation) setting similar to that of S. Cascadia. While remote turbidity triggering from distant events has been suggested in Cascadia, the close match with the onshore paleoseismic record over the last 3500 years precludes this mechanism. In addition, lacustrine paleoseismic records closely parallel the southward increase in event bed frequency found offshore, thus increasing event bed frequency remains best explained by southward increase in earthquake frequency in S. Cascadia.

\section{A 6,600-Year Historic and Stratigraphic Record of 9 Giant Megathrust Earthquakes and the Seismic Cycle at the Copper River Delta, Alaska} PLAFKER, G., US Geological Survey, California, USA, gplafker@usgs.gov; HAEUSSLER, P. J., US Geological Survey, Alaska, USA, pheuslr@usgs.gov; WITTER, R. C., US Geological Survey, Alaska, USA, rwitter@usgs.gov; SHERROD, B., US Geological Survey, Washington, USA, bsherrod@usgs.gov

The giant Mw 9.21964 Alaska earthquake was generated by $\geq 25 \mathrm{~m}$ slip on the eastern Aleutian Megathrust that resulted in regional coastal uplift including the Copper River Delta (CRD) that extends $67 \mathrm{~km}$ eastward from Cordova along the Gulf of Alaska coast. Coseismic uplift of $2.2 \pm 0.2 \mathrm{~m}$ in the Alaganic Slough estuary area of the CRD brought a $12 \mathrm{~km}$ wide intertidal zone of mud flats above the highest tide level (HTL) resulting in conversion of mud surfaces to fresh water peat marsh and forest. The base of the peaty soils records the 1964 uplift relative to HTL. Five power auger holes cored to $15 \mathrm{~m}$ depth, archive 8 pre-1964 peat layers $\sim 0.02-35 \mathrm{~cm}$ thick separated by intertidal mud layers $\sim 30-$ $250 \mathrm{~cm}$ thick. Each peat/mud couplet defines a complete earthquake cycle with the base of the peat closest to the "event horizon". Multiple high-precision 14C samples from peat event horizons were used to date and correlate between core holes and to calculate event return intervals (RI's). Our data indicate: (1) The 8 pre-1964 mean event horizons range from $\sim 780$ (E-1) to $\sim 6560$ (E-8) calendar years before present (cybp); (2) The Mw 9.21964 Alaska earthquake (E-0), with coseismic uplift of $2.2 \pm 0.2 \mathrm{~m}$, followed a recurrence interval (RI) of $\sim 780$ cybp; (3) The 7 pre-1964 RI's range from $~ 455-1300$ cybp; (4) Assuming uplift and magnitude scale roughly with RI, uplift per event is $\sim 1.2-2.9 \mathrm{~m}$ (average $\sim 1.5$ $\mathrm{m})$; and magnitudes of the 8 events for which RI's are known range from $\sim \mathrm{Mw}$ 9-9.3; (5) No additional peat beds that reflect coseismic uplift events were found within the Alaganic Slough area stratigraphy; (6) Energy release in this segment of the Aleutian Megathrust is primarily during giant $\mathrm{Mw} \geq 9$ seismic events; (7) Minimum mean RI is $\sim 480$ years and $\mathrm{Mw} \sim 9.05$; and (8) Maximum mean RI is $\sim 1125$ years and $\mathrm{Mw} \sim 9.3$.

\section{The Next Big Earthquake: The Usual and the Unusual Suspects Oral Session · Tuesday 15 May · 10:45 AM • Orchid AB Session Chairs: Sinan O. Akciz and Kate Scharer}

Paleo Earthquakes, Historical-Prehistorical Warnings, Surface Ruptures, and Unsuspected Active Faults in Peru and Ecuador

AUDIN, L., IRD-ISTerre, Grenoble, France, laurence.audin@ird.fr; BENAVENTE ESCOBAR, C. L., INGEMMET, Lima, Peru, cbenavente@ ingemmet.gob.pe; ALVARADO, A., IG-EPN, Quito, Ecuador, aalvarado@ igepn.edu.ec; ZERATHE, S., IRD-ISTerre, Grenoble, France, swann.zerathe@ ird.fr; HALL, S. R., COA, Maine, USA, shall@coa.edu; SAILLARD, M., IRDGeoazur, Nice, France, saillard@geoazur.unice.fr; BAIZE, S., IRSN, Fontenay aux Roses, France, stephane.baize@irsn.fr; JOMARD, H., IRSN, Fontenay aux Roses, France, herve.jomard@irsn.fr

The Andean range stretches for thousands of kilometers from Patagonia to Venezuela and its recent tectonic evolution results from the ongoing subduction of the Nazca plate. Since the 16th century, several crustal M7 did affect the Andean human settlements and this historic fact raises the issue of seismic hazard assessment for the exponentially growing megacities in South America. Indeed, due to the recurrent activity of the megathrust, shallow crustal earthquakes haz- 
ards are underestimated. We present the results of multidisciplinary studies of crustal deformation along newly described fault systems in Peru and Ecuador. High resolution satellite images, geodetic data, georadar, post seismic drone survey and field studies provide striking examples and evidences of the ongoing tectonic deformation that strengthen the observations from the longer-term Quaternary geomorphic record. In northern Ecuador, the Quito Fault extends over $60 \mathrm{~km}$ in the Interandean valley. Geodetic data indicate active shortening rates for Quito blind thrust up to $4 \mathrm{~mm} / \mathrm{yr}$. In the same region, the fault that produced the Ibarra historic earthquake source remains a matter of speculation (M 7), while it fully destroyed Ibarra and caused up to 70,000 casualties around Quito. Similarly in Peru, new direct $10 \mathrm{Be}$ dating of the $50 \mathrm{~km}$-long Purgatorio fault scarp suggest at least a major Mw7 event in the last $1 \mathrm{kyr}$, and the $200 \mathrm{~km}$ long Cordillera Blanca fault displays up to $3 \mathrm{~mm} / \mathrm{yr}$ slip rates for the Holocene but no historical earthquake. For several reasons, crustal fault activity $(<10 \mathrm{~mm}$ $\mathrm{yr}-1$ ) in the Andean forearc is difficult to document by GPS monitoring. The forearc sits above the seismically coupled megathrust, implying that present-day crustal deformation field is dominated by elastic deformation due to the subduction seismic cycle. Thus, the sole opportunity to document active fault activity for risk assessment is provided by tectonic geomorphology and paleoseismic studies on these faults.

\section{Hazards from the Sea: Rupture Scenarios for the San Diego Trough and San Pedro Basin Fault Systems, Offshore Southern California}

BORMANN, J.M., CSU, Long Beach, California, USA, jayne.bormann@csulb. edu; RUHL, C. J., UC Berkeley, California, USA, cruhl@ berkeley.edu; KENT, G. M., Nevada Seismological Laboratory, University of Nevada, Reno, Nevada, USA, gkent@unr.edu; DRISCOLL, N.W., Scripps Institution of Oceanography, UC San Diego, California, USA, ndriscoll@ucsd.edu

Determining where the next big Southern California earthquake may occur is complicated by the number of faults that cut the region and challenges associated with having many of these faults lie underwater. The hazard posed by submarine strike-slip faults for coastal populations in Southern California is poorly characterized and may be underappreciated as the structural relationships between faults may allow ruptures to propagate between systems. Recent marine geophysical investigations on the San Diego Trough (SDT) and the San Pedro Basin (SPB) faults demonstrate that these two northwest striking, right-lateral faults are separated by a gap of $<5 \mathrm{~km}$. Individual rupture scenarios for the SDT and SPB fault systems (https://earthquake.usgs.gov/scenarios/catalog/bssc2014/) include a M 7.3 event on the southern SDT fault, a M 7.3 event on the northern SDT fault, and a M 7.1 event on the SPB fault. A complete rupture of all three segments would extend offshore from Ensenada, Mexico to Los Angeles, California with a length $\geq 330 \mathrm{~km}$. Scaling relationships indicate that a strike-slip rupture of this length has the potential to produce a M 7.7-7.9 event. Combining individual rupture Shakemap scenarios with coastal population data suggests that $\geq 12,500,000$ people would be exposed to strong (MMI VI) shaking in an end-to-end rupture, with the strongest shaking in Ensenada and the Los Angeles Basin. At present, the paleoseismic histories of both faults are unknown. Here, we present observations from on-going submarine paleoseismic investigations using CHIRP and multichannel seismic reflection sub-bottom profiles, multibeam bathymetric data, and coring surveys to characterize recent earthquakes on the SDT and SPB fault zones. We use these constraints to evaluate the potential for rupture that spans both systems, and we will perform detailed shaking analysis for coastal communities in northwestern Baja California and Southern California based on multi-segment rupture scenarios.

Lidar Reveals New Geomorphic Evidence of Shaking and Slip on the Reelfoot Fault in the New Madrid Seismic Zone, Western Tennessee, U.S.A.

DELANO, I. E., US Geological Survey, Colorado, USA, jdelano@usgs.gov; GOLD, R.D., US Geological Survey, Colorado, USA, rgold@usgs.gov; BRIGGS, R. W., US Geological Survey, Colorado, USA, rbriggs@usgs.gov; DUROSS, C. B., US Geological Survey, Colorado, USA, cduross@usgs.gov; JIBSON, R. W., US Geological Survey, Colorado, USA, jibson@usgs.gov

The New Madrid Seismic Zone (NMSZ) is a major source of intraplate seismicity in eastern North America. Despite a sequence of major $(M \geq 7)$ earthquakes in 1811-1812 in the region, the paleoseismic record and surface expression of faulting is poorly preserved because of extensive agricultural activity and the humid subtropical climate. Recently collected 0.5 - and 1-m-resolution aerial lidar along the Chickasaw Bluffs in western Tennessee provide a new opportunity to evaluate geomorphic evidence of past earthquakes. Lidar-derived digital elevation models reveal a series of nested grabens that we interpret as sackungen (gravitational ridgetop spreading features) along the bluffs in the NMSZ. We mapped the distribution and orientation of sackungen along $\sim 170 \mathrm{~km}$ of the bluffs and find that sackungen only occur close $(<15 \mathrm{~km})$ to the Reelfoot thrust fault despite nearly homogenous regional bluff geology and relief. Additionally, sackungen appear preferentially oriented either parallel or normal to nearby fault trends. We interpret these relationships to indicate that the sackungen record earthquakes on nearby faults. These results are consistent with a companion trenching study of one of these sackungen. We also used lidar data to map evidence for the southern extension of the Reelfoot fault across the Obion River valley. The projection of the Reelfoot fault trace coincides with pronounced valley narrowing and high terrace remnants at the valley mouth, which could reflect downstream uplift. Additionally, the $\sim 25 \mathrm{ka}$ Finley terrace records $\sim 2 \mathrm{~m}$ of warping over $\sim 200$ $\mathrm{m}$, consistent with reverse motion on the fault. Locations of these features are consistent with seismic-reflection surveys elsewhere along the fault and a history of Obion valley damming. Together, these results present new opportunities to expand the paleoseismic record and use geomorphology to constrain the location and potential rupture length of the Reelfoot fault.

Paleoseismic Investigation of Sackung Features Extends the Late Quaternary Earthquake Record along the Reelfoot Fault, New Madrid Seismic Zone, U.S.A.

GOLD, R. D., US Geological Survey, Colorado, USA, rgold@usgs.gov; DUROSS, C. B., US Geological Survey, Colorado, USA, cduross@usgs.gov; JIBSON, R. W., US Geological Survey, Colorado, USA, jibson@usgs.gov; BRIGGS, R. W., US Geological Survey, Colorado, USA, rbriggs@usgs.gov; DELANO, J. E., US Geological Survey, Colorado, USA, jdelano@usgs.gov; MAHAN, S. A., US Geological Survey, Colorado, USA, smahan@usgs.gov; WILLIAMS, R. A., US Geological Survey, Colorado, USA, rawilliams@usgs. gov

Three sequences of earthquakes (1811-1812 AD, 1450 AD, and 900 AD) are widely recognized and well documented in the New Madrid Seismic Zone of the central U.S. The relatively short, $<550 \mathrm{yr}$, recurrence interval between these earthquakes contributes significantly to seismic hazard assessment in the region; however, it is unknown whether or not this recurrence interval has been constant throughout the late Quaternary. Extending the paleoseismic record beyond the most recent millennium has proven challenging given limited geomorphic, structural, and sedimentary evidence of prior earthquakes. We extend the record of paleoearthquakes along the Reelfoot fault by focusing on ground cracks related to ridge-top spreading, interpreted as sackungen. The sackungen occur along the bluffs above the eastern margin of the Mississippi River floodplain and are concentrated near $(<15 \mathrm{~km})$ the southeast-dipping Reelfoot reverse fault. We excavated a paleoseismic trench across sackungen at the Paw Paw site, which exposed four packages of colluvial sediment that postdate 30-13 ka Peoria loess. We interpret the colluvial packages to have been deposited following episodic opening/failure of the sackungen as a result of strong ground motions. Radiocarbon and luminescence dating, along with $\mathrm{Pb}$-Cs analyses, constrain the ages of the colluvial packages, which correspond to previously documented earthquakes, as well as an older earthquake at 3230-100 BC. If the sackungen have recorded all major earthquakes associated with the Reelfoot fault, then only four earthquakes have occurred along this fault since deposition of the Peoria Loess (since $\sim 13 \mathrm{ka}$ ), suggesting a long period of quiescence along the Reelfoot fault, with only a single early-to-mid Holocene earthquake. In contrast, the most recent millennium has been punctuated by an episode of clustered, major seismic events. This result has important implications for seismic-hazard and geodynamic modeling in the New Madrid Seismic Zone.

A 2000 Year Lacustrine Paleoseismic Record on the Peninsular Segment of the Northern San Andreas Fault at Lake Merced, San Francisco

GOLDFINGER, C., Oregon State University, Oregon, USA, gold@oce.orst. edu; HAUSMANN, R. B., Oregon State University, Oregon, USA, hausmanr@ oregonstate.edu; BLACK, B., Oregon State University, Oregon, USA, bran. black3125@gmail.com; BEESON, J., Oregon State University, Oregon, USA, jeff3467@gmail.com; REIDY, L., UC Berkeley, California, USA, Lreidy@ berkeley.edu

The Peninsula section of the San Andreas Fault is an obvious and significant hazard to San Francisco and peninsula cities, however the history past events on the SAF on the peninsula is poorly known. We opened a paleoseismic site at Lake Merced, within the city of San Francisco. The lake may be an asymmetrical pullapart basin with the NSAF system. We conducted a coring and geophysical investigation to test the site for its potential for development of a long-term earthquake history. We collected four main long cores of 5-7 meters, and 4 overlapping cores. The lake has a record of turbidites that dominate the 3-4 m lacustrine gyttja section, overlying a sharp contact with shelly-sandy estuarine material below. The lake record above the contact includes 15 turbidites spanning $\sim 2000$ years. The turbidites for the most part have sharp bases, some with load features, and fining upward sequences that can be correlated around the lake. Their individual 
thicknesses show little relation to stream input. Breaching of the spit at the north end of the lake has occurred in historic times, but appears to have drained the lake without open access to the sea, suggesting the event beds are not externally sourced. Radiocarbon dating thus far shows the uppermost 2 events to include bomb carbon, and occurred in $1955-57$ and 1976-1996. These two beds may relate to a local earthquake near the lake in 1957, and the Loma Prieta earthquake of 1989. The third event is thick, and has a model age of 1890 (1860-1930), likely the 1906 event, supported by anthropogenic Pb content. Events dated at 1720 , and $~ 1580$ underlie the 1906 bed, similar in age to those reported for the penultimate events on the North Coast and Peninsular NSAF segments respectively. The remaining event bed ages appear mostly compatible with turbidites at Noyo Canyon, and the Vedanta Marsh, suggesting that likely 6 and possibly 11 North Coast segment ruptures extended to the Peninsula segment.

\section{Numerical Modeling of Earthquake Ground Motion, Rupture Dynamics and Seismic Wave Propagation Oral Session · Tuesday 15 May · 8:30 AM • Brickell Session Chairs: Peter Moczo, Steve M. Day, and Jozef Kristek}

\section{A Computational Model of the Seismic Response in the Valley of Mexico after the Damaging M 7.1 Earthquake of September 19, 2017 \\ CRUZ-ATIENZA, V. M., Instituto de Geofísica, Universidad Nacional Autónoma de México, Mexico City, Mexico, cruz@geofisica.unam.mx; VILLAFUERTE, C. D., Instituto de Geofísica, Universidad Nacional Autónoma de México, Mexico City, Mexico, villafuerte.cd@gmail.com; TAGO, J., Facultad de Ingenieria, Universidad Nacional Autónoma de México, Mexico City, Mexico, josue.tago@gmail.com; CHALJUB, E., Institut des Sciences de la Terre, Grenoble, France, emmanuel.chaljub@univ-grenoble-alpes.fr; SANABRIA- GOMEZ, J. D., Universidad Industrial de Santander, Bucaramanga, Colombia, jsanabri@gmail.com}

Built-up on top of ancient lake deposits, Mexico City experiences some of the largest seismic site effects in the world. The M7.1 intermediate-depth earthquake of September 19, 2017 (S19) collapsed 43 one-to-ten story buildings in the city close to the western edge of the lake-bed sediments, on top of the geotechnicallyknown transition zone. In this work we explore the physical reasons explaining such a damaging pattern and the long-lasting strong motion records well documented from past events by means of new observations and high performance computational modeling. Besides the extreme amplification of seismic waves, duration of intense ground motion in the lake-bed lasts more than three times those recorded in hard-rock a few kilometers away. Different mechanisms contribute to the long lasting motions, such as the regional dispersion and multiplescattering of the incoming wavefield all the way from the source. However, recent beamforming observations at hard-rock suggest that duration of the incoming field is significantly shorter than the strong shaking in the lake-bed. We show that despite the highly dissipative shallow deposits, seismic energy can propagate long distances in the deep structure of the valley, promoting also a large elongation of motion. Our 3D simulations reveal that the seismic response of the basin is dominated by surface-waves overtones, and that this mechanism increases the duration of ground motion up to $280 \%$ and $500 \%$ of the incoming wavefield duration at 0.5 and $0.3 \mathrm{~Hz}$, respectively. Furthermore, our results indicate that the damage pattern of the $S 19$ earthquake is most likely due to the propagation of the fundamental mode in the transition zone of the basin generated as a consequence of a localized basin edge effect. Some conclusions contradicts what has been previously stated from observational and modeling investigations, where the basin itself has been discarded as a preponderant factor promoting long and devastating shaking in Mexico City. Reference: Cruz-Atienza, V. M., J. Tago, J. D. Sanabria-Gómez, E. Chaljub, V. Etienne, J. Virieux and L. Quintanar. Long Duration of Ground Motion in the Paradigmatic Valley of Mexico. NatureScientific Reports, 6, 38807; doi:10.1038/srep38807, 2016.

\section{A Unified Discrete Representation of the Elastic, Viscoelastic, and Poroelastic Interface and Strong Material Heterogeneity in the Finite-Difference Modeling of Seismic Wave Propagation}

MOCZO, P., Comenius University in Bratislava and Slovak Academy of Sciences, Slovakia, moczo@fmph.uniba.sk; GREGOR, D., Comenius University in Bratislava, Slovakia, gregor28@uniba.sk; KRISTEK, J., Comenius University in Bratislava and Slovak Academy of Sciences, Slovakia, kristek@fmph.uniba.sk

Moczo et al. (2002, 2014), Kristek \& Moczo (2003) and Kristek et al. (2017) developed the discrete representation of a strong discontinuous and smooth material heterogeneity in the elastic and viscoelastic media suitable for the finite-difference modelling of seismic wave propagation and earthquake ground motion. The representation is capable of sub-cell resolution and "sensing" an arbitrary shape and position of the interface in the grid. Extensive tests in canonical and complex realistic models confirmed accuracy and computational efficiency of the representation. With the proper discrete representation of material heterogeneity the most advanced finite-difference schemes can be more efficient in case of local surface sedimentary structures than the spectral-element and discontinuous-Galerkin methods (e.g., Chaljub et al. 2010, 2015; Maufroy et al. 2015). Is such a discrete representation possible also in the considerably mathematically and physically more complex poroelastic medium with larger number and more complex constitutive and governing equations? Yes, it is possible. We have developed a new discrete representation of the discontinuous and continuous material heterogeneity of the poroelastic medium. In our representation the stiffness matrix of the averaged medium has the same structure as the stiffness matrix for a smoothly heterogeneous medium but sufficiently accurately approximates boundary conditions at the interface. The same structure means that the number of algebraic operations in calculating stress and pressure is the same as in the smoothly heterogeneous poroelastic medium. We demonstrate the accuracy and the sub-cell resolution using a set of canonical configurations. We compare our seismograms with those calculated by the exact method developed by Diaz \& Ezziani (2008). We also compare our seismograms with those obtained with an independent numerical method for a structurally complex model.

\section{Numerical Simulation of M9 Megathrust Earthquakes in the Cascadia Subduction Zone}

ROTEN, D., San Diego State University, California, USA, droten@mail.sdsu. edu; OLSEN, K. B., San Diego State University, California, USA, kbolsen@ mail.sdsu.edu; TAKEDATSU, R., San Diego State University, California, USA, rtakedatsu@mail.sdsu.edu

We estimate ground motions in the Pacific Northwest urban areas during M9 subduction scenario earthquakes on the Cascadia megathrust by simulating wave propagation from an ensemble of kinematic source descriptions. Velocities and densities in our computational mesh are defined by integrating the regional Cascadia Community Velocity model (V1.6, Stephenson et al., 2017) including the ocean water layer with a local velocity model of the Georgia and Seattle basins (Molnar et al., 2011) including additional near-surface velocity information. We generate six source realizations, each consisting of a background slip distribution with correlation lengths, rise times and rupture velocities consistent with data from previous megathrust earthquakes (e.g., 2011 M 9 Tohoku or 2010 M 8.8 Maule). We then superimpose $\mathrm{M} \sim 8$ subevents, characterized by short rise times and high stress drops on the background slip model to mimic high-frequency strong ground motion generation areas in the deeper portion of the rupture (Frankel, 2016). The wave propagation is simulated using the discontinuous mesh (DM) version of the AWP finite difference code. We simulate frequencies up to $1.25 \mathrm{~Hz}$, using a spatial discretization of $100 \mathrm{~m}$ in the fine grid, resulting in surface grid dimensions of $6,540 \times 10,728$ mesh points. At depths below $8 \mathrm{~km}$, the grid step increases to $300 \mathrm{~m}$. We obtain stable and accurate results for the DM method throughout the simulation time of 7.5 mins as verified against a solution obtained with a uniform $100 \mathrm{~m}$ grid spacing. Peak ground velocities range between 60 and $80 \mathrm{~cm} / \mathrm{s}$ in downtown Seattle and between 25 and $34 \mathrm{~cm} / \mathrm{s}$ in downtown Vancouver, while spectral accelerations at $2 \mathrm{~s}$ range between 1.7 and $3.6 \mathrm{~m} / \mathrm{s} 2$ and 1.0 and $1.3 \mathrm{~m} / \mathrm{s} 2$, respectively. These long-period ground motions are not significantly reduced if plastic Drucker-Prager yielding in shallow cohesionless sediments is taken into account. Broadband synthetics $(0-10 \mathrm{~Hz})$ are generated by a hybrid technique.

\section{Can Triggered and Induced Earthquakes be Supershear Rupture Events? A Numerical Investigation}

IIN, L., Stanford University, California, USA, leijin@stanford.edu; ZOBACK, M. D., Stanford University, California, USA, zoback@stanford.edu

Fluid plays a pivotal role in triggering and inducing seismic events. However, the effect of fluid on the co-seismic rupture process remains largely unknown. To this end, we develop a fully dynamic spontaneous rupture model specific for fluid-related seismic events. Central to our model is the consideration of the fluid effect that accumulates over the previous quasi-static phase until the onset of rupture. This effect is resolved in two manners, including a fluid-solid decoupled approach and fluid-solid fully coupled poroelastic approach. Correspondingly, the resulting fault fluid pressure and poroelastic stress at their respective time of rupture onset is passed to the dynamic model via the fault boundary condition that follows a slip-weakening law. Under the assumption of an undrained coseismic fluid-solid system, we then discretize the fully dynamic Cauchy equation of motion using a split-node finite element method in space and a fully implicit Newmark family finite difference method in time; a fully implicit NewtonRaphson scheme is implemented iteratively for linearizing the nonlinear equa- 
tion within each time step, and a novel non-stationary preconditioner is designed to accelerate the convergence of a selected iterative linear solver. Using the above computational model, we perform several numerical experiments. Triggered and induced seismic events are simulated by designing different fault initial stress in relation to its peak and residual strength. The results suggest that, (1) both triggered and induced seismic events can undergo a supershear rupture process with a rupture velocity near the $\mathrm{P}$-wave velocity, owing to a reduced seismic ratio due to the fluid effect, (2) compared to a tectonic earthquake, triggered and induced seismic events are associated with radically different wave fields, and (3) in the coupled approach, the wave field can also become asymmetric due to different poroelastic stress on the two sides of the fault at the onset of rupture.

Developments in Propagation of Seismic Waves with the Generalized Finite Difference Method: Application at Interfaces

UREÑA, M., Universidad Nacional de Educación a Distancia, Madrid, Spain, miguelurenya@gmail.com; SALETE, E., Universidad Nacional de Educación a Distancia, Madrid, España, esalete@ind.uned.es; BENITO, J. J., Universidad Nacional de Educación a Distancia, Madrid, España, jbenito@ind.uned.es; UREÑA, F., Universidad Nacional de Educación a Distancia, Ciudad Real España, furenaprieto@gmail.com; GAVETE, L., Universidad Politécnica de Madrid, Madrid, España, lu.gavete@upm.es

The meshless generalized finite difference method is applied to solve the problem of seismic wave propagation. Schemes in generalized finite differences are obtained for the decoupled system P-SV and SH in homogeneous media and its stability is analyzed. Heterogeneous schemes in generalized finite difference for heterogeneus media, made up of different layers or subdomains are also obtained, considering a linear variation of the parameters at the interfaces. As the method allows using an irregular distribution of nodes, the order of approximation is preserved. Several examples are presented to show the accuracy of the proposed methodology.

Influence of Normal Pressure on the Stick-Slip Behavior of Sheared Granular Fault Gouge Using the Combined Finite-Discrete Element Method

GAO, K., Los Alamos National Laboratory, New Mexico, USA, kegao@lanl.gov; ROUGIER, E., Los Alamos National Laboratory, New Mexico, USA, erougier@ lanl.gov; EUSER, B. J., Los Alamos National Laboratory, New Mexico, USA, beuser@lanl.gov; GUYER, R. A., Los Alamos National Laboratory, New Mexico, USA, guyer@physics.umass.edu; JOHNSON, P. A., Los Alamos National Laboratory, New Mexico, USA, paj@lanl.gov; ZHOU, L., Los Alamos National Laboratory, New Mexico, USA, zlei@lanl.gov; KNIGHT, E. E., Los Alamos National Laboratory, New Mexico, USA, knighte@lanl.gov

The presence of randomly packed solid granular particles in fault gouge has considerable influence on the slip properties of tectonic faults. As a result, sheared granular layers undergoing stick-slip behavior are broadly employed to study the physics and dynamics of earthquakes (Geller et al., 2015; Johnson et al., 2008; Scuderi et al., 2017). Among the many numerical simulations of granular systems, the discrete element method (DEM) has been the one that is most frequently used to study the stick-slip behavior in granular fault gouge (Dorostkar et al., 2017; Ferdowsi, 2014). However, within the DEM framework, it is difficult to explicitly and precisely capture the deformation and stress distribution inside each individual particle. Here, a two-dimensional implementation of the combined finite-discrete element method (FDEM), which merges the finite element method (FEM) and the discrete element method (DEM), is used to explicitly simulate a sheared granular fault system. In the FDEM model, the deformation of plates and particles is simulated using the FEM formulation while particle-particle and particle-plate interactions are modeled using DEM-derived techniques. By employing the FDEM, we have investigated the influence of normal pressure on the stick-slip behavior of the granular fault gouge in terms of macroscopic friction coefficient, kinetic energy, gouge layer thickness, and recurrence time between slips. The simulation results show that the kinetic energy of the granular fault gouge system increases with increasing normal pressure, while the gouge layer thickness shows a decreasing trend and the macroscopic friction coefficient does not witness much change. Further analyses of the slip events reveal that as the normal pressure increases, more slip events with large kinetic energy release and long recurrence time occur, and the magnitude of gouge layer thickness drop also tends to be larger; while the macroscopic friction coefficient drop is getting smaller. The simulations not only reveal the behavior of stick-slip dynamics in granular fault gouge, but also demonstrate the capabilities of FDEM for studying stick-slip type behavior of granular fault gouge system.
EDGE: Towards Extreme-Scale Nonlinear Earthquake Simulations BREUER, A., UC San Diego, California, USA, anbreuer@ucsd.edu; HEINECKE, A., Intel Corporation, California, USA, alexander.heinecke@ intel.com; CUI, Y., SDSC, California, USA, yfcui@sdsc.edu

We present the status of recent and ongoing extensions to the Extreme-scale Discontinuous Galerkin Environment (EDGE) for seismic wave propagation. EDGE uses the Discontinuous Galerkin (DG-) Finite Element Method (FEM) to solve hyperbolic partial differential equations. EDGE targets seismic model setups with high geometric complexity and extreme-scale ensemble simulations, using beyond 500,000 computer cores. Exploitation of inter-simulation parallelism allows the software to reach significantly higher simulation throughput over traditional, isolated approaches. First, we present the status of EDGE's extension with a robust and accurate sub-cell finite volume limiter. Borrowing from recent developments in fluid and gas dynamics, this work overcomes limitations of EDGE's pure high-order DG-FEM-solver, e.g., spurious oscillations, in the presence of large gradients. Our sub-cell limiter temporarily subdivides "troubled" elements into a set of sub-cells and uses a robust finite volume solver to advance the solution on the sub-cell level. As an example, we showcase our limiter's performance, when applied to nonlinear rupture dynamics. Shock propagation, including the rupture tip, at the sub-cell level and support for arbitrary, unstructured meshes are key advantages of this approach. The second part of our presentation demonstrates EDGE's performance for the Deep Learning architecture Knights Mill. The rise of Deep Learning accelerated the path towards a lowered balance between memory and compute, as well as lowered precision in compute. First, our results show, that we are able to reduce EDGE's precision from double to single precision without loosing accuracy in established wave propagation benchmarks. Second, through kernel-optimizations, we are able to harvest Knights Mill's single precision deep-learning performance for traditional HPC. EDGE is available from http://dial3343.org.

\section{Modeling of Seismic Liquefaction Effects on Structure in the City of Medellin, Colombia}

MONTOYA-NOGUERA, S., Universidad EAFIT, Medellín, Colombia, smontoyan@eafit.edu.co; LOPEZ-CABALLERO, F., CentraleSupélec, France, fernando.lopez-caballero@centralesupelec.fr

In the last decade, a number of studies have been published on the seismic site response and the importance of site effects at the greater metropolitan area of Medellín in the Aburrá Valley, a seismically active region of the Colombian Andes. Most studies have focused on the topographic effect and the effect of the contrasts in the shear-wave velocity structure. In the central portion of the valley, along the Medellín River, broad alluvial deposits are found varying between 3 and $200 \mathrm{~m}$ in depth. Thick shallow sand layers have been found in these deposits, which combined with reported shallow water table; indicate high risk of seismic liquefaction. A typical building of Medellín standing on saturated liquefiable soil deposit is modeled taking into account both soil nonlinearity due to seismic liquefaction and soil-structure interaction. For this purpose, a fully coupled nonlinear model is used to represent the soil behavior. Additionally, an approximation of the effect of the soil on the structure's response via simplified relationship is used. The effect of variability of the shear-wave velocity profiles and of the shear modulus degradation curves on the structure's performance is investigated. The results identify and quantify the effects of seismic liquefaction on structures, highlighting the importance of its modelling in the city of Medellín.

\section{Strong Motion Simulation for the 2004 Southwest-0ff Kii Peninsula} Earthquake with Pseudo Point-Source Model

NOZU, A., Port and Airport Research Institute, Kanagawa, Japan, nozu@pari. go.jp

We have been testing the applicability of a new simplified source model called the "pseudo point-source model,"which was aimed to calculate strong ground motions (Nozu 2012). The model is simpler, and involves much less model parameters than the conventional characterized source model, which itself is a simplified expression of an actual earthquake source. In the model, the spatio-temporal distribution of slip within a subevent is not modeled. Instead, the source spectrum associated with the rupture of a subevent is modeled and it is assumed to follow the omega-square model. By multiplying the source spectrum with the path effect and the site amplification factor, the Fourier amplitude at a target site can be obtained. Then, combining it with Fourier phase characteristics of a smaller event, the time history of strong ground motions from the subevent can be calculated. Finally, by summing up contributions from the subevents, strong ground motions from the entire rupture can be obtained. In this study, the model was applied to the main shock of the 2004 southwest-off Kii Peninsula earthquake (Mw7.4), which occurred on September 5, 2004, $23: 57$ (JST) near the Nankai 
Trough, within the subducting Philippine Sea plate (e.g., Park and Mori 2005; Bai et al. 2007). Because of its location, strong motion records obtained during the earthquakes are suitable for the validation of strong motion simulation techniques. The pseudo point-source model for the earthquake was developed by appropriately locating point sources on the fault plane, based on the results of the waveform inversion. Then the model was used to simulate strong ground motions in a wide region. It was found that, when the model is used with an appropriate path model, it can accurately simulate strong ground motions at remote stations, even when the stations are located on deep sedimentary basins such as the Osaka, Nobi and Kanto plains.

\section{Kinematic Source Models for Earthquake Simulations with Fault-Zone Plasticity}

HU, Z., San Diego State University/UC San Diego, California, USA, zhh076@ ucsd.edu; ROTEN, D., San Diego State University, California, USA, droten@ mail.sdsu.edu; OLSEN, K. B., San Diego State University, California, USA, kbolsen@mail.sdsu.edu; DAY, S. M., San Diego State University, California, USA, sday@mail.sdsu.edu

Fault slip and surface deformation patterns are essential factors in seismic hazard assessment. However, slip inversions reveal a widely observed shallow slip deficit (SSD) which has not yet been clearly explained. One possible cause of the SSD is distributed plastic deformation in the fault damage zone near the surface. Roten et al. (2017) performed 3D dynamic rupture simulations of the 1992 M7.3 Landers earthquake in a medium governed by Drucker-Prager plasticity. The study showed that while linear simulations tend to underpredict SSD and offfault deformation (OFD), nonlinear simulations with moderately fractured rock mass can properly reproduce results that are consistent with the 30-60\% SSD and around $46 \%$ OFD reported in geodetic observations. Analysis of the Roten et al. (2017) results show that discrepancies between linear and nonlinear simulations are only significant in the top hundreds of meters of the surface-rupturing fault. Although inelastic responses in the fault damage zone provide more realistic representations of earthquake physics, it can be computationally expensive or numerically unfeasible (e.g., in adjoint methods) to include nonlinear effects in ground motion simulations. One solution proposed here is to use an equivalent kinematic source (EKS) model that mimics the fault-zone plastic effects. This method generates source-time-functions by modifying the slip rate time histories based on comparisons of linear and non-linear dynamic rupture models, which are then used as input to kinematic simulations. The EKS model is shown to capture the SSD and OFD patterns observed in dynamic simulations with fault-zone plasticity. Further verification of the method is needed before the anticipated use in practical applications such as the Southern California Earthquake Center (SCEC) CyberShake and Broadband platforms.

\section{Onshore Quaternary and Contemporary Tectonics: Implications for Seismic Hazards} Oral Session · Tuesday 15 May · 8:30 AM • Orchid AB Session Chairs: Lucille Piety and Joanna Redwine

\section{Quaternary Faults in the Vicinity of Puerto Rico and the Virgin Islands and Their Seismic Hazard}

TEN BRINK, U.S., US Geological Survey, Massachusetts, USA, utenbrink@ usgs.gov; CHAYTOR, J. D., US Geological Survey, Massachusetts, USA, jchaytor@usgs.gov

Multibeam bathymetry, high-resolution seismic reflection, ROV dives, historical earthquake analysis, GPS data, and stress models help guide the identification of Quaternary faults in the vicinity of Puerto Rico and the Virgin Islands (VI). Large historical earthquakes and tsunamis, although not well located on specific faults, nevertheless attest to seismic hazard from Mona and Anegada passages. Mona Passage west of Puerto Rico is characterized by distributed faulting that may extend onto the SW corner of the island, and is indicative of an oblique NE-SW extension. Anegada Passage east of Puerto Rico and south of the VI, exhibits a more complex and little understood pattern of faulting. Much of the extreme bathymetric variations there may be a relic of an older tectonic regime, preserved due to very low sedimentation rates. Much of the Quaternary sedimentary cover in both passages has also been removed by strong oceanographic currents, limiting our ability to estimate the motion on individual faults. The north shores of the islands and their proximal slopes appear to be devoid of large faults. Distally, however, the strike-slip Bunce Fault and other strike-slip and thrust faults associated with the oblique subduction of the Main aseismic ridge are likely recent features. The left-lateral component of the highly-oblique North America plate subduction is probably accommodated by the Bunce Fault, by oblique earthquake slip, and/or by aseismic slip, rather than by faults closer to shore or on land. The Investigator Fault System south of Puerto Rico is perched at the top of a steep slope $\sim 10 \mathrm{~km}$ from shore. Although the fault trace is linear, we did not identify evidence of lateral motion. Compressive deformation associated with the Muertos Fault at the base of the slope decreases progressively eastward. Despite Quaternary faults being generally located away from the islands, the islands are vulnerable to strong shaking because of the relatively low crustal attenuation.

\section{A Study of Seismic Hazard in Peru}

AGUINDA, C. R., PUC-RIO, Rio de Janeiro, Brasil, carloder.1@ hotmail.com; CELSO ROMANEL, C. R., PUC-RIO, Rio de Janeiro, Brasil, celso.romanel@ gmail.com

This research presents the study of seismic hazard for the territory of Peru. Seismic hazard is a probability that a very strong earthquake can happen in an area and in a certain number of years, with a level of seismic intensity that can exceed or can't exceed. To do the study one needs seismic sources, laws of attenuation, an analysis that takes into account all possibilities and combines the information in a result. The main objective is to quantify the exceedance probability rate for several levels of seismic acceleration with different periods of spectral acceleration to investigate the dynamic behavior of civil works. The parameters of the seismic sources are updated until 2016 by previous studies, where there are 6 sources of subduction interface, 14 sources of intraplate subduction and 9 continental sources, characterizing each source according to the distribution of doubly truncated Gutenberg-Richter. The a attenuation laws used in this research are the same ones that were used in the SENCICO web application developed with a software CRISIS2015 and incorporated through a logical tree with their respective weights for each attenuation laws. A probabilistic seismic hazard analysis (PSHA) will be done with open source software called OPENQUAKE developed by the Global Earthquake Model. The best tool of thi software is the sensitivity of the model is tested by changing the various parameter like hazard input model, calculation parameters. The results obtained will be all combinations with attenuation laws between different types of seismic sources for different levels of exceedance and different spectral accelerations.

\section{Marine Terraces and Quaternary Tectonic Uplift in Puerto Rico}

PRENTICE, C. S., US Geological Survey, California, USA, cprentice@usgs. gov; MUHS, D. R., US Geological Survey, Colorado, USA, dmuhs@usgs.gov; SIMMONS, K. R., US Geological Survey, Colorado, USA, ksimmons@usgs.gov; SCHUMANN, R., US Geological Survey, Colorado, USA, rschumann@usgs. gov; JOYCE, J., University of Puerto Rico, Mayagüez, Puerto Rico, USA, james. joyce@upr.edu

Marine terrace deposits associated with both the last-interglacial (LIG) and with apparent Holocene ages occur along the northern, northwestern, and southern coasts of Puerto Rico. We collected samples of fossil coral for U-series dating from eight localities around Puerto Rico, including nearby Isla de Mona, and Isla Desecheo, and Holocene marine fossils for radiocarbon and U-series dating from five localities around Puerto Rico. Ages of LIG samples range from $127 \mathrm{ka}$ to 113 $\mathrm{ka}$. Corals in growth position associated with the LIG occur at elevations that, when corrected for habitat depth, suggest apparent paleo-sea levels of $5-7.5 \mathrm{~m}$ above modern sea level. Notches and transported LIG corals occur at elevations of about $12 \mathrm{~m}$ above modern sea level. These results indicate slow long-term tectonic uplift rates for Puerto Rico, $<0.1 \mathrm{~m} / \mathrm{ka}$. A wave-cut paleoshoreline about 3-4 m above modern sea level is preserved near Salinas and near Patillas along the southern coast of Puerto Rico. Marine fossils collected from deposits below the paleoshoreline yield Holocene radiocarbon and U-series ages, suggesting the paleoshoreline is associated with a Holocene marine terrace. Holocene marine fossils (dated by $14 \mathrm{C}$ ) and paleoshorelines are also found at a height of about 3-5 $m$ above modern sea level in northwestern Puerto Rico, near Añasco, Rincón, and Maleza Alta. One hypothesis to explain the observations of both the LIG and Holocene marine terraces is the occurrence of infrequent uplift events in the last $\sim 120 \mathrm{ka}$, with one or more uplift events occurring during the Holocene. Large, infrequent earthquakes on the Puerto Rico trench and/or the Muertos trench could explain the observed elevations and ages of marine terraces deposits along the Puerto Rican coast. Alternative hypotheses for the occurrence of Holocene marine fossils include tsunami deposits and/or storm-surge deposits; however, these do not explain the presence of stranded wave-cut shorelines.

\section{Holocene Surface Rupture on the Salinas Fault and the Southeast Great Southern Puerto Rico Fault Zone and Implication for Seismic Hazard Assessments}

PIETY, L. A., Bureau of Reclamation, Colorado, USA, Ipiety@usbr.gov; REDWINE, J. R., Bureau of Reclamation, Colorado, USA, jredwine@usbr. gov; PRENTICE, C. S., US Geological Survey, California, USA, cprentice@ 
usgs.gov; DEROUIN, S. A., Bureau of Reclamation, Colorado, USA, sarah. derouin@gmail.com; KELSON, K. I., US Army Corps of Engineers, California, USA, keith.i.kelson@usace.army.mil; KLINGER, R. E., Bureau of Reclamation, Colorado, USA, rklinger@usbr.gov; MAHAN, S. A., US Geological Survey, Colorado, USA, smahan@usgs.gov

We excavated two trenches across topographic scarps on the Puerto Rico southern coastal plain: one across the west-striking Salinas fault and one across the northwest-striking Great Southern Puerto Rico fault zone (GSPRFZ). For the Salinas fault, topographic scarps are primarily south-facing and extend $\geq 22 \mathrm{~km}$ along hills several kilometers inland from the coast between Río Nigua and the city of Ponce. In contrast, topographic scarps along the southeast $8 \mathrm{~km}$ of the GSPRFZ face northeast and southwest. Based on stratigraphic relationships dated by optically stimulated luminescence and radiocarbon analyses, we interpret two surface-rupturing earthquakes on the Salinas fault in the past 20,000 years, and likely in the past 7400 to 10,400 years. Based on similarities in stratigraphy and soil development, but no numerical ages, we interpret that two surfacerupturing earthquakes on the southeast GSPRFZ also may have occurred in the past 20,000 years. The Salinas fault roughly aligns with the South Lajas fault that extends from the west coast of Puerto Rico into the hills west of Ponce. The last two surface-rupturing earthquakes on the South Lajas fault occurred in the past about 7000 to 7500 years. These results suggest the possibility that the southern coastal plain of Puerto Rico is traversed by a series of west-striking faults (e.g., Salinas, Lajas), which may or may not be continuous and kinematically linked, that these faults are distinct from the northwest-striking GSPRFZ, and that the eastern end of the Salinas fault approaches the GSPRFZ obliquely near the southeastern corner of the island. Although there is incomplete knowledge of faults on the southern coastal plain, reasonable scenarios for the rupture lengths, senses of slip, and timing of large earthquakes can be developed for probabilistic seismic hazard analyses of engineered facilities (e.g., bridges, dams, buildings).

\section{Active Plate Tectonics and Main Fault Systems in Colombia: An Updated Model for 3D Fault Geometries and Magnitudes}

TOBÓN LÓPEZ, A.M., Universidad de los Andes, Colombia, am.tobon2895@ uniandes.edu.co; HERRERA GARCÍA, D. C., Universidad de los Andes, Colombia,dc.herrera745@uniandes.edu.co; YAMIN, L. E., Universidad de los Andes, Colombia, lyamin@uniandes.edu.co; TARY, J. B., Universidad de los Andes, Colombia,jb.tary@uniandes.edu.co

Active plate tectonics in Colombia is dominated by the convergence of the oceanic Nazca and Caribbean plates along the northwestern margins of continental South American plate. As a consequence, two subduction zones and a complex fault system are present inside the northern Andean region. As the result of these interactions, large earthquakes occur in Colombia as well as shallow to intermediate-deep seismic events with a wide range of magnitudes. In this study we compile 3D active fault plane geometry models for 54 seismogenic sources for probabilistic seismic hazard applications. Three types of seismogenic sources are defined: 39 crustal fault systems ( 21 thrust, 9 sinistral, 9 dextral), 12 subducting slab segments ( 6 inslab, 6 interface) and 3 localized seismic clusters. This model considers a wide variety of geometric constraints, based on relevant references for the region. The earthquake distribution in depth illuminates the general extent of slab segments as planar clusters of events, while the main activity for localized seismic clusters is identified as punctual at different depth ranges. A compilation of active mapped fault corridors, tectonic block configuration and crustal thickness estimates is used to approximate planes for crustal rupture, for which associated seismicity do not exceed $50 \mathrm{~km}$ depth. Different scaling relationships for fault rates and geometries are used to estimate values for the maximum magnitude in terms of moment magnitude. Estimates range from $\mathrm{Mw} 7.2-8.4$ for crustal sources, $\mathrm{Mw} 8.4-8.8$ for subduction segments and $\mathrm{Mw}$ 5.9-7.5 for clusters. The seismic activity seems concentrated accross subduction zones rather than along the major fault systems, but with a clear contribution of crustal sources and localized clusters. Improving the characterization of the Colombian seismogenic systems, including their seismic activity, is essential to improve the seismic hazard models for Colombia.
Regional Seismic Network Approaches and Stakeholder Collaborations

Oral Session - Tuesday 15 May · 8:30 AM · Jasmine

Session Chairs: Michael West, Sergio Barrientos, Paul Bodin, Victor A. Huerfano, Xyoli Pérez-Campos, and Alexandros Savvaidis

\section{Low-Cost Seismic Data Acquisition Module Based on Open-Source Hardware and Software Tools}

RAMDEANE, A., University of the West Indies, Trinidad and Tobago, arvid. ramdeane@my.uwi.edu; MCGILLIVARY, K., University of the West Indies, Trinidad and Tobago, kadem100@gmail.com; LYNCH, L. L., University of the West Indies, Trinidad and Tobago, llynch@uwiseismic.com

The Seismic Research Centre of the University of the West Indies, Trinidad and Tobago, operates a network of about 70 seismic stations in the eastern Caribbean islands from St. Kitts to Trinidad. Since 2008 the Centre has embarked on an initiative to expand and modernize this network by furnishing the stations with various combinations of broadband and/or strong motion sensors, high dynamic range digitizers and networking equipment to link each station to centralized observatories via high speed digital data transmission medium. After accomplishing about a half the task, the centre has come to the realization that it has neither the fiscal nor the technical capability to complete the full upgrade and provide maintenance to a network totally equipped with commercial instrumentation in a sustainable manner. The primary inhibiting factors are 1) insular geographical layout of the network, giving rise to several access and communications related challenges and 2) the high cost of procuring and maintaining commercial instrumentation. The Centre has devised a sustainable solution to complete the upgrade. We have developed a low-cost digitizer that makes heavy use of opensource hardware and software tools. The hardware is based on an Arduino Mega microcontroller that is programmed to capture data from a 24-bit four-channel analogue-digital-converter. A GPS Arduino shield provides time synchronization and data is continuously fed to a Raspberry Pi asynchronously but in a deterministic manner. On the Raspberry Pi, data are inserted into a Ring Buffer structure from which Miniseed files are written to flash memory for long-term storage. Near real-time data can also be streamed out to subscribers via the seedlink protocol and/or also be fed to a local Earthworm or SeisComp installation for manipulation and processing. Our prototype costs a lot less than commercial digitizers do and the data quality is comparable. The component modules are easy to get, build up and replace, thus maintenance is much more feasible than commercial systems.

Near Real-Time Network-Wide Station State of Health and Waveform Quality Monitoring

HUTKO, A. R., University of Washington, Washington, USA, ahutko@uw.edu; HARTOG, J. R., University of Washington, Washington, USA, jrhartog@ uw.edu; MARCZEWSKI, K., University of Washington, Washington, USA, marczk@uw.edu; CONNOLLY, J., University of Washington, Washington, USA, joncon@uw.edu; REUSCH, M., University of Washington, Washington, USA, topo@uw.edu; BODIN, P., University of Washington, Washington, USA, bodin@uw.edu

The Pacific Northwest Seismic Network is responsible for monitoring seismic activity in Cascadia and is also part of the USGS ShakeAlert earthquake early warning system. Part of our mission is operating and maintaining our network of over 400 stations. Fulfilling our role effectively requires monitoring station state of health metrics, those related to waveform quality such as power spectral density estimates, and those specific to ShakeAlert. The later include frequency of potential triggers that exceed certain amplitude and signal-to-noise ratio criteria. Multiple tools are available for seismologists to assess state of health and waveform quality across many stations such as MUSTANG (IRIS), SeisNetWatch (ISTI), and Data Quality Analyzer (ASL) though none meet all of our needs. Some operate in near real-time and focus on state of health while others include metrics that require long data segments and cannot scale to near real-time for our network. To bridge the wide range of needs by the PNSN, we are developing the Seismic Quality Assessment Console (SQUAC). The interface will be a web-service based API to generate a page with table and map views of the network metrics with variable levels of network-station-location-channel granularity. The web interface will also include one-click on the fly generated charts of time histories of selected metrics as well as station-level plots of latest hour metrics and waveforms useful for technicians in the field. SQUAC will be able to digest any properly formed JSON message sent to the API and thus can ingest metrics from databases, AQMS messages, other APIs, upload via wget, etc. Currently at the PNSN 
we are seeding this with over 30 state of health and waveform quality metrics calculated hourly in near real-time using a light-weight ObsPy based package. These metrics are stored in a postgres database and monitored so that when thresholds are exceeded, SQUAC can "squawk" and quickly alert interested parties.

Local and Regional Earthquake Solutions from Joining Raspberry Shake and International Seismological Stations

BLANCO CHIA, I. F., Gempa Geoservices S.A., Antioquia, Colombia, fautinos@gmail.com; CHRISTENSEN, B., Gempa Geoservices S.A., Chiriqui, Panama, branden.christensen@osop.com.pa

Upon several local and regional earthquake events recorded around the world, we present results about joining some international stations with the new private seismological network of Raspberry Shakes. The earthquake locations are compared using parameters including latitude, longitude and depth error, as well as rms and gap. For doing this, we consulted international catalogues and collected event solutions reported on regions near densed Raspberry Shake station locations, and we performed an automatic relocation process integrating them with the Raspberry Shake records using the SeisComP3 suit. It is also presented an analysis of ground motion for significative earthquakes recorded by the network, as the ones occurred in Mexico on September 2017. In spite of the station location limitations, we found helpful the Raspberry Shake data for complementing the current available networks, and projecting it as a great solution for reducing azimuthal gaps, location parameter errors, and detection thresholds.

\section{Virtual Seismic Networks - Case Studies in Europe and the Arabian Peninsula}

FRANKE, M., Kinemetrics, Inc., California, USA, mf@kmi.com

In November 2001, four institutes in three countries (Austria, Italy and Slovenia) signed an agreement to exchange real-time seismic data in the Alpine-Adria region. The following year Earth Science Department of the university in Trieste (DST), the Italian National Institute of Oceanography and Applied Geophysics (OGS), the Office for Seismology of the Environmental Agency of the Republic of Slovenia (ARSO), and the Central Institute for Meteorology and Geodynamics (ZAMG) initiated a three-year project to exchange data in real-time. The goal was to establish a virtual seismic network with redundant data connections between the remote stations and data centers that has improved network geometry, accurate and consistent earthquake parameters. On the Arabian Peninsula through bilateral agreements three institutes in two countries exchanging seismic data in real-time: The National Center of Meteorology and Seismology (NCMS), the Dubai Seismic Network of the Dubai Municipality (both United Arab Emirates) and the Earthquake Monitoring Center (EMC) at the Sultan Qaboos University in Oman. Although all data centers maintain their independent earthquake catalogues, the virtual seismic network created by the real-time data exchange has a larger aperture and therefore provides better and faster locations for large earthquakes originating from the main seismic sources in Iran and the Maquaran Subduction zone. The presentation will show how these virtual seismic networks function, and what benefits they brought to the stakeholders.

\section{Geophysical Networks in Peru: A National Effort for Earthquake Disaster Management}

NORABUENA, E. O., Instituto Geofisico del Peru, Lima, Peru, enorabuena@ igp.gob.pe; OLIVA, J. C., Instituto Geofisico del Peru, Lima, Peru, joliva@igp. gob.pe; SALAZAR, J. E., Instituto Geofisico del Peru, Lima, Peru, jsalazar@igp. gob.pe

Since historical times the Peruvian subduction zone has been source of several damaging earthquakes, e.g. Lima 1940 (Mw 8.0), Nazca 1942 (Mw 8.0), Lima 1966 (Mw 8.0), Lima 1974 (Mw 8.0), Arequipa 2001 (Mw 8.4) and more recently, Pisco 2007 (Mw 7.9). Noteworthy are the Lima 1746 (Mw 8.6) and the Chimbote 1970 ( $\mathrm{Mw}$ 8.0) events; the first one generated a tsunami that killed about $95 \%$ of the port of Callao's population and the second triggered a massive mudslide in the Cordillera Blanca region causing a death toll of 70,000, the largest so far in Peruvian history. Additional geophysical hazards are associated to volcanic eruption and active fault dynamics. In order to reduce the vulnerability of the country to the impact of extreme events like the aforementioned ones, the Peruvian government is engaged in a budget by result program to improve its geophysical instrumentation nationwide. Currently there are 48 broad band stations operating under the Libra-II VSAT system plus additional internet systems which conform the Real Time National Seismic Network. In addition there is a network of 200 strong motion sensors distributed in urban areas nationwide, so far only 72 are continuously streamed to IGP (Instituto Geofisico del Peru) procesing center in Lima. On the other hand, small seismic networks operate real time around the main active volcanoes in southern Peru. In the last years, geophysical monitoring has been extended to measure interseismic crustal deformation mainly in seismic gap zones. For this purpose, a network of $19 \mathrm{cGPS}$ stations are operating in southern Peru (Moquegua-Tacna-Arica seismic gap). Similarly, the dynamics of main intraplate active faults are being monitored permanently. More recently, a prototype of seismic alarm system for the capital city is being developed taking advantage of an island $60 \mathrm{~km}$ offshore Lima. We present the current status of the Peruvian geophysical networks as well as the basic Seismic Alarm System for the Lima Region.

\section{The Brazilian Seismographic Network: Present Status and Society Related Applications}

COLLAÇO, B. B., Universidade De Sao Paulo, São Paulo, Brazil, bruno@ iag.usp.br; BIANCHI, M., Universidade De Sao Paulo, São Paulo, Brazil, m.bianchi@iag.usp.br; ASSUMPÇĀO, M. A., Universidade De Sao Paulo, São Paulo, Brazil, marcelo@iag.usp.br; CALHAU, J. C., Universidade De Sao Paulo, São Paulo, Brazil, jackson@iag.usp.br; BARBOSA, J. R., Universidade De Sao Paulo, Brazil, jroberto@iag.usp.br; GALHARDO, L. G., Universidade De Sao Paulo, São Paulo, Brazil, luiz.galhardo@iag.usp.br; NEVES, F. N., Universidade DeSao Paulo, São Paulo, Brazil, nevesanjos@gmail.com

The Brazilian Seismographic Network (RSBR) was deployed between 2009 and 2015 mainly with resources from PETROBRAS and is currently maintained by the Brazilian Geological Survey (CPRM). Four FDSN sub-networks (BL, BR, NB, ON) compose RSBR, with a total of 84 permanent stations. Data from RSBR are open-access and transmitted over satellite, $3 \mathrm{G}$ modems or WISP networks. For acquisition, real-time processing and distribution, RSBR uses SeisComP3. Besides the most common products of a seismic network, sometimes RSBR data was used to assist Brazilian society in curious ways. In two years of operation, the locally developed platform "Sentiu Aí?" ("Did you feel it?"), a tool to collect data from people who felt an earthquake, received more than 800 reports, helping RSBR seismologists to identify earthquakes that were not located by the realtime processing system. Recently, "Sentiu Aí?" received a mobile version, allowing faster and more accurate reports. In 2016, an explosion of a dynamite truck in southern Brazil was registered as an earthquake (M2.8) by RSBR stations up to $300 \mathrm{~km}$ away from the disaster. Due to temperature variations in the atmosphere, vibrations propagated more strongly in the opposite direction to the accident, confusing seismologists because people reported the "earthquake" from cities $\sim 60 \mathrm{~km}$ away from the epicenter. The collapse of a mine tailings dam in SE Brazil (2015) is another example of how RSBR was used in environmental studies. Soon after the dam collapse, a mixture of water, soil, and mine tailings flooded the village of Bento Rodrigues, following the course of the Doce River. The seismic noise generated by this turbulent current was recorded by RSBR stations up to more than $300 \mathrm{~km}$ distance, allowing seismologists to further analyze this aspect of the accident (Augurto-Detzel et al. 2016). These among other examples can help justify a seismic network in an aseismic country.

\section{The National Seismological Network of Costa Rica (Rsn): An Overview and Recent Developments}

LINKIMER, L., Universidad de Costa Rica, SJ, Costa Rica, lepolt.linkimer@ ucr.ac.cr; ARROYO, I. G., Universidad de Costa Rica, SJ, Costa Rica, ivonne. arroyo@ucr.ac.cr; ALVARADO, G. E., Instituto Costarricense de Electricidad, SJ, Costa Rica, galvaradoi@ice.go.cr; ARROYO-SOLÓRZANO, M., Universidad de Costa Rica, SJ, Costa Rica, mario.arroyosolorzano@ucr.ac.cr; BAKKAR, H., Instituto Costarricense de Electricidad, SJ, Costa Rica, hbakkar@ ice.go.cr

The National Seismological Network of Costa Rica (RSN) is a joint effort between the University of Costa Rica (UCR) and the Costa Rican Institute of Electricity (ICE). In this paper, we briefly describe its history, contributions, and seismic catalogue. We also address recent developments, such as: the expansion of the station network, the improvement on earthquake locations, and the use of new communication channels to share earthquake information. The RSN seismic catalogue contains almost 123,000 earthquakes recorded since 1974. The geographical distribution of the local seismicity highlights plate boundaries as well as regions located along the inland projection of several bathymetric highs in the Cocos plate. In 2015, 70 new short-period seismometers were installed to provide a new configuration with higher station density in Central Costa Rica. Also, earthquake locations were improved by integrating routines from the Seiscomp, Earthworm, and SeisAn software packages. Additionally, several tools for disseminating earthquake information were developed, for example an application for smartphones released in 2015 and a new website created in 2017. The RSN is also using Facebook and Twitter to engage and educate non-scientific audiences. 
The Chilean Seismic Network: Recent Advances

BARRIENTOS, S. E., CSN, Universidad de Chile, Chile, sbarrien@csn.uchile. $\mathrm{cl}$

Chile is frequently affected by large and potentially tsunamigenic and damaging earthquakes as a result of rapid convergence of the Nazca plate beneath the South America plate. Ten M8 or larger earthquakes have occurred along the Chilean coast in the past century, the largest of which was the $1960 \mathrm{M} 9.5$ Valdivia earthquake. After the 2010 M 8.8 Maule earthquake, Chile began installing a modern real-time network of digital broadband/strong-motion and Global Positioning System (GPS) stations to better prepare for future and expected large damaging earthquakes. The network was designed to provide fast and accurate estimates of earthquake source parameters of potentially devastating earthquakes for emergency response applications, and was also capable of comprehensive characterization of Chilean seismicity, necessary for long-term hazard assessment and mitigation activities. Beginning in 2013, the National Seismological Center (CSN) of the University of Chile initiated the implementation of a network of 65 permanent real-time broadband and strong motion stations and 130 Global Navigation Satellite Systems (GNSS) monuments and receivers. These integrated sensor systems were designed to provide accurate automatic earthquake locations and magnitudes necessary for tsunami warning and impact assessment. In nearreal-time applications, the GPS stations become critical for determination of fault finiteness of $\mathrm{M} \sim 7$ or larger earthquakes. Operations of these systems also provide new insights into long-term deformation and associated spatiotemporal variations in seismicity, which are necessary in long-term earthquake hazards assessment and mitigation. In addition to the real-time system described above, 297 strong motion offline instruments complement the network for engineering purposes. We will present recent results in rapid characterization of recent large earthquakes in the country from the M8.2, April 1, 2014 event to the M6.9, April 24, 2017 earthquake.

Assessment of the Impact of Hurricanes Irma and Maria on the Monitoring Capability of the Pacific Tsunami Warning Center for the Caribbean Region. SARDINA, V. H. R., Pacific Tsunami Warning Center, NOAA, NWS, Hawaii, USA, victor.sardina@noaa.gov; WALSH, D., Pacific Tsunami Warning Center, NOAA, NWS, Hawaii, USA, david.walsh@noaa.gov; KOYANAGI, K., Pacific Tsunami Warning Center, NOAA, NWS, Hawaii, USA, kanoa.koyanagi@noaa. gov; BECKER, N. C., Pacific Tsunami Warning Center, NOAA, NWS, Hawaii, USA, nathan.becker@noaa.gov; WEINSTEIN, S. A., Pacific Tsunami Warning Center, NOAA, NWS, Hawaii, USA, stuart.weinstein@noaa.gov; VON HILLEBRANDT-ANDRADE, C. G., Caribbean Tsunami Warning Program, NOAA, NWS, Puerto Rico, USA, christa.vonh@noaa.gov

In September of 2017, hurricanes Irma and Maria wrecked havoc across the Eastern Caribbean region. While obliterating most of the infrastructure in the Caribbean nations found along their path, leaving a trail of suffering and despair in their wake, both hurricanes gradually destroyed the existing seismic networks. We assess the impact of both hurricanes on the Pacific Tsunami Warning Center's monitoring capabilities for the Caribbean region relying on the computation of theoretical detection and response times while accounting for the additional station outages caused by both hurricanes. The results show that in the Caribbean region hurricanes Irma and Maria rendered inoperative an additional 14\% and $38 \%$ of the available 146 stations, respectively. Within the Eastern Caribbean region monitored by the PTWC, hurricanes Irma and Maria exacerbated station outages to an astonishing $47 \%$ and $81 \%$ of the available 76 stations, respectively. Puerto Rico, the Virgin Islands, and the Lesser Antilles suffered the brunt of both hurricanes, and their seismic networks essentially disappeared in a matter of weeks. The double punch delivered by two successive category 5 hurricanes added up to $02: 45$ extra minutes to the detection and response times in areas previously covered by a much denser seismic network. This degradation of PTWC's local monitoring capabilities prompted emergency adjustments, including the temporary reduction of the number of stations required for both earthquake detection, and ML magnitude release. These adjustments enabled a faster detection and response to 4.0 or larger magnitude earthquakes in the region than otherwise possible in the aftermath of the pervasive seismic networkoutages caused by hurricanes Irma and Maria.

Puerto Rico Seismic Network Operations, Damages, and Recovery from a Natech Disaster

VANACORE, E. A., Puerto Rico Seismic Network, University of Puerto Rico Mayagüez, Puerto Rico, USA, elizabeth.vanacore@upr.edu; BAEZ-SÁNCHEZ, G., Puerto Rico Seismic Network, Puerto Rico, USA, gisela.baez1@upr.edu; LUGO, J., Puerto Rico Seismic Network, Puerto Rico, USA, juanb.lugo@upr. edu; LOPEZ, A. M., University of Puerto Rico Mayagüez, Puerto Rico, USA, alberto.lopez3@upr.edu; HUERFANO, V. A., Puerto Rico Seismic Network,
University of Puerto Rico Mayagüez, Puerto Rico, USA, victor@prsnmail.uprm. edu

In 2017, Hurricanes Irma and Maria struck the Northeast Caribbean in the span of less than 2 weeks. These storms had a profound impact on the seismic and tsunami monitoring in the region. Here we will the discuss the impact of these storms on operations and equipment from the perspective of the Puerto Rico Seismic Network (PRSN). PRSN relies on 35 seismic stations and 15 geodetic stations to monitor the region. PRSN stations have been designed to withstand earthquakes, but suffered considerable damage due to the strong winds associated with Hurricanes Irma and Maria with critical damages to communications towers. This coupled with the collapse of telecommunication and power grids of Puerto Rico and the Virgin Islands during and after the hurricanes had severe effects not only to PRSN operations but also impacted regional monitoring. Additionally, the collapse of PR telecommunications grid during Maria eliminated communications between the eastern side of the island where PREMA's main office and the National Weather Service (NWS) are based and the western side where PRSN is based. During and in the immediate aftermath of Maria, using the satellite based EMWIN system and radio communications PRSN became the only information source for NWS warnings and bulletins, tsunami alerts, and earthquake information forwestern PR. Given the functional radio and geographic location of the PRSN, PRSN also became a critical communications relay for local emergency management in the immediate aftermath. Currently, the PRSN is operational and continuing to recuperate stations. However, PRSN is also redesigning our stations to improve station resiliency for future catastrophic events to maintain data continuity not only for the PRSN but also to ensure that partner agencies continue to receive critical data from the Northeast Caribbean. PRSN is additionally assessing our continuity of operations plan and implementation to improve the PRSN human response to future events.

\section{Improved Regional Seismic Monitoring at the USGS National Earthquake Information Center}

EARLE, P.S., US Geological Survey, Colorado, USA, pearle@usgs.gov; YECK, W. L., US Geological Survey, Colorado, USA, wyeck@usgs.gov; HAYES, G. P., US Geological Survey, Colorado, USA, ghayes@usgs.gov; GUY, M. R., US Geological Survey, Colorado, USA, mguy@usgs.gov; PATTON, J. M., US Geological Survey, Colorado, USA, jpatton@usgs.gov; AMBRUZ, N. B., US Geological Survey, Colorado, USA, nbambruz@usgs.gov; ARNOLD, M. A., US Geological Survey, Colorado, USA, marnold@usgs.gov; BENZ, H. M., US Geological Survey, Colorado, USA, benz@usgs.gov

The USGS National Earthquake Information Center (NEIC) has traditionally focused on monitoring teleseismic earthquakes with emphasis on the detailed characterization of large earthquakes. Yet the NEIC's responsibilities extend beyond global seismology. NEIC is the backup to U.S. regional networks in the Advanced National Seismic System (ANSS) and is the primary U.S. monitoring agency in areas not covered by regional networks. To better serve in these roles, the NEIC is developing systems that include the detection, location, and magnitude estimation of seismic activity at local and regional distances. The goal of this development is the rapid and accurate production of an earthquake bulletin using consistent techniques for earthquakes magnitude 2.5 and larger in the contiguous U.S. and magnitude 4.5 and larger outside the U.S. The first step in improving NEIC regional capabilities is the testing and implementation of a new event detection and association technique (GLASS 3.0), implementation of a frequency dependent broadband phase picker, and deployment of correlation detectors. The GLASS 3.0 associator allows for simultaneous processing of variably scaled detection grids, each with a unique set of nucleation criteria (e.g., nucleation threshold, minimum associated picks, nucleation phases, and station list). To ensure robust transition to a production environment, we have developed a standardized testing platform and an extensive dataset for algorithm tuning and validation. We test these new tools at local, regional, and global scales, compare our results with existing catalogs, and discuss lessons learned.

Keeping Up Appearances in the Pacific Northwest Seismic Network (PNSN) BODIN, P., University of Washington, Washington, USA, bodin@uw.edu; BIUNDO, M., University of Washington, Washington, USA, mbiundo@uw.edu; CONNOLLY,J., University of Washington, Washington, USA,joncon@uw.edu; CREAGER, K. C., University of Washington, Washington, USA, kcc@uw.edu; CROWELL, B. W., University of Washington, Washington, USA, crowellb@ uw.edu; HARTOG, J. R., University of Washington, Washington, USA, jrhartog@uw.edu; GIBBONS, D. A., University of Washington, Washington, USA, dgibbons@uw.edu; HAGEL, K., University of Washington, Washington, USA, hagel@uw.edu; HUTKO, A. R., University of Washington, Washington, USA, ahutko@uw.edu; KRESS, V., University of Washington, Washington, USA, kress@uw.edu; MALONE,S.D., University of Washington, Washington, 
USA, smalone@uw.edu; MARCZEWSKI, K., University of Washington, Washington, USA, marczk@uw.edu

Regional seismic networks (RSNs) in areas like Cascadia, with high seismic hazard but where earthquakes are not often felt, face special challenges maintaining the enthusiasm and involvement of stakeholders over time. Negative consequences of stakeholder disinterest include a society poorly preparedto face the very real hazard, and lack of stakeholder support to maintain regional monitoring excellence. In PNSN we have adopted a strategy of coupling a rather assertive social media and web presence with information products that provide compelling, informative, and relevant content and involve the entire RSN staff in Seattle. Cascadia, while shy on significant earthquakes over the past decade, does have both active volcanoes and abundant non-volcanic tremor to provide focus. Glacier-clad volcanoes are always noisy and tremor is frequent so there is almost always something to show and something to talk about. Research projects have led to the development of A. Hotovec-Ellis' (USGS) REDPy (Repeating Earthquake Detector) and A. Wech's (USGS) "Wechometer" tremor page. With help from L. Simmons (USGS) we have used the rumbling noise of football crowds and the nearly insane level of Seattle NFL enthusiasm to test our readiness for seismic crises and to explain to the public how Earthquake Early Warning could save lives and property. We have developed real-time waveform displays (QuickShake) so that stakeholders can look over our shoulder when there are interesting phenomena... swarms, aftershocks, etc. An example is our monitoring of the Rattlesnake Ridge (or Union Gap) landslide with T. Yelin and D. Bowen (USGS). We also aggressively market ANSS products, such as ShakeMap and ShakeCast, to regional stakeholders like the city of Seattle and to the US Department of Energy, for whom we monitor the Hanford nuclear reservation. It has been our experience that regional stakeholders highly value regional expertise and involvement with these 3rd-party information products.

\section{Seismic Monitoring of the Trans-Alaska Pipeline}

GARDINE, M. D., University of Alaska Fairbanks, Alaska, USA, mgardin2@ alaska.edu; RUPPERT, N. A., University of Alaska Fairbanks, Alaska, USA, naruppert@alaska.edu; WEST, M. E., University of Alaska Fairbanks, Alaska, USA,mewest@alaska.edu

In addition to being the authoritative regional seismic network for the state of Alaska, the Alaska Earthquake Center partners with other public and private stakeholders for customized event notifications and infrastructure monitoring. One such partnership is with Alyeska Pipeline Services Company, who operate the Trans Alaska Pipeline System-one of the world's largest pipeline systems, traversing 800 miles of the state with a 2016 flow of over 500,000 barrels of oil per day. The Alaska Earthquake Center provides customized earthquake monitoring for the pipeline, including operating elevenseismic stations along the pipeline with broadband seismometers and strong motion sensors, real-time peak acceleration monitoring and alarming, customized ShakeMap products, and high-priority event notifications. Data products are also sent to a second partner, Nyman and Associates, for integration with engineering fragility curves to produce highly specific reports of potential damage and points of inspection. Through this partnership, the Alaska Earthquake Center and Alyeska help minimize the potential hazards and economic impact associated with a seismic event along a critical piece of infrastructure in the state.

\section{The University of Utah Seismograph Stations: Mission and Operations}

PANKOW, K. L., University of Utah, Utah, USA, pankow@seis.utah. edu; KOPER, K. D., University of Utah, Utah, USA, koper@seis.utah.edu; BURLACU, R., University of Utah, Utah, USA, burlacu@seis.utah.edu; PECHMANN, J. C., University of Utah, Utah, USA, pechmann@seis.utah. edu; BLYCKER, W. L., University of Utah, Utah, USA, blycker@seis.utah. edu; DROBECK, D. L., University of Utah, Utah, USA, drobeck@seis.utah. edu; FARRELL, J. M., University of Utah, Utah, USA, jamie.farrell@utah. edu; HALE, J. M., University of Utah, Utah, USA, jmhale@seis.utah.edu; HATCH, C.S., University of Utah, Utah, USA, hatch@seis.utah.edu; MEIER, C. B., University of Utah, Utah, USA, cmeier@seis.utah.edu; ROBERSON, P. M., University of Utah, Utah, USA, robersoneq@gmail.com; RUSHO, J. A., University of Utah, Utah, USA, rusho@seis.utah.edu

The mission of the University of Utah Seismograph Stations (UUSS) is "Reducing the risk from earthquakes in Utah through research, education, and public service." UUSS performs this role by being one of three core State of Utah agencies that contribute to the Utah Earthquake Program, an active partner within the Advanced National Seismic System (ANSS), and part of the Department of Geology and Geophysics at the University of Utah. Within the Utah Earthquake Program, the role of UUSS is to operate a regional and urban seismic network and provide timely information and products related to local seismic events. Scientists within UUSS serve on the Utah Seismic Safety Commission and the Mine Safety Technical Advisory Council. Scientists also serve on local working groups related to Utah earthquake probabilities, ground motion analyses, generation of earthquake scenarios, and Quaternary fault studies, and provide consulting expertise for earthquake hazards to critical facilities such as dams, nuclear waste repositories, and nuclear power plants. In addition to the professional public service, UUSS personnel work to actively educate the general public through the UUSS web pages, press releases, talks to local groups, blogs and tweets, and media interviews. UUSS also participates in the education of the next generation of seismic network professionals. University of Utah undergraduates are trained as earthquake analysts. Both undergraduate and graduate students are encouraged to participate and assist in field activities to learn about seismic instrumentation, and some also participate in research related to seismic network operations. Key to serving the UUSS mission are both the years of expertise that have been gained through monitoring and research in the region and, equally as important, the local connections and relationships that have been fostered through the many years of interactions with local stakeholders.

Collaborative Real-Time Risk Reduction through Early Warning and Earthquake Monitoring with Stakeholders in Southern California

HAUKSSON, E., Caltech, California, USA, hauksson@gps.caltech.edu; ANDREWS, J., Caltech, California, USA, jrand@gps.caltech.edu; BHADHA, R., Caltech, California, USA, rayo@gps.caltech.edu; YU, E., Caltech, California, USA, eyu@gps.caltech.edu; ROSS, Z.E., Caltech, California, USA, zross@gps.caltech.edu; STUBAILO, I., Caltech, California, USA, stubailo@ gps.caltech.edu; THOMAS, V. I., US Geological Survey, California, USA, vthomas@usgs.gov; CLAYTON, R. W., Caltech, California, USA, clay@gps. caltech.edu; HEATON, T. H., Caltech, California, USA, heaton@ caltech.edu

Caltech and USGS operate the Southern California Seismic Network (SCSN) to provide timely disaster mitigation in the form of early warning (EEW), event notification, ShakeMap, and other data products to more than 20 million people, living astride the Pacific and North America plate boundary. The EEW project (ShakeAlert) analyzes SCSN data to issue warnings to pilot users such as major utilities, Cal OES, and schools, which also host sensors and provide user feedback. A seismic moment tensor to identify the causative fault and evaluate tsunami hazards is also determined. In case of unusual activity, seismologists provide near real-time situational awareness to warn of increased hazards levels. Automatic seismic swarm detectors identify possible onset of volcanic activity, alerting civic authorities. The SCSN processes real-time data from more than 16,000 earthquakes every year; in case of a large sequence, it may process more than 60,000 events. The Southern California Earthquake Data Center (SCEDC) archives the data and facilitates the use of the SCSN data for scientific research, earthquake engineering, and public communication. The in progress SCSN template-matching catalog will have a completeness level of approximately M0.5, as template matching detects 10 to 15 times more events than the regular cata$\log$. The SCSN records real-time seismic data from more than 500 stations. We use various tools to monitor the state of health of stations, to detect data latency, and sudden changes in data quality. Metadata are maintained in the Station Information System Database (SIS). We are migrating our real-time SCSN and SCEDC operations into the Amazon cloud (AWS) to distribute products from the AWS and maintain a long-term archive in the AWS Glacier facility. This will significantly reduce the vulnerability of SCSN/SCEDC operations during future damaging earthquakes in southern California, and enable deployment of new big data analytics based on machine learning.

\section{Keeping Tabs on Oklahoma Seismicity: The Oklahoma Geological Survey Regional Network}

WALTER, I. I., Oklahoma Geological Survey, Oklahoma, USA, jwalter@ ou.edu; CHANG, J. C., Oklahoma Geological Survey, Oklahoma, USA, jeffersonchang@ou.edu

The Oklahoma Geological Survey (OGS) monitors seismicity throughout the state of Oklahoma utilizing permanent and temporary seismometers installed by OGS and other agencies, while maintaining an earthquake catalog. In Oklahoma, prior to 2009 background seismicity rates were about 2 M3.0+ earthquakes per year, which increased to 579 and 903 M3.0+ earthquakes in 2014 and 2015, respectively. The peak in the seismicity rate has since fallen to 624 and 304 M3.0+ earthquakes in 2016 and 2017, respectively. The catalog is complete down to M2.4 from mid-2014 to present, despite the significant workload for a primarily state-funded regional network. Unique challenges associated with being the de-facto earthquake information source include providing regulators, i.e. the Oklahoma Corporation Commission, with earthquake locations and magnitude within minutes of an event so that their "traffic-light" protocol may be effectively applied. We are transitioning to running our information center 
solely on virtual machines (or "cloud-based" computers), which have the added advantage that memory, CPU, and hard-disk resources may be added a la carte and on-the-fly. In addition, we have begun a citizen-scientist driven, educational seismometer program by installing Raspberry Shake geophones throughout the state at local schools. Educational aspects of that program include teacher-driven curriculum development facilitated during professional development workshops for teachers. We will connect the Raspberry Shakes to our earthquake information center, and utilize the data for earthquake locations and research in areas of the state with sparse broadband or short-period seismographs. The future seismic hazard of the state portends a continued need for expansion and densification of seismic monitoring throughout Oklahoma.

\section{Meeting Alaska's Earthquake Needs in 2018}

WEST, M. E., University of Alaska Fairbanks, Alaska, USA, mewest@alaska. edu; RUPPERT, N.A., University of Alaska Fairbanks, Alaska, USA, naruppert@ alaska.edu; GARDINE, M. D., University of Alaska Fairbanks, Alaska, USA, mgardin2@alaska.edu; SULEIMANI, E., University of Alaska Fairbanks, Alaska, USA, ensuleimani@alaska.edu; DICKSON, I., University of Alaska Fairbanks, Alaska, USA, ijdickson@alaska.edu; BUURMAN, H., University of Alaska Fairbanks, Alaska, USA, hmbuurman@alaska.edu; GARDINE, L., University of Alaska Fairbanks, Alaska, USA, lagardine@alaska.edu

The Alaska Earthquake Center's mission is to advance the state's earthquake resilience by integrating monitoring, research, and public engagement. Previously, the Center approached this mission primarily by operating a network of seismic sensors and reporting on earthquake activity via traditional avenues such as cata$\log$ production and email alerts to emergency managers and journalists. This is no longer enough, though, as the advent of smart buildings, social media, and instant communication has raised expectations for direct engagement. The center has adopted several strategies to meet these expectations. Using social media, we address public demand for immediate post-earthquake information by serving interpreted products tailored to our stakeholders rather than cookie-cutter announcements. Becausestrong motion provides a link between abstract source parameters and how earthquakes impact society, we have emphasized the installation of strong-motion instrumentation and production of related products designed for news media and the general public. We also emphasize the common ground between different types of hazard monitoring, such as landslides and volcanic eruptions, which rely on seismic monitoring. We place a particularly strong emphasis on the integrated nature of tsunamis and earthquakes because in Alaska these are simply two facets of the same hazard. This approach helps compensate for the awkward bifurcation of these hazards at the federal level. Finally, in an era of political, programmatic, and budgetary volatility, the Alaska Earthquake Center draws purpose from our singular focus on the needs of state-level stakeholders.

\section{The Lamont-Doherty Cooperative Seismographic Network (LCSN) Service to Education and Community}

KIM, W. Y., Lamont-Doherty Earth Observatory, Columbia University, New York, USA, wykim@ldeo.columbia.edu; GOLD, M., Lamont-Doherty Earth Observatory, Columbia University, New York, USA, goldm @ldeo.columbia.edu; RAMSAY, J., Lamont-Doherty Earth Observatory, Columbia University, New York, USA, jramsay@ldeo.columbia.edu

Lamont-Doherty Cooperative Seismographic Network (LCSN) contributes to outreach in ways that are unique to its structure. It is unusual in using a variety of station keepers (college \& university faculty, secondary school teachers, museums, nature conservancies etc.) to engage a wide variety of audiences and to reach out to large numbers of the general public. It also provides professional development and improved awareness among station operators who are not professional seismologists. All of this is an example of involving the community to extend seismic observations and thereby makes science accessible to the public. The records obtained from the stations are used to teach the students seismogram interpretation in the classroom as class exercises. The community is served by providing the general public and news media information about the local earthquakes. The LCSN now consists of 41 broadband seismographic stations in New York, New Jersey, Connecticut, Pennsylvania, Delaware, Maryland, New Hampshire and Vermont operated by 48 cooperating partners, with Lamont-Doherty Earth Observatory (LDEO) in Palisades, NY serving as the lead institution. The broadband stations of LCSN are distributed in diverse environments such as a $45 \mathrm{~m}$ deep natural cave (Howe Caverns, Cobleskill, NY), middle of the most dynamic city in the world (Central Park in Manhattan), and relatively quiet mountain sites at Adirondacks. The LCSN is also participating in the Advanced National Seismic System (ANSS) led by the US Geological Survey for monitoring earthquakes in the Northeastern United States. The earthquakes that occur in the northeast U.S. are automatically detected and located in near-real time by using ANSS Quake Management System (AQMS), and are promptly reviewed by duty seismologists at the data collection center at LDEO. Earthquake information is reported in timely fashion in 24/7 operations together with NEIC in Golden, Colorado.

\section{One Year of Texas Seismological Network Seismic Data}

SAVVAIDIS, A., University of Texas at Austin, Texas, USA, alexandros. savvaidis@beg.utexas.edu; HUANG, D., University of Texas at Austin, Texas, USA, dino.huang@beg.utexas.edu; YOUNG, B. E., University of Texas at Austin, Texas, USA, bissett.young@beg.utexas.edu

In an effort to better understand the seismogenesis of earthquake events and to monitor earthquake activity, a statewide seismic monitoring program, known as TexNet (http://www.beg.utexas.edu/texnet), has been funded by the 84 th Texas Legislature to deploy seismic stations in Texas. The goal of TexNet is to provide authenticated data to evaluate the location, frequency, and likely causes of natural and induced seismicity. A better understanding of these seismic events will help stakeholders avoid operational procedures that may lead to the occurrence of induced earthquakes. On September of 2016 the first TexNet seismic station was deployed. Up to the end of 2017, 22 new, permanent 3-component broadband seismic stations have been installed. Along with 17 existing stations operated by various networks [US, N4, IM], they make up the backbone of the TexNet seismic monitoring network. These stations, together with 3 auxiliary stations, i.e., long term deployments of portable stations (20s seismometers), provide the observation of baseline seismicity of Texas. In addition, 33 portable pairs of seismometers and accelerometers are deployed to further examine seismic events, in four areas with dense populations or crucial infrastructure. Ground motion data from a total number of 58 additional seismic stations is available through TexNet hub, in real time as seedlink stream and also FDSNWS. For earthquake events which occurred after January 2017, TexNet publishes information of earthquake locations on its website. Both, raw data and earthquake locations provided through the Texas Seismological Network, is an excellent success story of a recent regional seismic network. TexNet has managed to minimize the uncertainties into earthquake locations and decrease the magnitude of completeness for the State. Also, it provides an excellent opportunity to the scientific community to better understand the seismicity in Texas, and increase the public and industry awareness.

\section{The Berkeley Digital Seismic Network}

HELLWEG, M., UC Berkeley, California, USA, peggy@seismo.berkeley.edu; ALLEN, R. M., UC Berkeley Seismo Lab, California, USA, rallen@ berkeley.edu; TAIRA, T., UC Berkeley Seismo Lab, California, USA, taira@seismo.berkeley. edu; HENSON, I., UC Berkeley Seismo Lab, California, USA, henson@seismo. berkeley.edu; UHRHAMMER, R. A., UC Berkeley Seismo Lab, California, USA, bob@seismo.berkeley.edu; ZUZLEWSKI, S., UC Berkeley Seismo Lab, California, USA, stephane@seismo.berkeley.edu

Since it began monitoring earthquakes in northern California almost 130 years ago, the University of California Berkeley Seismological Laboratory (BSL) has been striving to produce the highest quality and most complete seismic data possible in the most modern way. This goal continues to influence choices and investments in instrumentation, installation, telemetry, expertise and manpower. The Berkeley Digital Seismic Network (BDSN), the current incarnation of the BSL's seismic monitoring system, began in the mid-1980s with the installation of broadband (BB) instrumentation, and in the early 1990s a fully digitally telemetered network. The BDSN has grown from 3 high-quality, high dynamic range, $\mathrm{BB}$ installations to almost 50 stations, with almost 100 more stations expected as earthquake early warning funding supports seismic network buildout. In addition to three component $\mathrm{BB}$ seismometers and digital accelerometers, many stations also record C-GPS data, that are transmitted continuously to the BSL. Data from BDSN stations and other seismic stations in Northern California are available at the Northern California Earthquake Data Center (ncedc.org) using web serivces (http://service.ncedc.org/) from the DART (Data Available in Real Time) or from NCEDC archives. The BSL also participates in earthquake monitoring in Northern California, as part of the Northern California Seismic System. Data quality is important to the BSL, in terms of completeness, instrument response, and waveform content. To ensure completeness, we retrieve data from remote sites when telemetry allows. We also develop and apply tools to evaluate data for the latter two tasks. Our main effort is to complete the evaluation, without disturbing the data. Recently, we have investigated the responses of our aging STS-1 and STS-2 seismometers. We update results from STS-2 analysis. In addition, we demonstrate a technique to non-invasively estimate the response parameters of horizontal STS-1 seismometers. 
Science Gateways and Computational Tools for Improving Earthquake Research

Oral Session · Tuesday 15 May · 2:15 PM • Orchid AB

Session Chairs: Andrea Donnellan and Lisa Grant Ludwig

\section{Science Gateways for Enhancing Earthquake Science}

PIERCE, M. E., Indiana University, Indiana, USA, marpierc@iu.edu; WANG,

J., Indiana University, Indiana, USA, wang208@iu.edu

Science gateways are Web interfaces and middleware that both simplify access to supercomputers and expand the capabilities of their users through graphical user interfaces. Since initially conceived two decades ago, science gateways have matured into production services used daily by many scientists. For example, science gateway users of XSEDE supercomputers consistently outnumber regular command line users, and users of Galaxy (a bioinformatics gateway) and NanoHUB (a nanotechnology gateway) number in the tens of thousands. We believe there is a need and an opportunity to dramatically increase the use of gateways and related cyberinfrastructure in earthquake science. This can be done in three related ways: by simplifying access to popular modeling and simulating tools, by providing better mechanisms for interacting with data products such as InSAR and GPS data, and by enabling novel applications of machine learning technologies that are outside the expertise of many geoscientists to geophysi$\mathrm{cal}$ data sets. In this talk we introduce general science gateway concepts, provide an overview of the NASA-funded GeoGateway project, and describe how GeoGateway will evolve as we align it with the Apache Airavata framework for science gateways. We are developing GeoGateway as a means for geoscientists to access, integrate, and share multiple data sets, including InSAR, GPS, seismicity, and optical data. GeoGateway provides more than access to data sets: by coupling data to modeling and simulation codes, it enables users to easily incorporate data into their computational experiments. Looking forward, we also see important opportunities for coupling data to a range of machine learning techniques that can be used to identify features in data sets that are not readily discernible by human inspection. It is important to develop GeoGateway's capabilities within a general framework in order that we can take advantage of features already available from other science gateways. At the same time, GeoGateway has unique or forward-looking capabilities compared to many gateways, so innovations made by GeoGateway can be contributed back to open source science gateway frameworks. We thus describe the synergies between GeoGateway and the Apache Airavata framework for building science gateways, and how Apache Airavata can be used to build other science gateways.

\section{SCEC Tool for Distribution and Integration of Simulated Ground Motions} within the NEHRI-CI Portal

GOULET, C.A., University of Southern California, California, USA, cgoulet@ usc.edu; MAZZONI, S., Structural \& EQ Engineering Consultant, California, USA, silviamazzoni@yahoo.com; SILVA, F., University of Southern California, California, USA, fsilva@usc.edu; MAECHLING, P. J., University of Southern California, California, USA, maechlin@usc.edu; RATHJE, E. M., University of Texas, Austin, Texas, USA, e.rathje@mail.utexas.edu; COCKERILL, T., Texas Advanced Computing Center, Texas, USA, cockerill@tacc.utexas.edu

The Southern California Earthquake Center (SCEC) has been collaborating with the National Hazard Engineering Research Infrastructure (NHERI) to deliver simulated ground motions through a new web tool on the NHERI cyberinfrastructure portal, DesignSafe-CI. The NHERI DesignSafe-CI offers opportunities for engineering research for multiple natural hazards and integrates various engineering computational tools and data storage capabilities. Our NHERI_SCEC collaboration is focused around the development of data registration, discovery, distribution, and integration of simulated ground motion seismograms into the DesignSafe-CI portal. The broadband ground motion simulations were generated by the SCEC BroadBand Platform (BBP), an open-source computational platform that includes numerous simulation methods. Simulation methods from the BBP have been thoroughly validated and used in such projects as the South Western United States utilities project (SWUS) and the Pacific Earthquake Engineering Research (PEER) Next Generation Attenuation project for Central \& Eastern North America (NGA-East). The first subset of seismograms was selected to capture large-magnitude events not currently available in recorded ground motion databases such as those hosted by the PEER center. The seismograms provide ground motions large enough to push structural simulations well into the nonlinear range, providing engineers with the ability to test their models and designs under a wide range of seismic demands. An initial task was to develop a comprehensive flatfile that can accommodate the metadata related to ground motion simulations. The data-discovery tool was developed as a Jupyter Notebook that can be expanded to allow the inclusion of additional ground motion datasets. In this presentation, we introduce the key feature of the flatfile and introduce the interface integrated into DesignSafe-CI.

Exploring the Potential for Hosting a Geoscience Data Center in the Cloud TRABANT, C., IRIS DMC, Washington, USA, chad@iris.washington. edu; AHERN, T., IRIS DMC, Washington, USA, tim@iris.washington.edu; WATSON, I., IRIS DMC, Washington, USA, inge@iris.washington.edu; STULTS, M., IRIS DMC, Washington, USA, mike@iris.washington.edu; WEEKLY, R. T., IRIS DMC, Washington, USA, rtweekly@iris.washington.edu

The IRIS Data Management Center (DMC) has operated a public repository of seismological data for 3 decades supporting thousands of researchers. Since its founding, the DMC has operated its own infrastructure to support the computational and storage resources needed to support its mission. In the GeoSciCloud project, supported by the National Science Foundation's (NSF) EarthCube program, the DMC is deploying a subset of its archive and key software components into two cloud environments. This project will allow the DMC to evaluate the realities of operating in the cloud and explore the potential advantages and disadvantages. The two cloud environments selected for this project are Amazon's AWS and XSEDE's Jetstream and Wrangler systems. The XSEDE resources are operated on behalf of NSF by Indiana University jointly with the Texas Advanced Computing Center. The DMC has deployed a $\sim 40$ terabyte test data set and a subset of its web service-based data access architecture to both environments. The DMC is conducting an extensive evaluation of the capabilities of these deployments. To ensure these systems support and, ideally, improve upon real-world research use cases, the DMC is collaborating with scientists who will perform their own tests designed to meet their research needs. A promising, expected gain from cloud-like environments over DMC-operated systems is the ability to scale-out in order to handle more simultaneous users, both with respect to storage $\mathrm{I} / \mathrm{O}$ and processor intensive tasks. Another potential advantage is providing data within, or very near to, a powerful computing environment that researchers may also use. Also, evaluating the relative costs of the cloud environments against the DMC's own infrastructure will be critical. We will report on the status of this work and lessons learned so far.

\section{Displaying Multiple Data Types in the Geogateway Public Mapping System Inclucing a System for Rapid Surface Fracture Detection in Raw and Unwrapped Radar Interferograms}

PARKER, J. W., NASA Jet Propulsion Laboratory, California, USA, jay.w.parker@jpl.nasa.gov; DONNELLAN, A., NASA Jet Propulsion Laboratory, California, USA, andrea.donnellan@jpl.nasa.gov; PIERCE, M. E., Indiana University, Indiana, USA, marpierc@iu.edu; WANG, J., Indiana University, Indiana, USA, wang208@iu.edu

A new component of the public GeoGateway mapping system allows determination and display of instances and networks of fault slip from radar interferometer observations of the earth's surface. This component has added value through integration with a system that supports optional layered display of GPS stations, velocities, and patterns; radar interferometric images and displacement profiles; catalog seismicity; known fault systems; and user-supplied KMZ objects. Fault slip from creep, seismic triggering, aftershocks and general stress change is imaged and verified to better than $1 \mathrm{~cm}$ in desert environments and about $4 \mathrm{~cm}$ in moderately wooded and frequent-visit agricultural areas. The surface fracture characterization method has an initial version based on filling of bad data through interpolation and blurring, followed by the Canny edge detection algorithm from computer vision. This is used for highly stable (coherent) environments with largely continuous and packed unwrapped image products. A refinement begins with a raw, complex-valued interferogram and uses conjugation to find phase differences up to a full cycle, a method that works when image unwrapping fails. Illustration of the ulitity of the refined surface fracture imaging with other GeoGateway layers centeres on the Brawley Swarm deformation of 2012 and the South Napa earthquake slip of 2014.

\section{Developing Software to Evaluate the Liquefaction Potential by Using 2D} Numerical Modeling: Applications

DUQUE, E. P., Technical University of Loja, Loja, Ecuador, epduque@utpl.edu. ec; CRUZ, D. R., Technical University of Loja, Loja, Ecuador, dixon.cruz.j@ gmail.com; COLLAHUAZO, A. A., Technical University of Loja, Loja, Ecuador, aa.cb14@gmail.com; SERRANO, R. G., Technical University of Loja, Loja, Ecuador, rgserrano@utpl.edu.ec; ROJAS, H. V., Technical University of Loja, Loja, Ecuador, hvrojas@utpl.edu.ec; BRICEÑO, T. C., Technical University of Loja, Loja, Ecuador, tcbriceno@utpl.edu.ec

This article describes the developing of a computer tool to evaluate the liquefaction potential in seismic zones. The tool consists of: i) a pre-processing script, 
ii) calculation or process script, and iii) a post-processing script. The pre and post-processing stages are carried out by using the Matlab software through the GUIDE development environment, while the process uses OpenSees as a calculation engine. The layered deposit of cohesionless soil subject to a seismic base excitation is represented by a $2 \mathrm{D}$ finite element model using nine-node quadrilateral elements by considering the displacement and pressure of pores as degrees of freedom. The validation process showed that the generated soil column model properly represents the problem posed. The application of this tool was done by modeling 1325 samples corresponding to 14 theoretical scenarios in which the following variables were considered and permuted: depth of the soil column, stratigraphy, groundwater level, relative soil density, and intensity of seismic load. All this, in order to know the degree of influence of each of these parameters on the liquefaction phenomenon. The results showed that the phreatic level and the relative density of the soil are the most sensitive variables, which are in accordance with the theoretical foundations studied. Additionally, there was geotechnical information from two soil profiles of the Tarqui parish, Ecuador (area affected by soil liquefaction during the 2016 Ecuador earthquake). This information was used to evaluate and verify the susceptibility of these soils before the aforementioned phenomenon. Finally, It is worth mention that this tool is part of the Virtual Laboratory of the Technical University of Loja (UTPL), which is managed by its Research Group of Seismic Engineering and Seismology (GRISSUTPL) (http:www.ingenieriasismica.utpl.edu.ec/) keywords: Ecuador, Liquefaction of soils, earthquake, OpenSees, numerical modeling.

Tsunami Modeling and Hazard Assessment

Oral Session · Tuesday 15 May · 8:30 AM · Hibiscus A

Session Chairs: Stephanie L. Ross, Silvia Chacón, Juan J.

Horillo, Alberto Lopez, and Hong Kie Thio

\section{Benchmarking Multilayer-Hysea Model for Landslide Generated Tsunamis}

MACÍAS, I., Universidad de Málaga, Málaga, Spain, jmacias@uma.es; ESCALANTE, C., Universidad de Málaga, Málaga, Spain, escalante@uma.es; CASTRO, M. J., Universidad de Málaga, Málaga, Spain, mjcastro@uma.es

Landslide tsunami hazard may be dominant along significant parts of the coastline around the world, in particular in the USA or Caribbean Sea, as compared to hazards from other tsunamigenic sources. This fact motivated NTHMP about the need of benchmarking models for landslide generated tsunamis, following the same methodology already used for standard tsunami models when the source is seismic. To perform the above-mentioned validation process, a set of candidate benchmarks were proposed. These benchmarks are based on a subset of available laboratory data sets for solid slide experiments and deformable slide experiments, and include both submarine and subaerial slides. A benchmark based on a historic field event (Valdez, AK, 1964) close the list of proposed benchmarks. A total of 7 benchmarks. The Multilayer-HySEA model including non-hydrostatic effects has been used to perform all the benchmarking problems dealing with laboratory experiments proposed in the workshop that was organized at Texas A\&M University-Galveston, on January 9-11, 2017 by NTHMP. The aim of this presentation is to show some of the latest numerical results obtained with the Multilayer-HySEA (non-hydrostatic) model in the framework of this validation effort. Acknowledgements. This research has been partially supported by the Spanish Government Research project SIMURISK (MTM2015-70490-C0201-R) and University of Malaga, Campus de Excelencia Internacional Andalucía Tech. The GPU computations were performed at the Unit of Numerical Methods (University of Malaga).

The Probabilistic Tsunami Hazard Assessment Map for the Neam Region: Results of the Tsumaps-Neam Project

BASILI, R., Istituto Nazionale di Geofisica e Vulcanologia, Italy, roberto.basili@ ingv.it

Probabilistic Tsunami Hazard Assessment (PTHA) is an indispensable step for long-term coastal planning and for effectively designing and using Tsunami Warning Systems. In the last decade, Europe has promoted a better understanding of the tsunami phenomenon through research projects (e.g. TRANSFER, NEARTOWARN, ASTARTE) and started programs for preventing the tsunami impact along the coastlines of the North-East Atlantic, the Mediterranean, and connected Seas (NEAM) region (e.g. the Tsunami Early Warning and Mitigation System, NEAMTWS, coordinated by IOC/UNESCO). Building on the legacy of previous projects, and alongside networking activities at the global scale (Global Tsunami Model, GTM), the TSUMAPS-NEAM project produced the first region-wide long-term homogenous PTHA map from earthquake sources for the NEAM region. The hazard assessment was built upon state-of-the- art procedures and standards, enriched by some rather innovative/experimental approaches such as: (1) the statistical treatment of potential seismic sources, combining all the available information (seismicity, moment tensors, tectonics), and considering earthquakes occurring on major crustal faults and subduction interfaces; (2) an intensive computational approach to tsunami generation and linear propagation across the sea up to an offshore fixed depth; (3) the use of approximations for shoaling and inundation, based on local bathymetry, and for tidal stages; and (4) the exploration of several alternatives for the basic input data and their parameters which produces a number of models that are treated through an ensemble uncertainty quantification. This presentation will summarize how the TSUMAPS-NEAM project achieved its goals, illustrate the PTHA online data, and discuss possible strategies for future PTHA efforts. The TSUMAPS-NEAM Project (http://www.tsumaps-neam.eu/) was co-financed by the European Union Civil Protection Mechanism, Agreement Number: ECHO/SUB/2015/718568/ PREV26.

Testing Empirical Inundation in the Definition of Inundation Zones for Tsunami Early Warning

TONINI, R., Istituto Nazionale Di Geofisica e Vulcanologia, Italy, roberto. tonini@ingv.it; LORITO, S., Istituto Nazionale Di Geofisica e Vulcanologia, Italy, stefano.lorito@ingv.it; DI MANNA, P., Italian National Institute for Environmental Protection and Research, Italy, pio.dimanna@isprambiente. it; SELVA, J., Istituto Nazionale Di Geofisica e Vulcanologia, Italy, jacopo. selva@ingv.it; VOLPE, M., Istituto Nazionale Di Geofisica e Vulcanologia, Italy, manuela.volpe@ingv.it; VITTORI, E., Italian National Institute for Environmental Protection and Research, Italy, eutizio.vittori@isprambiente.it; ROMANO, F., Istituto Nazionale Di Geofisica e Vulcanologia, Italy, fabrizio. romano@ingv.it; BRIZUELA, B., Istituto Nazionale Di Geofisica e Vulcanologia, Italy, beatriz.brizuela@ingv.it; PIATANESI, A., Istituto Nazionale Di Geofisica e Vulcanologia, Italy, alessio.piatanesi@ingv.it

Numerical modeling is by far the most accredited method to model tsunami propagation and inundation. However, a massive use of tsunami numerical simulations still has important limits in some practical applications, due to the computational cost of inundation calculations and the availability of high-resolution topo-bathymetric DEMs. As an alternative, empirical inundation models can provide very rapid estimates. In Italy, evacuation maps are being developed in the frame of the Italian Tsunami Alert System (SIAM), constituted by the Italian Department of Civil Protection (DPC), the Istituto Nazionale di Geofisica e Vulcanologia (INGV) and the Italian National Institute for Environmental Protection and Research (ISPRA). Input for the evacuation maps is the regional seismic probabilistic tsunami hazard analysis (SPTHA), developed by the TSUMAPS-NEAM (http://www.tsumaps-neam.eu/) project. This SPTHA relies on numerical modeling up to the 50-m depth isobaths and a method for estimating the maximum runup with uncertainty, using local amplification factors based on site-specific coastal morphology. Inundation maps are then defined for a given return period and epistemic uncertainty level established by DPC. An empirical dissipation factor is then introduced to limit the maximum inundation distance. Using a GIS-based approach, the method combines these results with a detailed DTM and computes the inundation zones. The goal of this work is to test the proposed method against (probabilistic) inundation maps calculated for one or more short segments with detailed numerical simulations. The analysis aims to evaluate the effectiveness of empirical estimates as input for risk mitigation strategies and quantify the associated uncertainty.

\section{A Probabilistic Tsunami Hazard Model for New Zealand}

ALI, S. T., AIR Worldwide, Massachusetts, USA, sali@air-worldwide. com; BARBEROPOULOU, A., AIR Worldwide, Massachusetts, USA, abarberopoulou@air-worldwide.com; YANG., W., AIR Worldwide, Massachusetts, USA, wyang@air-worldwide.com; SHEN-TU, B., AIR Worldwide, Massachusetts, USA, bshen-tu@air-worldwide.com; MAHDYIAR, M., AIR Worldwide, Massachusetts, USA, mmahdyiar@air-worldwide.com; KLEIN, E. C., AIR Worldwide, Massachusetts, USA, eklein@ @air-worldwide.com

We have developed a fully probabilistic, tsunami hazard model for New Zealand by simulating the origin, propagation, and run up of tsunamis due to more than a thousand $\mathrm{Mw} \geq 7$ local and distant tsunamigenic earthquakes from stochastic earthquake catalogs, spanning 10,000 years, developed as part of regional probabilistic seismic hazard analyses. The model incorporates single and multi-segment fault rupture scenarios with variable slip, high-resolution ( 90 meter) bathymetry/ elevation data, variable manning coefficient maps derived from high-resolution land-use/land-cover datasets, levee location and height data (where available), as well as contribution from astronomical tides, to estimate maximum inundation depths and wave velocities along the $\sim 15,000-\mathrm{km}$-long coastlines of New Zealand. Observed inundation depths and tide gauge amplitudes/time-series 
data for historic tsunamigenic events, including the relatively recent, 2010 Maule (Chile), and 2016 Kaikoura (New Zealand) earthquakes were used to validate the model. We create maximum inundation depth maps for several return periods, and discuss their implications for quantifying risk.

\section{Simulation of PDC 2017 Asteroid Ocean Impact, Tsunami Generation, and Consequences on Japan's Coastlines}

EZZEDINE, S., Lawrence Livermore National Laboratory, California, USA, ezzedine1@llnl.gov; DEARBORN, D., Lawrence Livermore National Laboratory, California, USA, dearborn2@llnl.gov; MILLER, P., Lawrence Livermore National Laboratory, California, USA, miller3@llnl.gov; OMAN, L., NASA, Maryland, USA, luke.d.oman@nasa.gov; KOSHIMURA, S., Tohoku University, Sendai, Japan, koshimura@irides.tohoku.ac.jp

Despite that the annual probability of an asteroid impact on earth is low, but over time, such catastrophic events are inevitable. Interest in assessing the tsunami generation and impact consequences has led us to develop a physics-based framework to seamlessly simulate the event from source (asteroid entry) to ocean impact (splash) to long wave generation, propagation, and inundation of the shoreline. The non-linear effects of the asteroid impact on the ocean surface are simulated using the hydrocode GEODYN to create the impact source for the shallow water wave propagation code, SWW P. The GEODYN-SWW P coupling is based on the structured adaptive mesh refinement infrastructure; SAMRAI developed at LLNL and has been used in FEMA table-top exercises conducted in 2013 through 2017, and the 2015 \& 2017 Planetary Defense Conference exercise in Italy and Japan, respectively. We illustrate capabilities of this methodology by providing results of tsunami generation for different locations of asteroid impact off the East Coast of the United States, in the Gulf of Mexico, and near San Francisco. We present a comprehensive analysis of the PDC2017 asteroid impact on Japan's coastlines. Often the size of the asteroid is not deterministically known; thus, we explored the effect of asteroid size on the tsunami and landfall waves at several coastline cities of interest near the potential impact area. We construct the probability of wave height given the size of the asteroid and the location of the impact along the risk corridor. Such probability profiles can inform more sophisticated inundation models and advise emergency responses and disastermitigation efforts, and may be used for design of maritime protection (e.g. breakwaters walls) or assessment of risk to shoreline structures of interest (e.g. bridges, power plants). Finally, we compare asteroid-generated tsunamis to earthquake-generated tsunamis and the illustrate the impact of asteroids on climate change. This work was performed under the auspices of the U.S. Department of Energy by Lawrence Livermore National Laboratory under Contract DE-AC5207NA27344.

\section{Field Survey of the 1946 Tsunami in the Dominican Republic Based on} Eyewitness Interviews

FRITZ, H. M., Georgia Institute of Technology, Georgia, USA, fritz@gatech. edu; RIVERA, W. E., Oficina Nacional de Meteorología, Santo Domingo, Dominican Republic, wagner.rivera@hotmail.com; SALADO, J., Oficina Nacional de Meteorología, Santo Domingo, Dominican Republic, ing.jsalado@ gmail.com; MARTINEZ, C., Oficina Nacional de Meteorología, Santo Domingo, Dominican Republic, claudiomartin85@hotmail.com

On 4 August 1946 an Mw 8.1 earthquake occurred off the north-eastern shore of Hispaniola resulting in a destructive tsunami with order one hundred fatalities in the Dominican Republic and observed runup in Puerto Rico. In the far field the tsunami was recorded on tide gauges on the US Atlantic Coast. The earthquake devastated the Dominican Republic and extended into Haiti. This was one of the strongest earthquakes ever reported in the Caribbean. The immediate earthquake reconnaissance surveys focused on earthquake damage and were conducted in September 1946 (Lynch and Bodle, 1948; Small, 1948). The 1946 Dominican Republic tsunami eyewitness based field survey took place in three phases from 18 to 21 March 2014, 1 to 3 September 2014 and 9 to 11 May 2016. The International Tsunami Survey Team (ITST) covered more than $400 \mathrm{~km}$ of coastline along the northern Dominican Republic from La Isabela to Punta Cana. The survey team documented tsunami runup, flow depth, inundation distances, coastal erosion and co-seismic land level changes based on eyewitnesses interviewed on site using established protocols. The early afternoon earthquake resulted in detailed survival stories with excellent eyewitness observations recounted almost 70 years later with lucidity. The Dominican Republic survey data includes 29 runup and tsunami height measurements at 21 locations. The tsunami impacts peaked with maximum tsunami heights exceeding $5 \mathrm{~m}$ at a cluster of locations between Cabrera and El Limon. A maximum tsunami height of $8 \mathrm{~m}$ likely associated with splash up was measured in Playa Boca Nueva. Tsunami inundation distances of $600 \mathrm{~m}$ or more were measured at Las Terrenas and Playa Rincon on the Samana Peninsula. Some locations were surveyed twice in 2014 and 2016, which allowed to identify current coastal erosion rates. Field data points were corrected for predicted astronomical tide levels at the time of tsunami arrival in 1946. Individual tidal corrections applied to the raw field measurements were less than $\pm 0.5 \mathrm{~m}$ given the relatively small tidal range around Hispaniola Island. At least 10 significant tsunamis have been documented in the northern Caribbean since 1492, six of which are known to have resulted in loss of life (O'Loughlin and Lander, 2003). Rapid population increase in the Caribbean exposes more coastal residents and tourists to future tsunami events.

\section{Tsunami Mitigation Mapping Effort in the Gulf of Mexico} LUAN HORRILLO, J., Texas A\&M, Texas, USA, horrillj@tamug.edu

The devastating consequences of recent tsunami events in Indonesia (2004) and Japan (2011) have prompted a scientific response in assessing tsunami hazard even in regions where an apparent low risk or/and lack of complete historical tsunami record exists. Although a great uncertainty exists regarding the recurrence rate of large-scale tsunami events in the Gulf of Mexico (GOM) due to sparsity of data, geological and historical evidences indicate that the most likely tsunami hazard could come from a submarine landslide triggered by a moderate earthquake. Under these circumstances, the assessment of the tsunami hazard in the region is accomplished by means of using local ancient landslide information and also by using probabilistic approaches to identify more tsunami sources which are required to cover the entire GOM basin. By using 3D model for landslide source initial tsunami wave determination and 2D non-hydrostatic nested model for the propagation (15 to 5 to 3 arc-seconds) and inundation (1/3 arc-seconds), we are able to determine hazard to specific coastal locations, including maximum runup heights, inundation depth/extent, damaging currents and vorticity affecting communities and infrastructure, thus mitigating the impact of tsunamis according to mapping guidelines of the National Tsunami Hazard Mitigation Program.

\section{Long-Lived Tsunami Edge Waves during the 2017 M 8.2 Tehuantepec, Mexico, Earthquake and Their Implications for Hazards}

MELGAR, D., University of Oregon, Oregon, USA, dmelgarm@uoregon.edu; RUIZ-ANGUlO, A., Universidad Nacional Autónoma de México, Mexico, angel@atmosfera.unam.mx; RAMIREZ-HERRERA, M. T., Universidad Nacional Autónoma de México, Mexico, tramirez@igg.unam.mx; CORONA MORALES, N., El Colegio de Michoacan, Mexico, corona@colmich.edu.mx; ZAVALA-HIDALGO, J., Universidad Nacional Autónoma de México, Mexico, jzavala@atmosfera.unam.mx

Rare large normal faulting events can occur at subduction zones. Such is the case of the M8.2 Tehuantepec earthquake which ruptured away from the outer rise underneath the megathrust. The earthquake reactivated bend fault fabric and ruptured the entire lithosphere. Here we will discuss very long lived (48 hours) high amplitude tsunami edge waves observed at near source tide gauges during the event. We model the tsunami using a high resolution model of the earthquake source produced from all available regional geophysical observables. We find that the high amplitude and long duration of the edge waves is the result of the unique morphology of the Tehuantepec shelf. It is longer, and flatter than any continental shelf worldwide efficiently trapping the edge waves. The issue is important because edge-waves are a local site effect that compounds the tsunami hazard by amplifying the tsunami, delaying the highest wave arrival times, and extending the duration of high amplitude waves for many hours and potentially for days. Finally, we study the morphology of other continental shelves worldwide and identify hotspots where similar behavior will potentially be observed in future tsunamis.

\section{Tsunami Threat Assessment for the North and Central Pacific Coast of Costa Rica}

CHACON-BARRANTES, S. E., Universidad Nacional de Costa Rica, Heredia, Costa Rica, silviachaconb@gmail.com; AROZARENA-LLOPIS, I., Universidad Nacional de Costa Rica, Heredia, Costa Rica, iarozarena@gmail.com

Costa Rica has over 600 beaches, most of them populated. Tourism is a major economic activity of these coastal communities, present all year round due to tropical weather. There is a currently ongoing project to elaborate tsunami evacuation maps for the North and Central Pacific Coast of Costa Rica, funded by the National Emergency Commission (CNE). Twenty communities were chosen based on their tsunami risk. Tsunami vulnerability was defined by population and topographic conditions. To define the tsunami threat, the propagation of over 40 tsunamis was simulated numerically using ComMIT model over a $60 \mathrm{arcmin}$ grid. The topography data was obtained from a LIDAR survey and the bathymetric data from nautical charts and global bathymetry. Sources were considered around the Pacific Basin, both in the near and far field. The resulting tsunami heights were superimposed to obtain a joint maximum tsunami height 
for each community. The highest joint tsunami heights were obtained for the southwestern coast of the Nicoya Peninsula and some isolated spots elsewhere. The amplification of the tsunami energy in those places was very likely due to the narrow continental platform and the effect of submarine landslide scars. The results can be employed to prioritize tsunami preparedness and warning efforts.

\section{Pedestrian Evacuation Analysis in Case of Tsunami for the Puerto Rico} Municipalities of Aguadilla, Arecibo and Ponce

SEVERINO, V. E., University of Puerto Rico Mayagüez, Puerto Rico, vianca. severino@upr.edu; MALDONADO, J., USDA-NRCS, Kentucky, USA, javier. maldonado3@gmail.com; RUIZ, R., Puerto Rico Seismic Network, Puerto Rico, USA, roy.ruiz1@upr.edu; VANACORE, E. A., Puerto Rico Seismic Network, Puerto Rico, USA, elizabeth.vanacore@upr.edu; GONZALEZ, W., Puerto Rico Seismic Network, Puerto Rico, USA, wildaomaris@gmail.com

In the past decade, the world has witnessed of numerous tsunamis and earthquakes in different parts of the world such as Indonesia (2004), Peru (2007), Haiti and Chile (2010), Japan (2011) and the most recent one in Chile (2015) with waves close to $4.6 \mathrm{~m}$ and substantial damages. In Puerto Rico, the last tsunami that affected the island was in 1918, with waves greater than $5 \mathrm{~m}$ in height, causing damage and deaths, particularly in the western region, where first waves arrived in a matter of minutes. Pedestrian evacuation analysis permits evaluation of the travel time of an evacuation route taking into account different rates of pedestrian movement. According to data from the Puerto Rico Tsunami Ready program, more than 249,000 people reside within the tsuanami evacuation areas. It is important to know an estimate of the time of pedestrian evacuation of our exposed communities to demonstrate the danger of these and look for possible solutions to these cases. Here we present case study results of pedestrian analysis performed using Pedestrian Evacuation Analyst Tool in ArcGIS for three municipalities (counties) in Puerto Rico, Aguadilla, Arecibo, and Ponce. Based on these analysis, it is apparent that there are communities in Puerto Rico that their evacuation time is longer than the estimated arrival time of the tsunami. These regions require further consideration for additional mitigation including identifying alternate evacuation routes or identifying vertical evacuation sites. Results of the pedestrian analyses are publicly available through the Puerto Rico Tsunami Program Map Tool (TDST). This project provides valuable information for the emergency management officers and the residents to evaluate the risk and look for alternatives in order to lower the evacuation times of said exposed communities.

\section{Urban Liquefaction and Lateral Spread Investigations and Mapping \\ Oral Session • Tuesday 15 May · 2:15 AM • Hibiscus A Session Chairs: Gregory P. De Pascale and Jeffrey Bachhuber}

\section{Contemporary and Paleoliquefaction-Induced Lateral Spreading Mapping in Christchurch, New Zealand}

DE PASCALE, G. P., Department of Geology-University of Chile, RM, Chile, snowyknight@gmail.com; BACHHUBER, J., Pacific Gas and Electric, California, USA, jxbs@pge.com; RATHJE, E. M., University of Texas, Texas, USA, e.rathje@mail.utexas.edu

Earthquake triggered liquefaction and lateral spreading was widespread in Canterbury, New Zealand (NZ) during the 2010-2012 Canterbury Earthquake Sequence (CES) and led to $\sim \$ 20$ Billion NZD of damage. Although the causes and timing of liquefaction during the CES are well known, the geological controls on lateral spreading are more poorly- understood. We undertook a multidisciplinary investigation funded by the National Science Foundation (NSF) and explored lateral spreading in Christchurch during the CES using image differencing displacement maps, field mapping, shear wave velocity profiles, boreholes and cone penetration (CPT) soundings, and paleoseismic trenching with radiocarbon dating. Preliminary results suggest that cumulative displacements from the CES are less than those observed in our trench along faults and index beds in the subsurface, and along a key down-dropped soil, when combined with clear paleoliquefaction at the site (e.g. faulted pre- CES sand boils) suggest at least one major pre-CES lateral spreading event here. The results of this mapping with aid us with mapping liquefaction and lateral spreading globally.

Lateral Spreading Analyses of the Existing Shoreline at Treasure Island ESPINOSA, P. J., ENGEO Incorporated, California, USA, pespinosa@ engeo.com; HEIDARZADEH, B., ENGEO Incorporated, California, USA, bheidarzadeh@engeo.com; ELIAHU, U., ENGEO Incorporated, California, USA, ueliahu@engeo.com

Treasure Island is located in the central San Francisco Bay, immediately north of Yerba Buena Island, between the active San Andreas and Hayward faults. Treasure Island was constructed by placing hydraulic sand fill over natural shoal deposits within perimeter rock dikes. The natural shoal deposit consists of layers of clean sand, silty sand, and lenses of highly plastic clay. Full-scale and high-energy in-situ dynamic ground improvement test results indicated that, unlike the fill material, no appreciable ground improvement (i.e. densification) was observed within the shoal deposits. From a thorough geologic characterization of the shoal deposit and the results of laboratory cyclic direct simple shear tests on high-quality samples, it was concluded that the dynamic behavior of the natural shoal deposit could not be adequately captured by simplified conventional analytical methods, as the shoal deposit was found to be more resistant to seismically induced lateral deformation than could be predicted by simplified methods. Therefore, this study was undertaken to evaluate the seismic deformation of the existing shoreline at Treasure Island through a nonlinear dynamic deformation analysis. The scope of the study included seismic site response analyses, lateral deformation analyses using two-dimensional finite-element models in PLAXIS, pseudo-static hybrid deformation analyses, and comparisons with observed seismic performance of similar sites during past earthquakes. The shoal deposit was modeled using the UBC Sand model, with input parameters carefully selected to capture material behavior obtained through cyclic simple shear tests. Examination of PLAXIS analysis results indicates that the magnitude of lateral deformations at the location of the proposed development was negligible. A simplified method was also developed to be used as a screening tool for estimating the potential for lateral movement at other sites along the Treasure Island shoreline.

\section{Urban Liquefaction Mapping for Water System Seismic Reliability, Portland,} Oregon

HITCHCOCK, C., Infraterra, Inc., California, USA, chitchcock@ infraterra.com; HOEFT, J., SAGE Engineers, Inc., California, USA, jhoeft@ sageengineers.com; GREENFIELD, M., University of Washington, Oregon, USA, mike@greenfieldgeotechnical.com; MCCORMICK, E., Cascade GIS \& Consulting, LLC., Oregon, USA, erica@cascadeconsulting.net; BROSSY, C., Fugro, Inc., Idaho, USA, cooper.brossy@gmail.com; BACHHUBER, J., Pacific Gas \& Electric, California, USA, jxbs@pge.com; NISAR, A., Infraterra, Inc., California, USA, anisar@infraterra.com

Conventional regional-scale urban liquefaction hazard analyses are typically performed using surficial geologic data, supplemented by representative but often limited subsurface data. These studies often do not fully capture the complicated subsurface stratigraphy critical to characterizing the distribution and thickness of strata potentially susceptible to liquefaction or associated lateral spreading that is damaging to distributed lifeline systems. Additionally, extrapolation for large magnitude earthquakes, such as an $\mathrm{Mw}=9.0$ Cascadia Subduction Zone earthquake, is often required. We performed a regional liquefaction hazard study for the Portland Water Bureau (PWB) using data from hundreds of borings across the Portland metro region to delineate three-dimensional (3D) subsurface conditions that could influence liquefaction and affect PW B's system. The database of geotechnical samples developed for this study provided representative soil parameters within specific geologic units. These data were linked with GIS-based 3D maps of the geologic units for the Portland metro region developed by the Oregon Department of Geology and Mineral Industries and with depth to groundwater developed by the USGS. Our database includes interpretation of each sample's liquefaction susceptibility, triggering potential, and post-triggering behavior for an array of seismic loading conditions, including a large Cascadia Subduction Zone earthquake. These data were combined in GIS and also analyzed to estimate median lateral spreading deformation. The liquefaction and lateral spread results were then incorporated into GIS, combining the detailed 3D subsurface geologic maps, groundwater maps, and seismic hazard maps to produce deformation maps that closely match site-specific analyses and provide quantitative estimates of liquefaction hazards for the entire urban water system.

Seismic and Liquefaction Hazard Maps for Lake County, Northwestern Tennessee

CRAMER, C. H., CERI, University of Memphis, Tennessee, USA, ccramer@ memphis.edu; VAN ARSDALE, R. B., Department of Earth Science, University of Memphis, Tennessee, USA, rvanrsdl@memphis.edu; ARELLANO, D., Civil Engineering Department, University of Memphis, Tennessee, USA, darellan@ memphis.edu; PEZESHK, S., Civil Engineering Department, University of Memphis, Tennessee, USA, spezeshk@memphis.edu; HORTON, S. P., CERI, University of Memphis, Tennessee, USA, shorton@memphis.edu; WEATHERS, T., Department of Earth Sciences, University of Memphis, Tennessee, USA, 
twathers@memphis.edu; NAZEMI, N., Civil Engineering Department, University of Memphis, Tennessee, USA, nnazemi@memphis.edu; JIMENEZ, J. A., Civil Engineering Department, University of Memphis, Tennessee, USA, jjmenez1@memphis.edu; TOHIDI, H., Civil Engineering Department, University of Memphis, Tennessee, USA, htohidi@memphis.edu; OGWENO, L. P., CERI, University of Memphis, Tennessee, USA, logweno@memphis.edu

A five-year seismic and liquefaction hazard mapping project for five western Tennessee counties began in 2017 under a Disaster Resilience Competition grant from the U.S. Department of Housing and Urban Development to the State of Tennessee. The project supports natural hazard mitigation efforts in these five counties. The seismic hazard maps for Lake County in northwestern most Tennessee are being completed in early 2018. Additional geological, geotechnical, and geophysical information has been gathered in Lake Co. to improve the base northern Mississippi Embayment hazard maps of Dhar and Cramer (2017). Information gathered includes additional geological and geotechnical subsurface exploration logs, water table level data collection and measurements, new measurements of shallow and deep shear-wave velocity (Vs) profiles, and the compilation of existing Vs profiles in and around the county. Improvements are being made in the 3D geological model, water table model, the geotechnical liquefaction probability curves, and the Vs correlation with lithology model for Lake Co. Resulting improved soil response amplification distributions on a $1 \mathrm{~km}$ grid will be combined with the 2014 US Geological Survey seismic hazard model (Petersen et al., 2014) sources and attenuation models to add the effect of local geology for Lake Co. Resulting products will be similar to the Memphis and Shelby County urban seismic hazard maps recently updated by Cramer $e t$ al. (2018).

NGL: An Open Source Global Database for Next-Generation of Liquefaction Assessment

ZIMMARO, P., UC Los Angeles, California, USA, pzimmaro@ucla.edu; KWAK, D. Y., RMS, Inc, California, USA, dongyoup.kwak@rms.com; BRANDENBERG, S. J., UC Los Angeles, California, USA, sjbrandenberg@ ucla.edu; STEWART, J. P., UC Los Angeles, California, USA, jstewart@seas. ucla.edu

The Next-Generation Liquefaction (NGL) project is a multi-year communitybased research effort with the main goal of developing improved procedures to evaluate liquefaction susceptibility, triggering, and consequences. The NGL project consists of three components (1) an open-source case-history database, (2) supporting studies aiming to capture specific effects not constrained by data, and (3) model development. This study describes the structure of the NGL casehistory database and its main characteristics. A beta-version of the current release of the database is accessible on-line at http://www.uclageo.com/ngl/. The NGL database is developed as a formal relational database using the MySQL management system. It comprises three main sections: (1) site, (2) earthquake event, and (3) post-earthquake observation. In NGL, a case-history is defined as the intersection among the three. The NGL database utilizes the ESRI ArcGIS Interface and the Leaflet Javascript API to organize the data geo-spatially. As such, it provides invaluable visualization tools to analyze spatial distribution of recorded ground motions, site investigations, and observations. It also provides plotting tools to visualize geotechnical/geophysical in-situ investigations, laboratory tests, and post-earthquake observations (e.g. photos, displacement vectors, LiDAR, satellite observations, etc.). These graphical tools are especially valuable to analyze liquefaction occurrence in urban areas. The database currently hosts several case-histories from Christchurch (New Zealand) following the 2010-2011 Canterbury earthquake sequence and from the greater Tokyo area (Japan) following the 2011 Tohoku-Oki earthquake. In both cases, high-quality observations, along with field investigations and laboratory tests, are available. These earthquake events, are excellent examples on how the NGL database can provide the opportunity to greatly expand the number and quality of liquefaction case-histories globally.

\section{D/4D Seismic Imaging and Their Interpretation for Seismic Hazard Assessment}

Poster Session · Tuesday 15 May · Riverfront South

Seismic Structure of the Río De La Plata Craton from Surface Wave Tomography

BALESTRINI, F. I., Departamento de Sismología, Facultad de Ciencias Astronómicas y Geofísicas, Universidad Nacional de La Plata, Buenos Aires, Argentina, florbales@hotmail.com; ROSA, M. L., Departamento de Sismología,
Facultad de Ciencias Astronómicas y Geofísicas, Universidad Nacional de La Plata, Buenos Aires, Argentina, mlrosa@fcaglp.unlp.edu.ar

We present the results of a surface wave group velocity tomography study for the Rio de la Plata craton (RPC). This craton represents the oldest Precambrian region of the end of southwest Gondwana in South America. The results were then inverted to estimate crustal and lithospheric thicknesses. Previous studies carried out in South America did not map some areas of the continent such as the RPC, clearly because of the insufficient number of crossing paths. To improve the resolution of the previously obtained crustal and upper mantle images, the number of group velocity measurements for the craton area was increased, achieving a better coverage of paths and a more uniform azimuthal distribution which enhances the tomographic images. Surface wave dispersion curves were obtained by a multiple filter technique with a phase-matched filter to better isolate the fundamental mode. A 2D tomographic inversion of the group velocity was applied using a conjugate gradient method. Our results include both Love- and Rayleighwave inversions for periods from 10 to $100 \mathrm{~s}$. The obtained group velocity maps correspond well with the main tectonic structures along the studied area. Inversions of the group velocities were carried out to obtain the $S$-wave velocity distribution in the crustal region.

Crustal Structure in the Pantanal and Chaco Basin from Receiver Function RIVADENEYRA-VERA, J. C., Universidade De Sao Paulo, São Paulo, Brazil, carolina.rivadeneyra@gmail.com; BIANCHI, M., Universidade de São Paulo, São Paulo, Brazil, m.bianchi@iag.usp.br

Crustal structure is an important parameter in global and regional seismic studies. A widely used method to obtain important features of the crust and upper mantle is receiver function, that uses teleseismic data (in distances raging from 30 to 95 degrees). In Brazil it began to be utilized since 1993, however there is still a lack of information in some areas, where the results obtained show a poor lateral resolution and great uncertainties due local complications and density of stations, as in the area of Pantanal and Chaco basin. In order to obtain more detailed crustal information about theses areas and update the map of Brazilian crust thickness, we used data of 1452 teleseismic events occurred from 2010 to 2016, registered at 166 RSBR (Brazilian Seismographic Network) and XC (FAPESP 3-basins project) stations. Automated selection of traces is performed based on azimuth recovering, radial SNR values and fit percentage of the original trace recovering. Deconvolution of the signal were done in time domain using low frequencies, a move-out correction was made for each phase and the estimation of crustal thickness was performed on receiver function traces by the Zhu and Kanamori modified method. Results shows a thin crust of $32 \mathrm{~km} \pm 1.2 \mathrm{~km}$ in Pantanal basin and a thicker crust in Chaco basin $(37 \mathrm{~km} \pm 4 \mathrm{~km})$, we also found unreliable results in the Amazon area. These new results corroborate the pre-existent models of crustal thickness in the most studied areaof the eastern part of South America.

Joint Inversion of Rayleigh Waves Dispersion Curves and Ps-Receiver Functions in Libya for Crustal Thickness and 1D Shear Wave Velocity Model SOSA, U. A., Universidad Icesi, Valle del Cauca, Colombia, uasosa@icesi.edu. co; AGAIL, A., University of Texas at El Paso, Texas, USA, aaagail@miners.utep. edu; VELASCO, A. A., University of Texas at El Paso, Texas, USA, aavelasco@ utep.edu; ZAMORA, A., University of Texas at El Paso, Texas, USA, azamora3@ utep.edu

The use of a constrained joint inversion approach reduces the effect of noisy data into the inversion, since it make use of physically meaningful bound constraints to regularize the inversion process. In this study, we analyze waveforms data collected from the Libyan seismic network (LNSN) to compute Rayleigh wave dispersion curves and Ps-receiver functions. Rayleigh dispersion curves were measured for Rayleigh waves over periods of 20-80 s, and we invert the dispersion curves to obtain group velocities on a grid of $2.0^{\circ} \times 2.0^{\circ}$ at specific periods. We first calculate crustal thickness using a standard receiver functions stacking (RFS) methodology, and then jointly invert Rayleigh waves and Ps-receiver using a constrained joint inversion approach to produce 1-D shear wave velocity models beneath all the LNSN stations. The data is not optimal, and we are limited in the number of receiver functions and group velocity curves. Regardless, the constrained joint inversion approach allows us to produce 1-D shear wave velocity models beneath all the LNSN stations. The results indicated a well-constrained depth compared to those obtained by inverted RFS, even with low quality data present in some stations. The depth to the Moho beneath all stations includes stations (TBQ, GHD, and ZLA) not previously reported. In addition, we report differences in Moho's depth for other stations from previous results. Our results show a geological structure that highlights the local tectonic provinces. 
Crustal Structure of the Amazonian Craton and Adjacent Provinces in Brazil ALBUQUERQUE, D. F., Seismological Observatory of UnB, Federal District, Brazil, diogofarrapo@gmail.com; FRANÇA, G. S., Seismological Observatory of UnB, Federal District, Brazil, diogofarrapo@gmail.com; MOREIRA, L. P., Federal Institute of Brasília, Federal District, Brazil, lucas.paes.moreira@ gmail.com; ASSUMPÇÃO, M., Seismological Center, University of São Paulo, São Paulo, Brazil, marcelo@iag.usp.br; BIANCHI, M., Seismological Center University of São Paulo, São Paulo, Brazil, m.bianchi@iag.usp.br; BARROS, L. V., Seismological Observatory of UnB, Federal District, Brazil, lucas@unb.br; QUISPE, C. C., Geophysical Institute of Peru, Peru, gfcristobalcq@gmail.com; OLIVEIRA, M. E., Seismological Observatory of UnB, Federal District, Brazil, magdaestrelaoliveira@gmail.com

The study of the crust using receiver functions can provide valuable geological information, such asaverage crustal composition, its formation dynamics and the tectonic evolution of a region, as well as serve as an initial reference for the generation of seismic wave velocity models to improve earthquake location. To fill in gaps in information on the crust of the Amazonian Craton and adjacent provinces in Brazil, we used receiver functions and $\mathrm{H}-\mathrm{k}$ stacking to estimate crustal thicknesses and the $\mathrm{Vp} / \mathrm{Vs}$ ratios. The results indicate that the crust of the study region is predominantly felsic, with an average $\mathrm{Vp} / \mathrm{Vs}$ around 1.73 and an average thickness of $38.2 \mathrm{~km}$, with a range of $27.4-48.6 \mathrm{~km}$. Minimum curvature interpolation of the crustal thickness values has made it possible to delimitate of the Amazonian Craton, which corresponds to the area with an average thickness equal to or greater than $39 \mathrm{~km}$. In addition, it was possible to identify its potential cratonic blocks, as well as the Paranapanema Block of Paraná Basin. The geometry of the craton, defined by its crustal thickness, is corroborated by the distribution of natural seismicity that accompanies its edges. These are related to suture zones between the Amazonian, São Francisco/Congo and Paranapanema paleocontinents. The sedimentary basins that have undergone rifting processes have a thinner crust, usually less than $37 \mathrm{~km}$ thick. Due to the great variability of the results, it was not possible to determine a characteristic value of crustal thickness or $\mathrm{Vp} / \mathrm{Vs}$ ratio for each structural province located in the study region.

Seismic Structures beneath the Oklahoma Region and the Eastern Tennessee Seismic Zone

CHAI, C., University of Tennessee at Knoxville, Tennessee, USA, cchai1@utk. edu; MACEIRA, M., Oak Ridge National Laboratory \& University of Tennessee at Knoxville, Tennessee, USA, maceiram@ornl.gov; DELOREY, A. A., Los Alamos National Laboratory, New Mexico, USA, andrew.delorey@lanl.gov; JOHNSON, P. A., Los Alamos National Laboratory, New Mexico, USA, paj@ lanl.gov; AMMON, C. J., Penn State, Pennsylvania, USA, charlesammon@psu. edu; HERRMANN, R. B., Saint Louis University, Missouri, USA, rhb@eas.slu. edu

Seismicity in the eastern United States mainly occurs within localized seismic zones. A well-documented and significant increase in seismicity occurred in the Oklahoma (OK) region following increased wastewater injection associated with hydrocarbon extraction activity. Why does stable continental seismicity favor particular seismic zones? How does wastewater injection lead to increased seismicity? As a first step towards answering these fundamental scientific questions, we investigate subsurface seismic structures beneath two of these localized seismic zones, the OK region and the Eastern Tennessee Seismic Zone (ETSZ). The deployment of the EarthScope Transportable Array and local seismic networks provides the community an opportunity to estimate regional-scale crustal and upper mantle structure with higher resolution. Complementary geophysical observations have been collected and processed using seismic records from these deployments and other investigations. Reliable subsurface seismic images have been produced utilizing complementary observations at broad scales and these models serve well as a starting/initial model for building refined models. Building on these broader-scale efforts, we simultaneously invert local body-wave travel times, surface-wave dispersion, and gravity observations to estimate the subsurface structure beneath the OK and ETSZ regions. In OK, the subsurface velocity model outlines the Anadarko Basin nicely; and our relocated events agree well with other analyses. We explore the potential to use the resulting 3D elastic model to compute regional stress variations. To test the model in a region of natural seismicity, we apply the same methodology to the ETSZ and we jointly invert smoothed/interpolated P-wave receiver functions, surface-wave dispersions and gravity observations for seismic velocity images. The comparison allows us to explore the importance of local travel times for constructing models to estimate regional stress variations.

Seismic Anisotropy and Mantle Dynamics beneath the Arabian Plate QAYSI, S. I., Missouri University of Science \& Technology, Missouri, USA, siqvx8@mst.edu; LIU, K., Missouri University of Science \& Technology,
Missouri, USA, liukh@mst.edu; GAO, S., Missouri University of Science \& Technology, Missouri, USA, sgao@mst.edu

We investigate mantle seismic azimuthal anisotropy and deformation beneath the Arabian Plate and adjacent areas using data from 230 broadband seismic stations which include 160 stations managed by the Saudi Geological Survey. A total of about 4100 pairs of shear wave splitting parameters are obtained using the transverse minimization technique. The individual XKS (including PKS, SKS, and SKKS) splitting measurements were manually checked to ensure the quality. The well-defined parameters show dominantly N-S fast orientations at the majority of the stations, and NW-SE fast orientations along the Zagros Mountain front. No clear systematic variations of the splitting parameters as a function of back azimuth are detected, suggesting that a single layer of anisotropy with a horizontal axis of symmetry is adequate to interpret the shear wave splitting measurements. Large splitting times are observed beneath the Arabian Platform and the Red Sea areas as well as in the western region of Arabian Peninsula. Since lithospheric thickness beneath both the Arabian Platform and the Red sea areas is less than 80 $\mathrm{km}$, a significant contribution from lithosphere is unlikely. We propose that the observed seismic anisotropy is mainly originated from olivine lattice preferred orientation developed by simple shear between the lithosphere and asthenosphere associated with the northward (relative to the underlain asthenosphere) subduction of the Arabian Plate over the past $150 \mathrm{Ma}$.

Rayleigh Wave Group-Velocity across the Southern United States from Ambient Noise Tomography

BARMAN, D., Baylor University, Texas, USA, debajeet_barman1@baylor. edu; PULLIAM, J., Baylor University, Texas, USA, jay_pulliam@baylor.edu; QUIROS, D. A., Baylor University, Texas, USA, diego_quiros@baylor.edu

Characterizing lithospheric structure across the continental margin of the southern United States is critical to understanding the late Paleozoic accretionary history of Laurentia and the tectonics of the Alleghanian orogeny. Such a model may also shed light on the roles anomalous features such as the Sabine and Monroe Uplifts and Wiggins Arch played in the formation of North America's southern margin. To this end, we use vertical-component broadband data in its majority from the Transportable Array (TA) to model shear wave velocity structure across the region. Ambient noise recorded by 280 seismic stations during the period 2010-17 are cross-correlated to generate Green's functions for $\sim 40000$ station pairs, after application of a bandpass filter with corner periods at $7 \mathrm{~s}$ and $100 \mathrm{~s}$. Cross-correlations are stacked on a monthly basis to increase their signal-to-noise ratio (SNR) and frequency-time analysis (FTAN) is performed with a phasematched filter to produce group velocity dispersion curves. Group velocity maps of this region are generated for 10 s to 80 s. One-dimensional shear wave velocity models are generated for selected sites by convolving group velocity results with depth kernels produced by forward modeling. The Markov Chain Monte Carlo method is applied to estimate the maximum likelihood $S$ wave velocity model and, specifically, Moho depth. Preliminary results show strong correlations between Vs anomalies and large-scale terranes identified in geological studies. For example, a boundary between the Gondwana terrane and Laurentia is evident between $10 \mathrm{~s}$ and $20 \mathrm{~s}$ group velocity maps. At $30 \mathrm{~s}$ period a longitudinal feature is observed that could correspond to the South Georgia accreted terrane. There is a stark contrast in group velocities between Florida peninsula and the rest of the southeastern United States at 50 s period.

Crustal Structure Across the Appalachian Basin Using Joint Inversion of P-Wave Receiver Functions and Surface Wave Dispersion

HOMMAN, K. A., Penn State, Pennsylvania, USA, kah5265@psu.edu; NYBLADE, A. A., Penn State, Pennsylvania, USA, aan2@psu.edu

Induced seismicity as a result of hydraulic fracturing and the subsequent wastewater disposal process has been a concern in recent years. Although typically small magnitude events, these induced earthquakes can reach magnitudes large enough to cause damage to nearby structures. The majority of induced seismic events occur within old basement faults below the target formation. While most induced seismicity has occurred in the central United States, there are several instances of induced events occurring in the Appalachian Basin such as the magnitude 2.3 Lawrence County, PA event in 2016 and the magnitude 4.0 Youngstown, Ohio event in 2011. Using data from several permanent and temporary broadband seismic networks, this study aims to determine crustal structure and depth to basement across the Appalachian Basin by jointly inverting teleseismic $\mathrm{P}$-wave receiver functions and surface wave dispersion measurements. P-wave receiver functions are primarily sensitive to shear-wave velocity contrasts and vertical travel times whereas surface waves are sensitive to shear-wave velocities. The joint inversion of the two methods bridges resolution gaps associated with each data set, enabling the development of a higher resolution subsurface 
model. A better understanding of the crustal structure across the basin will allow identification of areas that may be of high risk for induced seismicity. Preliminary results indicate the use of high frequency receiver functions with dispersion measurements can image basement structure.

\section{Development of a 3D Seismic Velocity Model of the Bengal Basin and Adjacent Regions}

HUDA, M. M., The University of Memphis, Tennessee, USA, mmhuda@ memphis.edu; TABORDA, R., The University of Memphis, Tennessee, USA, ricardo.taborda@memphis.edu

Seismic velocity models are becoming increasingly important due to their use in simulation, and other applications in seismology and engineering. We describe the development of a three-dimensional seismic velocity model for the Bengal basin, covering Bangladesh and the neighboring regions of India and Myanmar. The model encompasses an area of $760 \times 780 \mathrm{~km} 2$. It is bordered by the stable Indian continent on the west and north-west, the Himalayas on the north and north-east, and the Burma plate on the east and south-east. The basin is shaped by the Ganges-Brahmaputra-Meghna delta-the largest delta system in the world - and rests over a sedimentary structure with thicknesses that can reach up to $20 \mathrm{~km}$ in depth. This is a region under high seismic hazard due to the collision between the Indian, Eurasian, and Burmese plates. The velocity model is developed based on available sedimentology and geological investigations. We collected and digitized information in the form of geological borehole logs; seismic, aeromagnetic and gravity profiles; and geologic mapping and contours developed from sedimentary deposition studies. Most of the borehole logs came from natural gas and other mineral exploration studies concentrated in the north-western and north-eastern regions. Aeromagnetic and gravity profiles were used to build contours of different sedimentary deposits and major velocity contrasts in the deep basin. The model is built as a computer code application interface (or API) designed to provide values of seismic velocities (Vp and Vs) and density. We have used the model to produce low frequency $(<0.5 \mathrm{~Hz})$ ground motion simulations of a few local earthquakes, and compared the results with available seismic data to test the model's reliability. In the future, as we continue to make improvements, we expect to use the model in simulations of past and scenario earthquakes to gain insights about the region's seismic hazard and the basin's response.

\section{Advances in Explosion Seismo-Acoustic Research} Poster Session · Tuesday 15 May · Riverfront South

\section{Local Monitoring of Underground Mining Explosions at Redmond, Utah}

DOWNEY, N. J., Sandia National Laboratories, New Mexico, USA, njdowne@ sandia.gov; ALBERT, S. A., Sandia National Laboratories, New Mexico, USA, salber@sandia.gov; ARROWSMITH, S. J., Sandia National Laboratories, New Mexico, USA, sjarrow@sandia.gov

As part of their normal operations, Redmond Salt Mine, located in Sevier Valley, central Utah, performs underground chemical explosions multiple times per night, 5 days per week. These explosions, of approximate yield 800lbs TNT equivalent each, are not routinely detected by the state-wide seismic network operated by the University of Utah Seismograph Stations (UUSS). However, they do provide a rare opportunity to study seismic events occurring at several locations within a large network of underground tunnels bored in a media of complex velocity structure. In October 2017, we initiated a long-term (minimum of one year) study of the explosions at Redmond Salt mine using temporary deployments of broadband seismic, nodal seismic and infrasound sensors around the mine site at offsets up to $30 \mathrm{~km}$. Our intent is to characterize the seismic signatures of the underground explosions, design automated event detection methods, determine the velocity structure of the regions around the mine, compare the signals from the explosions to those of natural seismicity in the region and evaluate methods by which the Redmond explosions can be detected on the UUSS network. Here we present a preliminary analysis of the first data recorded during this experiment in which we highlight the complexity of the Redmond explosions, compare them to earthquakes in the region, quantify the infrasound signatures of explosions, and evaluate the influence of the complex geology of Sevier Valley on seismic wave propagation.

\section{Seismic and Infrasound Analysis of Rocket Launches and Explosions at Kennedy Space Center}

THOMPSON, G., University of South Florida, Florida, USA, thompsong@usf. edu; MCNUTT, S. R., University of South Florida, Florida, USA, smcnutt@ usf.edu; BRAUNMILLER, J., University of South Florida, Florida, USA, jbraunmiller@usf.edu; BROWN, R. G., NASA Kennedy Space Center, Florida,
USA, r.g.brown@nasa.gov; FARRELL, A. K., University of South Florida, Florida, USA, akfarrell@mail.usf.edu; MEHTA, C. A., University of South Florida, Florida, USA, camehta@mail.usf.edu; STEFFAN, C. K., University of South Florida, Florida, USA, cksteffan@usf.edu

We installed a temporary 3-station seismic-infrasound network at Kennedy Space Center (KSC) in February 2016 to test sensor calibrations and train students in field deployment techniques. Each station featured a broadband 3-component seismometer and a 3 -element infrasound array. We recorded 3 rocket launches with this network. In May 2016 the network was scaled back to a single station due to other projects competing for equipment. A further 8 launches have been recorded with this station. We have also recorded 1 aborted launch, 3 static fire tests, 1 explosion sequence, and 33 sonic booms. Of the 11 launches recorded, 4 were SpaceX Falcon-9 rockets, 5 were ULA Atlas-V and 2 were ULA Delta-IV. A question we attempt to answer is whether the rocket engine type and launch trajectory can be determined with appropriate travel-time, amplitude-ratio and spectral techniques. We observe a frequency shift in seismic and infrasound spectrograms from all launches, with lower frequencies occurring later in the recorded signal as the rocket accelerates away from the array. By interpreting this as a Doppler shift, speed and distance from the station can be estimated. Locating rockets based on amplitude-ratio across the 3 station network is complicated by radiation effects. Jet noise is highly directional and peaks at an angle of about 30 degrees from the rocket's vertical axis. The largest signal recorded so far was the explosion of a SpaceX Falcon-9 rocket on September 1st, 2016 during a static fire test. We identified 153 airwave events in a sequence lasting 26 minutes, as the rocket and its payload were progressively destroyed and fire engulfed the launch pad. The peak pressure recorded was equivalent to a VEI 3 volcanic eruption, although the duration was much shorter. Combined video, audio, seismic and infrasound analysis indicates there was no precursory signal.

\section{An Alternative Detection Model for Waveform Correlation}

GANTER, T., Sandia National Laboratories, New Mexico, USA, tylergan29@ gmail.com; SUNDERMIER, A., Sandia National Laboratories, New Mexico, USA, asunder@sandia.gov; BALLARD, S., Sandia National Laboratories, New Mexico, USA, sballard999@gmail.com

Recent studies have suggested that a significant limiting factor in the application of waveform correlation to regional and global scale monitoring is the false alarm rate. The false alarms are not originating from detections on noise, but rather from seismic arrivals with unrelated source locations. Our research approach considers transient signals from non-collocated seismicity when designing new waveform correlation detectors. The new method derives a set of detectors to represent the unique characteristics of the template waveforms; these new detectors maximize the likelihood of detecting only the desired events, thereby minimizing false alarms. To examine the effectiveness of the new method, we created a waveform correlation template library for a single three-component seismic monitoring station. We review the results from applying the new detectors to a test set of seismic waveforms, then compare with the conventional waveform correlation matched filter technique.

\section{Regional 3-D Geophysical Characterization of the Nevada National Security Site}

PRESTON, L., Sandia National Laboratories, New Mexico, USA, Ipresto@ sandia.gov; POPPELIERS, C., Sandia National Laboratories, New Mexico, USA, cpoppel@sandia.gov; SCHODT, D., Sandia National Laboratories, New Mexico,USA, djschod@sandia.gov

One of the goals of the Source Physics Experiments (SPE) is to gain a better understanding of the generation and evolution of seismic wave types over a range of propagation distances. A fundamental first step in this is to synthesize seismic waves, which requires accurate 3-D earth structural models. We have developed a 3-D local-to-regional scale seismic velocity model of the Nevada National Security Site using a joint inversion of body wave travel times, gravity measurements, and surface wave dispersion curves. The body wave data set includes absolute and differential $\mathrm{P}$ - and $\mathrm{S}$-wave travel times from local earthquakes recorded on the University of Nevada Reno (UNR) southern Nevada network as well as active sources, including those from SPE. This data set alone amounts to over a million absolute body wave picks and over 500,000 high-quality differential picks. To enhance near-surface velocity resolution we also augment this data set with local measurements of gravity and surface wave dispersion. We have recently improved the 3-D earth model in Yucca Flat by including new local active source data, providing better coverage near the SPE sites. We used a weighted, linearized, iterative inversion scheme to combine these disparate data types in order to solve for the optimal 3-D P-and S-wave velocity model and hypocentral locations given observed data subject to model smoothness constraints. We discuss challenges 
associated with combining these disparate data sets, including differences in physics, resolution, weighting, and regularization. In addition, we will discuss the effect of adding these new data on the earth model. Sandia National Laboratories is a multimission laboratory managed and operated by National Technology and Engineering Solutions of Sandia LLC, a wholly owned subsidiary of Honeywell International Inc. for the U.S. Department of Energy's National Nuclear Security Administration under contract DE-NA0003525.

\section{Application and Validation of a Relative Relocation Technique for Explosion Monitoring}

BEGNAUD, M. L., Los Alamos National Laboratory, New Mexico, USA, mbegnaud@lanl.gov; ANDERSON, D. N., Los Alamos National Laboratory, New Mexico, USA, dand@lanl.gov; BLOM, P. S., Los Alamos National Laboratory, New Mexico, USA, pblom@lanl.gov; EULER, G. G., Los Alamos National Laboratory, New Mexico, USA, ggeuler@lanl.gov; PHILLIPS, W. S., Los Alamos National Laboratory, New Mexico, USA, wsp@lanl.gov; ROWE, C. A., Los Alamos National Laboratory, New Mexico, USA, char@lanl.gov; PABIAN, F., Retired, New Mexico, USA, fvpabian@gmail.com

Relative arrival times have been used in the past to produce relative relocations of earthquakes and explosions. Precise relocations of explosions have value in the context of the Comprehensive Nuclear-Test-Ban Treaty on-site inspection when data are available for a previous event. The Democratic People's Republic of Korea (DPRK) has now conducted 6 declared nuclear tests from 2006-2017. After the declared test in 2009 , many researchers applied relative relocation techniques to improve the accuracy and precision of the seismic event locations. Relative relocation methods require multiple events at the same location in order to utilize the differential arrivals between events. There are few locations in which such a scenario takes place with the same source type and similar location. However, there is still the overall unknown of the exact ground truth location for these events. We will demonstrate the application of a straight-forward master event methodology for doing relative relocations for DPRK events as well as a modified version of the master event method in a simultaneous, maximum likelihood solution. We also validate this methodology using a data set where we precisely know the locations of multiple, similarly-located explosive events with arrivals from common stations. Taking advantage of readily available waveforms, we are able to make relative picks for many stations at local, regional, and teleseismic distances, depending on the particular event and data set. Waveforms are manuallyaligned on the first few cycles in order to match the initial arrival information. We will compare the relative relocations with those obtained using more recent techniques that involve simultaneous inversion of data from multiple events. The application of the standard master event method consistently provides high relative accuracy and precision, even when the master and test events are separated by tens of kilometers.

Low Yield Seismic Source Analysis Using Local and Regional Observations KINTNER, J.A., Penn State, Pennsylvania, USA,jvk5803@psu.edu; AMMON, C. J., Penn State, Pennsylvania, USA, charlesammon@psu.edu; HOMMAN, K. A., Penn State, Pennsylvania, USA, kah5265@psu.edu; NYBLADE, A. A., Penn State, Pennsylvania, USA, aan2@psu.edu

Low-yield explosion monitoring introduces new challenges to the current approach to estimating source location, magnitude, and discrimination. Small sources require nearby short period observations, which have an increased sensitivity to geologic heterogeneity, poor signal-to-noise ratios, and in many cases are sparse. Local and regional short periods observations from small shallow seismic sources can be dominated by a regional phase shear waves and Rayleigh waves. Using teleseismic surface wave observations, Cleveland \& Ammon [2013] and Cleveland et al. [2015] show the value of using surface waves to estimate precise, relative locations in regions without a nearby seismic network. Using commonstation, nearby-event cross correlation time-shift measurements, much of the complexity in wave propagation caused by regional geological heterogeneity is removed (or at least, greatly reduced). In this work, we extend surface wave relocation methods to estimate precise relative locations of small (local magnitudes from 1 to 3) mine blast events across Pennsylvania using local and near-regional distance observations (out to $300 \mathrm{~km}$ in distance). We also exploit the cross correlation amplitude to estimate more precise relative magnitudes (actually $\log$ moments) and develop a more consistent relationship between explosion yield and relative magnitude for various mines throughout the Commonwealth. Our locations are precise enough to allow us to image a time-dependent migration of a mine wall in north-central Pennsylvania. In west-central Pennsylvania, application of the relative location approach collapses a diffuse distribution of smallmagnitude industrial events into five discreet clusters associated with particular operations in the area. The work demonstrates that cross correlation methods have the potential for achieving high precision relative location and magnitude estimates from local and regional observations of low yield seismic sources.

\section{Underground Explosions in Anisotropic Media: Coupling of Near- and Far-} Field Motions and Implications for SPE

HIRAKAWA, E. T., Lawrence Livermore National Laboratory, California, USA, hirakawa1@llnl.gov; EZZEDINE, S., Lawrence Livermore National Laboratory, California, USA, ezzedine1@llnl.gov

The Source Physics Experiment (SPE) is an ongoing effort to improve explosion monitoring by conducting a controlled series of chemical explosions at the Nevada National Security Site (NNSS) and using the resulting observations to improve and validate physics-based simulations of explosion phenomena. Phase I of SPE was conducted on the Climax Stock granite which contains a network of well-characterized joints. It has been shown that these pre-existing joints may be responsible for the tangential motion observed during SPE chemical explosions. Near-field motions generated with hydrodynamic non-linear source models have been coupled to elastic wave propagation codes to propagate these resulting motions into the far-field domain which is assumed to be elastic and isotropic. This is likely not the case as the pre-existing joints continue beyond the inelastic source region of the explosion. To alleviate this impediment, we extend the current near-field to far-field, hydrodynamic-to-elastic coupling, from anisotropicisotropic to fully anisotropic-anisotropic coupling. Near source hydrodynamic motions are computed using GEODYN-L while anisotropic elastic wave propagation is modeled using SW4. Motions are coupled between the two codes by introducing hydrodynamic motions from GEODYN-L as an internal boundary source to SW4. The anisotropic material model employed in the SW4 domain is derived from the properties of an observed fracture network with relatively wellconstrained joint size, density, orientation, and aperture. We show that consideration of anisotropic material in the elastic regime has an important effect on the propagation of tangential motion. Propagation of motions generated in an anisotropic source region into an isotropic far-field domain may hinder the continuity of the waves in general and may impede the shear motion generation. Prepared by LLNL under Contract DE-AC52-07NA27344. LLNL-ABS-744746.

Finite-Difference Algorithm for 3D Orthorhombic Elastic Wave Propagation JENSEN, R. P., Sandia National Laboratories, New Mexico, USA, rpjense@ sandia.gov; PRESTON, L., Sandia National Laboratories, New Mexico, USA, Ipresto@sandia.gov

A more realistic representation of the geologic subsurface assumes the rock behaves as an orthorhombic elastic medium as opposed to an isotropic elastic medium, which is commonly done. An orthorhombic medium is characterized by three mutually orthogonal symmetry planes comprising a dense system of vertically-aligned microfractures superimposed on a finely-layered horizontal geology. Mathematically, the elastic stress-strain constitutive relations for an orthorhombic body contain nine independent moduli. We are developing an explicit timedomain finite-difference (FD) algorithm for simulating three-dimensional (3D) elastic wave propagation in a heterogeneous orthorhombic medium. The particle velocity vector and the stress tensor are governed by a set of nine, coupled, firstorder, linear, inhomogeneous partial differential equations. All time and space derivatives in this system are discretized to achieve second-order and fourthorder numerical accuracy, respectively. Novel perfectly matched layer (PML) absorbing boundary conditions, specifically designed for orthorhombic media, are also implemented. This FD code is used to support the modeling component of the Source Physics Experiment (SPE), a series underground chemical explosions at the Nevada National Security Site. The data from the experiments are used to help determine event signatures that vary depending on geology, yield and depth of burial. We present simulations of the SPE Phase I series using our orthorhombic FD code and the subsequent comparison to the recorded data. These comparisons are used to calibrate the source and will be used for subsequent preand post-experiment modeling of SPE Phase II. Sandia National Laboratories is a multimission laboratory managed and operated by National Technology and Engineering Solutions of Sandia LLC, a wholly owned subsidiary of Honeywell International Inc. for the U.S. Department of Energy's National Nuclear Security Administration under contract DE-NA0003525.

Analysis of 3-Component Rotational and Translational Ground Motions from SPE Chemical Explosions, Historical Nuclear Explosions and Earthquakes ICHINOSE, G. A., Lawrence Livermore National Laboratory, California, USA, ichinose1@llnl.gov; MELLORS, R.J., Lawrence Livermore National Laboratory, California, USA, mellors1@ llnl.gov; FORD, S. R., Lawrence Livermore National 
Laboratory, California, USA, ford17@llnl.gov; ABBOTT, R.E., Sandia National Laboratory, New Mexico, USA, reabbott@sandia.gov

Four co-located 3-component (3-C) Eentec R-1 rotational velocity sensors and Episensor FBA ES-T translational accelerometers were deployed at the Nevada National Security Site to record three Source Physics Experiment (SPE) chemical explosions with yields of $90 \mathrm{~kg}$ (SPE1), $997 \mathrm{~kg}$ (SPE2), and $905 \mathrm{~kg}$ (SPE3) equivalent TNT. The 4 co-located sensors were deployed $1 \mathrm{~km}$ from ground zero within a granite outcrop. Three earthquakes were also recorded by this seismic array, a Ml 3.3 at $28 \mathrm{~km}$, a Ml 2.6 at $58 \mathrm{~km}$, and Ml 3.5 at $123 \mathrm{~km}$ distance from SPE. Igel et al. (2005) demonstrated using long period teleseismic surface waves that the vertical rotational velocity $(\Omega z)$ is in phase and scales in amplitude with the transverse ( $\mathrm{SH}$ ) translational acceleration (üT) by the horizontal phase velocity c (üT / $\Omega z=-2 c$ ). We expect this also holds true for higher frequency body-waves at local distances and the radial and transverse rotational velocities should scale with the vertical and radial accelerations (P-SV) by the phase velocity, e.g., üZ / $\Omega \mathrm{R} \sim \mathrm{c}(\mathrm{Li}$ and Baan, 2017). Using all 3-C of the rotational and translational motions, we measured the horizontal phase velocity of $450 \mathrm{~m} / \mathrm{s}$ and $1125 \mathrm{~m} / \mathrm{s}$ for 2 separate directions. In contrast, the horizontal velocity measured for the Ml 3.3 earthquake is $6 \mathrm{~km} / \mathrm{s}$ in the 0.1 to $10 \mathrm{~Hz}$ band. While the earthquakes showed high coherency between 3-C rotational and translational motions, the explosions exhibited more coherency with P-SV wave but less coherency for SH-wave radiation. This may be due to explosion $\mathrm{SH}$-waves originating from scattering rather than the source. This difference could be exploited as a discriminant between explosions and earthquakes. We explore such a discriminant using array-derived rotational motions from historical nuclear explosions recorded at regional distance. The ratio of peak-acceleration to peak-rotational-rate shows promise as a discriminant statistic. Prepared by LLNL under Contract DE-AC5207NA27344.

\section{Advances in Seismic Site Response Studies Given Limitations in Understanding of Site Conditions Poster Session · Tuesday 15 May · Riverfront South}

Evaluating Inversion Techniques for Soft Sites in Windsor, Ontario, Canada SHARMA, H. S., Western University, hema.b22@gmail.com; MOLNAR, S., Western University, smolnar8@uwo.ca; DARKO, A. B., Western University, abilsond@uwo.ca

This paper will illustrate a joint inversion analysis of the ambient noise data collected at six soft sites in Windsor, Ontario, Canada, using two different joint inversion methods. We also have geotechnical (borehole and CPT) data near the sites for verifying the applicability of these methods. For both the methods we will take fundamental mode Rayleigh wave dispersion curve and $\mathrm{H} / \mathrm{V}$ curve as an input. For the first method, most of energy propagation is assumed to be in the vertical direction. VS profile estimation will be done by matching the input curves with theoretical fundamental mode Rayleigh wave dispersion curve and the theoretical Rayleigh wave ellipticity curve, arriving at a best fit model iteratively. This inversion technique is based on the Neighborhood Algorithm (NA), which is a stochastic direct search method to find a global minimum. The previous search results guide the newer searches to find local minima and then these local minima are analysed to arrive at a global minimum. For the second method, the theoretical fundamental mode Rayleigh wave dispersion curve will be matched iteratively with the input dispersion curve, and the theoretical H/V curve (comprising of Rayleigh, Love, and/or body wave contributions) will be matched iteratively with the input $\mathrm{H} / \mathrm{V}$ curves to minimise the misfit and arrive at a best fit model to get an estimate of VS profile. This method is based on the theory of diffuse field assumption (DFA), which states that a diffusion-like field is generated when random seismic sources generate ambient noise. In DFA, the Green's function is proportional to the autocorrelation of seismic wavefields in frequency domain. VS depth profiles estimated by these two methods will be then validated using the geotechnical data. This study will help us in understanding the contribution of different wave types in the $\mathrm{H} / \mathrm{V}$ curves calculated using the ambient noise data and in determining the most efficient and applicable method for site assessment.

Understanding the Variations in Shear Wave Splitting Measurements Using Empirical and Simulated Seismic Waveforms

GRAHAM, K. M., Institute of Geophysics, SGEES, VUW, Wellington, New Zealand, fiikennyg@yahoo.com; SAVAGE, M. K., Institute of Geophysics, SGEES, VUW, Wellington, New Zealand, martha.savage@vuw.ac.nz; ARNOLD, R., School of Mathematics and Statistics, VUW, Wellington, New
Zealand, richard.arnold@vuw.ac.nz; ZAL, H.J., Institute of Geophysics, SGEES, VUW, Wellington, New Zealand, hubert.zal@vuw.ac.nz

The measurement of seismic anisotropy through Shear Wave Splitting (SWS), has widely been used by seismologists for the past three decades as a technique to characterize spatiotemporal variation in the stress fields. However, the potential of this technique is yet to be realized in part, because measurements on local earthquakes have often shown variations making interpretation difficult. Many studies have attributed these variations to physical mechanisms such as scattering of seismic waves (caused by scatterers along the wave's propagation path), different earthquake source mechanisms, gradual variation in velocity and anisotropy structures, and different anisotropic symmetry axes. In this study, we examine how these mechanisms affect SWS measurements with the aim of improving this technique. We use empirical and simulated waveforms to test the sensitivity of SWS measurement to these mechanisms. The Kaikōura and Seddon earthquake sequence provide a unique dataset to test how these mechanisms affect SWS measurements. We use a 3-D seismic simulation waveform algorithm (SpecFEM3D) that accounts for anisotropy, topography and heterogeneity to simulate waveforms in order to understand the effect of these mechanisms from a modeling perspective. Results from empirical studies using two permanent GeoNet stations, reveal a possible temporal variation in SWS measurements for a cluster of earthquakes before and after the Kaikōura main shock. The mean fast orientation at both stations for events before the main shock aligns with the NE-SW tectonic structures in the region. Analysis of events after the main shock show a bimodal (NE-SW and NW-SE mode) fast orientation distribution at a station away from the Awatere fault and a NE-SW fast orientation at a station close to the Awatere fault. This variation is examined using families of earthquakes (events with similar source mechanism) to understand how different earthquake source mechanisms affect our results.

\section{Lateral Variations in Vs30 at Six Sites Near Napa, California}

CATCHINGS, R. D., US Geological Survey, California, USA, catching@usgs. gov; GOLDMAN, M. R., US Geological Survey, California, USA, goldman@ usgs.gov; CHAN, J. H., US Geological Survey, California, USA, jchan@usgs. gov

During the 24 August 2014 Mw 6.0 South Napa earthquake, at least six strong motion recording sites within $20 \mathrm{~km}$ of the epicenter registered PGA shaking levels between $0.3 \mathrm{~g}$ and $0.6 \mathrm{~g}$. To characterized these sites in terms of Vs30, we recorded a combination of body (Vp and Vs) and surface waves along 100- to 250-m-long profiles adjacent to the sites, with each profile having dense ( 1 to $3 \mathrm{~m}$ ) shot and geophone spacings. Models of body-wave velocities ( $\mathrm{Vp}$ and $\mathrm{Vs}$ ), $\mathrm{Vp} / \mathrm{Vs}$ ratios, and Poission's ratios were developed using 2-D refraction tomography, and 2-D models of Vs were developed from surface waves (Rayleigh and Love) using a Multi-Channel Analysis of Surface Waves (MASW) method. As a result, we obtained three separate 2-D Vs models for each site. From the Vs models, we calculated Vs30 at every meter along each seismic profile to determine lateral variations in Vs30. We found significant lateral variations in Vs30 (up to $300 \mathrm{~m} / \mathrm{s}$ ) along most of the seismic profiles, and in most cases, lateral averages of Vs 30 were significantly different than the Vs30 value closest to the recording station. Our comparisons of Vs30 suggest that surface-wave-based Vs30, determined from profiles with only a few sources, can differ significantly from the tomographic Vs30 value directly beneath the recording site. We found that Vs determined from refraction tomography was more consistent with Vs determined from Love waves than Vs determined from Rayleigh waves. Two sites with the lowest average Vs30 experienced the highest PGA shaking levels. However, at least one distant $(12.5 \mathrm{~km})$ site with a high average Vs30 (up to $876 \mathrm{~m} / \mathrm{s}$ ) registered stronger shaking $(0.35 \mathrm{~g})$ than a closer $(9 \mathrm{~km})$ site with lower average Vs30 $(584 \mathrm{~m} / \mathrm{s})$. The 2-D velocity images suggest factors other than Vs30, such as local subsurface basement topography and other structures, may cause the high PGA values that may not be captured with 1-D analysis of Vs30.

Insights into the Influence of Local Site Amplification on Magnitude Determination: Key Observations and Modeling Using the Stochastic Method HOLT, J., University of Liverpool, United Kingdom, j.holt@liverpool.ac.uk; EDWARDS, B., University of Liverpool, United Kingdom, ben.edwards@ liverpool.ac.uk

Modern seismic hazard analyses relyon the reliability of seismic cataloguesto characterise regional seismicity. Local seismic networks will derive scaling relationships between ML, the magnitude of choice for routine observatory monitoring, and $\mathrm{M}$, the magnitude used for modern PSHAs. However, numerous studies have highlighted a discontinuity between $\mathrm{M}$ and $\mathrm{ML}$. We explore the role of site amplification on magnitude scales (utilisingKiK-Net[Japan]data), and the control onmagnitude scaling. ML (any given earthquake scenario) may beinfluenced 
by site factors; both the calculation of $\mathrm{ML}$ and site response depend on shear particlemotion. Network specific ML empirical correction tables ( $\triangle M L$, STN) are derived relative toresponse at 'hard-rock' sites, ora network average, to minimise this impact. However, this is not always practical due to sub-optimal local geology. Consequently, any empirical corrections may be biased, conditioned by unique local factors (e.g. 1/2/3D resonance [lin/non-lin], local G(R), high $\kappa_{0}$ etc.). 34 sites are selected; each with $\kappa_{0}$ values, $\mathrm{Vp} / \mathrm{Vs}$, and significant recorded events (100s-1000s). Observing relative differences of ML at the surface/borehole $(\triangle \mathrm{ML}, \mathrm{STN})$, we find particular $\mathrm{M}$ dependant $\triangle \mathrm{ML}$, STN trends. The Stochastic Method (Boore, 2003) is employed tomodel the trends, initially using empirical surface/borehole spectral ratios. We observe strong magnitude dependence in $\triangle \mathrm{ML}$, STN, both in real/simulated data. Simulations are performed usingavailable site response information are shown to closely match the empirical data. Subsequently, we replace surface/borehole ratio with;(i) linear 1D-SH amplification, (ii) QWL amplification, (iii) H/V ratio. We highlight the most influential parameters onML determination. Finally, we discuss how this insight may be used in the future to compute ML with greater confidence.

\section{Basin Effects in Kathmandu Valley, Nepal, during Strong Ground Motion of 2015 Gorkha Earthquake Using Kinematic Source Model}

AYOUBI, P., Caltech, California, USA, ayoubi@caltech.edu; ASIMAKI, D., Caltech, California, USA, domniki@caltech.edu

Basin effects is the phenomenon where earthquake waves become trapped and reverberate in concave-shaped bedrock depressions filled with soft sedimentary materials. The catastrophic effects of numerous earthquakes in the past have been attributed to basin effects, which can strongly affect the amplitude, frequency, and duration of strong ground motion and introduce spatial variability of seismic ground motion over short distances, especially near the basin edges. We here study the role of basin effects in Kathmandu Valley, Nepal, using observations of strong motion recordings and high rate GPS measurements of the $2015 \mathrm{Mw}$ 7.8 Gorkha mainshock, and 2D-3D ground motion simulations. We specifically study a 2D cross section of the Kathmandu valley subjected to vertically propagating SV plane waves, a typical assumption in most published works on basin effects; and the response of the same cross section using a realistic kinematic source model to estimate the full far-field waveform. We investigate the role -if any-that nonlinearity played in the exceptionally long period ground shaking that characterized the strong motion records of the Gorkha mainshock, by using both elastic and anelastic constitutive models of the basin. Preliminary results show that coupling seismological source models with fine resolution geotechnical basin properties and anelastic sediment response, even in a place like Kathmandu where there is very little available information on the site conditions and hardly any strong motion records from past events, can significantly improve ground motion predictions compared to the rudimentary approach of $1 \mathrm{D}$ site response or 2D/3D simulations of basin effects with elastic sediment models.

\section{Adjustments of the Amplification Factors for Site Response in Israel Based on Average Shear Wave Velocity and Peak Frequency}

BARAM, A., Ben-Gurion University of the Negev, Israel, almog.baram @gmail. com; KAMAI, R., Ben-Gurion University of the Negev, Israel, rkamai@bgu.ac.il; YAGODA-BIRAN, G., Geological Survey of Israel, Israel, gonyb @gsi.gov.il

Israel is situated along the Dead-Sea Transform, which is a left-lateral tectonic boundary, separating the Sinai sub-plate from the Arabian. According to the historical records, the recurrence interval of large destructive earthquakes in this region is in the order of 102 to 103 years. Due to relatively low seismicity rates and absence of local measurements, amendment 5 of the Israeli building code uses the National Earthquake Hazard Reduction Program (NEHRP) empirical site categories, differentiating velocity profiles by their time-averaged shear-wave velocity in the upper 30 meters (VS30). The NEHRP classification is based on Western US studies, showing relatively good correlation to site amplifications for that region. Moreover, the amplification factors derived from NEHRP classification are calculated with respect to a reference rock with VS30 of $760 \mathrm{~m} / \mathrm{sec}$, typical to rock sites in California. However, researchers from the Geophysical Institute in Israel (GII) have carried out numerous studies in Israel and suggested that the bedrock velocity in most of Israel is significantly higher, implying that the amplification factors that are currently being used are calculated based on erroneous assumptions, thus underestimating the expected ground motions. In this research, we use a large local database of velocity profiles, measured and compiled mostly by the GII, to construct a new generic reference-rock velocity-profile for Israel. Due to the lack of ground-motion measurements, the response-spectral amplification factors are then calculated, using a 1D linear-elastic computation. We test the correlation of different site proxies with the computed amplification and show that a double proxy, consisting of VS30 and the site peak frequency (fpeak), is the best combination in terms of both applicability and statistical cor- relation. Finally, a continuous functional form as well as new building code factors are suggested for improved site-response practice in Israel.

\section{Bedrock Site Conditions and Kappa in Charlevoix, Quebec.}

PALMER, S. M., University of Western Ontario, spalme22@uwo.ca; ATKINSON, G. M., University of Western Ontario, gatkins6@uwo.ca

The characterization of high-frequency $(\geq 10 \mathrm{~Hz})$ ground motions for hard rock sites in Eastern North America is a critical seismic response issue for major infrastructure, particularly nuclear power plants. The diminution of amplitudes with increasing frequency is modeled using kappa (Anderson and Hough, 1984 BSSA), which is a measure of the slope of amplitude decay at high frequencies in the spectral domain. This study examines kappa and its variability for 7 hard rock sites near Charlevoix, Quebec (Canada), using hundreds of recording from earthquakes of $M \geq 3$ within $150 \mathrm{~km}$. Kappa values are compared to bedrock velocities measured at the recording stations to gain insight into the relationship between kappa and physical rock properties. We also examine whether there is evidence of source or path effects on kappa.

\section{A Bayesian Application of SPAC to Resolve Vs30 Using Nodal Seismic Instruments \\ ZHANG, H., University of Utah, Utah, USA, zhang @seis.utah.edu; PANKOW, K. L., University of Utah, Utah, USA, pankow@ seis.utah.edu}

Vs30 is the average shear velocity within the top $30 \mathrm{~m}$ of the earth's crust, and is important for understanding ground motion amplification from large earthquakes. To resolve the Vs30, the spatial autocorrelation (SPAC) method is broadly applied. SPAC data is typically collected using an array of four or more broadband instruments. Through SPAC coherency functions, surface wave dispersion curves are extracted. Alternatively, SPAC coherency can be directly modeled to resolve the velocity model. Generally, manual, iterative procedures are employed to simulate the theoretical coherency functions, which gradually match the observations. Although the observations can be well-fit, it is impossible to quantitatively assess the resultant velocity model and the Vs 30 , since the inversion of the velocity model is non-unique. To overcome this issue, in this study, a Bayesian inversion, Markov Chain Monte Carlo method (MCMC), on the coherency functions is exploited. In this study, we also compare data and resulting coherency curves collected using 10 three-component Nodal seismic instruments to data collected using four broadband instruments. In the MCMC method, a velocity model is randomly generated, a fundamental dispersion curve is calculated, and then the theoretical SPAC coherency functions are estimated based on the dispersion curve. Comparison between the calculated and observed coherency functions is performed, and estimated with a misfit function. This operation is repeated 3000 times. At each step, the randomly generated velocity will be accepted if its misfit is less than the previous step. Otherwise, the ratio of the likelihood function associated with the misfit function to thatat the previous step may be accepted. If the current velocity model is rejected, the previous velocity will be used. After the 3000 velocity models have been derived, the 100 best velocity models are utilized to get the average velocity model and Vs30, as well as the uncertainties.

\section{Application of Active- and Passive-Seismic Array Techniques at Hard Rock Sites in Eastern Canada}

LADAK, S., Western University, sladak22@uwo.ca; MOLNAR, S., Western University, smolnar8@uwo.ca; ATKINSON, G. M., Western University, gatkins6@uwo.ca; PALMER, S. M., Western University, spalme22@uwo.ca

We aim to expand and apply the multi-channel analysis of surface waves (MASW) and ambient vibration array (AVA) methodologies to sites in Eastern Canada. We collected MASW and AVA recordings in attempts to retrieve shearwave velocity (Vs) depth profiles at multiple seismograph stations across Eastern Canada. Dispersion curves are calculated using frequency-wavenumber $(\mathrm{f}-\mathrm{k})$ and/or spatial autocorrelation (SPAC) methods as well as horizontal-to-verticalspectral ratios (HVSRs). Dispersion curves and HVSR amplification functions are inverted to acquire Vs profiles for each site. We are exploring the application of these active- and passive-seismic array methods at stiff soil or hard rock sites in Eastern Canada. Theoretically, hard rock sites should exhibit no amplification but some amplification at higher frequencies occurs in reality related to a weathered and/or fractured 'surficial' layer. We aim to retrieve Vs profiles that capture any near-surface sediments or weathered/fractured rock layering above more competent bedrock below. Additional processing and interpretation is required for these stiffer sites in comparison to typical soft soil conditions in order to extract dispersion and/or amplification characteristics to invert for the subsurface site conditions. This study will allow us to diversify and expand seismic array methodologies at more geologically complex sites. 
Improving the Potential of the H/v Spectral Ratio Technique by Using the Coda of Seismic Noise Autocorrelations

TCHAWE NZIAHA, F., Institut de Radioprotection et de Sûreté Nucléaire, France, flomin.tchawenziaha@interne.irsn.fr; FROMENT, B., Institut de Radioprotection et de Surete Nucleaire, France, berenice.froment@irsn.fr; CAMPILLO, M., ISTerre, France, michel.campillo@univ-grenoble-alpes.fr

It is well known that the earthquake ground response at a specific site is strongly controlled by local soil properties through the so-called site effects. Several geophysical methods have been developed to estimate the site amplification characteristics. Amongst them, the single-station horizontal to vertical spectral ratio technique (HVSR) has become very popular due to its ease of implementation. However the lack of sound theoretical basis behind this technique has led to various physical interpretations of HVSR measurements that are still debated. Till date, only the HVSR's peak frequency is considered as providing reliable information through the estimation of the site fundamental resonance frequency. In this study, we consider the Diffuse Field Assumption (DFA) that uses diffuse wavefield theory to link HVSR to the elastic properties of the subsoil, and could thus lead to very attractive applications of HVSR measurements. Pioneer applications of DFA for site effect studies make the hypothesis of an equipartitioned, diffuse seismic ambient noise. In order to get closer to the theoretical requirements in the DFA framework, we propose a HVSR computation that benefits from the diffuse nature of the so-called coda. Our approach takes advantage of both the seismic noise (recordable everywhere) and the diffuse character of coda waves, by computing the HVSR on the coda of the local Green's function reconstructed (at least partially) through noise autocorrelation. We test this "coda-based" approach (HVSRc) on data recorded within the Argostoli sedimentary basin (Cephalonia, Greece). Our results show that this HVSRc approach 1) improves the temporal stability of measurements compared to raw-noise-based HVSR (HVSRn) and 2) reveals some physical information hiding in the HVSRn measurements, in the form of a secondary higher-frequency peak. We also investigate the inversion of our HVSRc measurements to estimate the local 1D velocity profiles.

\section{Comparison of S-Wave HVSR from Earthquake Recordings and 1-D Site} Response Modeling

CARPENTER, N. S., Kentucky Geological Survey / University of Kentucky, Kentucky, USA, seth.carpenter@uky.edu; WANG, Z., Kentucky Geological Survey, Kentucky, USA, zhenming.wang@uky.edu; WOOLERY, E. W., University of Kentucky, Kentucky, USA, woolery@uky.edu

We calculated horizontal-to-vertical spectral ratios (HVSR) from earthquake $\mathrm{S}$-waves at selected broadband stations in or near the Wabash Valley and New Madrid seismic zones, central U.S. We also collected SH- and P-wave reflection/ refraction profiles to derive velocity models at these stations. Theoretical SH-wave transfer functions determined by Thomson-Haskell propagator matrices, for the range of observed SH-wave incidence angles, and by 1-D equivalent-linear analyses were compared with the HVSRs at each station. $S$-wave HVSR contains response peaks at the fundamental and higher modes within the frequency band of engineering interest $(0.1-20 \mathrm{~Hz})$. The observed peak frequencies are consistent with those predicted by the theoretical SH-wave transfer functions. The HVSR peak values, however, have variable degrees of consistency with those of the theoretical $\mathrm{SH}$-wave transfer functions at the same frequencies. The causes of the differences are investigated in terms of the vertical transfer function, the bedrockoverburden impedance contrast, damping, and nonlinearity.

\section{Investigating Basin Amplification Factors for Shaking in the Reno, Nevada,} Region for Local and Regional Events

DUNN, M., University of Nevada, Reno, Nevada, USA, michelledunn@nevada. unr.edu; LOUIE, J., University of Nevada, Reno, Nevada, USA, louie@seismo. unr.edu; SMITH, K. D., University of Nevada, Reno, Nevada, USA, ken@unr. edu; DICKENSON, S., New Albion Geotechnical, Inc., Nevada, USA, sed@ newalbiongeotechnical.com

The impacts of seismic shaking on urban basins have been in the news again this past year. Construction projects for tall buildings have been delayed out of concerns that current design standards may not sufficiently account for the shaking amplification that occurs in geologic basins. Building codes in Nevada pertaining to seismic hazard use the USGS National Seismic Hazard Mapping Program (NSHMP), which does not include site or basin amplification factors. The NGAWest2 ground motion prediction equation (GMPE) incorporates basin amplification factors homogeneously in one dimension, based on minimum depths to certain shear-velocity values (e.g., Z1.0, Z2.5) and on the geotechnical average velocity to $30 \mathrm{~m}$ depth (Vs30). We investigate whether such GMPEs may adequately predict amplifications recorded in the Reno-area urban basin of western
Nevada. We are quantifying and comparing basin amplification factors recorded from a series of local and regional events in and around the Reno-area basin. The focus of our analysis lies in the variation of amplification factor with spatially distributed source locations relative to the Reno-area urban basin. Broadband records we are examining include the: 2008 Mogul sequence; 2015 M4.3 Thomas Creek; and three 2016 M 5.5 Nine Mile Ranch events. Initial investigation is into peak ground velocity (PGV) ratios of basin over bedrock stations; leading to including other measures of shaking intensity such as $\mathrm{H} / \mathrm{V}$ spectra and duration. We have generated 3D physics-based SW4 synthetic seismograms for these events that partially account for basin effects at low frequencies of shaking $(<1.0$ $\mathrm{Hz}$ ), and we can examine how well the synthetic PGV ratios predict the recorded ratios. Using the computational models, we can perform sensitivity testing on the model through varying Vs30, basin shear velocity profiles, and incorporating deep volcanic sub-basins.

\section{Numerical Simulation of Microtremor Array Measurements at 2D and 3D Structures Using 3D Finite-Difference Method}

HAYASHI, K. H., OYO Corporation, California, USA, khayashi@geometrics. com; SUZUKI, H. S., OYO Corporation, Ibaraki, Japan, suzuki-haruhiko@ oyonet.oyo.co.jp; RYU, E. R., OYO Corporation, Ibaraki, Japan, ryu-ei@ oyonet.oyo.co.jp; TAHARA, M. T., OYO Corporation, Ibaraki, Japan, taharamichitaka@oyonet.oyo.co.jp

Demand on the development of non-invasive measurement methods for shallow $S$-wave velocity structure is increasing. Active and passive surface wave method will play important role in such measurements. Passive surface wave method or microtremor array measurements particularly receive large attention since the method can penetrate several hundreds to several kilometers easily. Applicability of microtremor array measurements to complex velocity structures with horizontal velocity change is the one of the issues to be figured out to apply the method to site investigations. We performed numerical simulation of microtremor array measurements at 2D and 3D structures using 3D finite-difference method to evaluate the effect complex structures on the analysis of microtremor array measurements. Two-layer models were used in the simulation. S-wave velocities of two layers are 200 and $400 \mathrm{~m} / \mathrm{s}$ respectively. Depth to the boundary ranges 20 to $40 \mathrm{~m}$. Receivers are deployed in a $100 \times 100 \mathrm{~m}$ square. The size of the model is $550 \times 550 \times 150 \mathrm{~m}$ cube. Sources are randomly distributed outside of receiver array to simulate ambient noise field. Cell size is $1 \mathrm{~m}$, time step is $0.25 \mathrm{~ms}$ and data length is $65 \mathrm{~s}$. A 3D viscoelastic finite-difference method with 4th order velocity stress staggered grid scheme was used to calculate seismic wave field. Ten records are calculated with different source distribution. Ambient noise data were processed by common mid-point spatial auto correlation (CMPSPAC). SPACs were calculated all possible pairs and SPACs whose CMP belonged to the same bin were grouped. A dispersion curve was calculated for each bin and an 1D inversion was applied to each dispersion curve with horizontal constraint. The $1 \mathrm{D}$ velocity profiles were interpolated to a $3 \mathrm{D}$ velocity model. Obtained velocity were models generally consistent with true models and the simulation shows the applicability of the microtremor array measurements to complex velocity structures.

\section{Comparison of Vs30 Determined from Rayleigh Waves and Love Waves at Six Strong Ground Motion Sites in Napa, California CHAN, J.H., US Geological Survey, California, USA, jchan@usgs.org}

The 24 August $2014 \mathrm{Mw} 6.0$ South Napa earthquake caused $\$ 400$ million in damage to private and commercial properties. Previous site response studies indicate areas that experienced extensive structural damage are underlain by deposits with low Vs30 values. The goal of our study was to evaluate shear-wave velocity to $30 \mathrm{~m}$ depth (Vs30) using body waves (see Catchings et al.) and surface waves at six broadband seismometer sites that registered PGA values between 0.3 to $0.6 \mathrm{~g}$ during the South Napa earthquake in 2014. We used active seismic sources, and up to 120 channels of $4.5-\mathrm{Hz}$ sensors to record seismic waves near broadband seismometers in the City and County of Napa and in the City of Vallejo. To increase the resolution of our data in the upper $30 \mathrm{~m}$, we used 3 -m geophone and shot spacing along each profile, which ranged in length from 85 to $260 \mathrm{~m}$. We used a $226-\mathrm{kg}$ accelerated weight-drop and seisgun to generate P- and Rayleigh-wave sources and a 3.5-kg sledgehammer and block to generate S- and Love wave sources. We found that Vs determined from Love Waves were generally lower than Vs determined from Rayleigh Waves at sites with Vs less than $500 \mathrm{~m} / \mathrm{s}$, and Vs from refraction tomography show similar results to those determined from multichannel analysis of surface waves (MASW) using Love waves. Our results suggest $S$-wave velocities vary up to $\sim 30 \%$ between refraction tomography and MASW methods, with the latter method generally producing lower velocities. The three methods are complimentary and can be highly useful in accurately evaluating site response. 
Ground Motion and Earthquake Engineering

Poster Session · Tuesday 15 May · Riverfront South

\section{Assessment of Code-Based Vertical Spectrum Functional Forms}

KALE, O., TED University Department of Civil Engineering, Ankara, Turkey, ozkan.kale@tedu.edu.tr; AKKAR, S., Bogazici University Kandilli Observatory and Earthquake Research Institute, Istanbul, Turkey, sinan.akkar@boun.edu.tr

Consideration of vertical seismic design loads is important for long-span structural systems, short-period structures and for some non-structural components in the buildings. To this end, seismic design codes utilize alternative approaches to define vertical design spectrum at different levels of complexity: either as a fraction of horizontal design spectrum or using a separate functional form having features different than the horizontal spectrum. In all cases a consistency between the horizontal and vertical design spectral ordinates is sought. In this paper, we consider a suite of modern seismic design codes (e.g., Eurocode 8, ASCE 7-05, ASCE 7-10 and ASCE 7-16) as well as horizontal, vertical and vertical-tohorizontal $(\mathrm{V} / \mathrm{H})$ ground-motion predictive models to assess the properness of vertical design spectrum expressions in these codes. We generated earthquake scenarios to represent different magnitude, distance and site combinations. We estimated the horizontal and vertical spectra for each one of these scenarios from the selected horizontal, vertical and $\mathrm{V} / \mathrm{H}$ ground-motion predictive models. We then compared the code-based (idealized) horizontal and vertical spectra of these cases with those obtained from the ground-motion predictive models. Our preliminary findings suggest that the current design code formulations are insufficient to properly address the vertical spectrum trends. We discussed the possible reasons behind the observed misrepresentation of idealized vertical spectra by the investigated codes. Our discussions may lead to the development of new rules for code-based vertical spectrum that is consistent with its horizontal counterpart.

\section{Environmental Seismology: Glaciers, Rivers, Landslides and Beyond}

Poster Session · Tuesday 15 May · Riverfront South

\section{Seismic Signatures of Changing Water Resources}

SYRACUSE, E. M., Los Alamos National Laboratory, New Mexico, USA, syracuse@lanl.gov; DELOREY, A. A., Los Alamos National Laboratory, New Mexico, USA, andrew.delorey@lanl.gov; MUIR, J., Caltech, California, USA jmuir@caltech.edu

In recent years, a dramatic and unsustainable mining of groundwater, our largest fresh water source, has taken place in the western US, with depletion rates currently at their highest. Paired with concurrent moderate-to-exceptional drought conditions in as much as a third of the contiguous US, the monitoring of groundwater resources is increasingly important. How do aquifers respond to stresses such as increased withdrawal rates and droughts? What does the end of a drought mean for groundwater availability? We employ the temporal monitoring of ambient-noise-based horizontal-to-vertical amplitude measurements (H/V, ellipticity) to reflect changing conditions within the shallow subsurface. Whereas the more commonly measured Rayleigh wave velocities have sensitivity kernels that peak at depths comparable to the period of the measured signal (e.g., $\sim 10 \mathrm{~km}$ depth for a $10 \mathrm{sec}$ period) and are an integration of the material sampled along the entire path, the amplitude-based ellipticity measurements are most sensitive to structure in the upper few kilometers beneath a station of interest. We present preliminary results of this analysis for southern California for 1999-2017.

\section{Wave-Driven Ice Shelf Rift Propagation}

LIPOVSKY, B. P., Harvard University, Massachusetts, USA, brad_lipovsky@ fas.harvard.edu

Distant storms, tsunamis, and earthquakes generate waves in floating ice shelves. In several instances, seismic observations have clearly demonstrated a mechanistic link between periods of elevated wave activity and iceberg calving. The detailed mechanical interpretation of observed seismograms is complicated, however, by the existence of numerous types of waves that propagate in the coupled ice-ocean-earth system. Here, I describe wave propagation in an elastic, finitethickness, buoyantly floating ice layer above a uniform and inviscid water layer. I place particular focus on waves with wavelength greater than the ice thickness, as have recently been observed on the Ross, Pine Island, and Amery Ice Shelves. I show that mode uncoupling occurs at long period such that waves occur as either symmetric or flexural modes. I calculate the stresses associated with the seismi- cally observed wave field on the Ross Ice Shelf. In the second part of this work, I place these stresses the context of linear elastic fracture mechanics. I show that long rifts in buoyantly floating ice shelves experience stabilization due to the inability of a thin elastic layer to effectively transmit stresses over long distances. I derive a rift tip equation of motion that shows excellent agreement with observed rift tip propagation velocities. The theory presented here paves the way to an improved depiction of ice shelf calving in predictive ice sheet models.

\section{Neotectonics}

GOMES, A. A., FABrandt, Minas Gerais, Brazil, sggmgeo@gmail.com; ASSUMPÇÃO, M., IAG-USP, São Paulo, Brazil, marcelo.assumpcao@iag.usp. br

Sink Holes and New Faults and Fractures in the Iron Quadrangle, Minas Gerais, Caused by Natural Earthquakes 1Antônio Augusto Seabra Gomes Júnior Fundação Alexander Brandt, 2Marcelo Assumpção - IAG-USP;3Issamu Endo - Escola de Minas de Ouro Preto On April 5, 2014, a series of collapsed sink holes, accompanied by extensive fracturing, appeared in the Moeda Plateau, near Itabirito, Minas Gerais, on an extensive dolomite lens $1.5 \mathrm{~km}$ long, $0.5 \mathrm{~km}$ wide and $0.6 \mathrm{~km}$ thick containing an active endokarst system, with hectometric voids. At the same time, five small earthquakes were felt in the area close to the new sinkholes. Fractures have two preferred orientations: a prominent $\mathrm{N} 110^{\circ}$, accompanied by another set of small fractures with general NS orientation. This arrangement is compatible with the general orientation of the regional stress field, roughly E-W compression and N-S extension. The fractures may indicate reactivation of pre-existing structures or even new ruptures in the shallow crust caused by earthquakes. Similar stress field has been observed since the Middle Miocene. Regional seismic stations (the nearest $120 \mathrm{~km}$ away) recorded five events between 14:08 and 14:22 (Local Time) with magnitudes from 1.8 to 2.7. Both the $\mathrm{P}$ and the $S$ waves have sharp arrivals. The $S$ wave is larger in the transverse component. These characteristics are more consistent with an earthquake, rather than a colapse, as the origin of the events, and indicate that the cave colapse was a consequence of the earthquakes. In addition, the seismic signals from all five events are almost identical, which indicates that all earthquakes occurred in the same fault or geological fracture, with the same type of faulting mechanism. Events with magnitudes $~ 3$ are not uncommon in Minas Gerais. This evidence of a sinkhole caused by small earthquakes shows that more attention should be paid to seismic risk in mining areas near carstic terrains, a common feature in Minas Gerais mining district.

\section{Landslide Micro-Seismicity: Description and Classification of Seismic Sources}

PROVOST, F., EOST-CNRS/University of Strasbourg, Bas-Rhin, France, f.provost@unistra.fr; MALET, J. P., EOST-CNRS/University of Strasbourg, Bas-Rhin, France, jeanphilippe.malet@unistra.fr; HIBERT, C., EOST-CNRS/ University of Strasbourg, France, hibert@unistra.fr; HELMSTETTER, A., ISTerre-CNRS/University of Grenoble-Alpes, France, helmstea@ujf-grenoble. fr; AMITRANO, D., ISTerre-CNRS/University of Grenoble Alpes, France, david.amitrano@ujf-grenoble.fr

In the last decade, numerous studies focused on the analysis of seismic waves generated by Earth surface processes such as mass instabilities. At close distances, the installation of seismometers on unstable slopes revealed a variety of endogenous seismic signals suspected to be generated by slope deformation, weathering of the slope material or fluid circulation. The complexity of the underground structure, its spatio-temporal variability (due to changes in the topography, variation of the water content, etc.) and the low magnitude of the sources $(\mathrm{ML}<0)$ make the analysis of the seismic signals difficult with traditional seismological approaches. Moreover, a standard classification for seismic sources endogenous to instable slopes is yet to be esablished. This prevents a more robust and consistent interpretation of the processes generating the recorded seismic signals. Taking profit of the growing number of monitored instable slopes (mainly in the European Alps), we aim to propose a typology of the sources generated by landslides deformation. The possible mechanisms of the seismic sources are also discussed. The datasets of 15 sites are gathered in the present study. The sites are representative of the various types of mass movements (i.e. slide, fall and topple, and flow) and rocks (i.e. consolidated to unconsolidated). The seismic networks are mostly similar, which is enabling comparison of the recorded seismic signals. Different signal properties are taken into account such as the duration, the spectral content, the spectrogram shape and the polarization. Finally, we observe that similar signals recorded at different sites present the same characteristics, which allow us to propose assumption on the dominant source mechanisms. The proposed typology aims to serve as a reference and a framework for further comparisons of the endogenous microseismicity recorded on mass movements. 
Repeating Quakes Triggered by Snow-Falls at Gugla Rock-Glacier: Transition between Stable Slip and Stick-Slip?

HELMSTETTER, A., University Grenoble Alpes, France, agnes.helmstetter@ univ-grenoble-alpes.fr; LIPOVSKY, B. P., Harvard University, Massachusetts, USA, brad_lipovsky@fas.harvard.edu; LAROSE, E., University Grenoble Alpes, France, eric.larose@univ-grenoble-alpes.fr; BAILLET, L., University Grenoble Alpes, France, laurent.baillet@univ-grenoble-alpes.fr; MAYORAZ, R., Service Géologique Canton du Valais, Switzerland, raphael.mayoraz@admin.vs.ch

Gugla rock-glacier is located in Zermatt Valley in Switzerland. This mass of rock debris and ice is moving at about $1 \mathrm{~cm} /$ day by creep and slip. It has been accelerating since the last decades as a result of global warming, threatening the villages located underneath. This rock-glacier has been instrumented with a network of 6 seismometers in October 2015. Tens of thousands of seismic events have been detected, with very diverse characteristics, associated with different processes (rockfalls, avalanches, fracture opening...). Seismic activity shows seasonal fluctuations, with a larger rate in spring and summer, when snow and ice are melting, yielding an acceleration of the rock glacier. In addition, a few bursts of activity occurred in winter during snow falls. While most seismic events occurred randomly in time and display Gutenberg-Richter magnitude distributions, events detected during snow falls occurred more or less regularly in time, with progressive variations of amplitude and recurrence times. Seismic signals have a duration of about $5 \mathrm{~Hz}$ and a frequency between 1 and $10 \mathrm{~Hz}$. Repeaters occurred immediately when snow episode started and lasted for several days afterwards. Inter-event times decrease progressively after snow-fall between a few minutes and several hours. These events are likely associated with the repeated failure of an asperity surrounded by aseismic slip. Similar observations of repeaters triggered by snow-falls at Mount Rainier have been reported by Allstadt and Malone (2014). We suggest that snowfalls induced an increase in normal stress, which triggered a transition between smooth aseismic slip and stick-slip behavior. This behavior can be modeled by a simple slider-block system governed by rate-andstate friction.

\section{Seismic Observations Following the July 2017 Pasco County, West Florida, Sinkhole Collapse}

BRAUNMILLER, J., University of South Florida, Florida, USA, jbraunmiller@ usf.edu; THOMPSON, G., University of South Florida, Florida, USA, thompsong@mail.usf.edu; MCNUTT, S. R., University of South Florida, Florida, USA, smcnutt@usf.edu; DORN, K. M., University of South Florida, Florida, USA, kmdorn@mail.usf.edu; GRAYBEAL, D. B., University of South Florida, Florida, USA, dbgraybeal@mail.usf.edu; FARRELL, A. K., University of South Florida, Florida, USA, akfarrell@mail.usf.edu; COLLINS, L. D., University of South Florida, Florida, USA, Icollins@usf.edu; DOERING, T., University of South Florida, Florida, USA, tdoering@usf.edu; EILERS, D., University of South Florida, Florida, USA, eilers@usf.edu; GONZALES, J., University of South Florida, Florida, USA, jorgegonzale@usf.edu; KIFLU, H. G., University of South Florida, Florida, USA, hgkiflu@mail.usf.edu; KRUSE, S., University of South Florida, Florida, USA, skruse@usf.edu; LANDRY, S., University of South Florida, Florida, USA, landry@usf.edu; ROBINSON, T., University of South Florida, Florida, USA, tonianr@mail.usf.edu; SPEED, G., University of South Florida, Florida, USA, gspeed@usf.edu; MCKENZIE, R., University of South Florida, Florida, USA, rwmcken2@usf.edu

A sinkhole collapse on 14 July 2017 destroyed two homes and required evacuation of 9 additional residences in Land O'Lakes, Florida. The sinkhole formed rapidly and within 10 hours reached most of its final size of approximately 40 by $50 \mathrm{~m}$ and a maximum depth of about $15 \mathrm{~m}$. According to Pasco County officials, this is the largest sinkhole to have formed in the county during the last 30 years. The site is located near two natural lakes and occurs within an area of well-developed karst. The county allowed USF geoscientists to study the sinkhole resulting in an extensive collection of LiDAR, GPR, and lake-bottom profiling data. The seismology group installed one broadband 3-component seismometer on $25 \mathrm{July}$ $\sim 20 \mathrm{~m} \mathrm{~W}$ of the sinkhole edge and a second one on 27 September about $10 \mathrm{~m} \mathrm{E}$ of the sinkhole edge. Data are recorded continuously at $200 \mathrm{~Hz}$. Drilling to understand soil structure integrity and remediation work to stabilize the sinkhole led to extreme noise levels during daytime operations through most of August 2017. Nighttime noise is lower, but due to nearby houses, sensors pick up strong $60 \mathrm{~Hz}$ noise caused by AC units. The only signal unequivocally attributable to the sinkhole occurred on 5 August just after stabilization work, consisting of partial back- filling with limestone rocks, began that caused the sinkhole to widen by about $3 \mathrm{~m}$ along its entire western edge. After completion of stabilization work, no further signals have been detected from the sinkhole. Besides sinkhole monitoring, we recorded several large global earthquakes, e.g., the $\mathrm{Mw}=8.2$ and $\mathrm{Mw}=7.1$ Mexico earthquakes on September 8 and 17, respectively, as well as Hurricane Irma as it passed within 20 miles as a quickly weakening category 1 hurricane. In addition to outreach and sinkhole documentation as part of a multi-sensor approach, we use the site to train seismology graduate students in field practices and conducted a class field trip.

\section{Seismic Monitoring of the Rattlesnake Ridge Rockslide, Union Gap, Washington}

MOORE, J. R., University of Utah, Utah, USA, jeff.moore@utah.edu; GEIMER, P. R., University of Utah, Utah, USA, paul.geimer@utah.edu; BURJÁNEK, J., Czech Academy of Sciences, Czech Republic, burjanek@ig.cas. cz; GIBBONS, D. A., University of Washington, Washington, USA, dgibbons@ uw.edu; MALONE, S. D., University of Washington, Washington, USA, smalone@uw.edu

Ground cracks indicating development of a large translational rockslide were noted in October 2017 at Rattlesnake Ridge, near Union Gap WA. Monitoring and characterization initiated thereafter revealed a rockslide consisting of approximately 3 million $\mathrm{m} 3$ of basalt sliding predominantly south on a gently dipping anticlinal bedding interface. Movement rates were reported to have initially accelerated, and then stabilized at around $7 \mathrm{~cm} /$ day in mid-January, 2018, and the system of ground cracks grew allowing better assessment of rockslide extents and kinematics. Possible hazard scenarios included rockfall or rock avalanche debris reaching a major interstate, therefore extensive emergency management operations were initiated. In order to assist risk management efforts, the Pacific Northwest Seismic Network installed a series of seismic stations on and around the active rockslide. These consisted of broadband and short-period seismometers, in some cases collocated with accelerometers. Scientific and hazard management goals for these data include identification of microseismicity originating from within the landslide or from related rockfalls, and assessment of resonant frequencies of the unstable rock mass, all of which may be monitored over time to provide additional, complementary data on instability development. Here we present initial results of seismic monitoring, including seismograms, spectrograms, event counts, cluster analysis, Real-time Seismic Amplitude (RSAM), resonance monitoring and noise characteristics, all with possible relevance for landslide hazard assessment.

\section{The Exotic Seismic Events Catalog (ESEC) Data Product}

BAHAVAR, M., IRIS DMC, Washington, USA, manoch@iris.washington.edu; VAN FOSSEN, M., IRIS DMC, Washington, USA, mick@iris.washington.edu; ALLSTADT, K. E., US Geological Survey, Washington, USA, kallstadt@usgs. gov; MALONE, S. D., University of Washington, PNSN, Washington, USA, smalone@uw.edu; TRABANT, C., IRIS DMC, Washington, USA, chad@iris. washington.edu

Exotic seismic sources are non-earthquake seismic sources such as landslides, debris flows, dam collapses, floods, glacier seismicity, and avalanches that generate seismic signals, but are rarely included in traditional earthquake catalogs. The Exotic Seismic Events Catalog (ESEC, http://ds.iris.edu/ds/products/ esec/) is a new Incorporated Research Institutions for Seismology (IRIS) Data Management Center data product that uses the US Geological Survey data release of seismogenic landslides, debris flows, and outburst floods (Allstadt $e t$ al., 2017) as its initial populating dataset. The ESEC identifies seismic waveforms for which there were detections, and shows example waveform figures. It also provides access to source parameter data such as location, and time of the event along with a selection of other event-specific information such as photos, imagery, and GIS files. The ESEC data product includes an interactive interface with maps and search queries to facilitate access to this catalog and help accelerate research in the area of environmental seismology. This catalog currently holds 113 events and is designed to allow new entries as information regarding new recent and historic events becomes available. Allstadt, K.E., McVey, B.G., and Malone, S.D., 2017, Seismogenic landslides, debris flows, and outburst floods in the western United States and Canada from 1977 to 2017: US Geological Survey data release, https://doi.org/10.5066/F7251H3W. 
Fault to Seismic Hazard Assessment (Fault2SHA) in Latin (Central and South) America

Poster Session · Tuesday 15 May · Riverfront South

Estimation of Seismic Source Recurrence Parameters without Knowledge of Time-Varying Level of Completeness

KIJKO, Andrzej, University of Pretoria South Africa, Gauteng, South Africa, andrzej.kijko@up.ac.za; SMIT, A., University of Pretoria South Africa, Gauteng, South Africa, ansie.smit@up.ac.za

The work provides a procedure for estimation of seismic source recurrence parameters (the b-value of the frequency-magnitude Gutenberg-Richter relation, the mean seismic activity rate $\lambda$ and seismic source characteristic, maximum possible earthquake magnitude mmax) without knowledge of the time-varying level of completeness. A weakness of the classic Aki-Utsu b-value estimator is its heavy dependence on the assumed level of magnitude completeness. This work provides two estimators for Gutenberg-Richter $b$-value, $\lambda$ and mmaxwhich are not dependent on the assumed level of completeness. The approach is applicable to seismic event catalogues with the time-varying completeness. Monte-Carlo simulations show that the proposed estimators by Method of Moments (MM) and the Maximum Likelihood (ML) techniques are especially effective when the empirical (apparent), incomplete frequency-magnitude distribution is gradually curved. Hoverer, the proposed procedure is not restricted to any particular shape of the apparent frequency-magnitude distribution. For purpose of illustration, the procedure is applied to assess recurrence parameters of the Ceres-Tulbagh area of South Africa. The seismic event catalogue of the Ceres-Tulbagh area starts from the 1620 year and is highly incomplete, with the time-varying level of completeness which is unknown.

Structural Architecture of the Western Transverse Ranges and Potential for Large Earthquakes-Trishear Forward Models

LEVY, Y., San Diego State University/UC San Diego, California, USA, uvlevy@ gmail.com; ROCKWELL, T. K., San Diego State University, California, USA, trockwell@mail.sdsu.edu; SHAW, J. H., Harvard University, Massachusetts, USA, shaw@eps.harvard.edu; PLESCH, A., Harvard University, Massachusetts, USA, plesch@fas.harvard.edu; DRISCOLL, N. W., UC San Diego, California, USA, ndriscoll@ucsd.edu; PEREA, H., UC San Diego, California, USA, hpereamanera@ucsd.edu

Fold-and-thrust belts evolve over time, can produce large-scale faults and potentially accommodate large magnitude earthquakes. The thrust fronts of these structures typically form large fold structures in their hanging walls, and they tend to propagate forward over time to form new thrust fronts. In the Santa Barbara and Ventura region of the Western Transverse Ranges (WTR) of southern California, the Pitas Point thrust is interpreted as the current thrust front structure, and spatially stable back thrusts accommodate deformation in the hanging wall block of the thrust sheet (More Ranch fault, Rincon Creek fault, other faults). We interpret the nearly continuous, overturned Tertiary stratigraphy of the Santa Ynez Mountains as a large anticlinorium that formed as the first thrust front over the (mostly) blind San Cayetano thrust, and that the thrust front propagated south with time to the Red Mountain fault and eventually to the currently active thrust front, the southwardvergent Pitas Point-Ventura fault. Our interpretation is based on combining various sources of data and previous models suggested by others. To test our interpretations of the evolution and structure of the WTR, we used Trishear forward modeling. We compared our results to the observed geology and the Trishear models are a good first-order match. While our solution is non-unique, it is consistent with all of the currently available data. We believe that this model resolves much of the ongoing debate regarding the dip direction of the primary structure at depth, and modeling of multiple cross-sections argues that all of the observed deformation can be explained by an evolved fold and thrust belt, which includes a regionally extensive decollement underlying the observed thrusts and folds. In addition, our fault model supports the contention that the WTR are capable of generating magnitude 8 earthquakes, based on scaling relations.

\section{Temporal Patterns of Earthquakes: Devil's Staircases and the Possible Causes}

LIU, M., University of Missouri, Missouri, USA, lium @missouri.edu; CHEN, Y., University of Missouri, Missouri, USA, yc2wc@mail.missouri.edu; LUO, G., Laboratory of Computational Geodynamics, Chinese Academy of Sciences, Beijing, China, gangluo@ucas.ac.cn

Earthquake recurrence interval is a fundamental concept of current earthquake models and a key parameter in earthquake hazard assessments. Whereas much effort has been devoted to estimate and refine the recurrence interval of large earthquakes on various faults, increasing evidence, especially from intracontinental faults, starts to paint a different temporal pattern of earthquakes: clusters of earthquakes within short periods, separated by long periods of quiescence. Such earthquake patterns can be mathematically described by the Cantor function, or the devil's staircases. Devil's staircase is a fractal property of complex dynamic systems in nature, including earthquakes. We show that seismicity at all scales, from global occurrence of large earthquakes to different tectonic regions to individual faults, demonstrates the devil's staircase patterns. The average length of the quiescence periods seems inversely related to the rates of tectonic loading. Thus large earthquakes in stable continents have longer quiescent periods than those in tectonically active continents, and earthquakes at plate boundary faults have the shortest quiescent periods. The periods and frequency of clustered earthquakes also vary significantly. We have developed three-dimensional viscoelastoplastic finite element models to investigate the underlying physics controlling the temporal patterns of seismicity. Our preliminary results confirm that tectonic loading rate is the key parameter for the length of the quiescent periods, viscous relaxation is a key process for earthquake clustering, and fault interactions a key factor for the devil's staircases of seismicity.

From the Seismic Cycle to Long-Term Deformation: Linking Seismic Coupling and Quaternary Coastal Geomorphology along the Andean Megathrust

SAILLARD, M., Université Côte d'Azur, IRD, CNRS, Observatoire de la Côte d'Azur, Géoazur, Alpes-Maritimes, France, saillard@geoazur.unice.fr; AUDIN, L., IRD, CNRS, Université Grenoble Alpes, ISTerre, Isère, France, laurence.audin@ird.fr; ROUSSET, B., IRD, CNRS, Université Grenoble Alpes, ISTerre, Isère, France, baptiste.rousset@univ-grenoble-alpes.fr; AVOUAC, J. P., Tectonics Observatory, Division of Geological and Planetary Sciences, Caltech, California, USA, avouac@gps.caltech.edu; CHLIEH, M., Université Côte d'Azur, IRD, CNRS, Observatoire de la Côte d'Azur, Géoazur, AlpesMaritimes, France, chlieh@geoazur.unice.fr; HALL, S. R., Earth Sciences Department, College of the Atlantic, Maine, USA, shall@coa.edu; HUSSON, L., IRD, CNRS, Université Grenoble Alpes, ISTerre, Isère, France, laurent. husson@univ-grenoble-alpes.fr; FARBER, D. L., Earth and Planetary Sciences Department, UC Santa Cruz, California, USA, farber2@mac.com

Measurement of interseismic strain along subduction zones reveals the location of both locked asperities, which might rupture during megathrust earthquakes, and creeping zones, which tend to arrest such seismic ruptures. The heterogeneous pattern of interseismic coupling relates to spatial variations of frictional properties along the subduction interface and may also show up in the fore-arc morphology. To investigate this hypothesis, we compiled information on the extent of earthquake ruptures for the last $500 \mathrm{yrs}$ and uplift rates derived from dated marine terraces along the central Peru to southern Chile coastline. We additionally calculated a new interseismic coupling model for that same area based on a compilation of GPS data. We show that the coastline geometry (i.e. the trenchto-coast distance), the latitudinal variations of long-term uplift rates and the spatial pattern of interseismic coupling are correlated. Zones of faster and long-term permanent coastal uplift, evidenced by uplifted marine terraces, coincide with peninsulas and also with areas of creep on the megathrust where slip is mostly aseismic and tend to arrest seismic ruptures. This correlation suggests that these areas prevent elastic strain buildup and inhibit lateral seismic rupture propagation. Correlation between the location of these regions across- and along-strike of convergence and the long-term morphology of the subduction margin suggests that the barrier effect might be due to rheology, namely, rate-strengthening friction, although geometric effects might also play a secondary role. Peninsulas are the surface expression of large subduction earthquakes segment boundaries and show evidence for their stability over multiple seismic cycles. We propose that the survey of the long-term deformation of the upper plate to better identify multicycles margin segmentation would be an interesting improvement in seismic hazard assessment in subduction zone.

Investigation of H/V Spectral Ratio (HVSR), Spectral Decay Parameter ( $\kappa$ ), and Strong-Motion Duration Based on a Ground-Motion Database of Chilean Subduction-Zone Earthquakes

YANG, S., University of Notre Dame, Indiana, USA, syang5@nd.edu; MAVROEIDIS, G. P., University of Notre Dame, Indiana, USA, g.mavroeidis@ nd.edu; SONNEMANN, T., University of Iceland, Reykjavik, Iceland, tsonne@ hi.is; HALLDORSSON, B., University of Iceland, Reykjavik, Iceland, skykkur@ hi.is; HRAFNKELSSON, B., University of Iceland, Reykjavik, Iceland, birgirhr@hi.is; DE LA LLERA, J. C., CIGIDEN, Pontifical Catholic University of Chile, Santiago, Chile, jcllera@ing.puc.cl; AGUIRRE, P., CIGIDEN, Pontifical Catholic University of Chile, Santiago, Chile, paula.aguirre@ cigiden. 
cl; POUlOS, A., CIGIDEN, Pontifical Catholic University of Chile, Santiago, Chile, alan.poulos@cigiden.cl

This study investigates the characteristics of $\mathrm{H} / \mathrm{V}$ spectral ratio (HVSR), spectral decay parameter $(\kappa)$, and strong-motion duration based on a ground-motion database of Chilean subduction-zone earthquakes. The database consists of 283 triaxial records from 22 subduction interface earthquakes $(9$ mainshocks and 13 aftershocks) with moment magnitudes ranging from 6.8 to 8.8 , recorded at 137 stations in Chile, between 1985 and 2015. Five distance measures (epicentral, hypocentral, subevent, rupture, and Joyner-Boore) are considered in the analysis. The mean HVSRs calculated from records on rock and soil sites exhibit remarkably different amplitudes and shapes. However, the mean HVSRs for both site classes are not strongly affected by earthquake type (mainshock vs. aftershock), location (north vs. central Chile), magnitude, focal depth, and distance. Furthermore, $\kappa$ values are estimated for all ground motion records, and regression analyses between $\kappa$ and distance are carried out for different earthquake types, locations, magnitudes, focal depths, and site classes. The results show that $\kappa$ is dependent on distance, with the subevent distance providing the most effective fit among different $x$-distance models, whereas the distance-dependence of $x$ is primarily affected by earthquake location and site classification. Finally, three strong-motion duration measures (5-75\% and 5-95\% significant durations, and RMS duration) are considered in the regression analyses between duration and distance for different earthquake types, locations, magnitudes, focal depths, and site classes. Overall, the duration of the Chilean ground-motion records increases with distance, and the duration of the vertical component is greater than the duration of the horizontal component. It is also demonstrated that earthquake location and site classification are the key parameters that affect the distancedependence of duration.

FAULT2SHA Working Group: Linking Faults to Seismic Hazard Assessment SCOTTI, O., Institut de Radioprotection et Sûreté Nucléaire, Paris, France, oona.scotti@irsn.fr; PERUZZA, L., Istituto Nazionale di Oceanografia e di Geofisica Sperimentale, Trieste, Italy, peruzzalaura@gmail.com

The objective of the Fault to Seismic Hazard Assessment (Fault2SHA) Working Group is to build a community of active fault-related researchers to exchange data, tools and ideas on how to best model faults in seismic hazard assessment in specific tectonic contexts. After a few meetings (Paris 2014, Chieti 2015) and thematic sessions at international conferences in 2016 (https://sites.google. com/site/linkingfaultpsha/home) the WG was officially established inside the European Seismological Commission (ESC) in 2016. Being a not-funded entity the WG acts on voluntary basis. The community involved is made of data providers, data modellers and data users willing to share data and methodological approaches. The WG milestones achieved since 2016 are: a paper on aftershock probabilistic seismic hazard based on fault data gathered by many European teams in the wake of the Amatrice, 2016 M6.0 earthquake (Peruzza et al., 2016); the organisation of an international workshop in Barcelonette in 2017, France, that gathered 50 participants from around the world; the publication of 10 papers in a special issue of the NHESS journal; the organisation of a training course in Paris in 2017, where geologists learned how to use some Fault2SHA tools. The WG has initiated other collaborative initiatives such as the establishment of natural laboratories in Italy and Spain. Preliminary results will be presented at SSA. In these laboratories we want to address specific issues and questions such as: Methods to define sections/ruptures; Physics-based approaches; Needs for the collection of data (volcanic area?) to update scaling laws; How to constrain slip on faults using geodesy? How to propagate uncertainty in fault-PSHA? The Fault2SHA session to be held during the 2018 SSA conference in Miami is an additional opportunity to widen the discussion beyond the European context and to open to new potential members the opportunity to join us at the next ESC meeting that will be held in 2018 in Malta.

Exposure of Chilean Tailings to Earthquake Hazards from Potentially Seismogenic Crustal Faults

EDWARDS, S., UCL Hazard Centre, University College London, London, United Kingdom, s.edwards@ucl.ac.uk; ARON, F., Pontificia Universidad Católica de Chile Chilean Ministry of Foreign Affairs Research Center for Integrated Disaster Risk Management, Santiago, Chile, faron@ing.puc.cl; CEMBRANO, J., Pontificia Universidad Católica de Chile-Research Center for Integrated Disaster Risk Management, Santiago, Chile, jcembrano@ing.puc. cl; CREMPIEN, J. G. F., Pontificia Universidad Católica de Chile-Research Center for Integrated Disaster Risk Management, Santiago, Chile, jocrempiend@ ing.puc.cl; GARDNER, J., University of Liverpool, Liverpool, United Kingdom, joseph.gardner@liverpool.ac.uk; NAZAR, R., Pontificia Universidad Católica de Chile, Santiago, Chile, renazar@uc.cl; OVALLE, C., Pontificia Universidad Católica de Chile, Santiago, Chile, covalle@ing.puc.cl; SANTIBÁÑEZ, I.,
Pontificia Universidad Católica de Chile Research Center for Integrated Disaster Risk Management, Santiago, Chile, ivsantibanez@uc.cl

Eighty-two percent of sand tailings dam incidents in Chile since 1915 have been seismically induced, including that which led to the $1965 \mathrm{El}$ Cobre disaster. Subduction earthquakes (magnitudes 7.5+, return periods 10s-100s of years) have been traditionally regarded as representing the principal seismic hazard in the country and characteristically produce moderate, but widespread, damage. In contrast, much shallower earthquakes may be generated by potentially seismogenic crustal faults (PSCFs); these have relatively lower maximum magnitudes (7.0-7.5) and longer return periods (100s-1000s of years), yet are capable of producing extensive local damage within $5 \mathrm{~km}$ of the fault rupture. To our knowledge, a systemic study of the exposure of tailings storage facilities (TSFs) to earthquakes that could be generated by PSCFs has not been undertaken in Chile. Our study has filled this gap through integrating two publically available data sets: the 2016 national tailings database of SERNAGEOMIN and the catalogue of PSCFs published by the South America Risk Assessment Project of the Global Earthquake Model. There are 696 registered TSFs of varying size, age, operational status and construction type distributed throughout central and northern Chile. Of these, 91 lie within $5 \mathrm{~km}$ of a PSCF and 17 have been authorized to store volumes of tailings $\geq 106 \mathrm{~m} 3$. In order to constrain the exposure of TSFs more robustly, a deterministic seismic hazard assessment along each major PSCF is now being undertaken. The completeness of the study is limited by the fact that it is anticipated that most PSCFs have poorly known fundamental fault parameters (e.g., slip rates and recurrence times), which have only been investigated systematically over the last 10 years. Despite that, recent large earthquakes nucleated on previously unidentified PSCFs have raised awareness of their potential hazard. Our main conclusion is that complete seismic risk assessments of TSFs in Chile must incorporate PSCFs.

Sensitivity of Seismic Hazard Assessments to Earthquake Catalogue Quality ONUR, T., Onur Seemann Consulting, Inc., tuna@onurseemann.com; GOK, R., Lawrence Livermore National Laboratory, California, USA, gok1@llnl.gov; GODOLADZE, T., Ilia State University, Georgia, tea_godoladze@iliauni.edu. ge

Earthquake catalogues are often used to delineate seismic sources and calculate magnitude-recurrence relations in probabilistic seismic hazard assessments (PSHA). The better the quality of the data in the earthquake catalogue (particularly magnitude and location estimates), the more reliable the seismic hazard estimates. In this study, we carry out sensitivity analyses to find out how strong the effect of improved magnitudes and locations is on the magnitude-recurrence relations. The catalogue we use for the sensitivity analysis was recently compiled for the Caucasus region, as a result of collaboration between Lawrence Livermore National Laboratory (LLNL) and Ilia State University Seismic Monitoring Center of Georgia. The catalogue work included improvement of locations using various relocation techniques and direct moment magnitude $(\mathrm{Mw})$ calculations using coda calibration technique, down to magnitudes of about 3.5 , for part of the catalogue where digital records were available. This eliminated the need for the magnitude conversions that introduce large uncertainties to the magnitude estimates. For the same events, existing magnitude calculations were also available, making it possible to calculate how sensitive the magnitude-recurrence relationships are to these improvements. The highest sensitivity to catalogue improvements is observed where earthquake activity is relatively sparse. However, even in seismically active areas, correction of systematic bias in magnitude estimates makes a significant impact on recurrence parameters. In addition, the magnituderecurrence relations are highly sensitive to major (larger than $\sim 10 \mathrm{~km}$ ) corrections in locations of moderate to large magnitude earthquakes.

\section{Seismic Hazard Assessment of the Kashmir Basin, Northwestern Himalaya: A Probabilistic Approach}

SANA, H., Department of Neotectonics and Thermochronology, Institute of Rock Structure and Mechanics, Czech Academy of Sciences, Czech Republic, ibnsana@gmail.com

Northwestern Himalaya is one of the most tectonically active domains of the Himalaya. This complex collisional tectonic setup is able to produce destructive earthquakes, most recent being the 8 October 2005 Kashmir earthquake (Mw 7.6). In this study, we present the probabilistic seismic hazard assessment of the Kashmir basin of northwestern Himalaya. The motivation for this study is the active tectonic setup surrounding a major population centre in the NW Himalaya, home to about 7 million people. Especially, when historical archives and instrumental earthquake records prove that the basin has suffered damage from historical as well as the recent earthquakes. The seismic hazard is assessed using point (zone free seismicity) and areal (seismic source zones) source mod- 
els, employing appropriate ground motion prediction equations to predict the ground motions. The seismic hazard maps are expressed in terms of g, with seismic hazard curves and design response spectra at 5\% damping for four major towns of the basin at the engineering bedrock. The hypocentral depth-wise hazard maps are shown in ranges of $0-25 \mathrm{Km}, 25-70 \mathrm{Km}$ and $\geq 70 \mathrm{Km}$ with $10 \%$ probability of exceedance in 50 years. This computation is based on smoothly-gridded seismicity for each respective depth zone with a return period of 475 years. While as based on seismic source zones the seismic hazard maps show predicted peak ground acceleration (PGA) and Pseudo Spectral acceleration (PSA) with $2 \%$ and $10 \%$ probability of exceedance within 50 years for engineering bedrock sites. The PSA maps are expressed in $\mathrm{g}$ at $0.2 \mathrm{sec}$ and $1 \mathrm{sec}$. From this study it is evident that, overall Kashmir basin shows a high seismic hazard, with southeastern part showing a higher hazard as compared to northwestern part. Among the major towns all show high predicted PGA, Anantnag shows the highest $(0.65 \mathrm{~g})$ with $10 \%$ probability of exceedance in 50 years. The present study thus advocates a significantly higher seismic hazard as compared to the BIS (2002) and consequently recommends updating of the building codes in the region.

\section{Probabilistic Seismic Hazard Assessment for Large Dam Area, Georgia (Sakartvelo) Case}

TSERETELI, N. S., M. Nodia Institute of Geophysics, TSU, Georgia, nino tsereteli@tsu.ge; VARAZANASHVILI, O., Institute of Geophysics of TSU, Georgia, otarivar@yahoo.com; ARABIDZE, V., Institute of Geophysics of TSU, Georgia, vakhtang.arabidze@tsu.ge; GOGOLADZE, Z., Institute of Geophysics of TSU, Georgia, zurab.gogoladze.3@gmail.com

The present work has been done in order to determine detailed seismic hazard that is required for designing a seismically resistant hydro power plant in the north-western part of Georgia. According to current normative seismic zoning map of Georgia, the investigated area as a whole is located in a zone of MSK intensity IX, and the investigated object is located directly in the area with the peak ground acceleration (PGA) $0.34 \mathrm{~g}$. It should be noted that the results of seismic hazard assessment of Georgia, obtained in the various international projects have shown that they are significantly different from the values of current acting normative seismic hazard map. In particular, on the normative map are very low values of PGA than those ones that are obtained by real calculations. Seismicity of the investigated area was studied in detail. For seismic hazard assessment of the significant object, two levels of ground motion were selected: Operating Basis Earthquake and Safety Evaluation. The analysis of the observed seismicity of the investigated area has been carried out. 22 of active faults were described to establish sesimotectonic conditions for investigated area. These faults were studied on the bases of geological, geophysical, geomorphological and seismological data. Seismic hazard curves of the object for macroseismic intensity for PGA and SA were calculated for rock using EZ-FRISK ${ }^{\text {ww }}$ software. On the basis of the results of deaggregation of probabilistic seismic hazard, scenario earthquakes have been selected and calculated their impact on the object. Deterministic assessment for the object were carried out for the largest magnitude in each SSZ at its closest distance to the object for fractile 0.5 and 0.84

\section{A New Seismic Hazard Model for Mainland China}

RONG, Y., FM Global, Massachusetts, USA, yufang.rong@fmglobal.com; XU, $X$. Institute of Geology, China Earthquake Administration, Beijing, China, xiweixu@vip.sina.com; MAGISTRALE, H., FM Global, Research Division, Massachusetts, USA, harold.magistrale@fmglobal.com; CHENG, J., China Earthquake Networks Center, China Earthquake Administration, Beijing, China, chengjia@seis.ac.cn; CHEN, G., Institute of Geology, China Earthquake Administration, Beijing, China, guihuachen@ies.ac.cn; SHEN, Z., Department of Earth, Planetary, and Space Sciences, UC Los Angeles, California, USA, zshen@ucla.edu

We are developing a new seismic hazard model for Mainland China by integrating historical earthquake catalogs, geological faults, geodetic GPS data, and geology maps. To build the model, we construct an Mw-based homogeneous historical earthquake catalog spanning from 780 B.C. to present, create fault models from active fault data, and derive a strain rate model based on the most complete GPS measurements and a new strain derivation algorithm. We divide China and the surrounding regions into about 20 large seismic source zones. For each zone, a tapered Gutenberg-Richter (TGR) magnitude-frequency distribution is used to model the seismic activity rates. The a- and b-values of the TGR distribution are calculated using observed earthquake data, while the corner magnitude is constrained independently using the seismic moment rate inferred from the geodetically-based strain rate model. Small and medium sized earthquakes are distributed within the source zones following the location and magnitude patterns of historical earthquakes. Some of the larger earthquakes are distributed onto active faults, based on their geological characteristics such as slip rate, fault length, down-dip width, and various paleoseismic data. The remaining larger earthquakes are then placed into the background. A new set of magnitude-rupture scaling relationships is developed based on earthquake data from China and vicinity. We evaluate and select appropriate ground motion prediction equations by comparing them with observed ground motion data and performing residual analysis. To implement the modeling workflow, we develop a tool that builds upon the functionalities of GEM's Hazard Modeler's Toolkit. The GEM OpenQuake software is used to calculate seismic hazard at various ground motion periods and various return periods. To account for site amplification, we construct a site condition map based on geology. The resulting new seismic hazard maps can be used for seismic risk analysis and management.

Historical Records of Seismic Activities in Coxim, Pantanal Wetlands

SILVA, L. J., Universidade Federal de Mato Grosso do Sul/CPAQ, Brasil, lucimarajose@gmail.com; ASSUMPÇĀO, M., Universidade de São Paulo/IAG, Brasil, marcelo@iag.usp.br; FACINCANI, E. M., Universidade Federal de Mato Grosso do Sul/FAENG, Brasil, edna_facincani@hotmail.com; PEREIRA, W. P., Universidade Federal de Mato Grosso do Sul/CPAQ, Brasil, wanlypereira@ hotmail.com; DOURADO, G. F., Universidade Federal de Mato Grosso do Sul/ PGTA, Brasil,edna_facincani@hotmail.com

The Pantanal Sedimentary Basin, located in the Upper Paraguay Basin, in the Center-West region of Brazil, is a Quaternary, tectonically active basin, characterized by transcurrent type faults, constituting the largest expression of Neotectonics in the state of Mato Grosso do Sul. Recent research shows that the municipality of Coxim-MS, located in this region, presents intense seismic activities. After historical surveys for this municipality, four main seismic events were identified: a) July 30, 1911, 8PM: the newspapers, O Commércio (Cuiabá-MT), Opinião Pública (Pelotas-RS), O Pharol (Juiz de Fora-MG) and several newspapers from Rio de Janeiro, reported on a 10-second earthquake accompanied by an intense noise and followed by other small earthquakes; b) May 8, 1931, 9PM: The newspaper A Noite (Rio de Janeiro-RJ), reported that Coxim was shaken by a violent earthquake, damaging buildings and alarming the population; $\mathrm{c}$ ) August 29, 1963, 11PM: Correio do Estado (Campo Grande-MS) reported a small earthquake that lasted five seconds, being felt with greater intensity in the Colony of Taquari; d) October 8, 1968, 12:26AM: Correio do Estado reported that residents of the northern region of Nhecolândia (located near Coxim) were awakened with a loud sound similar to a jet plane noise, followed by a tremor that lasted a few seconds, slamming doors and shaking furniture. Historically, the Pantanal Sedimentary Basin is one of the seismic regions of Brazil, highlighting that in this region there is a seismic belt, which extends from the Pantanal to Goiás state, arriving in Tocantins state. These newly discovered events, with estimated magnitudes up to 4, improve the seismic catalog of the Pantanal and will contribute to better seismic hazard estimates.

\section{Interaction Between Observations and Models in Seismo- Volcanic Studies \\ Poster Session · Tuesday 15 May · Riverfront South}

Earthquake Stress Changes before, during, and after the 2015 Eruption at Axial Seamount

MOYER, P. A., University of New Hampshire, New Hampshire, USA, pamela@ pamelamoyer.net; BOETTCHER, M. S., University of New Hampshire, New Hampshire, USA, margaret.boettcher@unh.edu; BOHNENSTIEHL, D. R., North Carolina State University, North Carolina, USA, drbohnen@ncsu.edu

The volcanic eruption in April and May, 2015 of Axial Seamount on the Juan de Fuca Ridge was well documented by geophysical, chemical, and biological sensors as part of the Ocean Observatory Initiative Cabled Array. Seven ocean bottom seismometers located within and along Axial caldera recorded seismicity associated with magmatic processes before, during, and after the eruption. The extensive amount of seismic data related to the eruption of Axial (including more than 100,000 earthquakes between January 2015 and November 2017) provides a unique opportunity to investigate how stress drop and stressing rate evolve with seafloor deformation and hydrothermal fluid flow associated with submarine volcanism. We calculate stress drop from corner frequency derived using an empirical Green's function spectral ratio method. Our initial stress drop analysis focuses on $\mathrm{MW} \geq 2$ earthquakes located within the caldera. For 62 earthquakes, we find stress drops from $0.02-5.8 \mathrm{MPa}$ and interpret these values in terms of changes in crustal strength associated with the eruption. We observe high stress drops during inflation prior to the eruption and a decrease in stress drop during or after the eruption. From observed rate changes in microseismicity, we calculate Coulomb stress changes using the rate and state friction model (e.g. Dieterich, 1994) and 
the Epidemic Type Aftershock Sequence model (e.g. Llenos et al., 2009). Where seismicity rates are driven by inflation and deflation of the magma chamber, we expect stress changes to correlate with caldera elevation and tilt. Where seismicity rates are governed by perturbations to hydrothermal flow, we expect stress changes to correlate with vent temperature and chemistry. We continue our analysis to determine spatial and temporal variations in stress drop and stressing rate in response to eruption processes at Axial.

\section{Earthquake Detection and High-Resolution Body-Wave Tomography at} Okmok Volcano, Alaska

HART, L.A., University of Wisconsin-Madison, Wisconsin, USA, Lhart2@wisc. edu; BENNINGTON, N. L., University of Wisconsin-Madison, Wisconsin, USA, ninfa@geology.wisc.edu; LANZA, F., University of Wisconsin-Madison, Wisconsin, USA, flanza@wisc.edu; ROECKER, S. W., Rensselaer Polytechnic Institute, New York, USA, roecks@rpi.edu; HANEY, M. M., Alaska Volcano Observatory, Alaska, USA, mhaney@usgs.gov; KEY, K. W., Lamont-Doherty Earth Observatory, New York, USA, kkey@ldeo.columbia.edu

Okmok Volcano, located on Umnak Island, Alaska, is one of the most active volcanoes in the Aleutian arc. Historically, it has hosted a number of explosive, phreatomagmatic eruptions, resulting in the formation of 15 vents and four post-eruptive cinder cones. To better understand characteristics of the magma reservoir at Okmok and the associated volcanic hazard this region represents, we carried out an amphibious geophysical study of the volcano from July 2015 to August 2016. As part of this field survey, a seismic array of 13 three-component seismometers was installed, which when coupled with the permanent network at Okmok, yielded a dense set of 25 seismic stations sampling across the volcano. We applied the REST auto-picking algorithm to the acquired dataset, and we were able to identify $~ 3400$ earthquakes, including over 35,000 P-and 3,439 S-wave arrival times. This results in a $68 \%$ increase in the total number of events detected at Okmokrelative to the earthquake catalog generated by the Alaska Volcano Observatory (AVO) usedin the most recent seismic tomographystudy of the area. Initial earthquake locations show events dispersed throughout the volcanic region, with the largest cluster of seismicity occurring in an active geothermal area located SW of the caldera. Current work focuses on estimating uncertainties associated with the initial detections. From these uncertainty estimates, we will create a robust catalog of events and associated body-wave arrival times. The dataset will be used to augment a previously existing seismic catalog to obtain an enhanced image of the velocity structure at Okmok. Results from this study will help us to gain an improved understanding of magma migration and storage beneath the caldera.

\section{Unrest at Masaya and Momotombo Volcano, Nicaragua, Investigated with a Temporary Seismic Network}

OBERMANN, A., SED/ ETH Zurich, ZH, Switzerland, anne.obermann@sed. ethz.ch; MOLINARI, I., ETH Zurich, Switzerland, irene.molinar@erdw.ethz. ch; GRIGOLI, F., SED/ETH Zurich, Switzerland, francesco.grigoli@sed.ethz. ch; STRAUCH, W., INETER, Managua, Nicaragua, wilfried.strauch@yahoo. com; WIEMER, S., SED/ETH Zurich, Switzerland, stefan.wiemer@sed.ethz.ch

Since the end of 2013, the region around the volcanoes Masaya and Momotombo, which includes Nicaraguans capital Managua, has shown unusually high seismic and volcanic activitiy. On April 10, 2013, a M6.3 earthquake occured near Momotombo volcano followed by intense aftershock activitiy and a migration of seismicity towards Managua. In the following twoyears, the seismic activity remained considerably higher than in the previous network operation time (1975-2013). In December 2015 and January 2016, Momotombo volcano erupted after 110 years of quiescence. Since Mid December 2015, Masaya volcano has a lava lake in its main crater with gradually increasing activity. With 30 broadband stations, we temporarily (Dec16-March17) densified the permanent Nicaraguan seismic network around these volcanoes. With this network, we obtain a first image of the depth of the magma chambers of the volcanoes using ambient seismic noise tomography. A detailed analysis of the present seismicity provides us with a better understanding of the underlying tectonic processes and possible interactiosn between seismic and volcanic activity.

\section{Coda Wave Interferometry, Cross-Terms Analysis of EGF at Popocatepetl} Volcano, Mexico

CARDENAS-SOTO, M., National Autonomous University of Mexico, Mexico City, Mexico, martinc@unam.mx; REYES-PIMENTEL, T. A., National Autonomous University of Mexico, Mexico City, Mexico, thaliareyes@gmail. com

We analyzed seismic noise records in four seismic broadband stations located in the Popocatépetl volcano for 2012-2013 period. The aim is to explore the cross- terms of the Empirical Green Function (EGF) to provide additional information on the structure and strain changes. We obtained hourly correlations as a result of stacking $60 \mathrm{~s}$ time windows, which were aligned (traces filtered between 5-8 $s$ period) by adaptive stacking in order to eliminate any clock deviation. Finally, almost 600 daily cross-correlations were stacking to recover robust EGFs for the nine tensor components. In a first step, we estimate dispersion curves from the causal and anti-causal parts of principal componentes of Green tensor. In the range of 0.5 to $8 \mathrm{~s}$ period, curves were grouped according to the contribution of Rayleigh and Love waves. Curves for the long paths $(\geq 9.5 \mathrm{~km})$ describe a layered structure with Vs values of $0.5 \mathrm{~km} / \mathrm{s}$ for the shallow subsurface, and $3.5 \mathrm{~km} / \mathrm{s}$ for the deep structure. Dispersion curves for short trajectories $(<7 \mathrm{~km})$ and close to the crater, exhibite Vs values similar to those long trajectories, but with an inversion velocity between 3 and $5 \mathrm{~s}$ period. Media velocity changes were estimated using the best fit of time delays obtained in a moving window of $10 \mathrm{~s}$ along the coda between $0.5-1.5 \mathrm{~Hz}$. The results show smooth variations associated with the occurrence of LP events. For some months, volcano-tectonic swarm events clearly are related to strain accumulative-release process. This result is not so evident when a combination of different seismic activity is present. However, analysis of cross-terms shows that the other tensor components could provide better dispersion curves and evident strain changes in the volcano.

\section{The Volcano-Tectonic Seismicity of Teide Volcano (Tenerife)}

PADILLA, G. D., Instituto Volcanológico de Canarias, S/C de Tenerife, Spain, german@iter.es; BARRANCOS, J., Instituto Volcanológico de Canarias, S/C de Tenerife, Spain, jbarrancos@iter.es; BURNS, F., Instituto Volcanológico de Canarias, S/C de Tenerife, Spain, fiona.burns.beca@iter.es; CABRERA PERÉZ, I., Instituto Volcanológico de Canarias, S/C de Tenerife, Spain, ivancbrprz@hotmail.com; D’AURIA, L., Instituto Volcanológico de Canarias, S/C de Tenerife, Spain, Idauria@iter.es; GARCÍA-HERNÁNDEZ, R., Instituto Volcanológico de Canarias, S/C de Tenerife, Spain, ruben.garcia.beca@ iter.es; MORALES, C., Instituto Volcanológico de Canarias, S/C de Tenerife, Spain, cecilia.morales.beca@iter.es; PRZEOR, M., Instituto Volcanológico de Canarias, S/C de Tenerife, Spain, monikaprzeor@hotmail.com; SOUBESTRE, J., Instituto Volcanológico de Canarias, S/C de Tenerife, Spain, jsoubestre@iter. es; PERÉZ, N., Instituto Volcanológico de Canarias, S/C de Tenerife, Spain, nperez@iter.es

Tenerife is an active volcanic island which experienced several eruptions of moderate intensity in historical times, and a few explosive eruptions in the Holocene. Since 2016 the island has shown evidence of ongoing unrest, with increased volcano-tectonic seismicity, occurrence of long-period events and marked changes in the diffuse gas emissions. On 02/10/2016 the occurrence of a remarkable swarm of long-period events was interpreted as the effect of a transient massive fluid injection episode into the deep hydrothermal system of Teide volcano. This injection caused the pressurization of the hydrothermal system testified by the increase in the diffuse $\mathrm{CO} 2$ emission from the summit crater of Teide volcano which increased from a background value of about 20 tons/day up to a peak of 175 tons/ day in Feb. 2017. The pressurization process has been accompanied by an increase in the volcano-tectonic seismicity of Teide volcano, recorded by the Red Sísmica Canaria, managed by Instituto Volcanológico de Canarias (INVOLCAN). The network began its full operability in Nov. 2016 and currently consists of 15 broadband seismic stations. Since Nov. 2016 the network detected more than 1000 small magnitude earthquakes, located beneath Teide volcano at depths usually ranging between 5 and $15 \mathrm{~km}$. On January 6 th 2017 a M=2.5 earthquake was recorded in the area, being one of the strongest ever recorded in decades. Most of the events show typical features of the microseismicity of hydrothermal systems: high spatial and temporal clustering and similar waveforms of individual events which are often overlapped. We present the spatial and temporal distribution of the seismicity of Teide volcano since Nov. 2016, comparing it also with the past seismicity of the volcano. Furthermore we analyze the statistical properties of the numerous swarms recorded until now and the spatial and temporal variations of the Gutenberg-Richter b-value.

\section{Upper Crustal Structure of the Ceboruco Volcano (Mexico) Revealed by Ambient Seismic Noise Tomography}

DE PLAEN, R. S. M., Universidad de Guadalajara, Jalisco, Mexico, raphael. deplaen@gmail.com; LEON, E., Universidad de Gualajara, Jalisco, Mexico, leonerne@gmail.com; NÚŇEZ-CORNÚ, F. J., Universidad de Guadalajara, Jalisco, Mexico, pacornu77@gmail.com; NÚŃEZ ESCRIBANO, D., Universidad de Guadalajara, Jalisco, Mexico, diana@sisvoc.mx; SANDOVAL, J. M., Universidad de Guadalajara, Jalisco, Mexico, juan.sandoval@cuc.udg.mx

Ceboruco volcano in Nayarit, Mexico, is one of the only historically active volcanoes at the western end of the Mexican volcanic belt. The need to characterize the magma chamber and the hydrothermal system motivated this first seismic 
tomography of the volcano, with a focus on the upper $15 \mathrm{~km}$ of the crust. Seismic interferometry applied to ambient seismic noise is increasingly used to retrieve the Green's function between pairs of stations. This technique allows producing high-resolution images of the upper crust with the advantage of using continuously available, non-destructive data. We use the cross-correlations of the ambient seismic wavefield recorded by a dense network of 25 temporary short-period stations deployed to image shallow crustal structure of Ceboruco. We present the preliminary shear-wave velocity model based on this analysis.

\section{Ambient Noise Tomography of Okmok Volcano, Alaska}

MILLER, D. J., University of Wisconsin-Madison, Wisconsin, USA, dmiller36@ wisc.edu; BENNINGTON, N. L., University of Wisconsin-Madison, Wisconsin, USA, ninfa@geology.wisc.edu; HANEY, M. M., Alaska Volcano Observatory, Alaska, USA, mhaney@usgs.gov; KEY, K. W., Lamont-Doherty Earth Observatory, New York, USA, kkey@ldeo.columbia.edu

Okmok volcano is a caldera in the Aleutian Arc that has produced at least 11 eruptions over the past century of observation. Between summers 2015 and 2016 we deployed a seismic array of 13 broadband instruments in and around the caldera. This array supplemented Okmok's 12 permanent seismometers operated by the Alaska Volcano Observatory. Using these seismic data, we perform ambient noise tomography to image the subsurface velocity structure at Okmok. We obtain Rayleigh and Love wave group and phase velocity maps in the $0.2-0.7$ $\mathrm{Hz}$ frequency band, with the latter being obtained via the spatial autocorrelation procedure. We then invert phase and group velocity maps for the shear-wave velocity structure. Relative to previous tomography studies of Okmok, our dense seismic array allows for enhanced imaging of the velocity structure at this volcano and therefore allows us to better constrain the distribution of magmatic fluids.

\section{Analysis of Reflected Body Wave Phases at the Altiplano-Puna Magma Body} near Uturuncu Volcano, Bolivia

FARRELL, A. K., University of South Florida, Florida, USA, akfarrell@mail.usf. edu; MCNUTT, S. R., University of South Florida, Florida, USA, smcnutt@usf. edu; THOMPSON, G., University of South Florida, Florida, USA, thompsong@ mail.usf.edu

Understanding the upper surface of a magma body is important to determine several features, such as the location of the boundary between country rock and partial melt, the topography along this boundary, the sharpness or gradational nature of the contact, and lateral changes in physical properties along this interface. Investigation of seismic energy reflected from the partial melt-country rock boundary can be used to understand this upper surface. We present the results of reflected body wave phase analysis at the largest continental crustal magma body in the world, the Altiplano-Puna Magma Body (APMB) of southwest Bolivia. Our study focuses beneath the PLUTONS seismic network, centering on dormant Uturuncu volcano $\left(22^{\circ} 16^{\prime} 12^{\prime \prime} \mathrm{S}, 67^{\circ} 10^{\prime} 48^{\prime \prime} \mathrm{W}\right)$ with a radius of $<50 \mathrm{~km}$. This includes most of area shown to be deforming in InSAR studies, but not the entire APMB surface. We analyzed reflected phases which occur between the Pand $S$-wave arrivals of local, within-network events at depths of $\leq 7 \mathrm{~km} \mathrm{bmsl}$. We used the seismic software packages Antelope and GISMO to identify the reflections using a combination of cross-correlation, frequency, and polarization analyses. This included a detailed study of how best to determine the frequency content of signals of $<0.5 \mathrm{~s}$ duration, to determine a filter for the data that highlights the motion of the reflected signals for polarization analysis. We also looked at events clustered by location with similar waveforms. One of these clusters, located $\sim 7.4$ $\mathrm{km}$ southwest of the volcano, showed that waveforms on a path to two seismic stations (PLLL and PLSS) encountered different substrate than those from paths to other stations. This is evidenced by a mean $\mathrm{Vp} / \mathrm{Vs}$ ratio of 1.47 for these two stations, compared to 1.64 for all other stations. Results suggest a sharp boundary for the upper surface of the magma body, modulated by variations in country rock.

\section{Seismic and Acoustic Monitoring at Volcán De Colima, Mexico.}

ARÁMBULA, R., University of Colima, Colima, Mexico, raul_arambula@ucol. $\mathrm{mx}$

The seismic and acoustic activity of the Colima Volcano is studied and monitored by the Seismic Network of the State of Colima (RESCO), which belongs to the University of Colima. Nine broadband stations around the volcano record seismic activity in real time. Additionally, an acoustic sensor installed by the UNAM near the seismic station of Montegrande recorded the most important explosions in January and February 2017. The seismic-acoustic monitoring includes the location of volcano-tectonic events (VTs), explosions, rockfalls, count of events automatically with Hidden Markov Models, evaluation of the seismic and acoustic energy of the explosions, RSEM, etc. In recent years (2013-present), the activity of the volcano has been intense, lava domes growths, lava flows, lava dome collapses, as well as moderate to large explosions. Particularly the explosions in 2017, in their acoustic signals had a characteristic waveform of ' $N$ '. The seismic energy observed in the explosions had values above $1 \mathrm{e}+8$ Joules, while that the acoustic energy only presented 5 explosions that exceeded this value. With these values the ratio between acoustic and seismic energy remained mostly less than 1 . This indicates that the seismic-acoustic source is probably generated in a long and narrow conduit, likewise, the volcanic columns were charged with ash according to the models of Johnson and Aster (2005). Similarly, the time between the arrival of the seismic wave and the acoustic wave is observed between 15.6 to $19.6 \mathrm{sec}$, which tells us that there are a small variation in the depth of the source. These explosions are lower in the seismic energy released compared to the 2005 activity.

\section{Toward an Automatic Recognition System Based on Machine Learning Techniques at Cotopaxi Volcano}

BAUTISTA, M. A., Universidad de las Fuerzas Armadas ESPE, Pichincha, Ecuador, mabautista1@espe.edu.ec; LARA-CUEVA, R. A., Universidad de las Fuerzas Armadas ESPE, Pichincha, Ecuador, ralara@espe.edu.ec; LARCO, J. C., Universidad de las Fuerzas Armadas ESPE, Pichincha, Ecuador, jclarco@ espe.edu.ec; BENÍTEZ, D. S., Universidad San Francisco de Quito, Pichincha, Ecuador, dbenitez@usfq.edu.ec; RUIZ, M. C., Instituto Geofísico de la Escuela Politécnica Nacional, Pichincha, Ecuador, mruiz@igepn.edu.ec

Cotopaxi is an active stratovolcano located in Ecuador, which has previously presented 5 eruptive periods since 1533 . The aim of this work is to develop an automatic recognition system based on machine learning techniques for both detection and classification of seismic events from Cotopaxi volcano. Our primary goal is an automatic recognition system that may help experts to make more appropriate decisions towards a real time system, which may allow authorities to launch effective early warnings. This work is divided in two stages: in the detection stage, a non-overlapping segmentation was used, with 15 -sec windows; in each window several features were extracted in the time, frequency, and scale domains by using methods such as moving average, power spectral density, and wavelet transforms, 84 features were extracted: 13 in the time domain, 21 in the frequency domain and 50 in the scale domain; this stage allows to identify the starting and ending point of the microseism; by using the Moving Average method, a threshold equal to 0.2 of the normalized signal was identified for the detector to allow the identification of the existence of a microseisms. The best result was obtained by using Support Vector Machine techniques, it presents a performance metrics with a $\mathrm{Nu}=0.5$ obtaining $99.72 \%$ accuracy with a BER of 0.0014. The following Machine Learning techniques were used for classification of seismic events: Decision Trees (DT), Linear and Non-linear Support Vector Machines (SVM). An analysis of the BER was performed, varying the percentage of the training and test matrices for the different Machine Learning techniques. This variation improves the performance measures. The system was trained to have the ability to identify Long Period (LP) and Volcano-Tectonic (VT) events; the best result (BER equal to 0.1125 with a $94.29 \%$ accuracy) were obtained with non-linear SVM.

\section{Evolution of Harmonic Tremor Coda Associated to Lp Events Recorded Previous to the January 4th, 2010, Eruption and 2016 Eruptive Cycle at Turrialba Volcano (Costa Rica)}

VAN DER LAAT, L., Universidad de Costa Rica-RSN, Costa Rica, leonardo. vanderlaat@ucr.ac.cr; MORA, M. M., Universidad de Costa Rica-RSN, Costa Rica, mauricio.mora@ucr.ac.cr; PACHECO-ALVARADO, J. F., Universidad Nacional_OVSICORI, Costa Rica, javier.pacheco.alvarado@una.cr; CORNEJO,G., CNCA_CENAT, Costa Rica, gcornejo@cenat.ac.cr

Turrialba volcano is a 3,440 masl stratovolcano located at the SE end of the Central Volcanic Range of Costa Rica. Since last eruption, 150 years ago, the volcano shows no signs of activity. However, during the 1990s, degassing and seismic activity began to appear and became more conspicuous in the 2000 decade. Prior to the first eruption on January 4th, 2010, there was a significant increase in the earthquake-volcanic activity, mainly earthquakes of long period (LP) and volcanic tremor. 17 days prior to the eruption, tremor levels decrease and a series of LP events followed by short-lived harmonic tremor (LP-HT) were recorded. These same events were also recorded before the eruptive sequence that began at the end of April 2016. In this work we analyze in detail the spectral characteristics of these LP and associated tremor. The family of events prior to the eruption of January 4, 2010 present clear trends such as: increase in the number of events and decrease in LP duration and in the initial frequency of the harmonic tremor. This behavior suggests a gradual increase of the pressure in the system as well as the process of opening a system. In contrast, prior to the 2016 sequence the characteristics of the LP and the tremor do not present such clear trends which is consistent with the condition of a more open system in 2016. Currently, efforts are 
being made to determine a location of these events in order to further constrain its physical interpretation. The LP-HT location will be determined using corrected seismic amplitudes observed in 11 stations around the volcano. The siteamplification correction factors were calculated for each station by comparing coda amplitudes of 25 regional earthquakes. The interpretation of these results are of value for understanding the behavior of the Turrialba volcano and represent an important input for the monitoring and prevention of disasters.

\section{Spectral Analysis for Characterizing Microseisms Produced in the Cotopaxi Volcano}

AGUINAGA, D. S., Universidad de las Fuerzas Armadas ESPE, Quito, Ecuador, dsaguinaga@espe.edu.ec; LARA-CUEVA, R. A., Universidad de las Fuerzas Armadas ESPE, Quito, Ecuador, ralara@espe.edu.ec; RUIZ, M. C., Escuela Politécnica Nacional, Quito, Ecuador, mruiz@igepn.edu.ec; BENÍTEZ, D. S., Universidad San Francisco de Quito, Quito, Ecuador, diegobenitez@hotmail. com

Ecuador is a zone of high volcanic seismicity, in such sense it is important to recognize the behavior of volcanoes before they enter into an eruption process. This requires the analysis and to identification of different types of seismic events from a volcano. Cotopaxi volcano, is one of the most active and it has high risk due to the close proximity of populated areas in its surroundings and therefore it is one of the most supervised volcanoes in Ecuador. In this paper, a review of the most used spectral techniques for the analysis and extraction of discriminant features of microseisms is presented, since microseisms are some of the most important sources of information for analyzing the behavior of different volcanoes. Hence, our aim is to extract spectral features, which may help to classify events correctly, this information may also allow authorities to give early alerts in the case of increasing volcanic activity in order to alert and safeguard human lives. The analysis is performed by using parametric and non-parametric spectral techniques, enabling a more detailed study of the spectral content and the confidence intervals of specific events by using bootstrap technique, the empirical bootstrap procedure was specifically used, this consists in resampling the data from the empirical distribution. A database from the Cotopaxi volcano corresponding to a single station, with a broadband seismometer, containing several seismic signals representing different types of volcanic events such as volcanotectonic (VT), long period (LP), hybrid (HYB) and tremors (TRE) registered in 2012, was used for the analysis. The results obtained show that LP events have a thin spectrum and their frequency range goes from $0.5 \mathrm{~Hz}$ to $6 \mathrm{~Hz}$, with a major spectral component around $3.2 \mathrm{~Hz}$, VT events have a wide spectrum and their frequency range goes up to $20 \mathrm{~Hz}$ with a major spectral component around 6.8 $\mathrm{Hz}$, and TRE events have a spectrum that goes below $3 \mathrm{~Hz}$.

\section{Identifying Changes in Magmatic Activity at Veniaminof Volcano, Alaska, over Multiple Eruptive Cycles via Ambient Noise Interferometry}

BENNINGTON, N. L., U. Wisconsin-Madison, Wisconsin, USA, nharrington@wisc.edu; HANEY, M. M., Alaska Volcano Observatory, Alaska, USA, mhaney@usgs.gov

Veniaminof volcano is one of the largest and most active volcanoes in the Aleutian Arc. Recent eruptions include predominantly phreatic events in 2002, $2005,2006,2008,2009$, and 2013. We have applied seismic interferometry via ambient noise in order to probe the subsurface of this volcano and determine temporal changes in seismic velocity from pre- through post-eruption. No changes in seismic velocity related to magmatism were observed for eruptions in 2002, $2005,2006,2008$, and 2009. Instead, changes in seismic velocity observed during these eruptions were easily related to changes in seismic velocity observed in non-eruptive years and attributed to seasonal variations in the hydrologic cycle. Notably, within the set of eruptions analyzed, the two largest events (2004 and 2013 eruptions: VEI $=2$ and 3, respectively) showed changes in seismic velocity that deviated largely from the seasonal trend. Decreases in seismic velocity preceding the 2004 and 2013 events were observed as early as 1-3 weeks prior to eruption. Such decreases in seismic velocity were sustained for the duration of the events. Finally, as the eruptions ceased, changes in seismic velocity returned to values matching the seasonal trend. In an attempt to analyze how changes in seismic velocity vary both in time and with depth, we determined dispersion curves at summit station VNSS over a moving time. Each dispersion curve was determined using a 20 day stack of correlations. We examined a 3-month long time period leading into the 2004 and 2013 eruptions. For the 2004 eruption, it was not possible to obtain consistent dispersion curves over time. However, the 2013 event showed repeatable dispersion curves that contained small but consistent changes in seismic velocity with time. Each 20-day dispersion curve was inverted for change in velocity with depth and the observed pattern suggests the propagation of a low velocity anomaly through the subsurface at depth and into the volcano's near surface.
Western Eger Rift in Central Europe: Active Magmatic Emplacement from Combined Seismological and Isotope Study

HRUBCOVA, P., Institute of Geophysics, The Czech Academy of Sciences, Czech Republic, pavla@ig.cas.cz; GEISSLER, W. H., Alfred Wegener Institute, Helmholtz-Centre, Bremerhaven, Germany, wolfram.geissler@awi. de; BRAEUER, K., Helmholtz-Centre for Environmental Research, Halle, Germany, karin.braeuer@ufz.de; VAVRYCUK, V., Institute of Geophysics, The Czech Academy of Sciences, Czech Republic, vv@ig.cas.cz; KAEMPF, H., Helmholtz Centre Potsdam GFZ, Potsdam, Germany, kaempf@gfz-potsdam.de

Seismicity at lithospheric plate boundaries can be accompanied by magmatic processes, which play fundamental role in formation and differentiation of the Earth's crust. These processes are connected with magmatic emplacement as a result of an ongoing magmatic activity at the lower crustal level. Though they are usually confined to lithospheric plate boundaries, they can also occur in intraplate setting, however there, they are a rare phenomenon not commonly observed or discussed. Seismic and seismological interpretation must be supplemented by multidisciplinary research helping in detection of such areas and leading to advanced tectonic implications. One of them is the western edge of the Eger Rift in central Europe as a part of the European Cenozoic Rift System. It is a geodynamic region abundant of repeated seismic swarms and mantle derived fluids emanating at the surface, Cenozoic volcanism, and neotectonic crustal movements at the intersections of major intraplate faults showing diverse phenomena and representing unique European intracontinental setting. Strong lateral variations of the lower crust documented from wide-angle data are supported by results from local seismicity and indicate two types of the magmatic emplacement at the crust-mantle level. Xenoliths from corresponding depths document the origin depths of the magma at the lower crust/upper mantle transition. Increased helium isotope ratios in CO2-rich gases evidence lithospheric mantle origin. The character of the lower crustal material enables to differentiate timing and tectonic setting of two episodes with different times of origin. As a result, spatial and temporal relations to recent geodynamic processes suggest active magmatic processes in the intracontinental setting in this area.

Earthquake-Volcano Conversations at Volcán Guagua Pichincha, Ecuador HERNANDEZ, S., Instituto Geofisico Escuela Politecnica Nacional, Texas, USA, shernandez@igepn.edu.ec; RUIZ, M. C., Instituto Geofisico, Escuela Politecnica Nacional, Pichincha, Ecuador, mruiz@igepn.edu.ec

The sensitivity of tectonic faults or volcanic plumbing systems to external stressors has been observational demonstrated, but much is unknown about the exact physics involved in these interactions. In the case of magmatic systems, this uncertainty undermines operational forecasting efforts. Volcán Guagua Pichincha (GGP), located in the Ecuadorean Andes, is an active stratovolcano of dacitic composition located $12 \mathrm{~km}$ west of nearly 2 million urban inhabitants. Seismic activity at Pichincha is typically characterized by regularly reoccurring, short duration seismic swarms recorded by a network of short-period and broadband seismometers. Prior work has established that the constituent events in these swarms contain highly similar waveforms indicating a stationary, repeatable, and non-destructive source. Exploiting this catalog and waveform data, we report on a compendium of earthquake-volcano interactions observed at GGP in the last 3 years including: 1.) material changes of the edifice, 2.) triggered seismicity, and 3.) triggered quiescence. We hypothesize that all of these effects occurred as a result of external stressors, with the most dramatic examples following the 16 April 2016 Mw7.8 Pedernales earthquake off the coast of Ecuador. While earthquakes both large and small will impart static and dynamic effects, the exact range of influence and ratio of importance (static vs. dynamic) will depend on the magnitude of the trigger and its distance from the volcanic edifice. In the case of earthquake-GGP interactions, we hypothesize that material changes and triggered seismicity are most sensitive to dynamic stress, while the lone example of triggered quiescence was due to wide-spread volumetric expansion following the Mw7.8 coastal thrust event.

\section{Microseismicity Studies in Chacana Megacaldera}

CÓRDOVA, A. E., Instituto Geofísico Escuela Politécnica Nacional, Pichincha, Ecuador, acordova@igepn.edu.ec; RUIZ, M. C., Instituto Geofisico Escuela Politecnica Nacional, Pichincha, Ecuador, mruiz@igepn.edu.ec; SEGOVIA, M. R., Instituto Geofisico Escuela Politecnica Nacional, Pichincha, Ecuador, msegovia@igepn.edu.ec

Chacana is a large $(50 \times 30 \mathrm{~km})$ quaternary caldera in the Northern Andes of Ecuador. The volcanic activity was rhyolitic and was dated between 205 and 2.7 Myrs. The last eruption corresponds to two andesitic lava flows occurred in 1760year BC. (Hall, M. \& Mothes, P., 2008). A temporal seismic network was installed above the caldera and worked for 4 months. It was composed to 10 Broad Band 
stations. Seismic activity was composed by long period events (LP), hybrid (HB), volcano-tectonic $(\mathrm{VT})$ and tremors. In total $715 \mathrm{LP}$ were recorded. $44 \%$ of this activity was concentrated in a large fault that connects two domes (Yanahurco and San Clemente). Considering the spectrum, duration and first arrivals, it is possible that this fault controls the movement of hydrothermal-magmatic fluids. $66 \%$ of the activity and some hybrid events occurred near Antisana volcano, then we consider that these events correspond to Antisana activity or are related to the movement of its glaciers. The temporal network also recorded 176 local earthquakes. Earthquakes have epicentral distance less than $32 \mathrm{~km}$ to this network. These events have $\mathrm{Vp} / \mathrm{Vs}$ ratio of 1.64 and a Poisson relation $=0.206 .10$ focal mechanisms were computed and they present a mechanism with NE-SW direction and inverse component, so they are associated with tectonic faults that exhibit a NE movement parallel to the direction of the North Andean sliver. Two earthquakes present focal mechanisms with a normal component and are located near the structural caldera edge and suggest that these faults generate a pull apart striking $\mathrm{N} 300^{\circ}$ with normal mechanism. However, we found values a compressional axis of $\mathrm{N} 58^{\circ}$ and a tensional axis of $\mathrm{N} 327^{\circ}$ with a rotation of approximately $40^{\circ}$ with respect to expected regional tectonic compression. This deviation could be related to the activity of the Antisana volcano or to internal processes in Chacana caldera.

\section{Analysis of the Seismicity in the Los Humeros Mexican Geothermal Field within the Framework of the Consortium Gemex}

OREGEL, L., Instituto de Investigaciones en Ciencias de la Tierra, UMSNH, Michoacan, Morelia, Mexico, luisgeofisc@gmail.com; FIGUEROA-SOTO, A. Instituto de Investigaciones en Ciencias de la Tierra, UMSNH, Michoacan, Morelia, Mexico, angfsoto@gmail.com; CALO, M., Instituto Geofisica Universidad Nacional Autónoma de México, Ciudad de Mexico, Mexico, calo@igeofisica.unam.mx; JOUSSET, P., GFZ German Research Center for Geosciences, Potsdam, Germany, pjousset@gfz-potsdam.de; MÁRQUEZRAMÍREZ, V. H., Centro de Geociencias Universidad Nacional Autónoma de México, Queretaro, Mexico, marvh@gmail.com

The geothermal field of Humeros Puebla, Mexico, is one of the most important in the country due to its production of $85 \mathrm{Mwh}$. Previous studies indicate that most of the seismicity is concentrated in two large areas mostly located in the northern part of the field, near the areas of injection and re-injection of fluids (Urban et al, 2013, Lermo et al, 2001, 2002, 2005, 2008). In the framework of the Working Package 5.2 of the GEMex bilateral project between Mexico and the European Union, a seismic network has been installed consisting of 26 short-period and 17 broad band stations. This seismic network represents the largest monitoring network installed in a geothermal field in Mexico. The seismic noise of the stations has been analyzed to determine i) the quality of the seismograms and ii) the level of noise in the high frequency range $(\geq 1 \mathrm{~Hz})$, which could be attributed to the extraction plants, steam pipelines or the effect of human activity. For this purpose, we analyzed the power spectral density function, through the implementation of routines in free software such as Seismic Analysis Code (SAC) and Jupyter. Likewise, the spectral ratios have been calculated for each station of the network in order to characterize and determine the site effects. We also present the location of the seismic events registered in the field since September 2017, calculated using a 1D velocity model presented by Urban and Lermo (2013). SEISAN software is used to locate the seismicity (Havskov and Ottemoller, 2003) and HypoDD double difference method (Waldhauser, 2001) to refine the event location. Our preliminary results indicate that the noise levels are acceptable compared with the model of Peterson (1993), which allows us to characterize local seismicity and low magnitude within the geothermal field.

\section{Clarifying the Velocity Structure of the Yellowstone Volcanic System}

CRONIN, R. A., University of Wisconsin, Wisconsin, USA, racronin@wisc. edu; BENNINGTON, N. L., University of Wisconsin, Wisconsin, USA, ninfa@ geology.wisc.edu; FARRELL, J. M., University of Utah, Wisconsin, USA, fishynp@gmail.com

In the past 2.1 million years, the Yellowstone volcanic system has experienced three caldera forming eruptions. The last eruption occurred $\sim 0.63 \mathrm{Ma}$ and released more than $1,000 \mathrm{~km} 3$ of material. For scale, the 1980 Mount Saint Helens eruption emitted about 1/1,000th the material of the last Yellowstone eruption. To better understand the distribution of magma storage within Yellowstone's current day volcanic system, we carried out a study of the three-dimensional (3D) velocity structure of the region. Currently, we are solving for the local velocity structure of Yellowstone using body wave data. This includes over 31,000 P and S arrival time picks, which were used in previous body wave tomography studies of the region. Importantly, we are incorporating a set of newly determined differential time data into the inversion. This set of differential time data includes over 1 million cross-correlations and 300,997 catalog differential times. Previous veloc- ity tomography studies show that the incorporation of differential time data better clarifies the velocity structure of a region. Future work focuses on carrying out a 3D joint inversion for the shear wave velocity (Vs) structure of Yellowstone. This inversion will improve on current models by jointly inverting for both body and surface wave data. Since body and surface waves are sensitive to different regions of the model space, joint inversion should allow us to obtain a more complete image of Yellowstone's velocity structure, and thereby a better understanding of magma storage.

Hidden Markov Models (HMM) Applied to Primary Processing of the Seismicity Activity of Nevado Del Huila Volcano, Colombia TRUJILLO-CASTRILLÓN, N., National Autonomous University of Mexico, Ciudad de Mexico, Mexico, canytas@gmail.com; VALDÉS-GONZÁLEZ, C. M., National Autonomous University of Mexico, Ciudad de Mexico, Mexico, cvaldesg@cenapred.unam.mx

The Automatic Classification program based in the Hidden Markov Models, HMM, was implemented to study the seismic activity of Nevado del Huila volcano (Colombia). This program was adapted by researchers of Granada University - Spain for the recognition of the seismic signals of volcanic origin, and it has been applied successfully to volcanoes like Etna and Stromboli, Italy (Ibañez et al., 2009), San Cristóbal and Telica, Nicaragua (Gutiérrez et al., 2009), and Colima, Mexico (Arámbula, 2011). The implementation of the program requires of following stages: 1) Selection and segmentation of an important number of seismic signals that represent the different types of events occurring regularly at the volcano. In this stage we selected and segmented: 438 volcanotectonic events (VT), 426 Long Period events (LP), 240 hybrid events (HB), 308 Tremor pulses, 322 Regional and Local Tectonic events (REG) and 408 segments of seismic background noise (SIL). 2) The training of the program and the recognition of isolated signals to obtain the characteristic model of each type of event. 3) The Recognition of these event types within continuous records. The accuracy obtained in training and recognition of isolated seismic signals was 91.25 $\%$. This percentage suggests that the automatic classification program is a useful and fairly trustworthy tool for monitoring of active volcanoes. Results with high accuracy depend uniquely on the selection and segmentation process of events. From the results obtained with the automatic classification program we develop as additional tool the primary processing of the seismicity classified. For this, first we identified basic characteristics such as maximum amplitude, dominant frequency and signal duration, then we computed some additional parameters such as reduced displacement for signals related to fluid dynamics (i.e. for LP, HB and $\mathrm{TR})$, as well duration magnitude (Mc) and energy released for all signals.

Spatio-Temporal Distribution of Volcanic-Tectonic Swarms in the Northern Interandean Valley, Ecuador

GARCÍA, A.P., Universidad Central del Ecuador, Pichincha, Quito, andy_gc2@ hotmail.es; HERNANDEZ, S., Instituto Geofisico, Escuela Politecnia Nacional, Pichincha, Ecuador, shernandez@igepn.edu.ec; RUIZ, A. G., Penn State, Pennsylvania, USA, agr132@psu.edu; PLAIN, M. J., Instituto Geofisico, Escuela Politecnica Nacional, Pichincha, Ecuador, mplain@igepn.edu.ec; CÓRDOVA, A. E., Instituto Geofisico, Escuela Politecnica Nacional, Pichincha, Ecuador, acordova@igepn.edu.ec; RUIZ, M. C., Instituto Geofisico, Escuela Politecnica Nacional, Pichincha, Ecuador, mruiz@igepn.edu.ec

The Interandean Valley in Northern Ecuador is traversed by both active volcanoes and holocene-epoch faults, many of which have hosted destructive earthquakes in the recent past. This area is currently monitored for seismic and volcanic activity by the Instituto Geofisico at the Escuela Politecnica Nacional (IGEPN) in Quito. Recently, the National Seismic Network (RENSIG) recorded several seismic swarms between January and May 2016, close to the cities of Ibarra and Atuntaqui. Here, we quantitatively analyze these swarms in an attempt to determine their origin and relationship with the seismic activity of nearby Cuicocha, Imbabura and Chachimbiro volcanoes. A subset of 50 events ( $M L v \geq 1.5)$ were extracted from the local IGEPN catalog and used as templates for a match filter technique. This effort resulted in the discovery of an additional 392 previously unidentified local events. A relative relocation technique (hypoDD) was applied to body wave arrival data picked from this expanded catalog. From 514 total earthquakes, the majority of foci lie between 5 and $25 \mathrm{~km}$ depth. For the best recorded events, composite focal mechanisms were extracted using polarity information and $\mathrm{Sv}$-/ $\mathrm{P}$-wave amplitude ratios. These efforts resulted in three high quality focal mechanism solutions that suggest strike slip motion of a fault plane oriented NE-SW, and coincide with the major San Isidro-Otavalo fault system located westward of Imbabura volcano. Preliminary results from this study establish a baseline of what locations, focal mechanisms, and activity rates are common in this area. Future studies possibly incorporating GPS, InSAR, and other data 
should therefore focus on correlating the seismic activity of these faults with the evolving activity of Cuicocha, Imbabura and Chachimbiro volcanoes.

\section{What Caused the Local Stress Perturbation in Long Valley, California?}

LIN, G., University of Miami, Florida, USA, glin@rsmas.miami.edu; CHRISTIAN, F., University of Bristol, United Kingdom, fa17101@bristol. ac.uk; AMELUNG, F., University of Miami, Florida, USA, famelung@rsmas. miami.edu

Long Valley in eastern California is sandwiched by the Sierra Nevada and the Basin and Range Province. There has been a stress perturbation in the vicinity of the caldera with respect to the regional stress field. Previous studies suggest that this perturbation is a result of the left-step offset in the Sierran range bounding normal faults instead of magma chamber inflation beneath Long Valley Caldera. In this study, we take advantage of the abundant seismic data and state-of-theart finite-element numerical modeling to reinvestigate this local stress anomaly. We utilize the HASH program to compute focal mechanisms from P-wave first motion polarity observations for the relocated earthquakes between 1984 and 2014. The final $\sim 42,000$ good-quality focal solutions are then used to invert for the stress fields in 11 sub-areas by applying the SATSI algorithm. The orientations of the inverted minimum horizontal principal stresses (ShMIN) greatly agree with previous studies based on analyses of focal mechanisms, borehole breakouts, and fault offsets. The NE-SW oriented ShMIN in the resurgent dome and south moat of the caldera is in contrast to the dominating $\sim \mathrm{E}-\mathrm{W}$ orientation in the western Basin and Range province and Mammoth Mountain. In order to examine the source of this stress direction difference, we apply 3-D Finite Element Modeling with different parameters and combinations of tectonic and magmatic stress sources to search for the model that best fits the observed ShMIN orientations. Our preliminary results show that the local stress perturbation in the Long Valley area may be explained by the combination of a regional tectonic stress and an ellipsoidal magma source located next to the Mono Craters, indicating that the Mono Craters may play an important role in the local stress distribution in the area, although the current deformation is dominated by Long Valley Caldera.

\section{Using SAR Data to Monitor the Dynamics of Ecuadorian Volcanoes}

MIRZAEE, S., University of Miami, Florida, USA, sara.mirzaee@rsmas.miami. edu; AMELUNG, F., University of Miami, Florida, USA, famelung@rsmas. miami.edu; RUIZ, M. C., Instituto Geofisico-Escuela Politécnica Nacional, Ladrón de Guevara, Quito, Ecuador, mruiz@igepn.edu.ec; MOTHES, P. A., Instituto Geofisico-Escuela Politécnica Nacional, Ladrón de Guevara, Ecuador, pmothes@igepn.edu.ec

The inflation of the ground surface can indicate that magma ascends to shallower levels and that a volcano gets ready for an eruption. These changes can be observed by the use of stacks of SAR images and performing an interferometric time series analysis to obtain the value and rate of displacements. Furthermore, backscatter values analysis gives a complementary understanding of what is happening on the earth's surface. We present InSAR time series analysis we have implemented to monitor the activities of the Ecuadorian volcanoes. SAR data are provided in the framework of the Group on Earth Observation's Ecuadorian Volcano Geohazard Supersite. We use data from TerraSAR-X and Sentinel-1 and inverse modelling to better understand the mechanism and dynamic of these volcanoes. The InSAR data reveal uplift at three volcanoes, Pichincha, Cayambe and Chiles at rates of $2-3 \mathrm{~cm} / \mathrm{yr}$. The uplift at Pichincha is limited to the caldera area, indicating a shallow ( $<1 \mathrm{~km}$ depth) source. The beginning of inflation coincides with the 2016 M7.8 earthquake, suggesting that it was triggered by the earthquake.

\section{Active Source Seismic Imaging of the Magmatic Plumbing System beneath Mount St. Helens}

LEVANDER, A. R., Rice University, Texas, USA, alan@rice.edu; KISER, E. D., University of Arizona, Arizona, USA, ekiser@email.arizona.edu; SCHMANDT, B., University of New Mexico, New Mexico, USA, bschmandt@ unm.edu; HANSEN, S. M., Macquarie University, New South Wales, Australia, quasielliptic@gmail.com; CREAGER, K. C., University of Washington, Washington, USA, kcc@uw.edu

The iMUSH project (imaging Magma Under St. Helens) included a 3D active source seismic experiment consisting of 23 large shots recorded at $~ 6000$ seismograph stations. The experiment included 3 dense linear profiles: Two profiles of 8 shots each were recorded by $\geq 1000$ receivers $(\sim 150 \mathrm{~m}$ apart $)$ and strike NW-SE and NE-SW. A third profileof 4 shots and $\geq 300$ receiversstrikes E-W. We have made CMP stacked sections and Kirchhoff depth migrations of the profiles using travel-times from 2D and 3D tomography velocity models derived from thedataset. We have also made autocorrelation estimates of the reflectivity beneath the receivers using shot and noise data, and depth converted them using the tomography velocity models. Bright reflections in the CMP sections, depth migrations, and autocorrelations coincide with abrupt velocity changes in the $2 \mathrm{D}$ velocity models in the mid to lower crust and at the Moho: Reflections appear at $20-25 \mathrm{~km}$ depth at the tops of two lower crustal high velocity $(\mathrm{Vp} \geq 7.5 \mathrm{~km} / \mathrm{s}$ ) bodies. One of these is directly beneath the MSH edifice, the other is $\sim 40 \mathrm{~km}$ to the SE under the 9ka Indian Heaven basaltic volcanic field. We interpret the high Vp bodies as cumulates from Quaternary or Tertiary volcanism. Separating the two high $\mathrm{Vp}$ bodies is a lower velocity column $(\mathrm{Vp} \leq 6.5 \mathrm{~km} / \mathrm{s})$ dipping SE from the midcrust to the Moho. The Moho reflection is bright under the region of low velocity and dims beneath both of the high velocity lower crustal bodies. The 1980 eruption seismicity extended from the MSH summit to $20 \mathrm{~km}$ depth, stopping above the bright reflection at the MSH high Vp body. Deep long period events under $\mathrm{MSH}$, often associated with motion of magmatic fluids, cluster at $20-30 \mathrm{~km}$ depth along the SE edge of this reflection. We suggest that lower crustal magmas migrate from the southeast at the edge of the high velocity body, and then laterally across its top before ascending vertically to the magma storage zone under the summit.

\section{Numerical Modeling of Earthquake Ground Motion, Rupture Dynamics and Seismic Wave Propagation} Poster Session · Tuesday 15 May · Riverfront South

\section{Jizhaigou ms7.0 Earthquake High-Frequency Ground Motion Simulation and Zhangzha Town Intensity Estimation \\ $\underline{\mathrm{CHEN}, \mathrm{X}}$., Institute of Geophysics, China Earthquake Administration, Beijing,} China, xueliang_chen@aliyun.com

Jiuzhaigou occurred Ms7.0 earthquakes which caused serious human and economic losses. We simulated the strong ground motion characteristic using the Empirical Green Function Method. We also estimated the ground motion intensity of Zhangzha town which lost earthquake record data. All the stations are within the scope of around $100 \mathrm{~km}$ and all the stations' PGA are larger than $10 \mathrm{gal}$. Because of lacking appropriate aftershock record data, we try to use the aftershocks of Wenchuan earthquake and Dingxi earthquake as green function to simulate Jiuzhaigou earthquake in the first time. The simulated results as a whole can indicate the characteristics of the ground motion intensity especially the high frequency component. PGA, Duration and Response Spectrum are also fitted well between the simulated values and observed values. This attempt also indicated that using other earthquake' s aftershock to simulate this event is feasible when lacking aftershock records. The PGA of Zhangzha town is estimated about 180 gal-300gal. We also discussed the criterion about how to choose aftershock as green function.

\section{Deterministic Waveform Modeling to Aid Gmpe Development in Areas of} Induced Seismicity, the Importance of Kinematic Finite Faults

ZUREK, B. D., ExxonMobil, Texas, USA, brian.d.zurek@exxonmobil. com; BURNETT, W. B., exxonmobil.com, Texas, USA, william.a.burnett@ exxonmobil.com; DEMARTIN, B., ExxonMobil, Texas, USA, brian.j.demartin@ exxonmobil.com

Ground motion models (GMMs) have historically been used as input in the development of probabilistic seismic hazard analysis (PSHA) and as an engineering tool to assess risk in building design. Generally these equations are developed from empirical analysis of observations that come from fairly complete catalogs of seismic events. One of the challenges when doing a PSHA analysis in a region where earthquakes are induced is that the catalog of observations is not complete enough to come up with a set of equations to cover all expected outcomes. This work is part of a study where we use a deterministic finite-difference wave-form modeling to compliment the traditional development of GMMs. Specifically we leverage our industry expertise in developing and applying detailed physics based subsurface models to accurately model the propagation of the wavefield from source to receiver. Of particular interest is how the source model representation scales with magnitude and how this translates to modeled ground motions at a surface. A kinematic fault rupture model is used to test the sensitivity of the GMMs to variability in the fault rupture process that is physically consistent with observations. These tests will aid in constraining the degree of variability in modeled ground motions due to a realistic range of fault parameters and properties. From this study it is our conclusion that in order to properly capture the uncertainty of the GMMs with magnitude up-scaling one needs to address the impact of uncertainty in the near field $(<10 \mathrm{~km})$ imposed by the lack of constraint on the finite rupture model. By quantifying the uncertainty back to physical principles it is our belief that it can be better constrained and thus reduce exposure to risk. Further, by investigating and constraining the range of fault rupture scenarios 
and earthquake magnitudes on ground motion models, hazard and risk analysis in regions with incomplete earthquake catalogs, can be better understood.

\section{Applications of the Generalized Finite Differences Method in Viscoelastic Media}

SALETE, E., Universidad Nacional de Educación a Distancia, Madrid, Spain, esalete@ind.uned.es; UREÑA, M., Universidad Nacional de Educación a Distancia, Madrid, Spain, miguelurenya @gmail.com; BENITO, J. J., Universidad Nacional de Educación a Distancia, Madrid, Spain, jbenito@ind.uned.es; UREÑA, F., Universidad Nacional de Educación a Distancia, Madrid, Spain, furenaprieto@gmail.com; GAVETE, L., Universidad Politécnica de Madrid, Madrid,Spain, lu.gavete@upm.es

The meshless generalized finite difference method is applied to solve problems of seismic wave propagation in viscoelastic media, with irregular distribution of nodes. Schemes in generalized finite differences are obtained for the decoupled wave systems P-SV and SH in homogeneous media, and the stability of the schemes is analyzed. These schemes are used to solve certain particular case and the accuracy and easyness of its application is shown.

Comparison of Observed and Synthetic Dynamic Ground Strains and Rotations in the Near-Fault Region of the 2004 Parkfield Earthquake

CAO, Y., University of Notre Dame, Indiana, USA, ycao2@nd.edu; MAVROEIDIS, G. P., University of Notre Dame, Indiana, USA, g.mavroeidis@ nd.edu; ASHOORY, M., The Catholic University of America, District of Columbia, USA, 61ashoory@cua.edu

Several studies have generated low-frequency dynamic ground deformations (strains and rotations) in the near-fault region of actual or hypothetical earthquakes using physics-based simulation techniques that incorporate modeling of the seismic source and wave propagation processes. However, no systematic attempt has been made to compare observed and synthetic near-fault dynamic ground strains and rotations in order to demonstrate the effectiveness of the simulation techniques in predicting dynamic ground deformations in the vicinity of the fault. Such a comparison is presented in this study for the $2004 \mathrm{Mw} 6.0$ Parkfield, California, earthquake, which occurred on the San Andreas Fault and was recorded by a dense network of instruments. Following the work of Spudich and Fletcher (2008), estimates of near-fault dynamic ground strains and rotations are obtained by applying time-dependent geodetic analysis to displacement time histories recorded by the UPSAR and Turkey Flat dense arrays. A forward ground-motion simulation of the 2004 Parkfield earthquake is performed using the fault and crustal models proposed by Liu et al. (2006), and low-frequency translational motions, strains, and rotations are generated at selected stations. The computations are carried out using the discrete wavenumber representation method and the generalized transmission and reflection coefficient technique. The synthetic motions are generally in good agreement with the recorded translational motions, the recorded borehole volumetric strains, the array-derived strains and rotations, and the finite-difference approximated displacement gradients in terms of both amplitude and waveform characteristics. The results indicate that numerical simulations based on kinematic source models can be an effective tool for characterizing and predicting low-frequency dynamic ground deformations in the near-fault region.

\section{The SCEC Broadband Platform: Open-Source Software for Strong Ground} Motion Simulation and Validation

SILVA, F., Southern California Earthquake Center, California, USA, fsilva@usc. edu; MAECHLING, P. J., Southern California Earthquake Center, California, USA, maechlin@usc.edu; GOULET, C. A., Southern California Earthquake Center, California, USA, cgoulet@usc.edu; VIDALE, J. E., Southern California Earthquake Center, California, USA, jvidale@usc.edu

The Southern California Earthquake Center (SCEC) Broadband Platform (BBP) is a carefully integrated and validated collection of open-source scientific software programs that can simulate broadband $(0-100 \mathrm{~Hz})$ ground motions for earthquakes at regional scales. The BBP uses earthquake rupture and wave propagation modeling software to simulate ground motions from earthquakes. Users input an earthquake location, fault plane geometry and moment magnitude, a list of station locations, and a 1D velocity model for the region of interest, and the BBP software calculates ground motions for the specified stations. The platform also includes validation tools to be used when historical events with recordings are simulated. The BBP scientific software modules implement kinematic rupture generation, low- and high-frequency seismogram synthesis using wave propagation through $1 \mathrm{D}$ layered velocity structures, a site-effects module, several ground motion intensity measure calculations, and various ground motion goodness-offit tools. These modules are integrated into a software system that provides user- defined, repeatable, calculation of ground-motion seismograms, using alternative simulation methods, and software utilities to generate tables, plots, and maps. The $\mathrm{BBP}$ has been developed over the last seven years in a collaborative project involving geoscientists, earthquake engineers, graduate students, and SCEC software developers. The Broadband Platform is continuously evolving and new versions of the BBP are released periodically on GitHub. The latest SCEC Broadband Platform software can be compiled and run on recent Linux systems with GNU compilers. It includes seven simulation methods, eight simulation regions covering California, Japan, Central and Eastern North America, and the ability to compare simulation results against empirical ground motion models. The release also includes updated ground motion simulation methods, and the ability to simulate multi-segment ruptures. Differentiating the P and SV Contribution to the Vertical Ground Motions,
Using 3D Wave-Propagation Simulations

FRID, M., Department of Geological and Environmental Sciences, Ben-Gurion University, Negev, Israel, fridmich@post.bgu.ac.il; KAMAI, R., Department of Structural Engineering, Ben-Gurion University, Negev, Israel, rkamai@bgu.ac.il

Vertical ground motions have been traditionally neglected in seismic-hazard analysis, because they were believed to have minor effects on civil structures. Specifically, the vertical site-response and the physical parameters which influence it are still poorly understood. In recently-published vertical GMPEs, the site-response component is still represented only by Vs30. However, several studies have shown that in some frequencies, the P-wave contribution to the upright direction could be as large as that of the SV-wave or even more. In this study, we hypothesize that the site-response component in vertical GMPEs can be better predicted by combining P- and S- related site parameters. Because the cost of probabilistic-based seismic hazard evaluation is directly related to the uncertainty estimate, such a knowledge gap motivates a proper study of $\mathrm{P} / \mathrm{SV}$ relation. In order to examine the relative contribution of P- and SV- waves on the vertical ground motion component, we conduct a series of 3D earthquake scenario simulations. The simulations are performed using the 4 th order seismic wave propagation platform (SW4), which is an open-source code utilizing a finite difference approach in a 3D heterogeneous geological model. The P- and SV- wave components are identified using spatial derivatives of the motion, and their ratio is studied in the frequency range of 0.1 to $10 \mathrm{~Hz}$. The dependence of the P/SV ratio on source and path features, such as the inclination angle and the number of soft layers is studied. This study is expected to facilitate a general understanding that will lead to a better implementation of site-response component in future vertical GMPEs.

\section{Simulation of Strong Ground Motion for Northeastern Region of India Using Empirical Green's Function Method}

SHARMA, B., National Centre for Seismology, Ministry of Earth Sciences, New Delhi, India, babita_s@rediffmail.com; MIYAKE, H., Earthquake Research Institute, University of Tokyo, Tokyo, Japan, hiroe@eri.u-tokyo.ac.jp; YOKOI, T., International Institute of Seismology and Earthquake Engineering, Building Research Institute, Tsukuba, Japan, tyokoi@kenken.go.jp; HAYASHIDA, T., International Institute of Seismology and Earthquake Engineering, Building Research Institute, Tsukuba, Japan, takumi-h@kenken.go.jp; MISHRA, O. P., National Centre for Seismology, Ministry of Earth Sciences, New Delhi, India, opmishra2010.saarc@gmail.com

The regions that have experienced great earthquakes in the past are the most probable candidates for the future major/great earthquakes. Seismic hazard assessments should be conducted for seismically active regions in a deterministic way, considering the worst-case scenario earthquakes. In this study the northeastern region of India has been chosen as the setting for simulations of strong ground motion for scenario earthquakes (Mw 7.0) using the empirical Green's function method with a characterized source model with asperities. Recordings of the 2009 Bhutan earthquake (Mw 5.1 and 6.1) are considered as empirical Green's functions. Source scaling for the validation of the technique was accomplished by simulation of the $\mathrm{Mw} 6.1$ event using recordings of the Mw 5.1 earthquake with the fault extended to $\mathrm{Mw}$ 7.0. The results indicate that the peak ground acceleration (PGA) for a maximum of $121 \mathrm{~cm} / \mathrm{s} / \mathrm{s}$ would be experienced in the northeastern region of India, in the case of a major earthquake of $\mathrm{Mw} 7.0$, and high levels of accelerations would be experienced around sites near the assumed rupture initiation zones. For validating our results, the estimated values of PGA for the scenario Mw 7.0 event were compared with predicted ones from existing ground motion prediction equations for the Himalayan region. The obtained PGA values have provided an idea about the level of accelerations experienced in the area for a hypothetical and probable, future Mw 7.0 earthquake. With the data of ground motions and PGA values obtained in the present analysis, future construction in the area can be regulated and built environments be strengthened accordingly. 

Near-Fault Broadband Ground Motion Simulations of the 2016 Meinong,
Taiwan, Earthquake

DIAO, H., Earthquake Research Institute, University of Tokyo, Tokyo, Japan, hongqi@eri.u-tokyo.ac.jp; MIYAKE, H., Earthquake Research Institute, University of Tokyo, Tokyo, Japan, hiroe@eri.u-tokyo.ac.jp; KOKETSU, K., Earthquake Research Institute, University of Tokyo, Tokyo, Japan, koketsu@ eri.u-tokyo.ac.jp

We perform near-fault broadband ground motion simulations of the 2016 Meinong, Taiwan, earthquake using the stochastic finite-fault modeling method into which we introduce the frequency-dependent radiation pattern of $S$ waves. We simulate the broadband ground motions that recorded large velocity pulses using two hybrid approaches: the hybrid stochastic-mathematic approach and the hybrid stochastic-deterministic approach, and also simulate ground motions that did not record large velocity pulses using the pure stochastic method. The simulated ground motions using the hybrid stochastic-mathematic approach can reproduce observed large velocity pulses of both East-West (EW) and NorthSouth (NS) components, and the simulated 5\%-damped spectral accelerations have overall good fitting to the observation data. Due to the limitation of the velocity structure models in Western Taiwan, although the simulated ground motions using the hybrid stochastic-deterministic approach can show similar velocity pulse shapes to the observation data, the simulated peak velocities underestimate the amplitudes of observed velocity pulses of EW and/or NS components. The peak values and spectral contents of the simulated ground motions using the pure stochastic method fit well to the observation data. Through comparing the current ground motion prediction equations developed for shallow crustal earthquakes in Taiwan with both of the observed and simulated peak ground acceleration and spectral acceleration of the Meinong earthquake, we find that the ground motion prediction equations without the directivity correction term underestimate the spectral accelerations at periods around $1 \mathrm{~s}$ and longer for stations that recorded large velocity pulses. Finally we simulate strong ground motions at two collapsed building sites in the Tainan city where there were no observed ground motions.

\section{A New Ground-Motion Model for Iran}

FARAJPOUR, Z., The University of Memphis, Tennessee, USA, zfrjpour@ memphis.edu; PEZESHK, S., The University of Memphis, Tennessee, USA, spezeshk@memphis.edu; ZARE, M., International Institute of Earthquake Engineering and Seismology, Tehran, Iran, mzare@iiees.ac.ir; ZAFARANI, H., International Institute of Earthquake Engineering and Seismology, Tehran, Iran, h.zafarani@iiees.ac.ir

In this study, we develop a new ground motion model for Iran which consists of four seismic regions: (1) Zagros, a continental-continental collision zone of Arabian plate and Central Iranian Microcontinent, (2) Alborz-Azarbaijan located in north and northwest Iran and it is part of Alpine-Himalayan seismic belt, (3) Kope Dagh, a segment of Alpine-Himalayan seismic belt, and (4) Central-East Iran, an intraplate subjected to the foregoing convergent zones. We consider regional differences via Mixed-effects regression model. A total of 1357 three component strong motion records from 1978 to 2013 processed from 211 earthquake events with moment magnitudes $4.5 \leq \mathrm{M} \leq 7.5$, and rupture distances RRUP $\leq 250 \mathrm{~km}$. The strong-motion records are selected from Iranian StrongMotion National Network which is operated by the Building and Housing Research Center (BHRC). We expanded the database created by Farajpour $e t$ al. (2017) to include the near source data by using strong-motion records from Turkey and Greece, which have similar tectonic activity and shallow crustal earthquakes with the focal depth less than $35 \mathrm{~km}$. The new GMM is derived for the Peak Ground Acceleration (PGA) and 5\%-damped pseudo-acceleration response-spectral ordinates at periods ranging from $0.01 \mathrm{~s}$ to $4.00 \mathrm{~s}$ and moment magnitudes ranging from 4.5 to 7.5. The GMM is developed for a reference soft rock with an averaged shear-wave velocity in the top $30 \mathrm{~m}$ of VS30 $=760 \mathrm{~m} / \mathrm{s}$. The distributions of inter-event and intra-event residuals are analyzed to show that the developed GMM has satisfactory performance with no discernible trends in residuals. Furthermore, a comparison of the newly developed GMM will be provided with recent published GMMs for the Iranian region.

\section{Numerical Simulations of Stress Variations with Depth near the Brittle-} Ductile Transition of a Strike-Slip Fault

ABOLFATHIAN, N., University of Southern California, California, USA, nabolfat@usc.edu; JOHNSON, C. W., Scripps Institute of Oceanography, California, USA, cwj004@ucsd.edu; BEN-ZION, Y., University of Southern California, California, USA, benzion@usc.edu

We perform quasi-static numerical simulations of several types of strike-slip faults and crustal structures to help interpreting stress tensor orientations derived from focal mechanism data around the San Jacinto fault zone. Specifically, we attempt to understand relations of observed rotation of the principal stress axes below 10 $\mathrm{km}$ depth to geometrical and rheological properties of the brittle-ductile transition zone. The examined structural models consist of vertical right-lateral frictional fault in horizontal crustal layers and ongoing tectonic loading. The following three different simple scenarios are used. In the first the fault is limited to the upper crust and does not extend into the transition zone. In the second the fault extends through the transition zone. In the third the fault extends through the transition zone and is surrounded by a weaker shear zone. The simulations employ the finite element software package PyLith for solving the partial differential equations describing the tectonic deformation. The model geometry is defined using CUBIT meshing software. The preliminary results indicate that the near field stress orientation is rotated when the fault extends into the transition zone. Further analysis will improve the model results with realistic initial stress distribution and describe to what extent the geometric structure and rheology of the crustal layers can affect the orientation variations of the stress tensor with depth.

\section{Studying the Shear Resistance Response to Rapid Normal-Stress Variations near the Free Surface on Experimental Thrust Faults}

TAL, Y., Caltech, California, USA, yuvaltal82@gmail.com; LAPUSTA, N., Caltech, California, USA, lapusta@caltech.edu; RUBINO, V., Caltech, California, USA, vito.rubino@caltech.edu; ROSAKIS, A., Caltech, California, USA, arosakis@caltech.edu

A proper formulation of the shear-resistance evolution during rupture is essential for analyzing many earthquake source problems, including the ground motion. While the shear resistance typically assumed to be proportional to normal stress, several studies show a gradual, slip-dependent, response of the frictional shear resistance to rapid variations in the normal stress. Here we use laboratory experiments of propagating dynamic ruptures together with computer simulations to investigate this problem. Our experiments produce variations in fault-normal stress due to the interaction of dynamic rupture with the free surface, similarly to what occurs in natural thrust events. The experiments also enable to study the potential fault opening and ground motion of the simulated thrust faults. In order to image and quantify the full-field behavior of dynamic ruptures, we use an experimental technique that combines ultra-high speed photography and digital image correlation to produce maps of dynamic displacements, velocities, strains, and stresses at intervals of less than a microsecond. This technique has been successfully used to characterize dynamic friction evolution in laboratory dynamic ruptures (Rubino et al., 2017). It allows us to image the evolution of fault-normal stress and fault-parallel shear stress, and thus to study how friction evolves under the conditions of rapid normal stress variations. We enhance the experiments with dynamic simulations, using a self-developed finite element simulator that enables an accurate modeling of the variation of normal stresses and the implementation of different friction formulations. The simulations help us to design the experiments, explore a wider range of geometries and loading conditions, constraint parameters and conditions that cannot be constraint solely by the experiment, and study how the ground motion would be affected by different assumptions about the friction evolution on the fault near the free surface.

The Effect of Small-Scale Random Heterogeneities in Local Surface Sedimentary Structures on Spatial Variability of Earthquake Ground Motion STRIPAJOVA, S., Comenius University Bratislava, BL, Slovakia, stripajova@ fmph.uniba.sk; KRISTEK, J., Comenius University Bratislava and Slovak Academy of Sciences, BL, Slovakia, kristek@fmph.uniba.sk; MOCZO,P., Comenius University Bratislava and Slovak Academy of Sciences, BL, Slovakia, moczo@ fmph.uniba.sk; BARD, P. Y., ISTerre, University Grenoble-Alpes/ IFSTTAR / CNRS, France, pierre-yves.bard@univ-grenoble-alpes.fr; HOLLENDER, F., CEA, France, fabrice.hollender@cea.fr

SIGMA, a R\&D program of EDF, AREVA, CEA and ENEL in 2011-2015, aimed to obtain robust and stable estimates of the seismic hazard. In the work package focused on estimating the amplification effects of local site conditions on earthquake ground motion (EGM) we numerically investigated potential of typical 2D and 3D surface sedimentary structures to undergo site effects. We performed 1D, 2D and 3D simulations for a shallow Mygdonian basin (Greece), a typical deep Alpine valley (Grenoble, France), two small shallow valleys, a midsize valley, and a large shallow valley. We also performed simulations for a variety of the model modifications to investigate EGM sensitivity to geometry, impedance contrast, attenuation and velocity gradient. We calculated amplification factors, and 2D/1D and 3D/2D aggravation factors for 10 EGM characteristics, using a representative set of recorded accelerograms to account for input motion variability. Here we extend the sensitivity study to small-scale random heterogeneities in sediments. We implemented small-scale random heterogenization of $\mathrm{P}$-wave and S-wave speeds, and density in sediments. We applied 3 different auto- 
correlation functions - Gaussian, exponential and von-Kármán (we use functions proposed by Frankel and Clayton 1986). They differ in the spectral falloff of their power spectra. We considered 3 different values of standard deviation $(5 \%$, $10 \%$ and $20 \%$ ) and fixed values of correlation lengths with a vertical-to-horizontal ratio 1:10. One numerical simulation means only one possible realization of a random process. Thus we performed several realizations for each of 9 combinations of the autocorrelation function and standard deviation. Based on the statistical analysis of the calculated EGM characteristics for thousands of receivers we quantified the effect of random heterogeneities on the amplification and aggravation factors. We quantified EGM spatial variability using coherency function.

\section{The 2017 Kos-Bodrum Earthquake}

CAKTI, E., Bogazici University, Turkey, eser.cakti@boun.edu.tr; SESETYAN, K., Bogazici University, Turkey, karin@boun.edu.tr; ALCIK, H., Bogazici University, Turkey, alcik@boun.edu.tr; HANCILAR, U., Bogazici University, Turkey, hancilar@boun.edu.tr

The M6.7Kos-Bodrum Earthquake of 21 July 2017 was the largest in a series of seismic events that took place in 2017 along Turkey's Aegean Sea coast. It was a normal-mechanism earthquake associated with the east-west trending Gokova system. The epicenter was between Turkey and Greece. The damage was limited in the Bodrum peninsula to the north. It was generally higher in the Kos island to the south including partial collapses and casulties. The main shock was recorded by the five-station Bodrum strong motion network operated by the Department of Earthquake Engineering of Bogazici University. All records can be classified as near field and include a distinctive pulse type motion evident in time-domain plots and in response spectra. Although the damage was limited in Bodrum and the ground motion levels were low, damage patterns of individual structures suggest a correlation with the directionality of the event. This study tries to estimate the spatial extent of regions in Bodrum and Kos where long period ground motion was dominant. To this aim we simulate the long-period strong motion deterministically. We compare the spatial distribution of simulated ground motion with that of damaged buildings and also try to correlate damages to individual properties with the long period features of ground motion.

\section{Salvus: A High-Performance Software Suite for Full-Waveform Modelling and Inversion}

AFANASIEV, M., ETH Zurich, Switzerland, michael.afanasiev@erdw.ethz. ch; BOEHM, C., ETH Zurich, Switzerland, christian.boehm@erdw.ethz.ch; VAN DRIEL, M., ETH Zurich, Switzerland, vandriel@tomo.ig.erdw.ethz. ch; KRISCHER, L., ETH Zurich, Switzerland, lion.krischer@erdw.ethz.ch; FICHTNER, A., ETH Zurich, Switzerland, andreas.fichtner@erdw.ethz.ch

The continuously increasing power of high-performance computing systems enables the application of full waveform inversion to a growing range of data sets yielding high-resolution images of the subsurface structure. This contribution focusses on methodological and algorithmic advances in Salvus, a comprehensive collection of software packages covering the complete toolchain of time-domain waveform inversion with modules for numerical wave propagation, meshing, inversion, and workflow management. Salvus' waveform propagator is based on a continuous high order finite/spectral element discretization and works on conforming unstructured hypercubic and simplicial meshes in 2 and 3 dimensions. A wide variety of wave propagation physics are implemented (acoustic, elastic, viscoelastic, coupled solid-fluid, poroelastic) and a particular focus of the package is a high level of generality without sacrificing performance (zero-cost abstractions). We additionally present a meshing toolbox that provides fully automated meshing for common domains in seismology and seismic exploration, including various local refinement schemes to adjust the element sizes to the velocity model. Furthermore, we introduce an automated, interactive, and graph-based workflow framework to steer the inversion procedure. It subdivides full waveform inversion into a sequence of tasks that are orchestrated by the workflow manager, thereby separating the numerical simulation from data processing and model handling. This enables us to automatically adjust the computational resources to the current needs, to distribute and execute tasks on remote clusters, and to foster data provenance and reproducibility. Several numerical examples ranging from laboratory over regional to planetary scale illustrate the wide range of applications that can be tackled with Salvus.

\section{Onshore Quaternary and Contemporary Tectonics: Implications for Seismic Hazards} Poster Session · Tuesday 15 May · Riverfront South

\section{Guaicaramo Fault System, Boyaca, Casanare, Cundinamarca and Meta Departments, Colombia: A Review}

CHICANGANA, G., Universidad Santo Tomas, Villavicencio, Colombia, Meta, Colombia, germanchicangana@usantotomas.edu.co; BOCANEGRA, A., Universidad Santo Tomas, Villavicencio, Colombia, Meta, Colombia, alfonsinabocanegra@usantotomas.edu.co; VARGAS JIMENEZ, C. A., Universidad Nacional de Colombia, Bogotá, Colombia, Distrito Capital, Colombia, cavargasj@unal.edu.co; KAMMER, A., Universidad Nacional de Colombia, Bogotá, Colombia, Distrito Capital, Colombia, akammer@unal.edu. co; ARBOLEDA, L., Universidad Santo Tomas, Villavicencio, Colombia, Meta, Colombia, leydyarboleda@usantotomas.edu.co

The Guaicaramo Fault System (GFS) consists of several parallel faults with $45^{\circ} \mathrm{NE}$ strike average and defines the eastern edge of the Colombian Eastern Cordillera. These faults cut Cretaceous and Paleogene sediments mainly, and have built an orogenic wedge that defines geomorphogically the Llanos Foothills in this región (For this región Paris et al. 2000, have classified the fauls central and southern Guaicaramo). The GFS was created from Late Miocene by the tectonic inversion of normal faults that originated mostly during a transtensional regime that developed during Late Oligocene-Early Miocene lapse, when the Panama arc began to adjust in the northwest corner of South America. In the last 3 millions years with the adjust of the Panama arc and the development of the current geometry of the subduction slab of Nazca plate under northwestern South America toward north of $4^{\circ} \mathrm{N}$, the orogenic wedge started to grow where its eastern boundary is the central and southern Guaicaramo faults planes. In this work was analizated the GFS in the limits of Boyaca, Casanare, Cundinamarca and Meta departments, where several hot springs are associated to the fault scarp of Southern Guiacaramo fault. These hot springs are an geotourism interest. It is sought here to try to understand the relationship that exists between the presence of hot springs with fault planes in deep and its tectonic activity with help of geologic and geophysic regional data review. In same way, a review of the seismology information is made with data available from National Colombian Seismological Network. In this región was occur the $\mathrm{M} 0=6.5$ earthquake of january 19, 1995 .

\section{Geophysical Imaging of a Near-Surface Fault System at Billecocha High Plateau, Ecuador}

PACHECO, D. A., Instituto Geofísico Escuela Politécnica Nacional, Pichincha, Ecuador,dpacheco@igepn.edu.ec; SAQUI, D. C., Facultad de Geología Escuela Politécnica Nacional, Pichincha, Ecuador, diana.saqui@epn.edu.ec; ALVARADO, A., Instituto Geofísico Escuela Politécnica Nacional, Pichincha, Ecuador, aalvarado@igepn.edu.ec; BARROS, J. G., Instituto Geofisico Escuela Politecnica Nacional, Pichincha, Ecuador, jgbarros@igepn.edu.ec; ESPÍN, P. A., Instituto Geofísico Escuela Politécnica Nacional, Pichincha, Ecuador, pespin@ igepn.edu.ec; SANTO, N. J., Instituto Geofísico Escuela Politécnica Nacional, Pichincha, Ecuador, jsanto@igepn.edu.ec; VIRACUCHA, C. R., Instituto Geofísico Escuela Politécnica Nacional, Pichincha, Ecuador, cviracucha@igepn. edu.ec

Refraction seismic profiles and Ground Penetration Radar (GPR) lines were acquired at Billecocha's High Plateau (BHP), Imbabura-Ecuador, to visualize a fault zone at the near-surface. The faults present at BHP occur about 4000 meters above sea level (masl) in a nature reserve in an area four $\mathrm{km}$ wide by ten $\mathrm{km}$ long. The processes responsible for the faults still remain in discussion. However they are located near densely populated urban centers, such as Ibarra, destroyed in 1868 by an earthquake. In this context, our work aims to fill the gap left by previous regional tectonic studies by providing an accurate near-surface image of the zone and evidence of the faults' kinematics. The design of the seismic experiment comprised dense profiles, using $4.5 \mathrm{~Hz}$ geophones. Both source points and receivers were spaced at $1 \mathrm{~m}$ interval along 3 profiles of $48 \mathrm{~m}$ long. The GPR reflection radargrams were acquired along ten $50 \mathrm{~m}$ long lines using two different antenna frequencies $(250$ and $100 \mathrm{MHz}$ ). Generalized Reciprocal Method and Seismic Traveltime Tomography were used to provide a preliminary image of the faults. The average velocity of the radar impulse was obtained with ground markers and was used to correct the radargrams. A multichannel analysis of surface waves (MASW) was also carried out to complement the study. Thanks to these technological applications at the study site a conspicuous normal fault zone is synergistically imaged. The thickness of the sedimentary layers were obtained comparing the images from the refraction and GPR surveys. An average for both P and $S$ wave velocities was estimated for the layers involved in the fault mechanism using the analysis of the refraction profiles and MASW. The $2 \mathrm{D}$ near-surface final 
image obtained provides a deeper insight into the architecture and kinematics of the fault system at BHP.

\section{Earthquake-Induced Landslides Estimates Based on Ground Motion Parameter Maps for Central Mexico}

VALENCIA, D. I., Instituto de Ingeniería, Universidad Nacional Autónoma de México, Distrito Federal, Mexico,dvalenciam@iingen.unam.mx; RAMÍREZGUZMÁN, L., Instituto de Ingeniería, Universidad Nacional Autónoma de México, Distrito Federal, Mexico, Lramirezg@iingen.unam.mx

We present a hybrid physics- and GMPE-based method to generate Ground Motion Parameter Maps (GMPM) together with landslides estimates due to earthquakes in Central Mexico. The maps are computed using Ground Motion Prediction Equations (GMPEs) and 3D simulations including topographic and realistic crustal models using the Finite Element Method to high and low frequencies, respectively. Peak ground acceleration, Arias intensity, and spectral accelerations are compared qualitatively and quantitatively against observed landslides. In our preliminary analysis, we do not find suitable correlations of the parameters with the available landslide information, perhaps due to the uncertainties in the source estimates or other factors not accounted. Finally, we explore surficial principal stress-based parameters together with Holocene deposit maps of Central Mexico. According to our preliminary analysis, regions with high stresses in soil deposits, not included in our $3 \mathrm{~d}$ model, are in some cases a fair seismic landslides susceptibility predictor.

\section{Sequence Stratigraphy of Upper Paleogene to Neogene Carbonates Exposed} from Guánica Bay to Guayanilla, Southern Puerto Rico

FLORES, V. E., University of Puerto Rico Mayagüez, Puerto Rico, USA, victor. flores2@upr.edu; SANTOS, H., University of Puerto Rico Mayagüez, Puerto Rico,USA, hernan.santos@upr.edu

Detailed stratigraphic columns were measured and microfacies analysis was performed in southwestern Puerto Rico to conduct a sequence stratigraphic analysis of Paleogene to Neogene strata. Two of the best exposed outcrops include the Guánica Bay and outcrops along Highway PR-132 in Guayanilla. Three depositional sequences, separated by two major sequence boundaries were found. The lower sequence occurs within the Juana Díaz Formation and is an open shelf to reef facies indicative of a Transgressive System Tract (TST), that is overlain by a High Stand System Tract (HST) marked by reef progradation. The HST in both Guánica Bay and Guayanilla is characterized by coral-rhodolith cyclicity however sections in Guánica Bay show pervasive recrystallization due to diagenetic alteration as a result of a long periods of exposure. This first sequence is Oligocene in age. The middle sequence, exposed at the eastern section of the Guánica Bay is also part of the Juana Díaz Formation and includes a turbiditic Lowstand System Tract (LST) of slopelike deposits flow, a TST constituted by coral rubble and skeletal grainstones belonging to a shallow island slope environment; and a HST that consists of an island slope chalk facies intercalated with turbidite grainstones derived storm events at the Guayanilla location. During the deposition of the middle sequence the Guánica Bay west section was topographically higher and exposed. The upper depositional sequence is Miocene in age and is composed of a TST with the transgression starting distally in the Guánica area and transgressing northward toward the Guayanilla area. These was correlated using high resolution $87 \mathrm{Sr} / 86 \mathrm{Sr}$ isotope concentrations of shallow marine mollusks Kuphus incrassatus in the Ponce Formation at the Guánica Bay and Guayanilla locations Facies patterns like the ones in the studied outcrops of southwestern Puerto Rico provide an exemplary environmental model of variability of paleodepositional relief, tectonic setting, variability in depositional setting of reef Sediment acumulations, the influence of storm events and variability in rock porosity by diagenetic processes yielding valuable models that may apply to potential OligoceneMiocene hydrocarbon reservoirs.

\section{The Next Big Earthquake: The Usual and the Unusual Suspects}

Poster Session · Tuesday 15 May · Riverfront South

Repeated Earthquake Uplift at Icy Point, Glacier Bay National Park, Alaska: Strain Partitioning at a Restraining Bend in the Fairweather Fault?

WITTER, R. C., US Geological Survey, Alaska, USA, rwitter@usgs.gov; KELSEY, H. M., Humboldt State University, California, USA, harvey.kelsey@ humboldt.edu; BENDER, A. M., US Geological Survey, Alaska, USA, abender@ usgs.gov; SCHARER, K. M., US Geological Survey, California, USA, kscharer@ usgs.gov; LEASE, R. O., US Geological Survey, Alaska, USA, rlease@usgs.gov

The Fairweather Fault accommodates $43-58 \mathrm{~mm} / \mathrm{yr}$ of right-lateral, strike-slip motion along the boundary between the North American plate and the Yakutat block in southeast Alaska. Near Icy Point, where the Fairweather Fault trends offshore, the Yakutat block translates through a $20^{\circ}$ restraining bend and $4-\mathrm{km}$ right step in the fault. Deformation within the fault bend drives surface uplift at Icy Point, where progressively abandoned marine and stream terraces only occur west of the fault. During the 1958, M7.8 Lituya Bay earthquake 2.5-4 m of dextral offset occurred on the fault at Icy Point, without uplift. West of the fault, lidar data reveal raised stream terraces that grade to a fight of $\sim 12$ uplifted marine terraces beveled into Icy Point. Marine terrace risers, ranging from 1 to 6 $\mathrm{m}$ high, imply repeated episodes of sudden relative sea-level (RSL) fall. Multiple fault strands cut stream terraces and show both right-lateral and west-side-up offsets. We infer that reverse faults, which offset marine terraces, and an inferred offshore thrust, contribute to terrace uplift. We reconstruct the RSL history of Icy Point from marine terrace shorelines ( $40-43 \mathrm{~m}$ high), and age estimates of glacial landforms and offset terrace sediment. Then we compare the Icy Point RSL history to a published, post-glacial RSL curve for Icy Strait on the opposite (eastern) side of the Fairweather Fault, which shows RSL 5-6 m lower than present at $7 \mathrm{ka}$. Differencing the two RSL histories over the past 6-7 ka, which accounts for the GIA and eustatic components of RSL change, implies $6.4-8.2 \mathrm{~mm} / \mathrm{yr}$ of tectonic uplift at Icy Point. These rates agree with the thermochronometric rock uplift rate of 5-10 mm/yr at Icy Point averaged over the past $300 \mathrm{ka}$. The Fairweather Fault accommodates both right-lateral and vertical displacement at Icy Point, but whether or not strain is partitioned into lateral and vertical displacement in separate earthquakes remains unclear.

\section{Preliminary Paleoseismology of the Buffalo Bowl Trench Site on the Teton Fault} DUROSS, C. B., US Geological Survey, Colorado, USA, cduross@usgs. gov; GOLD, R. D., US Geological Survey, Colorado, USA, rgold@usgs.gov; BRIGGS, R. W., US Geological Survey, Colorado, USA, rbriggs@usgs.gov; DELANO, J. E., US Geological Survey, Colorado, USA, jdelano@usgs.gov; OSTENAA, D. A., Ostenaa Geologic LLC, Colorado, USA, deano3geo@gmail. com; ZELLMAN, M. S., BGC Engineering Inc., Colorado, USA, mzellman@ bgcengineering.ca; SCHARER, K. M., US Geological Survey, Colorado, USA, kscharer@usgs.gov; MCPHILLIPS, D., US Geological Survey, Colorado, USA, dmcphillips@usgs.gov; CHOLEWINSKI, N., US Geological Survey, Colorado, USA, ncholewinski@usgs.gov; HETZEL, R., University of Münster, Germany, rahetzel@uni-muenster.de; HAMPEL, A., Leibniz Universität Hannover, Germany,hampel@geowi.uni-hannover.de; WITTKE, S., Wyoming Geological Survey, Wyoming, USA, seth.wittke@wyo.gov

The Teton normal fault runs along the eastern base of the prominent Teton range for $\sim 70 \mathrm{~km}$ and defines the northeastern margin of the Basin and Range extensional province (Wyoming, USA). The fault has a latest Pleistocene vertical slip rate of $\sim 1-2 \mathrm{~mm} / \mathrm{yr}$ as indicated by faulted Pinedale glacial surfaces. However, a paleoseismic record of two surface-faulting earthquakes on the fault at $\sim 8$ and $\sim 7-5 \mathrm{ka}$ (Granite Canyon site) suggests a Holocene slip rate of only $\leq 0.5 \mathrm{~mm}$ / yr. Uncertainty remains in which slip-rate values are most appropriate for hazard modeling. Additional questions stem from the fault's sparse paleoseismic data, including the completeness of the paleoseismic record and the rupture extent and recurrence of past large earthquakes. To address these questions, we excavated a trench across a $\sim 9$-m-high scarp at the Buffalo Bowl site on the southernmost third of the fault, $\sim 4 \mathrm{~km}$ southwest of Granite Canyon. The trench exposed $\sim 20^{\circ}$-east-dipping, coarse-grained alluvial-fan deposits vertically offset a total of $\sim 5 \mathrm{~m}$. The Teton fault is expressed as a $50^{\circ}-70^{\circ}$-east-dipping plane that juxtaposes weathered footwall bedrock and overlying fan gravel with scarp-derived colluvium. A 6-m-wide graben has trapped colluvial sediments near the base of the scarp. We interpret three surface-faulting earthquakes at the site using colluvial-wedge texture and fabric, cross-cutting fault relations, and evidence of weak pedogenic horizons within the wedges. Likely correlative footwall and hangingwall fan sediments are possibly latest Pleistocene to early Holocene in age and preserve displacement from a previously unrecorded Teton-fault earthquake. Pending radiocarbon ages for charcoal and luminescence ages for fine sand and silt will help resolve the timing of these earthquakes. Comparison of our paleoseismic results with the Granite Canyon record and other ongoing investigations will help resolve the fault's late Quaternary earthquake history and slip rate.

What Is the Source Fault of the 1562 Earthquake in the Dominican Republic? SCHARER, K. M., US Geological Survey, California, USA, kscharer@usgs. gov; PRENTICE, C. S., US Geological Survey, California, USA, cprentice@ usgs.gov; DELONG, S. B., US Geological Survey, California, USA, sdelong@ 
usgs.gov; GOLD, R. D., US Geological Survey, California, USA, rgold@usgs. gov; PEÑA, L., Universidad Catolica Madre y Maestra, Dominican Republic, ing.peluis@gmail.com

In northern Hispaniola, the strike-slip Septentrional Fault (SF) and the Northern Hispaniola Thrust (NHT) are both potential earthquake sources. While the NHT is known to have ruptured in 1946, and the western offshore portion of the SF is thought to have ruptured in 1842 based on damage reports, the age of the most recent earthquake (MRE) on the onshore SF is controversial (see Prentice et al., 2013). Paleoseismic investigations near the city of Santiago de los Caballeros provide important constraints. The MRE is constrained by radiocarbon dating to $1200 \mathrm{AD}$ at two sites. At a third site $20 \mathrm{~km}$ to the west, the MRE occurred between 780 and $1640 \mathrm{AD}$, consistent with the $1200 \mathrm{AD}$ age for the MRE but not definitively prehistoric. Based on four historic reports and contrary to the paleoseismic evidence, Ten Brink et al. (2011) propose that a damaging earthquake in 1562 ruptured the SF. We sought to test this idea by excavating near the third site at Santiago Viejo, the location of a Spanish church and settlement established in 1508 and destroyed by earthquake shaking in 1562 . The trenches were located within meters of the church foundation, which sits next to a subdued fault scarp that is the only geomorphic evidence of the SF in this area. We document a fault zone with fissures and faulting that produce $10-50 \mathrm{~cm}$ of vertical separation at the base of a thick organic-rich unit. The faults appear to terminate in this layer and do not offset an overlying unit that contains abundant cultural items. Unfortunately, unconformities in the section prevent application of an unequivocal radiocarbon age model to the contact above the faulting. We thus find no positive evidence for a historic event near Santiago as the cultural layer is not faulted, but formal uncertainties in the radiocarbon dates do not rule out a 1562 date. The source fault of the 1562 earthquake remains an important question, as locating it on the SF would reduce the time since the MRE by roughly half.

\section{A Paleoseismic Investigation of the Northern Teton Fault at the Steamboat Mountain Trench Site, Grand Teton National Park, Wyoming}

ZELLMAN, M. S., BGC Engineering, Inc., Colorado, USA, mzellman@ bgcengineering.com; DUROSS, C. B., US Geological Survey, Colorado, USA, cduross@usgs.gov; THACKRAY, G. D., University of Idaho, Idaho, USA, thacglen@isu.edu; BRIGGS, R. W., US Geological Survey, Colorado, USA, rbriggs@usgs.gov; CHOLEWINSKI, N., US Geological Survey, Colorado, USA, ncholewinski@usgs.gov; REYES, T., US Geological Survey, Colorado, USA, tareyes@usgs.gov; PATTON, N., University of Idaho, Idaho, USA, pattnich@isu.edu; MAHAN, S. A., US Geological Survey, Colorado, USA, smahan@usgs.gov

The Teton fault is the major range bounding normal fault along the eastern flank of the Teton Range in western Wyoming and a significant contributor to regional seismic hazard. The $\sim 70 \mathrm{~km}$-long fault has an estimated vertical slip rate of $\sim 1-2$ $\mathrm{mm} / \mathrm{yr}$; however, the history of large earthquakes on the fault remains uncertain because paleoseismic data are restricted to the central and southern parts of the fault near Leigh Lake, Granite Canyon, and Teton Village. Although the northern section has remained understudied, possible paleoliquefaction features along Jackson Lake suggest strong ground motion from earthquakes with inferred ages of $\sim 4$ and $\sim 1.6 \mathrm{ka}$. The ages differ from paleoseismic results from Granite Creek, but cannot be directly attributed to the Teton fault due to a lack of paleoseismic data for its northernmost section. To address the uncertainty in the paleoseismology of the northernmost Teton fault, we excavated two paleoseismic trenches at the Steamboat Mountain site, within $5-\mathrm{km}$ of the northern fault termination. The trenches crossed a $\sim 1-3 \mathrm{~m}$-high down-to-the-east, uphill-facing scarp that traverses a west-facing Pleistocene glacial and alluvial-fan surface. The trench exposed fine grained, well-stratified hanging wall deposits with intervals of charcoal and paleosols. These sediments interfinger with scarp-derived colluvial wedges that unconformably overlie coarse-grained, glacially derived footwall deposits. We infer two late Quaternary surface-faulting earthquakes at the site on the basis of two scarp-derived colluvial wedges exposed in each trench. Radiocarbon and luminescence samples (ages pending) will constrain the timing of earthquakes. Comparison of our results with existing and pending paleoseismic records for sites to the south and to the inferred paleoliquefaction ages will help to refine the timing and rupture length of Teton fault earthquakes.

\section{Regional Seismic Network Approaches and Stakeholder Collaborations}

Poster Session · Tuesday 15 May · Riverfront South

\section{Improvements to CISN Ground-Motion Packet Association Scheme}

HAGOS, L., California Geological Survey, California, USA, lijam.hagos@ conservation.ca.gov; HADDADI, H., California Geological Survey, California, USA, hamid.haddadi@conservation.ca.gov; BALTAY, A. S., US Geological Survey, California, USA, abaltay@usgs.gov; HELLWEG, M., UC Berkeley, California, USA, peggy@seismo.berkeley.edu; STEPHENS, C., US Geological Survey, California, USA, cdstephens@usgs.gov

Shortly after an earthquake, California Integrated Seismic Network (CISN) members exchange parametric ground-motion data from continuous real-time and triggered systems in the form of packets for use in applications such as ShakeMap. The packets contain peak ground motions and their lapse times but not phase information. When packets are exchanged without earthquake information, the network that receives the packets uses the peak ground-motion lapse times to associate them with an earthquake. Peak ground-motion parameters and their corresponding lapse times depend on several factors such as magnitude, source-site distance, regional velocity structure and site effects. We investigate the effects of these factors on the ground motion amplitudes and lapse times in order to develop a set of criteria for associating ground motion packets with an earthquake. The criteria we propose here can also be applied in the picking of amplitudes from waveforms in real time systems. By analyzing a large set of waveform and parametric data from the CISN for earthquakes of magnitude 3 and larger in California, we define a distance-dependent time window for association. Additionally, we use ground-motion prediction equations (GMPE) to define a magnitude-dependent distance, Dmax, the maximum fault distance at which the predicted peak ground acceleration fall below a threshold of $0.01 \% \mathrm{~g}$. We consider the Western United states (WUS) and the Central and Eastern US (CEUS) separately, yielding Dmax in $\mathrm{km}$ as $100^{*}(\mathrm{M}-1)$ for WUS and $500^{*}(\mathrm{M}-3)$ for CEUS. During rapid response to an earthquake when fault information is not available yet, we scale Dmax by estimates of fault-rupture lengths obtained from magnitude-length relationships to account for fault finiteness. Utilizing Dmax can filter out a significant number of very low ground motion amplitudes at greater distances that are prone to noise, and therefore improving the quality of data going into ShakeMap.

\section{Ana-Net Seismic Network: Eskisehir and Bursa, Turkey}

MUTLU, S. M., Anadolu University, Eskisehir, Turkey, sunaymutlu@anadolu. edu.tr; TÜN, M. T., Anadolu University, Eskisehir, Turkey, mtun@anadolu.edu. tr; PEKKAN, E. P., Anadolu University, Eskisehir, Turkey, epekkan@anadolu. edu.tr; GÜNEY, Y. G., Anadolu University, Eskisehir, Turkey, yucelguney@ anadolu.edu.tr

Ana-Net seismic network, located in Bursa and Eskisehir Provinces of Turkey, has an important role in determination of the focal mechanisms and the earthquake hazards of the sources of mainly North Anatolian Fault (NAF) and Eskisehir Fault Zone (EFZ). Ana-Net seismic monitoring network has strong / weak-motion stations with 26 stations, covering the provinces of Eskisehir and Bursa. It has been established between the dates 01.04.2005 and 08.02.2014. It is composed of 18 strong-motion and 8 weak motion stations. Eskisehir is situated within the second degree earthquake region on the seismic hazard zonation map of Turkey, published by the Ministry of Reconstruction and Settlement (1996). For this reason, it is generally considered that in Eskisehir there is no relevant degree of seismic hazard. However, several moderately sized historical earthquakes (between $M=5$ and $M=7$ ) have occurred in Eskisehir. At least 16 earthquakes $(M \geq 4)$ occurred on the EFZ in the 20th century and the most significant seismic event in the instrumental period was the 20.02 .1956 (M: 6.5). This network provides to be useful for research and practice in engineering and strong/ weak-motion seismology. Earthquakes were recorded by the array in the Eskisehir, Bursa and near of the region. To make accurate epicenter locations and to produce damage prediction maps after a strong earthquake in the region, We plan to establish additional stations near the Eskisehir and Bursa Basin. Ana-Net is part of the national strong/weak-motion network of the Disaster and Emergency Management Presidency-Earthquake Research Department (DEMP-ERD) -Ankara. Ultimately, in Ana-Net seismic network, the data received from the stations are automatically evaluated on-line in the Seiscomp 3 program. In addition, the seismic signals are evaluated manually and exact results are obtained.

The Jalisco Seismic Accelerometric Telemetric Network (RESAJ)

SANDOVAL, J. M., SisVOc, Universidad de Guadalajara, Jalisco, Mexico, ajuansandoval@hotmail.com; NÚÑEZ CORNÚ, F. J., SisVOc, Universidad de 
Guadalajara, Jalisco, Mexico, pacornu77@gmail.com; ALARCON, E., SisVOc, Universidad de Guadalajara, Jalisco, Mexico, edgar.alarcon.salazar@outlook. com; SUAREZ-PLASCENCIA, C., SisVOc, Universidad de Guadalajara, Jalisco, Mexico, carlos.csuarez@gamail.com; NÚÑEZ ESCRIBANO,D., SisVOc, Universidad de Guadalajara, Jalisco, Mexico, diana@sisvoc.mx; TREJOGOMEZ, E., SisVOc, Universidad de Guadalajara, Jalisco, Mexico, e291058@ gmail.com; GOMEZ, A., SisVOc, Universidad de Guadalajara, Jalisco, Mexico, a881965@yahoo.com.mx

The Jalisco region of western Mexico is the locus of interaction among the North America, Cocos and Rivera Plates, giving rise to the Jalisco Block. This region is one of the most tectonically active in Mexico, and includes the largest instrumentally recorded earthquake in Mexico in 1932, three important tsunamis in the last hundred years and two of the most active volcanoes in Mexico. Nevertheless, the first seismicity studies here, undertaken with temporary networks, did not commence until 1994. In 2008, the Government of Jalisco and the University of Guadalajara funded a research project to install a seismic network in the Jalisco Block region. The primary objective was to study the seismic hazard in the region and characterize seismic parameters to design building codes. The Red Sísmica Acelerometrica Telemetrica de Jalisco (RESAJ) began installation in 2009. Its central lab is at Centro de Sismología y Volcanología de Occidente (SisVoc), located at the Universidad de Guadalajara in Puerto Vallarta. Currently the RESAJ has 25 telemetered and two autonomous stations. The RESAJ serves as the seismological lab for the posgraduate program at SisVOc. The primary research goals of the project focus on identifying and characterize previously unknown seismogenic structures in the Jalisco region

\section{Seismometer Orientation of the Broadband Network of the Mexican Servicio Sismológico Nacional}

PÉREZ-VELÁZQUEZ, M. A., Facultad de Ingeniería, Universidad Nacional Autónoma de México, Mexico City, Mexico, mianpeve92@hotmail.com; PÉREZ-CAMPOS, X., Instituto de Geofísica, Universidad Nacional Autónoma de México, Mexico City, Mexico, xyoli@igeofisica.unam.mx; ESTRADA, J. A., Instituto de Geofísica, Universidad Nacional Autónoma de México, Mexico City, Mexico,jorgee@sismologico.unam.mx; CRUZ, J. L., Instituto de Geofísica, Universidad Nacional Autónoma de México, Mexico City, Mexico, jcruz@ sismologico.unam.mx; HURTADO, A., Instituto de Geofísica, Universidad Nacional Autónoma de México, Mexico City, Mexico, alhudi@sismologico. unam.mx; NAVARRO ESTRADA, F., Instituto de Geofísica, Universidad Nacional Autónoma de México, Mexico City, Mexico, fernando@sismologico. unam.mx; MENDOZA CARVAJAL, A. J., Instituto de Geofísica, Universidad Nacional Autónoma de México, Mexico City, Mexico, antonio@sismologico. unam.mx

The purpose of this work is to determine the quality of the information obtained from the seismological stations that constitute the Broadband Network of the Mexican Servicio Sismológico Nacional (National Seismological Service, SSN). We estimate the orientation of the seismometer installed at each site of the Broadband Network for different epochs; each epoch is defined by changes in digitizer or the seismometer. The correct orientation of the sensors is relevant to many seismological studies that involve rotation or require exact information regarding the orientation of the components. However, orienting a triaxial sensor is not an easy task, even for an experienced field engineer. Several factors can affect it during the installation of a seismometer. Between 2015 and 2017, all the seismometers were reoriented using a gyroscope, $62 \%$ of them were misoriented by more than $5^{\circ}$; however, the majority of those were less than $15^{\circ}$. This misorientation corresponds to the last instrumental epoch. To estimate the seismometer orientation during previous periods, we use two methods. The first one is based on the polarization of Rayleigh surface waves (Chael, 1997; Selby, 2001). The second uses a principal component analysis, a linear technique widely used in different branches of physics (Walck and Chael, 1991). The estimations obtained with both methods for the last epoch show high correlation with the measurements with the electronic gyroscope, validating the orientation estimation for the earlier instrumental epochs. Furthermore, we show the effect of sensor misorientation in earthquake location and estimation of receiver functions.

\section{Noise and Detection Levels of the Seismic Network of the Mexican Servicio Sismológico Nacional}

MONTOYA QUINTANAR, E., Facultad de Ingeniería, Universidad Nacional Autónoma de México, Mexico City, Mexico, montoyalifehouse@gmail.com; PÉREZ-CAMPOS, X., Instituto de Geofísica, Universidad Nacional Autónoma de México, Mexico City, Mexico, xyoli@igeofisica.unam.mx; CARDENAS MONROY, C., Instituto de Geofísica, Universidad Nacional Autónoma de México, Mexico City, Mexico, caridad@sismologico.unam.mx; ESPÍNDOLA, V. H., Instituto de Geofísica, Universidad Nacional Autónoma de México,
Mexico City, Mexico, vhespindola@sismologico.unam.mx; PÉREZ, J., Instituto de Geofísica, Universidad Nacional Autónoma de México, Mexico City, Mexico, jesus@sismologico.unam.mx; ESTRADA, J. A., Estrada, Mexico City, Mexico, jorgee@sismologico.unam.mx; BELLO, D. I., Instituto de Geofísica, Universidad Nacional Autónoma de México, Mexico City, Mexico, delia@sismologico.unam. mx; CÁRDENAS, A., Instituto de Geofísica, Universidad Nacional Autónoma de México, Mexico City, Mexico, arturo@sismologico.unam.mx; CONTRERAS RUIZ ESPARZA, M. G., Instituto de Geofísica, Universidad Nacional Autónoma de México, Mexico Mexico City, Mexico, moises@sismologico. unam.mx; CRUZ, J. L., Instituto de Geofísica, Universidad Nacional Autónoma de México, Mexico City, Mexico, jcruz@sismologico.unam.mx; GONZÁLEZ ÁVILA, D., Instituto de Geofísica, Universidad Nacional Autónoma de México, Mexico City, Mexico, danielg@sismologico.unam.mx; GONZÁLEZ-LÓPEZ, A., Instituto de Geofísica, Universidad Nacional Autónoma de México, Mexico City, Mexico, adrianag@sismologico.unam.mx; HURTADO, A., Instituto de Geofísica, Universidad Nacional Autónoma de México, Mexico City, Mexico, alhudi@sismologico.unam.mx; MENDOZA CARVAJAL, A. J., Instituto de Geofísica, Universidad Nacional Autónoma de México, Mexico City, Mexico, antonio@sismologico.unam.mx; NAVARRO ESTRADA, F., Instituto de Geofísica, Universidad Nacional Autónoma de México, Mexico City, Mexico, fernando@sismologico.unam.mx; RODRÍGUEZ RASILLA, I., Instituto de Geofísica, Universidad Nacional Autónoma de México, Mexico City, Mexico, ivan@sismologico.unam.mx; TAN, Y., Instituto de Geofísica, Universidad Nacional Autónoma de México, Mexico City, Mexico,yi@sismologico.unam. mx; VELA ROSAS, M. A., Instituto de Geofísica, Universidad Nacional Autónoma de México, Mexico City, Mexico, miguel@sismologico.unam.mx; MALDONADO, R., Instituto de Geofísica, Universidad Nacional Autónoma de México, Mexico City, Mexico, rafael@sismologico.unam.mx

We estimate the noise levels for sixty-three seismic stations that constitute the Broadband Network of the Mexican Servicio Sismológico Nacional (National Seismological Service, SSN). We analyze the noise median for each month the station has been in operation. In general, the noise level of the broadband network stations is within the noise model by Peterson (1993). However, there are few stations with a cultural noise contribution, reflected in high noise levels at high frequencies. Also, environmental variations at some stations, e.g., strong winds and storms affect the noise levels, mainly at low frequencies. In some sites, construction of new infrastructure (e.g., nearby buildings or highways), have permanently altered the noise levels. Stations closer to the coast exhibit a stronger contribution of microseisms, which manifest time variations related to meteorological phenomena. A historical examination helps us to establish the base noise level of each station, evaluate changes that could occur in the future and quantify data quality. Furthermore, based on the median noise level we evaluate the current detection level of the national network, which includes the Broadband Network and another 100 seismic stations from other regional and local networks, that send their data to the SSN for earthquake location. For this, we use the median noise level for each SSN station and an average noise level for the others. Given the current level in the country, we propose the installation of 52 new seismic stations to achieve homogeneous level detection in the whole nation.

\section{Seismicity in Pennsylvania and the Pennsylvania State Seismic Network} HOMMAN, K. A, Penn State, Pennsylvania, USA, kah5265@psu.edu; NYBLADE, A. A, Penn State, Pennsylvania, USA, aan2@psu.edu

Seismicity in Pennsylvania results from natural earthquakes, mining blasts, and other induced events. Earthquakes occur primarily in the northwestern and southeastern portions of the state. Seismic events caused by mine and quarry blasts occur throughout the state, mainly in the coal mining regions, and although rare, there have been seismic events associated with hydraulic fracturing. However, to date there are no known seismic events linked to wastewater injection. In 2006, The Pennsylvania State University, in collaboration with the Bureau of Topographic and Geologic Survey within the Pennsylvania Department of Conservation and Natural Resources (DCNR), began constructing a network of seismic stations to detect and locate seismicity in the state. Between 2006 and 2013, the network grew to a total of 10 seismic stations providing near real time, open access seismic data. In late 2015, an expansion of the network to 30 broadband seismic stations began with funding from the DCNR and the Pennsylvania Department of Environmental Protection (DEP). Construction of the 30-station network was completed in August 2016. The 30 stations in the network plus another 13 broadband stations operated by other organizations provide fairly even data coverage across the Commonwealth. Data from these stations, in addition to data from 28 stations in neighboring states, are used to monitor seismicity within Pennsylvania. In addition to the broadband seismic stations, in 20177 short-period stations were installed at two wastewater injection sites and have been included in the current PASEISnetwork. Data from 
the 71 broadband and 7 short-period stations are fed into anEarthWormsystem at Penn State for automatic event detection and location. To improve the automatic locations, the arrival times of $\mathrm{P}$ and $\mathrm{S}$ waves are repicked by hand and then used with the HYPOINVERSE code to obtain a refined location.

\section{xQuake: Re-Imagining Regional Network Operations}

LOHNSON, C. E., Introspective Systems LLC, Maine, USA, caryl.johnson@ introspectivesystems.com

$\mathrm{xQuake}$ provides a holistic approach to the integration of a regional seismic network's operations from analytics through scientific and social applications. Developed by the originator of the Earthworm architecture, $x Q u a k e$ leverages emerging technologies in the fields of streaming microservices, AI based adaptive analytics, cloud/local fusion, graph structured archival storage, and WebGL enabled visualization. While in some respects $x Q$ uake is reminiscent of the Earthworm architecture (aka Rings and Things), $\mathrm{xQuake's} \mathrm{foundation} \mathrm{is} \mathrm{the} \mathrm{open}$ source $\mathrm{xGraph}^{\mathrm{Tm}}$ framework which more closely resembles a self-organizing graph database with embedded analytics. The analytical framework in xQuake includes the simulated annealing and evolutionary programming algorithms from the GLASS 3.0 global associator developed under contract to the US Geological Survey (NEIC). $\mathrm{xQ}$ uake is a real-time system providing a stream of improving hypocenters as data is being integrated into the system. Two aspects of $x Q u a k e$ that directly address critical needs of regional networks are 1) that it does not require the use of expensive and proprietary DBMS systems, and 2) it provides a seamless fusion from global to extremely local operation to address the problem of false triggers from teleseismic events. WebGL based visualization components provide a $3 \mathrm{D}$ visualization engine spanning network configuration, operations, waveform analytics, and scientific inquiry. The $\mathrm{xQuake} \mathrm{system} \mathrm{is} \mathrm{being} \mathrm{released}$ under an open source license for non-commercial use to encourage and enable the seismological community to share and further develop xQuake's capabilities.

\section{Development of the Red Sísmica Canaria (C7)}

BARRANCOS, J., Instituto Volcanológico de Canarias, S/C de Tenerife, Spain, jbarrancos@iter.es; PADILLA, G. D., Instituto Volcanológico de Canarias, S/C de Tenerife, Spain, german@iter.es; D’AURIA, L., Instituto Volcanológico de Canarias, S/C de Tenerife, Spain, Idauria@iter.es; GARCÍA-HERNÁNDEZ, R., Instituto Volcanológico de Canarias, S/C de Tenerife, Spain, ruben.garcia. beca@iter.es; CABRERA PERÉZ, I., Instituto Volcanológico de Canarias, S/C de Tenerife, Spain, ivancbrprz@hotmail.com; SOUBESTRE, J., Instituto Volcanológico de Canarias, S/C de Tenerife, Spain, jsoubestre@iter.es; HERNÁNDEZ, P. A., Instituto Volcanológico de Canarias, S/C de Tenerife, Spain, phdez@iter.es; MELIAN, G., Instituto Volcanológico de Canarias, S/C de Tenerife, Spain, gladys@iter.es; PADRÓN, E., Instituto Volcanológico de Canarias, S/C de Tenerife, Spain, eleazar@iter.es; PERÉZ, N., Instituto Volcanológico de Canarias, S/C de Tenerife, Spain,nperez@iter.es

Since November 2016, Instituto Volcanológico de Canarias (INVOLCAN) started the deployment of a broadband seismic network on Canary Islands: Red Sísmica Canaria (RSC) (FDSN code C7; http://doi.org/doi:10.7914/sn/ c7) with both scientific research and volcano monitoring purposes. The network started with the installation of 15 broadband stations adquired throught the MAKAVOL project (MAC/3/C161) in Tenerife and Gran Canaria islands. All the stations consist in Nanometric Trillium Compact sensors equipped with a Centaur datalogger. This first nucleus of the network was devoted to the monitoring of volcanic seismicity of Tenerife Island. It was able to record the increase of the seismicity in 2017, because of a pressurization fo the hydrothermal system of the island, testified by the 5-fold increase in the diffuse $\mathrm{CO} 2$ emission from the crater of Mt. Teide volcano (Tenerife). Another improvement of the network was the acquisition of 15 more broadband stations in the framework of the VOLRISKMAC project (MAC3.5b/124; http://volriskmac.com). These new stations were deployed on Tenerife and La Palma islands and will be deployed on Gran Canaria and La Gomera islands as well. The first 5 stations on La Palma were deployed during the Octuber 2017 seismic crisis, related to a sub-crustal magmatic intrusion beneath the magmatic system of Cumbre Vieja volcano. We show the improvement of the detection capability and of the network performances during the network development as well as some relevant results of this first 18 months of network operativity.

\section{Preserving Seismic Data at the University of Utah Seismograph Stations}

RUSHO, J. A., University of Utah, Utah, USA, jon@seis.utah.edu; BURLACU, R., University of Utah, Utah, USA, burlacu@seis.utah.edu; BLYCKER, W. L., University of Utah, Utah, USA, blycker@seis.utah.edu; DROBECK, D. L., University of Utah, Utah, USA, drobeck@seis.utah.edu; HATCH, C. S., University of Utah, Utah, USA, hatch@seis.utah.edu; PANKOW, K.
L., University of Utah, Utah, USA, pankow@seis.utah.edu; KOPER, K. D., University of Utah, Utah, USA, koper@seis.utah.edu

The primary operational goal of the University of Utah Seismograph Stations (UUSS) is the collection and preservation of ground motion data. In 2007 the State of Utah provided funding for UUSS to design and build out a hardened seismic network. Initially, we took four steps toward realizing this goal: (1) a data center hot site was developed at the State of Utah backup facilities in Richfield, Utah, (2) data collection nodes were distributed across the State, (3) additional data nodes were built at radio relays on mountain tops, and (4) data feeds were established to the U. S. Geological Survey. This initial phase was targeted at removing the University of Utah as a single point of failure and providing multiple copies of seismic data for redundancy. Subsequently, data storage and computer redundancy have been increased at the mountain top relay sites and Raspberry Pi's have been added to stations without adequate storage to prevent data loss in the case of telemetry failures. To make this system work, the SEEDlink protocol is used to backfill data, and a local Common Wave Buffer (CWB) and the IRIS DMC are populated with continuous data. The next phase of preserving data involves keeping up with the ever changing technological and security advances. Current work involves migrating all aspects of the UUSS network to IPv6 (the next generation of the Internet Protocol) due to the limitation on static IP numbers, and upgrading cell modems to support $4 \mathrm{G}$ and IPv6 to handle upgrades from our Internet Service Providers.

The Northern California Seismic System: History, Operations, and Upgrades to Seismic Monitoring for Earthquake Early Warning

TERRA, F., UC Berkeley Seismology Lab, California, USA, terra@seismo. berkeley.edu; HELLWEG, M., UC Berkeley Seismology Lab, California, USA, peggy@seismo.berkeley.edu; CROKER, D., US Geological Survey, Menlo Park, California, USA, croker@usgs.gov; GEE, L., US Geological Survey Menlo Park, California, USA, lgee@usgs.gov

We describe the ongoing efforts of the Northern California Seismic System (NCSS) in upgrading and densifying the northern California regional seismic networks for Earthquake Early Warning (EEW) use. The NCSS was born in the late 1990s from the integration of UC Berkeley's Berkeley Digital Seismic Network (BDSN) and the USGS's Northern California Seismic Network (NCSN), previously two separate earthquake monitoring networks both in place since the mid-1960s to monitor Northern California earthquakes. The construction, implementation and operation of West Coast ShakeAlert, an earthquake early warning (EEW) system for the US West Coast is both an opportunity and a challenge for the NCSS. Upgrades and additions to network infrastructure of the NCSN and BDSN during the early 2000s mean that the seismic network in the San Francisco Bay Area is almost ready for EEW but gaps remained in other parts of Nor Cal. With funding from the state and federal governments, the NCSS, with collaborators at the California Geological Survey and other regional operators of seismic stations, is embarking on extensive upgrades to both the seismic networks and data telemetry systems. Our target is to have station spacing of $10 \mathrm{~km}$ or less in population centers and regions with high earthquake hazard, to achieve rapid detection and reporting. In less populated and lower hazard areas, station spacing will be $\sim 20 \mathrm{~km}$. For Northern California, about 100 new and upgraded stations are targeted to be deployed over the next 2 years. The goal is to reach as many as 400 stations with available future funding. When those deployments are complete, alert times will be reduced in all areas of the state. The initial station installation effort at the Berkeley Seismology Labencompasses the adoption of former EarthScope Transportable Array stations, and is currently underway. Station upgrades and new installations over the previous two years already improved the system. For example, station spacing for the San Francisco Bay Area is now less than $10 \mathrm{~km}$ and is expected to be closer to $5 \mathrm{~km}$ by the end of the current project improvements.

\section{Monitoring and Early Warning Center for Earthquakes and Tsunamis at INETER, Nicaragua - 2018}

TENORIO, V., INETER, Managua, Nicaragua, virginia.tenorio@gf.ineter. gob.ni; STRAUCH, W., INETER, Managua, Nicaragua, wilfried.strauch@ yahoo.com; TALAVERA, E., INETER, Managua, Nicaragua, emilio.talavera@ gf.ineter.gob.ni; ARGUELLO-MIRANDA, G., INETER, Managua, Nicaragua, greyving.arguello@gf.ineter.gob.ni; RAMIREZ, J., INETER, Managua, Nicaragua,javier.ramirez@sb.ineter.gob.ni; SANCHEZ,J., INETER, Managua, Nicaragua, jaqueline.sanchez@gf.ineter.gob.ni; HERRERA, M., INETER, Managua, Nicaragua, marthja.herrera@gf.ineter.gob.ni; ACOSTA, A., INETER, Managua, Nicaragua, jose.acosta@gf.ineter.gob.ni; MORALES, A., INETER, Managua, Nicaragua, allan.morales@gf.ineter.gob.ni; FLORES, P., INETER, Managua, Nicaragua, petronila.flores@gf.ineter.gob.ni; GUZMAN, C., INETER, Managua, Nicaragua, carlos.guzman@gf.ineter.gob. 
ni; GARCIA, F., INETER, Managua, Nicaragua, fernando.garcia@gf.ineter. gob.ni; NAMENDI, D., INETER, Managua, Nicaragua, domingonamendi@ gmail.com; GUZMAN, J. C., INETER, Managua, Nicaragua, juan.guzman@ gf.ineter.gob.ni

In the last years, the Monitoring and Early Warning Center for Earthquakes and Tsunamis at INETER, Nicaragua, has developed rapidly due to new responsibilities INETER acquired at national and international level. In 2015, it became home of the Central American Tsunami Advisory Center CATAC). In 2016, INETER started a cooperation with the Swiss Seismological Service on Earthquake Early Warning (EEW). To permit tsunami services and EEW for Nicaragua and Central America we extended our seismic network and intensified data exchange with the networks in the region. Computing hardware was greatly enhanced. We abandoned SEISAN (in place since 1991) for routine processing and rely now completely on the SeisComP3 package. In 2016, we started to use experimentally the EEW modules included in SeisComP3. In January of 2018, we installed the tsunami modules of the package. Seismic and tsunami processing is first done automatically but after a few minutes the seismologist on duty revise the results. We receive and process real time data from about 90 stations in Nicaragua, and around 250 stations from the other Central America countries, Guatemala, El Salvador, Honduras, Costa Rica and Panama. Additionally, we process around 200 global seismic station for our global locator. The monthly number of processed seismic events increased from around 120 to around 1000. The personnel working $24 \times 7$ was capacitated in the use of the software and the scientific exploitation of the data. The earthquake detection and location quality increased drastically for the events below the Pacific Ocean of Nicaragua, in the border regions to the neighboring countries and in the Caribbean Sea. Information and alarm messages are sent out automatically and manually to seismological and civil protection agencies in Central America. We thank JICA-Nicaragua, JMA/Tokio and University of Hokkaido for cooperation on CATAC, and of Swiss Technical Cooperation DEZA and SED/ETHZ on the development of EEW.

\section{Station and Telemetry Impact Metrics for Earthquake Early Warning Seismic Network Performance Evaluation}

BIASI, G. P., US Geological Survey, California, USA, gbiasi@usgs.gov; ALVAREZ, M. G., US Geological Survey, California, USA, malvarez@usgs.gov

Funding agencies and network operators share an interest in understanding the performance benefits from investments in seismic stations and telemetry. The earthquake early warning (EEW) mission comes with additional requirements for coverage and resilience compared to conventional regional seismic monitoring. EEW alerts require greater spatial coverage, and network communications have to maintain that coverage after a damaging earthquake in order to alert on large aftershocks. Network reliability under these circumstances requires independent telemetry modes and spatial interleaving to reduce exposure singlepoint-of-failure vulnerabilities. To measure the contributions of individual stations and telemetry investments in the context of the EEW mission, we adapt the alert time calculator from Hotovec-Ellis et al. (SRL, 2017). EEW alert times to some central point are calculated using the current network assuming sources on a grid covering the network region. A candidate new station is then added and the calculation is repeated. The new station decreases time to alert in some area around it. We summarize its effect in a new metric with units of $\mathrm{km}^{\wedge} 2$-seconds, for the total area improved times the alert time improvement. The impact of station removal is computed the same way except that alerts are delayed. We can compute telemetry system impact metrics by removing or adding related stations as a group. The impact score can be modified by a proxy probability of earthquake occurrence in the affected area. We use these approaches to evaluate station and backhaul telemetry plans for the West Coast ShakeAlert EEW system. This analysis identified opportunities to improve the SCSN network cell service or internet dependence is significant. Station and hub improvements are being implemented. We have also used these results to draft new plans for West Coast network telemetry coverage.

\section{Reclamation Dam Safety Office - Strong Motion Monitoring Program}

MEREMONTE, M., Bureau of Reclamation, Colorado, USA, mmeremonte@ usbr.gov; BESANA-OSTMAN, G., Bureau of Reclamation, Colorado, USA, gbesanaostman@usbr.gov; SCHWARZER, J., Bureau of Reclamation, Colorado, USA, jschwarzer@usbr.gov; SNOVER, D., Bureau of Reclamation, Colorado, USA, dsnover@usbr.gov; MAYBIN, N., Bureau of Reclamation, Colorado, USA, nmaybin@usbr.gov; NAKAMURA, S., Contractor to Bureau of Reclamation, Colorado, USA, snakamura@usbr.gov

The Bureau of Reclamation's Dam Safety Office ensures dams do not present unreasonable risk to people, property, and the environment. A component of dam safety is strong motion instrumentation of selected facilities and estimation of PGA's at non-instrumented facilities. The Strong Motion Monitoring Program (SMMP) providesearthquake notification, analysis, and related informationto dam safety personnel, facility managers, dam engineers, and cooperators to make informed decisions on implementation of Emergency Action Plans for facilities that may have been affected by strong ground shaking. The SMMP has been in operation since the early 1970s beginning with autonomous triggered accelerometers, converted to Plain Old Telephone Service in mid-1990s with triggered accelerometers, and, now, is in the process of converting to real-time continuous Ethernet. In conjunction with communication upgrades, strong motion instrumentation and infrastructure are being modernized along with supplementary data provided by a virtual array of nearby non-BOR seismic stations (ANSS, SCSN, NCSN, PNSN). These upgrades are occurring in parallel to implementation of Earthworm as the SMMP's production data acquisition, processing, and analysis system. Together the SMMP production system will provide high quality real-time continuous data to evaluate PGAs and RSAs for earthquakes at dams with instrumentation and estimated PGAs for others. With realtime continuous data (archival IRIS-DMC) we have opportunity to perform additional analyses to better analyze site response characteristics, evaluate structural responses from both natural and non-natural sources, verify numerical models, and correlate realtime data with GPS static monitoring and InSAR analysis. Acquiring realtime data reduces dependence on successful recording and timely transmittal of onsite triggered data ensuring waveforms are always available. Triggering will still be enabled for temporary onsite storage and later retrieval if required. The advantage of 24/7 communication is up-to-date state-of-health monitoring of instrumentation with timely reporting and analysis.

\section{Science Gateways and Computational Tools for Improving Earthquake Research}

Poster Session · Tuesday 15 May · Riverfront South

\section{Sensor Suite: The Albuquerque Seismological Laboratory Instrumentation} Testing Suite

HOLLAND, A. A., US Geological Survey, New Mexico, USA, aaholland@ usgs.gov; KEARNS, A., KBRwyle Albuquerque Seismological Laboratory, New Mexico, USA, akearns@usgs.gov; RINGLER, A. T., US Geological Survey, New Mexico, USA, aringler@usgs.gov; HOLLAND, J., US Geological Survey, New Mexico, USA, jholland@usgs.gov; STORM, T., US Geological Survey, New Mexico, USA, tstorm@usgs.gov; WILSON, D. C., US Geological Survey, New Mexico, USA, dwilson@usgs.gov

In order to make various algorithms for seismometer testing more accessible as well as use common testing parameters we have developed a new seismometer testing software package called: Albuquerque Seismological Laboratory (ASL) Sensor Test Suite. This software is written in Java and makes use of Seismological Exchange for Earthquake Data (SEED) format. The goal of this software is to provide a common collection of seismometer performance testing algorithms and to make some of the methods more standardized. Our goal is not to be all-inclusive, but instead focus on a few of the instrumentation tests we view as the most important when verifying a sensor's performance. The tests include self-noise, relative azimuth, relative gain, and estimation of the poles and zeros. For the selfnoise and the relative azimuth we also include three-component versions of these tests to allow for the case of sensors with different orientations (e.g. boreholes). We show applications of this software to various test data sets recorded at the ASL as well as data from the Global Seismographic Network (GSN). Use of this software, along with new absolute calibration techniques have led to more accurate metadata for the GSN and more precise test results for instruments tested at the ASL. The software has been made available on GitHub (https://github. com/amkearns- usgs/asl_sensor_suite.git) with the hope that it will be useful for other seismologists who need to quickly verify various sensor parameters without having to write their own versions of the algorithms.

\section{Design and Status of a Next Generation Miniseed Format}

CLINTON, J. F., ETH Zurich, ZH, Switzerland, jclinton@sed.ethz. ch; TRABANT, C., IRIS, Washington, USA, chad@iris.washington.edu; KRISCHER, L., ETH Zurich, ZH, Switzerland, lion.krischer@erdw.ethz.ch; FDSN WGII, A., FDSN, ZH, Switzerland, jclinton@sed.ethz.ch

Since its adoption by the International Federation of Digital Seismograph Networks (FDSN) in 1987, the SEED (Standard for the Exchange of Earthquake Data) format has become and still serves as the canonical format for passive source seismological data, and increasingly also for other datasets. In operational environments, for both data archival and exchange, it is common to handle the time 
series and related metadata components of this format separately, known respectively as miniSEED and dataless SEED. In 2013 the FDSN adopted a new, XMLbased standard known as StationXML to replace and extend dataless SEED. This new metadata standard provides much greater flexibility and was an important step in allowing future modifications to aspects such as the identifiers used to match time series data and metadata. In 2016, through Working Group II of the FDSN, work began to define the next generation of miniSEED, the time series component of the standard. While the current version of miniSEED has served the community very well for nearly three decades, the crucial issue motivating a change are limitations with the key identifiers. Specifically, identifiers capable of representing deployments with a very large number of nodes in addition to more instrument types are currently missing. Addressing these issues requires changes to key fields in miniSEED that render it incompatible with the current release. Such a small, but disruptive change affords the opportunity to address a number of historical issues and create new capability to address future needs. We aim to define a next generation format that fulfills the the primary use case of permanent archival, exchange and subsetting/selection of data supported by current miniSEED. This poster will report on the planning, design and current status of this next generation format.

\section{Using GeoGateway to Reveal Fracture-Advancing Step Tectonics following the $\mathbf{2 0 1 0}$ Mw 7.2 El Mayor-Cucapah Earthquake}

DONNELLAN, A., NASA Jet Propulsion Laboratory, Caltech, California, USA, andrea.donnellan@jpl.nasa.gov; PARKER, J. W., Jet Propulsion Laboratory, Caltech, California, USA, jay.w.parker@jpl.nasa.gov; HEFLIN, M., Jet Propulsion Laboratory, Caltech, California, USA, michael.heflin@jpl.nasa. gov; LYZENGA, G. A., Jet Propulsion Laboratory, Caltech, California, USA, lyzenga@g.hmc.edu; GRANT LUDWIG, L., UC Irvine, California, USA, Igrant@uci.edu; RUNDLE, J. B., UC Davis, California, USA, john.b.rundle@ gmail.com; WANG, J., Indiana University, Indiana, USA, wang208@iu.edu; PIERCE, M. E., Indiana University, Indiana, USA, marpierc@iu.edu

GeoGateway is a web-based science gateway that allows UAVSAR interferometric synthetic aperture radar data to be analyzed in the context of other geophysical, geologic, and geodetic data sources. We applied GeoGateway tools to measure crustal deformation surrounding the Yuha desert to characterize fault slip and broader deformation following the 4 April 2010 Mw7.2 El Mayor-Cucapah (EMC) earthquake. UAVSAR observations from October of 2009 to April 2017 of the Yuha desert and Ocotillo, CA, and GPS time series surrounding the region reveal a northward migrating pattern of deformation. The north end of the EMC rupture exhibits an asymmetric pattern of deformation with substantial and smooth deformation occurring northeast of the rupture and limited, but surface fracturing slip, to the northwest. The earthquake triggered about 1 $\mathrm{cm}$ of coseismic slip on the Yuha fault, which continued to slip postseismically. Following a logarithmic afterslip decay with a short timescale of 16 days, $2.5 \mathrm{~cm}$ of Yuha fault slip occurred by the 15 June 2010 Mw5.7 Ocotillo aftershock and 5 $\mathrm{cm}$ of slip occurred by 2017. The Ocotillo aftershock triggered $1.4 \mathrm{~cm}$ of slip on a northwest trend that extends to the Elsinore fault. By 7 years after the El MayorCucapah earthquake, $2.4 \mathrm{~cm}$ of slip had occurred with a distribution that follows an afterslip logarithmic decay consistent with a 16 day timescale. GPS data show broad coseismic uplift of the Salton Trough and subsidence west of the rupture extension, which continues following the earthquake. The data indicate that the Elsinore, Laguna Salada, and El Mayor-Cucapah ruptures are part of the same fault zone. The results also suggest that north-south shortening and east-west extension across the region drove fracture advancing step tectonics north of the El Mayor-Cucapah earthquake rupture.

\section{MSNoise-Not Only dv/v! (and ObsPy)}

LECOCQ, T., Royal Observatory of Belgium, Belgium, thomas.lecocq@ seismology.be; MORDRET, A., Massachusetts Institute of Technology, Massachusetts, USA, mordret@mit.edu; KRISCHER, L., ETH Zurich, Switzerland, lion.krischer@erdw.ethz.ch

MSNoise is an Open and Free Python package known to be the only complete integrated workflow designed to analyse ambient seismic noise and study relative velocity changes $(\mathrm{dv} / \mathrm{v})$ in the crust. It is based on state of the art and well maintained Python modules, among which ObsPy plays an important role. To our knowledge, it is officially used for continuous monitoring at least in three notable places: the Observatory of the Piton de la Fournaise volcano (OVPF, France), the Auckland Volcanic Field (New Zealand) and on the South Napa earthquake (Berkeley, USA). It is also used by many researchers to process archive data, e.g. focussing on fault zones, intraplate Europe, geothermal exploitations or Antarctica. We first present the general working of MSNoise, originally written in 2010 to automatically scan data archives and process seismic data in order to produce $\mathrm{dv} / \mathrm{v}$ time series. We demonstrate that its modularity provides a new potential to easily test new algorithms for each processing step. For example, to experiment new methods of cross-correlation (done by default in the frequency domain), stacking (default is linear stacking, averaging), or $\mathrm{dt} / \mathrm{t}$ or $\mathrm{dv} / \mathrm{v}$ estimation (default is moving window cross-spectrum "MWCS", so-called "doublet"), etc. Finally, we present the last major evolution of MSNoise, from a "single workflow: data archive to $\mathrm{dv} / \mathrm{v}$ " to a framework system that allows plugins and modules to be developed and integrated into the MSNoise ecosystem. Examples of plugins in development such as continuous PPSD (à la McNamarra \& Buland) or ambient noise tomography (ASNWT) will be presented. This poster will also present the latest developments of ObsPy and applications using it.

\section{Parsing and Transforming Textual Seismic Data Using Parser Generators} MACCARTHY, J. K., Los Alamos National Laboratory, New Mexico, USA, jkmacc@lanl.gov

One of the most common tasks in seismology is preparing data for analysis, which commonly involves parsing, transforming, and cleaning text data. When data are in tidy formats, like tabular files (e.g. CSV) or other structured files (e.g. JSON or $\mathrm{XML}$ ), parsing and transforming data can leverage existing tools. When data are semistructured or otherwise ad hoc, such as legacy "in-house" formats or data collected directly from instruments, existing tools for reading and parsing data may not exist. Writing ad hoc parsing scripts is a common solution, but these are generally fragile, inflexible, and require re-writing for each new format. Parser generators, originally developed in the fields of linguistics and computers science, were developed to solve these problems. Here, we present the application of parser generators towards the parsing and transforming of two non-standard seismic bulletin formats. Parsing is done by declaring a "grammar", or syntax, for the format, and then an existing parser generator tool is used to parse and optionally transform the data. A command-line utility written in Python, called Bulletproof, further facilitates parsing and conversion of new textual seismic data through a plugin infrastructure.

Tsunami Modeling and Hazard Assessment

Poster Session · Tuesday 15 May · Riverfront South

\section{Run-Up Estimation Using Non-Uniform Stochastic Sources: The South American Subduction Zone}

MEDINA, M., Seismic Risk Program, University of Chile, Santiago, Chile, miguel.medina@dgf.uchile.cl; RIQUELME, S., National Seismological Center, University of Chile, Santiago, Chile, sebastian@dgf.uchile.cl; FUENTES, M. A., Seismic Risk Program, University of Chile, Santiago, Chile, mauricio@ dgf.uchile.cl; HAYES, G. P., US Geological Survey, Colorado, USA, ghayes@ usgs.gov; MOORE, G., University of Washington, Washington, USA, ginevramoore@usgs.gov

Throughout history, megathrust earthquakes have produced large tsunamis that have devastated coastal cities in the near and far field. South America hosts one of the largest subduction zones in the world and it is important to study tsunamigenic earthquakes here to forecast and mitigate future catastrophes. We estimate the maximum magnitude of possible earthquakes along the South American subduction interface using scaling laws, subducting seafloor features, seismic-geodetic coupling and seismic history. We use the Slab2 subduction zone geometry model from the United States Geological Survey (USGS) to constrain the geometry of the interface. Then, we estimate tsunami run-up using numerical modeling for 100 non-uniform stochastic $\mathrm{k}^{2}$ sources in each targeted area. Our results show great variability in run-up distribution along the Nazca-South America subduction zone. The most vulnerable areas are: Valparaíso in Chile, with a most likely scenario of $20 \mathrm{~m}$ run-up and a maximum of $33 \mathrm{~m}$, and Lima in Perú, with a most likely scenario exceeding 25 meters of run-up and a maximum of 40 meters. Similar results are obtained in Huasco, Chile, and Iquique, Chile, and other areas along the Pacific Coast of South America. We conclude that tsunami hazard remains high along South America, even in areas where megathrust earthquakes have recently occurred.

Modeling the Tsunami Potential along the Pacific Coast of Central America CHACON-BARRANTES, S. E., Universidad Nacional de Costa Rica, Heredia, Costa Rica, silviachaconb@gmail.com; ZAMORA-SAUMA, N., CIGIDEN, Valparaíso, Chile, nzsauma@gmail.com; MENDOZA-GARCIA, D. P., Corporacion OSSO, Cali, Colombia, diana.mendoza@osso.org.co

At least 40 tsunamis have been generated along the Middle America Trench, according with tsunami catalogs. There are no records of mega earthquakes originated there; probably associated to the low coupling in some sections and the 
presence of seismic barriers. However, moderate ruptures have caused important tsunami runups in the region. The 1992 Nicaragua Mw 7.7 generated a tsunami with a maximum runup of $9.5 \mathrm{~m}$, the largest recorded in Central America, leaving over 300 deaths and considerable damages. The 2012 El Salvador Mw 7.3 tsunami had a maximum $6 \mathrm{~m}$ runup fortunately over a sparsely populated region. Both events were categorized as "tsunami-earthquakes", suggesting that this margin is prone to earthquakes rupturing along the shallow parts of the interplate seismogenic zone. In 2016 a group of experts met under the coordination of IOC/ UNESCO to discuss the tsunami potential along the Pacific Coast of Central America and the north of South America, by integrating several geophysical and geological criteria. Here we model the tsunami scenarios proposed at that meeting to contribute in assessing the tsunami threat for the region. Four scenarios were considered between Guatemala and Panamá and one offshore Colombia and Ecuador using NEOWAVE numerical model. The results show that the largest tsunamis could be originated along the segments between Guatemala and El Salvador, in Central America and along the Colombia-Ecuador tectonic margins. The latter would be the only one affecting the complete Central American Pacific Coast. These results are a contribution for the disaster management offices of the Central American countries to increase the tsunami preparedness within the region.

\section{A Working Group on Tsunami Source Synthesis for Hazards Mitigation in the United States}

ROSS, S. L., US Geological Survey, California, USA, sross@usgs.gov; EBLE, M. C., NOAA, Washington, USA, marie.c.eble@noaa.gov; NICOLSKY, D. J., University of Alaska Fairbanks, Alaska, USA, djnicolsky@alaska.edu; WILSON, R. I., California Geological Survey, California, USA, rick.wilson@conservation. ca.gov; RYAN, K. J., US Geological Survey, California, USA, kryan@usgs.gov

The need for a set of realistic and consistent tsunami source models was identified as a high priority for tsunami hazard mitigation at a 2016 workshop between US Geological Survey (USGS) scientists and the National Tsunami Hazards Mitigation Program (NTHMP). The NTHMP, a federal/state partnership group funded by the National Oceanic and Atmospheric Administration (NOAA), is composed of representatives (emergency managers and scientists) from the tsunami-vulnerable U.S. states and territories, plus representatives from NOAA, the USGS, and the Federal Emergency Management Agency (FEMA). Members of the NTHMP's Mapping and Modeling Subcommittee have formed a working group, supported by the USGS Powell Center, to produce a collection of vetted earthquake and landslide tsunami sources. The work of this group will transfer decades of research on subduction zone earthquakes and coastal landslides, along with expertise on tsunami modeling, to the mitigation community. The working group will start by addressing the scientific question of how increasing sophistication in tsunami source models impacts products such as evacuation plans, mitigation of damage, and land-use planning. It will then synthesize existing geological and geophysical knowledge of submarine earthquake faults and coastal landslide sources to produce a database of source models for use in creating hazards assessments for risk reduction. Here we report on the first Powell Center-supported workshop on tsunami source synthesis, held April 9-13, 2018. We will also seek community input on the types of models required to define an earthquake or landslide tsunami source in order to provide sufficient accuracy for mitigation products, while also considering the impact of additional computational expense on the number of sources and models to be created.

Operational Significance of the Quality of the Earthquake Source Parameters Listed in the Pacific Tsunami Warning Center's Observatory Messages versus the Tsunami Bulletins That Followed

SARDIÑA, V. H. R., Pacific Tsunami Warning Center, Hawaii, USA, victor. sardina@noaa.gov; WEINSTEIN, S. A., Pacific Tsunami Warning Center, NOAA, NWS, Hawaii, USA, stuart.weinstein@noaa.gov

The Pacific Tsunami Warning Center (PTWC) in Honolulu, Hawaii, routinely analyses most earthquakes with a 5.5 or larger magnitude occurring around the world. The PTWC first issues an unofficial observatory message (OM) containing a set of preliminary parameters for these events. When the estimated magnitude crosses the 6.5 magnitude threshold, however, the protocol calls for the issuance of at least a tsunami information bulletin. For years, PTWC geoscientists assumed that the inclusion of more stations in the initial analysis automatically improved the quality of the preliminary source parameters. We assessed the validity of these assumptions by matching 627 observatory messages issued by the PTWC between 2003 and 2017 with the official tsunami messages that followed. We then computed the epicentral offsets, magnitude residuals, and response times against the source parameters listed in later, more authoritative earthquake catalogs. These statistics reveal that for $54 \%$ of the earthquakes both the OMs and the official tsunami messages reported the same magnitude despite up to 20 additional minutes of processing time. Paradoxically, in another $17 \%$ of the cases, the magnitude residuals worsened instead of improving. In the remaining $29 \%$, the earthquake magnitude estimates saw improvements characterized by a median of 0.3 magnitude unit. These results show that, except when dealing with some very large or complex earthquakes, the quality of PTWC's earthquake preliminary parameters benefits little by the extra message delays incurred by adding more stations to the initial analysis. We conclude that in the overwhelming majority of cases waiting to include more stations in the initial analyses, or manually reviewing individual station magnitudes before issuing the first official message product turns into a waste of otherwise precious time, something particularly crucial when warning of an impending tsunami in the near field.

\section{Speeding Up and Boosting Tsunami Warning Alerts in Chile}

FUENTES, M. A., Department of Geophysics, University of Chile, Santiago, Chile, mauricio@dgf.uchile.cl; RIQUELME,S., National Seismological Center, University of Chile, Santiago, Chile, sebastian@dgf.uchile.cl; ARRIOLA, S., National Seismological Center, University of Chile, Santiago, Chile, sarriola@ ing.uchile.cl

Chile host a great tsunamigenic potential along its coast, even with the large earthquakes occurred during the last decade, there is still a large amount of seismic energy to release. This permanent feature and the fact that the distance between the trench and the coast is just $100 \mathrm{~km}$ creates a difficult environment to do real time tsunami forecast. In Chile tsunami warnings are based on reports of the seismic events (hypocenter and magnitude) and a database of precomputed tsunami scenarios. However, because yet there is no answer to image the finite fault model within first minutes (before the first tsunami wave arrival), the precomputed scenarios consider uniform slip distributions. Here, we propose a scheme of processes to fill the gaps in-between blind zones due to waiting of demanding computational stages. The linear shallow water equations are solved to obtain a rapid estimation of the run-up distribution in the near field. Our results show that this linear method captures most of the complexity of the run-up heights in terms of shape and amplitude when compared with a fully nonlinear tsunami code. Also, the run-up distribution is obtained in quasi real-time as soon as the seismic finite fault model is produced.

\section{Modeling Tsunami Inundation Effects from a Hypothetical Submarine Landslide from the Arecibo Amphitheater on the Coastal San Juan Metropolitan Area}

FELICIANO-CENTENO, L. M., University of Puerto Rico at Mayagüez, Puerto Rico, USA, lirca.feliciano@upr.edu; LÓPEZ-VENEGAS, A., University of Puerto Rico at Mayagüez, Puerto Rico, USA, alberto.lopez3@upr.edu

The island of Puerto Rico in the northeastern Caribbean is only $\sim 150 \mathrm{~km}$ south of the Puerto Rico Trench (PRT). With its earthquake and tsunamigenic potential, the PRT makes the island vulnerable to strong shaking and potentially devastating tsunami waves events. In 2018, there will be exactly 100 years since the last significant earthquake and tsunami affected the island, particularly, at the northwestern coast of the island. Moreover, bathymetric studies along the PRT have mapped large submarine landslides just $50 \mathrm{~km}$ north of the northern coast of Puerto Rico, which provide evidence that tsunamis from these sources could affect in the future. This study precisely simulates a hypothetical submarine landslide in this region, particularly at the well-known Arecibo Amphitheater. Here we present simulation results of a coupled approach between the 3D model for the waves induced by landslides, TSUNAMI3D, with a $2 \mathrm{D}$ depth integrated nonhydrostatic model, NEOWAVE to generate wave propagation and quantify inundation and run-up within the coastal area of San Juan, the capital city. The inundation generated by the simulation covers $27 \mathrm{~km} 2$, which is $18 \mathrm{~km} 2$ more than the inundation extent that was used for current evacuation maps. Considering scenarios from other tsunamigenic sources can improve existing tsunami evacuation maps.

\section{Honduras Tsunami Evacuation Maps, Plans, Procedures (Tempp)}

TORRES BERNHARD, L. E., Instituto Hondureño de Ciencias de la Tierra/ Universidad Nacional Autónoma de Honduras, Tegucigalpa, Honduras, lidia. torresb@unah.edu.hn; ESCOBAR, J. J., Departamento de Física de la Tierra/ Universidad Nacional Autónoma de Honduras, Tegucigalpa, Honduras, jjef2001@yahoo.com.mx; CARDONA, A. J., Instituto Hondureño de Ciencias de la Tierra/ Universidad Nacional Autónoma de Honduras, Tegucigalpa, Honduras, alex.cardona@unah.edu.hn

The TEMPP project in Honduras was a project designed to start from scratch until it created the local and regional capacities needed to prepare coastal communities for tsunami events. Two communities were chosen for this project, the community of Sambo Creek on the coast of the Caribbean Sea in northern Honduras 
and the community of Cedeño on the Pacific coast. After several deliberations, it was agreed that only the project in Cedeño would be worked on. TEMPP1 was a workshop whose fundamental purpose was to transfer the basic tool of tsunami modeling, in this case the program called COMMIT, to the specialists and technicians who would be responsible for modeling tsunami waves that could affect the communities previously chosen in the project. Multiple scenarios were modeled for the communities and those scenarios that represented the greatest danger were selected for subsequent analyzes. Under TEMPP2, national, regional and international experts in geology and seismology were brought together for the purpose of exchanging experiences and information on possible sources capable of generating tsunami waves. Various sources on historical tsunamis registered in the region were reviewed as well as geological and seismological information in order to characterize the sources in the best possible way. During the TEMPP3 the training on GIS was carried out for the elaboration of the evacuation map, also the field visit was made to georefy all the relevant places such as schools, hospitals, fire stations, police stations, etc. to be included in the evacuation map. TEMPP 4 was the workshop where the parameters for the simulation were established. The criteria were discussed and procedures were socialized with the different actors that would participate in the simulation. TEMPP5 was the realization of the simulation by tsunami for the community of Cedeño in the pacific coast of Honduras. The local police, fire brigade, schools, hospitals, etc. were involved. At the end of the drill, an evaluation was carried out by UNESCO in order to determine if the community met the requirements to be considered prepared for tsunami events. Finally, it was declared that this community was ready and it was certified as "tsunami ready".

\section{Advances on the Parameterization of Seismic Attenuation: Current Challenges and Opportunities Oral Session . Wednesday 16 May · 2:15 PM - Monroe Session Chairs: Ashly Cabas, Stefano Parolai, Celine Gélis, and Albert Kottke}

\section{Attenuation Differences between the Canadian Shield and Appalachian Orogeny in Eastern Canada}

BENT, A. L., Natural Resources Canada-Ottawa, allison.bent@canada.ca; PERRY, H. K. C., Natural Resources Canada-Ottawa, claire.perry@canada.ca

Seismic attenuation can provide insight into the tectonic history and underlying geophysical processes of a region but it also contributes to seismic hazard assessment as it affects the level of shaking from an earthquake. Spatially varying attenuation across tectonic zones has implications for hazard at regional scales. While not at a plate boundary, eastern Canada is tectonically complex with the Canadian Shield and Appalachians comprising two of the major geological provinces. The St. Lawrence River, home to several of the most seismically active regions in eastern Canada, marks much of the boundary between the two regions. Current seismic hazard models treat all of eastern Canada as one region in terms of crustal structure and attenuation but we find increasing evidence from a wide variety of data sets for differences in attenuation between the Shield and Appalachians with higher attenuation in the latter. Magnitude residuals for earthquakes occurring along the Shield-Appalachian boundary show that magnitudes are lower at stations on Appalachian crust at both local and regional distances suggesting higher attenuation. Station site corrections also indicate underestimation of magnitudes at Appalachian stations. Predicted ground motions from peak amplitudes of Lg arrivals exhibit a similar trend, indicating higher attenuation in the Appalachians compared to the Shield. Finally, consistently lower felt intensities reported from communities on the southern side of the St. Lawrence relative to the north also point to higher attenuation in the Appalachians.

\section{On Strong Positive Frequency Dependencies of Seismic Quality Factors} MOROZOV, I. B., University of Saskatchewan, igor.morozov@usask.ca; JHAJHRIA, A., Kurukshetra University, Haryana, India, a.jhajhria@kuk.ac.in; DENG, W., University of Saskatchewan,wubing.deng@usask.ca

Many seismic attenuation measurements, and particularly those using local earthquakes and seismic codas, result in large exponents $h \geq 1$ in the frequencydependent quality factor $\mathrm{Q}(\mathrm{f})=\mathrm{Q} 0 \mathrm{fh}$. However, such steep positive frequency dependences of $Q$ are highly problematic physically. Specifically, the case of $h=1$ corresponds to frequency-independent (elastic) amplitude decays with time and consequently requires no Q-type attenuation mechanisms. In this case, parameter $\mathrm{Q} 0$ actually describes the frequency-independent amplitude decay in access of some assumed geometric spreading $\mathrm{t}-\mathrm{a}$, where it is usually (often inaccurately) assumed $\mathrm{a}=1$. For $\mathrm{h} \geq 1$, there are three problems with physical meanings of such
Q-factors. First, contrary to the key premise of seismic attenuation, high-frequency parts of the wavefield are enhanced with increasing propagation times relative to the low-frequency ones. Second, such attenuation cannot be implemented by mechanical models of wave-propagating media. Third, the velocity dispersion associated with such $\mathrm{Q}(\mathrm{f})$ occurs over unrealistically short frequency range and has an unexpected oscillatory shape. Casesh $=1$ and $\mathrm{h} \geq 1$ are usually attributed to scattering; however, this scattering must exhibit fortuitous tuning into the observation frequency band, which is unlikely. Thus, the case $h \geq 1$ is not allowed physically and could serve as an indicator of problematic interpretations. Although case $0<\mathrm{h}<1$ is possible, its parameters $\mathrm{Q} 0$ and $\mathrm{h}$ may also be biased by the measurement procedure. The reason for these problems is that the inferred $Q$ values are affected by the conventional parameterization of attenuation by a $\mathrm{Q}$ factor. Both parameters $\mathrm{Q} 0$ and $\mathrm{h}$ are apparent, i.e. dependent on the selected parameterization and inversion method, and they should not be directly attributed to the subsurface. To avoid the uncertainties of $Q$, we recommend measuring and interpreting the amplitude-decay rates directly, such as by using parameter a above.

\section{Imaging Seismic Attenuation at the Brady Geothermal Field Using Interferometry}

MATZEL, E., Lawrence Livermore National Laboratory, California, USA, matzel1@Ilnl.gov; MORENCY, C., Lawrence Livermore National Laboratory, California, USA, morency1@llnl.gov; FEIGL, K., University of WisconsinMadison, Wisconsin, USA, feigl@wisc.edu; THURBER, C. H., University of Wisconsin-Madison, Wisconsin, USA, clifft@geology.wisc.edu

The Poroelastic Tomography experiment (PoroTomo) was conducted in March 2016 at Brady Hot Springs in Nevada. A key goal of the experiment is to understand how fluids travel from shallow aquifers, through faults and fractures, to deep geothermal reservoirs. As part of the effort, seismic, geodetic, and hydraulic technologies were tested and developed to fully characterize the rock mechanical properties. This abstract focuses on the application of seismic interferometry to image variations in seismic attenuation at the site. During the experiment, a large seismic array was deployed and recorded more than two weeks of continuous data, active vibroseis sweeps, local traffic noise, and the ambient seismic wavefield. In this study, we use several methods of seismic interferometry to investigate the site. We focus on two techniques: sweep interferometry uses the energy from the vibroseis sweeps as sources of high frequency energy; ambient noise correlation uses the energy of the ambient background field. In each case, the data recorded at one seismometer are correlated with the data recorded at another to obtain an estimate of the Green function between the two. The 238 geophones, concentrated over a 1.5 square-kilometer area, allow us to calculate nearly 30,000 paths, which we use to characterize the site and measure the localized wavefield. In collaboration with Ormat, pressures were changed during four stages of operation, including shutdown, followed by increased injection and pulsing. These changes caused measurable differences in the material properties beneath the site including the attenuation of seismic energy. We use two methods to study the changes in seismic attenuation at the site. The simplest is to measure the normalized amplitudes of the Green functions and to compare the values during each stage of operation. The second is to model the full waveform of the data, separating out contributions of Qs and Qp. Because P and S have different sensitivity to fluids in fractures and pores, the ratio of $Q s / Q p$ is highly sensitive to the fluid saturation. We see anomalously high values of Qs/Qp at depth at the injection site and following fault boundaries. Over the course of the experiment, we observe large changes in attenuation across the site, bounded by structural features.

\section{A Fortuitous Experiment on the Effect of Station Installation Parameters on Measures of Apparent Attenuation}

BEZADA, M. J., University of Minnesota, Minnesota, USA, mbezada@umn. edu; BYRNES, J., University of Minnesota, Minnesota, USA, jsbyrnes@umn. edu; EILON, Z., UC Santa Barbara, California, USA, eilon@ucsb.edu

In late August 2017 four broadband posthole seismometers where installed near the SPMN legacy TA station for two weeks in order to compare different installation configurations to each other and to the permanent vault installation. During that time, the five instruments recorded the M 6.3 event identified as a thermonuclear detonation in North Korea. The signal to noise ratios for these records are very good and the source time function is compact and simple, which makes them ideal for measuring teleseismic attenuation. Given that the five instruments were deployed within a few meters of each other, geologic structure sampled by the wavefields recorded by each of them is identical. Therefore, true relative attenuation between the different seismograms is zero. However, two of the four posthole records show significant differential attenuation with respect to the SPMN record when measured with the standard spectral slope method of Teng (1968). Furthermore, the result is highly dependent on the highest frequency considered. The posthole instruments were buried at depths of either $1 \mathrm{ft}$ or $3 \mathrm{ft}$ and either 
directly covered with the surrounding soil, or placed within a PVC pipe that was filled with sand before being covered with local soil. It is the instruments that were encased in PVC pipes that show the differential attenuation with respect to SPMN. Visual inspection of the records suggests that signal-generated noise is implicated in the spurious result. Using moving-window averaging or the multitaper method to smooth the spectra before taking the ratio has thus far not eliminated the problem. We compare these results to measurements obtained using a time-domain waveform matching approach (Bezada et al, 2017) and a procedure that considers both the amplitude and phase spectra (Eilon and Abers, 2017) to assess the robustness of each method with respect to signal-generated noise.

\section{Selection and Weighing of Ground Motion Models for Subduction Source Zones in Chile}

MARTINEZ, M. E., Golder Associates, Santiago, Metropolitan Reg, Chile, mmartinez@golder.com; LI, F., Golder Associates, Washington, USA, feli@ golder.com; HULL, A. G., Golder Associates, Washington, USA, ahull@golder. com

While the methodologies for probabilistic and deterministic seismic hazard analyses are now well established, the selection and weighting of ground motion models (GMM) that capture the epistemic uncertainty is often still treated arbitrarily. The wide availability of high-quality strong motion databases from Chile, however, offers the opportunity to quantify the GMMs that better represent the source-to-site attenuation of earthquake ground motions from subduction seismic zone sources in Chile, and perhaps western South America. We used the Bastías and Montalva (2016) strong motion database that includes records from the large interface earthquakes such as the 2010-M8.8 Maule earthquake. The logarithmic likelihood score (LLH) of Scherbaum et al. (2009) was used to evaluate the performance of seven local and global subduction zone GMM commonly used for seismic hazard assessment in western South America. Local GMMs selected for testing were Contreras and Boroschek (2015) (CB15) and Montalva et al. (2017) (M17). Global GMM candidates were Abrahamson et al. (2016) (AEA16), Atkinson and Boore (2003) (AB03), Youngs et al. (1997) (YEA97), Zhao et al. (2006) (ZEA06), and Zhao et al. (2016) (ZEA16). GMMs were tested using 1,017 M5.5+ interface and $67 \mathrm{M} 6.0+$ intraslab earthquake records from the Chile database. All but two of the seven GMMs predict reasonably well the ground motions for interface earthquakes. The CB15 GMM performs relatively poorly. $\mathrm{AB} 03$ predicts the median acceleration relatively well for moderate-tolarge earthquakes. AEA16 and ZEA06 predict relatively well strong ground motions within the test database, but ZEA16 does not perform as well as ZEA06. The older YEA97 GMM predicts well the ground motions from the plate interface, but not from the in-slab sources and should still be considered as a suitable GMM for subduction earthquakes in western South America.

Parameterizations, Uncertainties, and Spatial Scales of Seismic Attenuation MOROZOV, I. B., University of Saskatchewan, igor.morozov@usask.ca

Current descriptions of seismic attenuation in Earth's media almost invariably rely on the quality $(\mathrm{Q})$ factor and its derivative quantities such as $\mathrm{t}^{*}$, phase lag $\mathrm{f}$, and spectral parameter k. Q-based models are used at all scales and even in complex cases such as rock samples in the laboratory, finely-layered and scattering media, full-waveform inversions, seismic coda, and tidal deformations of the Earth. Nevertheless, it is important to differentiate between the Qs and similar quantities reported from observations and those used as properties of mechanical friction within the subsurface. Empirically-defined Qs are sensitive to model assumptions, such as simple forms of geometrical spreading and uniformlydistributed scattering in local-earthquake studies. In consequence of these assumptions, empirical coda and body-waveQs often exhibit strong frequency and lapse-time dependences. By making more accurate approximations or better parameterizations, reported $\mathrm{Q} 0$ values (at $1 \mathrm{~Hz}$ ) often increase by 20-30 times, and frequency dependences of $Q$ are reduced. By contrast to the empirical $Q$, no in situ "material Q" actually exists, but it always represents a proxy for certain first-principle physical effects. Examples of such effects for Earth's media are solid and fluid viscosity, several types of models for fluid-saturated rock, thermoelasticity, and reflection/transmission effects in layered structures. These effects can be described by Lagrangian mechanics. Each of these effects results in characteristic frequency-dependent $\mathrm{Q}$ which, however, also depends on the shape and size of the body considered, type of deformation, and also on boundary and thermodynamic conditions. Some of these models suggest nonlinearity of internal friction. Detailed modeling also reveals further fundamental limitations of thephenomenological Q. In particular, unambiguous $Q$ models should be spatially smooth and cannot be finely layered at scales shorter than several seismic wavelengths.
The Contribution of Scattering to Near-Surface Attenuation

PILZ, M., GFZ Potsdam, Brandenburg, Germany, pilz@gfz-potsdam.de

The $\kappa$ parameter (Anderson and Hough, 1984), and namely its path-corrected component $(\kappa 0)$, is important for predicting and simulating high-frequency ground motion. Nowadays, $x 0$ is believed to be a local site characteristic, in turn representing attenuation related to waves propagating vertically through the very shallow layers beneath the study site. Despite the known relevance of $k 0$ in a wide range of seismological applications, most methods for its calculation do not fully consider the influence of the scattering component. To isolate the effects of different attenuation mechanisms, we present a summary of statistical observations of the seismic wavefield. The intrinsic properties of the wavefield show a clear dependency on the local shallow subsoil conditions with differences in the structural heterogeneity of the shallow subsoil layers producing different scattering regimes. Such deviations from the ballistic behavior (i.e., direct waves that sample only distinct directions) are indicative for local structural heterogeneities and the associated level of scatter. Albeit the attenuation term related to scattering depends nonlinearly on the instrinsic term, the results indicate that the commonly used explanation for the high-frequency decay spectrum might not be appropriate but involving the amount of scattering might allow better constrained estimates of $\kappa 0$. Also, the typically assumed continuous decrease of $\kappa 0$ at very high Vs values may be erroneous, leading to underestimation of $\kappa 0$ and overestimating of the adjusted high-frequency ground motion.

\section{Effective Amplitude Spectrum (EAS) as a Metric for Ground Motion Modeling Using Fourier Amplitudes \\ GOULET, C. A., UC Berkeley, California, USA, goulet@berkeley.edu; KOTTKE, A., Pacific Gas and Electric Co., California, USA, aarkk@pge.com; BOORE, D. M., US Geological Survey, Menlo Park, California, USA, dboore@ yahoo.com; BOZORGNIA, Y., UC Los Angeles \& Berkeley, California, USA, yousef.bozorgnia@ucla.edu; HOLLENBACK, J., Formerly, UC Berkeley, California, USA, jhollenback@gmail.com; KISHIDA, T., Khalifa University, Abu Dhabi, UAE, adahiro.kishida@kustar.ac.ae; DER KIUREGHIAN, A., American University of Armenia, Yerevan, Armenia, adk@aua.am; KTENIDOU, O. J., University of Greenwich, UK, o.ktenidou@gre.ac.uk; KUEHN, N. M., UC Berkeley, California, USA, kuehn@ berkeley.edu; RATHJE, E. M., University of Texas, Austin, Texas, USA, e.rathje@mail.utexas.edu; THOMPSON, E. M., US Geological Survey, Golden, Colorado, USA, emthompson@usgs.gov; WANG, X. Y., University of Texas, Austin, Texas, USA, xy_wang@utexas.edu}

Pseudo-spectral acceleration (PSA) is the most commonly used intensity measure in earthquake engineering, as it serves as a simple approximate predictor of structural response for many types of systems. Therefore, most ground motion models (GMMs, aka GMPEs) provide median and standard deviation PSA using a suite of input parameters characterizing the source, path and site effects. Unfortunately, PSA is a complex metric: the PSA for a single oscillator frequency depends on the Fourier amplitudes across a range of frequencies. The Fourier Amplitude Spectrum (FAS) is an appealing alternative because its simple linear superposition allows effects to be modeled as transfer functions. For this reason, most seismological models (e.g., the source spectrum) are developed for the FAS. Using FAS in conjunction with random vibration theory (RVT) allows GMM developers to superimpose seismological models directly, computing PSA only at the end of the process. The FAS-RVT-PSA approach was used for the development of GMMs for the Next Generation Attenuation Relationships for Central \& Eastern North-America (NGA-East) project [PEER, 2018]. As part of the project, the team above developed a systematic processing algorithm for FAS that minimizes computational requirements and bias that results from the RVT approximation. We introduce the down-sampled orientation-independent FAS referred to as the effective amplitude spectrum (EAS) and recommended it as a new approach for characterizing the frequency content of ground motion records. This algorithm down-samples the EAS with a Konno and Ohmachi [1998] smoothing window with a width (bw) of $1 / 30$ and 100 frequency points per decade. This smoothing window was identified as having the least impact on a suite of RVT calibration properties. We applied this smoothing to the FAS delivered through the PEER ground motion portal for NGA-East and NGA-West2 databases.

Robustness of $x$ M Measurement: Insight from a Site-Specific Study in the Low-to-Moderate Seismicity Context of Southeastern France PERRON, V., Swiss Seismological Service/Swiss Federal Institute of Technology of Zurich, Switzerland, vincent.perron.mail@gmail.com; HOLLENDER, F., CEA/DEN, Saint-Paul-lez-Durance, France, fabrice.hollender@cea.fr; BARD, P. Y., University of Grenoble Alpes, ISTerre/CNRS/IRD/IFSTTAR, Grenoble, France, pierre-yves.bard@univ-grenoble-alpes.fr; GÉLIS, C., IRSN/ PRP-DGE/SCAN/BERSSIN, Fontenay-aux-Roses, France, celine.gelis@irsn. 
fr; GUYONNET-BENAIZE, C., CEA/DEN, Saint-Paul-lez-Durance, France, cedric.guyonnet-benaize@hotmail.fr; KTENIDOU, O. J., Department of Engineering Science University of Greenwich, United Kingdom, o.ktenidou@ greenwich.ac.uk

The site component of $\kappa(\kappa 0)$ is used in engineering seismology to describe the high-frequency attenuation at a site. It is an important input parameter for various applications (stochastic modeling, ground-motion prediction equations, host-to-target adjustments, etc.). Its evaluation faces, however, several issues as it is difficult to properly isolate $\kappa 0$ from the source and path terms of $\kappa$, and because its measurement is subjected to the operator subjectivity and to large uncertainties. This is particularly true in low-to-moderate seismicity areas because the quantity and bandwidth of the usable data are generally limited. Therefore, $\kappa 0$ measurements might have higher sensitivity to site amplification, frequency-dependent attenuation, and to the earthquake source properties. Here, the $k$ DS (displacement spectrum) approach of Biasi and Smith (2001) is compared with the original $\kappa$ AS (acceleration spectrum) approach of Anderson and Hough (1984) for three sites in an industrial area in Provence (southeastern France). A semiautomatic procedure is developed to measure individual values of kr that reduces inter-operator variability and provides the associated uncertainty. A good agreement is found between $x 0 \_A S$ and $x 0 \_D S$ for the two hard-rock sites, which yields $\kappa 0 \sim 30 \mathrm{~ms}$. The comparisons between these approaches are also used to infer the reliability of $\kappa$ measurements by addressing their sensitivity to site amplification, frequency-dependent attenuation, and the earthquake source properties. First, the impact of site amplification on $k 0$ estimates is shown to be very important and strongly frequency-dependent for stiff-soil sites, and nonnegligible for hard-rock sites. Second, frequency-dependent attenuation cannot be ruled out for $\kappa$, as indicated by comparison with the literature quality factor (Q) for the Alps. Finally, a source component for $\mathrm{kAS}$ is questionable from the comparison of $k r$ _AS evaluated for a cluster of events that shared the same path and site components.

Kappa Effects on Hard-Rock Ground Motions: An On-Going Research ABRAHAMSON, N. A., Pacific Gas and Electric, California, USA, abrahamson@berkeley.edu; SILVA, W. J., PEA, California, USA, pacificengineering@juno.com; DARRAGH, R. B., PEA, California, USA, pacificengineering@juno.com; KTENIDOU, O. J., University of Greenwich, UK, o.ktenidou@gre.ac.uk; YONG, A., US Geological Survey, California, USA, yong@usgs.gov; BOZORGNIA,Y., UC Berkeley, USA, yousef@berkeley.edu

Existing ground-motion models for the central and eastern United States (CEUS) are commonly developed for hard-rock site conditions using the omega-squared point-source earthquake model (Brune, 1970; 1971) and the kappa-scaling site attenuation relation (Anderson and Hough, 1984). This approach describes a large increase in the high frequency $(\geq 10 \mathrm{~Hz})$ ground motions at hard-rock sites when compared to soft-rock ground motions in the western United States (WUS) (Ktenidou et al., 2014; 2016; 2017). We describe a research project that addresses the high-frequency scaling of ground-motion models for hard-rock sites in both the WUS and CEUS regions. For the CEUS, the results of this study will complement the NGA-East GMPEs by addressing the kappa effects and providing hard-rock site factors that can be applied to the NGA-East GMPEs. For the WUS, the hard-rock site factors developed in this study can be used to scale the soft-rock ground motion (e.g. VS30 $=760 \mathrm{~m} / \mathrm{s}$ ) to hard-rock conditions. The project includes the collection of ground-motion data and site conditions for hard-rock and soft-rock sites world-wide, followed by the development of an initial model for hard-rock site factors for the CEUS and WUS, and then finalized by the model for hard-rock site factors for the CEUS and WUS. This presentation provides an overview of this on-going research project.

\section{Development and Validation of Statistical Models of Small-Scale Heterogeneities \\ Oral Session - Wednesday 16 May · 10:45 Am · Flagler \\ Session Chairs: G. Eli Baker, Kim B. Olsen, Yang Shen, Vernon Cormier, and W. Scott Phillips}

\section{Source Spectra for Explosion Monitoring}

PHILLIPS, W. S., Los Alamos National Laboratory, New Mexico, USA, wsp@ lanl.gov; YOO, S. H., Weston Geophysical, Massachusetts, USA, hoonthhoonth@ gmail.com; OLSEN, K. B., San Diego State University, California, USA, kbolsen@mail.sdsu.edu

We derive source spectra from local and regional distance, direct and coda waves, using empirical methods. The coda adds stability and measurement precision.
Source spectra can be used to estimate $\mathrm{Mw}$ for earthquakes, and yield, along with emplacement parameters for underground explosions. Propagation effects are eliminated using a 2-D attenuation and site response model, obtained using tomography techniques with a global, multiscale tessellation grid. Misfit is 0.1 ( $\log 10$ amplitude misfit ratio) for regional distance $\mathrm{Pg}, \mathrm{Sn}$, and Lg phases, but poor for Pn (0.3). Crustal phase misfits increase towards short distances. We constrain absolute levels using well studied earthquakes with moments calculated by various agencies, universities, and individual researchers. Full spectral constraints are implemented using corner frequencies estimated from coda spectral ratios for these events. The empirical method works well for practical, monitoring applications; however, new, physics based approaches are needed to answer science questions, and further validate the empirical approach. We have begun to use full wave and radiative transfer methods to validate one another, and explore questions that include the following: Do simulations support the scattering hypothesis for high frequency envelopes? Does scattering control the high frequency $\mathrm{P} / \mathrm{S}$ ratios we use for discrimination? Does the scattering of $\mathrm{Rg}$ produce the $\mathrm{S}$ waves we observe at distance? Are explosion wavefields the same as earthquake wavefields, or, can we effectively correct explosion amplitudes using propagation models derived from earthquake data? Finally, can we use the entire seismic envelope, or spectrogram, to obtain high quality source spectra, thus improve source parameters and explosion yield estimation, especially for small events?

\section{Modeling of High-Frequency Seismic Wave Scattering and Propagation Using Radiative Transfer Theory}

ZENG, Y., US Geological Survey, Colorado, USA, zeng@usgs.gov

This is a study of the non-isotropic scattering process based on radiative transfer theory and its application to the observation of the M4.3 aftershock recording of the 2008 Wells earthquake sequence in Nevada. Given a wide range of recording distances from 29 to $320 \mathrm{~km}$, the data provide a unique opportunity to discriminate scattering models based on their distance dependent behaviors. By applying the radiative transfer theory for a 3-D non-isotropic scattering (Sato, 1995) to the inversion of M4.3 Wells aftershock recordings, we find that a non-isotropic scattering model, dominated by forward scattering, provides the best fit to the observed high-frequency direct $S$-waves and $S$-wave coda velocity envelopes. The scattering process is governed by a Gaussian autocorrelation function, suggesting a Gaussian random heterogeneous structure for the Nevada crust. The model successfully explains the common decay of seismic coda independent of sourcestation locations as a result of energy leaking from multiple strong forward scattering, instead of backscattering governed by the diffusion solution at large lapse times. The model also explains the pulse-broadening effect in the high-frequency direct and early arriving $S$-waves, as other studies have found, and could be very important to applications of high-frequency wave simulation where scattering has a strong effect. We also find that regardless of its physical implications, the isotropic scattering model provides the same effective scattering coefficient and intrinsic attenuation estimates as the forward scattering model, suggesting that the isotropic scattering model is still a viable tool for study of seismic scattering and intrinsic attenuation coefficients in the Earth.

\section{Imaging the Heterogeneous Earth with Radiative Transfer}

MARGERIN, L., Institut de Recherche en Astrophysique et Planétologie / CNRS, France, ludovic.margerin@irap.omp.eu; CALVET, M., Institut de Recherche en Astrophysique et Planétologie, France, marie.calvet@irap.omp.eu

Because they explore a large volume of the crust or mantleand propagate in all possible directions, coda waves have long been considered to be devoid of local information on the Earth interior. But in the last ten years, experimental, numerical and theoretical results have accumulated, which force us to reconsider this picture. In this presentation, we will explain how radiative transfer may be used as a unifying approach for imaging in scattering media. First, the basic physics of radiative transfer will be recalled and illustrated with the aid of numerical simulations. Next, we will discuss applications of radiative transfer to the characterization of small-scale heterogeneities using observations of high-frequency seismogram envelopes. The development of sensitivity kernels for the spatio-temporal distribution of intensity in the coda will be reviewed. In particular, we will show how to calculate the partial derivativesof seismogram envelopes with respect to local perturbations of the parameters quantifying scattering and absorption in the medium, as well as scattering anisotropy. Numerical methods of computation will be briefly mentioned with an emphasis on spectral approaches and the Monte-Carlo method. The theory will be illustrated with both controlled numerical experiments and analyses of various datasets. Based on synthetic tests, trade-offs in the separation of scattering/absorption attenuation and scattering anisotropy will be discussed. Data from dense permanent networks will serve to highlight rapid spatial variations of attenuation as well as the correlations with surface geology (e.g. sedimentary basins, crystalline rocks,...) and other seismic 
observables (e.g. the $\mathrm{Vp} / \mathrm{Vsratio}$ ). Implications for seismic risk evaluation will be outlined.

\section{Trade-Offs in Parameters Describing Earth's Heterogeneity Spectrum and Intrinsic Attenuation}

CORMIER, V. F., University of Connecticut, Connecticut, USA, vernon. cormier@uconn.edu; SANBORN, C.J., University of Connecticut, Connecticut, USA, christopher.sanborn@uconn.edu

Using envelopes of regional high frequency seismograms synthesized by a 3-D radiative transport algorithm (Sanborn et al., 2017), we investigated tradeoffs in model parameters describing the heterogeneity spectrum and intrinsic attenuation of the crust and upper mantle. Probability density functions that control scattering directions, mean free paths, and polarizations suggest that the square of the velocity fluctuation parameter e (DVs/Vs) linearly trades-off with the scale length "a" that controls the corner of a von Karman spectrum and intrinsic Q in frequency bands for which the product of the wavenumber $k$ and scale length "a" are on the order of $\mathrm{ka}=1$. Fitting observations of waveforms in a series of different narrow pass bands significantly reduces the combinations of parameters describing the heterogeneity spectrum and viscoelastic attenuation that can produce good waveform fits. Application of multiple-time-lapse window methods (Hoshiba, 1993), which plot ratios of coda energies in different time windows and distances, designed to be sensitive to coda shapes, are capable of separating intrinsic attenuation measured by $1 / \mathrm{Q} s$ and scattering attenuation measured by the scattering coefficient $\mathrm{g}$, including estimates of their uncertainties. Sanborn, C., V.F. Cormier, and M. Fitzpatrick, 2017. Combined effects of deterministic and statistical structure on high frequency regional seismograms, Geophys. J. Int., 210(2), 1143-1159, doi: 10.1093/gji/ggx219. Hoshiba, M., 1993. Separation of scattering attenuation and intrinsic absorption in Japan using the multiple lapse time window analysis of full seismogram envelope, J. Geophys. Res., 98(B9), 15809-15824.

\section{Developing Integrated Deterministic and Stochastic Earth Models}

BAO, X., University of Rhode Island, Rhode Island, USA, xybao@uri.edu; WEI, X. Y., University of Rhode Island, Rhode Island, USA, xiaozhuo_wei@my.uri. edu; SHEN, Y., University of Rhode Island, Rhode Island, USA, yshen@uri.edu

Heterogeneities in the Earth likely follow a power-law distribution. Heterogeneities at large spatial scales can be imaged deterministically by seismic tomography, while small-scale heterogeneities can be characterized with stochastic models. To date, deterministic models and stochastic models have been developed separately and independently. In order to predict broadband wave fields, here we take an integrated approach to develop models that combine the deterministic and stochastic components of the Earth media. Our method includes three steps: (1) using the power-law distributions of existing tomographic models to determine the range of stochastic models, (2) evaluating and constraining stochastic models by comparing observations with synthetics, and (3) validating the resulting stochastic model with super-high-resolution tomography using dense seismic arrays. We focus on Southern California to develop and prove our method. First, we extrapolate the power spectra of existing three-dimensional deterministic models to short wavelengths in order to narrow the parameter space of stochastic models. We then seek the stochastic models which predict synthetics based on three-dimensional finite-difference simulations with the waveform characteristics that match those in high-frequency waveforms recorded by dense arrays. These waveform characteristics include the P-wave energy on the transverse component and the eigenvalues in empirical orthogonal functions. We validate the stochastic models with full-wave tomography by jointly inverting seismic data recorded by dense arrays and gravity measurements for velocity and density to extend the deterministic component to length scales less than $1 \mathrm{~km}$. We then use the resulting integrated deterministic and stochastic model to predict fullwave broadband waveforms and to estimate uncertainties in source locations and quantify other waveform characteristics due to scattering (e.g., coda Q).
Early Warning for Large Earthquakes and Tsunamis: Challenges, Case Studies and Innovations Oral Session - Wednesday 16 May · 8:30 AM · Jasmine Session Chairs: Christine J. Ruhl, Emrah Yenier, Men-Andrin Meier, Neil Spriggs, Diego Melgar, Marlon D. Ramos, and David Easton

\section{Earthquake Early Warning: The Road to Implementation}

NISHENKO, S., Pacific Gas and Electric Company, California, USA, spn3@ pge.com; MOLNAR, G., Pacific Gas and Electric Company, California, USA, gcme@pge.com; DE GUZMAN, R., Pacific Gas and Electric Company, California, USA, r3de@pge.com; ANDERSON, B., Pacific Gas and Electric Company, California, USA, bdac@pge.com

The Pacific Gas and Electric Company (PG\&E) is actively participating in the implementation of earthquake early warning (EEW) technology in California. Pilot projects at PG\&E are being used to demonstrate how EEW technology can potentially protect lives, lessen property damage, and ensure rapid service restoration throughout an earthquake impacted area. PG\&E's EEW program currently includes the following four initiatives 1) The pilot installation of an EEWbased elevator recall system at PG\&E's San Francisco headquarters. In addition to the physical installation, this pilot also addresses the policies, resources and processes involved to implement safety-related systems in a high-rise office building; 2) EEW notifications through the USGS ShakeAlert desktop application. ShakeAlert-based warnings are being evaluated for a larger pilot using network-wide desktop/laptop or Public Address notifications to alert employees and contractors to immediately take protective actions seconds before an earthquake strikes; 3) Wireless alerts using the Berkeley Seismological Lab cell phone application, MyEEW. MyEEW provides the capability for individualized earthquake notifications, and a number of PG\&E employees are currently betatesting the MyEEW application on company issued cell phones; 4) Membership in the California EEW Advisory Board and USGS Earthquake Early Warning External Working Group (EEWEWG). PG\&E actively engages with industry experts and advisory boards to provide feedback on policy and regulatory issues that can impact the implementation of EEW in the private-sector. Discussions on the reliability and limitations of EEW technology and as well as appropriate responses for individual situations are being integrated into company safety training and exercises.

\section{Quantitative Ground-Motion Evaluation of ShakeAlert Earthquake Early Warning Performance}

AAGAARD, B. T., US Geological Survey, California, USA, baagaard@usgs. gov; MINSON, S. E., US Geological Survey, California, USA, sminson@usgs. gov; BALTAY, A. S., US Geological Survey, California, USA, abaltay@usgs.gov; COCHRAN, E. S., US Geological Survey, California, USA, ecochran@usgs. gov; HANKS, T. C., US Geological Survey, California, USA, thanks@usgs.gov

Good performance of the ShakeAlert beta version early warning system is driven by sufficient accuracy in predicted shaking so that alert thresholds can be relatively close to damage thresholds. Otherwise, the alerts are dominated by false positives (alerts issued when the shaking is below damaging levels) and false negatives (alerts not issued when the shaking is above damaging levels). We compare modified Mercalli intensity (MMI) predicted from ShakeAlert for recent M4 and larger earthquakes in California against the observed MMI from ShakeMap. In cases with accurate, rapid estimates of earthquake magnitude and shaking, large areas would receive alerts before the onset of strong shaking; the optimal choice of the alert threshold is controlled by uncertainty in the local spatial variations of shaking. In cases in which earthquake magnitude is underestimated for several seconds, there is a significant zone where alerts would not arrive until after the onset of strong shaking unless a very low alert threshold is used; very low alert thresholds increase the overall probability of false positive alerts. In some cases, the errors in the estimated earthquake magnitude or location overwhelm the uncertainties in the predicted shaking from other factors; these cases increase the probability of delayed, false-positive, and false-negative alerts. We quantify these characteristics and the overall performance by computing the cost savings incorporating generic fragility curves and costs of taking action upon receiving an alert relative to a perfect earthquake warning system in which the predicted shaking exactly matches the observed shaking and warnings are issued instantaneously at the earthquake origin time. This metric can be applied over a region for a single earthquake, over a region for a suite of earthquakes, or at a single site for a suite of earthquakes. Furthermore, the alert threshold can be optimized by selecting a value that maximizes the cost-savings metric. 
A Pseudo Real Time Assessment of Earthquake Early Warning Algorithms YENIER, E., Nanometrics Inc., emrahyenier@nanometrics.ca; SPRIGGS, N., Nanometrics Inc., neilspriggs@nanometrics.ca

Earthquake early warning (EEW) systems are an important piece of seismic loss mitigation programs. They provide an advance notification of an on-going event before the arrival of damaging seismic waves to a target site. This notification can be used by various clients (e.g., government agencies, system control centers, emergency response teams, and public) to reduce the social and economic impacts of major earthquakes. EEW systems should be able to automatically distinguish seismic radiations from noise and estimate shaking intensity of not yet arrived waves from very first arrivals for maximized notification time. The accuracy of estimated source parameters and shaking intensities are as important as the advance warning time for achieving effective and trustworthy systems. In this study, existing EEW algorithms are tested in pseudo real time in order to identify their strengths and limitations from a perspective of warningrecipients. The evolutionary accuracies of estimated location, magnitude and ground-motion amplitudes are compared. The trade-offs between prediction accuracies and warning lead time are examined, and potential improvements with integration of machine learning techniques are explored.

Earthquake Early Warning Using Late-Onset P-Waves from Growing Ruptures KODERA, Y., Meteorological Research Institute, Japan Meteorological Agency Ibaraki,Japan, y_kodera@mri-jma.go.jp

Robust ground motion prediction for large earthquakes with complex rupture behavior is a challenging task for earthquake early warning (EEW). During the $2011 \mathrm{Mw} 9.0$ Tohoku-oki earthquake, high-frequency wave packets that caused severe shaking were separately observed in time, indicating that several strong motion generation areas (SMGAs) ruptured with different delays. Such strong motions would be difficult to robustly predict in advance only using waveforms observed in the initial rupture stage if earthquake rupture processes exhibit nondeterministic behavior. To robustly predict strong motions from growing ruptures, we developed a technique using late-onset $\mathrm{P}$-waves from the rupture areas. If $\mathrm{P}$-wave energy released by a growing rupture is sufficiently large, the $\mathrm{P}$-wave signals from the rupture would be clearly detectable although the signals may overlap with $S$-waves from the initial rupture. These large P-waves would lead to robust strong motion predictions for the corresponding $S$-waves because the P-waves directly carry information on the ongoing rupture development. First, we constructed an on-site algorithm that detects in real time P-waves from growing ruptures and predicts the corresponding $S$-wave seismic intensities. When applied to the Tohoku-oki earthquake, the on-site method successfully predicted strong motions from several SMGAs with high accuracy and several-second warning times. In addition, we combined the on-site algorithm with the PLUM method, which predicts seismic intensities directly from intensities observed near target sites, to lengthen available warning times given by the PLUM method. For the Tohoku-oki earthquake, the modified PLUM method provided additional warning times without greately decreasing the prediction accuracy for sites with high observed intensities. These findings indicate that the use of the late-onset P-waves is effective for improving EEW system performances for large earthquakes with complex source processes.

Real-Time Correction of Frequency-Dependent Site Amplification Factors in Time Domain: Introduction of Phase Delay for Real-Time Prediction of Duration of Ground Motion

HOSHIBA, M., Meteorological Research Institute, JMA, Japan, mhoshiba@ mri-jma.go.jp

We propose a method for real-time prediction of duration of strong ground motion for earthquake early warning (EEW). Because the long duration of shaking is often observed on basin structure, prediction of duration is important in EEW in addition to the strength of shaking. Although many of EEW system focus on rapid determination of source characteristics such as event hypocenter and magnitude, subject of EEW itself is the prediction of ground shaking, where hypocenter and magnitude are not necessarily required. Recently innovative methods have been proposed for the real-time prediction of ground motion without source characteristics, where current wavefield is estimated precisely using data assimilation, and then future wavefield is predicted based on physics of wave propagation (Hoshiba and Aoki, 2015; Kodera et al, 2018). Site amplification is an important factor for ground motion as well as source characteristics and path factors, and the site amplification is frequency dependent. Because the frequency dependence should be corrected in real-time for EEW, it is preferable to correct the frequency dependence in time domain. The correction was proposed in Hoshiba (2013) by using IIR filter, in which amplitude characteristics were taken into account but phase was not fully taken because minimum phase system is assumed in the IIR filter. Because of it, it was not easy to reproduce the long duration of ground motion on basin structure. Recently a method to introduce the phase characteristics was discussed in Pilz and Parolai (2016) on minimum phase assumption. In this presentation, we will propose a method to correct phase characteristics by changing the minimum phase IIR filter to mixed phase system. The introduction of the mixed phase makes it possible to reproduce the long duration of ground motion on basins, and leads to precise prediction of duration of shaking in EEW.

\section{Regional EEW Applications in Marmara Region (NW Turkey) for Distant Large} Earthquakes

PINAR, A., Bogazici University Kandilli Observatory and Earthquake Research Institute, Istanbul, Turkey, pinara@boun.edu.tr; KALKAN ERTAN, E., Bogazici University Kandilli Observatory and Earthquake Research Institute, Istanbul, Turkey, esra.kalkan@boun.edu.tr

KOERI (Kandilli Observatory and Earthquake Research Institute) operates a seismic network in Marmara Sea region (NW Turkey) consisting of broadband and strong motion stations which has a reliable topology for regional EEW studies. In addition, a seismic network of 10 strong motion stations located close to the North Anatolian Fault crossing the Sea of Marmara is utilized in onsite threshold based studies. The Virtual Seismologist, PRESTo and ELARMS2 are regional EEW applications which are operational at KOERI data center. In addition, the onsite EEW system is running for more than a decade. The early warning signal is communicated to the appropriate servo shut-down systems of the recipient facilities, that automatically decide proper action based on defined alarm levels. Warning time is a critical parameters in EEW studies affected by the difference between the arrival time of the P-wave at the seismometer and the picking time. We have observed that the main reason for delays in detecting earthquake is packet size of the waveform data. We confirm that Seiscom3 platform requires some time to locate earthquakes and it needs to be optimized for EEW studies. Even with current settings Istanbul could have up to 20 seconds of warning times for a possible Marmara earthquake in case the rupture initiates in western part of the Sea of Marmara. The observations reveal that each algorithm has its own strengths and weakness. We give an example event (11-05-2015 04:16 GMT Gemlik bay event, $M=3.9$ ) that was detected successfully by the three algorithms shown. The first estimation time of the origin time by the three algortihms was between 14-16 second. This examples shows that despite the proximity of the event to Istanbul Metropoliatan area a couple of seconds of warning time remains. The second example shows the neccessty of EEW for distant earthquakes where we utilize the offhore 2014 North Aegean Sea Earthquake $(M w=6.9)$. Because of the sparse seismic network the first estimation of the epicenter was done in 35 seconds after the origin time of the earthquake prividing about 50 seconds leading time for Istanbul area located about $300 \mathrm{~km}$ away from the epicenter where the long period waves were causative for 10-15 minute shaking duration of high rise buildings.

Performance of Seismic and Geodetic Earthquake Early Warnings for a Suite of Large Earthquakes Worldwide: Rapid Forecasts of Ground Motion

RUHL, C. J., UC Berkeley, California, USA, cruhl@berkeley.edu; MELGAR, D., University of Oregon, Oregon, USA, dmelgarm @oregon.edu; CHUNG, A. I., UC Berkeley, California, USA, aichung@berkeley.edu; GRAPENTHIN, R., New Mexico Tech, New Mexico, USA, rg@nmt.edu; ALLEN, R. M., UC Berkeley, California, USA, rallen@berkeley.edu

GNSS-based earthquake early warning (EEW) algorithms are designed to complement existing point-source seismic systems by estimating fault-finiteness and unsaturated moment magnitude for the largest, most damaging earthquakes. Because large earthquakes are rare and geodetic monitoring is relatively young, however, demonstrating the differential accuracy of ground motion estimates from seismic and geodetic warnings is difficult. Here, we quantify the timeliness and accuracy of seismic and geodetic alerts by testing a suite of large $(M \geq 6)$ earthquakes worldwide. We replay strong motion seismic data from each earthquake through the ElarmS seismic EEW algorithm in simulated real-time and use those alerts to trigger the Geodetic Alarm System (G-larmS). At each epoch, G-larmS then determines static offsets from the GNSS data, and inverts the offsets for slip on several a priori fault geometries. We calculate the predicted shaking intensity (Modified Mercali Intensity, MMI) time series for each event using the pointsource (ElarmS) and finite-fault (G-larmS) simulated real-time solutions at each epoch. Using an MMI-threshold approach to accurately characterize warning times, we classify true positive, true negative, false positive, and false negative alerts. We assess the success rate of both algorithms using these metrics and demonstrate the ground motion accuracy gained, if any, when using geodetic finitefault solutions in real time. 
Reliability of the W-Phase Inversion for Earthquakes with MW $>6.0$ to Be Used by the Central American Tsunami Advisory Center (CATAC)

ARGUELLO-MIRANDA, G. J., INETER, Nicaragua, greyvingnic@ @otmail. com; TANIOKA, Y., Hokkaido University, Japan, tanioka@sci.hokudai.ac.jp; STRAUCH, W., INETER, Nicaragua, wilfried.strauch@yahoo.com

This study was done in the framework of the project on the Reinforcement of the Central American Tsunami Advisory Center (CATAC) to be established at INETER in Managua, Nicaragua. To emit reliable and sufficiently fast tsunami services for local tsunamis it is necessary to determine, in near real time, the appropriate fault model needed for the tsunami simulation in the last years, the use of the W-Phase for the Moment Tensor determination became viable in Central America because of the recent installation of 120 s broadband stations and the establishment of fast and reliable data exchange between the Central American countries. To test the method, we have used a total of 26 earthquakes with moment magnitudes larger than 6.0 which have occurred, since 2012, in or near Central America. Among them were some larger earthquakes (e.g. 2012 Mw 7.3 off the Pacific Coast of El Salvador, 2017 Mw 8.2 near the Pacific Coast of Mexico, $2018 \mathrm{Mw} 7.7$ Swan Island North of Honduras) which have occurred at the Plate Boundaries off the Pacific and Caribbean coasts of Central America. These events have generated small tsunamis. The W-Phase inversions show a very stable nodal plane solution and accurate moment magnitudes at up to 10 degrees of epicenter distance, becoming available within a few minutes after origin time. We suggest using the W-phase inversion as a standard method for tsunami warning in Central America. We thank the Nicaraguan government and the Japanese International Cooperation Agency (JICA) for their support for the reinforcement of CATAC.

\section{Local Tsunami Warnings Using GNSS and Seismic Data}

HIRSHORN, B. F., SSA, Hawaii, USA, barryhirshorn@mac.com

Tsunami warning Centers (TWC's) must issue warnings based on imperfect and limited data. Uncertainties increase in the near field, where a tsunami reaches the closest coastal populations to the causative earthquake in a half hour or less. In the absence of a warning, the usual advice is "When the ground shakes so severely that it's difficult to stand, move uphill and away from the coast." But, what if the shaking is not severe? If, for example, the earthquake ruptures slowly (producing very little perceived shaking) this advice will fail. TWC's must therefore warn the closest coastal populations to the causative earthquake, where over $80 \%$ of the Tsunami based casualties typically occur, as soon possible after earthquake rupture begins. The NWS Tsunami Warning Centers (TWCs) currently issue local Tsunami Warnings for the US West Coast, Hawaii, and the Puerto Rico - Virgin Island region within 2-4 minutes after origin time. Coastal GNSS networks complement seismic monitoring networks, and enable unsaturated estimates of $\mathrm{Mw}$ (from Peak Ground Displacement) within 2-3 minutes of earthquake onset time, even for larger $\mathrm{Mw} 8$ to 9 events with much longer rupture durations. NASA/JPL, SIO, USGS, CWU, UCB and UW, with funding and guidance from NASA, and leveraging the USGS funded ShakeAlert development, have been working with the National Weather Service TWC's to incorporate realtime GNSS and seismogeodetic data into their operations. These data will soon provide unsaturated estimates of moment magnitude, Centroid Moment Tensor solutions, coseismic crustal deformation, and fault slip models within a few minutes after earthquake initiation. The sea floor deformation associated with the earthquake slip can then be used as an initial condition for an automatically generated tsunami propagation and coastal inundation model for coastal warnings.

\section{Tsunami Data Assimilation for Rapid Forecast: Application to Cascadia and New Zealand}

SHEEHAN, A. F., University of Colorado Boulder, Colorado, USA, anne. sheehan@colorado.edu; GUSMAN, A. R., Earthquake Research Institute, University of Tokyo, Tokyo, Japan, adit@eri.u-tokyo.ac.jp; SATAKE, K., Earthquake Research Institute, University of Tokyo, Tokyo, Japan, satake@ eri.u-tokyo.ac.jp; MAEDA, T., Earthquake Research Institute, University of Tokyo, Tokyo,Japan,maeda@eri.u-tokyo.ac.jp

We use a data assimilation method for a retrospective simulation of tsunami forecast using observed ocean bottom seismic (seafloor pressure) array data from offshore New Zealand and Cascadia. In the data assimilation method tsunami observations from a dense array are continuously assimilated to update the wavefield at each time step to forecast the coastal tsunami in the vicinity of the array, and a tsunami source is not required or assumed. Maeda et al. (2015) developed the data assimilation method for eventual use with the Seafloor Observation Network for Earthquakes and Tsunamis along the Japan Trench (S-net) cabled network of 150 seafloor observatories with pressure gauge and seismic instruments off the east coast of Japan. For the Cascadia example, we use the tsunami from the Mw 7.82012 Haida Gwaii earthquake as recorded on seafloor pressure gauges of the Cascadia Initiative ocean bottom seismic experiment. We use 45 tsunami waveforms from Cascadia Initiative stations offshore Washington, Oregon, and California and 4 tsunami waveforms from NOAA Deep-ocean Assessment and Reporting of Tsunamis (DART) stations. In the New Zealand example, we use the $2009 \mathrm{Mw}$ 7.6 Dusky Sound earthquake as recorded on 15 seafloor differential pressure gauges from the MOANA ocean bottom seismology experiment off the west coast of the South Island. In the Cascadia case the tsunami data assimilation method produces similar results as those from the traditional tsunami forecasting method which starts from a fault model. In the New Zealand case the data assimilation model suffered from lack of near-shore stations, requiring supplementing the gaps with synthetic data and fine-tuning of the smoothing matrix cutoff distance. These results illustrate that with an appropriate array of sensors, models continuously updated with real-time tsunami wave data could be used for rapid tsunami forecast.

\section{Exploring Rupture Dynamics and Seismic Wave Propagation along Complex Fault Systems}

Oral Session · Wednesday 16 May · 8:30 AM • Brickell

Session Chairs: Roby Douilly, Kenny Ryan, David D. Oglesby, Ruth Harris, and Eric Geist.

\section{Fully Physics-Based PSHA: Coupling RSOSim with Deterministic Ground} Motion Simulations

MILNER, K. R., Southern California Earthquake Center, California, USA, kmilner@usc.edu; SHAW, B. E., Lamont Doherty Earth Observatory, New York, USA, shaw@ldeo.columbia.edu; JORDAN, T. H., University of Southern California, California, USA, tjordan@usc.edu; CALLAGHAN, S., Southern California Earthquake Center, California, USA, scottcal@usc.edu

Probabilistic seismic hazard analysis (PSHA) is typically performed by combining an earthquake rupture forecast (ERF) with a set of empirical ground motion prediction equations (GMPEs). ERFs have typically relied on observed fault slip rates, scaling relationships, and regional magnitude-frequency distributions to estimate the rate of large earthquakes on pre-defined fault segments. GMPEs, which regress against recorded ground motions, often lack data at short site-rupture distances and for large, complex ruptures. The CyberShake platform (Graves et al., 2011) replaces GMPEs with deterministic three-dimensional ground motion simulations, characterizing the effects of basin response and other path effects which are parameterized or treated as aleatory variability in GMPEs. We replace traditional ERFs with a multi-cycle physics-based earthquake simulator, the Rate-State Earthquake Simulator (RSQSim), developed by Dieterich \& Richards-Dinger (2010). RSQSim simulations on the Uniform California Earthquake Rupture Forecast, Version 3 (UCERF3) fault system produce seismicity catalogs that match long term rates on major faults and yield remarkable agreement with UCERF3 when carried through to GMPE-based PSHA calculations. Averaged over a representative set of sites, the RSQSim-UCERF3 hazard-curve differences are comparable to, or even less than, the differences between UCERF3 and its predecessor, UCERF2, used in all CyberShake studies to date. Unlike traditional ERFs, RSQSim produces full slip-time histories for all simulated ruptures which can be used directly as input to deterministic wave propagation simulations. We couple the RSQSim model with CyberShake and the SCEC Broadband Platform to create the first fully physics-based PSHA model. Resultant ground motions match GMPE estimates of mean and variability of shaking well over magnitudes and distances for which GMPEs are well constrained. We will present these comparisons and preliminary CyberShake results using RSQSim.

\section{Dynamic Models of Earthquake Rupture along Branch Faults of the Eastern San Gorgonio Pass Region in California Using Complex Fault Structure} DOUILLY, R., UC Riverside, California, USA, roby.douilly@ucr.edu; OGLESBY, D. D., UC Riverside, California, USA, david.oglesby@ucr.edu; COOKE, M. L., University of Massachusetts Amherst, Massachusetts, USA, cooke@geo.umass.edu; BEYER, J. L., University of Massachusetts Amherst, Massachusetts, USA, jbeyer@geo.umass.edu

Compilations of geologic data have illustrated that the right-lateral Coachella segment of the southern San Andreas Fault is past its average recurrence time period. On its western edge, this fault segment is split into two branches: the Mission Creek strand, and the Banning fault strand, of the San Andreas fault. Depending on how rupture propagates through this region, there is the possibility of a through-going rupture that could lead to the channeling of damaging seis- 
mic energy into the Los Angeles Basin. The fault structures and rupture scenarios on these twho strands are potentially very different, so it is important to determine which strand provides a more likely rupture path, and the circumstances that control the rupture path. In this study, we focus on the effect of different assumptions about fault geometry and initial stress pattern on the rupture process to test those scenarios and thus investigate the most likely path of a rupture that starts on the Coachella segment. We consider three types of fault geometry based on the Southern Community Fault Model (SCEC) and the Third Uniform California Earthquake Rupture Forecast (UCERF3), and we create a 3D finite element mesh for each. These three meshes are then incorporated into the finite element method code FaultMod to compute a physical model for the rupture dynamics. We use a slip-weakening friction law, and consider different assumptions of background stress, such as constant tractions and regional stress regimes with different orientations. Both the constant and regional stress distributions show that it is more likely for the rupture to branch from the Coachella segment to the Mission Creek compared to the Banning fault segment, even if the closest connectivity is between the Coachella and Banning. For the regional stress distribution, we encounter cases of super-shear rupture for one of the SCEC fault geometry, and sub-shear rupture for the other two. The fault connectivity at this branch system seems to have a significant impact on whether a through-going rupture is more likely to occur or not.

Effect of the Gaochuan Right Bend on Fault Spontaneous Rupture Propagation in the 2008 Wenchuan Earthquake: Interpretation of Seismic Hazard in the Beichuan Area

ZHU, S., Institute of Crustal Dynamics, China Earthquake Administration, Beijing, China, zhusb@pku.edu.cn; YUAN, J., Institute of Crustal Dynamics, China Earthquake Administration, Beijing, China, yuenjay@sina.cn

The Beichuan area suffered the most serious seismic damage in the 2008 Wenchuan earthquake although the Beichuan is over $100 \mathrm{~km}$ away from the instrumental epicenter of the mainshock. The mechanism for this peculiar phenomenon remains unclear even though nearly 10 years has passed since the Wenchuan shock. For this purpose, we construct a spontaneous rupture model in which Gaochuan right bend (GRB) in the middle of Xingxiu-Beichuan fault, a major seismogenic fault for the Wenchuan event, is included. The simulated results show that the complex geometry of the GRB played a first-order role in controlling the rupture propagation. While rupture is initiated at the epicenter of the Wenchuan mainshock, it propagates spontaneously northeastward at the speed slower than the shear wave speed of local medium. When the rupture front spreads near the end of Yingxiu-Gaochuan fault, a new rupture is renucleated at the curve section of the Gaochuan bend, and propagates in the NE direction with the speed greater than the $S$ wave velocity. In particular, this rupture transition from subshear to supershear speed does not need time delay, much different from the case of fault step over which were studied well by previous workers. Due to the curved geometry of GRB, the stress regime on the fault section favors the supershear rupture formation. Once supershear rupture occurs along the Beichuan fault, seismic waves were focused and largely amplified with the form of Mach waves. The numerical result also illustrated that high values of spatial distribution of the strong ground motion acceleration are mainly located in the Beichuan area, directly leading to grave seismic catastrophe. Therefore, this work may give some insight into why the most serious hazard occurred in the Beichuan area, suggesting that comprehensive investigation of fault geometry is important in understanding earthquake dynamics and seismic hazard assessment.

\section{The Effect of Along-Strike Variation in Dip on Rupture Propagation on Strike- Slip Faults

LOZOS, J. C., CSU, Northridge, California, USA, julian.lozos@csun.edu

Strike-slip faults are nonplanar structures. Most large strike-slip faults have mapped complexities and discontinuities along strike, but seismological and geodetic inversions, as well as field geophysical studies, suggest dip can also vary substantially along the length of these faults. The southern San Andreas Fault, which twists from a northwest dip in the Carrizo Plain to vertical in the Mojave Desert to a southeast dip through San Gorgonio Pass, is a particularly notable example. A large body of observational and modeling research on the effects of along-strike geometrical complexity on rupture propagation already exists. However, I know of no previous existing modeling studies addressing the effect of an along-strike change in dip on rupture propagation on strike-slip faults. In this geometrical parameter study, I conduct 3D dynamic models of rupture propagation on strikeslip faults with a planar strike but a change in dip midway along the fault, in order to see how far rupture is able to propagate beyond the dip inflection point. I test a variety of dip angles, and I vary the abruptness at which the dip change occurs. I explore this parameter space for several initial stress amplitudes and orienta- tions. This study may help assess possible rupture segmentation and endpoints for strike-slip faults with variable dip, as well as providing potential explanations for rupture endpoints along apparently planar fault segments.

Earthquake Rupture Propagation and Termination in Fault Zones with AlongStrike Variation of Damage

HUANG, Y. H., University of Michigan, Ann Arbor, Michigan, USA, yiheh@ umich.edu; LOZOS, J. C., CSU, Northridge, California, USA, julian.lozos@ csun.edu

Faults are surrounded by a hierarchical structure of damaged rocks. Such damaged fault zones can extend several hundred meters across major faults such as $S a n$ Andreas, Nojima and North Anatolian faults. They also show along-strike variation of damage that may be correlated with historical earthquake ruptures. Due to the change of energy required for rupture propagation, the variation of fault zone structure can either prohibit or assist rupture propagation and significantly affect the final sizes of earthquakes. Recent dense array data recorded at the San Jacinto fault zone suggests the existence of three prominent fault zones across the Anza seismic gap and the south section of the Clark branch, whereas fault zones were not detected near the ends of the Anza seismic gap. We investigate the effects of along-strike variation of fault zone damage using dynamic rupture simulations, which calculate the time-varying rupture process by considering the interactions between fault stresses, friction, and material heterogeneities. We first focus on along-strike rupture propagation in a $2 \mathrm{D}$ configuration. We will show that, for small nucleation sizes and short rupture propagation distances, ruptures nucleated in fault zones tend to terminate when they enter intact rocks outside fault zones. The stopping effect is less pronounced when fault zones become wider, sharper and more damaged, indicating a temporal correlation between the fault zone structure and break-through ruptures. Moreover, break-through ruptures are also expected when a sufficiently-large high-stress asperity exists at the end of the fault zone. We will then present 3D scenarios of San Jacinto earthquake ruptures and investigate whether ruptures can break through the Anza seismic gap given the current stress state and the distribution of fault zones. Our results suggest that a priori knowledge of the fault zone structure is of great importance for predicting sizes of future large earthquakes on major faults.

\section{The Effects of Roughness and Off-Fault Plasticity on the Rupture Process during Multiple Slip Events}

TAL, Y., Caltech, California, USA, yuvaltal82@gmail.com; LAPUSTA, N., Caltech, California, USA, lapusta@caltech.edu

Measurements of fault geometry show that faults are rough at all scales. This deviation from planarity results in geometric asperities, which affect the nucleation and propagation of shear rupture. Simulations of the response to slow tectonic loading of rough faults governed by rate and state friction in an 2-D elastic medium (Tal et al., 2018) show that the roughness complicates the rupture process with asymmetric expansion of the rupture, non-monotonic increase in the slip rates, and the generation of multiple slip pulses. Moreover, with increasing roughness there is a transition from seismic slip to aseismic slip, in which the load on the fault is released by more slip events but with lower slip rate, seismic moment, and average static stress drop. The mortar-based finite element formulation used in these simulations enables an accurate modeling of the effects of the fault geometry, and by using a variable time stepping, with a transition between quasi-static and fully dynamic time schemes, all the stages in the seismic cycle are modeled. In this study, we further develop the simulations of rough faults by adding the following additional physics: the delayed response of the shear resistance on the fault to rapid variations of the normal traction; potential large reduction of the friction coefficient observed in at high-speed friction experiment; and inelastic response of the medium surrounding the fault, as expected next to sharp geometric irregularities and at the rupture front during the dynamic propagation of the rupture. We implement a combined rate-and-state flash heating friction law into the method, model the inelastic off-fault response using a return-mapping algorithm, and account for the effects of normal stress changes on the frictional resistance. Using 2-D simulations of earthquake sequences of at least two events, we aim to understand the effects of those additional complexities on the rupture process on rough faults throughout the seismic cycle.

Dynamic Rupture Simulations at the Scale of Megathrust Fault Systems GABRIEL, A.A., Ludwig Maximilians University of Munich, Bavaria, Germany, gabriel@geophysik.uni-muenchen.de; ULRICH, T., Ludwig Maximilians University of Munich, Bavaria, Germany, ulrich@geophysik.uni-muenchen. de; MADDEN, E. H., Ludwig Maximilians University of Munich, Bavaria, Germany, madden@geophysik.uni-muenchen.de; WOLLHERR, S., Ludwig Maximilians University of Munich, Bavaria, Germany, wollherr@geophysik. 
uni-muenchen.de; DURU, K. C., Ludwig Maximilians University of Munich, Bavaria, Germany, duru@geophysik.uni-muenchen.de

Typical subduction zones are characterised by curved thrust fault geometries that merge with the bathymetry under very shallow angles of narrow subduction wedges. Additionally, complicated networks of fault branches at high angles to the megathrust in the overriding and oceanic plates potentially generate strong gaining effects of vertical sea-floor displacements, making tsunami generation more likely. We present high-resolution physics-based numerical simulations of the 2004 Sumatra-Andaman earthquake, including non-linear frictional failure on a megathrust-splay fault system, off-fault plasticity, seismic wave propagation up to $2.2 \mathrm{~Hz}$ in 3D media and bathymetry. We specifically analyse splay fault slip transfering into vertical sea-floor displacement which may be required to generate large events despite the fact that observations suggest high-fluid pressure and low stress drops limiting the available energy. The earthquake scenario matches coseismic slip and horizontal and vertical surface displacements inferred from observations. We find a high sensitivity of splay fault activation and plasticity effects to the orientation of the background stress field in conjuncture with fault geometry. Considering the geometric complexity of subduction zones and their potentially characteristically long rupture duration, invariably leads to huge differences in element sizes and many thousands of time steps. Our largest model consists of up to 221 million elements and 111 billion degrees of freedom. Such high fidelity simulations were performed using recent advances applied to SeisSol (www.seissol.org), specifically through a novel clustered local-time-stepping scheme extended to the dynamic rupture implementation (Uphoff et al., SC17).

\section{Three-Dimensional Rupture Dynamics of Tsunamigenic Earthquakes Incorporating Inelastic Wedge Failure}

MA, S., San Diego State University, California, USA, sma@mail.sdsu.edu; NIE, S., San Diego State University, California, USA, shiying.nie@gmail.com

Shallow subduction zones (upper $10-15 \mathrm{~km}$ ) host earthquakes of anomalous attributes. These earthquakes occur on shallow-dipping plate interfaces (dips less than $\sim 15^{\circ}$ ) but are efficient in tsunamigenesis. They also have abnormally slow rupture velocity, long rupture duration, depletion in high-frequency radiation, and low moment-scaled radiated energy. Any good tsunamigenic earthquake models need to explain both efficient tsunami generation and anomalous rupture characteristics as a whole. Here we extend our previous 2D poroelastoplastic model of shallow subduction zone earthquakes (Ma, 2012; Ma and Hirakawa; 2013; Hirakawa and Ma, 2017) to 3D. We show that three-dimensional inelastic wedge failure in the presence of frictional heterogeneity leads to significant slow rupture velocity along strike (versus along dip in 2D), long rupture duration, and efficient tsunami generation. Large slip near the trench is not required; peak uplift is landward from the trench when significant wedge failure occurs. Simulations show consistently deep fast rupture velocity along strike and slow shallow rupture (due to velocity-strengthening friction and wedge failure), confirming a rupture model proposed by Seno and Hirata (2007) in explaining the anomalous geodetic observation on Andaman and Nicobar Islands 2000 s after the nucleation of the 2004 M9.2 Sumatra earthquake. This elastoplastic wedge model can also explain why the largest tsunami in the 2011 M9.0 Tohoku earthquake occurred at the coast of Sanriku ( $100 \mathrm{~km}$ northwest of the epicenter) while the large near-trench slip was not observed in the northern Japan Trench from the bathymetry before and after the earthquake (Fujiwara et al., 2017).

Reawakening of the Wharton Basin (Indian Ocean) Led to Unusual Ocean Plate Earthquakes during 2004-2016

RAJENDRAN, K., Indian Institute of Science, Karnataka, India, kusalaraj@ gmail.com; PARAMESWARAN, R. M., Jawaharlal Nehru Centre for Advanced Scientific Research, Karnataka, India, revathy.parameswaranm@gmail.com; RAJENDRAN, C. P., Jawaharlal Nehru Centre for Advanced Scientific Research, Karnataka, India, cprajendran@gmail.com

The 2004 earthquake on the Sumatra trench was followed by a series of large events, along the plate boundary and within the subducting plate. Post-2004, the Wharton Basin was unusually active, notably the 2012, largest strike-slip earthquakes ever recorded. Here we discuss two types of earthquakes, those close to the trench (intraslab) and those, away from the trench (intraplate). The 2005 and 2010 earthquakes were sourced closer to the trench and their mechanisms show strike-slip faulting with some oblique slip. With its shallow dip-slip component, the latter generated a mild tsunami whereas the former did not as it exhibited no dip-slip component. Sourced at $\sim 16 \mathrm{~km}$ and $35 \mathrm{~km}$ depth respectively, the 2005 and the 2010 earthquakes are believed to be the result of reactivation of the N-S fossil fabric within the subducting slab, following the post-2004 redistribution of stresses. Located within the oceanic plate, the 2012 and the 2016 earthquakes failed by pure strike-slip mechanism. While the deep centroid estimates from routine long-period modeling using Preliminary Reference Earth Model

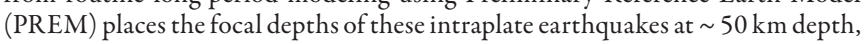
other models propose shallower focus, above the $600^{\circ} \mathrm{C}$ isotherm depth. Thus, the source model for the 2016 earthquake places its depth at $\sim 35 \mathrm{~km}$ and the rupture is interpreted as N-S and bilateral, which transects the orthogonal ridgeparallel fabric. Models of the 2012 earthquake also argue for complex and conjugate ruptures that involve the E-W fossil ridges. The deeper geometry of the faults inferred from geophysical evidence in the source zone of the 2012 earthquakes however suggest $\sim$ north-striking, east-dipping structures which possibly act as slip planes following the Olivine crystal preferred orientations, a model applicable also for the 2016 event. The 12-year history of the Wharton Basin presents ample evidence for its various modes of reawakening, following the 2004 megathrust earthquake.

\section{The Fault Geometry Explains the Rupture Complexity of the 2012 Mw 8.6 Indian Ocean Earthquake}

PARAMESWARAN, R. M., Jawaharlal Nehru Centre for Advanced Scientific Research, Karnataka, India, revathy.parameswaranm@gmail.com; RAJENDRAN, K., Indian Institute of Science, Karnataka, India, kusalaraj@ gmail.com; SOMALA, S. N., Indian Institute of Technology, Hyderabad, Andhra Pradesh, India, surendra@iith.ac.in; RAJENDRAN, C. P., Jawaharlal Nehru Centre for Advanced Scientific Research, Karnataka, India, cprajendran@gmail. com

The $2012 \mathrm{Mw} 8.6$ and Mw 8.2 Indian Ocean earthquakes, the largest instrumentally recorded strike-slip events, are reportedly associated with intriguing fault rupture geometry. The westward directionality of propagation and aftershocks of the Mw 8.6 mainshock had implied a causal relation to a complex geometry involving conjugate fault-legs spanning several hundreds of kilometers (e.g.: Meng et al., 2012; Hill et al., 2015). The Harvard GCMT depths for these events at $50 \mathrm{~km}$ however, remained highly contested given the multi-fault source mechanism and the existing gaps in our understanding of the seismogenic nature of the oceanic crust. Interestingly, recent seismic imaging of the Wharton Basin allows better constraints on the sub-surface structures and rheology of the lithosphere in this part of oceanic basin (e.g., Qin and Singh, 2015; Qin et al., 2017; Singh et al., 2017). The current study uses the newly available data on the geometry of the $\sim \mathrm{N}-\mathrm{S}$ faults and the improved velocity structure to generate a forward model of the Mw 8.6 mainshock using SPECFEM3D to recreate its most salient coseismic effects by computing the wave-propagation after event nucleation. The results agree with the observed NW-SE trend of aftershock growth and previously obtained back-projection results. We demonstrate that the fault mechanism of the mainshock can be explained by invoking a non-planar fault that curves at subMoho depths. The non-planar fault whose surface projection is consistent with the N-S transcurrent fault is explained using the Crystal Preferred Orientation (CPO) of Olivine, at $\sim 50 \mathrm{~km}$ depth.

\section{The Future of Telemetered Seismic Arrays-Where the Operation of the Network Ends and the Science Begins} Oral Session - Wednesday 16 May · 2:15 PM - Tuttle Session Chairs: Tim Parker, Dario Baturan, and David Eaton

\section{Plate Boundary Observatory GNSS Operations in Alaska: Challenges and Performance}

AUSTIN, K. E., UNAVCO, Washington, USA, austin@unavco.org; BOYCE, E., UNAVCO, Alaska, USA, boyce@unavco.org; FEAUX, K. F., UNAVCO, Colorado, USA, kfeaux@unavco.org; HODGKINSON, K. M., UNAVCO, New Mexico, USA, hodgkin@unavco.org; MATTIOLI, G. S., UNAVCO, Colorado, USA, mattioli@unavco.org; MENCIN, D., UNAVCO, Colorado, USA, mencin@unavco.org

The EarthScope Plate Boundary Observatory (PBO) GNSS network, funded by the NSF and operated by UNAVCO, in Alaska is comprised of 140 permanent GPS and GNSS stations. Of the Alaska portion of the network, 87 stations sit within the subduction zone footprint, including the volcano clusters on Akutan, Augustine, and Unimak. UNAVCO operates 18 real-time GNSS stations in Alaska, the majority of which sit above the subduction zone and as new communications avenues open up, will be adding more. The 1-sps real-time data are available from UNAVCO in BINEX and RTCM formats with Precise Point Position (PPP) solutions generated for each site using the NMEA format. The size and remoteness of Alaska requires the use of multiple modes of communications, depending on the localities. Satellite (VSAT and BGAN) modems are sometimes the only viable means of telemetry, especially along the Aleutian Arc, and tend to be more costly, slower and use more power resources compared to other sys- 
tems. As cellular service expands in the state, cell modems provide an easy and economical solution where coverage is available, but suffer from infrequent outages that are beyond our operational control. Radio networks are robust and economical when well designed, but depend on the telemetry solution at the central uplink site. Many of the villages are now receiving $3 \mathrm{G}$ and faster service via cell modem, and WISPs. In collaboration with other agencies UNAVCO operates 4 integrated GPS/seismic stations with the Alaska Earthquake Center, 9 with the Alaska Volcano Observatory, and 13 with the TA. These stations typically operate on shared telemetry with all parties sharing maintenance responsibilities. The Jan 232018 Mw7.9 Gulf of Alaska earthquake provided a great test case for the network as a whole. 14 of the 18 RT GNSS stations captured the earthquake. Given mid winter and the higher likelihood for stations going down, $~ 85 \%$ of the stations in Alaska returned high rate data from a post earthquake response and more recovery may be possible as some of the communications are restored

Evolution of the Alaska Volcano Observatory (Avo) Seismic Network PASKIEVITCH, J.F., US Geological Survey-AVO, Alaska, USA, jpaskie@usgs. gov; READ, C. W., US Geological Survey-AVO, Alaska, USA, cread@usgs.gov; KETNER, D. M., US Geological Survey-AVO, Alaska, USA, dketner@usgs.gov; KAUFMAN, A. M., UAFGI-AVO, Alaska, USA, amkaufman@alaska.edu

AVO has operated a seismic network since its inception in 1988. It started with about a dozen short-period (SP) analog seismic stations deployed throughout the Cook Inlet region. The network has expanded to now include over 200 stations, a mix of legacy SP and new digital broadband stations distributed along a 1700 mile swath of Alaska. The SP analog stations provided an affordable instrumentation package that allowed basic volcano monitoring, eruption detection in most cases, and eruption forecasting in some. AVO's slow but steady efforts to modernize and enhance this network are driven by the needs to 1) transition from aging analog instrumentation, 2) develop multi-parametric sites using easy-to-integrate instrumentation, and 3) increase capabilities to meet the National Volcano Early Warning System (NVEWS) plan - a national-scale plan to ensure volcanoes are monitored at levels commensurate to their threats. Digital instrumentation and communication platforms provide the infrastructure necessary for plug-n-play expansions - the easy ability to enhance a seismic station's value by adding infrasound, cameras, GPS, tilt. Implementation is slow due to the high costs of operating in the remote and challenging environments of Alaska. We have performed conversions and upgrades of our analog sites over the last 6 years at a pace of about 10 sites per year. The current network balance is about 146 analog and 71 digital stations. Much of this progress is due to collaborations with other operators, principally UNAVCO-PBO, IRIS-TA, NTWC, and UAFGI-AEC, with whom we share sites, telemetry, staff, and logistics. These relationships are crucial to recent and future advancements in monitoring; much more can be gained by these coalitions. As we consider remaining upgrades, especially in light of NVEWS guidelines, it is important to build site and telemetry infrastructure with our partners to allow most if not all stations to support a broad suite of instrumentation.

\section{Towards Generating Research Grade Seismic Catalogs in Near Real-Time}

REYNEN, A., Nanometrics Inc., andrewreynen@nanometrics.ca; YENIER, E. Nanometrics Inc., emrahyenier@nanometrics.ca; BATURAN, D., Nanometrics Inc., dariobaturan@nanometrics.ca

Accurate and complete seismic event catalogs generated in real-time provide valuable insight into induced seismic risk management and public safety strategies among others. However, due to the vast amount of seismic data being collected, the construction of such catalogs is labor intensive. Hence an automated process is sought to reduce the workload involved in catalog production. Conventionally events are detected by applying an autopicker to seismic data streams and grouping picks into sets corresponding to potential events; picks are generated when a threshold is surpassed on a characteristic function (CF) for a given channel. In the scenario of a small magnitude event it is likely only a few channels have visible arrivals and the threshold must be set low to increase the chances of detecting these signals. However, reducing the threshold also increases the number of false positives produced. This mixture of true and false picks in any given solution can introduce significant errors into the corresponding event location. In order to maintain the system sensitivity ie. number of true positives (earthquakes) while reducing the effect of false positives (sets of noise picks) we apply a technique we call Feature Weighted Beamforming (FWB). Features are computed from 3C seismograms utilising; spectral content, covariance between channels, and common CFs (STA/LTA, Kurtosis). Models relating the features to phase likelihood and station-event azimuth are formed using machine learning techniques. Likelihood values are referenced to P-S phase pairs which are stacked on a $4 \mathrm{D}$ grid representing event location and origin time. Preliminary results show a significant reduction in the distance between automatic solutions and their corresponding manually reviewed counterparts as compared to conventional pick- ing techniques, as well as a significant reduction in the number of false positive detections.

\section{Enhancing Explosive Volcanic Eruption Detection and Characterization Using Integrated Seismo-Acoustic Networks \\ MATOZA, R. S., UC Santa Barbara, California, USA, matoza@geol.ucsb.edu}

Infrasound technology adds to a growing suite of geophysical tools available to characterize, understand, and monitor volcanic processes. Explosive eruptions are seismo-acoustic phenomena, generating large-amplitude acoustic waves as well as seismic waves. Precursory and co-eruptive seismicity includes individual volcano-tectonic (VT) earthquakes, long-period (LP) $(0.5-5 \mathrm{~Hz})$ events, and various types of volcanic tremor. The typical seismic expression of a sustained explosive eruption, a broadband signal $(\sim 0.1-20 \mathrm{~Hz})$ known as eruption tremor, usually has a limited propagation distance. The maximum observation range for eruption tremor is typically a few tens of kilometers, or up to a few hundred kilometers for larger eruptions. In contrast, similar-sized explosive eruptions produce powerful broadband $(\sim 0.01-20 \mathrm{~Hz})$ infrasound signals that can be ducted efficiently over long ranges (thousands of kilometers) in atmospheric waveguides; these signals are routinely detected on sparse ground-based infrasound networks. Seismic networks may also record eruption infrasound as ground-coupled airwaves; we show examples at hundreds of kilometers from the source. We are developing methodologies to search systematically through multi-year data from regional and global infrasound and seismo-acoustic networks to identify, time, quantify, and catalog explosive volcanic eruption signals. Detecting, quantifying, and cataloging the global occurrence of explosive volcanism helps toward several goals in Earth sciences and has direct applications in volcanic hazard mitigation. Augmenting seismic networks with infrasound sensors in regions of dense volcanism will dramatically enhance volcanic signal detection, reduce latency, and improve discrimination capability.

\section{Transportable Array Alaska-Power and Telemetry System Design and Performance}

BLOOMQUIST, D. K., IRIS, Pennsylvania, USA, doug.bloomquist@iris.edu; BUSBY, R. W., IRIS, Massachusetts, USA, busby@iris.edu; ENDERS, M. L., IRIS, Alaska, USA, enders@iris.edu; MINER,J.E., IRIS, Alaska, USA, miner@ iris.edu; BIERMA, R. M., IRIS, Alaska, USA, bierma@iris.edu; THEIS, J. M., IRIS, Alaska, USA, jason.theis@iris.edu

The Alaska Transportable Array (ATA) is a broadband seismic network made up of 280 new and existing stations that uniformly cover Alaska and north-west Canada. Over five field season from 2013-2017, 194 new stations were installed. In order to meet the performance requirements for the network, new power systems and telemetry systems were designed and produced on a large scale. The majority of ATA stations are installed in completely off grid locations with no access to an established electrical grid or telecommunications network. These off grid stations are fully autonomous and use solar panels and batteries for power and satellite modems to transmit data in real time. The stations also integrate additional instrument packages that include pressure sensors, infrasound sensors and weather stations. ATA stations use a dual battery chemistry power system made up of rechargeable lithium batteries and sealed lead acid batteries to minimize the system's weight and maximize its energy storage. Savings in weight and volume significantly reduce the cost and complexity of the logistics needed to move the equipment from where it's fabricated to where it operates. The autonomous ATA stations use high bandwidth satellite modems on the Inmarsat satellite network to transmit station data in near real time. The modems are configured to transmit station data in real time during the summer when incoming solar energy can be harvested with solar panels to keep the station batteries charged. In the winter months, the modems are operated in a lower power mode to maximize battery life yet still deliver data with less than 1 hour of latency. Additionally, autonomous ATA stations use very low power and low bandwidth Iridium modems to provide power system data as well as backup station state of health data in the event of a failure of the primary satellite modem. This state of health data helps operators troubleshoot the cause of outages and improves station service planning and success.

The Southern California Seismic Network, a Telemetered Array for Seismology and Earthquake Early Warning

STUBAILO, I., Caltech, California, USA, stubailo@gmail.com; ALVAREZ, M. G., US Geological Survey, California, USA, malvarez@usgs.gov; BIASI, G. P., US Geological Survey, California, USA, gbiasi@usgs.gov; THOMAS, V. I., US Geological Survey, California, USA, vthomas@usgs.gov; HAUKSSON, E., Caltech, California, USA, hauksson@gps.caltech.edu; BHADHA, R., Caltech, California, USA, rayo@gps.caltech.edu; DEVORA, A., Caltech, California, 
USA, alberto@gps.caltech.edu; WATKINS, M., Caltech, California, USA, watkins@gps.caltech.edu

In operation under various names since 1920, the Southern California Seismic Network (SCSN) has been continuously monitoring earthquakes occurring from central California (just south of San Luis Obispo ) to the U.S.-Mexican border. This network is cooperatively operated and maintained by the US Geological Survey and Caltech, with funding from both federal and state sources. The SCSN is a part of the California Integrated Seismic Network (CISN), and also a contributing Regional Seismic Network within the Advanced National Seismic System (ANSS). With a wide scientific and public mission, the network has developed into a multipurpose observatory capable of satisfying multiple operational objectives. With over 400 stations, this mostly real-time digital network now comprises strong motion, weak-motion, and broadband instrumentation. As part of the Earthquake Early Warning (EWW) System, additional stations are currently being installed across Southern California. The design of these stations incorporates instrumentation and techniques that maximize the signal-to-noise ratios of the seismic wave field as well as reduce the latency of data transmission for $\mathrm{EWW}$. In this presentation we discuss the performance characteristics of this network showing the noise characteristics and data latency.

\section{Earthscope Transportable Array in Alaska: Overview and Future Plans} BUSBY, R. W., IRIS, Massachusetts, USA, busby@iris.edu; WOODWARD, R. L., IRIS, District of Columbia, USA, woodward@iris.edu; ADERHOLD, K., IRIS, District of Columbia, USA, kasey@iris.edu; ENDERS, M. L., IRIS, Alaska,USA, enders@iris.edu

The Alaska Transportable Array deployment was completely installed as of Sept 2017, totaling 280 stations, with 194 new stations and 86 existing stations, 28 of those upgraded with new sensor emplacement. We briefly summarize the deployment of this seismic network, describe the added meteorological instruments and soil temperature profilers, and review the overwinter performance, current operation, and plans for demobilization set to begin in 2019. The Alaska Transportable Array is entering a period of routine data collection, though certain data collection functions as well as field activities are seasonally dependent. We describe how we have addressed these challenges with emerging technologies, and more technical details are provided by Bloomquist (SSA, 2018). Performance of the stations are generally high quality, with very low noise and high data return despite the challenging environment. As with previous TA deployments in Cascadia and the Central and Eastern US (CEUSN), efforts are ongoing to extend observations in Alaska through station adoption or cooperation with other agencies. Some of these agencies represent interests outside of seismological research yet take advantage of the micro-research station features of an operational Alaska TA station: primarily the enclosure, power, and data communications. We identify timelines for that collaborative planning so as not to interfere with NSF objectives and land management agency approvals.

High Latitude Telemetry: Trades between Sample Rate, Power and Latency CARPENTER, P., PASSCAL Instrument Center, NMT, New Mexico, USA, pcarpenter@passcal.nmt.edu; NIKOLAUS, K., PASSCAL Instrument Center, NMT, New Mexico, USA, knikolaus@passcal.nmt.edu; BEAUDOIN, B. C., PASSCAL Instrument Center, NMT, New Mexico, USA, bruce@ passcal.nmt. edu

High-latitude telemetry is limited by communication network infrastructure, both terrestrial and space based. Few high-latitude regions of the Earth have cabled Internet or mains power, and satellite coverage is often constrained to polar orbiting constellations. These limitations are further complicated by extreme environmental conditions, months without solar charging, and costly logistics. In 2006, the IRIS PASSCAL Instrument Center began developing communications and power solutions for deployment of portable seismic stations in Antarctica. Over the last decade, improvements in power systems, station enclosures, and Iridium based telemetry has enabled real-time seismic data from some of the most remote, high-latitude seismic stations. However, telemetry in these environments require evaluating trades between sample rate, power, and latency, and these decisions directly impact logistics costs. Here we discuss these trades by highlighting several successful station telemetry configurations.
Long-Period Signals During Large Earthquakes on Alaska Transportable Array

ADERHOLD, K., IRIS, District of Columbia, USA, kasey@iris.edu; BUSBY, R. W., IRIS, District of Columbia, USA, busby@iris.edu; FRASSETTO, A., IRIS, District of Columbia, USA, andyf@iris.edu

The Alaska Transportable Array is a real-time seismic network of 280 new and contributing stations across Alaska and western Canada. The 194 new Alaska TA stations constructed from 2013-2017 have already recorded numerous earthquakes. The large geographic coverage and high station density has enabled the Alaska Earthquake Center to exceed the annual record for earthquakes detected and located in 2017. Among the earthquakes recorded by the Alaska TA are two large strike-slip earthquakes that occurred in south central Alaska: the 23 January 2018 M7.9 Ayjay earthquake and the 24 January 2016 M7.1 Iniskin earthquake. During both events, some nearby sensors recorded long-period signals during the time period that the body and surface waves arrived at the stations. We examine these signals at Alaska TA, Global Seismographic Network (GSN), and Alaska Earthquake Center (AEC) stations and characterize these long-period signals based on the possible origin of the signal being related to instrument or emplacement characteristics.

\section{The Canadian Cordillera Array: Towards a Multi-Disciplinary Geoscience} Program for Canada

BENT, A. L., Natural Resources Canada, allison.bent@canada.ca; BOGGS, K., Mount Royal University, kboggs@mtroyal.ca; EATON, D., University of Calgary, eatond@ucalgary.ca; JAMES, T. S., Geological Survey of Canada, thomas.james@canada.ca; AUDET, P., University of Ottawa, paudet.uottawa@ gmail.com; SIDERIS, M., University of Calgary, sideris@ucalgary.ca; ULMI, M., Geological Survey of Canada, malaika.ulmi@ canada.ca; FAYEK, M., University of Manitoba, mostafa.fayek@umanitoba.ca; ASTER, R. C., Colorado State University, Colorado, USA, rick.aster@colostate.edu; SCHUTT, D., Colorado State University, Colorado, USA, derek.schutt@ colostate.edu

The Canadian Cordillera Array (CCArray) is an initiative to install a Cordilleranscale open-data network in Canada with the goal of holistically examining the Earth system from the core to the magnetosphere. Building on the scientific momentum of previous Earth systems research and data acquisition initiatives in North America (e.g. Lithoprobe (1984 to 2004) and EarthScope (2004 to 2018 or later)), the vision for CCArray is to install a network of multidisciplinary telemetered observatories. The core CCArray network is envisaged to include broadband seismometers (including ocean bottom seismometers in the Beaufort Sea and offshore British Columbia) and Global Navigation Satellite System (GNSS) receivers. Solid Earth objectives include improving understanding of Earth structure, tectonics, earthquake occurrence and seismic hazard, glacial isostatic adjustment, induced and triggered seismicity from resource extraction, mountain glacier change, and better determining vertical land motion for robust relative sea-level projections. Associated broader Earth science objectives include establishment of Critical Zone Observatories, ionospheric and tropospheric investigations, and studies of the active zone and permafrost dynamics. Additional instrumentation and measurements at selected locations could include meteorological and atmospheric gas sensors, borehole temperature and moisture sensors, riometers and magnetometers, and relative and absolute gravity measurements. The intention is to continue operation of some stations to densify long-term monitoring across Canada. CCArray represents the initial component of an envisaged future pan-Canadian Earth observation network called Earth-system Observing Network—Réseau d'Observation du Système TerrestrE (EON-ROSE).

\section{Megathrust Earthquakes: Recurrence, Rupture Modes and Tsunamis (Parts 3 and 4) Oral Session - Wednesday 16 May · 8:30 AM - Tuttle Session Chairs: Peter Molnar, Peter Haeussler, and Brian F. Atwater}

What Does the Present State of Locking along the Aleutian Megathrust Tell Us about Earthquake and Tsunami Hazard?

WITTER, R. C., US Geological Survey, Alaska, USA, rwitter@usgs.gov; ENGELHART, S. E., University of Rhode Island, Rhode Island, USA, engelhart@uri.edu; BRIGGS, R. W., US Geological Survey, Colorado, USA, rbriggs@usgs.gov; KOEHLER, R. D., University of Nevada, Reno, Nevada, USA, rkoehler@unr.edu; NELSON, A. R., US Geological Survey, Colorado, USA, anelson@usgs.gov; GELFENBAUM, G., US Geological Survey, California, USA, ggelfenbaum@usgs.gov; HAEUSSLER, P. J., US Geological 
Survey, Alaska, USA, pheuslr@usgs.gov; VANE, C. H., British Geological Survey, United Kingdom, chv@bgs.ac.uk

Locking along the Aleutian megathrust varies in space and time based on 25 years of satellite geodesy (Freymueller et al., 2008). Here, we summarize tsunami histories at four eastern Aleutian sites where the megathrust exhibits different locking states. First, on the Shumagin Islands where megathrust creep dominates, we found scant evidence for tsunamis in the past $3.4 \mathrm{ka}$ and no evidence for vertical tectonic displacement $\geq 0.3 \mathrm{~m}$. We conclude that slip in the Shumagins occurs as persistent aseismic creep over millennia, punctuated by large earthquakes (up to M7.5 observed historically). Second, $300 \mathrm{~km}$ west near Sanak Island, upper-plate velocities from satellite geodesy imply a freely-slipping megathrust, yet nearby the M8.6, 1946 Unimak Island near-trench rupture generated a tsunami that ran up to $42 \mathrm{~m}$ at Scotch Cap. Coastal evidence at Sanak Island records the 1946 tsunami deposit, and four prehistoric tsunamis between $2-4.5$ ka likely generated by great $(M \geq 8)$ earthquakes in a currently creeping area. Third, the Fox Islands lie another $100 \mathrm{~km}$ west and span a transition from a creeping to a locked megathrust at the eastern end of the M8.6, 1957 Andreanof Islands rupture. Here, Stardust Bay (creeping) records six large tsunamis in the past $1.7 \mathrm{ka}$ where numerical models of the 1957 runup imply a near-trench rupture. Driftwood Bay (locked) holds evidence for eight large tsunamis in the past $2.2 \mathrm{ka}$. Neither site records the giant 1946 tsunami. Finally, similar tsunami histories at the two neighboring Fox Island sites show that there are few differences in tsunami hazard across a major change in megathrust locking. We find that past seismic and tsunami hazards are difficult to infer from present megathrust locking patterns. Next generation models that relate megathrust locking to hazard must account for poor constraints on near-trench locking, post-seismic locking that evolves over decades to centuries, and potential strain stored in millennial-scale supercycles.

\section{The Northern Caribbean Megathrust}

TEN BRINK, U. S., US Geological Survey, Woods Hole, Massachusetts, USA, utenbrink@usgs.gov

The highly-variable deformation mode along the NE Caribbean subduction/ collision zone probably precludes simultaneous rupture of the entire subduction zone, but may still lead to intraplate earthquakes and tsunamis. Under the Lesser Antilles, where subduction of the North American plate is at high angle, island arc volcanism and large earthquakes occur. The convergence component decreases significantly as the subduction zone curves westward into the Puerto Rico Trench. Tsunami deposits mapped on the island of Anegada, BVI were modeled to arise from an M8.2-8.45 thrust or outer-rise normal earthquake. North of Puerto Rico, the trench is unusually deep and wide, is associated with an extremely negative gravity anomaly, and coincides with trenchward tilting and motion of the island. Frequent deep earthquake swarms occur, but analyses of historical earthquakes and strain partitioning do not support large earthquakes. This segment of the trench is deduced to have low seismic coupling perhaps due to a slab tear. Farther west, north of Mona Passage and eastern Hispaniola, the subducting slab is associated with shallow trench floor and with frequent 20th century earthquakes, the largest (M7.8-8.1) was associated with a devastating local tsunami. Earthquake recurrence in this segment is estimated at $\geq 450 \mathrm{yr}$. Strike-slip earthquakes on Hispaniola due to strain partitioning have an estimated recurrence of $\sim 300 \mathrm{yr}$. Subduction ends in central Hispaniola, presumably because it is where the North American slab has reached during the past $\sim 40$ Ma. Western Hispaniola undergoes diffuse transpression that also generated devastating earthquakes in 1842 and 2010. Seismic and tsunami hazards also arise from the southward push of the northern Caribbean arc against the Caribbean interior, which manifest in opposing thrusting style across the subduction/ transpression boundary, and from internal deformation of the arc, likely resulting from the segmentation of the subduction zone.

The CASEIS Project: Toward a Better Understanding of the Seismic Cycle and Paleoseismology of the Lesser Antilles Megathrust

FEUILLET, N., Institut de Physique de Globe de Paris, France, feuillet@ipgp.fr; RATZOV, G., Geoazur-Université de Nice, Alpes-Maritimes, France, ratzov@ unice.fr; SEIBERT, C., Institut de Physique de Globe de Paris, France, seibert@ ipgp.fr; MORENA, P. F., IFREMER, France, pierre.morena@ifremer.fr; BIEBER, A., UQAR, bieber@uqar.ca; BECK, C., Université Savoie Mont Blanc, France, christian.beck@univ-smb.fr; CARLUT, J., Institut de Physique de Globe de Paris, France, carlut@ipgp.fr; CARON, B., ISTEP, France, benoit.caron@ upmc.fr; CATTANEO, A., IFREMER, France, antonio.cattaneo@ifremer. fr; DUCASSOU, E., EPOC-Université de Bordeaux, France, emmanuelle. ducassou@u-bordeaux.fr; GOLDFINGER, C., CEOAS-Oregon State University, Oregon, USA, gold@ coas.oregonstate.edu; KLINGELHOEFER, F., IFREMER, France, frauke.klingelhoefer@ifremer.fr; LE FRIANT, A., Institu de Physique du Globe de Paris, France, lefriant@ipgp.fr; MORENO,
E., LOCEAN_Muséum National d'Histoire Naturelle, France, eva.moreno@ mnhn.fr; MULDER, T., EPOC-Université de Bordeaux, France, thierry. mulder@u-bordeaux.fr; ST-ONGE, G., ISMER-Université du Québec à Rimouski, guillaume_st-onge@uqar.ca; CASEIS Scientific Team

The Lesser Antilles arc results from the subduction of the North American plate underneath the Caribbean plate at $2 \mathrm{~cm} / \mathrm{yr}$. The seismic potential remains poorly constrained, because possible great earthquakes were prior to modern times. The interplate has thus often been assumed to be aseismic, and geodetic models show low coupling along this boundary. Modern studies show that probably all subduction zones can produce large events, and it becomes urgent to re-evaluate the seismic potential of the Lesser Antilles. Three morphological segments are characterized by a narrowing forearc and accretionary wedge northwards. To address long-term earthquake recurrence by using turbidite paleoseismology in all segments, we collected 42 giant piston cores $(500 \mathrm{~m})$ aboard the R/V Pourquoi Pas? in 2016 during the CASEIS cruise. Aboard, we acquired petrophysical and diffuse spectral reflectance measurements on sediment cores. Later analyses include XRF, CT-scan, granulometry, paleomagnetic analyses, bio- and isotopic stratigraphy, and $14 \mathrm{C}$ dating. The deposits include turbidites interbedded with hemipelagites and tephra in numerous cores. Chirp data and core physical properties suggest that events are correlated between multiple sites over large distances within each segment, and could be triggered by large infrequent interplate earthquakes. Cores offshore Guadeloupe show four alternations of several metersthick turbidites $(\mathrm{Tu})$ and/or homogenites $(\mathrm{Hm})$ and hemipelagites. Such $\mathrm{Hm}$ or Tu deposits documented elsewhere may be related to megathrust events and tsunamis. The first $14 \mathrm{C}$ ages date the uppermost deposits at $\sim 6 \mathrm{kyr}$ and $\sim 8 \mathrm{kyr}$ BP offshore Guadeloupe and Anguilla respectively. Offshore Martinique, preliminary biostratigrapy and $14 \mathrm{C}$ ages indicate compatible recurrences over the last 50 kyr BP, and a large turbidite deposited within $2 \mathrm{kyr}$ BP. Ongoing work on older events and establishing a more detailed chronostratigraphic framework should infer long-term recurrence and its variability.

Megathrusts and Tsunamis in the Caribbean

VON HILLEBRANDT-ANDRADE, C. G., National Oceanic and Atmospheric Administration, Puerto Rico, USA, christa.vonh@noaa.gov

The Caribbean is host to significant subduction zones with faults and processes that have generated large historical earthquakes and tsunamis causing from dozens to several hundred thousand deaths. As we look ahead to planning for these events, especially the less frequent tsunami and considering the many competing hazards the Emergency Management Community haveto prepare for, one of the oft asked questions of the tsunami specialists is: How Large can Tsunamis be in the Caribbean. Is a Chile, Alaska, Tohoku or Sumatra type event possible? The UNESCO IOC Intergovernmental Coordination Group for Tsunamis and Other Coastal Hazards for the Caribbean and Adjacent Regions has been grappling with this question since its inception in 2005. Over the years Group of Experts (GE) have met and come to a consensus for scenarios for some of the areas that should be considered for hazard and risk assessments. Areas addressed by this approach have been Northern and Southern Hispaniola and Caribbean Central America. For the annual CARIBE WAVE exercises guidance is requestedfrom seismic experts of the host scenarios for input, sometimes taking the science beyond credible. For each scenario, the seismologists are asked to provide the latitude, longitude and depth for the four corner points of each fault segment, as well as the dip, rake, slip and rigidity. This information is necessary for the tsunami modelers. While none of the scenarios from the GE meet the Megathrust criteria, the tsunami impact is still significant. Having a consensus facilitates the buy in by the Emergency Management and Government authorities and helps focus the discussion on the possible impacts. For CARIBE WAVE exercises, Mw 9.0 events have been used, always being careful to note that they are for exercise purpose only. These scenarios havehelped the hundreds of thousands of participants become familiar with different tsunami event timelines and impacts and be better prepared for future events.

\section{Drilling Through the Seismogenic Zone of Large Megathrust Earthquakes: An On-Land Opportunity in Osa Peninsula, Costa Rica}

PROTTI, J. M., Observatorio Vulcanológico y Sismológico de Costa Rica, Universidad Nacional, Heredia, Costa Rica, marino.protti.quesada@una.cr; WIERSBERG, T., International Continental Scientific Drilling Program, GFZ, Potsdam, Germany, icdp-outreach@gfz-potsdam.de; NOREN, A., University of Minnesota, Minnesota, USA, noren021@umn.edu; SCHWARTZ, S. Y., UC Santa Cruz, California, USA, syschwar@ucsc.edu; BANGS, N., University of Texas, Austin, Texas, USA, nathan@ig.utexas.edu; BAUMGARTNER, P., University of Lausanne, Lausanne, Switzerland, peter.baumgartner@unil. ch; FISHER, D., Penn State University, Pennsylvania, USA, fisher@geosc.psu. edu; KANEDA, Y., Kagawa University, Kagawa, Japan, kanedayjp@yahoo. 
co.jp; LAFEMINA, P., Penn State University, Pennsylvania, USA, pcl11@psu. edu; NEWMAN, A. V., Georgia Tech, Georgia, USA, anewman@gatech.edu; SUYEHIRO, K., JAMSTEC, Yokohama, Japan, suyehiro@gmail.com

A great geographical-temporal opportunity exists in Osa peninsula, southern Costa Rica, to drill and instrument a locked segment of the Middle America Subduction Zone, where the plate interface beneath the peninsula is only 4 to $8 \mathrm{~km}$ deep. This section of the subduction zone has had large $(\mathrm{Mw}=7.2-7.4)$ earthquakes in 1853,1904, 1941 and 1983. With an average recurrence interval of roughly 40 years, the timing is right to drill, instrument and record data of unrivalled importance before, during and after the next large earthquake in this region. Trench-parallel, landward dipping reverse faults have been mapped on the peninsula, which could represent splay faults and conduits, similar to those imaged offshore Nankai; therefore this will be an ideal site to compare with very important results that are currently obtained in the Nankai Through. Since the trench is only $20-30 \mathrm{~km}$ from the peninsula, submarine cables with seafloor instrumentation, power and data transmission can be deployed and tight to borehole instrumentation, at a much lower cost than in other subduction zones. Drilling and instrumenting the holewould help establish the relationship between geology, upper plate structure, surface deformation and the characteristics of the locked interface. The integration of these datasets would be an opportunity to relate secular processes such as strain accumulation and seismic slip with the longer term evolution of the margin. This will be a chance to contribute to the international efforts done all over the world as part of a network of observatories to understand the genesis of large and destructive earthquakes and contribute to the reduction of their potential damage. The combination of low relative cost and huge scientific potential make the Osa Peninsula a compelling drilling target for the international community. Resources from ICDP and national scientific funding agencies could be leveraged to take advantage of this unique tectonic and temporal opportunity.

\section{How Large Can Megathrust Earthquakes Be in the Central American Subduction Zone?}

SUAREZ, G., Instituto de Geofísica, Universidad Nacional Autónoma de México, Mexico City, Mexico, gersua@yahoo.com

The subduction zone in Mexico has unique characteristics as compared to the other subduction zones in the western and eastern Pacific. In Mexico, the scale appears to be a two-to-one size compared to other subduction regimes. The distance from the trench to the coast and the average thickness of the continental lithosphere, above the locked interplate zone, is half of what is observed in other regions. The comparison between Mexico and Peru and Central Chile, where the slab also subducts sub-horizontally, clearly demonstrates this scaling. The result of this unique tectonic structure is that the maximum depth of seismogenic coupling in Mexico, as shown by geodetic studies and aftershock observations, is only $20 \mathrm{~km}$ deep, as opposed to the width of the interplate contact of up to 50 $\mathrm{km}$ observed in other subduction zones. The width of the locked interplate zone appears to be the limiting factor on the size of the largest earthquakes generated along the Pacific coast of Mexico. A comparison of great subduction earthquakes in Mexico and South America clearly brings out that the Mexican subduction zone has earthquakes that normally are not greater than $\mathrm{Mw}$ 8.1. In contrast, during the instrumental period of almost 120 years, South America has suffered much more frequent and larger events $(\mathrm{Mw} \geq 8.6)$. The reason may be the anomalously thin lithosphere of the continental plate, overlying the megathrust plate contact. Although earthquakes as large as Mw 8.6 are present in the Mexican subduction zone, as interpreted from the historical records, these great earthquakes are infrequent. Thus the average magnitude of large earthquakes appears to be controlled by the narrow seismogenic zone resulting from this unique tectonic environment. This limit on the size of great earthquakes in Mexico is important for the estimation of seismic risk in the region.

\section{Interseismic Coupling and Quaternary Coastal Tectonics along the Andean Megathrust}

AUDIN, L.,IRD-ISTerre, Grenoble, France, laurence.audin@ird.fr; SAILLARD, M., IRD-Geoazur, Nice, France, saillard@geoazur.unice.fr; BENAVENTE ESCOBAR, C. L., INGEMMET, Lima, Peru, cbenavente@ingemmet.gob.pe; ALVARADO, A., IG-EPN, Quito, Ecuador, aalvarado@igepn.edu.ec

The Andean margin is one of the most active subduction zone worldwide (e.g., the $1960 \mathrm{Mw} 9.5$ Chile or the Mw 8.81906 Ecuador earthquakes). We here propose that the interseismic coupling along the Andean megathrust relates to spatial variations along the interface as well as the fore-arc geology and inherited fault zones. For such matter, we compiled information on the extent of earthquake ruptures for the last 500 years, geodetic data and uplift rates derived from marine terraces from Ecuador to Chile. First, we show that 1) the coastline geometry, characterized by the distance between the coast and the trench, 2) the latitudinal variations of long-term uplift rates, 3) and the spatial pattern of interseismic coupling are correlated. In addition, the seafloor roughness of the subducting plate is usually thought to be a cause of segmentation along subduction zones. But, after discussing the role of inherited structures within the upper plate to the megathrust segmentation in Ilo area during the Arequipa earthquake, we suggested that the continental structure itself may exert some feedback control on the segmentation and thus participate in the rupture pattern of major subduction earthquakes. This hypothesis tends to correlate with similar observations on crustal faulting in Pichelemu area in Chile. Finally, it's now widely accepted that paleotsunami deposits can be used as the primary sources of information on past large megathrust events. In southern Ecuador and northern Peru, the low coupling areas suggest rather rare tsunamigenic events and sedimentary evidences represent a useful tool to extend the cataloging of large earthquakes in the past thousand years. All together these multidisciplinary approaches suggest that the spatial variations of frictional properties along the megathrust dictate the geomorphology of the coastal zone and can inform on the extent of seismic ruptures along strike.

\section{Large Earthquakes in Central Chile as Evidenced by Coastal Elevation Changes}

BARRIENTOS, S. E., CSN, Universidad de Chile, Chile, sbarrien@csn.uchile. cl; DEL CAMPO, F., CSN, Universidad de Chile, Chile, fdelcampo@csn.uchile. $\mathrm{cl}$

Chile is permanently exposed to the consequences of large earthquakes. Since 1900 , fourteen events with magnitudes around 8 or over have taken place in this country. Among these, is the 1960 event, the largest earthquake ever recorded since the beginning of instrumental seismology. With magnitudes that can reach values well over 8 , the events located along the boundary of the Nazca and South American plates are usually accompanied by noticeable coastal elevation changes and, depending on the amount of seafloor vertical displacement, by catastrophic tsunamis. Central Chile is no exception, large events ( $M$ around 8 or larger) which could be considered as rupturing the main portion of the seismogenic width have taken place in $1647,1730,1822,1906$ and 1985. Clearly, the 1730 event stands out as the largest of this sequence. Although the recurrence intervals have been very regular ( $82 \pm 6$ years), the rupture lengths differ substantially; the largest rupture, close to $600 \mathrm{~km}$, was that associated with the 1730 event. Exiguous evidence of coastal elevation changes as revealed by witness reports in 1822, in particular at Valparaíso of nearly three feet and four feet $30 \mathrm{~km}$ north of Valparaíso (Graham, 1824) and more abundant data for the 1906 event expressed in coastal uplift up to $1 \mathrm{~m}$ from Los Vilos to Pichilemu $\left(32.5^{\circ} \mathrm{S}-34.3^{\circ} \mathrm{S}\right.$; Steffen, 1907 ) are used as an indication of possible rupture areas associated with these events. For this last event, the recovered seismic moment is consistent with that derived from seismic estimations (Okal, 2005). Comparison of the 1906 rupture area with more precise determinations for the 1985 event (Barrientos, 2007), allow inferences of a variable mode of rupture in Central Chile. Updated plate locking models obtained by GNSS velocity estimations in the region, together with GNNS derived slip distribution for the April 24, 2017, M6.9 event are used to interpret the current state of preparation of the next large event in the area.

\section{Seismic Gaps and Asperities Along the South American Subduction Zone: An Update}

NISHENKO, S., Pacific Gas and Electric Company, California, USA, spn3@ pge.com; LAY, T., Department of Earth and Planetary Sciences, UC Santa Cruz, California, USA, tlay@ucsc.edu

So far this century, six $\mathrm{Mw} \geq 7.8$ earthquakes have ruptured portions of the subduction zone plate boundary of western South America along Ecuador, Peru, and Chile. Each source region had a history of prior great earthquakes and had not ruptured in recent decades. Their identification as seismic gaps, with the potential to host future great megathrust earthquakes, helped guide the selection of several regions for intensive earthquake research and monitoring. Reevaluations of older instrumentally recorded earthquakes, as well as paleoseismic studies of historic events have reduced the epistemic uncertainty in characterizing great earthquake rupture in the region. Comparisons of great earthquakes that have occurred along the same portion of the seismic zone have also demonstrated the range of aleatory variability between successive ruptures. Installation of dense seismic and geodetic monitoring arrays significantly enhanced the resolution of subsequent faulting processes. Patterns of heterogeneous pre-seismic and co-seismic deformation reflect spatial variations in the frictional properties of the megathrust. Localized areas of high coseismic moment release have been correlated with regions of high interseismic coupling or asperities. The persistent nature of these asperities and interactions between adjacent asperities on the megathrust influences the variability of great earthquake ruptures from cycle to cycle. Observations from the recent sequence of great earthquakes provides an opportunity to update the cur- 
rent perspective on earthquake hazard for the remaining seismic gaps along the South American subduction zone.

Case of an Orphan Tsunami on the Konkan Coast, Western India: A Distant Megathrust or a Near-Field Source?

RAJENDRAN, C. P., Jawaharlal Nehru Centre for Advanced Scientific Research, Bangalore, India, cprajendran@gmail.com; HEIDARZADEH, M., Brunel University London, United Kingdom, London, mohammad. heidarzadeh@brunel.ac.uk; KARTHIKEYAN, A., Jawaharlal Nehru Centre for Advanced Scientific Research, Bangalore, India, sabarigeo@gmail.com; RAJENDRAN, K., Indian Institute of Science, Bangalore, India, kusalaraj@ gmail.com; SANWAL, J., Jawaharlal Nehru Centre for Advanced Scientific Research, Bangalore, India, jaishrigeology@gmail.com; PARAMESWARAN, R. M., Indian Institute of Science, Bangalore, India, revathy.parameswaranm@ gmail.com

The last decade witnessed some unusually large tsunamis, and among these, the 2004 tsunami was an unprecedented experience for the coastal communities on the east coast of India. In comparison, the tsunami hazard for the west coast remains under-recognized. Our explorations led us to an intriguing near-beach $\sim 20$-m-thick sedimentary section of eolian sand at Kelshi, on the west coast, $\sim 120 \mathrm{~km}$ south of Mumbai. This section facing a tidal inlet shows three soilcompacted foundations (I, II and III), at about $1.5 \mathrm{~m}, 2 \mathrm{~m}$ and $3 \mathrm{~m}$ from the high tide level (HTL), which were active between 1450 and $1640 \mathrm{CE}$, as suggested by charcoal dates and also by pottery. At an elevation of $1 \mathrm{~m}$ from the HTL, we identified a thin $(10-20 \mathrm{~cm})$ band of laminated sand mixed with near-shore mollusc and gastropod shells. Thisdepositional event must have occurred before 1410 $-1456 \mathrm{CE}$, based on the charcoal date from the overlying strata. At $\sim 3 \mathrm{~m}$ from the HTL yet another, though a more prominent, band $(30-40 \mathrm{~cm})$ occurs, featuring flow structures interlayered with mollusc and gastropod shells that coexist with occasional human and bovine bones. The sedimentary structures include convolutions, dish and pillar structures along with sporadic heavy mineral-rich layers. We relate these anomalies at the Phase III occupation level to the impact of a strong current from the sea, contemporaneous also with the transportation of shells dated at 1508-1681 CE. While the 14th century tsunami, the penultimate to the 2004 Indian Ocean event could be related to the pre-Phase I depositional event, the causal mechanism for the 16th century features could be a more energetic tsunami run-up that chronologically matches with the $1524 \mathrm{CE}$ reports on "sea disturbances", sourced to the medieval Portuguese fleet. Numerical modelling of tsunami scenarios from near-field (e.g. local submarine landslides) and farfield (i.e. from the Makran subduction zone) are conducted to compare with the field data.

Microzonation Studies-Site Effects

Oral Session - Wednesday 16 May · 2:15 PM · Hibiscus B

Session Chairs: Ilias Papadopoulos and Michael Schmitz

Shear-Wave Velocity Model of the Santiago de Chile Basin as a Basis for the Identification of Stratigraphic and Topographic Site Effects

PILZ,M., GFZ Potsdam, Germany, pilz@gfz-potsdam.de

Sedimentary basins in seismic hazard areas are often sites of elevated seismic risk due to seismic wave resonance that enhance the seismic shaking in connection with dense urbanization and the location of infrastructure. Measurements of seismic noise at 146 sites have been carried out in the northern part of the Santiago de Chile basin first to determine the fundamental resonance frequency of the sites and then to invert the horizontal-to-vertical (H/V) spectra individually, considering additional geological and geophysical information as constraints, for estimating local $S$-wave velocity profiles which were found to vary substantially over short distances in the investigated area. The resulting $3 \mathrm{D}$ model was derived for a $26 \mathrm{~km} \mathrm{x} 12 \mathrm{~km}$ area by interpolation between the single $S$-wave velocity profiles and shows good agreement with the few existing velocity profiles but allows to image the entire area as well as deeper parts of the basin in much more detail than before. By applying complex trace analysis for seismograms recorded at network sites within the Santiago basin using the instantaneous polarization characteristics of the seismic signal for separating waves arriving at a single site at different times, we identify and extract basin-edge generated Rayleigh waves. It is found that the geometry of the basin edge plays a critical role in the generation of surface waves. In turn, these waves can significantly influence both the spatial distribution of the level of amplification and the temporal lengthening of ground motion, meaning that the spatial variability of ground motion in the basin is not only related to a simple $1 \mathrm{D}$ response but it is strongly modified by secondary waves generated at the edges of the basin.
Mapping of Vs30 and Seismic Microzones in Quito, Ecuador LEON, A. L., Geosoil Cia. Ltda., Ecuador, Quito, Ecuador, leonamanda44@ gmail.com; SCHMITZ, M., Prometeo Program IG-EPN, Ecuador; Simon Bolivar University, Venezuela; FUNVISIS, Venezuela, schmitzschutt@gmail. com; YEPES, H. A., IG-EPN, Ecuador, hyepes@igepn.edu.ec; ORDOÑEZ, J., Municipality of Metropolitan District of Quito, Ecuador, jorge82pato@gmail. com; HERNÁNDEZ, J. J., Consultant in Earthquake Engineering, Venezuela, juljavher@gmail.com; ALVARADO, A., IG-EPN, Ecuador, aalvarado@igepn. edu.ec; GARCÍA, K., FUNVISIS, Venezuela; Simon Bolivar University, Venezuela, kennyalejandrogarcia@gmail.com

With the purpose of putting the base for a seismic ordinance in the Metropolitan District of Quito (MDQ) in Ecuador that includes the results of seismic microzoning studies, a group of geo-scientists are working on the compilation and integration of previous studies with new information. The MDQ is characterized by a heterogeneous surface formed by basins and topographic reliefs located in an active tectonic zone driven by the subduction of the Nazca plate under the South American plate. The structural complexity of the region with local thrust faults is responsible for the high seismic hazard. As the seismic response is strongly influenced by the configuration of the shallow layers and by the depth of the sedimentary basin, we focus on shear wave velocity in the first $30 \mathrm{~m}$ (Vs30) and the configuration of soil profiles to bedrock for the definition of the seismic response at surface. For a preliminary map of Vs30 a relation between topographic relief and Vs30 was used, adjusted by the results of the compilation of pre-existing wells and the interpretation of new seismic data obtained by the ReMi method. The final map shows variationsmainly between $200 \mathrm{~m} / \mathrm{s}$ and $550 \mathrm{~m} / \mathrm{s}$. This, allowed a reinterpretation of all the informationresulting in a new map of microzones thatcovers the whole MDQ. Within the process of upgrade the existing seismic microzoning studiesan integration of geological, geomorphologicaland previously defined microzones of the DMQ was done, resulting in a map of 11 seismic microzones. They were subdivided due to their geological evolution and composition in: fluvial-lacustrine, colluvial, alluvial, lahars, cangahua and volcanic ash materials, with sedimentary depths down to the seismic bedrock ranging from 40 $\mathrm{m}$ at the edges up to $700 \mathrm{~m}$ in the center of the basin, and with lower Vs 30 velocities in the flat part of the basin. Finally, soil profiles were proposed for each seismic microzone and seismic response spectra are being calculated for each zone.

\section{Recent Seismic Microzonation Study for the Aburra Valley, Colombia}

YAMIN, L. E., Universidad de los Andes, Bogotá D.C., Colombia, lyamin@ uniandes.edu.co; RINCÓN, R., Universidad de los Andes, Bogotá D.C., Colombia, jr.rincon3391@uniandes.edu.co; PRADA, E., Universidad de los Andes, Bogotá D.C., Colombia, e.prada1744@uniandes.edu.co; HERRERA GARCÍA, D. C., Universidad de los Andes, Bogotá D.C., Colombia, dc.herrera745@uniandes.edu.co; DAZA, J. M., Universidad de los Andes, Bogotá D.C., Colombia,jm.daza670@uniandes.edu.co; GARCIA, A. P., Universidad de los Andes, Bogotá D.C., Colombia, ap.garcia1170@uniandes.edu.co

The city of Medellin and its metropolitan area (about 3 million inhabitants) are located in the Aburra valley in Colombia, which is an active seismic region. Colombian seismic design code (NSR-10) dictates that every city with a population over 100,000 inhabitants must have a seismic microzonation study. These studies aims to evaluate the amplification effects generated by the dynamic response of soil deposits, which substantially modifies the characteristics and intensity of a seismic event. Furthermore, these studies propose specific recommendations for seismic design of buildings and many other applications. The Aburra Valley presents a complex geological and geotechnical conditions, where the quality and quantity of available information is not sufficient for the purposes of these studies. Hence, a great uncertainty in the subsequent analysis and the final results is expected. This paper presents the overall methodology used for the microzonation study in the Aburra Valley considering the different sources of uncertainties. First, a bedrock level probabilistic seismic hazard assessment (PSHA) was performed to calculate hazard curves and uniform hazard spectra at the region. Several boreholes and geotechnical information were gathered throughout the study zone in order to characterize the variability of the soil deposits due to its geological origin. Several 1D soil dynamic response analysis were performed in order to characterize the spectral amplification surfaces and its uncertainty for different seismic intensities. Additionally, 2D models were analyzed to consider topographic amplification effects. Local seismic records were analyzed to calibrate and validate the microzonation results. Finally, the spatial distribution of seismic acceleration at surface level was calculated using new approaches in which the fundamental soil period of vibration is the main parameter of integration. Updated seismic design parameters were proposed in accordance to those stablished in NSR-10. 


\section{Hvsr Site Characterization of Texnet Seismic Stations in West Texas} YOUNG, B. E., University of Texas at Austin, Texas, USA, bissett.young@ beg.utexas.edu; SAVVAIDIS, A., University of Texas at Austin, Texas, USA alexandros.savvaidis@beg.utexas.edu; RATHJE, E. M., University of Texas at Austin, Texas, USA, e.rathje@mail.utexas.edu

The Texas Seismological Network, established by the 84th session of the Texas State Legislature, currently consists of 25 stations that comprise a backbone network across the state, supplemented by several portable arrays in four areas of localized seismicity. All portable installations have both a seismometer and an accelerometer. One array, located in the Snyder-Cogdell area, consists of 7 portable stations with interspatial distances varying between 2 and $25 \mathrm{~km}$. Another, located in the Delaware basin, consists of 7 portable stations in addition to 2 permanent stations located in that area. Interstation distances in that region are $50-80 \mathrm{~km}$. To better understand the site amplification for stations in west Texas, and get qualitative information of the site classification, we perform site characterization using the horizontal-to-vertical spectral ratio (HVSR) for earthquake and noise data. For these areas, we focus our investigation on earthquakes with local magnitudes that range between 1.5 and 3.1. For earthquakes, we analyzed data starting at the $S$ arrival and extending to the point where the signal dropped to normal background noise levels. For noise analysis, we used 24 hour records for each site, with earthquakes removed. Our analysis is concentrated on the frequency range between 1 and $50 \mathrm{~Hz}$. We find consistency in HVSR values across multiple earthquakes for the same stations with peaks that indicate soil resonant frequencies. Additionally, we observe a correlation between the resonant frequencies identified for stations within similar geological formations, indicating a transition from higher to lower frequencies moving from stiffer to looser materials. This trend is supported by results from the noise data.

\section{The Trinidad and Tobago Microzonation Project: Understanding and Quantifying Earthquake Hazard}

PAPADOPOULOS, I., Seismic Research Centre, University of West Indies, Trinidad and Tobago, ilias@uwiseismic.com; REDDOCK, K. H., Seismic Research Centre, University of West Indies, Trinidad and Tobago, hashimreddock@gmail.com; MANZANO, J., Seismic Research Centre, University of West Indies, Trinidad and Tobago, jevan.manzano@gmail.com GEORGE, C., Seismic Research Centre, University of West Indies, Trinidad and Tobago, corygeorge6@gmail.com; JACKSON, V. B., Seismic Research Centre, University of West Indies, Trinidad and Tobago, v.jackson436@gmail. com; CAMEJO, M., Seismic Research Centre, University of West Indies, Trinidad and Tobago, michal.camejo@gmail.com; LATCHMAN, J. L., Seismic Research Centre, University of West Indies, Trinidad and Tobago, j_latchman@ uwiseismic.com; ROBERTSON, R., Seismic Research Centre, University of West Indies, Trinidad and Tobago, richie_robertson@uwiseismic.com; LYNCH, L. L., Seismic Research Centre, University of West Indies, Trinidad and Tobago, llynch@uwiseismic.com; ASH, C., Seismic Research Centre, University of West Indies, Trinidad and Tobago, clevon.ash@uwiseismic.com; SEEMUNGAL, J., Seismic Research Centre, University of West Indies, Trinidad and Tobago, jseemungalsrc@gmail.com

In the past 30 years, there has been widespread attention to the impact of local geology, in urban areas, on ground motion during earthquakes. Numerous studies (e.g. Bard, 1999 and Haghshenas et al., 2008 for a literature review) have shown that the seismic amplification observed in sediments can vary significantly, even at small distances, as a result of changes in surface geology. Trinidad andTobago is prone to earthquakes and, therefore, at significant seismic risk. The Trinidad \& Tobago Microzonation Project (TTMP) aims to quantify the seismic hazard for the country by studying the local geology in ten major population centres across the country. We use ambient seismic noise recordings to derive our results. We recorded both single-site measurements, processed using the Horizontal to Vertical Spectral Ratio (HVSR) (Nakamura, 1989), and Microtremor Array Measurements (MAM) (Tokimatsu, 1997) techniques. Simulation of ambient noise, from Hisada's method and using RANSOURCE code (Moczo et al, 2002), is used as an independent test to strengthen the conclusions from the experimental results (Hisada, 1994, 1995). In the first urban area selected, the capital Port of Spain, more than 1100 single-site and 26 array recordings have been conducted. Results show a gradual deepening of the Port of Spain basin to the south, with significant sediment thickness $(\sim 160 \mathrm{~m})$. By integrating the results we are also able to derive a soil classification map according to NEHRP soil classification (BSSC, 2003). Shear wave velocity varies from $\sim 160 \mathrm{~m} / \mathrm{sec}$ in reclaimed land in the south to $\sim 3000 \mathrm{~m} / \mathrm{sec}$ for the massive Chancellor Schist to the north and Laventille Metalimestone east of the basin. Resonance frequency has a similar variation from south to north ranging between 0.4 to $10 \mathrm{~Hz}$. A local network of strong motion sensors is set to be installed, and define the amplification of sediments within the urban environment.

\section{Seismic Microzoning Study in Portoviejo, Ecuador}

SCHMITZ, M., FUNVISIS, Prometeo Program, Miranda, Venezuela, schmitzschutt@gmail.com; YEPES, H. A., IG-EPN, Pichincha, Ecuador, hyepes@igepn.edu.ec; HERNÁNDEZ, J. J., Consultant in Earthquake Engineering, Miranda, Venezuela, juljavher7@gmail.com; KOCH, R., Consultant in Geophysics, Pichincha, Ecuador, rominakoch7@gmail.com; PALACIOS, P. B., IG-EPN, Pichincha, Ecuador, ppalacios@igepn.edu.ec; MARRERO, J. M., EPN-Tech, Pichincha, Ecuador, josemarllin@gmail.com; SINGER, A., FUNVISIS, Miranda, Venezuela, singer.andre1@gmail.com; MARCIAL, D., IMME-UCV, Miranda, Venezuela, duilio.marcial@gmail. com; SÁNCHEZ, J., FUNVISIS, Miranda, Venezuela, sanchjav7@gmail.com; GARCÍA, K., FUNVISIS, Miranda, Venezuela, kennyalejandrogarcia@gmail. com; CÁRDENAS, D. R., EPN, Pichincha, Ecuador, diego.renato.cardenas@ gmail.com

Portoviejo is located in a sedimentary basin characterized by soft sedimentary deposits of fluvial-marine origin that gradually filled the estuary, surrounded by outcrops of heavily weathered shales. The seismic hazard is dominated by interface earthquakes of the subduction of the Nazca plate beneath the North Andean Sliver, but local faults with potential Q activity were identified during the study. The depth of the quaternary sediments and their properties has been studied with geotechnical and geophysical methods. Depth of the sedimentary basin is $50 \mathrm{~m}$ in the center of Portoviejo increasing towards NE to $160 \mathrm{~m}$. The depth of the seismic basement, characterized by Vs $\geq 1400 \mathrm{~m} / \mathrm{s}$ (consolidated layers of shale or sandstone within the shales) ranges between 100 and $200 \mathrm{~m}$ in the urban area. Seismic response is mainly conditioned by Vs 30 , and geotechnical characteristics, and only to a lesser extent to sediment thickness. Vs30 varies between 155 and $360 \mathrm{~m} / \mathrm{s}$ in the basin, corresponding to silty-clayey materials. The shales show Vs between 360 and $600 \mathrm{~m} / \mathrm{s}$. Five seismic microzones of similar seismic response are defined by the distribution of Vs 30 ranging from rigid soils with Vs $30 \geq 360 \mathrm{~m} / \mathrm{s}$ to very soft soils with Vs $30<180 \mathrm{~m} / \mathrm{s}$; microzone 6 is located in the floodplain of the Portoviejo River with very high liquefaction potential, and lateral spread due to the lack of lateral confinement. Downtown Portoviejo, strongly damaged in 2016, does not present any special subsoil configuration, nor in the observations from the aftershock recordings (greater amplifications are observed to the north), with the exception of liquefaction phenomena near the cemetery. Our results, which include PSH assessment, allow a greater detail with respect to the building code with spectra with values of the plateau $10-50 \%$ higher than the respective code spectra. Landslide hazard due to earthquakes is small in Portoviejo, with the exception for extreme events ( 2475 years return period).

\section{Geotechnical Microzonation of Portoviejo City: Index Properties of Soils and Correlations between Shear Wave Velocity (Vs) and Standard Penetration Test (SPT-N)}

ALVARADO, K., Escuela Politecnica Nacional, Quito, Ecuador, kellygeo86@ gmail.com; CÁRDENAS, D. R., Universidad Central del Ecuador, Quito, Ecuador, diego.renato.cardenas@gmail.com; REALPE, G. R., Pontificia Universidad Católica del Ecuador, Quito, Ecuador, grealper@hotmail.com; MUÑOZ, A. J., Pontificia Universidad Católica del Ecuador, Quito, Ecuador, mbjandres@gmail.com; YEPES, H. A., Instituto Geofísico, Escuela Politécnica Nacional, Quito, Ecuador, hyepes@igepn.edu.ec

On April 16th, 2016 several phenomena were generated in city of Portoviejo, associated with the Mw 7.8 earthquake. This incident led to catastrophic events. The city is characterized by predominating Holocene deposits mainly of fluvial environment, being relatively young deposits. These characteristics form a zone of high vulnerability to develop simultaneous phenomena as settlements, swellings, liquefaction. For which an empirical equation has been determined to appraise the elastic properties of the soil important for the analysis of the site response. In this way the shear wave velocity was evaluated through NSPT values obtained in 15 wells; calculating two equations for a depth of $0-5 \mathrm{~m}$ and $5-10 \mathrm{~m}$. A shallow geotechnical map was generated based on empirical correlations of index properties of soils obtained in laboratory tests. Five geotechnical zones were determined according to the approximate behavior of the soil. According to the distribution of soil properties a critical geotechnical zone is located in the Portoviejo downtown. This zone has materials with High Plastic Index producing they are highly compressible soils having the singularity that these values increase with depth. These has moisture content very close to its Liquid Limit thus they are less stable soils under a load. Additionally this zone has the highest percentage of fines inside the city and a high swelling potential that can cause damage to structures that are overlying these soils. However its swelling pressure is less than $30 \mathrm{kPa}$. Towards the north central zone of the city there is greater heterogeneity of soil index properties due to mixed fluvial-marine deposits and the presence of active tectonic structures. This zone has values of Plasticity Index lower than 20 which indicate that requires a low water content to reduce its shear strength, also it has 
been found to be more prone to water saturation especially in times of high rainfall and in seasons where the El Niño Phenomenon develops.

\section{Measuring Shear Wave Velocity with Permanently Deployed Cross-Hole Arrays}

STEIDL, J. H., Earth Research Institute, UC Santa Barbara, California, USA, steidl@eri.ucsb.edu; HEGARTY, P., Earth Research Institute, UC Santa Barbara, California, USA, hegarty@eri.ucsb.edu

At the Garner Valley Downhole Array, a permanently deployed cross-hole array experiment is used to measure shear-wave velocity in the near-surface soil. The cross-hole array includes two geophones and a solenoid-activated dual-direction hammer source at 5 meters depth. An accelerometer is mounted to the hammer strike plate. An additional two geophones are located at 2 meters depth in the same boreholes as the deeper geophones. The underground hammer source can be programmed to swing at user defined intervals. In addition, immediately following ground motions that exceed a pre-defined threshold, the hammer will automatically begin to swing at short time intervals. This cross-hole experiment is unique in that the velocity measurements made using the travel time across the two geophones will capture any potential decrease and recovery of shear wave velocity in the soil at 5 meters depth following a large event. While waiting for larger earthquakes, data from the cross-hole array can be used to identify any potential long-term temporal changes in velocity. Data from daily hammer tests collected from December 2010 to June 2012 and from weekly hammer tests collected from August 2015 to June 2017 are analyzed using normalized crosscorrelation between the two 5 meter geophones to estimate travel times, and thus shear wave velocity. The results show a strong correlation between water table height and the shear wave velocity in the sediment. A reduction in the shear wave velocity is seen as the water table rises, with changes of approximately $5 \%$ over the course of the seasonal water table variation. A similar permanent cross-hole array experiment was deployed at the Wildlife Liquefaction Array in the summer of 2016, and preliminary results from this experiment will also be presented.

Seismic Microzonation and Amplification Factor Determination in the NorthNortheast Area of Managua City, Nicaragua

CASTRILLO, E. N., UNAN-Managua, Managua, Nicaragua, app.nadks30@ gmail.com; ETO, K., Tokyo Soil Research, Co., Ltd., Earthquake Engineering Consulting Consulting Division, Tokyo, Japan, eto@tokyosoil.co.jp; YOKOI, T., International Institute of Seismology and Earthquake Engineering, Tsukuba, Japan, tyokoi@kenken.go.jp; HAYASHIDA, T., International Institute of Seismology and Earthquake Engineering, Tsukuba City, Japan, takmi-h@ kenken.go.jp.

Two set of key factors do influence the ground motion level that an earthquake can cause at a given site. Firstly, the inherent characteristics of the earthquake are magnitude, rupture mechanism and the location parameters such as distance to the source and depth. Secondly, dynamic properties of sites such as fundamental periods and shear wave velocity.

Only from those factors, currently it is possible to estimate dynamic behavior of the ground before a strong ground shaking takes place. The knowledge of the estimated ground shaking makes a huge difference, as this enables decision makers to take countermeasures through an earthquake resistant design of dwellings and buildings.

In this research the North-Northeast area of Managua city, Nicaragua was surveyed. Fundamental periods of the soils were determined using the spectral ratio method. Moreover, amplification factor of seismic waves was computed using information from shear wave velocity profiles through site response analysis. Response spectra were computed based on the interpolation of excitation method.

Transfer functions from the velocity structure obtained by microtremors method has shown that the fundamental periods of ground are categorized in two ranges: $\mathrm{To} 1=0.07$ to $0.15 \mathrm{~s}$ and $\mathrm{To} 2=0.15$ to $0.45 \mathrm{~s}$.

Shear wave velocity profiles at selected sites in the area were used to evaluate the site condition. In general the area can be classified as type $\mathrm{C}$ and $\mathrm{D}$ soils (NEHRP 2003).

By comparing response spectra of the ground motion with the design spectra obtained following the RNC-07 ground acceleration and amplification factors for the sites of the type $\mathrm{D}$ and $\mathrm{C}$, it was found that the acceleration response spectra of the analyzed earthquake records exceeds the design spectra.

Seismic Amplifications in the Valley of Mexico Using Spectral Ratios of Teleseismic Surface Waves Recorded with Broadband Stations

MARTINEZ-MENDOZA, G., Instituto de Geofísica, Universidad Nacional Autónoma de México, Mexico City, Mexico, kashiyer08@comunidad.unam.mx; VALDÉS-GONZÁLEZ, C. M., Centro Nacional de Prevención de Desastres,
Instituto de Geofísica, Universidad Nacional Autónoma de México, Mexico City, Mexico,cvaldesg@cenapred.unam.mx

We have performed $\mathrm{H} / \mathrm{V}$ ratios of Rayleigh waves for teleseismic events for stations located in four quadrants (along the back azimuth). The data comes from a network of 30 broadband seismometers of 19 earthquakes recorded from 2011 to 2013 with epicentral distances from 1,800 to $17,000 \mathrm{~km}$ and Mwfrom 7 to 9 . The seismic stations are located in the Mexico City region. Analysis of the data show peaks of amplification in the range of 10 to 30 seconds. The $\mathrm{H} / \mathrm{V}$ ratios were obtained from the spectral division of the Radial to vertical component, which contains the Rayleigh waves. We found at most, two peaks with amplifications of 4 times in the period range. The peaks are presented along stations that are aligned in the back-azimuth path. The H/V peaks will be correlated with shallow cortical structures in the complex valley. Furthermore, a correlation between these long periods peaks and the infrastructure (e.g. airport runways, elevated viaducts, dams, water and gas pipelines and large building) will be analyzed for seismic events that are rich in surface waves.

New Frontiers in Seismic and Acoustic Data Analysis Oral Session · Wednesday 16 May · 4:15 PM • Brickell Session Chairs: Daniel C. Bowman, Sarah A. Albert, and Matthew M. Haney

\section{The Signature of Wind Turbines in Seismic Background Noise}

MARCILLO, O. E., LANL, New Mexico, USA, omarcillo@lanl.gov; CARMICHAEL, J., Los Alamos National Laboratory, New Mexico, USA, joshuac@lanl.gov

Seismic and infrasound sensors can record noise from wind turbines (WTs) at distances of several $10 \mathrm{~s}$ of $\mathrm{km}$ from their source. Like other machines with rotating blades, WTs produce noise characterized by a series of sharp spectral peaks centered at the blade-passing frequency and its integer harmonics (F\&H noise). We demonstrate a methodology to detect F\&H noise in seismic records by estimating these fundamental frequencies and their harmonic sequences in ambient noise. We analyze several years of seismic data recorded on stations (e.g.: AMTX and NATX) within the US Seismic Network in Texas (US). Station AMTX has a high concentration of WTs within $100 \mathrm{~km}$ and shows persistent F\&H noise detections with multiple well-defined fundamental frequencies between 0.7 and $1 \mathrm{~Hz}$. Monthly detections at station AMTX follow the multi-year trend of statewide wind-generated electric power, which supports the assumption of the F\&H noise to be related to the operation of wind turbines.

Tracking Scattered Signals in the Acoustic Coda Using Independent Component Analysis in a Topographically Complex Setting

ALBERT, S. A., Sandia National Laboratories, New Mexico, USA, salber@ sandia.gov; BOWMAN, D. C., Sandia National Laboratories, New Mexico, USA,dbowma@sandia.gov

Like earthquakes, acoustic signals can consist of a "direct arrival" followed by a coda of scattered waves. In the acoustic case, the coda is generated from wave interactions with topography. The shape of the coda carries information about both the scatterer geometry and the atmospheric state between secondary sources and the receiver. This may permit inversion for the acoustic velocity structure of the lower atmosphere, particularly in regions with repeating infrasound sources in the same area (e.g. quarries, bombing ranges). This study presents results from an experiment using gradient flow Independent Component Analysis (ICA) on signals recorded from two $800 \mathrm{~kg}$ TNT equivalent explosions near Socorro, NM, USA. We show that gradient flow ICA is able to track signals scattered by the surrounding mountain ranges within the acoustic coda out to 30 seconds following the first arrival. Results are then compared with results from the Progressive Multi-Channel Cross Correlation (PMCC) method. The ICA algorithm strongly outperforms PMCC in this scenario. Suggestions for future research are given, including details on how this method can be used to invert for the vector wind field. Sandia National Laboratories is a multimission laboratory managed and operated by National Technology and Engineering Solutions of Sandia LLC, a wholly owned subsidiary of Honeywell International Inc. for the U.S. Department of Energy's National Nuclear Security Administration under contract DE-NA0003525.

Distinct Crater and Conduit Infrasound Reveal an Open Vent Volcano Running Out of Gas

LYONS, J. J., AVO_US Geological Survey, Alaska, USA, jlyons@usgs. gov; FEE, D., University of Alaska, Fairbanks, Alaska, USA, dfee1@alaska. 
edu; HANEY, M. M., AVO-US Geological Survey, Alaska, USA, mhaney@ usgs.gov; DIEFENBACH, A., CVO-US Geological Survey, Washington, USA, adiefenbach@usgs.gov; CARN, S., Michigan Technological University, Michigan, USA, scarn@mtu.edu

Open-vent degassing dominated activity at Mount Pagan, Mariana Islands dating back to at least 2013, when ground-based sensors were installed, to mid-2015 when degassing fell below detection limits. Gas sampling indicated shallow magma was the source, and an analysis of LP seismicity showed that repeated pressurization and venting of a shallow crack controlled degassing. Open-vent degassing also produced abundant infrasound, recorded on two 6-element arrays. Two main infrasound features are the focus of this study: 1) a $0.3 \mathrm{~Hz}$ iVLP and 2) a $1.7 \mathrm{~Hz}$ iLP. Tens of thousands of iVLPs and iLPs were recorded over the 22-month study period, and correlation and cluster analyses show little change in both waveform and frequency content, suggesting a non-destructive, repeating source. An interesting upper conduit-crater geometry was discovered in helicopter overflights of the summit crater, and to test the effects of the crater and conduit shape and size on the infrasound signals, a high-resolution ( $<1$ meter) DEM of the crater was produced by structure-from-motion using video captured during helicopter orbits. We perform full-waveform inversion of the infrasound data using the $3 \mathrm{D}$ topography, and show that a synthetic monopole source induces distinct resonance in the crater and upper conduit that mostly reproduces the iVLP and iLP signals, respectively. Further investigation of the infrasound catalogue shows that while the frequency content and waveforms remained stable through time, the amplitude of the iVLP events began decreasing months prior to cessation of degassing. Initially, the iLP amplitudes remained unaffected while the iVLP amplitudes dropped, but in the final months before degassing ended iLP amplitudes also began decreasing. We interpret this pattern as a progressive decline in the gas overpressure, initially resulting in a decreased ability to trigger resonance in the large crater volume, but eventually affecting the ability of the monopole source to induce resonance in the smaller upper conduit volume. We compare the infrasound amplitudes to passive $\mathrm{SO} 2$ degassing of measured from the OMI sensor on NASA's Aura satellite during the study period and find a remarkable similarity in the datasets, confirming that the subtle waning of infrasound amplitudes was a harbinger of an open vent volcano running out of gas.

Remote Explosive Volcanic Eruption Detection, Location, and Characterization Using the Earthscope Transportable Array in Alaska

SANDERSON, R.W., UC Santa Barbara, California, USA, rws@umail.ucsb. edu; MATOZA, R. S., UC Santa Barbara, California, USA, rmatoza@ucsb. edu; FEE, D., University of Alaska Fairbanks, Alaska Volcano Observatory, Alaska, USA, dfee1@alaska.edu; HANEY, M. M., Alaska Volcano Observatory, US Geological Survey, Alaska, USA, mhaney@usgs.gov; LYONS, J. J., Alaska Volcano Observatory, US Geological Survey, Alaska, USA, jlyons@usgs.gov

The current deployment of the EarthScope Transportable Array (TA) in Alaska affords an unprecedented opportunity to study explosive volcanic eruptions using a relatively dense regional seismo-acoustic network. Active volcanism in the Aleutian Arc poses a risk to both regional and international air traffic. Infrasound monitoring has demonstrated utility for the detection and characterization of explosive volcanism, but previous studies have utilized relatively sparse networks of infrasound arrays in comparison to the TA in Alaska (which uses single-sensor stations). Here we present capabilities for the detection, location, and characterization of remote explosive volcanic eruptions using seismic, infrasonic, and ground-coupled airwave phases. We combine data from the TA and additional regional networks, including data from the Alaska Volcano Observatory (AVO) and Alaska Earthquake Center (AEC). We implement a Reverse Time Migration (RTM) technique to locate explosive eruptions in Alaska, with a focus on the recent explosive activity at locally-unmonitored Bogoslof volcano (December 2016 - August 2017). More than 60 eruptive events from Bogoslof provide a unique validation dataset, allowing experimentation and optimization of different RTM strategies. We also apply RTM to eruptions from other Alaskan volcanoes (Cleveland, Pavlof) and Kamchatkan volcanoes (Bezymianny, Shiveluch). We are experimenting with different strategies and parameter choices for the RTM; challenges include varying signal durations and amplitudes, the source-receiver geometries, and most volcanic eruptions occurring outside the network. We employ Receiver Operating Characteristic (ROC) curves to characterize parameter choices, and investigate coherence weighting of infrasound for signal cleaning and selection. Our methods are useful for both (1) event detection using real-time data and (2) scanning data archives to identify and discriminate volcanic and non-volcanic events.

Volcanic Thunder from Explosive Eruptions at Bogoslof Volcano, Alaska HANEY, M. M., AVO_US Geological Survey, Alaska, USA, mhaney@usgs. gov; VAN EATON, A. R., Cascades Volcano Observatory, US Geological
Survey, Washington, USA, avaneaton@usgs.gov; LYONS, J. J., Alaska Volcano Observatory, US Geological Survey, Alaska, USA, jlyons@usgs.gov; KRAMER, R. L., Cascades Volcano Observatory, US Geological Survey, Washington, USA, rkraner@usgs.gov; FEE, D., Alaska Volcano Observatory, University of Alaska Fairbanks Geophysical Institute, Alaska, USA, dfee1@alaska.edu; IEZZI, A. M., Alaska Volcano Observatory, University of Alaska Fairbanks Geophysical Institute, Alaska, USA, amiezzi@alaska.edu

Lightning often occurs during ash-producing eruptive activity and its detection is now being used in volcano monitoring for rapid alerts. We report on infrasonic and sonic recordings of the related, but previously undocumented, phenomenon of volcanic thunder. We observe volcanic thunder during the waning stages of two explosive eruptions at Bogoslof volcano, Alaska, on a microphone array located 60 $\mathrm{km}$ away. Thunder signals arrive from a different direction than co-eruptive infrasound generated at the vent following an eruption on June 10, 2017, consistent with locations from lightning networks. For the March 8, 2017 eruption, arrival times and amplitudes of high frequency thunder signals correlate well with the timing and strength of lightning detections. In both cases, the thunder is associated with lightning that continues after significant eruptive activity has ended. Thus, the optimal observation time is during the minutes immediately after the cessation of eruptive activity when volcanic lightning continues in the detached plume-when the thunder signal is not masked by eruption noise. Of all the events in the 2016-17 Bogoslof eruption sequence, the March 8 and June 10 eruptions had the clearest volcanic thunder signals. Observations for other eruptive events with lightning detections were hampered by higher levels of background noise, non-optimal wind conditions, and volcanic activity that did not abruptly terminate. Further work is needed on the characteristics of volcanic thunder and its relation to lightning properties, such as frequency content of thunder and the nature of the lightning (intercloud or cloud-to-ground). These infrasonic and sonic observations of volcanic thunder offer a new avenue for studying electrification processes in volcanic plumes, provide ways of distinguishing volcanic thunder from eruption acoustic signals, and motivate improved methods of measuring volcanic thunder at close range and during explosive activity.

Observations and the Physics Behind Complex
Earthquakes
Oral Session · Wednesday 16 May · 2:15 PM · Brickell
Session Chairs: Zhongwen Zhan, Gavin Hayes, and Marine
Denolle

\section{Considering Green's Functions in Back-Projection}

WANG, D., China University of Geosciences, China, dunwang2004@yahoo.com

Back-projection methods have become popular and are widely used to track the rupture process of moderate to large earthquakes. However, there are problems in imaging detailed processes of earthquakes with smaller source dimensions. We developed a new inversion method, Image Deconvolution Back-Projection (IDBP) to determine the sources of high frequency energy radiation by linear inversion of observed images from a back-projection approach. The observed back-projection image for multiple sources is considered as a convolution of the image of the radiated energy and the array response for a point source. The array response that spreads energy both in space and time is evaluated by using data of a smaller reference earthquake that can be assumed to be a point source. The synthetic test of the method shows that the spatial and temporal resolution of the source is much better than that for the conventional back-projection method. We applied this new method to the 2001 M 7.8 Kunlun earthquake using data recorded by Hi-net in Japan. The new method resolves a sharp image of the high frequency energy radiation with a significant portion of supershear rupture.

\section{Search for Generic Rupture Properties Hidden by Earthquakes Diversity : Insights from the SCARDEC Source Time Functions Catalog}

VALLÉE, M., Institut de Physique du Globe de Paris, France, vallee@ipgp. fr; RENOU, J., Institut de Physique du Globe de Paris, France, renou@ipgp.fr; CHOUNET, A., Institut de Physique du Globe de Paris, France, chounet@ipgp. $\mathrm{fr}$

The search for key elements characterizing the earthquake rupture process is challenged by the specificities of each individual event. This results in a large diversity when looking at earthquakes as a whole. This diversity is well documented by the moment rate functions (or Source Time Functions-STF), one of the most robust seismological observables of the rupture process. Teleseismic STFs also have the potential to be automately extracted for each earthquake with magnitude above $5.7-6$, since the development of the digital global broadband seismic networks. 
This potential access to thousands of STFs, in all earthquake contexts and depths, motivated the development of the SCARDEC method, which simultaneously retrieves the static source parameters (depth, focal mechanism and magnitude) together with the STF. More precisely, the SCARDEC method retrieves apparent STFs (for each location and $\mathrm{P} / \mathrm{S}$ phase), which also offers the possibility to track first-order features of the space-time rupture process. The present study uses these STFs to further document how, and at which velocity, rupture develops. In a first step, we will review the information provided by a systematic search of the average rupture velocities. Second, we will focus on the most energetic phase of the STFs. Even if the times at which rupture strongly accelerates appears unpredictable (resulting in very different STF shapes), the characteristics of this acceleration provide constraints on the dynamics of the rupture. As a matter of fact, this acceleration is on average faster than what is predicted by a classical self-similar rupture growth (where the STF grows quadratically with time). This shows that during the main phase, rupture velocity and/or slip rate increase.

Toward a Temporal Evolution of the Earthquake Energy Budget: Body-Wave Radiated Energy Rate

DENOLLE, M. A., Harvard University, Massachusetts, USA, mdenolle@fas. harvard.edu

Assuming that the Green's function between the source and the receiver is properly removed, the only direct measurement we can make of the earthquake energy budget is radiated energy. Dynamic source processes, such as fault roughness or heterogeneity in frictional and pre-stress properties, induce local variations in rupture velocity and peak sliprate and excite high-frequency seismic waves. It is then desirable to zoom into the source moment-rate function and explore the temporal variation in radiated energy. Here we propose a new methodology to construct the radiated energy rate from source spectrograms and use an empirical Green's function approach to remove far-field path effects. The radiated energy rate is directly proportional to the squared moment acceleration. Pseudodynamic models allow us to confirm that local variations in rupture velocity and in peak slip rate both contribute to peaks in moment acceleration, and validate the metbod. We apply our technique to the M7.92015 Nepal earthquake. Beyond its resemblance to a pure Haskell model (radiation occurs at the beginning and at the end), we highlight details in the radiated energy rate that suggest distinct events within the rupture. These events are interpretable with the temporal correlation to published teleseismic backprojection results.

Earthquake Complexity Due to Interaction of Fault Geometry, Constitutive Properties, Prior Slip, Fluid Effects, and Inelastic Processes

LAPUSTA, N., Caltech, California, USA, lapusta@caltech.edu

The increasing stream of field observations uncovers an increasingly rich picture of the earthquake source. Combined with increasingly more sophisticated understanding of fault properties from the laboratory and theoretical modeling, these observations point to intricate interactions among spatial, and often temporal, variations in: (i) fault geometry, both large-scale and local (aka fault roughness); (ii) fault confinement due to both geometrically-induced variations in fault-normal stress and fluid-motion-induced variations in pore pressure; (iii) fault shear stress due to prior patterns of slow and fast slip and deformation processes in the bulk, (iv) low-slip-velocity friction in terms of velocity weakening (VW) vs. strengthening (VS) due to variations in composition, shear zone thickness, and other factors; (v) dynamic changes in shear resistance (often weakening) due to shear heating and other effects that vary with the shear zone thickness, composition, poroelastic properties, etc; (vi) inelastic bulk processes in the bulk that may augment the effective shear resistance of faults or modulate loading conditions in spatially heterogeneous and time-dependent ways; and potentially other factors. We will present cases in which it is relatively clear that a subset of these factors dominates the response, as well as ones where the interaction between several of them is likely key. For example, many observations on repeating earthquakes, even as large as $\mathrm{Mw} 6.0$, can be reproduced in relatively simple models of planar faults with VW friction patches surrounded by VS fault areas. At the same time, the unexpectedly large shallow slip in the $2011 \mathrm{Mw} 9.0$ Tohoku earthquake is most likely the result of several interacting factors, including the fault geometry, a particular set of friction and poroelastic properties, and prior slip history. This reality implies that there may be no single simple answer for earthquake complexity. Our best chance for identifying dominating factors in a particular setting would be to match all available observations-e.g., an entire pattern of slow slip and earthquake sequences, heat consraints etc-with a single physical model, since each isolated observation can be reproduced by a number of different models. This calls for further development of numerical models of long-term deformation with realistic fault and bulk rheologies and realistic geometries.
Complexity of Spatiotemporal Microfracturing Processes and Stress Field Evolution before and after Fault Slip: Laboratory Perspective

KWIATEK, G., Helmholtz Centre Potsdam GFZ German Research Centre for Geosciences, Germany, kwiatek@gfz-potsdam.de; GOEBEL, T. H. W., UC Santa Cruz, Santa Cruz, California, USA, tgoebel@ucsc.edu; ORLECKASIKORA, B., Institute of Geophysics, Polish Academy of Sciences, Warsaw, Poland, orlecka@igf.edu.pl; MARTÍNEZ-GARZÓN, P., Helmholtz Centre Potsdam GFZ German Research Centre for Geosciences, Germany, patricia@ gfz-potsdam.de; BOHNHOFF, M., Helmholtz Centre Potsdam GFZ German Research Centre for Geosciences, Germany, bohnhoff@gfz-potsdam.de; DRESEN, G., Helmholtz Centre Potsdam GFZ German Research Centre for Geosciences, Germany, dre@gfz-potsdam.de

In this study we investigate details of spatial and temporal evolution of the stress field and damage at a pre-existing fault surface during laboratory stick-slip friction experiments performed on Westerly Granite samples. Specimens were deformed at constant strain rate of $3 \times 10^{-6} \mathrm{~s}^{-1}$ and confining pressures of $150 \mathrm{MPa}$. Here we analyze a series of 6 macroscopic slip events, each associated with intense microseismic activity. The Acoustic Emission (AE) events were recorded using a 16-channel transient recording system. Monitoring and mapping AE properties allowed recovering spatiotemporal damage and stress evolution. We investigated source characteristics (magnitude, seismic moment tensors and focal mechanisms) as well as the statistical properties (b-, c-, d-value) of microseismicity to unravel the micromechanical processes governing nucleation and propagation of slip events. In addition, the calculated AE focal mechanisms were used to derive time-dependent local stress orientations, stress shape ratio, and additional parameters such as scaled shear traction, quantifying proximity to failure of individual fault patches. The calculated characteristics are used to evidence the clear complexity of the preparatory and post-slip damage and stress evolution framing the macroscopic slip in the microscale. The observed fault processes and characteristics are discussed in the context of global strain and stress changes, fault surface maturation (roughness), and earthquake stress drop.

Observed Characteristics of Induced Seismicity: From
Laboratory to Field Scale (Parts 1 and 2)
Oral Session . Wednesday $16 \mathrm{May} \cdot 2: 15 \mathrm{PM}$. Flagler
Continued: Thursday 17 May · 8:30 AM $\cdot$ Flagler
Session Chairs: Kayla A. Kroll, Elizabeth S. Cochran, and
Brett Carpenter

Reservoir Induced Seismicity in Brazil: Characteristics and New Cases BARROS, L. V., Seismological Observatory-University of Brasilia, Distrito Federal, Brazil, lucas.v.barrros@gmail.com; ASSUMPÇĀO, M., Seismological Center-University of São Paulo, São Paulo, Brasil, marcelo@iag.usp.br; RIBOTTA, L., Technological Institute of Research-São Paulo State, São Paulo, Brasil, ribotta@ipt.br; CARVALHO, J. M., Seismological ObservatoryUniversity of Brasilia, Brazil DF, Brasil, juraci@unb.be; DRUMOND, B., Seismological Observatory-University of Brasilia, Brazil DF, Brasil, bibi_ drumond@hotmail.com; ALBUQUERQUE, D. F., Seismological ObservatoryUniversity of Brasilia, Brazil DF, Brasil, diogofarrapo@gmail.com

The first observations of seismicity related to reservoir impoundment in Brazil occurred in the early 1970's. The largest reservoir-related earthquake (4.2 mb) occurred in 1974. Interest in reservoir-triggered seismicity contributed to motivate the development of Seismology in Brazil. After the 1980's and 1990's, with the decrease in the rate of dam construction in Brazil, interest in reservoirtriggered seismicity also decreased. This was due to the fewer large dams under construction, but also because of the feeling that the chance of a large event was small. No other magnitude larger than 4.0 had been observed since 1974. On November 5th, 2015, the catastrophic failure of the Fundão iron-ore tailings dam, in Mariana, Minas Gerais State, caused a huge mud flow which destroyed a nearby town and caused 19 deaths. It has been described as the worst environmental disaster in Brazil's history. About one hour before the failure, four small earthquakes with magnitudes up to 2.5 occurred $\sim 1 \mathrm{~km}$ from the dam. The earthquakes were regarded as too small to have caused a direct impact on the dam failure, and a liquefaction process was already developing leading the upstream dam to a critical state. Irrespective of any possible causal relation with the dam failure, the occurrence of the small events renewed Brazil's interest for reservoir triggered seismicity. Tailings dam can be taller than $100 \mathrm{~m}$ and the water saturated sediments could also contribute to increase pore pressures in the fractured rock mass beneath the tailings reservoir. Most tall tailings dam are now being monitored for local seismicity. For this reason, a reappraisal of all RTS cases in Brazil is impor- 
tant to help assess triggering hazard and plan mitigation policies. The probability of RTS occurrence in Brazil is not negligible, and should be taken into account to the dam safety projects. In fact, half of dams above $100 \mathrm{~m}$ high present RTS.

Criteria Used to Characterize and Classify Discrete Clusters of Earthquakes from 2012-2016 in North-Central Arkansas as Natural or Induced

AUSBROOKS, S. M., Arkansas Geological Survey, Arkansas, USA, scott. ausbrooks@arkansas.gov; HORTON, S. P., CERI, University of Memphis, Tennessee, USA, shorton@memphis.edu

North-central Arkansas has seen a significant increase in both unconventional resource development and seismicity within the Fayetteville Shale Play since 2009. The study area is historically seismically active, but it has seen a significant increase in seismic activity since 2009 that is likely a combination of both natural and human-induced clusters and even swarms of earthquakes. We reviewed regional earthquake catalogs to obtain key characteristics including location, magnitude, and depth of the earthquakes within each discrete cluster. We then determined if a spatial and temporal correlation existed between discrete individual clusters of regionally-detected earthquakes that had occurred within $5-\mathrm{km}$ of active Class II saltwater disposal wells, or within $5-\mathrm{km}$ of production wells undergoing hydraulic fracturing (using the hydraulic fracturing notifications-HFNs) during the time of the seismic activity. We used template matching to produce a catalog of potentially induced earthquakes for each cluster of earthquakes. We are developing criteria to rate and assign a probabilistic classification to these clusters of earthquakes as to their likelihood of being natural or induced. The information from this technique of discriminating natural from induced earthquakes can be used to help determine which earthquakes should be included in future USGS Short-term Induced Seismicity Models and the National Seismic Hazard Maps.

\section{Induced Seismicity in the High Agri Valley (Southern Italy): First Observations from the INSIEME Seismic Network}

STABILE, T. A., National Research Council of Italy, Potenza, Italy, tony. stabile@imaa.cnr.it; SATRIANO, C., Institut de Physique du Globe de Paris, Paris, France, satriano@ipgp.fr; ROMANELLI, M., National Institute of Oceanography and Experimental Geophysics, Trieste, Italy, mromanelli@ inogs.it; GUEGUEN, E., National Research Council of Italy, Potenza, Italy, erwan.gueguen@imaa.cnr.it; SERLENGA,V., National Research Council of Italy, Potenza, Italy, vincenzo.serlenga@imaa.cnr.it; BELLANOVA, J., National Research Council of Italy, Potenza, Italy, jessica.bellanova@imaa. cnr.it; GALLIPOLI, M. R., National Research Council of Italy, Potenza, Italy, mariarosaria.gallipoli@imaa.cnr.it; PRIOLO, E., National Institute of Oceanography and Experimental Geophysics, Trieste, Italy, epriolo@inogs.it; RIPEPI, E., National Research Council of Italy, Potenza, Italy, ermann.ripepi@ imaa.cnr.it; SAUREL, J. M., Institut de Physique du Globe de Paris, Paris, France, saurel@ipgp.fr

It is worldwide recognized that a range of human activities like water reservoir impoundment, mining activity, underground nuclear tests, enhanced geothermal systems, injection/withdrawal of fluids into/from the ground associated with the gas storage, the $\mathrm{CO} 2$ sequestration, and the exploitation of oil and gas fields are claimed as responsible for induced seismicity. Many areas where induced seismicity occurs still lack of well-designed microseismic monitoring networks, and seismicity data are often acquired in triggering mode or only available in terms of earthquake catalogs, thus limiting the capability of understanding the physical processes that control the induced seismicity. With the aim to overcome this issue, the deployment of dedicated microseismic networks with continuous data acquisition has become mandatory. In this context, an experimental temporary seismic network has been deployed around two clusters of induced events in the High Agri Valley (southern Italy) in the framework of the research project INSIEME (INduced Seismicity in Italy: Estimation, Monitoring, and sEismic risk mitigation) funded by the Italian SIR-MIUR program. More specifically, one of the two clusters is fluid-injection induced seismicity $(\mathrm{Ml} \leq 2)$ due to the disposal of the wastewater produced during the exploitation of the biggest onshore oil and gas field in west Europe at the Costa Molina 2 (CM2) injection well; the other cluster is continued-reservoir induced seismicity $(\mathrm{Ml} \leq 2.7)$ linked to the seasonal water level fluctuation of the artificial Pertusillo Lake. The seismic network is composed by 8 stations, four of them around each of the two clusters of induced events. All the stations are equipped with broadband sensors installed in PVC casings at different depths up to $50 \mathrm{~m}$. The sampling frequency of the continuous seismic data is $250 \mathrm{~Hz}$. Here we present the detailed characteristics of the seismic network and the first observations of induced microearthquakes in the study area.
How Widespread Is Human-Induced Seismicity in the USA and Canada? VAN DER BAAN, M., University of Alberta, Canada, mirko.vanderbaan@ ualberta.ca; CALIXTO, F. J., University of Alberta, Canada, jimmy_cm@ hotmail.com

There has been significant public and scientific interest in the observation of changed seismicity rates in North America since 2008, possibly due to human activities. Van der Baan and Calixto (Geochemistry, Geophysics, Geosystems, 2017) find that the seismicity rate in Oklahoma between 2008 and 2016 is strongly correlated to increased hydrocarbon production. The possibility of systematic correlations between increased hydrocarbon production and seismicity rates is a pertinent question since the United States became the world's largest hydrocarbon producer in 2013, surpassing both Saudi Arabia's oil production and Russia's dry gas production. In most areas, increased production is due to systematic hydraulic fracturing which involves high-pressure, underground fluid injection. Increased hydrocarbon production also leads to increased salt-water production which is often disposed of underground. Increased underground fluid injection in general may cause increased seismicity rates due to facilitated slip on pre-existing faults. Contrary to Oklahoma, analysis of oil and gas production versus seismicity rates in six other states in the United States and three provinces in Canada finds no state- or province-wide correlation between increased seismicity and hydrocarbon production, despite 8 - to 16 -fold increases in production in some states. However, in various areas, seismicity rates have increased locally. A comparison with seismic hazard maps shows that human-induced seismicity is less likely in areas that have historically felt fewer earthquakes. The opposite is not necessarily true.

\section{The Binary Forecast Approach to Induced Seismicity}

KAHUE, R., Western University, Canada, rkahue@uwo.ca; SHCHERBAKOV, R., Western University, Canada, rshcherb @uwo.ca

The Western Canada Sedimentary Basin has seen a recent increase in observed seismicity which is most likely linked to anthropogenic activities related to unconventional oil and gas exploration. Seismicity caused by these types of activities is called induced seismicity. The occurrence of moderate to larger induced earthquakes in areas where critical infrastructure is present can be potentially problematic. Here we use a binary forecast method to analyze well production and injection data to quantify future time periods of potential seismicity. The binary forecasting approach splits a region into bins to create a retrospective forecast. By testing the model with varying production/injection thresholds, a certain number of bins become alarm cells with each test. An alarm cell is a bin in which there is a higher likelihood for earthquakes to occur based on its total production/ injection value being higher than the threshold. Earthquakes that occur within an alarm cell in the retrospective forecast period contribute to the hit rate, while alarm cells that do not have an earthquake occur within them in the retrospective forecast period contribute to the false alarm rate. Previously we used spatial bins; here we use a modified method using temporal bins measured in months. In the resulting analysis the hit and false alarm rates are determined for each threshold. The receiver operating characteristic diagram is used for optimization by comparing and maximizing the difference between the hit and false alarm rates for a given set of initial parameters. This temporal approach provides monthly volume and hourly thresholds above which earthquakes above a given magnitude may occur in a future period when that threshold value is exceeded. Certain time periods are thus shown to be more prone to potential larger earthquakes for specific regions in Western Canada. This has implications for the potential link between oil and gas production and induced seismicity observed in the WCSB.

\section{Variations in Source Properties with Evolving Deep Injection at Ngatamariki Geothermal Field, New Zealand}

HOPP, C., Victoria University of Wellington, New Zealand, chet.hopp@ vuw.ac.nz; SAVAGE, M. K., Victoria University of Wellington, New Zealand, martha.savage@vuw.ac.nz; SEWELL, S., Victoria University of Wellington, New Zealand, stevensewell83@gmail.com; MROCZEK, S., Victoria University of Wellington, New Zealand, stefan.mroczek@vuw.ac.nz; TOWNEND, J., Victoria University of Wellington, New Zealand, john.townend@vuw.ac.nz

Fluid-induced seismicity (FIS) is a useful indicator of thermal and pressure change within a geothermal reservoir. Given the difficulty of making measurements in the space between wells, FIS provides one of the only direct observations of fluid-related reservoir processes. Understanding exactly why and how these microearthquakes occur helps us unravel the movement of fluid and heat at depth. At the Ngatamariki geothermal field, we expanded an initial earthquake catalog of over 1100 events using matched-filter detection to include over 5000 microearthquakes. These earthquakes are densely clustered in two areas of active fluid injection and, at times, the rate of seismicity is highly correlated 
with injection rate. We present focal mechanisms for larger events and discuss their relation to injection activities at the fields. In particular, we focus on the cold-water stimulation of wells NM08, NM09 and NM10. The seismic response to each of these treatments is distinct. In the northern part of the field, reverse faulting mechanisms on focal planes striking N-S or NW-SE dominate seismicity during the stimulation of NM08. These disagree with regional extension along the NE-SW structural trend. Stimulation of NM09, which deviates from the same wellpad as NM08, induced much less seismicity. In the southern portion of the field, NE-SW striking normal faulting characterizes the seismicity during the stimulation at NM10 as well as most of the seismicity in this portion of the field throughout our 3.5-year dataset. We interpret these differences to reflect distinct geology between the northern and southern parts of the field as well as permeability differences between wells, particularly NM08 and NM09. Finally, we present preliminary stress inversion results obtained from these mechanisms and discuss them in the context of developing injection and production activities at Ngatamariki.

\section{Using Fluid-Induced Microseismicity for Reservoir Characterization at} Decatur

GOERTZ-ALLMANN, B. P., NORSAR, Norway, bettina@norsar.no; KUEHN, D., NORSAR, GFZ, Germany, daniela@norsar.no; LANGET, N., NORSAR, Norway, nadege@norsar.no; JORDAN, M., SINTEF Industri, Norway, michael.jordan@ sintef.no; BAUER, R., Illinois State Geological Survey, Illinois, USA, rabauer@illinois.edu; OYE, V., NORSAR, Norway, oye@norsar. no; GREENBERG, S., Illinois State Geological Survey, Illinois, USA, sallieg@ illinois.edu

Better characterization of induced microseismic events can reveal important geomechanical parameters and support the assessment of seal integrity for fluid injection operations. The spatio-temporal evolution of seismicity in conjunction with source parameter analysis can provide more detailed insight into reservoir behavior. We perform a detailed characterization of microseismic events at the Illinois Basin-Decatur Project (IBDP), in Decatur, Illinois. About 4800 microseismic events were located with deep borehole sensors during the injection of 1 Mio tons of CO2 during 3 years. Using a waveform cross-correlation method, we can distinguish between events occurring in the sandstone reservoir and events only some tens of meters deeper in the adjacent uppermost crystalline basement. Full-waveform modeling can be used to identify observations of different phase arrivals. Further analysis of source parameters such as Brune stress drop and b-value, as well as the general evolution of microseismic clusters reveal a fluid-driven behavior of seismicity within a cluster, and a punctual hydraulic connection between reservoir and basement. Focal mechanisms are estimated for selected events by combining recordings from surface and downhole sensors. In addition, temporal changes in attenuation as measured from microseismic waveforms may also carry information about the progression of the CO2 plume. We apply a multiple empirical Green's function approach on repeating multiplets to compare spectral ratios. The method yields systematic spatial variations of $Q$. However, no temporal variations of $\mathrm{Q}$ can be resolved from the microseismic data alone. However, as part of seismic monitoring, we aim to establish a new data analysis workflow integrating active and passive seismic data for a more holistic 4D seismic monitoring system. The larger aperture and higher resolution achieved by combination of all available seismic data may allow for a more precise mapping of the injected fluid.

\section{Assessing the Connectivity of a Hydraulic Fractured Network Using 3D Topological Approaches}

VIEGAS, G., ESG Solutions, gisofer@gmail.com; BOSMAN, K., ESG Solutions, katie.bosman@esgsolutions.com; URBANCIC, T., ESG Solutions, ted.urbancic@esgsolutions.com

We use 3D topological approaches to characterize the extent of fracture connectivity and assess the percolation capability of Discrete Fracture Networks (DFNs) as related to hydraulic fracturing completion programs. The matrix permeability of unconventional reservoirs is very low (nanodarcies) making the primary source of hydrocarbon production the flow through the DFN generated by fracturing methods. Geomechanical based reservoir and frac models used to predict production and assess the effectiveness of the completion program, utilize fracture orientations and spacing, but do not consider the connectivity of the DFN that effectively allows hydrocarbons to percolate to the producing well. Here, we characterize the DFN connectivity of a treated shale reservoir, for which the orientation and length of the individual fractures associated with the generated microseismicity was determined by source spectral modeling, and moment tensor and stress inversions. We apply the well-known geological concepts of node and branch classification (topology), extending them to a $3 \mathrm{D}$ analysis. We use a rolling window along the length of the microseismic event distribution perpendicu- lar to the treatment well, to identify variations of the fracture connectivity with distance from the injection point based on the relative proportion of observed node types. We define 3 zones of enhanced permeability or interconnectivity based on the obtained values of connection per branch and line tied to percolation thresholds of the fracture system: a primary zone of significant permeability enhancement and high fracture connectivity dominated by doubly-connected fractures, representing a primary production region; a secondary zone somewhat stimulated, with some permeability enhancement dominated by partially connected fractures, representing a secondary production region; and a tertiary zone or non-stimulated zone dominated by isolated fractures representing a nonproducing region.

\section{Seismicity Induced by Hydraulic Fracturing in Ohio}

BRUDZINSKI, M. R., Miami University, Ohio, USA, brudzimr@miamioh. edu; FRIBERG, P. A., Instrumental Software Technologies, Inc., New York, USA, p.friberg@isti.com; KOZŁOWSKA, M., Miami University, Ohio, USA, kozlowma@miamioh.edu; SKOUMAL, R. J., US Geological Survey, California, USA, skoumarj@gmail.com; LANGENKAMP, T. R., Miami University, Ohio, USA, langentr@miamioh.edu; LOUGHNER, E. A., Cedarville University, Ohio, USA, eloughner@cedarville.edu; CURRIE, B. S., Miami University, Ohio, USA, curriebs@miamioh.edu; FASOLA, S. L., Miami University, Ohio, USA, fasolasl@miamioh.edu

We have investigated seismicity associated with hydraulic fracturing (HF) in Ohio since 2013, which provides an ideal setting for studying the relations between high pressure injection and earthquakes due to isolation from other injection activities. Our analysis using an array of local stations in Harrison County revealed 2 distinct groups: 1) deeper earthquakes in Precambrian basement, with larger magnitudes $(M \geq 2)$, b-values $<1$, and many post shut-in earthquakes, versus 2) shallower earthquakes in Paleozoic rocks $\sim 400 \mathrm{~m}$ below HF, with smaller magnitudes $(\mathrm{M}<1)$, b-values $\geq 1.5$, and few post shut-in earthquakes. Based on geologic history, laboratory experiments, and fault modeling, we interpreted the deep seismicity as slip on mature faults in older crystalline rocks and the shallow seismicity as slip on immature faults in younger sedimentary rocks. Wells inducing deeper seismicity produced more water than wells with shallow seismicity, indicating more extensive hydrologic connections outside the target formation, consistent with pore pressure diffusion influencing seismicity. However, the 2-3 hours between onset of HF and seismicity is too short for typical fluid pressure diffusion rates across distances of $\sim 1 \mathrm{~km}$ and argues for poroelastic stress transfer also having a primary influence on seismicity. We now extend our analysis to other cases of HF induced seismicity in the Appalachian Basin. While these cases did not have publicly available local arrays, a broader set of stations operated by Miami University, ODNR, USGS, and IRIS is sufficient to identify the primary patterns of these seismic sequences. We employ multistation template matching to improve detection, waveform correlation to improve phase arrivals, and double difference relocation to improve the hypocentral characterization. We also examine frequency-magnitude distributions and well production patterns to compare with the geologic and operational interpretations made in the Harrison County study.

On the Variability of the Seismic Response during Multiple Decameter-Scale Hydraulic Stimulations

VILLIGER, L. G., Swiss Seismological Service, ETH Zurich, Switzerland, linus.villiger@sed.ethz.ch; SELVADURAI, P. A., Swiss Seismological Service, ETH Zurich, Switzerland, paul.selvadurai@sed.ethz.ch; GISCHIG, V. S., Department of Earth Sciences, ETH Zurich, Switzerland, gischig@erdw.ethz.ch; DOETSCH, J., Department of Earth Sciences, ETHZurich, Switzerland, joseph. doetsch@erdw.ethz.ch; KRIETSCH, H., Department of Earth Sciences, ETH Zurich, Switzerland, hannes.krietsch@erdw.ethz.ch; DUTLER, N., Centre for Hydrogeology and Geothermics, University of Neuchâtel, Switzerland, nathan. dutler@unine.ch; JALALI, M., Department of Earth Sciences, ETH Zurich, Switzerland, mohammadreza.jalali@erdw.ethz.ch; VALLEY, B., Centre for Hydrogeology and Geothermics, University of Neuchâtel, Switzerland, benoit. valley@unine.ch; AMANN, F., Institute of Engineering Geology, Germany, amann@lih.rwth-aachen.de; WIEMER, S., Swiss Seismological Service, ETH Zurich,Switzerland, stefan.wiemer@sed.ethz.ch

To improve our understanding of the seismo-hydro-mechanical coupled processes associated with deep-geothermal reservoir creation, a decameter-scale In-situ Stimulation and Circulation (ISC) experiment was conducted at the Grimsel Test Site in Switzerland. The stimulation phase of the experiment included multiple hydraulic stimulations (i.e., hydraulic shearing and hydraulic fracturing tests) under repeatable pumping condition. The stimulations were performed in an exceptionally well characterized and instrumented crystalline rock mass (i.e., monitoring of pressure, strain, tilt and microseismicity). Induced 
seismicity during stimulation was continuously recorded with a dense network of uncalibrated piezo-electric sensors installed in the surrounding tunnels $(26$ sensors) and four monitoring boreholes ( 8 sensors) in close proximity $(5-25 \mathrm{~m})$ to the injection intervals. First analysis of stimulations targeting existing fault and shear zones showed a high variability in injectivity increase, whereby final injectivities remained on the same order of magnitude. The number of induced seismic events occurred predominantly during injection and varied from 300 to 5'500. Location of seismicity frequently coalesced into distinct clusters of small spatial extent $(0.5$ to $5 \mathrm{~m}$ ) in relatively short distance to the respective injection interval (max. $\sim 5 \mathrm{~m}$ ). To further investigate and compare seismicity of the different experiments and to relate seismicity to pressure propagation and strain evolution, event magnitudes have to be estimated-ideally absolute ones, which in turn require careful analysis of instrument and path effects. Thus, we investigate the application of a calibration technique developed in laboratory-scale experiments. The technique develops Empirical Green's Functions (EGFs) that incorporate wave propagation effects of the host rock, the instrument response, effects of the recording system (e.g., effects of filters and amplifiers) and the sensor coupling, directly.

\section{Ocean Bottom Seismology-Hurdles, Strategies and Outcomes \\ Oral Session - Wednesday 16 May $\cdot$ 10:45 AM $\cdot$ Hibiscus B Session Chairs: Charlotte A. Rowe, Francisco J. Núñez- Cornú, and Susan L. Bilek}

\section{Mermaid, Mug-Obs, Manta-Obs, Hydr-Obs; New Versatile Multidisciplinary Instruments for Monitoring Seismology in Deep Ocean.}

HELLO, Y. M., Geoazur, Paca, France, yann.hello@geoazur.unice.fr; NOLET, G., Geoazur, Paca, France, nolet@geoazur.unice.fr; YEGIKYAN, M., Osean, Paca, France, manuk.yegikyan@osean.fr; ROYER, J. Y., LGO_Université de Brest, France, jean-yves.royer@univ-brest.fr; CHARVIS, P., Geoazur, France, philippe.charvis@geoazur.unice.fr

Real time acquisition data for oceanographer is the next great challenge for the future. There are several attempts to monitor real time seismic activity, using regional scale wired nodes, such as Neptune, Antares or DONET. These initiatives are costly to install and to maintain. Among the most recent alternative we developed a 3-years autonomy OBS equipped with a Trillium $120 \mathrm{~s}$, a triaxial accelerometer, a differential and an absolute pressure gauge, and a hydrophone. MUG-OBS is a free-falling instrument rated down to $6000 \mathrm{~m}$. The installation of the sensor and data quality are monitored by acoustic commands from the surface. The major innovation is that it is possible to recover the data any time on demand using one of the 6 data-shuttles released from the surface by acoustic command. Networks of synchronized autonomous hydrophones for monitoring the low-level seismic activity of the ocean floor and low-frequency sounds from the ocean have been commonly deployed in the world ocean to monitor large sections of mid-oceanic ridges. HYDROBS is an improved system derivate from MUG that meet two requirements: an easy access to the data collected by the instruments together with long-term deployments - up to 4 consecutive years. HydrOBS is equipped with 4 hydrophones and data are recovered every year over a period of three years releasing 3 shuttles by acoustic. Mermaids have been developed to improve seismic data coverage in the oceanic domain for imaging of the Earth's interior. The first generation of Mermaids was housed in conventional Argo-type floats, while hardware and software was developed to analyze acoustic signals, determine whether an earthquake has been recorded, and whether the Mermaid should to come up to the surface and transmit to the satellite. The life time of the new generation of the Mermaids is 6 years if sampling continuously at depth of $2000 \mathrm{~m}$ for seismic signals, e.g. for seismic tomography by providing worldwide coverage of $\mathrm{P}$ wave arrival times.

\section{Smart Cables-Sensing the Oceanographic and Geophysical Pulse of the Planet}

HOWE, B. M., University of Hawaii at Manoa, Hawaii, USA, bhowe@ hawaii. edu

An international task force is working to integrate environmental monitoring sensors into submarine telecommunication cables. The SMART Cables Initiative - for Science Monitoring And Reliable Communications - is sponsored by several UN agencies and led by the Joint Task Force. The SMART cables concept calls for adding sensor suites to the repeaters of future submarine cables, which are spaced at intervals of $50-75 \mathrm{~km}$ along the ocean floor. Initially, temperature, pressure, and acceleration sensors will be integrated, with expanded capabilities in planning. As cables are replaced and expanded, this would create a global deep ocean sensor network capable of sustained, cost-effective data collection in the deep ocean to addresses two critical needs for science and society: 1) the near term need for improved resolution and rapidity in global tsunami warning and seismic monitoring, and 2) the long term need for sustained, cost-effective ocean and climate data from the deep oceans. The acceleration sensors will pick up strong ground motion from nearby earthquakes; recent instrumentation improvements allow sensing smaller or distant earthquakes. The inclusion of seismic sensors opens a new window of opportunity; we provide a discussion of the solid Earth modeling and expected ocean bottom seismology impacts of the initiative. The initiative has won endorsement from numerous scientific organizations, and modeling studies are underway to quantify the expected benefits of the improved sampling. The initiative, currently moving from the concept stage into prototyping, has the potential to provide a first order addition to the ocean and Earth observing system, with unique contributions that will strengthen and complement existing systems. See Joint Task Force (JTF), ITU/WMO/IOC SMART Cables for Observing the Ocean

\section{The Necessity for Long-Term OBS Deployments in Understanding Mid-Ocean Ridge Processes}

TOLSTOY, M., Lamont-Doherty Earth Observatory, Columbia University, New York, USA, mt290@columbia.edu; TAN, Y. J., Lamont-Doherty Earth Observatory of Columbia University, New York, USA, yjt@ldeo.columbia. edu; WALDHAUSER, F., Lamont-Doherty Earth Observatory of Columbia University, New York, USA, felixw@ldeo.columbia.edu; WILCOCK, W. S. D., School of Oceanography, University of Washington, Washington, USA, wilcock@uw.edu

Technological advances now allow Ocean Bottom Seismographs (OBS) to be deployed for over a year, recording at high sample rates. This provides the opportunity for sustained long-term observations at individual sites as opposed to brief snap-shots of seafloor seismic activity, often at disparate sites. This is particularly important in understanding the mid-ocean ridge (MOR) system, which is by far the most significant planetary source of volcanism, but where the seismic activity usually takes place far from shore, often at magnitudes below the detection threshold of the global seismic network. The limited multi-year data we have at MORs suggesta dynamic system where the character of earthquake activity changes dramatically through an eruption cycle. Only two sites have in situ OBS recordings of an eruption: Axial Seamount (2015) and the East Pacific Rise (EPR) at $9^{\circ} 50^{\prime} \mathrm{N}(2006)$. The recent Ocean Observatory Initiative (OOI) Cabled Array provides real-time high fidelity seismic data from Axial Seamount, with over 3 years of data recorded to date and an expectation of many more years to come. But Axial represents one of only a handful of MOR sites where multi-year continuous OBS arrays have been able to characterize microearthquake activity, with or without an eruption. Comparison with the EPR shows that Axial is likely heavily influenced by hot spot activity and shows distinct differences in eruptive style as well as seismic activity before and after. The OOI presents an exciting opportunity to get the first decadal scale picture of seismic activity at an active MOR site, but we also need to be careful to characterize other types of MOR settings to provide a balanced view of this critically important system. Even with decades of dense monitoring at much simpler fault or volcanic systems on land, we still don't fully understand how they work. Therefore significantly more data are required at MORs to be confident that we understand their most basic processes.

\section{The Caribe Norte Project: Studying the Southern Hispaniola Island Seismic Structure Using OBS \\ NÚNEZZ ESCRIBANO, D., SisVOc-Universidad de Guadalajara, Jalisco,} Mexico, diana@sisvoc.mx; CÓRDOBA BARBA, D., Universidad Complutense de Madrid, Madrid, Spain, dcordoba@fis.ucm.es

The complex tectonic region of NE Caribbean, where Hispaniola and Puerto Rico are located, is bordered by subduction zone with oblique convergence in the north and by incipient subduction zone associated to Muertos Trough in the south accommodated by the Septentrional-Oriente and Enriquillo-Plantain Garden Fault Zones. Central Caribbean basin is characterized by the presence of a prominent topographic structure known as Beata Ridge, whose oceanic crustal thickness is unusual whose northern part is colliding with central Hispaniola along a transverse NE alignment, which constitutes a morphostructural limit that could explain the extreme difference between west and east seismicity of the island. To study this region, the onshore-offshore CARIBE NORTE experiment was carried out in 2009. The use of a set of 12 OBS anchored in the southern of Dominican Republic was essential to better understand the crustal structure along three wide-angle seismic transects. These OBS and land seismic stations deployed along these seismic lines registered the marine shots provided by $\mathrm{R} / \mathrm{V}$ Hespérides. The analysis and subsequent interpretation of these data give a complete tectonic view about shallow, middle and deep structures in this region 
showing important tectonic differences between west and east mainly due to the presence of Beata Ridge, Muertos Thrust Belt and Muertos Trough.

Seismicity in the Northern Hikurangi Margin, New Zealand, and Spatial and Temporal Relationship with the October 2014 Slow Slip Event

YARCE, J., University of Colorado Boulder, Colorado, USA, jefferson.yarce@ colorado.edu; SHEEHAN, A. F., University of Colorado Boulder, Colorado, USA, anne.sheehan@colorado.edu; NAKAI, J. S., University of Colorado Boulder, Colorado, USA, jenny.nakai@colorado.edu; SCHWARTZ, S. Y., UC Santa Cruz, California, USA, syschwar@ucsc.edu; MOCHIZUKI, K., University of Tokyo, Tokyo, Japan, kimi@eri.u-tokyo.ac.jp

The Hikurangi subduction margin off the north island of New Zealand was the target of the "Hikurangi Ocean Bottom Investigation of Tremor and Slow Slip" (HOBITSS) experiment, which successfully recorded a slow slip event on seafloor pressure gauges in 2014. In addition to 24 absolute pressure gauges, the HOBITSS experiment included 10 broadband and 5 short period ocean bottom seismometers, all deployed for one year (May 2014 to June 2015) offshore the east coast of the North Island of New Zealand, near Gisborne. An initial catalog of local earthquakes was constructed using STA/LTA detection, event association, and manual picking of $\mathrm{P}$ and $\mathrm{S}$ wave arrivals from both offshore HOBITSS and on-land New Zealand GeoNet seismograph stations. We determined initial earthquake locations with the GENLOC algorithm using the iasp91 earth reference velocity model. We next used the VELEST software to simultaneously invert the seismic arrival times for earthquake locations and velocity model, obtaining new 1D velocity models for onshore and offshore. These two velocity models, together with the manually picked arrivals were then used in the BAYESLOC Bayesian multiple-event algorithm to relocate the events. These steps yielded a total of 3087 earthquakes ranging from magnitude $0.5-4.7$ and with a local magnitude of completeness of ML 1.5. Our results indicate that Hikurangi seismicity is concentrated in two NE-SW bands, one offshore beneath the Hikurangi trough and outer forearc wedge, one onshore beneath the eastern Raukumara Peninsula, and with a gap in seismicity between the two bands and beneath the inner forearc wedge. The majority of earthquakes are within the subducting slab rather than at the plate interface. Intriguingly, the gap in seismicity borders the slow slip patch along its down-dip edge. We do not find an increase in seismicity during the 2014 slow slip event, though seismicity is slightly higher in the month following the slow slip event.

Present-Day Plate Boundary Deformation and Seismic
Hazard in the Caribbean
Oral Session · Wednesday 16 May · 2:15 PM · Orchid AB
Session Chairs: Eric Calais, Steeve Symithe, O'Leary
Gonzalez Matos, and Valérie Clouard

\section{Is the Ancient Nortecubana Fold-and-Thrust Fault System Reactivated in} Extension Today?

BRIGGS, R. W., US Geological Survey, Colorado, USA, rbriggs@usgs.gov; GOLD, R. D., US Geological Survey, Colorado, USA, rgold@usgs.gov

The North Cuban fold and thrust belt formed in response to Caribbean:North America plate collision that largely ended $\sim 40 \mathrm{Ma}$. Today an arcuate band of seismicity extends $950+\mathrm{km}$ along the north shore of Cuba, signifying ongoing deformation along this ancient suture on a series of reverse faults collectively called the Nortecubana fault system. We use focal mechanisms from recent earthquakes and geomorphic observations to explore the hypothesis that modern deformation along the Nortecubana fault system accommodates regional extension. Several lines of evidence suggest that normal faulting dominates the Nortecubana fault system today. A primary observation is the 2014-01-09 Mw 5.0 earthquake near Corralillo, which had an extensional focal mechanism and nodal plane strikes and dips consistent with normal reactivation of a reverse fault. The drowned geomorphic character of the coastline and lack of clearly preserved elevated, abandoned Quaternary marine deposits between Playa Uvero $\left(-76.5^{\circ}\right)$ and Matanzas $\left(-81.3^{\circ}\right)$ is consistent with extension along the northern coast and down-to-the-south fault reactivation. West of Matanzas, MIS $5(\sim 125 \mathrm{ka})$ coral terraces at 3-6 m asl (Terraza Seboruco) appear to record a stable or slowly subsiding coastline in the latest Quaternary. Finally, abrupt rangefronts associated with apparent normal motion across ancient reverse/oblique faults such as the Cubitas and Pinar faults suggest that extension dominates the present-day geomorphology of northern Cuba. Large earthquakes on the Nortecubana fault system, if they occur, could pose a ground-shaking and tsunami-inundation hazard along the north shore of Cuba and tsunami hazard for the conterminous United
States. However, if normal faulting is the primary cause of earthquakes along the Nortecubana fault system, then tsunami hazard may be dominated by localized, high-runup events impacting the northern shore of Cuba rather than trans-basin tsunamis caused by submarine reverse-fault ruptures

Rayleigh Wave Group-Velocity across the Dominican Republic and Puerto Rico from Ambient Noise Tomography

QUIROS, D. A., Baylor University, Texas, USA, daq7@ cornell.edu; PULLIAM, J., Baylor University, Texas, USA, jay_pulliam @ baylor.edu; BARMAN, D., Baylor University, Texas, USA, debajeet_barman1@baylor.edu; POLANCO RIVERA, E., Universidad Autonoma de Santo Domingo, Dominican Republic, eugenio_polanco_rivera@msn.com; HUERFANO, V. A., Puerto Rico Seismic Network, UPRM, Puerto Rico, USA, victor@prsnmail.uprm.edu

The eastern North America-Caribbean (NA-CAR) plate boundary near the islands of Hispaniola and Puerto Rico is a complex transition zone in which strain is accommodated by two transform fault systems and oblique subduction. In 2013, scientists from Baylor University, the Autonomous University of Santo Domingo, and the Puerto Rico Seismic Network deployed 16 broadband stations on the Dominican Republic to expand the local permanent network. The goal of the Greater Antilles Seismic Program (GrASP) is to combine its data with that from permanent networks in Puerto Rico, Haiti, Cuba, the Cayman Islands, and Jamaica to develop a better understanding of the crust and upper mantle structure in the Northeastern Caribbean (Greater Antilles). One important goal of GrASP is to develop robust velocity models that can be used to improve earthquake location and seismic hazard efforts. In this study, we focus on obtaining Rayleigh wave group velocity maps from ambient noise tomography. Here we use verticalcomponent broadband data recorded at 53 stations between 2010 to present, to obtain Green's functions between 1165 pairs of stations. From these, we obtain dispersion curves by the application of FTAN methods with phase-matched filtering. Group velocity maps are generated between 4 to $40 \mathrm{~s}$. One-dimensional shear wave velocity models are generated for selected sites by convolving group velocity results with depth kernels produced by forward modeling. The Markov Chain Monte Carlo method is applied to estimate the maximum likelihood S wave velocity model and, specifically, Moho depth. Results show strong correlations with large-scale geological and tectonic features for periods between $4-40$ s, such as the Cordillera Central in both the Dominican Republic and Puerto Rico, the Mona Passage, and the NA-CAR subduction zone. Preliminary 1D shear wave velocity models suggest that the Moho underneath the Dominican Republic and Puerto Rico is in the range of 28 to $32 \mathrm{~km}$.

Seismic Anisotropy of the Crust and Upper Mantle across the CaribbeanNorth American Plate Boundary from Shear-Wave Splitting on Haiti POSSEE, D. I., University of Southampton, Hampshire, United Kingdom, djp1g15@soton.ac.uk; KEIR, D., Southampton University, Hampshire, United Kingdom, d.keir@soton.ac.uk; RYCHERT, C. A., University of Southampton, Hampshire, United Kingdom, c.rychert@soton.ac.uk; HARMON, N., University of Southampton, Hampshire, United Kingdom, n.harmon@noc. soton.ac.uk; EAKIN, C., Australian National University, Australia, caroline. eakin@anu.edu.au; ROLANDONE, F., UPMC Paris, France, frederique. rolandone@upmc.fr; LEROY, S., UPMC Paris, France, sylvie.leroy@upmc. fr; STUART, G., University of Leeds, United Kingdom, g.w.stuart@leeds. ac.uk; CORBEAU, J., UPMC Paris, France, jordane.corbeau@gmail.com; BOISSON, D., Université d'Etat d'Haiti, Haiti, dominique.boisson@fds.edu. ht; GUERRIER, K., Université d'Etat d'Haiti, Haiti, kelly.guerrier@fds.edu. ht; MOMPLAISIR, R., Université d'Etat d'Haiti, Haiti, roberte.momplaisir@ fds.edu.ht; ULYSSE, S., Université d'Etat d'Haiti, Haiti, sophia.ulysse@fds.edu. ht; PRÉPETIT, C., Bureau des Mines et de l'Energie, Haiti, bme@bme.gouv.ht

Hispaniola is situated across the Caribbean-North American plate boundary at a critical point in the transition from oblique subduction in the east to a transform plate boundary in the west. This results in a transpressional stress regime with deformation accommodated by numerous strike-slip, thrust and oblique fault structures that bisect the island. We used teleseismic and local earthquakes to measure shear wave splitting at 30 seismic stations that span Haiti N-S, which were part of the Trans-Haiti project. This allows us to constrain variations in the seismic anisotropy of both the crust and upper mantle across the plate boundary. In total 119 measurements were made on SKS phases and 780 on S phases from local earthquakes within the shear wave window. Three dominant fast polarisation directions are observed in the upper crust, which can be related to the regional stress field and fault networks. Delay times are typically $<0.15 \mathrm{~s}$. In regions of sparse faulting, fast directions align with the orientation of maximum horizontal stress $\left(20-60^{\circ} \mathrm{N}\right)$. By contrast, where fault density is high the fast directions parallel the strike of these structures. We observe two sets of fast directions that relate to active structures, the first at $120^{\circ} \mathrm{N}$ corresponds to thrust 
fault systems of a similar orientation. The second at $85^{\circ} \mathrm{N}$ is consistent with E-W strike-slip faulting, such as the Enriquillo-Plantain Garden fault zone in the south. This gives evidence that seismic anisotropy in the upper crust is controlled by the regional stress field relating to plate boundary deformation and locally modified according to the geometry of fault structures. SKS phases sample both crustal and upper mantle anisotropy and show an $\mathrm{E}-\mathrm{W}\left(100^{\circ} \mathrm{N}\right)$ fast polarisation direction with delay times of $1-2.5 \mathrm{~s}$. This is consistent with trench-parallel mantle flow observed in the Lesser Antilles subduction zone to the east or lithospheric fabrics relating to the E-W strike slip faulting that bisects Haiti.

\section{The Unusual January 2014 Northern Cuba Earthquake Sequence - A (Small) Shake-Up for Southern Florida}

BRAUNMILLER, J., University of South Florida, Florida, USA, jbraunmiller@ usf.edu; THOMPSON, G., University of South Florida, Florida, USA, thompsong@mail.usf.edu; MCNUTT, S. R., University of South Florida, Florida, USA, smcnutt@usf.edu

On 9 January 2014, a magnitude $\mathrm{Mw}=5.1$ earthquake occurred along the Bahamas-Cuba suture at the northern coast of Cuba revealing a surprising seismic hazard source for southern Florida where it was widely felt. Due to its location, the event and its aftershocks were recorded only at far distances resulting in high-detection thresholds, low location accuracy, and limited source parameter resolution. We use three-component regional seismic data to study the largest events of the sequence. High-pass filtered seismograms at the closest site $061 \mathrm{Z}$ in southern Florida are similar in character, suggesting a tight event cluster, which is confirmed by relative locations using the large-amplitude surface waves. Aligning the $061 \mathrm{Z}$ data on the $P$ arrival and low-pass filtering $(T \geq 10$ s) recovers a surprise polarity flip of the large amplitude surface waves on vertical seismograms for some aftershocks relative to the main shock. Regional moment tensor inversions confirm that the mechanism changes. Consistent with the GCMT solution, we find an $\sim \mathrm{E}-\mathrm{W}$ trending normal faulting mechanism for the main event and for one immediate aftershock. Two aftershocks indicate $\sim \mathrm{E}-\mathrm{W}$ trending reverse faulting with $\mathrm{P}$ - and T-axes flipped relative to the normal faulting events (and the same B-axes). Within uncertainties, the depths of the two event families are indistinguishable and indicate shallow faulting $(<10 \mathrm{~km})$. One intriguing possible interpretation is that both families ruptured the same fault with reverse mechanisms compensating for overshooting. However, activity could also be separated slightly with reverse mechanisms below extension or with slip on conjugate faults. The shallow source depth and the $200-\mathrm{km}$ long uplifted chain of islands indicate larger, shallow and thus potentially tsunamigenic earthquakes could occur just offshore posing a potential hazard to northern Cuba, Florida and the Bahamas.

\section{Seismic Hazard Analysis in Jamaica Incorporating Quaternary Faults} WONG, I. G., Lettis Consultants International, California, USA, wong@ lettisci.com; THOMAS, P. A., Lettis Consultants International, California, USA, thomas@lettisci.com; KOEHLER, R. D., Nevada Bureau of Mines and Geology, Nevada, USA, rkoehler@unr.edu; LEWANDOWSKI, N. S., Lettis Consultants International, California, USA, lewandowski@lettisci.com

The island of Jamaica is located in the interplate region between the Caribbean and North America plates and two major left-lateral strike-slip faults: the Septentrional-Oriente and the Enriquillo-Plantain Garden (EPG) fault zones. The majority of the $19 \mathrm{~mm} / \mathrm{yr}$ relative plate motion is partitioned between these two fault systems. GPS modeling suggests that 7 to $9 \mathrm{~mm} / \mathrm{yr}$ is distributed across southern Jamaica. Since 1678, 11 earthquakes of M 7.0 and larger have occurred within and adjacent to the island with the $1692 \mathrm{M} \sim 7.5$ Port Royal earthquake being the most significant event. Unlike previous probabilistic seismic hazard analyses (PSHA) which have relied almost solely on the historical earthquake record, we have evaluated the seismic hazard in Jamaica incorporating the known Quaternary faults. Although only the EPG fault has been the subject of paleoseismic investigations, we have estimated fault slip rates and their uncertainties based largely on geodetic studies. The faults included in our analysis are primarily the east-west-trending, strike-slip faults that accommodate most of the plate motion. We recognize that without fault-specific paleoseismic slip rate estimates, the epistemic uncertainties are large and hence should be included in the PSHA. There are other reverse/thrust Quaternary faults which were not included in the PSHA whose hazard contributions are at least partially accommodated by including gridded seismicity. A PSHA has been performed for selected locations on the island using the NGA-West2 ground motion models. For a typical building code return period of 2,475 years, the horizontal PGAs range from about 0.3 to more than $0.7 \mathrm{~g}$ with the highest hazard at sites adjacent to the major strike-slip faults. Comparisons with earlier studies based on historical seismicity indicate that they underestimate the seismic hazard in Jamaica, suggesting that even broad constraints on crustal fault slip rates improve PSHA results.
Real-Time GNSS Network Operations and Advances towards Early Warning Systems

Oral Session - Wednesday 16 May · 2:15 PM · Jasmine

Session Chairs: Alberto M. Lopez, Kathleen M. Hodgkinson, Diego Melgar, Sebastian Riquelme, David Mencin, and Victor A. Huerfano

\section{Quantifying the Value of Geodetic Data for Earthquake Early Warning} CROWELL, B. W., University of Washington, Washington, USA, crowellb@ uw.edu; RUHL, C. J., UC Berkeley, California, USA, cruhl@berkeley.edu; MELGAR, D., University of Oregon, Oregon, USA, dmelgarm @uoregon.edu; BODIN, P., University of Washington, Washington, USA, bodin@uw.edu; SCHMIDT, D. A., University of Washington, Washington, USA, dasc@uw.edu; ALLEN, R. M., UC Berkeley, California, USA, rallen@berkeley.edu

The value of geodetic data towards rapid non-saturating magnitude and source estimation for medium-to-large earthquakes has been thoroughly quantified and studied over the past decade. These efforts have led to the development of several GNSS-based algorithms for earthquake and tsunami early warning. There are still however questions as to how valuable the improved magnitude and source estimates will be to actual operational earthquake early warning; that is, will additional communities receive a warning with a geodetic source estimate that would not with a seismic source estimate and will such warnings be timely and effective? To explore these questions, we utilize both point-source geodetic magnitude estimates (i.e. peak ground displacement scaling) and finite-fault models derived from rapidly computed coseismic displacements. We first look at several large earthquake case studies around the world and how their ground motion prediction, and ultimately, warning times would be modulated by geodetic source information. Secondly, we leverage synthetic earthquake examples in Cascadia to quantify where geodetic information is most valuable with respect to population centers and the seismic hazards, identify the strengths and weaknesses in the current network design, and finally move towards making cost-benefit assessments based upon the Gutenberg-Richter frequency-magnitude distribution of earthquakes in different regions.

\section{Real-Time GNSS Data Network Operations for ShakeAlert}

ARANHA, M., UC Berkeley, California, USA, mario@seismo.berkeley.edu

ShakeAlert is an Earthquake Early Warning (EEW) System for the U.S. West Coast, developed by the USGS and its affiliates. As part of this system geodetic algorithms, applications software and real-time GNSS data products, primarily to measure large earthquakes, are being developed in partnership with academia including: Caltech, UCB, UW, CWU, UO, NMT and UNAVCO. Various real-time data production methods (differential/absolute, public domain/commercial, on-site/off-site) are being used to convert raw GNSS data to more precise position data. All these position data from different publishing sources are combined in real-time at each ShakeAlert Center where software applications implementing various geodetic EEW algorithms will utilize these data to produce timely warnings and reports in the event of a large earthquake along the U.S. West Coast. Given the complexity and constraints of the available telemetry, networking and computing infrastructure there are system design trade-offs in order to optimize data reliability, bandwidth utilization, accuracy, quality, high-volume, low-gappiness, low-latency and high-rate. With several institutions publishing large volumes of non-homogeneous data and compatibility issues with co-existing seismic EEW operations, there is need for standardization of data formats, transport mechanisms (e.g., NTRIP, AMQP, Earthworm), real-time monitoring/QC, software APIs, etc. This presentation will address in detail all these design considerations and more in the implementation of currently operational ShakeAlert data flow from GNSS receivers to geodetic EEW applications.

\section{West Coast Real-Time GPS in Support of Earthquake Early Warning MELBOURNE, T., Central Washington University, Washington, USA, tim @} geology.cwu.edu

Real-time GNSS position streams are desirable for a variety of rapid earthquake charactization applications that include Earthquake Early Warning. We report on our development of a comprehensive real-time GPS-based seismic monitoring system for the western US that includes the San Andreas transform system and Cascadia subduction zone. Our system is based around $1 \mathrm{~Hz}$ point positions computed in the ITRF reference frame using CWU's Fastlane real-time GPS analysis software. Resulting positions show typical RMS scatter of $3 \mathrm{~cm}$ in the horizontal and $5 \mathrm{~cm}$ in the vertical with latencies under 2 seconds. To facilitate their use for seismic monitoring, we broadcast the real-time solutions using custom-built 
aggregation software built on RabbitMQ exchange architecture. End users, once connected to the exchange, are pushed position streams for hundreds of stations. We currently analyze $\sim 650 \mathrm{PBO}$ and PANGA stations throughout the Cascadia and San Andreas fault systems and are gearing up to process all available realtime stations in the western US, roughly 1200 in total. Current recipients of these solutions via the RabbitMQ exchange include the three ShakeAlert centers at University of Washington, U. California Berkeley, USGS Menlo Park, and Caltech. In addition, CWU solutions are locally written from the RabbitMQ exchange onto a local Earthworm ring exported to NOAA's two Pacific and National Tsunami Warning Centers (PTWC \& NTWC) for rapid tsunami characterization purposes. For NOAA we have also developed a Kalman filter to combine CWU real-time PPP solutions with independent analyses in order to provide a merged data product. This may be adapted for Earthquake Early Warning, although the latency constraints are substantially more severe for EEW purposes (seconds) compared to local tsunami warning purposes (minutes). The merged solutions both provide redundant sources of measurements and improve the robustness and reliability of real-time point-position streams.

\section{Large Earthquake and Tsunami Characterization in Chile Using High Rate GPS and Strong Motion Data}

RIQUELME, S., University of Chile, Santiago, Chile, sebastian@dgf.uchile.cl

Recent efforts have been made to characterize large earthquakes in real time in Chile. In the last seven years Chile has been struck with 3 large earthquakes $(\mathrm{Mw} \geq 8)$. After the devastating Maule Earthquake, the National Seismological Center started to operate with the aim of monitoring real time events, passing from being an academic oriented network to an emergency response oriented network. Successfully, with the use of the W-phase and other methods, the CSN has been able to report the Iquique and the Illapel earthquakes with an accurate magnitude just six minutes after the occurrence of both events. Now, methodologies that include the use of geodetic and strong motion data are implemented in an integrated system that can characterize large earthquakes and tsunamis in real time.

Enhancing Tsunami Early Warning across the Americas through the Network of the Americas (NOTA) GNSS-Met Infrastructure

FEAUX, K. F., UNAVCO, Colorado, USA, kfeaux@unavco.org; HODGKINSON, K. M., UNAVCO, New Mexico, USA, hodgkin@unavco. org; MATTIOLI, G. S., UNAVCO, Colorado, USA, mattioli@unavco.org; MENCIN, D., UNAVCO, Colorado, USA,dmencin@unavco.org

UNAVCO supports a number of geodetic infrastructure projects across the Americas, including the NSF-funded EarthScope Plate Boundary Observatory (PBO), COCONet (Continuously Operating Caribbean GPS Observational Network) and TLALOCNet (Trans-boundary, Land and Atmosphere Longterm Observational and Collaborative Network. The ultimate goal for all of these networks, known collectively as the Network of the Americas (NOTA), is to provide free, high-quality, low-latency, open-format data, validated metadata, and data products for researchers, educators, students, and the private sector. High-rate GNSS data streams, collected and distributed by UNAVCO, are currently being used in prototype earthquake and tsunami early warning systems. We present a summary of the real-time GNSS assets in the Caribbean along with calculated earthquake detection thresholds for the current and potential future states of Caribbean GNSS stations with freely available real-time data streams for use in tsunami early warning systems. Our analysis is essential to identify critical gaps in existing networks prior to obtaining funding to enhance existing infrastructure and the final integration of GNSS into any operational tsunami early warning system.

Development and Testing of a Real-Time Geodetic Component for ShakeAlert MURRAY, J. R., US Geological Survey, California, USA, jrmurray@usgs.gov; CROWELL, B. W., University of Washington, Washington, USA, crowellb@ uw.edu; GRAPENTHIN, R., New Mexico Institute of Technology, New Mexico, USA,rg@nmt.edu; HODGKINSON, K. M., UNAVCO, Colorado, USA, hodgkinson@unavco.org; LANGBEIN, J., US Geological Survey, California, USA, langbein@usgs.gov; MELBOURNE, T., Central Washington University, Washington, USA, tim@geology.cwu.edu; MELGAR, D., University of Oregon, Oregon, USA, dmelgarm@uoregon.edu; MINSON, S. E., US Geological Survey, California, USA, sminson@usgs.gov; SCHMIDT, D. A., University of Washington, Washington, USA, dasc@uw.edu

Here we describe the framework we have devised for building a geodetic component of the ShakeAlert earthquake early warning (EEW) system. Real-time
Global Navigation Satellite System (GNSS) data enable direct measurement of large ground displacements during an earthquake. Algorithms using these data might improve EEW for M7+ events by producing non-saturating magnitudes and estimates of rupture extent. ShakeAlert currently uses algorithms based on seismic data alone, but ShakeAlert partners have developed geodetic methods that could enhance the system. GNSS data centers produce real-time position streams that ShakeAlert computers can ingest and deliver to geodetic alerting algorithms. Triggered by the first seismic alert, these algorithms output earthquake source parameters from which ShakeAlert software can predict ground motion. Geodetic input/output uses established ShakeAlert data formats and messaging protocols. A successful EEW system correctly alerts users in advance that they will feel shaking above a threshold value. Geodetic algorithm developers have tested their approaches independently, but apples-to-apples comparison using uniform input/output standards, test data, and evaluation metrics is needed. The ShakeAlert production system will adopt new algorithms if they improve overall performance in formalized testing. We are testing three algorithms in the ShakeAlert development environment, which mirrors the production system's computational infrastructure and allows simulated real-time replay of data streams. Test data consist of GNSS recordings from 25 M6-M9 earthquakes and synthetic data representing diverse event types. We adopt ShakeAlert metrics to evaluate the accuracy and timeliness of ground motion predictions and additional metrics for source characterization. These metrics will help identify the most valuable features for possible integration into a single geodetic (or seismo-geodetic) algorithm to submit for formalized testing.

\section{Plate Boundary Observatory GNSS Real Time Field Operations}

WALLS, C. P., UNAVCO, California, USA, walls@unavco.org; MANN, D., UNAVCO, California, USA, mann@unavco.org; HODGKINSON, K. M., UNAVCO, New Mexico, USA, hodgkin@unavco.org; AUSTIN, K. E., UNAVCO, Washington, USA, austin@unavco.org; DITTMAN, S. T., UNAVCO, Colorado, USA, dittman@unavco.org; FEAUX, K. F., UNAVCO, Colorado, USA, feaux@unavco.org; MATTIOLI, G. S., UNAVCO, Colorado, USA,mattioli@unavco.org

The EarthScope Plate Boundary Observatory (PBO) GNSS network, funded by the NSF and operated by UNAVCO, is comprised of $\sim 1100$ permanent GPS and GNSS stations across the United States. While the network was originally designed for tectonic and volcanic analysis, it has proven to be of significant value to stakeholders who use real-time data streams for early warning systems (i.e. earthquake, tsunami, meteorological). 721 ( 65\%) of these stations are currently streaming GPS $(n=504)$ or GNSS $(n=217)$ data in real-time with the majority of stations located along the Cascadia subduction zone and the San Andreas fault system. Of these, 44 GNSS streaming sites are located within $15 \mathrm{~km}$ of the west coast and provide data for real-time analysis of the ionosphere for tsunami wave height detection. Approximately 140 stations also stream meteorological data. The 1-sps real-time data are available from UNAVCO in BINEX and RTCM formats with Precise Point Position (PPP) solutions generated for each site using the NMEA format. A robust GPS/GNSS real-time stream is essential for any type of early warning application. High data completeness is needed to resolve peak ground displacements in surface waves and to estimate the coseismic offsets. Low latencies facilitate a rapid analysis of the incoming streams and improved warning for a larger area. Providing complete, low-latency GNSS real-time streams from the site to the processing center hinges critically on reliable data telemetry which in turn relies on hardened and adequately powered systems that are well maintained. Therefore, improving and hardening station telemetry whenever possible provides a high return on investment. Cell modems provide an easy and economical solution where coverage is available, but do suffer from infrequent outages that are beyond our operational control. Radio networks are robust and economical when well designed, but depend on the telemetry solution at the central uplink site. Most UNAVCO radio networks use cell modems for the final uplink, and only a few utilize a T1 line. Satellite links are power-hungry, expensive solutions and used when no other options are available. In weather friendly environments, VSat systems tend to be stable and completeness is generally high but have higher latencies and interruptions in service tend to be significantly longer than cell modems. We present performance metrics and operational challenges of running a real-time GNSS network.

Red Geodésica del Noroeste de México (REGNOM) in Northern Baja California

GONZALEZ-ORTEGA, J. A., CICESE, Baja California, Mexico, aglez@ cicese.mx; RAMON MORALES, E., CICESE, Baja California, Mexico, eramon@cicese.mx; VIDAL-VILLEGAS, J. A., CICESE, Baja California, Mexico,vidalv@cicese.mx; VALDEZ, A., CICESE, Baja California, Mexico, 
avaldez@cicese.mx; ARREGUI OJEDA, S., CICESE, Baja California, Mexico, sarregui@cicese.mx

Permanent continuous GPS stations in Baja California started to operate since 1995 as part of the Southern California Integrated GPS Network (SCIGN). Due to the occurrence of the El Mayor-Cucapah Mw7.2 earthquake in April 4, 2010, colleagues from Mexico and US started to work together in a NSF rapid response proposal to install 8 new continuous GNSS stations. Also, in the Mexicali Valley area, Geodesist without Borders, Caltech Tectonic Observatory Lab and Centro de Investigacion Cientifica y de Educacion Superior de Ensenada (CICESE) installed 7 new continuous GPS stations. Further, with the funding support from USGS, U.S. Northern Command, UNAVCO and CICESE, we started to install since 2015, 15 new continuous GNSS stations. This GNSS Network is formally named Red Geodesica del Noroeste de Mexico (REGNOM). REGNOM Network is optimized to support seismic research investigations, as they are co-located with seismological instruments of Red Sismica del CICESE (http:// resnom.cicese.mx). One of the main focus of REGNOM is to provide long term estimates of crustal deformation, characterization of elastic strain accumulation along different fault systems in northern Baja California and estimate regional reference frame for tectonic studies. All data products from archiving and processing are freely available from http://regnom.cicese.mx. As GNSS real-time data streaming is becoming essential to obtain: physical characteristics of earthquake rupture process, atmospheric studies, volcano and landslide monitoring; our near term plans include high-rate and low latency GNSS data. Here we describe our current development network status, plans for real-time data and institutional collaboration to further understand our complex-shared fault zone in southern California and northern Baja California.

Toward a Geodetic Near-Real Time System for Tectonic and Crustal Deformation Studies in Colombia and Venezuela South America

MORA-PAEZ, H., Servicio Geológico Colombiano, Bogotá D.C, Colombia, hmora@sgc.gov.co; AUDEMARD, F., Fundación Venezolana de Investigaciones Sismológicas, Caracas, Venezuela, faudemard@funvisis.gob.ve; MENCIN, D., UNAVCO Inc., Colorado, USA, dmencin@unavco.org; CARDONAPIEDRAHÍTA, L. A., Servicio Geológico Colombiano / Universidad Distrital Francisco Jose de Caldas, Bogota, Colombia, lacardonap@correo.udistrital.edu. co

GeoRED, the Spanish acronym for "Geodesia: Red de Estudios de Deformación" or "Geodesy: Deformation Studies Network", is a research, innovation and development project based on space geodesy, run by the Space Geodesy Research Group of the Geohazards Directorate of the Colombian Geological Survey, that takes a multifaceted approach to understanding the geodynamics and tectonics of northwestern South America with the ultimate goal to reduce the risks associated with active plate boundaries. The continuously operating reference station (CORS) network in Colombia is composed of 110 stations:94 GeoRED GNSS stations; 5 GNSS stations that are part of the COCONet (Continuously Operating Caribbean GPS Observational Network) project run by UNAVCO; the Bogotá IGS GNSS station (BOGT); and 10 stations installed under a collaborative partnership with local Colombian institutions, such as CENICAÑA (Sugar Cane Research Institute), National University of Colombia, Aburrá Valley Metropolitan Office, and the Bogota City Water Supply Company. Eight of the CORS stations have been co-collocated with seismic stations that are part of the National Seismological Network run also by the Colombian Geological Survey. Data generated at the CORS stations are transmitted to the data gathering center in Bogotá by one of a combination of communication pathways, ranging from high-speed direct connections to manual downloads. GNSS stations operated by FUNVISIS, installed under the frame of the COCONet Project operated by UNAVCO, will allow greater coverage of the area of interest and to improve the resolution of the analysis. Given the potential for very large and hazardous earthquakes on Colombia's Pacific and also Colombia and Venezuela Caribbean coasts, both active subduction zones, we analyze the current networks geometry and communications infrastructure andit is suitability for augmenting earthquake early warning systems in Colombia and Venezuela. We analyze the average noise level from each site for high-frequency GNSS data and then constrain the detection threshold based on a three sigma SNR based on peak ground displacement from at known faults. We use these to construct sensitivity maps for the region highlighting strengths, weaknesses and suitability for EEW.
Recent Advances in Dense Array Seismology Oral Session - Wednesday 16 May · 8:30 AM - Monroe Session Chairs: Ting Chen, Fan-Chi Lin, Norimitsu Nakata, and Catherine Snelson

\section{Using the Large-n Array to Constrain Shallow Velocity Structure in Oklahoma} HERRMANN, R. B., Saint Louis University, Missouri, USA, robert.b.herrmann@gmail.com

The determination of earthquake source parameters of small local earthquakes through waveform modeling requires a good velocity model. The question is how the data from Large-N deployments can help define the model. The data sets of the $2016 \mathrm{YW}$ array in Oklahoma permit a comparison of upper crustal models determined from teleseismic P-wave receiver functions and regional surfacewave dispersion in the $2-100 \mathrm{~s}$ period range to the very upper crustal structure estimated by the inversion local earthquake P-wave receiver functions and local dispersion in the $0.4-1.2 \mathrm{~s}$ period range. This comparison is possible because of relatively simple upper crustal structure that allows the assumption of a single $\mathrm{P}$-wave ray to the stations from the the large number of local earthquakes within $100 \mathrm{~km}$. The p-tau method is applied to the $12 \mathrm{~km}$ long record sections derived from ambient noise processing of the short-period sensor data to determine the fundamental and higher mode Love and Rayleigh wave phase velocities at the short periods. Only simple modifications to the existing joint inversion code were required to incorporate the local earthquake receiver functions. Results indicate that the shear-wave velocities in the upper 500 meters are $1000-1500 \mathrm{~m} / \mathrm{s}$. The velocity model that fits all observations is then used to create record sections for comparison to those of local earthquakes and ambient noise processing as a test of the final model.

\section{Earthquake Relocation above the Socorro Magma Body, Central New} Mexico, Using an 800+ Seismic Station Array

BILEK, S. L., New Mexico Institute of Mining \& Technology, New Mexico, USA, susan.bilek@nmt.edu; SCHMIDT, J., New Mexico Institute of Mining \& Technology, New Mexico, USA, jonathan.schmidt@student.nmt.edu; VIECELI, R. E., New Mexico Institute of Mining \& Technology, New Mexico, USA, rhiannon.vieceli@student.nmt.edu

Seismicity within the central New Mexico, USA region is dominated by deformation processes associated with the Socorro Magma Body (SMB), a large midcrustal continental magma body at 19-km depth within the Rio Grande Rift. Seismicity has been monitored in this region for decades by permanent short period network, and the resulting catalogs show long-term seismic activity punctuated by discrete earthquake swarms. Waveform characteristics, notably the observation of reflected phases arising from the magma body recorded on this sparse network, led to the discovery of the SMB and estimates of its spatial extent. To improve our understanding of current seismicity and refine maps of the spatial extent of the SMB, we deployed a mixed mode seismic array for 2 weeks over the northern portion of the magma body consisting of seven 3-component broadband seismometers and over 800 Fairfield vertical-component autonomous node $10 \mathrm{~Hz}$ seismographs. During the period of this temporary deployment, we detected over 200 possible earthquakes, with the majority located in the southern/western NM-AZ region. Thirty-three events, with preliminary duration magnitudes between -1.3 and 2.3 based on data from the broadband stations and nearby permanent network stations, were located within the SMB region. Here we present improvements on those locations using arrival times recorded on the node seismographs. Reflected phases are identified on both broadband and node seismograms and are used to improve depth estimates for these events where possible. We examine location uncertainties using subsets of node and broadband stations. We also explore source characteristics for these events using the full set of stations as well as mini-arrays of broadband and co-located nodes.

\section{Joint Body-Wave and Surface-Wave Tomography over a Partially Collapsed Nuclear Test, Nevada National Security Site}

ABBOTT, R. E., Sandia National Laboratories, New Mexico, USA, reabbot@ sandia.gov; PRESTON, L., Sandia National Laboratories, New Mexico, USA, Ipresto@sandia.gov; ONYANGO, E., University of New Mexico, New Mexico, USA, evans.onyango@gmail.com; WORTHINGTON, L. L., University of New Mexico, New Mexico, USA, Iworthington@unm.edu

We present preliminary P-wave and S-Wave velocity tomograms over a partially collapsed nuclear test at the Nevada National Security Site (NNSS). The HADDOCK legacy nuclear test was conducted in 1964 with an announced yield of less than 20 kilotons and depth-of-burial of 364 meters. The test is unusual in that the collapse of the test cavity did not reach the ground surface. With the 
goal of understanding the geophysical anomaly associated with a partial collapse, we acquired seismic data using a hybrid 2D/3D array of 1000 three-component sensors. Two seismic sources were used: a 13,000-kg weight-drop, and a much smaller, truck-mounted accelerated weight-drop. We calculated seismic tomograms using a joint inversion of refracted P-waves (over 250,000 travel times), and fundamental Rayleigh-wave phase-velocity dispersion curves (40 subarrays consisting of 1,000 stacked curves each). Our preliminary results indicate that the partial collapse is characterized by low velocities (relative to adjacent undisturbed material) near the working point of the explosion. Superjacent to the working point, low velocities extend to shallower depth for tens of meters before switching to a high velocity anomaly relative to adjacent undisturbed material. This high velocity anomaly extends to the surface. The depth of the transition from low- to high-velocity relative anomaly appears to be associated with the geologic contact of deeper volcanic tuff and overlying alluvium, implying very different material response to damage. Sandia National Laboratories is a multimission laboratory managed and operated by National Technology and Engineering Solutions of Sandia LLC, a wholly owned subsidiary of Honeywell International Inc. for the U.S. Department of Energy's National Nuclear Security Administration under contract DE-NA0003525.

\section{Characteristics of Airplanes and Helicopters Recorded by a Dense Seismic Array near Anza, California}

MENG, H., University of Southern California, California, USA, haoranme@ usc.edu; BEN-ZION, Y., University of Southern California, California, USA, benzion@usc.edu

We observe frequent air-traffic events in continuous seismic waveforms recorded for about 30 days by 1108 vertical geophones in a tight array on the San Jacinto fault zone. The waveforms of the air-traffic events resemble tremor or collections of small earthquakes. However, the time-frequency analysis shows clear Doppler effects that can be modeled with basic equations and fitted well with parameters corresponding to airplanes and helicopters. The flying traces can be inverted by fitting the fitted parameters at each station across the entire array. About 31 airtraffic events are detected per day in the relatively remote study area, with peak activity from about 8:00 to 18:00 and significantly fewer events between 23:00 and 4:00 local time. The average event duration is about $200 \mathrm{~s}$ so they cover together $\geq 7 \%$ of the day. To estimate the total time covered by earthquakes, we derive a scaling relation $\log \tau(M)=0.41 \mathrm{M}+0.89$ between earthquake duration and magnitudes using data of 266 earthquakes in the magnitude range $0 \leq \mathrm{M} \leq 3$. The results indicate that in most places the duration of air-traffic events is likely to exceed considerably the total time covered by earthquakes.

Dense Array Observations of Induced Seismicity: The LArge-n Seismic Survey in Oklahoma (LASSO) Experiment

DOUGHERTY, S. L., US Geological Survey, California, USA, sdougherty@ usgs.gov; COCHRAN, E. S., US Geological Survey, California, USA, ecochran@usgs.gov; HARRINGTON, R. M., Ruhr-Universität Bochum, Germany, rebecca.harrington@rub.de; ROSS, Z. E., Caltech, California, USA, zross@gps.caltech.edu

In response to the increased seismicity rate in northern Oklahoma, we deployed a temporary array of 1,833 vertical-component nodal seismometers. The LArge-n Seismic Survey in Oklahoma (LASSO) array operated for approximately one month in spring 2016, covering a $25-\mathrm{km}-\mathrm{by}-32-\mathrm{km}$ region with a nominal station spacing of $\sim 400 \mathrm{~m}$. We develop a local earthquake catalog from data recorded by the LASSO array, which allows us to investigate sequences of induced seismicity in this region of active wastewater injection with unprecedented clarity. We first identify earthquakes using a standard short-term average/long-term average detection technique. This technique finds 3,321 events, a factor of $\sim 60$ increase over the Oklahoma Geological Survey earthquake catalog. Initial hypocentral locations for these events indicate some instances of small-scale lateral and vertical spatiotemporal migration of seismicity. Several dense clusters of seismicity that were active throughout the deployment are also observed. We construct a database of template waveforms from these events and use this in a waveformcorrelation-based detection technique to identify additional smaller magnitude $(\mathrm{M}<2)$ earthquakes. Initial results from the application of this technique expand the earthquake catalog by $\sim 13,000$ events. We use this catalog to explore the spatiotemporal evolution of seismicity, particularly along individual fault segments. The locations and orientations of active faults may provide insights into interactions between small-scale fault structures as well as the potential locations of future induced earthquakes.
Large-N Gradiometry with Nodal Instrument Arrays

LANGSTON, C. A., The University of Memphis, Tennessee, USA, clangstn@ memphis.edu

Observations of the wave field at the surface of the Earth are fully characterized at a point by 3 orthogonal vector displacements, 3 horizontal strains, and 3 rigid body rotations. These $9 \mathrm{C}$ seismic observables can further be interpreted with a wave propagation model to infer basic attributes of the seismic waves including wave type (from the curl and divergence), azimuth of propagation, and horizontal phase velocity, among other parameters. If these point measurements are then distributed over a surface grid, then images of the wave field and its attributes can be empirically mapped forming tomographic images of the Earth structure effect on the seismic waves. Both the point measurements and expansion into a grid can be made by using dense arrays of seismometers where the seismic observations are incorporated into a finite difference scheme to compute strains and rotations. These kinds of arrays, sometimes called "geodetic" arrays, are becoming feasible to efficiently and cheaply deploy using high frequency $(5 \mathrm{or} 10 \mathrm{~Hz}$ dominant frequency) nodal instruments. Accurate computations of strains and rotations from seismic array data depend on precise knowledge of instrument orientations in the field. Estimates of relative amplitude statics and orientations can be made empirically by using teleseismic arrivals simultaneously recorded by the nodal instruments. Two nodal arrays are used to demonstrate the use of gradiometry for inferring wave attributes at a point and over an area. The IRIS Community Wavefields Experiment deployed during June-July 2016 affords a detailed look at instrument orientation and stability for computing wave gradients at a point and for comparison with standard array beamforming techniques. A Large-N experiment consisting of 384 vertical nodal seismometers deployed during an industrial 3D seismic experiment near Utica, Ohio, in 2013 demonstrates the variation of the high frequency wave field over a relatively small area of $\sim 200 \times 300 \mathrm{~m}$.

\section{Distributed Acoustic Sensing of the Seismic Wavefield at SAFOD}

ELLSWORTH, W. L., Stanford University, California, USA, wellsworth @ stanford.edu; YUAN, S., Stanford University, California, USA, syyuan@ stanford.edu; KARRENBACH, M., OptaSense, California, USA, martin. karrenbach@optasense.com; ZUMBERGE, M. A., UC San Diego, California, USA, mzumberge@ucsd.edu

An OptaSense Distributed Acoustic Sensing (DAS) model ODH3.1 was used to record local, regional and teleseismic earthquakes for one month at SAFOD using an optical fiber cemented behind casing. The fiber was interrogated between the surface and $800 \mathrm{~m}$ depth (top of basement). With this recording geometry, the DAS system captures the full vertical wavefield between the basement interface and free surface, revealing direct, converted and refracted waves. Both P- and Sstrain waves are clearly visible in the data. The main borehole at the San Andreas Fault Observatory at Depth (SAFOD) contains optical fibers cemented in place in between casing strings from the surface to just below the top of the basement. The fibers are under tension of approximately $1 \mathrm{~N}$ and are housed in a $0.9 \mathrm{~mm}$ diameter stainless steel tube. Earth strain is transmitted to the fiber by frictional contact with the tube wall. One fiber has been in use as a vertical strainmeter since 2005, measuring the total strain between 9 and $740 \mathrm{~m}$ by laser interferometry. The OptaSense DAS laser interrogator measures the strain over a gauge length with a set spacing between gauge intervals. For this experiment we set the gauge length to $10 \mathrm{~m}$ with $1 \mathrm{~m}$ spacing between gauges. Including the surface run of the fiber, this gives us 936 channels measuring the vertical strain at a sample interval of $0.4 \mathrm{msec}(2500 \mathrm{samples} / \mathrm{s})$. The incident and surface reflected wavefields can be separated by frequency-wavenumber filtering due to the large-aperture and fine spatial and temporal sampling. Up- and downgoing strain waves illuminate the subsurface within the sensor array's depth range. Accurate arrival time determinations of the initial arrival phase are possible due to consistent wave forms recorded at $1 \mathrm{~m}$ spatial intervals that can be used for fine-scale shallow velocity model estimation.

\section{Towards Noise Tomography and Passive Monitoring Using Distributed Acoustic Sensing}

PAITZ,P., ETH Zurich, ZH, Switzerland, patrick.paitz@erdw.ethz.ch; FICHTNER, A., ETH Zurich, Switzerland, andreas.fichtner@erdw.ethz.ch

Distributed Acoustic Sensing (DAS) has the potential to revolutionize the field of seismic data acquisition. Thanks to their cost-effectiveness, fiber-optic cables may have the capability of complementing conventional geophones and seismometers by filling a niche of applications utilizing large amounts of data. Therefore, DAS may serve as an additional tool to investigate the internal structure of the Earth and its changes over time; on scales ranging from hydrocarbon or geothermal reservoirs to the entire globe. An additional potential may be in the existence of large fibre networks deployed already for telecommunication purposes. These 
networks that already exist today could serve as distributed seismic antennas. We investigate theoretically how ambient noise tomography may be used with DAS data. For this we extend the theory of seismic interferometry to the measurement of strain. With numerical, 2D finite-difference examples we investigate the impact of source and receiver effects. We study the effect of heterogeneous source distributions and the cable orientation by assessing similarities and differences to the Green's function. We also compare the obtained interferometric waveforms from strain interferometry to displacement interferometric wave fields obtained with existing methods. Intermediate results show that the obtained interferometric waveforms can be connected to the Green's Functions and provide consistent information about the propagation medium. These simulations will be extended to reservoir scale subsurface structures. The presented research depicts the early stage of a combination of theoretical investigations, numerical simulations and real-world data applications.

A Large-Aperture Distributed Acoustic Sensing Array in Goldstone, California ZHAN, Z., Caltech, California, USA, zwzhan@caltech.edu; LINDSEY, N J., Lawrence Berkeley National Laboratory, California, USA, natelindsey@ berkeley.edu; IDINI, B., Caltech, California, USA, bidiniza@gps.caltech.edu; AJO-FRANKLIN, J. B., Lawrence Berkeley National Laboratory, California, USA, jbajo-franklin@lbl.gov; WILLIAMS, E., Caltech, California, USA, efwillia@gps.caltech.edu

Distributed Acoustic Sensing (DAS) has emerged as an attractive technology to build affordable and scalable dense seismic networks, especially in urban environment with existing telecommunication fibers. However, the instrument response and sensitivity of DAS, as well as effects of coupling, are not fully understood yet for seismological research purposes, especially at frequencies lower than $5 \mathrm{~Hz}$ for earthquake seismology. Here we convert a $20-\mathrm{km}$ long optical fiber deployed in Goldstone, California by the Jet Propulsion Laboratory to a 5000 sensor DAS array to test its sensitivity in recording local, regional, and teleseismic earthquakes. The relatively ideal fiber condition (e.g., long continuous fiber, low-noise environment, deeply buried fiber) and the nearby permanent broadband stations as references allow us to investigate the fidelity and variability of DAS waveforms in a wide frequency band. During the three months of experiment, we have recorded four $M \geq 7$ teleseismic earthquakes and five $M \geq 4$ regional earthquakes, in addition to many smaller events. We will show their waveforms and comparisons with those from broadband reference stations to assess the potential of the DAS technology for earthquake seismology applications.

Earthquake Characterization with a Dark Fiber DAS Array in Sacramento, California

LINDSEY, N. J., UC Berkeley, California, USA, natelindsey@berkeley.edu; DOU, S., Lawrence Berkeley National Laboratory, California, USA, sdou@lbl. gov; RADEMACHER, H., UC Berkeley, California, USA, horst@ berkeley.edu; TRACY, C., Lawrence Berkeley National Laboratory, California, USA, ctracy@ es.net; MONGA, I., Lawrence Berkeley National Laboratory, California, USA, imonga@es.net; AJO-FRANKLIN, J. B., Lawrence Berkeley National Laboratory, California, USA, jbajo-franklin@lbl.gov; ROBERTSON, M., Lawrence Berkeley National Laboratory, California, USA, mcrobertson@lbl.gov

Distributed Acoustic Sensing (DAS) is a novel seismological tool that uses optical Rayleigh scattering inside of a fiber-optic to measure ground motions over tens of linear kilometers at meter scale spatial resolution. We propose that the combination of DAS and excess telecommunications infrastructure-so-called "dark fiber" - can be used to address a diversity of earth science questions where access, security, logistical aspects, and cost and have historically hindered seismic observation. Here we focus on the earthquake detection, location, and characterization problem using a dark fiber DAS field example from California. Beginning in July 2017, approximately $20 \mathrm{~km}$ of unused telecommunications fiber-optic cable located near West Sacramento, CA was used as a dense ( 1 sensing point every 2 m), 10,000 component, horizontal DAS array. The volumetric flow rate of data was $\sim 8 \mathrm{~TB} /$ week. To identify and discriminate signals generated by moving automobiles and trains, earthquakes (local, regional, teleseismic), and optical noise we investigate a range of single-channel and array-based signal features that could be used to optimize this classification, including time and frequency features, coda shape, slowness, and back azimuth. A Guralp CMG-3T broadband seismometer was collocated with a portion of the DAS array, and presents a means of ground motion comparison to investigate DAS instrument response.

\section{Seismic Event Screening}

Oral Session . Wednesday 16 May • 8:30 AM • Orchid AB

Session Chairs: Raymond Willemann and David Bowers

\section{An Improved Semi-Automatic Shallow Event Depth Estimation Algorithm, Based on Cepstral Analysis}

KEMERAIT, R., US Air Force Technical Applications Center, Florida, USA, kemerait@aftac.gov; TIBULEAC, I. M., US Air Force Technical Applications Center, Florida, USA, itibulea@aftac.gov; CAPUANO, M. A., Kegman Inc., Florida, USA, acapuano@aftac.gov; PASCUAL, J. A., Securboration, Inc, Florida, USA, jpascual@ubqt.com; THURSBY, M., Modus Operandi, Florida, USA,mthursby@aftac.gov

An important parameter considered for event characterization is depth. One method used for depth estimation is determining the difference in arrival times between the initial $\mathrm{P}$ phase and the following depth-phase arrival resulting from a P-phase surface reflection. For deeper events, the first arrival and its depth phase are well separated, and the time difference is easily determined. However, this is not the case for very shallow events less than a few kilometers deep. The objective of this study is to test new digital data processing techniques to be applied to the cepstral analysis of depth phases, in order to reliably estimate depths of these very shallow events. In this case, parameters such as waveform sampling, window analysis length, and preliminary filtering and tapering become important for the accuracy of time-delay estimation. While developing a depth-refining tool, we address important issues identified by previous studies, such as: method repeatability, speed, error estimation and stability, and echo identification. For this reason, we have developed new metrics and implemented nested loop solution testing. The metrics include: power and complex cepstrum similarity; liftering adequacy; and success of the homomorphic deconvolution, which includes delay lag recovery, and deconvolved waveform comparison to the initial signal. Weights applied to each metric are set empirically, or based on the adequacy of the minimum phase signal approximation. In addition, optimization of a combination of processing techniques is discussed here. We focus on improving spectral and cepstral denoising, phase unwrapping and liftering. Arrays or networks are used to identify the depth phases. The algorithms are tested on a ground-truth database, with well-known depth events and on synthetic waveforms. Method advantages and limitations are discussed.

\section{Mapping Spectral Ratios to Discriminate between Shallow Low-Magnitude Earthquakes and Blasts}

KOLAJ, M., Canadian Hazards Information Service, michal.kolaj@ canada.ca

Discriminating between explosions, earthquakes and other seismic events using regional seismic networks remains a challenge. This is particularly true in areas containing both low-magnitude explosions (arising from construction and/or mining activity) and shallow earthquakes. Moreover, many discriminants are typically region dependent and display poor transportability. To this effect, a generalized workflow was developed to tune spectral ratio discriminants for a given area. In this technique, spectral ratios are calculated using RMS estimates made within 13 narrowband windows between 1 to $40 \mathrm{~Hz}$ on regional phases. Spectral ratios are then calculated between all phases and windows using a set of confirmed events, network averaged, and the discriminating power of each spectral ratio is calculated. These results are then visually displayed in a matrix scatter plot allowing the user (or a downstream automated tool) to assess the quality and choose appropriate spectral ratio discriminants. In a test study in New Brunswick, Canada, the methodology revealed that broadband high-frequency $\mathrm{Pg} / \mathrm{Lg}$ and low-frequency $\mathrm{Lg} / \mathrm{Rg}$ were able to consistently discriminate between low magnitude $(\mathrm{M}<2)$, shallow (depth $<3 \mathrm{~km}$ ) earthquakes and blasts related to road construction. The developed discriminants were then used to classify ten questionable low magnitude (M0.7 to M2.3) shallow events (nine blasts and one earthquake). Preliminary results of testing the method in the mining district of Sudbury, Canada revealed that there are no consistent spectral differences between rockbursts and in-mine blasts, but that the two can typically be separated from natural earthquakes.

\section{Investigating the Limits of Correlation Detectors as Discriminants}

YECK, W. L., US Geological Survey, Colorado, USA, wyeck@usgs.gov; BENZ, H.M., US Geological Survey, Colorado, USA, benz@usgs.gov; EARLE, P. S., US Geological Survey, Colorado, USA, william.luther.yeck@gmail.com; HARRIS, D. B., Deschutes Signal Processing LLC, 81211, Oregon, USA, oregondsp@ gmail.com

In much of the Central and Eastern United States (CEUS), the vast majority of observed seismic events are the result of surface mining activity. Monitoring 
and reporting these events creates an undue burden on seismic analysts when generating an earthquake bulletin and their removal from earthquake catalogs is necessary to support downstream products such as Probabilistic Seismic Hazard Analysis. Therefore, the ability to automatically discriminate these events can improve real-time monitoring operations. In recent years, correlation detectors have been routinely implemented to detect small magnitude or low signal-tonoise events and have been shown to be effective discriminants. Still, the limitations of these detectors are poorly documented. The CEUS offers a good location to test the abilities of these detectors due to the high-density of both low yield-sources and seismic stations. Here we discuss our investigations into the limitations of this class of detectors in the real-time identification and location of mining related seismicity. We test the use of various correlation detectors including match filters, subspace detectors, and multi-station network detectors. We explore the capabilities of these detectors as a function of source-station geometry and distance. We test the long-term use of these detectors, which has unique challenges in detecting mining-activity due to temporal variations in source locations and blasting characteristics. Our aim is to broaden our understanding of detectors for real-time operational applications at National Earthquake Information Center. Our results suggest that correlation detectors can effectively reduce the burden to analysts imposed by mining events, but design considerations (e.g. frequency band, template duration, network configuration) are required for their optimal use in network seismology.

Applications of Body-Wave Methods of Distinguishing Between Explosions, Cavity Collapses and Earthquakes to the Recent DPRK Events With Insights From the Nevada Source Physics Experiments

WALTER, W. R., Lawrence Livermore National Laboratory, California, USA, walter5@llnl.gov; DODGE, D. A., Lawrence Livermore National Laboratory, California, USA, dodge1@llnl.gov; ICHINOSE, G. A., Lawrence Livermore National Laboratory, California, USA, ichinose1@llnl.gov; MYERS, S. C., Lawrence Livermore National Laboratory, California, USA, myers30@llnt. gov; FORD, S. R., Lawrence Livermore National Laboratory, California, USA, ford17@llnl.gov; PITARKA, A., Lawrence Livermore National Laboratory, California, USA, pitarka1@llnl.gov; PYLE, M. L., Lawrence Livermore National Laboratory, California, USA, pyle4@llnl.gov; PASYANOS, M. E., Lawrence Livermore National Laboratory, California, USA, pasyanos1@llnl. gov; MATZEL, E., Lawrence Livermore National Laboratory, California, USA, matzel1@llnl.gov; RODGERS, A., Lawrence Livermore National Laboratory, California, USA, rodgers7@llnl.gov; MELLORS, R. J., Lawrence Livermore National Laboratory, California, USA, mellors1@llnl.gov; HAUK, T., Lawrence Livermore National Laboratory, California, USA, hauk1@llnl.gov; KROLL, K. A., Lawrence Livermore National Laboratory, California, USA, kroll5@llnl.gov.

Examination of regional distance seismic data from historic nuclear test sites has led to a variety of very effective discriminants between explosions, earthquakes and collapses. These include moment tensor techniques and body-wave based methods. Here we focus on the body-wave methods. We show that P/S ratios above about $\sim 2 \mathrm{~Hz}$ very effectively separate the six North Korean (DPRK) declared nuclear tests between 2006 and 2017 from natural earthquakes in the region. Similarly we show P/S ratios separate historic Nevada Test Site (NTS) nuclear explosions from western U.S. earthquakes. We show that combining P/S ratios with low to high frequency ratios can effectively separate post-explosion collapse events, such as the 1982 NTS Atrisco collapse and the apparent collapse that followed about eight and a half minutes after the September 3, 2017 DPRK explosion. Explosions often produce fewer and smaller aftershocks than comparably sized earthquakes, which has been proposed as a potential discriminant. We apply the body-wave techniques to the recent seismicity following the largest DPRK event, after first using correlation methods to build a more complete cata$\log$ of these events. We note from examination of the correlation of NTS explosions, that caution must be used when considering correlation alone to identify explosions. Despite the empirical effectiveness of the regional body-wave discriminants, the physical basis for the generation of explosion S-waves, and therefore the predictability of $\mathrm{P} / \mathrm{S}$ and low/high frequency techniques, as a function of path, frequency and event properties such as size, depth, and geology, remains incompletely understood. A goal of current research, such as the Source Physics Experiments (SPE), is to improve our physical understanding of the mechanisms of explosion $S$-wave generation and advance our ability to numerically model and predict them. We discuss the latest results of the SPE research as applied to bodywave discriminants here.

Discrimination of the DPRK Announced Underground Explosions and Their Aftershocks Using the $\mathbf{P g} / \mathrm{lg}$ Spectral Amplitude Ratio

KITOV, I., CTBTO, Wien, Austria, ivan.kitov@ctbto.org; LE BRAS, R. J., CTBTO, Wien, Austria, ronan.lebras@gmail.com; ROZHKOV, M., CTBTO,
Wien, Austria, mikhail.rozhkov@ctbto.org; SANINA, I., IDG Russian Academy of Sciences, Russian Federation, irina@idg.chph.ras.ru

We estimate the discrimination criterion based on the $\mathrm{P} / \mathrm{S}$ spectral amplitude ratios as applied to six tests conducted by North Korea and ten aftershocks induced by the last two explosions. We use data from IMS arrays USRK and KSRS and non-IMS 3-C stations SEHB (South Korea) and MDJ (China). The largest $\mathrm{P}$ and $\mathrm{S}$ phases at all stations are $\mathrm{Pg}$ and $\mathrm{Lg}$, respectively. Nine of the ten aftershocks were so weak (mb magnitude from 2.2 to 3.4 ) that we had to develop several detection and phase association procedures based on waveform cross correlation in order to create reliable event hypotheses. We have calculated Pg/ $\mathrm{Lg}$ spectral ratios for each of the four stations in six different frequency bands between $1 \mathrm{~Hz}$ and $12 \mathrm{~Hz}(10 \mathrm{~Hz}$ for stations with $20 \mathrm{~Hz}$ sampling rate). With increasing frequency, all stations demonstrate approximately the same level of deviation between the $\mathrm{Pg} / \mathrm{Lg}$ spectral amplitude ratios belonging to the DPRK explosions and their aftershocks. For a single station, simple statistical estimates show that the probability of any of six aftershocks to be a sample from the explosion population is smaller than $0.004 \%$ at KSRS and even lower at USRK. The probability of any of the DPRK explosions to be a representative of the aftershock population is defined by the distance of 20 or more standard deviations to the mean explosion $\mathrm{Pg} / \mathrm{Lg}$ value. For network discrimination, we use the Mahalanobis distance combining the $\mathrm{Pg} / \mathrm{Lg}$ values at three stations: USRK, KSRS and MDJ. At frequencies above $4 \mathrm{~Hz}$, the (squared) Mahalanobis distance, $\mathrm{D}$, between the populations of explosions and aftershocks is larger than 100 with the critical $\mathrm{D}=16.2$ corresponding to a level of significance $\alpha=0.001$. In the frequency band between 6 and $12 \mathrm{~Hz}$, the aftershocks Mahalanobis distance from the average explosion is larger than 10,000. These discrimination results are valid only for the aftershocks of the DPRK tests and cannot be directly extrapolated to the population of tectonic earthquakes.

\section{Uncertainty Estimation of Moment Tensor Source Types}

TAPE, C., University of Alaska Fairbanks, Alaska, USA, ctape@alaska.edu; ALVIZURI, C. R., University of Lausanne, Switzerland, celso.alvizuri@gmail. com; TAPE, W., University of Alaska Fairbanks, Alaska, USA, wtape@alaska. edu

A moment tensor is a symmetric matrix that expresses the source for a seismic event. Uncertainty characterization of moment tensors is vital for any interpretation about the moment tensor, such as whether an event is likely to be an earthquake or not. We provide a method for characterizing and visualizing the uncertainty for a full moment tensor. Our uncertainty summary has four components: (1) variation in waveform misfit for the best-fitting moment tensor at each lune point; (2) probability density $\mathrm{p}(\mathrm{v}, \mathrm{w})$ for moment tensor source type; (3) confidence curve Pcon $(\mathrm{V})$; (4) confidence parameter Pav, which is the area under the confidence curve, with large values representing high concentration of probability near the best-fitting moment tensor. These characterizations are facilitated by a uniform parameterization of moment tensors with fixed magnitude. The parameters describe the source type, with $\mathrm{v}$ and $\mathrm{w}$, and the orientation with strike angle, cosine dip angle, and rake angle. The parameterization is uniform in the sense that a uniform distribution of 5 -tuples in the coordinate domain corresponds to a uniform distribution in the moment tensor space. Stated otherwise, volumes (i.e. 5-volumes) in the coordinate domain are proportional to the corresponding volumes of moment tensors. Uncertainty in source type and be derived from the probability density $\mathrm{p}(\mathrm{v}, \mathrm{w})$ in source type, which is depicted easily on the vw rectangular domain. We discuss how this approach could be applied to event screening.

Identification of Small Seismic Events around North Korean Nuclear Test Site following the 3 September 2017 Underground Nuclear Test

KIM, W. Y., Lamont-Doherty Earth Observatory, Columbia University, New York, USA, wykim@ldeo.columbia.edu; RICHARDS, P. G., Lamont-Doherty Earth Observatory, Columbia University, New York, USA, richards@ldeo. columbia.edu

At least nine small seismic events were detected and located around the North Korean nuclear test site following the 3 September 2017 underground nuclear test. The magnitude of these shocks range from 2.3 to 3.5. Based on their proximity to the 3 September 2017 UNT, these shocks may be considered as aftershocks of the UNT. We assess the best method to classify these small events based on spectral amplitude ratios of regional $P$ and $S$ wave from the shocks. None of these shocks are classified as explosion-like based on $\mathrm{P} / \mathrm{S}$ spectral amplitude ratios. We examine additional possible small seismic events around the North Korean test site by using seismic data from stations in South Korea and northeastern China including IMS seismic arrays, GSN stations, and regional network stations. A linear discriminant function based on Mahalanobis methods applied to $\mathrm{P} / \mathrm{S}$ spec- 
tral ratios does a better job of screening events, than does a simple average of such ratios.

Combined Seismic/Geodetic Source-Type Inversion of the September 03, 2017, DPRK Nuclear Test

DREGER, D. S., UC Berkeley, California, USA, dreger@seismo.berkeley. edu; RODGERS, A., Lawrence Livermore National Laboratory, California, USA, rodgers7@llnl.gov; ICHINOSE, G. A., Lawrence Livermore National Laboratory, California, USA, ichinose1@llnl.gov; CHIANG, A., Lawrence Livermore National Laboratory, California, USA, chiang4@llnl.gov; FORD, S. R., Lawrence Livermore National Laboratory, California, USA, ford17@llnl.gov; WANG, T., Nanyang Technical University, Singapore, wang.teng@ntu.edu.sg

The September 3, 2017 announced DPRK nuclear test at the Punggye-ri site produced an exceptional regional distance seismic waveform data set, and unprecedented TerraSAR-X observations of the above shot ground displacement (e.g. Wang et al., 2017, 2018). Regional distance moment tensor solutions utilizing data from the CDSN, KSN, and the GSN recover a solution that is predominantly explosive in nature, but has a substantial deviatoric component, from large observed Love waves. The best fitting complete solution finds a total moment of $8.90 \mathrm{e}+16 \mathrm{Nm}(\mathrm{Mw} 5.2)$ that is decomposed as $53 \%$ isotropic, $40 \%$ double-couple, and 7\% CLVD, although the range of isotropic moment from the source-type analysis indicates that it could be as high as $60-80 \%$. The isotropic moment in the source-type inversion is $4.75 \mathrm{e} 16 \mathrm{Nm}$ ( $\mathrm{Mw}$ 5.05). Assuming elastic moduli from model MDJ2 the explosion cavity radius is approximately $51 \mathrm{~m}$, and the yield estimated using Denny and Johnson (1991) is $120-400 \mathrm{kt}$. The relatively large deviatoric component of the best fitting seismic waveform moment tensor solution fails to fit the displacement observations, however an examination of the source-type space of acceptable solutions fitting both regional waveforms and first-motions reveals a mechanism that to first-order explains the large radial outward deformation, and when combined with the collapse event that occurred 8.5 minutes later, the relatively low vertical deformation. In this study we utilize the SW4 finite-difference code to compute the above shot static deformation field considering the topography of the test site. Forward models of the explosion and collapse moment tensors are estimated and compared to the Terra-SAR-X observations. Finally, moment tensor basis Green's functions are computed with SW4, and a joint source-type inversion (Ford et al., 2012; Nayak and Dreger, 2015) of regional waveforms, first-motion polarities and the geodetic displacement field is attempted.

Deconvolution of the Source Spectra for the North Korean Underground Nuclear Tests

STROUJKOVA, A., Weston Geophysical Corp., Ohio, USA, ana_s@juno.com

Analysis of seismic source characteristics is important for seismic event identification. However, complexities along the propagation paths as well as the station site responses significantly affect seismic waveforms and spectra. A non-parametric inversion method (e.g. Andrews, 1986) was used to separate the source signatures and the propagation effects for six nuclear explosions conducted by the North Korea using seismic records from the stations located from regional to teleseismic distances. This technique recovers both propagation/site and source effects simultaneously by solving a linear system of equations. The recovered spectra were compared with the theoretical spectral models. The spectral corner frequencies of the recovered spectra appear to be lower than predicted by the Mueller-Murphy model (Mueller and Murphy, 1971), while the high-frequency roll-off is proportional to. Grid search minimization was used to determine the scaling relationship between the corner frequency and the low-frequency asymptote. Thus, in the framework of this approach we can successfully separate source spectra from site effects for nuclear explosions. $\overline{\text { Seismic Hazards and Historic Earthquakes in Puerto Rico }}$ and the Northern Caribbean Region

Oral Session - Wednesday 16 May · 4:15 PM · Orchid AB

Session Chairs: Roland LaForge, Dan McNamara, and

Charles Mueller

\section{Comparison of Two Probabilistic Seismic Hazard Models for Puerto Rico and} the U.S. Virgin Islands

MUELLER, C. S., US Geological Survey, Colorado, USA, cmueller@ usgs.gov; LAFORGE, R. C., LaForge GeoConsulting, Colorado, USA, laforgegeoconsulting@gmail.com

Probabilistic seismic hazard models for Puerto Rico and the U.S. Virgin Islands (PRVI) were developed in 2003 by the US Geological Survey (USGS Open-file Report 2003-379; GS03) and in 2005 by LaForge and McCann (GSA Special Paper 385; LM05). Both source models considered: (1) highly oblique convergence between North America and the PRVI microplate along the Puerto Rico subduction zone, (2) east-west extension in the Mona Passage and Anegada Passage regions, (3) the South Lajas, Septentrional, and Bowin crustal faults, and (4) background (catalog-based) sources. LM05 also modeled the onshore Cerro Goden fault. Some of the major sources lie offshore and are thus difficult to characterize, leading to some interesting modeling differences. These include segmentation and coupling on the subduction interface, allocation of GPS-determined extension rates at Mona and Anegada onto faults or into zones, and recurrence parameters for the Bowin and eastern Septentrional faults. LM05 included a model for the Muertos/Investigator structures, whereas GS03 did not. LM05 focused on Puerto Rico and did not completely characterize seismic hazards in the U.S. Virgin Islands. We will compare the source, recurrence, and groundmotion models, as well as results from the two studies. Considerations for future hazard modeling will be discussed, including recent paleoseismological studies on the Great Southern Puerto Rico fault zone.

\section{Assessing Earthquake Hazard in the Caribbean and Central America within the CCARA Project}

GARCIA,J.A., GEM Foundation, PV, Italy, julio.garcia@globalquakemodel.org; PAGANI, M., GEM Foundation, Pavia, Italy, marco.pagani@globalquakemodel. org; GEE, R., GEM Foundation, Pavia, Italy, robin.gee@globalquakemodel.org; POGGI, V., GEM Foundation, Pavia, Italy, valerio.poggi@globalquakemodel. org; STYRON, R., GEM Foundation, Pavia, Italy, richard.styron@ globalquakemodel.org; JOHNSON, K., GEM Foundation, Pavia, Italy, kendra. johnson@globalquakemodel.org

Central America and the Caribbean show complex tectonic settings, which are responsible for the occurrence of large destructive earthquakes, tsunamis, and explosive volcanoes. Among these, earthquakes represent a significant threat for the population. Several earthquakes with magnitude higher than 7.0 observed in historical times, caused extensive damage to buildings and structures, often associated to large numbers of casualties and even destruction of entire settlements. Recent earthquakes (e.g. Haiti $2010 \mathrm{M}=7.0$, Costa Rica $1991 \mathrm{M}=7.8$, Guatemala $1976 \mathrm{M}=7.5)$ had demonstrated the compelling need to assess seismic hazard within this region, in order to reduce the impact of such large events on the society. Nowadays, however, the knowledge on earthquake occurrence and seismic hazard in general is heterogeneous across the region. Although several seismic hazard studies have been carried out at both regional and national scales, most of these models have been derived using different approaches, assumptions and heterogeneous input information, often not publicly available. Within the CCARA project we produced a new and comprehensive hazard model, homogenous across the region, based on the collection, selection and harmonization of existing information from local and regional studies. The model developed offers a transparent, up-to-date and reproducible view of seismic hazard based on scientific knowledge available for the region. In this communication, we describe in detail the issues related to the preparation of the different input datasets (e.g. the earthquake catalogue, the database of active shallow faults and of strong motion recordings) necessary for the subsequent implementation of the new CCARA hazard model and we illustrate the main characteristic of the hazard input model created.

\section{Seismic Hazard Model for the Caribbean Region}

TORPEY, M., AIR Worldwide, Massachusetts, USA, mtorpey@air-worldwide. com; SHEN-TU, B., AIR Worldwide, Massachusetts, USA, bingming@airworldwide.com; SHABESTARI, K., AIR Worldwide, Massachusetts, USA, kshabestari@air-worldwide.com; ALI, S. T., AIR Worldwide, Massachusetts, USA, sali@air-worldwide.com; MAHDYIAR, M., AIR Worldwide, Massachusetts, USA, mmahdyiar@air-worldwide.com; LI, S., AIR Worldwide, 
Massachusetts, USA, sli@air-worldwide.com; VLACHOS, C., AIR Worldwide, Massachusetts, USA, cvlachos@air-worldwide.com; KIANIRAD, E., AIR Worldwide, Massachusetts, USA, ekianirad@air-worldwide.com; ZHU, J., AIR Worldwide, Massachusetts, USA, jzhu@air-worldwide.com; YIN, Y., AIR Worldwide, Massachusetts, USA, yyin@air-worldwide.com

The Caribbean region is a tectonically complex and active environment that has been host to many devastating earthquakes and tsunamis in the past, most notably, the 2010 Haiti Mw 7.0 earthquake. The oblique subduction of the North American plate beneath the Caribbean plate at the Puerto Rico Trench and Lesser Antilles subduction zone has the potential for generating large tsunamigenic events. Additional hazard comes from large strike-slip fault zones in the region such as the Enriquillo-Plantain Garden fault, the Oriente fault and the Walton fault. We are developing a seismic hazard model that incorporates liquefaction and tsunami modules to quantify hazard in the Caribbean. We compiled a unified moment magnitude historic earthquake catalog using the most recent global and regional historical earthquake catalogs and published literature as one of the key model input datasets. The model also incorporates the latest detailed geological and paleoseismological information on active faults and strain rate estimates from published kinematic models to constrain the seismic moment budget and the seismicity rate within each of the modelled source zones. The seismicity model is composed of both fault sources and areal sources for background seismicity and the rates are constrained by detailed fault information on well-known faults or historic and moment rates in the areal sources. The ground motion model employs a logic tree approach and incorporates ground motion prediction equations (GMPEs) from the most updated and robust models available globally, representative of different regions such as crustal and subduction zone environments. Our model also considers soil amplification and includes high-resolution soil maps for most of the modelled countries. We will present hazard results for peak ground acceleration (PGA) and spectra accelerations (SA) at important cities and discuss the similarities and differences between our results and other published results.

\section{Assessment of Ground Motion Prediction Equations and Site Corrections for Use in Haiti}

BENT, A. L., Natural Resources Canada-Ottawa, allison.bent@canada.ca; CASSIDY, J. F., Natural Resources Canada-Sidney, john.cassidy@canada.ca

To accurately predict shaking levels from an earthquake, and to improve earthquake hazard models, ground motion prediction equations (GMPEs) which properly account for attenuation are required. These vary from one region to another. Many researchers investigating seismic hazard in the Caribbean have noted a lack of regionally derived attenuation relations. Using data primarily from the 2010 Mw 7.0 Haiti earthquake and its hundreds of aftershocks, we develop an attenuation relation for Haiti, which is then validated and refined using data from subsequent regional earthquakes. Published GMPEs that were either developed for, or used in, other regions of the Caribbean do a reasonable job predicting shaking from Haitian earthquakes for some distance and magnitude ranges but none are fully satisfactory for the complete data set. We use these previous GMPE's as a starting point and then modify them as needed to develop improved GMPEs for Haiti. An important element in the development of GMPE's is correcting observations for local site effects. For example, stations on soft soil may amplify the shaking. With that in mind, we have developed site corrections for stations and applied those in our analysis.

\section{Address-Level Effects of the 1918 Puerto Rico Earthquake}

LAFORGE, R. C., LaForge GeoConsulting, Colorado, USA, laforgegeoconsulting@gmail.com; MCCANN, W. R., Earth Sciences Associates, Colorado,USA,wrmccann@comcast.net

The last major earthquake to affect Puerto Rico was a Mw 7.3 event that occurred in 1918 , about $30 \mathrm{~km}$ northwest of the northwest corner of the island, on a normal fault associated with the Mona Canyon rift. It was accompanied by a destructive tsunami. The most severe damage was sustained in the towns of Mayagüez, Aguadilla, Aguada, and Añasco. Fatalities numbered around 115 and infrastructure damage totaled about $\$ 63$ million in today's dollars. A 1918 report by Reid and Taber, as well as the local Special Earthquake Commission reports housed in the San Juan Archives, allowed for a detailed examination of building performance, and ground shaking and tsunami damage. As part of a NEHRP-funded study, the detailed building damage reports, and other documents and photographic images were copied digitally, compiled, and analyzed. These documents had lain unexamined in the Archive for the past 100 years, and included official correspondence, damage reports, monetary repair estimates of public and private infrastructure, and records of repair transactions. Of particular interest was a program whereby citizens could petition the government for the cost of repairing or replacing damaged or destroyed homes. This provided detailed descriptions of structural damage and tsunami runup heights at specific addresses. Petitions (not always complete) from Mayagüez, Aguadilla, and Añasco were carefully read, translated, and entered into spreadsheets. An analysis of the Aguadilla petitions, in conjunction with Lidar elevation data, permits a mapping of the maximum tsunami runup in that town. The results are consistent with the original Reid and Taber field observations as well as recent tsunami modeling studies, but provide more detail due to the address-level observations. This information should help calibrate tsunami generation and ground shaking (ShakeMap) models, as well as inform local emergency plans, for a repeat of such an event.

\section{Seismic Structure of Convergent Plate Margins}

Oral Session • Wednesday 16 May · 4:15 PM • Hibiscus A

Session Chairs: Min Chen and Jonathan R. Delph

\section{Contributions of Modern Seismic Imaging to Understanding the Andean Convergent Margin}

BECK, S. L., University of Arizona, Arizona, USA, slbeck@email.arizona. edu; PORTNER, D. E., University of Arizona, Arizona, USA, portner@ email.arizona.edu; BISHOP, B. T., University of Arizona, Arizona, USA, brandontbishop@email.arizona.edu; KOCH, C. D., University of Arizona, Arizona, USA, cdkoch@email.arizona.edu; RODRIGUEZ, E. E., University of Arizona, Arizona, USA, rodrigueze@email.arizona.edu; LYNNER, C., University of Arizona, Arizona, USA, cll44@email.arizona.edu; RYAN, J. C., University of Arizona, Arizona, USA, jgeoryan@email.arizona.edu; WARD, K. M., University of Utah, Utah, USA, kevin.m.ward@utah.edu; DELPH, J. R., Rice University, Texas, USA, jrdelph@rice.edu; WAGNER, S. L., DTM, Carnegie Institution of Washington, District of Columbia, USA, Iwagner@ carnegiescience.edu; ALVARADO, P., CONICET and Universidad Nacional de San Juan, San Juan, Argentina, alvarado@unsj.edu.ar; PORTER, R. C., Northern Arizona University, Arizona, USA, ryan.porter@nau.edu; SCIRE, A., New Mexico Institute of Mining and Technology, New Mexico, USA, ascire@ passcal.nmt.edu; LINKIMER, L., Universidad de Costa Rica, Costa Rica, linkimerl@gmail.com

Improved seismic images of the South American convergent margin are providing new insights to longstanding tectonic problems including: (1) the formation and destruction of thick continental crust, (2) the influence of flat slab subduction on the over-riding plate, and (3) the role of slab morphology on mountain building. We have used data from over 1000 seismic stations and multiple techniques to generate seismic images spanning $\sim 3000 \mathrm{~km}$ of the South American convergent margin. In the central Andes, the Altiplano and Puna Plateaus have thick crust but have different upper mantle seismic signatures with nearly complete lithospheric removal beneath the Puna and more piecemeal removal beneath the Altiplano. Both the central Altipano and northern Puna show radial anisotropy in the crust that is likely related to crustal flow and magmatic processes respectively. The active arc and backarc of the northern Puna Plateau show evidence of crustal structures associated with magmatic processes suggesting that locally magmatic addition plays a role in modifying the crust. The South American subduction zone has two regions of flat slab subduction beneath Peru, and central Argentina. The Argentina flat slab has high rates of seismicity while the Peru flat slab has much less seismicity suggesting a difference in hydration. Both these flat slab segments show indications of strong coupling to the over-riding plate, upper plate deformation and associated slab tears. The subducting Nazca slab penetrates into the lower mantle along most of the length of the central Andes but with different dips and slab thicknesses. We image a well defined slab beneath the south central Andes where many global models lack a slab anomaly. North of the Bolivia orocline the slab is steeper and appears to thicken in the Mantle Transition Zone (MTZ) compared to south of the orocline where the slab has a shallower dip and continues into the lower mantle with minor deformation in the MTZ.

Evidence for Slab Permeability-Controlled Tremor along the Cascadia Margin DELPH, J. R., Rice University, Texas, USA, jrdelph@rice.edu; LEVANDER, A. R., Rice University, Texas, USA, alan@ @rice.edu; NIU, F., Rice University, Texas, USA,niu@rice.edu

The dehydration of oceanic slabs during subduction is mainly thermally controlled and is manifested mechanically as intermediate-depth seismicity. In warm subduction zones, this dehydration also results in non-volcanic tremor, indicating relatively shallow slab dewatering. Along the Cascadia margin however, tremor density and intermediate-depth seismicity vary significantly from south to north despite little variation in the thermal structure of the Juan de Fuca Plate. To understand what controls these variations, we have constructed 3D vertical 
and horizontal shear-wave velocity models of the upper $80 \mathrm{~km}$ of the Cascadian margin through the joint inversion of Rayleigh- and Love-wave dispersion measurements and CCP-derived P-wave receiver functions. These models allow us to investigate variations in the seismic structure of the downgoing oceanic lithosphere and overlying mantle wedge, the character of the crust-mantle transition beneath the volcanic arc, and local to regional variations in crustal structure. Along the southern and northern portions of the Cascadia margin, high seismicity rates in the subducting plate and high tremor density correlate with low shear velocities in the overriding plate's forearc and relatively little arc volcanism. The slow shear-wave velocities in the forearc crust likely represent crustal modification through fluid intrusion after being released from the downgoing slab. The seismic characteristics of these zones combined with rather sparse arc volcanism may indicate that the slab has largely dewatered by the time it reaches sub-arc depths. In contrast, the central portion of the subduction margin shows relatively low seismicity and tremor density, with relatively higher shear velocities in the forearc. This region also contains most of the young stratovolcano edifices in the Cascades, indicating that water may be retained in the slab to depths where it can feed arc volcanism. We find that deformation in the Juan de Fuca Plate prior to subduction correlates well with the lateral variations in tremor, seismicity, velocity structure, and possibly volcanism, indicating that both the permeability structure of the subducting plate and it's thermal state are important controls on the release of fluid at shallow depths.

High Resolution Imaging of the Plate Interface in Central Alaskan Subduction Zone Using Autocorrelation with Local Earthquakes

KIM, D., Cornell University, New York, USA, dk696@cornell.edu; KERANEN, K. M., Cornell University, New York, USA, kmk299@cornell.edu; ABERS, G. A., Cornell University, New York, USA, gaa52@ cornell.edu; BROWN, L. D., Cornell University, New York, USA, ldb7@ cornell.edu

The physical properties of subducting slabs at convergent plate boundaries impact megathrust seismicity and arc volcanism, but remain incompletely understood. Slabs features are primarily imaged using phases from teleseismic earthquakes at frequencies below $1 \mathrm{~Hz}$, resulting in low-resolution images. Local earthquake sources with frequencies of $\geq 10 \mathrm{~Hz}$ on the other hand, provide a potential means for high resolution imaging of small-scale slab structure to depths through the seismogenic zone. Here we image the subducting Yakutat oceanic plateau in Alaska using autocorrelation of scattered energy within local earthquake coda and successfully produce a higher resolution image of the slab than visible in receiver functions. To validate our result, we also produced a synthetic autocorrelation section using the SPECFEM finite element method. Clear phases are observed at times that coincide with expected boundaries based on the a priori structural model based on earlier receiver function results. We associate these phases with a low-velocity zone atop the subduction oceanic plate, and we also image a later arrival observed only in the autocorrelation section associated with the base of the subducting Yakutat crust. Our results demonstrate the value of dense seismic arrays at tens to hundreds of meters spacing for mantle structures, providing a means to advance the characterization of subduction megathrusts.

Minimum 1D Velocity Model For The Central Ecuadorian Subduction Zone Inferred From The Aftershock Sequence Of The 2016 Mw 7.8 Pedernales Earthquake

LEÓN-RÍOS, S., University of Liverpool, Chile, sleonrios@gmail.com; RIETBROCK, A., Karlsruhe Institute of Technology, Germany, andreas. rietbrock@kit.edu; EDWARDS, B., University of Liverpool, United Kingdom, ben.edwards@liverpool.ac.uk; HOLT, J., University of Liverpool, United Kingdom, sgjholt@student.liverpool.ac.uk; AGURTO-DETZEL, H., GeoAzur, Universite Nice, France, agurto@geoazur.unice.fr; CHARVIS, P., GeoAzur, Universite Nice, France, philippe.charvis@geoazur.unice.fr; FONT, Y., GeoAzur, Universite Nice, France, yvonne.font@geoazur.unice.fr; NOCQUET, J. M., GeoAzur, Universite Nice, France, nocquet@geoazur.unice. fr; RÉGNIER, M., GeoAzur, Universite Nice, France, regnier@geoazur.unice.fr; BECK, S. L., GeoAzur, Universite Nice, Arizona, USA, slbeck@email.arizona. edu; MELTZER, A., Lehigh University, Pennsylvania, USA, ameltzer@lehigh. edu; ALVARADO, A., Instituto Geofisico de la Escuela Politecnica Nacional, Ecuador, aalvarado@igepn.edu.ec; CORDERO-SOTO, L., Lehigh University, Pennsylvania, USA, lis213@lehigh.edu; RUIZ, M. C., Instituto Geofisico de la Escuela Politecnica Nacional, Ecuador, mruiz@igepn.edu.ec; PERRAULT, M., Instituto Geofisico de la Escuela Politecnica Nacional, Ecuador, mperrault@ igepn.edu.ec

On 16th April 2016 a MW 7.8 earthquake occurred in the Pedernales region located in the central coastal segment of Ecuador. Immediately after the earthquake a dense temporary network (20-30 km in-between-station distance) was deployed in collaboration with several international institutions covering the rupture area (approximately $120 \times 50 \mathrm{~km}$ ). Instrumentation included OBS, strong motion, short period and broadband sensors, which complemented the permanent Ecuadorian network and recorded the developing aftershock sequence for one year after the mainshock. The Pedernales earthquake provided a unique opportunity to improve knowledge of subduction processes. Here we present a new minimum $1 \mathrm{D}$ velocity model representing the velocity structure of the region. This model will form a basis to be expanded upon in later research. A subset of 301 events with local magnitude (ML) greater than 3.5 , and recorded in the period between May and August 2016, were manually located using Seismic Data eXplorer (SDX) to get accurate P- and S-wave arrival times. Additional 44 events were manually located to achieve an event distribution. This high quality event data set with 210 events, azimuthal gap smaller than 200 degrees and 7775 picks (4334 P-phases and 3442 S-phases), was subsequently inverted for a minimum $1 \mathrm{D}$ velocity model for the area and station corrections using the velest software package. Obtained station corrections and $\mathrm{Vp} / \mathrm{Vs}$ suggest that the area can be represented with two models separated along strike. To check this hypothesis, we separated the region in two segments north (159 events) and south (51 events) and ran separated inversion following the same procedure used for the whole section. Segmentation may be related to a change in rheological conditions, mainly influenced by the subduction of seamounts coming from the Carnegie ridge. On the other hand, seismicity shows a finger-like distribution with events recorded close to the trench.

The Two Subduction Zones of the Caribbean-South American Plate Boundary LEVANDER, A. R., Rice University, Texas, USA, alan@rice.edu; CORNTHWAITE, J. P., Rice University, Texas, USA, jpcorn@rice.edu; BEZADA, M. J., University of Minnesota, Texas, USA, mbezada@umn.edu; NIU, F., Rice University, Texas, USA, niu@ rice.edu; MIAO, W., Rice University, Texas, USA,wm12@rice.edu

The Caribbean-South American (CAR-SA) plate boundary is a complex transform fault system connecting oppositely vergent subduction zones, the Antilles in the east, and a currently locked CAR-SA flat slab subduction zone in the west. Teleseismic P-wave tomography shows both the Atlantic (ATL) and the Caribbean (CAR) plates subducting in opposite directions to transition zone depths under northern South America. Receiver functions (RF) show a depressed 660 discontinuity and thickened transition zone associated with each subducting plate. In the east, the ATL part of the SA plate subducts westward beneath the CAR. The eastern end of the El Pilar-San Sebastian strike-slip system, a subduction-transform edge propagator (STEP) fault, lies above the point where the ATL tears away from SA as it descends into the mantle. The Paria cluster seismicity is the mechanical expression of the plate tear. Body wave tomography and LAB depth determined from RFs and Rayleigh waves suggest that the descending plate also viscously removes the bottom third to half of the SA continental margin lithosphere. This has left thinned continental lithosphere under northern $\mathrm{SA}$ as the subduction zone has migrated along its northern coast. The thinned lithosphere extends almost the entire length of the El Pilar-San Sebastian fault system, from $\sim 65$ o to $69 \mathrm{oW}$, and inland more than $100 \mathrm{~km}$. In northwestern SA the CAR plate subducts at $<30$ o to the ESE under northern Colombia to about Lake Maracaibo, Vn, and extends laterally from northernmost Colombia to perhaps as far south as the Bucaramanga nest seismicity. The flat slab is associated with three Neogene, basement cored, Laramide-style uplifts: the Santa Marta block, the Perija Range, and the Merida Andes. To the SE under Lake Maracaibo and the Merida Andes the CAR descends steeply to the transition zone. The steep descent suggests that the CAR plate is internally torn, separating the subducting CAR from CAR forming the seafloor to the north.

Structure and Dynamics of Earth's Mantle

Oral Session · Wednesday 16 May · 8:30 AM · Flagler

Session Chairs: Elizabeth A. Vanacore and Fenglin Niu

Lithospheric Structure and Dynamics of the Upper Mantle beneath East Asia CHEN, M., Michigan State University, Michigan, USA, chenmi22@msu.edu; NIU, F., Rice University, Texas, USA, niu@rice.edu; LIU, Q., University of Toronto, liuqy@physics.utoronto.ca; TROMP, J., Princeton University, New Jersey, USA,jtromp@princeton.edu

We recently developed a 3-D radially anisotropic model of the crust and upper mantle beneath East Asia (Chen et al., 2015a, 2015b, and Chen et al., 2017). Our model is inverted using a spectral-element-method based adjoint tomography from a large data set, comprising 1.7 million frequency-dependent travel time measurements from both body waves down to $12 \mathrm{~s}$ period and surface waves down to $20 \mathrm{~s}$ period. Updated and refined from a coarse and smooth initial 3-D 
mantle model (S362ANI, Kustowski et al., 2008), the final model (EARA2014) renders improved images of lithospheric structure beneath East Asia, best represented by high-shear-wave speed (high-V) anomalies. These strongly high- $V$ anomalies sharply delineate the slab structure and/or lithospheric architecture beneath Japan, China Continent, and the India-Eurasia convergence margin. The most striking feature revealed in our model is a T-shaped high-V structure with more than $2 \%$ shear wave speed increasing beneath South-Central Tibet, extending from a depth of $250 \mathrm{~km}$ to the bottom of transition zone, interpreted as an upper-mantle remnant from an earlier lithospheric foundering event. Its spatial correlation with ultrapotassic and adakitic magmatism supports the hypothesis of convective removal of thickened Tibetan lithosphere causing major uplift of Southern Tibet during the Oligocene. On the other hand, our tomographic proxy of the Pacific slab deep interface not only show exceptional consistency in closely following deep seismicity distribution, but also reveals complex geometry indicative of slab deformation due to stagnation and bending. Therefore, it can serve as a good baseline for a more detailed imaging of slab internal structure as well as for modeling the thermal, petrological, and dynamic processes of the Pacific slab in the mid-lower upper mantle.

Detailed Structure of the Upper-Mantle Discontinuities Using a Novel Approach and High-Frequency Triplication Data

PARK, S., Harvard University, Massachusetts, USA, sunyoungpark01@fas. harvard.edu; ISHII, M., Harvard University, Massachusetts, USA, ishii@eps. harvard.edu

Constraining elastic properties of the 410 - and $660-\mathrm{km}$ discontinuities is vital for understanding the mantle composition and dynamics. One approach to study the transition zone is to use the "triplicated" arrivals of seismic data. These arrivals provide strong constraints on the depth, width, and velocity across the discontinuities; however, it is difficult to distinguish the three individual phases that arrive close in time. In order to separate the three phases, we apply Radon transform to recordings from a dense array of stations. This approach unwraps the triplication pattern to isolate the phases, and brings out the high-frequency information that is not easily accessible in the original data. This method is applied to study the transition zone around the Kuril subduction zone, a region northeast of Japan. We take advantage of the High-Sensitivity Seismograph Network in Japan comprised of more than 700 stations whose dense sampling in distance allows us to capture the triplication pattern. The data are processed to obtain the variations in wave speeds around the discontinuities, providing topography and sharpness of discontinuities at various sampling locations. Both discontinuities exhibit local topography undulations consistent with the temperature effect; the 410 - and $660-\mathrm{km}$ discontinuities become shallower and deeper, respectively, nearer to the slab. Additional discontinuities around $660 \mathrm{~km}$ are also detected, which are attributed to the garnet transitions occurring at similar depths as the post-spinel transition. The wide transition observed for the 410-km discontinuity cannot be explained solely by the presence of water, suggesting the importance of other effects such as high Fe content of olivine or olivine-poor composition.

\section{Upper Mantle Transition Zone Thickness Variation under the Parnaíba Basin of Northeast Brazil}

ЦULIÀ, I., Universidade Federal do Rio Grando do Norte, Rio Grande do Norte, Brazil, jordi@geofisica.ufrn.br; COELHO, D. L. O., Universidade Federal do Rio Grande do Norte, Rio Grande do Norte, Brazil, locdiogo@gmail.com; WHITE, N. J., University of Cambridge, United Kingdom, njw10@ cam.ac.uk; RODRÍGUEZ-TRIBALDOS, V., University of Cambridge, United Kingdom, vr283@cam.ac.uk

The Parnaíba Basin of NE Brazil is-together with the Paraná and Amazon basins-one of the largest cratonic basins of the South American continent. Subsidence started in Paleozoic times in an intracontinental setting (before the opening of the South Atlantic Ocean) and has continued ever since through geological time. Traditionally, variations on the McKenzie-type model (i.e. mechanical stretching and cooling of the advected lithosphere) involving one or several aborted rifts under the basin's sediments or pure thermal cooling after some heating event had been proposed to explain its long-term subsidence; most recently, however, mechanisms invoking lithospheric flexure by a deep load have been put forward. Here, we investigate the presence of deep mantle downwellings under the basin that might be related to deep loads triggering elastic flexure of the overlying lithosphere. To this end, low-frequency $(\mathrm{f}<0.2 \mathrm{~Hz}) \mathrm{P}$-wave receiver functions have been developed at 9 broadband stations crossing the basin in the EW direction in order to image P-to-S conversions at the 410 and $660 \mathrm{~km}$ discontinuities bounding the upper mantle transition zone. The stations were deployed between 04/2016 and 03/2017 as part of the Parnaíba Basin Analysis Project (PBAP), a multi-disciplinary effort funded by BP Energy do Brasil thataims at improving our current knowledge of the origin and evolution of this large cratonic basin. Our results show that transition zone thickness is mostly normal $(250 \pm 10 \mathrm{~km})$, indicating that it is not thermally perturbed, and ruling out the presence of a cold, deep mantle downwelling under the basin. However, we observe that the $660-\mathrm{km}$ discontinuity is locally disrupted under the SW border of the basin, suggesting that deep mantle processes are at play. The relation of this perturbation to cratonic subsidence, nonetheless, is still unclear.

\section{Shear Wave Anisotropy, Mantle Flow, and Its Relationship to a Possible Slab Tear in the South Cocos Plate, Mexico}

VAZQUEZ ARAGON, L. A., Universidad Nacional Autónoma de México, Mexico City, Mexico, luis170595@gmail.com; VALENZUELA, R. W., Universidad Nacional Autónoma de México, Mexico City, Mexico, raul@ geofisica.unam.mx; PÉREZ-CAMPOS, X., Universidad Nacional Autónoma de México, Mexico City, Mexico, xyolipc@gmail.com; CLAYTON, R. W., Seismological Laboratory, Caltech, California, USA, clay@gps.caltech.edu

We measured shear wave anisotropy under the Geometry of Cocos (GECO) experiment, deployed at the eastern end of the Trans-Mexican Volcanic Belt. A tear in the south Cocos slab has been proposed [Dougherty and Clayton, 2014]. Two splitting parameters are used to quantify anisotropy. These are the delay time (delta $\mathrm{t}$ ) and the fast polarization direction (phi). The shear wave splitting method of Silver and Chan [1991] was used. A time window containing the SKS or PKS phase is selected. Then, the north-south and east-west components are rotated by 1 degree, ranging from $-90^{\circ}$ to $90^{\circ}$. For each rotation, the solutionis searched in 0.05 s increments, and the crosscorrelation and autocorrelation between the two traces is obtained. Next the eigenvalues are calculated for every possible combination of (delta t) and (phi). Finally, the minimum eigenvalue is chosen as the best solution. We check our results in two ways: by correcting the original records using the measured (delta $\mathrm{t}$ ) and (phi) in order to obtain a weaker SKS signal in the transverse component, and by comparing the waveforms and the arrival time difference between the fast and the slow components. The orientation of (phi), measured for western stations, is explained by subslab, entrained mantle flow under flat Cocos slab. While going from west to east. the slab geometry changes from flat to steeper subduction, and may be accompanied by a possible tear in the slab. For the eastern stations, (phi) is rotated $25^{\circ}$ clockwise relative to stations in the west. This phenomenon may be accounted for by mantle flow between the possible tear and by rollback of the slab. The orientation of the fast axes where the slab subducts steeply is consistent with both subslab entrained flow, and with corner flow in the mantle wedge between the Cocos and North American plates.

\section{The 3-D Reference Earth Model: Status and Preliminary Results}

LEKIC, V., University of Maryland, Maryland, USA, ved@umd.edu; MOULIK, P., University of Maryland, College Park, Maryland, USA, moulik@umd. edu; ROMANOWICZ, B., UC Berkeley, California, USA, barbara@seismo. berkeley.edu

One-dimensional reference Earth models (e.g. PREM) have proven indispensable in earthquake location, imaging of interior structure, understanding material properties under extreme conditions, and as a reference in other fields, such as particle physics and astronomy. Over the past three decades, 3D models of how properties vary both laterally and with depth have been developed. Though these models exhibit compelling similarities at large scales, differences in the methodology, representation of structure, and dataset upon which they are based, have prevented the creation of $3 \mathrm{D}$ community reference models. A 3D Reference Earth model (REM-3D) should ideally represent the consensus view of long-wavelength heterogeneity in the mantle through the joint modeling of large and diverse seismological datasets. To this end, we are compiling and reconciling reference seismic datasets of body wave travel-time, fundamental mode and overtone surface wave dispersion, and normal mode frequencies and splitting measurements. The goal is to compile a quality-controlled and comprehensive set of seismic observations that would enable construction of REM-3D, allow identification of outliers, and assist in more detailed studies of heterogeneity. The community response has been enthusiastic with several groups across the world contributing datasets. Here, we summarize progress made in the construction of the reference dataset and present a preliminary version of REM-3D in the upper-mantle. In order to determine the level of detail justified in REM-3D, we analyze the spectrum of discrepancies between models inverted with different data subsets. As a community reference model with quantified uncertainties and tradeoffs and an associated publicly available dataset, REM-3D will facilitate Earth imaging studies, earthquake characterization, inferences on temperature and composition in the deep interior, and be of improved utility to emerging scientific endeavors, such as geo-neutrino study. 
Testing PSHA Input Data, Source Models and Hazard Estimates

Oral Session - Wednesday 16 May · 2:15 PM • Hibiscus A

Session Chairs: David D. Jackson, Yufang Rong, Harold

Magistrale, and Jeremy Zechar

\section{One-Year Forecast for Induced and Natural Earthquakes in the Centra and Eastern United States}

PETERSEN, M. D., US Geological Survey, Colorado, USA, mpetersen@usgs. gov; MUELLER, C. S., US Geological Survey, Colorado, USA, cmueller@ usgs.gov; MOSCHETTI, M. P., US Geological Survey, Colorado, USA, mmoschetti@usgs.gov; HOOVER, S. M., US Geological Survey, Colorado, USA, shoover@usgs.gov; RUKSTALES, K. S., US Geological Survey, Colorado, USA, rukstales@usgs.gov; MCNAMARA,D. E., US Geological Survey, Colorado, USA, mcnamara@usgs.gov; WILLIAMS, R. A., US Geological Survey, Colorado, USA, rawilliams@usgs.gov; SHUMWAY, A. M., US Geological Survey, Colorado, USA, ashumway@usgs.gov; POWERS, P. M., US Geological Survey, Colorado, USA, pmpowers@usgs.gov; EARLE, P. S., US Geological Survey, Colorado, USA, pearle@usgs.gov; LLENOS, A. L., US Geological Survey, California, USA, allenos@usgs.gov; MICHAEL, A. J., US Geological Survey, California, USA, michael@usgs.gov

The USGS 2018 one-year probabilistic forecast for the central and eastern United States from induced and natural earthquakes is developed for consistency using the same probabilistic seismicity-based methodology as applied in the two previous forecasts. Rates of earthquakes M 3.0 and greater grew rapidly between 2008 and 2015 but have steadily declined over the past three years, especially in Oklahoma and southern Kansas where mitigation efforts seem to have been effective in limiting wastewater injection near previous earthquakes. Nevertheless, the seismicity pattern is complex and earthquakes are more spatially dispersed than in previous years. Some areas of west-central Oklahoma show increased activity rates where industrial activity has increased over the past year. Earthquake rates in Oklahoma (384 earthquakes of M3+ and $7 \mathrm{M} 4+$ ), Raton Basin (Colorado/ New Mexico border, 4 earthquakes M3+ and one M4+ earthquake), and the New Madrid seismic zone (11 earthquakes M3+) continue to be higher than historic levels. Almost all of these events occurred within the highest hazard regions of the 2017 forecast. Even with earthquake rates declined relative to 2016, the shortterm hazard for damaging ground shaking across much of Oklahoma remains at very high levels that are similar to high hazard areas in California. During 2017 M3 + earthquakes also occurred in or near Ohio, West Virginia, Missouri, Kentucky, Tennessee, Arkansas, Illinois, Oklahoma, Kansas, Colorado, New Mexico, Utah, Wyoming.

\section{Verification of the Probabilistic Seismic Hazard Maps for Japan by Comparing with Actually Observed Seismic Intensities}

KOKETSU, K., University of Tokyo, Japan, koketsu@eri.u-tokyo.ac.jp; KONDO, T., KAJIMA Corporation, Japan, rgbapp@gmail.com

The Probabilistic Seismic Hazard Maps for Japan (PSHMJ) have been criticized after the 2011 Tohoku earthquake. For example, Geller (2011) complained that recent damaging earthquakes occurred in places assigned a relatively low probability in the 2010 PSHMJ map of Intensity 6- or greater in 30 years. However, Miyazawa and Mori $(2009,2010)$ constructed maximum seismic intensity maps using recorded historical data for the past 500 years, and found that they agreed with the 2008 PSHMJ map of $10 \%$ in 50 years, which is equivalent to a hazard map of probable seismic intensity for a 475-year return period if we assume a Poisson distribution. We here explore a reason for the difference of the above two, using seismic intensities actually observed by the Japan Meteorological Agency and others. In Japan, we have seismic intensities actually observed in 1890 and later, and Miyakoshi et al. (2016) provided seismic intensity hazard curves at every grid point not only for the PSHMJ map of 2016 but also for those of 1890 , 1920, 1950, and 1980. If we assume a Poisson distribution for seismic intensities like Miyazawa and Mori (2009), a PSHMJ map of $64 \%$ in 30 years is equivalent to a hazard map of probable seismic intensity for a 30 -year return period. Therefore, we construct maximum seismic intensity maps using the observed intensities in 30 years from 1890, 1920, 1950, or 1980. We also construct PSHMJ maps of $1890,1920,1950$, or 1980 using the intensities estimated for a probability of $64 \%$ in 30 years. We then compare the observed and estimated intensities at a same site, finding that the correlation between them is positive but very weak. This weakness may correspond to Geller's (2011) criticism, probably because a period of 30 years is too short for a large intensity to be observed. If we adopt a period of 100 years, the correlation is certainly improved, approaching to the result of Miyazawa and Mori (2009) for a period of 500 years.
Testing Fault-Based Rupture Models

JACKSON, D. D., UC Los Angeles, California, USA, djackson@g.ucla.edu

PSHA models typically use instrumental seismic data, but seismic networks are too young to record many large (and thus infrequent) earthquakes. Nevertheless, PSHA source models should be consistent with the instrumental record. Comparing instrumentally observed earthquakes with fault models can be complicated because large earthquakes may not occur precisely on prescribed faults and they may involve multiple faults. Some tests amenable to probabilistic evaluation include participation (occurrence of rupture on specified fault sections) and breaching (rupture crossing specified boundaries along faults). The relevant sections and boundaries may but need not correspond to "segments" as assumed in characteristic earthquake models. The Working Group on California Earthquake Probabilities has published increasingly sophisticated earthquake rupture models since 1988, each specifying fault sections with rates of participation, breaching, or both. Here I compare some of the earlier models with instrumentally observed earthquakes both before and after the model start date. I only count earthquakes after 1933, when seismic networks became adequate. Some discrepancies occur even in retrospective comparisons, because the models were not constrained to fit only those seismic data. The discrepancies don't invalidate any of the models, but they deserve consideration because the models all share fault geometry and assumptions relating slip rate to earthquake rate.

\section{Simulation-Based Evaluation for Probabilistic Seismic Hazard Models-A} Case Study for Japan

MAK, S., GFZ-Potsdam, Germany, smak@gfz-potsdam.de; HIRATA, N., Earthquake Research Institute, The University of Tokyo, Japan, hirata@eri.utokyo.ac.jp; NAGAO, H., Earthquake Research Institute, The University of Tokyo, Japan, nagaoh@eri.u-tokyo.ac.jp; COTTON, F., GFZ-Potsdam, Germany, fcotton@gfz-potsdam.de; SCHORLEMMER, D., GFZ-Potsdam, Germany,ds@gfz-potsdam.de

A probabilistic seismic hazard analysis (PSHA) considers the occurrence of seismic strong ground motions as a random process. The performance of a PSHA, therefore, can only be evaluated in a statistical sense. The hazard curve and the hazard map are the most common forms to disseminate the results of a PSHA. They do not convey the information about the spatial correlation of seismic hazard. This hinders the comparison between the hazard forecast and the observed hazard because the observed hazards are spatially correlated. This is particularly important for regions where the seismic hazard is dominated by large seismic sources, such as the Nankai subduction zone in Japan. To fully incorporate the spatial correlation into an evaluation of PSHA, we represented a hazard forecast of a model by a set of simulated scenarios, an approach often used in scenariobased seismic risk analysis and the approach used in the Collaboratory for the Study of Earthquake Predictability (CSEP) for testing earthquake forecasts. We compared the hazard forecast based on the 2009 version of the National Ground Motion Forecast Maps (with the base time of time-dependent sources adjusted to 2000) with the PGV observations from 2000 to 2017. While the agreement between the forecast and the observation was investigated, the focus of this study is the statistical power of a PSHA test under the best available situations (i.e., the best-monitored region in a national sense that provides the best available data in both quantity and quality; the usefulness of a statistical test always depends on the amount of data available). The statistical power essentially estimates how wrong a hazard forecast needs to be in order to produce a detectable discrepancy between the forecast and the observation. This provides an estimate of the upper bound the error of a PSHA, which, by the principle of falsifiability of science, is also an empirical estimate of the credibility of a PSHA.

\section{Development of New Australian Magnitude Conversion Equations and Its Effects on Seismic Hazard Analyses}

GHASEMI, H., Geoscience Australia, Australian Capital Territory, Australia, hadi.ghasemi@ga.gov.au; ALLEN, T., Geoscience Australia, Australian Capital Territory, Australia, trevor.allen@ga.gov.au

All modern ground motion prediction equations (GMPEs) are now calibrated to the moment magnitude scale MW, it is therefore essential that earthquake rates are also expressed in terms of moment magnitudes for probabilistic seismic hazard analyses. However, MW is not routinely estimated for earthquakes in Australia because of Australia's low-to-moderate level of seismicity, coupled with the relatively sparse seismic recording networks. As a result, the Australian seismic catalogue has magnitude measures mainly based on local magnitudes, ML. To homogenise the earthquake catalogue based on a uniform MW, a "reference catalogue" that includes earthquakes with available MW estimates was compiled. This catalogue consists of 240 earthquakes with original MW values between 2.0 and 6.58. The reference catalogue served as the basis for the development of mag- 
nitude conversion equations between MW and ML. The conversions are developed using general orthogonal regression. Different functional forms for the conversion equations were considered and their impact on seismic hazard is explored. Synthetic earthquake catalogues with a "known" -b-value are generated about an arbitrary location. These catalogues are subsequently perturbed according to different magnitude adjustment assumptions. It is found that the results of seismic hazard analyses at our site are sensitive to the implementation algorithm of such equations. For the considered scenario, the results show a $20-40 \%$ reduction in PGA hazard (at the 10\% in 50-year probability of exceedance level), depending on the selection of the functional form as well as the method for applying the magnitude conversion equations.

\section{U.S. National Seismic Hazard Model Updates: 2018, 2020 and Beyond}

Oral Session - Wednesday 16 May · 8:30 AM • Hibiscus A

Session Chairs: Allison M. Shumway, Susan M. Hoover, Morgan P. Moschietti, Mark D. Petersen, and Peter M. Powers

\section{U.S. National Seismic Hazard Models}

PETERSEN, M. D., US Geological Survey, Colorado, USA, mpetersen@usgs. gov; SHUMWAY, A. M., US Geological Survey, Colorado, USA, ashumway@ usgs.gov; MUELLER, C. S., US Geological Survey, Colorado, USA, cmueller@ usgs.gov; POWERS, P. M., US Geological Survey, Colorado, USA, pmpowers@ usgs.gov; MOSCHETTI, M. P., US Geological Survey, Colorado, USA, mmoschetti@usgs.gov; BOYD, O. S., US Geological Survey, Colorado, USA olboyd@usgs.gov; THOMPSON, E. M., US Geological Survey, Colorado, USA, emthompson@usgs.gov; REZAEIAN, S., US Geological Survey, Colorado, USA srezaeian@usgs.gov; MCNAMARA, D. E., US Geological Survey, Colorado, USA, mcnamara@usgs.gov; LUCO, N., US Geological Survey, Colorado, USA, nluco@usgs.gov; FRANKEL, A. D., US Geological Survey, Washington, USA, afrankel@usgs.gov; RUKSTALES, K. S., US Geological Survey, Colorado, USA, rukstales@usgs.gov

The U.S. National Seismic Hazard Model (NSHM) will be updated in 2018 and 2020 to introduce new scientific data and models that have become available over the past years. These updates are planned to allow more time for the provisions update committee to analyze the consequences of the hazard model changes in the design criteria. To prepare these updates we held several meetings with scientists and engineers and participated in ground motion model projects such as NGA and site amplification projects. The 2018 model will consider: (1) an updated catalog and smoothed seismicity models, (2) new ground motion estimates based on NGA-East and other published models for updating ground motions at additional spectral periods and site classes in the central and eastern U.S., and (3) basin depth terms included in the NGA-West2 ground motion models for the western U.S. to account for enhanced long-period ground motions at soft soil sites overlying sedimentary basins. Preliminary 2018 ground motions near the New Madrid Seismic Zone are generally increased by less than $0.1 \mathrm{~g}$ compared to the 2014 NSHM model. We also calculated stronger ground shaking for long-periods at soft soil sites in the Los Angeles region compared to the 2014 NSHM. Long period ground motions can be a factor of two higher when considering basin terms in the ground motion models. This presentation will also discuss the 2020 update that will consider new science information that is provided by a June 2018 deadline (e.g., NGA-Subduction, basin 3-D simulations, and possibly new magnitude-area equations).

\section{Multi-Period and Multi-Vs30 Design Ground Motions}

REZAEIAN, S., US Geological Survey, Colorado, USA, srezaeian@usgs.gov; KIRCHER, C. A., Kircher and Associates, California, USA, cakircher@aol. com; SHUMWAY, A. M., US Geological Survey, Colorado, USA, ashumway@ usgs.gov; POWERS, P. M., US Geological Survey, Colorado, USA, pmpowers@ usgs.gov

The 2014 and previous versions of the USGS National Seismic Hazard Model (NSHM) outputted maps of probabilistic ground motions derived from hazard curves for peak ground acceleration (PGA) and 0.2 and $1.0 \mathrm{sec}$ spectral accelerations, for a reference site class BC (Vs $30=760 \mathrm{~m} / \mathrm{s})$. These probabilistic ground motions and hazard curves were used in calculating the design ground motions such as the risk-targeted maximum considered earthquake (MCEr) at short and long periods ( $S s$ and $S 1$ ) for use in building codes. For years, engineers have been using a simple three-domain spectral shape that depends only on Ss and S1 values and corresponding site amplification factors ( $\mathrm{Fa}$ and $\mathrm{Fv}$ ), to construct the design spectrum for all periods and site classes of interest. Recently, Project '17 of the Building Seismic Safety Council (BSSC) has proposed a change in order to address the issue that this simple three-domain spectral shape can be inadequate for softer soils at high-hazard locations. Project' 17 recommends the use of a multi-period and multi-Vs30 design spectrum, derived directly from the USGS hazard curves for 21 periods ranging from PGA to $10 \mathrm{sec}$ and eight site classes. Here, we use the 2014 USGS NSHM to calculate the design ground motion for 11 test periods (PGA, 0.1, 0.2, 0.3, 0.5, 0.75, 1, 2, 3, 4, and $5 \mathrm{sec}$ ) and the eight site classes determined by Project' 17 (A, B, BC, C, CD, D, DE, and E) in the western US (WUS). Due to the limitations of some ground motion models (GMMs) at certain periods and site classes, we eliminate a few GMMs from the 2014 NSHM and redistribute their weights to the remaining GMMs. We show that the simple three-domain spectral shape was inadequate for example sites. We also examine the validity of existing site amplification factors. For other US seismic regions, where GMMs are not sufficiently advanced to provide the entire range of periods and site classes, we will show how to use our knowledge from the WUS to construct approximate spectral shapes.

\section{NGA-Subduction Research Program}

BOZORGNIA, Y., UC Berkeley, California, USA, yousef@berkeley. edu; KISHIDA, T., UC Berkeley, California, USA, kishida@gmail.com; ABRAHAMSON, N. A., UC Berkeley, California, USA, abrahamson@ berkeley.edu; AHDI, S. K., UC Los Angeles, California, USA, sahdi@ucla. edu; ANCHETA, T., RMS, Oregon, USA, timothydancheta@gmail.com; ARCHULETA, R., UC Santa Barbara, California, USA, ralph@eri.ucsb.edu; ATKINSON, G. M., Western University, gmatkinson@aol.com; BOORE, D. M., US Geological Survey, California, USA, dboore@yahoo.com; CAMPBELL, K., CoreLogic, Oregon, USA, kcampbell@corelogic.com; CHIOU, B., Caltrans, California, USA, brian_chiou@dot.ca.gov; CONTRERAS, V., UC Los Angeles, California, USA, vcontreras@ucla.edu; DARRAGH, R. B., PEA, California, USA, bbalindavis@gmail.com; GREGOR, N., Bechtel Corp., California, USA, nick@ngregor.com; IDRISS, I. M., UC Davis, California, USA, imidriss@aol. com; JI, C., UC Santa Barbara, California, USA, ji@geol.ucsb.edu; KAMAI, R., Ben-Gurion University, Israel, rkamai@berkeley.edu; KUEHN, N. M., UC Berkeley, California, USA, kuehn@berkeley.edu; MAZZONI, S., UC Berkeley, California, USA, mazzoni@berkeley.edu; MUIN, S., UC Berkeley, California, USA, sifat.muin@berkeley.edu; PARKER, G., UC Los Angeles, California, USA, graceaparker@gmail.com; SILVA, W.J., PEA, California, USA, pacificengineering@juno.com; STEWART, J. P., UC Los Angeles, California, USA, jstewart@seas.ucla.edu; WALLING, M., Walling Consulting, Oregon, USA, lytmelanie@yahoo.com; WOODDELL, K., Pacific Gas and Electric, California, USA, katie.wooddell@gmail.com; YOUNGS, R., AMEC E\&I, California, USA, bob.youngs@amec.com; KWAK, D. Y., RMS, California, USA, duckkwak@g.ucla.edu; MAGISTRALE, H., FM Global, Massachusetts, USA, harold.magistrale@fmglobal.com

This presentation provides an overview of the NGA-Sub, a large multidisciplinary community-based research initiative to develop a comprehensive ground-motion database and multiple ground-motion models (GMMs) for subduction events. In this community-based project, we developed a database of ground motions recorded in worldwide subduction events. The database includes the processed recordings and supporting source, path, and site metadata from Japan, Taiwan, the US Pacific Northwest, Alaska, Latin America (including Mexico, Peru and Chile), and New Zealand. The NGA-Sub database includes 1,570 events with moment magnitudes ranging from 4 to 9.1. The subduction events are classified as interface, intraslab, or outer-rise events. The NGA-Sub ground-motion database has over 180,000 component records. This is by far the largest ground motion database that we have ever developed in any NGA project. Pseudospectral acceleration as well as Fourier amplitude spectra for frequencies from 0.1 to $100 \mathrm{~Hz}$ have been included in the database. In NGA-Sub, using the empirical ground-motion database and the supporting ground-motion simulations, multiple GMMs are developed. Following the tradition of previous NGA projects, the GMM modeling teams as well as database developers have had continuous technical interactions which resulted in much higher quality of the final products than each researcher could achieved individually. An overview of the NGA-Sub project is presented in this presentation.

\section{Cybershake Models of Seismic Hazards in Southern and Central California} JORDAN, T. H., University of Southern California, California, USA, tjordan@ usc.edu; CALLAGHAN, S., University of Southern California, California, USA, scottcal@usc.edu; GRAVES, R. W., US Geological Survey, California, USA, rwgraves@usgs.gov; WANG, F., AIR Worldwide Inc, Massachusetts, USA, fengo.win@gmail.com; MILNER, K. R., University of Southern California, California, USA, kmilner@usc.edu; GOULET, C. A., University of Southern California, California, USA, cgoulet@usc.edu; MAECHLING, P.J., University of Southern California, California, USA, maechlin@usc.edu; OLSEN, K. B., 
San Diego State University, California, USA, kbolsen@mail.sdsu.edu; CUI, Y., San Diego Supercomputer Center, California, USA, yfcui@sdsc.edu; JUVE, G., USC Information Sciences Institute, California, USA, gideonjuve@gmail. com; VAHI, K., USC Information Sciences Institute, California, USA, vahi@ isi.edu; YU, J., University of Southern California, California, USA, johnyu@ usc.edu; DEELMAN, E., USC Information Sciences Institute, California, USA, deelman@isi.edu; GILL, D., University of Southern California, California, USA, davidgil@usc.edu

CyberShake is a high-performance computational platform developed by the Southern California Earthquake Center (SCEC) to produce seismic hazard models from large suites of earthquake simulations. Code optimization and the development of workflow tools on the NCSA Blue Waters and OLCF Titan supercomputers have substantially reduced the computational costs. A recent workflow efficiently utilized both machines to generate 285 million two-component seismograms for the central California region from which 46 billion intensity measurements were extracted. We summarize the current suite of CyberShake models and apply averaging-based factorization $(\mathrm{ABF})$ to decompose each model into a hierarchy of site, path, directivity, stress-drop, and source complexity effects. We summarize how the strength of the directivity effect decreases with increasing source complexity, and how the site and path effects vary with differences in crustal structure. Comparisons quantified by the $\mathrm{ABF}$ variances indicate that simulation-based hazard models can potentially reduce sigma_T, the total unexplained variability in current ground-motion prediction equations, by as much as one-third.

\section{Incorporating Long-Period (T>1 S) 3D Simulations into the U.S. National Seismic Hazard Model}

MOSCHETTI, M. P., US Geological Survey, Colorado, USA, mmoschetti@ usgs.gov; THOMPSON, E. M., US Geological Survey, Colorado, USA, emthompson@usgs.gov; SHUMWAY, A. M., US Geological Survey, Colorado, USA, ashumway@usgs.gov; BOYD, O. S., US Geological Survey, Colorado, USA, olboyd@usgs.gov; PETERSEN, M. D., US Geological Survey, Colorado, USA, mpetersen@usgs.gov; LUCO, N., US Geological Survey, Colorado, USA, nluco@usgs.gov; FRANKEL, A. D., US Geological Survey, Washington, USA, afrankel@usgs.gov; GRAVES, R. W., US Geological Survey, California, USA, rwgraves@usgs.gov; JORDAN, T. H., University of Southern California, California, USA, tjordan@usc.edu; CALLAGHAN, S., SCEC, University of Southern California, California, USA, scottcal@usc.edu; GOULET, C. A., SCEC, University of Southern California, California, USA, cgoulet@usc. edu; MILNER, K. R., SCEC, University of Southern California, California, USA, kmilner@usc.edu; MAECHLING, P. J., SCEC, University of Southern California, California, USA, maechlin@usc.edu

With the introduction of additional periods into the design spectrum of U.S building codes, future National Seismic Hazard Models (NSHMs) must consider the effects of longer period $(T \geq 1 \mathrm{~s})$ earthquake ground motions. These longer period effects are highly sensitive to the presence of sedimentary basins and are included in most current ground motion models (GMMs) used in the western U.S. through proxy parameters for sediment thickness (i.e., depths to 1 and 2.5 $\mathrm{km} / \mathrm{s}$ horizons, $\mathrm{Z} 1$ and $\mathrm{Z} 2.5$, respectively). Observations and 3D earthquake simulations, however, indicate that the ground motions at sites within sedimentary basins are often far more complicated than can be predicted by single-parameter amplifications. We present initial results from the incorporation of long-period $(\mathrm{T} \geq 1 \mathrm{~s})$ basin effects into the NSHM using products derived from the Southern California Earthquake Center (SCEC) CyberShake simulations. These investigations focus only on the basin amplifications and attempt to minimize the effects of the absolute ground motion level, the finite-source features, and the path effects from the 3D simulations. Basin amplifications from the 3D simulations are used to replace the empirical basin terms in the GMMs using results from averaging-based factorization. The modified GMMs represent empirically constrained ground motion levels, magnitude and distance scaling, but with laterally varying basin amplifications specified by the 3D simulations. Hazard sensitivity results and comparisons with ground motion data are presented. Preliminary hazard calculations indicate that the resulting ground motions, with 2 percent probability of exceedance in 50 years, are more than 50 percent higher than what is predicted by GMMs. These effects are greatest in the deepest parts of the Los Angeles and Ventura basins. Comparison of the observed and modified-predicted ground motions, from small- to moderate-sized earthquakes, indicates laterally varying reductions in misfit.

Fault Scaling Relationships Depend on the Average Fault Slip Rate ANDERSON, J. G., University of Nevada Reno, Nevada, USA, jga@seismo. unr.edu; BIASI, G. P., US Geological Survey, California, USA, gbiasi@usgs.gov;
WESNOUSKY, S. G., University of Nevada Reno, Nevada, USA, wesnousky@ unr.edu

This study addresses whether knowing the slip rate on a fault improves estimates of magnitude (MW) of shallow, continental surface-rupturing earthquakes. Based on 43 earthquakes from the database of Wells and Coppersmith (1994), Anderson et al. (1996) previously suggested that estimates of MW from rupture length (LE) are improved by incorporating the slip rate of the fault (SF). We reevaluate this relationship with an expanded database of 80 events, that includes 56 strike-slip, 13 reverse, and 11 normal faulting events. When the data are subdivided by fault mechanism, magnitude predictions from rupture length are improved for strike-slip faults when slip rate is included; a slip rate term does not improve magnitude fits for reverse or normal faults. Whether or not the slip rate term is present, a linear model with $\mathrm{MW} \sim \log \mathrm{LE}$ over-all rupture lengths implies that the stress drop depends on rupture length-an observation that is not supported by teleseismic observations. We consider two other models, including one adapted from Chinnery (JGR, 1964) which we prefer because it has constant stress drop over the entire range of LE for any constant value of SF and because fits the data as well as the linear model. The dependence on slip rate for strike-slip faults is a persistent feature of all considered models. The observed dependence on SF supports the conclusion that for strike-slip faults of a given length, the static stress drop, on average, tends to decrease as the fault slip rate increases. Recent Findings and Recommendations for an Updated Hazard
Characterization of the Eglington Fault in Las Vegas Valley, Nevada

DEE, S. M., Nevada Bureau of Mines and Geology, Nevada, USA, sdee@unr. edu; DEPOLO, C. M., Nevada Bureau of Mines and Geology, Nevada, USA, eq_dude@sbcglobal.net; GOLD, R. D., US Geological Survey, Colorado, USA, rgold@usgs.gov; BRIGGS, R. W., US Geological Survey, Colorado, USA, rbriggs@usgs.gov

The Las Vegas Valley fault system (LVVFS) is a complex set of north- to northeasttrending, intra-basin Quaternary fault scarps up to $30 \mathrm{~m}$ high that displace alluvial fan, fine-grained basin fill, and paleo-spring deposits in the densely populated Las Vegas metropolitan area. Characterizing the seismic hazard of the LVVFS is currently the focus of a multi-year collaborative study involving researchers from the Nevada Bureau of Mines and Geology, University of Nevada, Las Vegas, and the US Geological Survey. The Eglington fault is the only LVVFS fault currently included on the National Seismic Hazard Map (NSHM), and is a priority focus in the early stages of the investigation. Substantial uncertainty remains regarding the seismogenic potential of the LVVFS. Two endmember hypotheses have been proposed regarding the mechanisms responsible for producing the scarps associated with the LVVFS, including the Eglington fault: 1) tectonic (e.g., coseismic surface rupture) and 2) non-tectonic (e.g., prehistoric differential sediment compaction). In this presentation, we will summarize existing geologic, geodetic, geophysical, and geochronologic data that provide insight into the mechanism(s) responsible for scarp formation within the LVVFS, and present unresolved problems with both endmember tectonic and non-tectonic scenarios. We will also discuss in-progress efforts to characterize the seismogenic potential of the Eglington fault including: planned paleoseismic trenching, geologic mapping using lidar and predevelopment topography derived from historical aerial photographs, Optically Stimulated Luminescence (OSL) dating of the Las Vegas basin stratigraphy, and evaluation of the potential for differential sediment compaction across the fault scarps. In addition, we will present the recommendations from the 2018 Working Group on Nevada Seismic Hazards, including the details of a logic tree framework to address uncertainty in the LVVFS hazard assessment.

\section{Rethinking the Seismic Hazard Characterization of the Cheraw Fault, Southeastern Colorado}

ZELLMAN, M. S., BGC Engineering, Inc., Colorado, USA, mzellman@ bgcengineering.com; OSTENAA, D. A., Ostenaa Geologic, LLC., Colorado, USA, deano3geo@gmail.com

The late Quaternary-active Cheraw (CF) fault in southeastern Colorado is one of the few faults in the Central and Eastern U.S. (CEUS) with known Holocene surface rupture. More than any other Colorado fault source, the CF contributes significant ground motion hazard to the Front Range cities of Pueblo, Colorado Springs, and Denver, across the full range of spectral, and annual exceedance periods. In both the USGS National Seismic Hazard Map and Electric Power and Research Institute (EPRI) CEUS source models, the favored characterization is a $46 \mathrm{~km}$ long fault, with a $60^{\circ} \mathrm{dip}$. Rates for in-cluster models are based on 3 event ages from paleoseismic trench data on the southern section of the fault. Rates for out-of-cluster models with long $(<100 \mathrm{ka})$ interseismic intervals are inferred from vertical surface offsets of a nearby undated Rocky Flats (RF) Pleistocene pediment alluvium assumed to be $\leq 1 \mathrm{Ma}$. Findings from our recent and ongo- 
ing studies provide insight for a revised CF source characterization. New LiDAR data shows the CF scarp to be at least $80 \mathrm{~km}$ long. Reprocessed, depth-migrated $2 \mathrm{D}$ industry seismic data shows the fault dip to be $\sim 75^{\circ}$ to depths of $2-3 \mathrm{~km}$ in basement. Paleoseismic trenching on the northern section, near Haswell, shows $\sim 9$ m of vertical offset in deformed Nussbaum alluvium. Luminescence ages constrain this deformation to $<\sim 126$ to $200 \mathrm{ka}$, and imply a much younger age for the southern trench-adjacent RF alluvium. Thus, available time for the long interseismic intervals between clustered events on out-of-cluster recurrence models is severely limited. Further extension of the fault scarp to the northeast supports plausible partial rupture models with up to 14 to $18, \mathrm{M} 6.5$ to 6.8 events in the past $100 \mathrm{ka}$; or alternatively, many fewer full-length ruptures of $\mathrm{M} \geq 7$. Rupture models most consistent with long interseismic intervals are those with infrequent, larger magnitude $(\mathrm{M} \geq 7)$, and near full-length $(\sim 80 \mathrm{~km})$ ruptures.

The Western Limit of Major Extension Associated with the lapetan Rifted Margin in the Southern and Central Appalachians: Implications for the National Seismic Hazard Maps

POWELL, C. A., The University of Memphis, Tennessee, USA, capowell@ memphis.edu; THOMAS, W. A., Emeritus University of Kentucky, Geological Survey of Alabama, Alabama, USA, geowat@uky.edu; HATCHER JR., R. D., University of Tennessee Knoxville, Tennessee, USA, bobmap@utk.edu

Specifying the location and extent of rifted crystalline crust (Precambrian basement) associated with the opening of the Iapetus Ocean in the eastern United States is important for seismic hazard evaluation. As currently mapped by the Central and Eastern U.S. Seismic Source Characterization for Nuclear Facilities (CEUS-SSC) Project, the western limit of major extensional faults and thinned extended crust produced by Iapetan rifting is within the Appalachian Plateau, to the west of the Valley and Ridge province. This limit was defined more than 20 years ago when little information was available about the crustal structure beneath the Appalachians and was based primarily on the distribution of earthquakes in two intraplate seismic zones, as well as some known basement faults. New estimates, using EarthScope, USArray and other data, show that the crustal thickness below the Blue Ridge, Valley and Ridge, and Appalachian Plateau provinces generally exceeds $45 \mathrm{~km}$ and is as much as $60 \mathrm{~km}$ in places. Such thick crust (equal to that typical of full-thickness continental crust) does not indicate significant extension as in rifted crust. We suggest that the western limit of major extensional faulting along the Iapetan rifted margin is located in the central Piedmont east of the Blue Ridge beneath the Blue Ridge-Piedmont megathrust sheet, and is closely associated with a prominent Bouguer gravity gradient (Appalachian gravity gradient). Only small Iapetan grabens and half grabens have been imaged with crustal seismic reflection data in the footwall beneath the Blue Ridge sheet. Our suggested location for the western limit of Iapetan rifting agrees with palinspastic reconstructions of the Iapetan rifted margin. Intracratonic grabens, inboard from the rifted margin, show only minor crustal extension and thinning. This seismotectonic model is a more credible representation of the basement below the southern and central Appalachians than the current model involving rifted crust.

Impact of Improved Gulf Coast Seismic Attenuation Boundary and Stress Parameter Estimates on Our Understanding of Seismic Hazard in the Southeastern United States

CRAMER, C. H., CERI, University of Memphis, Tennessee, USA, ccramer@ memphis.edu

Recently published studies of the seismic attenuation (Q) boundary and stress parameter estimates for the Gulf Coast and southeastern U.S. (SEUS) improve our understanding of seismic hazard for the SEUS. First, the improved Gulf Coast $\mathrm{Q}$ boundary location indicates a more restricted region of high attenuation in the SEUS than previous studies that were based on limited Q observations, seismotectonic regionalization, and crustal structure regionalization. Second, for earthquakes outside the Gulf Coast region and at long periods, the high attenuation region appears to be more restricted to close to the Gulf Coast. Third, most of Florida has less attenuation than the Gulf Coast region and is more like the central and eastern U.S. (CEUS) mid-continental attenuation, in keeping with the differing geological history of the Florida Peninsula from the Gulf Coast. Fourth, stress parameter, which is related to the high frequency energy and ground motion expected for CEUS earthquakes, appears to be lower in the south central U.S. than the east coast, northeastern U.S., and eastern Canada, but stil significantly higher than for the western U.S. And fifth, induced earthquakes in the CEUS appear to have similar stress parameter levels as shallow natural events. Thus seismic hazard from induced earthquakes is the same as for shallow natural earthquakes in a given region. In general seismic ground motions and hence hazard from large CEUS earthquakes is not reduced in Alabama, Georgia, and Florida due to Gulf Coast Q. At long periods for large earthquakes outside the Gulf Coast Q region, lower hazard from Gulf Coast Q is restricted to near the
Gulf Coast in Texas, Louisiana, and Mississippi. This pattern of seismic hazard is reflected in the intensity observations from the 1886 Charleston, South Carolina, M7.0 earthquake.

\section{Advances on the Parameterization of Seismic Attenuation: Current Challenges and Opportunities Poster Session · Wednesday 16 May · Riverfront South}

An Attenuation Study in the South Region of the Gulf of California, Mexico CASTRO, R. R., CICESE, Departamento de Sismología, Baja California, México, raul@cicese.mx; SINGH, S. K., Instituto de Geofísica, Universidad Nacional Autónoma de México, D. F., México, krishnamex@yahoo.com; JOSHI, A., Department of Earth Sciences, Indian Institute of Technology, Roorkee, India, anandfes@iitr.ac.in; SINGH, S., Department of Earth Sciences, Indian Institute of Technology, Roorkee, India, sandpfes@iitr.ac.in

We analyzed S-wave recordings from regional stations of the Broadband Seismological Network of the Gulf of California (RESBAN) operated by CICESE (Centro de Investigación Científica y de Estudios Superiores de Ensenada, B.C.) to study the variability of the quality factor $\mathrm{Q}$ with depth. We used earthquakes located by Sumy et al. (2013) in the southern gulf with hypocenters determined combining seismograms from an array of ocean-bottom seismographs, of the SCOOBA experiment, with onshore stations of the NARSBaja array. We also used hypocenters from other events relocated by Castro et al. (2017) in the same region. This well constrained catalog of seismicity that highlights zones of active tectonics and seismic deformation within the North America-Pacific plate boundary permit us study the attenuation characteristics of the $S$ waves in more detail than previous studies. We determined nonparametric attenuation functions in the distance range $10-250 \mathrm{~km}$ and used the 1-D velocity model of González-Fernández et al. (2005) to estimate $\mathrm{Q}$ at different frequencies and depths. To estimate $Q$ the geometrical spreading $G(R)$ is taken as $1 / R$ for $R<$ $100 \mathrm{~km}$ and $1 / \sqrt{ } \mathrm{R}$ for $\mathrm{R} \geq 100 \mathrm{~km}$. We found that at $4 \mathrm{~Hz} \mathrm{Q} \sim 770$ for the first 5 $\mathrm{km}$, increasing to $\sim 1200$ up to $10 \mathrm{~km}$ depth where $\mathrm{Q}$ starts to gradually decrease, reaching a value of $\mathrm{Q} \sim 980$ between $25 \mathrm{~km}$ and $40 \mathrm{~km}$ depth. We also used the same velocity model together with the discrete wavenumber method of Bouchon and Aki (1977) to calculate synthetic seismograms that permit us determine the geometrical spreading function for the south gulf region. The resulting function indicates that the rate of amplitude-decay with distance, due to the geometrical spreading in the Gulf of California, is approximately the same as that predicted by $G(R)=1 / R$ for $R<50 \mathrm{~km}$.

Crustal Lg-Wave Attenuation in Northwest China and Its Surrounding Areas ZHAO, L. F., Institute of Geology and Geophysics, Chinese Academy of Sciences, China, zhaolf@mail.iggcas.ac.cn; XIE, X. B., Institute of Geophysics and Planetary Physics, UC Santa Cruz, California, USA, xxie@ucsc.edu; YAO, Z. X., Institute of Geology and Geophysics, Chinese Academy of Sciences, China,yaozx@mail.iggcas.ac.cn

Northwest China and its surrounding areas are consisted of the Tien Shan Mountains and other four stable blocks: The Kazakh shield, Jungar, Tarim and Turpan-Hami basins. In response to the remote effect of the convergence between the Indian and Eurasian plates, the Tien Shan Mountains were formed by the reactivation of the Paleozoic structures in the Late Cenozoic. Previous studies revealed that the lithosphere beneath the Tien Shan may be thickened by the underthursting of the lithosphere in Tarim and kazakh, and then detached to lead to hot mantle material upwelling. Thus, there could be partial melting within the crust due to the intrusion of hot material. In this study, we constructed a $0.05-10.0 \mathrm{~Hz}$ broadband high-resolution crustal $\mathrm{Lg}$ wave attenuation model for Northwest China and its surrounding areas. Lg wave attenuation characteristics were investigated based on seismograms form 711 crustal earthquakes recorded between 1994 and 2017 at 383 regional stations distributed throughout the study regions. The attenuation models revealed obvious lateral heterogeneities which are consistent with geological features. The low QLg anomalies are observed in tectonically active regions, such as the Tien Shan Mountains, the northeastern margin of the Pamir Plateau and the northwestern margin of the Tibetan Plateau. In contrast, relatively high QLg anomalies are imaged in those stable blocks, such as the Tarim, Juggar and Turpan-Hami basins and Kazakh shield. The attenuation pattern shows that the large-scale tectonic boundaries are generally in high QLg gradients. In addition, strong earthquakes are mainly distributed within or near low QLg areas. This research was supported by the National Key Research and Development Program of China (2017YFC0601206) and the National Natural Science Foundation of China (grants 41674060, 41630210). 
Investigation of the Dependence of Kappa Values on the Onset of Soil Nonlinearity

II, C., North Carolina State University, North Carolina, USA, cji3@ncsu. edu; CABAS, A. C., North Carolina State University, North Carolina, USA, amcabasm@ncsu.edu

The high-frequency spectral decay parameter, kappa, is one of the most used values to describe seismic attenuations in engineering seismology. However, because of the limited number of strong ground motions from moderate-to-large earthquakes, the studies of the soil nonlinearity characteristics captured by kappa (especially the site-specific kappa component) have not received enough attention to date. To fill the identified gap in the literature, selected stations from the Kiban-Kyoshin network (KiK-net) database are used to assess the relationship between soil nonlinearity and site-specific kappa. The KiK-net database has the following advantages: Japan is one of the most seismically active areas and an abundance of ground motion recordings are available, and the KiK-net database includes two sets of sensors, one at the surface and one at depth (100-200 m), at each station. It allows the calculation of the difference of site-specific kappa between the values at the surface and at the borehole instrument to investigate the specific site effects such as near surface attenuation. The $0.03 \%$ shear strain index (as a ratio of peak ground velocity of the vibration excitation to the average shear wave velocity over the top $30 \mathrm{~m}$, PGV/VS30) has been adopted as the lower limit to identify the onset of soil nonlinear behavior. Thus, the correlations between site-specific kappa and VS30, depth at which the shear wave velocity exceeds $800 \mathrm{~m} / \mathrm{s}(\mathrm{H} 800), 1000 \mathrm{~m} / 3$ (z1), and $2500 \mathrm{~m} / \mathrm{s}$ (z2.5) are studies. Moreover, site-specific kappa from the selected nonlinear motions in this study is also compared to the corresponding values at the same sites when only using linear motions (i.e. motions that do not trigger nonlinear behavior).

Sensitivity Kernels for the Separation of Attenuation Processes: Scattering, Absorption, and Scattering Anisotropy

MARGERIN, L., Institut de Recherche en Astrophysique et Planétologie/ CNRS, France, ludovic.margerin@irap.omp.eu; CALVET, M., Institut de Recherche en Astrophysique et Planétologie, France, marie.calvet@irap.omp.eu

Among the physical processes that affect the amplitude of seismic waves, attenuation is one of the most poorly understood and undetermined factor. Two basic mechanisms control seismic attenuation in the crust: scattering by small-scale heterogeneities, and absorption of seismic energy by inelastic and irreversible processes. A number of techniques have been devised to retrieve attenuation information from the modeling of direct seismic waves emitted by earthquakes. A major issue with the use of ballistic signals lies in the fact that their amplitude is affected by multiple factors that are difficult to disentangle in practice: source radiation pattern, geometrical effects such as focussing/defocussing or site effects caused by surface layering. Moreover, since both scattering and absorption manifest themselves as an exponential decay of direct wave amplitude with distance, it is not possible to separate their effects from attenuation measurements based on ballistic waves only. We will show how to use radiative transfer in conjunction with perturbation theory to derive sensitivity kernels for the intensity detected in the coda. Compared to previous studies, we take into account the role of nonisotropic scattering which is controlled by the power spectrum of small-scale heterogeneities and strongly influences the shape of seismogram envelopes near the ballistic arrivals. Numerical evaluation of the kernels in a variety of isotropically and non-isotropically scattering media demonstrates that coda waves possess distinct spatial sensitivities to perturbations of absorption, scattering strength and scattering anisotropy. These results pave the way for the development of a genuine tomographic approach to the mapping of attenuation processes in the crust. Some preliminary applications to data will be shown.

Preliminary Investigations of the Kappa Parameter: From Exploration of Its Physical Interpretation to Application in a Host-to-Target Study

GÉLIS, C., IRSN, France, celine.gelis@irsn.fr; BONILLA, L. F., IFSTTAR, France, luis-fabian.bonilla-hidalgo@ifsttar.fr; CALVET, M., OMP, France, marie.calvet@irap.omp.eu; GATTI, F., Centrale Supelec, France, filippo.gatti@ centralesupelec.fr; LOPEZ-CABALLERO, F., Centrale Supelec, France, fernando.lopez-caballero@centralesupelec.fr; MARGERIN, L., OMP, France, ludovic.margerin@irap.omp.eu; PROVOST, L., IRSN, France, ludmila.provost@ irsn.fr; BERTRAND, E., CEREMA, France, etienne.bertrand@cerema. fr; COLVEZ, M., Centrale Supelec, France, martin.colvez@centralesupelec. fr; COURBOULEX, F., Geoazur, France, courboulex@geoazur.unice.fr; FROMENT, B., IRSN, France, berenice.froment@irsn.fr; GUÉGUEN, P., IFSTTAR-ISTERRE, France, philippe.gueguen@univ-grenoble-alpes.fr; LANGLAUDE, P., CEREMA, philippe.langlaude@cerema.fr; MAYOR, S. EDF, jessie.mayor@edf.fr; MONFRET, T., Geoazur, tony.monfret@geoazur. unice.fr; TCHAWE NZIAHA, F., IRSN, tflomin@yahoo.com; TOUHAMI, S., Centrale Supelec, sara.touhami@centralesupelec.fr

The high-frequency attenuation $\kappa$ introduced by Anderson and Hough (1984) is related to the attenuation of the seismic wavefield emitted by the source and travelling to the recording site. Anderson and Hough (1984) decomposed $\kappa$ in local $(\kappa 0)$ and regional attenuation $(\kappa \mathrm{R})$, respectively. In the last years, this parameter has become important in engineering seismology, in particular to take into account local site conditions in ground motion prediction studies. At the time of the meeting, we plan to present results on the following aspects. The approach of Anderson and Hough (1984) is applied to assess $\kappa$ at some stations located in areas of small-to-moderate seismic activity like mainland France and in more active regions. Values of $\kappa 0$ and $\kappa \mathrm{R}$ can be compared to intrinsic attenuation (e.g., Mayor et al., 2017 for France). Moreover, we look at the dependency of $\kappa(\kappa 0$ and $\kappa \mathrm{R}$ ) to intrinsic attenuation and scattering through numerical simulations of wave propagation. To do so, we model point sources at depth and study the waves recorded at the free surface for different properties of the propagation media. At last, we use the $x$ parameter in a host-to-target study in the Nice area, southeast of France. From different GMPEs, we compute site-specific response spectra using the approach of Al Atik et al. (2014). Computed spectra are compared with the ones obtained from recordings of different earthquakes.

\section{A New Model for Vertical-to-Horizontal Response Spectral Ratios for Central and Eastern North America}

PEZESHK, S., The University of Memphis, Tennessee, USA, spezeshk@ memphis.edu; FARHADI, A. F., The University of Memphis, Tennessee, USA, afarhadi@memphis.edu; HAJI-SOLTANI, A., The University of Memphis, Tennessee, USA, hjsltani@memphis.edu

It is a well-known fact that critical structures are required to be designed for the vertical effect of ground motions as well as the horizontal effects. We present a much-needed new model for the spectral ratio of vertical to horizontal component of earthquakes (V/H ratio) for Central and Eastern North America (CENA). The $\mathrm{V} / \mathrm{H}$ ratio model has the advantage of considering the earthquake magnitude, source to site distance, and shear-wave velocity of soil deposits in the upper $30 \mathrm{~m}$ of the site for PGA and a wide range of periods ( 0.001 to 10.0 seconds). The model evaluation will be based on a comprehensive set of regression analysis of the newly compiled Next Generation Attenuation (NGA-East) database of available CENA recordings with $M \geq 3.0$ and RRUP $<1000 \mathrm{~km}$. The median value of the geometric mean of the orthogonal horizontal motions rotated through all possible nonredundant rotation angles, known as the GMRotD50 (Boore et al., 2006), will be used along with the vertical component to perform regression using the maximum likelihood method. The earthquakes and recording stations in the Gulf Coast region are excluded due to their different ground-motion attenuation (Dreiling et al., 2014). However, the excluded data are evaluated in a parallel study to see if they can be represented by the same source parameters but different anelastic attenuation. The predicted ratios from the proposed model will be compared with recently published $\mathrm{V} / \mathrm{H}$ ratio models and can be used to develop the vertical response spectra for CENA sites.

\section{Separation of Intrinsic and Scattering Attenuation in the NMSZ of the Central United States}

NAZEMI, N., The University of Memphis, Tennessee, USA, nnazemi@memphis. edu; PEZESHK, S., The University of Memphis, Tennessee, USA, spezeshk@ memphis.edu; SEDAGHATI, F., The University of Memphis, Tennessee, USA, fsdghati@memphis.edu

Seismic waves attenuate due to intrinsic absorption and scattering. Due to material damping, seismic energy converts to heat as it propagates through the medium. This inherent property of material is called intrinsic attenuation. On the ray path, there may be some inconsistencies in the material, such as material variations or cracks. These lateral heterogeneities scatter the incoming seismic waves. They reflect, refract, and convert the waves. These waves are eventually captured by the seismographs at the tail portion, so called coda. Both parameters are characterized by the quality factor, $\mathrm{Q}$, which is the ability of a domain in conducting waves. This definition is inversely proportional to the damping. This definition is well matched with the intrinsic attenuation. Although scattering attenuation occurs through a different process, it is presented by the $Q$ values. In this study, we are trying to separate the intrinsic and scattering attenuations in the New Madrid seismic zone. Multiple lapse time window analysis is implemented in order to perform this task. In this method, seismic waves' energy are theoretically synthesized using compact formulation for multiple scattered waves (Zeng, 1991). Theoretical energy curves are characterized by seismic albedo, B0, and extinction length, Le-1. For three consecutive $20 \mathrm{sec}$ time windows starting from $\mathrm{S}$-wave arrival, these energy curves are compared to the envelope functions of 
same windows of seismogram. We used a grid search to locate the best matching pair of attenuation parameters. Values of seismic albedo is about 0.7 suggesting thatscattering attenuation is dominant in this area. Both intrinsic and scattering attenuation functions are frequency dependent. Results are compared to our previous findings using the coda normalization procedure. To have a qualitative comparison between single scattering and multiple scattering assumptions, we compared findings in this study with the Sedaghati and Pezeshk (2016) results.

Comprehensive Study of Attenuation Properties of the New Madrid Seismic Zone in the Central United States

NAZEMI, N., The University of Memphis, Tennessee, USA, nnazemi@memphis. edu; PEZESHK, S., The University of Memphis, Tennessee, USA, spezeshk@ memphis.edu; SEDAGHATI, F., The University of Memphis, Tennessee, USA, fsdghati@memphis.edu

New Madrid seismic zone (NMSZ) is an intraplate seismic zone buried under thick layers of sediments in the Mississippi embayment. Complicated geological structure obscures this seismic system and makes it difficult to study. NMSZ is capable of generating earthquakes with magnitudes as large as 7, which poses a considerable seismic hazard in this area. Consequently, it is crucial to obtain an insight into the crustal properties of the crust in the area. One important parameter in this realm is the quality factor $(\mathrm{Q})$ that quantifies the capability of the crustal material in conducting seismic waves. In this study, unique properties of coda waves are implemented to extract frequency dependent quality factor functions of S, P, and $\mathrm{Lg}$ waves in the area of interest. This method, called coda normalization, is a time domain method in which the amplitude of the desired phase is divided by the amplitude of a reference coda-wave window to eliminate site effects and instrument response, and to isolate source effects to invert for $\mathrm{Q}$ values. In a comprehensive study of attenuation properties in NMSZ, we estimated QP ( $\mathrm{f}$ )$=(115.80 \pm 1.36) f(0.495 \pm 0.129)$ and $Q s(f)=(161.34 \pm 1.73) f(0.613 \pm 0.067)$ for near-field waves up to a distance of $60 \mathrm{~km}$, and $\mathrm{QLg}(\mathrm{f})=(390 \pm 26) \mathrm{f} 0.56 \pm 0.04$ from 120 to $400 \mathrm{~km}$. It is worth mentioning that geometric spreading was fixed at 1.0 for near-field waves, and 0.5 for $\mathrm{Lg}$ waves, since simultaneous inversion of geometric spreading and quality factor was not possible. The intrinsic $(\mathrm{Q}-\mathrm{i})$ and the scattering (Q-sc) quality factors are inferred using Multiple Lapse Time Window (MLTW) analysis, assuming a uniform distribution of scatters and isotropic scattering regime. This method compares spatial and temporal distribution of energy and allows estimating seismic albedo, B0, and extinction length, Le -1, simply by comparing theoretical and observational seismic. Final results of our findings are compared to findings available in the literature.

\section{KO: Origin and Usability}

PAROLAI, S., Istituto Nazionale di Oceanografia e Geofisica Sperimentale, Italy, sparolai@inogs.it

Recent studies have focused on the analysis of the nature of $\mathrm{k} 0$, a term generally considered to be representative of the attenuation below a site, and its application for improving seismic hazard assessment. It follows that a better understanding of the nature of $\mathrm{k} 0$ (what does it exactly represent) and therefore of its correct application for improving the estimation of local shaking is mandatory. In this study, by means of the numerical simulation of vertically incident $\mathrm{SH}$ waves, I set out to clarify the contribution of the intrinsic attenuation and the transmission of the media within different portions of the seismic signal and, in particular, within time windows similar to what generally used for real data analysis. Numerical simulations were carried out using models with constant or increasing with depth velocities, that are perturbed with increasing random vertical impedance contrasts. The analysis allows us to quantify, for the analyzed situation, the apparent attenuation related to the transmission part and to outline the variability of the results depending on the chosen window of signal. Finally, an example of this method's application to real data collected from an array of borehole sensors is used to show some possible limits arising when $\mathrm{k} 0$ is adopted for correcting ground motion estimation from bedrock to the surface.

\section{Lg Attenuation in Oklahoma and Its Surrounding Regions}

AL NOMAN, M. N., CERI, University of Memphis, Tennessee, USA, malnoman@memphis.edu; LANGSTON, C. A., CERI, University of Memphis, Tennessee, USA, clangstn@memphis.edu; CRAMER, C. H., CERI, University of Memphis, Tennessee, USA, ccramer@memphis.edu

Increased seismicity in the Oklahoma and surrounding regions since 2008 and the passing of the EarthScope USArray through the region provides an opportunity to better define $\mathrm{Lg}$ attenuation in that region. Initial tomography results at 1 $\mathrm{Hz}$ by Gallegos et al. (2014) and a study of the location of the boundary between mid-continental low attenuation and Gulf Coast higher attenuation regions at 1.0 and $5.0 \mathrm{~Hz}$ by Cramer and Al Noman (2016) and Cramer (2017) provide insight into the problem of defining $\mathrm{Lg}$ attenuation in the Oklahoma region. The location of the mid-continental/Gulf Coast Q boundary in Oklahoma is complicated by other crustal structures, such as the Southern Oklahoma Rift. We address this problem using $\operatorname{Lg} Q$ tomography and increased raypath coverage from $\mathrm{M} 3$ earthquakes surrounding the study region. We determine frequency dependent attenuation models $Q(f)$ for the Oklahoma and surrounding region using direct $\mathrm{Lg}$ waves at regional distances of 200 to $1500 \mathrm{~km}$. Using automated processing we extracted the Lg-wave amplitude spectra between 0.05 and $10 \mathrm{~Hz}$ from vertical waveforms recorded at 314 TA stations from 207 crustal earthquakes $(\mathrm{M} \geq 3.0)$. We simultaneously determined the QLg distribution, source and site functions at different frequencies from the geometrical spreading corrected $\mathrm{Lg}$ amplitudes using a tomographic regularized inversion. The $1^{\circ} \times 1^{\circ}$ checkerboard test with synthetic data shows good resolution coverage over the region. The results at $1.0 \mathrm{~Hz}$ and $5.0 \mathrm{~Hz}$ show a trend of lower Q estimates near the Gulf Coast region while the central Oklahoma part reveals a higher $Q$ estimate. Initial investigation of Gulf-Coast regional attenuation pattern suggests a good agreement with the defined Q boundaries by Cramer (2017). We expect to investigate the attenuation estimates in more detail, and at other frequencies to develop a frequency dependent $\operatorname{Lg}$ attenuation map for this region.

\section{Spatial Variation of Crustal Attenuation Properties in Western Tibet}

BISWAS, R., Indian Institute of Technology Kharagpur, West Bengal, India, rbiswas32@gmail.com; SINGH, C., Indian Institute of Technology Kharagpur, West Bengal, India, chandrani@gg.iitkgp.ernet.in

Two-dimensional (2D) spatial attenuation maps are produced for the crust of western Tibet using local earthquakes which are recorded by an array of 30 broadband stations operated from July 2007 to May 2011. Initially estimation of coda waves attenuation $\left(\mathrm{Qc}_{\mathrm{c}-1}\right)$ is done using single isotropic model and subsequently relative contribution of scattering (Qsc-1) and intrinsic (Qi-1) attenuation have been calculated using Multiple Lapse Time Window Analysis (MLTWA) under the assumption of uniform distribution of multiple isotropic scattering effects for the frequency bands of $1-2,2-4,4-8,8-16$ and $12-24 \mathrm{~Hz}$, respectively. All the events are selected on the basis of high signal to noise ratio having hypocentral distance within $200 \mathrm{~km}$ from the respective stations. The obtained Q values show a strong frequency dependent nature which can be correlated to the degree of tectonic complexity and the heterogeneities present in the medium. As a whole, the intrinsic absorption is found to be the dominant mechanism at all the frequencieswhich is quite consistent with the geo-tectonic complexity in the region. The obtained values of $Q$ are in good agreement with other segments of Himalaya and Tibet as well as different tectonic regions in the world. Keywords: MLTWA, Intrinsic, scattering, coda wave, western Tibet

\section{Development and Validation of Statistical Models of Small-Scale Heterogeneities}

Poster Session · Wednesday 16 May · Riverfront South

Seismic Scattering from Topography and Small-Scale Crustal Heterogeneity: Application to the $\mathbf{2 0 0 9}$ North Korean Nuclear Test

YEH, T., Department of Geological Sciences, San Diego State University, California, USA, tyyeh316@gmail.com; OLSEN, K. B., Department of Geological Sciences, San Diego State University, California, USA, kbolsen@ mail.sdsu.edu

We simulate high-frequency $(0-4 \mathrm{~Hz})$ wave propagation to regional distances for the 2009 North Korea Nuclear Test (NKNT) using the SALSA3D velocity model. In our simulations, we address two major causes of generation of highfrequency energy-(1) crustal scattering due to small-scale velocity and density perturbations, and (2) scattering due to surface topography. We approximate the crustal media heterogeneities by spectral coloring of Gaussian random numbers. We show that ensembles of synthetics computed for models with small-scale crustal heterogeneities can reproduce the observed $0-4 \mathrm{~Hz}$ waveform characteristics fairly well at regional distances $(400+\mathrm{km})$. Particularly, the amplitudes of phases that are commonly used for discrimination of explosive events (e.g. Pn, $\mathrm{Pg}, \mathrm{Sn}$, and $\mathrm{Lg}$ ) are well reproduced at station INCN for both low frequencies $(<1 \mathrm{~Hz})$ and high frequencies $(<1 \mathrm{~Hz})$. Encouraged by the agreement at INCN, we present distance- and frequency-dependent ratios of these phases from the NKNT site to INCN. Beamforming for our synthetics at the 20 -station KS seismic array in South Korea provides apparent velocities and back azimuths in agreement with those for the main arrivals in the data. Since topography is not easily implemented in our staggered-grid finite-difference modeling code, we attempt to model topographic scattering using a shallow, near-surface layer of media heterogeneities. Toward this goal, we estimate the parameters characterizing the 
statistical distribution obtained by the surface elevation around the NKNTS, as a guidance for generating the random fields. Our results show that von Karman and power-law autocorrelation functions both provide reasonable models for the topographic variation around the NKNTS, with Hurst exponents of 0.6-0.8 The correlation length associated with the von Karman function is found to be poorly resolved, as it increases with the size of the area of analysis.

\section{Is It Possible to Use Teleseismic Scattered Waves to Determine the Receiver-} Side Stochastic Velocity Model?

WEI, X. Z., Graduate School of Oceanography, University of Rhode Island, Rhode Island, USA, xiaozhuo_wei@my.uri.edu; SHEN, Y., Graduate School of Oceanography, University of Rhode Island, Rhode Island, USA, yshen @uri.edu; BAO, X., Graduate School of Oceanography, University of Rhode Island, Rhode Island, USA, xybao@uri.edu; CHEN, L., State Key Laboratory of Lithospheric Evolution, Institute of Geology and Geophysics, Chinese Academy of Sciences; CAS Center for Excellence in Tibetan Plateau Earth Sciences, China, Ichen@ mail.iggcas.ac.cn; JIANG, M., Key Laboratory of Earth and Planetary Physics, Institute of Geology and Geophysics, Chinese Academy of Sciences; CAS Center for Excellence in Tibetan Plateau Earth Sciences, China, jiangmm@mail.iggcas. ac.cn

Numerous seismic studies have been conducted in the past decades, yielding images of large-scale structures and providing valuable insights into the dynamics and evolution of the Earth. However, due to sparse station coverage, smallscale heterogeneities, which may reflect the cumulated geological history and cause wave scattering (and thus scattering attenuation), are often poorly resolved. While previous studies have attempted to resolve these small-scale heterogeneities by modeling the scattered waves in stochastic media, these efforts mostly relied on local or regional earthquakes, limiting their applicability only to the regions of active seismicity. Thus, in order to broaden the investigation to both seismic and aseismic regions, we ask: Can teleseismic events provide us information about the stochastic nature of the media beneath the stations? One of the waveform characteristics we use to determine the stochastic properties of the media is the energy partition of teleseismic P-wave on the transverse component (PEPT). Our first target study region is the eastern margin of the Tibetan Plateau, where the highly deformed mountain belts are juxtaposed with the stable Yangtze Craton. The dense linear arrays deployed there allow us to investigate how the PEPT values change from one tectonic block to the other. Our observations show that inside the craton, the PEPT values are generally small, while the values inside the plateau are relatively high. Across the boundary between the craton and the plateau, there is an abrupt change in the PEPT values. The results match well with our expectations for the stable craton and the highly deformed mountain ranges, though forward full-wave modeling is needed to verify the contribution of scattering caused by surface topography to the total scattering and to determine the stochastic representations of the velocity structures beneath the two tectonic regions.

Modeling of Coda Wave Attenuation by Local Heterogeneity Scattering LARMAT, C. S., Los Alamos National Laboratory, New Mexico, USA, carene@ lanl.gov; MACCARTHY, J. K., Los Alamos National Laboratory, New Mexico, USA, jkmacc@lanl.gov; PHILLIPS, W. S., Los Alamos National Laboratory, New Mexico, USA, wsp@lanl.gov

This paper presents a numerical study of the wave trains known as coda that are observed on seismic records of local earthquakes $(\mathrm{Mw}<5)$ and small explosions at local distances $(<100 \mathrm{~km})$. We use spectral element numerical modeling to generate synthetic seismograms in local seismic models for a dominant frequency of about $5 \mathrm{~Hz}$. Our study will focus on the evolution of the amplitude and duration of the coda for direct $\mathrm{P}$ and $\mathrm{S}$ waves. We will investigate the interaction of energy loss due to scattering with intrinsic attenuation. We will also investigate if coda wave shape contains useful information for quantitative estimation of the strength of random heterogeneity following early work by Aki \& Chouet (1975) and Sato (1978). Different stochastic models will be proposed to vary the local velocity models in both hard-rock and sedimentary basins environments. This work is in preparation of modeling of wave propagation in the highly-scattering Moon crust. The stochastic models developed and validated with Earth observations will be applied to Moon seismic records.

Examination of the Reference-Phase Concept in Seismology in the Presence of Small-Scale Heterogeneities

ZHENG, Y., University of Houston, Texas, USA, yzheng12@uh.edu

The concept of the 'reference phase' is widely used in seismic tomography and imaging. Usually, a differential traveltime between the prominentreference phase and another seismic phase is used with the hope to eliminate the influence of unknown velocity structure on their common travel paths. It is well known that Earth has inhomogeneities at all spatial scales and small-scale heterogeneities may violate this concept. In this work, we will investigate the validity of the 'reference phase' concept in the presence of small-scale heterogeneities whose length scales are below the spatial resolution of deterministic approaches in seismic inversion. We will first invert for the small-scale heterogeneity spectrum using the coherence function methods using amplitude and traveltime fluctuations of the transmitted wave. The inverted spectrum provides a quantitative statistical description of the small-scale heterogeneities. Then, we will produce realizations of the statistical random models. We use full-wave finite difference method to compute the wave propagation in the random medium. Finally, we evaluate the reference phase concept.

\section{Early Warning for Large Earthquakes and Tsunamis: Challenges, Case Studies and Innovations}

Poster Session · Wednesday 16 May · Riverfront South

\section{Smart Seismic Hardware: New Strategies for Networking and Mitigation of False Alerts}

ALLARDICE, S. A., Güralp Systems Ltd, United Kingdom, sallardice@guralp. com; HILL, P., Güralp Systems Ltd, United Kingdom, phill@guralp.com

Güralp's range of 'smart' seismic hardware offer a simple interface with advanced on-board processing and can issue triggered event details and alerts with ultralow-latency. This means a delay time of just $40-60 \mathrm{~ms}$ from system triggering to issuing an alert. Güralp Data Interchange, (GDI) is an ultra-low latency data transmission protocol used by Guralp hardware which allows seismic waveforms to be transmitted sample by sample as they are acquired by the instrumentation. GDI adapts the size of the data packets to suit the network bandwidth available. This flexibility within the protocol means the lowest possible latency for the given network can be achieved. To ensure the alerts can be relied upon there is a requirement for a form of application to mitigate false positive results. Within the 'smart' range, a configurable voting mechanism is implemented on the Minimus to eliminate false positives which can incorporate a 'score' from different data sources i.e. Z channel on seismometer, N/S E/W channels on accelerometer and the internal Minimus MEMS. If the score exceeds the set threshold then an alert is sent to a predefined 'Master Minimus'. If the pre-configured threshold on the Master Minimus is triggered then the Master will issue the triggered event data and/or an alert. Minimus can issue alerts using Common Alert Protocol (CAP). Whenever the trigger conditions are met the Minimus can send a signed UDP packet to the configured CAP receiver which will then send the alert via SMS, e-mail or CAP forwarding, or multiples thereof. To increase network redundancy, parameters from each station or network can be streamed to multiple stations, networks or data centres, so that there is no one single point of failure.

\section{Determining Magnitudes of Large Earthquakes in Japan Using Seismic Stations in China}

WANG, D., China University of Geosciences, China, dunwang2004@yahoo.com

Rapid determination of earthquake magnitude is of importance for estimating shaking damages, and tsunami hazards. However, due to the complexity of source process, accurately estimating magnitude for great earthquakes in minutes after origin time is still a challenge. A recent example is the 2011 M9.0 Tohoku, Japan earthquake. We developed an approach that was originated from Hara[2007], estimating magnitude by considering P-wave displacement and source duration. The source duration is estimated using array data from regional seismic network (Hi-net). We applied this method to determine the magnitudes of large earthquakes $(M \geq=7)$ in and around Japan using seismic stations in China. Our results show the magnitudes of tested earthquakes are well determined in 5-10 min after the Origin times, with uncertainties of \pm 0.2 . Thus, this magnitude scale may be a promising aid for disaster mitigation right after a damaging earthquake, especially when dealing with the tsunami evacuation and emergency rescue.

\section{Reducing the False Alert Problem in Earthquake Early Warning: ElarmS Version 3.0 \\ CHUNG, A. I., UC Berkeley, California, USA, achung@berkeley.edu; HENSON, I., UC Berkeley, California, USA, ihenson@berkeley.edu; HELLWEG, M., UC Berkeley, California, USA, hellweg@berkeley.edu; ALLEN, R. M., UC Berkeley, California, USA, rallen@ berkeley.edu}

ElarmS is a network-based Earthquake Early Warning System (EEWS) that is currently operating and creating alerts for earthquakes throughout the West Coast of the United States. ElarmS is one of the algorithms contributing to the 
ShakeAlert EEWS, a prototype system that will begin publishing public alerts in late 2018. In 2013 significant improvements were made to ElarmS resulting in ElarmS version 2.0 (E2). Though E2 consistently had the fastest alert times and the most accurate magnitude estimates compared with other ShakeAlert algorithms, it created more false alerts. To address these false alerts, we have developed a revised version of ElarmS - ElarmS version 3.0 (E3). To remove bad triggers that are responsible for causing the false alerts, E3 employs filters that have been empirically developed using a database of triggers. New parameters that have been added to E3 include revised minimum amplitude checks, a "range posttrigger" parameter, a horizontal-to-vertical amplitude ratio check, and a limit for the maximum change in the length of the acceleration vector. To develop and test the new E3, we use the ShakeAlert Testing \& Certification (T\&C) dataset with waveforms from more than 100 local, regional, teleseismic, and anomalous events. We replayed the T\&C event dataset using both E2 and E3. As this dataset is heavily biased towards problematic waveforms/events, E2 created 54 false events with $M \geq 3$. Most of these false events were due to teleseismic earthquakes, though a few were either split events from larger earthquakes within the reporting region or poorly located events. In contrast, $\mathrm{E} 3$ created just $3 \mathrm{M} \geq 3$ from the same dataset. Of these 3 events, two were very poorly located real earthquakes that had occurred outside of the network. E3 will be the basis for the new EPIC algorithm, which will be the only ShakeAlert point-source algorithm.

\section{Updates on the Finite-Fault Rupture Detector Algorithm (Finder v.2)}

BÖSE, M., Swiss Seismological Service, ETH Zurich, Switzerland, maren. boese@sed.ethz.ch; SMITH, D. E., US Geological Survey, Pasadena, California, USA, deborahsmith@usgs.gov; MASSIN, F., Swiss Seismological Service, ETH Zurich, Switzerland, frederick.massin@sed.ethz.ch; ANDREWS, J., Caltech, California, USA, jrand@gps.caltech.edu; FELIZARDO, C., Caltech, California, USA, claude@gps.caltech.edu; CARRASCO, S., National Seismological Centre, University of Chile, Santiago, Chile, acarrasco@ csn.uchile.cl; CLINTON, J. F., Swiss Seismological Service, ETH Zurich, Switzerland,john.clinton@sed.ethz.ch

The Finite-Fault Rupture Detector (FinDer) algorithm provides real-time finitesource models for on-going fault ruptures. The FinDer algorithm determines a line-source model that is best suited to explain the current spatial ground-motion pattern observed at any given time in a dense seismic network. This is done via the cross-correlation of observed ground-motion amplitudes with theoretical templates modeled from empirical ground-motion prediction equations and a range of magnitude-dependent rupture lengths. The estimated line-source parameters (centroid, length, and strike) and uncertainties are updated every second to accommodate the temporal changes in the observed amplitudes caused by the evolving fault rupture. The FinDer v. 2 algorithm has been implemented in $\mathrm{C}++$ and integrated into the ShakeAlert and SeisComP3 seismic processing systems. We report the real-time and offline performances of FinDer in various regions including the Pacific Northwest, Switzerland, Chile, Central America, Central Italy, and Japan. We compare FinDer performance for different ground-motion metrics used for template generation, including peak-ground acceleration and velocity amplitudes, with and without site corrections. We typically obtain stable line-source solutions within a few seconds from event origin, provided the seismic network is sufficiently dense. Even when ground motions are available only at the nearest stations, FinDer can generate line-source estimates. From these estimates, seismic ground-motions can be predicted for surrounding areas often before the onset of strong shaking. These results demonstrate the potential of FinDer for earthquake early warning. For small earthquakes, generally $2.5<\mathrm{M}<5.0$, the FinDer-estimated rupture strike tends to coincide within 250 or less with one of the nodal planes of the fault plane solutions, suggesting an important role of rupture orientation in small earthquakes, which creates asymmetric ground-motion patterns.

First Experience with Seiscomp3 Based Tsunami Software for the Central American Tsunami Advisory Center (CATAC) at INETER, Nicaragua

STRAUCH, W., INETER, Managua, Nicaragua, wilfried.strauch@yahoo.com; WEBER, B., GEMPA, Brandenburg, Germany, info@gempa.de; MOELLER, M., GEMPA, Brandenburg, Germany, info@gempa.de; BLANCO, F., GEMPA, Brandenburg, Germany, info@gempa.de; RAMIREZ, J., INETER, Managua, Nicaragua, javier.ramirez@sb.ineter.gob.ni; TALAVERA, E., INETER, Managua, Nicaragua, emilio.talavera@gf.ineter.gob.ni; TENORIO, V., INETER, Managua, Nicaragua, virginia.tenorio@gf.ineter.gob.ni; ARGUELLO-MIRANDA, G. J., INETER, Managua, Nicaragua, greyving. arguello@gf.ineter.gob.ni

In January of 2018, we finished to install new hardware and software at the Central American Tsunami Advisory Center (CATAC), established at INETER in Nicaragua. CATAC is the most recent tsunami warning center integrating modules for earthquake detection, moment tensor analysis, tsunami simulation, decision support and warning dissemination based on the SeisComP3 framework. SeisComP3 is a seismological software package used already at BMKG (Indonesia), DGMET (Oman), TMD (Thailand) and CEA (France) where it has proven its performance many times in the last years. A Common Acquisition Protocol Server permits the acquisition of data from different sensor systems including seismic and tide gauge sensors and is used to confirm or cancel the tsunami warning. The moment tensor calculation supports the W-phase and provides reliable solutions in short time. The tsunami simulation is integrated with the seismic data processing, the computing is GPU-based allowing near real time results. It can react immediately on atypical events, e.g. "slow earthquakes", providing the process of tsunami simulation with updated hypocenter, focal mechanism and magnitude. The near real time simulations estimate arrival times and amplitudes of the tsunami waves for exposed coastlines. The dissemination system uses templates for the immediate publication of bulletins and warnings. We analyze the performance of the CATAC system using examples as the M 7.3 earthquake on January 10,2018, North of Honduras. The 15 persons working on tsunami warning in the 24/7 shifts and/or scientific-technical development at CATAC/INETER were trained in the use of the software. CATAC is developed by INETER with support from the government of Nicaragua. Nicaragua agreed a development project with the Japanese International Cooperation Agency (JICA) for the reinforcement of CATAC. The installation of SeisComP3 at CATAC/INETER is funded by JICA.

\section{Progress of the Japanese-Nicaraguan Project for the Establishment of the} Central American Tsunami Advisory Center (CATAC)

FURUKAWA, N., JICA-Nicaragua, Japan, furukawa.nobuo@friends.jica. go.jp; KUMAGAI, Y., JICA-Nicaragua, Japan, kumagai.yu@friends.jica.go.jp; STRAUCH, W., INETER, Managua, Nicaragua, wilfried.strauch@yahoo. com; TALAVERA, E., INETER, Managua, Nicaragua, emilio.talaveraq@ gf.ineter.gob.ni; TENORIO, V., INETER, Managua, Nicaragua, virginia. tenorio@gf.ineter.gob.ni; RAMIREZ, J., INETER, Managua, Nicaragua, javier.ramirez@gf.ineter.gob.ni; ARGUELLO-MIRANDA, G. J., INETER, Managua, Nicaragua, greyving.arguello@gf.ineter.gob.ni; CABRERA, A., INETER, Managua, Nicaragua, amilcar.cabrera@gf.ineter.gob.ni; HERRERA, M., INETER, Managua, Nicaragua, amilcar.cabrera@gf.ineter.gob.ni; ACOSTA, N., INETER, Managua, Nicaragua, norwin.acosta@gf.ineter.gob.ni; MORALES, A., INETER, Managua, Nicaragua, allan.morales@gf.ineter.gob. ni

In 2015, the Central American countries (Guatemala, El Salvador, Honduras, Nicaragua, Costa Rica and Panama) agreed to establish a Central American Tsunami Advisory Center (CATAC) at INETER in Managua, Nicaragua. This proposal was also approved by the Intergovernmental Oceanographic Committee (IOC) of UNESCO and the Intergovernmental Coordination Groups (ICG) of the Pacific Ocean Tsunami Warning Systems (PTWS) and the Caribbean Sea (CARIBEEWS). CATAC will provide scientific real-time technical tsunami services related to the Pacific Ocean and the Caribbean Sea to the Scientific Institutions and Civil Protection Agencies of the Central American countries. The issuance of tsunami advice to the population remains the responsibility of the national governments. In 2016, INETER started to establish CATAC. The Nicaraguan government agreed with the Japan International Cooperation Agency (JICA) to execute a technical assistance project to strengthen CATAC; this project began in October 2016. Progress was made in the development of the data processing system, the monitoring networks, the construction of the tsunami database, the training of personnel and the development of Standard Operating Procedures (SOP).

\section{SCSN Data Quality Control and Station Health Assessment Tools} STUBAILO, I., Caltech, California, USA, stubailo@gmail.com; ALVAREZ, M. G., US Geological Survey, California, USA, malvarez@usgs.gov; BHADHA, R., Caltech, California, USA, rayo@gps.caltech.edu; BRUTON, C., Caltech, California, USA, cpbruton@gps.caltech.edu; HAUKSSON, E., Caltech, California, USA, hauksson@gps.caltech.edu; WATKINS, M., Caltech, California, USA, watkins@gps.caltech.edu; THOMAS, V. I., US Geological Survey, California, USA, vthomas@usgs.gov

The USGS/Caltech Southern California Seismic Network (SCSN) is a modern digital ground motion seismic network. It develops and maintains Earthquake Early Warning (ShakeAlert) data collection and delivery systems in southern California as well as real-time ShakeAlert algorithms. Here we present recent and ongoing innovations in telemetry, data quality control, and data analysis that keep the network running efficiently and provide timely high-quality streaming data. EEW systems must process seismic data within a fraction of a second of acquisition. The SCSN maintains a robust and resilient network of more than 
350 seismic stations to achieve this goal. We have continued to improve the telemetry path diversity, minimize data transfer latency as well as developed new tools for latency monitoring and archiving. The latency data collection is done by an earthworm module that is user configured. It can collect latency channels under different names as mseed waveform data: L1Z (start of the packet), L2Z (middle of the packet) and L3Z (end of the packet) latency values. The latency data streams are archived with the same tools as the seismic data. We use PQLX for the data quality control because it enables monitoring of seismic signal performance for the entire network, and to identify anthropogenic noise sources and malfunctioning acquisition equipment. We have built a dynamic web-based display showing the summary noise analysis results. It sorts multiple channels separately and has mapping capabilities for an arbitrary number of the data points. This tool quickly identifies problematic sites and areas with elevated noise. It can also be used to report the worst $\mathrm{N}$ number of sites without analyzing all the data from the entire network.

\section{Exploring Rupture Dynamics and Seismic Wave Propagation along Complex Fault Systems} Poster Session · Wednesday 16 May · Riverfront South

Deterministic Seismic Hazard Analyses of Victoria, British Columbia, Canada: Considering an Active Leech River Fault

KUKOVICA, J. J., The University of Western Ontario, jkukovic@uwo. ca; MOLNAR, S., The University of Western Ontario, smolnar8@uwo.ca; GHOFRANI, H., The University of Western Ontario, hghofra@uwo.ca

The Leech River fault is situated on Vancouver Island near the city of Victoria, British Columbia, Canada. The $\sim 60 \mathrm{~km}$ transpressional reverse fault zone runs from east to west along the southern tip of Vancouver Island, dividing the lithologic units of metamorphic Jurassic-Cretaceous Leech River Complex to the north and igneous Eocene Metchosin formation to the south. Recent paleoseismic evidence suggests that at least two surface-rupturing events have exceeded a moment magnitude of 6.5 within the last 15,000 years (Morell et al., 2017). A seismically active Leech River fault poses considerable risk to the Greater Victoria area. We perform Deterministic Seismic Hazard Analyses (DSHA) for the city of Victoria with consideration of the Leech River fault as an active source. Our DSHA simulations for Victoria are accomplished using a 3D finite-difference wave propagation scheme for frequencies $\leq 2 \mathrm{~Hz}$ (Olsen, 1994) with stochastic finite-fault modelling (i.e., EXSIM) to include higher frequencies. Uncertainties in earthquake rupture parameters including rupture area and geometry (magnitude), propagation velocity, and slip distribution are captured within a suite of scenarios to assess earthquake ground shaking in Greater Victoria. The suite of deterministic earthquake scenarios is comprised of plausible rupture along the Leech River fault based on empirical slip models (e.g., 2011 M 6.3 Christchurch, New Zealand event) as well as randomized synthetic scenarios. We seek to understand what the implications of a significant rupture emitting from the Leech River fault would have on Victoria and southern British Columbia. Morell, K., Regalla, C., Leonard, L., Amos, C., \& Levson, V. (2017). Quaternary rupture of a crustal fault beneath Victoria, British Cloumbia, Canada. GSA Today, 27, doi: 10.1130/GSATG291A.1 Olsen, K. (1994). Simulation of three-dimensional wave propagation in the Salt Lake Basin. Ph.D. Thesis, University of Utah, Salt Lake City, Utah.

\section{3d Dynamic Rupture Simulations along Dipping Faults, with a Focus on the Salt Lake City Segment of the Wasatch Fault, Utah}

WITHERS, K. W., US Geological Survey, Colorado, USA, kwithers@usgs.gov; MOSCHETTI, M. P., US Geological Survey, Colorado, USA, mmoschetti@ usgs.gov; DURU, K. C., Munich University, Germany, kenneth.c.duru@gmail. com

We numerically model earthquake rupture along dipping faults, including both stochastic fault roughness and deterministic long-wavelength geometry, matching that of the Salt Lake City segment of the Wasatch fault, Utah. We seek to better understand the rupture process and assess broadband ground motions and variability by extending deterministic ground motion prediction in this region to higher frequencies. Our approach utilizes dynamic rupture simulations using a summation by parts method. The fault roughness generates realistic ground motion energy (from changes in acceleration as the rupture front propagates), in the sense that it has a flat acceleration spectrum across a broad bandwidth (up to $\sim 5 \mathrm{~Hz}$, the resolution of our computational mesh). We observe that a dipping fault decreases the range of stochastic variability in initial friction along the fault, compared to a vertical fault, for an equivalent amplitude-to-wavelength ratio, a. Using a slip-weakening friction law ( $\mathrm{dc} \sim 0.2 \mathrm{~m})$ and including off-fault nonlin- earity via a Drucker-Prager plasticity model, we find that the rupture propagates in a pulse-like manner, with a sufficiently large choice in the amplitude of fault roughness. Lithostatic stress conditions (in addition to hydrostatic pore pressure) are enforced, consistent with that of recently measured strain accumulation near the Wasatch fault. We find that rupture is highly dependent on the non-uniform stress distribution along both strike and dip imposed by the long-wavelength fault geometry, serving to impede or aid rupture, and the corresponding local rupture velocity and peak slip rates. Our initial simulations generate $\sim \mathrm{Mw} 7.0$ events along dipping normal faults ( $40 \times 20 \mathrm{~km}$ along strike and width, respectively), with ground motion near a median event and a level of intra-event variability near that of recent GMPE relations. Continuing work will analyze the dependence of rupture parameters and their correlation with variability in ground motion.

\section{Weakening of Fault Planes by Flash Melting Implies Near-Fault Anelastic Failure \\ SLEEP, N. H., Stanford University, California, USA, norm @stanford.edu}

Flash melting on real frictional contacts may greatly weaken fault surfaces with tiny slip-weakening distances of $\sim 10 \mu \mathrm{m}$. This mechanism allows near-total stress drops in small even laboratory earthquakes. It also major earthquakes on the San Andreas Fault to slip at average stresses of $\sim 10 \mathrm{MPa}$. However, the mechanism for moderate and large earthquakes implies excessive near-fault stresses and hence anelastic near-fault failure around the rupture tip. Nucleation patches begin with slow creep governed by rate and state friction. The critical size of these patches is already larger than the critical size for excessive near-fault stresses from flash melting. Macroscopic near-fault anelastic deformation increases the effective slip weakening distance so that excessive near-fault seismic waves do not occur. The associated distributed deformation produces undulations on an initially planar fault surface and leaves residual stresses, some of which are near failure. Subsequent events shake down stress concentrations and straighten undulations, but leave new concentrations and undulations in their wake. Rupture may jump to stress concentration once the $\mathrm{P}$ wave arrives. Strong high frequency $(\sim 10$ hz) $S$ waves impinge on the fault plane during the waning stages of slip. These waves stop sliding with flash weakening if their motion is unfavorably oriented and locally lock the fault. Renewed sliding requires rate and state strength and releases pulses of high-frequency waves.

\section{Ground Motion Simulation and Topography Amplification Effect on an ms6.6 Minxian Earthquake}

FU, C.H., Institute of Geophysics, CEA, Beijing, China, fuchanghua2004@163. com

An Ms6.6 Minxian earthquake occurred on July 22, 2013. It triggered a lot of landslides and caused severe economic losses and casualties. However, only a few seismic records were gathered in the areas of landslides. In order to provide enough ground motion parameters for seismic landslide analysis, this paper established 3-dimensional regional underground medium velocity structure model with two kinds of topography resolution, adopted two seismic source rupture processes, including the result inversed by teleseismic data and the one created by hybrid seismic source method, as scenario earthquakes, then used FiniteDifference method to simulate the ground motion. Finally, the time histories and intensity distributions of ground motion under different scenario earthquake and velocity structure model are acquired, topography amplification factors are also computed, and relationship between the topography amplification factor and topography slope is analyzed.

\section{Constraints on Spatial Distribution of Earthquakes within a 2-D Damaged Fault Zone in Seismic Cycles}

THAKUR, P., University of Michigan, Michigan, USA, prith@umich.edu; HUANG, Y. H., University of Michigan, Michigan, USA, yiheh@umich.edu

Observations of earthquakes on major faults (e.g. San-Andreas fault system) show that the seismicity is highly concentrated along a fault-parallel narrow zone of damaged rocks. The spatial extents and material properties of the damaged fault zone can have a crucial effect on earthquake source characteristics, such as the nucleation size, recurrence interval and hypocentral locations of earthquakes. These fault zones are usually a few hundred meters wide, but their depths are more debatable, with certain observations indicating a shallow depth $(\sim 5 \mathrm{~km})$, while other observations show them to extend through the seismogenic zone. Theoretically, it is easier to nucleate earthquakes within the fault zone since the nucleation size is proportional to the rigidity of the near-source medium. Therefore, it is expected that during seismic cycles earthquakes would occur dominantly within the fault zone and occasionally reach the deeper host rocks due to stress shadow effects. To test this hypothesis, we study the relationship between the along-dip slip distribution of earthquakes and damaged fault zones by simu- 
lating fault slip over multiple earthquake cycles using a spectral element method. Our model consists of a 2D strike-slip fault with antiplane shear, surrounded by a low-rigidity fault zone embedded in an elastic halfspace. A depth dependent initial shear stress profile is used in combination with a rate and state dependent friction law to induce spontaneous rupture, which propagates in accordance with the elastodynamic laws of motion. We will show how the hypocentral depth of a $\mathrm{Mw} \sim 7.0$ earthquake is controlled by the velocity weakening region and the damaged zone extent during earthquake cycles (e.g., Parkfield region of the SanAndreas fault). We will also present the dependence of the recurrence interval, shear stress, and slip evolution on the spatial extent of the damaged zone. Future work would incorporate the evolution of fault zone damage and the role of fluids.

\section{Three-Dimensional Simulation Methodology of Seismic Wave Propagation and Its Application in Wudu Basin, China}

LI, X. J., Institute of Geophysics, China Earthquake Administration, Beijing, China, beerli@vip.sina.com; ZHANG, X. L., College of Transportation Science \& Engineering Nanjing Tech University, China, zxInjut@163.com; ZHOU, Z. H., College of Transportation Science \& Engineering Nanjing Tech University, China, bjsmoc@163.com; PENG, X. B., Institute of Earthquake Engineering of Jiangsu Province, China, xiaobo_peng@163.com

The method widely used for the simulation of seismic wave propagation in three dimensional sedimentary basin is the finite element method combining with viscous-elastic artificial boundary. However, in the finite element method, the boundary surfaces are often limited in regular cases, such as a horizontal free surface, to determine the input wave motion on the artificial boundary. A degenerate model method is proposed in this study for determining the input wave motion on artificial boundary in three dimensional finite element model, in which the solution of the free fields outside and on the lateral artificial boundaries in three dimensional model is given based on four two-dimensional models, and the solution of the free fields outside and on the lateral artificial boundaries for each twodimensional model is given based on two one-dimensional models. Furthermore, an explicit finite element method with viscous-elastic artificial boundary is established for the simulation of seismic wave propagation in three dimensional site. The numerical results obtained from a free half space model indicates that the proposed input wave motion method is reasonable. In the Mw 7.9 Wenchuan earthquake on 12 May 2008, the Wudu township which is located in a sedimentary basin suffered serious damage even if it is far away from the fault rupture (the distance $\geq 100 \mathrm{~km}$ ). In order to interpret the abnormality of damage phenomenon, the elastic wave field simulation in the Wudu Basin is conducted by the proposed method based on the ABAQUS software. The simulation results reveals the basin edge and the basin focusing effect. The topography scatters the body waves and the surface wave generated is trapped at the shallow part of the basin, and most of the energy is reflected from the interfaces of soil strata and focused back into the basin. It results in extraordinary strong shaking patterns in Wudu basin area.

\section{The Future of Telemetered Seismic Arrays-Where the Operation of the Network Ends and the Science Begins Poster Session . Wednesday 16 May · Riverfront South}

\section{Station, Data, and Instrument Analysis of the Cascades Volcano Observatory's} Seismic Network Using Xmax and Other Tools

DAROLD, A. P., US Geological Survey, CVO, Washington, USA, adarold@ usgs.gov; HOLLAND, A. A., US Geological Survey, ASL, New Mexico, USA, aaholland@usgs.gov

For the seismic community quality waveform data is the starting point to quality seismic locations and research. Therefore, it is imperative that seismic station metadata be correct and up to date, station functionality monitored, and instrument response files be as accurate as possible to ensure that the network data is reliable. Quality and reliability of waveform data is the basis for completing a Quality Control (QC) study of the Cascades Volcano Observatory (CVO) seismic network (network code CC). The CC seismic network consists of 30 seismic stations throughout the Washington and Oregon Cascades focused on real-time monitoring the volcanoes that are classified as high-threat. CVO works in conjunction with the Pacific Northwest Seismic Network (PNSN) to provide metadata and real-time waveform data from the $\mathrm{CC}$ network to the Incorporated Research Institutions for Seismology (IRIS). QC analysis of this extent has never been completed on the CC network. A network wide analysis was completed in order to test sensor and data quality using open source software XMAX (ASL, https://github.com/usgs/xmax) and Evalresp (IRIS, https://ds.iris.edu/ds/ nodes/dmc/software/downloads/evalresp) to review both metadata and sensor functionality. The findings of this study show mostly minor metadata issues, a few problem sensors and a noisy vault. We are working with PNSN to rectify all metadata and sensor issues by mid 2018 and will publish a USGS Open File Report by the end of 2018. Moving forward these tools will be important for maintaining knowledge and awareness of station health and data quality and will comprise the routine quality check procedures for CVO. This work is the building block for the future of the waveform data quality and reliability of the CC network.

\section{Optimization of the Coefficients of a Filter Function That Maximizes the} Performance of a Real Time Microseismics Detector

RODRIGUEZ, M. I., Universidad de las Fuerzas Armadas ESPE, Quito, Ecuador, mjrodriguez13@espe.edu.ec; LARA-CUEVA, R. A., Universidad de las Fuerzas Armadas ESPE, Quito, Ecuador, ralara@espe.edu.ec; LARCO, J. C., Universidad de las Fuerzas Armadas ESPE, Quito, Ecuador, jclarco@espe.edu. ec; RUIZ, M. C., Escuela Politécnica Nacional, Quito, Ecuador, mruiz@igepn. edu.ec; BENÍTEZ, D. S., Universidad San Francisco de Quito, Quito, Ecuador, diegobenitez@hotmail.com

The probability of volcanic eruption increases as the quantity of local seismic events, such as Long Period (LP) and Volcano Tectonic (VT) events also increases. For this reason it is important to improve the performance for detecting LP and VT events, based on event recognition and on the detection of the endpoints of the even in its seismogram. The method proposed in this paper optimizes the function of a commonly use voice detector but tailored for microseisms applications in order to maximize the performance metrics such as precision, sensitivity, specificity, and balanced error rate, and also considering the processing time required by the algorithm. For that, it is required to ensure a good signalto-noise ratio, in order to accurately determine the onset and final timestamps of a detected event, and to achieve the maximum suppression of false positives. The ideal parameters for the detection of microseisms were also determined and adapted to work with data from the Cotopaxi volcano located in Ecuador, by using a dataset of microseisms, from a single station dotted with a broadband seismometer, provided by the Instituto Geofísico of the Escuela Politécnica Nacional (IGEPN)-institution in charge of monitoring this volcano-that contains 436 microseisms, including LP and VT seismic events, originated at Cotopaxi volcano during 2012. We determined that the optimal window should be of 10 samples without overlapping, the order of the filter should be of 7 grade and the decision threshold should be three times the average signal in the window in order to avoid the displacement in the filter output. By using these parameters in the voice activity detector, the initial and final timestamps of the microseisms event were obtained more precisely, and the accuracy in detection was near to $97 \%$, obtaining a considerable percentage for the use of this algorithm in the real time detection of volcanic events.

\section{The Broadband Seismic Network Kivusnet in the Virunga Volcanic Province (Democratic Republic of the Congo): Seismicity Catalogues and Fundamental Seismological Models after More Than 2 Years of Continuous Operation}

OTH, A., European Center for Geodynamics and Seismology, Luxembourg, adrien.oth@ecgs.lu; BARRIÈRE, J., European Center for Geodynamics and Seismology, Luxembourg, julien.barriere@ecgs.lu; D’OREYE, N., National Museum of Natural History, Luxembourg, ndo@ecgs.lu; MAVONGA, G., Goma Volcano Observatory, Democratic Republic of the Congo, mavotulu@ gmail.com; KERVYN, F., Royal Museum for Central Africa, Belgium, francois. kervyn.de.meerendre@africamuseum.be

Over the course of the past 5 years, the first dense real-time telemetered broadband seismic network in the Kivu Rift region (KivuSNet) was gradually deployed in the frame of several Belgo-Luxembourgish research projects (the most recent one being RESIST: "Remote Sensing and In Situ Tracking of geohazards", funded by the Belgian Science Policy and Luxembourg National Research Fund). The Kivu Rift is located in the bordering region of the Democratic Republic of Congo and Rwanda, in the Western branch of the East African Rift. Here the active volcanoes Nyamulagira and Nyiragongo threaten the city of Goma and neighbouring agglomerations. For many years already, urbanisation in that region undergoes sustained rapid growth, and the region counts 1 million inhabitants today. In 1977 and 2002, eruptions of Nyiragongo caused major disasters. Destructive earthquakes can also affect the region, as was the case in 2002 in Kalehe (Mw 6.2) along the western shore of Lake Kivu, or in 2008 in Bukavu (Mw 5.9), south of Lake Kivu. While the first stations were already installed in $2012 / 2013$, KivuSNet is fully operational with a sufficient station coverage only since October 2015. Today, KivuSNet is composed of 17 stations delivering continuous real-time data, many of these installed under difficult conditions in a hostile environment. Many KivuSNet stations are co-located with GNSS KivuGNet stations, and three KivuSNet sites are in addition equipped with infrasound arrays. This contribution will present the lessons learned from these more than 
2 years of continuous KivuSNet operation as well as the current status of seismological information as deduced from these data, including a robust 1D seismic velocity model and calibrated local magnitude scale for the Kivu Rift region. The complete seismicity catalogue (volcanic and tectonic events) has been relocated, and a spectral inversion carried out on a subset of the data to characterize source, path and site effects.

\section{Prototype Testing of the Trillium 360 Version 2 Seismometer with Improved Noise Performance}

BAINBRIDGE, G., Nanometrics Inc., geoffreybainbridge@nanometrics. ca; UPADHYAYA, S., Nanometrics Inc., sarveshupadhyaya@nanometrics. ca; TOWNSEND, B., Nanometrics Inc., brucetownsend@nanometrics.ca; MOORES, A., Nanometrics Inc., andrewmoores@nanometrics.ca; PARKER, T., Nanometrics Inc., New Mexico, USA, timparker@nanometrics.ca

There is a need for a new generation seismometer able to measure the smallest existing ground motion, in a form factor suitable for borehole, posthole, and portable deployment as well as traditional surface vaults. This is an active area of research with recently released products such as Trillium 360 (Version 1) pushing the boundaries of borehole sensor performance. This paper presents the latest test results for an improved Trillium 360 Version 2 product with even lower selfnoise. Tests were conducted at a new facility in Ottawa, Canada with multiple closely spaced boreholes drilled into hard rock to allow for side-by-side coherence testing in a down-hole environment.

\section{Keeping USArray Stations in Alaska: Which Ones, How Many, and Where?} BUURMAN, H., Alaska Earthquake Center, Alaska, USA, hmbuurman@ alaska.edu; WEST, M. E., Alaska Earthquake Center, Alaska, USA, mewest@ alaska.edu; ALASKA EARTHQUAKE CENTER STAFF, Alaska Earthquake Center, Geophysical Institute, University of Alaska Fairbanks, Alaska, USA, uafaec@alaska.edu

The USArray project represents a once-in-a-generation opportunity to fundamentally change geophysical monitoring in the US Arctic. The addition of more than 200 stations capable of recording seismic, infrasound, ground temperature and meteorological data has brought a diverse group of organizations to the table, fostering new connections and collaborations between scientists whose paths otherwise would not cross. With the array slated for removal beginning in 2019 , there is a window of opportunity to advocate for permanently retaining a subset of the USArray stations. The Alaska Earthquake Center has drafted a plan to permanently adopt a subset of the USArray stations and maintain them as part of the seismic network in Alaska. The expanded seismic network would substantially improve on the Alaska Earthquake Center's ongoing mission to advance Alaska's resilience to earthquake hazards. The many challenges in adopting USArray stations include choosing which stations to retain, upgrading the power systems to have $24 / 7$ data transmission through the long Alaskan winter months, and lowering the costs of continuous telemetry. The final station selection will also carefully consider the needs of partner organizations, since the USArray network currently fills important gaps in the weather, wildfire and climate research monitoring networks across Alaska.

\section{Megathrust Earthquakes: Recurrence, Rupture Modes and Tsunamis} Poster Session · Wednesday 16 May $\cdot$ Riverfront South

Gempa Nusantara: A New Digital Database of Felt Intensity for Historical Earthquakes in the Indonesian Archipelago

MARTIN, S. S., Earth Observatory of Singapore, Nanyang Technological University, Singapore, Singapore, smartin@ntu.edu.sg; LOCATI, M., Istituto Nazionale di Geofisica e Vulcanologia, Lombardy, Italy, mario.locati@ingv. it; SIEH, K. E., Earth Observatory of Singapore, Nanyang Technological University, Singapore, Singapore, sieh@ntu.edu.sg

Seismicity during Dutch colonial rule in Indonesia between 1800 and 1939 is poorly catalogued with existing summaries (e.g. Newcomb \& McCann, 1987) too brief for further quantitative assessment such as the calculation of intensity magnitudes (MI). We focus on this period in Indonesian history, collating and analysing reports from official documents and newspapers from the erstwhile Dutch East Indies. We scrutinize these for macroseismic intensity using the European Macroseismic Scale (EMS-98). This scale is closely related to the Modified Mercalli Intensity (MMI) scale but is associated with better guidelines with which to assess damage to built-up environments. Our approach enables us to uniformly assess felt intensities from Sumatra, Java, Bali, and Borneo along with instances of perceived shaking from the eastern Indonesian archipelago, and from the Malay peninsula including Singapore. Building upon previous work (Martin et al., 2015), we correlate our data, when possible, with regional, and teleseismic instrumental observations. This allows us to discriminate, for example, a possible M 6 doublet in the region of South Sumatra in 1908. Felt effects in west Malaysia and Singapore from numerous earthquakes in Sumatra were also collected, and unexpectedly, we found two widely felt earthquakes in Singapore in 1922 that likely originated in the region of the southern Malaya peninsula. All our observations contribute to a database named Gempa Nusantara which roughly translates to earthquakes (gempa) in the Indonesian archipelago (nusantara) in Bahasa Indonesia. This database uses a web application called MIDOP (Macroseismic Intensity Data Online Publisher) which is an open-source program written in PHP that has been previously utilized to publish intensity data in Europe (Locati et al., 2014). In our study we extend the capabilities of the MIDOP application further, particularly in equatorial regions, and use it to manage our data from historical Indonesian earthquakes.

\section{Cascadia Onshore-Offshore Site Response, Submarine Sediment Mobilization, and Earthquake Recurrence GOMBERG, J.S., US Geological Survey, Washington, USA, gomberg@usgs.gov}

Local geologic structure and topography may modify arriving seismic waves. The consequent variation in shaking, or 'site-response', may affect the distribution of slope-failures and redistribution of submarine sediments. I used seafloor seismic data from the 2011-2015 Cascadia Initiative and permanent onshore seismic networks to derive estimates of site-response, denoted $\mathrm{Sn}$, in low- and high-frequency $(0.02-1$ and $1-10 \mathrm{~Hz})$ passbands. Three shaking metrics (peak velocity, peak acceleration, and energy density) Sn vary similarly throughout the study region (onshore and offshore) and change primarily in the convergence direction, roughly east-west. In the two passbands, Sn patterns offshore are nearly opposite one another and range over an order of magnitude or more across Cascadia. Sn patterns may be attributed broadly to sediment resonance and attenuation. These findings, and an abrupt step in the east-west trend of $\mathrm{Sn}$ suggest that changes in topography and structure at the edge of the continental shelf significantly impact shaking. The variations in $\mathrm{Sn}$ also correlate with the edges of gravity lows diagnostic of marginal basins and with methane plumes channeled within shelfbounding faults. The offshore Sn exceeds the onshore $\mathrm{Sn}$ in both passbands. The relatively greatest and smallest $S$ n estimates at low- and high-frequencies, respectively, coincide with the steepest slopes and the shelf. These results should be considered in submarine shaking-triggered slope-stability failure studies. Significant north-south $\mathrm{Sn}$ variations are not apparent from the sparse sampling, but do not permit rejection of the hypothesis that the southerly decrease in intervals between shaking-triggered turbidites and inferred great earthquakes inferred by Goldfinger et al. [2012; 2013; 2016] and Priest et al. [2017] may be due to inherently stronger shaking southward.

\section{Tree-Ring Dating of the Penultimate Great Alaska Earthquake to the Winter of 1029-1030 Ce}

HAEUSSLER, P. J., US Geological Survey, Alaska, USA, pheustr@usgs.gov; BARCLAY, D. J., SUNY Cortland, New York, USA, david.barclay@cortland. edu

We date the penultimate megathrust earthquake in south-central Alaska by treering analysis. The study site near Girdwood is above the eastern Alaska-Aleutian megathrust. It subsided $1.7 \mathrm{~m}$ during the $1964 \mathrm{Mw} 9.2$ Great Alaska earthquake, which remains the second largest ever recorded. Beneath the modern salt marsh and ghost forest, killed in 1964, is a well-preserved and studied sequence of sediment showing repeated layers of forest and high-marsh soils capped by estuarine mud. The mud-over-peat contacts imply growth of a forest suddenly drowned by subsidence during past megathrust earthquakes. Within the soil below the penultimate earthquake contact, we collected tree-ring samples from five rooted subfossil trees. Ten ring-width series from four Picea (spruce) stumps were crossdated using standard procedures to form a 121-year-long site chronology, which we term the GDS1B chronology. This chronology was compared with composite chronologies from the nearby Prince William Sound region and the strongest match $(r=0.253, p<0.01$ in a 1-tailed test $)$ was with the AK094 master chronology from the International Tree Ring Data Bank. Based on this crossdate, the GDS1B chronology spans 909-1029 CE. Examination of the outer rings of the best-preserved samples found that three ended with latewood for 1029 while one appeared to have a little earlywood for 1030. These results suggest that the penultimate earthquake occurred after the end of the 1029 growing season and most likely was in early 1030 . This event date is consistent with a pooled radiocarbon age from three samples of outer wood from stumps in this penultimate earthquake forest bed that has a calibrated 2-sigma range of 1025-1205 cal. CE. Previous $14 \mathrm{C}$ dating of materials across the penultimate subsidence contact at 
sites across southern Alaska, placed the date of the last earthquake at 1046-1114 CE (Shennan et al. 2014), which is $17-85$ years younger, perhaps due to a paucity of immediate post-earthquake $14 \mathrm{C}$ samples.

\section{Earthquake Recurrence of the Northern Lesser Antilles Arc: Paleoseismologic Approach}

MORENA, P. F., Ifremer, Finistère, France, pierre.morena@ifremer.fr; CATTANEO, A., Ifremer, Finistère, France, antonio.cattaneo@ifremer. fr; RATZOV, G., Géoazur, Alpes Maritimes, France, ratzov@geoazur.unice. fr; FEUILLET, N., IPGP, Paris, France, feuillet@ipgp.fr; BECK, C., ISTerre, Savoie, France, christian.beck@univ-savoie.fr; GOLDFINGER, C., College of Earth, Ocean, and Atmospheric Sciences, Oregon State University, Oregon, USA, gold@ceoas.oregonstate.edu; PATTON, J. R., Humboldt State University, California, USA, jrp2@humboldt.edu; MORENO, E., MNHN, Paris, France, eva.moreno@mnhn.fr; SEIBERT, C., IPGP, Paris, France, seibert@ipgp.fr; KLINGELHOEFER, F., Ifremer, Finistère, France, frauke.klingelhoefer@ ifremer.fr

At the Lesser Antilles arc, the American plate subducts under the Carribean plate with a low velocity $(2 \mathrm{~cm} / \mathrm{a})$. The seismic potential of the northern segment (between Barbuda and Virgin Islands), where no major historic earthquake is recorded, raises many questions. Recent studies show that the area is weakly coupled, suggesting a seismic cycle that could last thousands of years. Here, the obliquity of the convergence (up to $55^{\circ}$ ) is partially accommodated by diffuse normal faults in the Anegada Passage and by the Bunce strike-slip fault which decouples the accretionary prism from the margin. The seismic behavior of the megathrust is thus likely different from the adjacent segments. The CASEIS cruise (DOI:10.17600/16001800) collected 42 sediment cores and geophysical data (backscatter, bathymetry, sub-bottom profiles) along the forearc and accretionary prism in order to constrain the seismic potential of the Lesser Antilles through a paleoseismological investigation based on earthquake-triggered turbidites. In the northern segment, turbidity currents flow through canyons incising the slope and megastructures like the Tintamarre spur. They deposit in pull-apart basins (Sombrero, Malliwana) or in 2-6 km-large sinks near the Bunce fault. Decimetric turbidites or metric turbidite-homogenite complexes $(\mathrm{HmTu})$ with intervening hemipelagites are retrieved in seven cores from the northern segment. We propose a preliminary correlation based on $14 \mathrm{C}$ dates, comparable sedimentary facies and sequences. The uppermost 20 to $70 \mathrm{~cm}$-thick turbidites are dated at $8 \mathrm{ka} \mathrm{BP}$ over $100 \mathrm{~km}$, supporting a regional earthquake trigger. Four deeper HmTu complexes possibly related to mega-earthquakes and/or tsunamis are older than $25 \mathrm{ka}$ BP. The most proximal core contains more turbidites, but likely records local tectonic activity. At this stage, potential seismic events appear diachronous compared to the adjacent Guadeloupe segment, but further analyses are required to improve the time series.

\section{Modeling "The Big One": Insights from 2-D Dynamic Rupture Simulations}

RAMOS, M.D., University of Michigan, Michigan, USA, ramosmd@umich.edu; HUANG, Y. H., Univeristy of Michigan, Michigan, USA, yiheh@umich.edu

It is not a question of if or why, but of where, how, and when the next Cascadia Subduction Zone (CSZ) megathrust earthquake will impact the Pacific Northwest. Synthetic ruptures from kinematic source models have attempted to account for future CSZ earthquake behavior and illustrate the importance of rupture directivity on ground motion amplification and duration in forearc basin sediments (e.g., Olsen et al., 2008; Delorey et al., 2014). However, these models do not incorporate source dynamics and are potentially missing finite fault effects that stem from stress heterogeneity or varying frictional properties. In particular, the "gap" region along the megathrust separating episodic tremor and slip (ETS) events from the up-dip seismogenic region deserves further scrutiny (Bruhat \& Segall, 2016, 2017) because its stress state could strongly influence down-dip rupture propagation and ground motions in populated regions such as Seattle and Portland. A realistic CSZ rupture model must thus prescribe an appropriate gap rheology in concurrence with a low effective normal stress in the ETS region and also consider different hypotheses about the degree of slip-deficit accumulated since the last megathrust rupture. We approach this problem with 2D dynamic rupture simulations along the northern, central, and southern CSZ. Earthquake rupture is treated as both a dynamic crack governed by a linear slip-weakening friction law and as a pulse operating under a rate-and-state-friction framework. We explore a range of potential nucleation sites and stress profiles along the seismogenic, gap, and ETS regions and discuss the implications for strong ground motion. Because seismic risk to the Pacific Northwest is increased if rupture can penetrate into the ETS region, our models attempt to constrain what physical conditions along the gap are necessary for this to occur and aim to inform seismic hazard analyses by respecting the earthquake source physics.
20th-Century Strain Accumulation on the Lesser Antilles Megathrust Based on Coral Microatolls

PHILIBOSIAN, B., US Geological Survey, California, USA, bphilibosian@ usgs.gov; FEUILLET, N., Institut de Physique du Globe de Paris, France, feuillet@ipgp.fr; JACQUES, E., Institut de Physique du Globe de Paris, France, jacques@ipgp.fr; MÉRIAUX, A.S., Newcastle University, U.K., anne-sophie. meriaux@newcastle.ac.uk; GUIHOU, A., CEREGE, Aix-Marseille Université, France, guihou@cerege.fr; ANGLADE, A., Institut de Physique du Globe de Paris_OVSG, France, anglade@ipgp.fr

The seismic potential of the Lesser Antilles megathrust remains poorly known, despite the potential hazard it poses to numerous island populations and its proximity to the Americas. As it has not produced any large earthquakes in the instrumental era, the megathrust is often assumed to be aseismic. However, historical records of great earthquakes in the 19thcentury and earlier, which were almost certainly megathrust ruptures, demonstrate that the subduction is not entirely aseismic. Recent occurrences of giant earthquakes in areas where such events were previously thought to be improbable have illustrated the importance of critically evaluating the seismic potential of other "low-hazard" subduction zones, such as the LesserAntilles. Using the method of coral microatoll paleogeodesy developed in Sumatra, we examine 20th-century vertical deformation on the forearc islands of the LesserAntillesand model the underlying strain accumulation on the megathrust. Our data indicate that the eastern coasts of the forearc islands have been subsiding up to $\sim 7 \mathrm{~mm} / \mathrm{yr}$ relative to the arc islands, suggesting that on the time scale of the 20thcentury, a portion of the megathrust just east of the forearc islands has been locked. Our findings are in contrast to recent GPS-based models that suggest little or no strain accumulation anywhere along the LesserAntilles megathrust. This discrepancy is potentially explained by the different time scales of measurement, as recent studies elsewhere have indicated that interseismic coupling patterns may vary on decadal time scales and that century-scale or longer records are required to accurately assess seismic potential. We also observe second-order variations in deformation rate which may be related to upper-plate faulting. The accumulated strain we have detected will likely be released in future earthquakes, uplifting previously subsiding areas and potentially causing widespread damage from strong ground motion and tsunami waves.

\section{Postseismic Deformation: The Esmeraldas, Ecuador, Seismic Sequence following the $\mathbf{2 0 1 6}$ Pedernales Megathrust Earthquake}

HOSKINS, M. C., Lehigh University, Pennsylvania, USA, mac716@lehigh.edu; MELTZER, A., Lehigh University, Pennsylvania, USA, ameltzer@lehigh.edu; SOTO-CORDERO, L., Lehigh University, Pennsylvania, USA, lis213@lehigh. edu; STACHNIK, J. C., Lehigh University, Pennsylvania, USA, jcs612@lehigh. edu; SIRAIT, A. M. M., Lehigh University, Pennsylvania, USA, amm616@ lehigh.edu; BECK, S. L., University of Arizona, Arizona, USA, slbeck@email. arizona.edu; LYNNER, C., University of Arizona, Arizona, USA, colton. lynner@gmail.com; RUIZ, M. C., Instituto Geofisico at the Escuela Politecnica Nacional, Ecuador, mruiz@igepn.edu.ec; ALVARADO, A., Instituto Geofisico at the Escuela Politecnica Nacional, Ecuador, aalvarado@igepn.edu.ec; HERNANDEZ, S., Instituto Geofisico at the Escuela Politecnica Nacional, Ecuador, shernandez@igepn.edu.ec; CHARVIS, P., Universite Nice Cote d'Azur IRD Geoazur, France, philippe.charvis@geoazur.unice.fr; FONT, Y., Universite Nice Cote d'Azur IRD Geoazur, France, font@geoazur.unice.fr; NOCQUET, J. M., Universite Nice Cote d'Azur IRD Geoazur, France, nocquet@geoazur.unice. fr; RÉGNIER, M., Universite Nice Cote d'Azur IRD Geoazur, France, regnier@ geoazur.unice.fr; AGURTO-DETZEL, H., Universite Nice Cote d'Azur IRD Geoazur, France, h.agurto.detzel@gmail.com; LEÓN-RÍOS, S. L., University of Liverpool, United Kingdom, leonrios@liverpool.ac.uk; RIETBROCK, A., University of Liverpool, United Kingdom, a.rietbrock@liverpool.ac.uk; ROLANDONE, F., Universite Nice Cote d'Azur IRD Geoazur, France, frederique.rolandone@upmc.fr

The north Ecuador subduction zone exhibits structural complexities, variations in plate coupling, and megathrust rupture patterns suggesting accumulated strain is released through large earthquakes clustered in space and time. In April 2016 the Mw 7.8 Pedernales earthquake ruptured a $\sim 100 \mathrm{~km}$ segment of the subduction zone north of the Carnegie Ridge. This portion of the subduction zone has ruptured on decadal time scales: Mw 8.8 (1906), Mw 7.8 (1942), Mw 7.7 (1958), and Mw 8.2 (1979). The 1942, '58, and '79 events ruptured patches, from south to north, of the same segment as the 1906 earthquake. The 2016 rupture overlaps the 1942 rupture. Aftershocks of the 2016 event were recorded by the permanent national network (RENSIG) and a dense rapid response temporary deployment onland and offshore. Aftershocks concentrate spatially in clusters outlining two patches of maximum slip and correlate with variations in plate coupling. Activity north of the rupture is sparse until 2.5 months after the mainshock when an earthquake swarm developed around Esmeraldas, $70 \mathrm{~km}$ north- 
east of the mainshock rupture. The Esmeraldas portion of the subduction zone ruptured in 1958, has exhibited slow slip, and sits astride an upper plate transpressional fault system. Between July 5-8, 2016 an earthquake swarm (84 events, ml 1.7-4.9) occurred beneath Esmeraldas causing additional damage to weakened buildings. Quality controlled relocation of events in the swarm outlines an apparent north-dipping upper plate splay fault. Hypocenters locate between 9 and 22 $\mathrm{km}$ depth, $5+\mathrm{km}$ above the plate interface. During the most active 3 hours of the swarm, a weak trend of shallowing hypocenter depths with time appears. Within the swarm repeating events (similar waveforms) are observed. Swarm like behavior continued for several weeks at reduced rates and intermittent seismicity continued for several months. These observations are consistent with previous observations linked to slow slip events in this margin.

The Mw 7.8 2016 Pedernales, Ecuador Earthquake Aftershock Sequence: a Detailed Spatio-Temporal Analysis of the Rupture Processes, Stress Patterns and Slip Behavior

SOTO-CORDERO, L., Lehigh University, Pennsylvania, USA, lis213@lehigh. edu; MELTZER, A., Lehigh University, Pennsylvania, USA, ameltzer@lehigh. edu; STACHNIK, J. C., Lehigh University, Pennsylvania, USA, jcstachnik@ gmail.com; AGURTO-DETZEL, H., Université Nice Côte d'Azur, IRD, CNRS, Géoazur, Valbonne, France, agurto@geoazur.unice.fr; ALVARADO, A., Instituto Geofísico, Escuela Politécnica Nacional, Quito, Ecuador, aalvarado@ igepn.edu.ec; BECK, S. L., University of Arizona, Arizona, USA, slbeck@ email.arizona.edu; BENZ, H. M., US Geological Survey National Earthquake Information Center, Colorado, USA, benz@usgs.gov; BERGMAN, E., Globa Seismological Services, Colorado, USA, bergman@seismo.com; CHARVIS, P., Université Nice Côte d'Azur, IRD, CNRS, Géoazur, Valbonne, France, philippe. charvis@geoazur.unice.fr; FONT, Y., Université Nice Côte d'Azur, IRD, CNRS, Géoazur, Valbonne, France, font@geoazur.unice.fr; HAYES, G. P., US Geological Survey National Earthquake Information Center, Colorado, USA, ghayes@usgs.gov; HERNANDEZ, S., Instituto Geofísico, Escuela Politécnica Nacional, Quito, Ecuador, hernandez.stephen@gmail.com; HOSKINS, M. C., Lehigh University, Pennsylvania, USA, mac716@lehigh.edu; LYNNER, C., University of Arizona, Arizona, USA, colton.lynner@gmail.com; NEALY, J., US Geological Survey National Earthquake Information Center, Colorado, USA, jenniferleighnealy@gmail.com; RÉGNIER, M., Université Nice Côte d'Azur, IRD, CNRS, Géoazur, Valbonne, France, regnier@geoazur.unice.fr; RIETBROCK, A., University of Liverpool, United Kingdom, a.rietbrock@ liverpool.ac.uk; YECK, W. L., US Geological Survey National Earthquake Information Center, Colorado, USA, wyeck@usgs.gov; C., Instituto Geofísico, Escuela Politécnica Nacional, Quito, Ecuador, mruiz@igepn.edu.ec; LEÓNRÍOS, S., University of Liverpool, United Kingdom, leonrios@liverpool.ac.uk

The epicentral region of the April 16, $2016 \mathrm{Mw} 7.8$ Pedernales earthquake lies north of the intersection of the Carnegie ridge and the Ecuador subduction zone. This segment has ruptured on decadal time scales in a series of megathrust events, Mw 8.8 (1906), Mw 7.8 (1942), Mw 7.7 (1958), and Mw 8.2 (1979), suggesting that accumulated strain is released through large earthquakes clustered in space and time. The 2016 rupture coincides with the rupture area of the Mw 7.81942 earthquake. Seismic data recorded by a dense array of 82 stations from Ecuador's national network and an international rapid response effort were processed and analyzed. Multiple combinations of detection and association algorithms were assessed to address the challenge of producing robust earthquake catalogs from aftershock sequences. Calibrated relocations using the Hypocentroidal Decomposition approach were determined for a subset of events for which we combine phase readings from local and temporary stations with regional and teleseismic phase readings from the NEIC. Preliminary aftershock locations through August 2017 (11502 events, $\geq 6$ phases, errors $<10 \mathrm{~km}, \mathrm{Mc1} 1.8$ ) show a sharp downdip limit of aftershocks and are characterized by a series of event clusters. Two distinct streaks of aftershocks outline the north and south ends of the rupture, and a third streak occurs between the two patches of slip defined by finite fault models. Aftershocks north of the main rupture are sparse until an earthquake swarm $\sim 2$ months after the mainshock in the vicinity of Esmeraldas, the portion of the subduction zone that ruptured in 1958. Eight months after the mainshock, a series of aftershocks in the Atacames area, north of the main rupture, caused additional structural damage. The spatial distribution of background seismicity and aftershocks is quite similar suggesting that background seismicity likely includes long-lived aftershocks from the ' 06 , ' 42 , and ' 58 large earthquakes as well as swarms associated with slow-slip events.

Characterizing the Temporal and Spatial Distribution of Earthquake Swarms in the Puerto Rico-Virgin Island Block

HERNANDEZ RAMIREZ, F. J., University of Puerto Rico Mayagüez, Puerto Rico, USA, francisco.hernandez@upr.edu; LOPEZ, A. M., University of Puerto
Rico Mayagüez, Puerto Rico, USA, alberto.lopez3@upr.edu; VANACORE, E. A., University of Puerto Rico, Puerto Rico, USA, elizabeth.vanacore@upr.edu

The presence of Tectonic Earthquake Swarms (TES) and sequences in the north and northeast of the island of Puerto Rico in the northeastern Caribbean have been recorded by the Puerto Rico Seismic Network (PRSN) since it started operations in 1974. A great wealth of seismic data has been archived during this period such that at least 10 years of catalog data can be used to characterize the seismic activity in the Puerto Rico-Virgin Islands (PRVI) region. This research uses two declustering methods to identify cluster events in the PRVI block. The first method, known as Model Independent Stochastic Declustering (MISD), filters the catalog sub-set into cluster and background seismic events. The second method uses a spatio-temporal algorithm applied to the catalog in order to link the separate seismic events into clusters. After using these two methods, identified clusters were classified into either earthquake swarms or seismic sequences. Results have allowed to identify and classify 128 clusters categorized in 11 distinctive regions based on their centers, and their spatio-temporal distribution have been used to determine interplate dynamics. This analysis yields implication on the behavior of the plate interface between the North American and Caribbean plates along the Puerto Rico trench.

\section{Microzonation Studies-Site Effects}

Poster Session · Wednesday 16 May · Riverfront South

\section{Standardized Seismic Microzoning to Estimate Probabilistic Seismic Hazard} in Conurbated Areas of Veracruz State, Mexico.

TORRES MORALES, G. F., Earth Science Center, University of Veracruz, México, Veracruz, Mexico, giltorresmorales@yahoo.com.mx; LEONARDO SUÁREZ, M., Instituto de Ingeniería, Universidad Nacional Autónoma de México, CDMX, México, mleonardosuarez@gmail.com; DÁVALOS SOTELO, R., Instituto de Ecología A.C., Veracruz, México, raymundo.davalos@inecol. mx; MORA GONZÁLEZ, I., Earth Science Center, University of Veracruz, México, Veracruz, México, imora@uv.mx; CASTILLO AGUILAR, S., Facultad de Ingeniería Civil, Zona Xalapa, Universidad Veracruzana, Veracruz, México, sacastillo@uv.mx

This article summarizes the results obtained from the projects "Seismic threat in the State of Veracruz and the Xalapa Conurbation Zone" and "Microzonification of geological and hydrometeorological hazards for the conurbated zones of Orizaba, Veracruz". These projects were sponsored by the Joint Funds PROMEP and CONACyT-Veracruz state government respectively. In the seismic microzonation study, the most important characteristics of the Conurbated Zones (CZ) of Orizaba, Veracruz and Xalapa were considered. Environmental vibration points were taken in the different geological-geotechnical zones to determine their dynamic and site effect characteristics using the Nakamura technique; permanent seismic monitoring stations have been installed in firm and soft terrain, using broadband seismometers. With the seismic monitoring stations, the technique of standard spectral ratios was applied. In addition, in sites considered representative of the geology and geotechnics for the CZ, seismic survey tests were performed with a seismograph of 24 channels and $4.5-\mathrm{hz}$ geophones. Also, environmental vibration of the vertical component of the movement of the terrain in these sites was registered to make linear and triangular arrangements with broadband seismographs, analyzing the data using the SPAC technique. The above, to estimate the shallow structure of shear velocities at each site, as well as a profile of the materials at each exploration point. Using the results of Seismic Microzonifications we applied the procedure of Huerta et al. 2011, which proposes to organize and condense the results obtained from traditional microzonifications to apply probabilistic seismic hazard calculation techniques. Site effects were incorporated for the study of the probabilistic seismic threat through a standard format proposed for seismic microzoning studies and their application in computer systems, which allows to optimize and condense the seismic microzoning studies of a city.

\section{Integrated Geophysical Study of the Kingston Metropolitan Area Using Ambient Noise}

PAPADOPOULOS, I., Seismic Research Centre, University of West Indies, Trinidad and Tobago, ilias@uwiseismic.com; HIGGINS, M., Department of Geoscience, Penn State, Pennsylvania, USA, mhh16@psu.edu; SMITH, D., Centre for Environmental Management, University of the West Indies, Mona, Jamaica, david.smith02@uwimona.edu.jm

The Kingston Metropolitan Area (KMA) is the largest and most populous city that serves as the centre of industry and commerce, as well as the capital, of the island-nation Jamaica at the north Caribbean Sea. Most of the KMA is built on 
the alluvium Liguanea Formation while the city outskirts overlay the White Limestone Supergroup at the north and east; and mangrove and saline wetland to the west. The Enriquillo-Plantain garden fault also runs through Kingston. This fault zone has ruptured in the past, producing the devastating 1692 (Black, 1988) and 1907 (Tomlinson and Robinson, 1977) earthquakes that destroyed the capital. The destruction of the 2010 Haiti earthquake on this fault zone highlights the seismic hazard exposure of over a million inhabitants in KMA. A rapid single-site survey collecting $\sim 200$ records of ambient noise was undertaken in the KMA in 2012. These records were processed using the Horizontal to Vertical Spectral Ratio method (Nakamura, 1989). A second survey in 2016 collected records from 8 sites using the Microtremor Array Measurements (MAM) acquisition technique (Aki, 1957) and processed using the f-k method (Tokimatsu, 1997). Data from both methods have been integrated to provide the sediments resonance frequency map, velocity profiles at the MAM sites and a NEHRP Soil Classification map covering the KMA and Portmore area. Results indicate that the resonance frequency ranges from above $5 \mathrm{~Hz}$ at the northern and eastern limestone hills to $0.3 \mathrm{~Hz}$ at the quaternary deposits of the Kingston downtown area. Portmore, Port Royal and Harbour View areas in the south show resonance frequency around 1 to $3 \mathrm{~Hz}$. The soil of Portmore along with that of Port Royal and Harbour View is characterised by NEHRP classification of D/E with Vs30 values of $\sim 220 \mathrm{~m} / \mathrm{s}$, while central and downtown area is classified as D with Vs30 $\sim 300 \mathrm{~m} / \mathrm{s}$. The eastern and northern part of KMA is classified as C with Vs30 value $\sim 380 \mathrm{~m} / \mathrm{s}$.

\section{On the Impacts of Disregarding the Correct Soil Type and/or Correct Structural} Period of Assets on the Portfolio Risk Assessment

SEDAGHATI, F., AON Benfield, Illinois, USA, farhad.sedaghati@aonbenfield. com; DANESHVARAN, S., AON Benfield, Illinois, USA, siamak.daneshvaran@ aonbenfield.com

All three components involved with the risk assessment study including hazard, exposure, and vulnerability have significant effects on the resultant loss estimations. In this study, we focus on the impacts of two specific elements of the hazard component: soil condition and structural period. Changing the soil type or structural period for a given building can significantly change the ground motion intensity measure (e.g., PGA and SA) which ultimately can lead to large changes to the loss estimations. The main objective of this study is to demonstrate effects of disregarding the soil condition and spectral period on loss distribution and a parametric analysis to see the sensitivity in the loss domain. In this regard, a portfolio of assets through the state of CA is considered. The portfolio consists of 10,000 identical single-family low-rise wood-frame structures constructed after 1950. This building type represents the W1-h-RES3AF-DF model from HAZUS. Each asset in this portfolio has the same nominal value of $\$ 2,000,000$. The vulnerability function is the same for all locations of the portfolio. Based on the USGS 2014 earthquake hazard model and UCERF3, we develop stochastic catalogs using a simplified approach to consider only faults having a high contribution to the total hazard for the region under consideration. The loss calculations are performed using the codes written in the R\&D team at Impact Forecasting at AON Benfield and the EP curves and average annual losses (AALs) are generated using the ELEMENTS software developed by AON Benfield. Using the tornado diagram, we show that the ignoring the structural period or soil type can result in overestimation/underestimation of ALL up to 2 times and significant deviation of the EP curve from the correct EP curve considering the real structural period or correct soil type. If bothelements are ignored, the catastrophe risk analysis results in overestimation/underestimation of ALLs and EP curves up to 4 times.

H/N Spectral Ratio Analysis for Site Characterization Beneath LPA (La Plata) Station, Buenos Aires, Argentina

ROSA, M. L., Departamento de Sismología, Facultad de Ciencias Astronómicas y Geofísicas, Universidad Nacional de La Plata, Buenos Aires, Argentina, mlrosa@fcaglp.unlp.edu.ar

The analysis of the horizontal to vertical Fourier amplitude spectral ratio (HVSR) is a powerful tool for investigating the local structure directly beneath the recording station. This technique has proven very convenient for estimating the fundamental frequency of soft deposits. The impedance contrast at the sedimentbedrock interface has a strong influence on the shape of the $\mathrm{H} / \mathrm{V}$ ratio curve. In this study, we present the results of the analysis of the H/V relation in the LPA (La Plata) permanent seismic station. This station is situated on the Río de La Plata Craton, near the northern edge of the Salado Basin. Previous studies using receiver function for this station indicated the existence of a sedimentary layer with a high velocity contrast relative to the basement rocks. The frequency of the $\mathrm{H} / \mathrm{V}$ peak at sites having a sediment-to-bedrock impedance contrast large enough approaches the fundamental resonance frequency of the soft layers. Therefore, this type of analysis is very useful because it can reveal the principal structural features beneath this seismic station.

\section{Preliminary Soil Characterization of the Most Affected Coastal Villages after the 16 April 2016 Mw 7.8 Pedernales Earthquake, Ecuador}

BARROS, J. G., Instituto Geofisico Escuela Politecnica Nacional, Pichincha, Ecuador, jgbarros@igepn.edu.ec; LAURENDEAU, A., Instituto Geofisico Escuela Politecnica Nacional, Pichincha, Ecuador, alaurendeau@igepn.edu.ec; PACHECO, D. A., Instituto Geofisico Escuela Politecnica Nacional, Pichincha, Ecuador, apacheco@igepn.edu.ec; ALVARADO, A., Instituto Geofisico Escuela Politecnica Nacional, Pichincha, Ecuador, aalvarado@igepn.edu.ec; AGUILAR, J., Instituto Geofisico Escuela Politecnica Nacional, Pichincha, Ecuador, jaguilar@igepn.edu.ec

On April 16, 2016, a large part of the Ecuadorian coast was shacked by an Mw7.8 earthquake, affecting nearly 30,000 homes and public buildings. Understanding soil characteristics of these affected areas is a necessary and useful aid to reconstruction efforts. To this end, the Instituto Geofísico at the Escuela Politécnica Nacional (IG-EPN) undertook data collection work with the aim of generating a reliable and freely accessible database consisting of dynamic soil characteristics for 8 villages located in the provinces of Manabí and Esmeraldas (Ecuador, http:// www.igepn.edu.ec/mapas/mapa-frecuencias-suelos-manabi). The study consisted in the installation of four seismic station arrays for approximately 7 days in each village, during which time various measurements of ambient noise and seismic profiles were made. Here we employ various methods to assess soil characteristics, including: single-sensor horizontal over vertical component $(\mathrm{H} / \mathrm{V})$ spectral ratios, relative spectral ratios at various sites of interest with respect to a reference site (SSR), and linear arrays for multi-channel analysis of surface waves (MASW). These experiments were conducted within the first six months after the earthquake. The fundamental soil frequency, approximate site amplification curves, and shear wave velocity profiles for the populations that were part of the study were all obtained. These parameters then allow us to identify which zones share similar response characteristics, which we then correlate with the Ecuadorian Construction Norms (NEC-15) to determine soil type. It is important to note that, while in almost all of the villages studied several peak frequencies are found, the clearest peaks are typically between 1 to $2 \mathrm{~Hz}$, indicating predominant soil types of type $\mathrm{D}$ and $\mathrm{E}$.

\section{The Preliminary Study of Seismic Microsonation and Seismic Hazard Assessment for Urban Areas of Gori (Georgia)}

GOGOLADZE, Z., Tbilisi State University, Institute of Geophysics, Tbilisi, Georgia, zurab.gogoladze.3@gmail.com; MOSCATELLI, M., National Research Council, Institute of Environmental Geology and Geoengineering, Rome, Italy, massimiliano.moscatelli@igag.cnr.it; TSERETELI, N. S., Tbilisi State University, Institute of Geophysics, Tbilisi, Georgia, nino_tsereteli@tsu.ge; ALBARELLO, D., University of Siena, Department of Environment, Earth and Physical Sciences, Siena, Italy, dario.albarello@unisi.it; GIALLINI, S., National Research Council, Institute of Environmental Geology and Geoengineering, Rome, Italy, giallini.s@gmail.com

Seismic risk is a crucial issue for South Caucasus, which is the main gateway between Asia and Europe. The goal of this work is to propose new methods and criteria for defining an overall approach aimed at assessing and mitigating seismic risk in Georgia. Seismic hazard assessment means the identification of zones of similar levels of earthquake hazard expressed with ground motion parameters (acceleration, velocity, displacement, Intensity). This abstract presents the results of preliminary study of seismic microzonation of the city of Gori (Georgia) that was done in the frame of CNR (National Research Councilof Italy) project-Preliminary study for the assessment of seismic risk in strategic cities of "Georgia." The city of Gori is the central of Shida Kartli region (Mkhare) and is located on both sides of Liachvi and Mtkvari rivers, in the $135 \mathrm{~km} 2$ around the Gori fortress. The seismic microzonation map of level 1 of Gori was carried out in the light of 1) already available data (i.e., topographic map and boreholes data), 2) results of new geological surveys and iii) geophysical measurements (i.e., MASW and noise measurements processed with HVSR technique). So we have done seismic free field investigations full of the city and over the most strategic buildings and important parts of Gori : the city hall, the hospital, the Rugby stadium, Castel of Gori and museums and central square. Our preliminary results highlights the presence of both stable zones susceptible to local amplifications and unstable zones susceptible to geological instability. Our results are directed to establish the set of actions aimed at risk mitigation before the initial onset of the emergency, and to the management of emergency once the seismic event has occurred. The products obtained will constitute the basic elements of an integrated system aimed at reducing the risk and improving the overall safety of people and infrastructure in Georgia. 
Typology of Horizontal-to-Vertical Ambient Noise Measurements in the Quito Basin, Ecuador

REYES, M.F., Escuela Politécnica Nacional, Pichincha,Ecuador, mafer_14agst@ hotmail.com; LAURENDEAU, A., Instituto Geofísico Escuela Politécnica Nacional, Francia, aurore.laurendeau@gmail.com; ALVARADO, A., Instituto Geofísico Escuela Politécnica Nacional, Ecuador, aalvarado@igepn.edu.ec; BONILLA, L. F., IFSTTAR, Ecuador, luis-fabian.bonilla-hidalgo@ifsttar. fr; BARROS, J. G., Instituto Geofisico Escuela Politécnica Nacional, Ecuador, jgbarros@igepn.edu.ec; GUÉGUEN, P., Universidad de Grenoble, Francés, philippe.gueguen@univ-grenoble-alpes.fr; MERCERAT, D., CEREMA, Francia, diego.mercerat@cerema.fr; PACHECO, D. A., Instituto Geofísco Escuela Politécnica Nacional, Ecuador, dpacheco@igepn.edu.ec; SCHMITZ, M., Instituto Geofísico Escuela Politécnica Nacional, Venezuela, schmitzschutt@ gmail.com; COURBOULEX, F., Universidad Géoazur, Francia, courboulex@ geoazur.unice.fr

Quito, the capital city of Ecuador, is threatened by an important seismic hazard due to different seismogenic zones surrounding the city and from the Nazca plate subduction zone. In particular, due to its configuration as a piggy-back basin, the seismic waves present a broadband amplification as it has already been shown in previous analyses (Laurendeau et al, 2017). From the analysis of accelerometric data recorded by the RENAC network, a low frequency amplification $(\sim 0.3 \mathrm{~Hz})$ has been ubiquitously found in the southern part of the basin The main objective of this work is to study the typology of horizontal-to-vertical ambient-noise measurements (mHVSR) to determine zones having similar behavior within the basin. The data from the 759 sites of the Guéguen et al. (2000) campaign were re-analyzed. They have the advantage to be numerous and well distributed in the Quito basin, but the results are limited between $1-20 \mathrm{~Hz}$ due to the cut-off frequency of the sensors used at that time. Additional 90 sites were analyzed from more recent measurements. These data are less numerous but the mHVSR are defined between $0.2-20 \mathrm{~Hz}$. So, these data were used to complete the information of the mHVSR limited to $1 \mathrm{~Hz}$. We defined four main families with a similar typology from the mHVSR with a frequency range between $0.2-20 \mathrm{~Hz}$ : (1) a flat response, which corresponds to sites located from the center to the northwest of the basin; (2) a clear peak, with sites mainly located on the southern part of the basin and few ones in the northwest; (3) multiple peaks, at the south of the city near the second family; (4) small $\mathrm{H} / \mathrm{V}$ spectral ratio amplitudes, observed at scattered sites over the basin. Then each family were divided in sub-families according to the frequency and the $\mathrm{H} / \mathrm{V}$ amplitude characteristics. This difference in response suggests distinct sedimentary structures between the northern and southern parts of the Quito basin.

Site Effects Characterization at Portoviejo City (Ecuador) by Normalizing Seismic Noise Spectra Using Aftershocks

PALACIOS, P. B., Instituto Geofisico Escuela Politecnica Nacional, Pichincha, Ecuador, ppalacios@igepn.edu.ec; YEPES, H. A., Instituto Geofisico Escuela Politecnica Nacional, Pichincha, Ecuador, hyepes@igepn.edu.ec; MARRERO, J. M., Instituto Geofisico Escuela Politecnica Nacional, Pichincha, Ecuador, jmarrero@igepn.edu.ec; RAMÓN, P., Instituto Geofisico Escuela Politecnica Nacional, Pichincha, Ecuador, pramon@igepn.edu.ec

During the April 16th $2016 \mathrm{Mw} 7.8$ interface subduction earthquake in central Ecuador, Portoviejo $(300.000 \mathrm{~h} ; 150 \mathrm{~km} \mathrm{~S}$ of the epicenter) suffered severe damage, mainly in the commercial district where the tallest and largest buildings were clustered. Questions arose whether or not the soil in downtown area was responsible of such concentrated impact, rendering important to understand the site effects and to see if they were responsible for the damage level. In this study we profit from the frequent occurrence of aftershocks during the weeks/months after the main shock. By means of a 7 -sensors broadband portable seismic network we measured the seismic noise in 144 locations in the city. The noise was carefully characterized during the quietest hours $(1-5 \mathrm{am})$. We used the concurrent aftershocks registered during each sub-net deployment to normalize each noise spectrum. Then, the Frequency Response Functions (FRFs) obtained with this approach for each site were used to get a broad image of the 2-D empiricallyderived soil response along the city. Additionally, the earthquake was recorded by two permanent accelerometers in the city. By deconvolving both records with the respective FRFs we estimated the arriving stiff soil waveforms without the site influences, and convolved them with the individual FRFs to get an general approximation of the earthquake displacements, velocities and accelerations in Portoviejo. FRF amplification factors and frequencies clearly differentiate between the city valley and the surrounding mountain slopes. No clear differences were found in the horizontal responses between the downtown commercial and surrounding districts in the flat zone of the valley. The only clear contrast was found in the amplification factors of vertical components in downtown Portoviejo with respect to other areas, where amplitudes between 2 and $3.4 \mathrm{~Hz}$ are 4-5 times larger, which suggests that rocking effects may have had a role in the building damages. Comparison with results obtained from a traditional geophysical-geotechnical microzonation study for Portoviejo (this meeting) show a general agreement of the larger horizontal amplification factors with the Vs 180-225 $\mathrm{m} / \mathrm{s}$ seismic microzone.

New Frontiers in Seismic and Acoustic Data Analysis

Poster Session - Wednesday 16 May · Riverfront South

\section{Moment Tensor Inversion in an Optimized, Three-Dimensional Seismic Earth's Model}

GUILLOT, L. F., CEA Centre-DAM France, Essonne, France, laurent.guillot. blr@gmail.com; BURGOS, G., Institut de Physique du Globe de Paris, Paris, France, burgos@ipgp.fr; LANDES, M., CSEM, Essonne, France, matthieu. landes@emsc-csem.org; TRILLA, A., CEA-DAM, Essonne, France, aurelie. trilla@cea.fr; SHAPIRO, N. M., Institut de Physique du Globe de Paris, Paris, France, nshapiro@ipgp.fr

The robustness of moment tensor inversion for source characterization relies on the accuracy of the seismic model, and the kind of method used to compute Green's tensor in it. Many moment tensor inversions are based on Green's functions calculated with approximate methods, and are built on 1-D models or ad hoc 3-D averages. Three-dimensional seismic models and fully numerical Green's functions can now be derived thanks to advances in high-performance computing and seismic techniques (e.g., adjoint methods and finite-difference or spectral element algorithms), but some issues remain: taking the crust into account, or imaging it, still is a difficult task; and if done, the necessary fine spatial discretization for numerical seismic wave propagation within this highly heterogeneous part of our planet, leads to time-consuming simulations, even for long-period signals. An eventual remedy is the construction of a crust with smooth, effective (or equivalent) seismic properties, using some filtering inherited from the homogenization theory. We have developped a non-linear, stochastic inversion procedure to generate 3-D models adapted to numerical simulation of the full seismic wavefield. This probabilistic approach is based on the parametrization of models using an optimized basis of smooth functions constructed by principal component analysis of a homogenized reference model. It provides a reduced and optimized parameter space for the Bayesian inversion of an ensemble of 1-D seismic models. An appraisal step of the ensemble of models is added to regularize the 3-D model laterally. Using CUB as a starting block, our procedure allows for the determination of a 3-D, effective, seismic Earth model, and of full 3-D Green's functions-procured at a relatively low numerical cost with spectral element simulations. As an illustration, we then invert for moment tensors associated to events occuring in WUS, and compare the results to those obtained using a more classical procedure.

\section{Seismo-Acoustic Signatures of Industrial Facilities}

MARCILLO, O. E., Los Alamos National Laboratory, New Mexico, USA, omarcillo@lanl.gov; MACEIRA, M., Oak Ridge National Laboratory, Tennessee, USA, maceiram@ornl.gov; GAMMANS, C., Los Alamos National Laboratory, New Mexico, USA, cgammans@lanl.gov

Operating industrial facilities generate mechanical energy that partitions into the air and ground as acoustic and seismic waves, respectively. When recorded in the very near field, as in 100s of meters, these signals display as a series of harmonic signals with their corresponding overtones embedded in broad band noise. The harmonic signals are usually related to the operation of machinery with rotating elements (e.g.: pump and fans), and the broadband noise results from the vibrations of these structures and the subsequent fluid displacement. Characterizing the seismo-acoustic signatures and their evolution present in the near-field of such facilities can provide a means to not only assess the structural state of the facilities but, also, to monitor different subaerial and underground operations allowing for potential geophysical monitoring of plant operations.

\section{Stochastic Summation of Smaller Earthquakes to Simulate Synthetic Strong Ground Motions: Extension to Double Corner Frequency Source Models SEDAGHATI, F., The University of Memphis, Tennessee, USA, fsdghati@ memphis.edu; PEZESHK, S., The University of Memphis, Tennessee, USA, spezeshk@memphis.edu; TAVAKOLI, B., Bechtel Power Corporation, California, USA, btavakol@bechtel.com}

Near source and high magnitude recordings of ground motion are of great interest to both seismologist and engineers particularly for performing PSHAand engineering design. There is an essential need to use synthetic data for tectonically 
inactive regions such as CENA. Stochastic summation of smaller earthquakes as Green's function (SSGFM) to predict broadband earthquake ground motions for future large earthquakes at sites of interest is a novel approach which is developed by using scaling and adding recordings of smaller earthquakes as empirical Green's functions. One important advantage of the SSGFM is that there is no assumption about the fault geometry and rupture process, and the methodology just relies on using seismic scaling relations. In this method, a specific number of small earthquakes (sub-events) are scaled, shifted, and then are added together to construct a target large earthquake time histories. To construct the summation scheme, it is assumed that the small and target events, both are considered as a point source conforming the "omega-square" source model having single corner frequency (SCF). Ordaz et al. (1995) and Kohrs et al. (2005) used this assumption and provided summation schemes to obtain scaling factor, number of subevents, and rupture times to follow the scaling relations. Careful investigation of the source suggests using double corner frequency (DCF) point source models to mimic the effects of finite fault rupture. The main difference between the SCF and DCF source models is the source duration resulting in different response spectra from these two models. In this study, we extend and modify the summation scheme of the SSGFM for sources that are better modeled with DCF shapes. To this end, we employ two generalized DCF source models. Then, we provide equations to determine the scaling factor, number of sub-events, and rupture times to be used within the framework of SSGFM. Through several examples, we will validate our approach.

\section{Crowd Sourcing Data Collection to Enhance the Understanding of Ground} Truth Events

HERTZOG, I. T., ENSCO, Florida, USA, hertzog.justin@ensco.com; ANTOLIK, M., ENSCO, Florida, USA, antolik.michael@ensco.com; MARIN, N., Ensco, Inc, Florida, USA, marin.nancie@ensco.com; BROGAN, R., ENSCO, Florida, USA, brogan.ronald@ensco.com; NAVA, S., ENSCO, Florida, USA, nava.sue@ensco.com

The inclusion of crowd sourcing based earthquake detection and characterization has proven to be very successful as a first alert in disaster scenarios and to increase coverage for earthquake detection where there are sparse sensor networks. A variety of crowd sourcing applications such as the USGS Twitter Earthquake Detector (TED), University of California Berkeley's MyShake, RaspberryShake, and RedVox Inc. Infracorder, are in use to name a few. Commercially available smartphones offer a lower deployment cost coupled with high data sampling rates, with drawbacks such as timing, durability, and sensitivity issues. We investigate the functionality of incorporating non-traditional information/data sources such as the use of smartphone and social media applications as a potential method to corroborate geophysical detections from traditional sensor network data. We compare data collected with smartphones collocated with traditional sensors in various environments. The use of non-traditional collection methods could potentially assist in identifying unknown sources and may enhance the scientific community's ground truth data collections.

\section{Detecting Real Earthquakes Using Imaginary Templates: Matched-Filter Detection without A-Priori Information}

CHAMBERLAIN, C. J., Victoria University of Wellington, Wellington, New Zealand, calum.chamberlain@vuw.ac.nz; TOWNEND, J., Victoria University of Wellington, New Zealand, john.townend@vuw.ac.nz; BARATIN, L. M., Victoria University of Wellington, New Zealand, laura-may.baratin@vuw.ac.nz

Matched-filter techniques are demonstrably the most effective way in current use of detecting repeating and near-repeating earthquakes in noisy data, but they rely on a-priori knowledge of the source. Matched-filter methods rely on the cross-correlation of previously identified waveforms as templates with continuous data; detections are made when the cross-correlation significantly exceeds the background correlation level. Therefore, they are able to detect events with overlapping waveforms and events below the noise-level, settings in which other detection methods often fail. Matched-filter techniques have been applied successfully to a range of situations, including detection of: repeating earthquakes, low-frequency earthquakes, explosions, and aftershocks. In all cases, pre-defined templates have to be constructed using waveforms characteristic of the events of interest, which typically limit their application to only finding signals from previously known sources. Here we demonstrate the use of synthetic templates to detect real earthquakes in a range of applications. By generalising the templates, the matched-filter method can be applied to seismicity throughout the crust and does not need to be restricted to near-repeating earthquakes. Moreover, by using synthetic templates, we are able to detect earthquakes within swarms that were otherwise missed by standard detection techniques and extend the catalogue of low-frequency earthquakes beneath the central Southern Alps, New Zealand to better characterise where slip is occurring on the deep-extent of the Alpine Fault.
Prediction and Separation of Surface Waves into Fundamental Mode and Overtones Based on the Nonlinear Dispersion Measurement

HU, H., University of Houston, Texas, USA, huhaoletitbe@gmail.com; ZHENG, Y., University of Houston, Texas, USA, yzheng24@central.uh.edu

Seismic surface waves are valuable for investigating subsurface structures. However, in many other applications such as in seismic reflection imaging, it is desirable to separate the surface waves from the data. We propose a data-driven approach to predict and separate surface waves from the data based on the nonlinear dispersion measurement. In addition, we can also separate the surface waves into fundamental mode and overtones. The procedure has two steps. We first estimate high-resolution surface wave phase velocities from the recorded data using our nonlinear signal comparison (NLSC) approach. This enables us to predict the surface waves at each receiver location. We then subtract the predicted surface waves from the input seismic data. We applied our approach on two synthetic datasets and one field active-source seismic gather. From these examples, we can see that our new approach could effectively predict and separate surface waves with high fidelity.

Teleseismic P-Wave Coda Auto-Correlations versus P-Wave Receiver Functions : A Case Study from the Mackenzie Mountains, Yukon, Canada, and Utility for Icecap and Ice Shelf Stations

BAKER, M. G., Colorado State University, Colorado, USA, mgbaker@ colostate. edu; ASTER, R. C., Colorado State University, Colorado, USA, rick.aster@ colostate.edu; SCHUTT, D., Colorado State University, Colorado, USA, derek. schutt@colostate.edu; CHAPUT, J. A., Colorado State University, Colorado, USA, chaput82@gmail.com; WITT, D., Colorado State University, Colorado, USA, derekwitt.geo@gmail.com

Auto-correlation of teleseismic P-wave coda is a recently developed technique capable of imaging crustal-scale features based on reflection signals from seismic discontinuities. Traditional P-wave receiver function analysis maps velocity contrasts based on P-to-S conversions and has been well utilized in a great many locations, but encounters difficulties in seismically complex environments: for example, where high impedance contrasts result in large magnitude reverberations that overwhelm the primary phases, or where high velocity layers or sloping interfaces invalidate assumptions of near-normal incidence. Deconvolution and multiple constraint alogrithms have been developed to address these issues but often introduce additional complexities and computational overhead. Autocorrelation has the advantages of being fast (when computed via the Cross Correlation Theorem), is not reliant on tuning parameters (e.g., water levels), directly exploits reverbatory phases for locating reflection horizons, and can be combined with a transformation to PSH wavevector coordinates to fully partition P-and S-wave energy into separate channels for joint inversion matching. We present a benchmark comparison of receiver function and auto-correlation inversions utilizing the first year of data from a 39 station broadband array spanning the Mackenzie Mountains, Yukon, Canada. Initial surveys of this region indicate a variety of seismically complicated crustal-scale structures, including large-scale strike-slip faulting, sloping interfaces, high velocity intrusions, and low velocity cratonic sediments. We also present application of the autocorrelation methodology to floating and grounded ice stations in Antarctica, where receiver function methods encounter particular difficulties due to the icecap and ocean.

\section{Multi-Scale Study of Ground Motion Coherence in Piñon Flats and the San Jacinto Fault Zone}

QIN, L., University of Southern California, California, USA, qinl@usc.edu; BEN-ZION, Y., University of Southern California, California, USA, benzion@ usc.edu; VERNON, F. L., Scripps Institution of Oceanography, California, USA, flvernon@ucsd.edu

We study the coherence of one-year continuous waveforms from the Piñon Flats Observatory Array (PY) and five dense linear arrays (JF, DW, SGB, RA, and BB from south to north) along the San Jacinto fault using the multitaper spectral analysis. The examined data include ambient noise and earthquake signals from local and teleseismic sources recorded by different types of seismometers at different locations. In the PY array, the coherence of noise data remains high in the $0.1-1.0 \mathrm{~Hz}$ band when the interstation distance is small $(<65 \mathrm{~m})$, and decreases quickly outside the dominant frequency band and with increasing station distances. The local earthquake signals exhibit high coherence up to $20 \mathrm{~Hz}$, while the teleseismic waves have high coherences in the low frequency band $(<0.1 \mathrm{~Hz})$. The coherences show complex daily variations up to $12 \mathrm{~Hz}$. The high coherence $(\geq 0.95)$ frequency bands in the two horizontal components exhibit seasonal variations. In addition, the coherences of horizontal components are higher in the $2-5 \mathrm{~Hz}$ band when compared to the vertical component, while the reverse is true in the low frequency range $(<0.1 \mathrm{~Hz})$. The coherence at PY also contains 
high anomalies in $\sim 2-4 \mathrm{~Hz}$ lasting for $\sim 16$ days before the 2016 M5.2 Borrego Springs event, which might be related to anthropogenic effects. In the JF and DW arrays, coherence exhibits similar patterns in $0.1-1.0 \mathrm{~Hz}$ without significant daily or seasonal changes, while in the SGB and RA arrays there are no highly coherent noise signals in $0.1-1.0 \mathrm{~Hz}$.

\section{Development of UNAM Institute of Engineering Multipurpose Seismic Data Logger}

TORRES, M., Instituto de Ingeniería, Universidad Nacional Autónoma de México, Distrito Federal, Mexico, mtn@pumas.iingen.unam.mx; SANTIAGO, L., Universidad Nacional Autónoma de México, Distrito Federal, Mexico, Isantiagoc@iingen.unam.mx; AYALA-HERNÁNDEZ, M., Universidad Nacional Autónoma de México, Distrito Federal, Mexico, mayalah@iingen. unam.mx; RAMIREZ, L., Universidad Nacional Autónoma de México, Distrito Federal, Mexico, Iramirezg@iingen.unam.mx; CASTRO-PARRA, G., Universidad Nacional Autónoma de México, Distrito Federal, Mexico, gcastrop@iingen.unam.mx; VELASCO-MIRANDA, J. M., Universidad Nacional Autónoma de México, Distrito Federal, Mexico, jvelascom@iingen. unam.mx; AGUILAR-CALDERÓN, L. A., Universidad Nacional Autónoma de México, Distrito Federal, Mexico, laguilarc@iingen.unam.mx; ALMORAMATA, D., Universidad Nacional Autónoma de México, Distrito Federal, Mexico, dalmoram@iingen.unam.mx; MOLINA AVILA, I., Universidad Nacional Autónoma de México, Distrito Federal, Mexico, imolinaa@iingen. unam.mx; MORA-CONTRERAS, A., Universidad Nacional Autónoma de México, Distrito Federal, Mexico, amorac@iingen.unam.mx; VÁZQUEZLARQUET, R., Universidad Nacional Autónoma de México, Distrito Federal, Mexico,rvazquezl@iingen.unam.mx

We present a low-cost seismic recording system intended to fulfill multiple seismic experiments and monitoring. The instrument was designed and crafted at the Institute of Engineering of the National Autonomous University of Mexico with the main objective of expanding the strong ground motion network and the pool of instruments for site and crustal characterization. The system consists of: 1) a 3-channel digital recorder with 24-bit resolution, 2) selectable sample rate of 100 or 200 samples per second, and 3) time control based on a real-time clock corrected by a GPS receiver. Moreover, the amplification stage input can select between various types of sensors, such as geophones, force balance accelerometers (FBA), MEMS type accelerometers, etc. The instruments will be used for large arrays in multiple experiments for recording earthquakes, aftershocks, seismic noise and measurement of vibrations in structures. Due, its low cost and the fact they are assembled in-house, modifications of the instruments can be made quickly to adjust the specific experiment requirements. Currently, three versions have been developed. The first version uses $2 \mathrm{G}$ force balance servo-accelerometers with the ability to continuously send data in real time through the Internet to a central registration point. The second instrument uses $1 \mathrm{~Hz}$ geophones for noise measurements in large autonomous arrays; the data is stored in a microSD flash memory. The last model uses MEMS type low noise capacitive accelerometers mainly for strong earthquakes and measurements in structures.

\section{Observations and the Physics Behind Complex \\ Earthquakes}

Poster Session · Wednesday 16 May · Riverfront South

\section{Exploring the Relation between Backprojection Images and Earthquake Source Processes}

YIN, J., Harvard University, Massachusetts, USA, jiuxun_yin@g.harvard.edu; DENOLLE, M. A., Harvard University, Massachusetts, USA, mdenolle@fas. harvard.edu

Backprojection (BP) of teleseismic $\mathrm{P}$ waves is a widely-used method to image in time and space the evolution of earthquake radiation. Theoretical studies indicate that the high-frequency bursts can be related to abrupt changes in rupture velocity. Furthermore, recent studies propose that the BP results, which exhibit difference in the frequency content, can reflect the stress status, frictional and/ or geometrical heterogeneity on the fault surface. However, the relation between earthquake physics and the spatiotemporal evolution from BP imaging remains unknown. Fukahata et al. (2014) suggest that the BP images are equivalent to either slip or slip rate on the fault, provided that the Green's functions from the sources to the receivers are incoherent. In this study, we relate the BP results and earthquake source process by testing both kinematic (pseudo-dynamic) and dynamic source models. With these source models, we perform a synthetic backprojection exercise in a simple purely elastic homogeneous whole space, allowing us to solve analytically for the far-field body waves. A 2D correlation coefficient is calculated between BP images and the spatial distribution of various source characteristic field (rupture velocity, slip, peak slip rate, and their gradient) for quantitative comparisons. Because kinematic models are computationally efficient, we run a suite of scenario sources to draw a statistical comparison between the source kinematics and the BP images. From dynamic models, we are able to explore the source physical space by looking at variations in frictional properties and draw comparison with the synthetic BP results.

\section{Subevent Characterization of the 2016 M7.8 Kaikoura Earthquake}

JIA, Z., Caltech, California, USA, zjia@caltech.edu; ZHAN, Z., Caltech, California,USA, zwzhan@gps.caltech.edu

The 2016 Kaikoura, New Zealand, M7.8 earthquake involved complex ruptures on more than a dozen faults, and the first-order pictures depicted by regional and teleseismic data are still in discrepancy. Most models dominated by far-field data show mainly slip on the megathrust interface, while models dominated by nearfield data prefer mostly crustal faulting with secondary interpolate contribution. One challenge for perhaps all finite-fault inversions of this earthquake is that assumptions must be made about where and when rupture starts on a particular fault. The large number of free parameters makes it difficult to assess the effects of these assumptions on the finite-fault models. Here we characterize the Kaikoura earthquake as a sequence of several subevents, each of which is a Haskell source with unilateral and constant rupture speed. With relative few free parameters, we conduct a non-linear search of the locations and timings of subevents to allow different rupture scenarios and to assess the model uncertainties. In the preliminary result, we find that the large energy release between 50 s and 80 s during the event consists of a deep thrust subevent and a shallow strike-slip subevent. As for these two major subevents, the thrust subevent is systematically earlier than the strikeslip subevent. This appears to favor that the megathrust slip is driving the shallow crustal faulting, instead of ruptures jumping from one crustal fault to another.

\section{Conditional Probabilities of Multi-Fault Ruptures and Earthquake Sequences} in California from the Physics-Based Rupture Simulator RSOSim

GILCHRIST, J. J., University of Southern California, California, USA, jacquig@gmail.com; JORDAN, T. H., University of Southern California, California, USA, tjordan@usc.edu; MILNER, K. R., University of Southern California, California, USA, kmilner@usc.edu

The SCEC5 Earthquake Gates Area (EGA) initiative proposes that earthquake gates (regions of fault complexity that can halt ruptures) control the occurrence and probability of large, multi-segment and multi-fault ruptures. Within the SCEC Collaboratory for Interseismic Simulation and Modeling (CISM), we are developing physics-based forecasting models for earthquake ruptures in California. As a part of this project, we employ the 3D boundary element code RSQSim (Dieterich \& Richards-Dinger, 2010) to explore the range of single and multi-fault ruptures, and earthquake sequences that occur at complex intersections of high slip-rate faults with the potential for large, damaging earthquakes. RSQSim models rupture nucleation by rate- and state-dependent friction and Coulomb stress transfer in complex, fully interacting fault systems. This simulator provides a basis for studying the probabilities of rare, complex ruptures because it generates synthetic catalogs with tens of millions of events that span up to a million years each. The Uniform California Earthquake Rupture Forecast Version 3 (UCERF3) fault and deformation models are used to specify the fault geometry and long-term slip rates. We compare the results from several RSQSim catalogs (with variations in model parameters) and UCERF3 to better understand how fault complexities affect the probabilities of large earthquakes. We look at several areas with complex fault geometry, including Cajon Pass, one of the SCEC5 EGA's, which marks the junction of the San Andreas, San Jacinto, and major thrust faults in the Transverse Ranges. Preliminary results indicate, for example, that the probability of a SAF rupture jumping onto the SJF is an order of magnitude higher if the rupture extends through the Southern Mojave and San Bernardino segments, past the junction of the SAF and SJF, than if it only ruptures the Southern Mojave.

\section{Data-Driven Estimation of Earthquake Rupture Dimensions from Early Aftershock Distributions}

MEIER, M. A., Caltech, California, USA, mmeier@caltech.edu; AMPUERO, J. P., Géoazur Laboratory, France, ampuero@gps.caltech.edu; VAN DER ELST, N. J., US Geological Survey, California, USA, nicholas.vanderelst@gmail.com; HAUKSSON, E., Caltech, California, USA, hauksson@caltech.edu; ROSS, Z. E., Caltech, California, USA, zross@gps.caltech.edu

Aftershock distributions are commonly used to constrain some of the most fundamental macroscopic properties of seismic ruptures, such as scaling relationships between rupture dimensions and main shock seismic moment. Although 
any individual aftershock sequence may have rather complicated aftershock patterns, there are well-defined average patterns of aftershock behavior in space, time, and magnitude. Here we aim at gaining a quantitative, data driven characterization of aftershock sequence evolution. The large number of cataloged aftershock sequences available today allows discerning clear scaling patterns, which previously may have been hidden by the large variability of individual sequences. Furthermore, the quantitative description of these patterns brings out which sequences are atypical and deserve special attention. We systematically analyze the spatial and temporal behavior of a large number of earthquake sequences from southern California and Japan. In particular we investigate i) how distributions of early aftershocks relate to main shock rupture areas, ii) scaling relations of estimated rupture dimensions with main shock seismic moment, and iii) whether there is a systematic relation between seismic moment and the aspect ratio of the rupture area. The latter is motivated by the recent observation that moment rate functions of subduction megathrust earthquakes grow linearly in time, rather than quadratically. If large ruptures expanded in a single predominant dimension, this would explain the observed linear trend and would produce larger rupture aspect ratios at larger magnitudes. In this sense we expect that the systematic characterization of aftershock patterns will shed light on the physical processes that govern earthquake growth and produced the observed rupture patterns.

High-Precision Relocation of the Aftershock Sequence of the November 14, 2016, Mw 7.8 Kaikoura Earthquake, New Zealand

LANZA, F., University of Wisconsin-Madison, Wisconsin, USA, flanza@wisc. edu; CHAMBERLAIN, C. J., Victoria University of Wellington, Welington, New Zealand, calum.chamberlain@vuw.ac.nz; JACOBS, K., GNS Science, Wellington, New Zealand, k.jacobs@gns.cri.nz; WARREN-SMITH, E.J., GNS Science, Wellington, New Zealand, e.warren-smith@gns.cri.nz; THURBER, C. H., University of Wisconsin-Madison, Wisconsin, USA, cthurber@wisc. edu; SAVAGE, M. K., Victoria University of Wellington, Wellington, New Zealand, martha.savage@vuw.ac.nz; TOWNEND, J., Victoria University of Wellington, Wellington, New Zealand, john.townend@vuw.ac.nz; KORTINK, M., Victoria University of Wellington, New Zealand, megan.kortink@vuw.ac.nz; GODFREY, H.J., Victoria University of Wellington, Wellington, New Zealand, holly.godfrey@vuw.ac.nz

The November 14, 2016 Mw 7.8 Kaikoura earthquake in northern South Island, New Zealand, was a complex, multi-fault rupture event and the latest in a series of damaging earthquakes in the Canterbury and Marlborough regions. The main shock ruptured from south to north, and triggered seismicity throughout the upper South Island and lower North Island. We utilize data from a temporary network (Seismic Triggering Response for Earthquakes around Wellington NZ: STREWN) deployed in northern South Island and southern North Island to precisely locate aftershocks. The 24 STREWN instruments were operational for approximately 6 months from late November 2016 to early May 2017. We used a newly-developed hybrid method for automated detection and onset estimation, ("REST": Roecker, pers. comm.), which combines a modified version of the nearest-neighbor similarity scheme of Rawles and Thurber (2015) with the auto-regressive approach of Kushnir et al. (1990). We then undertake iterative pick association and event location using a grid-search method. We applied this method to pick and locate 673 events. To assess automatic-pick quality the picks for a subset of 103 events $(M \geq 3)$ were compared with hand-picks. The comparison reveals agreement between REST P picks and manual P picks, but the automatic picker shows a higher fraction of poor or missing $S$ picks. By using the highquality picks obtained by combining automatic and manual picks, and utilizing a new 3D model of (Henrys et al., in prep.), we have obtained 3D velocity images and high-precision hypocenter relocations of these aftershocks. These results contribute to our understanding of tectonics a subduction to strike-slip transition, and shed new light on the geometry and interconnection of seismically active fault structures in central New Zealand and near the capital city, Wellington.

\section{Diverse Volumetric Faulting Patterns in the San Jacinto Fault Zone}

CHENG, Y., University of Southern California, California, USA, chengyif@ usc.edu; ROSS, Z. E., Caltech, California, USA, zross@gps.caltech.edu; BENZION, Y., University of Southern California, California, USA, benzion@usc. edu

We examine locations, magnitudes and faulting types of post-2000 earthquakes in the trifurcation area of San Jacinto fault zone to clarify basic aspects of failure processes in the area. Most $M \geq 3.5$ events have strike-slip mechanisms, occur within $1 \mathrm{~km}$ of the main faults (Clark, Buck Ridge, and Coyote creek) and have hypocenter depths of $10-13 \mathrm{~km}$. In contrast, many smaller events have normal source mechanisms and hypocenters in intra-fault areas deeper than $13 \mathrm{~km}$.
Additional small events with hypocenter depth $<13 \mathrm{~km}$ occur in off-fault regions and have complex geometries including lineations normal to the main faults. Five moderate earthquakes with $\mathrm{M}$ 4.7-5.4 have high aftershock rates $(\sim 150 \mathrm{M} \geq 1.5$ events within 1 day from the mainshock). To obtain more details on aftershock sequences of these earthquakes, we detect and locate additional events with the matched filter method. There are almost no aftershocks within $1 \mathrm{~km}$ from the mainshocks, consistent with large mainshock stress drops and low residual stress. The five aftershock sequences have little spatial overlap. While the mainshocks are on the main faults, most aftershocks are located in intra-fault and off-fault regions. Their locations and spatial distribution reflect the mainshock rupture directions and many also follow structures normal to the main faults. The significant diversity of observed features highlights the essential volumetric character of failure patterns in the area. The increasing rate of moderate events, highly productive aftershock sequences and large inferred stress drops may be indicative of approaching major event.

How Much Can We Resolve Acceleration and Deceleration of Earthquake Rupture Evolution?

OKUWAKI, R., University of Tsukuba, Tsukuba, Japan, rokuwaki@gmail.com; YAGI, Y., University of Tsukuba, Tsukuba, Japan, yagi-y@geol.tsukuba.ac.jp

Acceleration (ACC) and deceleration (DEC) of earthquake rupture evolution are critical phenomenon for understanding the earthquake source physics, which are realized when rupture is advanced by cascade triggering and when rupture front is disturbed by geometric/inhomogeneous barriers. Theoretical studies suggest that abrupt change of rupture evolution can enhance high-frequency (HF) radiation, and it is possible to track ACC and DEC with backprojection (BP) technique since it has been widely used for imaging HF radiation sources. Here we explored a resolvability of ACC and DEC with the BP technique. Conventionally, it was difficult to distinguish ACC and DEC from the BP image, since the image were usually composed of the normalized intensity of the stacked signal of only positive values (in a range of $0-1$ ). We propose new implementation of the hybrid BP (HBP) method; one of the variants of BP technique developed to enhance the depth resolution by using Green's functions (GFs). An explicit use of GFs enables us to extract the physical unit from the signal intensity as either velocity or acceleration. We stack the cross-correlation functions of the velocity waveforms and displacement GFs filtered in $0.5-2.0 \mathrm{~Hz}$ and project them onto the fault, which will correspond to the time derivative of slip rate; ACC and DEC, for the positive and negative values of stacked signals, respectively. We performed numerical test and application to the real earthquakes, showing that ACC and DEC were well resolved by the HBP method, only if the sources were isolated in both time and space, but if they were closely distributed, it was difficult to distinguish ACC and DEC from the image. In a real configuration of sources, they do not always separate each other, and the radiation phases of ACC and DEC may easily be canceled out in HF waveforms, especially for the later phases. Thus practically, it would be difficult to rigorously resolve $\mathrm{ACC}$ and $\mathrm{DEC}$ with the $\mathrm{BP}$ technique.

Fault Slip Associated with the M 5.3 September 2, 2017, Sulphur Peak, Idaho, Earthquake and Aftershock Sequence

FRED, F. F., US Geological Survey, California, USA, fpollitz@usgs.gov; WICKS, C. W., US Geological Survey, California, USA, cwicks@usgs.gov; YECK, W. L., US Geological Survey, Colorado, USA, wyeck@usgs.gov; EVANS, J., Utah State University, Utah, USA, james.evans@usu.edu

The M5.3 September 2, 2017 Sulphur Peak, Idaho, earthquake is one of the largest earthquakes in southern Idaho since the M6.9 1983 Borah Peak earthquake. It was followed by a vigorous aftershock sequence for several days thereafter that included four events above M4.5. The coseismic and early postseismic deformation was measured with both InSAR and GPS, yielding up to $3 \mathrm{~cm}$ subsidence just southwest of the mainshock epicenter and horizontal motions of $\sim 1 \mathrm{~mm}$ at sites $\sim 40 \mathrm{~km}$ east and west of the epicenter. We derive a dislocation model of the net slip during the $\sim 14$-day swarm from Sentinel 1A interferograms and GPS offsets, allowing for both fault zone collapse and normal faulting to account for the observed geodetic motions. Slip inversions yield negligible fault zone collapse but several decimeters of normal slip on a pair of $55^{\circ}$ east-dipping and $35^{\circ}$ westdipping faults that intersect at the mainshock hypocenter, with most of the slip occurring on the west-dipping fault. Previously mapped regional thrust structures dip westward, suggesting that the sequence reactivated one or more ancient thrust structures of the Aspen Range with normal slip. The inferred geodetic moment of $4.21 \times 10^{17} \mathrm{~N} \mathrm{~m}(\mathrm{Mw} 5.72)$ for the entire sequence greatly exceeds the $1.15 \times 10^{17} \mathrm{~N} \mathrm{~m}$ (Mw 5.34) seismic moment of the September 2 mainshock, showing that most of the moment release occurred during the aftershock sequence. 
Complex Seismic Sources for LP Events in Volcanic Environments: Model and Radiation Patterns

CONTRERAS ARRATIA, R. A., University of Leeds, United Kingdom, eerac@leeds.ac.uk; NEUBERG, J. W., University of Leeds, United Kingdom, j.neuberg@leeds.ac.uk

Long period (LP) seismicity is direct evidence of magma movement in the plumbing system and, therefore, it has implications for volcanic hazard forecast such as dome collapse. Following classic seismology seismic sources are assumed to involve planar fault surfaces. However, in volcanic plumbing systems there is evidence of more complex geometries which we explore as possible seismic sources, where magma undergoes brittle failure in zones where strain rate is high, e.g. at the conduit wall. LP events comprise a short period onset, which gives information about the source, and a long period coda, which contains information about the properties of the plumbing system. Here we test seismic sources for these events with geometries following the boundaries of dykes and conduits. We approximate these complex sources by superimposing several double couple sources to create both, seismic radiation patterns and use the QSEIS software to create synthetic seismograms. We find that the resulting waveforms represent the second derivative of the source time function which are used for each double couple, and the amplitude depends on the geometry of the complex source. Classic interpretations by moment tensor inversion could lead to misinterpretations of the source time function since complex source geometries are not taken into account.

\section{Ocean Bottom Seismology-Hurdles, Strategies and} Outcomes

Poster Session · Wednesday 16 May · Riverfront South

\section{Study of the May 2016 Seismic Swarm at Rivera Plate Using OBS and Onland} Stations

NÚNEZZ-CORNÚ, F. J., SisVOc, Universidad de Guadalajara, Jalisco, Mexico, pacornu77@gmail.com; CÓRDOBA BARBA, D., Universidad Complutense de Madrid, Madrid, España, dcordoba@fis.ucm.es; DAÑOBEITIA, J. J., UTMCSIC, Madrid, España, jjdanobeitia@utm.csic.es; BANDY, W., Instituto de Geofísica Universidad Nacional Autónoma de México, Mexico City, Mexico, bandy@geofisica.unam.mx; MORTERA-GUTIERREZ, C., Instituto de Geofísica Universidad Nacional Autónoma de México, Mexico City, Mexico, cmortera@geofisica.unam.mx; NÚNEEZESCRIBANO, D., SisVOc, Universidad de Guadalajara, Jalisco, Mexico, diana@sisvoc.mx; ALARCON, E., SisVOc, Universidad de Guadalajara, Jalisco, Mexico, edgar.alarcon.salazar@outlook. com; SANDOVAL, J. M., edgar.alarcon.salazar@outlook.com, Jalisco, Mexico, ajuansandoval@hotmail.com

The second stage of Tsujal Project includes the study of passive seismic activity in the region of the plate Rivera and Jalisco block by anchoring OBS and densifying the network of seismic stations on land for at least four months. This stage began in April 2016 with the deployment of 25 Obsidian stations with sensor Le-3D MkIII from the northern part of Nayarit state to the south of Colima state, including the Marias Islands. This temporal seismic network complements the Jalisco Seismic Network (RESAJ) for a total of 50 stations. Offshore, ten OBS type LCHEAPO 2000 with 4 channel $(3$ seismic short period and 1 pressure sensor) were deployed, in the period from 19 to 30 April 2016 using the BO El Puma from UNAM. The OBS were deployed in an array from the Marias Islands to offcoast of the border of Colima and Michoacan states. On May 4, an earthquake with $\mathrm{Ml}=4.2$ took place in the contact area of the Rivera Plate, Cocos Plate and the Middle America Trench, subsequently occurred a seismic swarm with over 200 earthquakes until May 16, including an earthquake with $\mathrm{Ml}=5.0$ on May 7. A second swarm took place between May 28 and Jun 4 including an earthquake with $\mathrm{Ml}=4.8$ on Jun 1 . OBS were recovered between the 3 th and 7 th of November. An analysis of the quality of different location methods is presented: automatic preliminary RESAJ location using Antelope; location with revised RESAJ phases in Antelope; relocation of RESAJ data with hypo and a regional velocity model; relocation of RESAJ data with hypo adding data from the temporal seismic network stations; and finally the relocation adding the data from the OBS network.
Güralp Systems: Illuminating the Oceans with an Ocean Bottom Family for All Requirements

ALLARDICE, S. A., Güralp Systems Ltd, United Kingdom, sallardice@guralp. com; MANGANO, G., Güralp Systems Ltd, United Kingdom, gmangano@ guralp.com

With $70 \%$ of the Earth covered in water, there is a significant gap in the seismic data catalogue. Güralp Systems have understood this and have been developing broadband Ocean Bottom Seismometers (OBS) systems for the past 25 years. There is a package available to suit a variety of deployment methods, from OBS boreholes and coreholes, cabled solutions and freefall systems up to $6000 \mathrm{~m}$. Güralp have deployed systems in a range of ocean environments, from the Japan Trench to the North Sea, including passive and active seismic surveys, ambient noise recording, real-time reservoir monitoring and ocean bottom observatories. These applications can be achieved with Güralp's OBS family; Maris, Orcus, Liber and Breve. The Orcus is the flagship cabled solution for real-time data, permanent observatories and earthquake early warning requirements. It consists of a 3 component, broadband, $120 \mathrm{sec}-50 \mathrm{~Hz}$ seismometer and 3 component force balance accelerometer. Our other cabled OBS offering, the Maris, is housed in titanium or stainless steel in the form of a slim-line silhouette design which can be pushed or cored into the seafloor. It is a 3 component broadband sensor which can be deployed as a single unit or a string of up to eight instruments at any angle. The Liber is the flagship autonomous system capable of being deployed up to $6000 \mathrm{~m}$. The system can accommodate deployment lengths from 6 to 8 months, dependent on user requirement. The Breve is our portable, shallow water $(<150 \mathrm{~m})$ free fall OBS. It is equipped with an acoustic release and pop-up buoy for recovery, however the casing itself is rated to $2000 \mathrm{~m}$ therefore can be deployed deeper when using an ROV. The systems are available with a number of ancillary products, including but not limited to; APGs, DPGs, hydrophones, compass, magnetometers and acoustic current meters. Güralp have continually supported the research community and supplied industry clients with innovative OBS designs to meet operational requirements.

Increased Global Seismic Sampling via Proposed Transoceanic SMART Cable Sensors - Comparing Ray Coverage through the SALSA3D Global Model

ROWE, C. A., Los Alamos National Laboratory, New Mexico, USA, char@lanl. gov; BEGNAUD, M. L., Los Alamos National Laboratory, New Mexico, USA, mbegnaud@lanl.gov; SYRACUSE, E. M., Los Alamos National Laboratory, New Mexico, USA, syracuse@lanl.gov; HOWE, B. M., University of Hawaii, Hawaii, USA, bhowe@hawaii.edu

With the exception of isolated and largely near-shore deployments of oceanbottom seismometers (OBSs), most seismic instrumentation is located on land, although two-thirds of Earth's surface is covered with oceans. Large earthquakes are generally confined to subduction zones or other plate boundaries, leading to an uneven distribution of seismic sources. This heterogeneity, coupled with the land-based limitations for most for the Earth's interior, leads to significant unsampled parts of the Earth. Our work is motivated by the planning of a Joint Task Force to develop concepts and applications for Science Monitoring and Reliable Telecommunication (SMART) cables. Over a million kilometers of submarine telecommunication cables currently exist, which are unavailable to the scientific community for acquisition of geophysical data. If these cables are gradually replaced by SMART cables with oceanographic and seismic sensors at roughly $75 \mathrm{~km}$ intervals, one significant benefit to our science will be the near-ubiquitous extent of seismic receivers across the oceans, affording an unprecedented opportunity for both monitoring and modeling. In previous work we presented ray tracing through a $1 \mathrm{D}$ reference model to predict improvements to ray coverage afforded by sensors on SMART cables, compared to existing landbased seismic network coverage. Here we extend that modeling, tracing P and S rays through the SALSA3D global tomographic model. We compare results of this exercise to those for the iasp91 model with, and without, the SMART cable sensors.

Improved Focal Mechanisms and Spatial Stress Patterns Pertaining to Shallow Slow Slip in the Northern Hikurangi, New Zealand

WARREN-SMITH, E. I., GNS Science, New Zealand, e.warren-smith@ gns.cri.nz; CHON, E. R., University of Colorado at Boulder, Colorado, USA, enrique.chon@colorado.edu; FRY, B., GNS Science, New Zealand, b.fry@gns. cri.nz; SHEEHAN, A. F., University of Colorado at Boulder, Colorado, USA, anne.sheehan@colorado.edu; WALLACE, L. M., GNS Science, New Zaaland, l.wallace@gns.cri.nz; MOCHIZUKI, K., ERI, University of Tokyo, Japan, 
kimi@eri.u-tokyo.ac.jp; SCHWARTZ, S. Y., UC Santa Cruz, California, USA, syschwar@ucsc.edu

Slow slip events (SSEs) on the northern Hikurangi are commonly associated with increased seismicity rates, yet limited network azimuthal coverage for offshore earthquakes means source properties, such as focal mechanisms, are difficult to constrain. Here, we utilize $\geq 20$ ocean-bottom seismometers and pressure sensors deployed as part of the Hikurangi Ocean Bottom Investigation of Tremor and Slow Slip (HOBITSS) experiment (May 2014 - June 2015), to offer improved constraints on focal mechanisms of earthquakes during the deployment. This network recorded a shallow MW6.8 SSE in September-October 2014, and hence allows analysis of both microseismicity and earthquakes $M \geq 4$ pertaining to the onset, development and shutdown of slow slip. We focus on 14 well-constrained events $M \geq 2.9$ to demonstrate the improved coverage provided by OBS stations, and to optimise a non-linear location procedure using a 3D velocity model. We then adopt this workflow and implement a Bayesian method to constrain focal mechanisms for many more events ( 100 per month) as small as $\sim$ M1.5 occurring within the network. Earthquakes exhibit a range of mechanism types, dominated by dip-slip events in the subducting Pacific plate, with strike-slip events occurring at both shallow and deeper $(\geq 40 \mathrm{~km})$ depths. 3D stress inversions of our improved focal mechanisms indicate large-scale margin-parallel contraction consistent with previous Hikurangi and global subduction zone studies. Smaller scale rotations in Shmax correlate with subduction zone contours, and we present a preliminary investigation of spatio-temporal changes in the stress field pertaining to the SSE.

\section{Insights from Operations of the U.S. Ocean Bottom Seismograph Instrument Pool}

WOODWARD, R. L., IRIS, District of Columbia, USA, woodward@iris.edu; ADERHOLD, K., IRIS, District of Columbia, USA, kasey@iris.edu

Over the past six years, the U.S. Ocean Bottom Seismograph Instrument Pool has undertaken a wide range of experiments. These experiments have addressed diverse scientific objectives through the deployment of instruments at different scales, geometries, water depths, and seasons. Overall, the experiments have been characterized by excellent instrument return rates, generally high data return, and an evolving set of instrument capabilities. These recent experiments provide insight and motivation for developments in areas such as instrument emplacement, deployment duration, communications (continuous or periodic), and standardized design elements - all key capabilities for future large-scale and/or longterm geophysical projects. Thus, we examine the characteristics, performance, and results of OBS experiments that have been done over the past six years as a key to understanding and motivating future technical directions for this important capability.

\section{Temporal Variations in Seismic Anisotropy during the 2014 Gisborne SSE,} New Zealand

ZAL, H. J., Victoria University of Wellington, Wellington, New Zealand, hubertzal@yahoo.com; JACOBS, K., GNS Science, Wellington, New Zealand, k.jacobs@gns.cri.nz; SAVAGE, M. K., Victoria University of Wellington, Wellington, New Zealand, martha.savage@vuw.ac.nz; MROCZEK, S., Victoria University of Wellington, Wellington, New Zealand, s.mroczek@outlook.com GRAHAM, K. M., Victoria University of Wellington, Wellington, New Zealand, kenny.graham @vuw.ac.nz; YARCE, J., CIRES, University of Colorado, Boulder Colorado, USA, jefferson.yarce@ colorado.edu; TODD, E., University of Otago, New Zealand, Otago, New Zealand, erin.todd@otago.ac.nz; SHADDOX, H., UC Santa Cruz, California, USA, hshaddox@ucsc.edu; NAKAI, J. S., CIRES, University of Colorado, Boulder, Colorado, USA, jenny.nakai@colorado.edu; IWASAKI, Y., Earthquake Research Institute, Tokyo, Tokyo, Japan, yiwasaki@ eri.u-tokyo.ac.jp; SHEEHAN, A. F., CIRES, University of Colorado, Boulder, Colorado, USA, anne.sheehan@colorado.edu; MOCHIZUKI, K., Earthquake Research Institute, Tokyo, Tokyo, Japan, kimi@eri.u-tokyo.ac.jp

In October 2014, a 2-week long slow slip event (SSE) occurred near Gisborne at the northern Hikurangi Margin, New Zealand. It was recorded by offshore instruments, deployed by the Hikurangi Ocean Bottom Investigation of Tremor and Slow Slip (HOBITSS) project. This study uses data compiled from May 2014 to July 2015, recorded on 15 HOBITSS ocean bottom seismometers as well as 12 Geonet stations around the time of this uniquely recorded SSE. We use the $\mathrm{S}$-wave splitting technique to detect stress and fluid changes associated with slow slip. The shear wave splitting fast polarization direction is often inferred to represent the maximum horizontal stress directions (SHmax) in crustal studies and has been shown to vary temporally at volcanoes and in association with large earthquakes. Using Multiple Filter Automatic Splitting Technique (MFAST) we analyse more than 3000 local earthquakes to look for temporal changes in
S-wave fast polarization directions and delay times during the Gisborne 2014 SSE. Because $S$-wave splitting results are sensitive to variations in earthquake locations, we also analyse results from individual spatial earthquake clusters to test the robustness of temporal changes and to better indicate where the measured anisotropy originates. The mean fast directions in the area show a NE-SW trending fast polarization direction similar to local SHmax directions mapped by previous studies and to local fault trends. Preliminary SWS results at LOBS stations show approximately 5-10 degrees of change in fast polarization direction from before to after the SSE. We also observe increased delay times $(\sim 0.5$ seconds) occurring around the time of the SSE with a slow decrease in delay time in the following months. We hypothesize an initial movement of fluids in cracks due to changes in stress during the SSE, followed by a relaxation period where cracks slowly return to their previous state.

\section{Ocean Bottom Seismometer Data Quality Using MUSTANG}

ADERHOLD, K., IRIS, District of Columbia, USA, kasey@iris.edu; WOODWARD, R. L., IRIS, District of Columbia, USA, woodward@iris. edu; SHARER, G., IRIS, Washington, USA, gillian@iris.washington.edu; KEYSON, L., IRIS, Washington, USA, laura@iris.washington.edu

Data standardization and quality control at the U.S. Ocean Bottom Seismograph Instrument Pool has yielded many benefits. Archiving data in SEED format at the Incorporated Research Institutions for Seismology Data Management Center (DMC) has increased the discoverability and accessibility of ocean bottom seismology (OBS) data. Standard data format also encourages researchers to develop and share open source software to calculate instrument orientations or perform standard corrections on the data. This lowers the barrier to using OBS data and has resulted in significant growth and diversification of the OBS user community, evident in attendance at the biannual symposium. Data are also processed automatically to produce a set of useful metrics available through the DMC's MUSTANG service. The metrics can be used to quickly assess station performance after an experiment, identify instrumentation issues, aid researchers in pre-processing data for research-ready data sets, compare noise quality between different instrumentation or siting, and even perform a first-order orientation of the horizontal components. Looking at past experiments we can assess the performance of seismometers in distinct noise environments (open ocean, coastal, lake), varying water depths, different instrument packages or shielding, and to look at seasonal trends in noise for planning future experiments. As we look to new innovations in OBS technology such as shielding, burial emplacement, and longer term deployments, it will be important to quantify improvement and fulfillment of requirements for future research targets such as GSN Oceans or the Subduction Zone Observatory.

\section{Real-Time GNSS Network Operations and Advances towards Early Warning Systems}

Poster Session - Wednesday 16 May · Riverfront South

\section{Meeting the Requirements of Early Warning Systems in Real-Time GNSS Operations}

HODGKINSON, K. M., UNAVCO, Colorado, USA, hodgkinson@unavco.org; MENCIN, D., UNAVCO, Colorado, USA, dmencin@unavco.org; SIEVERS, C., UNAVCO, Colorado, USA, csievers@unavco.org; FOX, O., UNAVCO, Colorado, USA, fox@unavco.org; MATTIOLI, G. S., UNAVCO, Colorado, USA,mattioli@unavco.org

UNAVCO streams data from $~ 800$ real-time, GNSS sites (RT-GNSS) from a combination of NSF-sponsored networks that together span large segments of the North American-Pacific plate boundary, the EarthScope Plate Boundary Observatory (PBO), the Caribbean plate boundary (COCONet) and Mexico's Pacific plate boundary (TLALOCNet). Raw data streams are transmitted from the remote GNSS sites to UNAVCO's data operations center where Precise Point Position (PPP) estimates are generated and distributed in real-time. Recent work has shown that GNSS-defined peak ground displacements (PGD) provide a magnitude scaling relation that, unlike estimates based on the first seconds of the P-wave, does not saturate above M7. The inclusion of RT-GNSS PGD data can therefore greatly enhance the accuracy of early warning systems by providing improved magnitude estimates of large earthquakes. To take full advantage of this, not only must the data be complete and low latency, but it is essential that the PPP estimates have sufficiently low noise-levels such that long-period surface waves can be detected in real-time. Here, we show that we can combine the ambient noise levels in the GNSS PPP solutions with the GNSS-derived PGD scaling relationship to assess the ability of the PBO, TLALOCNet and COCONet networks to unambiguously detect the long-period surface waves generated by 
large earthquake events. This enables implementation of tools for evaluating and continuously monitoring the capability of magnitude-threshold detection level for RT-GNSS networks. We find that with the current network configuration, RT-GNSS PGD would be detectable for most UCERF3-defined faults in California but this capability is decreased for events along sections of theCascadia and Mexican Pacific plate boundaries.

\section{Real Time GNSS Network in Northern Ecuador}

IARRIN TAMAYO, P., Instituto Geofísico - Escuela Politécnica Nacional, Pichincha, Ecuador, pjarrin @igepn.edu.ec; MOTHES, P. A., Instituto Geofísico - Escuela Politécnica Nacional, Pichincha, Ecuador, pmothes@igepn.edu.ec; NOCQUET, J. M., Geoazur, IRD, Université de Nice Sophia-Antipolis, PACA, France,nocquet@geoazur.unice.fr; ALVARADO, A., Instituto Geofísico Escuela Politécnica Nacional, Pichincha, Ecuador, aalvarado@igepn.edu.ece; ROLANDONE, F., Institute de Sciences de la Terre de Paris-UPCM, Paris, France, frederique.rolandone@upcm.fr; RUIZ, M. C., Instituto Geofísico Escuela Politécnica Nacional, Pichincha, Ecuador, mruiz@igepn.edu.ec

GPS measurements in the years prior to the 2016 Pedernales earthquake had indeed shown rapid strain accumulation with spatially heterogeneous patterns of interseismic coupling in central-northern Ecuador, mainly confined within the shallowest $35 \mathrm{~km}$ of the megathrust (Nocquet et al., 2014; Chlieh et al., 2014; Nocquet et al., 2017). After the Pedernales earthquake, and taking into account historical earthquakes occurring in 1906, 1942, 1958 and 1979 along the Ecuador-Colombia subduction zone, we see the need to improve our monitoring capacity and generate early warning predictions, especially for tsunami threats. Rapid advances in GNSS real time technology to monitor transient ground motions and the advantage of not becoming saturated in terms of coseismic displacements makes it especially valuable for monitoring earthquakes and potential tsunamis threats. Using this new technology, we present our real time GNSS network in northern Ecuador developed by the Instituto Geofísico of the National Polytechnic School (IG-EPN). Our network includes 5 real time GNSS stations combined with 3 GNSS base stations and 1 Seismo-Geodetic system (GNSS and accelerometer) in an arrangement of two sub-networks along of Esmeraldas province. Acquisition, analysis, alerting and visualization of data are done with Trimble 4D control monitoring software using satellite transmission. Preliminary results show the need to develop and implement an automatic open code that allows us to integrate these results with seismic data solutions during crises moments.

\section{COCONet Mirror Data Center at INETER, Nicaragua, and Early Warning in} Central America

RAMIREZ, A., INETER, Managua, Nicaragua, javier.ramirez@sb.ineter. gob.ni; STRAUCH, W., INETER, Managua, Nicaragua, wilfried.strauch@ gf.ineter.gob.ni

TheNicaraguan Institute for Terrestrial Studies (Instituto Nicaraguense de Estudios Territoriales, INETER) received a grant to develop a mirror data center to host and serve COCONet data and metadata from UNAVCO and serve as a geodetic seamless archive center through web services (GSAC-WS). INETER, headquartered in Managua, Nicaragua is serving the western circum-Caribbean region. INETER provides monitoring, early warning, research, data, education, and support for all hazards in Nicaragua, especially earthquakes, tsunamis, volcanic unrest, landslides. INETER is hosting the Central American Tsunami Advisory Center (CATAC) and works on the development of Earthquake Early Warning (EEW) for Nicaragua and Central America and pretends to integrate the real-time use of GPS and GNSS data in these initiatives. We present information on the use of the data in the last years.

\section{GPS2EW: A Python Class That Can Be Used to Transmit GNSS Data to an Earthworm System}

HERNANDEZ RAMIREZ, F. J., University of Puerto Rico Mayagüez, Puerto Rico, USA, francisco.hernandez@upr.edu; LOPEZ, A. M., University of Puerto Rico Mayagüez, Puerto Rico, USA, alberto.lopez3@upr.edu; VANACORE, E. A., University of Puerto Rico Mayagüez, Puerto Rico, USA, elizabeth.vanacore@ upr.edu; HUERFANO, V. A., University of Puerto Rico Mayagüez, Puerto Rico, USA, victor.huerfano@upr.edu

The implementation of GNSS data at seismic networks has shown to be a critical addition to earthquake and tsunami monitoring as demonstrated by events such as the 2011 Tohoku earthquake. Currently, seismic networks are seeking methodologies to integrate real-time GNSS data into normal operations to strengthen earthquake and tsunami early warning systems. To be an effective tool such GNSS data must provide reliable and high latency real-time displacement data (displacementgrams). In order to generate displacementgrams in
Earthworm it is necessary to bring the $1 \mathrm{~Hz}$ real-time site positions $(\mathrm{X}, \mathrm{Y}, \mathrm{Z})$ into a geojson module and distribute them using RabbitMQ. This methodology has been incorporated into a python class named GPS2EW. Currently, Puerto Rico Seismic Network(PRSN) is using a python script to extract the GSOF message from Trimble's RTX service, but it can also be implemented for any other $1 \mathrm{~Hz}$ precise point positioning provider. GPS2EW takes the $1 \mathrm{~Hz}$ position data and formats it into the geojson specification and transmits it to RabbitMQ. It is buffered there until Earthworm's geojson2ew module retrieves it and ingests it into an Earthworm ring such as a tracebuf2 message. The advantage of this methodology is that only require the modules pika and json from the python library set. Currently, this methodology is being alpha tested at PRSN but it would require bridging the displacementgrams with a real-time earthquake monitoring system capable of producing earthquake source parameters.

\section{The GNSS Component of the Puerto Rico Seismic Network}

LOPEZ, A. M., University of Puerto Rico Mayagüez, Puerto Rico, USA, alberto. lopez3@upr.edu; HUERFANO, V. A., Puerto Rico Seismic Network, Puerto Rico, USA, vhuerfano@prsnmail.uprm.edu; VANACORE, E. A., Puerto Rico Seismic Network, Puerto Rico, USA, elizabeth.vanacore@upr.edu

For more than two decades the Puerto Rico-Virgin Islands region has been monitored for crustal deformation using GPS geodesy. This objective was first done through a campaign style network that consisted of a dozen sites collecting one measurement annually during the nineties. Today, fifteen continuously operating GPS sites distributed throughout Puerto Rico and the Virgin Islands form the Puerto Rico Seismic Network (PRSN) GPS network. These sites provide data in two forms; $1 \mathrm{~Hz}$ Real-time data available through an NTRIP Caster and $1 \mathrm{~Hz}$ and 30 sps BINEX archived files transferred from site to PRSN hourly and daily, respectively. Here we present data flow methods employed at PRSN to bring continuously operated GPS station data from the field back to PRSN, both in Real-time form and archived. This presentation seeks to encourage other GPS or GNSS networks in the Caribbean, particularly those hosting COCONet sites, to develop their own data acquisition methods based on the solutions that have been either adopted or developed at the PRSN. Empowering Caribbean networks to have control over their data is critical for capacity building and enables the region to develop scientifically as well as increase their education in matters of earthquake and tsunamis.

\section{GNSS Network of the Mexican National Seismological Service} MENDOZA CARVAJAL, A. J., Instituto de Geofísica, Universidad Nacional Autónoma de México, Mexico City, México, antonio@sismologico.unam.mx; ESTRADA, J. A., Instituto de Geofísica, Universidad Nacional Autónoma de México, Mexico City, México, jorgee@sismologico.unam.mx; PÉREZ, J., Instituto de Geofísica, Universidad Nacional Autónoma de México, Mexico City, México, jesus@sismologico.unam.mx; NAVARRO ESTRADA, F., Instituto de Geofísica, Universidad Nacional Autónoma de México, Mexico City, México, fernando@sismologico.unam.mx; CRUZ, J. L., Instituto de Geofísica, Universidad Nacional Autónoma de México, Mexico City, México, jcruz@ sismologico.unam.mx; HURTADO, A., Instituto de Geofísica, Universidad Nacional Autónoma de México, Mexico City, México, alhudi@sismologico. unam.mx; RODRÍGUEZ RASILLA, I., Instituto de Geofísica, Universidad Nacional Autónoma de México, Mexico City, México, ivan@sismologico. unam.mx; TAN, Y., Instituto de Geofísica, Universidad Nacional Autónoma de México, Mexico City, México, yi@sismologico.unam.mx; PÉREZ-CAMPOS, X., Instituto de Geofísica, Universidad Nacional Autónoma de México, Mexico City, México, xyoli@igeofisica.unam.mx; CABRAL-CANO, E., Instituto de Geofísica, Universidad Nacional Autónoma de México, Mexico City, México, ecabral@igeofica.unam.mx; SALAZARTLACZANI, L., Instituto de Geofísica, Universidad Nacional Autónoma de México, Mexico City, México, Isalazar@ igeofisica.unam.mx; HURTADO, H. M., Instituto de Geofísica, Universidad Nacional Autónoma de México, Mexico City, México, hugomelendez040@gmail. com

Strong motion instrumentation in Mexico dates from the seventies, accumulating a considerable historical record of significant earthquakes. Such information has been mainly for seismic engineering and seismological research. Having an adequate infrastructure allows us to understand the origin and consequences of the seismic activity, based on timely and reliable information, to facilitate decision making by the authorities, especially in a seismic crisis. However, seismic data is not always the best for a better and faster characterization of the seismic source, raising the need to install GNSS systems and to explore new methodologies and technologies in order to have high real-time accurate positioning. Therefore, the Mexican Servicio Sismológico Nacional (National Seismological Service, SSN) has installed in 42 out of the 63 seismic stations nationwide, GNSS systems for real-time displacement monitoring. This infrastructure integrates receivers from 
the SSN and the Transboundary Land and Atmosphere Long-term Observation and Collaborative network (TLALOCnet); 19 stations include the Trimble RTX option that allows obtaining solutions in real time. The data is shared in streaming with other research groups, including the Mexican Space Weather Service. The acquisition system facilitates monitoring the state of health of the stations. The real-time data is transmitted using the RT17 and NTRIP protocols at 1 sample per second. The SSN uses different telecommunication technologies, like satellite datalinks and the mobile networks, to send the data from the GNSS receiver to the acquisition system. The data repository has crude GPS observables with one sample every $15 \mathrm{~s}, 1 \mathrm{~Hz}$, and $5 \mathrm{~Hz}$ in case of large-scale seismic events.

Recent Advances in Dense Array Seismology

Poster Session · Wednesday 16 May · Riverfront South

Shallow Rigidity Structure From Low-Frequency Wind-Induced Ground Motions Using Co-Located Pressure and Seismic Sensors

WANG, J., UC Santa Barbara, California, USA, jiongwang@umail.ucsb.edu; TANIMOTO, T., UC Santa Barbara, California, USA, toshiro@geol.ucsb.edu

Using data from the USArray Transportable Array (TA) stations and the Southern California Network, we analyzed the wind-induced ground motions recorded by the co-located seismometers andpressure sensors in these networks. Adopting a model by Sorrells (1971), we formulated an equation to retrieve shallow rigidity structure from the co-located seismic and barometric data at low frequencies (below $0.05 \mathrm{~Hz}$ ). We then applied it to retrieve shallow rigidity structure around 50 to 100 meters (depth depends on frequency and wind speed) below many TA stations. Our results can be compared with the USGS Global Vs30 model. We find generally good agreement between our results and the Vs30 model in the Great Appalachian Valley (high rigidity and high S-wave velocity from the Vs30 model) and in the Mississippi Alluvial Plain (low rigidity and low Vs30) but there are some regions with inconsistent results; clearly, the co-located seismic and pressure sensors provide a new approach to test the global Vs30 model. The regions with inconsistent results need to be examined further, as theknowledge of shallow elastic structure is important for ground-motion prediction studies.

\section{Anatomy of Old Faithful from Subsurface Seismic Imaging of Yellowstone National Park, Upper Geyser Basin}

WU, S. M., University of Utah, Utah, USA, sinmei.wu@utah.edu; LIN, F. C., University of Utah, Utah, USA, fanchi.lin@utah.edu; FARRELL, J. M., University of Utah, Utah, USA, jamie.farrell@utah.edu; WARD, K. M., University of Utah, Utah, USA, kevin.m.ward@utah.edu; KARPLUS, M., University of Texas at El Paso, Texas, USA, mkarplus@utep.edu; SMITH, R. B., University of Utah, Utah, USA, robert.b.smith@utah.edu

The Upper Geyser Basin (UGB) in Yellowstone contains one of the highest concentrations of hydrothermal features on Earth including the iconic Old Faithful geyser. Although this area has been the focus of many geological, geochemical, and geophysical studies, the shallow $(<200 \mathrm{~m})$ subsurface structure remains poorly characterized due to limited instrument implementations in this delicate and sensitive environment. The recent availability of seismic dense arrays (large$\mathrm{N})$ permits an environmental-friendly approach to investigate the detailed crustal structure from the low-cost and easy-deployed geophones. To probe the detailed structure in relation to the hydrothermal plumbing of the UGB, we deployed large-N arrays of 3C 5-Hz geophones in both November of 2015 and 2016, composed of 133 stations with $\sim 50 \mathrm{~m}$ spacing, and 519 station locations, with an $\sim 20$ $\mathrm{m}$ spacing, respectively. We constructed cross-correlation functions (CCFs) and extracted Rayleigh-wave signals between $1-10 \mathrm{~Hz}$ via seismic signals excited by nearby hydrothermal features. We observe a clear lateral velocity boundary at $3.3 \mathrm{~Hz}$ frequency that delineates a higher phase velocity of $\sim 1.6 \mathrm{~km} / \mathrm{s}$ in the NE and a lower phase velocity of $\sim 1.0 \mathrm{~km} / \mathrm{s}$ in the $S W$ corresponding to the local geologic formation of rhyolitic and glacial deposits, respectively. We also image a relatively shallow (10-60 m deep) large reservoir with an estimated porosity $30 \%$ located $\sim 100 \mathrm{~m}$ southwest of Old Faithful from the significant spatial-dependent waveform distortions and delays between $5-10 \mathrm{~Hz}$. This reservoir is likely controlled by the local geology with a rhyolitic deposit in the NE acting as a relatively impermeable barrier to vertical fluid ascent. In addition to the static structure, we observe temporal variations in both phase and amplitude from the minutely CCFs with regard to the potential influences from instrument resonance, seismic source, and structure. The preliminary results of variations will be demonstrated and discussed.
Advanced Structural Health Monitoring System for US Department of Veterans Affairs Hospital Buildings

KALKAN, E., US Geological Survey, California, USA, ekalkan@usgs.gov; FLETCHER, J., US Geological Survey, California, USA, jfletcher@usgs. gov; FRIBERG, P. A., Instrumental Software Technologies, New York, USA, p.friberg@isti.com; BAKER, L. M., US Geological Survey, California, USA, baker@usgs.gov; ARCHILLA, J., US Department of Veterans Affairs, District of Columbia, USA, juan.archilla@va.gov

In collaboration with the VA, the US Geological Survey has developed structural health monitoring (SHM) software that utilizes vibration inputs to continually analyze and archive the response characteristics of a building in near real-time. The SHM software is built on the Earthworm (EW) system (Johnson et al., 1995), which is an open data processing platform that allows any continuous waveform data to be collected into ring buffers from a digitizer for further analyses (http:// www.isti2.com/ew). The SHM software initially determines baselines for a suite of structural response parameters, and then continuously examines the response for changes in these parameters. The structural parameters monitored currently are inter-story drift ratios, shear-wave travel times throughout the building, and base-shear capacity-demand ratio. The SHM software is integrated with a webenabled SHM data management framework to support aggregation, storage, and reporting of SHM data obtained and analyzed from instrumented hospital buildings to record strong shaking from earthquakes. By analyzing and characterizing the threshold values for building-specific engineering demand parameters, the SHM software can determine inspection priority to be low, moderate, high or very high and thus assist efforts in evaluating the safety and integrity of buildings in the aftermath of an earthquake. The SHM software is scalable-to support an arbitrary number of sensors, and it is extensible - to accommodate new data streams without the need to rewrite storage and display logic. The SHM software works on site or remotely. The software was validated using both ambient and low- and high-intensity shaking data inputs to a full-scale seven-story reinforced concrete building section tested on the UC San Diego shake table.

\section{Zland 3C 5Hz Node Test Results}

SWEET, J. R., IRIS, New Mexico, USA, justin.sweet@iris.edu; ANDERSON, K. R., IRIS, New Mexico, USA, kent@iris.edu

The IRIS/PASSCAL Instrument Center currently has a small pool of FairfieldNodal Zland 3C 5Hz nodes for community use. In an effort to further refine our best practices for node installation, we have conducted several tests designed to elucidate how PIs can minimize the time needed for node installation while also maximizing data quality and data return. As nodal experiments grow ever larger, these types of time-saving best practices should prove very beneficial to PIs and their deployment teams. Using data from 363 Zland 3C 5Hz nodes collected during the IRIS Wavefields Community Demonstration Experiment in Oklahoma, we present a detailed view of how node performance varied across the network. We examine the behavior of GPS timing with the passage of storms, and how differing levels of ground saturation affect node data quality. Our prior work has already shown that variation in local wind speed is directly tied to increased noise levels across the network in discrete frequency bands. The proximity of a large $(150+)$ wind turbine installation to our network seems a likely source for this noise. In addition to results from the Wavefields experiment, we present results of ongoing lab and field testing at PASSCAL that attemptto quantify node tilt sensitivity. We also investigate benefits and drawbacks of nodes installed: a) on the surface, b) partially buried, and c) fully buried to determine the level of effort required for high-quality data return. Lastly, we determine how accurate GPS timing is affected by moving a node away from the point of activation to better quantify how much latitude PIs have for moving nodes in the field.

\section{Using Cross-Correlation Methods to Characterize Earthquakes Associated with the Socorro Magma Body}

VIECELI, R. E., New Mexico Institute of Mining \& Technology, New Mexico, USA, rev5028@gmail.com; BILEK, S. L., New Mexico Institute of Mining \& Technology, New Mexico, USA, susan.bilek@nmt.edu; WORTHINGTON, L. L., University of New Mexico, New Mexico, USA, Iworthington@unm.edu; SCHMANDT, B., University of New Mexico, New Mexico, USA, bschmandt@ unm.edu; ASTER, R. C., Colorado State University, Colorado, USA, rick.aster@ colostate.edu; DODGE, D. A., Lawrence Livermore National Laboratory, California, USA, dodge1@llnl.gov; PYLE, M. L., Lawrence Livermore National Laboratory, California, USA, pyle4@llnl.gov; WALTER, W. R., Lawrence Livermore National Laboratory, California, USA, walter5@llnl.gov

The Socorro Magma Body (SMB), a thin, sill-like body with a top surface-depth of $19 \mathrm{~km}$ situated within the Rio Grande Rift in central New Mexico, is one of the largest recognized continental mid-crustal magma bodies in the world by area. 
SMB-associated inflation leads to slow regional uplift of a few $\mathrm{mm} / \mathrm{yr}$ and has been linked to longstanding concentrated shallow seismicity with variable spatial and temporal occurrence, including early 20th century events of magnitude 5.5-6. Recent small earthquakes (magnitudes $\sim 3$ to -1 ) have been monitored with a variety of broadband and short-term local seismic networks over the past several decades, but these routine catalogs have not been relocated or fully interpreted in terms of newer models of the structure or its emplacement and history. In February 2015 seismic data were collected above the northern, most rapidly uplifting region of the SMB with a densely spaced temporary array, consisting of 7 broadband and 804 short period Fairfield nodal seismographs. The total array area was $\sim 50 \times 25 \mathrm{~km}$ with node spacing of $\sim 300 \mathrm{~m}$. Here, we exploit all available seismic network data in a correlation framework developed at Lawrence Livermore National Laboratory to detect events and characterize earthquake swarms, clusters, and patterns occurring over the last $\sim 15$ years. Initial results using long- term stations include 1,262 detectors corresponding to local, cataloged events, as well as 2,534 detectors not associated with the catalog. A subset of data from the central region of the SMB was investigated using a lower correlation threshold and resulted in 184 detectors that returned 7,455 detections. We use an existing $1 \mathrm{D}$ velocity model to initially locate all catalog and non-catalog detections with Bayesloc. We also develop an updated 1D velocity model for the region using VELEST and refine locations using Bayesloc. This enhanced catalog will be utilized in interpreting the recent seismicity of the SMB.

\section{Local-Similarity Based Seismic Event Detection and Location in the Western Alps with a Dense Linear Array}

ZHAI, Q., Georgia Institute of Technology, Georgia, USA, qszhai@gatech. edu; PENG, Z., Georgia Institute of Technology, Georgia, USA, zpeng@gatech. edu; LI, Z., Caltech, California, USA, zefengli@gps.caltech.edu; ZHAO, L., Institute of Geology and Geophysics, Chinese Academy of Sciences, Beijing, China, zhaoliang@mail.iggcas.ac.cn

Many recent structural imaging studies involve deployment of dense linear seismic arrays (e.g., HiClimb, CIFALPS) across a target region. These dense arrays can also record many local and regional seismic events that could be used to illuminate fault structures and tectonic processes. Recently Li et al. (2018) developed a local similarity method to detect weak seismic events recorded by Large-N arrays. It computes cross-correlation (CC) for each station with its nearest neighbors and then directly stacks the CC traces into an array-averaged one. Such direct stacking works well for small-aperture arrays (up to ten kilometers) but is not suitable for wide-aperture ones (tens and hundreds of kilometers) because of the time delays at different stations. In this study, we update the local similarity method with time-shift stacking using predicted travel times from a local $1-D$ velocity model. We use a grid-search strategy to detect local events with the highest stacked CC value given a set of hypothetical source locations, similar to the source-scanning algorithm (Kao and Shan, 2004) or the match-and-locate algorithm (Zhang and Wen, 2015). This results in more robust detections than simple stacking and meanwhile provides the estimate of event locations. We apply this updated method to one-year recordings of the China-Italy-France Alps (CIFALPS) dense linear array ( $10 \mathrm{~km}$ spacing and $\sim 400 \mathrm{~km}$ long) deployed along the Western Alps in 2012-2013. We find many new events that are not listed in the existing regional earthquake catalogs. Our results suggest that this method can provide high-resolution seismic event detection and location for both regular linear arrays and Large- $\mathrm{N}$ arrays.

\section{High-Resolution Reflection Imaging of Fractures Using Cross-Dipole Shear Source in a Wellbore}

LI, D., University of Houston, Texas, USA, david.zn.li@gmail.com; TIAN, X., University of Science and Technology of China, Anhui, China, tianxiao@ mail.ustc.edu.cn; HU, H., University of Houston, Texas, USA, hhu5@ central. uh.edu; TANG, X., China University of Petroleum-East China, Shandong, China, tangxiam @aliyun.com; ZHENG, Y., University of Houston, Texas, USA, yzheng24@central.uh.edu

High-resolution characterization of fractures near a well bore is important for many scientific and engineering applications, ranging from natural gas production to nuclear waste storage. Here, we consider single-well reflection imaging, which uses high-frequency sonic data $(\mathrm{kHz})$ recorded by acoustic logging tools to image geologic features near a borehole. In this single-well imaging survey, a tool containing acoustic sources and receivers is placed inside a fluid-filled borehole. The acoustic source produces seismic waves, which propagate into the geological formation near the well. When these waves hit a scatter, they bounce back and are recorded by the receivers. Recently, the development of cross-dipole shear-wave acquisition system allows us to image up to $\sim 10$ 's of meters away from the well. However, these dipole sources produce dispersive Stoneley and flexural waves, which propagate along the surface of the borehole. Stoneley waves can be used to estimate the formation S-wave velocity around the wellbore. However, because the amplitudes of the Stoneley waves are much greater than the amplitudes of the reflected shear waves, the Stoneley waves are treated as noise for seismic imaging and must be removed. In this paper, we propose a new algorithm to image fractures in the rock formation around a fractured gas reservoir using cross-dipole data. The survey consists of a tool containing eight cross-dipole receivers and one dipole source placed inside of a vertical well. First, we show how to remove the large-amplitude Stoneley waves from the data using our nonlinear signal comparison (NLSC) algorithm. We then apply a beam migration to image fractures and we are able to image within $20 \mathrm{~m}$ of the vertical well.

\section{Utilization of Dense Surface Seismic Array for Detection of Low Magnitude Intermediate Depth Earthquakes from Bucaramanga Nest}

ALALLI, A. A., Stanford University, California, USA, alalli@stanford.edu; BEROZA, G. C., Stanford University, California, USA, beroza@stanford.edu

Intermediate-depth earthquakes $(50-300 \mathrm{~km}$ deep) are relatively poorly understood when compared to their deep and shallow earthquake counterparts. The most studied and active intermediate-depth earthquakes are located in the Bucaramanga Nest in Colombia. This active seismic patch $(4 \times 4 \times 8 \mathrm{~km})$ is known to exhibit both spatially and temporally repeated earthquakes that are recorded and observed on the Colombian Seismic Network (RSNC). Although this sparsely distributed receiver network across Colombia is utilized mainly for relocation purposes, and is limited in producing only earthquake catalogs complete up to M2.0 and greater. The objective of our research is to push the detection threshold down to include lower magnitude earthquakes $(M<2.0)$ occurring from the intermediate-depth Bucaramanga earthquake nest utilizing a dense surface seismic array that was deployed a few hundred kilometers northwest of the earthquake nest. The array is about $70 \mathrm{~km} 2$ with over 4500 single component (z-direction) receivers, spaced $100 \mathrm{~m}$ apart, and was left recording continuously for 4 days. By utilizing the close geophone spacing, we try to detect new smallermagnitude earthquakes $(M<1)$ across the 4 -day recording period using the larger magnitude detected earthquakes from the RSNC catalog observed during the same time period of the recording surface array as reference earthquakes and cross-correlate each reference earthquake's waveform with the whole surface array recording time series. Our Preliminary results suggest that the dense surface array is capable of detecting additional lower magnitude earthquakes absent from the RSNC catalog. One of the biggest challenges is related to poor $\mathrm{S} / \mathrm{N}$ ratio across parts of the dense array and complicates the waveform-based detection. Proper signal processing is necessary to do prior to waveform-based crosscorrelation detection and will be investigated in future work.

\section{Seismic Tomography at Brady Geothermal Field, Nevada, With Dense Nodal and Fiber-Optic Seismic Arrays}

NAYAK, A., University of Wisconsin Madison, Wisconsin, USA, anayak5@ wisc.edu; THURBER, C. H., University of Wisconsin Madison, Wisconsin, USA, clifft@geology.wisc.edu; PARKER, L., University of Wisconsin Madison, Wisconsin, USA, Iparker4@wisc.edu; LI, P., University of Wisconsin Madison, Wisconsin, USA, peng.li@wisc.edu; FRATTA, D., University of Wisconsin Madison, Wisconsin, USA, fratta@wisc.edu; ZENG, X., Chinese Academy of Sciences, China, xzeng28@wisc.edu; AK, E., University of Wisconsin Madison, Wisconsin, USA, eak@wisc.edu; FEIGL, K., University of Wisconsin Madison, Wisconsin, USA, feigl@wisc.edu; LORD, N., University of Wisconsin Madison, Wisconsin, USA, lord@geology.wisc.edu; POROTOMO TEAM, University of Wisconsin Madison, Wisconsin, USA, feigl@wisc.edu

We deployed dense seismic arrays to image the shallow structure in the injection area of the Brady Hot Springs geothermal site in Nevada. The arrays were composed of $2385 \mathrm{~Hz}$, three-component nodal instruments and $\sim 9,000 \mathrm{~m}$ of distributed acoustic sensing (DAS) fiber-optic cable installed in surface trenches plus $\sim 400 \mathrm{~m}$ installed in a borehole. The geophone array had an instrument spacing of about $60 \mathrm{~m}$ in the target zone, whereas DAS channel separations were about $1 \mathrm{~m}$, with a $10 \mathrm{~m}$ averaging (gauge) length. The acquisition systems provided 15 days of continuous data including active source and ambient noise signals. A large vibroseis truck was operated at 191 locations, exciting a swept-frequency signal from 5 to $80 \mathrm{~Hz}$ over 20 seconds using three vibration directions. Sweeps were repeated up to four times during different stages of geothermal plant operation: initial normal operation, shut-down, high and oscillatory injection and production, and final normal operation again. After removing the sweep signals, the first P-wave arrivals were automatically picked using a combination of methods. The resulting travel times were used to invert for the 3D P-wave velocity structure. Models with $100 \mathrm{~m}$ and $50 \mathrm{~m}$ horizontal node spacing were obtained, with vertical node spacing of 10 to $50 \mathrm{~m}$. The travel time data were fit to about $30 \mathrm{~ms}$, close to our estimated picking uncertainty. However, many automatic picks were of poor quality, 
and parts of the 3D model were not well resolved due to a lack of picks for some nodes and vibe points. We are carrying out a second round of automatic picking using trace-to-trace correlation, with high-quality, reviewed picks as the master traces for the correlations. We will present our updated 3D P-wave velocity model along with comparisons to other existing information for the structure at the Brady site. We will also present preliminary results from a search for temporal changes in P-wave travel times caused by the changes in fluid injection and production. This work was funded by the Office of Energy Efficiency and Renewable Energy, U.S. Department of Energy, under Award Number DE-EE0006760.

\section{Large-N Seismic Deployment at the Source Physics Experiment (SPE) Phase II Site}

CHEN, T., Los Alamos National Laboratory, New Mexico, USA, tchen@lanl. gov; SNELSON, C., Los Alamos National Laboratory, New Mexico, USA, snelsonc@lanl.gov

The Source Physics Experiment (SPE) is a multi-institutional, multi-disciplinary project that consists of a series of chemical explosions conducted at the Nevada National Security Site (NNSS). The goal of SPE is to understand the complicated effect of geological structures on seismic wave propagation and source energy partitioning, develop and validate physics-based modeling, and ultimately better monitor nuclear explosions. SPE Phase I is located in the hard rock geology, and SPE Phase II is located in the weak rock geology. Deployment of a large number of seismic sensors is planned for SPE Phase II to image the full 3-D wavefield. This large-N seismic deployment will operate near the site of SPE Phase II for four months, recording controlled-sources, earthquakes, and ambient noise. This presentation focuses on the design of the large-N seismic deployment. We show how we optimize the sensor layout based on the geological structure and experiment goals with a limited number of sensors. We predict the recordings of the Large-N array assuming some geophysical models, and estimate how well the Large- $\mathrm{N}$ array may improve our understanding of subsurface structure and source characteristics.

\section{Seismic Reflection Imaging With Earthquake Sources and Dense Arrays:} Beyond Structural Imaging From P-Wave Reflections

QUIROS, D. A., Baylor University, Texas, USA, diego_quiros@baylor.edu; PULLIAM, J., Baylor University, Texas, USA, jay_pulliam @ baylor.edu

Recent studies showed that microearthquakes recorded by a dense array of receivers at the surface have the same raypath geometry as Reverse Vertical Seismic Profiling (RVSP) surveys, which in principle, allows the use of microearthquake sources combined with RVSP processing to produce high-resolution 3D reflection images of structure beneath the receiver array. Earlier examples of the method produced 2D and 3D reflection profiles from a single microearthquake source, with a later example using multiple events to generate a 3D reflection volume underneath the Piedmont Province in Central Virginia. Although the true power of using microearthquakes for reflection imaging lies in the prospect of using redundancy generated from multiple sources, the complexities that result from double couple sources present several challenges. Some of these challenges have been addressed extensively in previous studies, such as hypocenter uncertainty, and sparse illumination from an aftershock distribution, but other issues, such as spurious phases $\left(\mathrm{SD}, \mathrm{PzS}, \mathrm{Sz}_{\mathrm{P}}, \mathrm{SzS}_{\mathrm{z}}\right)$ in P-wave reflection images have not been properly addressed, mostly because previous studies were restricted by using vertical component seismographs. In this study we take advantage of $3 \mathrm{C}$ nodal dense arrays that recorded local seismicity to tackle the issue of these spurious phases. Given that the phases $\mathrm{PzP}, \mathrm{PzS}, \mathrm{S}_{z} \mathrm{P}$, and $\mathrm{SzS}$ are all illuminating the structure beneath the receiver array we use wavefield separation and RVSP processing of microearthquakes to generate different structural images from reflected and converted phases.

Shallow Sedimentary Structure of the Tangshan Earthquake Region Unveiled by Dense Seismic Array and Microtremor Survey

$\underline{B A O}, F$., Institute of Geodesy and Geophysics, Chinese Academy of Sciences, Hubei, China, baofeng@whigg.ac.cn; LI, Z. W., Institute of Geodesy and Geophysics, Chinese Academy of Sciences, Hubei, China, zwli@whigg.ac.cn

The Tangshan fault belt is deemed as the seismogenic fault for the 1976 Ms7.8 Tangshan earthquake, which is one of the most devastating earthquakes in the last 100 years in the world and caused more than 240,000 deaths. The dense array ambient vibration surveys with $\sim 4 \mathrm{~km}$ inter-station distance 146 stations were applied in the spring of 2017. The sedimentary resonance frequencies were measured by the Horizontal-to-Vertical Spectral Ratio (HVSR) method to gain sedimentary thickness distribution and basement morphology. Furthermore, a $\sim 1 \mathrm{~km}$ inter-station distance seismic profile was deployed along a line perpendicular to the strike of the Tangshan fault belt to investigate the detailed shallow sedimentary structures. Extensive tests are conducted to evaluate and verify the reliability of the HVSR curves. With these HVSR curves, the two-dimensional Quaternary sedimentary structures cross the fault belt are imaged by frequencyto-depth conversion. Two-dimensional HVSR profile clearly reveals two seismic impedance interfaces at $\sim 100 \mathrm{~m}$ and $300 \sim 800 \mathrm{~m}$ depth. The thickness of the unconsolidated and semi-consolidated sedimentary is $\sim 100 \mathrm{~m}$ with very small variations, which is consistent with the seismic reflection interface from shallow seismic reflection exploration. While the buried depth of the Quaternary sedimentary basement increases from 300 to $800 \mathrm{~m}$ from the west to the east along the profile, which is also consistent with the Quaternary sediment depth derived from previous studies. It is worth noting that the depth of the Quaternary sedimentary basement just beneath the Tangshan fault belt varies rapidly with $\sim 200$ meters, which well agrees with the spatial characteristics of the Tangshan fault revealed by deep seismic reflection profiling. It may suggest that the Tangshan fault belt has been significantly ruptured and modified by strong earthquake activities since Quaternary.

\section{Seismic Event Screening}

Poster Session · Wednesday 16 May · Riverfront South

Further Development and Testing of ML-MC as a Depth Discriminant at Local Distances

SCALES, M. M., University of Utah, Utah, USA, scales@seis.utah.edu; VOYLES, J. R., University of Utah, Utah, USA, jonathanvoyles1@gmail.com; HALE, J. M., University of Utah, Utah, USA, jmhale@seis.utah.edu; KOPER, K. D., University of Utah, Utah, USA, koper@seis.utah.edu; BURLACU, R., University of Utah, Utah, USA, burlacu@seis.utah.edu; PECHMANN, J. C., University of Utah, Utah, USA, pechmann@seis.utah.edu

Seismic source discrimination at local distances $(<200 \mathrm{~km})$ is becoming increasingly important within the nuclear monitoring community. A study conducted by Koper et al. (2016) found that the difference between local magnitude (ML) and coda/duration magnitude (MC) could distinguish between mining-induced seismicity and natural seismicity in Utah. They found that the shallower mining-induced earthquakes (depths $<2-3 \mathrm{~km}$ ) had more negative ML-MC values than the generally deeper $(\geq 5 \mathrm{~km})$ tectonic events. Similar results showing that ML-MC decreases as source depth approaches the surface have recently been found in Yellowstone, Oklahoma, and Italy. Here we investigate how well direct measurements of peak amplitude $(\mathrm{A})$ and duration $(\mathrm{t})$ made at individual stations can be used as proxies for the network averaged ML-MC values. In particular, we investigate how $\log 10(\mathrm{~A} / \mathrm{t})$ varies as a function of distance, how quickly the variance decreases as more stations are averaged together, and whether individual station corrections are warranted. We also examine how changes to the procedures used to measure $\mathrm{A}$ and $\mathrm{t}$ affect the performance of $\log 10(\mathrm{~A} / \mathrm{t})$ as a depth discriminant. We aim to replicate and explain our ML-MC observations using a three-dimensional, fourth-order, finite-difference code (SW4) to synthesize high-frequency waveforms in realistic Earth models that contain topographic and volumetric scattering. The ultimate goal of this study is to introduce a new depth discriminant to nuclear monitoring practices that can be applied to all networks and help differentiate mid- and lower- crustal earthquakes from potential explosions.

Discrimination of Anthropogenic Events and Tectonic Earthquakes in Utah Using a Quadratic Discriminant Function Approach with Local-Distance Amplitude Ratios

TIBI, R., Sandia National Laboratories, New Mexico, USA, rtibi@sandia.gov; KOPER, K. D., Department of Geology and Geophysics, University of Utah, Salt Lake City, Utah, USA, koper@seis.utah.edu; PANKOW, K. L., Department of Geology and Geophysics, University of Utah, Salt Lake City, Utah, USA, pankow@seis.utah.edu; YOUNG, C., Sandia National Laboratories, New Mexico,USA, cjyoung@sandia.gov

Most of the commonly used seismic discrimination approaches are designed for regional data. Relatively little attention has focused on discriminants for local distances $(<200 \mathrm{~km})$, the range at which the smallest events are recorded. We take advantage of the variety of seismic sources and the existence of a dense regional seismic network in the Utah region to evaluate amplitude ratio seismic discrimination at local distances. First, we explored phase-amplitude Pg-to-Sg ratios for multiple frequency bands to classify events in a dataset that comprises populations of single-shot chemical explosions, shallow and deep ripple-fired mining blasts, mining-induced events, and tectonic earthquakes. We achieved a limited success. Then, for the same dataset, we combined the Pg-to-Sg phase-amplitude ratios with Sg-to-Rg spectral amplitude ratios in a multivariate quadratic dis- 
criminant function (QDF) approach. For two-category, pairwise classification, seven out of ten population pairs show misclassification rates of about $20 \%$ or less, with five pairs showing rates of about $10 \%$ or less. The approach performs best for the pair involving the populations of single-shot chemical explosions and mining-induced events. By combining both Pg-to-Sg and Rg-to-Sg ratios in the multivariate QDFs, we are able to achieve an average improvement of about $4-14 \%$ in misclassification rates compared to Pg-to-Sg ratios alone. When all five event populations are considered simultaneously, as expected, the potential for misclassification increases and our QDF approach using both Pg-to-Sg and $\mathrm{Rg}$-to-Sg ratios achieves an average success rate of about $74 \%$, compared to the rate of about $86 \%$ for two-category, pairwise classification.

\section{Present-Day Plate Boundary Deformation and Seismic Hazard in the Caribbean Poster Session - Wednesday 16 May • Riverfront South}

\section{Moment Tensor Solutions along the Northern Caribbean Plate Boundary in Western Hispaniola (Haiti)}

CORBEAU, J., Institut de Physique Du Globe de Paris, Martinique, corbeau@ ipgp.fr; CLOUARD, V., IPGP, Martinique, clouard@ipgp.fr; GONZALEZ, O. L., CENAIS, Cuba, oleary@cenais.cu; ROLANDONE, F., ISTeP UPMC, France, frederique.rolandone@upmc.fr; LEROY, S., ISTeP UPMC, France, sylvie.leroy@upmc.fr; MERCIER DE LÉPINAY, B., Géoazur, France, bmercier@geoazur.unice.fr

The relative motion of the Caribbean plate with respect to the North American plate is oblique to the plate boundary, which implies both transpression and partitioning. The plate motion appears to be partitioned and accommodated in the Hispaniola region along two major E-W left-lateral strike-slip structures, the Septentrional-Oriente Fault Zone (SOFZ) in the north and the EnriquilloPlantain-Garden Fault Zone (EPGFZ) in the south, and across the North-Haitian thrust fault (NHF), the fold-and-thrust Trans-Haitian belt and the Massif de la Selle in southern Haiti. A major issue in Haiti further to the destructive earthquake of January 12th, 2010 near Port-au-Prince is the localization of the present seismic activity, the identification of the active faults and the determination of their characteristics. We use the local seismicity recorded at 27 broadband seismic temporary stations deployed along a $200 \mathrm{~km}$-long N-S transect across Haiti during the Trans-Haiti project from April 2013 to June 2014. 36 moment tensors for earthquakes with magnitudes between 3 and 4 were calculated by full waveform inversion using the ISOLA software. The analysis of the new moment tensors for the Haiti upper lithosphere indicates that normal, thrust and strikeslip faulting are present, with a predominance of thrusting events near the city of Port-au-Prince, the location of the January 12th, 2010 earthquake. Strike-slip faulting events are located in the southern part of Haiti, along the EPGFZ. Most of the normal faulting events are located in the area of the Azuei and Enriquillo lakes. A cluster of 6 thrust faulting events of the end of June 2013 is also imaged in the north of the Enriquillo lake. The preliminary seismic data of our Haitian network, even noisy, tend to confirm that the current deformation is in majority compressive and located at the eastern end of the major EPGFZ.

The Role of Long-Term Tectonic Deformation on the Distribution of PresentDay Seismic Activity in the Caribbean and Central America

SCHOBELOCK, J. I., Virginia Polytechnic Institute and State University, Virginia, USA, jpent8@vt.edu; STAMPS, D. S., Virginia Polytechnic Institute and State University, Virginia, USA, dstamps@vt.edu; PAGANI, M., Global Earthquake Model, Pavia, Italy, marco.pagani@globalquakemodel.org; GARCIA, J. A., Global Earthquake Model, Pavia, Italy, julio.garcia@globalquakemodel.org; STYRON, R., Global Earthquake Model, California, USA, richard.styron@ globalquakemodel.org

The Caribbean and Central America region (CCAR) undergoes the entire spectrum of earthquake types due to its complex tectonic setting comprised of transform zones, young oceanic spreading ridges, and subductions along its eastern and western boundaries. CCAR is, therefore, an ideal setting in which to study the impacts of long-term tectonic deformation on the distribution of presentday seismic activity. In this work, we develop a continuous tectonic strain rate model based on inter-seismic geodetic data and compare it with known active faults and earthquake focal mechanism data. We first create a $0.250 \times 0.25$ o finite element mesh that is comprised of block geometries defined in previously studies. Second, we isolate and remove transient signals from the latest open access community velocity solution from UNAVCO, which includes 339 velocities from COCONet and TLALOCNet GNSS data for the Caribbean and Central America, respectively. In a third step we define zones of deformation and rigidity by creating a buffer around the boundary of each block that varies depending on the size of the block and the expected deformation zone based on locations of GNSS data that are consistent with rigid block motion. We then assign each node within the buffer a 0 for the deforming areas and a plate index outside the buffer for the rigid. Finally, we calculate a tectonic strain rate model for CCAR using the Haines and Holt finite element approach to fit bi-cubic Bessel splines to the the GNSS/GPS data assuming block rotation for zones of rigidity. Our model of the CCAR is consistent with compression along subduction zones, extension across the mid-Pacific Rise, and a combination of compression and extension across the North America-Caribbean plate boundary. The majority of CCAR strain rate magnitudes range from -60 to 60 nanostrains/yr. Modeling results are then used to calculate expected faulting behaviors that we compare with mapped geologic faults and seismic activity.

Seismic Hazards and Historic Earthquakes in Puerto Rico and the Northern Caribbean Region Poster Session · Wednesday 16 May · Riverfront South

\section{Hazard Implications from High-Precision Earthquake Relocations in the} Dominican Republic

MARTINEZ, C. M., Baylor University, Texas, USA, christina_martinez1@ baylor.edu; MEJIA, H. P., Baylor University, Texas, USA, hannah_mejia@ baylor.edu; PULLIAM, J., Baylor University, Texas, USA, jay_pulliam@ baylor.edu; POLANCO RIVERA, E., Autonomous University of Santo Domingo, Santo Domingo, Dominican Republic, eugenio_polanco_rivera@ msn.com; MARTINEZ, F., Autonomous University of Santo Domingo, Santo Domingo, Dominican Republic, fmartinez51@uasd.edu.do; LEONEL C, J. M., Autonomous University of Santo Domingo, Santo Domingo, Dominican Republic, jleonel78@uasd.edu.do; HUERFANO, V. A., Puerto Rico Seismic Network, University of Puerto Rico, Mayagüez, Puerto Rico, victor@prsnmail. uprm.edu

Accurate earthquake locations are critical to identifying faults, understanding tectonics, and estimating a region's seismic hazard. The Dominican Republic and neighboring Haiti have been the site of numerous devastating earthquakes. A complex pattern of tectonic stresses is created by (a) the oblique subduction of the southward-dipping North American plate in the north, (b) the east-west-trending Septentrional Northern transform fault system, (c) Enriquillo Plantain Garden fault zone in the south, and (d) convergent motion generating great topographical variations, including the Cordillera Central in the center of the island. However, the seismic hazard associated with the island's faults and the precise locations and characteristics of the faults are poorly known. To improve understanding of seismic hazard on the island of Hispaniola, we relocated events recorded by a temporarily densified broadband network from 2013 to 2017. Fifteen hundred events of magnitude greater than 2.5 were recorded in the span of four years, 150 of which have magnitudes greater than 4 . Each event has an average of $15 \mathrm{P}$ wave arrival picks and $8 \mathrm{~S}$ wave arrival picks. Both single-event and double-difference techniques are used, in conjunction with a new 1D model for the Dominican Republic, to improve the accuracy of earthquake locations and the geometry of associated fault zones. We will compare the "traditional" (single-event) relocations with those generated by a double difference technique. The catalog relocated in the new $1 \mathrm{D}$ produces several nearly linear features that may be previously undiscovered faults. We intend to relocate events in new 3D models, as well, and thereby investigate the distribution of faults at crustal depths, as well.

\section{Probabilistic Seismic Hazard Modeling for Puerto Rico and the U.S. Virgin Islands}

MCNAMARA, D. E., US Geological Survey, Colorado, USA, mcnamara@usgs. gov; MUELLER, C. S., US Geological Survey, Colorado, USA, mueller@usgs. gov; PETERSEN, M. D., US Geological Survey, Colorado, USA, mpetersen@ usgs.gov; POWERS, P. M., US Geological Survey, Colorado, USA, powers@ usgs.gov; SHUMWAY, A. M., US Geological Survey, Colorado, USA, ashumway@usgs.gov; HOOVER, S. M., US Geological Survey, Colorado, USA, shoover@usgs.gov

The most recent USGS Probabilistic Seismic Hazard Assessment (PSHA) for Puerto Rico and the U.S. Virgin Islands was completed in 2003. An update is planned in order to inform building codes and other structural-design guidelines, as well as earthquake-mitigation and emergency-response plans. Recently the USGS National Seismic Hazard Model Project (NSHMP) implemented a new PSHA software system (nshm-haz) which replaces legacy Fortran codes and provides a modern platform to compute future seismic hazard models. In this study, we use the new nshm-haz system to explore: 1) updates to the earthquake 
source model since 2003, 2) new ground motion models, and 3) new fault slip rates. We present the sensitivity study, and calibrate against the 2003 seismic hazard model for Puerto Rico and the U.S. Virgin Islands.

\section{Seismic Structure of Convergent Plate Margins}

Poster Session • Wednesday 16 May · Riverfront South

Margin-Wide Continental Crust Anisotropy in the Mexican Subduction Zone. HUESCA-PEREZ, E., CONACYT-Centro de Investigacion Cientifica y de Educación Superior de Ensenada, Baja California Sur, Mexico, ehuesca@gmail. com; VALENZUELA, R. W., Universidad Nacional Autónoma de México, Mexico,raul@ollin.geofisica.unam.mx; ORTEGA, R., Centro de Investigación Cientifica y de Educación Superior de Ensenada, Mexico, ortegarobe@gmail. com; HUSKER, A. L., Universidad Nacional Autónoma de México, Mexico, uskerhay@gmail.com; GUTIERREZ, E., CONACYT-Centro de Investigacion Cientifica y de Educación Superior de Ensenada, Mexico, edahigure@gmail.com; CABRAL-CANO, E., Universidad Nacional Autónoma de México, Mexico, ecabralcano@gmail.com

We present new shear wave anisotropy measurements in the continental crust along the Mexican subduction zone obtained from tectonic tremor. The new measurements were made in the states of Jalisco and Michoacán, and also in Oaxaca state. In order to make a complete analysis of the anisotropic crustal structure, we also include measurements reported in Guerrero state by Huesca-Pérez et al. (2016). The only measurements of crustal anisotropy previously available in the subduction zone were performed by Soto et al. (2009) in Jalisco and Michoacán using local seismicity. However, tectonic tremor is abundant and offers an opportunity to determine anisotropy parameters. Polarization and splitting analyses were performed using broad-band, three-component seismograms. Results show that splitting times range between 0.07 and $0.34 \mathrm{~s}$. These values are similar to the splitting magnitudes typically observed in the continental crust. Fast polarization azimuths are variable and heterogeneous in Jalisco and Michoacán and do not align with the local stress field, thus suggesting that the anisotropic structure, in general, could be controlled by local foliations or geological structures. In Oaxaca, fast polarization directions tend to align with Quaternary faults and are oblique with respect to the local stress field, which suggests that geological structures are the source of anisotropy. The along-margin anisotropic structure in the Mexican subduction zone is heterogeneous and oblique to the stress field, and consequently could be mainly controlled by structure. However, several other factors such as nonlinear strain in the continental crust as a result of Slow Slip Events, variations of pore fluid pressure, deep crustal mineralogy, and/or upper crust foliations and schistosity (as is the case in Guerrero state) could be inducing the observed anisotropy pattern.

\section{Seismic Structure of the Austral Basin, Patagonia, Using Surface Wave Phase Velocity}

DUCA, L., Departamento de Sismología, Facultad de Ciencias Astronómicas y Geofísicas, Universidad Nacional de La Plata, Buenos Aires, Argentina, leticiaduca@gmail.com; ROSA, M. L., Departamento de Sismología, Facultad de Ciencias Astronómicas y Geofísicas, Universidad Nacional de La Plata, Buenos Aires, Argentina, mlrosa@fcaglp.unlp.edu.ar; FLORES, G., YPF SA, Buenos Aires, Argentina, gonzalo.flores@ypf.com

The construction of crustal and uppermost mantle velocity models is a basic and essential subject in seismology because is vital to an understanding of continental tectonics and is often required as a priori information for various geological and geophysical researches. Surface waves phase velocity provides information that is useful in developing shear wave velocity models at regional scales. The seismic structure of the Patagonian region is poorly understood because the availability of stations is scarce compared to other regions of South America. A better knowledge of the velocity structure in this area will improve earthquake location, providing the structural framework for an assessment of natural hazards and valuable information of the Earth's dynamics. In this work phase velocity dispersion curves of earthquake-generated surface waves were used to determine models of the crust and uppermost mantle seismic structure for the Austral basin. This basin is located in southern Patagonia and its evolution is due to the interaction between the South American plate and the Antarctic plate. Rayleigh- and Lovewave phase velocity curves were obtained using two methods based on different seismic stations configurations. Our models reveal a sedimentary low velocity layer of about $8 \mathrm{~km}$ and a Moho depth of about $35 \mathrm{~km}$, which is compatible with estimated values obtained from other geophysical methods. Results from this study help constrain the seismic characteristics of the area and will contribute to better define the regional tectonics of Patagonia.

\section{Lg 0 Model for Western Tibet}

JAISWAL, N., Indian Institute of Technology Kharagpur, West Bengal, India, namrataj.iitkgp@gmail.com; SINGH, C., Indian Institute of Technology Kharagpur, West Bengal, India, chandrani@gg.iitkgp.ernet.in

We investigate the Lg wave attenuation characteristics for the Western Tibet using a tomographic regionalization method. A total of 378 regional events of magnitudes $(\mathrm{Mb})$ greater than 4.5 , and focal depth less than $50 \mathrm{Km}$, recorded at 52 stations are considered. The $\mathrm{Lg}$ wave attenuation coefficient at $1 \mathrm{~Hz}(\mathrm{LgQ} 0)$ is calculated in the group-velocity window $3.6-2.8 \mathrm{Km} / \mathrm{s}$ by using the two-station method (TSM). This method considers the spectra from two stations which are (1) aligned approximately with the source and (2) separated enough to permit the use of the standard TSM for Lg Q measurement and also has the advantage to remove the source effect during the analysis. Out of initial 11,767 TSM pairs, 3,371 high-quality inter-station paths have been selected as input for the tomographic inversion. We have observed the lowest $\operatorname{LgQ} 0(<50)$ structure in the westernTibetan Plateau, lower LgQ0 (50-100) values in the Himalayas and higher LgQ0 (100-300) zone in the Lhasa Terrain. We interpret these observations in terms of both intrinsic and scattering effects caused by the presence of partial melting, crustal thickness as well as heterogeneities present below the area.

Characteristics of the Double Benioff Zones in the Hikurangi Subduction Zone, New Zealand, Based on Nested Regional-Global Seismic Tomography and Waveform Cross-Correlation Relocation

AZIZ ZANJANI, F., University of Miami, Florida, USA, fzanjani@rsmas. miami.edu; LIN, G., University of Miami, Florida, USA, glin@rsmas.miami. edu; THURBER, C. H., University of Wisconsin-Madison, Wisconsin, USA, cthurber@wisc.edu

Double Benioff Zones (DBZs) have been previously observed in the Hikurangi trench, New Zealand. The correlation between seismicity and velocity heterogeneities can help understanding of their occurrence. Therefore, seismic tomography is commonly applied to identify the position and extent of the down-going slabs at depth in addition to crustal and upper mantle velocity heterogeneities. Previous studies developed three-dimensional seismic velocity models based on local and regional data. The recent availability of multiscale seismic tomography and waveform cross-correlation can boost the structural and seismicity resolution especially in areas with sparse data. Here, we investigate the characteristics of the DBZs along the strike of Hikurangi. We obtain local and regional waveform data from Geonet and teleseismic arrival times reported by the International Seismological Center for events within magnitude range of $2-5$ between January 2012 and July 2017. We apply the teletomoDD algorithm based on absolute and differential times in different scales. This algorithm uses nested regional-global model parameterization that builds a coarser global model encompassing a finely gridded regional one. A differential-time relocation method based on waveform cross-correlation data improves the relative locations with $\sim 500 \mathrm{~m}$ uncertainties in both horizontal and vertical. Our preliminary relocation results show a clear DBZ in the north and south of the trench, but the DBZ disappears in the central North Island. We also observe a decrease in DBZ layer separation and bending of the slab from the north to the south of the trench. Seismicity in the upper and lower planes if correlated with velocity anomalies provides insights about the causes of the within-slab-deformation (e.g. slab dehydration). Tracking such correlation along the trench may explain the presence/absence of the DBZs in some cross-sections and thereafter the mechanism responsible for intermediate-depth earthquakes.

\section{Frequency-Dependent Crustal Attenuation from Lg-Waves in Alaska}

JAMBO, E., University of Memphis, Tennessee, USA, ejambo@memphis.edu

The increase of station coverage since 2014 due to the presence of the EarthScope USArray (TA) in Alaska provides an opportunity to investigate crustal attenuation in Alaska using Lg-waves. Lg waveforms provide a good measure of apparent attenuation because they propagate as multiple reflected shear waves trapped within the crust. $\mathrm{Lg}$ is often the strongest phase on the seismogram at regional distances from $2^{\circ}$ to $25^{\circ}$. Although there have been other studies to determine attenuation in Alaska, theyfocused on small areas where data were available at the time of the study. The goal of our study is to investigate crustal attenuation throughout Alaska and define the locations and characteristics of $Q$ transitions or boundaries, if there are any. Our approach is similar to that of Benz et al. (1997) and McNamara et al. (1996). This approach allows quantifying the attenuation of the crust using $\mathrm{Lg}$ Fourier spectral amplitude in narrow frequency bands of earthquakes that occurred within a given region and the inversion includes source and station terms. Initial results using the ML 5.3 Tok, Alaska, earthquake of 2017/02/13 that occurred in eastern south-central Alaska show Q at $1 \mathrm{~Hz}(\mathrm{Qo})$ to generally be around $100-150$ in south central, eastern, and south- 
eastern Alaska, with the power on frequency (eta) ranging from 0.75 to 1.1 . These results are somewhat lower than the more restricted results of McNamara (2000) in south central Alaska of $\mathrm{Qo}=220$ and eta $=0.66$. There may be an azimuthal dependence in Qo in southeastern central Alaska with somewhat higher values parallel to the structural grain compared to perpendicular to the structural grain. For ray paths crossing the western cordillera into Canada, the Qo appears to be about 50 and eta about 1.1. Differences in Qo parallel and perpendicular to the structural grain have been observed elsewhere.

The Seismic Strong Motion Array Project (SSMAP) and September 5, 2012, Mw=7.6 Nicoya, Costa Rica, Earthquake Investigation during 2006-2016 SIMILA, G. W., CSU Northridge, California, USA, gerry.simila@csun. edu; MOHAMMADEBRAHIM, E., CSU Northridge, California, USA, ehsangfk@gmail.com; QUINTERO, R., OVSICORI Universidad Nacional, Heredia, Costa Rica, ronnie.quintero.quintero@una.ca

Seismic gaps along the subduction zones are locations where large earthquakes have not occurred in a long time. These areas are considered locked and are accumulating large amounts of strain energy that will ultimately be released in major earthquake. The Nicoya Peninsula in northwestern Costa Rica was considered a zone with this type of seismic gap. The previous major earthquakes in Nicoya occurred on 1853, 1900 and 1950, which indicates about a 50-year recurrence interval for the characteristic earthquake cycle. With the goals to: 1) record and locate strong subduction zone mainshocks [and foreshocks, "early aftershocks", and preshocks] in Nicoya Peninsula, at the entrance of the Nicoya Gulf, and in the Papagayo Gulf regions of Costa Rica, and 2) record and locate any moderate to strong upper plate earthquakes triggered by a large subduction zone earthquake in the above regions, a seismic strong motion array (SSMAP project) was installed in the Nicoya Peninsula, array composed of 10 sites with Geotech A900 accelerographs. Also, the OVSICORI-UNA network was upgraded with ES-T episensors that could record the large event. On September 5, 2012, a Mw=7.6 earthquake occurred in the seismic gap and appears to be the expected event based on the 50 years recurrence interval, but was instead 62 years later. The main shock focal mechanism was thrust faulting of the Cocos plate in the Middle America trench with strike N54W and dip 20 degrees NE. The mainshock location was $9.671 \mathrm{~N}$ and $85.878 \mathrm{~W}$. The maximum accelerations from two A900 stations perpendicular to the trench, Fortuna (distance $112 \mathrm{~km}$ ) and Pedernal (distance $128 \mathrm{~km}$ ) were: $13.8 \%$ and $8.9 \% \mathrm{~g}$; although the main acceleration was recorded at Dulce Nombre de Nicoya 122\% g. The October 10 (MW 5.3) and 24 (Mw 6.6) aftershocks recorded at Tamarindo were accelerations of $2.4 \%$ and $8.2 \% \mathrm{~g}$. We also relocated 50 events from 2006 to 2016 for moderate magnitudes $(4<\mathrm{Mw}<6.5)$, mainly located in Nicoya Peninsula region.

\section{Interdisciplinary Seismotectonic Analysis in the Broken Foreland of the NW Argentine Andes}

ZECKRA, M., University of Potsdam, Brandenburg, Germany, zeckra@unipotsdam.de; ARNOUS, A., Universidad Nacional de Tucumán, Tucumán, Argentina, aarnous.aa@gmail.com; ARANDA VIANA, G., Universidad Nacional de Salta CONICET-IBEGIO, Salta, Argentina, german.aranda. gn20@gmail.com; CRIADO SUTTI, E. J. M., Universidad Nacional de Salta CONICET-IBEGIO, Salta, Argentina, ejmsutti@gmail.com; KRÜGER, F., University of Potsdam, Germany, kruegerf@geo.uni-potsdam.de; STRECKER, M. R., University of Potsdam, Germany, manfred.strecker@geo.uni-potsdam. de; HONGN, F., Universidad Nacional de Salta CONICET-IBEGIO, Salta, Argentina,fhongn@aol.com

The extensive spatial impact of the ongoing orogenesis in the south central Andes leads to significant recent tectonic activity in great distance to the driving forces of the plate boundary. The complex multi-stage evolution of the Santa-BárbaraSystem morpho-strucural province in the foreland of the NW Argentine Andes comprises reactivated inherited structures as well as Quaternary structures. The easternmost extension of the Andean deformation front is only poorly constrained yet. Recently, the need for a better understanding of the neotectonic settings for hazard and risk mitigation efforts became obvious in 2015, when a Mw 5.7 earthquake hit the town of El Galpón in the Salta Province. For this reason, we installed a local seismological network around the estimated epicenter and noteworthy geological structures. We were able to collect 15 months of continuous data from 13 stations showing a wide range of earthquake sources. Besides local crustal events, including aftershocks of the 2015 events, we also observed interplate activity underneath the Puna plateau and very deep earthquakes at approximately $600 \mathrm{~km}$ depth. Together with the analysis of seismic-reflection lines crossing the study area we detected the fault, which is responsible for the majority of localized seismic events. In addition, for a number of suspected surface fault locations seismic-refraction and $2 \mathrm{D}$ electrical resistivity tomographies were carried out. The outcome from these surveys were merged with information from geological mapping and geomorphological analyses of DEMs and river networks. Thus, we can distinguish between active and non-active tectonic structures and identify their geometries. The multidisciplinary integration of geoscientific information portrays the seismotectonic set-up of the easternmost margin of the NW Argentine Andes in its entirety. Thereby, this work contributes to the comprehension of the regional, large-scale processes of convergent plate margins.

Structure and Dynamics of Earth's Mantle

Poster Session . Wednesday 16 May · Riverfront South

Upper-Mantle Seismic Anisotropy beneath the Amazonian Craton and Central Brazil from Analysis of Shear-Wave Splitting

VILLANOVA, L., Universidade de Brasilia, DF, Brazil, lyaravillanova@yahoo. com; CONDORI, C., Universidade de Brasilia, Lima, Peru, gfcristobalcq@gmail. com; GONZAGA, M., Universidade de Brasilia, DF, Brazil, marcoagonzag@ gmail.com; FRANÇA, G.S., Universidade de Brasilia, DF, Brazil, georgefranca@ gmail.com

The Amazonian Craton, composed of the Guyana and Guaporé Shields, is one of oldest complex tectonic structures located in the north of the South American stable platform. Currently, following the new addition to the Brazilian Seismological Network, several geophysical studies have been carried out in this region, focusing on understanding the structure of the lithosphere. Aspects like the dynamic and deformation processes of the lithosphere and stratosphere remain poorly understood. Seismic anisotropy, or the directional dependence of seismic wave speeds, can potentially provide us with insight into the dynamics of recent and past deformational processes in the upper-mantle. In this study, we applied the shear wave splitting method to study the seismic anisotropy of the upper-mantle in the Amazonian Craton and Central Brazil. We analyze shear wave splitting for core phases (SKS and SKKS) at 15 broadband seismic stations of the Brazilian Seismological Network (RSBR). We measure the splitting parameters, (fast-polarization direction $\Phi$ and delay time $\delta \mathrm{t}$ ), using the technique of Silver and Chan (1991). Our preliminary results show evidences of complex seismic anisotropy in the upper-mantle beneath all the seismic stations, with the average values of $\delta$ t varying between 0.8 and 1.1 seconds and $\Phi$ predominantly oriented to the ENE-WSW which is close to the absolute plate motion direction, consistent with observations seen in previous work. On the other hand, stations on or near the rift (between Guyana and Guaporé Shields) show fast-polarization directions aligned parallel to the rift axis. Keywords: seismic anisotropy, uppermantle, Amazonian Craton, shear wave splitting, South American plate

\section{Structural Complexity and Anisotropy of the Crust and Upper Mantle along the St. Lawrence Corridor, Eastern Canada}

BENT,A.L., Natural Resources Canada-Ottawa, allison.bent@canada.ca; KAO, H., Natural Resources Canada-Sidney, honn.kao@canada.ca; DARBYSHIRE, F. A., Université du Québec à Montréal, darbyshire.fiona_ann@uqam.ca

The highly populated St. Lawrence corridor in eastern Canada comprises three active seismic zones separated by regions of low seismicity. Understanding the unequal distribution of seismicity has potential implications for hazard assessment. The region is known to be tectonically complex with the Canadian Shield to the north of the river and the Appalachians to the south. To better define the structural complexities, teleseismic receiver function models were developed for seismograph stations along the St. Lawrence supplementing gaps in the broadband coverage of the Canadian National Seismograph Network with temporary stations and taking advantage of the additional coverage provided by the US Transportable Array. Pervasive features, such as a high velocity lid and low velocity mid-crustal layer, are observed allowing for the ID models to be combined to develop a pseudo-3D model for the region from the Charlevoix Seismic Zone to Montreal. Modeling the region from Charlevoix northeast to the mouth of the St. Lawrence River is ongoing but in its early stages. The models at individual stations are azimuthally dependent with apparently higher crustal shear velocities for waves coming from the south. Evaluation of the azimuthal dependence suggests that it can be explained by the uppermost layer dipping toward the north or northeast. A further contribution from anisotropy cannot be ruled out. Evidence for anisotropy at greater depths is obtained from SKS splitting. Fast-polarization directions are subparallel to the strike of the St. Lawrence valley in the east and parallel to the valley further west, with a slight rotation of fast orientation from west to east. Delay times for single measurements vary from 0.4 to 1.6 seconds, averaging $\sim 1$ second. This delay time requires an upper-mantle component, likely a combination of contributions from "fossil" lithospheric anisotropy and mineral alignments due to present-day sublithospheric mantle flow. 
Multi-Scale Mantle Structure underneath North America from a New Tomographic Model of Seismic Shear Velocity

PORRITT, R. W., University of Texas, Institute For Geophysics, Texas, USA, rwporritt@gmail.com; BECKER, T. W., University of Texas, Institute For Geophysics, Texas, USA, twb@ig.utexas.edu; AUER, L., TRACKTICS GmbH Switzerland, ludwig.auer@gmail.com; BOSCHI, L., Sorbonne Universités, UPMC Univ Paris 06, CNRS, Institut des Sciences de la Terre de Paris, France, larryboschi@gmail.com

The USArray has facilitated a revolution in the integration of seismic imaging and geodynamic modeling. We present a whole-mantle, variable resolution, shearwave tomography model based on newly available and existing seismological datasets including regional body-wave delay times and multi-mode Rayleigh and Love wave phase delays. The dataset of previously published delays contributes $\sim 600,00$ S+ body wave delays, distributed globally, $\sim 160,000 \mathrm{~S}$ wave delays used in the DNA13 regional tomographic model focused on the western and central US, and $\sim 86,000 S$ and SKS delays measured on stations in western South America. Additionally, we derive $\sim 4,100,000 \mathrm{~S}+$ body wave delays through correlation of observed waveforms with 1-D PREM synthetics computed with Syngine for stations in the continuous US, Alaska, and the global seismic networks (IU, II). The surface wave dataset includes fundamental mode and overtone Rayleigh wave data from Schaeffer and Lebedev (2014), ambient-noise derived Rayleigh wave and Love wave measurements from Ekstrom (2013), newly computed fundamental mode ambient noise Rayleigh wave phase delays for the continuous US up to July 2017, and other, previously published, measurements. These datasets, along with a data-adaptive parameterization utilized for the SAVANI model (Auer $e t$ al., 2014), allow significantly finer-scale imaging than previous global models, rivaling that of regional-scale approaches, under the USArray footprint in the continuous US, while seamlessly integrating into a global model. We parameterize the model for both vertically (vSV) and horizontally (vSH) polarized shear velocities by accounting for the different sensitivities of the various phases and wave types. The resulting, radially anisotropic model allows for a range of new geodynamic analysis, including estimates of mantle flow or seismic anisotropy, without generating artifacts due to edge effects, or requiring assumptions about the structure of the region outside the well resolved model space. Our model images a number of geologically important features, including the Farallon slab and its constituent components, a complex undulating cratonic lithosphere, and a broad low velocity zone under the Cordillera.

Sks Seismic Anisotropy Observations in Mid-Plate South America: Investigating Mantle Flow and Effects of Cratonic Keels

DE MELO, B. C., Universidade de São Paulo, Brazilo, brunamelo@usp.br; ASSUMPÇÃO, M., Universidade de São Paulo, Brazil, marcelo@iag.usp.br

Seismic anisotropy at continental regions, mainly in stable areas, gives important information about past and present tectonic events and helps us in understanding patterns of upper mantle flow in a way not achieved by other methods. The measurement of shear wave splitting (SWS), at individual stations, from core refracted phases (such as SKS phases), indicates the amount and orientation of the seismic anisotropy in the upper mantle. Previous studies of SWS in South America concentrated mainly along the Andes and in southeast Pantanal and Parana-Chaco basins, as a part of the FAPESP "3-Basins Thematic Project". The results from both temporary deployments and from the Brazilian permanent network provides a more complete and robust anisotropy map of the South America stable platform. We compare our results with different anisotropy proxies: absolute plate motion given by the hotspot reference frame HS3-NUVEL-1A, upper mantle flow induced by the Nazca plate subduction (Hu et al., 2017), global anisotropy from surface wave tomography, and geologic trends. We observe a poor correlation of the anisotropy directions with geological trends and a better correlation with the mantle flow model. Therefore, our observed anisotropy is mainly due to upper-mantle flow, with little contribution from frozen lithospheric anisotropy. Also, deviations from the mantle flow model are due to flow surrounding cratonic nuclei not used in the model: the keel of the São Francisco craton and a possible cratonic nucleus beneath the northern part of the Paraná Basin (called Paranapanema block). Large delay times at the Pantanal Basin may indicate a stronger asthenospheric channel, a more coherent flow, or a thicker asthenosphere. Small delays beneath the northern Paraná Basin may indicate thinner anisotropic asthenosphere beneath the Paranapanema block.
Spiral 1.0: Global Tomography Model of Travel Times and Surface Waves with Transversely Isotropic Crust and Mantle

SIMMONS, N. A., Lawrence Livermore National Lab, California, USA, simmons27@llnl.gov; MYERS, S. C., Lawrence Livermore National Lab, California, USA, myers30@llnl.gov

SPiRaL version 1.0 is a global-scale joint image of shear and compressional wave speeds derived from millions of travel time arrivals and global surface wave dispersion estimates for Rayleigh and Love waves. We incorporate several modeling elements used to construct the previous LLNL-G3D series of models (Simmons et al. 2011; 2012; 2015) including multiple-event relocation procedures, multiresolution imaging with spherical tessellation hierarchies, joint inversion with mineral physics constraints and 3-D ray tracing for $\mathrm{P}$ - and $\mathrm{S}$-wave phases at regional and teleseismic distances. The new model also incorporates surface wave dispersion estimates for Rayleigh and Love group and phase velocities from recent surface wave maps spanning periods from 25 to 200 seconds (Ma et al. 2014; Ma and Masters 2014). The SPiRaL model consists of over 1.7 million nodes with 5 modeled values at each node including Vp, Vs, and 3 parameters needed to fully account for transverse isotropy for P-, Sh-, and Sv-waves at any arbitrary direction of travel. The bulk (average) strength of anisotropy in the upper mantle is consistent with past waveform- and surface-wave based studies, however there is an indication that the radial anisotropy in the transition zone might be stronger than previously realized. The SPiRaL model represents a significant step towards a global-scale model, with regional-scale details, that can predict multiple seismic observables significant to seismic monitoring including accurate travel times at all distances as well as waveform features important to source characterization. This work performed under the auspices of the U.S. Department of Energy by Lawrence Livermore National Laboratory under Contract DE-AC5207NA27344.

Influence of Postcritical Reflection and Refraction on SmKS

WANG, L., China University of Petroleum at Beijing, Beijing, China, crystal. wangliwei@gmail.com; NIU,F., Rice University, Texas, USA, niu@rice.edu

Although it is generally thought that the Earth's outer core is well mixed due to vigorous convection, and is therefore more or less compositionally homogeneous, there are, however, increasing evidence that suggests stratification may exist within the outermost outer core due to the presence of light elements. Recent seismic studies show that top a few hundreds kilometers of outer core possess a P-wave velocity slightly lower than the PREM model, which cannot be explained by self-compression of a chemically homogeneous outer core. Most studies utilize the SmKS arrival, which is a core phase being reflected $\mathrm{m}-1$ times from the lower side of the core-mantle boundary (CMB) and can be observed at epicentral distances of $120^{\circ}-180^{\circ}$. Differential arrival times between SmKS pairs, such as S3KS and SKKS, S4KS and S3KS, are usually employed in determine the P-wave velocity structure in the top part of the outer core since these pairs have very similar traveling ray paths in the mantle. Since there is a $\pi / 2$ phase shift between two consecutive SmKS arrivals due to the internal caustic surface for underside reflection, measuring the differential times between the two arrivals using waveform cross-correlation requires an operation of Hilbert transform of the first arrival before the regular cross-correlating. We investigated the SmKS waveforms of deep earthquakes occurring in South America recorded by several large and dense seismic arrays in China, and measured the differential arrival times of the SmKS pairs. We found significant waveform distortion of the SmKS caused by postcritical refraction and reflection at the CMB. For example, the $\pi / 2$ phase between SKKS and S3KS cannot be confirmed from some major arc records at $\sim 170^{\circ}$. This waveform distortion can introduce significant bias to the measured differential times, leading to incorrect estimate of P-wave velocity of the outer core.

Testing PSHA Input Data, Source Models and Hazard Estimates

Poster Session · Wednesday 16 May · Riverfront South

Overview and Testing Validation of NSHM for Japan with Earthquake Records

MORIKAWA, N., NIED, Ibaraki, Japan, morikawa@bosai.go.jp; HAO, K. X. S., NIED, Ibarki, Japan, kenxshao@gmail.com; FUJIWARA, H., NIED, Ibaraki, Japan, fujiwara@bosai.go.jp

We conduct the national seismic hazard maps (NSHM) for Japan (2005 present) under the guidance of the Headquarters for Earthquake Research Promotion of Japan (HERP). The recent destroyed earthquakes have occurred in three earthquake source categories of EQ-I: Subduction-zone large earthquakes; EQ-II: 
Subduction-zone earthquakes without specified source faults, and EQ-III: Shallow earthquakes in-land and offshore regions. The various improvements have been made after the 2011 Tohoku earthquake such as 1) seismic activity model, 2) the long-term evaluation of magnitude and occurrence probability for a large earthquake, 3) the maximum magnitude of background earthquakes, and 4) developing new earthquake models for major active faults. The complexity and variation of earthquake occurrence still remain unknown even if the concept of probabilistic seismic hazard assessment (PHSA) was gradually understood after arguments in dozens of years. To test the variation of seismic activities, we developed probabilistic seismic hazard maps (forecasted PSHM) within a period of 30 years starting from 1890, 1920, 1950, 1980 and 2010. These forecasted PSHMs are calibrated by the recorded earthquake data (experienced SHM) with the same periods mentioned above. As an index of maps comparison, the total amount of the meshes whose seismic intensity is greater than 6-Lower have been accounted between the forecasted PSHM and experienced SHM. The mesh numbers of the forecasted PSHM have coincidentally with that of the experienced SHM for EQ-I and III, on other hands, have somewhat overestimate for the EQ-II. Of them, the forecasted PSHM from 2010 underestimated that of experienced PSHM which consists of only the 2011 great $M=9$ Tohoku earthquake that was not considered it before. We will continue to study the epistemic uncertainty, improve PSHM for Japan and provide information to the engineering community.

Finite Fault Distance Distribution in Probabilistic Seismic Hazard and the Relationship between Extended Source Distances

ORTEGA, R., CICESE, Mexico, ortega@cicese.mx; GUTIERREZ, E., CICESE, Mexico, edahigure@gmail.com; CARCIUMARU, D., CICESE, Mexico, danadierna@gmail.com; HUESCA-PEREZ, E., CICESE, Mexico, ehuesca@gmail.com

We present a method to compute the conditional and no-conditional probability density function (PDF) of the finite fault distance distribution (FFDD). Two cases are described: lines and areas. The case of lines has a simple analytical solution while, in the case of areas, the geometrical probability of a fault based on the strike, dip, and fault segment vertices is obtained using the projection of spheres in a piecewise rectangular surface. The cumulative distribution is computed by measuring the projection of a sphere of radius $r$ in an effective area using an algorithm that estimates the area of a circle within a rectangle. The conditional probability of distance given magnitude is also presented using different scaling laws. A simple model of constant distribution of the centroid at the geometrical mean is discussed, in this model hazard is reduced at the edges because the effective size is reduced. Nowadays there is a trend of using extended source distances in PSHA, however it is not possible to separate the fault geometry from the GMPE. This work can be used to check analytically simple source models using modern techniques of PSHA.

\section{Assessing the Applicability of Ground-Motion Models for Induced Seismicity Application in Central and Eastern North America}

FARHADI, A. F., The University of Memphis, Tennessee, USA, afarhadi@ memphis.edu; PEZESHK, S., The University of Memphis, Tennessee, USA, spezeshk@memphis.edu

This study aims to present a relatively short list of interim induced proxy ground motion models (GMMs) suitable for induced seismicity application in central and eastern North America (CENA). Induced proxy GMMs are models not established from datasets strictly made of induced events but can be used to predict ground motions from such events. For this purpose, we test a long list of GMMs against a dataset of induced earthquakes using the popular LLH method of Scherbaum et al. (2009) and its natural extension known as the multivariate logarithmic score of Mak et al. (2017). Our dataset is a subset of Rennolet et al. (2017) and at PGA is composed of 2414 time histories from 384 CENA induced events with hypocentral distances below $50 \mathrm{~km}$ and moment magnitudes from 3.5-5.8. Candidate GMMs are from two categories, including purely empirical models developed from the NGA-West2 database and indigenous models of CENA. The NGA-West2 database contains a large number of shallow small-tomoderate magnitude events from California that may approximate characteristic features of induced events in CENA. Some of the CENA models have considered near distance saturation for small-to-moderate magnitude range and/or have explicitly modeled source parameter as a function of focal depth that may make them reasonable induced proxy GMMs. Evaluation results indicate better performance of models of group 1 compared to CENA regional models. We recommend three models including Atkinson (2015), Chiou and Youngs (2014), and Abrahamson et al. (2014) above other candidate models and introduce them as most suitable induced proxy GMMs.
Study on the Uniform Earthquake Catalogue and Seismicity of Himalaya Areas

XU, G., Institute of Geophysics, CEA, Beijing, China, xugy1971@163.com; WANG, S., Institute of Geophysics, CEA, Beijing, China, suwang11@163.com

Using the earthquake catalogues from China and ISC (International Seismological Centre), the uniform catalogue of Himalaya and adjacent areas has been established for the seismic hazard analysis and seismic hazard map of Himalaya areas according to according to the following principles. 1) The earthquake parameters should be taken from China catalog if the events occurred in China. 2) The earthquake parameters should be taken from ISC catalog if the events occurred out of China. 3) The earthquake parameters should be checked if the events occurred on the China border areas based on the data of earthquake stations. There are 17886 events with event magnitude 4.0 and greater in the catalogue, among them, there are 65 ones with magnitude 7 and greater. Based on the catalogue, the seismicity of the Himalaya and adjacent areas has been analyzed, and the following conclusions are made. 1) The epicenters generally follow a NW-trending band distribution along the Himalayan arc. At the eastern and western ends, that is, the structural knots of the Himalayas, the epicenter strips are respectively turned to the NE-trending. 2) Intermediate-depth earthquake are distributed on both east and west ends of the Himalayan arc structure belt, that is, the Pamir at the west end and the Assam at the east end. In the QinghaiTibet Plateau and the front of the Himalaya arc, events are basically shallow earthquakes. 3) Earthquakes with magnitude greater than 4.5 are basically complete since 1960 A.D.. 4) The b-values of magnitude - frequency relationship for the study areas are between 0.9 and 1.0 .

\section{Selection of Ground Motion Models for Probabilistic Seismic Hazard Analysis in Iran \\ FARAJPOUR, Z., The University of Memphis, Tennessee, USA, zfrjpour@} memphis.edu; KOWSARI, M., University of Iceland, Reykjavik, Iceland, milad@ hi.is; PEZESHK, S., The University of Memphis, Tennessee, USA, spezeshk@ memphis.edu; HALLDORSSON, B., University of Iceland, Reykjavik, Iceland, skykkur@hi.is

Ground motion models (GMMs) are the most essential component of probabilistic seismic hazard analysis (PSHA), in which their validity is basically dependent on the sufficiency of the data. The quality and quantity of the recorded data have increased over the last couple of decades; however, even for the best-investigated regions (e.g., Western North America), the uncertainty in the median ground motion seems to be between $20-50 \%$ at short periods and even higher at longer periods. In the current practice of PSHA, the different estimates of the ground motions predicted by different empirical GMMs are attributed to the epistemic uncertainty. The epistemic uncertainties arise from the lack of knowledge which is reflected in imperfect models and can be handled by data-driven selection methods which reduce subjectivity and guide the selection process in a quantitative way. In this study, we review three data-driven selection methods, including the log-likelihood (LLH), the Euclidean distance-based ranking (EDR), and the deviance information criterion (DIC) to evaluate the performance of six empirical GMMs against a recently updated and compiled Iranian strong motion database. The Iranian database contains 1356 records from 208 events up to 2013, with the moment magnitude range of $4.5 \leq \mathrm{M} \leq 7.5$, and distances up to 400 $\mathrm{km}$ including a variety of fault mechanisms. The results are presented for peak ground acceleration (PGA) and 5\%-damped pseudo-acceleration spectra (PSA) at different periods. Through the Bayesian statistics the DIC method is shown to optimize the GMM selection for a given region which then leads to an unbiased assessment of earthquake hazard using logic trees. Moreover, the DIC method offers the clear advantage of partially removing the ergodicity assumption from the GMM selection process and therefore allows a more objective representation of the expected ground motion at a specific site. That in turn has important implications for standard PSHA practice.

\section{One-Year Hazard Models, Their Performance and Uncertainties}

MOUSAVI, S. M., Stanford University, California, USA, mmousavi@stanford. edu; BEROZA, G. C., Stanford University, California, USA, smousavi05@ gmail.com

Beginning in 2016, the USGS started to produce one-year PSHA models to account for the elevated seismicity in this region mainly due to the wastewater injection. We assess the full 2016 model by comparing the model forecast with the observed instrumental ground motions in PGA and spectral response acceleration for $1 \mathrm{hz}$ and $5 \mathrm{~Hz}$ over the entire CEUS. Our results indicate that the observed hazard is generally consistent with that forecast by the model. Our results show that for mapped hazard level ( $1 \%$ probability of exceedance in one year) and using only one year of observation, is unlikely to reveal the inconsis- 
tency between the observed and forecasted hazards with high confidence due to the low number of earthquakes CEUS. We also explore the variability in 2016 and 2017 models due to epistemic uncertainty in its informed submodel. We find that variability is highest in low seismicity areas. Average variability increased in the 2017 one-year model relative to 2016 model. The highest hazard variation in the final model is associated with different ground motion models and maximum magnitudes used in the logic tree, while the variability due to the smoothing distance is minimal.

U.S. National Seismic Hazard Model Updates: 2018, 2020 and Beyond

Poster Session · Wednesday 16 May $\cdot$ Riverfront South

Sensitivity of Performance-Based Design to Ground Motion Characteristics SAFAK, E., Bogazici University, Kandilli Observatory and Earthquake Research Institute, Istanbul, Turkey, erdal.safak@boun.edu.tr; CAKTI, E., Bogazici University, Kandilli Observatory and Earthquake Research Institute, Istanbul, Turkey, eser.cakti@boun.edu.tr

With the introduction of performance-based design, the tools and techniques for seismic design of structures are becoming more advanced and sophisticated. The requirements to account for nonlinear behaviour in performance-based design, construction of more complex structures (e.g., super tall and slender buildings), more accurate structural modelling and analysis tools, more powerful computers, and large amount of data collected from instrumented structures are also contributing to this. Consequently, the analysis results are now more sensitive to the characteristics of input motions, and engineers are asking for a more precise description of ground shaking. Response spectra are becoming no longer sufficient for the performance-based seismic design. This paper outlines some of the ground motion parameters that are not accounted for in current design codes, but can make a big difference in the results of performance-based seismic analysis and design. They are related to long-period components of ground motions, duration of shaking, rotational effects due to surface waves, processing of earthquake records, sensitivity of nonlinear response to the build-up of shaking intensity, and the bi-directional modelling of shaking. Examples are presented to justify the need for additional ground motion information, and suggestions are made how to quantify and utilize this information in seismic design.

Implementation of Western U.S. Sedimentary Basin Effects into the 2018 Update of the USGS National Seismic Hazard Model

SHUMWAY, A. M., US Geological Survey, Colorado, USA, ashumway@usgs. gov; PETERSEN, M. D., US Geological Survey, Colorado, USA, mpetersen@ usgs.gov; BOYD, O.S., US Geological Survey, Colorado, USA, olboyd@usgs.gov; THOMPSON, E. M., US Geological Survey, Colorado, USA, emthompson@ usgs.gov; FRANKEL, A. D., US Geological Survey, Washington, USA, afrankel@usgs.gov; MOSCHETTI, M. P., US Geological Survey, Colorado, USA,mmoschetti@usgs.gov; LUCO, N., US Geological Survey, Colorado, USA, nluco@usgs.gov; REZAEIAN, S., US Geological Survey, Colorado, USA, srezaeian@usgs.gov; POWERS, P. M., US Geological Survey, Colorado, USA, pmpowers@usgs.gov

In the 2014 USGS National Seismic Hazard Model (NSHM), we accounted for average sedimentary basin effects in the western U.S. (WUS) by using default basin depths ( $\mathrm{Zx}$, the depth to a generic shear-wave velocity horizon) calculated from the second Next Generation Attenuation ground motion models for the WUS (i.e., NGA-West2 GMMs). These default Zx terms underestimate the hazard at long periods $(\geq 1 \mathrm{sec})$ in areas of the WUS with deep basins, as shown by observed ground motions and 3D simulations. As part of the development of the 2018 update of the NSHM, we show the sensitivity of hazard to basin depths derived from three sources: (1) Zx terms from local seismic velocity models in four regions (Los Angeles, Bay Area, Salt Lake City, and Seattle), (2) Zx terms calculated from laterally varying VS30 over the entire WUS from the USGS Vs30 database (largely informed by slope-based proxies), and (3) Zx terms from a composite model based on regional and national velocity models over the entire WUS. For subduction GMMs, Zx is not currently a model parameter. Previous studies suggest that Z2.5 (depth to $2.5 \mathrm{~km} / \mathrm{s}$ shear-wave velocity) and the NGAWest2 Campbell and Bozorgnia (2014; CB14) GMM are a better estimate for predicting ground motions in the Seattle region than Z1.0 (depth to $1.0 \mathrm{~km} / \mathrm{s}$ shear-wave velocity), because of the presence of shallow glacial soils with Vs30 of about $1.0 \mathrm{~km} / \mathrm{s}$. Therefore, we have modified the subduction GMMs used in the NSHM to use the CB14 site parameters (i.e., VS30 and Z2.5). Hazard com- parisons show using Zx terms, calculated from either VS30 or from regional and national velocity models, results in up to two times higher hazard at long periods and soft soil sites than using default Zx terms for WUS basins. Feedback from the scientific community in a March 2018 NSHM workshop will inform our implementation of basin effects into the 2018 NSHM, the results of which will be presented.

2018 Update to the Earthquake Catalog Applied in the National Seismic Hazard Model

HOOVER, S. M., US Geological Survey, Colorado, USA, shoover@usgs.gov; MUELLER, C. S., US Geological Survey, Colorado, USA, cmueller@usgs.gov; MOSCHETTI, M. P., US Geological Survey, Colorado, USA, mmoschetti@ usgs.gov; PETERSEN, M. D., US Geological Survey, Colorado, USA, mpetersen@usgs.gov

The US Geological Survey (USGS) National Seismic Hazard Models (NSHMs) are updated about every six years and are utilized by the building code community. The NSHM was last updated in 2014, but the next update will be in 2018 to provide the building code community with a shorter update schedule (about four years) that will contain fewer changes to the model than a six-year update. One change that is being considered for the 2018 update to the NSHM is to use a minimum catalog magnitude of $\mathrm{M}$ (moment magnitude) 3.0, instead of M 2.7, for the central and eastern United States (CEUS). M 2.7 is roughly equivalent to $\mathrm{Mb}$ / Mblg 3.0, which was used in the NSHM prior to 2014. Increasing the minimum catalog magnitude will better match the catalog completeness and minimize the effect of magnitude uncertainty for smaller earthquakes. Two considerations for making this change are (1) relations to convert between amplitude-based local magnitudes and moment magnitude, and (2) catalog completeness over time of the source catalogs (i.e., USGS ComCat) and the NSHM catalog. Besides the minimum catalog magnitude, additional efforts include updating the NSHM catalog with recent events from 2013-2017, and removing anthropogenic earthquakes using polygons and time windows based on recent publications. Once the induced earthquakes are removed, the CEUS has a relatively low rate of seismicity, so it is important to update the catalog periodically. The effect on seismic hazard due to the earthquake catalog update will be shown.

\section{Implementation of NGA-East Ground Motion Models into the 2018 Update of the USGS National Seismic Hazard Model}

SHUMWAY, A. M., US Geological Survey, Colorado, USA, ashumway@usgs. gov; PETERSEN, M. D., US Geological Survey, Colorado, USA, mpetersen@ usgs.gov; MCNAMARA, D. E., US Geological Survey, Colorado, USA, mcnamara@usgs.gov; REZAEIAN, S., US Geological Survey, Colorado, USA, srezaeian@usgs.gov; POWERS, P. M., US Geological Survey, Colorado, USA, pmpowers@usgs.gov

As part of the development of the 2018 update of the USGS National Seismic Hazard Model (NSHM), we implemented the Pacific Earthquake Engineering Research Center's USGS specific Next Generation Attenuation ground motion models for the central and eastern U.S. (NGA-East USGS GMMs) and an updated suite of the NGA-East Seed GMMs. Unlike the suite of central and eastern U.S. (CEUS) GMMs that were used in the 2014 NSHM, the new NGAEast USGS and Seed GMMs provide a broader range of spectral periods, including longer periods, as well as provide a site amplification model that allows the hazard to be calculated for soft soils. The NGA-East USGS GMM is a wrapper around multiple weighted models derived from the NGA-East Seed GMMs via Sammon's mapping, a process that gives consideration to distance, magnitude, and spectral period spaces not adequately represented by the Seed GMMs. For the updated suite of NGA-East Seed GMMs, we used a weighting scheme similar to the CEUS GMMs in the 2014 NSHM, which is based on the model type (e.g., hybrid, stochastic, etc.) and geometric spreading. We present sensitivity calculations showing the effect on hazard when the NGA-East USGS and Seed GMMs are used with different weights and logic tree options. We will also show the effects of the NGA-East site amplification model, which will permit for the first time, the calculation of hazard at soft-soil sites in the CEUS. Initial results show that hazard is higher near the New Madrid seismic zone (NMSZ) when using the NGA-East USGS and Seed GMMs, but lower in areas away from the NMSZ. We also share feedback from the scientific community gathered at a March 2018 NSHM workshop that helped inform our modeling decisions.

Basin Amplification Factors for Cascadia Estimated from the 2011 Tohoku, Japan, Earthquake

SKARLATOUDIS, A., AECOM, California, USA, andreas.skarlatoudis@ aecom.com; SOMERVILLE, P., AECOM, California, USA, paul.somerville@ 
aecom.com; HOSSEINI, M., AECOM, California, USA, mehrdad.hosseini@ aecom.com

There is currently a boom in the design and construction of very tall buildings in Seattle and Bellevue. The seismic responses of these buildings are controlled by the response of the Seattle basin to crustal, slab and subduction earthquakes. The design response spectrum in the ASCE 7- 10 seismic provisions uses the parameter TL to define the design spectrum at long periods. In this work, we investigate the development of an improved representation of the long period spectrum for use in building codes. We perform a validation of simulation-based methods for estimating basin amplification effects using data and simulations of the largest events of the 2011 Tohoku earthquake sequence. We implement two approaches to develop basin amplification models. The first approach is to measure basin amplification factors in recorded strong ground motions at basin sites with respect to published ground motion prediction equations for subduction events without considering basin effect terms in these models. The second approach is to measure basin amplification factors in simulated strong ground motions at basin sites using a 3D model with respect to simulations for a reference $1 \mathrm{D}$ non-basin model. The amplifications that we obtain from observations and 3D simulations in the Kanto and Niigata basins follow the trend of the lower bound amplification for station QAW located in the Seattle basin as estimated by Frankel et al. (2015). The fairly good agreement between our measured and simulation-based amplifications in the Kanto and Niigata basins demonstrates the viability of the results of Frankel et al. (2015)and the use of simulation methods to estimate amplification in the Seattle Basin from large subduction earthquakes in the absence of recorded data.

\section{A Hybrid Empirical Ground Motion Model for the Island of Hawaii} HAJI-SOLTANI, A., Muesser Rutlege Consulting Engineers, New York, USA, hjsltani@memphis.edu; PEZESHK, S., The University of Memphis, Tennessee, USA,spezeshk@memphis.edu

The main purpose of this study is to develop a new Ground Motion Model (GMM) for the island of Hawaii using the hybrid empirical method (HEM). The HEM uses stochastically simulated Ground Motion Intensity Measures (GMIMs) in the host and target regions to develop adjustment factors that are applied to empirical GMIM predictions in the host region. The island of Hawaii, the target region in this study, has been the site of numerous large earthquakes. The crustal earthquakes in the island of Hawaii originate from volcanic activity and include both swarms of small-magnitude volcanic events and larger tectonic events. Considering western North America as the host region, we will use five NGA-WEST2 GMMs developed by the Pacific Earthquake Engineering Research center. For the required seismological parameters in western United States, we will use Zandieh et al. (2017) results in which a set of point-source inversions have been performed to match the median NGA-West2 GMPEs for moment magnitudes $M$ of $3.0-8.0$, rupture distances of $1-400 \mathrm{~km}$, spectral periods of 0.01-10 sec, and NEHRP B/C boundary site conditions. For the island of Hawaii, we will use results of an ongoing study by Haji-Soltani and Pezeshk (2018) in which the geometrical spreading and quality factor functions are investigated for the island of Hawaii. The new GMM will be derived for the $5 \%$-damped pseudo-acceleration response spectra for a reference rock site with $\mathrm{VS} 30=760 \mathrm{~m} / \mathrm{s}$. A moment magnitude range of 4.0 to 8.0 and rupture distances of up to $400 \mathrm{~km}$ will be considered.

\section{Hybrid Empirical Ground-Motion Prediction Equations for the Gulf Coast Region}

PEZESHK, S., The University of Memphis, Tennessee, USA, spezeshk@ memphis.edu; ZANDIEH, A., Lettis Consultants International, Inc, Colorado, USA, arash.zandieh@live.com; HAJI-SOLTANI, A., Muesser Rutlege Consulting Engineers, New York, USA, hjsltani@memphis.edu

The main purpose of this study is to develop ground motion prediction equations (GMPEs) for the Gulf Coast region of the United States using a hybrid empirical method (HEM). This project contributes toward development of a new set of GMPEs for the Gulf Coast region, which will be consistent with the available recordings. This research supplement recent GMPEs developed by the Pacific Earthquake Engineering Research Center (PEER) Next Generation Attenuation (NGA-East) GMPEs for the Central and Eastern North America (CENA) regions. Recently, a number of GMPEs for CENA are developed as part of NGA-East project conducted by the PEER. However, in majority of them, ground motions recorded in the Gulf Coast region were excluded due to considerably different attenuation attributes in this region (EPRI, 1993). The Gulf Coast region exhibits significantly different ground-motion attenuation because of the thick sediments in the region (Dreiling et al. 2014). The purpose of this study is to develop specific GMPEs for use in the Gulf Coast region using the HEM.
Because the strong motion data set is sparse in the Gulf Coast region, the hybrid empirical method represents an appropriate and robust approach which has been generally accepted to develop GMPEs. The 2018 Working Group on Nevada Seismic Hazards: Future Directions for
Improvement of the National Seismic Hazards Map in Nevada

KOEHLER, R. D., NBMG, University of Nevada, Reno, Nevada, USA, rkoehler@unr.edu; ANDERSON, J. G., Nevada Seismological Laboratory, University of Nevada, Reno, Nevada, USA, jga.seismo@gmail.com

The Nevada Bureau of Mines and Geology and the Nevada Seismological Laboratory convened the Working Group on Nevada Seismic Hazards in February 2018. The purpose of the workshop was to review ongoing earthquake hazard research in Nevada, provide insight and advice regarding technical issues related to earthquake hazards, and to identify priorities for future research that will benefit the National Seismic Hazard Map (NSHM). The workshop will occur after the abstract deadline for this meeting, so outcomes were not known when this abstract was prepared. Our presentation will summarize the outcomes of the workshop as they pertain to future updates of the NSHM. Specifically, we will present research priorities for paleoseismic, seismologic, geophysical, and geodetic studies determined to be important for improving the NSHM in the Reno/Carson/Lake Tahoe and Las Vegas urban areas. Building on the outcomes of the workshop, it is anticipated that future collaborative research between the USGS, State government, and academia will contribute valuable information to the NSHM.

\section{New Paleoseismic Data from the Frenchman Mountain Fault, Las Vegas, Nevada}

DEE, S. M., Nevada Bureau of Mines and Geology, Nevada, USA, sdee@unr. edu; DEPOLO, C. M., Nevada Bureau of Mines and Geology, Nevada, USA, eq_dude@sbcglobal.net; TAYLOR, W. J., University of Nevada, Las Vegas, Nevada, USA, wanda.taylor@unlv.edu; MAHAN, S. A., US Geological Survey, Colorado, USA, smahan@usgs.gov

The Frenchman Mountain fault is an 18 -km long, north- and northeast-striking, west-dipping, range-bounding normal fault on the eastern side of the Las Vegas metropolitan area. The fault is expressed along the western flank of Frenchman and Sunrise mountains as a zone of sub-parallel scarps in alluvial fan surfaces, bedrock range front scarps, and shear planes juxtaposing Quaternary sediments against bedrock. The fault is assigned a geologic vertical slip rate of $0.015 \mathrm{~mm} / \mathrm{yr}$ in the 2014 USGS Hazard Map. Recent geodetic studies across Las Vegas Valley suggest potential for a $0.2 \mathrm{~mm} / \mathrm{yr}$ normal slip rate. Previous studies of the fault have documented evidence for late-Quaternary paleoearthquakes, but did not include dating of deposits, recurrence estimates or slip rates. A previously excavated exposure of the fault in Quaternary fan deposits was recently investigated in much greater detail. The excavation was originally part of an unpublished fault investigation conducted by a local consulting company for a planned housing development. The fault exposed in the excavation is buried by unfaulted, alluvial fan deposits, and is on strike with 2-8 $\mathrm{m}$ high Quaternary fault scarps to the north and south. Our new logging of the excavation documents evidence for three paleoearthquakes on an $85^{\circ}$ west-dipping fault zone. Evidence for these events includes offset stratigraphy and three scarp derived colluvial wedges. Optically stimulated luminesce (OSL) samples were collected from all colluvial wedge packages, the faulted stratigraphy beneath the wedge, and the overlying unfaulted fan gravels; results of the OSL dating are pending, although preliminary data suggests all events are older than Holocene. Quaternary units beneath the colluvial wedge packages have a total vertical displacement of $1.6 \mathrm{~m}$ across the fault zone. The oldest recorded faulting event (E3) has a vertical displacement of $0.8 \mathrm{~m}$. The two youngest events (E1 and E2) have a combined vertical displacement of $0.8 \mathrm{~m}$.

\section{A Preliminary Model to Evaluate Long-Term Earthquake Risk Associated With National Bridge Inventory Infrastructure}

IAISWAL, K. S., US Geological Survey, Colorado, USA, kjaiswal@usgs.gov; LUCO, N., US Geological Survey, Colorado, USA, nluco@usgs.gov; LIN, K., US Geological Survey, Colorado, USA, klin@usgs.gov; ROZELLE, J., Federal Emergency Management Agency, Colorado, USA, jessee.rozelle@fema.dhs.gov

We present a preliminary model to systematically quantify the long-term earthquake risk of over six hundred thousand bridges located throughout the conterminous United States. The model uses (1) the 2014 US Geological Survey's longterm earthquake shaking hazard model, (2) the 2017 National Bridge Inventory (NBI) data available through the Federal Highway Administration (FHWA), and (3) earthquake fragility/vulnerability relationships for bridges available through the Federal Emergency Management Agency's (FEMA) Hazus program. Each 
year, the FHWA compiles bridge inventory data from US states, federal agencies, and tribal governments. These agencies compile comprehensive details as part of the bridge inspection process in accordance with the National Bridge Inspection Standards. The NBI dataset contains the most up-to-date stock of the nation's bridges, and lists a number of attributes pertaining to each bridge structure, such as, location, year built, bridge type, number of spans, length, skew, and inspection date. We use these attributes to categorize each bridge into a model structure type category, for example, using the Hazus Bridge Classification Scheme for vulnerability and risk analyses. For each bridge site, we first obtain an earthquake shaking hazard curve defined in terms of spectral acceleration $(\mathrm{Sa})$ at a spectral period of $1.0 \mathrm{sec}$, and then integrate it with the bridge-specific fragility curve to compute long-term earthquake risk. Attributes such as the skewness and number of spans are accounted for in the evaluation of damage potential through fragility relationships from FEMA's Hazus methodology for damage/risk assessment. Earthquake risk herein refers to a probability of experiencing slight, moderate, extensive, or complete damage states during the useful life of each bridge structure. In this presentation, we summarize some key findings and discuss potential improvements to these preliminary assessments.

\section{The 8th September Mw8.2 Tehuantepec and 19th September Mw7.1 Puebla-Morelos, Mexico Earthquakes: Reconnaissance Findings and Impact on Urban Areas in South-Central Mexico \\ Oral Session · Thursday 17 May · 3:45 PM • Brickell \\ Session Chairs: Emel Seyhan, Jorge Aguirre, and Leonardo Ramírez-Guzmán}

The M8.2 and M7.1 September Seismic Events in Mexico: A Perspective from the Strong Motion Recording Center at UNAM

PEREZ-YANEEZ, C., Instituto de Ingenieria, Universidad Nacional Autónoma de México, CDMX, MEXICO, cperezy@iingen.unam.mx; RAMÍREZGUZMÁN, L., Instituto de Ingenieria, Universidad Nacional Autónoma de México, Distrito Federal, Mexico, Iramirezg@iingen.unam.mx; MACIASCASTILLO, M. A., Instituto de Ingenieria, Universidad Nacional Autónoma de México, Distrito Federal, Mexico, mmaciasc@iingen.unam.mx; RUIZ, A. L., Instituto de Ingenieria, Universidad Nacional Autónoma de México, Distrito Federal, Mexico, aruizg@iingen.unam.mx; DELGADO-DIANCE, R., Instituto de Ingenieria, Universidad Nacional Autónoma de México, Distrito Federal, Mexico, rdelgadod@iingen.unam.mx; LEONARDO-SUÁREZ, M. Instituto de Ingenieria, Universidad Nacional Autónoma de México, Distrito Federal, Mexico, mleonardos@iingen.unam.mx; SANDOVAL-GOMEZ, H., Instituto de Ingenieria, Universidad Nacional Autónoma de México, Distrito Federal, Mexico, hsandovalg@iingen.unam.mx; ALCÁNTARA-NALASCO, L., Instituto de Ingenieria, Universidad Nacional Autónoma de México, Distrito Federal, Mexico, lalcantaran@iingen.unam.mx; TEJADA, C., Instituto de Ingenieria, Universidad Nacional Autónoma de México, Distrito Federal, Mexico,ctejadam@iingen.unam.mx

The operation of the Strong Motion Network at the Institute of Engineering and the strengthening of its recording center's infrastructure for the monitoring of the seismic activity of the country, have allowed having timely information after the occurrence of an earthquake. The availability of 264 accelerometric signals received in real time (36 three-component stations from our network and 52 from the National Seismological Service) are used to generate automatic regional ground motion parameter maps and detailed maps for the Valley of Mexico, based on algorithms and systems developed at our institution. The information is broadcasted via e-mail to a specific list of users and via fiber optic and radio to communicate the data products automatically and reliably to the government. The information generated feeds a geographic information system which provides a broad preliminary view of the peak ground motion values and spectral acceleration in infrastructure and exposed zones to help manage seismic emergency crisis and perform accurate loss estimations in Mexico. An overview of the computer platform for the acquisition of signals, processing, storage and dissemination of products is presented, as well as the strong motion recorded parameters for the September 08 (M8.2) and 19 (M7.1) earthquakes, and some reflections based on the experience.

Analysis of the Ground Motions of the September 7th and 19th 2017 Tehuantepec and Puebla-Morelos Earthquakes

SAHAKIAN, V. I., US Geological Survey, Earthquake Science Center, California, USA, vsahakian@usgs.gov; MELGAR, D., University of Oregon,
Oregon, USA, dmelgarm@uoregon.edu; RAMÍREZ-GUZMÁN, L., Instituto de Ingenieria, Universidad Nacional Autónoma de México, Mexico City, Mexico, Iramirezg@iingen.unam.mx; QUINTANAR, L., (Instituto de Geofísica), Universidad Nacional Autónoma de México, Mexico City, Mexico, luisq@ollin. geofisica.unam.mx; PÉREZ-CAMPOS, X., (Instituto de Geofísica), Mexico City, Mexico, xyoli@geofisica.unam.mx; BALTAY, A. S., US Geological Survey, Earthquake Science Center, California, USA, abaltay@usgs.gov

We examine the observed ground motions from the 2017 M8.2 Tehuantepec and M7.1 Puebla-Morelos earthquakes and their relations to predicted ground motions. These two events were both deep $(\geq 50 \mathrm{~km})$, inslab, normal-faulting events that caused significant damage to various regions of Mexico and with respect to megathrust events represent comparatively small but non-trival components of seismicity and hazard in the country. Ground-motion prediction equations (GMPEs) are an integral part of seismic hazard assessment-from hazard maps to rapid-response ShakeMaps, providing a framework for understanding median ground motions in a region as well as interpreting physical processes. We compute ground motion residuals for the Tehuantepec and Puebla-Morelos earthquakes from four GMPEs to study regional differences-a regional GMPE (Garcia et al., 2005), global inslab and active shallow-crust GMPEs (Zhao et al., 2006), and a subduction zone GMPE with inslab event adjustments (BC Hydro, or Abrahamson et al., 2015). Ground motions from both events are well-modeled at the near-source $($ Repi $<20 \mathrm{~km})$ stations, indicating that they have average stress drop for their event-type. While recordings of the Puebla-Morelos earthquake are generally well-modeled, the Tehuantepec earthquake is not well-modeled by any GMPE due to low attenuation at longer distances (Rrup $\geq 100 \mathrm{~km}$ ). Finally, there are significant basin effects for both earthquakes in Mexico City and Puebla at periods longer than SA 0.5s. Large, positive residuals are observed in these locations, and additionally, are observed in Oaxaca during the Tehuantepec earthquake for higher frequencies ( SA 1.0s to PGA). This indicates that basins and valley regions are not appropriately modeled with basic site terms and Vs30 relationships, and require more work to adequately represent the amplified ground motions that may be observed in such densely-populated regions. Spectral Ratios of Mexico City Motions during the 19 September 2017 Mw 7.1
Puebla Earthquake Confirm Frequencies in the Zoning Maps

CELEBI, M. K., SSA-EERI, California, USA, celebi@usgs.gov; SAHAKIAN, V. J., US Geological Survey, California, USA, vsahakian@usgs. gov; MELGAR, D., University of Oregon, Oregon, USA, dmelgarm @uoregon. edu; QUINTANAR, L., Universidad Nacional Autónoma de México, Mexico City, Mexico, luisq@ollin.geofisica.unam.mx; RAMÍREZ-GUZMÁN, L., Universidad Nacional Autónoma de México, Mexico City, México, Iramirezg@ iingen.unam.mx

One important element of understanding basin response to strong shaking is the analysis of spectral ratios, which may provide information about the dominant frequency of ground motion at specific locations. Spectral ratios computed from accelerations recorded by strong-motion stations in Mexico City during the mainshock of the September 19, 2017, Mw7.1 Puebla-Mexico City earthquake facilitate revisiting the validation of site frequencies previously observed by studies and aftershock recording (Çelebi and others, 1987), and are also reflected in the older seismic zoning map (in effect at the time of the 19 September 1985 Mw8.1 Michoacan earthquake) as well as the more detailed current zoning map in effect since 2004 (in the Mexican Seismic Design Code). Even though the number of stations in each of the zones (Zone I, II and IIIa, b, c, d) is not the same, they still allow confirmation of site frequencies (periods) attributable to the specific zones (particularly those in Zone IIIa, b, c, d). Spectral ratios are computed with two different methods: (1) ratio of smoothed amplitude spectrum of a horizontal channel in direction $\mathrm{X}$ of a station w.r.t. the smoothed amplitude spectrum of the horizontal channel in the same $\mathrm{X}$ direction of a reference stiff soil (or rock) station, and (2) H/V ratio (or also known as Nakamura method), of both horizontal and vertical channels of the same station. We show a comparison of the identified frequencies (periods) derived by both methods and find they are very similar and also in good agreement with those indicated in the zoning maps of Mexico City in the 2004 Seismic Design Code.

3-D Velocity Structure of the Mexico City Basin and Ground Motion Simulation of the 7.1 19 September 2017 Earthquake

RABADE, S., Universidad Nacional Autónoma de México, Distrito Federal, Mexico, san.rabade@gmail.com; BAENA-RIVERA, M., Universidad Nacional Autónoma de México, Distrito Federal, Mexico, mbaenar@gmail.com; CONTRERAS, M., Universidad Nacional Autónoma de México, Distrito Federal, Mexico, moisescontreras@hotmail.com; RAMÍREZ-GUZMÁN, L., Universidad Nacional Autónoma de México, Distrito Federal, Mexico, Iramirezg@iingen.unam.mx; AGUIRRE-GONZALEZ, J., Universidad 
Nacional Autónoma de México, Distrito Federal, Mexico, joagg@pumas.iingen. unam.mx; AYALA-HERNÁNDEZ, M., Universidad Nacional Autónoma de México, Distrito Federal, Mexico, san.rabade@gmail.com; MACIASCASTILlO, M. A., Universidad Nacional Autónoma de México, Distrito Federal, Mexico, mmaciasc@iingen.unam.mx; AGUILAR-CALDERÓN, L. A., Universidad Nacional Autónoma de México, Distrito Federal, Mexico, laguilarc@iingen.unam.mx; ALMORA-MATA,D., Universidad Nacional Autónoma de México, Distrito Federal, Mexico, dalmoram@iingen.unam. mx; CASTRO-PARRA, G., Universidad Nacional Autónoma de México, Distrito Federal, Mexico, gcastrop@iingen.unam.mx; DELGADO-DIANCE, R., Universidad Nacional Autónoma de México, Distrito Federal, Mexico, rdelgadod@iingen.unam.mx; LEONARDO-SUÁREZ, M., Universidad Nacional Autónoma de México, Distrito Federal, Mexico, mleonardos@iingen. unam.mx; MOLINA AVILA, I., Universidad Nacional Autónoma de México, Distrito Federal, Mexico, imolinaa@iingen.unam.mx; PEREZ-YAÑEZ, C., Universidad Nacional Autónoma de México, Distrito Federal, Mexico, cperezy@ iingen.unam.mx; RUIZ-GORDILLO, A. L., Universidad Nacional Autónoma de México, Distrito Federal, Mexico, aruizg@iingen.unam.mx; SANDOVALGOMEZ, H., Universidad Nacional Autónoma de México, Distrito Federal, Mexico, hsandovalg@iingen.unam.mx; TORRES-NOGUEZ, M., Universidad Nacional Autónoma de México, Distrito Federal, Mexico, mtorresn@iingen. unam.mx; VELASCO-MIRANDA, J. M., Universidad Nacional Autónoma de México, Distrito Federal, Mexico, jvelascom@iingen.unam.mx; ALCÁNTARANOLASCO, L., Universidad Nacional Autónoma de México, Distrito Federal, Mexico, lalcantaran@iingen.unam.mx; VÁZQUEZ-LARQUET, R.,Universidad Nacional Autónoma de México, Distrito Federal, Mexico, rvazquezl@iingen. unam.mx; MORA-CONTRERAS, A., Universidad Nacional Autónoma de México, Distrito Federal, Mexico, amorac@iingen.unam.mx

Mexico City was built on an islet of the former lake Texcoco. As a consequence of the gradual growth of Mexico's capital, replacing the water body, the city experiences some of the most outstanding site effects worldwide, including the long duration and large amplification of seismic waves. To explain the city's anomalous ground motion, we constructed a basin structure and studied the ground motion using recorded and simulated ground motions. The 3D velocity model of Mexico's capital (CDMX-E3D) presented here is based on an ongoing array deployment and geotechnical information. The velocity model is more detailed in the Xochimilco sub-basin, home of more than 1.5 million people, where several collapses and damages were reported during the September 19th earthquake. We used noise recordings of 20 moving arrays of 18 broadband seismometers deployed for five days with interstation distance $\sim 500 \mathrm{~m}$. With this data, we estimated the shallow crustal structure of the Xochimilco sub-basin employing ambient noise tomography. Using the newly developed model we carried out low-frequency $(\mathrm{f}<1.25 \mathrm{~Hz})$ finite-element ground motion simulations of the September 19th earthquake. These simulations show great amplification in the Xochimilco region as well as a belt region in the northwestern area of the city, where damage is prevalent in large magnitude earthquakes. This Project was funded by the Secretaria de Ciencia, Tecnología e Innovación (SECITI) of Mexico City. Project SECITI/073/2016.

\section{Uncertainty and Analysis of Soil Fundamental Periods Changes in the Valley of Mexico}

BAENA-RIVERA, M., Instituto de Ingenieria Universidad Nacional Autónoma de México, CDMX, Mexico, mbaenar@gmail.com; RABADE, S., Instituto de Ingenieria Universidad Nacional Autónoma de México, CDMX, Mexico, san. rabade@gmail.com; CONTRERAS, M., Instituto de Ingenieria Universidad Nacional Autónoma de México, CDMX, Mexico, moisescontreras@hotmail. com; RAMÍREZ-GUZMÁN, L., Instituto de Ingenieria Universidad Nacional Autónoma de México, CDMX, Mexico, tramirezg@iingen.unam.mx; AGUIRRE-GONZALEZ, J., Instituto de Ingenieria Universidad Nacional Autónoma de México, CDMX, Mexico, joagg@pumas.iingen.unam.mx; AGUILAR-CALDERÓN, L. A., Instituto de Ingenieria Universidad Nacional Autónoma de México, CDMX, Mexico, laguilarc@iingen.unam.mx; ALMORAMATA, D., Instituto de Ingenieria Universidad Nacional Autónoma de México, CDMX, Mexico, dalmoram@iingen.unam.mx; AYALA-HERNÁNDEZ, M., Instituto de Ingenieria Universidad Nacional Autónoma de México, CDMX, Mexico, mayalahe@iingen.unam.mx; CASTRO-PARRA, G., Instituto de Ingenieria Universidad Nacional Autónoma de México, CDMX, Mexico, gcastrop@iingen.unam.mx; DELGADO-DIANCE, R., Instituto de Ingenieria Universidad Nacional Autónoma de México, CDMX, Mexico, rdelgadod@ iingen.unam.mx; LEONARDO-SUÁREZ, M., Instituto de Ingenieria Universidad Nacional Autónoma de México, CDMX, Mexico, mleonardos@ iingen.unam.mx; MACIAS-CASTILLO, M. A., Instituto de Ingenieria Universidad Nacional Autónoma de México, CDMX, Mexico, mmaciasc@ iingen.unam.mx; MOLINA AVILA, I., Instituto de Ingenieria Universidad
Nacional Autónoma de México, CDMX, Mexico, imolinaa@iingen.unam.mx; PEREZ-YAŇEZ, C., Instituto de Ingenieria Universidad Nacional Autónoma de México, CDMX, Mexico, cperezy@iingen.unam.mx; RUIZ-GORDILLO, A. L., Instituto de Ingenieria Universidad Nacional Autónoma de México, CDMX, Mexico, aruizg@iingen.unam.mx; SANDOVAL-GOMEZ, H., Instituto de Ingenieria Universidad Nacional Autónoma de México, CDMX, Mexico, hsandovalg@iingen.unam.mx; TORRES-NOGUEZ, M., Instituto de Ingenieria Universidad Nacional Autónoma de México, CDMX, Mexico, mtorresn@iingen. unam.mx; VELASCO-MIRANDA, J. M., Instituto de Ingenieria Universidad Nacional Autónoma de México, CDMX, Mexico, jvelascom@iingen.unam. mx; VÁZQUEZ-LARQUET, R., Instituto de Ingenieria Universidad Nacional Autónoma de México, CDMX, Mexico, rvazquezl@iingen.unam.mx; MORACONTRERAS, A., Instituto de Ingenieria Universidad Nacional Autónoma de México, CDMX, Mexico, amorac@iingen.unam.mx

The characterization and evolution of the uppermost sedimentary layers of the Valley of Mexico are permanent tasks of several research groups. The site effect and design spectra in Mexico's capital are, in part, defined by the fundamental soil period (Ts). Therefore, most of the efforts focus on obtaining reliable estimates of Ts. In this study, a thorough $\mathrm{H} / \mathrm{V}$ (horizontal-to-vertical) spectral ratio analysis to estimate Ts and its uncertainty is performed over a particular site in Mexico City using 48 months of ambient seismic noise (ASN) measured between 2013 and 2017. A collection of earthquakes including the recent 19th September 2017 event (M 7.1), recorded at the station were analyzed using $\mathrm{H} / \mathrm{V}$ spectral ratios. We evaluated the possibility of a Ts change over time due to the subsidence of the soil by the constant extraction of groundwater for the supply of the population. We conclude that the uncertainty associated with the Ts determination does not confirm such a change, or at least define it. Also, three days of ASN recorded in 220 stations in the southernmost part of the Valley of Mexico is used to estimate the Ts values and its associated uncertainty maps using $\mathrm{H} / \mathrm{V}$ spectral ratios. A comparison with Ts values given by the Complementary Technical Standards for Earthquake Design of Mexico City published in December 2017 was made, revealing differences of more than $20 \%$ in several sites. Acknowledgments: Records used in this research are obtained by the Seismic Instrumentation Unit of the Institute of Engineering at the National Autonomous University of Mexico. This Project was funded by the Secretaria de Ciencia, Tecnología e Innovación (SECITI) of Mexico City, Project SECITI/073/2016.

\section{Adaptation of New Technologies and Methods to Drive New Discoveries in Seismology and Geodesy} Oral Session - Thursday 17 May · 1:30 PM • Monroe Session Chairs: Sarah E. Minson and Elizabeth S. Cochran

\section{A FAST Data-Mining Approach for Similar Earthquake Detection}

YOON, C. E., Stanford University, California, USA, ceyoon@stanford.edu; BEROZA, G. C., Stanford University, California, USA, beroza@stanford.edu; BERGEN, K. J., Stanford University, California, USA, kbergen@stanford. edu; RONG, K., Stanford University, California, USA, krong@stanford.edu; ELEZABI, H., Stanford University, California, USA, hashem@stanford.edu; BAILIS, P., Stanford University, California, USA, pbailis@cs.stanford.edu; LEVIS, P., Stanford University, California, USA, pal@cs.stanford.edu

The Fingerprint and Similarity Thresholding (FAST) earthquake detection algorithm finds small earthquakes hidden in continuous seismic data through an uninformed search for similar signals at all times (Yoon et al., 2015). FAST does not assume prior knowledge of template waveforms, nor does it use labeled earthquake waveform examples to recognize new earthquakes, which are examples of informed search. FAST enables detection of similar-waveform earthquakes in long-duration continuous data, up to a decade long, by adapting data-mining techniques originally developed for audio and image search within massive databases. FAST converts seismic waveforms into compact binary features called "fingerprints", designed to be discriminative: similar earthquake waveforms have highly similar fingerprints, while fingerprints extracted from noise have low similarity. FAST then uses locality-sensitive hashing to organize the fingerprints into a database, and efficiently search for similar fingerprints with high probability by avoiding unnecessary comparison of dissimilar fingerprints. We extend singlestation FAST to detect similar earthquakes over a network of multiple seismic stations, reducing the chance of false detections from repeating noise at one station (Bergen and Beroza, 2018). Instead of associating phase arrivals from a single earthquake, we apply pair-wise pseudo-association, which exploits the fact that the relative arrival time difference between a pair of similar earthquakes is the same across all stations. We introduce an open-source, parallel, Python/ C++ FAST software package, which can be applied to detect similar-waveform 
earthquakes in any seismic network, with varying duration of continuous data and number of stations. So far, FAST has successfully detected small earthquakes in continuous data sets with duration ranging from 20 hours to 10 years, and on networks with 1 to 22 stations.

\section{Generalized Seismic Phase Detection with Deep Learning}

ROSS, Z. E., Caltech, California, USA, zross@gps.caltech.edu; MEIER, M. A., Caltech, California, USA, mmeier@caltech.edu; HAUKSSON, E., Caltech, California, USA, hauksson@gps.caltech.edu

In recent years, various techniques exploiting the waveform similarity of clustered earthquakes have been used to increase the detection sensitivity of earthquakes, typically by more than an order of magnitude. These approaches are powerful because they use exact copies of seismograms to match against, but for this same reason, are of limited utility in detecting events that have never been seen before. To overcome this challenge, we develop and implement a framework for generalized seismic phase detection using deep learning. The networks are trained and validated on millions of hand-labeled records and are shown to detect seismic phases with high reliability. We demonstrate the full applicability of the method on a large aftershock sequence and compare the results to that of template matching and STA/LTA detectors. The developed approach is shown to be a promising alternative for earthquake detection, and has potential applications to earthquake early warning.

\section{Multiscale Analysis of the Global Seismicity}

D’AURIA, L., Instituto Volcanológico de Canarias, S/C de Tenerife, Spain, Idauria@iter.es; BARRANCOS, J., Instituto Volcanológico de Canarias, S/C de Tenerife, Spain, jbarrancos@iter.es; GARCÍA-HERNÁNDEZ, R., Instituto Volcanológico de Canarias, S/C de Tenerife, Spain, ruben.garcia.beca@iter.es; PADILLA, G. D., Instituto Volcanológico de Canarias, S/C de Tenerife, Spain, german@iter.es

We mapped at a global scale the Gutenberg-Richter parameters and the average seismic energy release rate using a novel multiscale approach. This approach consist essentially in considering all the possible spatial scales around a given point and extracting a robust median from the computed b-values. This approach has been shown to have the capability of determining automatically the spatial scales relevant to the considered dataset without "a priori" choices. The determination of the a-value is hence straightforward and allows computing the average seismic energy release rate. Interesting by-products of this computation are the determination of the relevant spatial scale and of the completeness magnitude. For the purposes of this work we considered earthquakes from the USGS catalog located after 1973 and having a magnitude equal or higher than 4 . The datased consists of about 400,000 events, with about half of them being located within the crust. Using these data we realized two global maps with a $25 \mathrm{~km}$ spatial resolution. The first map considers only the crustal seismicity discarding the depth information. It required the computation of multiscale $b$-values for about 1 million points. The second takes into account also the depth information, allowing to image the depth distribution of the b-value related to the deep seismicity. This 3D map required the computation over about 30 million points. Both maps required massive HPC computing with a total computation time of few weeks. We show spatial variation of the b-value and of the average energy release rates for the crust in different geodynamic environments. In particular we focus on the Euro-Mediterranean region and North-America. For the 3D map we show some relevant result about variations along subducting slabs, in particular we present 3D maps for the Nazca slab.

\section{Earthquake-Induced Gravity Changes as Precursors of the Direct Seismic Waves}

VALLÉE, M., Institut de Physique Du Globe de Paris, Paris, France, vallee@ ipgp.fr; AMPUERO, J. P., Geoazur, IRD, Université de Nice-Sophia Antipolis, France, ampuero@geoazur.unice.fr; JUHEL, K., Institut de Physique Du Globe de Paris, France, juhel@ipgp.fr; BERNARD, P., Institut de Physique Du Globe de Paris, France, bernard@ipgp.fr; MONTAGNER, J. P., Institut de Physique Du Globe de Paris, France, jpm@ipgp.fr; BARSUGLIA, M., AstroParticule et Cosmologie, CNRS, Université Paris Diderot, France, barsu@apc.in2p3.fr

After an earthquake, the earliest deformation signals are not expected to be carried by the fastest $(\mathrm{P})$ elastic waves but by the speed-of-light changes of the gravitational field. The observations of these weak signals, and their full understanding, would provide a new data type with a strong potential for a rapid estimate of the earthquake magnitude. We show here that gravity perturbations are particularly well observed with broadband seismometers at distances between 1000 and 2000 kilometers from the source of the 2011, moment magnitude 9.1, Tohoku earthquake. We can accurately model them by a new formalism, taking into account that a ground-attached seismometer is sensitive to two effects: (1) the gravity changes at the seismometer location, mostly caused by the transient dilations/ compressions of the medium by the earthquake "classical" elastic waves; and (2) the motions themselves induced by the gravity changes everywhere in the Earth. The latter effect can be understood as an elastic relaxation of the Earth in order to react to the gravity changes. These prompt elasto-gravity signals open the window for minute time-scale magnitude determination for great earthquakes, in particular in places where good-quality broadband seismometers can be installed in front of the megathrust area, at distances ranging from a few hundreds to a few thousands of kilometers. In North America, the seismic monitoring of both the Cascadia and Alaska subduction zones would benefit from the early detection of such gravity changes.

\section{How Well Can We Resolve Surface Deformation Using Lidar, UAVSAR and Optical Imagery?}

DELONG, S. B., US Geological Survey, California, USA, sdelong@usgs.gov; DONNELLAN, A., Jet Propulsion Laboratory/Caltech, California, USA, andrea.donnellan@jpl.nasa.gov; PICKERING, A. J., US Geological Survey, California, USA, apickering@usgs.gov; SCOTT, C.P., Arizona State University, Arizona, USA, cpcott1@asu.edu; PARKER, J. W., Jet Propulsion Laboratory/ Caltech, California, USA, jay.w.parker@jpl.nasa.gov

GPS geodesy and traditional surveying methods are proven methods for measuring surface deformation at discrete fault-crossing profiles. UAVSAR has proven invaluable in characterizing slip distributions and spatial patterns of deformation across larger areas, but suffers from areas of decorrelation and tropospheric effects. Recent studies have demonstrated that repeat airborne and terrestrial lidar can be used to map three-dimensional patterns of deformation following earthquakes, and the use of repeat optical imagery to map horizontal plate motions has also been demonstrated. These recent developments beg further investigation into the sensitivity and uncertainty of these methods. This includes evaluation of our ability to measure very small rates of deformation such as those along creeping faults, and to determine patterns of deformation in complex fault zones and away from primary fault zones, either distributed through adjacent crust or on distinct secondary structures. Here we review recent methodological developments and present new data from the creeping San Andreas and west Napa faults aimed at further testing the application terrestrial lidar, UAVSAR and UAV and spaceborne optical imagery. We are testing the use of new algorithms for UAVSAR data analysis, and the use of algorithms including Cosi-CORR, windowed ICP, and structure-from-motion photogrammetry to measure fine-scale patterns of surface deformation. We also employ feature extraction from lidar point clouds to create geodetic markers that can be tracked through time and space. We will highlight the challenges and applicability of multiple techniques that show promise for new levels of understanding of how tectonic deformation is manifest at Earth's surface.

\section{Applications of Machine Learning and Data Science in Seismology \\ Oral Session · Thursday 17 May $\cdot$ 10:45 AM $\cdot$ Hibiscus A Session Chairs: Qingkai Kong, Chengping Chai, Zefeng Li, Min Chen, and Rongrong Wang}

Training a Deep Neural Network to Generate Full Seismograms KRISCHER, L., ETH Zurich, Switzerland, lion.krischer@erdw.ethz.ch; FICHTNER, A., ETH Zurich, Switzerland, andreas.fichtner@erdw.ethz.ch

Easy and fast access to synthetic waveforms is paramount for a myriad of applications in seismology and various approximate techniques for their calculation have been developed over the decades; each with their own shortcomings and tradeoffs. Realistic numeric calculations through three dimensional complex media at high frequencies on the other hand are computationally too expensive to run routinely and will remain so for the foreseeable future. Seismic velocity models at global and continental scales are comparatively smooth and seismograms at adjacent stations, or from similar sources, vary little. Given enough training data, deep neural networks might be able to learn some underlying function or representation to quickly generate synthetic seismograms for unseen sources and new receivers. Possible applications for this are numerous and range from probabilistic source inversions, over optimal experiment design, to seismic hazard estimations. We report the design and rational of a deep neural network architecture made up of a series of fully connected layers converting the inputs to an intermediate representation. A number of transposed convolutional layers follows to produce the output. Inputs to the network are source and receiver parameters, its outputs are 
the numeric values of the synthetic seismograms. Successful applications to three dimensional complete seismograms including body and surface waves as well as physics like anisotropy and attenuation, but with a radially symmetric velocity model, are shown. Unlimited training as well as validation data is available for that case. Furthermore we present first experiments of training a neural network on data calculated through a three dimensional velocity model with severe restrictions on the available data.

\section{Deep Learning Aftershock Location Patterns}

DEVRIES, P., Harvard University, Massachusetts, USA, phoeberobinson@fas. harvard.edu; VIEGAS, F., Google, Massachusetts, USA, viegas@google.com; WATTENBERG, M., Google, Massachusetts, USA, wattenberg@google.com; MEADE, B., Harvard University, Massachusetts, USA, meade@fas.harvard.edu

Aftershocks represent the most ubiquitous observations of earthquake triggering. Maximum aftershock sizes and temporal decay are well described by empirical laws (e.g., Bath's law and Omori's law), but explaining and forecasting the spatial distribution of aftershocks has proven more difficult. Static elastic Coulomb failure stress change is perhaps the most commonly invoked criterion to explain the spatial distributions of aftershocks, but its applicability has been disputed in some cases. We use a machine learning approach to find a static stress-based criterion that forecasts aftershock locations without prior assumptions about aftershock fault orientation. We show that a neural network trained on $85,000+$ mainshockaftershock pairs can explain aftershock locations in an independent testing data set of 24,000+ mainshock-aftershock pairs more accurately (Area under curve or AUC $=0.869)$ than static elastic Coulomb failure stress change $(\mathrm{AUC}=0.606)$. We find that the learned aftershock pattern is physically interpretable; the second invariant of the deviatoric stress tensor explains $97 \%$ of the variance in the neural network forecast.

High Resolution Travel Time Tomography with Local Sparsity Regularization and Dictionary Learning, with Application to Ambient Noise Tomography on a Dense Seismic Array

BIANCO, M. J., Scripps Institution of Oceanography, UC San Diego, La Jolla, CA, California, USA, mbianco@ucsd.edu; GERSTOFT, P., Scripps Institution of Oceanography, UC San Diego, La Jolla, CA, California, USA, pgerstoft@ ucsd.edu; OLSEN, K. B., Department of Geological Science, San Diego State University, San Diego, CA, California, USA, kbolsen@mail.sdsu.edu; LIN, F. C., Department of Geology and Geophysics, University of Utah, Salt Lake City, Utah, USA, u0919412@utah.edu

We present a $2 \mathrm{D}$ travel time tomography method which models rectangular groups of slowness pixels from discrete slowness maps, called patches, as sparse linear combinations of atoms from a dictionary. We further propose to adapt the dictionary atoms to slowness data using dictionary learning, a form of unsupervised machine learning. We call this sparse regularization the local model, as it constrains the local or small-scale relationships of the pixels. Relative to conventional tomography methods, which constrain models to be exclusively smooth or discontinuous, the sparse local model permits smooth and discontinuous features where warranted by data. In this locally-sparse travel time tomography (LST) method, the local model is integrated via an averaging procedure with the overall slowness map, called the global model, which constrains large-scale features using L2-norm regularization. Since LST does not enforce global pixel correlations, the global slowness is obtained by inverting a sparse tomography matrix, which requires less computation than dense matrices of equivalent dimension. With efficient dictionary learning algorithms, the LST method scales well to tomography problems with large numbers of rays and pixels. We develop a maximum a posteriori formulation for LST, which is solved as an iterative inversion algorithm. We apply the LST approach to ambient noise tomography on a dense seismic array located in Long Beach, California (2011) and obtain high resolution Rayleigh surface wave phase speed maps of the region. This 'large N' array contained more than 5200 stations resulting in $\sim 14$ million unique ray paths. The new maps obtained are consistent with previous results, and show increased contrast along fault lines. Further, the distribution of phase speeds show strong correlation with underlying oil fields in the area (Long Beach, Wilmington), indicating that the Rayleigh waves resolve surface sediments related to the hydrocarbon areas.
Rapid Earthquake-Induced Damage Detection Using Satellite Imagery and Machine Learning Algorithms for the September 19, 2017, M7.1 Central Mexico Earthquake

RASHIDIAN, V., Tufts University, Massachusetts, USA, vahid.rashidian@ tufts.edu; KOCH, M., Boston University, Massachusetts, USA, mkoch@bu.edu; BAISE, L. G., Tufts University, Massachusetts, USA, laurie.baise@tufts.edu

Rapid detection and classification of damage after earthquakes is important for loss estimation, rapid response, and research. We use optical satellite imagery after the recent M 7.1 Central Mexico earthquake on September 19, 2017 to develop a damage catalog for Mexico City. The satellite imagery before and after the earthquake are freely available through the Digital Globe disaster program with a spatial resolution of less than 1-meter. The pre-event image was taken on June 15, 2017 through GeoEye-1 sensor and the post-event image was taken on September 20, 2017 through WorldView-2 sensor. Machine learning algorithms (MLAs) including feed-forward and radial basis artificial neural networks (ANNs) are used to detect and classify building damage after the earthquake. MLAs work with nonlinear datasets, learn from limited training data, and have been successfully used in other classification problems. In addition to the spectral information of the imagery, textural and structural features such as dissimilarity and Laplacian of Gaussian (LoG) filter are used as the inputs to the MLAs and result in an improvement of the overall accuracy of the classification. Terrestrial images taken by individuals from the damaged buildings after the earthquake, which are available online and through reconnaissance reports, are used as ground truths to develop both training and testing data for the region. There are more than 1000 buildings that are partially damaged while around 20 are reported as collapsed. As the spatial and spectral resolution of the imagery are not high enough to detect the partial damages to the buildings, this study only focuses on totally collapsed structures. The classification results are validated using 2 -fold cross-validation with a confusion matrix and to evaluate the overall accuracy of the algorithms. The results of this work provide preliminary evidenced that collapse catalog using MLAs and high resolution (1-m) optical imagery can be developed to inform loss estimation, rapid response and research efforts after major earthquakes.

\section{WaveNet-An Open Geoscience Database Initiative for Automatic Event Picking and Beyond \\ TU, N., Tongji University, Shanghai, China, ntu@tongji.edu.cn; WANG, R.,} Michigan State University, Michigan, USA, wangron6@msu.edu

The advancements in deep learning techniques have the potential to revolutionize the way we process and interpret geoscience data. As in the field of computer vision, where the advancement is driven by the neural network model itself and the tremendous collection of labeled images - notably the ImageNet databaseto train the model, successful applications of deep learning techniques in geoscience also rely on large amount of geoscience data labeled by experts with high precision. While in the ImageNet project, the labeling process can be performed by laymen, tasks to label geoscience data, such as event picking in seismic data, require various degrees of professional training. In this regard, labeled data of the highest quality should come directly from well-trained geoscientists. As each of us only have limited amount of labeled data, and increased amount of labeled data means increased prediction precision in the realm of deep learning, we call for a global collaboration towards an open geoscience database. Each geoscientist contributes his/her own share of data to this database, and reaps benefits from the improved prediction accuracy of the model, which he/she can either download or use on the cloud to process his/her unlabeled data. That is to say, we use a "crowd sourcing" strategy to collect high-precision labeled data. Prototyping this database-WaveNet as we call it -involves working out standards related to data handling and processing. In its current phase, we focus onautomating the tedious task of picking first-arrivals. Once we have collected "enough" data, we will run a basic benchmark with the databaseto get both a qualitative and quantitative understanding of the improvements this database may result in. Then, to leverage the collective wisdom of the deep-learning experts, we consider the choice of setting up a benchmark contest to find the best possible deep-learning model (or probably several models for different tasks) for the database.

\section{PhaseNet: A Deep-Neural-Network-Based Seismic Arrival Time Picking Method \\ ZHU, W., Stanford University, California, USA, zhuwq@stanford.edu; BEROZA, G. C., Stanford University, California, USA, beroza@stanford.edu}

As the number of seismic sensors continues to grow, it is becoming increasingly difficult for analysts to pick seismic phases manually and comprehensively, yet such efforts are fundamental to earthquake monitoring. Despite years of improvements in automatic phase picking, it is difficult to match the performance of experienced analysts. A more subtle issue is that different seismic analysts may 
pick phases differently, which can introduce bias into earthquake locations. Deep neural networks have recently made rapid progress in feature learning, and with sufficient training, have achieved super-human performance in many applications. We present a deep-neural-network-based arrival-time picking method called "PhaseNet" that picks the arrival time of both P and S waves. PhaseNet uses three-component seismic waveforms as input and generates probability distributions of $\mathrm{P}$ arrivals, $\mathrm{S}$ arrivals, and noise. Peaks in probability provide accurate arrival times for both $\mathrm{P}$ and $\mathrm{S}$ waves, and have the potential to increase the number of $S$-wave observations dramatically over what is currently available. This will enable both improved locations and improved shear wave velocity models. PhaseNet is trained on the prodigious available data set provided by analystlabeled P and S arrival times from the Northern California Earthquake Data Center. The dataset we use contains more than seven million waveform samples extracted from over thirty years of earthquake recordings. We demonstrate that PhaseNet achieves much higher picking accuracy and greater recall rate than existing methods.

\section{Machine Learning Applied to Probing Fault Physics}

JOHNSON, P. A., Los Alamos National Laboratory, New Mexico, USA, paj@ lanl.gov; HULBERT, C. L., Los Alamos National Laboratory, New Mexico, USA, chulbert@lanl.gov; ROUET-LEDUC, B. P. G., Los Alamos National Laboratory, New Mexico, USA, bertrandrl@lanl.gov; MARONE, C. J., Penn State, Pennsylvania, USA, cjm38@psu.edu; TRUGMAN, D. T., Los Alamos National Laboratory, New Mexico, USA, dtrugman@lanl.gov; GUYER, R. A., Los Alamos National Laboratory, New Mexico, USA, guyer@physics.umass.edu; MCBREARTY, I. W., Univeristy Wisconsin, Wisconsin, USA, imcbrearty@ lanl.gov; LUBBERS, N., Los Alamos National Laboratory, New Mexico, USA, nlubbers@lanl.gov; BARROS, K., Los Alamos National Laboratory, New Mexico,USA, kbarros@lanl.gov

Machine learning has been applied to a number of problems in geoscience for decades. In general, applications used only portions of available data due in part to limited data and computing power. For instance, considerable work has been done using earthquake catalogs. Catalogs are assembled by hand or in some automated manner applying classical data processing techniques. Thus, out of both necessity and lack of understanding, vast amounts of existing data have gone unused. We know that fundamental information is embedded in many conventional geophysical continuous data signals, but that our ability to extract this information is limited by several factors: (a) it is often not apparent to human inspection and/or (b) when it is apparent, it requires a protracted expert analysis to interpret; (c) and/or we may be asking the wrong question of the data (human bias or ignorance). Our strategy is based on lessons learned from previous attempts to apply data-analytics, such as failed attempts at earthquake prediction. While machine learning offers a powerful path to extracting information rapidly from complex datasets, it must be strongly coupled to a fundamental understanding of the physical system to be meaningful and believable. We provide an overview of our work applying machine learning approaches to continuous seismic data streams. The primary focus of the work described will be on faulting and earthquakes, however we are turning our attention to many geological phenomena at many scales.

\section{Deep Convolutional Neural Networks for Phase Picking in Oklahoma Based on Transfer Learning}

ZHU, L., Georgia Institute of Technology, Georgia, USA, lijun.zhu@gatech. edu; LI, C., Georgia Institute of Technology, Georgia, USA, Ichenyu@gatech. edu; PENG, Z., Georgia Institute of Technology, Georgia, USA, zpeng@gatech. edu; MENG, X., University of Southern California, California, USA, xmeng. gatech@gmail.com; MCCLELLAN, J. H., Georgia Institute of Technology, Georgia, USA, jim.mcclellan@gatech.edu

Oklahoma has experienced an abrupt increase of induced seismicity in the last decade. Detection of small-magnitude earthquakes is essential because a complete earthquake catalog is the basis for understanding injection-induced seismicity in Oklahoma. Machine learning, especially deep learning, provides robust tools for image classification and feature extraction with complex structures. Convolutional neural networks (CNN) have been recently applied to continuous seismic waveform recordings to perform efficient phase picking and event detection (Zhu et al. 2017). In this work, we would like to verify the idea of transfer learning, which refines an existing classifier trained on a large dataset to a small dataset with a limited number of labeled samples in a different geographic region. Specifically, we transfer the knowledge learned from our recently developed CNN trained on a seismic dataset in China after the 2008 M7.9 Wenchuan earthquake (Zhu et al. 2017) to Oklahoma region. Using the single station CNN trained on the Wenchuan dataset, together with 895 local/regional catalog events recorded in central Oklahoma (Chen et al., 2018), we will refine part of the net- works to pick the arrival times of the local seismicity in Oklahoma. The refined CNN results will then be compared with the matched filter results using the same catalog events as templates to verify its effectiveness. Updated results will be presented at the meeting.

\section{A Convolutional Neural Network for Intermediate-Depth Earthquake Detection and Magnitude Estimation}

FLOREZ, M. A., Massachusetts Institute of Technology, Massachusetts, USA, mflorez@mit.edu; PRIETO, G. A., Unversidad Nacional de Colombia, Bogota D. C., Colombia, gaprietogo@unal.edu.co

Earthquake detection remains one of the fundamental operations in observational seismology. Despite the explosion in quality and quantity of seismic data our ability to build dense and complete seismicity catalogs remains limited. Recent approaches exploit the self-similarity of earthquakes and rely on using the waveforms of a few well known events as templates. Terabytes of continuous seismic signals at multiple stations are cross-correlated against these templates and thousands of events with high waveform similarity may be easily identified. This procedure, known as template matching, is computationally expensive and fails for events whose waveforms are significantly different from the templates. Also, the magnitudes of completeness of intermediate-depth earthquake catalogs are typically large. A dense catalog with a small magnitude of completeness not only allows for a detailed study of seismicity patterns, but also enables the mapping of small-scale b-value anomalies. We propose a Convolutional Neural Network $(\mathrm{CNN})$ architecture for the simultaneous detection of intermediatedepth earthquakes, the precise picking of $\mathrm{p}$ - and s- wave arrival times and the estimation of their local magnitude. We test our implementation using a synthetically generated dataset and propose a training scheme that leverages both real and synthetic data for optimal results. As an example we apply our technique to a cluster of intermediate-depth intraplate earthquakes in northern Chile. We are able to detect eight times more events than in the initial catalog and use the picked arrival times to relocate them. We clearly resolve a double-planed structure at depth. Furthermore, we build a detailed b-value map and find that high b-value anomalies correlate well with regions were dehydration is expected.

\section{Operational Experience with Next-Generation Automatic Association Software NET-VISA}

LE BRAS, R.J., CTBTO, Wien, Austria, ronan.lebras@gmail.com; ARORA, N., Bayesian Logic Inc., California, USA, nimar.arora@gmail.com; KUSHIDA, N., CTBTO, Wien, Austria, noriyuki.kushida@ctbto.org; MIALLE, P., CTBTO, Wien, Austria, pierrick.mialle@ctbto.org; TOMUTA, E., CTBTO, Wien, Austria, elena.tomuta@ctbto.org

The NET-VISA software produces an automatic combined seismic, hydroacoustic and infrasound bulletin resulting from the key step of assembling detections from multiple stations within the processing chain of the International Data Centre (IDC) of the Comprehensive Nuclear-Test-Ban Treaty (CTBTO). The IDC waveform analysts are systematically evaluating the results of using it as a complement to the current operational software Global Association (GA), which is nearing its 19th anniversary in continuous operation at the IDC. Events that otherwise have been missed by the standard processing are presented to the analysts from a processing pipeline running in parallel with the GA software. After just seven days of evaluation, the number of events added to the Reviewed Event Bulletin (REB) that originate with NET-VISA represent on average $12.3 \%$ of the total of the events in the REB. Out of this total, the number of events with a valid body wave (mb) or local magnitude (ML) larger than or equal to 4 is $3.5 \%$, indicating that most added events fall below this threshold. This paper will present a more complete analysis based on multiple weeks of operational use.

\section{Challenges and Chances for the Widespread Implementation of Earthquake Early Warning (EEW)} Oral Session - Thursday 17 May $\cdot 3: 45 \mathrm{PM} \cdot$ Monroe Session Chairs: Wilfried Strauch and Victor A. Huerfano

Toward Earthquake Early Warning in Central America STRAUCH, W., INETER, Nicaragua, wilfried.strauch@yahoo.com; CLINTON, J. F., ETH Zurich, ZH, Switzerland, jclinton@sed.ethz.ch; MASSIN, F., ETH Zurich, ZH, Switzerland, frederik.massin@sed.ethz.ch; RAMIREZ, J., INETER, Nicaragua, javier.ramirez@sb.ineter.gob.ni

Citizens of Central America are exposed to damaging shallow crustal earthquakes and tsunamigenic subduction zone earthquakes, in addition to living amongst multiple active volcanoes. In response to these hazards, most coun- 
tries in the region operate relatively sophisticated, dense seismic networks, and data is openly shared in the cross border 'Regional Seismic Network of Central America'-crucially important given the small size of many nations and the international scope of the events. Yet significant populations continue to reside in weak buildings, including adobe, that can be expected to perform poorly during strong shaking. The success of the EEW system in Mexico following the 2017 Central Mexico Earthquake demonstrates how EEW can be effective in the region and can play a role in reducing losses during devastating ground motions. Since 2016, SED (Switzerland) and INETER (Nicaragua) have been collaborating in a project funded by the Swiss Development Agency to explore the feasibility of EEW in the region. EEW has strong potential for the whole region since, in addition to the dense networks and data sharing, and most networks operate SeisComP3 as real time monitoring system-the same ecosystem SED uses to develop EEW algorithms. INETER now operates a test EEW system deploying VS and FinDer within SeisComP3, despite relatively limited resources. In a new phase of the project, we will cooperate with other Central American seismological institutions and intend to extend EEW operation into all countries in the region, building capacity and understanding of EEW, implementing best practice in network operation, and monitoring performance. The long term goal of the collaboration is to provide public EEW. We intend to work with key stakeholders including Civil Protection Institutions, central and local Governments and Social Scientists, to develop appropriate strategies for alert dissemination and public reaction.

The Potential Utility of an Earthquake Early Warning System in Eastern Canada

CRANE, S. I., Canadian Hazards Information Service, stephen.crane@canada. ca; PERRY, H. K. C., Canadian Hazards Information Service, claire.perry@ canada.ca; MCCORMACK, D., Canadian Hazards Information Service, david. mccormack@canada.ca

Although damaging earthquakes in eastern Canada are relatively infrequent, a moderate or large earthquake has the potential to be felt, or even damaging, at large distances. The wide extent of strong shaking is caused by low attenuation in the region, allowing seismic waves to propagate efficiently throughout eastern North America. For example, the 1925, M6.2 earthquake occurring near Charlevoix, Quebec had an estimated modified Mercalli intensity (MMI) of V-VI in Ottawa and Montreal, roughly $300-400 \mathrm{~km}$ from the epicenter, and MMI IV in Toronto and New York City, approximately $800-900 \mathrm{~km}$ away from the epicenter. With the potential of future earthquakes affecting urban centers, an earthquake early warning system (EEWS) would be useful for alerting communities, infrastructure and individuals of expected ground shaking, with potentially significant lead-times. There are several issues to overcome in developing a functional EEWS in eastern Canada. One challenge, for example, is to cover a large area with a low network density. The Canadian National Seismic Network (CNSN) is currently being upgraded, providing an opportunity to selectively increase network density with a focus on optimizing the station positioning for improved EEWS performance. Other challenges with EEWS in eastern Canada, include maintaining public awareness when events are rarely felt, and developing an appropriate alerting strategy that maximizes warnings to zones at risk while minimizing the potential for false alerts. We discuss potential solutions to these challenges, and the wider application to eastern North America.

\section{Earthquake Early Warning Feasibility Study for the New Madrid Seismic}

\section{Zone}

OGWENO, L. P., The University of Memphis-CERI, Tennessee, USA, logweno@memphis.edu; WITHERS, M. M., The University of MemphisCERI, Tennessee, USA, mwithers@memphis.edu; CRAMER, C. H., The University of Memphis_CERI, Tennessee, USA, ccramer@memphis.edu

Research in the last decade on Earthquake Early Warning Systems (EEWSs) has undergone rapid development in terms of theoretical and methodological advances in real-time data analysis, improved telemetry, and computer technology and is becoming a useful tool for practical real time seismic hazard mitigation. The main focus of this study is to undertake a feasibility study of an EEWS for the New Madrid Seismic Zone (NMSZ). The NMSZ covers a wide area with several heavily populated cities, vital infrastructures, and facilities located within a radius of less than $70 \mathrm{~km}$ from the epicenters of the 1811-1812 earthquakes. One of the challenges associated with the NMSZ is that while low to moderate levels of seismic activity are common, larger earthquakes are rare (i.e. there are no instrumentally recorded data for earthquakes with magnitudes greater than M5.5 in the NMSZ). We also recognize that it may not be realistic to provide early warning for all possible sources as is done on the west coast U.S. and we therefore focus on a specific source zone. We examine the stations within the NMSZ in order to answer the question "What changes should be applied to the NMSZ network to make it suitable for earthquake early warning (EEW)". We also explore needed changes to the AQMS RT data acquisition system to make it useful for EEW. Our results show that EEW is feasible, though several technical challenges remain in incorporating its use with the present network.

MyShake - Building an Earthquake Early Warning System Using Smartphones KONG, Q., UC Berkeley, California, USA, kongqk@berkeley.edu; INBAL, A., UC Berkeley, California, USA, ainbal@berkeley.edu; ALLEN, R. M., UC Berkeley, California, USA, rallen@berkeley.edu

MyShake is a global smartphone seismic network that harnesses the power of crowdsourcing. It is driven by the citizen scientists that running MyShake on their smartphones to detect earthquake. It has two components: an android application running on the personal smartphones to detect earthquake-like motion, and a network detection algorithm to aggregate results from multiple smartphones to detect earthquakes. Our goal is to build an earthquake early warning system across the globe using smartphones. This will be potentially a cheap and fast way for countries with high seismic risk but cannot afford traditional seismic networks. The MyShake application was released to the public on Feb 12th 2016. Until now, more than 300,000 people downloaded MyShake app across the world. Within 2 years preparation, we will start to find pilot places to issue warnings this year. In this presentation, I will present how to build a lowcost earthquake early warning system for Latin America and other less developed regions using the daily used smartphones. In addition, I will show our observations of using MyShake as an earthquake early warning system and share some examples of the real-world applications to recent earthquakes, which illustrate the performance of the current system as well as the limitations.

\section{An Analysis of Real-Time GNSS Solutions from the M8.2 September 2017 Tehuantepec Earthquake and M7.9 January 2018 Kodiak Earthquake and Implications for Earthquake and Tsunami Early Warning Systems}

MENCIN, D., UNAVCO, Colorado, USA, mencin@unavco.org; HODGKINSON, K. M., UNAVCO, Colorado, USA, hodgkinson@unavco. org; MATTIOLI, G. S., UNAVCO, Colorado, USA, mattioli@unavco.org; SIEVERS, C., UNAVCO, Colorado, USA, csievers@unavco.org

The 2017-09-08 earthquake M8.2 located $98 \mathrm{~km}$ SSW of Tres Picos, Mexico and 2018-01-23M 7.9 earthquake located 280km SE of Kodiak, Alaska are the first great earthquakes to occur within the UNAVCO RT-GNSS footprint, which allows for a rigorous analysis of our dynamic and static processing methods. The need for rapid geodetic solutions ranges from seconds (EEW systems) to several minutes (Tsunami Warning and NEIC moment tensor and finite fault models). Here, we compare and quantify the relative processing strategies for producing static offsets, moment tensors and geodetically determined finite fault models using data recorded during this event. We also compare the geodetic solutions with the USGS NEIC seismically derived moment tensors and finite fault models, including displacement waveforms generated from these models. We define kinematic post-processed solutions from GIPSY-OASISII (v6.4) with final orbits and clocks as a "best" case reference to evaluate the performance of our different processing strategies. We find that static displacements of a few centimeters or less are difficult to resolve in the real-time GNSS position estimates, including the 5-min arc averages produced by UNR. The standard daily 24 -hour solutions provide the highest-quality data-set to determine coseismic offsets, but these solutions are delayed by up to 48 hours after the event. Dynamic displacements, estimated in real-time, however, show reasonable agreement with final, post-processed position estimates, and while individual position estimates have large errors, the real-time solutions offer an excellent operational option for EEW systems, including the use of estimated peak-ground displacements and directly inverting for finite-fault solutions. In the near-field, we find that the geodeticallyderived moment tensors and finite fault models differ significantly with seismically-derived models, highlighting the utility of using geodetic data in hazard applications. 
Earthquake Source Parameters: Theory, Observations and Interpretations

Oral Session - Thursday 17 May · 8:30 AM · Jasmine

Session Chairs: Vaclav Vavrycuk, Grzegorz Kwiatek, and

Douglas Dreger

Geomechanical Insights from Numerical Modeling of Intact Rock Failure: Event Characteristics and Stress Drops

VAN DER BAAN, M., University of Alberta, mirko.vanderbaan@ualberta.ca; CHORNEY, D., University of Alberta, drchorne@gmail.com

A common assumption in the analysis of seismological data is that stresses are essentially homogeneous within an area or layer. This would imply for instance that only shear failure is possible in triaxial deformation tests when large differential stresses are imposed on the sample walls. Laboratory experiments however often find that acoustic emissions are characterized by predominantly tensile instead of shear failure mechanisms. We show using numerical simulations that both a strong- and weak-force network develops during triaxial deformation tests, causing significant stress heterogeneity and anisotropy. Acoustic emissions occur predominantly within the weak-force network such that tensile failure becomes feasible. We also find that stress drops are inversely proportional to the confining stress, in that they are largest for samples failing in a brittle fashion and close to zero for those samples displaying ductile deformation patterns. Finally, we observed systematic relationships between observed b-values, the number of acoustic emissions and stress-strain curves. These systematic trends may make it feasible to invert for stress changes in the Earth purely from the patterns in observed b-values and the amount of seismicity.

\section{A Unified Theory for Faulting Style, Tectonic Regime, and Earthquake-Size Distribution}

PETRUCCELLI, A., University of Bologna, Italy, antonio.petruccelli4@unibo. it; SCHORLEMMER, D., Helmholtz Centre Potsdam, Germany, danijel. schorlemmer@gfz-potsdam.de; TORMANN, T., Swiss Seismological Service ETH Zurich, Switzerland, thessa@sed.ethz.ch; RINALDI, A. P., Swiss Seismological Service ETH Zurich, Switzerland, antoniopio.rinaldi@sed.ethz. ch; WIEMER, S., Swiss Seismological Service ETH Zurich, Switzerland, stefan. wiemer@sed.ethz.ch; GASPERINI, P., University of Bologna, Italy, paolo. gasperini@unibo.it; VANNUCCI, G., National Institute of Geophysics and Volcanology, Italy, gianfranco.vannucci@ingv.it

Advancing in earthquakes forecasting is strictly linked to knowledge of stressing conditions on faults. Fault orientation and differential stress are related according to Anderson's faulting theory: thrust faults suffer higher differential stresses than normal faults, with strike-slip in the middle of them. Independently, laboratory measurements on acoustic emissions and latest evidences from natural seismicity have established that differential stress also controls earthquake populations' size distribution, or b-value, in an inverse linear way. Our global survey of earthquakes-size distribution reveals that observed spatial variations are consistent with faulting theory: different tectonic regimes are characterised by distinctive b-values, higher along the mid-oceanic ridges, lower in the subduction zones, and intermediate in the continental zones. So far, however, there has been no quantitative comparison and theory that unifies Anderson's faulting theory, differential stress dependency and earthquake size distribution. To develop such a theory, using a ternary b-value analysis combined with a Mohr-Coulomb criterion, we identify a systematic second-order effect of faulting geometry on earthquakessize distribution: steep normal faults are found to have the highest b-values, while flat thrust faults have the lowest ones. Our theory predicts that, contrary to what proposed, the highest-lowest b-values should be observed not for "pure" normalthrust mechanisms, providing then a new tool to be used for seismic hazard purposes.

Utilizing Stochastic Methods to Characterize Deformation Associated with Hydraulic Fracture Stimulations

VIEGAS, G., ESG Solutions, gisofer@gmail.com; URBANCIC, T., ESG Solutions, ted.urbancic@esgsolutions.com

We use the collective behavior of micro-seismic events generated during the hydraulic fracture stimulation of a shale reservoir to characterize the spatialtemporal evolution of the deformation of the reservoir rock. Our analysis is based on the study of the "seismic flow of rocks" developed by Riznichenko and Kostrov in the 60's and 70's, where rock volumes are considered as continuous medium under quasi-plastic deformation that contain earthquake sources (medium particles) which result from and contribute to the volume deformation. As such, the cumulative seismicity describes the deformation and stress changes in the rock volume. The approach is valid for volumes containing large numbers of earthquakes that are much larger than the earthquakes sources over time periods much larger than the earthquakes recurrence times, which is the typical case of hydraulic fracturing treatments where hundreds of micro-seismic events are generated over a 3 to 4 hour injection period in a volume surrounding the perforation where fluids are being injected. We use spatial and temporal clustering approaches to form groupings of micro-seismic events and perform statistical analysis on the source properties (seismic moment, radiated energy, source radius, seismic efficiency, etc.) and inter-relationships (inter-event times and distances) to characterize and map the dynamic response of the rock volume to stimulation. We decompose the overall rock response into 3 competing indices or dynamic parameters: Plasticity Index, PI (relates to anelastic deformation); Stress Index, SI, (relates to the stress-induced fracturing); Diffusion Index, DI, (relates to the diffusion of seismicity), and identify and track areas in the rock volume where deformation is more likely to result from stress transfer or fluid induced mechanism. We find the method successful in characterizing the large scale dynamic response of the rock volume to the injection program.

\section{Stress Drop and Scaling of Earthquakes at the Geysers Geothermal Field, California}

DREGER, D. S., UC Berkeley, California, USA, dreger@seismo.berkeley.edu; BOYD, O. S., UC Berkeley, California, USA, sierra@seismo.berkeley.edu; TAIRA, T., UC Berkeley, California, USA, taira@berkeley.edu; GRITTO, R., Array Information Technology, California, USA, roland.gritto@arrayinfotech. com

Seismicity from the EGS demonstration experiment at The Geysers, CA Prati-32 injection well has been investigated for the seismic moment tensor, in situ stress, and the scaling of earthquake source parameters. One objective is to develop an approach for estimating a statistical representation of the fracture network generated from the injection of fluids into hot dry rock. We have performed finitesource inversion of seismic moment rate functions obtained for earthquakes spanning the magnitude range of Mw 1 to 5 in the vicinity of the EGS demonstration site to investigate the scaling of source dimension, slip, and stress drop. We find that these small earthquakes are not simple ruptures and can have strong directivity effects, with multiple asperities of slip. Rupture area is found to be consistent with the Wells and Coppersmith (1994) and Leonard (2010) scaling laws developed for much larger $(\mathrm{Mw} \geq 5.5)$ earthquakes. Owing to the complex nature of the kinematic finite-source models we use the method of Ripperger and Mai (2004) to compute the static stress change. We find that peak stress drops can be large, however, on average they are consistent with the aforementioned source scaling laws. Finally, we demonstrate how seismic moment tensor, in situ stress inversion, and finite-source modeling can be used to characterize the statistical fracture density and fracture network induced by fluid injection.

\section{Validation of a 3-Stage Source Scaling for Crustal Earthquakes}

MIYAKE, H., Earthquake Research Institute, University of Tokyo, Tokyo, Japan, hiroe@eri.u-tokyo.ac.jp; IRIKURA, K., Aichi Institute of Technology, Aichi, Japan, irikura@geor.or.jp; MIYAKOSHI, K., Geo-Research Institute, Osaka, Japan, ken@geor.or.jp; KAMAE, K., Research Reactor Institute, Kyoto University, Osaka, Japan, kamae@rri.kyoto-u.ac.jp

Source scaling is a fundamental issue to understand earthquakes. A magnitude and $\log$ area $(\mathrm{M}-\log \mathrm{A})$ relation is a key scaling to link modeling of seismic source and ground motion. Currently, scenario seismic hazard maps in Japan adopt a 3 -stage M- $\log A$ scaling for crustal earthquakes, although many national seismic hazard maps use a linear or bilinear scaling. The 3 -stage $\mathrm{M}$-logA scaling is originally proposed by Scholz (2002). Recent development of slip inversions enabled us to improve quantitative estimates of the scaling. Based on the source characterization of slip inversions, the M-logA scaling for crustal earthquakes are: The first circular-crack model stage of $\mathrm{A}(\mathrm{km} 2)=2.23 \times 10-15(\mathrm{Mo}(\mathrm{Nm}) \mathrm{x}$ 107)2/3 by Somerville et al. (1999) for $\mathrm{Mw}<6.5$, the second L-model stage of A $(\mathrm{km} 2)=4.24 \times 10-11(\mathrm{Mo}(\mathrm{Nm}) \times 107) 1 / 2$ by Irikura and Miyake $(2001,2011)$ for $\mathrm{Mw}=6.5 \sim 7.4$ after fault width saturation, and the third W-model stage of A $(\mathrm{km} 2)=1.0 \times 10-17 \mathrm{Mo}(\mathrm{Nm})$ by Murotani et al. $(2015)$ for $\mathrm{Mw} \geq 7.4$ after fault displacement saturation. The 3 -stage M-logA scaling shows the first bending at $\mathrm{L} \sim \mathrm{Wmax}$ without significant gaps that pointed out by past 2-D numerical simulations. The second L-model stage is similar to Hanks and Bakun (2002) that is well constraint by megafault systems. We also confirmed that dynamic rupture simulations for strike-slip faulting using 3-D FDM of Dalguer et al. (2008) naturally reproduce the 3 -stage $\mathrm{M}$-logA scaling. To fit the scaling between slip inversions and dynamic rupture simulations, slight increase of stress drop from 2.3 to over 3.0 MPa is required in the second L-model stage. Those are compatible with the static models by Fujii and Matsu'ura (2000) and Shaw and Scholz (2001). 
Finally, we validate the 3 -stage source scaling and other published scaling (e.g., Leonard, 2010) for recent crustal earthquakes with slip inversions, and compare their performance.

\section{Characteristics of Recent Aftershock Sequences of Moderate Earthquakes in Japan \\ MORI, J.J., Kyoto University, Kyoto, Japan, mori@eqh.dpri.kyoto-u.ac.jp}

Spatial and temporal distributions of aftershocks were studied for recent moderate earthquakes that occurred at shallow depth onshore of Japan and were well recorded by the regional networks. These events include the 2000 Western Tottori (Mw 6.7), 2004 Niigata Chuetsu (Mw 6.6), 2005 Fukuoka (Mw 6.6), 2007 Noto Peninsula (Mw 6.7), 2007 Niigata Chuetsu-oki (Mw 6.8), 2008 Iwate-Miyagiken (Mw 6.8), 2016 Kumamoto (Mw6.2) and 2017 Tottori (Mw6.2) earthquakes. All of these earthquakes are approximately of similar size, however, the rates of aftershock activity are quite different. The 2004 Niigata and 2008 IwateMiyagi earthquakes have significantly more aftershocks than the other 7 events. In the spatial locations of the aftershocks, these two earthquakes have more complex spatial distributions with more aftershocks occurring away from the mainshock fault plane. There appears to be a correlation between the rate of aftershock activity and the spatial complexity of the locations. The sequences with higher rates of aftershock occurrence may be associated with aftershocks triggered in a volume around the mainshock. In contrast, for the other sequences, aftershocks occur mainly in a planar pattern close to the mainshock fault plane. The early time sequences of the aftershocks for these events were also examined. Using continuously recorded seismograms from nearby borehole stations of Hi-net, aftershocks were identified and counted. From about one minute following the mainshock origin time, we estimate that we can identify aftershocks with magnitudes down to $\mathrm{Mj}$ 3.5. For the first few minutes the rate of aftershocks is quite similar for all of the mainshocks. The higher rate of aftershocks for the 2004 Niigata and 2008 Iwate-Miyagi earthquakes appears to begin about 10 minutes after the mainshock. This suggests that the enhanced triggering of aftershock for these two earthquakes may be caused by some changes in the aftershock region several minutes after the mainshock.

\section{Anomalous High Stress Drop Earthquake Produced by Compressive Fault} Steps in the West Bohemia Swarm Region

VAVRYCUK, V., Institute of Geophysics, The Czech Academy of Sciences, Czech Republic, vv@ig.cas.cz; ADAMOVA, P., Institute of Geophysics, The Czech Academy of Sciences, Czech Republic, adamova@ig.cas.cz

Analysis of observations of the 2008-2014 seismic activity in West Bohemia, Czech Republic, provides evidence of interaction of compressive fault steps which induced an anomalously strong earthquake. The studied focal zone is formed by two parallel strike-slip faults with a step and overlap of about $200 \mathrm{~m}$. The fault segments were activated successively by the 2008 and 2011 earthquake swarms with magnitudes of the strongest events of 3.8 and 3.7, respectively. The separate fault segments were linked during the 2014 mainshock-aftershock activity. The strongest earthquake with magnitude of 4.2 occurred on a new fracture formed between the existing parallel fault segments. It displayed a high stress drop and a reverse focal mechanism inconsistent with the regional background stress. Inversion of focal mechanisms for stress revealed a local stress anomaly characterized by interchanging the $\sigma 2$ and $\sigma 3$ principal stress axes in the area of the fault interaction. The modeling of the Coulomb stress change confirmed that the stress anomaly can significantly alter or even completely disturb the regional background stress. The results indicate that breaking a barrier between fault segments under compressive stress regime can be particularly dangerous because it might generate an earthquake stronger than the strongest earthquakes observed at the individual fault segments. This finding is scale invariant and should be valid even for large earthquakes.

Complex Source Spectra in Small Earthquakes Caused by Multiple Asperities WANG, Y., UC San Diego, California, USA, yow004@ucsd.edu; DAY, S. M., San Diego State University, California, USA, sday@mail.sdsu.edu

In order to characterize earthquake rupture features, it is a fundamental task to explore earthquake parameters such as the seismic moment, the rupture dimension and the static stress drop. Spectral analysis is one widely used method to investigate these source parameters. Therefore, as the basis of the spectral analysis, a physically plausible and observationally consistent source spectral model is essential in interpreting recorded data. A successfully applied source model is the omega-square model, characterized by a flat low-frequency spectral asymptote and a high-frequency asymptote proportional to the inverse square of frequency (Aki, 1967). Multiple theoretical studies have derived source spectral models, usually in agreement with the standard omega-square model but with more model-dependent complexities, and these are useful in connecting spectral properties with stress drop estimates. (Brune, 1970; Madariaga, 1976; Boatwright, 1980; Kaneko and Shearer, 2014,2015; Wang and Day, 2017). The improvement of seismograms in quantity and quality in recent years has enabled recording of more small events with extensive station coverage and broad spectral bandwidth, potentially revealing more rupture detail. As an example, many small crustal events in the northern Ibaraki prefecture and the Fukushima prefecture Hamadori area of Japan, are reported to deviate systematically from the standard omega-square model, with evidence of a double-corner-frequency shape, with lowand high-frequency bumps in residual spectra that may reflect source complexity (Uchide and Imanishi, 2016). We attribute this spectral shape to a multi-asperity source model. By simulating a dynamic multi-asperity scenario, we find (1) a high frequency decay with omega-square asymptote that is mainly controlled by outer marginal stopping phases, (2) an intermediate-frequency slope lower than 2 that is controlled by multiple asperities (with the difference in decaying rate between intermediate- and high-frequency band contributing a high-frequency bump in residual spectra), and (3) a spectral bump at low frequency that results from constructive interferences of asperity pulses (contributing the low frequency bump in residual spectra). In the future, we would like to generalize a spectral model to deal with the multi-asperity case and better characterize source complexities and stress regimes.

\section{Three-Dimensional Directivity Analysis for Resolving Source Parameters and Rupture Complexities}

PARK, S., Harvard University, Massachusetts, USA, sunyoungpark01@fas. harvard.edu; ISHII, M., Harvard University, Massachusetts, USA, ishii@eps. harvard.edu

Rupture properties, such as rupture direction, length, propagation speed and source duration, provide important insights into earthquake mechanisms. One approach to estimate these properties is to investigate the rupture directivity effect using the body-wave duration measurements. We demonstrate that the directivity effect should be treated as a three-dimensional problem, rather than assuming a horizontal or a likely fault plane. For example, ignoring the distance dependence of observed duration can significantly bias the earthquake duration, especially for nearly vertical rupture propagation. The three-dimensional directivity analysis can be further extended to include multiple subevents for complex ruptures. In contrast to the simple unilateral case, the durations of non-unilateral ruptures often do not exhibit the simple sinusoidal pattern, and shows that complex earthquakes need to be studied with caution, e.g., the shortest observed duration cannot be used to infer the rupture direction. Based upon the framework, we apply a new inversion approach to two deep-focus events in the Sea of Okhotsk region, an Mw 7.7 event that occurred on 2012 August 14 and an Mw 8.3 event from 2013 May 24, to obtain the source duration, the rupture extent, speed, and direction. The duration measurements for the $\mathrm{Mw} 8.3$ event show significant deviation from a simple sinusoidal pattern associated with the unilateral propagation, indicating that the event involves multiple subevents. When the multi-episode analysis is applied, two propagation directions are obtained, one towards the southwest and another towards southeast. The two-episode model gives a better fit to the data than the unilateral model, and is compatible with the back-projection analysis, demonstrating that the rupture propagation of the $\mathrm{Mw}$ 8.3 event is complex.

\section{The Virginia City, Nevada, Earthquake Sequence: Exploring Complexities in Source Properties of Small Events ( $M \sim 3$ ) and Fault Geometry}

HATCH, R. L., University of Nevada Reno, California, USA, rachelhatch11@ gmail.com; RUHL, C. J., UC Berkeley, California, USA, cruhl@berkeley.edu; ABERCROMBIE, R. E., Boston University, Massachusetts, USA, rea@bu.edu; SMITH, K. D., University of Nevada, Reno, Nevada, USA, ken@unr.edu

We attempt a detailed analysis of a small earthquake sequence to reveal how seismicity migrates across complex structures and how stresses change both in space and time, while also exploring mechanisms of driving forces (i.e. aseismic slip, fluid migration). The Virginia City, Nevada earthquake sequence $(\mathrm{M}<=3.2)$ occurred within the Walker Lane from 2010-2016. Recent increases in station quality and coverage at the Nevada Seismological Laboratory, enable earthquake sequences east of the Sierra Range to be studied in detail, despite the relatively small magnitudes. Our aim is to contribute to a further understanding of the region's seismicity and the complexities of Walker Lane area; specifically, to characterize seismically active structures and source properties in order to understand the seismic hazard implications. To investigate this sequence, we use absolute relocations and the relative relocation program GrowClust, calculate focal mechanisms, and compile measurements of stress drop and directivity of larger events $(M \geq 2)$. We are able to relocate 366 of the 429 events detected by the network, with an average relative error of $<105 \mathrm{~m}$. Relocations show three well-defined 
linear structures spanning $\sim 1 \mathrm{~km}$, ranging from $8-10 \mathrm{~km}$ in depth. First-motion focal mechanisms indicate both normal and strike-slip movement. During the 9-day, most active period of the sequence, we detect a clear migration of seismicity, from east to west, with each structure activating in turn. We calculate spectral ratios and get preliminary results of stress drops for 10 of the events in the sequence, averaging 2 and $6 \mathrm{MPa}$ for both $\mathrm{P}$ and $\mathrm{S}$ waves, respectively. Using the computed source-time functions and a wide coverage of NSL stations, we observe variation in source duration with azimuth and constrain possible rupture directivity. Additionally, $54 \%$ of events tested show complexities in the source time functions, and are not well fit by a simple circular rupture model.

\section{The Eigenvalue Lune as a Window on Moment Tensors}

TAPE, C., University of Alaska Fairbanks, Alaska, USA, ctape@alaska.edu; TAPE, W., University of Alaska Fairbanks, Alaska, USA, wtape@alaska.edu

A moment tensor is a symmetric matrix that expresses the source for a seismic event. The fundamental lune of eigenvalues is a certain subset of the unit sphere whose points represent the source types for all moment tensors. Familiar source types such as double couple or pure isotropic have natural locations on the lune. Although the lune consists only of source types, it gives a useful, if incomplete, picture of moment tensor space as a whole. For each subset B of the lune we therefore consider the associated set BU of unit moment tensors that have their source types in B. We then wish to get a sense of BU from looking at B. We succeed in calculating both the volume and the angular diameter of BU. We also calculate the angular diameter and the volume of the set LambdaU of unit moment tensors that have source type Lambda, and we plot the results as contours on the lune. We show that great circle arc lengths on the lune are closely related to angles between moment tensors, and that arc length on the lune gives a natural measure of difference in source type. We show how to calculate volume elements for a variety of moment tensor coordinates. Volumes are relevant in part because we equate fractional volume with the probability that expresses randomness. We thus can find the probability that a random moment tensor have its source type in a given subset of the lune. These insights could be useful for characterizing uncertainties for individual events and for distinguishing source types among a set of events. Additional challenges of uncertainty characterization are expected if additional source parameters are considered, such as magnitude, hypocenter, origin time and source-time function.

Seismic Source Parameters Inversion for Earthquakes in Bardarbunga Volcano for the Current Seismicity and the 2014-2015 Caldera Collapse Related Events

CARDOZO, F. R., Universidad Nacional Autónoma de México, Distrito Federal, Mexico, felixrc@comunidad.unam.mx; HJÖRLEIFSDÓTTIR, V., Geophysics Institute, Universidad Nacional Autónoma de Mexico, Distrito Federal, Mexico,vala@igeofisica.unam.mx; JÓNSDÓTTIR, K., Icelandic Meteorological Office, Iceland, kristin.jonsdottir@vedur.is; GEIRSSON, H., University of Iceland, Iceland, hgeirs@hi.is

Volcanic earthquakes are controlled by a wide range of physical parameters. The relative importance of such parameters, and how they are connected, can be difficult to discern, due to limited observations. However, large eruptions are outstanding opportunities for studying those parameters, since the magnitude seismicity could be unusually large, such as the Holuhraun fissure eruption due to Bardarbunga caldera collapse. The fissure eruption in Holuhraun in September 2014, due to the laterally propagating dike that connects this lava field with the Bárdarbunga caldera, was coincident in time with the subsidence of approximate $70 \mathrm{~m}$ in the caldera (Guðmundsson et al., 2016). Some of the earthquakes associated with the caldera subsidence exhibit large non-double-couple components (NDCC) in their seismic moment tensors. This could be due to one of several phenomena, including intrusive processes like dikes or sills (Kanamori et al 1993, Riel et al. 2014) as well as geometric effects due slip on a curved fault (Nettles \& Ekström, 1998). Historically, the largest earthquakes in Bardarbunga before the 2014-2015 caldera collapse had shown large NDCC in their moment tensors (1976-1996, Nettles and Ekström, 1998), similarly to the 2014-2015 seismicity. However, the ancient focal mechanisms were reverse, completely opposed to the 2014-2015 ones. Currently, some of the seismic activity that continues in Bárdarbunga after the eruption and caldera collapse, exhibits waveforms with reverse polarity, compared to the ones registered during the eruption (Jónsdóttir, et al.,2017). In addition, for the largest recent events, we have inverted seismic moment tensors and as a result, we have found large NDCC with the reverse focal mechanism, similarly to the 1976-1996 seismicity. The historical changes in the moment tensors and the inversions in the polarity could indicate that the slip on the ring fault is now going in the opposite direction and that the caldera is now inflating. We have inverted seismic moment tensor for intermediate magnitude earthquakes $(4.0<=\mathrm{Mw} .<=4.8)$ during the 2014-2015 eruption and caldera collapse, as result, we have observed a systematic increase in the NDCC component with magnitude. This finding would provide key insights regarding the main mechanism that originates the NDCC moment tensors.

\section{Inversion for Focal Mechanisms Using Waveform Envelopes and Inaccurate Velocity Models}

CARVALHO, J. M., Universidade de Brasilia, Distrito Federal, Brazil, juraci-br@hotmail.com; BARROS, L. V., University of Brasilia, Brasilia/DF, Brazil, lucas@unb.br; ZAHRADNIK, J., Faculty of Mathematics and Physics, Charles University, Prague, Czech Republic, jz@karel.troja.mff.cuni.cz

The major challenge for the moment tensor determination is associated to relatively low magnitude events $(\mathrm{Mw} \sim 4)$ recorded by few (e.g. 4) regional stations at relatively large distances $(300-600 \mathrm{~km})$ and analyzed with standard velocity models of the region. Difficulties arise from the fact that synthetics in standard models, e.g. those routinely used in location, cannot properly match real waveforms; un-modeled time shifts and amplitude differences appear. The situation is even worse when real waveforms can be matched, but the retrieved focal mechanism is incorrect. This paper investigates an alternative methodology, more robust with respect to inappropriate velocity model: the inversion of waveform envelopes. The envelopes are derived from normalized waveforms and inverted by grid search for the strike, dip, and rake, and the moment is obtained by the least-squares method. The method is proposed on an empirical basis, by studying effects of velocity models upon synthetic waveforms and finding that information about focal mechanism is encoded in the variation of the envelope shapes and amplitudes among the seismogram components. Besides synthetic tests, the method has been tested on real data comprising two earthquakes in Brazil: the Mara Rosa (Mw 4.3, 2010) and Maranhão (Mw 4.3, 2017) and compared with the trustable solutions from previous studie based on ad-hoc path-specific velocity models. We obtained the same mechanism with a routinely available 1-D model and a single-station polarity constraint. The envelope inversion is a promising technique which might be useful in similar sparse networks, such as the one in Brazil, where standard waveform inversion in general is not fully efficient.

\section{Directly Estimating Earthquake Rupture Area Using Second Moments to Reduce the Uncertainty in Stress Drop}

MCGUIRE, J., Woods Hole Oceanographic Institution, Massachusetts, USA, jmcguire@whoi.edu; KANEKO, Y., GNS Science, New Zealand, y.kaneko@gns. cri.nz; FAN, W., Woods Hole Oceanographic Institution, Massachusetts, USA, wfan@whoi.edu

The key kinematic source parameters: rupture velocity, duration and area, shed light on earthquake dynamics, provide direct constraints on stress-drop, and have implications for seismic hazard. However, for moderate and small earthquakes, these parameters are usually poorly constrained. Numerical experiments by Kaneko and Shearer $[2014,2015]$ demonstrated that standard spectral fitting techniques can lead to roughly 1 order of magnitude variation in stress-drop estimates that do not reflect the actual rupture properties even for simple crack models. For a suite of their models, the area averaged static stress drop is nearly constant for models with the same underlying friction law, yet corner frequency based stress-drop estimates vary by a factor of 5-10 even for noise free data. Alternatively, we simulated inversions for the rupture area as parameterized by the second moments of the slip distribution. This approach yields estimates of stress drop that vary by only $10 \%$ between the models but are slightly larger than the true area-averaged values. We simulate inversions for the second moments for the various models and find that the area can be estimated well when there are at least 15 available measurements of apparent duration. The improvement compared to corner-frequency based approaches results from the second moments accounting for directivity and removing the assumption of a circular rupture area. We also develop a new method that determines the minimum and maximum values of rupture area that are consistent with a particular dataset at the $95 \%$ confidence level. For synthetic datasets with 20+ randomly distributed observations and $10 \%$ noise levels, we find that the maximum and minimum bounds on rupture area typically vary by only a factor of two and that the minimum stress drop is often more tightly constrained than the maximum. Examples of the $\min / \max$ rupture area inversions will be presented for earthquakes in Southern California and Oklahoma.

Odd Moment Tensor

ALDRIDGE, D. F., Retired, New Mexico, USA, dfaldri53@gmail.com; HANEY, M. M., US Geological Survey, Alaska, USA, mhaney@usgs.gov; 
LEANEY, W. S., Schlumberger, Texas, USA, leaney@slb.com; CHAPMAN, C. H., Schlumberger, England, chchapman@slb.com

The interesting question "Why do nominal compressional (P-wave) seismic energy sources generate so much shear ( $\mathrm{S}$-wave) energy?" arises in both explosion and exploration seismology. The relative amount of $\mathrm{P}$ vs $S$ energy is an important, but not definitive, discriminant between explosive (chemical or nuclear) and earthquake (shear and/or tensile dislocation) seismic sources. A long-established (and over-simplified) model of a buried explosion is a spherical cavity subject to uniform radial surface traction (time-varying pressure). Spherically-symmetric and radially-polarized P-waves diverge from the source zone. The moment density tensor representation consists of three orthogonal force dipoles of equal magnitude, activated with same waveform. The tensor is isotropic, and is thus even in the mathematical sense. Many common seismic sources (double couple with no net moment) also lead to an even tensor. However, the same cavity subject to tangential (or twisting) traction about a symmetry axis radiates only $S$-waves. The moment tensor characterizing such a torque source is odd. These two source types are end members on a continuum between pure $\mathrm{P}$ and pure $S$ generators. In this study, we derive a general $3 \times 3$ moment tensor with nine independent elements. Two important implications of an odd moment tensor pertain to forward modeling and inversion of seismic data. For forward modeling via the first-order coupled velocity-stress PDE system, even and odd parts constitute particular inhomogeneous (body source) terms, differentiated with respect to time and space, respectively. Most moment tensor inversion algorithms presently restrict consideration to symmetry, which biases results if the actual tensor has an odd part. Synthetic and field examples of data generated by "nominal P" sources containing clear $S$ arrivals are given. Finally, we demonstrate construction of a dipole seismic source by superposing two point moment sources of opposite polarity, with infinitesimal separation.

\section{A Proposed Rupture Scenario for the 1925 Santa Barbara, California, Earthquake}

HOUGH, S. E., US Geological Survey, California, USA, hough@usgs.gov; MARTIN, S. S., Earth Observatory of Singapore, Singapore, 7point1@gmail. com

The 29 June 1925 Santa Barbara earthquake is among the largest 20th century earthquakes in southern California. The earthquake predated the installation of strong motion and local monitoring instruments in southern California; some instrumental data are, however, available from long-period instruments at regional and teleseismic distances. The current catalog moment magnitude, $\mathrm{MW}$ 6.8, was estimated from an instrumental recording at Berkeley (Hanks et al., 1975) and recent analysis of original intensity data (Bakun, 2006). Earlier published magnitudes estimated from original intensity assignments by the Coast and Geodetic Survey were lower (MI6.3). In this study, we revisit original accounts and assign modified Mercalli intensity values at 239 locations, including detailed damage information from 144 specific locations in Santa Barbara. Comparing the reinterpreted intensities with Did You Feel it? intensities for recent earthquakes in California, we estimate Mw6.5, with a plausible range of 6.3-6.6. We further consider reported instrumental amplitudes at regional and teleseismic distances to estimate an instrumental moment magnitude of MW6.6 0.5 . Our preferred final estimate is Mw6.5. Based on available constraints including aftershock locations inferred from data recorded on portable instruments, we propose that the earthquake nucleated east of the city of Santa Barbara, closer to the coast than previously estimated, and ruptured unilaterally $\sim 30 \mathrm{~km}$ to the west, possibly along the south-dipping Rincon Creek/Mesa/More Ranch reverse fault system. Relatively high intensities $\sim 50 \mathrm{~km}$ west of Santa Barbara can then be explained by directivity rather than involvement of the Santa Ynez fault, as early studies suggested. Finally, we present evidence suggesting that the earthquake might have been induced by oil industry activities in the Summerland oil field.

Rupture Lengths of Intraplate Earthquakes in Brazil Determined by Relative Location of Aftershocks: Evidence for Depth Dependence of Stress Drops

ASSUMPÇÃO, M., University of São Paulo, SP, Brazil, marcelo.assumpcao@ iag.usp.br; CIARDELLI, C., University of São Paulo, SP, Brazil, caio.ciardelli@ iag.usp.br

Whether intraplate and interplate earthquakes have different average source propertieshas been long debated. It has been proposed that intraplate events tend to rupture smaller areas with higher stress drops. We estimate rupture lengths of several Brazilian earthquakes by accurately locating their immediate aftershocks. The sparsity of stations in low-seismicity regions, such as Brazil, hinders accurate epicentral determination. Cross-correlation of $\mathrm{P}-, \mathrm{S}$ - and $\mathrm{Lg}$ waves can accurately locate the aftershocksrelative to one another. In several cases, it was possible to infer the rupture length by the distribution of the early aftershocks, with the later aftershocks tending to span a larger area. We studied seven aftershock sequences with regional stations. The mainshock occurs close to the foreshocks, which act as triggers to the main rupture. The immediate aftershocks tend to occur in a circle around a central (presumably stress-free) zone, interpreted as the rupture of the mainshock. Published data from other events, based mainly on local networks, were added toempirically relaterupture length and $\mathrm{Mw}$. These data suggest that stress-drops in Brazil vary mostly between 0.1 and $10 \mathrm{MPa}$, a similar to many other studies worldwide. However, the mean stress drop (about $1 \mathrm{MPa}$ ) is smaller than the mean values of both interplate and intraplate events globally (mostly between 2 and $10 \mathrm{MPa}$ ). A possible dependence of stress drops with hypocentral depth may explain this difference: Brazilian intraplate earthquakes tend to be shallower than most other mid plate regions giving rise to smaller stress drops, on average. This result has important implications for seismic hazard estimation when GMPE equations from other intraplate regions are used in Brazil.

\section{Earthquake Stress Drops Determined from Arias Intensity}

BALTAY, A.S., US Geological Survey, Menlo Park, California, USA, abaltay@ usgs.gov; HANKS, T. C., US Geological Survey, Menlo Park, California, USA, thanks@usgs.gov

We estimate earthquake stress drop directly from the Arias intensity database of NGA-West 2 and compare those estimates to other methods for calculating stress drop from the same database, taking careful consideration of the assumptions of each method. Arias intensity is an engineering measure proportional to the integral of the square of the absolute value of acceleration, over the significant duration of the signal [Arias, 1970]. As such, it is closely related to the root-meansquare acceleration, and can readily be connected to stress drop using the relationship of Hanks and McGuire [1981]. Implicit in that estimation is the assumed equality between earthquake source duration and the inverse of the corner frequency. In the NGA-West2 database Arias intensity measurements are tabulated for each ground-motion record, with two pieces of information at each 5th-percentile of duration: the value of the cumulative intensity at each percentile, and the time at which that intensity is reached. We first estimate the stress drop for all records in the NGA-West 2 database from the Arias intensity, and then explicitly consider the relationship between the observed duration and the derived source corner frequency from the estimated stress drop. We find the observed duration depends not only on the source duration but also on the path distance, consistent with Boore and Thompson [2014]. We also compare the stress drop determined from this method to that estimated from PGA and spectra methods for the same data, as well as the empirical event-term determined from ground-motion prediction equations. The variability of the Arias intensity-based stress drop is as low as that of eGf-based stress drops from Baltay et al. [2010, 2011], nearly on par with variability seen in ground-motion prediction equations. The Arias intensity stress drop is a novel and promising approach for understanding stress drop variability and physical connections to ground motion uncertainty.

\section{Systematic Observations of the Slip-Pulse Properties of Large Earthquakes} MELGAR, D., University of Oregon, Oregon, USA, dmelgarm @uoregon.edu; HAYES, G. P., US Geological Survey NEIC, Colorado, USA, ghayes@usgs.gov

In earthquake dynamics there are two end member models of rupture: propagating cracks and self-healing pulses. These arise due to different properties of ruptures and have implications for seismic hazard; rupture mode controls nearfield strong ground motions. Past studies favor the pulse-like mode of rupture, however, due to a variety of limitations, it has proven difficult to systematically establish their kinematic properties. Here we synthesize observations from a database of $\geq 150$ rupture models of earthquakes spanning M7-M9 processed in a uniform manner and show the magnitude scaling properties (rise time, pulse width, and peak slip rate) of these slip pulses indicates self-similarity. Self similarity suggests a weak form of rupture determinism, where early on in the source process broader, higher amplitude slip pulses will distinguish between events of increasing magnitude. Indeed, we find by analyzing the moment rate functions that large (M7.5+) and very large (M8.5+) events are statistically distinguishable relatively early (at $\sim 15$ seconds) in the rupture process. This suggests that with dense regional geophysical networks the potential strong ground motions from a large rupture can be identified before their onset across the source region.

Variability in Seismic Source Spectra and Stress Drop from Repeating Earthquake Sequences along the Nicoya Peninsula Megathrust CHAVES, E. J., Department of Earth and Planetary Sciences, UC Santa Cruz, California, USA, echavess@ucsc.edu; SCHWARTZ, S. Y., Department of Earth and Planetary Sciences, UC Santa Cruz, California, USA, syschwar@ucsc. 
edu; ABERCROMBIE, R. E., Department of Earth and Environment, Boston University, Massachusetts, USA, rea@bu.edu

Using template-matching, we identify clusters of repeating events, RE, before and after a megathrust earthquake and analyze temporal and spatial variations in stress drop, SD. An increasing number of observations in different tectonic regimes and laboratory experiments have revealed conflicting answers about whether earthquake SD scales with magnitude. In theory measuring SD should be simple, in practice it has been very difficult to characterize in a robust manner. $\mathrm{RE}$ provide an opportunity to measure and constrain $S D$ variability. We analyze temporal and spatial changes in source parameters of earthquakes on the plate interface that occur before and after the 2012 M7.6 Nicoya, Costa Rica earthquake. RE (M2.2-3.3), identified in the aftershock catalog during the 4 months following this event are used as templates to extend the catalog of RE from 2007 through 2015. This search yields 26 clusters that repeat at least once per year. We analyze scaling relations and self-similarity of the earthquake source spectra for more than 100 earthquakes, including the 26 clusters of RE and non-repeating aftershocks of the Nicoya earthquake (M2.5-5.5). We correct spectra of larger events for attenuation using the empirical Green's function, eGF, method and evaluate the complexity of the eGF spectral ratio based on its fit to a Boatwright source model. Thus far, $38 \%$ of the events analyzed exhibit complexity (variance $<85 \%$ ) that cannot be accounted for using simple rupture models. We eliminate complex events from further analysis. Measurements from only the "simple spectra" in our event catalog show invariance of SD with depth and no spatial variability. However, results from a single family of RE with simple spectra through time, reveal temporal changes in SD before and after the 2012 earthquake that are accompanied by a reduction in relative magnitude of 0.3 units. We interpret these changes as reflecting variations in loading rate along the plate interface.

Emergency Management, Resilience and Preparedness Oral Session · Thursday 17 May · 10:45 PM • Monroe Session Chairs: Victor A. Huerfano, Christa G. von Hillebrandt-Andrade, Elizabeth A. Vanacore, and Ronald Jackson

2018 Honduras Earthquake and Tsunamis: Notification and Response Process VON HILLEBRANDT-ANDRADE, C. G., National Oceanic and Atmospheric Administration, Puerto Rico, USA, christa.vonh@noaa.gov; BROME, A., Caribbean Tsunami Information Centre, Barbados, a.brome@ unesco.org; ALIAGA, B., United Nations Educational, Scientific and Cultural Organization, Paris, France, b.aliaga@unesco.org

On January 10, 2018 at 2h51 UTC (January 9 between 8:51 and 10:51 PM local time) a Mw 7.6 earthquake occurred offshore Swan Island (Honduras). Fortunately there was no significant damage from the earthquake and the tsunami was small. This was the first time the Pacific Tsunami Warning Center (PTWC) issued a Tsunami Threat for the Caribbean since the enhanced tsunami products for the UNESCO IOC Tsunami and Other Coastal Hazards Warning System for the Caribbean and Adjacent Regions (CARIBE EWS) were adopted in 2015. It was also the first time a Tsunami Advisory was issued for Puerto Rico and the US and British Virgin Islands (PR/VI). While the first message that was issued was based on the earthquake, following messages integrated the tsunami forecast and observations. The earthquake was felt in some countries; others for whom the Tsunami Threat/Advisory was issued did not report feeling the earthquake which is often the first sign of a potential threat, making even more important the official alerting process. Both the international and domestic text products were timely sent by the PTWC to designated authorities and posted on the tsunami.gov website. For the international stakeholders it is their responsibility thru their designated Tsunami Warning Focal Point/National Tsunami Warning Center to determine the threat level. In the case of PR/VI, the alert level (Warning, Advisory, Watch or Information) is established by the PTWC. In either case, international or domestic, it is the responsibility of the national/ local governments to decide on the actions to be taken (evacuate or not evacuate) and to notify the public. The event timeline, as well as the UNESCO IOC CARIBE EWS after action report will be presented. In addition to identifying the strengths and gaps of tsunami warning system, the event review is also important considering the impact that hurricanes Irma and Maria had on local communication and emergency response systems and the public.
The Effects of Natural Disasters on the Demand for Education and Outreach in Puerto Rico: Why Now?

GOMEZ, G., University of Puerto Rico Mayagüez, Puerto Rico, USA, ggomez@ prsnmail.uprm.edu; VANACORE, E. A., University of Puerto Rico Mayagüez, Puerto Rico, USA, elizabeth.vanacore@upr.edu

In September of 2017 Puerto Rico experienced the devastation of two hurricanes, Irma and Maria. On January 10, 2018 a 7.6 Mw earthquake near Honduras promoted the activation of the tsunami advisory for Puerto Rico. These three recent events have changed the life of Puerto Ricans and have raised an urgency to be better prepared in case of natural disasters that may be affecting our welfare at any time. The Puerto Rico Seismic Network Education and Outreach department $(\mathrm{E} \& \mathrm{O})$ serves the entire Island community for earthquakes and tsunamis education and preparedness. The E\&O department, impacts thousands of people in our community not including larger annual exercise (ShakeOut and Caribe Wave) through talks, conferences, workshops and fairs. From September 20th until December the requests for talks and conferences decreased to almost zero due to the devastation of the Island. The lack of power and water supply, inaccessible roads, collapsed bridges, floods, and lack of communications affected our activities. This, plus the long recovery process changed the priorities of our citizens. By January 2018, the raised awareness of the fragility of our wellbeing and partial recovery from the hurricanes, caused a significant increase in demand for $\mathrm{E} \& \mathrm{O}$ services with many communities indicating a raised urgency to be prepared and take the right actions now, before another disaster strikes. A second peak in requests occurred after the tsunami advisory level message issued for Puerto Rico. Despite outreach efforts to present tsunami and earthquake information to the community through talks, web page, educational material, the media, among others, the community became aware that they have not taken the time to learn and understand the tsunami protocols. Here we present the effects of natural disasters on community demand for $\mathrm{E} \& \mathrm{O}$ services and methods employed to take advantage of the receptiveness of our citizens in order to understand these natural phenomena.

\section{Developing Local-Context Messages for Protective Actions during Earthquakes in Anse-a-Veau, Haiti}

MENTOR WILLIAM, G., Geohazards International, Haiti, mentor@geohaz. org; RODGERS, J. E., Geohazards International, California, USA, rodgers@ geohaz.org; DEVILME, G., Geohazards International, Haiti, gefthe@geohaz. org; ORTIZ MILLAN, M., Geohazards International, California, USA, ortizmillan@geohaz.org

In the unnerving seconds when earthquake shaking begins, a person's action may spell the difference between safety and suffering. Various messages that describe protective actions have been issued in the United States, such as: Drop, Cover and Hold on, triangle of life, stand in a doorway. But these may not be the safest actions in the far more vulnerable built environments that exist in many earthquake-prone countries. The safest response may depend on the intensity of shaking, building type, a person's location in the building, and access to exits. Factors such as culture, gender, folklore and literacy may influence a person's trust in the message as well as their ensuing behavior. GeoHazards International developed evidence-based guidance to create effective messages for earthquake protective actions in diverse contexts. They devised a local process and local factors to consider. Sixty-nine multidisciplinary disaster professionals, from 22 countries, contributed experiences, critiques, and key considerations. Applying the locallybased process in a pilot program to develop locally appropriate earthquake safety messages, GeoHazards International worked with the community of Anse-àVeau, a coastal city in Haiti that was hit by a M 6.5 of earthquake and tsunami in 1952. The goal was to create messages that people understand, trust, and practice, so they take the safest action during an earthquake or tsunami. Members of the diverse, newly-created Anse- à-Veau earthquake safety committee and Haitian experts conducted training for residents and local authorities, so that they were able to understand their hazard risk and identify local vulnerabilities. This strategy, which fully engages the community, will subsequently make Anse-à-Veau more prepared and resilient to future earthquakes and tsunamis. Lessons learned from this project will be incorporated to update the guidance.

Previsioni Operative Del Terremoto, Sōsa-Jō No Jishin Yochi, and Operational Earthquake Forecasts: Exploring How Operational Earthquake Forecasts Are Communicated in Italy, Japan, New Zealand, and the United States MCBRIDE, S. K., US Geological Survey, California, USA, skmcbride@usgs. gov; WEIN, A. M., US Geological Survey, California, USA, awein@usgs.gov; MARZOCCHI, W., Istituto Nazionale di Geofisica e Vulcanologia, Rome, Italy, warner.marzocchi@ingv.it; KAMAYA, N., Japan Meteorological Agency, Japan, noriko.kamaya@nifty.com; MICHAEL, A. J., US Geological Survey, California, USA,michael@usgs.gov; BECKER, J. S., GNS Science, New Zealand, j.becker@ 
gns.cri.nz; POTTER, S. J., GNS Science, New Zealand, s.potter@gns.cri.nz; PAGE, M. T., US Geological Survey, California, USA, mpage@usgs.gov; VAN DER ELST, N. J., US Geological Survey, California, USA, nvanderelst@usgs. gov; GERSTENBERGER, M., GNS Science, New Zealand, m.gerstenberger@ gns.cri.nz

Earthquake forecasts have been produced by statistical seismologists in a variety of forms for almost forty years. These forecasts, meant to illuminate potential futures of earthquake sequences, have undergone a variety of changes in that time, with the goal of clearly and usefully communicating scientific information to key stakeholders (e.g., decision makers, emergency managers, building engineers) and members of the public. Probabilities are notoriously difficult to communicate, particularly when risk actions are involved. Further complicating an already complex science communication issue is the different types of forecasts produced by four different countries-Japan, Italy, New Zealand and the United States of America. These four countries are producing forecasts that meet the standards of the Collaboratory for the Study of Earthquake Predictability (CSEP). This presentation describes the different types of contemporary forecasts being produced in these four countries, with a focus on the processes of message development and channels used for communication with particular audiences, specifically emergency managers, building engineers, decision makers, planners, and vested audiences. Further, the research uses thematic analysis of available forecasts to examine content and presentation over time with respect to best-communication practice literature. Cultural and social contexts, as well as lessons learned from each country, will be shared to inform development of forecasts for future use.

\section{No Blank Slates: Socio-Technical Systems Theory as a Guiding Principle for Disaster Response and Recovery}

PEREZ-LUGO, M., University of Puerto Rico Mayagüez, Puerto Rico, USA, marla.perez2@upr.edu; ORTIZ GARCIA, C., University of Puerto Rico Mayagüez, Puerto Rico, USA, cecilio.ortiz@upr.edu; LOPEZ, I., University of Puerto Rico Mayagüez, Puerto Rico, USA, ibrahim.lopez@upr.edu

On December of 2017, already three months after the disastrous hit of Hurricane Maria to Puerto Rico, the president of the Smart Electric Power Alliance said to two E\&E News reporters: "Here we are, sadly, in a position where Puerto Rico is as close to a blank slate as we ever thought realistically would come to pass". The New York Times echoed that statement is a series of articles citing good intentioned citizens saying that this was "a chance to work on a blank canvas". Since then, more than two dozen U.S. consortiums and renewable energy companies have landed on Puerto Rico looking to implement innovative energy technologies and models in their desire to rebuild the ravaged island. In that process, they have become part of Puerto Rico's energy debate inside and outside the archipelago. However, the argument of the blank slate is founded on a problematic premise: that energy systems are only physical systems and that they do not involve sociological dimensions such as values, beliefs, institutions, norms and power relationships among stakeholders. In other words, that premise presupposes that energy transitions do not require regime changes, and even if they do, that is accomplished by an injection of new external actors. The Socio-technical Systems (STS) theory has contradicted this premise for more than twenty years. As Verbong and Geels (2006), and Geels (2005), have proposed, socio-technical regimes have at least two main sociological dimensions: actors and formal, normative and cognitive rules. STS also suggests that existing sociotechnical regimes are characterized by path dependence and lock-in, resulting from stabilizing mechanisms on those two dimensions in conjunction with the system's material and technical elements such as the grid, generation plants, and the energy resources among others (Unruh, 2000; Walker, 2000). This theory can explain why almost five months after the impact of Hurricane Maria, and the influx of many external actors such as FEMA, the US Corps of Engineers, and multinational private companies, more than half of the population is still lacking electric service in the island. It also can illuminate why disaster response and external aid often fails in reaching their goals.

\author{
Forecasting Aftershock Sequences in the Real World \\ Oral Session · Thursday 17 May · 3:45 PM · Hibiscus A \\ Session Chairs: Matthew C. Gerstenberger, Sara K. Mcbride, \\ Nick Horpsool, and David A. Rhoades
}

\section{Non-Parametric Aftershock Forecasts Based on Similar Sequences in the Past}

VAN DER ELST, N. J., US Geological Survey, California, USA, nvanderelst@ usgs.gov; PAGE, M. T., US Geological Survey, California, USA, mpage@usgs. gov

The basic premise behind aftershock forecasting is that sequences in the future will be similar to those in the past. Forecast models typically use empirically tuned parametric distributions to approximate past sequences, and project those distributions into the future. While parametric models do a good job of describing average outcomes, they fail to capture the full range of variability between sequences, and can suffer from over-tuning of the parameters. In particular, parametric forecasts may produce a high rate of "surprises" - sequences that land outside the forecast range. Here we present a non-parametric forecast method based on finding past sequences that are similar to the target sequence. We quantify similarity based on the observed event count within a specified differential magnitude threshold relative to the mainshock. The forecast is then constructed from the distribution of past sequences outcomes, weighted by their similarity. We compare the similarity forecast with the Reasenberg and Jones (RJ89) method, for a set of global aftershock sequences of $M \geq 6$ mainshocks. We implement a RJ89 forecast using a global average prior and sequence-specific Bayesian updating. The similarity forecast is somewhat less precise than the RJ89 forecast, with $85 \%$ of sequences falling within a factor of two of the median forecast value, whereas the fraction is $90 \%$ for RJ89. However, the surprise rate is much lower for the similarity forecast; fewer than $3 \%$ of sequences exceed the upper $2.5 \%$ range of the similarity forecast, whereas this number is $10 \%$ for the Poissonian RJ89 forecast. The similarity forecast may be useful to emergency managers and nonspecialists when confidence or expertise in parametric forecasting may be lacking. The method makes over-tuning impossible, and minimizes the rate of surprises. At the least, this forecast constitutes a useful benchmark for more precisely tuned parametric forecasts.

\section{Evolution of Aftershock Sequences Based on the Geometry of Successive Focal Mechanisms}

TOWNEND, J., Victoria University of Wellington, Wellington, New Zealand, john.townend@vuw.ac.nz

Detailed studies of the evolution of aftershock sequences have focused overwhelmingly on the timing and location of individual earthquakes and their interpretation in terms of empirical and physical models of stress transfer controlled by the mainshock alone or by the mainshock and only the largest aftershocks. While the gross spatial and temporal features of aftershock sequences can be accounted for with this approach, the role played by smaller-scale interactions between low-magnitude aftershocks remains unclear. To date, comparatively little attention has been paid to aftershocks' focal mechanisms, which, in principle, enable incremental stress changes associated with lower-magnitude aftershocks to be computed and incorporated in stress transfer models. In this study, we analyse the moment tensors of earthquakes that occurred in the South Island of New Zealand following the 2010 Darfield (Canterbury) and 2016 Kaikōura earthquakes. We consider the interaction between one earthquake and the next in terms of the vector joining their hypocenters and represented in a coordinate system defined by the earlier event's focal mechanism. This approach enables us to describe the sequence of focal mechanisms with reference to a common coordinate system and thus investigate whether the faulting geometry of each aftershock contributes to the sequence's overall evolution.

\section{Earthquake Statistics in the Eastern Tennessee and New Madrid Seismic Zones Are Inconsistent with Ongoing Aftershock Sequences}

LEVANDOWSKI, W., Colorado College, Tennessee, USA, wlevandowski@ coloradocollege.edu; POWELL, C. A., University of Memphis, Tennessee, USA, capowell@memphis.edu

A key challenge to understanding intraplate seismic hazard is separating aftershock sequences that are not representative of long-term earthquake rates. First, we use modern frequency-magnitude relations to investigate whether high seismicity rates in the Eastern Tennessee Seismic Zone (ETSZ) are plausibly a transient response to a large but unknown prehistoric event. The expected rate of aftershocks depends on the magnitude of the mainshock; to be conservative, we begin by assuming that the entire $\sim 250-\mathrm{km} \mathrm{NE}$ trend of epicenters defines that maxi- 
mum length of a plausible rupture, which corresponds to a M8 event. Modern frequency-magnitude relations in the ETSZ would require that this putative M8 earthquake occurred 175 years ago, but no such event has been documented since European colonization $\sim 400$ years ago. We next take a Monte Carlo approach to propagate uncertainty in b-value, modern annual earthquake rates, the exponent of Omori decay and associated constants. Of these realizations, $96 \%$ require the mainshock within the past 400 years, meaning that there is only a $4 \%$ chance that ETSZ seismicity solely reflects aftershocks of an unknown event. We perform a similar analysis using the known mainshocks of 1811-1812 in the New Madrid Seismic Zone, finding that modern rates of seismicity have only a $6 \%$ probability of solely representing aftershocks. The median of the realizations suggests that only half of modern earthquakes are likely to be aftershocks. Therefore, the present mapping of elevated hazard in the ETSZ and New Madrid is warranted.

Examples of Various Operational Earthquake Forecasting Products Using the HayWired Planning Scenario, including One Very Quick (and Not-So-Dirty) Hazard-Map Option

FIELD, E. H., US Geological Survey, Golden, Colorado, USA, field@usgs.gov; MILNER, K. R., University of Southern California, California, USA, kmilner@ usc.edu

In an effort to help address debates on the usefulness of Operational Earthquake Forecasting $(\mathrm{OEF})$, we illustrate a number OEF products that could be automatically generated in near real time. We use an M 7.1 main shock on the Hayward fault to exemplify, which is very similar to the USGS HayWired earthquake planning scenario. Given there is always some background level of hazard or risk, we emphasize that probability gains (the ratio of short-term to long-term-average estimates) should be of particular interest to users. We also illustrate how such gains are highly sensitive to forecast duration and latency, with the latter representing how long it takes to generate the forecast and/or to take action. The influence of fault-based information, which has traditionally been ignored in OEF, is also evaluated using the newly developed UCERF3-ETAS model. We find that the inclusion of faults only makes a difference for hazard and risk metrics that are dominated by large-event likelihoods. We also show how the ShakeMap of a main shock represents a decent estimate of the ground motions that have a $6 \%$ chance of being exceeded due to aftershocks in the week that follows. The ultimate value of these types of OEF products can only be determined in the context of specific uses, and because these vary widely, institutions responsible for providing OEF products will depend heavily on user feedback, especially when making resourceallocation decisions.

Expanding the US Geological Survey's Efforts to Effectively Communicate Operational Earthquake Forecasts

MCBRIDE, S. K., US Geological Survey, California, USA, skmcbride@usgs. gov; HARDEBECK, J. L., US Geological Survey, California, USA, jhardebeck@ usgs.gov; WEIN, A. M., US Geological Survey, California, USA, awein@usgs. gov; MICHAEL, A. J., US Geological Survey, California, USA, michael@usgs. gov; FIELD, E. H., US Geological Survey, California, USA, field@usgs.gov; PAGE, M. T., US Geological Survey, California, USA, mpage@usgs.gov; VAN DER ELST, N. J., US Geological Survey, California, USA, nvanderelst@usgs. gov

For over a decade, the US Geological Survey (USGS) has been communicating operational earthquake forecasts to various public audiences. During that time, these forecasts have been communicated using myriad of channels and formats, including text, maps, graphics, and tables. Each new forecast was presented differently using a variety of channels and at varying times during the response to an earthquake. Social science research demonstrates that consistency in formatting and messaging is preferred when communicating forecasts so audiences can better contextualize and understand the information presented. Further, information about aftershocks are required almost immediately by media and key stakeholders' post-earthquake. To be both consistent and timely when issuing forecasts, templates for pre-planned communication response are required to effectively and efficiently communicate information. The templates, developed by the USGS with expert and practitioner input, support earthquake forecasts for various situations: main shock (and aftershocks), swarms, and "earthquakes of note." It should be noted that automated templates for forecasts have been produced but only for the state of California. Different earthquakes require unique responses, including "earthquakes of note" e.g. earthquakes of public interest or shaking in unusual locations. Swarms present a unique challenge because most (but not all) do not produce a large earthquake. Further, we have learned from workshops with different stakeholders (e.g. emergency managers, urban and regional planners) that customizable templates are preferred, to meet the information needs of the various audiences. Once the templates are tested, these will be distributed via the USGS web site, social media, and broadcast media channels when earthquakes occur. Effectiveness will be measured using broadcast and social media analysis and iterated as evidence requires.

Increasing Testability-Expanding Possibilities and
Future Developments of the Collaboratory for the Study of
Earthquake Predictability
Oral Session · Thursday 17 May $\cdot 8: 30 \mathrm{AM} \cdot$ Hibiscus B
Sesson Chairs: Andrew Michael, Danijel Schorlemmer,
Maximilian Werner, and Warner

The Collaboratory for the Study of Earthquake Predictability: Achievements and Priorities

JACKSON, D. D., UC Los Angeles, California, USA, djackson@g.ucla.edu; WERNER, M. J., University of Bristol, United Kingdom, max.werner@bristol. ac.uk; SCHORLEMMER, D., GFZ Potsdam, Germany, ds@gfz-potsdam.de

The Collaboratory for the Study of Earthquake Predictability (CSEP) is global platform for conducting prospective earthquake forecasting and prediction experiments. Since its inception in 2006 in California, CSEP has grown to encompass four testing centers around the world, and is now prospectively evaluating over four hundred models in testing regions in California, Italy, New Zealand, Japan, the western Pacific and at global scale. Here, we review a decade of CSEP achievements, and state our priorities for future activities. Achievements encompass new scientific insights into earthquakes and their predictability, progress in evaluation methodology, and broader impacts in seismic hazard assessments and risk reduction strategies. Scientific highlights include: (1) the numerous small earthquakes provide information about future moderate-to-large earthquakes; (2) geodetic strain rate models capture earthquake potential, and, when coupled with smoothed seismicity models, provide the most informative forecasts; (3) a new generation of physics-based Coulomb/rate-state models are now able to compete with statistical models in forecasting the space-time evolution of earthquake sequences; More broadly, CSEP has highlighted the benefits and scientific importance of prospective and independent testing to establish credible benchmarks of the forecast skill of competing hypotheses and models. These and other CSEP results have effected changes to several earthquake source models of official seismic hazard models, including in California, New Zealand and Italy. In this way, CSEP has contributed to safer and better-informed societies. Future activities will be guided by three main objectives: (1) Improve the discrimination capability of forecast testing by expanding the spatial and temporal distribution of earthquake data. (2) Develop procedures and requisite cyberinfrastructure for testing earthquake forecasts worldwide, focusing on new types of earthquake forecasts. (3) Test key hypotheses that underlie earthquake forecasting models.

\section{Simulations of Data Based Scenarios to Investigate the Significance of Data Quality in Seismicity Studies \\ ADAMAKI, A.K., Uppsala University, Sweden, angeliki.adamaki@geo.uu.se}

Studying the earthquake processes involves the exploration of the available data to extract all possible information required for the deeper understanding of the underlying physical mechanisms. When a theoretical concept, in the form of a physical and/or statistical model, is developed and applied, data of the best possible quality (in terms of precision, sample size etc) is essential for the adequate estimation of the required parameters. In the present work, issues relevant to data sets extracted from earthquake catalogues and their effect on seismicity studies are discussed, based on simulations of seismicity data. For example, the realizations of data based scenarios presented here for the investigation of earthquake predictability give evidence of a potential use of foreshocks in earthquake forecasting, if more data becomes available. Assuming that an ideal improvement of the seismic networks can be achieved, an increase of network sensitivity by 1.5 magnitude unit would enable us to correctly detect 4 times more foreshock sequences. The corresponding number of false detections would also increase but remain relatively lower. However, real data sets can be far from perfect even if numerous earthquakes are recorded, and results might be misleading if e.g. the magnitude of completeness is underestimated due to errors in the reported magnitudes. The analyses of stochastic magnitude catalogues which include databased errors reveal and quantify the significant impact the quality and size of a data set might have on the estimated catalogue properties, and as a result on seismic hazard assessment. 
Testing Planned USGS Aftershock Forecasts Requires Simulation-Based Tests, Which Demonstrate Limitations of the Reasenberg and Jones Method MICHAEL, A. J., US Geological Survey, California, USA, michael@usgs.gov

Tests of operational earthquake forecasts (OEF) by the Collaboratory for the Study of Earthquake Predictability (CSEP) are necessary to validate and improve OEF methods. The relevant CSEP tests rely on Poisson statistics and focus on 1-day forecasts, updated daily. That approach provides a simple set of independent forecasts but is incompatible with the aftershock forecasts planned for release by the USGS. The USGS aftershock forecasts will be released very shortly after large earthquakes, without waiting for the next day, and each forecast will include a variety of overlapping time windows such as the next week, month, and year. These forecasts will be updated on a regular basis and when significant aftershocks occur. Because these updates will occur before the previous time windows have all ended, this will result in an even larger set of dependent forecasts. Additionally, the updated version (Page et al., 2016) of Reasenberg and Jones (1989) includes non-Poissonian uncertainties that combine epistemic uncertainty in the parameters and aleatory variability. And planned Epidemic Type Aftershock Sequence (ETAS) forecasts are fundamentally non-Poissonian, even without epistemic uncertainties. Thus, the Poisson uncertainty formulations used in existing CSEP tests are inadequate. Fortunately, new simulation-based methods under development within CSEP provide the necessary foundation to address dependent forecasts and non-Poissonian uncertainty. Applying these tests to synthetic data demonstrates their utility. These improved tests show that, if the world resembles ETAS behavior, the Reasenberg and Jones method will fail good tests because the lack of secondary aftershocks causes it to underestimate the variability of aftershock sequences. Testing approaches that correspond to the way the USGS forecasts will be issued will enable meaningful retrospective tests of our methods before the system goes public and continual tests of prospective forecasts in the future.

\section{Turing-Style Tests for Synthetic Earthquake Catalogs}

PAGE, M. T., US Geological Survey, California, USA, pagem@caltech.edu; VAN DER ELST, N. J., US Geological Survey, California, USA, nvanderelst@ usgs.gov

Epidemic-Type Aftershock Sequence (ETAS) catalogs generated from the 3rd Uniform California Earthquake Rupture Forecast (UCERF3) model are unique in that they are the first to combine a complex, fault-based long-term forecast with short-term earthquake clustering statistics. We present Turing-style tests to examine whether these synthetic catalogs can successfully imitate observed earthquake behavior in California. We find that UCERF3-ETAS is more spatially diffuse than the observed historic catalog in California and that it is lacking quiet periods that are present in the real catalog. While mean aftershock productivity of the observed catalog is matched closely by UCERF3-ETAS, the observed catalog has more inter-sequence productivity variability and small mainshocks have more foreshocks. Many of the differences we find in UCERF3-ETAS are foreseeable from its modeling simplifications. The tests we present here can be used on any model which produces suites of synthetic catalogs; as such, in addition to providing avenues for future improvements to the model, they could also be incorporated into testing platforms such as Collaboratory for the Study of Earthquake Predictability (CSEP).

\section{Regional Evolution of Coda Waves' Attenuation in the NW South America} VARGAS JIMENEZ, C. A., Universidad Nacional de Colombia, Bogota, Colombia, cavargasj@unal.edu.co; OCHOA, L. H., Universidad Nacional de Colombia at Bogota, Bogota, Colombia, lhochoag@unal.edu.co

Several studies in some regions of the world have shown during last decades that coda waves' attenuation may vary as a response to different processes in the Earth interior, e.g. evolution of cracks due to stress variations, migration of fluids, and mobility of magmas. It means, that permanent monitoring of coda waves derived from seismological records from the same area, using identical lapse time since the $\mathrm{S}$-wave onset, and application of similar signal processing techniques is an interesting approach for detecting changes related to the evolution of regions with tectonic or volcanic activity. Nevertheless, these observations are not detected in other regions, probably due to the concurrence of additional processes not yet identified or inadequately understood. In addition, contrasting seismological information among active regions may also promote diverse sensitivity and reduce the hope of success in the volcanic and earthquake forecasting or prediction studies. In this work is reported the estimation of approximately $180.000 \mathrm{Qc}$ values using a lapse time of $10 \mathrm{~s}$ since the $\mathrm{S}$-wave onset, several frequency bands and applying the Sato (1977) technique. Estimations were performed with seismological local records (hypocenter distances less than $200 \mathrm{~km}$ ) detected by the National Seismological Network of Colombia in the period June 1993 to October
2017. Comparing time series of $\mathrm{Qc}$ and $\mathrm{mL}(\geq 6.0)$ allow to detect a cyclic behavior of this inverse attenuation parameter, which presents a stage of mean value reduction with ahigh variability that matches with a period of approximately 5 years of high earthquake activity in the NW South America (1995-2000). The Qc cycle looks of approx. 25 year and suggests that a new seismic crisis coming soon. Other observations and explanations to this phenomenon are presented and suggested.

Observed Characteristics of Induced Seismicity: From
Laboratory to Field Scale (Parts 3 and 4)
Oral Session · Thursday 17 May · $8: 30 \mathrm{AM} \cdot$ Flagler
Session Chairs: Kayla A. Kroll, Elizabeth S. Cochran, and
Brett Carpenter

\section{Earthquakes and Human Activities to Induce Them in Oklahoma}

WALTER, J. I., Oklahoma Geological Survey, Oklahoma, USA, jwalter@ ou.edu; CHANG, J. C., Oklahoma Geological Survey, Oklahoma, USA, jeffersonchang@ou.edu; MURRAY, K. E., Oklahoma Geological Survey, Oklahoma, USA, kyle.murray@ou.edu; BOAK, J., Oklahoma Geological Survey, Oklahoma, USA,jboak@ou.edu

The rate of earthquakes across the United States mid-continent has dramatically increased since 2009 . The historically high seismicity rates across the midcontinent have been largely driven by substantial increases in seismicity occurring within Oklahoma, including several magnitude $5.0+$ earthquakes. Prior to 2009, background seismicity rate was about $2 \mathrm{M} \mathrm{3.0+}$ earthquakes per year; this increased to 579 and peaked at 903 M 3.0+ earthquakes in 2014 and 2015, respectively. The increase in Oklahoma seismicity was roughly coincident with an oil and gas boom focused around the Mississippian Limestone and Hunton Limestone. Those plays contain substantial amounts of co-produced formation brines. Common disposal practices involved disposing of wastewater in deep underground injection wells completed into upper parts of the basement and the karstic Arbuckle Group, which directly overlies the basement over most of Oklahoma. From 2010 to late 2014, statewide disposal rates increased from $\sim 30$ million bbls/month to $\sim 90$ million bbls/month. The increase in seismicity rate roughly correlates to the increase in monthly injection rates, though with a lag greater than a year or so in many sub-regions of Oklahoma. The statewide disposal is down to $\sim 40$ million bbls/month and the earthquakes have also declined, due to targeted and statewide reductions in permitted disposal directed by the Oklahoma Corporation Commission, to economic factors, and to changes in disposal practices, i.e. injecting into shallower units. As injection and the seismicity rate have declined in 2016 and 2017, we have observed continued seismic activity at greater well-to-earthquake distances, particularly long-duration foreshock and aftershock sequences, and aftershock sequences that seem depleted in larger magnitude aftershocks. In light of the observed time-lagged coherence between wastewater injection and seismicity rate, several groups strive to estimate the future seismic hazard in Oklahoma and consensus has yet to be reached. However, it appears that the seismic hazard likely remains high in the next several years and elevated over the next several decades. Thus, Oklahoma still needs significant scientific infrastructure and intellectual investment in order to make progress in understanding and mitigation of induced seismicity.

\section{How Faults Wake Up: The Guthrie-Langston, Oklahoma, Earthquakes} SCHOENBALL, M., Lawrence Berkeley National Laboratory, California, USA, schoenball@lbl.gov; WALSH, F. R., Decision Geomechanics, California, USA, frwalsh@stanford.edu; WEINGARTEN, M., Stanford University, California, USA, mweingarten@stanford.edu; ELLSWORTH, W. L., Stanford University, California, USA, wellsworth@stanford.edu

Large-scale wastewater disposal has led to a fast-paced reawakening of faults in the Oklahoma/Kansas region. High resolution earthquake relocations show that the inventory of ancient basement faults in the study region differs from results of seismic surveys and geologic mapping focused on the sedimentary cover. We analyze the evolution of seismic activity in the Guthrie-Langston sequence in central Oklahoma in greater detail. Here, seismic activity has reactivated a network of at least $12 \mathrm{sub}$-vertical faults in an area less than $10 \mathrm{~km}$ across. Recorded activity began in late 2013 and peaked about 6 months later and includes two M4 earthquakes. These earthquakes characteristically occur at about $4 \mathrm{~km}$ depth below the top of the basement and do not reach the sedimentary cover. The sequence shows a radial growth pattern despite being no closer than $10 \mathrm{~km}$ to significant wastewater disposal activity. Hydrologic modeling suggests that activity initiated with a time lag of several years relative to early injection activity. Once initiated, earth- 
quake interactions contribute to the propagation of seismicity along the reactivated faults. As a result, the spatio-temporal evolution of the seismicity mimics a diffusive pattern that is typically thought to be associated with injection activity. Analysis of the Fault Slip Potential shows that most faults are critically stressed in the contemporary stress field. Activity on some faults, for which we find low slip probability, suggest a significant contribution of geomechanical heterogeneities to the reawakening of these ancient basement faults.

\section{More Stress Drop Estimates for Injection-Induced Earthquakes in Oklahoma and Southern Kansas}

WONG, I. G., Lettis Consultants International, California, USA, wong@ lettisci.com; DARRAGH, R. B., Pacific Engineering \& Analysis, California, USA, pacificengineering@juno.com; SILVA, W. J., Pacific Engineering \& Analysis, California, USA, pacificengineering@juno.com; KISHIDA, T., Khalifa University, United Arab Emirates, tadahiro.kishida@kustar.ac.ae

Significant issues regarding injection-induced earthquakes are whether 1) their stress drops are similar to or lower than tectonic earthquakes in the central and eastern U.S. (CEUS) and 2) correspondingly, whether their ground motions are similar or lower. Several analyses have been performed to date using both intensity observations and strong motion/broad-band data with conflicting conclusions. In this study, we add to the collection of stress drop studies. Based on a database compiled and initially processed by the USGS (Rennolet et al., 2017), we are computing the stress drops from about 90 induced earthquakes ranging from M 2.8 to 5.8 including the three largest Oklahoma earthquakes. In addition, we have analyzed a suite of 41 CEUS tectonic earthquakes from M 2.6 to 5.8 to compare stress drops. A broad-band inversion technique that inverts for stress drop, kappa and $Q(f)$ from multiple earthquakes was used. The approach uses nonlinear least-squares to judge the fit of the vector-average Fourier amplitude spectra (FAS) from the recordings compared to the FAS from the point-source model. The preliminary results of the inversion clearly show that the induced earthquake stress drops are significantly smaller than stress drops from tectonic earthquakes. An average stress drop for 26 induced earthquakes in Oklahoma and southern Kansas was 25 bars compared to 55 bars for the 41 CEUS tectonic events. We also evaluated whether there was a dependence of stress drop on magnitude, depth, and style of faulting. We observed that both shallow induced earthquakes and shallow tectonic earthquakes have low stress drops (< $<0$ bars). We did not observe a correlation with style of faulting or magnitude. Why different analyses of stress drops arrive at different conclusions will need to be resolved if reliable estimates of induced earthquake ground motions for large magnitudes at short distances, the area of most engineering relevance, are to be obtained.

Determining Periodicity in Non-Homogeneous Catalogs Using a Modified Schuster Test with Application to Induced Seismicity in Oklahoma

PEARSON, K. M., University of Maryland, Maryland, USA, karen.melinda@ gmail.com; THOMAS, A. M., University of Oregon, Oregon, USA, amt. seismo@gmail.com; LEKIC, V., University of Maryland, Maryland, USA, ved@ umd.edu

For years, scientists have tried to determine whether periodicities exist in earthquake catalogs. These studies have ranged from global to local and looked for influence due to both diurnal tides and seasonality related to snowmelt or rainfall cycles. However, the standard test for periodicity, the Schuster Test, is valid only under the condition of homogeneity in the catalog. When the fundamental earthquake rate has changed over time, as is the case with many locations experiencing an increase in earthquakes due to wastewater injection from oil production activity, the heteroscedasticity prevents a direct application of the Schuster Test for interpretable results. Herein we formulate and validate a modified Schuster Test that is appropriate for use when the background rate of seismicity is changing. When applied to seismicity catalogs of induced seismicity in Oklahoma, we rule out a signature of tidal triggering and identify a number of spurious periodicities whose significance would be overestimated by the traditional Schuster Test.

\section{Physics-Based Induced Earthquake Forecasting: Case Studies from Texas and Oklahoma}

ZHAI, G., Arizona State University, Arizona, USA, gzhai@asu.edu; SHIRZAEI, M., Arizona State University, Arizona, USA, shirzaei@asu.edu

The recent dramatic increase in seismic events in the Central and Eastern United States is suggested to be linked to underground high-volume fluid injection. Some researchers investigated the qualitative correlation between the injection operations and induced seismicity. However, they ignored the physical process governing poroelastic fluid diffusion and earthquake nucleation. Thus, we propose a physics-based induced earthquake forecasting model which couples linear poroelasticity to rate-and-state earthquake model, considering the complex rela- tionship between injections and consequent seismicity. Firstly, we implement a coupled flow and poroelastic model to simulate the evolution of pore pressure and poroelastic stresses in time and space. Secondly, we use local geology and maps of existing faults to calculate the rate of Coulomb failure stress change. Thirdly, we import the maps of Coulomb stress change rate into a seismicity rate model. Finally, the estimated seismicity rate changes are used within a probabilistic model to evaluate the time-dependent seismic hazard for each given fault. Both Texas and Oklahoma experienced intensive deep waste fluid injections and seismicity increases. To investigate the associated link, we apply our method to the time-varying injections at 96 Ellenberger wells in the Barnett Shale during 2007-2015 and 855 Arbuckle wells in Oklahoma during 1995-2017. In both study areas, earthquake locations correlate well with pore pressure and poroelastic stress, although poroelastic stress is smaller than pore pressure. Given the good quality of earthquake record in Oklahoma, the predicted earthquake magnitudetime distribution shows excellent fit to observation, confirming the performance of the model. The obtained time-dependent seismic hazard is spatiotemporally heterogeneous. Decreasing injection rates does not necessarily reduce probabilities immediately. The presented framework can be used for operational induced earthquake forecasting.

Quasi-Static Fault Dislocation Driven by Fluid Diffusion and Poroelastic Stressing as a Possible Source Model of Slow Slip Events: A Numerical Investigation

IIN, L., Stanford University, California, USA, leijin@stanford.edu; ZOBACK, M. D., Stanford University, California, USA, zoback@stanford.edu

Slow slip events (SSEs) are commonly observed at a plate interface between a viscously slipping portion and a seismogenenic zone. Recently, SSEs have also been reported following in-situ fluid injection experiments. Almost all exiting models of SSEs are friction-based, utilizing unstable-stable transitional fault frictional behavior, in conjunction with suitable rheology of fault zones in the presence of hydrostatic pressure or overpressure. Inspired by the theory of poroelasticity, here we propose a fluid-based alternative model in which spontaneous quasi-static shear dislocation is initiated and sustained by the time-dependent poroelastic stress generated by the transient fluid pressure gradient. This model relies on the key assumption that the fault is critically stressed and has an exceedingly low frictional strength. We test our model via a series of $2 \mathrm{D}$ numerical experiments in the framework of coupled poromechanics. We simulate fluid injection into a faulted porous medium by solving the fluid diffusion equation. At each time step, the pressure gradient is passed as an equivalent body force vector to the quasi-static force balance law to solve for the displacement while allowing slip to occur simultaneously on the fault. Therefore, the slip rate is controlled by the fluid diffusion. We designed several cases in which the diffusivity of the matrix and the fault are on the order of $10-3 \mathrm{~m} 2 / \mathrm{s}$ and $10-4 \sim 102 \mathrm{~m} 2 / \mathrm{s}$, respectively. Depending also on other parameters including injection pressure and mechanical properties, the modeled dislocation is on the order of $10-4 \sim 10-5 \mathrm{~m}$ and the sliding velocity, $10-7 \sim 10-9 \mathrm{~m} / \mathrm{s}$, suggesting our model as a promising alternative source model of SSEs.

\section{Active Pressure Management as a Tool to Reduce Induced Seismicity}

KROLL, K. A., Lawrence Livermore National Laboratory, California, USA, kroll5@llnl.gov; WHITE, J. A., Lawrence Livermore National Laboratory, California, USA, white230@llnl.gov; RICHARDS-DINGER, K. B., UC Riverside, California, USA, keithrd@ucr.edu

It has been suggested that industrial operators may modify injection or production rates to actively manage fluid pressures in disposal reservoirs as a means of reducing the risk of induced seismicity. Therefore, we evaluate the efficacy of such active pressure management techniques by coupling a geomehanical reservoir model with an earthquake simulator. We use RSQSim, a 3D physics-based simulator that produces synthetic catalogs of earthquakes induced by the decreases in effective normal stress related to the fluid overpressures generated at a disposalsite. RSQSim, is governed by the rate- and state-dependent friction, which gives rise to similar spatiotemporal clustering observed of induced seismicity. These simulations provide rich earthquake catalogs based on stress changes due to fault interaction and external stress perturbations from fluid injection. Statistical data can be drawn from these catalogs that may contribute to the formalization of optimal injection operations designed to minimize risk at a given site. Here, we simulate seismicity induced by injection in a number of wells near a single optimally oriented fault with fractally distributed initial shear stresses. We evaluate the spatiotemporal distribution of events, the total number, the maximum magnitude, and the total seismic moment released with many pre-existing stress states. We conduct simulations for three constant volume injection scenarios designed to strategically modify overpressure in the reservoir. The scenarios consist of 1) injection into all wells, 2) injection and selective shut-in of some wells 
closest to the fault, and 3) injection at distant wells and production at one or more close wells. Results from simulations such as these will aid in the design of a sitespecific storage plan geared toward maximum volume disposal while limiting the risk of induced seismicity. This work is funded by the DOE under the NRAP program and prepared by LLNL under Contract DE-AC52-07NA27344.

Monte Carlo Simulations for Analysis and Prediction of Non-Stationary Magnitude-Frequency Distributions in Probabilistic Seismic Hazard Analysis REYES CANALES, M., University of Alberta, reyescan@ualberta.ca; VAN DER BAAN, M., University of Alberta, mirko.vanderbaan@ualberta.ca

We describe a first principles methodology to evaluate statistically the hazard related to non-stationary seismic sources like induced seismicity. We use timedependent Gutenberg-Richter parameters, which leads to a time-varying rate of earthquakes. This is achieved by deriving analytic expressions for occurrence rates which are verified using Monte Carlo simulations. We show twoexamples: (1) a synthetic case with two seismic sources (background and induced seismicity); and (2) a recent case of induced seismicity, the Horn River Basin, Northeast British Columbia. In both cases, the statistics from the Monte Carlo simulations agree with the analytical quantities. The results show that induced seismicity can change seismic hazard rates but that this greatly depends on both the duration and intensity of the non-stationary sequence as well as the chosen evaluation period. Further studies will include extensions to handle spatial source distributions as well as ground motion analysis in order to generate a complete methodology for non-stationary probabilistic seismic hazard analysis.

Improving Earthquake Rate Models for One-Year Hazard Forecasts in Southern Kansas

LLENOS, A. L., US Geological Survey, California, USA, allenos@usgs.gov; MICHAEL, A. J., US Geological Survey, California, USA, michael@usgs.gov; NORBECK, J. H., US Geological Survey, California, USA, jnorbeck@usgs. gov; RUBINSTEIN, J. L., US Geological Survey, California, USA, jrubinstein@ usgs.gov

The recent one-year seismic hazard assessments for natural and induced seismicity in the central and eastern US (CEUS) (Petersen et al., 2016, 2017, 2018) rely on earthquake rate models based on declustered catalogs (i.e., catalogs with foreshocks and aftershocks removed), as is common practice in probabilistic seismic hazard analysis. However, standard declustering can remove over $90 \%$ of some induced sequences in the CEUS, and the choices of whether and how to decluster can lead to seismicity rate estimates that vary by up to factors of 10-20 (Llenos and Michael, AGU, 2016). Moreover, the current one-year models do not incorporate fluid injection, which is a significant contributor to the seismicity rate increase in the CEUS (Ellsworth, Science, 2013). Therefore, in order to improve the accuracy of hazard assessments, we are exploring ways to make forecasts that are based on full, rather than declustered, catalogs and that can be informed by fluid injection data. We focus on southern Kansas, where the USGS has operated a seismic network since 2014, following the sharp increase in seismicity that began in 2013. We develop earthquake rate models using the space-time Epidemic-Type Aftershock Sequence (ETAS) model (Ogata, JASA, 1988; Ogata, AISM, 1998; Zhuang et al., JASA, 2002), which characterizes both the background seismicity rate as well as aftershock triggering. After the model parameters are fit to the seismicity data from a given year, forecasts of the full catalog for the following year can then be made using a suite of 100,000 ETAS model simulations based on those parameters. We also explore the use of a hydromechanical model of earthquake nucleation to forecast changes in the background seismicity rate based on fluid injection data. Results suggest that the ETAS model is a useful framework for combining background rate changes informed by fluid injection data with spatiotemporal earthquake interactions to produce one-year forecasts.

What Is the Maximum Spatial Reach of Fluid-Injection Operations? Examining Seismicity Decay and Poro-Elastic Effects around Injection Wells

GOEBEL, T.H.W., UC Santa Cruz, California, USA, thw.goebel@gmail.com; BRODSKY, E.E., UC Santa Cruz, California, USA, brodsky@ucsc.edu

Fluid injection induced seismicity is commonly modeled by assuming purely fluid-pressure-driven earthquakes. However, this assumption is challenged by induced sequences with observed far-field triggering. To unravel triggering mechanisms of injection-induced earthquakes, we examine the spatial decay and space-time migration of $\sim 30$ induced seismicity cases. We limit our analysis to point source, single well injectors in the context of scientific, geothermal and wastewater injection. We perform an initial quality assessment, excluding datasets that cannot be distinguished from random Gaussian location uncertainty and uniform background seismicity. The spatial decay of the remaining 19 cases is determined from the areal density of surface distances between wells and earth- quakes. All sequences show a spatial gap between well locations and the location of highest seismicity density. Moreover, we observe two different types of spatial decay: 1) Sequences with a near-well density plateau and rapid spatial decay and 2) sequences with steady decay, that extend to distances of more than $\sim 10 \mathrm{~km}$ in some cases. Induced sequences with abrupt decay are dominated by squareroot space-time migration, a characteristic of pressure diffusion. Sequences with steady spatial decay are dominated by linear migration or the absence of migration. The steady decay can be described by a power-law with an exponent of 1.8 , which is significantly smaller (i.e. more gradual) than the spatial decay of aftershocks. This power-law behavior may be indicative of poro-elastically induced earthquakes which lack the commonly expected rapid spatial decay and gradual spatial-temporal expansion of fluid-pressure-driven induced seismicity sequences. Far-reaching poro-elastic stresses can lead to inflated hydraulic-diffusivity-estimates and a strongly underestimated spatial reach of injection wells.

Plate Boundary Segmentation and Coupled-to-Creeping Plate and Block Boundary Faults

Oral Session · Thursday 17 May · 10:45 AM · Tuttle

Session Chairs: John C. Weber and Omar J. Perez

A Geologic Recipe for Transient Slip within the Seismogenic Zor. Insight from the Guerrero Seismic Gap, Mexico

HUSKER, A. L., Universidad Nacional Autónoma de Mo ico, CDMX, Mexico, allen@igeofisica.unam.mx; FERRARI, L., Univ rsidas Nacional Autónoma de México, Mexico, luca@unam.mx. AR No GALVAN, C., Universidad Nacional Autónoma de México, Mu-ico, claudiar@igeofisica. unam.mx; CORBO-CAMARGO, F., Univo rond Nau nal Autónoma de México, Mexico, fercorbo@geociencias.unam. x; ANATE-FLORES, J. A., Universidad Nacional Autónoma de M 2 , Me co, arzateja@gmail.com

The Guerrero seismic Gap in Mexin ha low coupling compared to the rest of the plate interface. This : 1 ne to the occurence ofslow slip events (SSEs) within the seismogenic zone $\mathrm{n}$ theGa al ough they have a much wider downdip extent. The SSEsare limm do rep at within the same region every 4 years. Here we examine the geolos ical. $\mathrm{d}$ ge sphysical evidence for the mechanism that allows for transient slip in $C$ ap nd.. $\mathrm{n}$ no other point along the $1000+\mathrm{km}$ subduction zone within the re athrustregion. We find that long lasting past magmatic activity most a ly proa 'ced an impermeable gabbroic layer in the lower crust within the Gap. ' $\mathrm{N}$ is body has acted as a seal to trap fluids and over-pressurize the plate in face; th reby generating a transient slip region allowing for SSEs to invade he $s$ ismogenic zone. This suggests that transient slip can occur in typic the ser mogenic regions, but requires special conditions. It also adds to the rowi g evi yce that the Guerrero Gap may have lowered seismic hazard comparo to the rest of the coast, which is opposite to what is reported by government agencies.

Along Strike Locking Characteristics of the Plate Boundary Zone of the Southeastern Caribbean Basin

HIGGINS, M., Department of Geosciences, Penn State, Pennsylvania, USA, mhh16@psu.edu; LAFEMINA, P., Department of Geosciences, Penn State, Pennsylvania, USA, pcl11@psu.edu; WEBER, J. C., Grand Valley State University, Pennsylvania, USA, weberj@gvsu.edu; GEIRSSON, H., University of Iceland, Faculty of Earth Sciences, Iceland, hgeirs@hi.is

The CA-SA plate boundary zone of the southeastern region of the Caribbean Basin is characterized by the transition from dextral shear in northern Venezuela and the island of Trinidad, to underplating and subducting of SA beneath the CA plate along the Lesser Antilles. Neotectonics studies supports this tectonic regime with a CA-SA relative motion of $\sim 22 \mathrm{~mm} / \mathrm{yr}$. The El Pilar Fault Zone (EPFZ), of northeastern Venezuela, has been shown to be a primary fault that accommodates up to $\sim 18 \mathrm{~mm} / \mathrm{yr}$ of CA-SA motion and has produced several large-magnitude earthquakes in recent history, notably the Cariaco 1997 Earthquake. Moving eastward, the EPFZ steps over to the Warm Springs Fault in the Gulf of Paria pull-apart basin which continues to the Central Range Fault (CRF) onshore Trinidad. On the island of Trinidad, the plate boundary slip is partitioned between three faults, the North Coast Fault, CRF, and the Soldado fault $(\sim 3.5 \mathrm{~mm} / \mathrm{yr}, 15 \mathrm{~mm} / \mathrm{yr}$ and $\sim 3.5 \mathrm{~mm} / \mathrm{yr}$ respectively). Several previous workers have used geodesy to determine locking and creep characteristics of the EPFZ and CRF. This work investigates the locking on segments of the EPFZ and CRF using published geodetic data (Weber et al., 2011; Reinoza et al., 2015) and InSAR measurements. Employing a Monte Carlo approach with the simple elastic dislocation model for segments of the EPFZ, it was found that the El Pilar is locked to a depth of $\sim 7 \mathrm{~km}$ in the region near the city of Cumana and, moving 
eastward, transitions to creep over a distance of $15 \mathrm{~km}$. The same technique was carried out for the CRF and it was found to be creeping on the CRF.

\section{Episodic Forearc Sliver Creep during Relocking of the Nicoya, Costa Rica, Megathrust: An Unexpected Observation}

HOBBS, T. E., Georgia Institute of Technology, Georgia, USA, tiegan.hobbs@ eas.gatech.edu; NEWMAN, A. V., Georgia Institute of Technology, Georgia, USA, anewman@gatech.edu; PROTTI, J. M., Observatorio Vulcanologico y Sismologico de Costa Rica, Heredia, Costa Rica, marino.protti.quesada@una.cr

Following the $2012 \mathrm{Mw} 7.6$ Nicoya, Costa Rica earthquake, campaign and continuous GPS were used to collect 5 years of postseismic surface deformations. Linear yearly velocities show reversal from uniform seaward to uniform landward motion. This transition from afterslip to interseismic motion is expected. We also observe, unexpectedly, an intervening episode of purely northwestward trenchparallel motion, interpreted as forearc sliver translation. This forearc event occurs during the relocking phase, and involves trench-parallel velocities in excess of the background sliver transport rate. During this episode there is effectively no trench-normal component of velocity. We compare to non-forearc velocities, and contemporaneous seismicity. Inversion shows that afterslip is followed by relocking which propagates toward the center of the seismogenic zone. This relocking regresses during the sliver translation event, and resumes after it is finished. Together these observations suggest that during relocking, temporarily weakened oblique faults can generate unanticipated trench parallel motions as part of the postseismic repertoire. The downgoing slab exerts an oblique landward force on the forearc. Due to several years of unclamping on the arc fault system, the backstop fault has greatly diminished shear strength. This results in the purely strikeparallel motion of the forearc observed herein, with no strike-normal stress accumulation. This finding has important implications for active tectonics. Firstly, forearc-bounding faults may be unclamped by postseismic processes, allowing for creeping. This may affect activity at arc volcanic systems. Secondly, what has been regarded as constant, long-term sliver motion may be accommodated episodically when bounding faults are weakened. Finally, it appears that relocking involves unstable megathrust frictional conditions. Tenuous coupling on the fault interface during relocking can be interrupted by large-scale forearc sliding.

\section{Factors Controlling Plate Boundary Segmentation in the Gulf of California} PERSAUD, P., Louisiana State University, Louisiana, USA, ppersaud@lsu.edu; STOCK, J. M., Caltech, California, USA, jstock@gps.caltech.edu

The Gulf of California in northwestern Mexico is an oblique-extensional plate boundary that formed in a region with a complex geological history. The pre-rift lithosphere of the Gulf was influenced by Mesozoic arc magmatism followed by the shutting down of subduction and foundering of slab fragments that have been imaged beneath parts of Baja California. This was followed by a $\sim 12-6$ Ma period of broadly distributed deformation involving normal, strike-slip and transtensional faulting that spanned the width of the Gulf Extensional Province and extended into the continental borderland west of Baja California. The Gulf of California opened roughly $\sim 6 \mathrm{Ma}$ as the plate boundary shifted $\sim 250 \mathrm{~km}$ inland rupturing weakened continental crust and separating Baja California from mainland Mexico. Despite the rapid localization of strain along the full length of the Gulf in a region that now has mostly new crust, the plate boundary shows a wide variation in deformation styles suggesting that magmatism, sediment supply and the local stress field may be key players. The northern segment has the characteristics of a wide rift, with a plate boundary jump at $\sim 2 \mathrm{Ma}$, evidence for lower crustal flow, and broadly distributed extensional strain and small gradients in topography and crustal thinning. New oceanic crust here is limited to the lower crust in the rift basins. In contrast, the central segment has $\geq 7 \mathrm{~km}$ thick, $\sim 280 \mathrm{~km}$ wide oceanic crust, and is a magma-rich, narrow rift land the only Gulf basin with on axis regions of partial melt at $26-50 \mathrm{~km}$ depth. The Alarcon Basin in the south has $\sim 6 \mathrm{~km}$ thick oceanic crust, but is a magma-poor, wide rift 1 . Its margins have substantial Moho topography suggesting no lower crustal flow during rifting. Interestingly, tomographic images show asthenospheric upwelling beneath the Alarcon and the northern rift basins, but in the central Gulf upwelling is instead focused beneath a transform fault. 1Lizarralde et al., Nature 448, 466-469.

Fault Creep and Strain Partitioning in Trinidad and Tobago: Geodetic Measurements, Models, and Origin of Creep

WEBER, J. C., Grand Valley State University, Michigan, USA, weberj@gvsu. edu; GEIRSSON, H., University of Iceland, Iceland, hgeirs@ hi.is; LAFEMINA, P., Penn State, Pennsylvania, USA, plafemina@psu.edu; ROBERTSON, R., The University of the West Indies Seismic Research Centre, Trinidad and Tobago, richie.robertson@gmail.com; LATCHMAN, J. L., The University of the West Indies Seismic Research Centre, Trinidad and Tobago, j_latchman@uwiseismic. com; CHURCHES, C., Grand Valley State University, Michigan, USA, churchec@mail.gvsu.edu; SHAW, K., Grand Valley State University, Michigan, USA, shawken@mail.gvsu.edu; HIGGINS, M., Penn State, Pennsylvania, USA, machelhiggins@hotmail.com; MILLER, K., The University of the West Indies, Trinidad and Tobago, keith.miller@sta.uwi.edu

Plate boundaries generally exhibit complex strain partitioning across multiple faults. We studied active faults in Trinidad and Tobago in the Caribbean-South American (CA-SA) transform plate boundary zone using episodic GPS (eGPS) data from 19 sites and continuous GPS (cGPS) data from 8 sites, then modeled these data using a series of simple screw dislocation models. Our best-fit model for interseismic fault slip requires $12-15 \mathrm{~mm} / \mathrm{yr}$ of right-lateral movement and very shallow locking $(0.2 \pm 0.2 \mathrm{~km})$, essentially creep, across the Central Range Fault (CRF), $3.4+0.3 /-0.2 \mathrm{~mm} / \mathrm{yr}$ across the Soldado Fault in south Trinidad, and $3.5+0.3 /-0.2 \mathrm{~mm} / \mathrm{yr}$ of (coupled) shear on fault(s) between Trinidad and Tobago. The CRF creeps along a physical boundary between rocks associated with thermogenically generated petroleum in south and central Trinidad from rocks containing only biogenic gas to the north. A string of active mud volcanoes aligns with the trace of the Soldado Fault along Trinidad's south coast. Fluid (oil and gas) overpressure, as an alternative or in addition to weak material in fault cores, may thus cause these two faults to creep. Together, the CRF, El Pilar, San Sebastian, and La Victoria Faults form a highly segmented, right-stepping CA-SA transform system. Although creep has been now been verified on several segments, Parkfield (SAF) segment-type partial coupling, full coupling, and timevarying slip likely occurs on other segments. Improved geodetic coverage (more cGPS sites, a higher density of sites, longer time series, more InSAR studies, and 3-D modeling of these data), creep and strain meters, and microseismic networks will be required to better identify and map individual segment behavior, and to better determine the associated seismic hazard on each.

\section{How Are Fault Zone Architecture and Mode of Slip Affected by Normal Stress and Alternating Cycles of Gouge Production and Attenuation?} FLETCHER, J. M., CICESE, Baja California, Mexico, jfletche@cicese. mx; TERAN, O. J., Microseismic, Texas, USA, oteran@microseismic.com; ROCKWELL, T. K., San Diego State University, California, USA, trockwell@ mail.sdsu.edu; OSKIN, M. E., UC Davis, California, USA, oskin@geology. ucdavis.edu

The structural style of a fault is generally thought to reflect its mechanical behavior. Stick slip behavior is associated with simple narrow fault zones that have a single high-strain core. These are commonly developed from quartzo-feldspathic protoliths and this structural style is thought to result from the positive feedback between comminution and transformation weakening (Chester et al., 1993). Stable sliding behavior is commonly associated with complex wide fault zones that have multiple anastomosing high-strain cores. These are commonly developed from phyllosilicate rich protoliths, and are thought to reflect strain hardening (Faulkner and Rutter, 2003). The MW 7.2 El Mayor-Cucapah earthquake of 2010 produced a cascading rupture that propagated through a complex network of intersecting faults that cut metamorphic and plutonic rocks exposed in northern Baja California. Coseismic slip of 1-6 m was accommodated by fault zones displaying the full spectrum of previously mentioned styles, which demonstrates that stick-slip mode is not restricted to a certain type of fault. As fault zone complexity and width increase, coseismic slip becomes more broadly distributed on a greater number of scarps that form wider arrays. Thus the slip of a single earthquake replicates many of the fabric elements of the long-lived fault. In addition to protolith, we find that orientation strongly affects fault zone complexity, which increases with decreasing dip. Projecting regional stress onto individual faults, shows that fault zone complexity increases systematically with resolved normal stress, which is known to increase gouge production in laboratory experiments (Yoshioka, 1986). The progressive rotation of faults is thus a previously unrecognized form of strain hardening. We also conclude that regardless of protolith, all faults should experience alternating cycles of stick slip, gouge production and weakening followed by creep, ductile attenuation of gouge and strengthening.

\section{Geodetic Characterization of Kinematic Segmentation Along the Presqu'ile Du Sud / Enriquillo Fault System in Southern Haiti}

SYMITHE, S. I., Université d'Etat d'Haiti, Port-au-Prince, Haiti, symithesteevej@gmail.com; CALAIS, E., Ecole Normale Supérieure, Paris, France,eric.calais@ens.fr

The $\sim 3 \mathrm{M}$ inhabitant capital region of Haiti, severely affected bythe devastating January 12, 2010, M7.0 earthquake, continues toexpand at a fast rate. Accurate characterization of regionalearthquake sources is key to inform urban development and constructionpractices through improved regional seismic hazard estimates. Werecently showed, using Global Positioning System (GPS) measurementsand simple elastic models, thatseismogenic strain accumulation insouthern 
Haiti involves an overlooked component of shortening on asouth-dipping reverse fault along the southern edge of the Cul-de-Sacbasin at $9+-3 \mathrm{~mm} / \mathrm{yr}$, in addition to the well-known component ofleft-lateral strike-slip motion at $6+-2 \mathrm{~mm} /$ yr (Symithe and Calais, Tectonophysics, 2016; Calais et al., C.R. Geosciences, 2016). Here we use a significantly improved regional GPS velocity field torevisit the issue of kinematic segmentation in southern Haiti, with a transition from purely strike-slip motion on the quasi-verticalPresqu'Ile du Sud fault, into highly oblique motion on a south-dippingfault along the southern edge of the Cul-deSac basin. Reversefaulting on such a south-dipping plate-boundary fault implies groundshaking in Port-au-Princetwice stronger than expected if the majorfault was purely strike-slip, as currently assumed in the seismichazard map integrated into the Haiti National Building Code.

\section{The Kinematics of the Southwestern Caribbean from Geodetic GPS Data Modeling}

RUIZ, A. G., Penn State, Pennsylvania, USA, agr132@psu.edu; LAFEMINA, P., Penn State, Pennsylvania, USA, pcl11@psu.edu; CAMACHO, E. I., Universidad de Panama, Panama, ecamacho507@hotmail.com; ESPINOZA, O., Instituto Geografico de Panama, Panama, oespinoza@anati.gob.pa; MORA PAEZ, H., Servicio Geologico Colombiano, Panama, hmora@sgc.gov.co

The oblique convergence of Cocos plate (CO) and the collision of Cocos Ridge, with the SW margin of the Caribbean (CA) plate drives the NW escape of the Central American Fore arc (CAFA) and the NW motion of the Panama region (PR). Motion of the PR is further modified due to its collision with the South American plate (SA). Using a new velocity field from 252 GPS sites, 48 in Panama, mapped active faults, focal mechanism solutions from the GCMT and a local catalog, we explore the kinematics of the southwestern Caribbean (SWC). We test a suite of block configurations within the PR using the TDEFNODE code. Our results suggest that the SWC is segmented into several small rigid blocks; CAFA, Panama Pacific (PANP), Panama (PANA) and Panama east (PANE) that is in agreement with the relative motion of the active faults that accommodate the eastward motion of the PR and its collision with SA. The Euler vectors for CAFA, Choco $(\mathrm{CH})$ and North Andes (ND) blocks are better resolved, but for PANP, PANA and PANE are less resolved. However, our results and block configuration gives a better constraint of the kinematics of the SWC. We suggest that the PANA-PANE boundary along the Panama Canal Fault system (PCFS) is taking advantage of the geological boundary of the Chorotega terrain on the west, and the Panama-Choco terrain on the east. Although trenching along the PCFS suggested 2 to $8 \mathrm{~mm} / \mathrm{yr}$ of strike slip motion, we did not observe these rates in our GPS observations. Furthermore, few focal mechanism solutions are in agreement with this proposed boundary. The best fit model indicates high coupling $\geq 50 \%$ into the block bounding faults and highlight for potential destructive and/or tsunamigenic earthquakes into offshore seismogenic zones. The best- fit model highlighted high coupling along the Maracaibo trench, the convergent margin of South America-Caribbean plates, and account for potential big earthquakes in response to its strain accumulation. Future investigations and incorporating new GPS sites along the whole ND block could better improve our understanding of the nature and kinematics of the ND block, and the Caribbean plate, account for seismic hazards in this populated region.

\section{Interaction between Seismicity and Slow Deformation Signals in the Eastern Sea of Marmara Region, Turkey}

MARTÍNEZ-GARZÓN, P., GFZ Potsdam, Germany, patricia@gfz-potsdam. de; KWIATEK, G., GFZ Potsdam, Germany, kwiatek@gfz-potsdam.de; MENCIN,D.,UNAVCO, Colorado,USA, mencin@unavco.org; BOHNHOFF, M., GFZ Potsdam, Germany, bohnhoff@gfz-potsdam.de; JOHNSON, W., UNAVCO, Colorado, USA, johnson@unavco.org; DRESEN, G., GFZ Potsdam, Germany, dre@gfz-potsdam.de; NURLU, M., AFAD, Turkey, murat.nurlu@ afad.gov.tr

The energy accumulated in a fault can be released seismically or through a number of slow-processes covering a broad range of frequencies and source durations. The interaction between seismic and slow deformation still remains to be understood and can have a significant effect on the seismic hazard and subsequent risk. Here, we report on a slow-slip event lasting several-hours and recorded in a strainmeter. Also, we analyze seismic waveform recordings framing this event. The recordings were achieved by the GONAF (Geophysical downhole Observatory at the North Anatolian Fault) observatory offshore of Istanbul where a $\mathrm{M} \geq 7$ earthquake is pending. The continuous seismic recordings are analyzed both manually and automatically to detect any type of embedded seismic signals. To locate the signals, we developed a beamforming grid-search algorithm utilizing $\mathrm{P}$ - and S- waveform envelopes and polarization analysis to resolve best location for desired time. While computationally expensive, synthetic tests demonstrate the improvement achieved in hypocentral location with respect to other commonly used methods. We also study potential triggering of the slow-slip signal through waveforms of regional and teleseismic earthquakes. Results indicate an increase of the local seismicity during the days (and hours) before the slow-slip event, a gap in the seismic activity during the slow-slip and a seismicity recovery shortly after. Furthermore, $1.5 \mathrm{~h}$ before the slow-slip event, a number of weak emergent tremor-like signals with frequencies ranging $[2-10] \mathrm{Hz}$ are observed. These signals appear to concentrate at both ends of the Armutlu fault as part of the offshore NAFZ along which the slow-slip event was detected. The occurrence of tremor-like signals and slow-slip release could indicate potential nucleation areas of a larger earthquake on this fault and thus are of high importance for evaluating subsequent hazard and risk scenarios of this active transform fault segment.

Long-Term OBS Observations in the Sea of Marmara, Northwest Turkey PINAR, A., Bogazici University, Kandilli Observatory and Earthquake Research Institute, Istanbul, Turkey, pinara@boun.edu.tr; COŞKUN, Z., Bogazici University, Kandilli Observatory and Earthquake Research Institute, Istanbul, Turkey, zeynep.coskun@boun.edu.tr; KALAFAT, D., Bogazici University, Kandilli Observatory and Earthquake Research Institute, Istanbul, Turkey, kalafato@boun.edu.tr; YAMAMOTO, Y., Research and Development Center for Earthquake and Tsunami, JAMSTEC, Yokohama, Japan, yamamotoy@ jamstec.go.jp; TAKAHASHI, N., National Research Institute for Earth Science and Disaster Resilience, Tsukuba, Japan, narumi@bosai.go.jp; ÇITAK, S., Research and Development Center for Earthquake and Tsunami, JAMSTEC, Yokohama, Japan, citak@jamstec.go.jp; POLAT, R., Bogazici University, Kandilli Observatory and Earthquake Research Institute, Istanbul, Turkey, remzi. polat@boun.edu.tr; TURHAN, F., Bogazici University, Kandilli Observatory and Earthquake Research Institute, Istanbul, Turkey, fatih.turhan@boun.edu.tr; KANEDA, Y., Kagawa University, Istanbul, Turkey, kanedaykg@cc.kagawa-u. ac.jp; OZENER, H., Bogazici University, Kandilli Observatory and Earthquake Research Institute, Istanbul, Turkey, ozener@boun.edu.tr

Local extensional and contraction features corresponding to subsidence and uplift are determined around the North Anatolian fault zone (NAFZ), namely Main Marmara Fault (MMF), crossing the Sea of Marmara. Long term Ocean Bottom Seismograph (OBS) observation have been carried out through a joint Turkish-Japanese project called Mardim. Presently, three deployments and recovery of 15 OBS stations spanning the time period from September, 2014 until May, 2017 have been done. Using the recovered OBS data 3D tomographic images of the region around NAFZ are constructed. High precision locations of the hypocenter illuminated the orientation and the geometry of the fault segments constituting MMF (Yamamoto $e$ t al., 2015; 2017). The data from the OBS deployments in 2014-2015; 2015-2016 and 2016-2017 are utilized to estimate focal mechanisms for the events taking place around the Western and Central Marmara fault segments, and offshore Ganos fault. The data from the 15 OBS stations deployed close to MMF at intervals of about $10 \mathrm{~km}$ are integrated with the land seismic stations of Kandilli Observatory and Earthquake Research Institute (KOERI) so as to improve the azimuthal and take-off angle coverage on the focal sphere. The 3D velocity structure of Yamamoto $e t$ al. (2015) retrieved for the area beneath the OBS stations are used to estimate the take-off angles. The polarity data acquired from the three locations mentioned above are compiled to constitute data sets which were invertedto obtain simultaneously a stress tensor and focal mechanisms. The analysis show that the horizontal maximum compressive stress axes is oriented roughly NW-SE which is slightly different at each cluster. Fault segmentation along the NAFZ explains the extensional and compressional features revealed by several normal and reverse fault plane solutions. The fault plane solutions derived from the Central segments around the Central High show predominantly thrusting, being an evidence for uplifting.

\section{Modern Kinematics of the Cordillera Blanca Fault, Northern-Central Peru, from GPS Geodesy}

NORABUENA, E. O., Instituto Geofisico del Peru, Lima, Peru, enorabuena@ igp.gob.pe; WEBER, J. C., Grand Valley State University, Michigan, USA, weberj@gvsu.edu; DE LA CRUZ, Y., Instituto Geofisico del Peru, Lima, Peru, ydelacruz@igp.gob.pe; SALAZAR, J. E., Instituto Geofisico del Peru, Lima, Peru,jsalazar@igp.gob.pe

The Cordillera Blanca batholith is an intrusive emplacement of Miocene age $(5 \mathrm{Ma})$ that lies over the northern-central Peruvian Andes. Its western flank is bounded by a normal fault that extends for about $220 \mathrm{~km}$ in a NW-SE direction and dips west at a low angle. There is no historical evidence of large earthquakes associated with this fault, but geological studies indicate Quaternary or Holocene activity with as much as $2.5 \mathrm{~m}$ of vertical slip. Other related events in the neighborhood of the Cordillera Blanca Fault are the 1942 Quiches (M 6) earthquake and the 1970 Chimbote earthquake (Mw 8). The Chimbote event caused the highest death toll of all times in Peru (70,000 casualties) as it triggered 
a massive mudslide that swept all along its path and buried the town of Yungay. The ice-and-snow covered, elevated peaks (up to 18,000 ft.) in the Cordillera Banca mountains, as well as the existance of the active bounding normal fault system, represent a big hazard to this region. This study presents the first geodetic estimates of the modern kinematics of the Cordillera Blanca Fault and uses GPS measurements carried out between 2014 and 2017, as well as baseline changes observed between two cGPS stations across its southern end.

\section{Seismo-Geodetic Monitoring of the Marmara Seismic Gap}

OZENER, H., Bogazici University, Kandilli Observatory and Earthquake Research Institute, Geodesy Department, Turkey, ozener@boun.edu.tr; BULUT, F., Bogazici University, Kandilli Observatory and Earthquake Research Institute, Geodesy Department, Turkey, bulutf@boun.edu.tr; DOGRU, A., Bogazici University, Kandilli Observatory and Earthquake Research Institute, Geodesy Department, Turkey, asli.dogru@boun.edu.tr

The North Anatolian Fault Zone in the Sea of Marmara did not generate a M $\geq 7.0$ earthquake since 1766. This fault section stores $\sim 20 \mathrm{~mm}$ annual slip deficit and therefore is expected to accommodate at least one at most three $M \geq 7.0$ in near future. In this study, we continuously monitor this critically strained fault section using seismo-geodetic stations that are equipped with $100 \mathrm{~Hz}$ sampling seismographs and $1 \mathrm{~Hz}$ sampling GPS recorders. This configuration allows covering a broad spectral band and is sensitive to both fast/slow tectonic motions at large/ small temporal and spatial scale, from milliseconds to years, from centimeters to tens of kilometers. Therefore, recorded seismo-geodetic data will be used to identify (1) along-fault variation of the slip deficit, (2) fault segmentation, (3) interaction between slip-deficit and background seismicity, (4) pre-seismic seismo-geodetic symptoms and (5) co-seismic slip in case of M 7.0 earthquake(s).

\section{Spatial Complementarity of Tectonic Earthquake Swarms on a Transform} Plate Boundary in North Iceland

PASSARELLI, L., GFZ Potsdam, Germany, luigi@gfz-potsdam.de; RIVALTA, E., GFZ Potsdam, Brandenburg, Germany, rivalta@gfz-potsdam.de; JONSSON,

S., KAUST, Saudi Arabia, sigurjon.jonsson@kaust.edu.sa; HENSCH, M., Regierungspräsidium Freiburg, State Bureau of Geology, Resources and Mining, Seismological Survey Baden-Württemberg, Germany, hensch@lgrb. uni-freiburg.de; METZGER, S., GFZ, Germany, metzger@gfz-potsdam.de; JAKOBSDOTTIR, S., The Icelandic Centre for Research, Reykjavík, Iceland, ssj@simnet.is; MACCAFERRI, F., GFZ, Germany, macca@gfz-potsdam.de; CORBI, F., Uni Roma Tre, Italy, fabio.corbi@uniroma3.it; DAHM, T., GFZ, Germany, torsten.dahm@gfz-potsdam.de

Here we investigate persistent and intense tectonic earthquake swarm (TES) activity recorded in the last 20 years on the Húsavík-Flatey Fault (HFF), a ridgetransform plate boundary fault system offshore Northern Iceland. We relocate the seismicity, calculate focal mechanisms and analyze statistically the seismic catalog. In the catalog we identify six energetic TESs, some of which are composed by distinct sub-swarm sequences, leading to a total of 16 swarms that occurred along a $\sim 30 \mathrm{~km}$ segment of the HFF. In spite of the overall low seismic moment released seismically, the TESs have exhibited spatial complementary arrangement with subsequent swarms filling gaps left by earlier swarms, a pattern that suggests additional, aseismic slip and moment release. In addition, each swarm usually started locally and then migrated outwards, showing faster migration in the rake direction and acceleration (or constant-speed), which is inconsistent with what would be expected from diffusive processes. The static stress drop associated with the TESs on the HFF is similar to the low values seen for global compilations of slow slip events (SSEs), showing that the fault area illuminated by earthquakes during the swarms may be more representative of the total and hidden moment release than the cumulative seismic moment of the swarm earthquakes. We estimate that the proportion of aseismic moment associated with the TESs is between 2 and 700 times larger than the respective cumulative seismic moment. The scaling properties of these and other TESs observed worldwide indicate that the importance of TESs in releasing tectonic strain at plate boundaries may be in some cases underestimated.

\section{Long-Term and Short-Term Slow Slip Events at the Southcentral Alaska} Subduction Zone

$\underline{\text { FU, Y. }}$, Department of Geology, Bowling Green State University, Ohio, USA, yfu@bgsu.edu; MCGUIRE, J., Department of Geology, Bowling Green State University, Ohio, USA,jmcgui@bgsu.edu; FREYMUELLER, J. T., Geophysical Institute, University of Alaska Fairbanks, Alaska, USA, jfreymueller@alaska.edu

Slow Slip Events (SSEs) have been discovered at the Southcentral Alaska Subduction Zone since GPS measurement started in Alaska in 1993. Ohta et al. [2006] identified a 3 year long-term SSE between 1998 and 2001 in Upper Cook
Inlet. Wei et al. [2012] found another SSE between 2010 and 2011 in Lower Cook Inlet. Fu and Freymueller [2013] reported a large SSE in Upper Cook Inlet starting from the end of 2008. Li et al [2016] identified a slow slip event lasting at least 9 years occurred from 1995 to 2004 beneath Lower Cook Inlet. In addition to those long-term SSEs, we also discovered several short-term SSEs at the Southcentral Alaska Subduction zone, which lasted from weeks to months. For example, continuous GPS measurement clearly showed transient short-term SSEs in 2005, 2006 and 2007. In this study, we analyze the distributions of those long-term and short-term SSEs, and discuss their features of spatiotemporal variations. Our preliminary results indicate at upper Cook Inlet, both long-term and short-term SSEs occurred at the same location, which is downdip of the rupture of the 1964 M9.2 Prince William Sound earthquake. This part of plate interface behaves as a buffer region to transfer and release strain and stress with time in a complicated way.

On the Interaction of the North Andes Plate With the Caribbean and South American Plates in Northwestern South America From Gps Geodesy and Seismic Data

PEREZ, O. J., Simon Bolivar University, Caracas, Venezuela, ojperez@usb.ve; UZCATEGUI, R., Simon Bolivar University, Caracas, Venezuela, ruzcategui@ usb.ve; MORA-PAEZ, H., Colombian Geological Survey, Bogota, Colombia, hmora@scg.gov.co; WESNOUSKY, S. G., University of Nevada, Nevada, USA, wesnousky@urn.edu; SZELIGA, W., Central Washington University, Washington, USA,walter@geology.cwu.edu

We examine the hypocentral distribution of seismicity and a series of geodetic velocity vectors obtained from Global Positioning System (GPS) observations between 1994 and 2015 both off-shore and mainland northwestern South America $\left[66^{\circ} \mathrm{W}-77^{\circ} \mathrm{W} ; 8^{\circ} \mathrm{N}-14^{\circ} \mathrm{N}\right]$. Our analysis, that includes a kinematic block modeling, shows that east of the Caribbean-South American-North Andes plates triple junction at $\sim 68^{\circ} \mathrm{W} ; 10.7^{\circ} \mathrm{N}$, right-lateral easterly oriented shear motion $(\sim 20 \pm 2.0 \mathrm{~mm} / \mathrm{yr})$ between the Caribbean and South-America plates is split along two easterly striking, right-lateral strike slip subparallel fault zones: the San Sebastián fault that runs offshore the Venezuelan coast and slips about $17.0 \pm 0.5 \mathrm{~mm} / \mathrm{yr}$, and the La Victoria fault, located onshore to the south, which is accumulating strain equivalent to $3.0 \pm 0.5 \mathrm{~mm} / \mathrm{yr}$. West of the triple junction, relative right-lateral motion between the Caribbean and South American plates is mostly divided between the Morrocoy and Boconó fault systems which strike northwest and southwest from the triple junction, respectively, and bound the intervening North Andes plate that shows an easterly oriented geodetic slip of $15.7 \pm 1.0 \mathrm{~mm} / \mathrm{yr}$ relative to the South American plate. Slip on the Morrocoy fault is right-lateral and transtensional. Motion across the Boconó fault is also right-lateral but instead transpressional, divided between $\sim 9$ to $12 \mathrm{~mm} / \mathrm{yr}$ of right-slip on the Boconó fault and 1 to $5 \mathrm{~mm} / \mathrm{yr}$ of convergence across adjacent and subparallel thrust faults. Farther west of the triple junction, $\sim 800 \mathrm{~km}$ away in northern Colombia, the Caribbean plate subducts to the southeast beneath the North Andes plate at a geodetically estimated rate of $\sim 5-8 \mathrm{~mm} / \mathrm{yr}$.

Retrieval of Fine Scale Information Using Seismic Noise Oral Session - Thursday 17 May · 8:30 Am • Monroe Session Chairs: Julien Chaput and Thomas Lecocq

\section{Applications of Blind Signal Separation to Ambient Seismic Field Cross- Correlation}

LIU, X., Stanford University, California, USA, liuxin@stanford.edu; BEROZA, G. C., Stanford University, California, USA, beroza@stanford.edu; NAKATA, N., University of Oklahoma, Oklahoma, USA, nnakata@ou.edu

The ambient noise field in the real world contains both diffuse and non-diffuse components. The non-diffuse field is connected with signals from physical sources that are not sufficiently scattered and it degrades the convergence of the correlation functions derived from the ambient noise field towards the stationto-station Green's function. We apply Blind Signal Separation (BSS) to separate the diffuse and the non-diffuse components from cross-correlations of ambient seismic noise and reduce the effects of spurious arrivals from non-diffuse sources on ambient field cross-correlation. In addition to reducing non-diffuse contributions to the direct surface wave arrivals of noise cross-correlation, we also apply this method to identifying spurious arrivals in the coda of cross-correlation due to non-diffuse sources. Separating the spurious arrivals potentially enhances the scattered surface wave and body wave responses. Our method also shows promise for separating surface wave higher modes. We apply this technique to seismic arrays in southern California and dense arrays in Groningen, Netherlands, with examples showing reduced bias and improved imaging results. 
Towards Structural Imaging Using Scattering Artifacts Detected in Ambient Field Correlations

RETAILLEAU, L., Stanford, California, USA, retaille@stanford.edu; BEROZA, G. C., California Geological Survey Menlo Park, California, USA, beroza@stanford.edu

Correlations of the ambient seismic field have been used successfully for tomographic imaging of the Earth on a wide range of scales. This is based on the theoretical and experimentalobservations that correlation functions computed between the signals recorded by two stations contain an approximation of the impulse response (Green's function) between thesestations. The waves that comprise the ambient field are subject to scattering due to the heterogeneous earth which can generate supplementary arrivals on the correlations functions. It is possible to use these effects of scattering that do not correspond to thepropagation between the two stations considered, to locate potential external sources of signal. For this analysis, we use correlation functions computed from continuous signals recorded between 2001 and 2017 by seismic stations in Central California. We identify supplementary arrivals in the correlation functions and use array analysis to map the source ofscattering effects linked to strong structural variations. We are particularly interested in imaging scatters that result in coupling between the P-SV and SH systems because they are aconsequence of lateral heterogeneities in Earth structure. For that reason, we particularly focus on components of the correlation tensor, different from the Vertical-Vertical component, andwe expect the Radial/Vertical to Transverse components to be particularly helpful.

\section{Global-Scale Full Waveform Ambient Noise Inversion}

SAGER, K., ETH Zurich, Switzerland, korbinian.sager@erdw.ethz.ch; ERMERT, L., ETH Zurich, Switzerland, laura.ermert@erdw.ethz.ch; BOEHM, C., ETH Zurich, Switzerland, christian.boehm@erdw.ethz.ch; KRISCHER, L., ETH Zurich, Switzerland, lion.krischer@erdw.ethz.ch; AFANASIEV, M., ETH Zurich, Switzerland, michael.afanasiev@erdw.ethz.ch; FICHTNER, A., ETH Zurich, Switzerland, andreas.fichtner@erdw.ethz.ch

In earthquake tomography, modern tomographic methods exploit waveforms for the benefit of improved resolution. However, these techniques cannot be applied to noise correlation functions without knowing the distribution of noise sources. To overcome this limitation, we develop a method - referred to as full waveform ambient noise inversion - that is valid for arbitrary noise source distributions in both space and frequency, accounts for 3D heterogeneous and attenuating media and the full seismic wave propagation physics. The fundamental idea is to drop the principle of Green function retrieval, which is the basis for current noise tomographic studies, and to establish correlation functions as self-consistent observables in seismology. Based on a synthetic study in $2 \mathrm{D}$, investigating the prerequisites for a joint inversion for noise sources and Earth structure, we extend the waveform modelling and inversion package Salvus (http://salvus.io). It allows us to compute correlation functions in 3D media with heterogeneous noise sources at the surface and the corresponding sensitivity kernels for the distribution of noise sources and Earth structure. We present sensitivity kernels for different cross-correlation time lags and various noise source distributions, and study the effect of 3D heterogeneous Earth structure. For a validation of full waveform ambient noise inversion, we apply it to a global dataset focusing on the Earth's hum period band.

\section{Imaging Medium Changes at Depth Using 3-D Probabilistic Body- and Surface-Wave Sensitivity Kernels}

OBERMANN, A., SED/ETH Zurich, ZH, Switzerland, anne.obermann@sed. ethz.ch; PLANĖS, T., University of Geneva, Switzerland, thomas.planes@unige. ch

In the context of seismic monitoring, recent studies made successful use of seismic coda waves to detect andmedium changes and locate them on the horizontal plane. Locating the depth of the changes, however, remains a challenge. We build 3D sensitivity kernels as a linear combination of body- and surface-wave sensitivity and show their potential and limitations for imaging purposes at depth. We use both, numerical simulations and real data applications.

On the Nature of Higher-Order Ambient Seismic Field Correlations SHENG, Y., Stanford University, California, USA, yixiao2@stanford.edu; NAKATA, N., University of Oklahoma, Oklahoma, USA, nnakata@ou.edu; BEROZA, G. C., Stanford University, California, USA, beroza@stanford.edu

We find that higher-order ambient seismic field correlations, specifically C3 (correlation of the coda of correlations) of long-duration data sets from Southern California are symmetric despite the fact that the background wavefield is strongly directional. We demonstrate that this symmetry arises primarily from the structure of the $\mathrm{C} 3$ time series analysis, rather than the diffuse character of the coda. For that reason, the resulting ambient-field Green's function symmetry may not be diagnostic of correlation quality. We propose an alternative pre-stack processing scheme that constructs $\mathrm{C} 3$ correlations from each $\mathrm{C} 1$ coda time window, but stacks the results only at the final step of processing. Our pre-stack C3 method essentially avoids the cross-correlation between coda windows from different realizations, which leads to faster convergence and therefore shows potential to extract arrivals at higher frequencies than standard processing.

\section{Seismic Studies of Earth's Crust and Lithosphere Oral Session - Thursday 17 May · 1:30 PM · Flagler} Session Chair: Elizabeth A. Vanacore

\section{New Constraints on Seismic Anisotropy beneath the Eastern Ghats Mobile Belt and Adjacent Archean Cratons Contact Boundary}

JANA, N., Indian Institute of Technology Kharagpur, West Bengal, India, niptika.jana.1201@gmail.com; SINGH, A., Indian Institute of Technology Kharagpur, West Bengal, India, arun@gg.iitkgp.ernet.in; TIWARI, A. K., Indian Institute of Technology Kharagpur, West Bengal, India, aktiwari@iitkgp. ac.in; SINGH, C., Indian Institute of Technology Kharagpur, West Bengal, India, chandrani@gg.iitkgp.ernet.in

We investigate seismic anisotropy signatures of Eastern Ghats Mobile Belt (EGMB) and adjacent Archean cratons, namely Singhbhum and Bastar in southeastern India. The craton and Eastern Ghats contact boundary is defined as a collisional suture which has witnessed episodes of rifting related to the breakup of supercontinent Columbia, superimposed with later episodes of collision of eastern India with Antarctica during Rodinia assembly. With intent to capture signatures of collision, 19 broadband seismic stations are installed along two distinct profiles covering craton and Eastern Ghats contact boundary. Shear wave splitting analyzes using SKS and SKKS waveforms resulted in 85 high-quality measurements. Our results reveal that the delay times vary from $0.4 \mathrm{~s}$ to as high as $2.0 \mathrm{~s}$, and the orientation of the fast polarization directions at most of the stations are North-East directed while a few stations exhibit East-West orientations. The observed North-East orientation of the fast polarization axis lying close to the Absolute Plate Motion (APM) direction of the Indian plate are in accordance with earlier results of Indian shield, which shows the dominance of plate motion related strain of the Indian plate. The observed stacked splitting parameters concentrates on smaller delays $(\sim 0.7 \mathrm{~s})$ compared to global average of $\sim 1 \mathrm{~s}$ observed for continental shields and Indian shield. The buck in trend akin to APM direction of Indian plate and variation in delay times among closely spaced stations is indicative of rather complex architecture and deformation patterns in suture zones formed subsequent to the Grenvilian and Pan-African orogen. Therefore, frozen anisotropy and multiple layers of anisotropy with different symmetry axis contribute to the variation of the delay times and fast polarization directions in the region, along with APM related strain of Indian plate.

\section{Remote Dynamic Triggering in Southeast Africa}

NEVES, M., Georgia Institute of Technology, Georgia, USA, miguel.neves@ eas.gatech.edu; PENG, Z., Georgia Institute of Technology, Georgia, USA, zpeng@gatech.edu; CUSTÓDIO, S., Instituto Dom Luiz, Faculdade de Ciências, Universidade de Lisboa, Portugal, sicustodio@fc.ul.pt

We present results of the first systematic search for evidence of dynamic triggering of microearthquakes in southeast Africa. We analyzed seismic waveforms from 53 broadband and short-period stations in SE Africa, to identify increases in the rate of microearthquakes and tremor coincident with the passage of the Mw8.62012 Indian Ocean earthquake teleseismic waves (Neves et al., 2018). We computed $\beta$-values to evaluate the statistical significance of the observed increase in seismic activity, and statistically significant dynamic triggering at 7 stations. Two of these stations are located in the northeast coast of Madagascar. The other 5 stations are located in the Kaapvaal Craton, southern Africa, around one of the most active clusters of seismicity in the region that has been associated with a combination of natural and anthropogenic factors. We found no evidence of dynamically triggered microearthquakes in stations located near the structures of the East African Rift system (EARS). We also did not find any evidence of deep tectonic tremor in the entire region. Although hydrothermal activity has been identified close to the stations that recorded dynamic triggering, it also exists near the EARS structures where no triggering was observed. Our results suggest that factors other than solely tectonic regime and geothermalism are needed to explain the mechanisms underlying earthquake triggering. Further investigation revealed a higher vertical to horizontal peak-ground velocity ratio in the stations where triggering occurred, suggesting a local distortion of the wavefield, 
possibly due to topography, structure or site effects, that may facilitate triggering. We are in the process of analyzing additional mainshocks located at the African Continent to better constrain the factors that favor dynamic triggering in the region and study the effects of dynamic stresses in the intermediate-distant ranges. Updated results will be presented in the meeting.

\section{From Individual Station Magnitudes to Event Average: What Does Average} Mean and Does It Matter?

BENT, A. L., Natural Resources Canada-Ottawa, allison.bent@canada.ca

Whatever magnitude scale is used to define the size of an earthquake, the value is almost always an average of magnitude values obtained from many individua stations. Average, however, can be defined in a multitude of ways. Using data from over 4000 earthquakes in eastern Canada each with magnitude values from at least five stations, the effects of how these data are combined are examined. The first part of the study explores how the definition of average (mean, median, $20 \%$ and $40 \%$ trimmed mean) affects the final magnitude value. For this study, magnitudes were calculated to an additional decimal place to highlight small differences. When the data set as a whole is examined the difference between the various averages is negligible, with the mean difference between any two definitions of average being less than 0.02 magnitude units. Calculating both the mean and median and then comparing them is a simple way of flagging events whose magnitudes should perhaps be examined in more detail. Next, station corrections or mean residuals were determined for all stations whose magnitudes were used for at least five earthquakes in the data set. The corrections were then applied to the raw station magnitudes before calculating the event magnitude. The corrections for most stations are lower than 0.2 magnitude units. Overall, the application of station corrections has little effect on the event magnitude. The impact can be greater when the number of station magnitudes is small and/or some of the stations used have large corrections. Finally, source and path effects as well as station distribution can impact the event magnitude as oversampling at some azimuths may bias the final value. This does not appear to be a problem in general but further study exploring the effects of azimuthal averaging is ongoing as the station correction data for some stations have an apparent azimuthal dependence.

Lithospheric Structure of the Pantanal Basin from the Analysis of Fundamental and Higher Modes Surface Waves

D'ONOFRIO, A. F., Departamento de Sismología, Facultad de Ciencias Astronómicas y Geofísicas, Universidad Nacional de La Plata, Buenos Aires, Argentina, andresfdonofrio93@gmail.com; FLORES, G., YPF SA, Buenos Aires, Argentina,gonzalo.flores@ypf.com; ROSA, M. L., Departamento de Sismología, Facultad de Ciencias Astronómicas y Geofísicas, Universidad Nacional de La Plata, Buenos Aires, Argentina,mlrosa@fcaglp.unlp.edu.ar

The study of crustal and lithospheric thicknesses provides valuable information about the Earth's dynamics, allowing to identify stress patterns, isostatic compensation degrees and to generate crustal evolution models. Lithospheric thickness in South America is poorly understood, being the Andean region the most studied. The aim of this work is to evaluate the lithospheric structure of the Pantanal basin analyzing $S$-wave velocity models obtained from the fundamental and higher modes of surface wave from regional earthquakes recorded at the Brazilian Seismic Network Stations (BRASIS). Surface wave group velocity curves were obtained by a multiple filter technique and the classical two-station method was applied to get the fundamental and higher mode phase velocity curves. Inversions of these curves were carried out to obtain the velocity profile for the lithospheric region. This new models reach depths up to $150 \mathrm{~km}$ enhancing the lithospheric structure knowledge. This work represents the first analysis of phase velocity using higher modes for the Pantanal basin.

\section{Evidence of a Low Frequency Wave-Packet within Records of the 2016} Central Italy Seismic Sequence

FAMIANI, D., Istituto Nazionale di Geofisica e Vulcanologia, Italy, daniela.famiani@ingv.it; CULTRERA, G., Istituto Nazionale di Geofisica e Vulcanologia, Italy, giovanna.cultrera@ingv.it; MERCURI, A., Istituto NazionalediGeofisica eVulcanologia, Italy, alessia.mercuri@ingv.it; MICHELE, M., Istituto Nazionale di Geofisica e Vulcanologia, Italy, maddalena.michele@ ingv.it; VASSALLO, M., Istituto Nazionale di Geofisica e Vulcanologia, Italy, maurizio.vassallo@ingv.it

This work focuses on the observation of data recorded by the seismic temporary network installed in the Amatrice area, under the umbrella of the Italian Center for Seismic Microzonation (http://www.centromicrozonazionesismica.it), following the M 6.0 earthquake of August 24, 2016 in Central Italy. The aim was studying the presence of an evident late low frequency wave packet observed in some of the recorded aftershocks. In order to interpret this phenomenon, we combined a beam-forming analysis performed on these data with the statistics on residuals of localizations related to the same events, recorded by the Italian Seismic Network (RSN). The total number of analyzed events, characterized by $M \geq=3$ and epicentral distances between 30 and $55 \mathrm{Km}$, is 356 . By observing the seismic traces of these events there was an evidence, in some of them, of a low frequency packet appearing 10 seconds after the first arrival. The evidence of this packet was correlated with epicentral distance and focal depth. For a subset of stations, considered as an array, a beam-forming analysis was performed by using the ObsPy toolbox (M. Beyreuther et al., 2010). Results of this analysis gave information in terms of slowness and azimuth to distinguish the main seismic phases of the considered events. In addition, by using locations of the RSN records (Chiaraluce et al., 2017), we performed a parallel analysis within the subset of events with clear evidence of the low frequency packet. We relocated these events by using the NonLinLoc code, with a fixed 1D P-wave velocity model, and varying the Vp/ $\mathrm{Vs}$ ratio in the range 1.6-2.0. We found that the $\mathrm{P}$ phases residuals are not influenced by the $\mathrm{Vp} / \mathrm{Vs}$ ratio changes whereas the higher the $\mathrm{Vp} / \mathrm{Vs}$ the lower are the $\mathrm{S}$ phases residuals. Higher values of $\mathrm{Vp} / \mathrm{Vs}$ ratio, fixing $\mathrm{Vp}$ values, could mean a decrease of Vs connected to particular effects during the seismic waves path, that are probably due to geological heterogeneities at local or larger scale.

\begin{tabular}{l}
\hline ShakeMap-Related Research, Development, Operations \\
and Applications \\
Oral Session · Thursday $17 \mathrm{May} \cdot 3: 45 \mathrm{PM} \cdot$ Flagler \\
Session Chairs: David J. Wald, Eric M. Thompson, and \\
Charles B. Worden
\end{tabular}

Integrated Research, Development, and Operations of USGS Real-Time Earthquake Shaking and Impact Information Systems

WALD, D. I., US Geological Survey, Colorado, USA, wald@usgs.gov; ALLSTADT, K. E., US Geological Survey, Colorado, USA, kallstadt@usgs. gov; HAYES, G. P., US Geological Survey, Colorado, USA, ghayes@usgs.gov; HEARNE, M., US Geological Survey, Colorado, USA, mhearne@usgs.gov; JAISWAL, K. S., US Geological Survey, Colorado, USA, kjaiswal@usgs.gov; LIN, K., US Geological Survey, Colorado, USA, klin@usgs.gov; MARANO, K. D., US GeologicalSurvey, Colorado, USA, kmarano@usgs.gov; QUITORIANO, V., US Geological Survey, California, USA, vquitoriano@usgs.gov; SLOSKY, D., US Geological Survey, Colorado, USA, dslosky@usgs.gov; THOMPSON, E. M., US Geological Survey, Colorado, USA, emthompson@usgs.gov; WORDEN, C. B., US Geological Survey, Colorado, USA, cbworden@usgs.gov

In addition to providing situational awareness, USGS systems developed for near-real-time earthquake shaking and impact assessment are also used widely for scientific analyses, planning, and financial decision-making. The diversity of applications and societal import of these systems mandates continual research and development, as well as operational, content, and delivery innovations. An update is provided on software modernization and further integration of the "Did You Feel It?” (DYFI), ShakeMap, ShakeCast, and PAGER and related systems. In addition to thorough improvements to these systems, new products include probability of ground failure that augment real time shaking-based loss estimates. We also combine PAGER with FEMA's Hazus loss estimates for domestic earthquakes to provide more detailed post-earthquake information than from PAGER alone. Our products build sequentially upon one another: DYFI feeds intensity data to ShakeMap; ShakeMap's intensity measure grid is the input for ground failure, PAGER, Hazus, and ShakeCast computations. We also report on a new suite of tools, scenarios and historical data sets which-in parallel to their real-time analogues - serve widely as test events, for planning exercises, and for calibrating models of shaking, ground failure, and impacts. Software integration of these systems has been accomplished by refactoring all code into a common Python development protocol, with GitHub code management, unit and system testing, and continuous integration. A side benefit of software uniformity is a greater depth of expertise among our team members for developmental and operational proficiency on all systems. Lastly, our recent developments have facilitated integration of recent scientific developments into our hazard and loss algorithms. Advancements include allowing for multiply-weighted GMPEs, the inclusion of directivity, spatial variability, and ground failure, and employing advanced engineering building modules for loss estimates.

ShakeMap Ground-Motion Interpolation Using the Multivariate Normal Distribution

WORDEN, C. B., Synergetics Inc./US Geological Survey, Colorado, USA, cbworden@gmail.com; THOMPSON, E. M., US Geological Survey, Colorado, 
USA, emthompson@usgs.gov; WALD, D. J., US Geological Survey, Colorado, USA,wald@usgs.gov

A key update in the next major release of ShakeMap is the application of the multivariate normal distribution (MVN) to ground motion interpolation. The MVN provides a complete solution to the problem of ground-motion interpolation, fully accounting for the correlation among the instrumental observations both spatially and across intensity measure types (IMTs), and is therefore an important improvement over the current ShakeMap interpolation scheme. Practical application of the MVN in a ShakeMap setting, however, is challenging for several reasons: 1) the large size of typical ShakeMap output grid makes computation of the complete MVN impractical on commonly available computers; 2) a large number of IMTs in the input may also inflate the required matrices to impractical dimensions; 3) the lack of currently available empirical cross-correlation functions between some ShakeMap IMTs [e.g., between peak ground velocity (PGV) and Modified Mercalli Intensity (MMI)] prevents a straightforward implementation of the MVN in some cases; 4) the computation of the eventspecific bias is complicated by the presence of multiple IMTs in the input and heteroskedastic inter-event residuals in some ground motion models. Here, we describe a number of adaptations and simplifying assumptions made to overcome these, and other, obstacles. For instance, we discuss a piecewise application of the MVN that produces output grids of amplitude and variance, without the necessity of computing the full covariance matrix of the output grid. We also show that the down-weighting of uncertain data as described by Worden et al. (BSSA, in press) allows for the inclusion of data converted from one IMT to another, while accounting for the uncertainty inherent in the conversion. This approach enables, for example, the inclusion of PGV data in a map of MMI despite the lack of an empirical cross-correlation function, by first applying an appropriate conversion of PGV to MMI.

\section{Introducing a European Integrated Shakemap System}

CAUZZI, C., Swiss Seismological Service at ETH Zürich, Switzerland, carlo. cauzzi@sed.ethz.ch; CLINTON, J. F., Swiss Seismological Service at ETH Zürich, Switzerland, jclinton@sed.ethz.ch; FAENZA, L., Italian National Institute of Geophysics and Volcanology, Italy, licia.faenza@ingv.it; HEIMERS, S., Swiss Seismological Service at ETH Zürich, Switzerland, stefan.heimers@ sed.ethz.ch; KOYMANS, M., Royal Netherlands Meteorological Institute, Netherlands, mathijs.koymans@knmi.nl; LAUCIANI, V., Italian National Institute of Geophysics and Volcanology, Italy, valentino.lauciani@ingv.it; LUZI, L., Italian National Institute of Geophysics and Volcanology, Italy, lucia. luzi@ingv.it; MICHELINI, A., Italian National Institute of Geophysics and Volcanology, Italy, alberto.michelini@ingv.it; PUGLIA, R., Italian National Institute of Geophysics and Volcanology, Italy, rodolfo.puglia@ingv.it; RUSSO, E., Italian National Institute of Geophysics and Volcanology, Italy, emiliano. russo@ingv.it; SLEEMAN, R., Royal Netherlands Meteorological Institute, Netherlands, reinoud.sleeman@knmi.nl; JOZINOVIĆ, D., Italian National Institute of Geophysics and Volcanology, Italy, djozinovi@gmail.com

Strong-motion data dissemination in Pan-Europe is undergoing remarkable improvements. Two new modern strong-motion portals were recently developed within project NERA, mainly based on the European Integrated Waveform Data Archive (EIDA), namely: (a) an automatic peak-motion database (RRSM) that delivers earthquake and peak-motion information within minutes of any event with $\mathrm{M} \geq=3.5$; (b) a manually revised strong-motion $(\mathrm{M} \geq=4.0)$ database tailored to engineering applications (ESM). Within projects EPOS-IP and SERA, the content of the two databases has been made accessible via event, station, peakmotion and waveform webservices, largely improving users' access and automation of downstream products, like ShakeMap. In this contribution we present ShakeMapEU (http://shakemap-eu.ethz.ch/), that uses the USGS ShakeMap codes and input from the RRSM and ESM to deliver maps of ground shaking within minutes of any event with $M \geq=4.0$ in the Euro-Mediterranean region. The maps are initially constrained by the earthquake locations and magnitudes provided by the Euro-Mediterranean Seismological Centre (EMSC) along with the recordings of the RRSM, and subsequently updated with manually revised ESM ground-motion estimates. ShakeMapEU uses ground-motion prediction tools suitable for Pan-Europe and the seismo-tectonic regionalisation of project SHARE. It implements the authoritative configuration for Switzerland and Italy and will in the future include any other authoritative regional configuration. The system is based on ShakeMap 3.5. A transition to ShakeMap 4.0, including new developments concerning map and web rendering, is planned in the future. The main goals of ShakeMapEU are: (i) to provide a single source for ShakeMaps at the European scale that builds on EIDA and modern future-proof community software and tools; (ii) to serve as a backup to local authoritative ShakeMap implementations and; (iii) to deliver ShakeMaps for regions where no local capability is yet available.
Shake-Map Movie by Using Data Assimilation and Correction of Site Amplification in Time Domain

HOSHIBA, M., Meteorological Research Institute, JMA, Japan, mhoshiba@ mri-jma.go.jp

Monitor of spatial distribution of ground shaking, that is shake-map, is important for rapid assessment of earthquake damage. Shake-maps usually indicate distribution of eventual distribution of ground shaking (PGA, PGV or seismic intensity), and it does not contain information of time evolution of ground shaking. Here we propose to extend it to shake-map of ongoing ground shaking (hereinafter "shake-map movie") which gives us time-trace of ground shaking at locations where seismometers do not exist. Real-time application of the shake-map movie enables us to envision distribution of the ground shaking of near future. In this context, shake-map movie is a powerful tool for earthquake early warning. Data assimilation is a technique for precise estimation of the present condition, and it is widely used in meteorology and oceanography in geophysics. We apply the data assimilation technique to estimate the real-time shake-map movie, in which simulation of seismic wave propagation is incorporated into the actual monitor of the shaking. In the data assimilation technique, not only present data, but also all past data are used to estimate the present distribution of ground shaking. The incorporation of past data leads to more precise estimation, as compare with just drawing the contour of present distribution. For application to actual observation, frequency-dependent site amplification factors should be corrected. For the correction of the site amplification in real-time, IIR filters are created which are consistent with the frequency dependence and applicable in time domain. In this presentation, we will show examples of the shake-map movie by applying it to the 2011 Tohoku earthquake (Mw9.0), the 2016 Kumamoto earthquake (Mw7.1), and the 2015 Bonin Islands earthquake (Mw7.9; focal depth 683km).

\section{Real-Time Earthquake Impact Mapping in Indonesia: The Case of the 2016 Aceh Earthquake (M 6.5)}

PRAMONO, S., Indonesian Agency for Meteorological, Climatological and Geophysics, Jakarta, Indonesia, sigit.pramono@bmkg.go.id; MURJAYA, J., Indonesian Agency for Meteorological, Climatological and Geophysics, Jakarta, Indonesia, jaya.murjaya@bmkg.go.id; PERMANA, D., Indonesian Agency for Meteorological, Climatological and Geophysics, Jakarta, Indonesia, dadang.permana@bmkg.go.id; RUDYANTO, A., Indonesian Agency for Meteorological, Climatological and Geophysics, Jakarta, Indonesia, ariska. rudyanto@bmkg.go.id; SAKTI, A., Indonesian Agency for Meteorological, Climatological and Geophysics, Jakarta, Indonesia, artadi.sakti@bmkg.go.id; SYUKUR, F., Indonesian Agency for Meteorological, Climatological and Geophysics, Jakarta, Indonesia, fajri.syukur@bmkg.go.id; GHASEMI, H., Geoscience Australia, Australian Capital Territory, Australia, hadi.ghasemi@ ga.gov.au; BUGDEN, C., Geoscience Australia, Australian Capital Territory, Australia, craig.bugden@ga.gov.au; ALLEN, T., Geoscience Australia, Australian Capital Territory, Australia, trevor.allen@ga.gov.au; MORGAN, C., Geoscience Australia, Australian Capital Territory, Australia, charlotte. morgan@ga.gov.au; BUSTHOMI, I., DMInnovation, Jakarta, Indonesia, ivan. busthomi@dminnovation.org

Indonesia is one of the most earthquake disaster-prone countries in the world due to its tectonic activity and high population exposure. To assist with the earthquake response process, Indonesia's Agency of Meteorology, Climatology and Geophysics (BMKG) generates near-real-time maps of ground motion and shaking intensity (i.e. ShakeMaps) following significant earthquakes. The original ShakeMaps are based on empirical predictions using basic hypocentre and magnitude information, and are generally generated within 5 minutes of the earthquake's origin. Such maps are updated automatically by incorporating recorded ground motion data from Indonesia's national Strong-Motion Network. This network, operated and maintained by BMKG, currently includes 278 strongmotion stations, and in 2017 has recorded more than 5000 records from 620 events. The ShakeMap products are subsequently used by Indonesian National Board for Disaster Management (BNPB) to produce near-real time earthquake impact maps in terms of the population exposed to different levels of ground shaking as well as expected number of fatalities. In this paper, we describe the implementation of real-time earthquake impact alerting systems within BMKG and BNPB. We also demonstrate the use of these systems in response to the recent MW 6.5 Kota-Banda Aceh earthquake that occurred on the 7th of December 2016 at a depth of $15 \mathrm{~km}$. The earthquake was reported to have caused 104 fatalities and $\sim 8000$ number of displaced people. The integrated ShakeMap system automatically generated shaking estimates calibrated by BMKG's strong-motion network within 10 minutes of the event's origin time. The BMKG Shakemaps are automatically uploaded to the InaSAFE Realtime platform, managed by BNPB, to estimate the number of people exposed. It has been observed that recorded 
ground motions as well as number of casualties are generally consistent with theoretical models.

\section{Structure and Geodynamics of the Caribbean Plate Boundaries}

Oral Session · Thursday 17 May · 8:30 AM - Tuttle

Session Chairs: Alan Levander and Fenglin Niu.

\section{Mantle Structure of the Caribbean and Its Geodynamic Consequences}

GOVERS, R., Utrecht University, Netherlands, r.govers@uu.nl; BROERSE, T., Utrecht University, Netherlands, d.b.t.broerse@uu.nl; VAN BENTHEM, S., Utrecht University, Netherlands, steempien@yahoo.co.uk; SPAKMAN, W., Utrecht University, Netherlands, w.spakman@uu.nl; WORTEL, R., Utrecht University, Netherlands,m.j.r.wortel@uu.nl

We study the Caribbean plate and its underlying mantle. We investigate whether predictions of mantle structure from tectonic reconstructions are in agreement with a detailed tomographic image of seismic P-wave velocity structure under the Caribbean region. In the upper mantle, positive seismic anomalies are imaged under the Lesser Antilles and Puerto Rico. These anomalies are interpreted as remnants of Atlantic lithosphere subduction and confirm tectonic reconstructions that suggest at least $1100 \mathrm{~km}$ of convergence at the Lesser Antilles island arc during the past $\sim 45 \mathrm{Myr}$. The imaged Lesser-Antilles slab consists of distinct northern and southern anomalies, separated by a low velocity anomaly across most of the upper mantle, which we interpret as the subducted North-South America plate boundary. The southern edge of the imaged Lesser Antilles slab agrees with tearing of South America lithosphere along a semi-vertical shear zone. Regional seismicity suggests that the active STEP is located close to Trinidad/Tobago. The resulting STEP Fault zone aligns with the San Sebastián/El Pilar plate boundary (Clark et al., 2008). We discuss new results of mechanical experiments aimed at better constraining the location of lithospheric tearing. The northern Lesser Antilles slab is continuous with the Puerto Rico slab along the northeastern plate boundary. This results in an amphitheater-shaped slab and it is interpreted as westward subducting North America lithosphere that remained attached to the surface along the northern boundary. We use mechanical models to demonstrate that the trench parallel motion of this western edge of the slab ("slab edge push") is a major driver of deformation of tectonic blocks in the northeastern Caribbean plate boundary zone. Geological observations suggest that that slab edge push was the dominant driver of deformation in the northeastern Caribbean plate boundary zone since $30 \mathrm{Ma}$.

\section{Seismic Imaging of the Lesser Antilles Subduction Zone with the VOILA Project}

RYCHERT, C. A., University of Southampton, Hampshire, United Kingdom, c.rychert@soton.ac.uk; HARMON, N., University of Southampton, Hampshire, United Kingdom, n.harmon@soton.ac.uk; CHICHESTER, B., University of Southampton, United Kingdom, ben.chichester@southampton. ac.uk; COLLIER, J., Imperial College London, United Kingdom, jenny. collier@imperial.ac.uk; HENSTOCK, T., University of Southampton, United Kingdom, then@noc.soton.ac.uk; HICKS, S., University of Southampton, United Kingdom, s.hicks@soton.ac.uk; KRÜGER, F., Potsdam, Germany, frank.krueger@geo.uni-potsdam.de; RIETBROCK, A., KIT, Germany, andreas. rietbrock@kit.edu

The Volatiles in the Lesser Antilles (VOILA) project is a multidisciplinary experiment to understand the pathway of fluids and volatiles in the Lesser Antilles subduction system, where oceanic lithosphere from the slow-spreading Mid Atlantic Ridge is descending in the mantle. Here we present results from the passive seismic ocean bottom deployment of 32 instruments on the back arc and forearc regions. We use teleseismic Rayleigh wave dispersion and S-to-P receiver functions to image the slab, upper plate, and wedge structures. We calculated receiver functions using a multitaper method. We measure dispersion from 18-111 s period, which increases from 3.64 at $18 \mathrm{~s}$ period to 4.21 at $111 \mathrm{~s}$. Receiver functions image the Moho that varies from 29 to $40 \pm 4 \mathrm{~km}$ depth beneath the arc. In the northern and central section of the arc we image the base of the upper plate at $73 \pm 5 \mathrm{~km}$ depth beneath the arc and backarc. The slab itself dips too steeply to be imaged using this method. In the southern arc we image a negative phase that may be related to a more gradually dipping slab at $101-117 \pm 5 \mathrm{~km}$. The receiver functions are in good agreement with constraints from surface waves. At $18-33$ s period we observe low velocities beneath the arc across the region, with higher velocities on either side, consistent with thickened crust and possibly a low velocity mantle wedge region beneath the active arc region. At 40-81 s period a $\mathrm{N}-\mathrm{S}$ trending high velocity region, $\sim 100 \mathrm{~km}$ wide, is observed, which shifts position westward with increasing period, migrating from the forearc to beneath the arc, which we interpret as the slab. At longer periods (81-111s) the high velocity anomaly persists north of Gaudeloupe, suggesting the slab may persist to greater depths in this region.

Mutual Subduction: A Review of Observations from the Southern Caribbean Margin and Some Outstanding Questions

BEZADA, M. J., University of Minnesota, Minnesota, USA, mbezada@umn. edu; CORNTHWAITE, J. P., Rice University, Texas, USA, jpcorn@ @ice.edu; NIU, F., Rice University, Texas, USA, niu@rice.edu; LEVANDER, A. R., Rice University, Texas, USA, alan@rice.edu

The most evident surface expression of the Caribbean-South America plate boundary is the strike-slip San Sebastian - El Pilar fault system. However, the boundary also comprises two convergent segments. In the east, the Atlantic (oceanic continuation of South America) subducts beneath the Caribbean, while in the west, the Caribbean subducts beneath South America. While Atlantic subduction is straightforward and undisputed, a general dearth of intermediatedepth seismicity, absence of megathrust earthquakes in the historical record, and absence of subduction-related volcanism, along with the relatively low resolution of early tomography studies, led several authors to conclude that any subduction of the Caribbean beneath South America was only incipient. Recent body-wave tomography has shown conclusively that Caribbean subduction beneath South America is well established. Indeed a Caribbean slab can be imaged initially subducting at a shallow angle, before dipping near-vertically near the Merida Andes. The Caribbean slab can be traced to the bottom of the transition zone, documenting a minimum of $\sim 900 \mathrm{~km}$ of subduction. In both of the subduction segments that bracket the strike-slip portion of the boundary, only part of the plate subducts. In each case, the subducting slab must tear from the non-subducting lithosphere that it was continuous with pre-subduction. In the east, the Paria cluster of seismicity in eastern Venezuela has been identified as the likely location of this tear, but seismic imaging strongly suggests that this does not represent a clean cut through the entire lithosphere. In the west, there are no conspicuous concentrations of seismicity that would suggest the location of a tear, although one must exist. We present the latest high-resolution seismic images of the upper mantle that underpin the assertions made above, and consider the implications of the imaged subduction geometry.

\section{What Can Earthquakes Tell Us of Plate Interactions in Northern South America?}

PRIETO, G. A., Universidad Nacional de Colombia, Colombia, gaprietogo@ unal.edu.co; DIONICIO, V., Servicio Geologico Colombiano, Colombia, Idionicio@sgc.gov.co; MONSALVE, G., Universidad Nacional de Colombia, Colombia,gmonsalvem@unal.edu.co

The northern edge of South America features the interaction of three major plates (and probably multiple minor ones). This complex setting includes the subduction of the Nazca plate, showing flat subduction in the north and strong variability of subducting angle to the south. The Caribbean plate is subducting to the north, also with potential flat subduction, although evidence still requires additional imaging efforts that are underway today. The shallow structure in northern South America also features major crustal faults, but it is still not clear how deformation is distributed. We review the seismicity in northern south America, recorded by the Servicio Geológico Colombiano over the last 10 years. We focus in particular in three major features of the seismicity. The Bucaramanga Nest represents the largest concentration of intermediate-depth earthquakes in the world (per volume), nevertheless it is still debated whether it is related to the Nazca plate, the Caribbean plate or a collision between the two. Towards the South, another large concentration of intermediate-depth earthquakes is related to the change between flat-subduction and steep subduction of the Nazca plate. The seismicity is concentrated along the subducting plate, but also shows seismicity in the mantle wedge, an unusual feature, that may provide key constraints of mantle temperature and mantle wedge flow. Finally, by relocating crustal seismicity in northern Colombia, we highlight some of the major faults that accommodate plate motion and the collision with the Panama Arc.

Inferences of Slab Tears throughout the Caribbean from Integrated Seismic Methods

MILLER, M. S., Australian National University, Australian Capital Territory, Australia, meghan.miller@anu.edu.au; HARRIS, C. W., University of Southern California, California, USA, cwharris@usc.edu; PORRITT, R. W., University 
of Texas at Austin, Texas, USA, rwporritt@gmail.com; HODGES, M., CSU Long Beach, California, USA, michaelrhodges@gmail.com

We present new tomographic models in combination with recent shear wave splitting results to aid in understanding the tectonic history of the Caribbean. Our recent results for $201 \mathrm{SK}(\mathrm{K}) \mathrm{S}$ shear wave splitting results at 20 stations in the northeastern Caribbean indicated a relatively simple trench-parallel pattern. These results agree with previous splitting measurements. This was used to infer that the slab was continuous beneath this part of the arc. However, additional data and analyses from other methods suggest that the slab may be torn. To investigate possible slab tearing, we use $~ 20,000$ teleseismic $\mathrm{P}$ and PP travel time residuals from 535 events recorded at 130 broadband seismometers to construct a new finite-frequency upper mantle P-wave tomographic model. We observe an arcuate-shaped, subducted slab beneath the Lesser and Greater Antilles island arcs. We also observe that this subducted Atlantic oceanic lithosphere is divided into three sections by two lateral discontinuities. A southern Lesser Antilles slab, which extends continuously from the near the coast of South America to $15 \mathrm{~N}$, is separated above $\sim 200 \mathrm{~km}$ from a northern Lesser Antilles slab, which extends from $\sim 15 \mathrm{~N}$ to western Puerto Rico, and then separated above $\sim 300 \mathrm{~km}$ from a narrow slab beneath eastern Hispaniola. A new ambient noise tomography model utilizing continuous data from 176 stations recorded between 2011 and 2015 allows for analysis of uppermost mantle structure up to crustal depths. North of $\sim 13 \mathrm{~N}$, at $10 \mathrm{~km}$ depth, high velocity anomalies follow a similar arcuate shape as imaged in the mantle with the P-wave tomography. This shape is disrupted beneath central Hispaniola, suggesting slab fragments imaged in the mantle may also be reflected at even shallower depths. At $20 \mathrm{~km}$ depth, we observe a sharp offset between low and high velocity anomalies along the Greater Antilles, sug gesting deep seated faulting associated with the offset between North America and the Caribbean.

\section{The Recent Earthquakes that Shocked Mexico in September 2017 \\ Oral Session · Thursday 17 May · 10:45 AM • Brickell Session Chairs: Arturo Iglesias, Vala Hjörleifsdóttir, Víctor M. Cruz-Atienza, and Roberto Ortega-Ruiz}

The September 19th, 2017, (M7.1), Intermediate-Depth Mexican Earthquake: An Energetically Inefficient Deadly Shock

MIRWALD, A., Instituto de Geofísica, Universidad Nacional Autónoma de México, Mexico City, Mexico, aron.mirwald@gmail.com; CRUZ-ATIENZA, V. M., Instituto de Geofísica, Universidad Nacional Autónoma de México, Mexico City, Mexico, cruz@geofisica.unam.mx; IGLESIAS, A., Instituto de Geofísica, Universidad Nacional Autónoma de México, Mexico City, Mexico, arturo@ geofisica.unam.mx; DIAZ-MOJICA, J., Instituto de Geofísica, Universidad Nacional Autónoma de México, Mexico City, Mexico, eljonjairo@gmail.com; HJÖRLEIFSDÓTTIR, V., Instituto de Geofísica, Universidad Nacional Autónoma de México, Mexico City, Mexico, vala@igeofisica.unam.mx; SINGH, S. K., Instituto de Geofísica, Universidad Nacional Autónoma de México, Mexico City, Mexico, krishnamex@yahoo.com

On September 19th 2017, a magnitude 7.1 earthquake occurred between the states of Morelos and Puebla, Mexico. The event was a normal-faulting intraplate earthquake with a focal depth of $57 \mathrm{~km}$. Although intermediate depth earthquakes (IDE) of this kind are relatively frequent across the globe, the physics of their source process is still not well understood. Due to the high confining pressure and temperature at depths below $50 \mathrm{~km}$, rocks ought to deform by ductile flow rather than the brittle failure governing most of shallow, interplate earthquakes. We performed a dynamic source inversion of the M7.1 event using six strong motion records with epicentral distances smaller than $110 \mathrm{~km}$. We implemented a new Particle Swarm Optimization algorithm for this purpose that takes advantage of parallel computing and allows a statistical analysis of the solution. Consistently with similar Mexican earthquakes (Díaz-Mojica et al., 2014), the inversion of the M7.1 event revealed that the rupture speed $(\mathrm{Vr} / \mathrm{Vs} \sim 0.3-0.5)$ and radiation efficiency $(0.02-0.28)$ are low. Besides, as expected for intraslab earthquakes, the stress drop ( 20 MPa) is high. Similar results where recently found using an independent method for an IDE below the Wyoming Craton in US (Prieto et al., 2017) suggesting that slow, inefficient source processes may characterize earthquake ruptures below the brittle-ductile transition of the lithosphere. Although such rupture properties are typical of tsunami earthquakes, the M7.1 shock produced Fourier accelerations about two times larger than those observed between 1 and $2 \mathrm{~s}$ for earthquakes with similar magnitude reduced to the same hypocentral distance (Singh et al., 2018). It is possible that rupture directivity contributed to this observation. Our results also show that $\sim 72 \%$ of the total energy change produced by the event was not radiated. This means that the specific fracture energy was close to $2 \times 10^{7} \mathrm{~J} / \mathrm{m}^{2}$ in average, which is about 10 times larger than expected for shallow crust earthquakes. Recent studies suggest that thermal shear runaway is the leading rupture mechanism of IDEs (Prieto et. al., 2013). This mechanism produces a highly localized ductile deformation in the fault zone inhibiting brittle fracture but allowing large particle accelerations.

Intraslab Earthquake Faulting in Subduction Zones: The Role of Seafloor Fabric During the M 7.1 and M 8.2 September 2017 Mexico Earthquakes MELGAR, D., University of Oregon, Oregon, USA, dmelgarm @uoregon.edu; RUIZ-ANGULO, A., Universidad Nacional Autónoma de México, Mexico, angel@atmosfera.unam.mx; PÉREZ-CAMPOS, X., Universidad Nacional Autónoma de México, Mexico, xyolipc@sismologico.unam.mx; GARCIA, E. S., Kyoto Unviersity, Japan, garcia.soliman.2x@kyoto-u.ac.jp; MANEA, M., Universidad Nacional Autónoma de México, Mexico, marina@geociencias. unam.mx; MANEA, V. C., Universidad Nacional Autónoma de México, Mexico, vlad@geociencias.unam.mx; XU, X., UC San Diego, California, USA, xix016@ ucsd.edu; SPICA, Z., Stanford University, California, USA, zspica@stanford. edu; GENG, J., Wuhan University, China, jgeng@whu.edu.cn; HAMMOND, W. C., University of Nevada Reno, Nevada, USA, whammond@unr.edu; RAMIREZ-HERRERA, M. T., Universidad Nacional Autónoma de México, Mexico, tramirez@igg.unam.mx; CORONA MORALES, N., El Colegio de Michoacan, Mexico, corona@colmich.edu.mx; ZAVALA-HIDALGO, J., Universidad Nacional Autónoma de Mexico, Mexico, jzavala@atmosfera.unam. mx; CABRAL-CANO, E., Universidad Nacional Autónoma de México, Mexico, ecabral@geofisica.unam.mx; RAMÍREZ-GUZMÁN, L., Universidad Nacional Autónoma de México, Mexico, tramirezg@iingen.unam.mx; ESPÍNDOLA, V. H., Universidad Nacional Autónoma de México, Mexico, victore@sismologico. unam.mx

Two large normal faulting intraslab events occurred in rapid succession in Mexico in 2017, the 8th September M8.2 Tehuantepec, and 19th September M7.1 Puebla-Morelos earthquakes. Here we will discuss detailed source models of both earthquakes produced from inversion of all available regional geophysical data. This includes, strong motion, high-rate GPS, static GPS, tide gauge, and oceanbottom pressure data. Although the commonly accepted hypothesis for intraslab earthquakes is slab dehydration, we show that for both events also pre-existing seafloor fabric plays a determining role. During the Tehuantepec earthquake, the chain of events is that a bend fault first formed from reactivated fabric in the outer rise rotates through the megathrust and, with help from wholesale deviatoric tension and strong slab pull, hosts the normal faulting event. The earthquake ruptured from the megatrhust down to the edge of the lithosphere, and we find robust evidence that embrittlement is much deeper than previously thought and extends to temperatures as high as $1100^{\circ} \mathrm{C}$. Similarly during the Puebla-Morelos intraslab event we find that bend faulting at the edge of the flat slab segment hosts the normal faulting event. Similarly we show from an analysis of the seafloor morphology that abyssal hill fabric formed during seafloor spreading and advected through the subduction system, represents a key pre-existing weakness plane that promotes the intraslab event. Sharp bending as the flat slab unfurls into the mantle produces a substantial bending moment placing the top half of the subducted lithosphere under flexural extension.

\section{A Study of Excitation and Ground Motion Relations in Central Mexico Based on the Earthquakes of September 2017 \\ ORTEGA, R., CICESE, Baja California Sur, Mexico, ortega@cicese. mx; CARCIUMARU, D., CICESE, Mexico, danadierna@gmail.com; QUINTANAR, L., Universidad Nacional Autónoma de México, Mexico, luisq@ollin.igeofcu.unam.mx}

In this study, we present preliminary results of ground motion relations in central Mexico. The amplitudes of maximum peak ground acceleration and pseudo-absolute acceleration spectra are difficult to model because it is important to consider the complex geometry of the source. In general, the ground motion prediction equations that have been developed over the years include sources of inter- and intra-slab and active tectonic sources indistinctly. The distance is also difficult to assess using only one metric. At first glance there are some inconsistencies in previous published GMPE's and the ground motion records of the earthquakes of September 2017. For example, the amplitudes of the earthquake of September 19 seem to fit better than the Tehuantepec earthquake but the geometry of the source is difficult to reconcile in the source model of the Tehuantepec earthquake. The original database of earthquakes that created the GMPEs did not include any earthquake of size and faulting style similar to Tehuantepec one. We also compared other ground motion relations that were obtained from random vibration theory simulations applying some scaling laws. Our preliminary results show that the Tehuantepec earthquake requires special considerations to model 
the source rupture and it is of major importance for future probabilistic seismic hazard analysis.

\section{Earthquake Triggering and Stress Changes in the September 2017 Mexican Earthquake Sequence}

FIELDING, E. J., NASA Jet Propulsion Laboratory, Caltech, California, USA, eric.j.fielding@jpl.nasa.gov; GOMBERT, B., IPGS, Université de Strasbourg/ EOST, France, gombert@unistra.fr; DUPUTEL, Z., IPGS, Université de Strasbourg/EOST, France, zacharie.duputel@unistra.fr; HUANG, M. H., University of Maryland, College Park, Maryland, USA, mhhuang@umd.edu; LIANG, C., Seismological Laboratory, Caltech, California, USA, cunrenl@ caltech.edu; JIANG, J., UC San Diego, California, USA, junle@ucsd.edu; SIMONS, M., Seismological Laboratory, Caltech, California, USA, simons@ caltech.edu; BEKAERT, D., NASA Jet Propulsion Laboratory, Caltech, California, USA, david.bekaert@jpl.nasa.gov; MOORE, A. W., NASA Jet Propulsion Laboratory, Caltech, California, USA, angelyn.w.moore@jpl.nasa. gov; LIU, Z., NASA Jet Propulsion Laboratory, Caltech, California, USA, zhen.liu@jpl.nasa.gov; AMPUERO, J. P., Seismological Laboratory, Caltech, California, USA, ampuero@gps.caltech.edu; GONZALEZ-ORTEGA, J. A., CICESE, Baja California, Mexico, aglez@cicese.mx

Southern Mexico was struck by four earthquakes with $\mathrm{Mw} \geq 6$ and numerous smaller earthquakes in September 2017, starting with the 8 September Mw 8.2 Tehuantepec Earthquake beneath the Gulf of Tehuantepec offshore Chiapas and Oaxaca. We study whether this M8.2 earthquake triggered the three subsequent large $M \geq 6$ quakes in southern Mexico to improve understanding of earthquake interactions and time-dependent risk. All four large earthquakes were extensional despite the subduction of the Cocos plate at the convergent plate boundary. The traditional definition of aftershocks: likely an aftershock if it occurs within two rupture lengths of the main shock soon afterwards. Two $\mathrm{Mw} 6.1$ earthquakes, half an hour after the M8.2 beneath the Tehuantepec gulf and on 23 September near Ixtepec in Oaxaca, both fit as traditional aftershocks, within $200 \mathrm{~km}$ of the main rupture. The 19 September Mw 7.1 Puebla earthquake was $\sim 600 \mathrm{~km}$ away from the M8.2 shock, outside the standard aftershock zone. Geodetic measurements from interferometric analysis of synthetic aperture radar (InSAR) and time-series analysis of GPS station data constrain finite fault static slip models for the M8.2, M7.1, and M6.1 Ixtepec earthquakes. We include open-ocean tsunami waveforms for the M8.2 inversions. We analyzed InSAR data from Copernicus Sentinel-1A and -1B satellites and JAXA ALOS-2 satellite. Our Bayesian (AITar) static slip model for the M8.2 quake shows significant slip extended $\geq 150 \mathrm{~km}$ and possible $220 \mathrm{~km} \mathrm{NW}$ from the hypocenter and there is a high probability that the slip extended to depths of at least $70 \mathrm{~km}$ indicating slab pull stress state. Our slip model for the M7.1 earthquake is similar to the v2 NEIC FFM. Inversions for the M6.1 Ixtepec quake confirm shallow depth in the upper-plate crust and show centroid is about $30 \mathrm{~km} \mathrm{SW}$ of the preliminary NEIC epicenter but consistent with cluster relocations. The NEIC updated epicenter and Mexican SSN location are closer to the InSAR-constrained location.

\section{The September 2017 Earthquakes in Mexico from Social Media}

VELA ROSAS, M. A., Instituto de Geofísica, Universidad Nacional Autónoma de México, Mexico City, Mexico, miguel@sismologico.unam.mx; PÉREZCAMPOS, X., Instituto de Geofísica, Universidad Nacional Autónoma de México, Mexico City, Mexico, xyoli@igeofisica.unam.mx; PÉREZ, J., Instituto de Geofísica, Universidad Nacional Autónoma de México, Mexico City, Mexico, jesus@sismologico.unam.mx; CARDENAS MONROY, C., Instituto de Geofísica, Universidad Nacional Autónoma de México, Mexico City, Mexico, caridad@sismologico.unam.mx; ESPÍNDOLA, V. H., Instituto de Geofísica, Universidad Nacional Autónoma de México, Mexico City, Mexico, vhespindola@sismologico.unam.mx; BELLO,D. I., Instituto de Geofísica, Universidad Nacional Autónoma de México, Mexico City, Mexico, delia@ sismologico.unam.mx; CONTRERAS RUIZ ESPARZA, M. G., Instituto de Geofísica, Universidad Nacional Autónoma de México, Mexico City, Mexico, moises@sismologico.unam.mx; GONZÁLEZÁVILA, D., Instituto de Geofísica, Universidad Nacional Autónoma de México, Mexico City, Mexico, danielg@ sismologico.unam.mx; GONZÁLEZ-LÓPEZ, A., Instituto de Geofísica, Universidad Nacional Autónoma de México, Mexico City, Mexico, adrianag@ sismologico.unam.mx; MALDONADO, R., Instituto de Geofísica, Universidad Nacional Autónoma de México, Mexico City, Mexico, rafael@sismologico. unam.mx; MONTOYA QUINTANAR, E., Instituto de Geofísica, Universidad Nacional Autónoma de México, Mexico City, Mexico, edgar@sismologico.unam. mx; RODRÍGUEZ RASILLA, I., Instituto de Geofísica, Universidad Nacional Autónoma de México, Mexico City, Mexico, ivan@sismologico.unam.mx; TAN, Y., Instituto de Geofísica, Universidad Nacional Autónoma de México,
Mexico City, Mexico, yi@sismologico.unam.mx; CÁRDENAS, A., Instituto de Geofísica, Universidad Nacional Autónoma de México, Mexico City, Mexico, arturo@sismologico.unam.mx; CRUZ, J. L., Instituto de Geofísica, Universidad Nacional Autónoma de México, Mexico City, Mexico, jcruz@sismologico.unam. mx; HURTADO, A., Instituto de Geofísica, Universidad Nacional Autónoma de México, Mexico City, Mexico, alhudi@sismologico.unam.mx; NAVARRO ESTRADA, F., Instituto de Geofísica, Universidad Nacional Autónoma de México, Mexico City, Mexico, fernando@sismologico.unam.mx; MENDOZA CARVAJAL, A. J., Instituto de Geofísica, Universidad Nacional Autónoma de México, Mexico City, Mexico, antonio@sismologico.unam.mx; ESTRADA, J. A., Instituto de Geofísica, Universidad Nacional Autónoma de México, Mexico City, Mexico,jorgee@sismologico.unam.mx

After the earthquakes of September 7 (local time) and 19,2017, in Mexico, much of the activity of Mexican seismologists has clarified the popular concern about the possible unique characteristics of these. From another point of view, a particularity is evident: the most significant earthquakes and consequences in Mexico have been social media. In perspective, it is indisputable that for institutions and experts in seismology-because it is always in the collective interest as constantly as the movements of the earth-one of the challenges is also communication. The great demand for reliable and detailed information on these earthquakes -and their consequences- originated a public discourse that, by itself, emphasized technical concepts to make them accessible and supported the demystification, changing even the general interests on the subject. It is also true that false and apocryphal information, massive rumors and disinformation were especially adverse. Recognizing that several negative aspects are not exclusive or intrinsic to digital platforms, we must be more explicit how to lessen their impact. An analysis of the dissemination of these seismic events through social media (of the Mexican Servicio Sismológico Nacional, National Seismological Service, in particular) and the behavior of users, allows us to make some proposals for a better practice when reporting seismic events (seismic and seismicity reports), also contemplating diverse characteristic aspects of the magnitude, location, mechanism, and technological tools for the transmission of information. More importantly, this brief work leads to reassess the role of disseminators of science that should be appropriated by institutions responsible for providing seismic information to the population.

\section{The 8 September 2017 Earthquake: An Example of Large Scale Lithospheric} Faulting in the Subducted Cocos Plate

SUAREZ, G., Instituto de Geofísica, Universidad Nacional Autónoma de México, Mexico City, Mexico, gersua@yahoo.com; SANTOYO, M. A., Instituto de Geofísica, Universidad Nacional Autónoma de México, Mexico City, Mexico, santoyo@geofisica.unam.mx; HJÖRLEIFSDÓTTIR, V., Instituto de Geofísica, Universidad Nacional Autónoma de México, Mexico City, Mexico, valahjorleifs@gmail.com; IGLESIAS, A., Instituto de Geofísica, Mexico City, Mexico, guidibuchi@gmail.com; VILLAFUERTE, C. D., Instituto de Geofísica, Universidad Nacional Autónoma de México, Mexico City, Mexico, villafuerte. cd@gmail.com; CRUZ-ATIENZA, V. M., Instituto de Geofísica, Universidad Nacional Autónoma de México, Mexico City, Mexico, cruz.atienza@gmail.com

The 8 September 2017 earthquake took place in the Tehuantepec gap, in southeastern Mexico, where no large quakes have taken place since 1902. The 8 September earthquake, however, did not rupture the megathrust plate contact between the Cocos and the North American plates. The 2017 earthquake occurred within the subducting slab at a depth of $57 \mathrm{~km}$, immediately downdip of the interplate locked zone. The source mechanism shows normal faulting on a nearly vertical fault plane. The rupture initiated at the bottom of the subducted lithosphere and propagated towards the surface, breaking through the entire subducted lithosphere. An unusually long, complex, and copious aftershock sequence followed the earthquake. The distribution of the aftershock sequence shows a complex distribution. The main rupture is clearly delineated by a $160-\mathrm{km}$-long fault, sub-parallel to the oceanic trench, immediately beneath the interplate contact. The aftershocks also concentrate in intraslab faults $\sim 50 \mathrm{~km}$ down-dip from the main rupture. These aftershock clusters have the same dip as the main rupture and also suggest rupturing through the entire lithosphere. The tensional state of stress is reflected at a large scale within the subducted plate. This deformation pattern suggests the detachment of the slab induced by its own gravitational weight, pulling it away from the strongly coupled interplate contact. Recent earthquakes in the region, in 1931 (Mw7.8) and 1999 (Mw7.5), also show the large-scale detachment of the downgoing Cocos plate, suggesting that the megathrust plate interface is locked and possibly primed for a great earthquake. A very large event in 1787 ( $\mathrm{Mw}$ 8.6) occurred in an adjacent segment of the Mexican subduction zone, indicating that this region has been the site of great events in the past. 
The 2017/09/08 Mw 8.2 Tehuantepec, Mexico, Earthquake: A Large but Compact Dip-Slip Faulting Event Severing the Slab

HJÖRLEIFSDÓTTIR, V., Instituto de Geofísica, Universidad Nacional Autónoma de México, CDMX, Mexico, vala@igeofisica.unam.mx; IGLESIAS, A., Instituto de Geofísica, Universidad Nacional Autónoma de México, CDMX, Mexico, arturo@igeofisica.unam.mx; SUAREZ, G., Instituto de Geofísica, Universidad Nacional Autónoma de México, CDMX, Mexico, gersua@yahoo. com; SANTOYO, M. A., Instituto de Geofísica, Universidad Nacional Autónoma de México, CDMX, Mexico, santoyo@geofisica.unam.mx; VILLAFUERTE, C. D., Instituto de Geofísica, Universidad Nacional Autónoma de México, CDMX, Mexico, villafuerte.cd@gmail.com; JI, C., Department of Earth Science, UCSB, California, USA, ji@geol.ucsb.edu; SINGH, S. K., Instituto de Geofísica, Universidad Nacional Autónoma de México, CDMX, Mexico, krishnamex@ yahoo.com; CRUZ-ATIENZA, V. M., Instituto de Geofísica, Universidad Nacional Autónoma de México, CDMX, Mexico,cruz@geofisica.unam.mx

The Mw 8.2 September 8 earthquake occurred in the middle of the "Tehuantepec Gap,"a segment of the Mexican subduction zone that has no historical mentions of a large earthquake. It was, however, not the expected subduction megathrust earthquake, but rather an intraplate, normal faulting event, in the subducting oceanic Cocos plate. We inverted for the slip on the fault plane, using; 1) local strong motion and high rate GPS records and 2) teleseismic body and surface waves, together with static GPS offsets. From the hypocenter at a depth of 50 $\mathrm{km}$, the rupture propagated NW on a near-vertical plane, breaking towards the surface. Most of the slip was concentrated in the distance range $30-100 \mathrm{~km}$ from the hypocenter and at depth between 15 and $50 \mathrm{~km}$, with maximum slip of $\sim 15 \mathrm{~m}$. The earthquake seems to have broken the entire lithosphere, estimated to be 35 $\mathrm{km}$ based on the plate age. The strike of the fault is sub- parallel to the trench, aligned with the existing fabric on the incoming plate, suggesting a reactivation of previous structures. We relocated the aftershocks and found that they occurred along the fault plane during the first day after the event, with activation of other parallel structures within the subducting plate, towards the east, as well as in upper plate, in the following days. Coulomb stress modeling suggests that the stress on the plate interface, updip of the earthquake, is reduced. There are several other examples of large intraslab normal faulting earthquakes, near the downdip edge (1931 Mw 7.8 and $1999 \mathrm{Mw} 7.5$, Oaxaca) or directly below (1997 Mw 7.1, Michoacan) the coupled plate interface, along the Mexican subduction zone. The possibility of events of similar magnitude to the 2017 earthquake occurring close to the coastline, all along this part of the subduction zone, cannot be ruled out.

\section{Numerical Simulations of Tsunami Scenarios for the Southern Coast of Mexico}

SALAZAR-MONROY, E. F., National Autonomous University of Mexico, Mexico City, México, edifesamo14@gmail.com; CRUZ-JíMENEZ, H., National Autonomous University of Mexico, Mexico City, Mexico, hugocj75@ gmail.com; SILVA-CASARIN, R., Universidad Nacional Autónoma de México Engineering Institute, Mexico City, Mexico, rsilvac@iingen.unam. mx; RAMÍREZ-GUZMÁN, L., Universidad Nacional Autónoma de México Engineering Institute, Mexico City, Mexico, Iramirezg@iingen.unam.mx

On September 7th, 2017, a Mw 8.2 earthquake occurred off the coast of Chiapas (Mexico), inside the subducting Cocos slab. The normal mechanism event started at a depth of $50 \mathrm{~km}($ SSN, 2017), causing a small tsunami. The latter was recorded at the central and southern stations of the Servicio Mareografico Nacional of Mexico (SMN), with a maximum height of $3.42 \mathrm{~m}$ at Puerto Chiapas station. We simulated the tsunami using the Carnegie Mellon Finite Element Toolchain Hercules (Tu et al., 2006) to obtain the dynamic seafloor deformation (SFD) for an area of $235 \mathrm{~km} 2$ around the rupture area; considering the finite source model by Melgar et al. (2017). The SFD was introduced into the GeoClaw software (Clawpack Development Team, 2016) to compute the tsunami wave propagation. Comparisons of the observed and computed tsunami waveforms reveal a fair fit at the Salina Cruz and Puerto Madero stations. Additionally, we performed two simulations for shallow inverse faults, and perform a preliminary comparison of the tsunami inundation against the one caused by the September 7th, 2017 quake at the Chiapas-Oaxaca coast.

Intraslab Morelos-Puebla, Mexico, Earthquake of 19 September 2017 (Mw 7.1): Ground Motion and Damage Pattern in Mexico City

SINGH, S. K. Instituto de Geofísica, Universidad Nacional Autónoma de México, Mexico City, Mexico, krishnamex@yahoo.com; REINOSO, E., Instituto de Ingeniería, Universidad Nacional Autónoma de México, Mexico City, Mexico, ereinosoa@iingen.unam.mx; ARROYO,D., Universidad Autónoma
Metropolitana, Mexico City, Mexico, aresda@correo.azc.uam.mx; ORDAZ, M., Instituto de Ingeniería, Universidad Nacional Autónoma de México, Mexico City, Mexico, mordazs@iingen.unam.mx; CRUZ-ATIENZA, V. M., Instituto de Geofísica, Universidad Nacional Autónoma de México, Mexico City, Mexico, cruz.atienza@gmail.com; PÉREZ-CAMPOS, X., Instituto de Geofísica, Universidad Nacional Autónoma de México, Mexico City, Mexico, xyoli@igeofisica.unam.mx; IGLESIAS, A., Instituto de Geofísica, Universidad Nacional Autónoma de México, Mexico City, Mexico, arturo@igeofisica.unam. mx; HJÖRLEIFSDÓTTIR, V., Instituto de Geofísica, Universidad Nacional Autónoma de México, Mexico, Mexico, vala@igeofisica.unam.mx

The intraslab earthquake of 2017 was the second most destructive in the history of Mexico City, next only to the interplate earthquake of 1985 (Mw8.0). PGA of $59 \mathrm{gal}$ at the SM station of CU, located on basalt lava flows and in continuous operation since 1964, was the largest ever, twice the PGA during the 1985 earthquake (29 gal). The 2017 earthquake has raised questions that are critical in fathoming the seismic vulnerability of the city. Was such an intraslab earthquake ( $\mathrm{Mw} 7$ at a hypocentral distance of $127 \mathrm{~km}$ ) unexpected? Were the recorded ground motions in the city unusually high? Why did the damage patterns during the earthquakes of 2017 and 1985 differ? $\mathrm{Mw} \sim 5.9$ events have occurred in recent years near the 2017 earthquake. Three $\mathrm{Mw} \geq 6.9$ earthquakes have occurred since 1964 in the distance range $184-225 \mathrm{~km}$. Thus, $\mathrm{Mw}$ and $\mathrm{R}$ of the 2017 earthquake was not surprising. However, Fourier acceleration spectra at CU of 10 intraslab earthquakes with the largest PGAs, reduced to a common $\mathrm{R}=127 \mathrm{~km}$, shows that the amplitudes of the 2017 events were abnormally high in 1-2 s range. With respect to site-specific GMPE, the observed PGV and Sa at $1<\mathrm{T}<2 \mathrm{~s}$ were also anomalously high. Yet, as the recordings at 65 sites in the city attest, Sa exceeded the design spectra of Mexico City's 1987 building code at only few sites. The intraslab earthquakes occur closer to the city, at greater depth, and involve higher stress drop than their interplate counterparts. Consequently, the ground motion is relatively enriched at high frequencies as compared to the interplate earthquakes which is dominated by lower frequency waves $(\mathrm{f}<0.5 \mathrm{~Hz})$. This explains the observed difference in the damage pattern during 2017 and 1985. The damage during 2017 occurred at sites with a natural period, Ts, between 0.5 and $2 \mathrm{~s}$; during 1985 the damage was concentrated at sites with $1.6<\mathrm{Ts}<3 \mathrm{~s}$. This damage pattern will, no doubt, repeat in the city during future strong intraslab and interplate earthquakes.

\section{Analysis of the 19 September 2017 (Mw=7.1) Mexico Earthquake and Its Aftershock Sequence}

IGLESIAS, A., Universidad Nacional Autónoma de México, Mexico City, Mexico, arturo@geofisica.unam.mx; MÉNDEZ, M., Universidad Nacional Autónoma de México, Mexico City, Mexico, amaterasu743@gmail.com; HJÖRLEIFSDÓTTIR, V., Universidad Nacional Autónoma de México, Distrito Federal, Mexico, vala@geofisica.unam.mx; FRANCO, S. I., Universidad Nacional Autónoma de México, Distrito Federal, Mexico, sifs23@gmail. com; SINGH, S. K., Universidad Nacional Autónoma de México, DF, Mexico, krishnamex@yahoo.com; LEGRAND, D., Universidad Nacional Autónoma de México, Distrito Federal, Mexico, denis@geofisica.unam.mx; SANTOYO, M. A., Universidad Nacional Autónoma de México, Michoacan, Mexico, santoyo@ geofisica.unam.mx; REAL, J., Universidad Nacional Autónoma de México, Distrito Federal, Mexico, real@geofisica.unam.mx; PAYERO, J. S., Universidad Nacional Autónoma de México, DF, Mexico, juan_payero_dejesus@yahoo.com; KOSTOGLODOV, V., Universidad Nacional Autónoma de México, Distrito Federal, Mexico,vladikost@gmail.com

The 19 September 2017 earthquake, which occurred in Central Mexico, caused severe damage to important cities of Central Mexico including Mexico City. Authorities reported that 369 persons were killed by the earthquake (more than $60 \%$ in the Mexico City) and hundreds of buildings collapsed or were seriously damaged. Hypocentral location reveals an intermediate-depth earthquake located inside the subducted Cocos plate. Using regional broad band data (400 $\mathrm{km}<\mathrm{R}<900 \mathrm{~km}$ ) we inverted for the Regional Moment Tensor (RMT) and obtained the following solution: NP1 $=303^{\circ},=45^{\circ},=-79^{\circ}$; NP2 $=107^{\circ},=47^{\circ}$, $=-101^{\circ}$, similar to that reported by GCMT: NP1 $=300^{\circ},=44^{\circ},=-83^{\circ}$; NP2 $=149^{\circ},=46^{\circ}$, and $=-97^{\circ}$. RMT yields a scalar moment of $4.22 \times 1026$ dyn- $-\mathrm{cm}$ as compared to $6.51 \times 1026$ dyn-cm reported by GCMT. Three portable broad band stations were installed surrounding the epicenter of the mainshock within 48 hrs. Only 12 small earthquakes $(M<4.1)$ were recorded in the next 2 months. We found that the hypocentral locations are better correlated with the fault plane dipping to northeast $\left(=303^{\circ},=45^{\circ}\right.$, and $\left.=-79\right)$. Local network also recorded shallow triggered seismicity which were located northwest of the epicenter at a distance $<100 \mathrm{~km}$. 


\section{Tsunami Outreach, Education and Warning Dissemination: Cross-Disciplinary Opportunities for Increasing Tsunami Resiliency \\ Oral Session · Thursday 17 May · 8:30 AM • Brickell \\ Session Chairs: Lori Dengler, Christa G. von Hillebrandt- Andrade, and Rick I. Wilson}

The Tsunami during the September 8, 2017, Tehuantepec, Mexico Earthquake-Physical Observations and Warning Response

RAMIREZ-HERRERA, M. T., Universidad Nacional Autónoma de México, Laboratorio de Tsunamis y Paleosismología, Instituto de Geografía, Ciudad de Mexico, Mexico, maria_teresa_ramirez@yahoo.com; CORONA MORALES, N., El Colegio De Michoacán, La Piedad, Michoacán, México, corona@ @olmich. edu.mx; RUIZ-ANGULO, A., Centro de Ciencias de la Atmósfera, Universidad Nacional Autónoma de México, Ciudad de México, México, angel@atmosfera. unam.mx; MELGAR, D., Department of Earth Sciences, University of Oregon, Oregon, USA, dmelgarm@uoregon.edu; ZAVALA-HIDALGO, J., Centro de Ciencias de la Atmósfera, Universidad Nacional Autónoma de México, Ciudad de México, México,jzavala@atmosfera.unam.mx

The September 8th 2017, Mw8.2 earthquake offshore Chiapas, Mexico, is the largest earthquake recorded history in Chiapas since 1902. It caused damage in the states of Oaxaca, Chiapas and Tabasco. This earthquake, a deep intraplate event on a normal fault on the oceanic subducting plate, generated a tsunami recorded at several tide gauge stations in Mexico and on the Pacific Ocean. We covered ground observations along $41 \mathrm{~km}$ of the coast of Chiapas, encompassing the 8 sites with the highest projected wave heights based on our preliminary tsunami model (maximum tsunami amplitudes between -94.5 and $-93.0 \mathrm{~W}$ ). The maximum runup was $\sim 3 \mathrm{~m}$ at Boca del Cielo, and maximum inundation distance was $190 \mathrm{~m}$ in Puerto Arista, corresponding to the coast directly opposite the epicenter and in the central sector of the Gulf of Tehuantepec. In general, our field data agree with the predicted results from the preliminary tsunami model. Tsunami scour and erosion, and lateral spreading was evident on the Chiapas coast. Tsunami deposits, mainly sand, reached up to $32 \mathrm{~cm}$ thickness thinning landwards up to $172 \mathrm{~m}$ distance. We collected information regarding the tsunami early warning system as part of eyewitness interviews during the post-tsunami survey. Even though the Mexican tsunami early warning system (CAT) issued several warnings, the tsunami arrival struck the Chiapas coast prior to the arrival of official warnings to the residents of small coastal towns, owing to the multiranked notification system. Thus, a tsunami early warning system with a direct warning to all coastal communities is needed. Some people evacuated under their own initiative, indigenous Ikoot community though were self-organized, calling people to move to higher ground, but some did not evacuate. Tsunami educational material has been produced in different languages and made available online however, its distribution has not been effective. Therefore, communitybased education and awareness programs are needed.

Tsunami Public Awareness and Education Strategy for the Caribbean and Adjacent Regions - Principles and Implementation

BROME, A., UNESCO/IOC CTIC, Barbados, a.brome@unesco.org; ALIAGA, B., UNESCO/IOC, France, b.aliaga@unesco.org

At least 75 tsunamis have impacted the region over the last 500 years causing over 3000 deaths. Tsunamis are rapid onset potentially high impact hazards. Due toincreasing urbanisation incoastal locales and the low frequency of tsunamis, preparedness and response must be in the psyche of our vulnerable populationsto save lives and property. The Tsunami Public Awareness and Education (PAE) Strategy emphasises a mitigation approach in building long-term tsunami awareness and education within the 48 Member States and territories of the Intergovernmental Coordination Group for the Tsunami and Other Coastal Hazards Warning System for the Caribbean and Adjacent Regions (ICG/ CARIBE EWS). The strategy is placed within the context of broader international, regional and national disaster risk reduction initiatives, the need for institutional capacity and support, partnerships and shared responsibility across all levels of society to secure resilience. Critical guidance includes audience selection, the effectiveness of multi-media tools and redundant warning dissemination mechanisms, message standardization and increased information flow forsuccessful PAE programming. In recognising the fundamental role of PAE for effective evacuation and warning dissemination to minimise hazard impacts; the Strategy also addresses key synergies between tsunamis and other hazards- earthquakes, landslides, hurricanes and other coastal hazards e.g. coastal flooding and storm surges, which frequently impact the region. These realities of linkages were vividly displayed during the 2017 Atlantic Hurricane season. Regional-level Strategy implementation has largely focused on developing tools for broad audiences, trainings and executing community programmes. Proposed initiatives advance specialised educationand sectoral application. The Strategy provides a pioneering, harmonized, regional-level framework for tsunami risk reduction through PAE.

\section{Lessons for Tsunami and Earthquake Resilience from Hurricanes Irma and} Maria in the Northeastern Caribbean

VON HILLEBRANDT-ANDRADE, C. G., National Oceanic and Atmospheric Administration, Puerto Rico, USA, christa.vonh@noaa.gov; VANACORE, E. A., Puerto Rico Seismic Network, Puerto Rico, USA, elizabeth.vanacore@upr.edu; BAEZ-SÁNCHEZ, G., Puerto Rico Seismic Network, Puerto Rico, USA, gisela.baez1@upr.edu

In September 2017 the Northeastern Caribbean was battered by two Category 5 hurricanes, Irma and Maria. While Irma's destructive forces were most devastating to Antigua \& Barbuda, Anguilla, the British Virgin Islands, the Northern US Virgin Islands, Maria completed the destruction of the region with its fury focusing on Dominica, St. Croix (USVI) and Puerto Rico. There are many parallels between these hurricanes and earthquakes and tsunamis which are examined in the hopes of improving resilience to the more infrequent geophysical events. Issues like onset, duration, impact and damage, response and recovery will be addressed. Unlike Earthquakes and Tsunamis which are no notice/extremely rapid onset events, the hurricanes provided advance warning giving some time to take safety measures. In the case of the hurricanes, the winds blew for hours limiting any type of emergency response, in this case there is closer tie in with tsunamis rather than earthquakes. The images of the damage along the coastlines due to storm surge and river flooding recall scenes from recent tsunamis and are a powerful reminder of the destructive forces of water. One of the most significant impacts from the hurricanes was the sudden complete loss of power, communication and road connectivity. In the response and recovery phase personal, community and institutional empowerment has been recognized. Although the Puerto Rico Seismic Network was left with limited earthquake data due to the loss of all but 4 stations after Maria, it used the resources it had to serve as a focal point for emergency communications. Once again the elderly and those with less economic resources have been the most vulnerable. Debris has been a major issue, but probably small in comparison with what we would be facing from an earthquake and tsunami. The presentation will focus on how the Irma and Maria experience can be used to educate also on earthquakes and tsunamis and build back better, more resilient.

\section{Tsunami Response Lessons Learned in Puerto Rico from the January 10, 2018, 7.6 Mw Honduras Event}

BAEZ-SÁNCHEZ, G., Puerto Rico Seismic Network, Puerto Rico, USA, gisela. baez1@upr.edu; COLON, B., Puerto Rico Seismic Network, Puerto Rico, USA, benjamin.colon1@upr.edu; MARTINEZ, J. F., Puerto Rico Seismic Network, Puerto Rico, USA, jmartinez@prsnmail.uprm.edu; MENDEZ-YULFO, R., Puerto Rico Seismic Network, Puerto Rico, USA, ricardo.mendez@upr.edu; VANACORE, E. A., Puerto Rico Seismic Network, University of Puerto Rico Mayagüez, Puerto Rico, USA, elizabeth.vanacore@upr.edu; HUERFANO, V. A., Puerto Rico Seismic Network, Puerto Rico, USA, victor@ prsnmail.uprm.edu

The 7.6 Mw Honduras event provided a valuable test of logistical and community preparedness for tsunamis in Puerto Rico (PR) and Virgin Islands (VI). This event provided an opportunity to quantify the extent of the continued recovery of the local emergency alert systems in Puerto Ricopost Hurricanes Irma and Maria and highlighted gaps in public and emergency management knowledge. In the immediate time after the event, PR and the VI were placed under a tsunami advisory by the Pacific Tsunami Warning Center. Consequently, the Puerto Rico Seismic Network (PRSN) retransmitted this information as mandated by our mission and role as a Tsunami Warning Focal Point Alternate. Here we present and evaluate the PRSN response to the event as well as detail continued damages to the communication systems from the 2017 hurricanes detected in this response. In this poster we review the PR/VI tsunami protocol and highlight the need for more formal education on tsunami threats and responses; PRSN is planning to address this issue in the following fiscal year by providing training with evaluation metrics to ensure that local emergency managers have solid knowledge of threat levels and the appropriate response. 
A Century Later: An Historical Novel of the 1918 Puerto Rico Earthquake and Tsunami

VON HILLEBRANDT-ANDRADE, C. G., National Oceanic and Atmospheric Administration, Puerto Rico, USA, christa.vonh@noaa.gov; BAYRÓN TORO, F., Retired Professor, Puerto Rico, fbayron@hotmail.com

A Century Later is an historical novel based on the life of a Catholic nun who died in the San Antonio Hospital in Mayagüez, Puerto Rico, as a consequence of the October 11, 1918, M 7.3 earthquake. During 100 years her story and tragedy were unknown. The author, Fernando Bayrón Toro, a professor, historian, writer, political scientist and lawyer, researched archives in Puerto Rico and Europe for this work. The novel includes many facts and photographs from the earthquake and tsunami and helps clarify the earthquake and tsunami impact. In Mayagüez, for example, one of the oft asked questions is where did the tsunami reach when it flooded the city. Gleaming over maps and plans and in discussion with scientists he helps answer this question. While the novel makes for interesting reading, it also serves the purpose of sensitizing and educating the reader on earthquakes and tsunamis. People reading this book hopefully will be more likely to take proactive measures to prepare for such an event. Earthquake and tsunami awareness also is increased thru the public presentations on the book.

\section{Uncertainty in Ground Motion Estimation; Seismological and Engineering Perspectives}

Oral Session · Thursday 17 May · 10:45 AM · Hibiscus B

Session Chairs: Valerie J. Sahakian, Annemarie S. Baltay, and

Kathryn E. Wooddell

Analysis of the Effect of Near Surface Slips on Strong Ground Motion: An Example of the Main Shock of the $\mathbf{2 0 1 6}$ Kumamoto Earthquakes

NAGASAKA, Y., Port and Airport Research Institute, Kanagawa, Japan, nagasaka-y@pari.go.jp; NOZU, A., Port and Airport Research Institute, Japan, nozu@pari.go.jp

The main shock of the 2016 Kumamoto earthquakes occurred on April 16, 2016, at 01:25 (JST), with Mw7.0. The rupture of the crustal earthquake reached to the surface and more than $30 \mathrm{~km}$ of surface ruptures appeared after the earthquake. Strong motions around the surface ruptures showed large peak velocities and permanent displacements, which could affect the damage around the source region. In general, permanent displacements around surface ruptures are generated from the shallow part of the fault because near and intermediate field terms attenuate with distance. Thus, strong motion records around surface ruptures can be used to investigate the behavior of the shallow part of a fault. In this study, in order to reveal the dynamic behavior of the near surface fault and its effects on strong motions, we analyzed near fault strong motion records of the 2016 Kumamoto earthquake. Velocities and displacements were estimated by numerical integration of accelerations in time domain and baseline correction (c.f. Iwan 1985, Boore 2001) to avoid distorting the waveforms. The result showed that large velocity pulses of around $0.5 \mathrm{~Hz}$ occurred simultaneously with the onset of permanent displacements at many stations. This could imply that these large velocities were generated near the surface. In addition to well-known fault parallel fling pulses, velocity pulses exceeding $50 \mathrm{~cm} / \mathrm{s}$ in the radial direction were significant at some stations around the Futagawa fault such as KMM006 and KAWAYO. These pulses could be due to the radial component of near and intermediate-P terms. These results show that strong motions from the shallow part of a fault have to be considered in the strong ground motion simulations especially for near fault region although they have often been ignored.

\section{The Case for Mean Rupture Distance in Ground Motion Estimation}

THOMPSON, E. M., US Geological Survey, Colorado, USA, emthompson@ usgs.gov; BALTAY, A. S., US Geological Survey, California, USA, abaltay@ usgs.gov

We discuss the virtues of mean rupture distances, which are more physically representative of the distance to an earthquake and are simpler to use than minimum distances. The arithmetic, geometric, harmonic, and root-mean-squared (RMS) distances are examples of a mean distance, in contrast to minimum distances such as rupture- or Joyner-Boore distance. To accurately model near-source ground motions, many current ground motion prediction equations (GMPEs) require numerous modifications of minimum rupture distances, including additional distance definitions and saturation terms and result in complicated functional forms. The meaning of these additional distance definitions can become obscured for complex but realistic ruptures. The use of mean distance is more physically plausible and results in a simpler GMPE that models near-source ground motion as accurately as other GMPEs that have more inputs and more complex functional forms. An additional benefit of mean distance is that it provides a mechanism to account for spatially variable slip. As a demonstration, we develop a GMPE for shallow crustal earthquakes with the Next Generation Attenuation(NGA)West2 project database. Specifically, we use the generalized mean distance, also known as the power mean, where the power varies with frequency. The harmonic, geometric, arithmetic, and RMS means are the power mean with powers of $-1,0$, 1 , and 2, respectively. We show that this new GMPE fits the NGA-West2 database as well as the NGA-West2 GMPEs and exhibits similar near-source amplitude scaling. We validate this GMPE against the 2016 Kaikoura, New Zealand, earthquake which was not used in our GMPE model development and find that our GMPE fits the data about as well as other GMPEs that are based on minimum distances. We currently cannot take full advantage of mean distance because we do not have a database of ground motions associated with variable-slip models, thus the regression uses uniform slip.

\section{Reducing Uncertainties of Ground Motion Estimations-The Effect of Rupture Directivity}

KURZON, I., The Geological Survey of Israel, Israel, ittaik@gsi.gov.il

Ground motions are in first order a function of magnitude and distance of a given earthquake; this observation is fundamental in the study of earthquakes, and is widely used for the different estimation of earthquake magnitudes. However, in the second order and above, there is a wide range of factors affecting ground motions, and in many cases obscuring the contributions of magnitude and distance, and leading to large uncertainties related to the observed ground motions. Such observations are the basic motivation for developing Ground Motion Prediction Equations (GMPEs), trying to make some sense out of all those second and third order factors at the site, path or source of the analyzed earthquakes. We present a method in which GMPEs are used not only for obtaining attenuation curves for the practical needs of seismic hazard analysis, but also as a powerful research tool for exploring the factors controlling ground motions. In this method we set several stages of regression analysis in order to isolate the different factors controlling ground motions at the San Jacinto Fault Zone (SJFZ), such as rupture directivity and fault zone amplification. The regression scheme includes a built-in time domain tool for the analysis of rupture directivity, and is showing: a) reasonable solutions in reference to the local tectonics at the SJFZ, and b) consistent solutions from a statistical point of view. There are several levels of confidence when using this tool, and in the process of obtaining the GMPEs we have used the basic level of confidence. Since then we added extra levels of confidence, in which the results are more robust, and could be used also as an alternative to focal mechanism techniques. Recent earthquake rupture simulations we have been doing lately are adding even more confidence, aiming to achieve not only statistical consistency of the time-domain directivity analysis, but also robustness on an event by event basis.

\section{Moving Toward Region-Specific Ground-Motion: Reducing Uncertainty in Gmpes with Physical Representations of Path Effects}

SAHAKIAN, V. I., USGS Earthquake Science Center, California, USA, vsahakian@usgs.gov; BALTAY, A. S., US Geological Survey Earthquake Science Center, California, USA, abaltay@usgs.gov; HANKS, T. C., US Geological Survey Earthquake Science Center, California, USA, thanks@usgs. gov; BUEHLER, J. S., Scripps Institution of Oceanography, California, USA, jsbuehle@gmail.com; VERNON, F. L., Scripps Institution of Oceanography, California, USA, flvernon@ucsd.edu; KILB, D., Scripps Institution of Oceanography, California, USA, dkilb@ucsd.edu

Path-specific ground-motion models, or fully non-ergodic ground-motion prediction equations (GMPEs) are the next step in improving ground-motion estimation, in particular for critical facilities where design targets fall at very low probabilities of exceedance. Statistical approaches in regions with high seismicity rates have been shown to be robust methods for moving towards fully non-ergodic models, however in seismically quiet regions, these methods will not reduce uncertainty in path terms; we work to include known, regional properties into GMPEs to reduce uncertainty. These results are then included as local path term adjustments, to demonstrate the GMPE's uncertainty reduction. With a relationship between crustal properties and ground-motion amplitudes, obtainable physical properties which remain constant on human timescales may be included into GMPEs as path effects. We test our method in the seismically active Southern California region, which hosts a myriad of studies on crustal properties (seismic velocity, attenuation, fault and geologic mapping). With dense station coverage from four networks, we compute PGA for over 130,000 earthquake recordings $(0.5<\mathrm{M}<4.5,5<\mathrm{Rrup}<180 \mathrm{~km})$. We develop a regional GMPE with a mixed effects approach, and simultaneously obtain event, site, and path residuals, as well as $3 \mathrm{D}$ raypaths for each recording. Next, we compute values of the velocity gradi- 
ent along each path to compare to each recording's path residual. We observe a moderate negative correlation between the path residual and that path's gradient of velocity, implying a relationship between amplitude and structural heterogeneity. In addition, we compute a path tomography model, or 3D volume with the mean path residual in each grid cell. We compare this to a volume of crustal velocity (Vs), and find that for velocity alone there is no correlation. Finally, we repeat the analysis with a $\mathrm{Q}$ model to investigate the effects of attenuation on path residuals.

\section{Probabilistic Seismic Hazard Analysis Using Non-Ergodic Ground-Motion} Prediction Equations

ABRAHAMSON, N. A., UC Berkeley, California, USA, abrahamson@ berkeley.edu; KUEHN, N. M., UC Berkeley, California, USA, kuehn@ berkeley. edu; WALLING, M., GeoEngineers Inc, Washington, USA, melanie.a.walling@ gmail.com; LANDWEHR, N., University of Potsdam, Germany, landwehr@ cs.uni-potsdam.de

With an increasing number of strong-motion records over the last decade, it has become clear that there are significant differences in ground-motion scaling even within relatively small regions such as California. These differences are typically not modeled in ground-motion prediction equations (GMPEs)-they are based on the so-called ergodic assumption. By including the systematic source, path and site effects in fully non-ergodic GMPEs it is possible to reduce the value of the standard deviation of aleatory variability by about $30-40 \%$. To justify the use of the reduced aleatory variability, the systematic effects for every possible source/ site combination, together with their epistemic uncertainty need to be estimated. The added cost of using a non-ergodic GMPE in seismic hazard analysis is that the epistemic uncertainty of the systematic effects need to be propagated in the hazard analysis to obtain the full hazard distribution. It is important to include these epistemic uncertainties: ignoring them will lead to underestimation of the hazard. We build a non-ergodic GMPE for California, based on the assumption that the systematic source, path and site effects are spatially correlated. We calculate hazard for three sites in California and show the impact of incorporating the non-ergodic GMPE into seismic hazard analysis. For sites that have abundant data in their vicinity, the non-ergodic hazard changes compared to the ergodic on, while for sites with sparse date the mean hazard stays the same, but there is a large increase in the epistemic uncertainty range of the hazard. This nonergodic framework provides a smooth transition in the hazard as new data is collected or as 3-D simulations are performed. We also outline how to apply non-ergodic hazard analysis outside of California in regions with very sparse data, by transferring the covariance structure of the systematic effects from California to other regions.

\section{Near-Surface P- and S-Wave Speeds Estimated Based upon Body-Wave Polarization}

PARK, S., Harvard University, Massachusetts, USA, sunyoungpark01@fas. harvard.edu; ISHII, M., Harvard University, Massachusetts, USA, ishii@eps. harvard.edu

Near-surface structure is crucial in understanding earthquake hazards, since seismic speed is directly related to the level of ground shaking. A novel technique to constrain seismic wave speed immediately beneath a seismic instrument is introduced based upon the polarization measurements of teleseismic body-wave arrivals. We demonstrate a counter-intuitive relationship that the P-wave polarization direction is only sensitive to subsurface shear wave speed but not to compressional wave speed, while the $S$-wave polarization direction is sensitive to both wave speeds. This approach is applied to the High-Sensitivity Seismograph Network in Japan, where the results are benchmarked against the borehole data available at most stations. There is a good agreement between polarization-based estimates and the well measurements at as shallow as $100 \mathrm{~m}$, confirming the efficacy of the new method in resolving the shallow structure. The lateral variation of wave speeds shows that sedimentary basins and mountainous regions are characterized by low and high wave speeds, respectively. Moreover, the analysis is extended into three dimensions by examining the frequency dependence, and preliminary results using US broadband stations show zones of high seismic risk. This versatile technique requires minimal computational resources and can be applied to any single three-component seismograph. It can also provide means of monitoring changes that occur within the very upper crust such as from volcanic or hydrological phenomena. It opens a new path to a reliable, non-invasive, and inexpensive hazard assessment even for locations where a drilling or a field experiment using vibro-trucks or explosives is not a practical option, and reduces uncertainties and ambiguities in the measurements of the near-surface seismic wave speeds.
The Influence of Site Response on Corner Frequency Obtained Using Spectral Ratio and Direct Spectral Fitting Methods

BOYD, O.S., US Geological Survey, Colorado, USA, olboyd@usgs.gov

Systematic differences exist in the estimates of corner frequency observed in earthquake spectra between direct spectral fitting methods and spectral ratio methods. Corner frequency is thought to be related to stress changes during an earthquake and is an important variable in high frequency ground motion estimates and seismic hazard assessment. In direct spectral fitting methods, practitioners may predict and account for the effects of path and site attenuation, site amplification, geometric spreading, and earthquake moment, whereas in spectral ratio methods, the effects of path and site are assumed to be removed by using ratios of collocated earthquakes. An assumption is still required, however, for the moment of one of the two earthquakes. Here we investigate the differences in methods and corner frequency estimates between multiple studies for earthquakes common to the Boyd et al. (2017) spectral ratio study. The simplest comparison study, which measures peaks in velocity spectra, makes no corrections for path and site attenuation, site response, geometric spreading, or moment, and has corner frequency values that are a factor of 2 higher than Boyd et al. (2017). Studies based on an underlying empirical ground motion prediction model, which make assumptions regarding path and site attenuation and site response, yield estimates similar to Boyd et al. (2017) in California but are close to a factor of 2 greater in the central and eastern United States. Other spectral ratio methods and methods that use spectral ratios to remove site response have estimates that are closer to Boyd $e t$ al. in the CEUS. While many potential explanations may account for the differences between studies, we investigate the role of site response. In particular, we consider the influence of the subsurface velocity gradient, non-vertically incident wave propagation, and site attenuation. The former two effects may bias corner frequency estimates high in some studies in the CEUS.

Evaluating and Improving Ground Motion Predictions for Scenario Earthquakes in the San Francisco East Bay by Integrating Earthquake Ground-Motion Simulations and Noise-Derived Empirical Green's Functions TAIRA, T., Berkeley Seismological Laboratory, California, USA, taira@ berkeley.edu; RODGERS, A., Lawrence Livermore National Laboratory, California, USA, rodgers7@llnl.gov

Simulations of scenario earthquake ground motions play an increasingly important role in improving seismic hazard assessment. In the San Francisco Bay Area (SFBA) the USGS has developed a 3D geologic/seismic model. Simulations of large magnitude (M) 7 Hayward Fault scenario earthquakes show dramatic differences in peak ground motions across the fault, arising from wavespeed differences, which introduce the uncertainty in ground motion estimation. Preliminary comparison of observed and simulated waveforms from M 4 earthquakes reveals bias in the travel times of direct $S$-waves for paths crossing the East Bay Hills, east of Hayward Fault. To reduce the uncertainty in ground motion prediction for scenario earthquakes, we systematically evaluate bias in the current USGS 3D velocity model of the SFBA with emphasis on the East Bay Hills where strong ground motions are predicted. Our work involves performing earthquake ground motion simulations incorporating the USGS 3D velocity model for moderate Bay Area local earthquakes (M 3.5-4.5) including the recent 2018 $\mathrm{Mw} 4.4$ Berkeley earthquake to quantify the accuracy of 3D model predictions by comparing observed and simulated waveforms. We also retrieve noise-based empirical Green's functions (NEGFs) from ambient noise cross-correlation and earthquake coda waves to illuminate path-specific bias in the USGS 3D velocity model. We will report resultant path-specific bias to update the current 3D velocity model. Results from our work will provide the groundwork for the USGS $3 \mathrm{D}$ velocity model improvement and will result in improved accuracy of scenario ground-motion maps at the SFBA.

Variability in Ground Motions Due to the Presence of the Built Environment TABORDA, R, University of Memphis, Tennessee, USA, ricardo.taborda@ memphis.edu; ISBILIROGLU, Y., RIZZO Associates, Pennsylvania, USA, yigit. isbiliroglu@rizzoassoc.com

Spatial variability and ground motion uncertainty during earthquakes can significantly influence both our interpretation of seismic data and the behavior of structures. Spatial variations typically observed in ground motions are mostly the consequence of wave interferences, refraction, and scattering resulting from heterogeneities in the transmitting media, basin, site, and topography effects. Also influential but often ignored is the presence of the built environment, especially in densely urbanized areas. In this study we investigate the extent to which the presence of building-foundation systems can modify earthquake ground motions and contribute to their variability. We perform a series of three-dimensional wave propagation simulations, with and without the presence of (simplified) build- 
ing models, and analyze the potential correlations that exist between wave-field perturbations and the collective characteristics of building clusters. We identify parameters that could serve as proxies to characterize urban environments and measure the changes on the ground motion in terms of spatial distribution, amplitude, duration, and frequency content. The overall objective of this ongoing study is to arrive at conclusions relevant to urban planning and seismic hazard analysis. A future phase of our effort will attempt to identify some of the observations from our models in strong motion data from monitoring stations located within dense urban areas.

\section{Implementing Inter-Period Correlations into the SDSD Broadband Ground Motion Method}

WANG, N., San Diego State University/UC San Diego, California, USA, naw021@ucsd.edu; TAKEDATSU, R., San Diego State University, California, USA, rtakedatsu@mail.sdsu.edu; OLSEN, K. B., San Diego State University, California, USA, kbolsen@mail.sdsu.edu; DAY, S. M., San Diego State University, California, USA, sday@mail.sdsu.edu

Earthquake ground motion records reveal period-dependent correlations, which has implication for seismic risk (Bayless and Abrahamson, 2017). The empirical inter-period correlations of epsilon (the residual between simulations and the mean of the simulations in Fourier Amplitude Spectra (FAS) space) using the Effective Amplitude Spectrum (EAS) computed from the PEER NGA-West2 database resemble a two-sided exponential function. We attempt to incorporate such correlation into the current San Diego State University (SDSU) Broadband (BB) ground motion generator module, which combines deterministic (lowfrequency) and stochastic (high-frequency) components. Here, we assume that the Fourier amplitude at frequency f0is correlated with the Fourier amplitude at fwithcorrelation coefficient $\exp (-|\mathrm{f}-\mathrm{f} \mathrm{f}| / \mathrm{a})$ and define a one-sided decaying exponential filter function $g=\mathrm{H}(\mathrm{f}) \exp (-\mathrm{f} / \mathrm{a})$, where ais a constant. To improve the EAS correlation in the current SDSU module, we first generate uncorrelated uniformly distributed Fourier spectral amplitudes with unit mean for different realizations, and convolve them with g, which are then multiplied with the Fourier amplitude of the high-frequency ground motion synthetics calculated using Zeng et al. (1991)'s scattering theory. Using our improved method, the BB results for 7 western U.S. events and 2 Japan events with Mw5.0-7.2 show that the empirical inter-period correlations of EAS are well predicted in the SDSU module for a large number of realizations from a single event with unbiased goodness-of-fit of the spectral accelerations in the presence of correlated synthetics.

\section{USGS Seismic Hazard User-Needs}

Oral Session - Thursday 17 May · 8:30 AM · Hibiscus A

Session Chairs: Susan M. Hoover, Nico Luco, Peter M.

Powers, and Sanaz Rezaeian

\section{Feedback from the 2015 ATC/USGS Seismic Hazard User-Needs Workshop}

OLSEN, A. H., Risk Management Solutions, California, USA, aolsen@alumni. caltech.edu; LUCO, N., US Geological Survey, Colorado, USA, nluco@usgs. gov; POWERS, P. M., US Geological Survey, Colorado, USA, pmpowers@usgs. gov

On September 21 and 22, 2015, the Applied Technology Council/United States Geological Survey (ATC/USGS) Seismic Hazard User-Needs Workshop brought together over 100 geologists, engineers, and other professionals. The participants represented the broad and varied groups of professionals who use seismic hazard information developed by the USGS National Seismic Hazard Modeling Project (NSHMP). These users range from practitioners who do their own seismic hazard analyses to structural engineers to public-sector professionals who interpret seismic hazard in the context of public policy. Several broad user needs emerged and were reiterated during the two-day workshop. There was no question of the need for the work that the USGS NSHMP does, including the collection and assessment of geological studies, ground motion models, and hazard algorithms-formalized as seismic hazard models - as well as the user support provided by the NSHMP personnel. The seismic hazard products available at the NSHMP's website are essential to most user groups; the more technical users routinely use the Quaternary fault, hazard curve, deaggregation, and United States design maps tools. These users emphasized the importance of the timely update of the online hazard products and documentation for their work. Users also identified the need for earthquake scenarios or deterministic ground motions.
Earthquake scenarios would be used by technical and non-technical users, and the description of seismic hazard as a suite of deterministic ground motions could augment probabilistic hazard values, providing a parallel way to understand and communicate seismic hazard. As the NSHMP works toward the 2018 and 2020 updates of the National Seismic Hazard Model, this presentation summarizes the feedback and findings from the User-Needs Workshop associated with the 2014 update.

\section{Overview of the USGS Unified Hazard Tool}

POWERS, P.M., US Geological Survey, Colorado, USA, pmpowers@usgs.gov

The US Geological Survey's (USGS) earthquake hazards website, https:// earthquake.usgs.gov/hazards/, is the central distribution point for the National Seismic Hazard Models (NSHMs), maps, and data for the United States and its territories. The website has evolved over time, moving increasingly from providing static data to delivering data and analyses dynamically through web-services and interactive web-applications. The tools we had historically supported (e.g. interactive deaggregations, custom hazard maps) were developed on an ad-hoc basis, with each having its own codebase, despite computing or providing similar and often related data. In 2017, we retired most legacy applications and replaced them with a new Unified Hazard Tool (UHT), https://earthquake.usgs.gov/ hazards/interactive/. The UHT is built off a single codebase that provides hazard data, calculations and deaggregations and earthquake probabilities and rates via a single web interface. Moreover, the UHT provides access to the source and ground motion models (GMMs) in each NSHM, thereby making it easier than ever to access and evaluate these models. For example, it is now possible to query the magnitude frequency distributions associated with a specific source; it is also possible to compute deterministic response spectra using multiple GMMs. The tool is backed by web services that are open to access by third-party applications. We provide an overview of the features of the UHT and discuss our roadmap for adding new features and enhancements. Now that the UHT has been in deployed for over a year, we also seek feedback as to whether the tool is meeting user needs (i.e. has some feature of a retired tool not been adequately replaced by the UHT), and what features, changes, or enhancements are most desired by the community so that we may best prioritize our development efforts.

Project '17: Improving Earthquake Ground Motion Maps for Building Codes LUCO, N., US Geological Survey, Colorado, USA, nluco@usgs.gov; REZAEIAN, S., US Geological Survey, Colorado, USA, srezaeian@usgs. gov; STEWART, J. P., UC Los Angeles, California, USA, jstewart@seas. ucla.edu; HAMBURGER, R. O., Simpson Gumpertz \& Heger, California, USA, rohamburger@sgh.com; CROUSE, C. B., AECOM, Washington, USA, cb.crouse@aecom.com; FURR, J. C., CSA Engineering, Tennessee, USA, julief@csastructures.com; KIRCHER, C. A., Kircher \& Associates, Consulting Engineers, California, USA, cakircher@aol.com

Circa 1997, a committee of earthquake engineers and scientists referred to as Project '97 developed ground motion maps for the NEHRP (National Earthquake Hazard Reduction Program) Recommended Provisions for Seismic Regulations for New Buildings and Other Structures. The maps were subsequently adopted into the 1998 American Society of Civil Engineers Minimum Design Loads for Building and Other Structures and the 2000 International Building Code. For the first time, these building code maps were derived directly from the US Geological Survey (USGS) National Seismic Hazard Model. Ten years later, a Project ' 07 committee reassessed the procedures by which the maps were derived from the USGS model, resulting in the current Risk-targeted Maximum Considered Earthquake (MCER) ground motion maps. Another ten years later, Project ' 17 is proposing further modifications to the maps. Like its predecessors, Project ' 17 is organized by the Building Seismic Safety Council, with funding from the Federal Emergency Management Agency and scientific support from the USGS. Project ' 17 is focused predominantly on three issues pertaining to the current building code maps: (1) A perceived instability of the maps across editions of the building code documents, which is largely a consequence of the periodic updates of the USGS seismic hazard model; (2) an observed underestimation of ground motions at sites with relatively low average shear wave velocities, vS, as obtained by applying building code soil adjustments to the maps, which are for a relatively high reference vS; and (3) a move away from so-called characteristic earthquakes that are used in computing deterministic ground motion caps to the otherwise probabilistic maps, with the advent of the latest Uniform California Earthquake Rupture Forecast within the USGS hazard model. In this presentation, we summarize the map-related changes being proposed by Project ' 17 to address these issues. 
An Overview of the Use of NSHMP Products in the Insurance Industry SHOME, N., Risk Management Solutions, California, USA, nilesh@ stanfordalumni.org; NYST, M., Risk Management Solutions, California, USA, marleen.nyst@rms.com

The earthquake hazard program by the United States Geological Survey (USGS) develops a number of useful products including the national hazard maps based on the National Seismic Hazard Mapping Project (NSHMP). These maps are used extensively to design and retrofit buildings and different structures like bridges. The multi-billion-dollar insurance industry also uses the hazard information extensively to estimate earthquake insurance premiums, to manage their capital for pay-out at certain loss levels, as well as to transfer some of their risk to the reinsurance industry and capital market. Since the insurance industry manages the earthquake risk based on losses from individual earthquakes, the hazard results from NSHMP are not used directly in the insurance industry. We will explain how catastrophe modeling companies like Risk Management Solutions (RMS) use the underlying data of the NSHMP to develop risk metrics for insured risk management. Commonly used risk metrics are average annual loss (AAL) and exceedance probability (EP) curves. AAL is the product of location loss and annual rate for all events, and is used to set annual premiums, while keeping the long-term risk in mind. The EP curve is also derived from the full set of events that impact the exposure. It provides an estimate of the probability of exceeding a particular loss level and is used for quantification to solvency assessment and portfolio management. We will discuss the challenges in using the data and the java programs developed by NSHMP and UCERF3 and how this can be improved for a more efficient adoption of the NSHMP updates in the insurance industry. In addition, we will discuss how we are using the induced seismicity models developed by the USGS and the challenges in using the model.

\section{Adaptation of New Technologies and Methods to Drive New Discoveries in Seismology and Geodesy Poster Session · Thursday 17 May · Riverfront South}

Development of Integrated Accelerographs Using Mems Technology with Efficient Real-Time Data Transmission and Deployment of a Collaborative Seismic Network.

MARTÍN AGÚNDEZ, E., Instituto Geográfico Nacional, Madrid, Spain, emartin@fomento.es; MARTÍN GARCÍA, E., EDINTEC, Ingeniería y Tecnología, Madrid, Spain, emartin@edintec.es; BRAVO MONGE, J. B., Instituto Geográfico Nacional, Madrid, Spain, jbbravo@fomento.es

Having a dense network of high-resolution accelerometers based in "Feedback" systems in a reasonable amount of time, is crucial for national seismic networks such as the Spanish seismic network IGN. However, this requirement is in conflict with the tight budgets that would made this virtually unreachable. IGN has designed, developed and manufactured integrated and comprehensive accelerographs that allow near real-time transmission of seismic data, based on what is known as MEMS technology. This type of instrumentation enables compliance with the requirement to produce accurate ShakeMaps based on large amounts of observed data, and not deducted (deducted of very simple analytical attenuation laws, almost in its entirety). It would also be very important for the development of Technical Building Regulations in areas of seismic risk. All of this with prices at least ten times cheaper than high-resolution accelerographs. With the aim to demonstrate its reliability, it has been realize a testing process of these MEMS accelerometers in a vibrant table at CEDEX and its comparison with a high resolution commercial accelerometer Guralp CMG-5T, and even the recorded accelerograms in 2013 seismic crisis at Torreperogil village, in the province of Jaén. Currently, the IGN is deploying several devices on focused areas such as Alhama Fault at Murcia Region (southeast of the Iberian Peninsula) and Aran Valley in the Catalonian Pyrenees. This new network is a densification of the existing accelerograph network based on standard commercial accelerometers and through volunteer citizens finds the installation places.

Determination of the B-Value through a Novel Multiscale Spatio-Temporal Approach

GARCÍA-HERNÁNDEZ, R., Instituto Volcanológico de Canarias, S/C de Tenerife, Spain, ruben.garcia.beca@iter.es; D’AURIA, L, Instituto Volcanológico de Canarias, S/C de Tenerife, Spain, Idauria@iter.es; BARRANCOS, J., Instituto Volcanológico de Canarias, S/C de Tenerife, Spain, jbarrancos@iter.es; PADILLA, G. D., Instituto Volcanológico de Canarias, S/C de Tenerife, Spain, german@iter.es

The estimation of the spatial and temporal variations of the Gutenberg-Richter $\mathrm{b}$-value is of great importance in different seismological applications. One of the problems affecting its estimation is the heterogeneous distribution of the seismicity which makes its estimate strongly dependent upon the selected spatial and/or temporal scale. This is especially important in volcanoes where dense clusters of earthquakes often overlap the background seismicity. Proposed solutions for estimating temporal variations of the $b$-value include considering equally spaced time intervals or variable intervals having an equal number of earthquakes. Similar approaches have been proposed to image the spatial variations of this parameter as well. We propose a novel multiscale approach, based on the method of Ogata and Katsura (1993), allowing a consistent estimation of the b-value regardless of the considered spatial and/or temporal scales. Our method, named MUST-B (MUltiscale Spatial and Temporal characterization of the B-value), basically consists in computing estimates of the b-value at multiple temporal and spatial scales, extracting for a give spatio-temporal point a statistical estimator of the value, as well as an indication of the characteristic spatio-temporal scale. This approach includes also a consistent estimation of the completeness magnitude (Mc) and of the uncertainties over both $\mathrm{b}$ and Mc. We applied this method to example datasets for volcanic (Long Valley Caldera) and tectonic (Central Italy) areas as well as for induced seismicity zones and an example application at global scale.

Optimization of Data Functionals for Full-3D Tomography by Seismogram Decomposition and Resynthesis

IUAREZ, A., University of Southern California, California, USA, alanjuar@ usc.edu; JORDAN, T. H., University of Southern California, California, USA, tjordan@usc.edu

Full three-dimensional tomography (F3DT) is a computationally intensive methodology for imaging the Earth structure through the iterated assimilation of waveform data into 3D models of seismic wave propagation. F3DT performance is strongly determined by data resolution, often limited by the ability to identifying coherent seismic phases, measuring the phase and amplitude spectra, and modeling the effects of interference from other signals. For seismograms computed for a 1D Earth model, the decomposition into standard seismic phases is relatively straightforward, e.g., numerical synthesis of traveling modes or generalized rays, but these classical techniques are of limited utility for structures with strong 3D heterogeneity. We present a new technique for systematically separating seismic phases using time-frequency spectra computed by the S-transform (Stockwell et al., 1996), which is a linear transformation based on Gaussian wavelets. Iterative waveform stripping decomposes seismograms in the spectral domain into a finite set of wave packets using time-frequency filters centered in the spectrum local maxima. Subsets of waveforms are then combined into waveforms that can be used in seismic source and structural inversion. Weights for the combinations are estimated by the Sum-of-Wavelets Theorem (Gee \& Jordan, 1992). This algorithm allows the identification of seismic phases that are not predicted by a 1D structural model, such as basin-edge conversions, increasing the structural information that can be derived from a single seismogram. We demonstrate the flexibility of the algorithm to analyze large data sets by showing examples of seismogram decomposition and tomographic kernels computed from real data from earthquakes in Southern California.

Vision and Numerical Simulation-Based Ground Deformation Testing Method CHEN, S., Institute of Geophysics, CEA, Beijing, China, chensuchina@126.com; ZHAO, S. C., Beijing University of Technology, Beijing, China, 406298173@ qq.com; FU, L., Institute of Geophysics, CEA, Beijing, China, fuleichina@yeah. net; LI, X. J., Institute of Geophysics, CEA, Beijing, China, beerli@vip.sina.com

To resolve the problem of ground motion observation which lead to the widespread concern in the field of seismic engineering, this study provided a non-contact ground deformation testing method based on vision technology and numerical simulation. Studies are carried out on key technologies of this dynamic ground deformation testing system, such as the vision data of target in real time which is acquired by the visual testing technology was automatically analyzed, using the obtained relative displacement as the bond quantity which is continuously iterated through the numerical simulation system to finally output the more accurate absolute displacement of the ground surface. The result shows that the precision of measurement can get to $\mathrm{mm}$ which meets the accuracy requirements of ground motion monitoring, and the accuracy and feasibility of visual testing technology is verified. The test method not only fills in the blank of the real-time monitoring instruments for ground displacement during the earthquake, but also provides more accuracy and wider range of data for the research on seismic source and fault information inversion and recognition of the ground motion characteristics. 
Exploring Subtle Temporal Changes in Earthquake Catalogs to Guide Identification of Dynamically Triggered Events

KILB, D., UC San Diego, California, USA, dkilb@ucsd.edu; PANKOW, K. L., University of Utah Seismograph Stations, Utah, USA, pankow@seis.utah.edu

In studies of remote dynamic triggering, the common practice is to be reactionary, in that the impetus is to select a large earthquake and then systematically search for an increase in small earthquakes at remote distances. This approach requires specifying a duration (e.g., 5, 12, $24 \mathrm{hrs)}$ used to search for seismicity rate changes. Rarely is the null hypothesis, that the rate change is merely a random occurrence, fully tested. Here, we take a different approach and simply count the number of events (above the magnitude of completeness) in a moving window of a given duration (e.g., 5, 12, $24 \mathrm{hrs}$ ), creating a catalog of count values for each sub-window over the full duration of a catalog. As expected the count increases substantially when there are local mainshock/aftershock sequences; however other rate increases can be identified as well. To identify times when the counts are significantly high (probabilities $\geq=96 \%$ ), we use five times the standard deviation of the mean following Chebyshev's Inequality Theorem. Applying this method to regional earthquake catalogs, we successfully find statistically high counts following the 2002 M7.9 Denali, Alaska, earthquake in Yellowstone and Utah indicative of the already known remote triggering. In addition, we find evidence of potential remote triggering in Montana following the 2002 M7.6 Papua Indonesia earthquake, and in Yellowstone following the 1985 M8.0 Michoacan, Mexico, earthquake. There can be a strong trade off between the length of the moving window and the robustness of the results. If the window becomes too small, an unrealistically large number of times may be flagged. These results indicate that we can use a simple earthquake count within temporal windows to identify potential remote triggering.

\section{Fiber Optic Gyroscope Road-Map for Highest Rotational Ground Motion Sensitivity on the Field}

GUATTARI, F., iXblue, France, frederic.guattari@ixblue.com; DE TOLDI, E., iXblue, France, elliot.de-toldi@ixblue.com; BIGUEUR, A., iXblue, France, alexandre.bigueur@ixblue.com; BERNAUER, F., Department of Earth \& Environmental Sciences, LMU, Germany, fbernauer@geophysik.unimuenchen.de; WASSERMANN, J., Department of Earth \& Environmental Sciences, LMU, Germany, jowa@geophysik.uni-muenchen.de; GEBAUER, A., Forschungseinrichtung Satellitengeodäsie, Geodätisches Observatorium Wettzell, TUM, Germany, gebauer@fs.wettzell.de; SCHREIBER, K. U., Forschungseinrichtung Satellitengeodäsie, Geodätisches Observatorium Wettzell, TUM, Germany, ulrich.schreiber@bv.tu-muenchen.de

When the ground moves, it does not only shake in translation, but it twists too! Indeed, any motion has 6 degrees of freedom. But all the seismometers provide only translation measurement. Rotational seismology is a hot topic in seismology since instruments have been built to bring first ground rotation measurement. It started as laboratory instrument with ultimate performances thanks to Giant Ring Laser Gyroscope. It is now portable on field with optimized performances thanks to Fiber Optic Gyroscope. And now Giant Fiber Optic Gyroscope arises to make extreme performances deployable. Based on experiences developing very low noise fiber-optic gyroscopes (FOG), recent performance results on deployable large fiber-optic coils of up to $1 \mathrm{~m}$ diameter are presented, with a focus on comparison with Array Derivated Method (ADR) and Giant Ring Laser Gyroscopes (Giant-RLG). The goal for constructing large FOGs is to evaluate experimentally the physical limits of this kind of technology and to get closer of most innovative seismologic application. While these experiments are probing the fundamental limits of the FOG technology, they also serves as a first step for a cost effective very low noise laboratory rotational seismometer and would contribute in a second step to performance improvements on the portable rotational seismometer 'blueSeis-3A'. To demonstrate a very low self-noise and characterize the quality of the data provided by a new instrument, the ideal way is a direct co-location measurement with an already qualified and much more precise instrument. The Giant-RLG, as the one located in Wettzell (Germany) is the ideal instrument to do so. Results of different prototypes on the road map will be presented to underline the applicability of each technological response to the Large-FOG requirements. Finally we conclude with the achieved results with a $1 \mathrm{~m}$ scale diameter FOG having $6000 \mathrm{~m}$ of fiber length upgraded with patented optical intensity noise subtraction.

RTX Correction Accuracy and Real-Time Data Processing of the New Integrated SeismoGeodetic System with Real-Time Acceleration and Displacement Measurements for Earthquake Characterization Based on High-Rate Seismic and GPS Data

ZIMAKOV, L., Trimble Inc., Texas, USA, leonid_zimakov@trimble. com; RACZKA, J., Trimble Inc., Texas, USA, jared_raczka@trimble.com;
BARRIENTOS, S. E., National Seismological Center, University of Chile, Chile, sbarrien@dgf.uchile.cl

We will discuss and show the results obtained from an integrated SeismoGeodetic System, model SG160-09, installed in the Chile (Chilean National Network), Italy (University of Naples Network), and California. The SG160-09 provides the user high rate GNSS and accelerometer data, full epoch-by-epoch measurement integrity and, using the Trimble RTPD Client, the ability to create combined GNSS and accelerometer high-rate $(200 \mathrm{~Hz})$ displacement time series in realtime for Earthquake Early Warning application. The SG160-09 combines seismic recording with GNSS geodetic measurement in a single compact, ruggedized package. The system includes a low-power, 220-channel GNSS receiver powered by the latest Trimble-precise Maxwell ${ }^{\mathrm{w}} 6$ technology and supports tracking GPS, GLONASS and Galileo signals. The receiver incorporates on-board GNSS point positioning using Real-Time Precise Point Positioning (PPP) technology with satellite clock and orbit corrections delivered over IP networks. The seismic recording element includes an ANSS Class A, force balance triaxial accelerometer with the latest, low power, 24-bit A/D converter, which produces high-resolution seismic data. The SG160-09 processor acquires and packetizes both seismic and geodetic data and transmits it to the central station using an advanced, errorcorrection protocol with back fill capability providing data integritybetween the field and the processing center. The SG160-09 has been installed in three seismic stations in different geographic locations with different Trimble global reference stations coverage The hardware includes the SG160-09 system, external Zephyr Geodetic-3 GNSS antenna, and both radio and high-speed Internet communication media. Both acceleration and displacement data was transmitted in real-time to the centralized Data Acquisition and Processing Centers for real-time data processing. Command/Control of the field station and real-time GNSS position correction are provided via the Pivot software suite. Data from the SG160-09 system was used for seismic event characterization along with data from traditional stand-alone broadband seismic and geodetic stations installed in the network. Our presentation will focus on the key improvements of the network installation with the SG160-09 system, RTX correction accuracy obtained from Trimble Global RTX tracking network, rapid data transmission, and real-time data processing for strong seismic events and aftershock characterization.

\section{Next Generation Autonomous Broadband Node}

PARKER, T., Nanometrics, New Mexico, USA, timbobparker@gmail.com; PIGEON, S., Nanometrics, sylvainpigeon@nanometrics.ca; PELYK, N., Nanometrics,nicholaspelyk@nanometrics.ca

The surge of using geophoned autonomous nodes for scientific projects is advancing passive imaging and monitoring techniques for scientific research, oil and gas projects, hydrology, civil engineering and new applications for short term dense seismic monitoring. The concept of a small, minimal configuration, low power, simple deployments without worry of environmental conditions can be applied to temporary broadband sensor system deployments using the next generation of direct bury broadband sensors. We explore some preliminary scientific deployment scenarios that can be used for broadband studies or as an example of a much smaller logistics next generation Earthscope array type station with little if any difference in noise performance and a potentially order of magnitude less cost. The concept of research grade latency can be applied for telemetry to recover quasi realtime data or very low cost system state of health.

\section{Spatial Improvement in the Location of Mid-Alaska Faults Using the Condensation Method \\ AZIZZADEH-ROODPISH, S., University of Memphis, CERI, Tennessee,} USA, szzzdhrd@memphis.edu; CRAMER, C. H., University of Memphis, CERI, Tennessee, USA, ccramer@memphis.edu

Statistical methods have proven to be of significant help in extracting hidden information from a huge amount of data available in different scientific areas such as seismology. In this research, potentially active faults in mid-Alaska are investigated by means of one of these statistical approaches, called the condensation method, introduced by Kamer et al. (2015). The goal of the condensation method is to improve the spatial information content of seismic catalogs by exploiting the heterogeneity of the probability distribution functions of event locations. Basically, the events are first ranked by decreasing location errors and then the weight from events with large location uncertainty, known as "sources", are transferred to the ones with smaller location uncertainty, known as "targets", which lets us account for location error information within a point based spatial analysis and obtain a set of weights that provide an optimal spatial representation. The Minto Flat Fault Zone in Mid-Alaska is selected as a seismically active region, with no mapped faults, in which the method is particularly productive. The relocated catalog from the Alaska Earthquake Center is used in a conden- 
sation method analysis, and the reported horizontal and vertical standard location errors of that catalog are used to estimate an isotropic overall variance for each event in the catalog. Having reliable earthquake locations are important for a reliable interpretation of seismicity patterns. The resulting condensed catalog highlights major mapped fault traces and reveals possible additional structures and we are hopeful that applying this technique can be helpful in the further investigation of interior Alaska seismicity.

\section{Applications of Machine Learning and Data Science in Seismology}

Poster Session · Thursday 17 May · Riverfront South

\section{The Decadal Periodicity of Large Mexican Earthquakes (Magnitude $\geq 7$ )}

VELASCO HERERRA, V. M. N., Institute of Geophysics of the National Autonomous University of Mexico, Distrito Federal, Mexico, vmv@geofisica. unam.mx

One of the main problems related to the study of earthquakes is to know where and when they will occur. It is well established that these events are essentially random. However, this hypothesis may be incorrect, at least for the large Mexican earthquakes (Magnitude 27 ). The large Mexican earthquakes reported in the instrumental era from 1900 to 2017 and the large historical earthquakes in Mexico between 1400 and 1900, is reanalysed. We used the Morlet wavelet to analyze the phase of each of the periodicities found by the wavelet analyses and local variations of power spectral density in large Mexican earthquakes reported. We find that by studying the last large Mexican earthquake events reported from 1900 through 2017, these events occur preferentially in the positive phase of the oscillation of 10-years periodicity. We interpret this empirical result to support that large Mexican earthquakes events are not a result of purely stochastic processes. Also, in this study, we approach the large Mexican earthquakes reported in the instrumental era, in order to estimate the next season of for large Mexican earthquakes since year 2017 based on the Least Squares Support Vector Machines.

Detection of Seismic Signals under Low Snr Condition Using an Artificial Neural Network: Toward the Development of a Dense Low-Cost Citizen Seismic Network in Japan

TAKAHASHI, K., Yokohama City University, Kanagawa, Japan, n175224a@ yokohama-cu.ac.jp; UEMATSU, H. U., Yokohama City University, Kanagawa, Japan, uematsu.hiroki@gmail.com; ZHE, S. Z., RIKEN, Saitama, Japan, sunzhe839@gmail.com; MICHELETTO, R. M., Yokohama City University, Kanagawa, Japan, ruggero@yokohama-cu.ac.jp; KIM, A., Yokohama City University, Kanagawa, Japan, ahyik@yokohama-cu.ac.jp

We have developed a low cost seismic network in Yokohama, Japan, called Citizen Seismic Network (CSN). Differently from national seismic networks that generally have high quality and highcost sensors uniformly distributed on the territory, our seismic sensors are simpler devices, but they are low cost and so they can be placed in great number in homes, private buildings, schools etc. The network has the advantage to be dense and able to monitor local scale seismic motions in areas linked to community's life. Each sensor unit is composed of a 12 bits MEMS accelerometer and a Raspberry Pi. Since the units are installed under high-noise environments made by human activity that are often misinterpreted as seismic signals, the application of conventional detection methods usingamplitude ratio (e.g. STA/LTA) is problematic. To overcome this issue, we developed an original artificial neural network (ANN) that uses pattern recognition to detect the seismic waves from other signals. We trained the ANN using threecomponent accelerograms data sets obtained from conventional seismometers, but adding our sensor background noise for compatibility with signals output from our devices. In a first training stage, we optimized the number of input units and the size of training data. Then, using the trained ANN, we tried to identify seismic signals that were not used in the training process. As a result, $95 \%$ of the P-waves were successfully detected. Overall, our results indicate that our method alsoreduces the false detection significantly compared with STA/LTA methods. Our results show that it is possible to realize low cost seismic sensors not only as reasonable motion detectors, but also as $\mathrm{P}$-wave detectors for intensities above 3 (Japanese scale). In conclusion, we believe that our CSN network can be used as a complementary system to national earthquake early warning networks and that it can be useful to disaster prevention in highly populated metropolitan areas.

Earthquake Catalog Reconstruction from Analog Seismograms: Application to the Rangely Experiment Microfilms

WANG, K., Stanford University, California, USA, kaiwenw@stanford.edu; ELLSWORTH, W. L., Stanford University, California, USA, wellsworth@ stanford.edu; BEROZA, G. C., Stanford University, California, USA, beroza@ stanford.edu; RUBINSTEIN, J. L., US Geological Survey, Menlo Park, California, USA, jrubinstein@usgs.gov

Before the digital era of seismic recordings, decades of seismic data were recorded in analog form and many of these seismograms are still in good condition. Despite the abundance of analog recordings, surprisingly few efforts have been made to analyze them automatically. One common format is the $16 \mathrm{~mm}$ Develocorder film, which was traditionally read and measured by an analyst on a projection system. In those recordings, up to 20 channels are recorded as a day-long strip chart on microfilm. In this format overlap between channels becomes a difficult problem when trying to recover the signal as a vector time series. This is particularly true for the most interesting signals written by earthquakes. In this study, we establish a workflow based on scanned 2-D images instead of 1-D time series waveforms. Each day-long strip of film is scanned into $~ 700$ images that totals about $10 \mathrm{~GB}$ in size. We process these analog seismogram images using machinelearning algorithms, and apply it to data from the Rangely Experiment in earthquake control conducted by the U. S. Geological Survey from 1969 to 1975 in an oil field in western Colorado. The goal of our research is to build a detailed catalog of the earthquakes induced by injection based on the Develocorder films. We first detect events on each channel using the horizontal variances within a moving window. Then we associate the detections among the network and reject the unreasonable ones. We also apply 2-D image correlation to recognize the time code, correct for the misalignment of the microfilms, recover the station locations from the original map, and characterize the earthquake waveforms. After these automatic procedures, we are able to build a detailed catalog of local events. Our processing techniques have the potential for wide application to the decades of historical data before the digital era in seismology.

\section{Time-Domain Receiver Function Deconvolution Using Genetic Algorithm} MOREIRA, L. P., Federal Institute of Education, Science and Technology of Brasilia, Distrito Federal, Brazil, lucas.moreira@ifb.edu.br

Receiver Functions (RF) are well know method for crust modelling using passive seismological signals. Many different techniques were developed to calculate the RF traces, applying the deconvolution calculation to radial and vertical seismogram components. A popular method used a spectral division of both components, which requires human intervention to apply the Water Level procedure to avoid instabilities from division by small numbers. One of most used method is an iterative procedure to estimate the RF peaks and applying the convolution with vertical component seismogram, comparing the result with the radial component. This method is suitable for automatic processing, however several RF traces are invalid due to peak estimation failure. In this work it is proposed a deconvolution algorithm using Genetic Algorithm (GA) to estimate the RF peaks. This method is entirely processed in the time domain, avoiding the timeto-frequency calculations (and vice-versa), and totally suitable for automatic processing. Estimated peaks can be used to generate RF traces in a seismogram format for visualization. The RF trace quality is similar to traditional methods for high magnitude events, furthermore, it increases the overall performance for high number of events per station.

\section{A Non-Linear Filter to Enhance Microearthquake Detection}

SALEHIOZOUMCHELOUEI, R., Universidad de La Laguna, S/C de Tenerife, Spain, alu0100941135@ull.edu.es; RAJAEITABRIZI, Y., Universidad de La Laguna, S/C de Tenerife, Spain, alu0100941142@ull.edu.es; D’AURIA, L., Instituto Volcanológico de Canarias, S/C de Tenerife, Spain, Idauria@iter. es; SÁNCHEZ DE LA ROSA, J. L., Universidad de La Laguna, S/C de Tenerife, Spain,jsanrosa@ull.edu.es

The detection of microearthquakes is an important task in various seismological applications as volcano seismology, induced seismicity, and mining safety. Together with improvements in the seismic network technologies (e.g. network densification, borehole installations) it can benefit from techniques of digital signals processing, aimed at enhancing signals related to microearthquakes from the background noise, or in other words it is necessary to improve the signal/ noise ratio. We propose a novel technique based on a non-linear filtering procedure, which has shown to be more efficient, compared to traditional filtering, in enhancing signals related to small microarthquakes from continuous recordings. The implemented technique consists in a preliminary filtering of the signal followed by an adaptive spectral subtraction. Filter bandpass is between $5 \mathrm{~Hz}$ and $40 \mathrm{~Hz}$ to eliminate both low and very-high frequency noise. It is applied using a sliding window of 1024 samples in order to take into account gradual changes in the background noise spectrum. Windows are classified as "noise only" or "meaningful signal" (which can be either a microearthquake or any other relevant transient signal) using different features as the signal energy and the zero-crossing 
rate. Windows recognized to consist of noise only are continuously accumulated in a dynamic buffer which allows the average noise spectrum to be estimated in an adaptive manner. We applied this procedure to some seismic swarms recorded by Red Sísmica Canaria, managed by Instituto Volcanológico de Canarias (INVOLCAN), on Tenerife and La Palma islands, comparing results from the proposed detection algorithm with standard approaches.

\section{Making Realistic Synthetic Seismic Waveforms with Generative Adversarial Networks}

LI, Z., Caltech, California, USA, zefengli@caltech.edu; HAUKSSON, E., Caltech, California, USA, hauksson@caltech.edu; MEIER, M. A., Caltech, California, USA, mameier@caltech.edu; ZHAN, Z., Caltech, California, USA, zwzhan@caltech.edu

Today machine learning is being applied to solve various problems in seismology using large available datasets. In many cases these data have already been analyzed by humans and serve as training or testing datasets. However, for some important problems in seismology we are severely data-limited. In particular, the enormous numbers of free parameters in deep learning algorithms require amounts of data that are often far larger than what is available today. This data limitation is especially severe for very large events, which are rare but very important cases. Traditional data-augmentation methods include interpolation and adding random noise to existing data. Here we suggest a way to generate realistic synthetic seismic waveforms using generative adversarial networks (GANs). We train a GAN to capture the major features of a large data set of real seismic waveforms, and to synthesize new waveforms. We show that these synthetic waveforms are realistic enough to fool professionals and contain realistic physical features, e.g. major body wave packets, coda wave decay and frequency dispersion. Compared to simulated synthetic waveforms, they contain some realistic high-frequency features that are not easily modeled by more traditional waveform simulation methods. Beyond augmenting the test data, the GANs can have potentially wide applications in seismology, such as seismic event/phase discrimination, clipped waveform completion, and waveform up-sampling. Updated results will be presented in the meeting.

Waveform Classification Using Statistical Learning Algorithms to Characterize Data Features from a Dense Deployment of Geophones atop an Active Fault Zone

ЦOHNSON, C. W., UC San Diego, California, USA, cwj004@ucsd.edu; VERNON, F. L., Scripps Institute of Oceanography, California, USA, flvernon@ ucsd.edu; BEN-ZION, Y., University of Southern California, California, USA, benzion@usc.edu

We develop data based classifiers for earthquakes, microseisms, and ambient noise for a compressed parameterization of the waveforms and utilize statistical learning techniques to train a model to identify previously undetected signals in upper portions of the crust. In May 2016 a dense array deployment of 1,100 vertical geophones recorded ground motions at the San Jacinto Fault Zone at the location of a borehole seismometer. The data set provides a unique opportunity to characterize the shallow subsurface from $0-1 \mathrm{~km}$ depth. The detection of shallow microseismic events requires the distinction between shallow seismic energy and local high-frequency ambient noise or atmospheric processes. The classification procedure involves manually identifying and labeling signals present in subsets of the data. The process requires the calculation of features as scaler metrics, i.e. hundreds of temporal and spectral properties of the time series, that represent a compact expression of the data. The scaler metrics are derived using seismological knowledge of waveforms to maintain a physics based representation of the data. Each waveform is labeled to represent a specific source type, e.g. a local or regional earthquake, anthropogenic machines, atmosphere coupling, etc., and this requires exploratory data analysis to properly define the required features for each classification type and properly weigh them for increased model performance. The labeled features are used with supervised learning techniques to train an advanced statistical model to classify data using the compressed features. We are using 2,000 hand-picked earthquakes as waveform templates to develop the compact features. We then use a Random Forest classification algorithms with the labeled data features. The features are evaluated for significance in the model performance and those not contributing are removed. The preliminary results shown here are providing new detections of localized sources of energy.
Machine Learning Aspects in the Smartphone Seismic Network KONG, Q., UC Berkeley, California, USA, kongqk@berkeley.edu; INBAL, A., UC Berkeley, California, USA, ainbal@berkeley.edu; ALLEN, R. M., UC Berkeley, California, USA, rallen@ berkeley.edu

MyShake is a global smartphone seismic network that harnesses the power of crowdsourcing. It has an Artificial Neural Network (ANN) algorithm running on the phone to distinguish earthquake motion from human activities recorded by the accelerometer on board. Once the ANN detects earthquakelike motion, it sends a 5-min chunk of acceleration data back to the server for further analysis. The time-series data collected contains both earthquake data and human activity data that the ANN confused. In this presentation, we will show the Convolutional Neural Network (CNN) we built under the umbrella of supervised learning to find out the earthquake waveform. The waveforms of the recorded motion could treat easily as images, and by taking the advantage of the power of CNN processing the images, we achieved very high successful rate to select the earthquake waveforms out. Since there are many non-earthquake waveforms than the earthquake waveforms, we also built an anomaly detection algorithm using the CNN. Both these two methods can be easily extended to other waveform classification problems.

\section{DeepDetect: An Application of Deep Densely Connected Convolutional} Neural Network to Earthquake Detection

WU, Y., University of Rochester, New York, USA, ywu74@ur.rochester.edu; ZHOU, Z., University of Rochester, New York, USA, zzhou31@ur.rochester. edu; CHEN, T., Los Alamos National Laboratory, New Mexico, USA, tchen@ lanl.gov; LIN, Y., Los Alamos National Laboratory, New Mexico, USA, ylin@ lanl.gov

Earthquake detection is a fundamental element in seismic data processing. How to automatically detect earthquakes in an accurate and efficient way is of particular interest as today's seismic data volume is rapidly growing. Here we present a software package, DeepDetect, to accurately and efficiently detect earthquakes from continuous seismic records. We build our algorithm on the convolutional neural network (CNN) to detect earthquakes and identify the arrival time of each event. The CNN is the backbone of our model, which serves the purpose of extracting features from the waveform. A classifier and a regressor are built on top of the CNN backbone. The classifier aims to detect events from the signal and the regressor further predicts the arrival time of the event detected by the classifier. We demonstrate the capability of our algorithm using the dataset from IRIS Community Wavefield Experiment in Oklahoma. We show that our algorithm can not only capture most earthquakes but also accurately identify the arrival time of each event, holding great potential for efficient earthquake detection.

\section{Detection of Background Seismic Waves Anomalies with a Hierarchical Temporal Memory (HTH) Cortical Algorithm}

TAKAHASHI, K., Yokohama City University, Kanagawa, Japan, n175224a@ yokohama-cu.ac.jp; MICHELETTO, R. M., Yokohama City University, Kanagawa, Japan, ruggero@yokohama-cu.ac.jp

We used an unsupervised cortical algorithm to detect in real time anomalies in simulated and real seismic signals. The algorithm works on-line receiving continuous seismic acceleration signals from a streaming station. This could be a software source that is simulating the data stream from a suitable algorithm, or could be data timeseries from a database of real seismic events. Our system is based on the Numenta HTM engine that implements a cortical algorithm based on an innovative neural model in which dendrites act as coincidence detectors and synapses are formed continuously. The HTM networks learns and adapts to the seismic background noises and it is able to notice anomaliesin real time and without the necessity of supervision. This approach to seismic detection could be useful not only to recognize earthquakes and contribute to early warning networks, but also could be of importance for detecting variations of the background noises characteristics that are not detectable with conventional methods or by conventional machine learning methods. We will show tests that demonstrate the ability of the HTM algorithm to recognize efficiently simulated and real earthquake waves we will report on our tests on seismic noises of specific types. Our approach points forward the possibility of the use of HTM networks to recognize signals form different kinds of seismic sources and types.

A Deep Learning Approach for Enhanced Classification of Global Seismic Waveforms

SMITH, K. E., Florida Institute of Technology, Florida, USA, ksmith012007@ my.fit.edu; SMITH, A. O., Florida Institute of Technology, Florida, USA, 
anthonysmith@fit.edu; PETER, A. M., Florida Institute of Technology, Florida, USA, apeter@fit.edu

Over the past 50 years global seismic detection has matured considerably due to the importance of differentiating seismic events: man-made (mining explosions) from natural phenomena (earthquakes, volcanoes). Where there is still some prevalent concern with these seismological advancements is in separating these classes. This concern derives from the fact that a seismic signature lacks easily defined features which complicates the discrimination process for a variety of detection methods. This paper aims to address this issue, by evaluating state-of-the-art machine learning algorithms, and compare several deep classification techniques. We target deep learning methods (Deep Neural Networks, Convolutional Neural Networks, and Long-Short Term Memory Networks) due to their ability to mimic human-like neural connections and support data-specific feature extraction to classify waveform signatures. Our proposed algorithms show noteworthy accuracy, opening up the realization of automated network seismic discrimination. Our results show evidence that deep learning should be considered the leading candidate for classifying seismic waveforms and will further advance the gap between machine learning and geological sciences.

MLP Networks to Associate Arrival Times in Noisy and Dense Earthquake Sequences

MCBREARTY, I. W., Los Alamos National Laboratory, New Mexico, USA, imcbrearty@lanl.gov; DELOREY, A. A., Los Alamos National Laboratory, New Mexico, USA, andrew.delorey@lanl.gov; JOHNSON, P. A., Los Alamos National Laboratory, New Mexico, USA, paj@lanl.gov

The concept of picking earthquake phase arrivals and associating them to a common event is simple, but hard to implement in a robust and reliable manner when there are multiple overlapping events and false arrival time picks. Related issues include determining precisely if and when an event has occurred when noisy and false arrivals are included in the data set, and determining how many different unique events have occurred when move-out times are possibly overlapping. Interestingly when these challenges are posed as a precise mathematical problem, simple and accurate solutions arise through the use of basic multilayer perceptron (MLP) supervised classification and regression frameworks. For a predetermined velocity model, we obtain distinct (shallow) MLP networks to classify an arbitrary set of arrival times on $\$ \mathrm{n} \$$ stations between a true $\mathrm{P}$ or $\mathrm{S}$ phase recorded event and noise (i.e. a false set of arrivals), determine the distinct number of unique events in a time window, determine which set of arrivals associate to a common event, and also, using a denoising autoencoder framework, predict arrival times on stations missing arrival time detections during an event. Discrete (i.e. vectors of arrival time data) and continuous (i.e. encoding of arrival time data as time-dependent Gaussian pulses) implementations are used. Synthetic tests of the method and applications to field data from the IPOC network of Northern Chile are presented.

\section{Challenges and Chances for the Widespread Implementation of Earthquake Early Warning (EEW) Poster Session · Thursday 17 May · Riverfront South}

\section{Rapid Estimation of Instrumental Intensity Using Shakemap in South Korea}

HAN, S., Korea Metrological Administration, South Korea, ssinaehan@gmail. com; JO, E., Korea Metrological Administration, South Korea, jey0817@korea.kr; HWANG, E. H., Korea Metrological Administration, South Korea, hkawon1@ korea.kr; YUN, H. J., Korea Metrological Administration, South Korea, hkjin@ kma.go.kr

The Korea Meteorological Administration (KMA) is currently operating an Earthquake Early Warning System (EEWS), which issues an alert consist of probable seismic intensities of whole southern Korean peninsula within 25 seconds after detecting an earthquake bigger than magnitude 5.0. The system additionally provides an seismic report including the earthquake epicenter, magnitude, and instrumental intensity map in $5 \mathrm{~min}$ to provide the more precise information. KMA began to produce the instrumental intensity map using the ShakeMap program in March 2017. After modifying the part of ShakeMap process to reflect the unique seismic characteristics of Korean peninsula, the service for whole nation was implemented from July 2017. The KMA ShakeMap system calculates PGM (peak ground motion) values by using observed data and interpolates with value of PGM and GMPE (GroundMotion Prediction Equation) model. The intensity map is produced through converting the peak ground motion values of each grid point to Modified Mercalli Intensity via GMICE (Ground Motion-Intensity Coversion Equation). Therefore, to determine appropriate GMPE and GMICE models is important step for our processing flow. We determined to use "BA08" GMPE model for the event of magnitude smaller than 5.3 and "Zhao06_crustal" model for event of magnitude bigger than 5.3 after verifying the models with observed ground motion data. The GMPE model and observed PGM (Peak Ground Motion) data are more consistent after setting up the process for removing outliers and correcting bias above magnitude 1.0. We used the modified "Wald99" GMICE model to fit the KMA data especially on intensity 2 to 3 . We also changed grid spacing from 0.025 to 0.05 to effectively reduce the processing time from $30 \mathrm{sec}$ to $20 \mathrm{sec}$ on average. We present an example Shakemap processing flow for Pohang earthquake (ML 5.4) that caused the worst damage than other earthquakes ever occurred in Korean peninsula.

Machine Learning Magnitude Estimate in Earthquake Early Warning Systems LI, Z., Caltech, California, USA, zefengli@caltech.edu; HAUKSSON, E., Caltech, California, USA, hauksson@ caltech.edu; HEATON, T. H., Caltech, California, USA, heaton@caltech.edu

Rapid and precise determination of earthquake magnitude is of critical importance in earthquake early warning systems. A single station magnitude estimate that relies on a single feature of the waveform recorded near the epicenter, may have large uncertainties and may lead to false and missed alarms. In this study we show that, with state-of-the-art machine learning tools, a single station magnitude estimate can be much more accurate than those obtained with traditional methods. We trained an ensemble of convolutional networks using a large amount of historic data recorded in Japan and California to infer the magnitude directly from $P$ waves of $3 \mathrm{~s}$ duration. The test results show that the networks estimate $94 \%$ of magnitudes in Japan within 1-unit difference from catalog ones and 99\% in California. The trained networks require minimal computational effort when operating online and can be conveniently transferred to other regions even with a short history of seismic instrumentation.

\section{Building Eew in Nicaragua: Performance and Perspectives}

MASSIN, F., Swiss Seismological Service, ETH Zurich, Switzerland, fmassin@ sed.ethz.ch; STRAUCH, W., Instituto Nicaragüense de Estudios Territoriales, Managua, Nicaragua, wilfried.strauch@gf.ineter.gob.ni; CLINTON, J. F., Swiss Seismological Service, ETH Zurich, Switzerland, jclinton@sed.ethz.ch; BOESE, M., Swiss Seismological Service, ETH Zurich, Switzerland, maren.boese@ sed.ethz.ch; RAMIREZ, J., Instituto Nicaragüense de Estudios Territoriales, Managua, Nicaragua, javier.ramirez@sb.ineter.gob.ni

Earthquake early warning (EEW) systems aim at providing real-time estimates of event parameters or expected ground motion over wide ranges of source dimensions. In 2016, SED and INETER started a joint project funded by the Swiss Development Agency to assess the feasibility of EEW in the Nicaragua in particular and in Central America in general. The project is appropriate as SED develops EEW algorithms (Virtual Seismologist, VS and Finite Fault Detector, FinDer) that operate within SeisComP3, which is widely used across Central America, and many regions are already covered by dense seismic networks that include strong motion sensors. VS provides fast network-based magnitude estimates for point source solutions using conventional phase association. FinDer matches the evolving patterns of ground motion to track rupture extent in realtime, critical for a region where tsunamigenic earthquakes are expected. We document performance of the EEW system, and compare with expected EEW delays assuming a fully operational network. We show that the existing network is EEW-capable. However, it is a major challenge to maintain the network at a level required to provide reliable and accurate alerts. Issues with stations being out of operation; streaming with broken signals or incorrect timing; or simply having too high latencies or wrong calibration, continue to provide false, delayed or missed alerts. Nevertheless, we document the improvements in the EEW performance during our tuning of the system. Currently, first alerts can be provided within 20s for on-shore earthquakes in Nicaragua and within 40s for offshore earthquakes. However, there is potential to provide alerts within 10 to $15 \mathrm{~s}$ onshore and 20 to 25s off-shore earthquakes. For M6.5 events onshore, and M7.5 offshore, this corresponds to alerts being received in advance of strong shaking for regions shaken by intensities $\geq=$ VII. We demonstrate how improved network density and algorithms can further improve EEW alert times.

Determination of Earthquake Early Warning Parameters for the New Madrid Seismic Zone

OGWENO, L. P., The University of Memphis-CERI, Tennessee, USA, logweno@memphis.edu; WITHERS, M. M., University of Memphis, Tennessee, 
USA, mwithers@memphis.edu; CRAMER, C. H., University of Memphis, Tennessee, USA, ccramer@memphis.edu

Increasing vulnerability of metropolitan areas within stable continental regions (SCR), such as Memphis, TN and St. Louis, MO near the New Madrid Seismic Zone (NMSZ), to earthquakes and the very low probability level at which short term earthquake forecasting is possible make an earthquake early warning system (EEWS) a viable alternative for effective real-time risk reduction in these cities. In this study, we explore practical approaches to earthquake early warning (EEWS), and test the adaptability and potential of the real-time monitoring system in the NMSZ. We determine empirical relations based on amplitude and frequency magnitude proxies from the initial four seconds of the P-waveform records available from the Cooperative New Madrid Seismic Network (CNMSN) database for magnitude $M \geq 2.5$. The amplitude based proxies include low pass filtered peak displacement $(\mathrm{Pd})$, peak velocity $(\mathrm{Pv})$, and integral of the velocity squared (IV2), whereas the frequency based proxies include predominant period (tau-p), characteristic period (tau-c), and log average period (tau-log). Very few studies have considered areas with lower magnitude events. With an active EEW system in the NMSZ, damage resulting from the catastrophic events, as witnessed in 1811-1812, may be mitigated in real-time.

\section{Earthquake Source Parameters: Theory, Observations and} Interpretations

Poster Session · Thursday 17 May · Riverfront South

Towards Quasi-Automated Estimates of Directivity and Related Source Properties of Small to Moderate Southern California Earthquakes with Second Seismic Moments Using Weighted Stacked EGFs

MENG, H., University of Southern California, California, USA, haoranme@ usc.edu; BEN-ZION, Y., University of Southern California, California, USA, benzion@usc.edu; MCGUIRE, J., Woods Hole Oceanographic Institution, Massachusetts, USA,jmcguire@whoi.edu

We develop a method for quasi-automated estimation of directivity, rupture area, duration, and centroid velocity of earthquakes with second seismic moments. The method is applied to small to moderate earthquakes in southern California. P and $S$ phase picks are given by a 1-D ray tracing algorithm and cataloged event locations. These are refined for deconvolution by using a grid search on zerocrossings within a short time window around the automated P/S picks. Source Time Functions (STFs) of target events are derived using deconvolution with a stacked empirical Green's function (seGf). The use of seGf suppresses non-generic source effects such as directivity in individual eGf's. The seGf for each target event is based on stacking individual eGfs (normalized by seismic potencies) selected by spatial and magnitude criteria as well as performances in the projected Landweber deconvolution. A weighted stack of eGfs, with weight coefficients grid searched and determined by waveform fits, helps further to correct inaccuracies of focal mechanisms. Compared with a single eGf, analysis with a weighted stack can significantly improve waveform fit and typically allows getting STFs at 5-10 more stations. The method is suitable for analysis of large seismic datasets and it works for target events in southern California with magnitudes as small as 3.5. Most events analyzed so far have significant directivities.

Comparison of Brune-Type Stress Drops Obtained from the Improved Coda-0 Method and Spectra Decomposition Method

WANG, W., Scripps Institution of Oceanography, California, USA, weiwang053@gmail.com; SHEARER, P.S., Scripps Institution of Oceanography, California, USA, pshearer@ucsd.edu

Analysis of the seismograms recorded by the seismic station array provides the fundamental information of earthquake source spectra and site effects. Previous studies use different sections of the seismograms, e.g. the direct $P$ and $S$ waves and coda waves, to study the two terms. Both stress drops derived from the source spectra and site effects have practical implications for the strong ground motion prediction. In this study, our aim is to comprehensively compare the source spectra and site effects derived from direct waves and coda waves separately and to explore the self-similar scaling of the earthquake source properties. We analyze around 1500 earthquakes with the local magnitude (ML) range between 1.2 and 3.5 in the San Jacinto Fault region. Both the spectra decomposition method (Peter et al., 2006 and Trugman \& Shearer, 2017) and the improved Coda-Q method (Wang \& Shearer, 2017) are applied to derive the source spectra and site effects. To fit the source spectra by using the Brune-type crack source model, both self-similarity and none self-similarity are explored by assuming the constant stress drops or the moment dependent stress drops. The error estimations of both methods will be discussed in this study. This work will provide a systematic comparison of source spectra and site effects from direct waves and coda waves. Furthermore, another comprehensive analysis of the earthquake source spectra and site effects will be conduct in the southern California.

The mblg 3.9 September 13, 2017, Earthquake on the Virginia-West Virginia Border: A Significant Shock in the Giles County Seismic Zone DEPAOLIS, J. M., Virginia Polytechnic Institute and State University, Virginia, USA, jessicad@vt.edu; CHAPMAN, M. C., Virginia Polytechnic Institute and State University, Virginia, USA, mcc@vt.edu

On September 13, 2017 the USGS NEIC reported a duration magnitude MD 3.2 earthquake at $37.473 \mathrm{~N} 80.703 \mathrm{~W}$, depth $18 \mathrm{~km}$ near Lindside, West Virginia, close to the Virginia-West Virginia border. The earthquake was felt primarily in Monroe, Mercer and Summers counties, West Virginia and in Giles, Montgomery, Pulaski and Bland counties, Virginia. The maximum intensity reported to the USGS Did You Feel It? program was IV MM. The earthquake occurred in an area of moderate seismicity known as the Giles County Seismic Zone (GCSZ). The largest shock in the GCSZ occurred in 1897 near Pearisburg, VA, with mblg magnitude estimated from the felt area at 5.8. We relocated the hypocenter of the September, 2017 earthquake using a locally specific velocity model, at $37.4775 \mathrm{~N}, 80.7035 \mathrm{~W}$, depth $21 \mathrm{~km}$. We estimated the mblg magnitude at $3.90+0.26$ using 26 stations at regional distances, and determined a duration magnitude MD of $3.71 \pm 0.17$, using 33 stations. The duration magnitude is based on a correlation between the log of short-period signal duration and mblg. We determined a focal mechanism using $27 \mathrm{P}$ polarities, $12 \mathrm{SH}$ polarities and $16 \mathrm{SH} / \mathrm{P}$ amplitude ratios. The nodal planes with least rms amplitude ratio error are: strike N91E, dip 69 deg., rake -22 deg.; auxiliary plane strike N189E, dip 69 deg., rake -158 deg. This event is notable because it is the largest shock in the GCSZ since May, 1974 (mblg 3.7). This recent shock, like many others in the GCSZ, shares characteristics with those in the Eastern Tennessee Seismic Zone (ETSZ), which is also in the Appalachian Valley and Ridge province. The 2017 GCSZ focal mechanism is mostly strike-slip with a small normal component, on steeply dipping nodal planes trending approximately N-S and E-W. This type of mechanism is dominant in the ETSZ. Also, in both areas, focal depths tend to be greater than $12 \mathrm{~km}$, unlike shocks to the east in the Blue Ridge, Piedmont and Coastal Plain provinces which tend to occur at shallower depths.

The 1 May 2017 British Columbia Earthquake Doublet and Implications for Complexity near the Southern End of the Denali Fault System

HE, X., Sun Yat-Sen University, Guangdong, China, hexiaohui@foxmail.com; NI, S. D., Institute of Geodesy and Geophysics, Chinese Academy of Sciences, China, sdni@whigg.ac.cn; ZHANG, P., Sun Yat-Sen University, China, zhangpeizhen@mail.sysu.edu.cn; FREYMUELLER, J. T., University of Alaska, Alaska, USA, jfreymueller@alaska.edu; WANG, K., Geogical Survey of Canada, kelin.wang@canada.ca

On May 1, 2017,, two M6+ earthquakes occurred in northwestern British Columbia separated by about 2 hours. Despite their close distance about $10 \mathrm{~km}$, the two events have different focal mechanisms, with first earthquake featuring a thrust focal mechanism and the second strike slip. Both focal plane solutions are inconsistent with slip on the nearby southeastern Denali fault system. To resolve their ruptured fault planes, we invert for the point source parameters, and analyze rupture directivity via waveform modeling. The results indicate that the first event ruptured upwards along a steep SW-dipping fault (strike $153 \%$ dip $61^{\circ} /$ rake $113^{\circ}$ ) with rupture length about $8 \mathrm{~km}$, and the second event ruptured to the ESE along a left-lateral fault (strike $292^{\circ}$ /dip $36^{\circ}$ /rake $54^{\circ}$ ) with rupture length about $6 \mathrm{~km}$. We infer that the earthquake doublet is related to slip on the active Duke River fault, and the involved faults could be associated with the transpression caused by collision of the Yakutat block.

\section{Deviatoric Moment Tensor Solutions for Small Intraplate Earthquakes in Northeast Brazil from P, SV, and SH Spectral Amplitudes}

FERREIRA, P. A. R., Universidade Federal do Rio Grando do Norte, Rio Grande do Norte, Brazil, pedro_enrre@hotmail.com; JULIÀ, J., Universidade Federal do Rio Grando do Norte, Rio Grande do Norte, Brazil, jordi @ geofisica. ufrn.br; DA SILVA, S. L. E. F., Universidade Federal do Rio Grande do Norte, Rio Grande do Norte, Brazil, sergioluiz.pesquisa@gmail.com

The Brazilian Northeast is regarded as one of the most seismically active regions in intraplate South America. Although damaging earthquakes have occasionally been experienced in the region, seismic activity typically occurs as swarms of shallow earthquakes $(<12 \mathrm{~km})$ with maximum magnitudes in the $4.0-4.5$ $\mathrm{mb}$ range and durations between a few months and many years. Seismic activity is routinelly monitored through the permanent Rede Sismográfica do Nordeste 
(RSisNE), and through temporary, small-aperture aftershock monitoring networks that are deployed shortly after felt earthquakes are reported by the population. Intraplate seismic activity has been originally related to the presence of pre-existing zones of weakness favorably oriented with the regional stress field, but composite fault-plane solutions from first-motion polarities-further constrained with hypocentral aftershock locations-developed so far have been inconclusive in this regard. In this work, we apply a novel methodology to determine deviatoric moment tensor solutions from P, SV, and SH spectral amplitudes (with polarity attached) to develop focal mechanisms for individual intraplate earthquakes in NE Brazil. Preliminary results developed for the São Caetano/ PE sequence of 2010 and other seismic sequencies within the NE Brazil region demonstrate that a variety of focal mechanisms-including normal, strike-slip, and reverse faulting-may occur within the same sequence, and that local stress concentrators might be modifying the regional stress field at short length scales within the region.

\section{Seismic Activity Migration in a Strike-Slip Fault of Porto Dos Gaúchos Seismic Zone (Pgsz)—Amazon Craton Brazil}

BARROS, L. V., Seismological Observatory of the University of Brasilia, Distrito Federal, Brazil, lucas@unb.br; ASSUMPÇÃO, M., University of São Paulo; Institute of Astronomy, Geophysics and Atmospheric Sciences, São Paulo, Brazil, marcelo.assumpcao@iag.usp.br; QUINTERO, R., OVSICORI_UNA, Costa Rica, ronnieq@gmail.com; CARVALHO, J. M., Seismological Observatory of the University of Brasilia, Distrito Federal, Brazil, juraci@unb.br; BOWEN, B. D., Seismological Observatory of the University of Brasilia, Distrito Federal, Brazil,bibi_drumond@hotmail.com

Porto dos Gaúchos seismic zone (PGSZ) is already a well-known seismogenic zone in terms of stress regime, fault location and physical dimension. It is located in a Phanerozoic sedimentary basin; such $500 \mathrm{~m}$ thickness sediments overlie the crystalline basement of the Amazon Craton-Brazil. Recently we detected $15 \mathrm{~km}$ away from the PGSZ area, another seismic activity that seems to be an extension of the PG fault. The largest earthquake ever observed in the stable continental interior of the South American plate occurred on January 31, 1955, magnitude $6.2 \mathrm{mb}, 100 \mathrm{~km}$ to SW of PGSZ (in Serra do Tombador-ST). Since then no other earthquake has been located near the ST epicenter. However, in PG a recurrent seismicity has been observed since 1959. Two magnitudes 5 earthquakes occurred in 1998 and 2005 with intensities up to VI and V, respectively. These two main shocks were followed by aftershock sequences, both studied by local seismic networks lasting up today. Both sequences occurred in the same WSW-ENE oriented fault zone with right-lateral strike-slip mechanisms. The epicentral zone is near the northern border of Parecis basin, where there are buried grabens, generally trending WNW-ESE, such as the Mesoproterozoic Caiabis graben. Not considering the possibility of miss location in the ST earthquake, its isolated occurrence, from the perspective of new studies on intraplate seismicity, lead us to think that the PGSZ was activated by stresses released by the event of 1955 and that the seismogenic fault of ST would have closed a activity cycle. This would explain its seismic quiescence. However, other studies are necessary to prove this hypothesis, such as the measurement of the deformation rate in the area and confirmation of the epicenter of the ST earthquake. On the other hand, when dealing with intraplate seismicity, what is valid for the New Madrid Seismic Zone (the base of the studies of the authors) may not be valid for other important seismic zones like the PGSZ.

\section{Constraints on the Source Mechanism of the Damaging Seismic Event of August 21, 2017, on Ischia Island (Southern Italy)}

BRAUN, T., Istituto Nazionale di Geofisica e Vulcanologia, Italy, thomas. braun@ingvit; FAMIANI, D., Istituto Nazionale di Geofisica e Vulcanologia, Italy, daniela.famiani@ingv.it; CESCA, S., Helmholtz-Zentrum Potsdam, Germany, cesca@gfz-potsdam.de

On Aug. 21, 2017, a MD4.0 earthquake struck Ischia island, claiming two lives and provoking severe building damages, disproportionate to the moderate magnitude of the event. Hypocenter locations based on arrival times were afflicted by a large uncertainty and the proposed moment tensor solutions resulted inconsistent among themselves. These contradictory observations gave motivation to recalculate earthquake parameters by alternative approaches. P-phase particle motion, the evaluation of the rotated spectra, and ts-tp lead to a hypocentral depth of $2 \mathrm{~km}$, in the same epicentral area as the devastating seismic event that struck Ischia in 1883. The full moment tensor solution reveals non-double couple contributions of $62 \%$ - fitting best for a shallower source depth and estimating a higher magnitude of Mw4.2. To fit the first motion polarity mismatch observed at the closest station IOCA we suggest a complex rupture process, where a first shallow normal faulting event activates a subsequent collapse.
The 2017 Earthquake Sequence near Sulphur Peak, Idaho KOPER, K. D., University of Utah, Utah, USA, koper@seis.utah.edu; PECHMANN, J. C., University of Utah, Utah, USA, pechmann@seis.utah. edu; HALE, J. M., University of Utah, Utah, USA, jmhale@seis.utah.edu; BURLACU, R., University of Utah, Utah, USA, burlacu@seis.utah.edu; PANKOW, K. L., University of Utah, Utah, USA, pankow@seis.utah.edu; YECK, W. L., US Geological Survey/NEIC, Colorado, USA, wyeck@usgs.gov; BENZ, H. M., US Geological Survey/NEIC, Colorado, USA, benz@usgs.gov; HERRMANN, R. B., Saint Louis University, Missouri, USA, rbh@slu.eas. edu; TRUGMAN, D. T., Los Alamos Narional Laboratory, New Mexico, USA, dtrugman@ucsd.edu; SHEARER, P. M., Scripps Institution of Oceanography, California, USA, pshearer@ucsd.edu

On 2 September 2017, an Mw 5.3 normal-faulting earthquake occurred in the Intermountain Seismic Belt about $15 \mathrm{~km}$ east of Soda Springs, ID, near Sulphur Peak. It was widely felt throughout southeastern Idaho, northern Utah, and western Wyoming, but caused little damage. It appears to be co-located with two earlier seismic sequences, one in 1960 and the other in 1982. To achieve high-accuracy locations, the University of Utah and the USGS partnered with the Idaho Geological Survey to deploy eight telemetered seismographs in the epicentral region. Using absolute and differential arrival times we determined high-accuracy locations for a catalog of $\sim 1,100$ aftershocks, complete to ML 2.5. Initial locations were determined with HYPOINVERSE using a local $1 D$ velocity model, and further refined using joint hypocentral decomposition (MLOC) and cluster-based relative relocation (GrowClust). For 76 of the largest events in the sequence, we inverted regional distance waveforms for moment tensors. The small uncertainties in absolute hypocenters imply that two first-order observations about the 2017 Sulphur Peak sequence are robust. First, the events are to the east of the west-dipping Eastern Bear Lake Fault, perhaps in a complex fracture zone within the footwall. Second, the events are confined to the upper crust, with a maximum depth of $\sim 10 \mathrm{~km}$. Like previous seismicity in this region-such as the M4.7 Soda Springs sequence of 1982 and the M5.7 Draney Peak sequence of 1994-the 2017 Sulphur Peak sequence had an energetic aftershock sequence with the cumulative aftershock moment $0.7-1.4$ times as large as the mainshock moment. The unusually high productivity of the sequence is evident from the fact that 17 aftershocks had magnitudes larger than the upper bound expected from Bath's Law, and 16 of the 17 occurred within ten days of the mainshock. Following Reasenberg and Jones [1994], the expected number of such aftershocks is $0-4$, and the probability of observing 16 is only $2.3 \times 10-12$.

\section{New Relocated Seismicity Using an Improved Crustal Structure Model in the Eastern Sierras Pampeanas $\left(29^{\circ} \mathrm{s}-32^{\circ} \mathrm{s}\right)$, Andean Retroarc of Argentina}

VENERDINI, A. L., Centro de Investigaciones de la Geósfera y la Biósfera, Departamento de Geofísica y Astronomía, Universidad Nacional de San Juan, San Juan, Argentina, agostina.venerdini@unsj-cuim.edu.ar; ALVARADO, P., Centro de Investigaciones de la Geósfera y la Biósfera, Departamento de Geofísica y Astronomía, Universidad Nacional de San Juan, San Juan, Argentina, alvarado@unsj.edu.ar; AMMIRATI, J. B., Centro Sismológico Nacional Universidad de Chile, Santiago, Chile, jbaptiste@ing.uchile.cl; ARAUJO, M., Instituto Nacional de Prevención Sísmica, San Juan, Argentina, maraujo@ inpres.gov.ar; GILBERT, H., Department of Earth, Atmospheric and Planetary Sciences, Purdue University, Indiana, USA, hersh @ purdue.edu; LINKIMER, L., Escuela Centroamericana de Geología Universidad de Costa Rica, San José, Costa Rica, linkimerl@gmail.com; BECK, S. L., University of Arizona Department of Geosciences, Arizona, USA, slbeck@email.arizona.edu; ANDERSON, M., Colorado College, Colorado, USA, megan.anderson@coloradocollege.edu

We used seismic broadband records from the SIerras Pampeanas Experiment using a Multicomponent BRoadband Array and the Eastern Sierras Pampeanas array to analyze modern shallow seismicity using a new seismic velocity model for the continental crust of the Eastern Sierras Pampeanas (ESP). The ESP, located in the central part of Argentina, more than $700 \mathrm{~km}$ east from the trench, are the easternmost manifestation of crustal deformation in the Andean retroarc between 29 and $32^{\circ} \mathrm{S}$. We obtained a crustal velocity model using the joint inversion of teleseismic receiver functions and surface wave data, calibrated with gravity measurements. This model describes in detail the crustal seismic velocity variations beneath the ESP. Then, weanalyzedcrustal earthquakes recorded by the arrays that occurred during 2008-2010. An average of 49 Pand $S$ wave arrivals per event were picked and resulted in 31 new earthquake locations. Errors in location appeared to be improved with values on average of $1.2 \mathrm{~km}$ in latitude, $1.7 \mathrm{~km}$ in longitude and $2.7 \mathrm{~km}$ in focal depth. The average rms is $0.27 \mathrm{~s}$ and the average azimuthal gap is $104^{\circ}$. In addition, we determined first motion focal mechanisms further constrained with amplitude ratios SH/P, SV/P and SV/SH. Finally, we inverted these focal mechanism solutions to estimate the regional stress tensor. We observe that most of the analyzed seismicity beneath the ESP 
is located between 10 and $25 \mathrm{~km}$ depths in the central part between $30.5-31.5^{\circ} \mathrm{S}$. Our focal mechanisms are mainly reverse and consistent. These small to moderate size earthquakes should not be underestimated in this region of Argentina that concentrates $1.33 \mathrm{M}$ inhabitants, one nuclear power plant, 12 large dams Historical and modern seismicity seem to agree with shallow focal depths, which enhance the seismic hazard in this region. Future work will include more seismicity and seismic sources, aftershocks and structure characterization.

Seismic Swarm Activity in a Non-Volcanic Area -Umm-Lujj, Western Saudi Arabia

YOUSSOF, M., King Abdullah University of Science and Technology, Makkah, Saudi Arabia, mohammed.soliman@kaust.edu.sa; MAI, P. M., King Abdullah University of Science and Technology, Makkah, Saudi Arabia, martin.mai@ kaust.edu.sa; HOSNY, A., National Research Institute of Astronomy and Geophysics, Cairo, Egypt, ahhosny2000@yahoo.com; PARISI, L., KAUST, Makkah, Saudi Arabia, laura.parisi@kaust.edu.sa; ZAHRAN, H., Saudi Geological Survey, Makkah, Saudi Arabia, zahran.hm@sgs.org.sa; SAMI, M., Saudi Geological Survey, Makkah, Saudi Arabia, salam.ms@sgs.org.sa

An unusual, ongoing, earthquake swarm is currently active in a non-volcanic area in western Saudi Arabia near the town of Umm-Lujj. Since February 2017, hundreds of earthquakes have been recorded continuously, with a maximum magnitude reaching MI 3.7. Although this earthquake swarm occurs only about 75 $\mathrm{km} \mathrm{NW}$ of the volcanic area of Harrat Lunayyir, it does not appear to be directly associated with it. The latter experienced a magmatic dike intrusion in 2009 with intense seismic activity (including a surface rupturing $\mathrm{Mw} 5.7$ earthquake). We use seismological data, recorded by the Saudi Geological Survey (SGS) that operates 45 broadband seismic stations. We analyze the continuous seismic waveform data provided by the SGS broadband stations to map the spatial and temporal distribution of seismicity in an effort to gain insights on the underlying physical processes that are responsible for this swarm. We use double-difference algorithm to determine the relative distances between earthquakes. The relocation results using both $\mathrm{P}$ - and $\mathrm{S}$ - phases greatly improve the earthquake locations. We identified 3 events clusters, each at a different depth level. These clusters are concentrated within a well-definedrock volume of roughly $10 \mathrm{~km} 3$. The dominant cluster of these events is shallow ( $4-8 \mathrm{~km}$ depth). The deepest cluster includes events occur as deep as $16 \mathrm{~km}$. The results may reveal an image of the NW-SE Najd fault system (a complex set of strike-slip faults and shear zones across the Precambrian of Arabia). Using the well-relocated events, we assemble the body wave arrival times that are inverted for the local velocity and attenuation models. The focalmechanism solutions of the largest earthquakes ( $\geq \mathrm{Ml} 2.0$ ) vary widely, indicative of a highly fractured complex fault system and without a clear correlation to the regional stress field of Red Sea. This observation is in agreement with the complex local tectonics of the shear system which accommodates the swarm sequence.

Focal Mechanism of the 5.1 Mw 2014 Lloja Earthquake, Bolivia: Fobing the Transition Between Extensional Stresses of the Central Altipla. n and Compressional Stresses of the Sub-Andes

FERNANDEZ, A. M., Observatorio San Calixto-La Pa Bo 'ivia, La Paz, Bolivia, tonino.gafm@gmail.com; ASSUMPÇĀO, M., Geophy ics D vartment, University of São Paulo, São Paulo, Brazil, marcelo@ia unn br; CIARDELLI, C., Geophysics Department, University of São Paulo, São n ylo., Brazil, marcelo@iag.usp.br; NIETO, M., Observatorio San colix , La Paz, Bolivia, mnieto@osc.org.bo

On 1st October 2014 a $5.1 \mathrm{Mw}$ shallow earthquak curred near Lloja town in the central Andes (altitude $3000 \mathrm{~m}$ ) wb 20 rustal tresses change from extensional in the high plateau to compress onal in the sut Andean lowlands. Besides its interesting tectonic setting, this $\mathrm{rtb}_{4} \mathrm{uake}$. also important because of potential seismic risk to urban aro like a Paz, only $65 \mathrm{~km}$ away. The epicenter was determined with the 1 -st $1 \mathrm{D} \mathrm{m}$, del . or this region of Bolivia using the closest local stations. The so tion is wit in a few $\mathrm{km}$ of the epicenter using a 3D model and the RSTT chn, we witl regional stations. These two epicenters are less than $5 \mathrm{~km}$ from the 6 GS 1 , tion but differ by more than $10 \mathrm{~km}$ from the IDC and ISC lo tions 1 wo ifferent focal mechanisms had been published: normal fault with strik ip component by USGS and a pure strike-slip solution by GCMT. P- 4 -wave larities from local and regional stations were used to show that the best lution is a normal fault with strike-slip component similar to the USG Cross-co elation of $\mathrm{P}$ and $\mathrm{S}$ waves of six small aftershocks (magnitudes fron 2.0 3.3) recorded at regional stations allowed accurate determination f relat e hyp centers. The aftershocks are aligned approximately along the $\mathrm{N}-\mathrm{S}$ a recin, uggesting that the NNE-SSW nodal plane is the fault. The afterhocks a locatud at less than $2 \mathrm{~km}$ from each other, consistent with the expected ruptus la gth of a $5.1 \mathrm{Mw}$ mainshock. No other focal mechanism was known in the Lloja region. In the sub-Andean lowlands, to the SE and NW of Lloja,
NE-SW compression predominates with mainly reverse faulting. In the western part of the Altiplano most events are normal and strike-slip faults with variable $T$ and $\mathrm{P}$ axis orientations. The Lloja mechanism is a normal fault with a large strikeslip component. The NE-SW P axis is consistent with the sub-Andean compression but the normal faulting component indicates that plateau spreading stresses are still present.

\section{Non-Linear Inversion of the Earthquake Source Spectrum Using a Seismic Cluster Method}

RIVERA, E., Departamento de Geología, Universidad de Chile, Chile, efrain@ dgf.uchile.cl; LEYTON, F., Centro Sismológico Nacional, Universidad de Chile, Chile, leyton@csn.uchile.cl; RUIZ, S., Departamento de Geofísica, Universidad de Chile, Chile, sruiz@dgf.uchile.cl; PRIETO, G. A., Departamento de Geociencias, Universidad Nacional de Colombia, Colombia, gaprietogo@unal. edu.co

We perform a non-linear inversion of the earthquake source spectrum, using a Neighborhood Algorithm implementation. Following the method used by Ko et al (2012), using sets of a clusters of nearby earthquakes, we assume that the outgoing seismic ray of each cluster travels by the same path to the each station that register it, as well as, imposing a single corner frequency per event. This method, unlike simple inversion methods, takes advantage of "multiple-earthquake multiple-station" redundancy, reducing the degrees of freedom in the inversion. The method was tested using a simple theoretical spectra and theoretical spectra with added noise, obtaining a better restriction for the parameters of attenuation ( $\mathrm{Q}$ value) and corner frequency ( $\mathrm{fc}$ ), compared to methods with individualearthquake fitting, besides inverting the spectrum decay (n). The aim of this work is apply the previously described method and obtained the source parameters, for the estimation of stress drop and energy radiated for the interplate seismicity occurred from 2008 to 2015, including the last earthquake of Iquique 2014 (Mw 8.1) and the intermediate-depth seismicity from 2011 to 2013, in Northern Chile. We will study the parameters obtained in order to relate the occurrence of a large subduction earthquake and the intraplate seismicity occurred before, looking for differences in both types of earthquakes and their temporal and spatial relationships.

\section{Stress Drop Investigation of $M>4$ Induced Earthquakes in Western Canada Using Empirical Green's Function Method}

HOLMGREN, I. M., Western University of Ontario, Ontario, Canada, jholmgr@uwo.ca; ATKINSON, G. M., Western University of Ontario, Ontario, Canada,gmatkinson@aol.com

Stress drop is an important ground-motion parameter as it controls the relative amount of high-frequency energy. We use the Empirical Green's function (EGF) method to determine the stress drops of three earthquakes in Alberta, Canada, linked to hydraulic fracturing, with moment magnitudes $(\mathrm{M})$ greater than 4 . The EGF method is based on taking the spectral ratio of the ground motions from the $\mathrm{M} \geq 4$ earthquakes to those of smaller collocated earthquakes; path and site effects cancel in the spectral division, leaving the source spectral ratio. To ensure the smaller earthquakes have similar focal mechanisms to the targeted earthquakes, cross-correlation is performed. The source spectra can then be fit to Brune's source model, and the corner frequencies and stress drops estimated for the three $M \geq 4$ events. Results from this study will be used to compare source properties of induced events in western Canada to those in other regions. The results will also be used to compare classic stress drop estimates with stress parameter values inferred from stochastic models of high-frequency ground motions.

\section{Study of the Earthquake of October 06, 2011. in Jujuy and Its Distribution of Aftershock}

LOPEZ, L., Instituto Nacional de Prevención Sísmica, San Juan, Argentina, llopez@inpres.gob.ar; SÁNCHEZ, G., Instituto Nacional de Prevención Sísmica, San Juan, Argentina, gsanchez@inpres.gob.ar; ARAUJO, M., Instituto Nacional de Prevención Sísmica, San Juan, Argentina, maraujo@inpres.gob.ar

The seismic deformation in the Andean retro arc zone is characterized by having compressive earthquakes at superficial and intermediate dephts. Examples of these are; the earthquakes of September 13, 1962 in Talavera del Esteco, Salta with a magnitude of 7,0 associated to a maximun intensity of IX in the Modified Mercalli Scale (IMM); the earthquakes of September 23, 1887 in the boundary between Argentina and Bolivia in the province of Salta with a maximun intensity in the Modified Mercalli Scale (IMM) of IX (INPRES, 2017) and the earthquake of January 16, 1944 in San Juan with an M=7,0 (Alvarado and Beck,2006). The aim of this job is to obtain a seismotectonic analysis of Jujuy earthquake on 6 October 2011, at 11:12 local time (14:12 UTC), with epicenter at about 100 $\mathrm{km}$ east of San Salvador de Jujuy city. This research includes an accurate determi- 
naton of its location parameters, focal mechanism and the aftershock sequence to have a better knowledge of the seismogenic source of this seismic event. The relocation of the hypocenters was carried out with software hypoDD (Walhauser, 2002) and the velocity model used in this process is the used for INPRES (Sánchez et al., 2013). The results obtained show improvements in the definition about the rupture zone due to the aftershock propagation and detection of active secundary seismic sources associated to the main fault. The results are compared with previous studies to understand the seismic surface deformation in the transition zone between thin-skinned deformation observed in the Bolivian Andes and the Basement deformation observed in Sierras Pampeanas (Jordan et al., 1983).

The 2016 Capellades Earthquake and Its Seismic Sequence: Expression of Strike-Slip Faulting in the Volcanic Arc of Costa Rica

LINKIMER, L., Universidad de Costa Rica, SJ, Costa Rica, lepolt.linkimer@ ucr.ac.cr; ARROYO, I. G., Universidad de Costa Rica, SJ, Costa Rica, ivonne. arroyo@ucr.ac.cr; SOTO, G. J., Universidad de Costa Rica, SJ, Costa Rica, gerardo.sotobonilla@ucr.ac.cr; PORRAS, J., Universidad de Costa Rica, SJ, Costa Rica, juan.porrasloria@ucr.ac.cr; ARAYA, M. C., Universidad de Costa Rica, SJ, Universidad de Costa Rica, mariacristina.araya@ucr.ac.cr; MORA, M. M., Universidad de Costa Rica, SJ, Costa Rica, mauricio.mora@ucr.ac.cr; TAYLOR, M., Universidad de Costa Rica, SJ, Costa Rica, magda.taylor@ucr. ac.cr

On 30 November 2016 at 18:25 (1stDecember at 00:25, UTC time) a Mw 5.5 earthquake occurred at $2.7 \mathrm{~km}$ depth near the town of Capellades de Alvarado, Costa Rica. It was the main shock of an earthquake sequence including foreshocks and aftershocks, located between the active volcanoes Irazú and Turrialba. This is the most recent of a series of damaging earthquakes originated in the faults crossing the Central Volcanic Range, which constitutes the northern boundary of the most populated area of the country. Using mainly the seismic records from the National Seismological Network (RSN), we present in this study a seismological analysis of the earthquake sequence and the location and characteristics of the fault that originated this seismicity. Additionally, we describe the geotectonic context of the fault and the Capellades earthquake effects. The earthquake sequence shows a clear $8-\mathrm{km}$ long alignment striking north-northwest between Irazú and Turrialba volcanoes. The joint interpretation of the earthquake relocation, the main-shock moment tensor solution, and the focal mechanisms of 17 events allows for determining the source in a nearly vertical strike-slip fault, in agreement with regional active fault systems. This structure had not been previously recognized and has been named Liebres Fault in this study. The main shock was felt in most of the country, with a maximum intensity of VI+. This earthquake has been the largest in the eastern part of the Central Volcanic Range since the 1952 Patillos earthquake (Ms 5.9) and the first $\mathrm{Mw} \geq 5.0$ earthquake recorded by the RSN in the Turrialba volcano edifice. Despite the proximity to this active volcano, which has been erupting periodically since 2010, there were no immediate eruptive effects.

\section{Small Effective Stress Drop of Hydraulic Induced Seismicity and Aseismic} Deformation

FISCHER, T. J., Charles University, Faculty of Science, Czechia, fischer@natur. cuni.cz; HAINZL, S., German Centre of Geosciences GFZ Potsdam, Germany, hainzl@gfz-potsdam.de

The concept of effective stress drop of a seismic sequence is based on the cumulative seismic moment and area activated by seismic ruptures. The analysis of endmember cases of clustered seismicity shows that the estimated effective stress drop of a cluster is only in agreement with the stress drop of a single event rupturing the same area if no aseismic deformation takes place and rerupturing of asperities occurs during the sequence. The evolution of the cumulative seismic moment release as function of the cluster radius can be used to discriminate different processes: the exponent of seismic moment scaling with radius indicates if the ruptured area is uniformly loaded or whether external loading takes place. Our analysis of 13 sequences ranging from injection-induced activity to natural swarm and aftershock activity shows standard cubic scaling of the total seismic moment in most cases. Slightly higher exponents in the case of injection-induced sequences are indicative of the ongoing local forcing related to the massive fluid injections during the cluster evolution, while lower exponents down to 1 in the case of creeping events might be related to a decreasing/fractal asperity density. Three seismicity groups can be distinguished: a normal-stress-drop group of geothermal injections, swarms and mainshock-aftershock sequences, a lowstress-drop group of shale and gas fracking, and the very low-stress-drop case of creeping events. The small effective stress drop can be interpreted by small shear modulus of the rocks, or alternatively, by a large portion of creep in the total slip. Then the seismic events with normal static stress drop would account only for a small portion of deformation. This is probably the case of hydraulic fracturing.
Considering the rigidity of sands and shales is of the same order as of other types of rocks, it appears that during hydraulic fracturing of these formations a high portion of strain is released aseismically.

Understanding the Source Fault of the 5 April 2017 Earthquake Sequence near Mashhad, Iran, Using Regional Moment Tensor Analysis

GRAYBEAL, D. B., University of South Florida, Florida, USA, dbgraybeal@ mail.usf.edu; BRAUNMILLER, J., University of South Florida, Florida, USA, jbraunmiller@usf.edu

Iran, located at the center of the Arabia-Eurasia continental collision, is tectonically complex and high in seismic activity, with five earthquakes of magnitude Mw6 or larger in the country in 2017 alone. One of these is the Mw6.1 earthquake on 5 April 2017 that shook Mashhad, the second largest city in Iran with a population of more than 3 million people, and the surrounding region in northeastern Iran, causing severe damage and killing at least two people. As part of a regional moment tensor catalog for $\mathrm{Mw} \geq 4.0$ earthquakes in Iran, seismic data from the mainshock and 21 aftershocks were examined. Seven well-constrained moment tensors and centroid depths were resolved; these show shallow, principally reverse faulting in the upper $\sim 10 \mathrm{~km}$ of the crust with NNE-oriented P-axes consistent with the direction and low rates inferred from GPS data. We combine these moment tensors with afterchock relocations and other geologic data to constrain the source fault of the earthquake sequence to understand the seismic hazard implications for Mashhad, located less than $100 \mathrm{~km}$ northwest of the epicenter region. Temporal Stress Drop Variation of Microearthquakes Potentially Induced by
Highly Pressurized Fluid Observed in the 2009 Hakone Volcano, Japan

KIM, A., Yokohama City University, Kanagawa, Japan, ahyik@yokohama-cu. ac.jp; YUKUTAKE, Y., Hot Spring Research Institute of Kanagawa Prefecture, Kanagawa, Japan, yukutake@onken.odawara.kanagawa.jp; FUJIOKA, M., Yokohama City University, Kanagawa, Japan, ahyik@yokohama-cu.ac.jp

It has been widely accepted that increase of pore pressure due to inflow of fluid into the fault zone trigger earthquakes. One of the direct evidences of the effect is earthquake triggered by controlled fluid injection. Source parameters of such seismicity have been intensively studied to understand its source process and to control the injection. On the other hand, although it has been noticed that many of natural earthquake swarms were possibly triggered by fluid flow, only a few stress drop studies has been done. This is mainly due to band-limitation of available data since those earthquakes are generally weak $(M<3)$. Studying their source parameters and comparing with those of other tectonic and controlled injection seismicities are important to understand the mechanism of the swarms and future disaster mitigation. In this study, we investigated the stress drop of 53 microearthquakes $(1.6<\mathrm{Mw}<3.2)$ recorded by $200 \mathrm{~Hz}$ sampled local seismic network during 2008 swarm sequence in the Hakone volcanic area, Japan. Those events are potentially induced by highly pressurized fluid supplied from underground. Although median of the resultant stress drop is comparable with that of the global tectonic earthquakes, significant temporal variation is observed throughout the swarm sequence. The notable feature is that 1) lower stress drop was observed at the initial stage and it gradually increased as time progresses and 2) after the occurrence of the largest event, stress drop decreased and the feature observed at initial stage is disappeared. The b-value analysis indicates the difference of the triggering process at initial and later stage of the swarm sequence: the fluid plays important role at only the initial stage and other factors (e.g. stress fluctuation caused by occurrence of other earthquakes) dominate earthquake triggering at later stage.

Intraplate Stress Field in South America Derived from Earthquake Focal
Mechanisms
DIAS,F.L., Observatorio Nacional (MCTI), Rio de Janeiro, Brazil, fabioludias@
gmail.com; ASSUMPÇÃO, M., University of São Paulo, São Paulo, Brazil, gmail.com; ASSUM

We present an updated compilation of earthquake focal mechanisms (FM) in Brazil together with the sub-Andean region through more obtained solutions together with published results from the literature and international agencies catalogs. Stress orientations from breakouts and in-situ measurements were also compiled. For Brazil, we have 88 earthquakes with the FM determined since 1978. They show reverse, strike-slip and normal faulting while events in the subAndean region have reverse (majority) or strike-slip FM. For sub-Andean region have reverse (majority) or strike-slip FM. Normal FM can be found only in high attitudes. The FM were grouped by proximity to be inverted for the stress tensor. In SE Brazil and the Chaco-Pantanal basins, S1 tends to be oriented roughly E-W with $S 2$ approximately equal to $S 3$. This stress pattern changes to purely compres- 
sional in the São Francisco craton. A rotation of SHmax from E-W to SE-NW is suggested towards the Amazon region. Along the Atlantic margin, the regional stresses are affected by coastal effects. This coastal effect tends to make SHmax parallel to the coastline and Shmin (usually S3) perpendicular to the coastline. Breakout data and in-situ measurements are available are generally consistent with the pattern derived from the FM. In the sub-Andean region, the intermediate principal stress (S2) is also compressional, a feature that is not always reproduced in numerical models published in the literature. In mid-plate South America stresses seem to vary in nature and orientation. Although numerical models of global lithospheric stresses tend to reproduce the main large-scale features in most mid-plate areas, the S1 rotation from E-W in SE Brazil to SE-NW in the Amazon region are not well explained by the current numerical models. This means that the observed stress pattern in mid-plate South America should provide new insights into upper mantle dynamics, distinct from current global convection models.

Determination of Focal Mechanisms and Depths of Small Magnitude Local and Regional Earthquakes Recorded by a Sparse Seismic Network DAHAL, N. R., Boston College, Massachusetts, USA, dahaln@bc.edu; EBEL, J. E., Boston College, Massachusetts, USA, ebel@bc.edu

Determination of precise focal mechanisms and depths of small magnitude earthquakes using regional network stations is important in order to understand earthquake source processes and seismic hazard. We present a technique that can accurately determine focal mechanisms and depths of small magnitude earthquakes $(2.5<\mathrm{M}<4)$ using only a few regional seismic stations. We filter observed seismograms as well as synthetic seismograms through the frequency band of 1-3 $\mathrm{Hz}$, which has a good signal-to-noise ratio (SNR) for the small earthquakes of the magnitude that we are working with. The waveforms are processed to their envelopes in order to make the waveforms relatively simple for the modeling. We have tested the method on 17 aftershocks of modified duration magnitude $\left(\mathrm{MD}^{*}\right)$ between 3.6 and 2.5 and 1 aftershock of magnitude Mw 3.14 of the 2011 Mineral Virginia Mw5.7 earthquake. We have also tested the method on 5 aftershocks of 2013 Ladysmith, Quebec earthquake of magnitudes between Mn 2.8 and Mn 3.7. Our focal mechanisms and depths are consistent with the focal mechanisms and depths that were previously reported for these events computed using data from a deployment of portable seismic stations deployed after the mainshock for Mineral Virginia Aftershocks and our depths are consistent with the depths computed using Regional Depth Phase Modeling (RDPM) Technique for the aftershocks of Ladysmith Quebec earthquake. This study confirms that the envelopes of the seismic waveforms can be used to extract the focal mechanisms and focal depths of an earthquake as low as M2.5 using only a few regional seismic network stations at epicentral distances of $200-500 \mathrm{~km}$. Our method is extremely useful for determining accurate focal mechanisms and depths of small magnitude events in areas where the regional seismic network coverage is sparse.

Co-Seismic Slip Distribution Inversion Applied to the Mutata Earthquake, Colombia

NARANJO, D. F., Universidad de Los Andes, Colombia, df.naranjo10@ uniandes.edu.co; TARY, J. B., Universidad de los Andes, Colombia, jbtary@ gmail.com

Colombia is located on the South American plate with two zones of subductions, one to the west on the Pacific side (Nazca plate), and one to the North on the Caribbean side (Caribbean plate). This leads to the presence to large and complex fault system within Colombia. On September 14, 2016, a Mw 6.0 earthquake occurred in Northwestern Colombia on the Uramita fault close to Mutata at a depth of approximately $18 \mathrm{~km}$. The moment tensor calculated by the USGS for this event shows a thrust fault focal mechanism with a fault plane dipping at $35^{\circ}$ and a small right-lateral component. Interestingly, the moment tensor decomposition shows a double couple component of only $55 \%$. This event is both one of the most superficial and one of the strongest seismic events that occurred in Colombia since the installation of the national seismological network (RSNC) in 1993. In this work, we invert for the slip distribution on the fault plane for this seismic event using a combination of broad-band and near-field data provided by the USGS and the RSNC. We first choose the fault plane using the moment tensor and the information on the fault system available. The fault plane is then divided in a number of rectangular sub-faults in order to calculate the contributions of slip from each patch in the source region. To solve the slip inversion, we finally use the multiple shock sequence method with a least-squares fit. The slip distribution is also compared with the aftershocks distribution in order to investigate their coseismic triggering by the mainshock. Very few earthquakes from Colombia were studied in order to determine their slip distribution. This study is then a first step toward a better understanding of their complex rupture, and to better estimate seismic hazards in the region.
Inversion of S-Coda and P-Coda for the Prospection of Mud Diapirs in the Sinú Belt, Colombia

SUAREZ CARVAJAL, C. F., Universidad Nacional de Colombia, Bogotá, Colombia, cfsuarezc@unal.edu.co; VARGAS JIMENEZ, C. A., Universidad Nacional de Colombia, Bogotá, Colombia, cavargasj@unal.edu.co

The diapirism process in Colombia has generated the mud volcanoes in the Sinú Belt, which extends from the Urabá Gulf to the Barranquilla region, including land and marine areas. Most of these events have been associated with the presence of faults that have allowed the mud to rise to the surface. The implementation of an inversion scheme of the S-coda and P-coda waves was proposed in order to estimate the non-homogeneous spatial distribution of the scattering and attenuation coefficients and their relationship with the structures that originate the mud volcanism and thus quantify and characterize the terrestrial medium, allowing to make a structural analysis in the Sinú belt and establish the recurrence of these volcanic events associated with seismicity. The approach proposed in this work shows promising results in the characterization of temporal variations of volcanic structures due to its greater sensitivity to small changes than the direct waves-based analysis of velocity or attenuation.

\section{Earthquake Source Mechanisms and Their Characteristics in the Dominican Republic}

LEONEL, C. J. M., Centro Nacional de Sismologia, Universidad Autonoma de Santo Domingo, Santo Domingo/D.N., Dominican Republic, jleonel78@uasd. edu.do; POLANCO RIVERA, E., Centro Nacional de Sismologia, Universidad Autonoma de Santo Domingo, Santo Domingo/D.N., Dominican Republic, eugenio_polanco_rivera@msn.com; MEJIA, H. P., Baylor University, Texas, USA, jay_pulliam@baylor.edu; PULLIAM, J., Baylor University, Texas, USA, jay_pulliam@baylor.edu; HUERFANO, V. A., University of Puerto Rico at Mayagüez, Puerto Rico, USA, victor@prsnmail.uprm.edu; MARTINEZ, F., Centro Nacional de Sismologia, Universidad Autonoma de Santo Domingo, Santo Domingo/D.N., Dominican Republic, fmartinez51@uasd.edu.do

The island of Hispaniola, of which the Dominican Republic (DR) comprises the eastern two-thirds, is subject to a complex array of tectonic stresses. The southward-dipping North American tectonic plate is subducting obliquely under the Caribbean plate in the north, two significant transform fault systems transect the island from east to west, and the island is believed to have accreted from at least three distinct terranes through transform and convergent motions. Further, the Dominican Republic is the site of dramatic topography, from a broad, flat but uplifted plain in the east to the highest mountains in the Caribbean. These features are largely the result of offsets that were accompanied by earthquakes and the historical record contains numerous descriptions of devastating events. However, in the modern, instrumented era the frequency of large earthquakes has been fairly low, which has made it difficult to characterize of the range of potential earthquake sources. The Centro Nacional de Sismologia (CNS), an organized research unit of the Autonomous University of Santo Domingo, is tasked with maintaining the network, analyzing its data, and compiling a comprehensive earthquake catalog. With the current network, which was expanded in 2013, approximately one thousand earthquakes per year are recorded and located in the DR with magnitudes between 2 and 6 . We will present the focal mechanisms of $\sim 146$ earthquakes with magnitude 4 or greater recorded by ten or more stations since 2013. (The largest event to have occurred within the borders of the DR since 2013 is a magnitude 5.8.) Mechanisms, determined with first motion polarities and S/P amplitude ratios, for events with focal depths in the shallow to mid-crust share properties that correspond to surface tectonics but a set of intermediate-depth events beneath the eastern DR and the Mona Passage show a greater variety.

\section{A Unified Earthquake Catalog in the Caucasus}

GOK, R., Lawrence Livermore National Laboratory, California, USA, gok1@ Ilnl.gov; GODOLADZE, T., Illia State University, Georgia, tea_godoladze@ iliauni.edu.ge; ONUR, T., Onur and Seemann Consulting, tuna@onurseemann. com; YETIRMISHLI, T., Republic Seismic Survey Center, Azerbaijan, gyetirmishli@gmail.com

As a result of collaboration between Lawrence Livermore National Laboratory (LLNL) andIlliaState University Seismic Monitoring Center of Georgia, a comprehensive earthquake catalog was compiled for the Caucasus and neighboring areas as part of a broader probabilistic seismic hazard assessment (PSHA) project. Instrumental seismic observation in the Caucasus began in 1899, when the first seismograph was installed in Tbilisi, Georgia. Seismic network in the Caucasus region improved significantly during Soviet times, however much of this analog data is preserved in paper archives. Digital era further improved the ability to collect and archive data. As of today, more than hundred broad-band seismic sta- 
tions (including IRIS/PASSCAL temporary array) is in operation. In addition, paper bulletins of 15,000 earthquakes were digitized, merged and compiled collectively throughout several workshops. Participant countries in the Caucasus provided both analog and digital data for events with magnitudes 3.7 and above. Data was archived in a web-based database, specifically designed for this project and made accessible to the project participants. The whole catalog represents 118 years of seismic monitoring in the Caucasus, bringing together all the available datasets, and generating the most complete catalog in the region, temporally and geographically. In addition to the compilation of this significant dataset, a careful re-analysis of magnitude and relocation calculations was undertaken. Moment magnitude solutions based on waveform modeling and coda calibration technique were calculated where quality of the available data allowed it. For contemporary PSHA, Mw is the preferred magnitude scale. For many of the events in the compiled catalog, more than one solution is available. In this case, directly calculated moment magnitudes $(\mathrm{Mw})$ were favored, followed bymb and the derived magnitude data from Soviet magnitude scales e.g. K, MLH, MPV.

Relocation of the Aftershock Sequence of the 1982 Miramichi, New Brunswick, Canada, Mb 5.7 Earthquake

MA, S. M., Carleton University, Ontario, Canada, shutian33@yahoo.ca; MOTAZEDIAN, D. M., Carleton University, Ontario, Canada, dariush. motazedian@carleton.ca

On 9 January 1982 a strong earthquake with mb 5.7 occurred in Marimichi region, New Brunswick, Canada. It was followed by an extensive aftershock sequence. As the seismic stations were not well deployed the aftershocks were not well located. On 23 January a seismic station (KLN) about $20 \mathrm{~km}$ east of the earthquake sequence was deployed. Since then aftershocks were well registered at this station. The other two existing regional seismic stations, EBN and GGN, also have seismogram records, which are strong enough to be used for location program operation. Theoretically three arrival time readings of a P, S, or Pn phase at three different stations could be used to determine the epicenter and the origin when the focal depth solution is available or assigned a default value. The arrival times of the Pg and $\mathrm{Sg}$ at station KLN, the arrival time of the Pg at EBN, and the arrival time of the Pn phase at GGN were used to determine the epicenter and the origin for 67 aftershocks at the focal depth retrieved previously. Due to the observed arrival times of $\mathrm{Pg}$ and $\mathrm{Sg}$ at the same three stations were used for each aftershock, the errors in the relocated epicenters are consistent. As such the distribution pattern of the epicenters is reliable. The epicenter distribution trend is at a north-east direction, meaning that the faulting in the epicenter region is at a north-east direction, consistent with the topographic trend in that region.

Source Parameter Variability of Intermediate-Depth Earthquakes in Japan Estimated from Empirical Green's Functions

CHU, S. A., Stanford University, California, USA, schu3@stanford.edu; BEROZA, G. C., Stanford University, California, USA, beroza@stanford.edu; ELLSWORTH, W. L., Stanford University, California, USA, wellsworth@ stanford.edu

The mechanism of intermediate-depth earthquakes occurring within subducting slabs remains controversial. Two proposed mechanisms for these earthquakes are dehydration embrittlement and thermal shear instability. By analyzing the stress drops and radiated energies determined from the recorded waveforms of these earthquakes, we can constrain the radiated efficiencies of the events and hence determine to what degree the mechanisms causing them are dissipative. We use the method of empirical Green's functions (eGfs) and spectral ratios to obtain stress drops for moderate to large (M4.0 and greater) intermediate-depth earthquakes since 2006 in the Kyushu and Hokkaido regions of Japan using data from the Hi-Net, F-Net, and Kiban seismic networks. With events at intermediate depth, the quality of small events usable as eGfs is a major limiting factor of the spectral ratio method. We examine the robustness of stress drop estimates determined from different source models, varying falloff rate and number of corner frequencies to better constrain the uncertainty in these estimates. We also look at the effects of near-source heterogeneities on the eGf waveforms, as in practice the data for intermediate-depth earthquakes often does not allow us to select smaller events within one source radius of the larger event. We are able to constrain the source parameters for the larger events, and can place bounds on them for the smaller events. The two loci of intermediate-depth earthquake activity differ in the character of the subducting plate, in that the Kyushu events occur in a plate that is younger and warmer. While we find generally larger stress drops and lower radiated efficiencies than shallow events in both regions, the difference is not as marked as has been found in previous studies of regions with anomalously high intermediate-depth activity, such as the Bucaramanga Nest in Colombia.
Earthquake Source Parameters for Chilean Events for Use in the NGASubduction Project

CONTRERAS, V., UC Los Angeles, California, USA, vcontreras@ucla. edu; STEWART, J. P., UC Los Angeles, California, USA, jstewart@seas.ucla. edu; DARRAGH, R. B., Pacific Engineering and Analysis, California, USA, pacificengineering@juno.com; KISHIDA, T., tadahiro.kishida@kustar.ac.ae, California, USA, tkishida@berkeley.edu; YOUNGS, R., Wood plc, California, USA, bob.youngs@woodplc.com

The NGA-Subduction project is currently under development, focusing on analyzing the collected data for different regions affected by subduction-zone earthquakes around the world. As part of this effort, an earthquake-source database has been developed for events with ground motion recordings obtained in Chilean territory. Data from the South American subduction zone, and particularly from Chilean earthquakes, are critical for the success of this project, due to the availability of data from many large $(M \geq 7.5)$ interface subduction events and the importance of significant regional path effects previously observed in Chile but not evident elsewhere. The source database contains information on seismic moment, moment magnitude, hypocenter location, nodal planes, and fine-fault geometric parameters. More than 40 different finite-fault models have been collected and evaluated, introducing a uniform and consistent procedure for fault trimming, where only the trimmed portion of the fault plane with significant slip is used for source-to-site distance calculations. For events that lack published finite-fault models, uniform protocols are applied to assign the source parameters and a simulation-based representation of the finite-fault parameters is used for distance calculation. To support the use of these simulations for subduction-zone earthquakes, relationships for M-rupture area, $\mathrm{M}$-aspect ratio, and hypocenter locations in the down-dip and along-strike directions are developed.

\section{Stress Processes and Their Relation to the Tectonic Environment}

ZUNIGA, F. R., Universidad Nacional Autónoma de México, Centro de Geociencias, Querétaro, Mexico, ramon@geociencias.unam.mx; RODRIGUEZPEREZ, Q., CONACYT and Centro de Geociencias, Universidad Nacional Autónoma de México, Querétaro, Mexico, quetza@geociencias.unam.mx; MÁRQUEZ-RAMÍREZ, V. H., Universidad Nacional Autónoma de México, Centro de Geociencias, Querétaro, Mexico, marvh@geociencias.unam.mx

We have compiled a thorough database of earthquake source parameters for seismic events occurring in Mexico, obtained by means of two different methods: finite-fault slip inversions and spectral analysis. From this compilation we employed stress drop and apparent stress values calculated for three (subduction, strike-slip, and deep intra-plate) tectonic environments and compared the results of employing a formulation, which allows investigating the difference between average final stress and frictional stress (a quantity which has been referred to as "shoot stress"). By analyzing these results we want to discern if Orowan's model is obeyed by events occurring ina particular tectonic environment. Comparing all three types we observed that subduction events are the ones, which more closely follow Orowan's model. Strike-slip events are not too far apart from this condition. Deep intra-plate events, on the other hand, depart further from this model. We also calculated the partial stress drop ratio (e), which is the ratio between the static stress drop and the average dynamic stress drop (Brune, 1976), since Orowan's model would predict an e ratio equal to one. We found that in the case of subduction events, e ratios mostly indicate a partial stress drop process while intraplate and strike-slip events show a mixture of both partial and overshoot stress processes. We also notice that the e ratios for intraplate events have an apparent dependence on magnitude, which is not seen for the other two types of events. If the e ratio is close to 2 (maximum overshoot), it would indicate that the average frictional stress is equal to the "average" stress. In our study, some events are close to this condition, for the three types analyzed. It is important to emphasize that all these estimates are highly compromised by uncertainties in the estimation of energy, moment and static stress drop, but it is useful to attempt to make inferences as those above which can help differentiate between probable variations in source processes acting at different tectonic environments, depth, etc.

\section{Spectral Analysis of Earthquakes with Hypocenter in Basin of Mexico}

RAMÍREZ, J. E., National Polytechnic Institute, Mexico, jelihu.ramirez@ gmail.com; BELLO, D. I., National Autonomus University of Mexico, CDMX, Mexico, iresinedel23@gmail.com

We present attenuation $\left(\mathrm{t}^{*}\right)$ and source parameters $(\Delta \sigma \mathrm{y} \mathrm{Mw})$, obtained through spectral analysis, for earthquakes with hypocenter within the basin of Mexico. These events were recorded by the Red Sísmica del Valle de México (RSVM, Valley of Mexico Seismological Network), composed of 31 broadband stations distributed in Mexico City and surroundings. We analyze events from 2013 to 
2016, and selected five with the objective to compare $\mathrm{t}^{*}, \Delta \sigma \mathrm{y} \mathrm{Mw}$ and look for spatial variations within the basin. Based on a Brune's model spectrum, we analyze all the easily-distinguishable $S$ wave recorded on the horizontal components (N-S and $\mathrm{E}-\mathrm{W})$. Large part of the basin is in an old dry lake. This fact makes it complicated and heterogenous. By studying $\mathrm{t}^{*}$ and $\Delta \sigma$, we can characterize the basin.

Estimating Source Time Functions Using Empirical Green's Function Methods in the Presence of Noise

GALLEGOS, A. C., Air Force Research Laboratory, New Mexico, USA, drestar63@gmail.com; XIE, J., Air Force Research Laboratory, New Mexico, USA,jiakang.xie@gmail.com

In prior work, we studied the reliability of two approaches to extract Source Time Functions (STFs): the traditional Empirical Green's Function (EGF) approach (Hartzell 1978), which ignores the small STF duration, and the Multi-Channel Deconvolution (MCD) approach (Plourde \& Bostock 2017). The analysis used synthetic waveforms made by convolving a realistic Green's function waveform with finite-duration STF pairs. Convolutions are implemented using Toeplitz matrices and STFs are solved for via convex optimization. For EGF, we concluded that while a reasonable large event STF solution can be found via regularization, its duration and shape vary with the subjective choice of damping parameter. The only uniquely obtained information is the differential duration and moment ratio between large and small STFs. For MCD, we found that the inverse problem tends to suffer from instability that violates the discrete Picard Condition. We sought an approximate solution using 1stor 2nd-order Tikhonov regularization. Testing both, we developed a procedure to ascertain an appropriate damping and STF duration based on L-curves. These were used to successfully find accurate solutions using either regularization. In this work, we extend the tests to synthetics containing realistic noise to see its effects. We set the SNR at 4 and bandpass the waveforms between $0.1-3.5 \mathrm{~Hz}$. For EGF, we find noise sometimes causes an underestimation of differential duration. Noise also causes bias to the large STF solutions, e.g. erroneous extra pulses and asymmetry. For MCD, we apply our developed procedure with 1st and 2nd-order Tikhonov. We find that noise slightly complicates our process for finding damping and duration. However, we are still able to find solutions that are reasonably close to the true STF. We note that for noisy synthetics the performance of 1 st and 2nd-order regularization visually varies from case to case, allowing us to select the final solution using the optimal regularization.

\section{The 8th September Mw8.2 Tehuantepec and 19th September Mw7.1 Puebla-Morelos, Mexico Earthquakes: Reconnaissance Findings and Impact on Urban Areas in South-Central Mexico \\ Poster Session · Thursday 17 May · Riverfront South}

Initial Aftershock Locations of the September 2017 Tehuantepec, Mexico, ( $m=8.2)$ Earthquake from a Temporary Seismic Network

VELASCO, A. A., University of Texas El Paso, Texas, USA, aavelasco@utep. edu; KARPLUS, M., University of Texas El Paso, Texas, USA, mkarplus@utep. edu; ORNELAS, O., Universidad Autonoma Cuidad Juarez, Cuidad Juarez, Mexico, oornelas@uacj.mx; GONZALEZ-HUIZAR, H., University of Texas at El Paso, Texas, USA, hectorg@miners.utep.edu; HUSKER, A. L., National Autonomous University of Mexico, Mexico City, DF, Mexico, allen@igeofisica. unam.mx; PÉREZ-CAMPOS, X., National Autonomous University of Mexico, Mexico City, DF, Mexico, xyoli@geofisica.unam.mx; AYALA, S., University of Texas El Paso, Texas, USA, sayalacortez@miners.utep.edu

The September 7 Tehuantepec, Mexico (M=8.2) and the September 19 MorelosPuebla, Mexico $(M=7.1)$ earthquakes ruptured with extensional faulting within the Cocos Plate at $\sim 70-\mathrm{km}$ and $\sim 50-\mathrm{km}$ depth, respectively, as it subducts beneath the continental North American Plate. Both earthquakes caused significant damage and loss of life. These events were followed by a $\mathrm{M}=6.1$ extensional earthquake at only $\sim 10-\mathrm{km}$ depth in Oaxaca on September 23, 2017. Many questions remain about these earthquakes, including: Did the Cocos Plate earthquakes load the upper plate, and could they possibly trigger an equal or larger earthquake on the plate interface? Are these the result of plate bending? Do the aftershocks migrate to the locked zone in the subduction zone? Why did the intermediate depth earthquakes create so much damage? Are these earthquakes linked by dynamic stresses? Is it possible that a potential slow-slip event triggered both events? To address some of these questions, we deployed 10 broadband seismometers near the epicenter of the Tehuantepec, Mexico earthquake and 51 UTEP-owned nodes (5-Hz, 3-component geophones) to record aftershocks and augment temporary and permanent networks deployed by the Universidad Nacional Autónoma de México (UNAM). The 10 broadband instruments were in place in early Oct. 2017 and will be deployed for 6 months, while the nodes were deployed 25 days. Using data from our temporary network for the first several months of the deployment plus UNAM permanent stations from this same time window, we build an initial database of automated detections and locations of the aftershocks, using detection and association parameters optimized for local seismic networks. Our initial analysis will allow us to investigate fault geometries from the aftershock locations, and in the future, will allow for the analysis of stress release and orientation from the determination of fault plane solutions, plus site effects and characteristics in regions of extensive damage.

\section{Macroseismic Intensities from the Puebla-Morelos Earthquake of 19 September 2017 (Mw 7.1)}

MONTALVO-ARRIETA, J. C., Universidad Autonoma de Nuevo Leon, Nuevo León, Mexico, jmontalvoa87@gmail.com; PÉREZ-CAMPOS, X., Universidad Nacional Autónoma de México, Mexico City, México, xyoli@geofisica.unam. mx; RAMÍREZ-GUZMÁN, L., Universidad Nacional Autónoma de México, Mexico City, México, Iramirezg@iingen.unam.mx; SOSA-RAMIREZ, R. L., Universidad Autonoma de Nuevo Leon, Nuevo León, Mexico, rociososarmz@ gmail.com

In this work, we present an analysis of the macroseismic intensity map obtained from ¿Sintió un sismo? (Did you feel it?), from 19 September Mw7.1 PueblaMorelos earthquake using the correlation with VS30 site classification. We also obtain the relationship between instrumental PGA, PGV and MMI. The Puebla-Morelos earthquake originated $120 \mathrm{~km}$ from Mexico City and was felt in central - southern Mexico; approximately 24.7 million inhabitants distributed in several states felt this earthquake. This intraplate earthquake occurred at a depth of $57 \mathrm{~km}$ in the subduction of the Cocos plate under the North America plate, with a normal fault mechanism. We received 5220 surveys, distributed in 2397 zip codes from 19 different Mexican states, through the web site ¿Sintió un sismo? The methodology used to generate the Community Internet Intensity (CII) is based on the "Did you feel it?" program. Central Mexico is the area with more damage and injuries reported, which are correlated to the maximum MMI reported of VI to IX. Most of the CII surveys are from the main cities in the region where Internet coverture was better, immediately after the occurrence of the strong earthquake. The narrow band where 46 buildings collapsed in Mexico City was correlated with intensities of IX. Far from the epicentral area, in the southern portion of Mexico, there are several regions with intensities ranges of $\mathrm{V}-$ VIII. The ground shaking in these places was correlated with the presence of soft sediments with VS30 values ranging between 180 to $360 \mathrm{~m} / \mathrm{s}$, located along some major river valleys, in the mouth of the main rivers of southern Mexico, and at both coastal regions, the Gulf of Mexico and the Pacific Ocean,. The relationship between instrumental PGA and PGV and MMI obtained in this study can be taken as the first step to the generation of maps of estimated shaking intensities within few minutes after the occurrence of an earthquake based on the recorded peak motions as in ShakeMap.

\section{Remotely-Triggered Slip in Mexico City Induced by the September 2017} Mw7.1 Puebla Earthquake.

SOLANO-ROJAS, D., University of Miami, Florida, USA, dsolano@rsmas. miami.edu; HAVAZLI, E., University of Miami, Florida, USA, ehavazli@rsmas. miami.edu; CABRAL-CANO, E., Universidad Nacional Autónoma de México, Mexico City, Mexico, ecabral@geofisica.unam.mx; WDOWISNKI, S., Florida International University, Florida, USA, swdowins@ @iu.edu

The September 19th, 2017 Puebla earthquake caused life loss and severe property damage in Mexico City, even though the epicenter was located $\sim 100 \mathrm{~km}$ away from the city. Mexico City is built on a thick clay-rich sedimentary sequence and, hence, is susceptible to land subsidence (at rates as high as $350 \mathrm{~mm} / \mathrm{yr}$ ), surface faulting, and seismic acceleration during earthquakes. The earthquake damage in the eastern part of the city, characterized by the collapse of several buildings, can be explained by seismic amplification. However, the damage in the southern part of the city, characterized by the collapse of small houses and surface faulting, requires a different explanation. We present here geodetic observations suggesting that the surface faulting in Mexico City triggered by the Puebla earthquake occurred in areas already experiencing differential displacements. Our study is based on Sentinel-1 A satellite data from before and after the earthquake. We process the data using Interferometric Synthetic Aperture Radar (InSAR) to produce a coseismic interferogram. The results of our analysis reveal the locations and patterns of coseismic phase discontinuities, mainly in the piedmont of the Sierra de Santa Catarina, which agree with the location of earthquake's damage reported by official and unofficial sources (GCDMX, 2017; OSM, 2017), the location of preexisting, subsidence-related faults (GCDMX, 2017), and differen- 
tial displacements identified using a Fast Fourier Transform residual technique on high-resolution InSAR results from 2012 (Solano-Rojas et. al, 2017). We propose that the seismic energy released by the 2017 Puebla earthquake induced fast soil consolidation, which remotely triggered slip on the preexisting subsidencerelated faults. The slip observed during this earthquake represents a hazard that needs to be considered in future urban development plans of Mexico City.

\section{Analysis of the Alpha Combination Rules in the Seismic Response of Typical Buildings in Mexico City}

SÁNCHEZ, J., Instituto de Ingeniería, Distrito Federal, Mexico, jsanchezs@ ingen.unam.mx; RAMÍREZ-GUZMÁN, L., Instituto de Ingeniería, Distrito Federal, Mexico, Iramirezg@iingen.unam.mx

Mexico City's building code considers rules to include the bidirectional building response in the design process. The so-called $\alpha$ combination rules account for the impact of $100 \%$ and $\alpha$ times the ground motion acting in orthogonal directions. Thus, it allows estimating the forces a structure will resist. Here, based on fully $3 \mathrm{D}$ ground motion simulations including the soil-structure interaction, we present a preliminary analysis of the uncertainty in the $\alpha$ parameter in soft soil deposits in Mexico City. The study is performed for a typical structure located in the Lake zone coupled with a realistic velocity model of the basin and a detailed model of the building. The seismic wave propagation and the building response is performed using the Finite Element Method for eight scenarios, mostly subduction earthquakes. We observe that differences in the optimal $\alpha$ parameter estimated per simulation are not adequate to establish a preferred value.

\section{Spatial Distribution of Site Response and Building Damage in Mexico City} Resulting from the September 19, 2017, M7.1 Central Mexico Earthquake

PONTRELLI, M. A., Tufts University, Massachusetts, USA, marshall. pontrelli@tufts.edu; BAISE, L. G., Tufts University, Massachusetts, USA, laurie.baise@tufts.edu

Since the 1985 Michoacan Earthquake, the soft, high water content clays filling the lakebed of Lake Texcoco are known to exhibit resonance at a frequency of about $0.5 \mathrm{~Hz}$ and cause significant site response in Mexico City. The data from the Puebla Earthquake on 19 September 2017 also displays this behavior in the ground motion amplification. Relative to nearby sites, the high ground acceleration in the lakebed sediments are a contributing factor of damage to some of the Mexico City's buildings, a similar outcome to that of the 1985 Michoacan Earthquake. Since 1985, there have been significant improvements to the seismic network, allowing for a more detailed evaluation of ground motions and site response across Mexico City. In this study, we used recorded ground motion data from 61 CIRES stations located in Mexico City during the Puebla earthquake. To get values of soil resonance and their associated amplifications at sites across Mexico City, we used the H/V spectral ratio method and the spectral ratio of the station on the lakebed and a station on firm ground. We mapped the amplification in terms of resonance frequency and amplification across Mexico City. In addition, we compare the results with building damage data from the Puebla and Michoacan earthquake. The spatial distribution of building damage during the Peublo earthquake differs from the Michoacan earthquake, but is consistent with site response.

\section{Emergency Management, Resilience and Preparedness}

Poster Session · Thursday 17 May · Riverfront South

\section{Annualized Earthquake Loss Estimations for Istanbul}

HANCILAR, U., Bogazici University, Turkey, hancilar@boun.edu.tr; SESETYAN, K., Bogazici University, Turkey, karin@boun.edu.tr; CAKTI, E., Bogazici University, Turkey, eser.cakti@boun.edu.tr

In this study, we compute annualized earthquake losses for two building inventories of Istanbul city. The latest building inventory, dated 2009, contains about 1.2 million buildings. There are approximately 0.75 million buildings in the 2002 version of the inventory. The buildings are classified with respect to three attributes: i) Type of the lateral load carrying system; ii) Number of floors and iii) Construction year. Capacity and fragility curves are then assigned to each building typology identified in the inventory. Spectral acceleration-displacement based damage assessment methodology is implemented. Damage analyses are conducted under site-specific ground motions computed for eight return periods. Probabilistic loss curves are developed. Annualized earthquake loss estimates and their spatial distributions throughout the city are compared.

\section{The Diploma in Seismology for High-School Teachers}

BELLO, D. I., Universidad Nacional Autónoma de México, Distrito Federal, Mexico, delia@sismologico.unam.mx; PÉREZ-CAMPOS, X., Universidad Nacional Autónoma de México, Distrito Federal, Mexico, xyolipc@sismologico. unam.mx; DOMINGUEZ, J., Universidad Nacional Autónoma de México, Distrito Federal, Mexico, jaimedr64@gmail.com; CRUZ, J. L., Universidad Nacional Autónoma de México, Distrito Federal, Mexico, jcruz@sismologico. unam.mx; NAVARRO ESTRADA, F., Universidad Nacional Autónoma de México, Distrito Federal, Mexico, fernando@sismologico.unam.mx; MENDOZA CARVAJAL, A. J., Universidad Nacional Autónoma de México, Distrito Federal, Mexico, antonio@sismologico.unam.mx; PÉREZ-SANTANA, J. A., Universidad Nacional Autónoma de México, Distrito Federal, Mexico, jesus@sismologico.unam.mx; CAMPOS, Y., Universidad Nacional Autónoma de México, Distrito Federal, Mexico, yolacamposc@gmail.com

The high school Physics programs in Mexico do not consider the immediate application of the concepts learned by the students. According to some pedagogical theories, most of the acquired knowledge is assimilated when experimenting and developing projects. It is in high school when young people are exploring for experiences to decide the area in which they want to focus their studies. There is little interest in Earth sciences, reflected by the number of students in those areas, which may be due mainly to the lack of exposure and examples. We are working on a project that seeks, through the preparation of high-school teachers, to awake student curiosity in seismology. Based on the above, and taking as examples the successful programs "Seismographs in Schools" from IRIS and "Geoscience Information For Teachers" from EGU, the Mexican Servicio Sismológico Nacional (National Seismological Service, SSN) has launched a project that includes three stages:1) design and delivery of a diploma for high-school teachers; 2)installation of short period seismographs at each teachers' schools; and 3)active participation of teachers and their students in research projects based on the data collected in their schools. We are in the first stage, which has the support of the project DGAPA-PAPIME PE107317. The diploma for high-school teachers is a 170 hours course that offers an introduction in topics related to seismology. It starts with basic concepts of physics, and examples of what they can offer their students in their classroom. The content seeks to apply some of the learning, and concepts of the physics courses in high school by the analysis of the information recorded in seismograms. In addition to the material presented to the participant through an online platform, and during sessions, they work on an integrating project, which objective is to prepare them in the use of seismographs and their data in their classes and begin in scientific research themselves and their students.

\section{Implementation of the Tsunami Ready Pilot Project in Grenada}

HINCAPIÉ-CÁRDENAS, C., Global Matrix Engineering, Puerto Rico, USA, c.hincapie@globalmatrixeng.com; VON HILLEBRANDT-ANDRADE, C. G., NOAA NWS Caribbean Tsunami Warning Program, Puerto Rico, USA, christa.vonh@noaa.gov; RODRÍGUEZ, C., Global Matrix Engineering, Santo Domingo, Dominican Republic, carlos.rodriguez@globalmatrixeng.com

The Tsunami Ready Pilot Project is a community performance based recognition project for coastal communities interested in strengthening their tsunami preparedness, adapting and adopting good practices to minimize loss of life and property. Ten important elements are considered in the pilot project guidelines, divided in three major components: mitigation, preparedness and response. Grenada is a tri-island state-Grenada, Carriacou and Petite Martinique located in the southern Caribbean, with a total estimated population of 108,339 people for 2018. History shows that tsunamis have affected Grenada during the past centuries. In 1867, a magnitude 7.5 earthquake originated in the Anegada Trough-USVI, produced a tsunami that reached the island with a registered wave height of $3.1 \mathrm{~m}(10.2 \mathrm{ft})$ at Gouyave. Records also show that in 1902 pyroclastic flows from the eruption of the Soufriere Volcano of St. Vincent, could have generated the waves of up to $1 \mathrm{~m}(3.3 \mathrm{ft})$ that were observed in harbors of Grenada and other neighnoring islands. To fulfill the mitigation component of the Tsunami Ready Guidelines, tsunami hazards for Grenada were identified using ComMIT (tsunami modeling software). Seven different earthquake sources along the Lesser Antilles, Venezuela/Trinidad, and the South Caribbean Deformed Belt were modeled as well as a simulated wave produced by the Kick em' Jenny (KeJ) submarine volcano. The St. Patrick parish located north to Grenada, was selected for piloting the Tsunami Ready project due to the proximity of this community to the KeJ volcano and their interest in preparedness for Tsunamis. During the CaribeWave 2017 exercise 21,000 people from the community were registered as participant. Continuing the preparedness steps for tsunamis, an evacuation map with tsunami evacuation routes and assembly points were determined and approved thru community engagement. Tsunami signage artwork and locations were also discussed with locals in a meeting organized by the National Disaster Management Agency. The Tsunami Plan with Standard 
Operating Procedures needs to be completed to receive the verification visit of the National Tsunami Board. Hopefully during the current semester, St. Patrick will be designated as the first Tsunami Ready community in Grenada and the first one considering a volcano as tsunami source.

\section{Toward a Reliable Tsunami Early Warning System in Puerto Rico}

HUERFANO, V.A., Puerto Rico Seismic Network, Puerto Rico, USA, victor@ prsnmail.uprm.edu; BAEZ-SÁNCHEZ, G., Puerto Rico Seismic Network, Puerto Rico, USA, gisela.baez1@upr.edu

The term early warning is used in many fields to describe the provision of information on an emerging dangerous hazard that enables advance action to reduce the associated risks to the lives and property. Early warning systems exist for natural and biological hazards, procedures are also used in social, industrial and personal emergencies as a fundamental element in disaster risk reduction. Although in the Caribbean there is a comprehensive tsunami warning system. Particularly in Puerto Rico and the Virgin Islands, there is a tsunami protocolwhich has been widely evaluated (i.e. yearly tsunami exercise Caribe Wave), a tsunami program is in place (TsunamiReady) and state-of-the-art seismic, geodetic and sea level networks monitor all the seismic and water level in the Caribbean. The past cat 5 Hurricanes demonstrate that the system is vulnerable. In this poster, we intent to present the effects of the Hurricanes in the local tsunami warning system in Puerto Rico. We will propose some ideas to improve the system, practical actions and recommendations will be described towards the full recovery of the system as well as cutting-edge resilience measurement tools to help exposed communities and the emergency management officers for future planning.

Forecasting Aftershock Sequences in the Real World Poster Session · Thursday 17 May · Riverfront South

Using Aftershock Forecast Modeling to Refine the Location and Magnitude of the 1936 Milton-Freewater Earthquake near the Oregon-Washington Border, U.S.A.

BROCHER, T. M., US Geological Survey, California, USA, brocher@usgs.gov; SHERROD, B., US Geological Survey, Washington, USA, bsherrod@usgs.gov

Aftershock forecast modeling is an important tool for investigating the locations and magnitudes of historical earthquakes as well as for short-term earthquake forecasting. Although the 16 July 1936 M6 Milton-Freewater earthquake is the largest historical earthquake in eastern Oregon, having been widely felt in eastern Washington, northeastern Oregon, and northern Idaho, its location is uncertain. Various studies have reported its epicenter as lying within $30 \mathrm{~km}$ of the intersection of the Hite and Wallula faults. In the absence of reported coseismic surface rupture, we estimate the mainshock location and magnitude from aftershock forecast modeling that considers the numbers of reported aftershocks at six different locations in the day following the quake. The estimated epicenter and magnitude derived from the aftershock modeling compare favorably to the ISC-GEM solution, an S-P time recorded at Spokane, the directions of observed horizontal motions, and the distribution of ground failure and liquefaction. The aftershock modeling constrains the epicenter of the 1936 earthquake with an accuracy of about $5 \mathrm{~km}$ and is most consistent with an epicenter midway between Umapine and Milton-Freewater, above an estimated $10 \mathrm{~km}$ long subsurface rupture between them. This suggested epicenter and rupture plane are consistent with the elongation of ground failure along the Wallula faultand the fault's strike along one of the focal planes indicating that the earthquake may have primarily ruptured the eastern end of NW-trending Wallula fault. Aftershock forecast modeling indicates a mainshock magnitude between 6.2 to 6.4 , in agreement with reported instrumental magnitudes but higher than the range derived from seismic intensity data (5.1 to 5.5). This discrepancy may result from a systematic underestimation of the seismic intensities in the epicentral region: felt reports justify a maximum Modified Mercalli intensity of VIII instead of the VII previously assigned.

Real-Time Completeness of the USGS ComCat Earthquake Catalog and Implications for Operational Aftershock Forecasting

HARDEBECK, J.L., US Geological Survey, California, USA, jhardebeck@usgs. gov; LLENOS, A. L., US Geological Survey, California, USA, allenos@usgs.gov; MICHAEL, A. J., US Geological Survey, California, USA, michael@usgs.gov;
PAGE, M. T., US Geological Survey, California, USA, mpage@usgs.gov; VAN DER ELST, N. J., US Geological Survey, California, USA, nvanderelst@usgs. gov

Aftershock forecasts often depend on the characteristics of the ongoing sequence up to the time of the forecast. The observed aftershocks may be used to fit sequence-specific parameters for clustering models and to seed simulations of future aftershocks. However, the catalog magnitude of completeness may be elevated immediately following a large mainshock, due to decreased detection of smaller events, complicating the use of the early aftershocks. Simple functions have been found to describe the time-dependent magnitude of completeness following global (Page et al., BSSA, 2016) and California (Helmstetter $e t$ al., BSSA, 2006) mainshocks. As a further complication, the real-time earthquake catalog typically has omissions and errors not present in the final catalog. This real-time catalog incompleteness must also be quantified to avoid underestimating the probability of future aftershocks in real-time forecasts. We study the real-time completeness of the USGS ComCat catalog using snapshots downloaded periodically following selected $M \geq 6$ global and $M \geq 5$ U.S. earthquakes. We find that real-time catalog snapshots during roughly the first month of an aftershock sequence have a higher magnitude of completeness than the final cata$\log$, with a typical difference of $0.3-0.8$ magnitude units. We also find that the time-dependent magnitude of completeness equations developed using the final catalogs (Page et al., BSSA, 2016; Helmstetter et al., BSSA, 2006) can describe the completeness of the real-time catalogs during the first month with adjusted parameter values. Accounting for the real-time catalog completeness brings the aftershock productivity estimated from the real-time catalogs closer to the productivity estimated from the final catalog, increasing the accuracy of aftershock forecasts based on the real-time catalogs.

\begin{tabular}{l}
\hline Increasing Testability-Expanding Possibilities and \\
Future Developments of the Collaboratory for the Study of \\
Earthquake Predictability \\
Poster Session . Thursday 17 May · Riverfront South
\end{tabular}

Status of the Collaboratory for the Study of Earthquake Predictability (CSEP) and Prospects for Future Infrastructure Development

SAVRAN, W.H., University of Southern California, California, USA, wsavran@ usc.edu; WERNER, M. J., University of Bristol, England, max.werner@bristol. ac.uk; SILVA, F., University of Southern California, California, USA, fsilva@ usc.edu; YU, J., University of Southern California, California, USA, johnyu@ usc.edu; MAECHLING, P. J., University of Southern California, California, USA, maechlin@usc.edu; VIDALE, J. E., University of Southern California, California, USA, jvidale@usc.edu; JORDAN, T. H., University of Southern California, California, USA, tjordan@usc.edu

The Collaboratory for the Study of Earthquake Predictability (CSEP) supports an international effort to conduct and rigorously evaluate earthquake forecasting experiments. CSEP testing centers are now operational in California, New Zealand, Japan, China, and Europe with 442 models currently under evaluation. The California testing center, operated by SCEC, is testing 30-minute, 1-day, 3-month, 1-year, and 5-year forecasts for California, the Western Pacific, and global regions. SCEC's operational CSEP testing center supports high-resolution global experiments, including the Global Earthquake Activity Rate (GEAR) model, and are verifying the new capacity for ensemble models and non-Poissonian simulation-based forecast models. CSEP also supports retrospective forecast testing (i.e., testing forecasting models on previously recorded earthquake sequences). After a decade of operations, CSEP's evolving scientific and processing demands require changes to the CSEP cyberinfrastructure. We are working with scientists and CSEP operational groups to develop the necessary scientific and technical requirements. These changes include support for fault-based forecasts (e.g., UCERF3) and improved support for external and retrospective forecasts. Also, we would benefit from computer system improvements to enable CSEP to distribute operational processing onto multiple servers, to reduce need for operational support, and to simplify data-management practices. In particular, the utilization of numerical simulations is accelerating as forecasting models become more complex and incorporate more physics; hence, the ability to compute large-scale simulations and post-process the huge data volumes they produce will be a major driver of CSEP cyberinfrastructure development. 


\section{Observed Characteristics of Induced Seismicity: From Laboratory to Field Scale}

Poster Session · Thursday 17 May · Riverfront South

\section{Development of a Matched Filter Catalog in Southern Kansas}

COCHRAN, E. S., US Geological Survey, California, USA, ecochran@ usgs.gov; ROSS, Z. E., Caltech, California, USA, zross@gps.caltech.edu; HARRINGTON, R. M., Ruhr-Universität Bochum, Bochum, Germany, rebecca.harrington@rub.de; DOUGHERTY, S. L., US Geological Survey, California, USA, sdougherty@usgs.gov; RUBINSTEIN, J. L., US Geological Survey, California, USA, jrubinstein@usgs.gov

Seismicity catalogs that are complete to small magnitudes are valuable for investigating the relationship between seismicity and saltwater disposal (SWD). In southern Kansas, the rate of earthquakes rose rapidly starting in 2013 following expansion of energy production into the area, demanding the disposal of large volumes of fluid by-products (saltwater) into deep wells. Rubinstein et al. [2018] developed a catalog of earthquakes for southern Kansas from mid-March 2014 through December 2016 using routine earthquake detection techniques. We use an expanded version of the catalog (March 2014-December 2017)and a matched-filter algorithm to expand the available catalog from approximately 5,000 to over 100,000 earthquakes. From the matched-filter catalog we identify template events with a significant number of associated detections and examine the characteristics of these 'families' of earthquakes. For the most prolific families, we examine the spatial and temporal distribution of these events within the study area, their recurrence times, and any relationships to larger magnitude earthquakes and/or disposal wells.

Reconciliation of Fault Maps and Induced Seismicity in Oklahoma Through Aeromagnetic Imaging of the Crystalline Basement

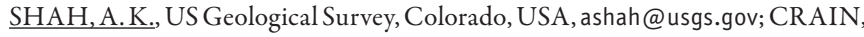
K., Oklahoma Geological Survey, Oklahoma, USA, kevin.crain@ou.edu; SCHULTZ, W. H., US Geological Survey, Colorado, USA, whschultz@usgs. gov; WILLIAMS, R. A., US Geological Survey, Colorado, USA, rawilliams@ usgs.gov

Numerous earthquake sequences associated with induced seismicity in Oklahoma occur along linear trends, suggesting the re-activation of ancient faults. Very few of these sequences are aligned with mapped faults, however, making seismic hazard difficult to estimate. This difference may arise because the earthquakes occur mostly in the basement, while the fault maps are based mostly on data describing sedimentary cover. Alternatively, it is possible that very minor but optimally oriented faults, fractures and/or joints are being ruptured in the induced seismicity setting. To address these possibilities, aeromagnetic surveys were flown over north-central Oklahoma Aug-Oct. 2017, providing imagery of the crystalline basement. Analyses of the magnetic anomaly and its derivatives show that some mapped faults are aligned with magnetic lineaments, but many more are not. In contrast, most major and many minor earthquake sequences are aligned with magnetic lineaments or occur between offsets in magnetic features, interpreted as piercing points along a fault. These observations suggest that most earthquake sequences occur along pre-existing basement faults, but that corresponding fault offset in the sedimentary cover is limited or nonexistent. This is further supported by reflection seismic data that image the crystalline basement in several locales. A curvature analysis of the magnetic data reveals optimally oriented lineaments throughout the area, highlighting magnetic contacts that may represent faults. We also find minor, optimally oriented earthquake sequences on sub-optimally oriented lineaments, suggesting the presence of additional fault systems that contain seismogenic segments. Lastly, there are other earthquake sequences which are not aligned with clear magnetic lineaments. Together these data suggest the presence of numerous potentially seismogenic faults in the region.

\section{Influence of Crustal Structure on High-Frequency ( $>1 \mathrm{~Hz}$ ) Ground Motions from Induced Earthquakes in Oklahoma}

MOSCHETTI, M. P., US Geological Survey, Colorado, USA, mmoschetti@ usgs.gov; HERRMANN, R. B., St. Louis University, Missouri, USA, rbh@ eas.slu.edu; RAMÍREZ-GUZMÁN, L., Universidad Nacional Autónoma de México, Mexico, leoramirezg@gmail.com; FRANKEL, A. D., US Geological Survey, Washington, USA, afrankel@usgs.gov

We investigate the effects of crustal structure on high-frequency $(f \geq 1 \mathrm{~Hz})$ ground motions from induced earthquakes in Oklahoma using recorded waveforms and 1-and 3-D waveform modeling. This work was motivated by previous comparisons of observed response spectral accelerations with the values from ground motion prediction equations (GMPEs) suggesting that the induced ground motions from Oklahoma exhibit a faster-than-expected attenuation with distance. We compiled records from well-recorded earthquakes and computed 5-percentdamped single-degree-of-freedom response from well-recorded earthquakes for various oscillator periods. The acceleration response waveforms comprise strong multiples that develop with increasing distance and exhibit the feature that the relative amplitudes of these multiples evolve with distance. Waveform modeling reproduces these multiplesand indicates strong sensitivity of the ground motion attenuation to focal depth, to the thickness of the Paleozoic sediments, and to seismic impedance between the basement rocks and the Paleozoic sediments. We employ 3-D earthquake simulations to investigate the effect of the thinning of the Paleozoic sediments in Oklahoma to the northeast on ground motions. Simulations indicate strong azimuthal- and frequency-dependent variations in the response waveforms. These results indicate that the unique wave-propagation characteristics from induced earthquakes in Oklahoma should be considered in regional ground motion prediction and seismic hazard analyses.

\section{A Rare Case of Seasonal Induced Seismicity in Southeast Brazil}

CONVERS, J.A., Universidade De Sao Paulo,São Paulo, Brazil, jaime.convers@ gmail.com; ASSUMPÇÃO, M., Universidade De Sao Paulo, Sao Paulo, Brazil, marcelo@iag.usp.br; BARBOSA, J. R., Universidade De Sao Paulo, Sao Paulo, Brazil,jroberto@iag.usp.br

We document a rare case of induced seismicity, associated with rainwater percolation into fractured rock and shallow confined aquifers in southern Brazil, located in the interior of the state of Sao Paulo. We observed that the seismicity during 2016 and 2017 followed the rainy seasons of southern Brazil (from Januaryto July). We investigate this seasonal seismicity with temporary seismic station deployments and locatemore than 500 earthquakes with magnitudes up to $\mathrm{M}$ 2.8. We analyze the seismicity for its temporal, spatial and faulting mechanism, and find a trend of increased seismicity coincident with the months of higher precipitation and a correlation with the location of water wells drilled after 2014 and used for irrigation during the dry months. While we do not see a direct correlation of seismicity depths with the preliminary Time-Domain Electromagnetic Method studies of the rock layer depths, we find the seismicity resembling a planar delineation that makes us believe the temporal and spatial characteristics of the seismicity facilitate slip of what is most likely a pre-existing faultcontaining fractured basaltic rock While rain and water wells alone do not necessarily implyinduced earthquakes, when coupled with water pumped from reservoirs during dry months, and wells with improper casing drilled into fractured basaltic fractured rock layers, it can promote rapid modifications in the pore-pressure conditions from rainwater percolating from an upper aquifer into a confined aquifer in the basaltic rock layer. We estimate that since this type of seismicity is not originated under extreme conditions, we can more similar cases where these conditions are given. This should both motivate and inform closer monitoring of areas where the conditions for this seismicity can be met, and possibly monitor factors influencing the state of health of reservoirs in confined aquifers.

Re-Analyses of Seismic Data from Temporary and Permanent Networks as a
Tool for Monitoring Induced Seismicity: A Case Study from the Cavone Oilfield (Central-Northern Italy)

ANSELMI, M., Istituto Nazionale di Geofisica e Vulcanologia, Italy, mario. anselmi@ingv.it; IOVINE, S., Istituto Nazionale di Geofisica e Vulcanologia, Università "La Sapienza" di Roma, Italy, simone.iovine@hotmail.it; DE GORI, P., Istituto Nazionale di Geofisica e Vulcanologia, Italy, pasquale.degori@ingv. it; BUTTINELLI, M., Istituto Nazionale di Geofisica e Vulcanologia, Italy, mauro.buttinelli@ingv.it; CHIARABBA, C., Istituto Nazionale di Geofisica e Vulcanologia, Italy, claudio.chiarabba@ingv.it; BATTAGLIA, M., Università "La Sapienza" di Roma, Italy, maurizio.battaglia@uniroma1.it

The careful seismic monitoring of oil reservoir exploitation represents a critical tool to identify the triggers of induced seismicity. In this framework, we present preliminary results of an application of seismic monitoring carried out in the area of the Cavone oilfield in Central-Northern Italy. The principal purpose of the study was to investigate tectonic structures, earthquakes distribution and migration, as a tool for monitoring induced seismicity. The target area includes Reggio Emilia and Ferrara cities. We investigated the whole recorded seismicity related to recent seismic sequences: the Reggio Emilia of the October the 15th 1996 (ML 5.1), and the two main-shocks of Ferrara in May the 20th 2012 (MW 5.8) and the Mirandola in May the 29th (MW 5.6). This sequence raised the question of whether these earthquakes might have been triggered by activities due to oil and gas production but recent studies suggest that the combined effects of fluid production and injection from the Cavone field were not a driver for the observed seismicity. We used about 700 earthquakes, recorded by both the permanent and temporary seismic networks managed, to develop a robust three-dimensional seismic velocity model using an iterative linearized tomographic technique. The 
tomographic $\mathrm{Vp}$ and $\mathrm{Vp} / \mathrm{Vs}$ features, together with the 3D location of all the earthquakes, allowed us to analyze in detail the behavior of the seismogenic structures involved in the seismic sequences. In particular, we have been able to image the crustal structures of the NW-dipping back-thrust (part of the western segment of the main thrust of the Ferrara arc, the location of the hypocenter of the main shock of the 1996 sequence), the Ferrara Middle Thrust and the Mirandola Thrust. The Mirandola thrust lies beneath the Cavone anticlinal structure, close to the hypocenter of the main shocks of May the 20th and 29th, 2012.

\section{Interferometric Time-Lapse Velocity Analysis: Application to a Salt-Water Disposal Well in British Columbia, Canada}

VAEZI, Y., University of Alberta, now at Nanometrics Inc., yvaezi@ualberta. ca; VAN DER BAAN, M., University of Alberta, mirko.vanderbaan@ualberta.ca

We investigate the possibility of passive monitoring of a salt-water disposal well in British Columbia, Canada, using continuously-recorded ambient seismic noise. We find seismic velocity variations induced by a reduction of injection pressure in an effort to mitigate an elevated level of seismicity, most likely associated with the disposal of salt water. The relative velocity variations are derived from time shifts measured between consecutive crosscorrelation functions for each station pair in a surface array composed of five broadband seismometers. The probable driving mechanisms responsible for the velocity changes are reduced pore pressures and/or lowered poroelastic stresses beyond the injection wellbore, respectively. Hydrologic data (e.g., snow and rain fall), noise energy trends, and fluctuations in the incident direction of dominant noise sources do not correlate with the estimated relative velocity variations. Velocity variations are detected ahead of the zone of induced seismicity, thus indicating that seismic interferometry may aid in mitigation efforts to reduce the risk of induced seismicity by (1) providing verifiable and repeatable measurements of physical changes within the surrounding area and (2) providing hard constraints for modeling efforts to constrain how and where pore-pressure fronts change.

\section{Hypocentral Focal Depth Determination Based on Pn and Pg Relative Location Method: A Case Study of the 2016 Mw5.1 Fairview Sequence, Oklahoma}

WANG, X. T., Institute of Geodesy and Geophysics, Chinese Academy of Sciences, China, wangxt@whigg.ac.cn; LI, Z. W., Institute of Geodesy and Geophysics, Chinese Academy of Sciences, China, zwli@whigg.ac.cn; NI, S. D., Institute of Geodesy and Geophysics, Chinese Academy of Sciences, China, sdni@asch.whigg.ac.cn

Hypocentral focal depth is an important parameter for calculating ground motions in evaluating seismic hazard, and it provides essential constraints on discriminating natural and induced earthquakes(Ellsworth, 2013; Keranen et al., 2014). Due to sparse seismograph network and inaccurate crustal velocity structure, hypocentral depth may suffer from large uncertainties if only based on the arrival time of the direct waves. We developed a $\mathrm{Pn} / \mathrm{Pg}$ relative location method to determine the hypocentral depth more accurately. Pg phases are used to refine the horizontal location of main shock, and the Pn phases are included to increase the constraints on the hypocenter depth. With reference events, the effects of inaccurate velocity models can be reduced effectively. There are two different results on focal depth of $2016 \mathrm{Mw} 5.1$ Fairview earthquake sequence. Yeck et al. [2016] concluded that the earthquake sequence nucleated near the base of the seismogenic zone and ruptured to shallow part. Incontrast, Goebel et al. [2017] found the earthquakes started shallow and penetrated to large depth about $10 \mathrm{~km}$. The discrepancy of hypocentral depths of the mainshock and foreshocks between different studies is probably due to no nearby seismic stations before February 13, 2016 and/or difference of crust velocity models. In this study, we determine the hypocenters of two lager aftershocks in July 2016 based on the portable seismographic observation records, then adopted them as reference events. By using Pn/Pg relative location method, we determined the hypocentral depth of the 2016 Mw5.1 Fairview earthquake, large foreshock and aftershocks. The results showed that the hypocentral depth of the mainshock is about $7 \mathrm{~km}$, consist with the result of Goebel et al. (2017) and Schoenball and Ellsworth(2017). More study are needed to analyze the seismogenesis of the earthquake sequence, including determining focal depth of many smaller earthquakes.

Comparative Study of Earthquake Clustering in Relation to Hydraulic Activities at Geothermal Fields in California

MARTÍNEZ-GARZÓN, P., GFZ Potsdam, Germany, patricia@gfz-potsdam. de; ZALIAPIN, I., University of Nevada Reno, Nevada, USA, zal@unr.edu BEN-ZION, Y., University of Southern California, California, USA, benzion@ usc.edu; KWIATEK, G., GFZ Potsdam, Germany, kwiatek@gfz-potsdam.de; BOHNHOFF, M., GFZ Potsdam, Germany, bohnhoff@gfz-potsdam.de

We investigate earthquake clustering properties from three geothermal reservoirs to clarify how earthquake patterns respond to hydraulic activities. We process $\approx 9$ years from four datasets corresponding to the Geysers (both the entire field and a local subset), Coso and Salton Sea geothermal fields, California. For each, the completeness magnitude, b-value and fractal dimension are calculated and used to identify seismicity clusters using the nearest-neighbor approach of Zaliapin and Ben-Zion [2013a, 2013b]. Estimations of temporal evolution of different clustering properties in relation to hydraulic parameters point to different responses of earthquake dynamics to hydraulic operations in each case study. The clustering at the Geysers at local scale and Salton Sea are most and least affected by hydraulic activities, respectively. The response of the earthquake clustering from different datasets to the hydraulic activities may reflect the regional seismotectonic complexity as well as the dimension of the geothermal activities performed (e.g. number of active wells and superposition of injection + production activities). Two clustering properties significantly respond to hydraulic changes across all datasets: the background rates and the proportion of clusters consisting of a single event. Background rates are larger at the Geysers and Coso during high injection-production periods, while the opposite holds for the Salton Sea. This possibly reflects the different physical mechanisms controlling seismicity at each geothermal field. Additionally, a lower proportion of singles is found during time periods with higher injection-production rates. This may reflect decreasing effective stress in areas subjected to higher pore pressure and larger earthquake triggering by stress transfer.

\section{Identifying the Trigger of the Irving-Dallas, North Texas, Earthquake Sequence}

DESHON, H. R., Southern Methodist University, Texas, USA, hdeshon@smu. edu; QUINONES, L., Southern Methodist University, Texas, USA, lquinones@ smu.edu; OGWARI, P., Southern Methodist University, Texas, USA, pograwi@ smu.edu; JEONG, S., Southern Methodist University, Texas, USA, seonguj@ smu.edu; BRUDZINSKI, M. R., Miami University, Ohio, USA, brudzimr@ miamioh.edu; MAGNANI, M. B., Southern Methodist University, Texas, USA, mbmagnani@smu.edu

The 2014-present Irving-Dallas earthquakes in north Texas generated a series of $\mathrm{M} \geq 3.4$ earthquakes in January 2015 and the continuing small $(\mathrm{mL}<3)$ events along the same fault continue to contribute to the increased hazard forecast and risk for the Dallas-Fort Worth Metroplex. While the events most likely are related to oil and gas operations, particularly wastewater injection, as reported for all other earthquakes in the Fort Worth Basin, the direct physical mechanism that triggered events in Irving-Dallas remains an enigma. In the Irving/Dallas area, nearby Class-II injection wells are at $\geq 10 \mathrm{~km}$ distance, and there are two, now inactive, Barnett shale production well $<1 \mathrm{~km}$ from the activated fault. In past publications, we have hypothesized that the dense northeast-southwest (NE-SW) trending basement fault system that extends into the injection (Ellenburger) and production (Barnett) formations provide pathways for enhanced fluid pressure changes. Here, we summarize and update the community on a range of modeling and earthquake source investigations aimed at unraveling the cause of the IrvingDallas earthquakes. Template matching work indicates the sequence began in late 2013 or early 2014 with a series of small magnitude events. Double-difference locations, focal mechanisms, and stress drop studies map how recorded seismicity (post-January 2015) and moment release has migrated around the $15 \mathrm{~km}^{\wedge} 2$ fault plane. A nearby 3D seismic reflection survey confirms the strike, dip of the fault, and the minimum offsets and fault densities of NE-SW trending structures along the eastern edge of the basin, and these faults appear to be oriented for failure in the current stress regime. Pore pressure diffusion modeling conducted using the known fault structures and injection histories of the closest wells, which lie to the west of the sequence at the DFW International Airport, do not appear to be solely responsible for increasing fluid pressures in Irving-Dallas. Initial estimates of poroelastic and Coulomb stress changes associated with earthquakes and high volume injection located to the southwest, in Johnson County, are smaller than would be expected to trigger events, even on critically stressed faults. Updated modeling and full consideration of available hypotheses will be presented.

Discerning and Characterizing Induced Seismicity in Texas Using Regional Multistation Template Matching

BRUDZINSKI, M. R., Miami University, Ohio, USA, brudzimr@miamioh.edu; SKOUMAL, R. J., US Geological Survey, California, USA, skoumarj@gmail. com; DESHON, H. R., SMU, Texas, USA, hdeshon@mail.smu.edu; SMITH, S., Lettis Consultants International, California, USA, sarah.l.r.smith@gmail. com; CURRIE, B. S., Miami University, Ohio, USA, curriebs@miamioh.edu; 
SMART, K. J., Southwest Research Institute, Texas, USA, ksmart@swri.org; MORRIS, A. P., Southwest Research Institute, Texas, USA, amorris@swri.org

To better characterize seismicity in Texas over the past 10 years, we have employed a regional multistation template matching (RMTM) technique to cataloged events across the state. Applying waveform correlation to a consistent set of regional stations that record continuously through time results in more constant detection at a lower magnitude threshold, providing a larger, more uniform catalog of earthquakes for investigation. When compared with catalogs from local arrays in North Texas, results from RMTM aresuccessful at generating a more complete catalog than traditional regional network detection, indicating that RMTM can be a cost-effective alternative when local deployments are not readily available. The lower magnitude completeness threshold from RMTM enables improved characterization of frequency-magnitude distributions, which are important for developing forecasting models for induced seismicity. We find several cases where the catalog from RMTM helps to better determine the temporal span of seismic activity and allows for improved spatiotemporal correlation calculations with specific industry operations. As with prior investigations using RMTM in other regions, seismicity correlated with fluid injection is typically swarm-like. While most of the swarm-like seismicity detected from RMTM in Texas can be associated with wastewater disposal activities, we also find seismicity induced by hydraulic fracturing.

\section{A Notable Earthquake Swarm in Alabama: Natural or Anthropogenic?}

CHEN, J., Auburn University, Alabama, USA, jzc0111@auburn.edu; WOLF, L. Auburn University, Alabama, USA,wolflor@auburn.edu

Seismicity in the central and eastern U.S. is generally characterized by lowmagnitude $(M<4)$, randomly distributed earthquakes in areas of low to moderate strain rates. In November 2014, however, an unusual swarm of earthquakes began in northwestern Greene County, Alabama. The magnitudes of these earthquakes are small $(\mathrm{M}<3.8)$, with many events only lightly felt by residents in the area. This study investigates the spatiotemporal and waveform characteristics of the Greene Country earthquake cluster to explore its possible source and the physical mechanism responsible for its occurrence. Although the possibility that the swarm is related to wastewater disposal or resource extraction cannot be ruled out, our analysis suggests that the swarm may equally represent a continuation or southwesterly migration of the Southern Appalachian seismic zone (SASZ). Earthquake relocations and calculated focal mechanisms are consistent with slip along northeast-trending faults that support both explanations. However, the large distance between the epicentral area and areas of active wells exceeds that typically associated with induced seismicity and would necessitate a hydrologic connection along regional faults that allows propagation of a pore-pressure front from the area of resource recovery to the area of earthquake activity.

\section{Plate Boundary Segmentation and Coupled-to-Creeping Plate and Block Boundary Faults Poster Session · Thursday 17 May · Riverfront South}

The Case of Western Corinth Gulf (Greece): A Detachment Zone or Seismic Aseismic Transition?

MESIMERI, M., Aristotle University of Thessaloniki, Greece, mmesimer@ geo.auth.gr; KARAKOSTAS, V., Aristotle University of Thessaloniki, Greece, vkarak@geo.auth.gr

Corinth Gulf is one the most seismically active rifts worldwide, with several low in magnitude earthquakes as well as a few stronger ones $(M \geq 6)$, especially in its western part. This study focuses on the spatiotemporal properties of the seismic activity occurred between 2008-2014, when the national seismological network was denser. In this respect, a highly accurate earthquake catalog consisting of $\sim 22,000$ events was compiled using double difference technique and differential times from both phase picked data and cross correlation measurements. The locations showed the existence of a very shallow north dipping structure in the western part of Corinth Gulf, which is void of spatiotemporal clusters, whereas seismic excitations are placed above that zone in shallower depths. The waveform database was searched for repeating events (i.e., events with identical waveforms) and the repeaters were classified into multiplets of repeating sequences. These repeaters revealed two patterns of activity namely continuous type and burst-like repeaters. Continuous type repeaters last the entire study period, have low slip rates and are located on the shallow north dipping zone, which was found void of spatiotemporal clusters. On the other hand, burst-like repeaters are located above the shallow north dipping zone, in areas where seismic excitations occur and evidence was found that their occurrence can be related to fluid intrusion. The major finding of this study is that the spatial distribution of the relocated seismicity revealed two patterns of activity in the western subarea, namely, strongly clustered seismicity in both space and time in depths shallower than $10 \mathrm{~km}$ and below that activity a very narrow shallow north dipping zone which consists of continuous type repeaters. Based on the properties of the continuous type repeaters, the aseismic slip along the shallow dipping zone, was calculated.

Systematic Detections of Microearthquakes and Repeators in Parkfield Long before and after the 2004 M6 Earthquake

NEVES, M., Georgia Institute of Technology, Georgia, USA, miguel.neves@ eas.gatech.edu; PENG, Z., Georgia Institute of Technology, Georgia, USA, zpeng@gatech.edu; MENG, X., University of Washington, Washington, USA, xmeng@uw.edu; DANIELS, C., Georgia Institute of Technology, Georgia, USA, cdaniels9@gatech.edu; LIN, G., University of Miami, Florida, USA, glin@ rsmas.miami.edu

The Parkfield segment of the San Andreas Fault (SAF) is one of the best instrumented seismic regions, due to the famous Parkfield Earthquake Prediction Experiment (Bakun et al., 2005). As a result, the 2004 Mw6.0 Parkfield earthquake generated a wealth of data to study seismic activity before and after the mainshock. Recently, Shelly (2017) released a 15-yr catalog of more than 1 million low-frequency tremor events along the Parkfield-Cholame section of the SAF, based on waveform matching with 88 tremor families. However, except a few previous studies that focused on microseismicity in a short time period (Peng and Zhao, 2009; Meng et al., 2013) or repeating earthquakes only (Lengline and Marsan, 2009), there is no systematic long-term detection of microseismicity in this region. Building upon previous studies of microearthquake detection in the region (e.g. Peng and Zhao, 2009), we perform a systematic detection of microearthquakes with a template matched filter detection technique within one year around the $2004 \mathrm{Mw} 6.0$ Parkfield earthquake mainshock. We take advantage of additional seismic datasets that have not been fully used before and improve the detection of early aftershocks in the first tens seconds after the mainshock. With the analysis of a larger time span, we intend to further investigate and understand the migration patterns of the aftershock sequence and determine if any seismic signals are detected in the time period before the mainshock that could indicate a foreshock sequence. We also plan to relocate those newly detected microearthquakes and search for repeating events that occur at virtually the same location. Updated results will be presented at the meeting.

\section{A High-Precision Continuous Catalogue of Low-Magnitude Earthquakes in the Central Southern Alps, New Zealand}

MICHAILOS, K., Victoria University of Wellington, Wellington, New Zealand, konstantinos.michailos@vuw.ac.nz; CHAMBERLAIN, C. J., Victoria University of Wellington, Wellington, New Zealand, calum.chamberlain@ vuw.ac.nz; SMITH, E.g. C., Victoria University of Wellington, Wellington, New Zealand, euan.smith@vuw.ac.nz; SAVAGE, M. K., Victoria University of Wellington, Wellington, New Zealand, martha.savage@vuw.ac.nz; TOWNEND, J., Victoria University of Wellington, Wellington, New Zealand, john.townend@vuw.ac.nz

The Alpine Fault is inferred to be late in its typical 300-year cycle of M8 earthquakes based on paleoseismological evidence. The central Southern Alps exhibit the highest deformation and uplift rates along the Alpine Fault. However, levels of contemporary earthquake activity $(M \geq 2)$ are low when compared to adjacent areas. Compiling a micro-earthquake catalogue for the central Southern Alps may help better understand the distribution of deformation in a region prior to the next major earthquake. We have created an almost decade long earthquake catalogue containing 9,111 earthquakes spanning the time period between late 2008 and early 2017. The earthquake locations are based on high-quality picks $(83,138 \mathrm{P}$ - and $67,119 \mathrm{~S}$-phase picks of which approximatelly $35 \%$ are manual). To quantify the spatial distribution of the seismic moment release, we have derived a new local magnitude scale based on Mw values. Magnitudes range between ML -1.5 and 4.6 and have a magnitude of completeness of 1.1 with a b-value of 0.85 . The seismogenic cut-off depths vary from 8 to $20 \mathrm{~km}$ and show both strike parallel and strike perpendicular variations that are strongly related to lateral changes in thermal structure and strain rate.

Mejillones Peninsula in Northern Chile Controlled by Hydrated Interface and Subducted Oceanic Plate

PASTEN-ARAYA, F., Universidad Catolica del Norte, Chile, fpa007@ucn.cl; SALAZAR, P., Departamento de Geología, Universidad Catolica del Norte; CIGIDEN, Chile, pasalaz@ucn.cl; RUIZ, S., Departamento de Geofísica, Universidad de Chile, Chile, sruiz@dgf.uchile.cl; RIVERA, E., Departamento de Geofísica, Universidad de Chile, Chile, efrain@dgf.uchile.cl; POTIN, B., Centro Sismológico Nacional, Universidad de Chile, Chile, bpotin@csn.uchile. 
cl; CRUZ, E., Departamento de Geología, Universidad Catolica del Norte; CIGIDEN,Chile, eaci_89@hotmail.com; JALDíN, D., Departamento de Geología, Universidad Catolica del Norte; CIGIDEN, Chile, djaldin7@gmail. com; VILlarRoEl, J., Departamento de Geología, Universidad Catolica del Norte; CIGIDEN, Chile, j.villarroel.ibarra@gmail.com; TORRES, E., Departamento de Geología, Universidad Catolica del Norte; CIGIDEN, Chile, e.torres.liquitay@hotmail.com; ECHEVERRÍA, J., Departamento de Geología, Universidad Catolica del Norte; CIGIDEN, Chile, jordan.er911@gmail.com; BLOCH, W., Freie Universität Berlin, Germany, wasja@geophysik.fu-berlin.de

The interplate of subduction zones present several seismogenic behaviors. This variability is controlled by frictional properties, changes in the reologhy or by the presence of fluid. The interplate zone beneath Mejillones Peninsula in Northern Chile, is characterized by presenting seismic and aseismic behavior and a low plate coupling. We deployed a local seismological network in the vicinity of the Mejillones Peninsula, consisting of 24 short-period seismometers, which was operational for 2 years. The first step was to build a seismic catalog of more than 2.000 events placed below the Mejillones Peninsula, then we locate manually determining the arrival times of the $P$ and $S$ waves. We use NonLinLoc and HypoDD programs. Finally, we compute a 3D velocity tomography model and related the seismicity. Through the seismicity and tomography, we study the tectonic structure of the interplate zone beneath Mejillones Peninsula. The results show that the seismicity is more intense in the north of the peninsula than in the south and where we find swarm-type seismicity with reapeters. This coincides with the $\mathrm{Vp} / \mathrm{Vs}$ ratios, which are higher in the north than in the south. A high rate of seismicity is concentrated within the oceanic crust, which we interpreted as hydrated structures formed in the outer-rise of Nazca Plate. The presence of swarms with reapeters along with high P-S seismic velocity ratios within and in the continental crust, is interpreted as a high pore-fluid pressure. Due to the high P-S velocity ratios and distribution of seismicity, we propose that fluids contributed by slab structures, increasing the hydration levels in the interface and on the oceanic plate, influencing the strength of the interplate and controlling the seismogenic behavior of this subduction zone.

Constraints from 3D Earthquake Location for Aftershocks of the Mw=7.8 2016 Pedernales Earthquake (Ecuador Subduction Zone)

FONT, Y., Geoazur-IRD, Alpes-Maritimes, France, font@geoazur.unice.fr; AGURTO-DETZEL, H., Université Côte d'Azur, IRD, CNRS, Observatoire de la Côte d'Azur, Géoazur, France, agurto@geoazur.unice.fr; ALVARADO, A., Instituto Geofísico, Escuela Politécnica Nacional, Ecuador, aalvarado@igepn. edu.ec; RÉGNIER, M., Université Côte d'Azur, IRD, CNRS, Observatoire de la Côte d'Azur, Géoazur, France, regnier@geoazur.unice.fr; ROLANDONE, F., Sorbonne Universités, UPMC Université Paris 06, CNRS, Institut des Sciences de la Terre de Paris,, France, frederique.rolandone@upmc.fr; CHARVIS, P., Université Côte d'Azur, IRD, CNRS, Observatoire de la Côte d'Azur, Géoazur, France, charvis@geoazur.unice.fr; MOTHES, P. A., Instituto Geofísico, Escuela Politécnica Nacional, Quito, Ecuador, Ecuador, pmothes@igepn.edu. ec; NOCQUET, J. M., Université Côte d'Azur, IRD, CNRS, Observatoire de la Côte d'Azur, Géoazur, France, nocquet@geoazur.unice.fr; JARRIN TAMAYO, P., Instituto Geofísico, Escuela Politécnica Nacional, Ecuador, pjarrin@igepn. edu.ec; AMBROIS, D., Université Côte d'Azur, IRD, CNRS, Observatoire de la Côte d'Azur, Géoazur, France, ambrois@geoazur.unice.fr; MARON, C., Université Côte d'Azur, IRD, CNRS, Observatoire de la Côte d'Azur, Géoazur, France, maron@geoazur.unice.fr; CHEZE, J., Université Côte d'Azur, IRD, CNRS, Observatoire de la Côte d'Azur, Géoazur, France, cheze@geoazur.unice. fr; RUIZ, M. C., Instituto Geofísico, Escuela Politécnica Nacional, Ecuador, mruiz@igepn.edu.ec; SINGAUCHO, J. C., Instituto Geofísico, Escuela Politécnica Nacional, Ecuador, jcsingaucho@igepn.edu.ec; DE BARROS, L., Université Côte d'Azur, IRD, CNRS, Observatoire de la Côte d'Azur, Géoazur, France, debarros@geoazur.unice.fr; RAMOS, C., Instituto Geofísico, Escuela Politécnica Nacional, Ecuador, cramos@igepn.edu.ec; RIETBROCK, A., University of Liverpool, UK, United Kinhdom, a.rietbrock@liverpool.ac.uk; DESCHAMPS, A., Université Côte d'Azur, IRD, CNRS, Observatoire de la Côte d'Azur, Géoazur, France, deschamps@geoazur.unice.fr; COURBOULEX, F., Université Côte d'Azur, IRD, CNRS, Observatoire de la Côte d'Azur, Géoazur, France, courboulex@geoazur.unice.fr; PONCE, G., Instituto Geofísico, Escuela Politécnica Nacional, Ecuador, gponce@igepn.edu.ec; BECK, S. L., University of Arizona, Arizona, USA, slbeck@email.arizona.edu; MELTZER, A., Lehigh University, Pennsylvania, USA, asm3@lehigh.edu

The Mw7.8 Pedernales earthquake is associated with the subduction of the Nazca Plate beneath the South American Plate. The mainshock caused many casualties and widespread damages across the Manabi province. The $150 \mathrm{~km}$-long coseismic rupture area is found beneath the coastline, near $25 \mathrm{~km}$ depth. The rupture propagated southward and involved the successive rupture of two discrete asperi- ties, with a maximum slip $(\sim 6 \mathrm{~m})$ on the southern patch. The rupture area is consistent with the highly locked regions observed on interseismic coupling models, overlaps the 7.2 Mw rupture zone, and terminates near where the $1906 \mathrm{Mw}$ 8.8 megathrust earthquake rupture zone ends. Two neighboring highly coupled patches remain locked: (A) southern to and updip of the coseismic rupture zone and (B) northern and downdip. In this study, we relocate the aftershocks and compare the seismicity distribution to the interseismic coupling and the rupture area. We use continuous seismic traces recorded on the permanent network partly installed in the frame of the collaboration between l'Institut de Recherche pour le Développement (IRD-France) and the Instituto Geofísico, Escuela Politécnica Nacional, Quito, Ecuador. Detections are conducted using Seiscomp in play-back mode. Arrival-times are manually picked. To improve earthquake location, we use the MAXI technique and a heterogeneous a priori P-wave velocity model that approximates the large velocity variations of the Ecuadorian subduction system. Aftershocks align along 3 to 4 main clusters that strike perpendicularly to the trench, and mostly updip of the co-seismic rupture. Aftershock seismicity develops indifferently over portions of plate interface that are known to be strongly locked or almost uncoupled. The seismicity pattern is similar to the one observed during a decade of observation during the interseismic period with swarms such as the Galera alignment, Jama and Cabo Pasado, and between Manta and Puerto Lopez.

\section{Estimating the Locations of Past and Future Large Earthquake Ruptures Using Recent M4 and Greater Events}

EBEL, J.E., Boston College, Massachusetts, USA, ebel@bc.edu

A study of the occurrences of recent $M \geq 4$ earthquakes in California shows that these events occur preferentially at the edges of past major ruptures, with the effect lessening with decreasing magnitude below M4. Prior to several large California mainshocks, the $M \geq 4$ seismicity was uniformly spread along the future fault ruptures without concentrations at the fault ends. On these faults, the rates of the $M \geq 4$ earthquakes prior to the mainshocks were much greater than the rates of the recent $M \geq 4$ earthquakes. A similar study of earthquakes in Japan shows that modern $M \geq 4$ earthquake also preferentially occur at the ends of past major ruptures, and this pattern seems to hold for large earthquakes that occurred as many as several hundred years ago. In contrast, the recent $M \geq 4$ earthquakes in Turkey do not preferentially cluster at the ends of the major ruptures on the North Anatolian Fault during the 20th century. The fault ruptures of many of the major North Anatolian earthquakes during the 20th century overlap, and for many of the fault ruptures the modern $\mathrm{M} \geq 4$ earthquakes concentrate in the overlap areas. It appears that it is isolated or non-overlapping major fault ruptures for which the modern $M \geq 4$ earthquakes preferentially occur at the fault ends, whereas the modern $M \geq 4$ earthquakes tend to occur between the fault ruptures in places where the major fault ruptures significantly overlap.

\section{Ground Motion to Intensity Conversion Equations (GMICEs) for Chilean Megathrust Earthquakes}

CILIA, M. G., University of Birmingham, London, United Kingdom, marcella. cilia@hotmail.co.uk; BAKER, L. M., US Geological Survey, California, USA, baker@usgs.gov

We determine empirical relationships between instrumental peak ground motions and observed intensities for three recent Chilean megathrust (interplate subduction) earthquakes: the November 14, $2007 \mathrm{Mw} 7.7$ Tocopilla earthquake, and two great earthquakes, the February 27, $2010 \mathrm{Mw} 8.8$ Maule earthquake and the April 1, $2014 \mathrm{Mw} 8.2$ Iquique earthquake. Most great $(M \geq 8)$ earthquakes, like these, occur within subduction zones. Yet, few ground motion to intensity conversion equations (GMICEs) exist for subduction earthquakes. We pair instrumental peak ground motions, both acceleration (PGA) and velocity $(\mathrm{PGV})$, with intensities derived from on-site surveys of earthquake damage and volunteered felt reports. We fit a linear predictive equation between the geometric mean of the maximum PGA or PGV of the two horizontal components and intensity using an ordinary least squares regression. We use a weighting scheme to express the uncertainty of the intensity value assigned in each pairing based on the proximity of the instrument (station) to the nearest intensity observation. We find the best fitting predictive equations (GMICEs) for MMI from PGA, in $\mathrm{cm} / \mathrm{s} / \mathrm{s}$, or $P G V$, in $\mathrm{cm} / \mathrm{s}$, are:
PGA MMI $=2.10 \log \mathrm{PGA}+0.26$
$\mathrm{MMI}=6.78 \log \mathrm{PGA}-10.54$
PGV MMI $=3.72 \log$ PGV +1.10
$\mathrm{MMI}=5.05 \log \mathrm{PGV}-0.55$
$\mathrm{II} \leq \mathrm{MMI} \leq \mathrm{V}$
$\mathrm{V}<\mathrm{MMI} \leq \mathrm{IX}$
$\mathrm{II} \leq \mathrm{MMI} \leq \mathrm{V}$
$\mathrm{V}<\mathrm{MMI} \leq \mathrm{IX}$

We find existing GMICEs consistently overpredict intensity for these events, and existing inverse GMICEs underpredict the measured peak ground motions. We evaluate the effectiveness of existing GMICEs to reduce the misfit between predicted and observed intensities. We show that predictions for Chilean sub- 
duction events are improved when the corrections to global GMICEs are applied to peak ground motions instead of intensities. We conclude that the distinctive characteristics of Chilean megathrust earthquakes warrant the development of separate GMICEs for specific subduction zone regions.

\section{Spatiotemporal Evolution of Source Properties in the Colombia Seismic Sequence}

AGUILAR, A. L., Universidad Nacional de Colombia, Colombia, alaguilars@ unal.edu.co; PRIETO, G. A., Universidad Nacional de Colombia, Colombia, gaprietogo@unal.edu.co

More than 300 earthquakes have been reported by the Colombian Seismic Network (RSNC) in a seismic zone in southwestern Colombia since 2012 ranging from Ml 0.8 up to $\mathrm{Ml} 5.3$, with at least $3 \mathrm{M} 4.5+$ earthquakes in a span of 1 month in 2016. Some of these events have been widely felt in major cities in Colombia and are well recorded by the local network. We study the temporal and spatial evolution of these earthquakes, and in particular focus in the short seismic sequence in 2016. Earthquakes show migration towards the SW, along an apparent fault trace and show clear Omori-type aftershock behavior. Using an empirical Green's function approach, we study the changes in source parameters of the seismic sequence and try to identify if ruptures show any preferential directivity. Temporal or spatial variations of these source parameters may be indicative of changes in the medium before and after the mainshock.

Collecting New High-Resolution Seismic Data across the Hayward Fault Zone

QUESENBERRY, C.E., CSU, East Bay, California, USA, ceq93@att.net

The Hayward Fault is an active strike-slip fault trending southeast to northwest through the east bay region of California's San Francisco Bay Area, which has caused approximately $100 \mathrm{~km}$ of offset during the last $10 \mathrm{Ma}$. Along a $30 \mathrm{~km}$ segment, between the City of Oakland in the north and the City of Fremont in the south, the Hayward Fault cuts through a tectonic body of Mesozoic gabbroic and volcanic rocks known as the San Leandro Block. In 2013, the United States Geological Survey (USGS) and the California State University East Bay (CSUEB) collaborated on the East Bay Seismic Experiment (EBSE) in order to examine the structure of fault zones in the vicinity of the CSUEB main campus. Sparse-data P-wave tomography from the EBSE survey, across the San Leandro Block at a study area on an undeveloped parcel in the City of Hayward, identifies the probable orientation of the Hayward Fault and an unnamed fault in the shallow subsurface of that study area. However, the USGS geophysics group from the Menlo Park Earthquake Science Center is interested in developing highresolution seismic velocity models and tomographic images across the Hayward Fault Zone at the same study area. On November 18, 2017, the USGS geophysics group in collaboration with researchers from CSUEB coordinated a P-wave seismic survey across the study area. We hand-augured $63 \sim 45 \mathrm{~cm}$ deep boreholes across a $310 \mathrm{~m}$ long survey line as placement locations for a Betsy Seisgun seismic source; we then hand-augured 3 additional $\sim 2 \mathrm{~m}$ deep boreholes as placement locations for larger charge. $4.5 \mathrm{~Hz}$ P-wave geophones were placed at each of the 63 Betsy source locations. Our 2017 survey produced a much larger data set than the previous 2013 EBSE survey, which used only 3 geophones. Assignment of P-wave first arrivals was completed by graduate student Collin Quesenberry using SeisImager ${ }^{\text {Tit }}$ PickWin software supplied by CSUEB. The resultant P-wave velocity data will be processed into a tomographic velocity model with the aid of the USGS. One of our immediate conclusions is the topsoil at our location is highly unconsolidated and caused unusual damping of Seisgun generated P-waves. In response to this first conclusion, we are planning a similar seismic survey across the same study area using a more powerful seismic source than the Betsy Seisgun. Results of this project will be shared between the USGS and CSUEB, and used for Collin Quesenberry's graduate thesis.

\section{Structural Setting along the Western North Anatolian Fault and Its Influence} on the 2014 North Aegean Earthquake (M 6.9)

BULUT, F., Bogazici University, Kandilli Observatory and Earthquake Research Institute, Geodesy Department, Turkey, bulutf@boun.edu.tr; OZENER, H., Bogazici University, Kandilli Observatory and Earthquake Research Institute, Geodesy Department, Turkey, ozener@boun.edu.tr; DOGRU, A., Bogazici University, Kandilli Observatory and Earthquake Research Institute, Geodesy Department, Turkey, asli.dogru@ boun.edu.tr; AKTUG, B., Ankara University, Geophysics Department, Ankara, Turkey, bahadir.aktug@ankara.edu.tr; YALTIRAK, C., Istanbul Technical University, Faculty of Mines, Department of Geological Engineering, Ayazaga, Istanbul 34426, Turkey, Turkey, yaltirak@ itu.edu.tr

We investigated microseismicity, geodetic slip and structural setting along the western North Anatolian Fault NAF to characterize their influence on pre-, coand post-seismic stages of the 2014 North Aegean Earthquake (M 6.9). We identified that the NAF in North Aegean Sea (NAS) operates beneath three basins and two transpressional ridges rather than a single through-going basin. Refined hypocenters indicate that NAF is a narrow shear-zone in the east, and systematically expands towards the west. Microseismicity has a wide spread epicentral pattern at pre-seismic stage of the 2014 earthquake, but later tightens during postseismic stage. This suggests that pre-seismic strain accumulation was completed on the main fault and transferred to surrounding secondary structures, and the slip returns back to the main fault following the mainshock. Overall microseismicity pattern shows that seismogenic zone becomes deeper to the west and shallower to the east. Three fault segments merged with two step-overs have failed during the 2014 North Aegean Earthquake rupturing a $\sim 90 \mathrm{~km}$ section of the NAF. There, co-seismic slips reach up to $\sim 80 \mathrm{~cm}$ beneath western step-over and remains below $\sim 60 \mathrm{~cm}$ beneath eastern step-over. Along-fault pre- and co-seismic slips show a complementary pattern verifying that the 2014 mainshock generated the highest slip at pre-seismically locked patches, located beneath transpressure ridges hosting two step-overs. High pre-shock concentrations underneath suggest fracturing at seismogenic basement overcoming frictional strength at these two fault step-overs.

Retrieval of Fine Scale Information Using Seismic Noise Poster Session . Thursday 17 May · Riverfront South

Improving the Cross-Correlation of Ambient Noise Using Discrete Wavelets CABRERA PERÉZ, I., Instituto Volcanológico de Canarias, S/C de Tenerife, Spain, ivancbrprz@hotmail.com; D’AURIA, L., Instituto Volcanológico de Canarias, S/C de Tenerife, Spain, Idauria@iter.es; SOUBESTRE, J., Instituto Volcanológico de Canarias, S/C de Tenerife, Spain, jsoubestre@iter.es; BARRANCOS, J., Instituto Volcanológico de Canarias, S/C de Tenerife, Spain, jbarrancos@iter.es; PADILLA, G. D., Instituto volcanológico de Canarias, S/C de Tenerife, Spain,german@iter.es

In recent years the development of techniques of seismic tomography using ambient seismic noise opened new possibilities in the field of scientific and industrial exploration of the Earth's crust. The major drawback of this technique is the need for long field surveys, with acquisition times usually spanning from a few weeks to a few months, depending on the specific case. This technique essentially consists in retrieving empirical Green's functions (GFs) between pairs of stations by crosscorrelating the background noise signals to determine surface waves dispersion curves. Depending on the considered frequencies and the distances between the stations, the achievement of reliable GFs depends on the length and the quality of the considered signals. In practice a long recording is split into smaller windows, on which cross-correlations are computed. The resulting functions are then stacked, after removing noisy windows where transient signals may disrupt the retrieval of GFs. In this work we show how the use of the Discrete Wavelet Transform (DWT) offers many benefits in the estimation of GFs. First of all it provides a natural signal separation in dyadic frequency bands, making superfluous the use of spectral normalization of the signals. Furthermore it allows a separate estimation of the GFs in each frequency band, optimizing the elimination of noisy windows and hence reducing the time required for the field surveys. A single processing run, can allow obtaining GFs already separated in different frequency bands. This can be useful for the application of multi-scale inverse method to model the data. We propose a workflow starting from raw seismograms and leading to separate GFs for each frequency band. We test the proposed method on datasets acquired on Tenerife (Canary Islands) with the purpose of ambient noise tomography for geothermal exploration. We compare the retrieved results with those obtained with standard approaches.

\section{Crustal Radial Anisotropy Model along the Polenet-Anet Transect}

MORDRET, A., MIT, Massachusetts, USA, mordret@mit.edu; XU, Z., Boise State University, Idaho, USA, zongboxu@boisestate.edu; MIKESELL, T. D., Boise State University, Idaho, USA, dylanmikesell@boisestate.edu

Radial anisotropy, also called transverse radial isotropy, can indicate the dominant orientations of crustal fabrics. Along with isotropic velocities, radial anisotropy is a key component to understand crustal structures and their history. It can be extracted from the discrepancy between Rayleigh and Love wave propagation speed, indicating a difference between vertically polarized shear-wave speed and horizontally polarized shear-wave speed, respectively. It is only since the emer- 
gence of ambient seismic noise tomography that we are able to analyze surface wave propagation at periods short enough to be sensitive to the crust and the shallow subsurface. We used 2 years (2010-2011) of continuous seismic records from the POLNET-ANET seismic network deployed in West Antarctica to compute the 9 components of the correlation tensor between each pair of stations. From the vertical and radial components, we extract Rayleigh wave propagation in the form of group and phase velocity dispersion curves. The transverse components give access to Love wave propagation. The different Rayleigh wave measurements are averaged before the tomography and their statistics are used to infer the measurements uncertainties. We regionalize the velocities along the transect at individual periods between 2 and $20 \mathrm{~s}$ for the 4 types of velocity, then we use a Neighborhood Algorithm to invert at depth the local dispersion curves to build a 2D anisotropic shear-wave velocity model along the POLENET-ANET transect. We relate and interpret the structures in both isotropic and anisotropic models to the known structures in West Antarctica as seen by previous works in the region.

\section{Preliminary Results of the LARGE-MEM Project}

LECOCQ, T., Royal Observatory of Belgium, Belgium, thomas.lecocq@ seismology.be

The LARGE-MEM project is a small-scale but dense noise-based study aiming at better understanding rainfall and groundwater storage effects on seismic velocities measured by a dense seismic network. The goal of LARGE-MEM is to demonstrate that the actual quantity and location of water in the subsurface can be estimated from measurements using a LargeN array. To achieve this, the data from superconducting and absolute gravimeters located in a gallery under the study site will be used to measure precisely the mass of water sampled by the seismic waves. In this communication, we report on the first tests of the the recently acquired nodes and their deployment on the forested hill.

\section{Seismic Studies of Earth's Crust and Lithosphere} Poster Session · Thursday 17 May · Riverfront South

\section{Seismicity in the Taquari Megafan: Pantanal Basin in Mato Grosso do Sul Brazil}

FACINCANI, E. M., Federal University of Mato Grosso do Sul, Mato Grosso do Sul, Brazil, edna_facincani@ hotmail.com; ASSUMPÇĀO, M., University of São Paulo, São Paulo, Brazil, marcelo@iag.usp.br; SILVA, T. G., Federal University of Mato Grosso do Sul, Mato Grosso do Sul, Brazil, tiago.gomes@ufms.br; SILVA, L. J., Federal University of Mato Grosso do Sul, Mato Grosso do Sul, Brazil, lucimarajose@gmail.com; DIAS, F. L., National Observatory of Rio de Janeiro, Rio de Janeiro, Brazil, fabioludias@gmail.com; PEREIRA, W.P., Federal University of Mato Grosso do Sul, Mato Grosso do Sul, Brazil, wanlypereira@ hotmail.com; DOURADO, G. F., Federal University of Mato Grosso do Sul, Mato Grosso do Sul, Brazil, gustavo.gfd@ hotmail.com

Pantanal is a sedimentary basin of quaternary age, located in the Center-West region of Brazil, in the Upper Paraguay River Basin, constituting a seismogenic zone. The physiography of the area is characterized by the presence of fluvial megafans, mostly sandy, modern and associated with fault lines and structural lineaments. The Taquari Megafan is the largest of the Pantanal fluvial fans, constituting, therefore, the most remarkable feature of the basin seismicity. The region is structured by faults of reverse type generated under compressive stress, coinciding with epicenters of current earthquakes, which are evidenced by instrumental data. In the Mato Grosso do Sul state, the first seismographic station installed was the Aquidauana (AQDA) - MS, in May 2003, being an important landmark for seismology, as part of a research project titled "Integrated Seismographic Network of Brazil (BRASIS)", with the Institute of Astronomy, Geophysics and Atmospheric Sciences (IAG-USP). The seismic data analyzed presented magnitudes $\geq 3$.5, between 2003 and 2017. Six seismic events were recorded in Pantanal, four of which occurred in the Taquari Megafan, with magnitudes ranging from 3.5 to $4.8 \mathrm{Mb}$. Thus, it was possible to identify a major seismogenic zone in the Pantanal Sedimentary Basin, in the Nhecolândia region. The two most significant earthquakes that had their calculated focal mechanisms occurred in Coxim (2009) and Miranda (2015), with magnitudes 4.8 and 4.0Mb, respectively, with depths around $5 \mathrm{~km}$, as the result of transpressive and compressive stresses in both cases. Despite being a region in subsidence, the neotectonic stresses in the upper crust are compressive. The Pantanal Basin crustal thinning might be considered one of the hypothesis of its origin which is related to its seismicity.
The Importance of Additional Travel Times from Temporary Deployments for the Bulletin of the ISC

KORGER, E. I. M., International Seismological Centre, United Kingdom, edith@isc.ac.uk; BROWN, L., International Seismological Centre, United Kingdom, lonn@isc.ac.uk; LIESER, K., International Seismological Centre, United Kingdom, kathrin@isc.ac.uk; HARRIS, J., International Seismological Centre, United Kingdom, james@isc.ac.uk; EVE, J., International Seismological Centre, United Kingdom, john@isc.ac.uk; STORCHAK, D. A., International Seismological Centre, United Kingdom, dmitry@isc.ac.uk

The mission of the ISC is to maintain the definitive long-term record of global seismicity. Using the ISC services, researchers around the globe are able to request seismic arrival times, hypocentres, magnitudes, amplitudes, and other seismic parameters for either re-computed and verified data (ISC Reviewed Bulletin), or original data submitted directly by the contributing agencies. This is possible thanks to the non-governmental status of the ISC, broad international cooperation, and financial support of 65 institutions in 48 countries. Currently the ISC receives bulletin contributions regularly from about 150 permanent agencies/networks around the world, making use of approximately 8,000 permanent stations each year. However, due to the distribution of landmasses and earthquakes, there are still vast areas with poor ray-path coverage. Temporary stations are usually deployed conforming to the demands of specific research projects, including aftershock deployments, tomography, and moment tensor derivation. After specific research has been finished and authors have published their findings according to their individual research programs, seismological bulletins, if produced, provide a great opportunity to add new seismic travel times to ISC catalogued events, improving station azimuthal coverage and better constraining main source parameters. With permission and help from principal investigators of many temporary seismic deployments, a large volume of absolute travel times, hypocentres and moment tensors has already been added to the ISC Bulletin. In this poster, we present examples of the benefit of including these additional bulletins into the ISC Bulletin.

\section{ShakeMap-Related Research, Development, Operations and Applications \\ Poster Session · Thursday 17 May · Riverfront South}

\section{Measurement and Modeling of Ground Motions in Myanmar for Seismic Hazard Assessment}

WOLIN, E., US Geological Survey, Colorado, USA, wolin.emily@gmail.com; HTWE, Y. M. M., Department of Meteorology and Hydrology, Myanmar, jianyou.wu007@gmail.com; KYAW, T. L., Department of Meteorology and Hydrology, Myanmar, tunlin03@gmail.com; TUN, P. P., Department of Meteorology and Hydrology, Myanmar, ppt.nov08@gmail.com; HTWE, S. H., Department of Meteorology and Hydrology, Myanmar, suhninnhtwe23@gmail. com; WAI, K. M. L., Department of Meteorology and Hydrology, Myanmar, khaingmarlar.09@gmail.com; HOUGH, S. E., US Geological Survey, California, USA, hough@usgs.gov

An important first step in assessing the seismic hazard for any region is the selection or development of appropriate ground-motion prediction equations (GMPEs) that adequately describe the expected shaking from a specified earthquake. In this study, we apply the log-likelihood method of Scherbaum et al. (2004) to analyze residuals between predictions from a suite of GMPEs developed for tectonically active regions and ground-motion observations recorded by the Myanmar National Seismic Network (MNSN). Following major upgrades beginning in January 2016 (Hrin Nei Thiam et al., 2017), the MNSN now comprises $\geq 12$ real-time broadband and/or strong-motion stations distributed throughout the country. During its first two years of operation, the upgraded MNSN recorded multiple $M \geq 4$ events per month, including two deep M6.8 earthquakes near Chauk and Kale in 2016, and the M5.1 Taikkyi earthquake in 2017. We will briefly discuss ongoing work to evaluate the suitability of low-cost, low-power Raspberry Shake instruments to augment monitoring by the MNSN. We measure peak ground acceleration (PGA) for $\mathrm{M} \geq 3.5$ events within Myanmar and within $300 \mathrm{~km}$ of MNSN stations. We compare these PGA measurements with predicted ground motions from GMPEs developed for tectonically active regions as part of the NGA West and NGA West-2 model suite, including Chiou and Youngs (2008), among others. VS30 for MNSN stations is estimated from topographic slope using the proxy method of Wald and Allen (2007), and site amplification factors are calculated using the relationships of Seyhan and Stewart (2014). The results of this analysis will be used to inform decisions regarding the configuration of real-time ShakeMaps, produced by the Myanmar Department of Meteorology and Hydrology for rapid earthquake response. 
Near-Real-Time Ground Failure Estimates: A New USGS Real-Time Earthquake Product

ALLSTADT, K. E., US Geological Survey, Colorado, USA, kallstadt@usgs.gov; THOMPSON, E. M., US Geological Survey, Colorado, USA, emthompson@ usgs.gov; HEARNE, M., US Geological Survey, Colorado, USA, mhearne@ usgs.gov; WALD, D. J., US Geological Survey, Colorado, USA, wald@usgs. gov; NOWICKI JESSEE, M. A., University of Indiana Bloomington, Indiana, USA, manowick@indiana.edu; BIEGEL, K. M., US Geological Survey (now at University of Calgary), Colorado, USA, kmbiegel@gmail.com; HAMBURGER, M. W., University of Indiana Bloomington, Indiana, USA, hamburg@indiana. edu

We present a newly-developed USGS product that provides quantitative estimates of the severity and extent of earthquake-triggered landslide and liquefaction hazards in near-real-time for significant earthquakes worldwide. We anticipate that this product will be helpful for situational awareness and response efforts. The product is integrated with the existing suite of USGS real-time earthquake products. The algorithm receives shaking estimates from ShakeMap and provides outputs consistent with direct use by the USGS loss estimation products (PAGER and ShakeCast) and downloadable in standard GIS formats for other purposes. The summary webpage consists of interactive maps displaying preferred and alternative models for each ground failure type along with summary statistics, providing a basis for direct comparison between differing models and different triggering events. Optional alert levels based on the estimated hazard and population exposure can be used to rapidly identify earthquakes for which one or both of these ground failure hazard types may present a significant concern. The maps may be particularly useful when direct observations of ground failure are not possible due to time-of-day, weather conditions, or remote and rugged terrain. The product may also be applied to analyze significant past or future ("scenario") earthquakes. This initial product provides the base upon which we aim to build more sophisticated ground failure models and derivative products. Continued evaluation of models against recent datasets is required, as is iterative evaluation of the product presentation based on both peer and user feedback. Ongoing research and development includes (1) interpreting ground failure probabilities in the context of rapid ground failure estimation using satellite image decorrelations, and (2) incorporating more site-specific geotechnical constraints in the place of the global proxies for which the models were calibrated.

\section{Tectonic Classification of Earthquakes for Gmpe Selection}

THOMPSON, E. M., US Geological Survey, Colorado, USA, emthompson@ usgs.gov; HEARNE, M., US Geological Survey, Colorado, USA, mhearne@ usgs.gov; WORDEN, C. B., US Geological Survey, Colorado, USA, cbworden@ usgs.gov; HAYES, G. P., US Geological Survey, Colorado, USA, ghayes@usgs. gov; WALD, D. J., US Geological Survey, Colorado, USA, wald@usgs.gov

Tectonic classification of earthquakes is a key component of the USGS Global ShakeMap system because it serves as the basis for the selection of ground motion prediction equations (GMPEs). GMPE selection has a significant impact on the estimated ground motion intensities and therefore downstream USGS products (e.g., PAGER, ShakeCast). The current method of earthquake regionalization provides a seismotectonic classification of the event (e.g., "subduction zone interface" or "active crustal"), which is then mapped to an appropriate GMPE. The existing algorithm needs to be updated to account for issues that were not originally anticipated, such as the classification of induced earthquakes, and to account for the uncertainty of the classification. Uncertainty in the classification arises from many sources, including 1) uncertainty in the location of the earthquake and its treatment as a point source, 2) uncertainty in the focal mechanism, and 3) the precision of the boundaries between different tectonic environments. In the presence of such inherent uncertainty in the classification, we propose a probabilistic approach, where all classes are assigned a likelihood, rather than reporting a single "best guess" classification. The resulting ground motions are computed as a weighted combination of the GMPEs that are assigned to each region, where each region may be assigned one or more GMPEs with varying weights. This approach accounts for the uncertainty inherent to the regionalization, and helps to minimize artificial changes in ShakeMap versions due to a change in the tectonic classification. Our primary motivation is for assigning GMPEs in ShakeMap, but we do anticipate several other applications, such as the development of probabilistic seismic hazard models and earthquake early warning alerts.
Shakemap Based on Instrumental and Macroseismic Data in France: Feedback on Modified v3.5 and Expectation on V4

SCHLUPP, A., EOST/ University of Strasbourg, Bas-Rhin, France, antoine. schlupp@unistra.fr; GRUNBERG, M., EOST/ University of Strasbourg, BasRhin, France, marc.grunberg@unistra.fr

The seismicity of France is moderate in its Metropolitan part and related to a subduction context in its West Indies part. RESIF network (www.resif.fr) and, West Indies (IPGP-OVS) and bordering countries observatories provide us instrumental data. These accelerometric and velocimetric data are available in near real time. The BCSF-RENASS (EOST) provides Intensities, preliminary values are based on rapid citizen testimonies, frequently several thousands for $\mathrm{Mw} \geq \approx 4.5$, and final values EMS98 are based on study including field investigations if damage. With about 1 city per 15 square $\mathrm{km}$, we sample in details the territory when the about 400 seismic stations give irreplaceable precise ground motion parameters but very locally and most of the times at a farther epicentral distance. The USGS ShakeMap V3.5 run over the Pyrenees since 2012 (www.sispyr.eu) and since 2016, it runs for the whole territory of France at BCSF-RENASS (www. franceseisme.fr). We summarise few feedback on V3.5 and expectation on V4. We had to adapt the ShakeMap V3.5 for region with moderate size events. We obtain a huge improvement at any distance by including intensities but we need to weight their contribution depending the quality of data, preliminary or final, and the possible lack of data near the epicenter. Despite we added new GMPE or IPE; we need to use different regional attenuation law versus the location of the epicenter. An expectation would be to select automatically the GMPE or IPE that fit at best with the observations. Moreover, the variation of the attenuation versus azimuth seems to be strongly smoothed by the GMPE and IPE used. The V3.5 helped us to detect important ML overestimation in few regions, but the ShakeMap has still a strong dependency to the hypocenter localization, which cannot be corrected for example by using collected macroseismic data. We built a ShakeMap WG that brings together the French researchers and observatories (transversal action seismicity RESIF).

\section{ShakeMaps for Nicaragua and Central America Based on Seiscomp3 at INETER}

CAUZZI, C., Swiss Seismological Service at ETH Zürich, ZH, Switzerland, carlo.cauzzi@sed.ethz.ch; CLINTON, J. F., Swiss Seismological Service at ETH Zürich, Switzerland, jclinton@sed.ethz.ch; MASSIN, F., Swiss Seismological Service at ETH Zürich, Switzerland, fmassin@sed.ethz.ch; STRAUCH, W., Instituto Nicaragüense de Estudios Territoriales, Managua, Nicaragua, Nicaragua,wilfried.strauch@yahoo.com; RAMIREZ, J., Instituto Nicaragüense de Estudios Territoriales, Managua, Nicaragua, Nicaragua, javier.ramirez@ sb.ineter.gob.ni

Since 2016 SED and INETER are working jointly to build a prototype earthquake early warning and earthquake rapid information system for Nicaragua and also potentially for other countries in Central America (CAM). The project primarily requires implementing and testing state-of-the-art software and standard seismological services / tools in Nicaragua, and optimising the seismic network performance and design, targeting minimal latencies for real-time applications. ShakeMap is amongst the products calibrated and delivered within this project. We present herein the initial customisation of USGS ShakeMap 3.5 for Nicaragua and CAM, and encourage community contributions to further developments. The system, ShakeMapCAM (http://shakemapcam.ethz.ch), produces near-real-time maps of different ground-motion intensity measures (IMs) MMI, PGA and PGV—-for each M4.5+ earthquake in the region. It is triggered by automatic and manual locations made on an authoritative SeisComP3 (SCP3) server at INETER. Real-time operations started in Nov. 2016, and all M5+ events in the INETER SCP3 catalogue in the period Sept. 2014-Oct. 2016 were processed offline. We chose the ground-motion models (GMMs) based on the 2010 RESIS-II Seismic Hazard Model for CAM, including regionalisation according to the source depth. Peak ground motions are converted to MMI using global conversion equations. Local site amplification is accounted for through Vs,30 derived from topographic slope. Since data sharing across networks in CAM is excellent and should continue to improve in the framework of our joint project, ShakeMapCAM can serve the wider region. Alternatively, since most regional networks also operate SCP3, similar versions can run in each country. Future work will include: updating the site amplification model using local information; improving the shaking predictions based on local data and the weighted average of different GMMs; broadening the options for IMs; transitioning to ShakeMap 4

Estimating Fatalities Associated with Seismically Induced Landslides NOWICKI JESSEE, M. A., Indiana University, Indiana, USA, anowicki28@ gmail.com; HAMBURGER, M. W., Indiana University, Indiana, USA, 
hamburg@indiana.edu; ALLSTADT, K. E., US Geological Survey, Colorado, USA, kallstadt@usgs.gov; THOMPSON, E. M., US Geological Survey, Colorado, USA, emthompson@usgs.gov; WALD, D. J., US Geological Survey, Colorado, USA, wald@usgs.gov; FERRARA, M. R., University of British Columbia, madisonferrara93@gmail.com; MCLEAN, A., Indiana University, Indiana, USA, alemclea@umail.iu.edu; FITZGERALD, C., Indiana University, Indiana, USA, csfitzge@umail.iu.edu

Earthquake-induced landslides cause a significant portion of earthquakerelated fatalities and economic losses, and can have long-lasting negative societal impacts. We present a method to estimate the impact of seismically induced landslides on affected populations using the output of the USGS near-real-time earthquake products. Using a newly developed, comprehensive dataset of 196 historical earthquakes, including 127 events with known landslide fatality counts, we develop an empirical model that estimates the order of magnitude of potential fatalities based on the exposure of population to expected landslide occurrence. Using the grid of landslide probabilities output by the USGS Ground Failure earthquake product, we estimate population exposure by multiplying the predicted probability grid with a gridded global population database adjusted for population growth. We then sum over the entire grid for each event, and term this the predicted 'landslide exposure index.' We examine income level of the country of each earthquake as a secondary factor to represent relative vulnerability of the surrounding area. We compare these values to the number of actual fatalities for 91 training events in order to calibrate a model that can be used to predict the order of magnitude of potential fatalities due to plausible future earthquakes using scenario earthquakes. We observe a significant positive correlation between predicted and observed fatalities, with high variability in fatality rates for similar exposure levels. This suggests that other factors (e.g., building type, time of day, landslide density, effect of urbanization on population) may improve this estimate. Ultimately, the outputs of this method can be integrated into the USGS near-real-time earthquake information system. The outputs can provide input for use in the Ground Failure alert level designation and also an estimate of landslide fatalities, which are currently not included in PAGER's loss estimates.

\section{The 1918 Puerto Rico Earthquake as a Test Case of ShakeMap 4.0 Multi-} GMPE Capabilities

MARANO, K. D., US Geological Survey, Colorado, USA, kmarano@usgs. gov; WALD, D. J., US Geological Survey, Colorado, USA, wald@usgs.gov; HEARNE, M., US Geological Survey, Colorado, USA, mhearne@usgs.gov; THOMPSON, E. M., US Geological Survey, Colorado, USA, emthompson@ usgs.gov; WORDEN, C. B., US Geological Survey, Colorado, USA, cbworden@ usgs.gov

Puerto Rico has experienced strong, damaging earthquakes over its 500-year history due to its proximity to the plate boundary zone between the Caribbean and North American plates. The relative infrequency of these earthquakes, and their associated tsunamis, when compared to the much more pressing concern presented by the yearly hurricane season, means that the very real threat of another destructive earthquake is often overlooked. Yet, as demonstrated by the October 11, 1918 Mona Passage earthquake - in which 116 people were killed and damage was widespread over western parts of the island-the seismic hazard to Puerto Rico is considerable. The macroseismic observations across Puerto Rico from the 1918 event are well described in a classic Earthquake Investigation Report by Reid and Taber (1919), making it a valuable test case for the capabilities of and improvements to ShakeMap 4.0. We compare ground motions modeled using a single Ground Motion Prediction Equation (GMPE) in ShakeMap 3.5, both with and without intensity observations, to those calculated using the multiple, weighted GMPE capabilities of ShakeMap 4.0. The improved functionality of ShakeMap 4.0, including its ability to better accommodate macroseismic data, overcomes some of the limitations noted for both purely-predictive and datadriven ShakeMaps generated by earlier versions of the software. Additionally, we iterate on a variety of possible fault orientations for the 1918 earthquake and develop a preferred fault model that best fits the intensity observations. As demonstrated via this test case, we are now able to produce higher quality predictive ShakeMaps, improving USGS loss estimation products (e.g., PAGER) for scenario exercises and real events, enhancing the quality of earthquake hazard and loss information that is disseminated to at-risk populations, government agencies, and response personnel.

\section{Intensity Prediction Equations for Costa Rica}

PORRAS, J., Universidad de Costa Rica, San José, Costa Rica, juan.porrasloria@ ucr.ac.cr; LINKIMER, L., Universidad de Costa Rica, San José, Costa Rica, linkimerl@gmail.com

In this study, we approximate the expected Modified Mercalli Intensity (MMI) for earthquakes in Costa Rica by calculating an Intensity Prediction Equation (IPE) and by using instrumental records. The IPE relates MMI with Magnitude $(\mathrm{Mw})$ and hypocentral distance $(\mathrm{R})$ and has been determined based on 3581 reported intensities from 13 recent earthquakes with magnitudes between 4.9 and $7.7 \mathrm{Mw}$. The general equation obtained is: $\mathrm{IMM}=2.07+1.538^{*} \mathrm{M}+0.0016^{*} \mathrm{R}$ $-3.952 * \log 10 \mathrm{R}$ Two additional IPE were determined for subduction and crustal earthquakes. Our results show that there is a larger attenuation for crustal earthquakes as compared to subduction. In the case of the instrumental intensity maps, we utilized the ground motion recordings of the National Seismological Network of Costa Rica (RSN) and reported intensities for three relevant events (4.9, 5.4, and 5.5 Mw) during 2016. For these instrumental intensity maps, we conclude that Ground Motion to Intensity Conversion Equation (WA99) and the Ground Motion Conversion Equation (ZH06) best fit the observed intensities and may be used for the Costa Rican tectonic context. The MMI estimation based on IPE and instrumental maps represent an effort to provide automatic intensity estimations after earthquakes and are very important for emergency response and seismic hazard assessment.

\section{Structure and Geodynamics of the Caribbean Plate Boundaries}

Poster Session · Thursday 17 May · Riverfront South

\section{2-D Modeling of the Crustal Structure of Merida Andes, Venezuela, from Wide-Angle Seismic and Gravity Studies}

YEGRES, L. A., Venezuelan Foundation for Seismological Research, Miranda, Venezuela, lyegres@funvisis.gob.ve; SCHMITZ,M., Venezuelan Foundation for Seismological Research, Miranda, Venezuela, mschmitz@funvisis.gob.ve; SANCHEZ, J. R., Venezuelan Foundation for Seismological Research, Miranda, Venezuela, jsanchez@funvisis.gob.ve; ÁVILA, J. M., Venezuelan Foundation for Seismological Research, Miranda, Venezuela, javila@funvisis.gob.ve; RONDON, F. J., Venezuelan Foundation for Seismological Research, Miranda, Venezuela, frondon@funvisis.gob.ve

The Merida Andes (MA) is an orogeny delimiting the Maracaibo block to the west, in response to the subduction of the Caribbean Plate beneath South American continent. 2-D seismic and gravity modeling of the crustal structure of MA was carried out along the profile Central Andes with a length of 380 $\mathrm{kmfrom}$ the coast of Falcon, crossing perpendicular to the mountain range of the MA until its southeastern end in the Barinas-Apure basin. In the seismic data obtained from 11 shot points with 0.2 to 1 tons of explosive charges and recorded by 480 Texan recorders, we observed critical PmP reflections at distances of about $60 \mathrm{~km}$ for the northern part of the profile (Falcón Basin), and 120 to $90 \mathrm{~km}$ for the central and southern part of the profile, corresponding to the axis of the orogen and the Barinas Basin, respectively. Derived values for the depth of the Moho discontinuity range from $29 \mathrm{~km}$ depth for the Falcon basin, to $40-53 \mathrm{~km}$ close to the core of the chain, and $35 \mathrm{~km}$ at the southern end of the profile in Barinas basin. The crustal root is defined with a maximum depth of $53 \mathrm{~km}$, which is displaced with respect to the highest part of the chain at this segment, approximately $10 \mathrm{~km}$ towards the northwest. 325 gravity stations were acquired along the profile and modeled together with satellite gravity data in a high resolution 2D gravity forward model, which confirms the strong variations of the thickness of the crustal root and its asymmetry. Cenozoic sediments with a P-wave velocity $(\mathrm{Vp})$ ranging from 2 to $4 \mathrm{~km} / \mathrm{s}$ are underlain by Cretaceous sediments, ( $\mathrm{Vp}=4$ to 5 $\mathrm{km} / \mathrm{s}$ ) with a maximum depth of 10 and $6 \mathrm{~km}$ in the Maracaibo and BarinasApure basins, respectively. The crystalline basement shows Vp between 5.5 and $6.3 \mathrm{~km} / \mathrm{s}$ and a density of $2.78 \mathrm{~g} / \mathrm{cm} 3$ down to about $15 \mathrm{~km}$ beneath the basins and $25 \mathrm{~km}$ beneath the orogen. The lower crust is modeled with Vp of 6.5 to 7 $\mathrm{km} / \mathrm{s}$ and a density of $2.84 \mathrm{~g} / \mathrm{cm} 3$, underlain by the upper lithospheric mantle, with Vp greater than $7.7 \mathrm{~km} / \mathrm{sand}$ a density of $3.22 \mathrm{~g} / \mathrm{cm} 3$. The density model suggests the existence of an incipient A-subduction of continental South America towards the Maracaibo block. 
Analysis of Travel Time Curves for Puerto Rico Seismic Network Stations VENTURA, W. A., Universidad de Puerto Rico Mayagüez, Puerto Rico, USA, wilnelly.ventura@upr.edu; VANACORE, E. A., Puerto Rico Seismic Network, Puerto Rico, USA, elizabeth.vanacore@upr.edu

Puerto Rico Seismic Network's (PRSN) current 1-D crustal structure velocity model is more than 20 years old. Since then, the PRSN has increased its detection capability by increasing station coverage and upgrading existing equipment. Anecdotal evidence from senior data analysts indicate that travel time residuals vary with azimuth. Analysts have observed that data from stations in the northwest region of Puerto Rico demonstrate consistently high travel time residual values for earthquakes located on the eastern side of the island and vice versa. To examine and quantify the anecdotal evidence of this behavior, travel time curves were generated for four PRSN seismic stations located at Aguadilla (AGPR), Cabo Rojo (CRPR), Vieques (MTP) and Anegada (ABVI). The traveltime curves were generated using all available PRSN pick data from 19,689 earthquakes between January 2010 and December 2016. For each station of the travel time curves, travel time residuals and azimuthal variation of the travel time curve and residuals were generated. The analysis showed consistent non-symmetric residuals in AGPR with excess negative residuals and MTP with positive residuals, relating to probable high and low lithospheric velocity structures respectively. The travel time curves for these stations are consistent with the anomalies observed in the residuals. The travel time curve for CRPR also exhibited anomalous behavior consistent with observation at AGPR but did not have anomalous residuals. The analysis indicates that the Puerto Rico and Virgin Island Region exhibits complex 3D structures. Further studies are required to identify and characterize the regional $3 \mathrm{D}$ crustal velocity model.

\section{Lithospheric Structure beneath Northwestern Venezuela from Deep Seismic Profiling}

MAZUERA,F.,Central University of Venezuela, Caracas, Venezuela, mazueraf@ gmail.com; SCHMITZ, M., Venezuelan Foundation for Seismological Research, Caracas, Venezuela, mschmitz@funvisis.gob.ve; ESCALONA, A., University of Stavanger, Rogaland, Norway, alejandro.escalona@uis.no; LEVANDER, A. R., Rice University, Texas, USA, alan@rice.edu; ZELT, C., Rice University, Texas, USA, czelt@rice.edu

Northwestern Venezuela is located in a zone of complex deformation due to the Caribbean-South American plate interactions. Several models regarding the shallow and deep structure of the region have been proposed. Nevertheless, most of these studies are based on basin-scale observations, and they lack crustal observations in order to support the interpretation of lithospheric structures. In 2014, new deep seismic profiles have been acquired across the Merida Andes orogenic belt, and the adjacent sedimentary basins, with $2000 \mathrm{~km}$ of 2D seismic profiles. It is presented an integrated analysis of the $560 \mathrm{~km}$ longNorthern Andes seismic profile, oriented in a NNW direction, covering areas from the Proterozoic basement of GuyanaShield to both Paleozoic and Mesozoic-Cenozoic terranes. The profile cuts perpendicular to the main Boconostrike-slip fault system, aiming to image the collision zones (sutures), the crustal and lithospheric structure, and its impact onthe understanding of continental margin evolution. 13 land shots with explosive charges between 0.2 and 1.6 tons were recorded by 545 seismometers (Texans). 2-D P-wave models from first arrival tomography and ray tracing modeling show velocities between $3.2-5.7 \mathrm{~km} / \mathrm{s}$ for sedimentary cover; $6.1-6.5 \mathrm{~km} / \mathrm{s}$ for upper crust, and 6.7 to 7.2 , and 7.8 to $8.4 \mathrm{~km} / \mathrm{s}$ for lower crust and upper mantle, respectively. The most prominent features imaged were a crustal thinning beneath the Falcon basin due to a previous history as a back-arc basin. In addition, lateral variability suggests collisional process related to suture zones between both Proterozoic and Paleozoic, and Paleozoic and Mesozoic-Cenozoic provinces. No crustal root associated to the Merida Andes was observed, contrary to the two southernmost profiles, indicating that the Northern Andes profile is located north of the Andean crustal domain. Finally, the Caribbean slab was observed in a low-angle subduction context beneath NW South America.

Crustal Structure in the Dominican Republic from Receiver Function Analysis KUMAR, S., Indian Institute of Technology, Indian School of Mines, Jharkhand, India, sachinism15@gmail.com; NTULI, G., CTBTO, Austria, giftntul@gmail.com; AGRAWAL, M., Indian Institute of Technology, Indian School of Mines, Jharkhand, India, mohit@iitism.ac.in; PULLIAM, J., Baylor University, Texas, USA, jay_pulliam@baylor.edu; POLANCO RIVERA, E., Autonomous University of Santo Domingo, Dominican Republic, eugenio polanco_rivera@msn.com; HUERFANO, V. A., Puerto Rico Seismic Network, Puerto Rico, USA, victor@prsnmail.uprm.edu

The Dominican Republic (DR) comprises the eastern two-thirds of the island of Hispaniola, which is located on the Caribbean-North American plate bound- ary. Geological studies have led to a description of the shallow structure and stratigraphy of the island but little is known about the lower crust and mantle due to a dearth of broadband seismic data. Since August 2013 a seismic network consisting of 20 broadband, three-component seismic stations has been deployed in the DR. Here we report on a receiver function study of crustal thickness and bulk composition using teleseismic $\mathrm{P}$-wave data. We compute teleseismic receiver functions using an iterative time domain deconvolution technique and determine crustal properties via $\mathrm{H}-\kappa$ stacking. Three distinct, fault-bounded crustal domains, defined by characteristic Moho depths and bulk crustal Vp/Vs, are found in the DR. In the northern domain, the Moho has an average depth of $\sim 32 \mathrm{~km}$ with $\mathrm{Vp} / \mathrm{Vs}$ ratio $1.84 \pm 0.1$. Moho depths in the southern domain average $\sim 33 \mathrm{~km}$ and $\mathrm{Vp} / \mathrm{Vs}$ averages $1.68 \pm 0.1$. Thicker crust is found beneath the Cordillera Central, in the island's center, where Moho depths average $\sim 39 \mathrm{~km}$ and $\mathrm{Vp} / \mathrm{Vs}$ is $\sim 1.72 \pm 0.1$, while the crust at coastal areas of Dominican Republic has Moho depths of $\sim 29 \mathrm{~km}$ and $\mathrm{Vp} / \mathrm{Vs}$ of $1.77 \pm 0.1$. An E-W transect across the island's center and four N-S transects were produced to show variations of crustal thickness and bulk $\mathrm{Vp} / \mathrm{Vs}$ ratios. We interpret the southern domain to be a terrane accreted from the Caribbean Large Igneous Province. The thicker crust and average $\mathrm{Vp} / \mathrm{Vs}$ ratio in the island's center likely indicates an igneous root of the Cordillera Central, which includes Pico Duarte, the highest peak in the Caribbean. Lithospheric Structure and Tectonic Implications of the Dominican Republic
from Local and Teleseismic Tomography

MEJIA, H. P., Baylor University, Texas, USA, hannah_mejia@baylor.edu; PULliAM, J., Baylor University, Texas, USA, jay_pulliam@baylor.edu; HUERfano, V. A., University of Puerto Rico at Mayagüez, Puerto Rico, USA, victor@prsnmail.uprm.edu; POLANCO RIVERA, E., University of Santo Domingo, Dominican Republic, eugenio_polanco_rivera@msn.com

Oblique convergence between the Caribbean (CAR) and North American (NOAM) plates near Hispaniola and the island's observed clockwise rotation have led to competing hypotheses to explain its tectonics. Clockwise rotation of Hispaniola could be the result of slab edge push generated by (a) subducting NOAM plate, (b) two subducted lithospheric slabs, one southward-dipping from the NOAM plate and one northward-dipping from the CAR Plate at the Muertos Trough interacting at depth, or (c) collision with the carbonate Bahamas Platform. Any of these scenarios or a combination of them can cause intermediate-depth earthquakes. Examining the location of intermediate depth earthquakes along with regional tomography, recorded via a dense temporary network of seismic stations, has the potential to resolve differences between competing hypotheses. A new 1D P velocity model was determined and then used as a starting model for iterative, nonlinear inversion for 3D structure. A catalog of over 2000 teleseismic events and 200 moderate-sized local events recorded by a total of 30 stations during the interval 2013-2017 is used. The catalog averages $25 \mathrm{P}$ and $S$ wave arrival picks per event with the largest local event magnitude being 5.8. While some events are located as deep as $185 \mathrm{~km}$, over $80 \%$ are shallower than $35 \mathrm{~km}$. The intermediate-depth earthquakes appear to be associated with a slow $\mathrm{P}$ velocity anomaly. The shape of the slow anomaly suggests a southwarddipping NOAM subducting slab with a change in dip from $30^{\circ}$ to $50^{\circ}$ at $\sim 67 \mathrm{~km}$ depth. Deeper intermediate-depth earthquakes mark the leading edge of the feature we interpret to be the NOAM slab at $\sim 100 \mathrm{~km}$ depth. A slow velocity zone extends to the surface beneath central Hispaniola and may be associated with the uplifted Cordillera Central, which includes Pico Duarte, the highest point in the Caribbean. There is no indication in the tomography of a northward-dipping CAR slab subducted beneath eastern Hispaniola.

\section{Shear Wave Velocity Structure of the Lithosphere beneath the Eastern Caribbean Revealed by Ambient Noise Tomography}

ARNAIZ-RODRÍGUEZ, M. S., Universidad Central de Venezuela, Venuzuela, marianoarnaiz@gmail.com; NIU, F., Rice University, Texas, USA, niu@ rice.edu; SCHMITZ, M., Fundación de Investigaciones Simológicas, Caracas, Venezuela, schmitzschutt@gmail.com; LEVANDER, A. R., Rice University, Texas, USA, alan@rice.edu

We investigate shear-wave velocity structure of the eastern Caribbean lithosphere using continuous seismic records from broadband stations deployed around the study area. We construct cross-correlation functions of ambient noise for two time periods, 2003-2005 and 2011-2013, based on data availability. Phase velocities of fundamental-mode Rayleigh waves are measured from the dailystacked cross-correlation functions using a phase-matched-filter based method, and they are further projected on a set of $2^{\circ} \times 2^{\circ}$ grids, as suggested by checkerboard tests. The grid phase velocity dispersion data are inverted for 1D shear velocity profiles. The $3 \mathrm{D}$ velocity model indicates that the mean shear velocity in the lithospheric mantle is lower than the global average. Similar results have been 
reported beneath other large igneous provinces. Meanwhile, the lithosphereasthenosphere boundary is located at depths between $\sim 50 \mathrm{~km}$ and $\sim 75 \mathrm{~km}$, which is thinner than a normal oceanic lithosphere with an age of $\sim 126-150 \mathrm{Ma}$. We speculate that low velocities in the lithosphere are associated with its composition together with a slightly elevated thermal state. Significant amount melts are likely produced beneath the thickened oceanic crust during the formation of the Caribbean Large Igneous Province (CLIP). Meanwhile the plume head has also been eroding the Caribbean lithosphere. In a later stage after the magmatic event, the melts crystalized and formed pyroxenite, which possesses a low seismic velocity but a high density, resulting in a thin lithosphere with a reduced wavespeed. A thick buoyant crust overlying on a thin denser lithospheric mantle may explain the subduction configuration in the eastern Caribbean.

\section{The Seismicity of the Isthmus of Panama: Recent Findings.}

CAMACHO, E. I., Universidad de Panama, Panama, Panama, eduardo. camachoa@up.ac.pa; TAPIA, A. A., Universidad de Panama, Panama, Panama, aalaint@hotmail.com

The Isthmus of Panama is in the Panama microplate, which presents some complicated plate boundaries. Historically this region has been shaken by some large destructive earthquakes: September 7, 1882 (Mw7.9), which also caused a destructive tsunami, and July 18, 1934 (Mw7.5), but its seismicity and seismic hazard is much smaller when compared with the surrounding regions of the Caribbean and Central America. The recent improvement of the seismic networks in the country has provided data which confirms the existence of subduction in southwestern Panama, east of Burica peninsula, near the border with Costa Rica and probably related to the convergence of the Cocos Ridge. Recent activity in southern Panama also confirms the strike slip character of the faults in the Sona-Azuero fault zone. Finally, the April 2017 sequence in western Panama also confirms the existence of strike slip faults, capable of generating destructive earthquakes, in the highlands of Panama. All these results are important to understand more precisely the seismotectonics of the Isthmus of Panama and contribute to mitigate the seismic hazard in this region of Central America, through less uncertain hazard assessments.

\section{Uncertainty in Ground Motion Estimation; Seismological and Engineering Perspectives}

Poster Session · Thursday 17 May · Riverfront South

Further Validation of a Dynamic Earthquake Model to Produce Realistic Near-Field Ground Motion

MA, S., San Diego State University, California, USA, sma@mail.sdsu.edu

I further validate the dynamic earthquake model of Andrews and Ma (2016), which uses heterogeneous stress drop with a self-similar power-law spatial spectrum on a planar fault to produce realistic ground motion. Andrews and $\mathrm{Ma}$ (2016) compared ground motion at a Joyner-Boore distance of $10 \mathrm{~km}$ for MW 7 earthquakes on a vertical strike-slip fault. The calculated mean response spectrum of 10 random realizations agrees remarkably well with the ground-motion prediction equation (GMPE) of Boore et al. (2014), which is within $25 \%$ of one stan dard deviation at frequencies up to $3 \mathrm{~Hz}$. The standard deviation of the calculated ground motion is a substantial fraction of that of the GMPE. I focus on MW 6.5 vertical strike-slip earthquakes, where the fault dimension reduces approximately from $60 \mathrm{~km} \times 15 \mathrm{~km}$ for M7 to $30 \mathrm{~km}$ x $15 \mathrm{~km}$, a factor of 2 reduction. Special attention is paid to ensure that the lowest Fourier mode of the 2D stress field matches the target moment magnitude due to the change of fault aspect ratio. This lowest Fourier mode determines the amplitudes of higher modes and is the fundamental parameter in the Andrews and $\mathrm{Ma}$ (2016) model; other adjustable parameters have secondary effects. Again standard deviations of the pseudospectral velocity (PSV) and peak ground velocity (PGV) show a large fraction of those of the GMPE up to $3 \mathrm{~Hz}$. However, the means of PSV and PGV from the model slightly underestimate those of the GMPE. One possible reason is less of directivity effect for a smaller fault for M6.5. Another important reason may be that modeled ruptures extended all the way to the surface. Buried ruptures generate higher ground motion than surface-rupturing events (Dalguer $e t$ al., 2008; Pitarka $e t$ al., 2009). I am investigating the effect of limiting the rupture extent to depth and will provide the latest results on the validation.
An Empirical Model for Fourier Amplitude Spectra Using the NGA-West2 Database

BAYLESS, J. R., UC Davis, California, USA, jeff.bayless@aecom.com; ABRAHAMSON, N. A., UC Davis, California, USA, abrahamson@berkeley. edu

We develop an empirical ground-motion model (GMM) for Fourier amplitude spectra (FAS) using the PEER NGA-W2 database of ground motions from crustal earthquakes (Ancheta et al., 2014). GMMs have traditionally been developed for 5\%-damped response spectra (PSA), however, there are some available models for FAS (e.g. Bora et al., 2015; Stafford et al., 2006; Yenier and Atkinson, 2015). There are two key advantages of developing FAS model over PSA models: the FAS is more closely related to the physical behavior so that it is easier to apply seismological constraints to the GMM; and the Fourier spectrum is linear which allows ground motion from small magnitude earthquake to be used to constrain the linear path and linear site effects without the spectral shape dependence of PSA. The GMM features a magnitude scaling formulation guided by Chiou and Youngs (2014). Large-magnitude near-fault saturation to capture the effects of extended ruptures is included and guided by broadband simulations up to M8.0. The GMM features stronger near-fault magnitude scaling (less saturation) than the CY14 model for PSA. The model includes terms for anelastic attenuation, site effects (Vs and kappa), style of faulting, hanging wall, and depth to top of rupture. The model coefficients are smoothed in a series of steps to assure smooth spectra and to constrain the extrapolation. An essential feature of forward-application for GMMs is their ability to reliably extrapolate to the key large magnitude and short distance ranges that often control the hazard. This allows for the GMMs to be applied beyond the ranges well constrained by empirical data. Our model is applicable to crustal earthquakes in the range M3-8, with rupture distances $0-300 \mathrm{~km}$, for sites with Vs30 between $150-2,000 \mathrm{~m} / \mathrm{s}$, and over the frequency range $0.1-100 \mathrm{~Hz}$. Models for the between-event, within-event, and total standard deviation are provided.

\section{Bayesian Uncertainty Quantification and Sensitivity Analysis of PSHA} Results

KUEHN, N. M., UC Berkeley, California, USA, kuehn@berkeley.edu; ABRAHAMSON, N. A., UC Berkeley, California, USA, abrahamson@ berkeley.edu; MOLKENTHIN, C., University of Potsdam, Germany, cmolke@ math.uni-potsdam.de

Many inputs in the calculation of probabilistic seismic hazard analysis are known only with considerable uncertainty. Thus, it is important to capture the range of uncertain inputs in the PSHA results. This requires repeated hazard calculations with different sets of input parameters. It is also of interest which of the uncertain inputs have the greatest influence on the hazard results, which can be achieved by systematically varying the inputs and observing the variation in the hazard results. Repeated hazard calculations are computationally expensive, which can make large scale uncertainty quantification and sensitivity analysis prohibitive. We propose to use an emulator as a computationally efficient approximation to hazard calculations that can be used to address these questions. The emulator is estimated based on a few hazard runs for varying inputs, and is subsequently used to draw inferences about the distribution of hazard results for uncertain inputs. The emulator is cast in a Bayesian fashion, which allows to carry its associated uncertainties through the analysis. In particular, the emulator models the output, as a function of the input, as a Gaussian process (GP), and inferences about the distribution of the hazard outputs can be drawn from the posterior distribution of the GP. We illustrate the approach by performing uncertainty quantification and sensitivity analysis for a suite of simple hazard problems. The emulator achieves similar accuracy as a full Monte Carlo simulation, while requiring many fewer runs of the hazard code.

\section{Investigating Ground Motion Variability from Shaking Simulations with Complex Earthquake Sources}

SIVASUBRAMONIAN, J., King Abdullah University of Science and Technology, Makkah, Saudi Arabia, jayalakshmi.sivasubramonian@kaust.edu. sa; MAI, P. M., King Abdullah University of Science and Technology, Makkah, Saudi Arabia,martin.mai@kaust.edu.sa

Earthquake ground motions are strongly affected by complexities of the source, source-to-site distance and the site conditions. These complexities are often too simply parameterized in empirical Ground Motion Prediction Equations (GMPEs), leading to substantial variability in the predictions. Due to limited available data, ground motion variability is often modeled as being constant (e.g., Boore \& Atkinson 2008), however, further quantifying ground-motion variability, and ideally reducing it, is important for improved seismic hazard assessment. To address this problem, one can use simulation-based approaches to analyze the 
simulated ground motion and estimate their variability with respect to GMPEbased methods (e.g. Vyas et al., 2016). However, such simulations require detailed modelling of the earthquake source and precise quantification of its effect on ground motions. In this study, we simulate ground motions for M7 strike slip earthquakes for a dense grid of stations with source-to-site distances $1 \leq \mathrm{R} \leq 20 \mathrm{~km}$. To focus on source-related effects, we assume initially a homogenous half space. We create rupture scenarios with different hypocenter locations on a rupture plane with constant slip, rise time and rupture velocity. Our results show strong distance-dependence of PGV in the along-strike direction of the fault, which can be explained by the isochrone theory. However, in the fault-normal direction, the theory works differently for near field $(<5 \mathrm{~km})$ and far field PGV. Furthermore, simulated ground motions are found to be lower for shallow $(\mathrm{H}=3 \mathrm{~km})$ compared to deeper focal depths $(\mathrm{H}=13 \mathrm{~km})$. Considering the local on-fault rupture evolution and the radiation-pattern effects, we conjecture that as the rupture propagates towards these sites, seismic radiation is more dispersed, hence leading to lower ground motions. We investigate the source effect on ground motion variability by varying the rupture velocity, focal depth and slip distribution on rupture plane.

Investigation of the Regional Effects on Ground Motion Predictive Models for Western Turkey: Preliminary Results

TANIRCAN, G., Boğazici University Kandilli Observatory and Earthquake Research Institute, Turkey, birgore@boun.edu.tr; YENIER, E., Nanometrics Inc., emrah.yenier@gmail.com; AKKAR, S., Boğazici University Kandilli Observatory and Earthquake Research Institute, Turkey, sinan.akkar@boun. edu.tr; PINAR, A., Boğazici University Kandilli Observatory and Earthquake Research Institute, Turkey, pinara@boun.edu.tr; KALE, O., TED University, Turkey, ozkan.kale@tedu.edu.tr

Regional differences in ground-motion amplitudes are investigated by using the conventional residual analyses of strong-motion and broad-band data compiled from the Marmara and Aegean regions in Turkey. A ground-motion dataset compiled from the earthquakes occurred between 1976 and 2017 is used for this purpose. The lower magnitude limit of the dataset is ML 3.5 whereas epicentral distances of the recordings are within $300 \mathrm{~km}$. The events are shallow crustal having hypocentral depths less than $30 \mathrm{~km}$. Simple H/V ratios of accelerograms are calculated to estimate resonance frequencies for strong-motion stations lacking geotechnical/geophysical investigations. This procedure led the soil classification of ground motions recorded at these stations. Geometric means of horizontal peak accelerations (PGA) as well as 5\% damped linear elastic response accelerations $(\mathrm{Sa})$ at various structural periods are calculated and are used together with the most recent local ground-motion predictive model by Kale et al. (2015; BSSA 105, 963-980) that is exclusively developed from the strong-motion accel- erograms collected from entire Turkey. The between- and within-event residuals are computed separately for Marmara and Aegean Regions, which feature two distinct seismotectonic regimes, and they suggest biased ground-motion estimates in terms of source and path. The biased ground-motion estimates advocate the influence of regional differences that Kale et al. cannot capture because this model is not sensitive to regional variations in stress drop, anelastic attenuation or geometrical spreading in mainland Turkey. The results of this study will serve to develop a region-dependent ground-motion predictive model for Turkey that will be a product of the "Updating and Extending the European Seismic Hazard Model" task in SERA project (Horizon 2020-Seismology and Earthquake Engineering Research Infrastructure Alliance for Europe).

\section{Assessment of Strong Ground Motion Variability in Japan}

NAMPALLY, S., King Abdullah University of Science and Technology, Makkah, Saudi Arabia, subhadra.nampally@kaust.edu.sa; MAI, P. M., King Abdullah University of Science and Technology, Makkah, Saudi Arabia, martin. mai@kaust.edu.sa

The variability (sigma) of ground motion has a significant impact on seismic hazard and risk assessment on a regional scale. The residuals between observed and predicted ground motions (using a ground-motion prediction equation, GMPE) are used to assess the repeatable source, path and site effects. Quantifying residuals by removing the ergodic assumption and thereby (hopefully) reducing the total sigma associated with GMPE helps to more accurately quantify the hazard levels, in particular at low probabilities of exceedance. In this study, we investigate variations in sigma and its components (source-specific, path-specific and sitespecific), the between-event variability $(\tau)$ and within-event variability $(\Phi)$ using strong motion data from Japanese KiK network. The analysis is carried out on 3000 recordings, from 80 shallow earthquakes recorded at 128 sites at distances $(\mathrm{R} \leq 150 \mathrm{~km})$. We apply the GMPE for shallow crustal earthquakes for Japan by Zhao et al (2016) as reference to predict the geometric mean of the horizontal peak ground accelerations and response spectral ordinates in the period range $0.01-5 \mathrm{~s}$. The dataset is divided into clusters of recordings from earthquakes to estimate location and path terms following the region-less approach (Lin et al 2011). These location and path terms are correlated, such that the degree of correlation depends on the separation distance between paths which is quantified by the closeness index (CI). We then calculate the between-event and within-event variability, and bin the data for different spectral acceleration values at periods of $0.01,0.1,0.3,0.5,1$ and $3 \mathrm{~s}$. The between-event variability accounts for different source parameters (e.g. stress drop, rise time, rupture velocity), while the withinevent variability accounts for the radiation pattern, directivity, 3-D wave propagation, and site response. These spatial correlations can be incorporated into sitespecific GMPE for more accurate ground motion predictions. 


\section{Index of Authors}

Aagaard, B. T. 846

Abbott, R. E. 819, 866

Abercrombie, R. E. 912, 914

Abers, G. A. 872

Abolfathian, N. 834

Abrahamson, N. A. 845,875 , 933, 958

Acosta, A. 839

Acosta, N. 881

Adamaki, A. K. 917

Adamova, P. 912

Aderhold, K. 852, 893

Afanasiev, M. 835, 924

Agail, A. 816

Agrawal, M. 957

Aguaiza, S. 799

Aguilar, A. L. 719, 953

Aguilar, J. 887

Aguilar-Calderón, L. A. 890, 905, 906

Aguinaga, D. S. 830

Aguinda, C. R. 806

Aguirre, P. 825

Aguirre-Gonzalez, J. 905, 906

Agurto-Detzel, H. 872, 885, 886,952

Ahdi, S. K. 787, 875

Ahern, T. 812

Ajo-Franklin, J. B. 868

Ak, E. 896

Akkar, S. 798, 823, 959

Aktug, B. 953

Al Noman, M. N. 879

Alalli, A. A. 896

Alarcon, E. 837, 892

Alaska Earthquake Center Staff 884

Albarello, D. 887

Albert, S. A. 818,857

Albuquerque, D. F. 817,859

Alcántara-Nolasco, L. 905

Alcik, H. 835

Aldridge, D. F. 913

Al-Enezi, A. 797

Ali, S. T. 813,870

Aliaga, B. 915, 931

Al-Jeri, F. 797

Allardice, S. A. 880,892

Allen, R. M. 811, 847, 864, $880,910,938$

Allen, T. 874, 926

Allstadt, K. E. 791, 824, 925, 955

Almora-Mata, D. 890, 905, 906

Al-Qazweeni, J. 797

Alvarado, A. 795, 796, 802, $835,854,855,872,885$, $886,887,888,894,952$

Alvarado, G. E. 808

Alvarado, K. 856

Alvarado, P. 871,941

Alvarado, R. C. 871

Alvarez, M. G. $840,851,881$

Alvizuri, C. R. 869

Amann, F. 861

Ambrois, D. 952
Ambruz, N. B. 809

Amelung, F. 799, 832

Amitrano, D. 823

Ammirati, J. B. 941

Ammon, C. J. 817, 819

Ampuero, J. P. 890, 907, 929

Amundson, J. 792

Ancheta, T. 875

Anderson, A. 792

Anderson, B. 846

Anderson, D. N. 819

Anderson, J. G. 876, 904

Anderson, K. R. 895

Anderson, M. 941

Andrews, J. 810, 881

Anglade, A. 885

Anselmi, M. 949

Anthony, R. E. 791

Antolik, M. 889

Antoun, T. 785

Arabidze, V. 827

Arámbula, R. 829

Aranda Viana, G. 900

Arango-Galvan, C. 920

Aranha, M. 864

Araujo, M. 941,942

Araya, M. C. 943

Arboleda, L. 835

Archilla, J. 895

Archuleta, R. 875

Arellano, D. 815

Arguello-Miranda, G. J. 839, 848,881

Aristizábal, C. 788

Arnaiz-Rodríguez, M. S. 957

Arnold, M. A. 809

Arnold, R. 820

Arnous, A. 900

Aron, F. 795, 796, 826

Arora, N. 909

Arozarena-Llopis, I. 814

Arregui Ojeda, S. 865

Arriola, S. 842

Arrowsmith, S. J. 818

Arroyo, D. 930

Arroyo, I. G. 808, 943

Arroyo Solórzano, M. 794, 808

Arzate-Flores, J. A. 920

Ash, C. 856

Ashoory, M. 833

Asimaki, D. 788, 821

Assumpção, M. 808, 817, $823,827,859,901,914$, $941,942,943,949,954$

Aster, R. C. 791, 792, 799, $852,889,895$

Atkinson, G. M. 821, 875, 942

Audemard, F. 866

Audet, P. 852

Audin, L. 795, 796, 802, 825,854

Auer, L. 901

Ausbrooks, S. M. 860

Austin, K. E. 850, 865

Ávila, J. M. 956

Avouac, J. P. 825
Ayala, S. 946

Ayala-Hernández, M. 890, 905, 906

Ayoubi, P. 821

Aziz Zanjani, F. 899

Azizzadeh-Roodpish, S. 936

Bachhuber, J. 815

Baena-Rivera, M. 905, 906

Baez-Sánchez, G. 809, 931, 948

Bahavar, M. 824

Bailis, P. 906

Baillet, L. 791, 824

Bainbridge, G. 884

Baise, L. G. 908, 947

Baize, S. 795, 802

Baker, L. M. 895, 952

Baker, M. G. 792, 889

Bakkar, H. 808

Balestrini, F. I. 816

Ballard, S. 818

Baltay, A. S. $837,846,905$, 914, 932

Bandy, W. 892

Bangs, N. 853

Bao, F. 897

Bao, X. 846,880

Baram, A. 821

Baratin, L. M. 889

Barberopoulou, A. 813

Barbosa, J. R. 808, 949

Barclay, D. J. 884

Bard, P. Y. 786, 788, 834, 844

Barman, D. 817,863

Barrancos, J. 799, 828, 839, 907, 935,953

Barrientos, S. E. 809, 854, 936

Barrière, J. 798, 883

Barros, J. G. 835, 887, 888

Barros, K. 909

Barros, L. V. 817, 859, 913, 941

Barsuglia, M. 907

Bartel, B. 718

Bartholomaus, T. 792

Basili, R. 813

Battaglia, M. 949

Baturan, D. 851

Bauer, R. 861

Baumgartner, P. 853

Bautista, M. A. 829

Bayless, J. R. 958

Bayrón Toro, F. 932

Beaudoin, B. C. 852

Beauval, C. 788,795

Beck, C. 853,885

Beck, S. L. $871,872,885$, $886,941,952$

Becker, J. S. 915

Becker, N. C. 809

Becker, T. W. 901

Beeson, J. 803

Begnaud, M. L. 819, 892

Bekaert, D. 929

Bell, S. W. 790

Bellanova, J. 860

Bello, D. I. 838, 929, 945,947
Benavente Escobar, C. L. 802,854

Bender, A. M. 836

Benítez, D. S. 800, 829, 830, 883

Benito, J. J. 805, 833

Bennington, N. L. 828, 829, 830,831

Bent, A. L. $843,852,871$, 900, 925

Benz, H. M. 809, 868, 886, 941

Ben-Zion, Y. 784, 834, 867, $889,891,938,940,950$

Bergen, K. J. 906

Bergman, E. 886

Bernard, P. 907

Bernardino, M. V. 790

Bernauer, F. 936

Beroza, G. C. 783, 784, 896, 902, 906, 908, 923, 924 . 937, 945

Bertrand, E. 878

Besana-Ostman, G. 840

Beyer, J. L. 848

Bezada, M. J. 843, 872, 927

Bhadha, R. 810, 851, 881

Bianchi, M. 808, 816, 817

Bianco, M. J. 908

Biasi, G. P. 840, 851, 876

Bieber, A. 853

Biegel, K. M. 955

Bierma, R. M. 851

Bigueur, A. 936

Bilek, S. L. $801,866,895$

Bird, A. L. 794

Bishop, B. T. 871

Biswas, R. 879

Biundo, M. 809

Black, B. 802, 803

Blanco Chia, J. F. 808

Blanco, F. 881

Bloch, W. 951

Blom, P. S. 819

Bloomquist, D. K. 851

Blycker, W. L. 810, 839

Boak, J. 918

Bocanegra, A. 795, 835

Bodin, P. 807, 809, 864

Boehm, C. 835, 924

Boese, M. 939

Boettcher, M.S. 827

Boggs, K. 852

Bohnenstiehl, D. R. 827

Bohnhoff, M. 859, 922, 950

Boisson, D. 863

Bonilla, L. F. 878,888

Bonner, J. 785

Boore, D. M. 844, 875

Borcherdt, R. D. 789

Bormann, J. M. 803

Boschi, L. 901

Böse, M. 881

Bosman, K. 861

Bowen, B. D. 941

Bowman, D. C. $718,786,857$

Boyce, E. 850

Boyd, O. S. 875, 876, 903 , 911, 933

Bozorgnia, Y. 787, 844, 845, 875

Bradley, C. R. 784

Braeuer, K. 830

Brandenberg, S. J. 816

Braun, T. 941

Braunmiller, J. 799, 818, 824, 864, 943

Bravo Monge, J. B. 935

Brenes-Marin, J. 800

Breuer, A. 805

Briceño, T. C. 812

Bridgeland, W. T. 802

Briggs, R. W. 803, 836, 837, 
Cardenas Monroy, C. 838 , 929

Cardenas-Soto, M. 828

Cardona, A. J. 842

Cardona-Piedrahíta, L. A. 866

Cardozo, F. R. 913

Carlut, J. 853

Carmichael, J. 857

Carn, S. 857

Caron, B. 853

Carpenter, N.S. 822

Carpenter, P. 852

Carrasco, S. 881

Carvalho, J. M. 859, 913, 941

CASEIS Scientific Team 853

Cassidy, J. F. 794, 871

Castillo Aguilar, S. 886

Castrillo, E. N. 857

Castro, M. J. 813

Castro, R. R. 877

Castro-Parra, G. 890, 905 , 906

Catchings, R. D. 783, 820

Cattaneo, A. 853, 885

Cauzzi, C. 926, 955

Celebi, M. K. 797, 905

Celso Romanel, C. R. 806

Cembrano, J. 795, 826

Cesca, S. 941

Chacon-Barrantes, S. E. 814 , 841

Chai, C. 817

Chaljub, E. 804

Chamberlain, C. J. 889, 891, 951

Champenois, J. 795

Chan, J. H. 783, 820, 822

Chang, J. C. 810,918

Chapman, C. H. 913

Chapman, M. C. 940

Chaput, J. A. 792, 799, 889

Chartier, T. 795

Charvis, P. 862, 872, 885, 886, 952

Chaves, E. J. 914

Chávez-García, F. J. 783

Chaytor, J. D. 806

Chen, G. 827

Chen, J. 951

Chen, L. 880

Chen, M. 872

Chen, S. 787,935

Chen, T. 897, 938

Chen, X. 832

Chen, Y. 825

Cheng, J. 827

Cheng, Y. 891

Cheze, J. 952

Chiang, A. 870

Chiarabba, C. 949

Chicangana, G. 795, 835

Chichester, B. 927

Chiou, B. 875

Chlieh, M. 825

Cholewinski, N. 836, 837

Chon, E. R. 892

Chorney, D. 911

Chouet, B. 799

Chounet, A. 858

Christensen, B. 808

Christenson, B. 799
Christian, F. 832

Christiansen, L. A. 784

Chu, S. A. 945

Chung, A. I. 847,880

Churches, C. 921

Ciardelli, C. 914, 942

Cilia, M. G. 952

Çıtak, S. 922

Clayton, R. W. 810, 873

Clements, T. H. 792

Clinton, J. F. 840, 881, 909 , 926, 939, 955

Clouard, V. 898

Cockerill, T. 812

Coelho, D. L. O. 873

Collaço, B. B. 808

Collahuazo, A. A. 812

Collier, J. 927

Collins, L. D. 824

Colon, B. 931

Colvez, M. 878

Condori, C. 900

Connolly, J. 807, 809

Contreras Arratia, R. A. 892

Contreras, M. 905, 906

Contreras Ruiz Esparza, M. G. 838,929

Contreras, V. 875, 945

Convers, J. A. 949

Cooke, M. L. 848

Corbeau, J. 863, 898

Corbi, F. 923

Corbo-Camargo, F. 920

Cordero-Soto, L 872

Córdoba Barba, D. 862, 892

Córdova, A. E. 830, 831

Cormier, V. F. 846

Cornejo, G. 829

Cornthwaite, J. P. 872, 927

Corona Morales, N. 814, 928, 931

Coşkun, Z. 922

Cotton, F. 874

Courboulex, F. 878, 888, 952

Cox, B. R. 787

Crain, K. 949

Cramer, C. H. $815,877,879$, 910, 936, 939

Crane, S. J. 910

Creager, K. C. 809,832

Crempien, J. G. F. 796

Criado Sutti, E. J. M. 900

Criley, C. J. 783

Croker, D. 839

Cronin, R. A. 831

Crouse, C. B. 934

Crowell, B. W. $809,864,865$

Cruz, D. R. 812

Cruz, E. 951

Cruz, J. L. 838, 894, 929, 947

Cruz-Atienza, V. M. 804, 928, 929, 930

Cruz-Jímenez, H. 930

Cui, Y. 805,875

Cultrera, G. 786, 925

Currie, B. S. 861,950

Cushing, E. M. 786

Custódio, S. 924

da Silva, S. L. E. F. 940

Dahal, N. R. 944

Dahm, T. 923
Daneshvaran, S. 887

Daniels, C. 951

Dañobeitia, J. J. 892

Darbyshire, F. A. 900

Darko, A. B. 820

Darold, A. P. 883

Darragh, R. B. 845,875 , 919, 945

D’Auria, L. 799, 828, 839, $907,935,937,953$

Dávalos Sotelo, R. 886

Dawson, P. 799

Daza, J. M. 855

de la Llera, J. C. 825

de Melo, B. C. 901

de Toldi, E. 936

De Barros, L. 952

De Gori, P. 949

De Guzman, R. 846

De la Cruz, Y. 922

De Pascale, G. P. 815

De Plaen, R. S. M. 828

Dearborn, D. 814

Dee, S. M. 876, 904

Deelman, E. 875

del Campo, F. 854

Del Valle-Rosales, M. 783

Delano, J. E. 803,836

Delgado-Diance, R. 905, 906

DeLong, S. B. 836, 907

Delorey, A. A. 784, 817, 823, 939

Delph, J. R. 871

deMartin, B. 832

Deng, W. 843

Denolle, M. A. 788, 792, 859,890

DePaolis, J. M. 940

dePolo, C. M. 876, 904

Der Kiureghian, A. 844

Derouin, S. A. 806

Deschamps, A. 952

DeShon, H. R. 950

Devilme, G. 915

Devora, A. 851

DeVries, P. 908

Dhulipala, S. 794

Di Manna, P. 813

Diao, H. 834

Dias, F. L. 943, 954

Diaz-Mojica, J. 928

Dickenson, S. 822

Dickson, I. 811

Diefenbach, A. 857

Dietze, M. 790

Dionicio, V. 927

Dittman, S. T. 865

Dodge, D. A. 869,895

Doering, T. 824

Doetsch, J. 861

Dogru, A. 923, 953

Dominguez, J. 947

Donnellan, A. 812, 841, 907

D'Onofrio, A. F. 925

D'Oreye, N. 798, 883

Dorn, K. M. 824

Dou, S. 868

Dougherty, S. L. 867, 949

Douilly, R. 848

Dourado, G. F. 827, 954

Downey, N. J. 818
Dreger, D. S. 870, 911

Dresen, G. 859, 922

Driscoll, N. W. 803, 825

Drobeck, D. L. 810,839

Drumond, B. 859

Duca, L. 899

Ducassou, E. 853

Dunn, M. 822

Duputel, Z. 929

Duque, E. P. 812

Dura, T. 802

DuRoss, C. B. $803,836,837$

Duru, K. C. 849,882

Dutler, N. 861

Eakin, C. 863

Earle, P. S. 809, 868, 874

Eaton, D. 852

Ebel, J. E. 944, 952

Ebinger, C. J. 800

Eble, M. C. 842

Echeverría, J. 951

Edwards, B. 820, 872

Edwards, S. 826

Eilers, D. 824

Eilon, Z. 843

Elezabi, H. 906

Eliahu, U. 815

Eliassi, M. 785

Ellsworth, W. L. 867, 918, 937, 945

Enders, M. L. 851, 852

Engelhart, S. E. 802, 852

Enkin, R. 802

Ermert, L. 924

Escalante, C. 813

Escalona, A. 957

Escobar, J.J. 842

Espín, P. A. 835

Espíndola, V. H. 838, 928, 929

Espinosa, P. J. 788, 815

Espinoza, O. 922

Estrada, J. A. 838, 894, 929

Eto, K. 857

Euler, G. G. 819

Euser, B. J. 805

Evans, J. 891

Eve, J. 954

Ewald, M. 802

Ezzedine, S. 785, 814, 819

Facincani, E. M. 827,954

Faenza, L. 926

Faizan, A. A. 798

Famiani, D. 925, 941

Fan, W. 913

Fang, H. 783

Farajpour, Z. 834, 902

Farber, D. L. 825

Farhadi, A. F. 878, 902

Farrell, A. K. 818, 824, 829

Farrell, J. M. 810, 831, 895

Fasola, S. L. 861

Fayek, M. 852

FDSN WGII, A. 840

Feaux, K. F. 850,865

Fee, D. 799, 857, 858

Feigl, K. 843, 896

Feliciano-Centeno, L. M. 842

Felizardo, C. 881

Fernandez, A.M 942

Ferrara, M. R. 955

Ferrari, L. 920

Ferreira, P. A. R. 940 
Gee, R. 870

Geertsema, M. 791

Geimer, P. R. 792, 824

Geirsson, H. 798, 913, 920, 921

Geissler, W. H. 830

Gelfenbaum, G. 852

Gélis, C. $786,844,878$

Geng, J. 928

George, C. 856

George, D. M. 791

Gerstenberger, M. 915

Gerstoft, P. 792, 908

Ghasemi, H. 874, 926

Ghofrani, H. 882

Giallini, S. 887

Gibbons, D. A. 809,824

Gilbert, H. 941

Gilchrist, J. J. 890

Gill, D. 875

Gischig, V. S. 861

Goda, K. 796

Godfrey, H. J. 891

Godoladze, T. 826, 944

Goebel, T. H. W. 859, 920

Goertz-Allmann, B. P. 861

Gogoladze, Z. 827, 887

Gok, R. 826, 944

Gold, M. 811

Gold, R. D. 803, 836, 863, 876

Goldfinger, C. 802,803, 853,885

Goldman, M. R. 783, 820

Gomberg, J. S. 884

Gombert, B. 929

Gomes, A. A. 823

Gomez, A. 837

Gomez, G. 915

Gómez, J. C. 788

Gomez-Capera, A. A. 795

Gonzaga, M. 900

Gonzales, J. 824

Gonzalez, O. L. 898

Gonzalez, W. 815

González Ávila, D. 838, 929

Gonzalez-Huizar, H. 946

González-López, A. 838, 929

Gonzalez-Ortega, J. A. 865, 929

Goulet, C. A. $812,833,844$, 875,876

Govers, R. 800, 927

Graham, K. M. 820, 893

Grant Ludwig, L. 841

Grapenthin, R. 847,865

Graves, E. 792

Graves, R. W. 875,876

Graybeal, D. B. 824, 943

Greenberg, S. 861

Greenfield, M. 815

Gregor, D. 804

Gregor, N. 875

Grigoli, F. 828

Gritto, R. 911

Grunberg, M. 955

Gu, C. 797

Guattari, F. 936

Gueguen, E. 860

Guéguen, P. 878, 888

Guerrier, K. 863

Guihou, A. 885
Guillot, L. F. 888

Güney, Y. G. 837

Gusman, A. R. 848

Gutierrez, E. 899, 902

Guy, M. R. 809

Guyer, R. A. 805, 909

Guyonnet-Benaize, C. 844

Guzman, C. 839

Guzman, J. C. 839

Haddadi, H. 837

Haeussler, P. J. 802, 852, 884

Hagel, K. 809

Hagos, L. 837

Hainzl, S. 943

Haji-Soltani, A. 878, 904

Hale, J. M. 810, 897, 941

Hall, S. R. 802, 825

Halldorsson, B. 825, 902

Haller, K. M. 795

Hamburger, M. W. 955

Hamburger, R. O. 934

Hamilton, T. 802

Hammond, W. C. 928

Hampel, A. 836

Han, S. 939

Hancilar, U. 835, 947

Haney, M. M. 718, 828, 829, $830,857,858,913$

Hanks, T. C. 846, 914, 932

Hansen, S. M. 832

Hao, K. X. S. 901

Hardebeck, J. L. 917, 948

Harmon, N. 863, 927

Harmsen, S. C. 795

Harrington, R. M. 867, 949

Harris, C. W. 927

Harris, D. B. 868

Harris, J. 954

Hart, L. A. 828

Hartog, J. R. 807, 809

Hashash, Y. M. A. 787

Hastings, N. 794

Hatch, C. S. 810,839

Hatch, R. L. 912

Hatcher Jr., R. D. 877

Hauk, T. 869

Hauksson, E. 810, 851, 881, $890,907,938,939$

Hausmann, R. B. 802,803

Havazli, E. 946

Hayashi, K. H. 822

Hayashida, T. 833, 857

Hayes, G. P. $801,809,841$, $886,914,925,955$

Hayward, C. 786

$\mathrm{He}, \mathrm{X} .940$

Hearne, M. 925, 955, 956

Heaton, T. H. 810, 939

Heflin, M. 841

Hegarty, P. 857

Heidarzadeh, B. 788, 815

Heidarzadeh, M. 855

Heimers, S. 926

Heinecke, A. 805

Hello, Y. M. 862

Hellweg, M. 811, 837, 839, 880

Helmstetter, A. 791, 823, 824

Hensch, M. 923

Henson, I. 811, 880

Henstock, T. 927

Herman, M. 800
Hernandez, S. 799, 830, 831, 885,886

Hernández, J. J. 855, 856

Hernández, P. A. 839

Hernandez Ramirez, F. J. 886,894

Herrera, M. 839, 881

Herrera García, D. C. 807 , 855

Herring, T. 797

Herrmann, R. B. 817,866 , 941, 949

Hertzog, J. T. 889

Hetzel, R. 836

Hibert, C. 791,823

Hicks, S. 927

Higgins, M. 886, 920, 921

Hill, P. 880

Hillers, G. 784

Hincapié-Cárdenas, C. 947

Hirakawa, E. T. 819

Hirata, N. 788,874

Hirshorn, B. F. 848

Hitchcock, C. 815

Hjörleifsdóttir, V. 913, 928, 929, 930

Hobbs, T. E. 921

Hodges, M. 927

Hodgkinson, K. M. 850, 865, 893,910

Hoeft, J. 815

Holland, A. A. 840,883

Holland, J. 840

Hollenback, J. 844

Hollender, F. 786, 834, 844

Holmgren, J. M. 942

Holt, J. 820, 872

Homman, K. A. $817,819,838$

Hongn, F. 900

Hoover, S. M. 874, 898, 903

Hopp, C. 860

Horton, B. P. 802

Horton, S. P. 815,860

Hoshiba, M. 847, 926

Hoskins, M. C. 885,886

Hosny, A. 942

Hosseini, M. 903

Hough, S. E. 801, 914, 954

Hovius, N. 790

Howe, B. M. 862, 892

Hrafnkelsson, B. 825

Hrubcova, P. 830

Htwe, S. H. 954

Htwe, Y. M. M. 954

Hu, H. 889,896

Hu, Z. 806

Huang, D. 811

Huang, M. H. 929

Huang, Y. H. $849,882,885$

Huda, M. M. 818

Hudson, K. H. 787

Hudson, M. B. 787

Huerfano, V. A. 809,863 , 894, 898, 931, 944, 948, 957

Huesca-Perez, E. 899, 902

Hulbert, C. L. 909

Hull, A. G. 796, 844

Hurtado, A. 838, 894, 929

Hurtado, H. M. 894

Husker, A. L. 899, 920, 946

Husson, L. 825
Hutko, A. R. 807, 809

Hwang, E. H. 939

Ichinose, G. A. $819,869,870$

Idini, B. 868

Idriss, I. M. 875

Iezzi, A. M. 799, 858

Iglesias, A. 928, 929, 930

Ilhan, O. 787

Inbal, A. 910, 938

Innanen, K. A. 789

Iovine, S. 949

Irikura, K. 911

Isbiliroglu, Y. 933

Ishii, M. 873, 912, 933

Iverson, R. M. 791

Iwasaki, Y. 893

Jackson, D. D. 874, 917

Jackson, V. B. 856

Jacobs, K. 891, 893

Jacques, E. 885

Jaiswal, K. S. 795, 904, 925

Jaiswal, N. 899

Jakobsdottir, S. 923

Jalali, M. 861

Jaldín, D. 951

Jambo, E. 899

James, T.S. 852

Jana, N. 924

Jarrin Tamayo, P. 796, 894, 952

Jensen, R. P. 819

Jeong, S. 950

Jhajhria, A. 843

Ji, C. $875,878,930$

Jia, Z. 890

Jiang, J. 929

Jiang, M. 880

Jibson, R. W. 803

Jimenez, J. A. 815

Jin, L. 804, 919

Jo, E. 939

Johnson, C. E. 839

Johnson, C. W. 834, 938

Johnson, J. B. 798

Johnson, K. 870

Johnson, P. A. $805,817,909$, 939

Johnson, R. 799

Johnson, W. 922

Jolly, A. 799

Jomard, H. 795, 802

Jones, C. H. 790

Jónsdóttir, K. 913

Jonsson, S. 923

Jordan, M. 861

Jordan, T. H. 848, 875, 876, $890,935,948$

Joshi, A. 877

Journeay, J. M. 794

Jousset, P. 831

Joyce, J. 806

Jozinović, D. 926

Juan Horrillo, J. 814

Juarez, A. 935

Juhel, K. 907

Julià, J. 873,940

Juve, G. 875

Kaempf, H. 830

Kahue, R. 860

Kaip, G. 792

Kalafat, D. 922

Kalakonas, P. 793

Kale, O. 798, 823, 959

Kalkan, E. 895 
Kowsari, M. 902

Koyanagi, K. 809

Koymans, M. 926

Kozłowska, M. 861

Kramer, R. L. 858

Kress, V. 809

Krietsch, H. 861

Krischer, L. 835, 840, 841, 907, 924

Kristek, J. 804, 834

Kroll, K. A. 869, 919

Krüger, F. 900, 927

Kruse, S. 824

Ktenidou, O. J. 844, 845

Kuehn, D. 861

Kuehn, N. M. 844, 875, 933 , 958

Kukovica, J. J. 882

Kuleli, S. 797

Kumagai, Y. 881

Kumar, S. 957

Kurzon, I. 932

Kushida, N. 909

Kwak, D. Y. 787, 816, 875

Kwiatek, G. 859,922, 950

Kyaw, T. L. 954

Kyle, P. R. 799

Labedz, C. 792

Ladak, S. 821

Lafemina, P. 853, 920, 921, 922

LaForge, R. C. 870,871

Lamontagne, A. M. 792

Landes, M. 888

Landry, S. 824

Landwehr, N. 933

Langbein, J. 865

Langenkamp, T. R. 861

Langet, N. 861

Langlaude, P. 765,878

Langston, C. A. 786, 867, 879

Lanza, F. 828, 891

Lapusta, N. 834, 849, 859

Lara-Cueva, R. A. 800, 829, 830, 883

Larco, J. C. 829,883

Larmat, C. S. 784,880

Larose, E. 791, 824

Latchman, J. L. 856, 921

Lauciani, V. 926

Laurendeau, A. 887, 888

Lay, T. 854

Le Bras, R. J. 869, 909

Le Friant, A. 853

Leaney, W.S. 913

Lease, R. O. 836

Lecocq, T. 841, 954

Lees, J. M. 786, 799

Legrand, D. 930

Lei, Z. 784

Lekic, V. 873,919

Leon, A. L. 855

Leon, E. 828

León-Ríos, S. 872, 885, 886

Leonardo-Suárez, M. 793, 886, 905, 906

Leonel, C. J. M. 944

Leroy, S. 863, 898

Levander, A. R. 832, 871, $872,927,957$

Levandowski, W. 916
Levis, P. 906

Levy, Y. 825

Lewandowski, N.S. 864

Leyton, F. 942

Li, C. 909

Li, D. 896

Li, F. 796, 844

Li, P. 896

Li, S. 870

Li, S. Y. 797

Li, X. J. 787, 883, 935

Li, Y. L. 793

Li, Z. 896, 938, 939

Li, Z. W. 897,950

Liang, C. 929

Lieser, K. 954

Lin, F. C. 895, 908

Lin, G. 832, 899, 951

Lin, K. 904, 925

Lin, Y. 938

Lindsey, N. J. 868

Linkimer, L. 794, 808, 871, 941, 943, 956

Lipovsky, B. P. 823, 824

Liu, K. 817

Liu, M. 825

Liu, X. 783, 923

Liu, Z. 929

Liu, Q. 872

Llenos, A. L. 874, 920, 948

Locati, M. 884

Logan, M. 791

Lokajicek, T. 790

Lopez, A. M. 809, 886, 894

Lopez, I. 916

Lopez, L. 942

Lopez-Caballero, F. 805, 878

López-Venegas, A. 842

Lord, N. 896

Lorito, S. 813

Loughner, E. A. 861

Louie, J. 822

Lowry, D. 796

Lozos, J. C. 849

Lu, M. 793

Lubbers, N. 909

Luco, N. 795, 875, 876, 903 , 904, 934

Lugo, J. 809

Luo, G. 825

Luzi, L. 926

Lynch, L. L. 807, 856

Lynner, C. 871, 885, 886

Lyons, J. J. 857, 858

Lyzenga, G. A. 841

Ma, Q. 797

Ma, S. 850,958

Ma, S. M. 945

Maccaferri, F. 923

MacCarthy, J. K. 841, 880

Maceira, M. 817, 888

Macías, J. 813

Macias-Castillo, M. A. 905, 906

Madden, E. H. 849

Maechling, P. J. 812, 833, $875,876,948$

Maeda, T. 848

Magistrale, H. 827,875

Magnani, M. B. 950

Mahan, S. A. $803,806,837$, 904
Mahdyiar, M. 813,870

Mai, P. M. 942, 958, 959

Mak, S. 874

Maldonado, J. 815

Maldonado, R. 838, 929

Malet, J. P. 791, 823

Malone, S. D. 809,824

Manea, M. 928

Manea, V.C. 928

Mangano, G. 892

Mann, D. 865

Manzano, J. 856

Marafi, N. 801

Marano, K. D. 925,956

Marcial, D. 856

Marcillo, O. E. 857,888

Marczewski, K. 807, 809, 810

Margerin, L. 845,878

Marin, N. 889

Mariniere, J. 795

Maron, C. 952

Marone, C. J. 909

Márquez-Ramírez, V.H. 831 , 945

Marrero, J. M. 793, 794, 856,888

Martin, S. S. 884,914

Martín Agúndez, E. 935

Martín García, E. 935

Martinez, C. 814

Martinez, C. M. 898

Martinez, F. 898, 944

Martinez, J. F. 931

Martinez, M. E. 796, 844

Martínez, B. 793

Martínez-Garzón, P. 859, 922, 950

Martinez-Mendoza, G. 857

Marzocchi, W. 915

Mashagiro, N. 798

Massin, F. 881, 909, 939, 955

Matoza, R.S. 799, 851, 858

Mattioli, G.S. 850, 865, 893,910

Matzel, E. 843,869

Mavonga, G. 883

Mavroeidis, G. P. 825,833

Maybin, N. 840

Mayor, S. 765, 878

Mayoraz, R. 791, 824

Mazuera, F. 957

Mazzoni, S. 812, 875

McBrearty, I. W. 909, 939

McBride, S. K. 915, 917

McCann, W. R. 871

McClellan, J. H. 909

McCormack, D. 910

McCormick, E. 815

McFarlin, H. L. 799

McGillivary, K. 807

McGuire, J. 913, 923, 940

McKenzie, R. 824

McLean, A. 955

McNamara, D. E. 874,875 , 898, 903

McNutt, S. R. 798, 799, 818, $824,829,864$

McPhillips, D. 836

Meade, B. 908

Medina, M. 841

Mehta, C. A. 818

Meier, C. B. 810
Meier, M. A. 890, 907,938

Mejia, H. P. 898, 944, 957

Melbourne, T. 864,865

Melgar, D. 814, 847, 864, $865,905,914,928,931$

Melian, G. 839

Mellors, R. J. 819, 869

Meltzer, A. 872, 885, 886, 952

Mencin, D. 850, 865, 866, $893,910,922$

Méndez, M. 930

Mendez-Yulfo, R. 931

Mendoza Carvajal, A. J. 838, 894, 929, 947

Mendoza-Garcia, D. P. 841

Meng, H. 867, 940

Meng, X. 909, 951

Mentor William, G. 915

Mercerat, D. 888

Mercier de Lépinay, B. 898

Mercuri, A. 925

Meremonte, M. 840

Mériaux, A. S. 885

Mesimeri, M. 951

Metzger, S. 923

Mialle, P. 909

Miao, W. 872

Michael, A. J. 874, 915, 917 918, 920, 948

Michailos, K. 951

Michéa, D. 791

Michele, M. 925

Micheletto, R. M. 937, 938

Michelini, A. 926

Mikesell, T. D. 953

Milker, Y. 802

Miller, D. J. 829

Miller, K. 921

Miller, M. S. 927

Miller, P. 814

Milner, K. R. 848, 875, 876, 890,917

Miner, J. E. 851

Minson, S. E. 846,865

Mirwald, A. 928

Mirzaee, S. 832

Mishra, O. P. 833

Miyake, H. 833, 834, 911

Miyakoshi, K. 911

Mochizuki, K. 863, 892, 893

Moczo, P. 804, 834

Moeller, M. 881

Mohammadebrahim, E. 900

Molina Avila, I. 890, 905 906

Molinari, I. 828

Molkenthin, C. 958

Molnar, G. 846

Molnar, S. $820,821,882$

Momplaisir, R. 863

Monfret, T. 765,878

Monga, I. 868

Monsalve, G. 927

Montagner, J. P. 907

Montalvo-Arrieta, J. C. 946

Montoya-Noguera, S. 805

Montoya Quintanar, E. 838 , 929

Moore, A. W. 929

Moore, G. 801, 841

Moore, J. R. 792

Moores, A. 884

Mora González, I. 886 
Nikolaus, K. 852

Nisar, A. 815

Nishenko, S. 846, 854

Niu, F. 871, 872, 901, 927, 957

Nocquet, J. M. 795, 796, 872, $885,894,952$

Nolet, G. 862

Norabuena, E. O. 808, 922

Norbeck, J. H. 920

Noren, A. 853

Nowicki Jessee, M. A. 955

Nozu, A. 805, 932

Ntuli, G. 957

Núñez Escribano, D. 828, $837,862,892$

Núñez-Cornú, F. J. 828, 837, 892

Nurlu, M. 922

Nyblade, A. A. 792, 817, 819,838

Nyst, M. 935

Obermann, A. 828, 924

Obryk, M. 791

Ochoa, L. H. 918

Oglesby, D. D. 848

Ogwari, P. 950

Ogweno, L. P. 815, 910, 939

Okuwaki, R. 891

Oliva, J. C. 808

Oliva, S. J. 800

Oliveira, M. E. 817

Olsen, A. H. 934

Olsen, K. B. 804, 806, 845 , $875,879,908,934$

Oman, L. 814

Onur, T. 826, 944

Onyango, E. 866

Ordaz, M. 930

Ordoñez, J. 855

Oregel, L. 831

Orlecka-Sikora, B. 859

Ornelas, O. 946

Ortega, R. 899, 902, 928

Ortiz Garcia, C. 916

Ortiz Millan, M. 915

Oskin, M.E. 921

Ostenaa, D. A. 836,876

Oth, A. 798,883

Ovalle, C. 826

Oye, V. 861

Ozener, H. 922, 923, 953

Pabian, F. 819

Pacheco, D. A. 799, 835, 887,888

Pacheco-Alvarado, J. F. 800, 829

Padilla, G. D. 799, 828, 839, 907, 935, 953

Padrón, E. 839

Pagani, M. 870, 898

Page, M. T. 915, 916, 917, 918, 948

Paitz, P. 867

Palacios, P. B. 793, 794, 799 , 856,888

Palmer, S. M. 821

Pankow, K. L. 810, 821, 839, $897,936,941$

Papadopoulos, I. 856, 886

Parameswaran, R. M. 850, 855
Parisi, L. 942

Park, D. 787

Park, J. 786

Park, S. 873, 912, 933

Park, S. J. 794

Parker, G. 875

Parker, J. W. 812, 841, 907

Parker, L. 896

Parker, T. 719, 884, 936

Parol, J. 797

Parolai, S. 879

Pascual, J. A. 868

Paskievitch, J. F. 851

Passarelli, L. 923

Pasten-Araya, F. 951

Pasyanos, M. E. 786, 869

Patton, J. M. 809

Patton, J. R. 885

Patton, N. 837

Payero, J. S. 930

Pearson, K. M. 919

Pechmann, J. C. 810, 897, 941

Pekkan, E. P. 837

Pelyk, N. 936

Peña, L. 836

Peng, X. B. 883

Peng, Z. 896, 909, 924, 951

Perea, H. 825

Pereira, W. P. 827,954

Perez, O. J. 923

Peréz, N. 799, 828, 839

Pérez, J. 838, 894, 929

Pérez-Campos, X. 838, 873, $894,905,928,929,930$, 946, 947

Pérez-Estay, N. 795

Perez-Lugo, M. 916

Pérez-Santana, J. A. 947

Pérez-Velázquez, M. A. 838

Perez-Yañez, C. 905, 906

Permana, D. 926

Perrault, M 872

Perron, V. 786, 844

Perry, H. K. C. 843,910

Persaud, P. 921

Perton, M. 784

Peruzza, L. 826

Peter, A. M. 938

Petersen, M. D. 795, 874, $875,876,898,903$

Petruccelli, A. 911

Petruzalek, M. 790

Pezeshk, S. 815, 834, 878, $879,888,902,904$

Philibosian, B. 885

Phillips, W. S. $819,845,880$

Piatanesi, A. 813

Pickering, A. J. 907

Pierce, M. E. 812, 841

Piety, L. A. 806

Pigeon, S. 936

Pilz, M. 844, 855

Pinar, A. 847,922, 959

Pitarka, A. 869

Plafker, G. 802

Plain, M. J. 831

Planès, T. 924

Plesch, A. 825

Plescia, S. 801

Poggi, V. 870
Polanco Rivera, E. 863, 898, 944, 957

Polat, R. 922

Pollitz, F. F. 891

Ponce, G. 796, 952

Pontrelli, M. A. 947

Poppeliers, C. 785,818

PoroTomo Team 896

Porras, J. 943, 956

Porritt, R. W. 901, 927

Porter, R. C. 871

Portner, D. E. 871

Possee, D. J. 863

Potin, B. 951

Potter, S. J. 915

Poulos, A. 825

Powell, C. A. 877,916

Powers, P. M. 874, 875, 898, 903, 934

Prada, E. 855

Pramono, S. 926

Prentice, C. S. 806,836

Prépetit, C. 863

Preston, L. 785, 818, 819, 866

Prieto, G. A. 797, 909, 927, 942, 953

Priolo, E. 860

Proaño, E. 800

Protti, J. M. 718, 853, 921

Provost, F. 791, 823

Provost, L. 878

Przeor, M. 828

Puglia, R. 926

Pulliam, J. 817, 863, 897, 898, 944, 957

Pyle, M. L. 869, 895

Qaysi, S. I. 817

Qin, L. 889

Qiu, H. 784

Quesenberry, C. E. 953

Quinones, L. 950

Quintanar, L. 905, 928

Quintero, R. 900, 941

Quiros, D. A. $817,863,897$

Quispe, C.C. 817

Quitoriano, V. 925

Rabade, S. 905, 906

Raczka, J. 936

Rademacher, H. 868

Rajaeitabrizi, Y. 937

Rajendran, C. P. 850,855

Rajendran, K. 850, 855

Ramdeane, A. 807

Ramirez, A. 894

Ramirez, J. 839, 881, 909, 939, 955

Ramírez, J. E. 945

Ramírez-Guzmán, L. 793, $836,890,905,906,928$, 930, 946, 947, 949

Ramirez-Herrera, M. T. 814, 928, 931

Ramon Morales, E. 865

Ramón, P. 793, 794, 799, 888

Ramos, C. 952

Ramos, M. D. 885

Ramsay, J. 811

Raoof, J. 784

Rashidian, V. 908

Rathje, E. M. 787, 812, 815, 844,856

Ratzov, G. 853, 885
Read, C. W. 851

Real, J. 930

Realpe, G. R. 856

Reddock, K. H. 856

Redwine, J. R. 806

Régnier, M. 796,872,885, 886,952

Reidy, L. 803

Reinoso, E. 930

Rengers, F. K. 791

Renou, J. 858

Retailleau, L. 924

Reusch, M. 807

Reyes Canales, M. 920

Reyes, M. F. 888

Reyes, T. 837

Reyes-Pimentel, T. A. 828

Reynen, A. 851

Rezaeian, S. 875, 903, 934

Ribotta, L. 859

Richards, P. G. 869

Richards-Dinger, K. B. 919

Rietbrock, A. 872, 885, 886, 927, 952

Rinaldi, A. P. 911

Rincón, R. 855

Ringler, A. T. 791, 840

Ripepi, E. 860

Riquelme, S. 841, 842, 865

Rivadeneyra-Vera, J. C. 816

Rivalta, E. 923

Rivera, E. 942, 951

Rivera, W.E. 814

Roberson, J. 810

Roberson, P. M. 810

Robertson, M. 868

Robertson, R. 856,921

Robinson, T. 824

Rockwell, T. K. 825, 921

Rodgers, A. 869, 870, 933

Rodgers, J. E. 915

Rodriguez, E. E. 871

Rodriguez, M. J. 883

Rodríguez, C. 947

Rodriguez-Perez, Q. 945

Rodríguez Rasilla, I. 838, 894, 929

Rodríguez-Tribaldos, V. 873

Roecker, S. W. 800, 828

Rojas, H. V. 812

Rolandone, F. 863, 885, 894, 898,952

Romanelli, M. 860

Romano, F. 813

Romanowicz, B. 873

Romsos, C. 802

Rondon, F. J. 956

Rong, K. 906

Rong, Y. 827

Rosa, M. L. 784, 816, 887, 899,925

Rosakis, A. 834

Ross, S. L. 842

Ross, Z.E. 810, 867, 890, 891, 907, 949

Rossiter, M. 796

Roten, D. 804, 806

Rouet-LeDuc, B. P. G. 909

Rougier, E. 784, 805

Rousset, B. 825

Rowan, L. 718

Rowe, C. A. $801,819,892$

Royer, J. Y. 862

Rozelle, J. 904

Rozhkov, M. 869 
Savage, M. K. 820, 860, $891,893,951$

Savran, W. H. 948

Savvaidis, A. 811,856

Scales, M. M. 897

Schalk, J. 792

Scharer, K. M. 836

Schleicher, L. S. 793

Schlupp, A. 955

Schmandt, B. 832, 895

Schmidt, D. A. 864,865

Schmidt, J. 866

Schmitz, M. 855, 856, $888,956,957$

Schobelock, J. J. 898

Schodt, D. 818

Schoenball, M. 918

Schöpa, A. 790

Schorlemmer, D. 874, 911,917

Schreiber, K. U. 936

Schultz, W.H. 949

Schumann, R. 806

Schutt, D. 852, 889

Schwartz, S. Y. 853,863 , 892,914

Schwarzer, J. 840

Scire, A. 871

Scott, C. P. 907

Scotti, O. 795, 826

Sedaghati, F. 878, 879, 887,888

Seemungal, J. 856

Segovia, M. R. 830

Seguel, M. 796

Seibert, C. 853,885

Selva, J. 813

Selvadurai, P. A. 861

Serlenga, V. 784, 860

Serrano, R. G. 812

Sesetyan, K. 835, 947

Severino, V.E. 815

Sewell, S. 860

Seydoux, L. 799

Shabestari, K. 870

Shaddox, H. 893

Shah, A.K. 949

Shapiro, N. M. 799, 888

Sharer, G. 893

Sharma, B. 833

Sharma, H.S. 820

Shaw, B. E. 848

Shaw, J. H. 825

Shaw, K. 921

Shcherbakov, R. 860

Shearer, P. M. 940,941

Sheehan, A. F. 848, 863, 892,893

Shelly, D. R. 783

Shen, Y. 846, 880

Shen, Z. 827

Sheng, Y. 924

Shen-Tu, B. 813,870

Sherrod, B. 802, 948

Shi, J. 788

Shirzaei, M. 919

Shome, N. 935

Shumway, A. M. 795, 874, $875,876,898,903$

Sickler, R. R. 783

Sideris, M. 852

Sieh, K. E. 884
Sievers, C. 893,910

Silva, F. 812, 833, 948

Silva, L. J. 827, 954

Silva, T. G. 954

Silva, W. J. 845, 875, 919

Silva-Casarin, R. 930

Simila, G. W. 900

Simmons, K. R. 806

Simmons, N. A. 901

Simons, M. 929

Singaucho, J. C. 952

Singer, A. 856

Singh, A. 924

Singh, C. $879,899,924$

Singh, S. 877

Singh, S. K. 877, 928, 930

Sirait, A. M. M. 885

Sivasubramonian, J. 958

Skarlatoudis, A. 903

Skoumal, R.J. 861, 950

Sleeman, R. 926

Sleep, N. H. 882

Slosky, D. 925

Smart, K. J. 950

Smets, B. 798

Smit, A. 825

Smith, A. O. 938

Smith, D. 886

Smith, D. E. 719, 881

Smith, E. G. C. 951

Smith, J. B. 791

Smith, K. D. 822, 912

Smith, K. E. 938

Smith, R. B. 895

Smith, S. 950

Snelson, C. 897

Snover, D. 840

Solano-Rojas, D. 946

Somala, S. N. 850

Somerville, P. 903

Sonnemann, T. 825

Sosa, U. A. 816

Sosa-Ramirez, R. L. 946

Soto, G. J. 943

Soto-Cordero, L. 885,886

Soubestre, J. 799, 828, 839,953

Spakman, W. 927

Speed, G. 824

Spica, Z. 784, 928

Spriggs, N. 847

Stabile, T. A. 784,860

Stachnik, J. C. 885,886

Stamps, D. S. 898

Steffan, C. K. 818

Steidl, J. H. 857

Stephen, R. 792

Stephens, C. 837

Stephenson, W. J. 801

Stewart, J. P. 787, 788, $816,875,934,945$

Stock, J. M. 921

St-Onge, G. 853

Storchak, D. A. 954

Storm, T. 840

Strauch, W. 828, 839, 848, 881, 894, 909 , 939, 955

Strecker, M. R. 900

Stripajova, S. 834

Stroujkova, A. 870

Stuart, G. 863
Stubailo, I. $810,851,881$

Stults, M. 812

Stump, B. W. 786

Styron, R. 870, 898

Suarez Carvajal, C. F. 944

Suarez, G. 719, 854, 929, 930

Suarez-Plascencia, C. 837

Suleimani, E. 811

Sundermier, A. 818

Suyehiro, K. 853

Suzuki, H. S. 822

Svitek, T. 790

Sweet, J. R. 895

Symithe, S. J. 921

Syracuse, E. M. 823,892

Syukur, F. 926

Szeliga, W. 923

Taborda, R. 818, 933

Tago, J. 804

Tahara, M. T. 822

Taira, T. 811, 911, 933

Takahashi, K. 937, 938

Takahashi, N. 922

Takedatsu, R. 804,934

Tal, Y. 834, 849

Talavera, E. 839, 881

Tan, Y. 838, 894, 929

Tan, Y. J. 862

Tang, X. 896

Tanimoto, T. 792,895

Tanioka, Y. 848

Tanircan, G. 959

Tao, D. W. 797

Tape, C. 869, 913

Tape, W. 869, 913

Tapia, A. A. 958

Tary, J. B. 807,944

Tavakoli, B. 888

Taylor, M. 943

Taylor, W. J. 904

Tchawe Nziaha, F. 765, 822,878

Teague, D. P. 787,788

Tejada, C. 905

ten Brink, U.S. 806, 853

Tenorio, V. 839, 881

Teran, O. J. 921

Terra, F. 839

Thackray, G. D. 837

Thakur, P. 882

The Cascadia Recurrence Project Team, C.R.P.T. 801

Theis, J. M. 851

Thomas, A. M. 919

Thomas, P. A. 864

Thomas, V. I. 810, 851, 881

Thomas, W. A. 877

Thompson, E. M. 844, $875,876,903,925$, 932, 955,956

Thompson, G. 799, 818, $824,829,864$

Thurber, C. H. 783,843 , $891,896,899$

Thursby, M. 868

Tian, X. 896

Tibi, R. 897

Tibuleac, I. M. 868

Tiwari, A. K. 924
Tobón López, A. M. 807

Todd, E. 893

Tohidi, H. 815

Toksöz, M. N. 797

Tolstoy, M. 862

Tomuta, E. 909

Tonini, R. 813

Tormann, T. 911

Torpey, M. 870

Torres, E. 951

Torres, M. 890

Torres Bernhard, L. E. 842

Torres Morales, G. F. 886

Torres-Noguez, M. 905 , 906

Touhami, S. 765,878

Townend, J. 860, 889, 891, 916, 951

Townsend, B. 884

Townsend, M. 785

Trabant, C. $812,824,840$

Tracy, C. 868

Trejo-Gomez, E. 837

Trilla, A. 888

Tromp, J. 872

Trugman, D. T. 909, 941

Trujillo-Castrillón, N. 831

Tsai, V. 792

Tsereteli, N.S. 827,887

Tu, N. 908

Tun, P. P. 954

Tün, M. T. 837

Turhan, F. 922

Turowski, J. M. 790

Uematsu, H. U. 937

Uhrhammer, R. A. 811

Ulmi, M. 852

Ulrich, T. 849

Ulysse, S. 863

Upadhyaya, S. 884

Urbancic, T. 861, 911

Ureña, F. 805, 833

Ureña, M. 805, 833

Uzcategui, R. 923

Vaca, S. 796

Vaezi, Y. 950

Vahi, K. 875

Valdés-González, C. M. 831,857

Valdez, A. 865

Valencia, D. I. 836

Valenzuela, R. W. 873 , 899

Vallée, M. 718, 858, 907

Valley, B. 861

Van Eaton, A. R. 858

Van Fossen, M. 824

Van Arsdale, R. B. 815

van Benthem, S. 927

Van der Baan, M. 860, 911, 920, 950

van der Elst, N. J. 890, 915, 916, 917, 918 948

van der Laat, L. 829

van Driel, M. 835

Vanacore, E. A. 809, 815, $886,894,915,931$, 957

Vane, C. H. 852

Vannucci, G. 911

Varazanashvili, O. 827 
Ward, K. M. 871, 895

Warren-Smith, E. J. 891 , 892

Wassermann, J. 936

Watkins, M. 851, 881

Watson, I. 812

Wattenberg, M. 908

Wauthier, C. 800

Wdowisnki, S. 946

Weathers, T. 815

Weber, B. 881

Weber, J. C. 920, 921, 922

Weekly, R. T. 812

Wei, X. Z. 846,880

Wein, A. M. 915, 917

Weingarten, M. 918

Weinstein, S. A. 809, 842

Werner, M. J. 796, 917 , 948

Wesnousky, S. G. 876, 923

West, M. E. 810, 811, 884

White, J. A. 919

White, N. J. 873

Wicks, C. W. 891

Wiemer, S. 828, 861, 911

Wiens, D. 792

Wiersberg, T. 853

Wilcock, W. S. D. 862

Williams, E. 868
Williams, R. A. 803,874 , 949

Wilson, D. C. 791, 840

Wilson, R. I. 842

Wirth, E. A. 801

Withers, K. W. 882

Withers, M. M. 910, 939

Witt, D. 889

Witter, R. C. 802,836 , 852

Wittke, S. 802, 836

Wolf, L. 951

Wolin, E. 954

Wollherr, S. 849

Wong, I. G. 864, 919

Wooddell, K. 875

Woodward, R. L. 852, 893

Woolery, E. W. 822

Worden, C. B. 925, 955, 956

Wortel, R. 927

Worthington, L. L. 866 , 895

Wu, S. M. 895

Wu, Y. 938

Wurman, G. 788

Xie, J. 946

Xie, X. B. 785, 877

Xu, G. 902
Xu, X. 827, 928

Xu, Z. 953

Yagi, Y. 891

Yagoda-Biran, G. 821

Yaltırak, C. 953

Yamamoto, Y. 922

Yamin, L. E. 807, 855

Yáñez, G. 795

Yang, C. 797

Yang, S. 825

Yang., W. 813

Yao, Z. X. 785, 877

Yarce, J. 863, 893

Yeck, W. L. 809, 868, 886, 891,941

Yegikyan, M. 862

Yegres, L. A. 956

Yeh, T. 879

Yenier, E. 847, 851, 959

Yepes, H. A. 793, 794, $795,855,856,888$

Yetirmishli, T. 944

Yin, J. 890

Yin, Y. 870

Yokoi, T. 833, 857

Yong, A. 787, 845

Yoo, S. H. 845

Yoon, C. E. 906

Young, B. E. 811,856
Young, C. 897

Youngs, R. 875, 945

Youssof, M. 942

Yu, E. 810

Yu, J. 875, 948

Yuan, J. 849

Yuan, S. 867

Yukutake, Y. 943

Yun, H.J. 939

Zafarani, H. 834

Zahradnik, J. 913

Zahran, H. 942

Zal, H.J. 820, 893

Zaliapin, I. 950

Zamora, A. 816

Zamora-Sauma, N. 841

Zandieh, A. 904

Zare, M. 834

Zavala-Hidalgo, J. 814 , 928, 931

Zeckra, M. 900

Zellman, M.S. 836, 837, 876

Zelt, C. 957

Zeng, X. 783, 896

Zeng, Y. 845

Zerathe, S. 802

Zhai, G. 919

Zhai, Q. 896
Zhan, Z. 868, 890, 938

Zhang, H. 783, 821

Zhang, L. 796

Zhang, P. 940

Zhang, X. L. 883

Zhao, L. 896

Zhao, L. F. 785,877

Zhao, S. C. 935

Zhao, X. 785

Zhe, S.Z. 937

Zheng, Y. 880, 889, 896

Zhou, L. 805

Zhou, Z. 938

Zhou, Z. H. 883

Zhu, J. 870

Zhu, L. 909

Zhu, S. 849

Zhu, T. 789

Zhu, W. 908

Zimakov, L. 936

Zimmaro, P. 816

Zoback, M. D. 804, 919

Zumberge, M. A. 867

Zuniga, F. R. 945

Zurek, B. D. 832

Zuzlewski, S. 811 